Supporting Information for

\title{
Binuclear Pd(I)-Pd(I) Catalysis Assisted by Iodide Ligands for Selective Hydroformylation of Alkenes and Alkynes
}

\author{
Yang Zhang $^{1}$, Sebastian Torker ${ }^{1,2 *}$, Michel Sigrist ${ }^{1}$, Nikola Bregović ${ }^{1}$, and Paweł Dydio ${ }^{1 *}$ \\ ${ }^{1}$ University of Strasbourg, CNRS, ISIS UMR 7006, 8 allée Gaspard Monge, 67000 Strasbourg, France \\ ${ }^{2}$ Department of Chemistry, Merkert Chemistry Center, Boston College, Chestnut Hill, MA 02467, USA \\ * E-mails: dydio@unistra.fr; torker@unistra.fr
}

\section{Table of contents}

1. Supplementary Methods S3

2. Preparation and characterization of starting materials __ S4

2.1 Preparation and characterization of xantphos $-\mathrm{PdI}_{2} \_\mathrm{S} 4$

2.2 Preparation and characterization of alkene substrates __ S4

2.3 Preparation and characterization of alkyne substrates ___ S6

3. Evaluation of reaction parameters __ S17

3.1 Evaluation of palladium sources - hydroformylation of alkenes___ S17

3.2 Evaluation of solvents - hydroformylation of alkenes___ S18

3.3 Evaluation of ligands - hydroformylation of alkenes _ S19

3.4 Evaluation of ratios of palladium source, ligand, or additives __ S20

3.5 Evaluation of pressure and solvent - different substrates _ S21

3.6 Evaluation of palladium sources and additives - hydroformylation of alkynes___ S22

3.7 Evaluation of other carbonylation reactions - alkoxy-, amino-, and thiocarbonylation of alkenes _ S23

4. General procedure for Pd-catalyzed hydroformylation of alkenes and alkynes __ S24

5. Characterization of the aldehyde products ___ S25

6. Modular synthesis of 1,5-bisarylpyrazole derivatives___ S42

7. Mechanistic experiments __ S46

7.1 Activation of xantphos-Pd(II) $\mathrm{X}_{2}$ bearing different anions under syngas ___ S46

7.1.1 Preparative synthesis of $\left[(\text { xantphos })_{2} \mathrm{Pd}_{2}(\mu-\mathrm{H})(\mu-\mathrm{CO})\right]^{+} \mathrm{TFA}^{-} \_\mathrm{S} 71$

7.1.2 Activation of xantphos-Pd(TFA $)_{2}$ under $\mathrm{D}_{2} / \mathrm{CO}$

7.2 Activation of xantphos-Pd(II) $\mathrm{I}_{2}$ under dihydrogen__ S82 
7.3 Reaction of xantphos-Pd(II) $\mathrm{X}_{2}$ and an alkene under syngas S85

7.4 Studies of CO insertion into a Pd-alkyl bond in the presence of different anions S116

7.5 Synthesis of [xantphos-Pd- $\beta$-acyl]Cl and [xantphos-Pd- $\beta$-acyl]BF 4 S130

7.6 Synthesis of [xantphos-Pd- $\alpha$-acyl] $\mathrm{BF}_{4}$ S135

7.7 Synthesis of xantphos- $\mathrm{Pd}\left(\mathrm{CH}_{3}\right) \mathrm{Cl}$ and xantphos- $\mathrm{Pd}\left(\mathrm{CH}_{3}\right) \mathrm{BF}_{4}$ S138

7.8 Synthesis of the (xantphos) $)_{2}-\mathrm{Pd}_{2}\left(\mathrm{BF}_{4}\right)_{2}$ S139

7.9 Synthesis of the xantphos $-\mathrm{Pd}_{2} \mathrm{I}_{2}$ complex S142

7.10 Evaluation of reactivity of reaction intermediates - stoichiometric experiments S144

7.11 Analysis of reaction intermediates with high resolution mass spectrometry S156

7.12 Kinetic experiments S163

7.13 Evaluation of the resting state of the catalytic cycle by the in-situ ${ }^{1} \mathrm{H}$ NMR spectroscopy S174

7.14 Evaluation of the catalytic activity of isolated intermediates by the in-situ ${ }^{1} \mathrm{H}$ NMR spectroscopy $\mathrm{S} 175$ 7.15 Evaluation of the catalytic reaction under $\mathrm{D}_{2} / \mathrm{CO}$ by the in-situ ${ }^{2} \mathrm{H}$ NMR spectroscopy deuterioformylation study S177

8. Density Functional Theory (DFT) Calculations S178

8.1 Computational details S178

8.2 Modeling of dispersion interactions S178

8.3 Free energy surfaces for reaction of cationic $\mathrm{L}-\mathrm{Pd}-\mathrm{acyl}^{+}$intermediate S179

8.3.1 Reaction of cationic L-Pd-acyl ${ }^{+}$intermediate with LPdHX (transition states A and B) S179

8.3.2 Reaction of cationic $\mathrm{L}-\mathrm{Pd}-\mathrm{acyl}^{+}$intermediate with $\mathrm{I}_{2} \mathrm{Pd}-\mathrm{H}^{-}$anion (transition states $\mathrm{C}, \mathrm{C}^{\prime}$ and $\mathrm{D}$ ) S179

8.3.3 Reaction of cationic $\mathrm{L}-\mathrm{Pd}-\mathrm{acyl}^{+}$intermediate with $\mathrm{H}_{2}$ (transition state $\mathrm{E}$ ) S179

8.3.4 Reaction of cationic L-Pd-acyl ${ }^{+}$intermediate with $\mathrm{HI}$ (transition state F) S180 8.4 The effect of nonlocal dispersion on the free energy surfaces S185

9. Coordinates after optimization with M06L/Def2SVP S187

10. References S251

11. Copies of NMR spectra S257

11.1 Synthetic alkenes and alkynes S257

11.2 Aldehyde products S276

11.3 Bisarylpyrazole derivatives S321

12. ORTEP diagrams of X-ray structures S325 


\section{Supplementary Methods}

Unless stated otherwise, all reactions and manipulations were conducted on the laboratory bench or in a well-ventilated fume hood in air with reagent grade solvents. Reactions under inert gas atmosphere were carried out in the oven-dried glassware in a nitrogen-filled glovebox or by standard Schlenk techniques under nitrogen. Unless noted otherwise, all reagents and solvents were purchased from commercial suppliers and used without further purification. For experiments under inert gas atmosphere, dichloromethane (DCM), tetrahydrofuran (THF), toluene, hexane and diethyl ether $\left(\mathrm{Et}_{2} \mathrm{O}\right)$ were degassed by purging with nitrogen for 15 min and dried with an INERT solvent purification system containing a one-meter column of activated alumina; dried and degassed solvents were purchased from commercial suppliers and used as received. Column chromatography was carried out either with the aid of the Biotage Isolera instrument using Merck Kieselgel 60 (230-400 mesh) or with the aid of CombiFlash EZ Prep Chromatography System with integrated ELSD using the RediSep Rf (Gold) Silica Gel Disposable Flash columns. TLC was carried out on Merck Kieselgel F254 plates. TLC visualization was carried out with ultraviolet light $(254 \mathrm{~nm})$, followed by staining with a $1 \%$ aqueous $\mathrm{KMnO}_{4}$ solution. NMR spectra were acquired on the $400 \mathrm{MHz}$ or $500 \mathrm{MHz}$ Bruker instruments at the Institute of Science and Supramolecular Engineering (ISIS) or at the Department of Chemistry, University of Strasbourg, Strasbourg. NMR spectra were processed using the MestReNova 10.0 software. Chemical shifts are reported in parts per million (ppm) and referenced to residual solvent peaks or tetramethylsilane (TMS). Coupling constants are reported in hertz (Hz). GC-FID analysis was obtained either on a Shimadzu GC-2010 Plus instrument equipped with a SH-Rxi-5MS column (25 m x $0.20 \mathrm{~mm}$ ID x $0.33 \mu \mathrm{m}$ film) connected to a FID detector, or on a ThermoFisher TRACE 1300 instrument equipped with a HP-5 column (25 m x 0.20 mm ID x 0.33 $\mu \mathrm{m}$ film). GC-MS analysis was obtained on a Shimadzu QP2020 (EI) instrument equipped with a SHRxi-5MS column (25 m x 0.20 mm ID x $0.33 \mu \mathrm{m}$ film). GC-FID and NMR yields were calculated using 1,3,5-trimethoxybenzene or 1,4-dimethoxybenzene as the internal standards. GC-FID yields were corrected for response factors for all compounds. High-resolution electrospray ionization mass spectra (HR-MS ESI) were obtained at the Analytical Facility of the Department of Chemistry, University of Strasbourg. High-resolution atmospheric pressure photoionization mass spectra (HR-MS APPI) were obtained on Thermo Exactive Plus EMR with a MasCom GC-APPI Interface (at ISIS). 


\section{Preparation and characterization of starting materials}

\subsection{Preparation and characterization of xantphos $-\mathrm{PdI}_{2}$}

Under a nitrogen atmosphere, a $4 \mathrm{~mL}$ flame-dried vial was charged with $\mathrm{PdI}_{2}(54 \mathrm{mg}, 0.15 \mathrm{mmol})$, xantphos (115.6 mg, $0.2 \mathrm{mmol})$, and dichloromethane $(2 \mathrm{~mL})$. The reaction mixture was allowed to stir at room temperature for $16 \mathrm{~h}$. The volatiles were removed under reduced pressure. The solid residue was carefully washed with anhydrous $\mathrm{Et}_{2} \mathrm{O}(3 \times 2.0 \mathrm{~mL})$ and dried under high vacuum, yielding the title complex as a crimson solid. The NMR data match previously reported data for the title product. ${ }^{1}$

${ }^{1} \mathbf{H}$ NMR $\left(400 \mathrm{MHz}, \mathrm{CD}_{2} \mathrm{Cl}_{2}\right) \delta$ 6.80-8.01 (br m, 26H), 1.78 (br s, 6H).

${ }^{31} \mathbf{P}\left\{{ }^{1} \mathbf{H}\right\}$ NMR $\left(203 \mathrm{MHz}, \mathrm{CD}_{2} \mathrm{Cl}_{2}\right) \delta 19.5$ (s, cis), 7.1 (s, trans), in a 1:3.5 ratio.

\subsection{Preparation and characterization of alkene substrates}

\section{$N$-Allyl phthalimide 1s}

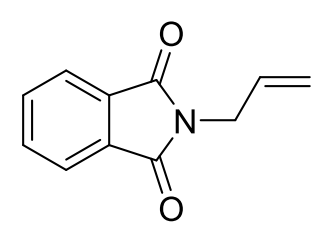

A reaction flask was charged with isoindoline-1,3-dione $(1.47 \mathrm{~g}, 10.0 \mathrm{mmol}), 3$ bromoprop-1-ene (1.12 mL, $13 \mathrm{mmol}), \mathrm{K}_{2} \mathrm{CO}_{3}(1.8 \mathrm{~g}, 13 \mathrm{mmol})$, and DMF (30 mL). The reaction mixture was allowed to stir at room temperature, and the progress of the reaction was followed by the TLC analysis. After $6 \mathrm{~h}$ the reaction was completed, as judged by TLC. The reaction mixture was slowly poured into water $(100 \mathrm{~mL})$. The aqueous phase was extracted with $\mathrm{CH}_{2} \mathrm{Cl}_{2}(5 \times 20 \mathrm{~mL})$. The organic extracts were combined, washed with water $(3 \times 40 \mathrm{~mL})$, and dried over $\mathrm{MgSO}_{4}$. After filtration, the volatile material from the filtrate was evaporated under reduced pressure. The residue was subjected to column chromatography on silica gel, with a mixture of petroleum ether and ethyl acetate (95:5) as the eluent. Fractions containing the pure product were combined, and the solvent was evaporated, yielding the title product $(1.85 \mathrm{~g}, 99 \%)$ as white crystals. The NMR data match previously reported data for the title product. $^{2}$

${ }^{1}$ H NMR (400 MHz, CDCl $)$ ) 7.87-7.85 (m, 2H), 7.73-7.71 (m, 2H), 5.94-5.84 (m, 1H), 5.28-5.18 (m, $2 \mathrm{H}), 4.30(\mathrm{dt}, J=6.0 \mathrm{~Hz}, 1.2 \mathrm{~Hz}, 2 \mathrm{H})$. 


\section{(Z)-1-(Triisopropylsiloxy)-1-propene 1t}

TIPSO_ To a solution of chlorotriisopropylsilane $(1.99 \mathrm{~g}, 10.3 \mathrm{mmol})$ and propanal $(500 \mathrm{mg}, 8.6$ $\mathrm{mmol})$ in DMF $(8 \mathrm{~mL})$ at $0{ }^{\circ} \mathrm{C}, \mathrm{Et}_{3} \mathrm{~N}(2.4 \mathrm{~mL}, 17.2 \mathrm{mmol})$ was added. The mixture was heated to $60{ }^{\circ} \mathrm{C}$ and allowed to stir for $48 \mathrm{~h}$ at $60{ }^{\circ} \mathrm{C}$. Then, the reaction mixture was allowed to cool to room temperature. Cold pentane $(100 \mathrm{~mL})$ and $5 \%$ aqueous $\mathrm{HCl}(80 \mathrm{~mL})$ were added. The organic layer was separated, washed with $5 \%$ aqueous $\mathrm{NaHCO}_{3}(3 \mathrm{x} \sim 50 \mathrm{~mL})$, and dried over $\mathrm{Na}_{2} \mathrm{SO}_{4}$. After filtration, the volatile material from the filtrate was evaporated under reduced pressure. The residue subjected to column chromatography on silica gel, with petroleum ether as the eluent. Fractions containing the pure product were combined, and the solvent was evaporated, yielding the title product $(0.38 \mathrm{~g}, 20 \%)$ as a colorless liquid. The NMR data match previously reported data for the title product. ${ }^{3}$

${ }^{1}$ H NMR (400 MHz, CDCl $) \delta 6.29(\mathrm{dq}, J=5.9,1.7 \mathrm{~Hz}, 1 \mathrm{H}), 4.45(\mathrm{dq}, J=5.9,6.6 \mathrm{~Hz}, 1 \mathrm{H}), 1.59$ (dd, $J$ $=1.7,6.6 \mathrm{~Hz}, 3 \mathrm{H}), 1.21-1.11(\mathrm{~m}, 3 \mathrm{H}), 1.07(\mathrm{~d}, J=6.1 \mathrm{~Hz}, 18 \mathrm{H})$.

\section{N-Boc-N-vinylformamide $1 u$}

Under a nitrogen atmosphere, to a solution of $\mathrm{N}$-vinylformamide $(4.18 \mathrm{~mL}, 60 \mathrm{mmol}, 1$
$\mathrm{Boc}^{\mathrm{O}}$ equiv. $)$ in $\mathrm{THF}(200 \mathrm{~mL}), \mathrm{Boc}_{2} \mathrm{O}(15.7 \mathrm{~g}, 72 \mathrm{mmol}, 1.2$ equiv. $)$ and 4dimethylaminopyridine (73 $\mathrm{mg}, 0.6 \mathrm{mmol}, 0.01$ equiv.) were added. The reaction mixture was allowed to stir for $22 \mathrm{~h}$ at room temperature, and the volatiles were removed under reduced pressure. The residue was subjected to column chromatography on silica gel, with a mixture of petroleum ether and ethyl acetate (80:20) as the eluent. Fractions containing the pure product were combined, and the solvent was evaporated, yielding the title product $(9.55 \mathrm{~g}, 93 \%)$ as a colorless liquid. The NMR data match previously reported data for the title product. ${ }^{4}$

${ }^{1}$ H NMR (400 MHz, CDCl 3$) \delta 9.23(\mathrm{~s}, 1 \mathrm{H}), 6.57(\mathrm{dd}, J=16.2,9.7 \mathrm{~Hz}, 1 \mathrm{H}), 5.65(\mathrm{dd}, J=16.2,1.2 \mathrm{~Hz}$, $1 \mathrm{H}), 5.01(\mathrm{~d}, J=9.7 \mathrm{~Hz}, 1 \mathrm{H}), 1.54(\mathrm{~s}, 9 \mathrm{H})$.

\section{2-(But-3-en-1-yl)-2-1,3-dioxolane 1x}

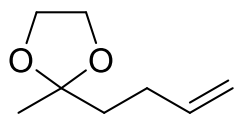

The mixture of ethane-1,2-diol (6.35 g, $102 \mathrm{mmol})$, hex-5-en-2-one (1.96 g, $20.0 \mathrm{mmol})$ and $p$-TsOH $(20 \mathrm{mg})$ in dry benzene $(75 \mathrm{~mL})$ was heated to reflux for 2 days, during which the produced water was azeotropically removed with the aid of the Dean-Stark apparatus. Upon completion and cooling to room temperature, the reaction mixture was washed with saturated aqueous $\mathrm{NaHCO}_{3}(2 \times 50 \mathrm{~mL})$. The combined aqueous layers were extracted with $\mathrm{CH}_{2} \mathrm{Cl}_{2}(3 \times$ 
$50 \mathrm{~mL}$ ). The organic phases and extracts were combined and dried over anhydrous $\mathrm{MgSO}_{4}$. After filtration, the volatile material from the filtrate was evaporated under reduced pressure, yielding the pure product $(2.52 \mathrm{~g}, 89 \%)$ as a colorless liquid. The NMR data match previously reported data for the title product. ${ }^{5}$

${ }^{1} \mathbf{H}$ NMR $\left(400 \mathrm{MHz}, \mathrm{CDCl}_{3}\right) \delta$ 5.85-5.82 (m, 1H), 5.05-4.94 (m, 2H), $3.94(\mathrm{~m}, 4 \mathrm{H}), 2.17(\mathrm{~m}, 2 \mathrm{H}), 1.73$ $(\mathrm{m}, 2 \mathrm{H}), 1.33(\mathrm{~s}, 3 \mathrm{H})$.

\section{2-vinyl-1H-benzo[f]isoindole-1,3(2H)-dione 1qB}

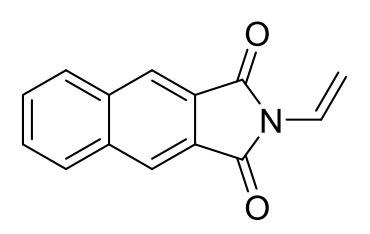

Naphtho[2,3-c]furan-1,3-dione (100 mg, $0.5 \mathrm{mmol}, 1$ equiv.) and formamide (2.0 $\mathrm{mL}, 50 \mathrm{mmol}, 100$ equiv.) were added in a $10 \mathrm{~mL}$ microwave vial and sealed with a microwave cap. The mixture was heated twice at $200^{\circ} \mathrm{C}$ for $30 \mathrm{sec}$ with $10 \mathrm{sec}$ pre-stirring, using microwave reactor. The mixture was cooled to $0{ }^{\circ} \mathrm{C}$, and cold water $(5 \mathrm{~mL})$ was added into the tube. The solid was filtrated over a filter paper, washed with water $(5$ $\mathrm{mL})$ and hexane $(5 \mathrm{~mL})$, and dried under reduced pressure to afford $1 \mathrm{H}$-benzo[f]isoindole-1,3(2H)-dione (75 mg, $0.37 \mathrm{mmol}, 75 \%$ yield) as a beige solid, which was used without further purification.

$1 H$-benzo[f]isoindole-1,3(2H)-dione (0.4 g, $2.0 \mathrm{mmol}, 1$ equiv.), palladium(II) chloride (36 mg, $0.2 \mathrm{mmol}, 0.1$ equiv.), lithium chloride ( $16 \mathrm{mg}, 0.2 \mathrm{mmol}, 0.1$ equiv.) and vinyl acetate $(5.0 \mathrm{~mL}, 55 \mathrm{mmol}$, 27 equiv.) were added in a microwave tube sealed with a microwave cap. After stirring for $31 \mathrm{~h}$ at $80{ }^{\circ} \mathrm{C}$, the resulting mixture was allowed to cool to room temperature. Purification by silica gel chromatography (a mixture of hexane and ethyl acetate in gradient 17/1 to 10/1 as the eluent) afforded the title product $(112 \mathrm{mg}, 25 \%)$ as a colorless solid. The NMR data match previously reported data for the title product. ${ }^{6}$

${ }^{1} \mathbf{H}$ NMR $\left(400 \mathrm{MHz}, \mathrm{CDCl}_{3}\right) \delta 8.37(\mathrm{~s}, 2 \mathrm{H}), 8.07(\mathrm{dd}, J=6.1,3.4 \mathrm{~Hz}, 2 \mathrm{H}), 7.72(\mathrm{dd}, J=6.3,3.3 \mathrm{~Hz}, 2 \mathrm{H})$, $6.97(\mathrm{dd}, J=16.4,9.7 \mathrm{~Hz}, 1 \mathrm{H}), 6.20(\mathrm{~d}, J=16.4 \mathrm{~Hz}, 1 \mathrm{H}), 5.12(\mathrm{~d}, J=9.9 \mathrm{~Hz}, 1 \mathrm{H})$.

\subsection{Preparation and characterization of alkyne substrates}

General procedure $A:^{7}$

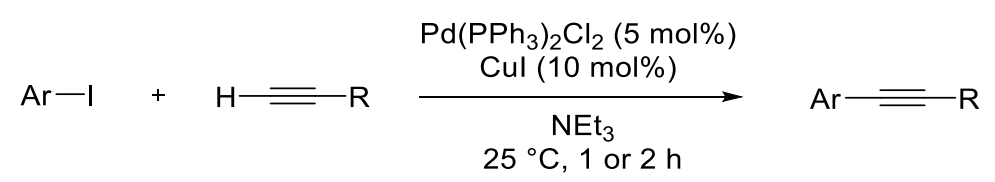

To a mixture of $\mathrm{Pd}\left(\mathrm{PPh}_{3}\right)_{2} \mathrm{Cl}_{2}(175 \mathrm{mg}, 0.25 \mathrm{mmol}), \mathrm{CuI}(95 \mathrm{mg}, 0.5 \mathrm{mmol})$ and an alkyl or aryl iodide $(5 \mathrm{mmol})$, triethylamine $(10 \mathrm{~mL})$ was added. After stirring for $10 \mathrm{~min}$, a terminal alkyne $(7.5 \mathrm{mmol})$ was slowly added. The progress of the reaction was followed by TLC or GCMS analyses. After GCMS 
analysis showed the reaction to be complete, the mixture was filtered through a short plug of celite, which was then washed with ethyl acetate $(3 \times 50 \mathrm{~mL})$. The filtrate was concentrated, and the product was isolated from the residue by column chromatography on silica gel with a mixture of petroleum ether and ethyl acetate as the eluent. Fractions containing the pure product were combined, and the solvent was evaporated, affording the target product.

\section{General procedure $B:^{8}$}

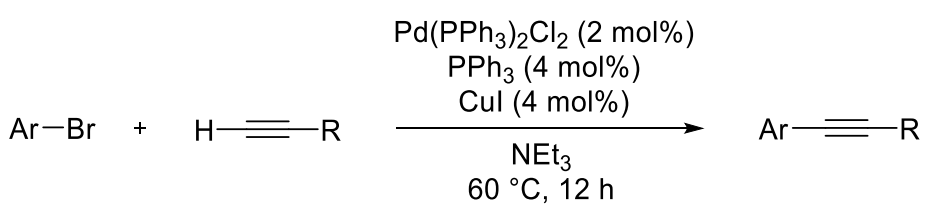

To a mixture of $\mathrm{Pd}\left(\mathrm{PPh}_{3}\right)_{2} \mathrm{Cl}_{2}(70 \mathrm{mg}, 0.10 \mathrm{mmol})$, CuI (38 mg, $\left.0.20 \mathrm{mmol}\right)$ and triphenylphosphine $(52 \mathrm{mg}, 0.20 \mathrm{mmol})$ in triethylamine $(10 \mathrm{~mL})$, an aryl or alkyl bromide $(5 \mathrm{mmol})$ was added. To remove the oxygen from the flask, a stream of nitrogen was passed through the mixture for 30 min. Then, a degassed terminal alkyne $(5 \mathrm{mmol})$ was added. The resulting mixture was heated at $60{ }^{\circ} \mathrm{C}$ overnight under nitrogen. A saturated aqueous $\mathrm{NH}_{4} \mathrm{Cl}$ solution $(50 \mathrm{~mL})$ was added. The mixture was extracted with ethyl acetate $(3 \times 50 \mathrm{~mL})$. The combined organic layers were washed with water $(2 \times 50$ $\mathrm{mL})$ and brine $(50 \mathrm{~mL})$. The organic phase was dried over anhydrous $\mathrm{MgSO}_{4}$. After filtration, the volatile material from the filtrate was evaporated under reduced pressure. The residue was subjected to column chromatography on silica gel with a mixture of petroleum ether and ethyl acetate as the eluent. Fractions containing the pure product were combined, and the solvent was evaporated, affording the target product.

\section{General procedure $C:^{9}$}

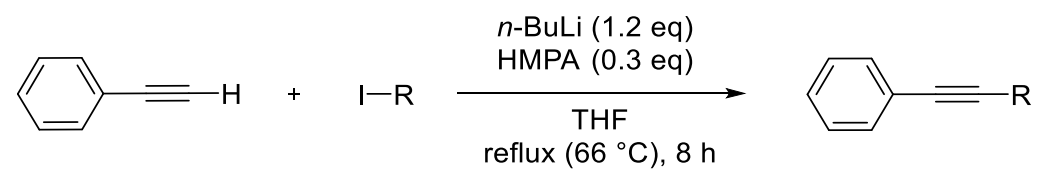

A mixture of phenylacetylene $(2.15 \mathrm{~mL}, 19.60 \mathrm{mmol})$ in THF $(30 \mathrm{~mL})$ was deoxygenated by passing a stream of nitrogen for $30 \mathrm{~min}$, then cooled to $-40{ }^{\circ} \mathrm{C}$, followed by dropwise addition of $n$-butyllithium (1.6 $\mathrm{M}$ in hexanes, $14.7 \mathrm{~mL}, 23.5 \mathrm{mmol})$ at $-40{ }^{\circ} \mathrm{C}$. After stirring for $30 \mathrm{~min}$, $\mathrm{HMPA}(1 \mathrm{~mL}, 5.5$ mmol) was added. The reaction mixture was allowed to warm to room temperature for 20 min. To this mixture an alkyl or aryl iodide $(29.4 \mathrm{mmol})$ was added. The reaction mixture was heated to reflux $\left(66^{\circ} \mathrm{C}\right)$ for $8 \mathrm{~h}$. Upon cooling to room temperature, a saturated aqueous $\mathrm{NH}_{4} \mathrm{Cl}$ solution $(50 \mathrm{~mL})$ was added. The 
mixture was washed with diethyl ether $(3 \times 50 \mathrm{~mL})$. The combined organic phases were dried over anhydrous $\mathrm{MgSO}_{4}$. After filtration, the volatile material from the filtrate was evaporated under reduced pressure. The residue was subjected to column chromatography on silica gel with a mixture of petroleum ether and ethyl acetate as the eluent. Fractions containing the pure product were combined, and the solvent was evaporated, affording the target product.

\section{But-1-yn-1-ylbenzene 4b}

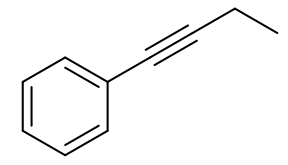

The compound was prepared according to the general procedure $\mathrm{C}$ by reaction of phenylacetylene (2.15 mL, $19.6 \mathrm{mmol}), 1$-iodoethane $(3.35 \mathrm{~mL}, 16.4 \mathrm{mmol})$, and was isolated by column chromatography (silica gel, 0-5\% ethyl acetate in petroleum ether), yielding the title product $(1.4 \mathrm{~g}, 66 \%)$ as a colorless oil. The NMR data match previously reported data for the title product. ${ }^{10}$

${ }^{1} \mathbf{H}$ NMR $\left(400 \mathrm{MHz}, \mathrm{CDCl}_{3}\right), \delta$ 7.39-7.46 (m, 2H), 7.27-7.34 (m, 3H), $2.45(\mathrm{q}, J=7.5 \mathrm{~Hz}, 2 \mathrm{H}), 1.27(\mathrm{t}, J$ $=7.5 \mathrm{~Hz}, 3 \mathrm{H})$.

\section{Hex-1-yn-1-ylbenzene 4c}

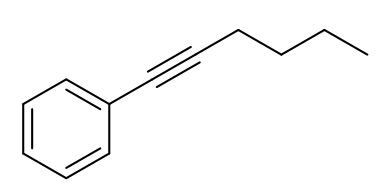

The compound was prepared according to the general procedure $\mathrm{C}$ by reaction of phenylacetylene $(2.15 \mathrm{~mL}, 19.6 \mathrm{mmol})$, 1-iodobutane $(3.35 \mathrm{~mL}, 29.40 \mathrm{mmol})$, and was isolated by column chromatography (silica gel, $0-5 \%$ ethyl acetate in petroleum ether), yielding the title product $(2.14 \mathrm{~g}, 69 \%)$ as a colorless oil. The NMR data match previously reported data for the title product. ${ }^{10}$

${ }^{1} \mathbf{H}$ NMR (400 MHz, $\left.\mathrm{CDCl}_{3}\right), \delta$ 7.39-7.38 (m, 2H), 7.27-7.26 (m, 3H), $2.41(\mathrm{t}, J=6.9 \mathrm{~Hz}, 2 \mathrm{H}), 1.59$ (quin, 2H), 1.49 (sext, 2H), $0.95(\mathrm{t}, J=7.1 \mathrm{~Hz}, 3 \mathrm{H})$.

\section{Oct-1-yn-1-ylbenzene 4d}

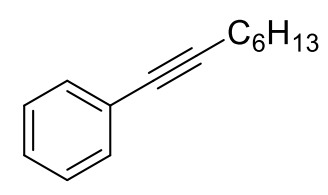

The compound was prepared according to the general procedure A by reaction of iodobenzene $(0.56 \mathrm{~mL}, 5 \mathrm{mmol}), 1$-octyne $(1.11 \mathrm{~mL}, 7.5 \mathrm{mmol})$, and was isolated by column chromatography ( silica gel, 0-5\% ethyl acetate in petroleum ether), yielding the title product (486 mg, 52\%) as a yellowish oil. The NMR data match previously reported data for the title product. ${ }^{11}$ 
${ }^{1} \mathbf{H}$ NMR $\left(400 \mathrm{MHz}, \mathrm{CDCl}_{3}\right), \delta$ 7.40-7.38 (m, 2H), 7.27-7.25 (m, 3H), $2.40(\mathrm{t}, J=7.1 \mathrm{~Hz}, 2 \mathrm{H}), 1.63-1.56$ (quin, 2H), 1.51-1.41 (m, 2H), 1.39-1.25 (m, 4H), $0.91(\mathrm{t}, J=7.0 \mathrm{~Hz}, 3 \mathrm{H})$.

\section{Dodec-1-yn-1-ylbenzene 4e}

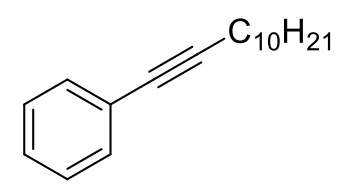

The compound was prepared according to the general procedure $\mathrm{C}$ by reaction of phenylacetylene $(2.15 \mathrm{~mL}, 19.60 \mathrm{mmol}), 1$-iododecane $(2.8 \mathrm{~mL}, 13.13 \mathrm{mmol})$, and was isolated by column chromatography (silica gel, $100 \%$ petroleum ether), yielding the title product $(270 \mathrm{mg}, 12 \%)$ as a colorless oil.

${ }^{1}$ H NMR (400 MHz, CDCl $), \delta$ 7.40-7.38 (m, 2H), 7.28-7.26 (m, 3H), $2.40(\mathrm{t}, J=7.1 \mathrm{~Hz}, 2 \mathrm{H}), 1.60(\mathrm{~m}$, $2 \mathrm{H}), 1.50-1.38(\mathrm{~m}, 2 \mathrm{H}), 1.30-1.27(\mathrm{~m}, 12 \mathrm{H}), 0.88(\mathrm{t}, J=6.7 \mathrm{~Hz}, 3 \mathrm{H})$.

${ }^{13} \mathbf{C}\left\{{ }^{1} \mathbf{H}\right\} \mathbf{N M R}\left(101 \mathrm{MHz}, \mathrm{CDCl}_{3}\right), \delta$ 131.5, 128.2, 127.4, 124.1, 90.5, 80.5, 31.9, 29.6, 29.6, 29.4, 29.2, 29.0, 28.8, 22.7, 19.4, 14.1.

HRMS (APPI) m/z calcd. for $\mathrm{C}_{18} \mathrm{H}_{26}\left([\mathrm{M}+\mathrm{H}]^{+}\right)$: 242.2029; found: 242.2028 .

\section{Prop-1-yne-1,3-diyldibenzene 4f}

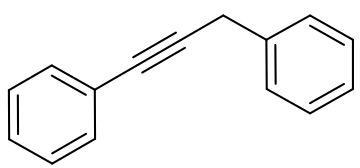

The compound was prepared according to the general procedure A by reaction of iodobenzene $(0.56 \mathrm{~mL}, 5 \mathrm{mmol}), 3$-phenyl-1-propyne $(0.93 \mathrm{~mL}, 7.5 \mathrm{mmol})$, and was isolated by column chromatography (silica gel, $100 \%$ petroleum ether), yielding the title product (445 mg, 46\%) as a yellowish oil. The NMR data match previously reported data for the title product. ${ }^{12}$

${ }^{1} \mathbf{H}$ NMR $\left(400 \mathrm{MHz}, \mathrm{CDCl}_{3}\right), \delta$ 7.47-7.42 (m, 4H), 7.37-7.24 (m, 6H), $3.85(\mathrm{~s}, 2 \mathrm{H})$.

\section{(4-Methyl-1-pentyn-1-yl)benzene 4g}

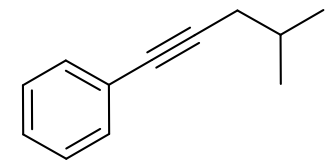

The compound was prepared according to the general procedure $\mathrm{C}$ by reaction of phenylacetylene (2.15 mL, $19.60 \mathrm{mmol}), 1$-iodo-2-methylpropane (3.38 mL, 29.40 mmol), and was isolated by column chromatography (silica gel, 100\% petroleum ether), yielding the title product (130 mg, 4\%) as a colorless oil. The NMR data match previously reported data for the title product. ${ }^{13}$

${ }^{1} \mathbf{H}$ NMR (400 MHz, $\left.\mathrm{CDCl}_{3}\right), \delta$ 7.42-7.39 (m, 2H), 7.29-7.26 (m, 3H), 2.30 (d, J = 6.6 Hz, 2H), 1.96-1.87 (m, 1H), $1.05(\mathrm{~d}, J=6.6 \mathrm{~Hz}, 6 \mathrm{H})$. 


\section{(Cyclohexylethynyl)benzene $4 \mathrm{~h}$}

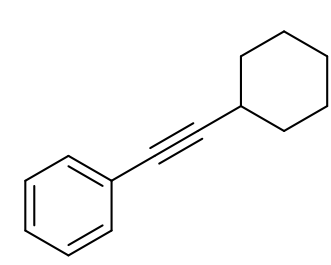

The compound was prepared according to the general procedure A by reaction of iodobenzene $(0.56 \mathrm{~mL}, 5 \mathrm{mmol})$, ethynylcyclohexane $(0.98 \mathrm{~mL}, 7.5 \mathrm{mmol})$, and was isolated by column chromatography (silica gel, $100 \%$ petroleum ether), yielding the title product $(705 \mathrm{mg}, 77 \%)$ as a yellowish oil. The NMR data match previously reported data for the title product. ${ }^{14}$

${ }^{1} \mathbf{H}$ NMR $\left(400 \mathrm{MHz}, \mathrm{CDCl}_{3}\right), \delta$ 7.41-7.38 (m, 2H), 7.30-7.26 (m, 3H), 2.59 (m, 1H), 1.90-1.86 (m, 2H), 1.78-1.73 (m, 2H), 1.57-1.49 (m, 3H), 1.40-1.29 (m, 3H).

${ }^{13} \mathbf{C}\left\{{ }^{1} \mathbf{H}\right\} \mathbf{N M R}\left(101 \mathrm{MHz}, \mathrm{CDCl}_{3}\right), \delta$ 131.8, 128.4, 127.6, 124.4, 94.7, 80.7, 33.0, 29.9, 26.2, 25.2.

\section{1-Methyl-4-(oct-1-yn-1-yl)benzene 4i}

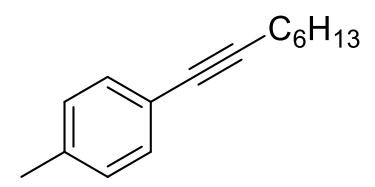

The compound was prepared according to the general procedure A by reaction of 4-iodotoluene (1090 mg, $5 \mathrm{mmol}), 1$-octyne (1.11 mL, $7.5 \mathrm{mmol})$, and was isolated by column chromatography (silica gel, $100 \%$ petroleum ether), yielding the title product (490 mg, 49\%) as a yellowish oil. The NMR data match previously reported data for the title product. ${ }^{11}$

${ }^{1} \mathbf{H}$ NMR $\left(400 \mathrm{MHz}, \mathrm{CDCl}_{3}\right), \delta 7.29(\mathrm{~d}, J=7.8 \mathrm{~Hz}, 2 \mathrm{H}), 7.08(\mathrm{~d}, J=7.8 \mathrm{~Hz}, 2 \mathrm{H}), 2.39(\mathrm{t}, J=7.8 \mathrm{~Hz}, 2 \mathrm{H})$, $2.38(\mathrm{~s}, 3 \mathrm{H}), 1.63-1.57(\mathrm{~m}, 2 \mathrm{H}), 1.48-1.42(\mathrm{~m}, 2 \mathrm{H}), 1.36-1.30(\mathrm{~m}, 4 \mathrm{H}), 0.91(\mathrm{t}, J=6.7 \mathrm{~Hz}, 3 \mathrm{H})$.

\section{1-Methoxy-4-(1-octyn-1-yl)benzene 4j}

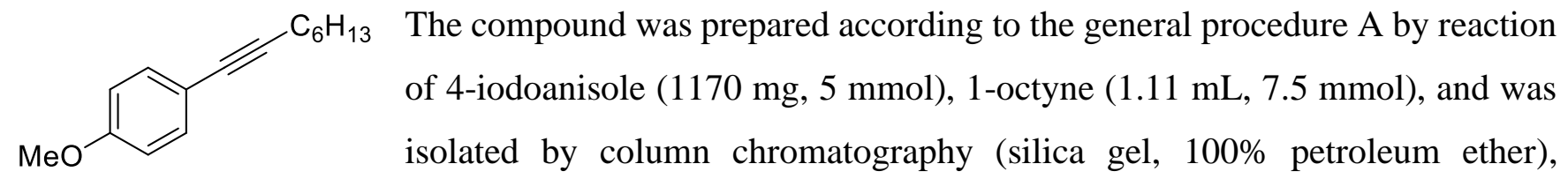
yielding the title product (720 mg, 67\%) as a brown oil. The NMR data match previously reported data for the title product. ${ }^{11}$

${ }^{1} \mathbf{H}$ NMR $\left(400 \mathrm{MHz}, \mathrm{CDCl}_{3}\right), \delta 7.33(\mathrm{~d}, J=8.7 \mathrm{~Hz}, 2 \mathrm{H}), 6.81(\mathrm{~d}, J=8.7 \mathrm{~Hz}, 2 \mathrm{H}), 3.80(\mathrm{~s}, 3 \mathrm{H}), 2.38(\mathrm{t}, J$ $=7.1 \mathrm{~Hz}, 2 \mathrm{H}), 1.63-1.57(\mathrm{~m}, 2 \mathrm{H}), 1.48-1.41(\mathrm{~m}, 2 \mathrm{H}), 1.37-1.31(\mathrm{~m}, 4 \mathrm{H}), 0.90(\mathrm{t}, J=6.8 \mathrm{~Hz}, 3 \mathrm{H})$. 


\section{Methyl(4-(oct-1-yn-1-yl)phenyl)sulfane 4k}

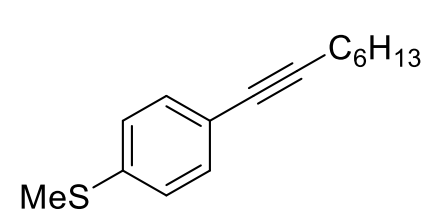

The compound was prepared according to the general procedure $\mathrm{B}$ by reaction of 4-bromothioanisole (1015 mg, $5 \mathrm{mmol}), 1$-octyne (0.74 mL, $5 \mathrm{mmol})$, and was isolated by column chromatography (silica gel, 100\% petroleum ether), yielding the title product (678 $\mathrm{mg}, 58 \%)$ as a yellowish oil.

${ }^{1}$ H NMR (500 MHz, $\left.\mathrm{CDCl}_{3}\right), \delta$ 7.31-7.29 (m, 2H), 7.16-7.13 (m, 2H), $2.47(\mathrm{~s}, 3 \mathrm{H}), 2.39(\mathrm{t}, J=7.1 \mathrm{~Hz}$, 2H), 1.62-1.56 (m, 2H), 1.47-1.41 (m, 2H), 1.35-1.29 (m, 4H), $0.90(\mathrm{t}, J=7.0 \mathrm{~Hz}, 3 \mathrm{H})$.

${ }^{13} \mathbf{C}\left\{{ }^{1} \mathbf{H}\right\}$ NMR $\left(101 \mathrm{MHz}, \mathrm{CDCl}_{3}\right), \delta$ 138.2, 132.0, 126.4, 120.9, 90.7, 80.4, 31.5, 28.9, 28.8, 22.7, 19.6, 15.9, 14.2 .

HRMS (APPI) m/z calcd. For $\mathrm{C}_{15} \mathrm{H}_{20} \mathrm{~S}\left([\mathrm{M}+\mathrm{H}]^{+}\right)$: 232.1280; found: 232.1283.

\section{N-(4-(Oct-1-yn-1-yl)phenyl)acetamide 41}

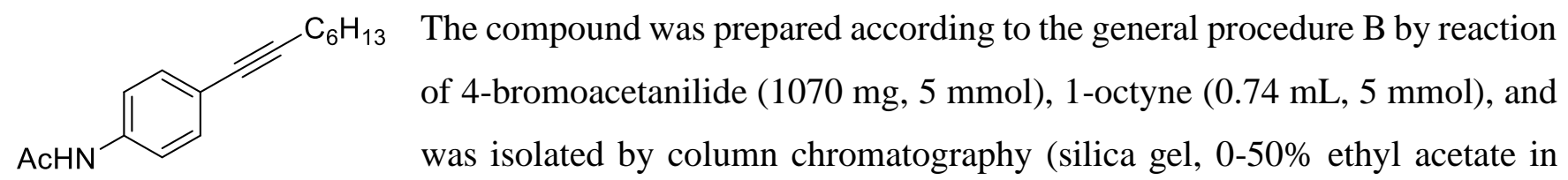
petroleum ether), yielding the title product (50 $\mathrm{mg}, 4 \%)$ as a grey solid.

${ }^{1} \mathbf{H}$ NMR $\left(400 \mathrm{MHz}, \mathrm{CDCl}_{3}\right), \delta 7.43(\mathrm{~d}, J=8.2 \mathrm{~Hz}, 2 \mathrm{H}), 7.34(\mathrm{~d}, J=8.2 \mathrm{~Hz}, 2 \mathrm{H}), 7.11(\mathrm{~s}, 1 \mathrm{H}), 2.37(\mathrm{t}, J$ $=7.1 \mathrm{~Hz}, 2 \mathrm{H}), 2.17(\mathrm{~s}, 3 \mathrm{H}), 1.62-1.55(\mathrm{~m}, 2 \mathrm{H}), 1.47-1.41(\mathrm{~m}, 2 \mathrm{H}), 1.34-1.30(\mathrm{~m}, 4 \mathrm{H}), 0.90(\mathrm{t}, J=6.7 \mathrm{~Hz}$, $3 \mathrm{H})$.

${ }^{13} \mathbf{C}\left\{{ }^{1} \mathbf{H}\right\}$ NMR $\left(101 \mathrm{MHz}, \mathrm{CDCl}_{3}\right), \delta$ 168.2, 137.3, 132.4, 120.0, 119.4, 90.2, 80.3, 31.5, 28.9, 28.8, 24.9, $22.7,19.6,14.2$.

HRMS (APPI) m/z calcd. For $\mathrm{C}_{16} \mathrm{H}_{22} \mathrm{NO}\left([\mathrm{M}+\mathrm{H}]^{+}\right)$: 244.1696; found: 244.1691.

\section{1-fluoro-4-(1-octyn-1-yl)benzene $4 \mathrm{~m}$}

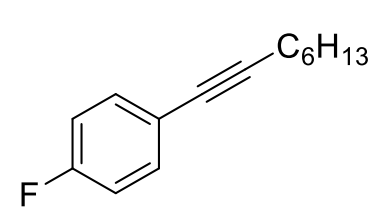

The compound was prepared according to the general procedure A by reaction of 1-fluoro-4-iodobenzene (544 mg, $2.45 \mathrm{mmol})$, 1-octyne (0.5 mL, $3.5 \mathrm{mmol})$, and was isolated by column chromatography (silica gel, 100\% petroleum ether), yielding the title product (260 mg, 52\%) as a yellowish oil. The NMR data match previously reported data for the title product. ${ }^{15}$

${ }^{1} \mathbf{H}$ NMR $\left(400 \mathrm{MHz}, \mathrm{CDCl}_{3}\right) \delta$ 7.44-7.32 (m, 2H), 7.04-6.94 (m, 2H), $2.41(\mathrm{t}, J=7.1 \mathrm{~Hz}, 2 \mathrm{H}), 1.67-1.57$ (m, 2H), 1.51-1.42 (m, 2H), 1.37-1.32 (m, 4H), 0.97-0.87 (m, 3H). 


\section{1-Chloro-4-(1-octyn-1-yl)benzene 4n}

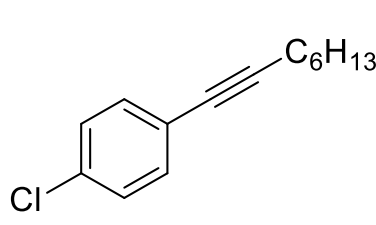

The compound was prepared according to the general procedure A by reaction of 1-chloro-4-iodobenzene (1192 mg, $5 \mathrm{mmol}), 1$-octyne $(1.11 \mathrm{~mL}, 7.5 \mathrm{mmol})$, and was isolated by column chromatography (silica gel, 100\% petroleum ether), yielding the title product (540 mg, 48\%) as a yellowish oil. The NMR data match previously reported data for the title product. ${ }^{15}$

${ }^{1} \mathbf{H}$ NMR $\left(400 \mathrm{MHz}, \mathrm{CDCl}_{3}\right), \delta 7.32(\mathrm{~d}, J=8.4 \mathrm{~Hz}, 2 \mathrm{H}), 7.25(\mathrm{~d}, J=8.4 \mathrm{~Hz}, 2 \mathrm{H}), 2.39(\mathrm{t}, J=7.1 \mathrm{~Hz}, 2 \mathrm{H})$, 1.63-1.56 (m, 2H), 1.48-1.40 (m, 2H), 1.37-1.25 (m, 4H), 0.91 (t, $J=6.9 \mathrm{~Hz}, 3 \mathrm{H})$.

\section{Methyl 4-(oct-1-yn-1-yl)benzoate 4o}

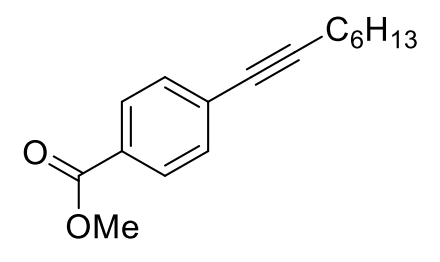

The compound was prepared according to the general procedure B by reaction of methyl 4-bromobenzoate (526 mg, $2.45 \mathrm{mmol})$, 1-octyne (0.4 mL, $2.7 \mathrm{mmol})$, and was isolated by column chromatography (silica gel, 0-50\% ethyl acetate in petroleum ether), yielding the title product $(250 \mathrm{mg}, 42 \%)$ as a yellow solid.

The NMR data match previously reported data for the title product. ${ }^{16}$

${ }^{1} \mathbf{H}$ NMR $\left(400 \mathrm{MHz}, \mathrm{CDCl}_{3}\right) \delta 7.97(\mathrm{~d}, J=8.0 \mathrm{~Hz}, 2 \mathrm{H}), 7.46(\mathrm{~d}, J=8.1 \mathrm{~Hz}, 2 \mathrm{H}), 3.92(\mathrm{~s}, 3 \mathrm{H}), 2.44(\mathrm{t}, J$ $=7.1 \mathrm{~Hz}, 2 \mathrm{H}), 1.69-1.57(\mathrm{~m}, J=14.6,7.4 \mathrm{~Hz}, 2 \mathrm{H}), 1.47(\mathrm{dt}, J=13.9,7.0 \mathrm{~Hz}, 2 \mathrm{H}), 1.34(\mathrm{~d}, J=3.2 \mathrm{~Hz}$, $4 \mathrm{H}), 0.92(\mathrm{t}, J=6.5 \mathrm{~Hz}, 3 \mathrm{H})$.

\section{1-(4-(Oct-1-yn-1-yl)phenyl)ethan-1-one 4p}

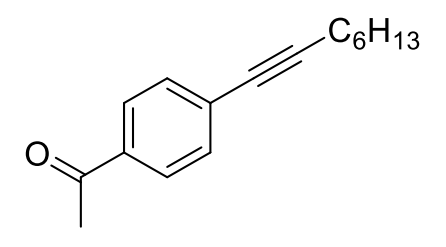

The compound was prepared according to the general procedure $\mathrm{B}$ by reaction of 4'-bromoacetophenone (995 mg, $5 \mathrm{mmol}), 1$-octyne $(0.74 \mathrm{~mL}, 5 \mathrm{mmol})$, and was isolated by column chromatography (silica gel, $0-15 \%$ ethyl acetate in petroleum ether), yielding the title product $(763 \mathrm{mg}, 67 \%)$ as a yellowish oil.

The NMR data match previously reported data for the title product. ${ }^{17}$

${ }^{1} \mathbf{H}$ NMR $\left(400 \mathrm{MHz}, \mathrm{CDCl}_{3}\right), \delta 7.87(\mathrm{~d}, J=8.4 \mathrm{~Hz}, 2 \mathrm{H}), 7.46(\mathrm{~d}, J=8.4 \mathrm{~Hz}, 2 \mathrm{H}), 2.58(\mathrm{~s}, 3 \mathrm{H}), 2.43(\mathrm{t}, J$ $=7.1 \mathrm{~Hz}, 2 \mathrm{H}), 1.65-1.58(\mathrm{~m}, 2 \mathrm{H}), 1.49-1.42(\mathrm{~m}, 2 \mathrm{H}), 1.36-1.30(\mathrm{~m}, 4 \mathrm{H}), 0.90(\mathrm{t}, J=6.7 \mathrm{~Hz}, 3 \mathrm{H})$. 


\section{1-(oct-1-yn-1-yl)-4-(trifluoromethyl)benzene 4q}

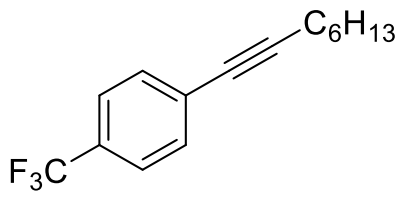

The compound was prepared according to the general procedure A by reaction of 1-trifluoromethyl-4-iodobenzene $(350 \mathrm{~mL}, 2.45 \mathrm{mmol}), 1$-octyne $(0.5 \mathrm{~mL}$, $3.5 \mathrm{mmol}$ ), and was isolated by column chromatography (silica gel, 100\% petroleum ether), yielding the title product (380 mg, 61\%) as a yellowish oil. The NMR data match previously reported data for the title product. ${ }^{18}$

${ }^{1} \mathbf{H}$ NMR $\left(400 \mathrm{MHz}, \mathrm{CDCl}_{3}\right) \delta 7.53(\mathrm{dd}, J=21.2,8.3 \mathrm{~Hz}, 4 \mathrm{H}), 2.45(\mathrm{t}, J=7.1 \mathrm{~Hz}, 2 \mathrm{H}), 1.71-1.22(\mathrm{~m}, 10$ $\mathrm{H}), 0.93(\mathrm{dt}, J=9.2,7.0 \mathrm{~Hz}, 3 \mathrm{H})$.

\section{1-(1-Octyn-1-yl)-3,5-bis(trifluoromethyl)benzene 4r}

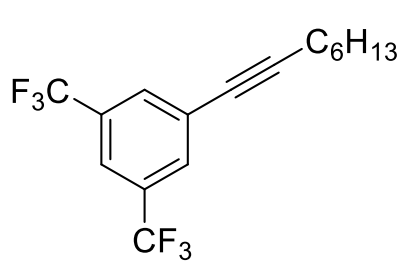

The compound was prepared according to the general procedure $\mathrm{B}$ by reaction of 1,3-bis(trifluoromethyl)-5-bromobenzene (1.47 g, $5 \mathrm{mmol}$ ) and 1-octyne $(0.74 \mathrm{~mL}, 5 \mathrm{mmol})$, and was isolated by column chromatography (silica gel, 0$15 \%$ ethyl acetate in petroleum ether), yielding the title product ( $1.2 \mathrm{~g}, 75 \%)$ as a yellow liquid. The NMR data match previously reported data for the title product. ${ }^{19}$

${ }^{1} \mathbf{H}$ NMR $\left(400 \mathrm{MHz}, \mathrm{CDCl}_{3}\right), \delta 7.81(\mathrm{~s}, 2 \mathrm{H}), 7.74(\mathrm{~s}, 1 \mathrm{H}), 2.43(\mathrm{t}, J=7.1 \mathrm{~Hz}, 2 \mathrm{H}), 1.62$ (quin, $J=7.4 \mathrm{~Hz}$, 2H), 1.49-1.41 (m, 2H), 1.37-1.30 (m, 4H), $0.91(\mathrm{t}, J=6.7 \mathrm{~Hz}, 3 \mathrm{H})$.

\section{1-Methyl-2-(1-octyn-1-yl)benzene 4s}

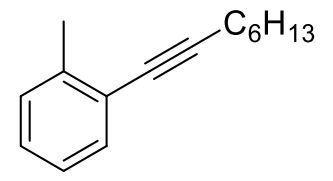

The compound was prepared according to the general procedure A by reaction of $2-$ iodotoluene $(0.64 \mathrm{~mL}, 5 \mathrm{mmol})$ and 1-octyne $(1.11 \mathrm{~mL}, 7.5 \mathrm{mmol})$, , and was isolated by column chromatography (silica gel, $0-15 \%$ ethyl acetate in petroleum ether), yielding the title product (573 mg, 57\%) as a slightly yellow oil. The NMR data match previously reported data for the title product.$^{11}$

${ }^{1} \mathbf{H}$ NMR $\left(400 \mathrm{MHz}, \mathrm{CDCl}_{3}\right), \delta 7.36(\mathrm{~d}, J=7.3 \mathrm{~Hz}, 1 \mathrm{H}), 7.17-7.08(\mathrm{~m}, 3 \mathrm{H}), 2.45(\mathrm{t}, J=7.0 \mathrm{~Hz}, 2 \mathrm{H}), 2.42$ (s, 3H), 1.66-1.58 (m, 2H), 1.53-1.44 (m, 2H), 1.34-1.27 (m, 4H), $0.91(\mathrm{t}, J=6.7 \mathrm{~Hz}, 3 \mathrm{H})$. 


\section{2-(1-Octyn-1-yl)naphthalene $4 t$}

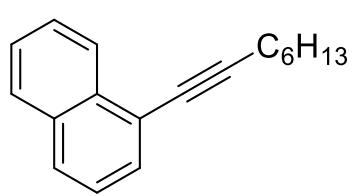

The compound was prepared according to the general procedure B by reaction of 1-bromonaphthalene (623 mg, $2.45 \mathrm{mmol})$, 1-octyne $(0.4 \mathrm{~mL}, 2.6 \mathrm{mmol})$, and was isolated by column chromatography (silica gel, $100 \%$ ethyl acetate in petroleum ether), yielding the title product $(215 \mathrm{mg}, 37 \%)$ as a yellowish oil. The NMR data match previously reported data for the title product. ${ }^{20}$

${ }^{1} \mathbf{H}$ NMR $\left(400 \mathrm{MHz}, \mathrm{CDCl}_{3}\right) \delta 8.37(\mathrm{~d}, J=8.3 \mathrm{~Hz}, 1 \mathrm{H}), 7.86(\mathrm{~d}, J=7.5 \mathrm{~Hz}, 1 \mathrm{H}), 7.80(\mathrm{~d}, J=8.3 \mathrm{~Hz}, 1 \mathrm{H})$, $7.64(\mathrm{dd}, J=7.1,0.8 \mathrm{~Hz}, 1 \mathrm{H}), 7.61-7.49(\mathrm{~m}, 2 \mathrm{H}), 7.42(\mathrm{dd}, J=8.2,7.2 \mathrm{~Hz}, 1 \mathrm{H}), 2.60(\mathrm{t}, J=7.1 \mathrm{~Hz}, 2 \mathrm{H})$, $1.74(\mathrm{dt}, J=19.7,7.2 \mathrm{~Hz}, 2 \mathrm{H}), 1.64-1.51(\mathrm{~m}, 2 \mathrm{H}), 1.45-1.35(\mathrm{~m}, 4 \mathrm{H}), 1.00-0.93(\mathrm{~m}, 3 \mathrm{H})$.

\section{2-(1-Octyn-1-yl)naphthalene $4 u$}

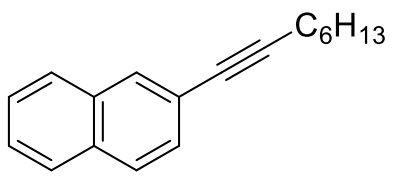

The compound was prepared according to the general procedure B by reaction of 2-bromonaphthalene (1.04 g, $5 \mathrm{mmol}), 1$-octyne $(0.74 \mathrm{~mL}, 5 \mathrm{mmol})$, and was isolated by column chromatography (silica gel, 100\% ethyl acetate in petroleum ether), yielding the title product $(351 \mathrm{mg}, 30 \%)$ as a yellowish oil.

${ }^{1} \mathbf{H}$ NMR $\left(400 \mathrm{MHz}, \mathrm{CDCl}_{3}\right), \delta 7.91(\mathrm{~s}, 1 \mathrm{H}), 7.80-7.74(\mathrm{~m}, 3 \mathrm{H}), 7.48-7.44(\mathrm{~m}, 3 \mathrm{H}), 2.46(\mathrm{t}, J=7.1 \mathrm{~Hz}$, 2H), 1.65 (quin, $J=7.5 \mathrm{~Hz}, 2 \mathrm{H}), 1.52-1.46(\mathrm{~m}, 2 \mathrm{H}), 1.37-1.29(\mathrm{~m}, 4 \mathrm{H}), 0.92$ (t, $J=6.7 \mathrm{~Hz}, 3 \mathrm{H})$.

${ }^{13} \mathbf{C}\left\{{ }^{1} \mathbf{H}\right\}$ NMR $\left(101 \mathrm{MHz}, \mathrm{CDCl}_{3}\right), \delta 133.19,132.57,131.12,128.89,127.91,127.82,127.70,126.47$, $126.34,121.56,91.06,81.02,31.55,28.93,28.82,22.74,19.69,14.25$.

HRMS (APPI) m/z calcd. for $\mathrm{C}_{18} \mathrm{H}_{20}\left([\mathrm{M}]^{+}\right)$: 236.1559; found: 236.1560 .

\section{tert-Butyl 5-(oct-1-yn-1-yl)-1H-indole-1-carboxylate $4 \mathrm{v}$}

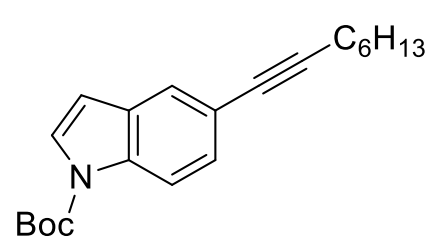

tert-Butyl 5-bromo-1H-indole-1-carboxylate: The compound was prepared following the literature procedure ${ }^{21}$ : To a solution of 5-bromoindole $(0.79 \mathrm{~g}$, $4 \mathrm{mmol})$ in dichloromethane $(4 \mathrm{~mL})$, triethylamine $(0.66 \mathrm{~mL}, 1.2$ equiv. $)$ and 4-dimethylaminopyridine (48 mg, 0.1 equiv.) were added. The mixture was allowed to stir at room temperature until the materials were completely dissolved. A solution of $\mathrm{Boc}_{2} \mathrm{O}$ (0.37 mL, 2.4 equiv.) in dichloromethane $(1 \mathrm{~mL})$ was added. The reaction mixture was allowed to stir at room temperature for $20 \mathrm{~h}$. A saturated aqueous solution of $\mathrm{NH}_{4} \mathrm{Cl}(10 \mathrm{~mL})$ and dichloromethane $(10 \mathrm{~mL})$ were added. The organic layer was washed with water $(10 \mathrm{~mL})$ and brine $(10 \mathrm{~mL})$, and then dried over $\mathrm{MgSO}_{4}$. After filtration, the volatile material from the filtrate was evaporated under reduced pressure. The 
residue was subjected to column chromatography on silica gel, with a mixture of $0-10 \%$ ethyl acetate in petroleum ether as the eluent. Fractions containing the pure product were combined, and the solvent was evaporated, affording tert-butyl 5-bromo-1H-indole-1-carboxylate.

The title compound: The compound was prepared according to the general procedure B by reaction of synthesized tert-butyl 5-bromo-1H-indole-1-carboxylate (700 mg, $2.50 \mathrm{mmol}), 1$-octyne $(0.37 \mathrm{~mL}, 2.50$ $\mathrm{mmol}$ ), and was isolated by column chromatography (silica gel, 0-10\% ethyl acetate in petroleum ether), yielding the title product (160 mg, 20\%) as a yellowish oil.

${ }^{1} \mathbf{H}$ NMR $\left(400 \mathrm{MHz}, \mathrm{CDCl}_{3}\right), \delta$ 8.05-8.01 (m, 1H), $7.61(\mathrm{~s}, 1 \mathrm{H}), 7.59-7.57(\mathrm{~m}, 1 \mathrm{H})$, 7.36-7.32 (m, 1H), 6.51-6.50 (m, 1H), $2.42(\mathrm{t}, J=7.1 \mathrm{~Hz}, 2 \mathrm{H}), 1.67(\mathrm{~s}, 9 \mathrm{H}), 1.64-1.59(\mathrm{~m}, 2 \mathrm{H}), 1.51-1.41(\mathrm{~m}, 2 \mathrm{H}), 1.37-1.29$ $(\mathrm{m}, 4 \mathrm{H}), 0.91(\mathrm{t}, J=6.8 \mathrm{~Hz}, 3 \mathrm{H})$.

${ }^{13} \mathbf{C}\left\{{ }^{1} \mathbf{H}\right\}$ NMR $\left(101 \mathrm{MHz}, \mathrm{CDCl}_{3}\right), \delta 149.7,130.6,127.9,126.7,124.3,118.4,115.1,107.2,89.04,84.0$, 81.1, 31.6, 29.0, 28.8, 28.3, 28.0, 22.7, 19.6, 14.3 .

HRMS (APPI) m/z calcd. for $\mathrm{C}_{21} \mathrm{H}_{28} \mathrm{NO}_{2}\left([\mathrm{M}+\mathrm{H}]^{+}\right)$: 326.2115; found: 326.2108 .

\section{5-(Oct-1-yn-1-yl)benzo[b]thiophene 4w}

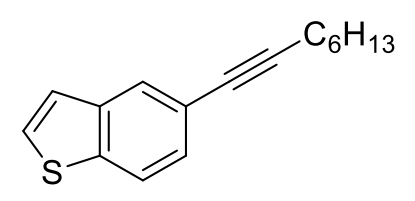

The compound was prepared according to the general procedure B by reaction of 5-bromobenzo[b]thiophene $(1.07 \mathrm{~g}, 5 \mathrm{mmol}), 1$-octyne $(0.74 \mathrm{~mL}, 5 \mathrm{mmol})$, and was isolated by column chromatography (silica gel, 100\% in petroleum ether), yielding the title product (594 $\mathrm{mg}, 49 \%$ ) as a yellowish oil.

${ }^{1} \mathbf{H}$ NMR $\left(500 \mathrm{MHz}, \mathrm{CDCl}_{3}\right), \delta 7.87(\mathrm{~d}, J=1.1 \mathrm{~Hz}, 1 \mathrm{H}), 7.78(\mathrm{~d}, J=8.3 \mathrm{~Hz}, 1 \mathrm{H}), 7.44(\mathrm{~d}, J=5.4 \mathrm{~Hz}$, $1 \mathrm{H}), 7.36(\mathrm{dd}, J=8.3,1.5 \mathrm{~Hz}, 1 \mathrm{H}), 7.28(\mathrm{dd}, J=5.4,0.6 \mathrm{~Hz}, 1 \mathrm{H}), 2.43(\mathrm{t}, J=7.1 \mathrm{~Hz}, 2 \mathrm{H}), 1.63$ (quin, $J$ $=7.3 \mathrm{~Hz}, 2 \mathrm{H}), 1.51-1.45(\mathrm{~m}, 2 \mathrm{H}), 1.38-1.28(\mathrm{~m}, 4 \mathrm{H}), 0.92(\mathrm{t}, J=6.7 \mathrm{~Hz}, 3 \mathrm{H})$.

${ }^{13} \mathbf{C}\left\{{ }^{1} \mathbf{H}\right\}$ NMR $\left(101 \mathrm{MHz}, \mathrm{CDCl}_{3}\right), \delta$ 139.7, 139.0, 127.6, 127.2, 126.8, 123.8, 122.4, 120.2, 90.1, 80.8, 31.6, 28.9, 28.8, 22.7, 19.6, 14.2.

HRMS (APPI) m/z calcd. for $\mathrm{C}_{16} \mathrm{H}_{18} \mathrm{~S}\left([\mathrm{M}]^{+}\right)$: 246.1123; found: 246.1124 .

\section{5-(Oct-1-yn-1-yl)benzofuran 4x}

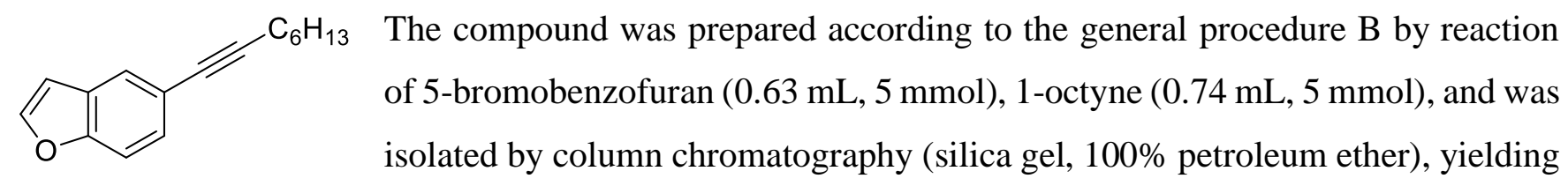
the title product (454 mg, 40\%) as a yellowish oil. 
${ }^{1} \mathbf{H}$ NMR $\left(500 \mathrm{MHz}, \mathrm{CDCl}_{3}\right), \delta 7.65(\mathrm{~d}, J=1.4 \mathrm{~Hz}, 1 \mathrm{H}), 7.61(\mathrm{~d}, J=2.2 \mathrm{~Hz}, 1 \mathrm{H}), 7.41(\mathrm{~d}, J=8.5 \mathrm{~Hz}$, $1 \mathrm{H}), 7.34(\mathrm{dd}, J=8.5 \mathrm{~Hz}, 1.6 \mathrm{~Hz}, 1 \mathrm{H}), 6.72(\mathrm{dd}, J=2.2,0.9 \mathrm{~Hz}, 1 \mathrm{H}), 2.42(\mathrm{t}, J=7.1 \mathrm{~Hz}, 2 \mathrm{H}), 1.62$ (quin, $J=7.3 \mathrm{~Hz}, 2 \mathrm{H}), 1.50-1.44(\mathrm{~m}, 2 \mathrm{H}), 1.36-1.32(\mathrm{~m}, 4 \mathrm{H}), 0.91(\mathrm{t}, J=6.7 \mathrm{~Hz}, 3 \mathrm{H})$.

${ }^{13} \mathbf{C}\left\{{ }^{1} \mathbf{H}\right\}$ NMR $\left(101 \mathrm{MHz}, \mathrm{CDCl}_{3}\right), \delta$ 154.3, 145.7, 128.1, 127.6, 124.6, 118.8, 111.4, 106.6, 89.0, 80.8, 31.6, 29.0, 28.8, 22.7, 19.6, 14.2.

HRMS (APPI) m/z calcd. for $\mathrm{C}_{16} \mathrm{H}_{18} \mathrm{O}\left([\mathrm{M}]^{+}\right)$: 226.1352; found: 226.1351.

\section{3-(Oct-1-yn-1-yl)furan $4 y$}

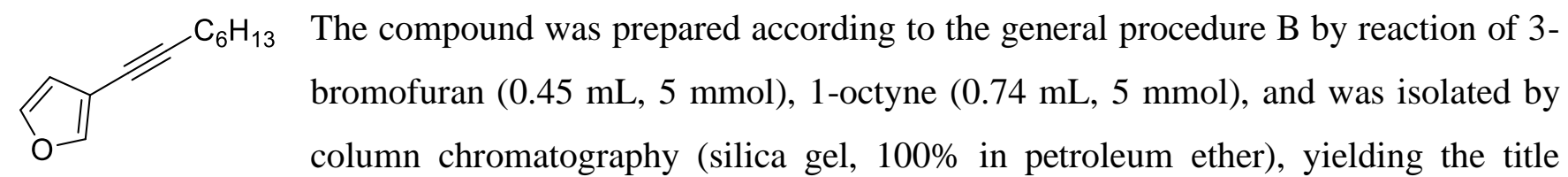
product $(50 \mathrm{mg}, 5 \%)$ as a yellowish oil. The NMR data match previously reported data for the title product. $^{22}$

${ }^{1}$ H NMR (400 MHz, CDCl $), \delta 7.54(\mathrm{~s}, 1 \mathrm{H}), 7.33$ (t, $\left.J=1.65 \mathrm{~Hz}, 1 \mathrm{H}\right), 6.40-6.39$ (dd, $J=1.65 \mathrm{~Hz}, 1.1 \mathrm{~Hz}$, $1 \mathrm{H}), 2.36(\mathrm{t}, J=7.1 \mathrm{~Hz}, 2 \mathrm{H}), 1.61-1.54(\mathrm{~m}, 2 \mathrm{H}), 1.46-1.39(\mathrm{~m}, 2 \mathrm{H}), 1.32-1.25(\mathrm{~m}, 4 \mathrm{H}), 0.90(\mathrm{t}, J=6.9$ $\mathrm{Hz}, 3 \mathrm{H})$. 


\section{Evaluation of reaction parameters}

\subsection{Evaluation of palladium sources - hydroformylation of alkenes}

Table S1.

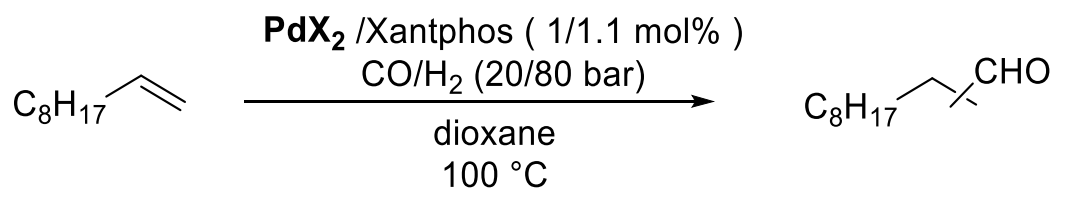

\begin{tabular}{ccc}
\hline Entry & $\mathbf{P d X}_{2}$ & ${\text { Yield }(\boldsymbol{n} / \boldsymbol{i}) \%^{\mathbf{a}}}^{\mathbf{2}}$ \\
\hline 1 & $\mathrm{Pd}(\mathrm{OAc})_{2}$ & 0 \\
2 & $\mathrm{Pd}(\mathrm{TFA})_{2}$ & 0 \\
3 & $\mathrm{Pd}(\mathrm{acac})_{2}$ & 0 \\
4 & ${\mathrm{Pd}(\mathrm{OTf})_{2}}_{2}$ & 0 \\
5 & ${\mathrm{Pd}\left(\mathrm{BF}_{4}\right)_{2}\left(\mathrm{CH}_{3} \mathrm{CN}\right)_{2}}_{2}$ & $11(90 / 10)$ \\
7 & $\mathrm{PdCl}_{2}$ & $25(73 / 27)$ \\
8 & $\mathrm{PdBr}_{2}$ & $99(58 / 42)$ \\
\hline
\end{tabular}

a) Conditions: $0.5 \mathrm{mmol}$ of 1-decene, $1.0 \mathrm{~mol} \% \mathrm{PdX}_{2}, 1.1 \mathrm{~mol} \%$ xantphos, $\mathrm{CO} / \mathrm{H}_{2}(20 / 80 \mathrm{bar}), 1 \mathrm{~mL}$ dioxane, $100{ }^{\circ} \mathrm{C}, 16$ h. Yields and the $n / i$ ratios in parentheses were determined by analysis of ${ }^{1} \mathrm{H}$ NMR spectra or GCMS/GC-FID traces using 1,4-dimethoxylbenzene as an internal standard. 


\subsection{Evaluation of solvents - hydroformylation of alkenes}

Table S2.

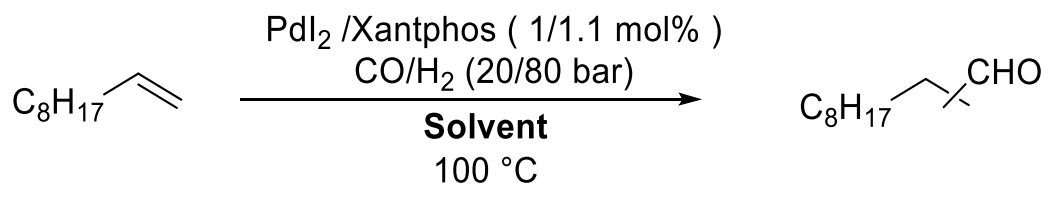

\begin{tabular}{ccc}
\hline Entry & Solvent & Yield $(\mathbf{n} / \mathbf{i}) \boldsymbol{\%}^{\mathbf{a}}$ \\
\hline 1 & DCM & $43(33 / 67)$ \\
2 & Toluene & $41(50 / 50)$ \\
3 & THF & $16(71 / 29)$ \\
4 & Ethyl ether & $90(47 / 53)$ \\
5 & ACN & trace \\
6 & Hexane & $29(50 / 50)$ \\
7 & $1,4-$ Dioxane & $99(58 / 42)$ \\
\hline a) Conditions: 0.5 mmol of 1-decene, 1.0 mol\% PdI $2,1.1$ mol\% xantphos, 100 bar CO/H $\mathrm{H}_{2}(20 / 80), 1 \mathrm{~mL}$ solvent, $100{ }^{\circ} \mathrm{C}, 16$ \\
h. Yields and the $n / i$ ratios in parentheses were determined by analysis of ${ }^{1} \mathrm{H}$ NMR spectra or GCMS/GC-FID traces using \\
1,4-dimethoxylbenzene as an internal standard.
\end{tabular}




\subsection{Evaluation of ligands - hydroformylation of alkenes}

Table S3.

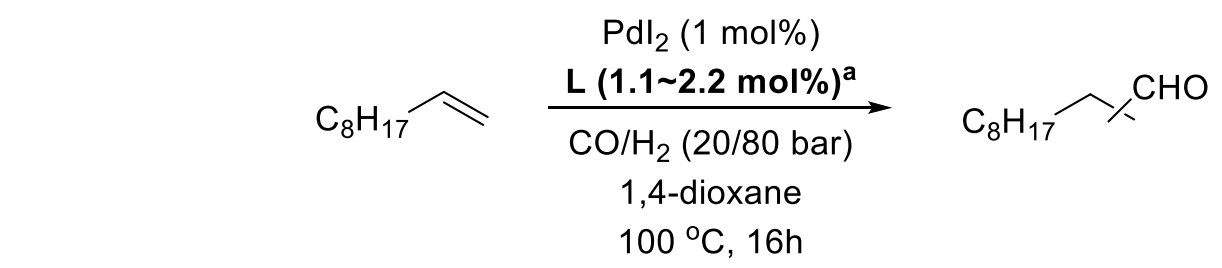<smiles>CC1(C)c2cccc(-c3ccccc3)c2Oc2c(-c3ccccc3)cccc21</smiles>

$\mathrm{L}_{1} 100 \%(58 / 42)$<smiles>c1ccc(-c2ccc3ccccc3c2-c2c(P(c3ccccc3)c3ccccc3)ccc3ccccc23)cc1</smiles>

Rac $\mathrm{L}_{6} 21 \%(82 / 18)$

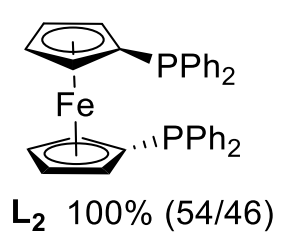<smiles>c1ccc(PCc2ccccc2-c2ccccc2-c2ccccc2Pc2ccccc2)cc1</smiles>

$\mathrm{L}_{7} 25 \%(64 / 36)$<smiles>CC(CCCPc1ccccc1)Cc1ccccc1</smiles><smiles>CC(C)(C)[Pb]1Cc2ccccc2CP1[15NH2]</smiles>

$\mathbf{L}_{\mathbf{8}}$ trace<smiles>Pc1ccccc1P(c1ccccc1)c1ccccc1</smiles>

$\mathrm{L}_{5} \quad 95 \%(58 / 42)$<smiles>Pc1ccccc1P</smiles>

$\mathrm{L}_{9} 13 \%(43 / 57)$

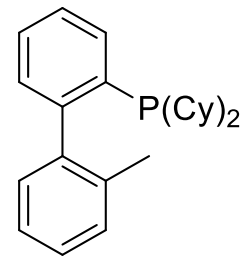

$\mathrm{L}_{10} 30 \%(39 / 61)$

$$
\begin{aligned}
& \mathrm{PR}_{3}\left(\mathrm{~L}_{11}-\mathrm{L}_{15}\right) \\
& L_{11} R=\text { phenyl, 93\% (49/51) } \\
& \mathrm{L}_{12} \mathrm{R}=\text { 2-methoxyl-phenyl, trace } \\
& \mathrm{L}_{13} \mathrm{R}=3 \text {,5-bis(trifluoromethyl)phenyl, trace } \\
& \mathrm{L}_{14} \mathrm{R}=\text { cyclohexyl, 34\% (40/60) } \\
& \mathrm{L}_{15} \mathrm{R}=\text { phenoxyl, trace }
\end{aligned}
$$

Conditions: $0.5 \mathrm{mmol}$ of 1-decene, $1.0 \mathrm{~mol} \% \mathrm{PdI}_{2}, 1.1 \mathrm{~mol} \% \mathrm{~L}_{1}-\mathrm{L}_{10}\left(2.2 \mathrm{~mol} \%\right.$ for $\left.\mathrm{L}_{11}-\mathrm{L}_{15}\right)$, CO/ $\mathrm{H}_{2}(20 / 80 \mathrm{bar}), 1 \mathrm{~mL} 1,4-$ dioxane, $100{ }^{\circ} \mathrm{C}, 16 \mathrm{~h}$. Yields and the $n / i$ ratios in parentheses were determined by analysis of ${ }^{1} \mathrm{H}$ NMR spectra or GCMS/GCFID traces using 1,4-dimethoxylbenzene as an internal standard. 


\subsection{Evaluation of ratios of palladium source, ligand, or additives}

Table S4.

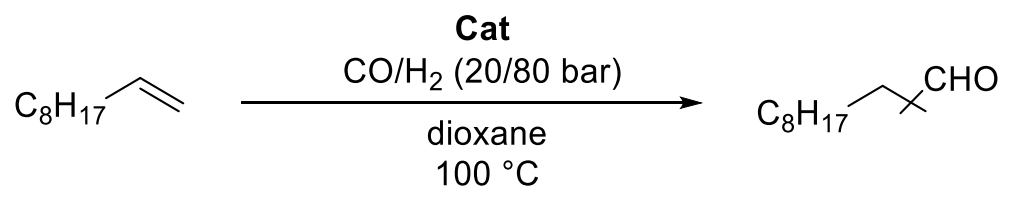

\begin{tabular}{|c|c|c|}
\hline Entry & Cat. $(\mathrm{mol} \%)$ & Yield $\%^{a}$ \\
\hline 1 & $\mathrm{PdI}_{2}(0.5)+$ xantphos $(0.25)$ & 78 \\
\hline 2 & $\mathrm{PdI}_{2}(0.5)+$ xantphos $(0.4)$ & 99 \\
\hline 3 & $\mathrm{PdI}_{2}(0.5)+$ xantphos $(0.5)$ & 80 \\
\hline 4 & $\mathrm{PdI}_{2}(0.5)+$ xantphos $(0.6)$ & 11 \\
\hline 5 & xantphos-PdI $2(0.5)$ & 80 \\
\hline 6 & xantphos-PdI $2(0.5)+\mathrm{PdI}_{2}(0.5)$ & 61 \\
\hline 7 & xantphos $-\mathrm{PdI}_{2}(0.5)+\mathrm{PdCl}_{2}(0.5)$ & 54 \\
\hline 8 & xantphos-PdI $2(0.5)+\mathrm{Pd}(\mathrm{OAc})_{2}(0.5)$ & 49 \\
\hline 9 & xantphos-PdI $2(0.5)+\mathrm{Pd}_{2}(\mathrm{dba})_{3}(0.5)$ & 32 \\
\hline 10 & xantphos-PdI $2(0.5)+$ xantphos $(0.5)$ & 12 \\
\hline 11 & xantphos-PdI $2(0.5)+$ TBAI $(0.5)$ & 70 \\
\hline
\end{tabular}

a) Conditions: $0.5 \mathrm{mmol}$ of 1-decene, $\mathrm{CO} / \mathrm{H}_{2}$ (20/80 bar), $1 \mathrm{~mL}$ 1,4-dioxane, $100{ }^{\circ} \mathrm{C}, 16 \mathrm{~h}$. Yields were determined by analysis of ${ }^{1} \mathrm{H}$ NMR spectra or GCMS/GC-FID traces using 1,4-dimethoxylbenzene as an internal standard. 


\subsection{Evaluation of pressure and solvent - different substrates}

Table S5.

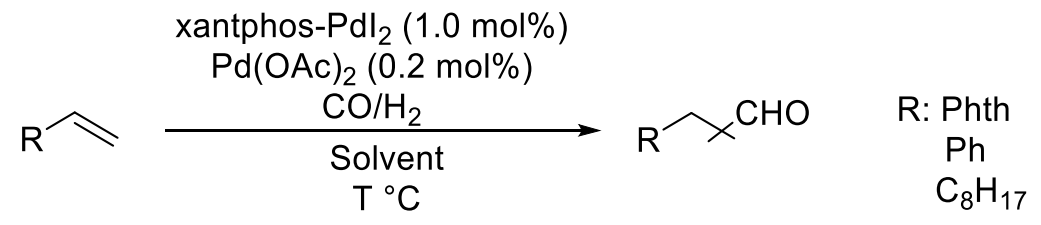

\begin{tabular}{|c|c|c|c|c|}
\hline $\mathrm{R}(\mathrm{mmol} / \mathrm{mL})$ & $\mathrm{CO} / \mathrm{H}_{2}$ (bar) & Solvent & Temp. ${ }^{\circ} \mathrm{C}$ & Aldehyde $(n / i) \%^{a}$ \\
\hline $\mathrm{C}_{8} \mathrm{H}_{17}(0.5)$ & $20 / 80$ & Dioxane & 100 & $99(45 / 55)$ \\
\hline $\mathrm{C}_{8} \mathrm{H}_{17}(0.25)$ & $20 / 80$ & Toluene & 70 & $99(45 / 55)$ \\
\hline $\mathrm{C}_{8} \mathrm{H}_{17}(0.125)$ & $20 / 80$ & Toluene & 70 & $99(45 / 55)$ \\
\hline $\mathrm{C}_{8} \mathrm{H}_{17}(0.125)$ & $20 / 60$ & Toluene & 70 & $99(48 / 52)$ \\
\hline $\mathrm{C}_{8} \mathrm{H}_{17}(0.25)$ & $15 / 15$ & Toluene & 70 & $72(54 / 46)$ \\
\hline $\mathrm{Ph}(0.125)$ & $20 / 80$ & Toluene & 70 & $99(78 / 22)$ \\
\hline $\mathrm{Ph}(0.125)$ & $15 / 15$ & Toluene & 70 & $70(72 / 27)$ \\
\hline $\mathrm{Ph}(0.125)$ & $15 / 15$ & $\mathrm{CH}_{2} \mathrm{Cl}_{2}$ & 70 & $99(82 / 18)$ \\
\hline $\mathrm{Ph}(0.125)$ & $5 / 5$ & Toluene & 70 & $70(80 / 20)$ \\
\hline $\mathrm{Ph}(0.125)$ & $5 / 5$ & $\mathrm{CH}_{2} \mathrm{Cl}_{2}$ & 70 & $56(80 / 20)$ \\
\hline $\mathrm{Ph}(0.125)$ & $0.5 / 0.5$ & $\mathrm{CH}_{2} \mathrm{Cl}_{2}$ & 70 & $9(-/-)$ \\
\hline Phth (0.125) & $15 / 15$ & DCM & 70 & $99(95 / 5)$ \\
\hline Phth (0.125) & $5 / 5$ & DCM & 70 & $99(95 / 5)$ \\
\hline Phth (0.125) & $0.5 / 0.5$ & $\mathrm{CH}_{2} \mathrm{Cl}_{2}$ & 70 & $27(99 / 1)$ \\
\hline
\end{tabular}

a) Conditions: $16 \mathrm{~h}$; Yields and the $n / i$ ratios in parentheses were determined by analysis of ${ }^{1} \mathrm{H}$ NMR spectra or GCMS/GCFID traces using 1,4-dimethoxylbenzene as an internal standard. 


\subsection{Evaluation of palladium sources and additives - hydroformylation of alkynes}

Table S6.

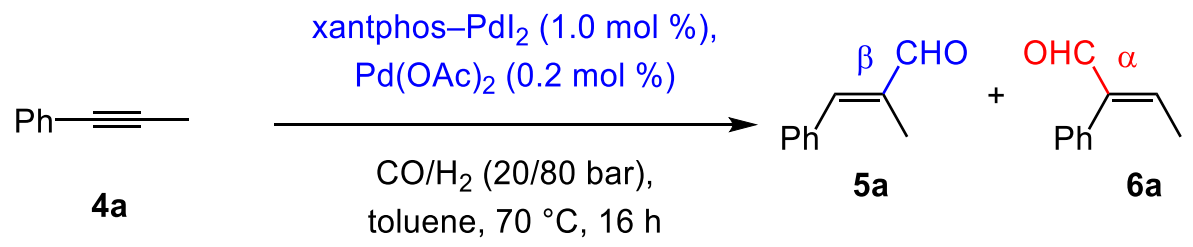

\begin{tabular}{|c|c|c|}
\hline Entry & Variation of conditions & Yield (5a :3a)\% \\
\hline 1 & none & $96 \%(95: 5)$ \\
\hline 2 & xantphos-Pd(AcO $)_{2}$ & $<2 \%$ \\
\hline 3 & xantphos-Pd(acac $)_{2}$ & $<2 \%$ \\
\hline 4 & xantphos $-\mathrm{Pd}\left(\mathrm{BF}_{4}\right)_{2}$ & $<2 \%$ \\
\hline 5 & xantphos-PdCl 2 & $<2 \%$ \\
\hline 6 & xantphos $-\mathrm{PdBr}_{2}$ & $<2 \%$ \\
\hline 7 & no $\mathrm{Pd}(\mathrm{OAc})_{2}$ & $<2 \%$ \\
\hline 8 & $2 \mathrm{~mol} \%$ p-TsOH$* \mathrm{H}_{2} \mathrm{O}$, no $\mathrm{Pd}(\mathrm{OAc})_{2}$ & $\begin{array}{c}40 \%(95: 5) \\
+29 \% \text { mixture of side-products }\end{array}$ \\
\hline 9 & $\begin{array}{c}\text { xantphos-Pd(acac })_{2} \\
2 \mathrm{~mol} \% \text { p-TsOH* } \mathrm{H}_{2} \mathrm{O}, \text { no } \mathrm{Pd}(\mathrm{OAc})_{2}\end{array}$ & $14 \%(68: 32)$ \\
\hline
\end{tabular}

Reactions with $0.125 \mathrm{mM}$ alkyne. Conversion, yield, and (5a:6a) regioselectivity determined by analysis of ${ }^{1} \mathrm{H}$ NMR spectra or GCMS/GC-FID traces using 1,4-dimethoxylbenzene as an internal standard. 


\subsection{Evaluation of other carbonylation reactions - alkoxy-, amino-, and thiocarbonylation of alkenes}

a. Alkoxycarbonylation of alkenes

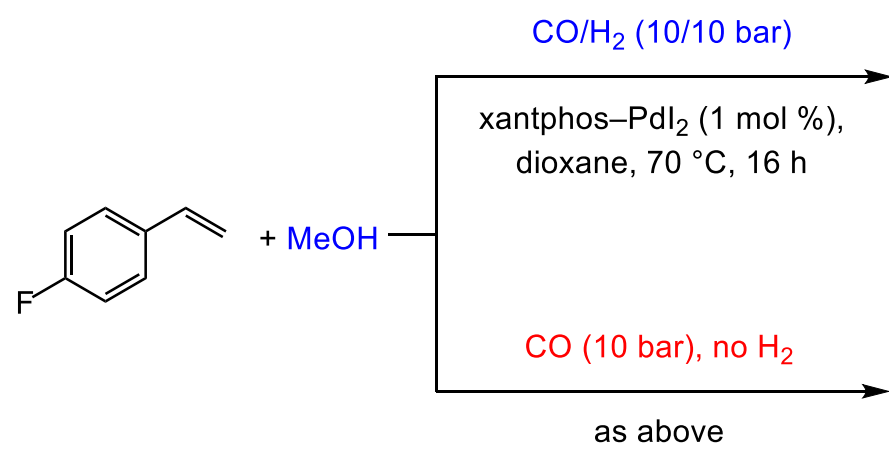

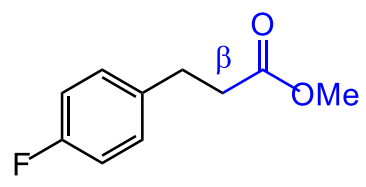

$99 \%$ yield, $88: 12 \beta: \alpha$

no reaction

Hydrogen is critical for catalytic activity in the absence of Brønsted acid.

b. Amino- or thiocarbonylation of alkenes<smiles>N[Pb]=Cc1ccc(F)cc1</smiles><smiles>N[Pb]=C[I+]c1ccccc1</smiles><smiles>C=Cc1ccc(F)cc1</smiles><smiles>C=C[PH2+]C=[C+][AsH2]</smiles>

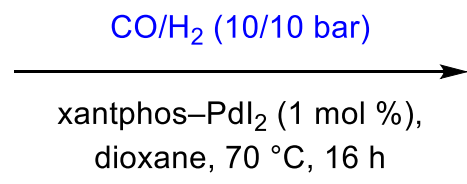

as above

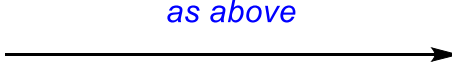

as above

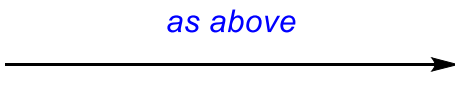

as above<smiles>[B]C(=O)CCc1ccc(F)cc1</smiles>

$98 \%$ yield, $85: 15 \beta: \alpha$<smiles></smiles>
$98 \%$ yield, $87: 13 \beta: \alpha$<smiles>O=C([Hg])CCc1ccc(F)cc1</smiles>
$99 \%$ yield, $88: 12 \beta: \alpha$<smiles>O=C([Hg])CC[18O]</smiles>

$99 \%$ yield, $84: 16 \beta: \alpha$

Highest reported to date yields and selectivities for these transformations.

Fig. S1 Alkoxy-, amino-, and thiocarbonylation of alkenes in the presence of xantphos-PdI $I_{2}$ and syngas. 


\section{General procedure for Pd-catalyzed hydroformylation of alkenes and alkynes}

CAUTION: Syngas and CO are highly TOXIC and flammable. Therefore, all manipulations with syngas and CO should be performed with great care in a well-ventilated fume hood. The use of a personal detector of $\mathrm{CO}$ is highly advised.

Under nitrogen atmosphere, a $2 \mathrm{~mL}$ oven-dried vial was charged with a Teflon-coated magnetic string bar and a clear deep-red stock solution of xantphos $-P d I_{2}(0.0025 \mathrm{mmol}, 1 \mathrm{~mol} \%)$ and $P d(O A c)_{2}(0.0005$ mmol, 0.2 mol\%) in $2 \mathrm{~mL}$ of toluene. (The higher catalyst loading was used in case of less reactive substrates). An olefin or alkyne $(0.25 \mathrm{mmol})$ was added into the mixture. The vial was closed with a cap containing a Teflon-coated septum, which was then punctured with a needle (the tip of the needle should not be in contact with the reaction mixture). The charged vial was placed into a 300-mL stainless steel Parr autoclave, charged with an insert suitable for 12 reaction vials for conducting parallel reactions, and equipped with a heating mantel, temperature controller and an internal thermocouple, enabling to maintain the internal temperature of the autoclave as required. Before starting the catalytic reactions, the charged autoclave was purged three times with 40 bar of syngas and then pressurized subsequently with 40 bar syngas and 60 bar dihydrogen. Then the reaction mixture was allowed to stir (800 rpm) at the indicated temperature, typically 70 or $100{ }^{\circ} \mathrm{C}$, for indicated time, typically $18 \mathrm{~h}$. Upon cooling to room temperature, the pressure was released, the autoclave was opened, the solution of an internal standard (1,3,5-trimethoxybenzene) was added to the reaction mixture. The conversion, yield, and regioselectivity were measured by GC-FID or ${ }^{1} H$-NMR. After removing the volatiles under reduced pressure, the aldehyde product was isolated by column chromatography on silica gel.

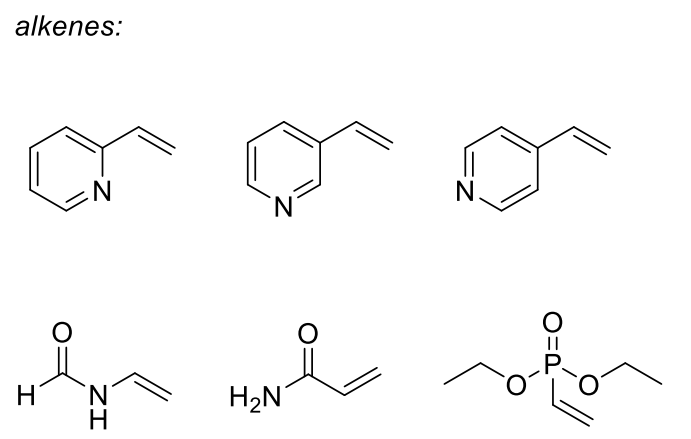

alkynes:

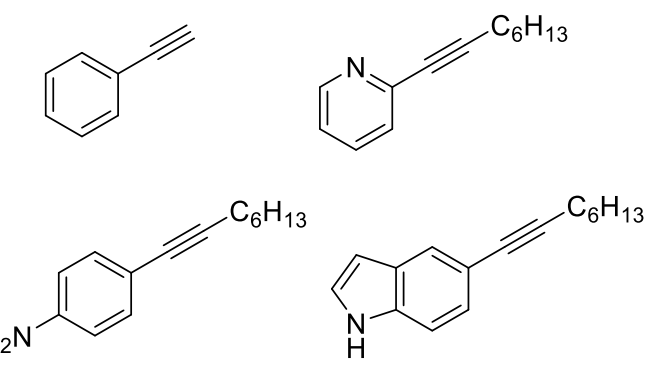

Chart S1 Examples of alkene and alkyne starting materials that did no yield aldehyde products in appreciable amounts under conditions described above. 


\section{Characterization of the aldehyde products}

\section{3-Phenylpropanal ( $\beta$ ) and 2-phenylpropanal ( $\alpha)$ 2a}<smiles>CC(C)Cc1ccccc1</smiles>

The compound was prepared according to the general procedure by reaction of styrene $(0.057 \mathrm{~mL}, 0.25 \mathrm{mmol})$ and was isolated by column chromatography (silica gel, 0-20\%

$\mathrm{Et}_{2} \mathrm{O}$ in petroleum ether) to give a colorless oil. The isolated material contained a mixture of 3-phenylpropanal (80\%) and 2-phenylpropanal (20\%). The NMR data match previously reported data for the title products. ${ }^{23}$

${ }^{1}$ H NMR (400 MHz, CDCl 3$) \delta 9.83(\mathrm{t}, J=1.2 \mathrm{~Hz}, 1 \mathrm{H})(\beta), 9.83(\mathrm{~d}, J=1.4 \mathrm{~Hz}, 1 \mathrm{H})(\alpha), 7.31(\mathrm{tt}, J=6.8$, $1.6 \mathrm{~Hz}, 2 \mathrm{H}), 7.25-7.18(\mathrm{~m}, 3 \mathrm{H}), 3.57(\mathrm{dq}, J=7.1,1.2 \mathrm{~Hz}, 2 \mathrm{H})(\alpha), 2.97(\mathrm{t}, J=7.6 \mathrm{~Hz}, 2 \mathrm{H}), 2.79(\mathrm{dt}, J=$ 7.6, $1.2 \mathrm{~Hz}, 2 \mathrm{H})(\beta), 1.45(\mathrm{~d}, \mathrm{~J}=7.1 \mathrm{~Hz}, 3 \mathrm{H})(\alpha)$.

\section{3-(3,5-Bis(trifluoromethyl)phenyl)propanal $2 \mathrm{~b}$}<smiles>O=CCCc1cc(C(F)(F)F)cc(C(F)(F)F)c1</smiles>

The compound was prepared according to the general procedure by reaction of 3,5-bis(trifluoromethyl)styrene $(0.060 \mathrm{mg}, 0.25 \mathrm{mmol})$ and was isolated by colorless oil.

column chromatography (silica gel, $0-20 \% \mathrm{Et}_{2} \mathrm{O}$ in petroleum ether) to give a

${ }^{1} \mathbf{H}$ NMR (400 MHz, CDCl 3$) \delta 9.84(\mathrm{~s}, 1 \mathrm{H}), 7.73(\mathrm{~m}, 1 \mathrm{H}), 7.66(\mathrm{~m}, 2 \mathrm{H}), 3.08(\mathrm{t}, J=7.2 \mathrm{~Hz}, 2 \mathrm{H}), 2.88(\mathrm{t}$, $J=7.2 \mathrm{~Hz}, 2 \mathrm{H})$.

${ }^{13} \mathbf{C}\left\{{ }^{1} \mathbf{H}\right\}$ NMR $\left(101 \mathrm{MHz}, \mathrm{CDCl}_{3}\right) \delta 199.8,143.1$ (s), $132.0(\mathrm{q}, J=33.0 \mathrm{~Hz}), 128.8$ (br s), 123.4 (q, 272.6 $\mathrm{Hz}), 120.6(\mathrm{~m}), 44.7,27.7$.

${ }^{19}$ F NMR $\left(376 \mathrm{MHz}, \mathrm{CDCl}_{3}\right) \delta-62.9$.

EI-MS m/z: $270[\mathrm{M}]^{+}$.

\section{3-(4-(Trifluoromethyl)phenyl)propanal 2c}

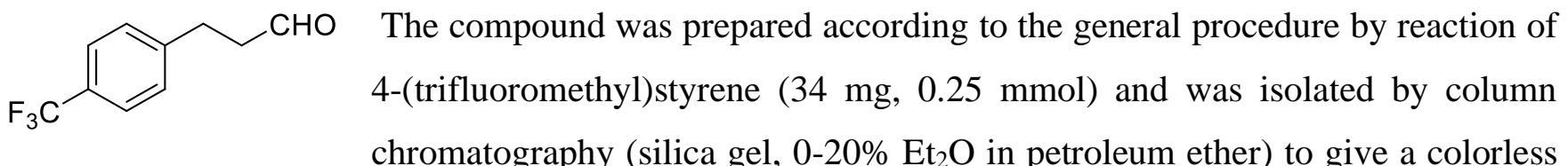
oil. The NMR data match previously reported data for the title product. ${ }^{24}$

${ }^{1}$ H NMR (400 MHz, CDCl 3$) \delta 9.73(\mathrm{~s}, 1 \mathrm{H}), 7.46(\mathrm{~d}, J=8.0 \mathrm{~Hz}, 2 \mathrm{H}), 7.22(\mathrm{~d}, J=8.0 \mathrm{~Hz}, 2 \mathrm{H}), 2.92(\mathrm{t}, J$ $=7.4 \mathrm{~Hz}, 2 \mathrm{H}), 2.73(\mathrm{t}, J=7.4 \mathrm{~Hz}, 2 \mathrm{H})$. 


\section{3-(4-(Cyano)phenyl)propanal 2d}

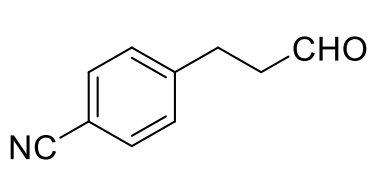

The compound was prepared according to the general procedure by reaction of

4-cyanostyrene ( $34 \mathrm{mg}, 0.25 \mathrm{mmol}$ ) and was isolated by column chromatography (silica gel, 0-20\% $\mathrm{Et}_{2} \mathrm{O}$ in petroleum ether) to give a colorless oil. The NMR data match previously reported data for the title product. ${ }^{25}$

${ }^{1} \mathbf{H}$ NMR (400 MHz, $\left.\mathbf{C D C l}_{3}\right) \delta 9.82(\mathrm{~s}, 1 \mathrm{H}), 7.59(\mathrm{~d}, J=8.4 \mathrm{~Hz}, 2 \mathrm{H}), 7.32(\mathrm{~d}, J=8.4 \mathrm{~Hz}, 2 \mathrm{H}), 3.02(\mathrm{t}, J$ $=7.3 \mathrm{~Hz}, 2 \mathrm{H}), 2.84(\mathrm{t}, J=7.4 \mathrm{~Hz}, 2 \mathrm{H})$.

\section{3-(4-Bromophenyl)propanal 2e}

CHO The compound was prepared according to the general procedure by reaction of 4-bromostyrene $(0.038 \mathrm{~mL}, 0.25 \mathrm{mmol})$ and was isolated by column chromatography (silica gel, $0-20 \% \mathrm{Et}_{2} \mathrm{O}$ in petroleum ether) to give a colorless oil.

The NMR data match previously reported data for the title product. ${ }^{26}$

${ }^{1} \mathbf{H}$ NMR (400 MHz, CDCl$) \delta 9.80(\mathrm{t}, J=1.3 \mathrm{~Hz}, 1 \mathrm{H}), 7.39(\mathrm{~d}, J=8.5 \mathrm{~Hz}, 2 \mathrm{H}), 7.07(\mathrm{~d}, J=8.5 \mathrm{~Hz}, 2 \mathrm{H})$, $2.91(\mathrm{t}, J=7.3 \mathrm{~Hz}, 2 \mathrm{H}), 2.77(\mathrm{tt}, J=7.3,7.6 \mathrm{~Hz}, 2 \mathrm{H})$.

\section{3-(4-Fuorophenyl)propanal $2 f$}

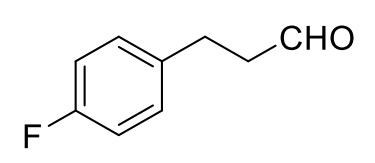

fluorostyrene $(0.038 \mathrm{~mL}, 0.25 \mathrm{mmol})$ and was isolated by column chromatography (silica gel, 0-20\% $\mathrm{Et}_{2} \mathrm{O}$ in petroleum ether) to give a colorless oil. The NMR data match previously reported data for the title product. ${ }^{27}$

${ }^{1} \mathbf{H}$ NMR (400 MHz, CDCl $) \delta 9.82(\mathrm{t}, J=1.3 \mathrm{~Hz}, 1 \mathrm{H}), 7.15(\mathrm{~d}, J=8.4 \mathrm{~Hz}, 2 \mathrm{H}), 6.97(\mathrm{~d}, J=8.4 \mathrm{~Hz}, 2 \mathrm{H})$, $2.93(\mathrm{t}, J=7.8 \mathrm{~Hz}, 2), 2.77(\mathrm{tt}, J=7.6,7.8 \mathrm{~Hz}, 2 \mathrm{H})$.

\section{4-(3-Oxopropyl)phenyl acetate $2 \mathrm{~g}$}

CHO The compound was prepared according to the general procedure by reaction of 4-acetyl-styrene $(0.048 \mathrm{mg}, 0.25 \mathrm{mmol})$ and was isolated by column chromatography (silica gel, $0-20 \% \mathrm{Et}_{2} \mathrm{O}$ in petroleum ether) to give a colorless oil. The NMR data match previously reported data for the title product. ${ }^{28}$

${ }^{1} \mathbf{H}$ NMR (400 MHz, CDCl$) \delta 9.78(\mathrm{t}, J=1.6 \mathrm{~Hz}, 1 \mathrm{H}), 7.19(\mathrm{~d}, J=8.4 \mathrm{~Hz}, 2 \mathrm{H}), 7.00(\mathrm{~d}, J=8.4 \mathrm{~Hz}, 2 \mathrm{H})$, $2.93(\mathrm{t}, J=7.5 \mathrm{~Hz}, 2 \mathrm{H}), 2.75(\mathrm{t}, J=7.5 \mathrm{~Hz}, 2 \mathrm{H}), 2.29(\mathrm{~s}, 3 \mathrm{H})$. 


\section{3-(4-Methoxyphenyl)propanal $2 \mathrm{~h}$}

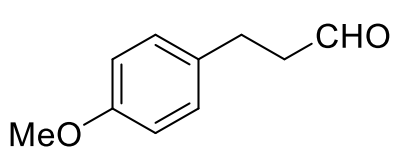

The compound was prepared according to the general procedure by reaction of 4-methoxyl-styrene $(0.041 \mathrm{mg}, 0.25 \mathrm{mmol})$ and was isolated by column chromatography (silica gel, $0-20 \% \mathrm{Et}_{2} \mathrm{O}$ in petroleum ether) to give a colorless oil. The NMR data match previously reported data for the title product. ${ }^{29}$

${ }^{1} \mathbf{H}$ NMR (400 MHz, CDCl $) \delta 9.80(\mathrm{t}, J=1.5 \mathrm{~Hz}, 1 \mathrm{H}), 7.11(\mathrm{~d}, J=8.7 \mathrm{~Hz}, 2 \mathrm{H}), 6.84(\mathrm{~d}, J=8.7 \mathrm{~Hz}, 2 \mathrm{H})$, $3.78(\mathrm{~s}, 3 \mathrm{H}), 2.91(\mathrm{t}, J=7.2 \mathrm{~Hz}, 2 \mathrm{H}), 2.74(\mathrm{~m}, 2 \mathrm{H})$.

\section{3-(4-(tert-Butyl)phenyl)propanal 2i}

CHO The compound was prepared according to the general procedure by reaction of $t \mathrm{Bu}$ 4-tert-butylstyrene $(0.091 \mathrm{~mL}, 0.25 \mathrm{mmol})$ and was isolated by column chromatography (silica gel, $0-20 \% \mathrm{Et}_{2} \mathrm{O}$ in petroleum ether) to give a colorless oil.

${ }^{1} \mathbf{H}$ NMR (400 MHz, CDCl$) \delta 9.83(\mathrm{t}, J=1.6 \mathrm{~Hz}, 1 \mathrm{H}), 7.32(\mathrm{~d}, J=7.8 \mathrm{~Hz}, 2 \mathrm{H}), 7.13(\mathrm{~d}, J=7.9 \mathrm{~Hz}, 2 \mathrm{H})$, $2.94(\mathrm{t}, J=7.6 \mathrm{~Hz}, 2 \mathrm{H}), 2.78(\mathrm{t}, J=7.6 \mathrm{~Hz}, 2 \mathrm{H}), 1.31$ (s, 9H).

${ }^{13} \mathbf{C}$ NMR $\left(101 \mathrm{MHz}, \mathrm{CDCl}_{3}\right) \delta 202.0,149.3,137.3,128.1,125.6,45.4,34.5,31.5,27.7$.

HRMS (APPI) m/z calcd. For $\mathrm{C}_{13} \mathrm{H}_{19} \mathrm{O}\left([\mathrm{M}+\mathrm{H}]^{+}\right)$: 191.1430; found: 191.1432.

\section{3-(o-Tolyl)propanal $2 \mathrm{j}$}

The compound was prepared according to the general procedure by reaction of 2CHO methyl-styrene $(0.030 \mathrm{mg}, 0.25 \mathrm{mmol})$ and was isolated by column chromatography (silica gel, $0-20 \% \mathrm{Et}_{2} \mathrm{O}$ in petroleum ether) to give a colorless oil. The NMR data match previously reported data for the title product. ${ }^{30}$

${ }^{1} \mathbf{H}$ NMR (400 MHz, $\left.\mathbf{C D C l}_{3}\right) \delta 9.86(\mathrm{t}, J=1.4 \mathrm{~Hz}, 1 \mathrm{H}), 7.19-7.10(\mathrm{~m}, 4 \mathrm{H}), 2.98(\mathrm{t}, J=7.8 \mathrm{~Hz}, 2 \mathrm{H}), 2.75$ (t, $J=7.8 \mathrm{~Hz}, 2 \mathrm{H}), 2.34$ (s, 3H).

\section{3-(Anthracen-9-yl)propanal 2k}<smiles>O=CCCc1c2ccccc2cc2ccccc12</smiles>

The compound was prepared according to the general procedure by reaction of 9vinylanthracene $(0.051 \mathrm{mg}, \quad 0.25 \mathrm{mmol})$ and was isolated by column chromatography (silica gel, $0-20 \% \mathrm{Et}_{2} \mathrm{O}$ in petroleum ether) to give a colorless oil. The NMR data match previously reported data for the title product. ${ }^{31}$ 
${ }^{1}$ H NMR (400 MHz, CDCl $) \delta 9.95(\mathrm{t}, J=1.0 \mathrm{~Hz}, 1 \mathrm{H}), 8.38(\mathrm{~s}, 1 \mathrm{H}), 8.22-8.20(\mathrm{~m}, 2 \mathrm{H})$, 8.04-8.01 (m, 2H), 7.56-7.47 (m, 4H), $3.95(\mathrm{t}, J=8.0 \mathrm{~Hz}, 2 \mathrm{H}), 2.95(\mathrm{td}, J=8.0,1.2 \mathrm{~Hz}, 2 \mathrm{H})$.

\section{3-Phenylbutanal 21}<smiles>CC(CC=O)c1ccccc1</smiles>

The compound was prepared according to the general procedure by reaction of $\alpha$ methylstyrene $(0.041 \mathrm{~mL}, 0.25 \mathrm{mmol})$ and was isolated by column chromatography ( silica gel, $0-10 \% \mathrm{Et}_{2} \mathrm{O}$ in petroleum ether) to give a colorless oil. The NMR data match previously reported data for the title product. ${ }^{32}$

${ }^{1}$ H NMR (400 MHz, CDCl 3$) \delta 9.71(\mathrm{t}, J=2.0 \mathrm{~Hz}, 1 \mathrm{H}), 7.38-7.09(\mathrm{~m}, 5 \mathrm{H}), 3.36(\mathrm{q}, J=7.1 \mathrm{~Hz}, 1 \mathrm{H}), 2.82-$ $2.60(\mathrm{~m}, 2 \mathrm{H}), 1.32(\mathrm{~d}, J=7.0 \mathrm{~Hz}, 3 \mathrm{H})$.

\section{Diphenylpropanal $2 \mathrm{~m}$}

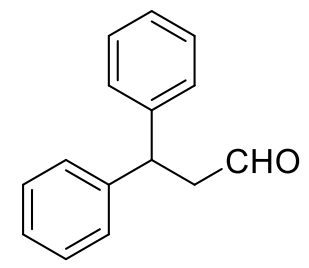

The compound was prepared according to the general procedure by reaction of 1,1 diphenylethylene $(0.045 \mathrm{~mL}, 0.25 \mathrm{mmol})$ and was isolated by column chromatography (silica gel, 0-10\% $\mathrm{Et}_{2} \mathrm{O}$ in petroleum ether) to give a colorless oil. The NMR data match previously reported data for the title product. ${ }^{32}$

${ }^{1} \mathbf{H}$ NMR (400 MHz, CDCl$) \delta 9.74(\mathrm{t}, J=1.9 \mathrm{~Hz}, 1 \mathrm{H}), 7.32-7.19(\mathrm{~m}, 10 \mathrm{H}), 4.63(\mathrm{t}, J=7.8 \mathrm{~Hz}, 1 \mathrm{H})$,

$3.18(\mathrm{dd}, J=7.8,1.9 \mathrm{~Hz}, 2 \mathrm{H})$.

\section{3-(4-Fluorophenyl)butanal 2n}<smiles>CC(CC=O)c1ccc(F)cc1</smiles>

The compound was prepared according to the general procedure by reaction of 4fluoro- $\alpha$-methylstyrene (34 $\mathrm{mg}, 0.25 \mathrm{mmol}$ ) and was isolated by column chromatography ( silica gel, $0-20 \% \mathrm{Et}_{2} \mathrm{O}$ in petroleum ether) to give a colorless oil.

The NMR data match previously reported data for the title product. ${ }^{33}$

${ }^{1}$ H NMR (400 MHz, CDCl $) \delta 9.70(\mathrm{t}, J=1.8 \mathrm{~Hz}, 1 \mathrm{H}), 7.20-7.15(\mathrm{~m}, 2 \mathrm{H}), 7.01-6.97(\mathrm{~m}, 2 \mathrm{H}), 3.35(\mathrm{~m}$, $1 \mathrm{H}), 2.76-2.62(\mathrm{~m}, 2 \mathrm{H}), 1.30(\mathrm{~d}, J=7.2 \mathrm{~Hz}, 3 \mathrm{H})$.

\section{3-(3,4-Dimethoxyphenyl)-2-methylpropanal 20}

$\mathrm{CHO}$ The compound was prepared according to the general procedure by reaction of
methyl isoeugenol $(44.5 \mathrm{mg}, 0.25 \mathrm{mmol})$ and was isolated by column 
chromatography (silica gel, 0-20\% $\mathrm{Et}_{2} \mathrm{O}$ in petroleum ether) to give a colorless oil.

${ }^{1}$ H NMR (400 MHz, CDCl $) \delta 9.71(\mathrm{~d}, J=1.6 \mathrm{~Hz}, 1 \mathrm{H}), 6.80-6.68(\mathrm{~m}, 3 \mathrm{H}), 3.86(\mathrm{~s}, 6 \mathrm{H}), 3.02(\mathrm{dd}, J=$ 13.9, $6.2 \mathrm{~Hz}, 1 \mathrm{H}), 2.69-2.62(\mathrm{~m}, 1 \mathrm{H}), 2.56(\mathrm{dd}, J=13.9,6.2 \mathrm{~Hz}, 1 \mathrm{H}), 1.09$ (d, $J=6.9 \mathrm{~Hz}, 3 \mathrm{H})$.

${ }^{13}$ C NMR $\left(101 \mathrm{MHz}, \mathrm{CDCl}_{3}\right) \delta 204.7,149.0,147.7,131.4,121.1,112.2,111.3,56.0,55.9,48.3,36.5$, 13.4 .

HRMS (APPI) m/z calcd. for $\mathrm{C}_{12} \mathrm{H}_{17} \mathrm{O}\left([\mathrm{M}+\mathrm{H}]^{+}\right)$: 208.1172; found: 208.1127.

\section{2-Methyl-3-phenylpropanal 2p}

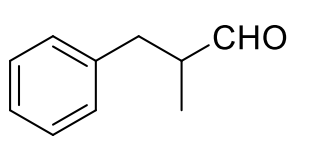

The compound was prepared according to the general procedure by reaction of trans-

$\beta$-methyl-styrene (30 mg, $0.25 \mathrm{mmol}$ ) and was isolated by column chromatography ( silica gel, 0-20\% $\mathrm{Et}_{2} \mathrm{O}$ in petroleum ether) to give a colorless oil. The NMR data match previously reported data for the title product. ${ }^{34}$

${ }^{1} \mathbf{H}$ NMR (400 MHz, CDCl 3$) \delta 9.72(\mathrm{~s}, 1 \mathrm{H}), 7.33-7.29(\mathrm{~m}, 2 \mathrm{H}), 7.25-7.18$ (m, 3H), 3.09 (dd, J = 13.2, 5.6 $\mathrm{Hz}, 1 \mathrm{H}), 2.71-2.65(\mathrm{~m}, 1 \mathrm{H}), 2.59(\mathrm{dd}, J=13.2,5.6 \mathrm{~Hz}, 1 \mathrm{H}), 1.10(\mathrm{~d}, J=6.8 \mathrm{~Hz}, 3 \mathrm{H})$.

\section{3-(1,3-Dioxoisoindolin-2-yl) propanal 2q}

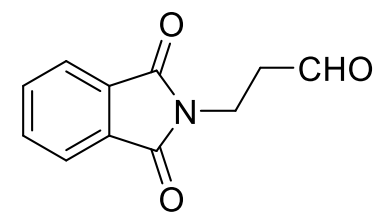

The compound was prepared according to the general procedure by reaction of $\mathrm{N}$ vinyl phthalimide ( $74 \mathrm{mg}, 0.5 \mathrm{mmol}$ ) and was isolated by column chromatography (silica gel, 0-40\% $\mathrm{Et}_{2} \mathrm{O}$ in petroleum ether) to give a colorless oil. The NMR data match previously reported data for the title product. ${ }^{35}$

${ }^{1} \mathbf{H}$ NMR (400 MHz, CDCl $) \delta 9.82(\mathrm{t}, J=2.1 \mathrm{~Hz}, 1 \mathrm{H}), 7.86-7.84(\mathrm{~m}, 2 \mathrm{H}), 7.73-7.71(\mathrm{~m}, 2 \mathrm{H}), 4.04(\mathrm{td}, J$ $=7.0,1.8 \mathrm{~Hz}, 2 \mathrm{H}), 2.88(\mathrm{t}, J=7.0 \mathrm{~Hz}, 2 \mathrm{H})$.

\section{4-(1,3-Dioxoisoindolin-2-yl)butanal 2r}<smiles>O=CCCCN1C(=O)c2ccccc2C1=O</smiles>

The compound was prepared according to the general procedure by reaction of $\mathrm{N}$-allyl phthalimide (94 $\mathrm{mg}, 0.25 \mathrm{mmol}$ ) and was isolated by column chromatography (silica gel, $0-40 \% \mathrm{Et}_{2} \mathrm{O}$ in petroleum ether) to give a colorless oil. The NMR data match previously reported data for the title product. ${ }^{36}$

${ }^{1}$ H NMR (400 MHz, CDCl 3$) \delta 9.76(b s, 1 H), 7.83(\mathrm{~d}, J=5.2 \mathrm{~Hz}, 2 \mathrm{H}), 7.71$ (d, J= 5.2 Hz, 2H), $3.73(\mathrm{t}$, $J=7.0 \mathrm{~Hz}, 2 \mathrm{H}), 2.53(\mathrm{t}, J=7.2 \mathrm{~Hz}, 2 \mathrm{H}), 2.00(\mathrm{t}, J=7.2 \mathrm{~Hz}, 2 \mathrm{H})$. 


\section{4-Phenoxybutanal 2s}<smiles>O=CCCCOc1ccccc1</smiles>

The compound was prepared according to the general procedure by reaction of allyl phenyl ether $(0.035 \mathrm{~mL}, 0.25 \mathrm{mmol})$ and was isolated by column chromatography (silica gel, $0-20 \% \mathrm{Et}_{2} \mathrm{O}$ in petroleum ether) to give a colorless oil. The NMR data match previously reported data for the title product. ${ }^{37}$

${ }^{1}$ H NMR (400 MHz, CDCl 3$) \delta 9.85(\mathrm{t}, J=1.4 \mathrm{~Hz}, 1 \mathrm{H}), 7.32-7.24(\mathrm{~m}, 2 \mathrm{H}), 6.95$ (tt, $\left.J=7.4,1.1 \mathrm{~Hz}, 1 \mathrm{H}\right)$, $6.88(\mathrm{dt}, J=7.8,1.0 \mathrm{~Hz}, 2 \mathrm{H}), 4.01(\mathrm{t}, J=6.0 \mathrm{~Hz}, 2 \mathrm{H}), 2.68(\mathrm{td}, J=7.1,1.3 \mathrm{~Hz}, 2 \mathrm{H}), 2.13(\mathrm{tt}, J=7.0,6.0$ $\mathrm{Hz}, 2 \mathrm{H})$.

\section{2-methyl-3-(triisopropylsilyloxy)propanal 2t}<smiles>CC(C=O)CO[SbH]=[In]</smiles>

The compound was prepared according to the general procedure by reaction of tert-

butyl formyl(vinyl)carbamate $(43 \mathrm{mg}, 0.25 \mathrm{mmol})$ and was isolated by column chromatography (silica gel, $0-20 \% \mathrm{Et}_{2} \mathrm{O}$ in petroleum ether) to give a colorless oil. The NMR data match previously reported data for the title product. ${ }^{38}$

${ }^{1} \mathbf{H}$ NMR (400 MHz, CDCl $) \delta 9.78(\mathrm{~d}, J=1.5 \mathrm{~Hz}, 1 \mathrm{H}), 3.97(\mathrm{dd}, J=10.0,5.1 \mathrm{~Hz}, 1 \mathrm{H}), 3.90(\mathrm{dd}, J=$ 10.0, 6.4 Hz, 1H), 2.59-2.55 (m, 1H), 1.11 (d, J=7.0 Hz, 3H), 1.08-1.04 (m, 21H).

\section{tert-Butyl formyl(3-oxopropyl)carbamate 2u}<smiles>O=CCCNC(=O)O</smiles>

The compound was prepared according to the general procedure by reaction of tertbutyl formyl(vinyl)carbamate $(43 \mathrm{mg}, 0.25 \mathrm{mmol})$ and was isolated by column chromatography (silica gel, $0-20 \% \mathrm{Et}_{2} \mathrm{O}$ in petroleum ether) to give a colorless oil.

${ }^{1}$ H NMR (400 MHz, CDCl$) \delta 9.76(t, J=1.7 \mathrm{~Hz}, 1 \mathrm{H}), 9.14(\mathrm{~s}, 1 \mathrm{H}), 3.95(\mathrm{t}, J=7.4 \mathrm{~Hz}, 2 \mathrm{H}), 2.68(\mathrm{td}, J$ $=7.1,1.7 \mathrm{~Hz}, 2 \mathrm{H}), 1.54(\mathrm{~s}, 9 \mathrm{H})$.

${ }^{13}$ C NMR $\left(101 \mathrm{MHz}, \mathrm{CDCl}_{3}\right) \delta 199.9,163.0,152.0,84.8,42.8,34.7,28.2$.

HRMS (APPI) m/z calcd. for $\mathrm{C}_{9} \mathrm{H}_{16} \mathrm{NO}_{4}\left([\mathrm{M}+\mathrm{H}]^{+}\right)$: 202.1072; found: 202.1074.

\section{Methyl 2-methyl-4-oxobutanoate 2v}<smiles>COC(=O)C(C)CC=O</smiles>

The compound was prepared according to the general procedure by reaction of methyl methacrylate $(0.028 \mathrm{~mL}, 0.25 \mathrm{mmol})$ and was isolated by column chromatography ( silica gel, $0-30 \% \mathrm{Et}_{2} \mathrm{O}$ in petroleum ether) to give a colorless oil. The NMR data match previously reported data for the title product. ${ }^{39}$ 
${ }^{1} \mathrm{H}$ NMR (400 MHz, CDCl $) \delta 9.76(\mathrm{~d}, J=1.1 \mathrm{~Hz}, 1 \mathrm{H}), 3.69(\mathrm{~s}, 3 \mathrm{H}), 2.99-2.87(\mathrm{~m}, 2 \mathrm{H}), 2.48(\mathrm{dd}, J=$ $17.5,5.0 \mathrm{~Hz}, 1 \mathrm{H}), 1.22(\mathrm{~d}, J=7.0 \mathrm{~Hz}, 3 \mathrm{H})$.

\section{Ethyl 4-oxobutanoate 2w}

EtOOC CHO The compound was prepared according to the general procedure by reaction of ethyl gel, $0-30 \% \mathrm{Et}_{2} \mathrm{O}$ in petroleum ether) to give a colorless oil. The NMR data match previously reported data for the title product. ${ }^{40}$

${ }^{1} \mathbf{H}$ NMR (400 MHz, CDCl 3$) \delta 9.81(\mathrm{t}, J=0.8 \mathrm{~Hz}, 1 \mathrm{H}), 4.17(\mathrm{q}, J=7.2 \mathrm{~Hz}, 2 \mathrm{H}), 2.79$ (br t, $J=6.6 \mathrm{~Hz}$, $2 \mathrm{H}), 2.62(\mathrm{t}, J=6.6 \mathrm{~Hz}, 2 \mathrm{H}), 1.26(\mathrm{t}, J=7.2 \mathrm{~Hz}, 3 \mathrm{H})$.

\section{5-(2-Methyl-1,3-dioxolan-2-yl)pentanal 2x}

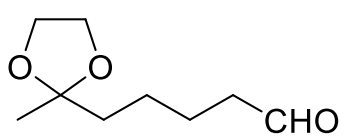

The compound was prepared according to the general procedure by reaction of 2(but-3-en-1-yl)-2-methyl-1,3-dioxolane (36 $\mathrm{mg}, 0.25 \mathrm{mmol}$ ) and was isolated by column chromatography (silica gel, $20-50 \% \mathrm{Et}_{2} \mathrm{O}$ in petroleum ether) to give a colorless oil. The NMR data match previously reported data for the title product. ${ }^{43}$

${ }^{1}$ H NMR (400 MHz, CDCl $) \delta 9.76(\mathrm{t}, J=2.2 \mathrm{~Hz}, 1 \mathrm{H}), 3.92(\mathrm{~m}, 4 \mathrm{H}), 2.44(\mathrm{~m}, 2 \mathrm{H}), 1.68-1.63(\mathrm{~m}, 4 \mathrm{H})$, 1.45-1.42 (m, 2H), $1.30(\mathrm{~s}, 3 \mathrm{H})$.

\section{Cyclooctanecarbaldehyde $2 y$}

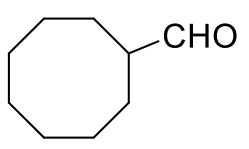

The compound was prepared according to the general procedure by reaction of cyclooctene $(0.065 \mathrm{~mL}, 0.5 \mathrm{mmol})$ and was isolated by column chromatography (silica gel, $0-5 \% \mathrm{Et}_{2} \mathrm{O}$ in petroleum ether) to give a colorless oil. The NMR data match previously reported data for the title product. ${ }^{41}$

${ }^{1} \mathbf{H}$ NMR (400 MHz, $\left.\mathbf{C D C l}_{3}\right) \delta 9.61(\mathrm{~s}, 1 \mathrm{H}), 2.41-2.34(\mathrm{~m}, 1 \mathrm{H}), 1.98-1.92(\mathrm{~m}, 2 \mathrm{H}), 1.77-1.67(\mathrm{~m}, 2 \mathrm{H})$, $1.59-1.52(\mathrm{~m}, 10 \mathrm{H})$.

\section{Bicyclo[2.2.1] heptane-2-carbaldehyde $2 \mathrm{z}$}<smiles>O=CC1CC2CCC1C2</smiles>

The compound was prepared according to the general procedure by reaction of norbornene (47 mg, $0.5 \mathrm{mmol}$ ) and was isolated by column chromatography (silica gel, 0-5\% $\mathrm{Et}_{2} \mathrm{O}$ in 
petroleum ether) to give a colorless oil. The NMR data match previously reported data for the title product. $^{42}$

${ }^{13}$ C NMR (101 MHz, $\left.\mathrm{CDCl}_{3}\right) \delta 203.1,54.6,38.2,36.5,36.0,30.1,29.5,29.3$.

\section{5,5-Dimethylhexanal 2aa/ 2ab}

The compound was prepared according to the general procedure by reaction of 4,4-
dimethylpent-1-ene $(0.033 \mathrm{~mL}, 0.125 \mathrm{mmol})$ and was isolated by column chromatography (silica gel, $0-5 \% \mathrm{Et}_{2} \mathrm{O}$ in petroleum ether) to give a colorless oil. The same compound was formed when (Z)-4,4-dimethylpent-2-ene was used in place of 4,4-dimethylpent-1-ene. The NMR data match previously reported data for the title product. ${ }^{44}$

${ }^{1} \mathbf{H}$ NMR (400 MHz, $\left.\mathbf{C}_{6} \mathbf{D}_{\mathbf{6}}\right) \delta 9.33(\mathrm{t}, J=1.8 \mathrm{~Hz}, 1 \mathrm{H}), 1.78(\mathrm{td}, J=7.3,1.7 \mathrm{~Hz}, 2 \mathrm{H}), 1.35-1.21(\mathrm{~m}, 2 \mathrm{H})$, $0.96-0.86(\mathrm{~m}, 2 \mathrm{H}), 0.79(\mathrm{~s}, 9 \mathrm{H})$.

\section{(E)-2-methyl-3-phenylacrylaldehyde 5a}

The compound was prepared according to the general procedure by reaction of prop-
1-yn-1-ylbenzene $(29.0 \mathrm{mg}, 0.25 \mathrm{mmol})$ and was isolated by column chromatography (silica gel, $0-20 \% \mathrm{Et}_{2} \mathrm{O}$ in petroleum ether) to give a colorless oil. The NMR data match previously reported data for the title product. ${ }^{45}$

${ }^{1} \mathbf{H}$ NMR (500 MHz, CDCl$) \delta 9.60(\mathrm{~s}, 1 \mathrm{H}), 7.54(\mathrm{~d}, J=8.0 \mathrm{~Hz}, 2 \mathrm{H}), 7.48-7.38(\mathrm{~m}, 3 \mathrm{H}), 7.28(\mathrm{~s}, 1 \mathrm{H})$, $2.09(\mathrm{~d}, J=1.3 \mathrm{~Hz}, 3 \mathrm{H})$.

\section{(E)-2-benzylidenebutanal 5b}

The compound was prepared according to the general procedure by reaction of but-1-yn-1-ylbenzene (32.5

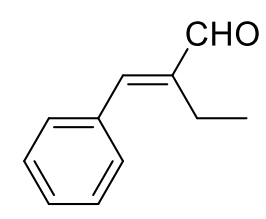
$\mathrm{mg}, 0.25 \mathrm{mmol}$ ) and was isolated by column chromatography (silica gel, $0-20 \% \mathrm{Et}_{2} \mathrm{O}$ in petroleum ether) to give a colorless oil.

${ }^{1} \mathbf{H}$ NMR (500 MHz, $\left.\mathbf{C D C l}_{3}\right) \delta 9.55(\mathrm{~s}, 1 \mathrm{H}), 7.51(\mathrm{~d}, J=7.7 \mathrm{~Hz}, 2 \mathrm{H}), 7.45(\mathrm{t}, J=7.4 \mathrm{~Hz}$,

$1 \mathrm{H}), 7.41$ (d, $J=7.3 \mathrm{~Hz}, 2 \mathrm{H}), 7.21(\mathrm{~s}, 1 \mathrm{H}), 2.57$ (q, $J=7.5 \mathrm{~Hz}, 2 \mathrm{H}), 1.15$ (t, $J=7.5 \mathrm{~Hz}, 3 \mathrm{H}$ ).

${ }^{13}$ C NMR (126 MHz, $\left.\mathrm{CDCl}_{3}\right) \delta 195.8,149.7,144.6,135.0,129.8,129.7,129.0,18.2,13.0$.

HRMS (APPI) m/z calcd. for $\mathrm{C}_{11} \mathrm{H}_{13} \mathrm{O}\left([\mathrm{M}+\mathrm{H}]^{+}\right)$: 161.0883; found: 161.0882 . 


\section{(E)-2-benzylidenehexanal 5c}

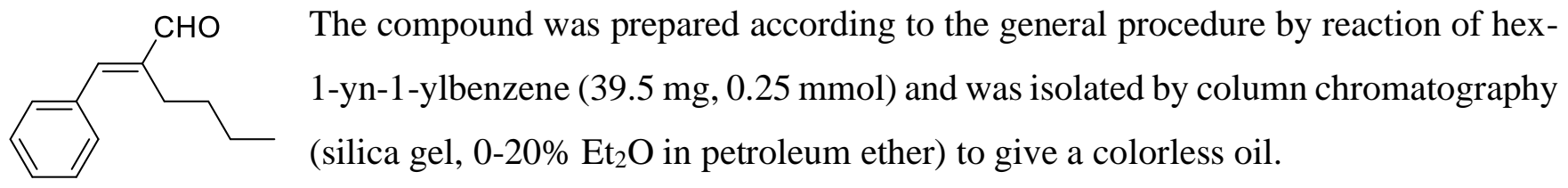

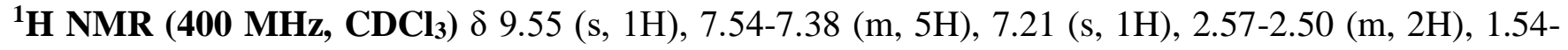
$1.34(\mathrm{~m}, 4 \mathrm{H}), 0.93(\mathrm{t}, J=7.1 \mathrm{~Hz}, 3 \mathrm{H})$.

${ }^{13}$ C NMR (126 MHz, CDCl $) \delta 195.9,150.0,143.5,135.1,129.8,129.7,128.9,30.6,24.7,23.2,14.0$.

HRMS (APPI) m/z calcd. for $\mathrm{C}_{13} \mathrm{H}_{16} \mathrm{O}\left([\mathrm{M}]^{+}\right)$: 188.1201; found: 188.1203.

\section{(E)-2-benzylideneoctanal 5d}

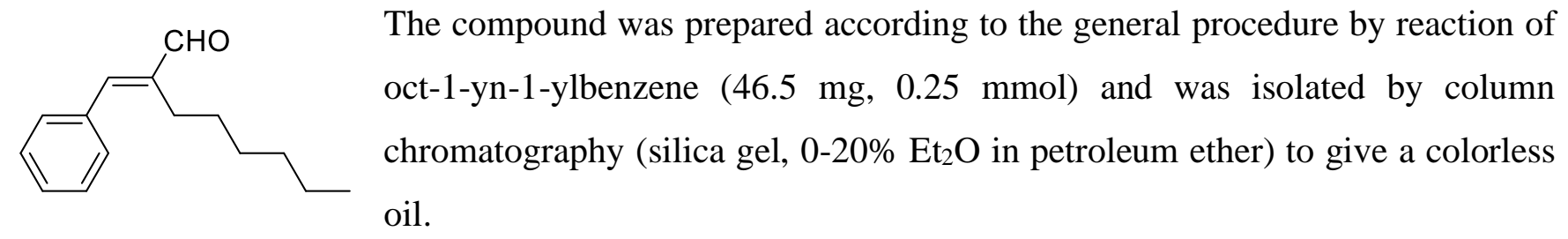

${ }^{1}$ H NMR (500 MHz, CDCl 3 ) $\delta 9.55(\mathrm{~s}, 1 \mathrm{H}), 7.55-7.36(\mathrm{~m}, 5 \mathrm{H}), 7.21(\mathrm{~s}, 1 \mathrm{H}), 2.56-2.49$ (m, 2H), 1.531.44 (m, 2H), 1.41-1.34 (m, 2H), 1.33-1.25 (m, 4H), 0.88 (t, $J=6.3 \mathrm{~Hz}, 3 \mathrm{H})$.

${ }^{13}$ C NMR (126 MHz, CDCl $) \delta 196.1,150.1,143.7,135.3,130.0,129.9,129.1,31.9,29.9,28.6,25.1$, 22.9, 14.4 .

HRMS (APPI) m/z calcd. for $\mathrm{C}_{15} \mathrm{H}_{21} \mathrm{O}\left([\mathrm{M}+\mathrm{H}]^{+}\right)$: 217.1587; found: 217.1586.

\section{(E)-2-benzylideneododecanal 5e}

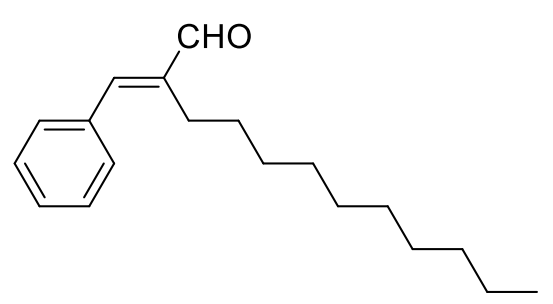

The compound was prepared according to the general procedure by reaction of dodec-1-yn-1-ylbenzene $(60.5 \mathrm{mg}, 0.25 \mathrm{mmol})$ and was isolated by column chromatography (silica gel, 0-20\% $\mathrm{Et}_{2} \mathrm{O}$ in petroleum ether) to give a colorless oil.

${ }^{1} \mathbf{H}$ NMR (500 MHz, $\left.\mathbf{C D C l}_{3}\right) \delta 9.55(\mathrm{~s}, 1 \mathrm{H})$, 7.54-7.36 (m, 5H), 7.21 (s, 1H), 2.56-2.49 (m, 2H), 1.53-

$1.21(\mathrm{~m}, 16 \mathrm{H}), 0.88(\mathrm{t}, J=6.8 \mathrm{~Hz}, 3 \mathrm{H})$.

${ }^{13}$ C NMR (126 MHz, CDCl $) \delta 195.9,149.9,143.5,135.1,129.8,129.7,128.9,32.1,30.1,29.8,29.7$, 29.5, 29.5, 28.4, 25.0, 22.8, 14.3.

HRMS (APPI) m/z calcd. for $\mathrm{C}_{19} \mathrm{H}_{28} \mathrm{O}\left([\mathrm{M}]^{+}\right)$: 272.2140; found: 272.2141 . 


\section{(E)-2-benzyl-3-phenylacrylaldehyde $5 f$}

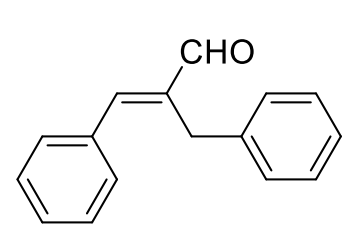

The compound was prepared according to the general procedure by reaction of prop-1-yne-1,3-diyldibenzene ( $48 \mathrm{mg}, 0.25 \mathrm{mmol}$ ) and was isolated by column chromatography (silica gel, $0-20 \%$ ethyl acetate in petroleum ether) to give a colorless oil.

${ }^{1} \mathbf{H}$ NMR $\left(400 \mathrm{MHz}, \mathrm{CDCl}_{3}\right), \delta 9.70(\mathrm{~s}, 1 \mathrm{H}), 7.52(\mathrm{~s}, 1 \mathrm{H}), 7.52-7.45(\mathrm{~m}, 2 \mathrm{H}), 7.41-7.38(\mathrm{~m}, 3 \mathrm{H}), 7.26(\mathrm{t}$, $J=3.7 \mathrm{~Hz}, 2 \mathrm{H}), 7.22-7.15(\mathrm{~m}, 3 \mathrm{H}), 3.95(\mathrm{~s}, 2 \mathrm{H})$.

${ }^{13}$ C NMR (101 MHz, $\left.\mathrm{CDCl}_{3}\right), \delta 195.4,151.8,140.7,138.5,134.7,130.2,130.0,129.1,128.9,128.2$, 126.5, 30.7 .

HRMS (APPI) m/z calcd. for $\mathrm{C}_{16} \mathrm{H}_{14} \mathrm{O}\left([\mathrm{M}]^{+}\right)$: 222.1045; found: 222.1046.

\section{(E)-2-benzylidene-4-methylpentanal 5g}

The compound was prepared according to the general procedure by reaction of (4-

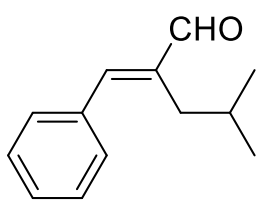
methyl-1-pentyn-1-yl)benzene (39.5 mg, $0.25 \mathrm{mmol}$ ) and was isolated by column chromatography (silica gel, $0-20 \%$ ethyl acetate in petroleum ether) to give a colorless oil.

${ }^{1} \mathbf{H}$ NMR $\left(400 \mathrm{MHz}, \mathrm{CDCl}_{3}\right), \delta 9.57(\mathrm{~s}, 1 \mathrm{H}), 7.53(\mathrm{~d}, J=7.3 \mathrm{~Hz}, 2 \mathrm{H}), 7.49-7.35(\mathrm{~m}, 4 \mathrm{H}), 2.50(\mathrm{~d}, J=7.3$ $\mathrm{Hz}, 2 \mathrm{H}), 1.92-1.87(\mathrm{~m}, 1 \mathrm{H}), 0.88(\mathrm{~d}, J=6.7 \mathrm{~Hz}, 6 \mathrm{H})$.

${ }^{13}$ C NMR (101 MHz, $\left.\mathrm{CDCl}_{3}\right), \delta$ 196.1, 150.9, 142.6, 135.3, 129.9, 129.7, 128.9, 33.1, 27.7, 22.8.

HRMS (APPI) m/z calcd. for $\mathrm{C}_{13} \mathrm{H}_{16} \mathrm{O}\left([\mathrm{M}]^{+}\right)$: 188.1201; found: 188.1202 .

\section{(E)-3-cyclohexyl-2-phenylacrylaldehyde $6 \mathrm{~h}$}

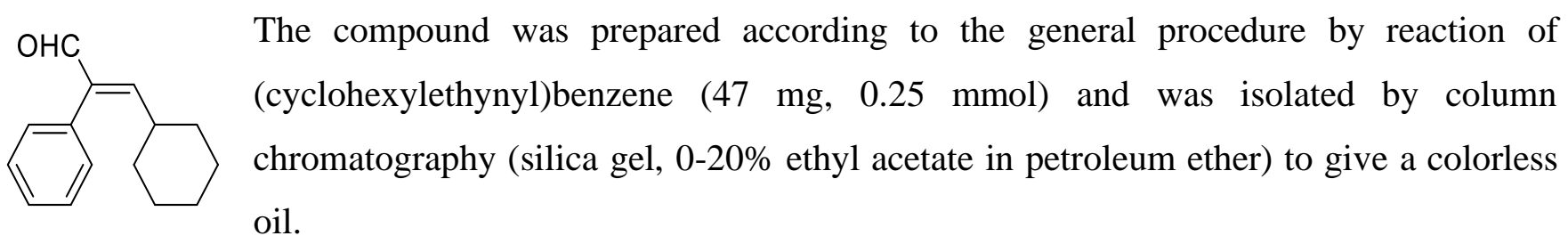

${ }^{1} \mathbf{H}$ NMR $\left(400 \mathrm{MHz}, \mathrm{CDCl}_{3}\right), \delta 9.53(\mathrm{~d}, J=2.1 \mathrm{~Hz}, 1 \mathrm{H}), 7.48-7.32(\mathrm{~m}, 5 \mathrm{H}), 7.21(\mathrm{~s}, 1 \mathrm{H}), 2.78$ (dddd, $J=$ 12.1, 9.9, 3.4, $1.7 \mathrm{~Hz}, 1 \mathrm{H}), 2.02(\mathrm{qd}, J=12.6,3.3 \mathrm{~Hz}, 2 \mathrm{H}), 1.77(\mathrm{~m}, 2 \mathrm{H}), 1.70-1.63(\mathrm{~m}, 1 \mathrm{H}), 1.54-1.51$ $(\mathrm{m}, 1 \mathrm{H}), 1.25(\mathrm{~m}, 4 \mathrm{H})$.

${ }^{13}$ C NMR (101 MHz, $\left.\mathrm{CDCl}_{3}\right), \delta$ 196.0, 150.3, 147.4, 135.5, 129.2, 129.2, 128.8, 37.9, 29.9, 26.8, 25.9.

HRMS (APPI) $\mathrm{m} / \mathrm{z}$ calcd. for $\mathrm{C}_{15} \mathrm{H}_{18} \mathrm{O}\left([\mathrm{M}]^{+}\right)$: 214.1358; found: 214.1352 . 


\section{(E)-2-(4-methylbenzylidene)octanal 5i}

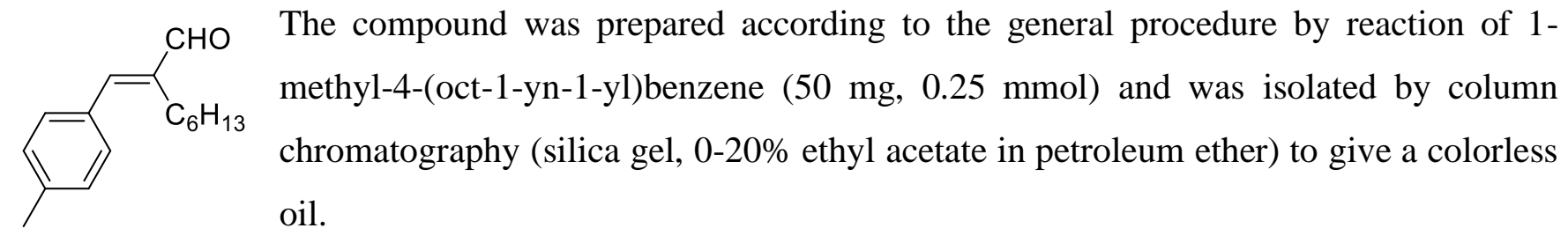

${ }^{1} \mathbf{H}$ NMR $\left(400 \mathrm{MHz}, \mathrm{CDCl}_{3}\right), \delta 9.52(\mathrm{~s}, 1 \mathrm{H}), 7.41(\mathrm{~d}, J=8.0 \mathrm{~Hz}, 2 \mathrm{H}), 7.26(\mathrm{~d}, J=7.8 \mathrm{~Hz}, 2 \mathrm{H}), 7.16(\mathrm{~s}$, $1 \mathrm{H}), 2.56-2.51(\mathrm{~m}, 2 \mathrm{H}), 2.40(\mathrm{~s}, 3 \mathrm{H}), 1.53-1.45(\mathrm{~m}, 2 \mathrm{H}), 1.42-1.35(\mathrm{~m}, 2 \mathrm{H}), 1.34-1.27(\mathrm{~m}, 4 \mathrm{H}), 0.88(\mathrm{t}, J$ $=6.6 \mathrm{~Hz}, 3 \mathrm{H})$.

${ }^{13}$ C NMR (101 MHz, $\left.\mathrm{CDCl}_{3}\right), \delta$ 196.0, 150.1, 142.7, 140.2, 132.4, 130.0, 129.7, 31.7, 29.8, 28.3, 24.9, 22.8, 21.6, 14.2.

HRMS (APPI) m/z calcd. for $\mathrm{C}_{16} \mathrm{H}_{22} \mathrm{O}\left([\mathrm{M}]^{+}\right)$: 218.1665; found: 218.1666 .

\section{(E)-2-(4-methoxybenzylidene)octanal 5j}

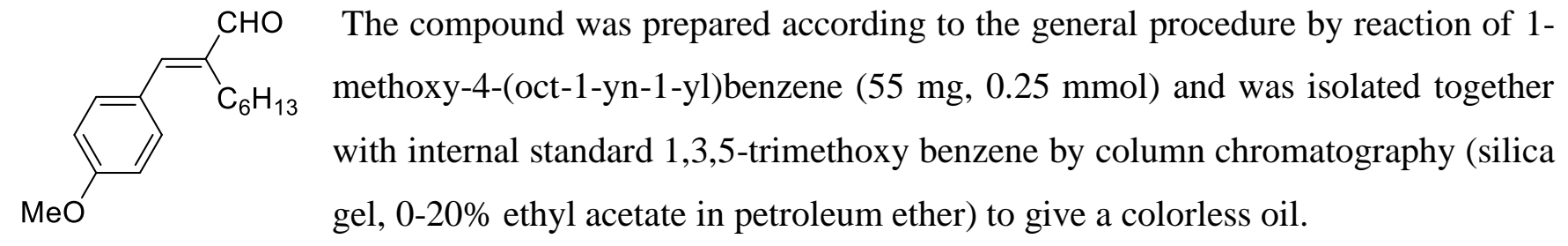

${ }^{1} \mathbf{H}$ NMR $\left(400 \mathrm{MHz}, \mathrm{CDCl}_{3}\right), \delta 9.50(\mathrm{~s}, 1 \mathrm{H}), 7.49(\mathrm{~d}, J=8.8 \mathrm{~Hz}, 2 \mathrm{H}), 7.12(\mathrm{~s}, 1 \mathrm{H}), 6.98(\mathrm{~d}, J=8.8 \mathrm{~Hz}$, $2 \mathrm{H}), 3.87(\mathrm{~s}, 3 \mathrm{H}), 2.56-2.51(\mathrm{~m}, 2 \mathrm{H}), 1.53-1.45(\mathrm{~m}, 2 \mathrm{H}), 1.42-1.35(\mathrm{~m}, 2 \mathrm{H}), 1.34-1.27(\mathrm{~m}, 4 \mathrm{H}), 0.88(\mathrm{t}, J$ $=6.6 \mathrm{~Hz}, 3 \mathrm{H})$.

${ }^{13} \mathrm{C}$ NMR $\left(101 \mathrm{MHz}, \mathrm{CDCl}_{3}\right), \delta$ 195.9, 160.9, 149.9, 141.4, 131.9, 127.8, 114.5, 55.6, 31.8, 29.8, 28.2, 24.9, 22.8, 14.2.

HRMS (APPI) m/z calcd. for $\mathrm{C}_{16} \mathrm{H}_{22} \mathrm{O}_{2}\left([\mathrm{M}]^{+}\right)$: 246.1620; found: 246.1616.

\section{(E)-2-(4-(methylthio)benzylidene)octanal 5k}

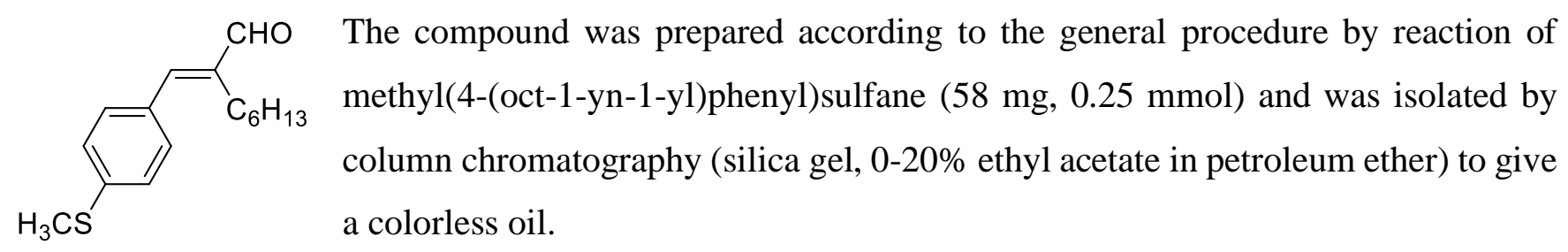


${ }^{1} \mathbf{H}$ NMR $\left(400 \mathrm{MHz}, \mathrm{CDCl}_{3}\right), \delta 9.57(\mathrm{~s}, 1 \mathrm{H}), 7.72(\mathrm{~d}, J=8.3 \mathrm{~Hz}, 2 \mathrm{H}), 7.63(\mathrm{~d}, J=8.3 \mathrm{~Hz}, 2 \mathrm{H}), 7.23(\mathrm{~s}$, $1 \mathrm{H}), 2.77(\mathrm{~s}, 3 \mathrm{H}), 2.53-2.48(\mathrm{~m}, 2 \mathrm{H}), 1.52-1.46(\mathrm{~m}, 2 \mathrm{H}), 1.41-1.33(\mathrm{~m}, 2 \mathrm{H}), 1.30-1.24(\mathrm{~m}, 4 \mathrm{H}), 0.87(\mathrm{t}, J$ $=6.7 \mathrm{~Hz}, 3 \mathrm{H})$.

${ }^{13} \mathrm{C}$ NMR (101 MHz, $\left.\mathrm{CDCl}_{3}\right), \delta$ 195.4, 147.7, 147.0, 145.1, 137.9, 130.4, 124.1, 44.1, 31.6, 29.7, 28.5, 25.0, 22.7, 14.2.

HRMS (APPI) m/z calcd. for $\mathrm{C}_{16} \mathrm{H}_{22} \mathrm{OS}\left([\mathrm{M}]^{+}\right)$: 202.1391; found: 202.1387.

\section{(E)-N-(4-(2-formyloct-1-en-1-yl)phenyl)acetamide 51}

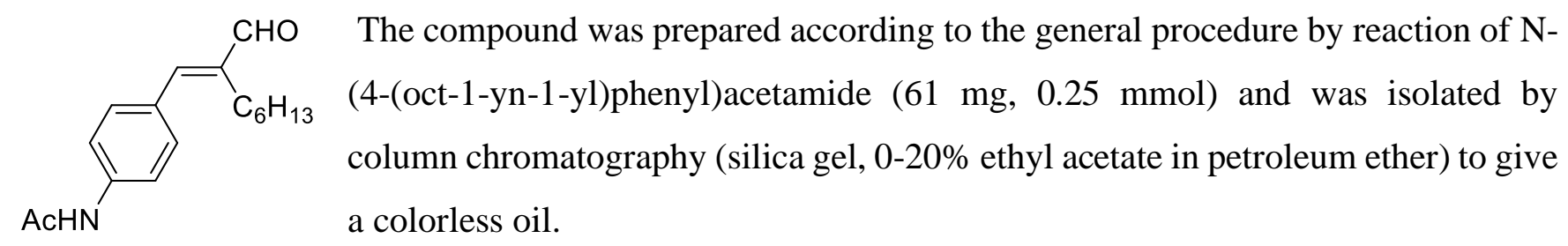

${ }^{1}$ H NMR (400 MHz, $\left.\mathrm{CDCl}_{3}\right), \delta 9.51(\mathrm{~s}, 1 \mathrm{H}), 7.60(\mathrm{~d}, J=8.5 \mathrm{~Hz}, 2 \mathrm{H}), 7.48(\mathrm{~d}, J=8.5 \mathrm{~Hz}, 2 \mathrm{H}), 7.26(\mathrm{~s}$, $1 \mathrm{H}), 7.13(\mathrm{~s}, 1 \mathrm{H}), 2.53(\mathrm{~m}, 2 \mathrm{H}), 2.22(\mathrm{~s}, 3 \mathrm{H}), 1.50-1.14(\mathrm{~m}, 8 \mathrm{H}), 0.88(\mathrm{t}, J=7.9,5.8 \mathrm{~Hz}, 3 \mathrm{H})$.

${ }^{13} \mathrm{C}$ NMR (101 MHz, $\left.\mathrm{CDCl}_{3}\right), \delta$ 195.8, 168.5, 149.3, 142.6, 139.2, 131.04, 131.98, 119.6, 31.7, 29.9, 29.8, $28.3,24.9,22.8,14.2$.

HRMS (APPI) m/z calcd. for $\mathrm{C}_{16} \mathrm{H}_{22} \mathrm{NO}\left(\left[\mathrm{M}-\mathrm{CHO}^{+}\right)\right.$: 244.1701; found: 244.1696.

\section{(E)-2-(4-fluorobenzylidene)octanal $5 \mathrm{~m}$}

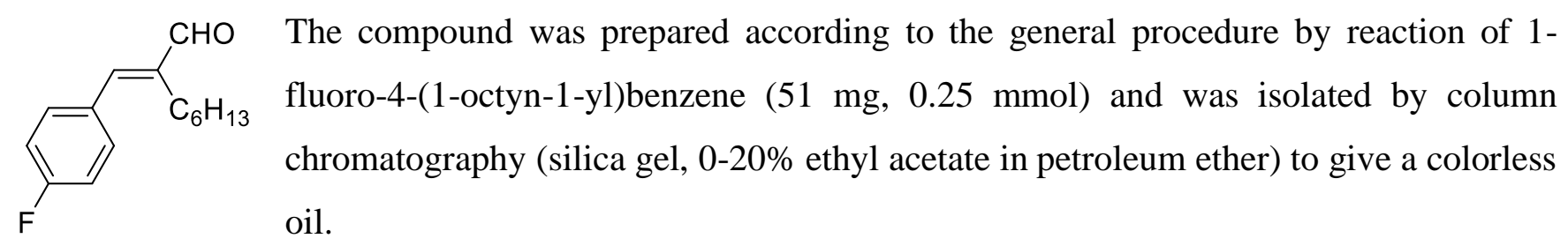

${ }^{1}$ H NMR (400 MHz, CDCl3), $\delta 9.55$ (s, 1H), 7.51 (dd, $J=8.6,5.4$ Hz, 2H), 7.18-7.13 (m, 2H), 2.54-2.50 (m, 2H), 1.49-1.29 (m, 8H), 0.91-0.88 (m, 3H)

${ }^{13} \mathbf{C}\left\{{ }^{1} \mathbf{H}\right\}$ NMR $\left(101 \mathrm{MHz}, \mathrm{CDCl}_{3}\right), \delta 195.6,162.1,148.5,143.2,131.8(\mathrm{~d}, J=8.5 \mathrm{~Hz}), 131.3,116.1(\mathrm{~d}, J$ $=21.8 \mathrm{~Hz}), 31.7,29.7,28.3,24.8,22.7,14.2$.

${ }^{19}$ F NMR $\left(376 \mathrm{MHz}, \mathrm{CDCl}_{3}\right) \delta-110.2$.

HRMS (APPI) m/z calcd. for $\mathrm{C}_{15} \mathrm{H}_{20} \mathrm{FO}\left([\mathrm{M}+\mathrm{H}]^{+}\right)$: 235.1492; found: 235.1491. 


\section{(E)-2-(4-chlorobenzylidene)octanal 5n}

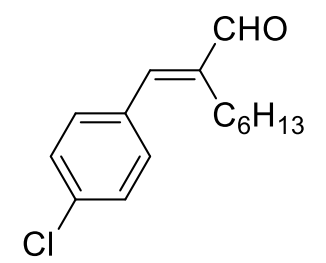

The compound was prepared according to the general procedure by reaction of 1 chloro-4-(oct-1-yn-1-yl)benzene $(55 \mathrm{mg}, 0.25 \mathrm{mmol})$ and was isolated by column chromatography (silica gel, $0-20 \% \mathrm{Et}_{2} \mathrm{O}$ in petroleum ether) to give a colorless oil.

${ }^{1}$ H NMR (500 MHz, CDCl $) \delta 9.54(\mathrm{~s}, 1 \mathrm{H}), 7.42(\mathrm{~s}, 4 \mathrm{H}), 7.16(\mathrm{~d}, J=9.8 \mathrm{~Hz}, 1 \mathrm{H})$, 2.53-2.46 (m, 2H), 1.51-1.22 (m, 8H), $0.88(\mathrm{t}, J=6.5 \mathrm{~Hz}, 3 \mathrm{H})$.

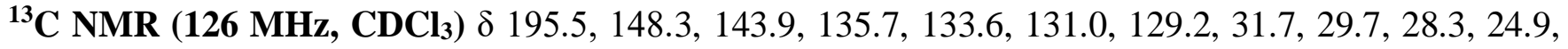
22.7, 14.2.

HRMS (APPI) m/z calcd. for $\mathrm{C}_{15} \mathrm{H}_{20} \mathrm{ClO}\left([\mathrm{M}+\mathrm{H}]^{+}\right)$: 251.1197; found: 251.1197.

\section{Methyl-(E)-4-(2-formyloct-1-en-1-yl)benzoate 50}

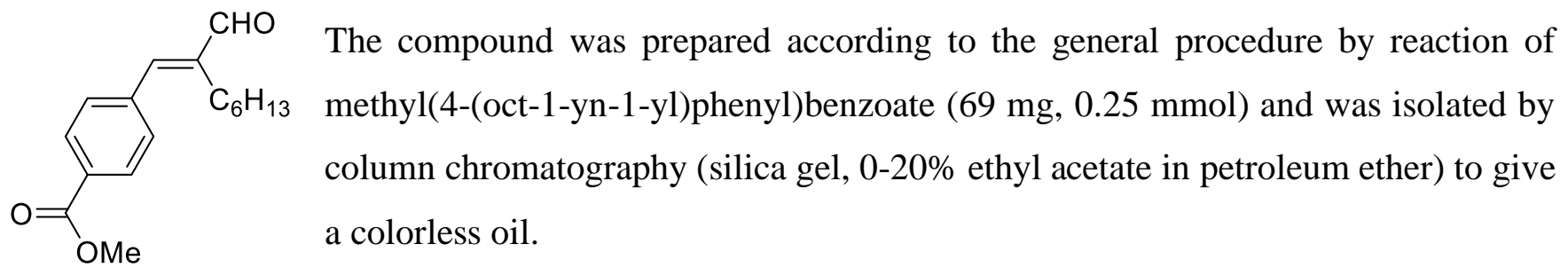

${ }^{1} \mathbf{H}$ NMR $\left(400 \mathrm{MHz}, \mathrm{CDCl}_{3}\right), \delta 9.58(\mathrm{~s}, 1 \mathrm{H}), 8.11(\mathrm{~d}, J=8.3 \mathrm{~Hz}, 2 \mathrm{H}), 7.54(\mathrm{~d}, J=8.3 \mathrm{~Hz}, 2 \mathrm{H}), 7.24(\mathrm{~s}$, $1 \mathrm{H}), 3.95(\mathrm{~s}, 3 \mathrm{H}), 2.53-2.48(\mathrm{~m}, 2 \mathrm{H}), 1.52-1.24(\mathrm{~m}, 8 \mathrm{H}), 0.87(\mathrm{t}, J=6.8 \mathrm{~Hz}, 3 \mathrm{H})$.

${ }^{13} \mathrm{C}$ NMR (101 MHz, $\left.\mathrm{CDCl}_{3}\right), \delta$ 195.5, 166.6, 148.2, 145.1, 139.5, 130.7, 130.1, 129.5, 52.5, 31.6, 29.7, $28.5,25.0,22.7,14.2$.

HRMS (APPI) m/z calcd. for $\mathrm{C}_{17} \mathrm{H}_{23} \mathrm{O}_{3}\left([\mathrm{M}+\mathrm{H}]^{+}\right)$: 295.1640; found: 295.1641 .

\section{(E)-2-(4-acetylbenzylidene)octanal 5p}

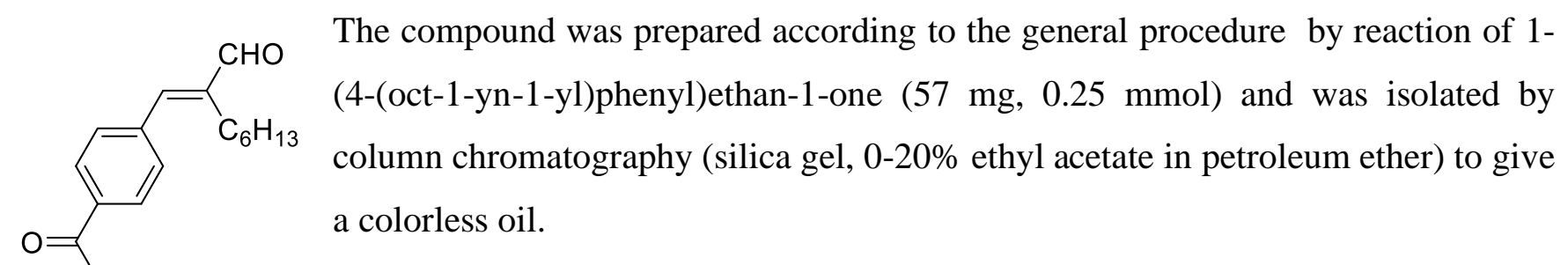

${ }^{1} \mathbf{H}$ NMR $\left(400 \mathrm{MHz}, \mathrm{CDCl}_{3}\right), \delta 9.58(\mathrm{~s}, 1 \mathrm{H}), 8.03(\mathrm{~d}, J=8.4 \mathrm{~Hz}, 2 \mathrm{H}), 7.57(\mathrm{~d}, J=$ $8.3 \mathrm{~Hz}, 2 \mathrm{H}), 7.24$ (s, 1H), 2.64 (s, 3H), 2.54-2.49 (m, 2H), 1.51-1.45 (m, 2H), 1.41-1.35 (m, 2H), 1.29 (dd, $J=6.4,3.4 \mathrm{~Hz}, 4 \mathrm{H}), 0.88(\mathrm{t}, J=6.7 \mathrm{~Hz}, 3 \mathrm{H})$.

${ }^{13} \mathrm{C}$ NMR (101 MHz, $\left.\mathrm{CDCl}_{3}\right), \delta$ 197.5, 195.4, 148.0, 145.3, 139.6, 137.3, 129.7, 128.8, 31.6, 29.7, 28.5, 26.9, 25.1, 22.7, 14.2. 
HRMS (APPI) m/z calcd. for $\mathrm{C}_{17} \mathrm{H}_{22} \mathrm{O}\left([\mathrm{M}]^{+}\right)$: 258.1614; found: 258.1616.

\section{(E)-2-(4-trifluoromethylphenyl)octanal 5q}

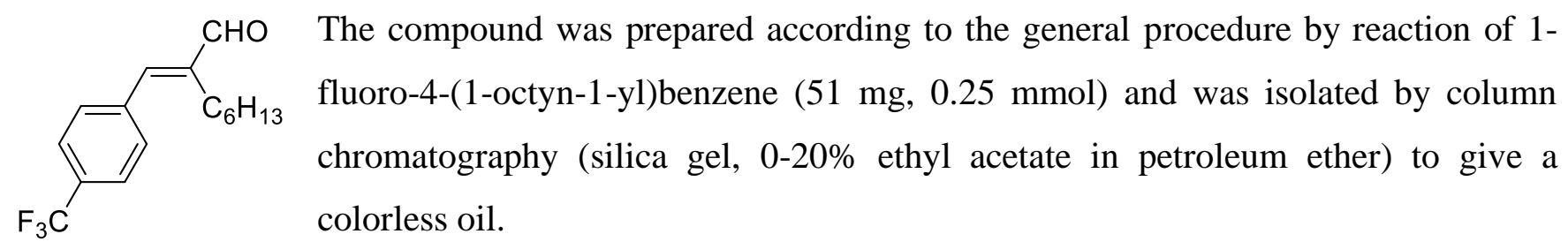

${ }^{1} \mathbf{H}$ NMR $\left(400 \mathrm{MHz}, \mathrm{CDCl}_{3}\right), \delta 9.58(\mathrm{~s}, 1 \mathrm{H}), 7.71(\mathrm{~d}, J=8.2 \mathrm{~Hz}, 2 \mathrm{H}), 7.58(\mathrm{~d}, J=8.2 \mathrm{~Hz}, 2 \mathrm{H}), 7.24(\mathrm{~s}$, $1 \mathrm{H}), 2.52-2.47(\mathrm{~m}, 2 \mathrm{H}), 1.50-1.42(\mathrm{~m}, 2 \mathrm{H}), 1.40-1.33(\mathrm{~m}, 2 \mathrm{H}), 1.28(\mathrm{dt}, J=9.8,5.0 \mathrm{~Hz}, 4 \mathrm{H}), 0.87(\mathrm{t}, J=$ $6.8 \mathrm{~Hz}, 3 \mathrm{H})$.

${ }^{13} \mathrm{C}$ NMR (101 MHz, $\left.\mathrm{CDCl}_{3}\right), \delta 195.4,147.5,145.3,138.6,131.1$ (q, $\left.J=32.8 \mathrm{~Hz}\right), 129.7,125.9$ (q, $J=$ $3.8 \mathrm{~Hz}), 124(\mathrm{q}, J=272 \mathrm{~Hz}), 31.7,29.7,28.5,25.0,22.7,14.2$.

${ }^{19}$ F NMR $\left(376 \mathrm{MHz}, \mathrm{CDCl}_{3}\right) \delta-62.8$.

HRMS (APPI) m/z calcd. for $\mathrm{C}_{16} \mathrm{H}_{20} \mathrm{~F}_{3} \mathrm{O}\left([\mathrm{M}+\mathrm{H}]^{+}\right)$: 285.1460; found: 285.1457.

\section{(E)-2-(3,5-bis(trifluoromethyl)benzylidene)octanal 5r}

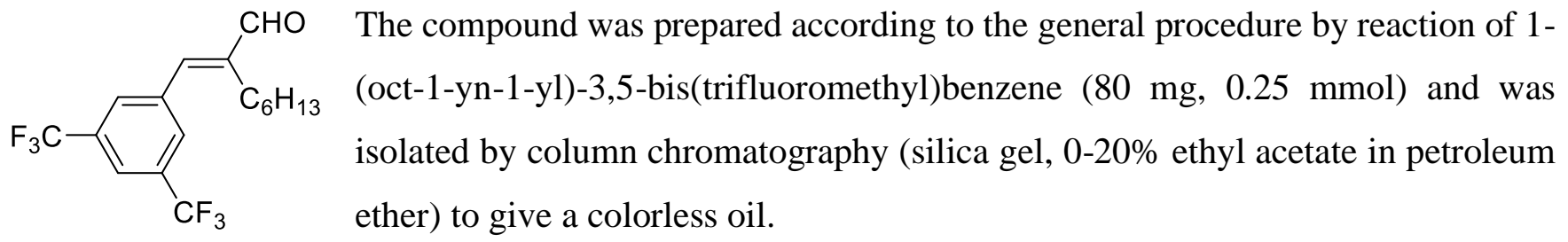

${ }^{1} \mathbf{H}$ NMR $\left(400 \mathrm{MHz}, \mathrm{CDCl}_{3}\right), \delta 9.61$ (s, 1H), 7.90 (s, 3H), 7.26 (s, 1H), 2.53-2.44 (m, 2H), 1.52-1.47 (m, 2H), 1.41-1.34 (m, 2H), 1.30-1.25 (m, 4H), $0.88(\mathrm{t}, J=6.7 \mathrm{~Hz}, 3 \mathrm{H}) ;\left(400 \mathrm{MHz}, \mathrm{C}_{6} \mathrm{D}_{6}\right), \delta 9.27(\mathrm{~s}, 1 \mathrm{H})$, $7.62(\mathrm{~s}, 1 \mathrm{H}), 7.38(\mathrm{~s}, 2 \mathrm{H}), 6.18(\mathrm{~s}, 1 \mathrm{H}), 2.28-2.24(\mathrm{~m}, 2 \mathrm{H}), 1.40-1.34(\mathrm{~m}, 6 \mathrm{H}), 0.86(\mathrm{t}, J=7.1 \mathrm{~Hz}, 3 \mathrm{H})$

${ }^{13} \mathrm{C}$ NMR (101 MHz, $\left.\mathrm{CDCl}_{3}\right), \delta 194.7,146.4,145.1,137.0,132.6(\mathrm{q}, J=33.3 \mathrm{~Hz}), 129.2,123.2(\mathrm{q}, J=$ $273.5 \mathrm{~Hz}), 122.8$ (sept, $J=3.8 \mathrm{~Hz}$ ), 31.5, 29.6, 28.9, 25.1, 22.7, 14.1.

${ }^{19}$ F NMR $\left(376 \mathrm{MHz}, \mathrm{CDCl}_{3}\right) \delta-63.1$.

HRMS (APPI) m/z calcd. for $\mathrm{C}_{17} \mathrm{H}_{19} \mathrm{~F}_{6} \mathrm{O}\left([\mathrm{M}+\mathrm{H}]^{+}\right)$: 353.1334; found: 353.1329 . 


\section{(E)-2-(2-methylbenzylidene)octanal 5s}

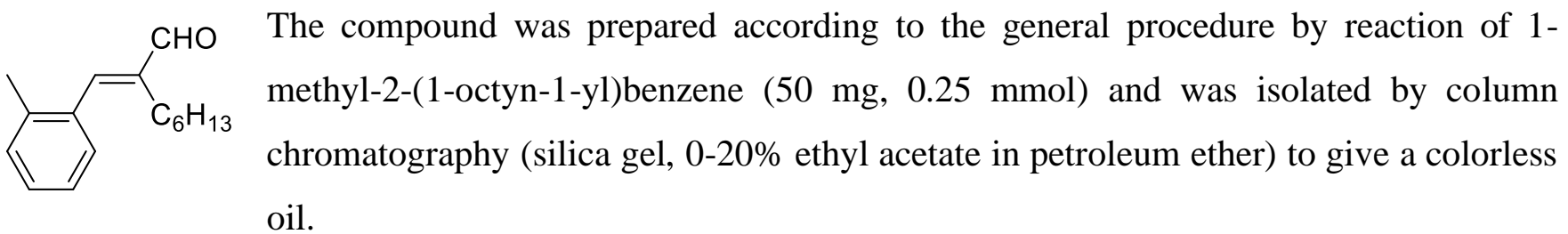

${ }^{1} \mathbf{H}$ NMR $\left(400 \mathrm{MHz}, \mathrm{CDCl}_{3}\right), \delta 9.61(\mathrm{~s}, 1 \mathrm{H}), 7.39(\mathrm{~s}, 1 \mathrm{H}), 7.31-7.24(\mathrm{~m}, 4 \mathrm{H}), 2.40-2.34(\mathrm{~m}, 2 \mathrm{H}), 2.33(\mathrm{~s}$, $3 \mathrm{H}), 1.46-1.35(\mathrm{~m}, 2 \mathrm{H}), 1.29-1.19(\mathrm{~m}, 6 \mathrm{H}), 0.84(\mathrm{t}, J=6.8 \mathrm{~Hz}, 3 \mathrm{H})$.

${ }^{13}$ C NMR (101 MHz, $\left.\mathrm{CDCl}_{3}\right), \delta$ 195.8, 149.0, 144.3, 136.8, 134.4, 130.5, 129.2, 128.3, 126.0, 31.6, 29.5, 28.6, 24.9, 22.7, 20.1, 14.2.

HRMS (APPI) m/z calcd. for $\mathrm{C}_{16} \mathrm{H}_{22} \mathrm{O}\left([\mathrm{M}]^{+}\right)$: 230.1665; found: 230.1671

\section{2-(Naphthalen-1-ylmethylene)octanal $5 t$}

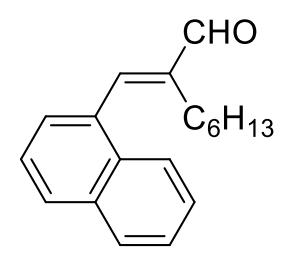

The compound was prepared according to the general procedure by reaction of 1-(oct-

1-yn-1-yl)naphthalene (59 mg, $0.25 \mathrm{mmol}$ ) and was isolated by column

chromatography (silica gel, 0-20\% $\mathrm{Et}_{2} \mathrm{O}$ in petroleum ether) to give a colorless oil.

${ }^{1}$ H NMR (500 MHz, CDCl $) \delta 9.77$ (s, 1H), 8.00-7.82 (m, 4H), 7.60-7.44 (m, 4H),

2.44-2.37 (m, 2H), 1.48-1.37 (m, 2H), 1.22-1.08 (m, 6H), 0.78 (t, J=6.8 Hz, 3H).

${ }^{13}$ C NMR (126 MHz, CDCl$) \delta 195.5,148.2,145.8,133.6,132.3,131.3,129.6,128.8,126.8,126.5$,

$126.3,125.3,124.3,31.5,29.5,28.7,25.3,22.6,14.1$.

HRMS (APPI) m/z calcd. for $\mathrm{C}_{19} \mathrm{H}_{22} \mathrm{O}\left(\left[\mathrm{M}^{+}\right)\right.$: 266.1665; found: 266.1662 .

\section{(E)-2-(Naphthalen-2-ylmethylene)octanal 5u}

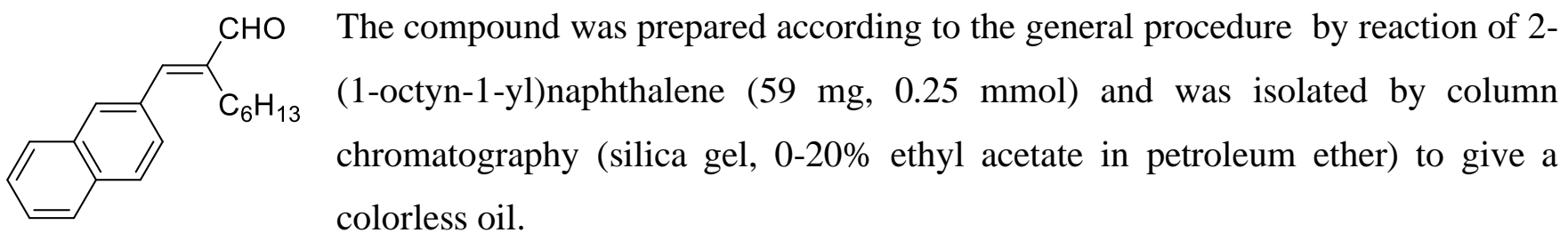

${ }^{1} \mathbf{H}$ NMR $\left(400 \mathrm{MHz}, \mathrm{CDCl}_{3}\right), \delta 9.61(\mathrm{~s}, 1 \mathrm{H}), 7.99$ (s, 1H), 7.91-7.87 (m, 3H), 7.63-7.60 (m, 1H), 7.58-

$7.51(\mathrm{~m}, 2 \mathrm{H}), 7.37(\mathrm{~s}, 1 \mathrm{H}), 2.65-2.59(\mathrm{~m}, 2 \mathrm{H}), 1.58-1.50(\mathrm{~m}, 2 \mathrm{H}), 1.47-1.38(\mathrm{~m}, 2 \mathrm{H}), 1.37-1.27(\mathrm{~m}, 4 \mathrm{H})$, $0.89(\mathrm{t}, J=6.9 \mathrm{~Hz}, 3 \mathrm{H})$.

${ }^{13} \mathbf{C}\left\{{ }^{1} \mathbf{H}\right\}$ NMR $\left(101 \mathrm{MHz}, \mathrm{CDCl}_{3}\right), \delta 195.9,145.0,143.7,133.6,133.3,132.7,130.2,128.7,128.6,127.8$, $127.5,126.9,126.6,31.7,29.8,28.5,25.1,22.8,14.2$. 
HRMS (APPI) m/z calcd. for $\mathrm{C}_{19} \mathrm{H}_{22} \mathrm{O}\left([\mathrm{M}]^{+}\right)$: 266.1665; found: 266.1662 .

tert-Butyl (E)-5-(2-formyloct-1-en-1-yl)-1H-indole-1-carboxylate 5v

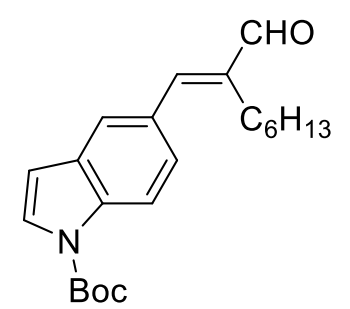

The compound was prepared according to the general procedure by reaction of tertbutyl 5-(oct-1-yn-1-yl)-1H-indole-1-carboxylate $(81.4 \mathrm{mg}, 0.25 \mathrm{mmol})$ and was isolated by column chromatography (silica gel, $0-20 \% \mathrm{Et}_{2} \mathrm{O}$ in petroleum ether) to give a colorless oil.

${ }^{1} \mathrm{H}$ NMR (500 MHz, $\left.\mathbf{C D C l}_{3}\right) \delta 9.55(\mathrm{~s}, 1 \mathrm{H}), 8.20(\mathrm{~d}, J=8.5 \mathrm{~Hz}, 1 \mathrm{H}), 7.73(\mathrm{~s}, 1 \mathrm{H})$, $7.64(\mathrm{~d}, J=3.6 \mathrm{~Hz}, 1 \mathrm{H}), 7.47(\mathrm{dd}, J=8.7,1.2 \mathrm{~Hz}, 1 \mathrm{H}), 7.30(\mathrm{~s}, 1 \mathrm{H}), 6.62(\mathrm{~m}, 1 \mathrm{H}), 2.64-2.55(\mathrm{~m}, 2 \mathrm{H})$, 1.69 (s, 9H), 1.53 (dd, $J=10.1,5.8 \mathrm{~Hz}, 2 \mathrm{H}), 1.46-1.36$ (m, 2H), 1.31 (dd, $J=6.9,3.2 \mathrm{~Hz}, 4 \mathrm{H}), 0.89$ (t, $J$ $=7.0 \mathrm{~Hz}, 3 \mathrm{H})$.

${ }^{13}$ C NMR (126 MHz, CDCl $\left.\mathbf{3}\right) \delta$ 207.2, 196.0, 150.9, 149.5, 142.4, 130.8, 129.7, 127.2, 126.3, 122.9, 115.5, 107.6, 31.7, 31.1, 29.7, 28.3, 28.3, 24.9, 22.8, 14.2.

HRMS (APPI) m/z calcd. for $\mathrm{C}_{22} \mathrm{H}_{30} \mathrm{NO}_{3}\left([\mathrm{M}+\mathrm{H}]^{+}\right): 356.2220$; found: 356.2209 .

\section{(E)-2-(benzo[b]thiophen-5-ylmethylene)octanal 5w}

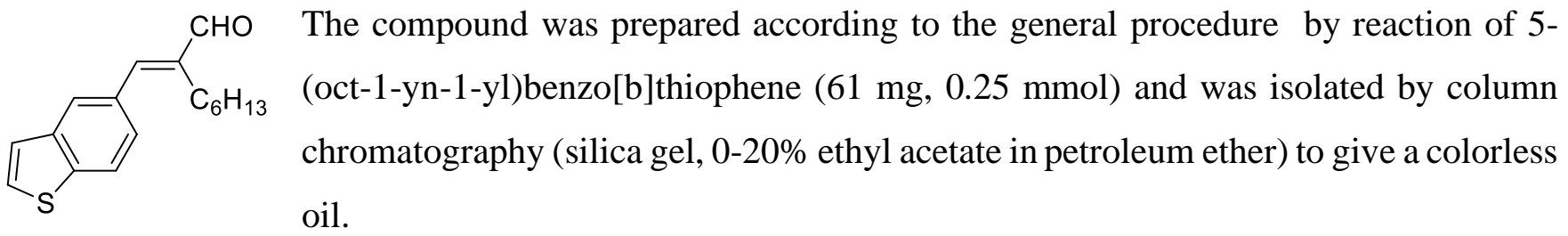

${ }^{1} \mathbf{H}$ NMR (400 MHz, CDCl $), \delta 9.56(\mathrm{~s}, 1 \mathrm{H}), 7.76(\mathrm{~s}, 1 \mathrm{H}), 7.68(\mathrm{~d}, J=2.1 \mathrm{~Hz}, 1 \mathrm{H}), 7.57(\mathrm{~d}, J=8.6 \mathrm{~Hz}$, $1 \mathrm{H}), 7.46(\mathrm{dd}, J=8.6,1.4 \mathrm{~Hz}, 1 \mathrm{H}), 7.31(\mathrm{~s}, 1 \mathrm{H}), 6.84-6.81(\mathrm{~m}, 1 \mathrm{H}), 2.60-2.55(\mathrm{~m}, 2 \mathrm{H}), 1.55-1.48(\mathrm{~m}, 2 \mathrm{H})$, $1.40(\mathrm{p}, J=6.9 \mathrm{~Hz}, 2 \mathrm{H}), 1.36-1.28(\mathrm{~m}, 4 \mathrm{H}), 0.88(\mathrm{t}, J=6.9 \mathrm{~Hz}, 3 \mathrm{H})$.

${ }^{13} \mathbf{C}\left\{{ }^{1} \mathbf{H}\right\}$ NMR (101 MHz, $\left.\mathrm{CDCl}_{3}\right), \delta$ 195.9, 155.4, 150.6, 146.2, 142.5, 130.1, 128.2, 126.6, 123.0, 112.0, 107.0, 31.7, 29.7, 28.3, 24.9, 22.8, 14.2.

HRMS (APPI) m/z calcd. for $\mathrm{C}_{17} \mathrm{H}_{20} \mathrm{OS}\left([\mathrm{M}]^{+}\right): 272.1229$; found: 272.1229 . 


\section{(E)-2-(benzofuran-5-ylmethylene)octanal 5x}

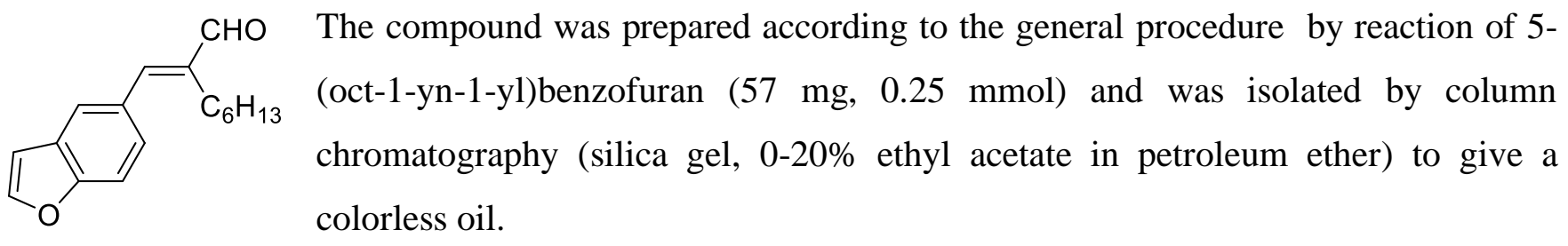

${ }^{1} \mathbf{H}$ NMR $\left(400 \mathrm{MHz}, \mathrm{CDCl}_{3}\right), \delta 9.58(\mathrm{~s}, 1 \mathrm{H}), 7.98-7.92(\mathrm{~m}, 2 \mathrm{H}), 7.52(\mathrm{~d}, J=5.4 \mathrm{~Hz}, 1 \mathrm{H}), 7.50-7.47(\mathrm{~m}$, $1 \mathrm{H}), 7.38(\mathrm{~d}, J=5.4 \mathrm{~Hz}, 1 \mathrm{H}), 7.33(\mathrm{~s}, 1 \mathrm{H}), 2.61-2.57$ (m, 2H), 1.56-1.50 (m, 2H), 1.46-1.33 (m, 2H), 1.33$1.28(\mathrm{~m}, 4 \mathrm{H}), 0.88(\mathrm{t}, J=6.9 \mathrm{~Hz}, 3 \mathrm{H})$.

${ }^{13} \mathbf{C}\left\{{ }^{1} \mathbf{H}\right\}$ NMR $\left(101 \mathrm{MHz}, \mathrm{CDCl}_{3}\right), \delta$ 195.9, 150.3, 143.2, 141.0, 140.1, 131.4, 127.8, 125.6, 125.2, 124.3, 123.0, 31.7, 29.7, 28.3, 25.0, 22.8, 14.2.

HRMS (APPI) m/z calcd. for $\mathrm{C}_{17} \mathrm{H}_{20} \mathrm{O}_{2}\left([\mathrm{M}]^{+}\right)$: 256.1456; found: 256.1456.

\section{(E)-2-(furan-3-ylmethylene)octanal 5y}

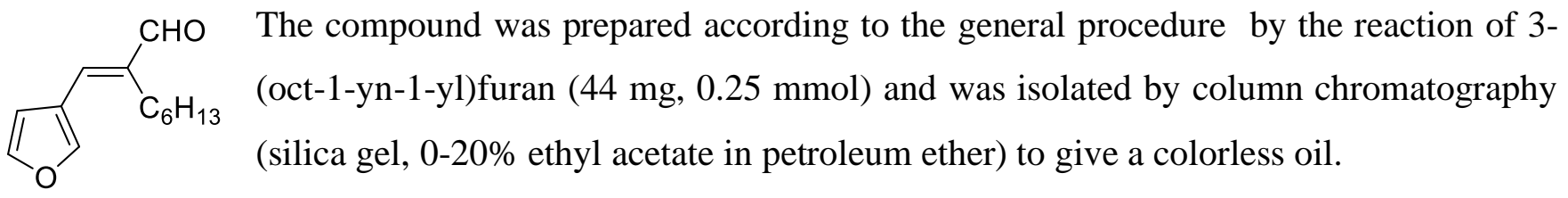
${ }^{1}$ H NMR (400 MHz, CDCl 3$), \delta 9.47$ (s, 1H), 7.75 (s, 1H), 7.52 (s, 1H), 7.03 (s, 1H), 6.65 (s, 1H), 2.50-2.45 (m, 2H), 1.47-1.37 (m, 4H), 1.32-1.25 (m, 4H), $0.88(\mathrm{t}, J=6.8 \mathrm{~Hz}, 3 \mathrm{H})$.

${ }^{13} \mathbf{C}\left\{{ }^{1} \mathbf{H}\right\}$ NMR $\left(101 \mathrm{MHz}, \mathrm{CDCl}_{3}\right), \delta 194.9,145.1,144.5,142.1,139.7,121.9,110.3,31.8,29.8,28.1$, $25.1,22.8,14.2$.

HRMS (APPI) m/z calcd. for $\mathrm{C}_{13} \mathrm{H}_{18} \mathrm{O}_{2}\left([\mathrm{M}]^{+}\right)$: 206.1307; found: 206.1303.

\section{(E)-2,3-diphenylacrylaldehyde $5 z$}

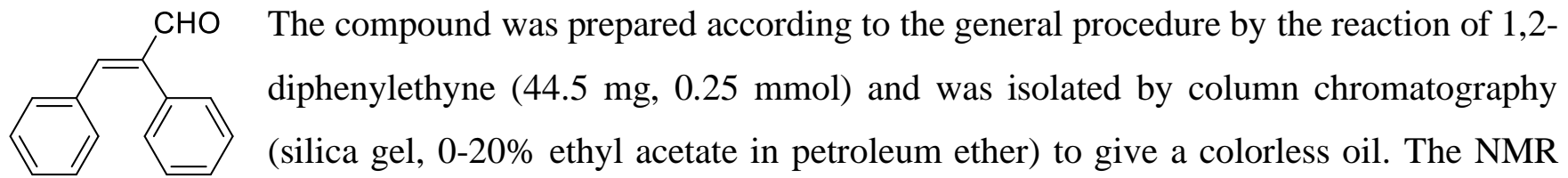
data match previously reported data for the title product. ${ }^{46}$

${ }^{1}$ H NMR (400 MHz, CDCl $) \delta 9.78(\mathrm{~s}, 1 \mathrm{H}), 7.43-7.39$ (m, 4H), 7.30-7.18 (m, 7H). 


\section{Modular synthesis of 1,5-bisarylpyrazole derivatives}

\section{Gram-scale synthesis of $(E)$-2-methyl-3-phenylacrylaldehyde 5a}

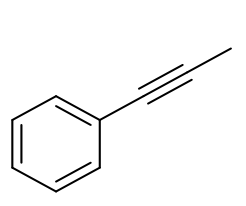

$1.2 \mathrm{~g}$ scale
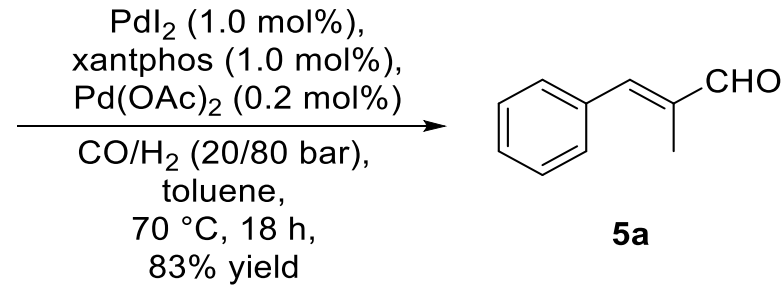

$5 a$

The compound was prepared according to the general procedure by the reaction of prop-1-yn-1ylbenzene (1.2 g, $10.3 \mathrm{mmol})$ and was isolated by column chromatography (silica gel, 0-20\% $\mathrm{Et}_{2} \mathrm{O}$ in petroleum ether) to give the title product as a colorless oil $(1.25 \mathrm{~g}, 8.58 \mathrm{mmol})$ in $83 \%$ yield. The NMR data match previously reported data for the title product. ${ }^{45}$

${ }^{1}$ H NMR (500 MHz, CDCl $) \delta 9.60(\mathrm{~s}, 1 \mathrm{H}), 7.54(\mathrm{~d}, J=8.0 \mathrm{~Hz}, 2 \mathrm{H}), 7.48-7.38(\mathrm{~m}, 3 \mathrm{H}), 7.28(\mathrm{~s}, 1 \mathrm{H})$, $2.09(\mathrm{~d}, J=1.3 \mathrm{~Hz}, 3 \mathrm{H})$.

\section{Synthesis of 1,5-bisarylpyrazoles}<smiles>CC(C=O)=Cc1ccccc1</smiles>

$5 a$

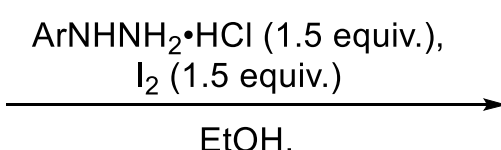

reflux, $18 \mathrm{~h}$

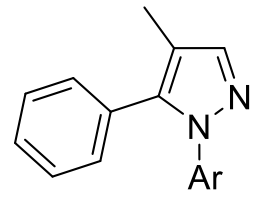

7a. $\mathrm{Ar}=2,4-\mathrm{Cl}_{2} \mathrm{Ph}, 74 \%$

7b. $\mathrm{Ar}=\mathrm{Ph}, \mathbf{4 1 \%}$

1,5-Bisarylpyrazole derivatives were prepared by following the reported procedure (with small modifications): ${ }^{47}$ Under nitrogen atmosphere, to a stirred solution of $\alpha, \beta$-unsaturated aldehyde 5a (5.0 mmol) and hydrazine hydrochloride $\mathrm{ArNHNH}_{2} \cdot \mathrm{HCl}(7.5 \mathrm{mmol})$ in ethanol $(100 \mathrm{~mL})$, molecular iodine (7.5 mmol) was added. The reaction was heated to reflux for overnight. The reaction mixture was concentrated, quenched with $5 \% \mathrm{Na}_{2} \mathrm{~S}_{2} \mathrm{O}_{3}$, and then washed with ethyl acetate $(150 \mathrm{~mL} \times 3)$. The combined organic layers were dried over anhydrous sodium sulfate. After filtration, the volatile material from the filtrate was evaporated under reduced pressure. The product was purified by column chromatography on silica gel, with a mixture of petroleum ether and ethyl acetate as the eluent. Fractions containing the pure product were combined, and the solvent was evaporated, yielding the corresponding pyrazoles $7 \mathbf{a}$ and $7 \mathbf{b}$. 
1-(2,4-dichlorophenyl)-4-methyl-5-phenyl-1H-pyrazole 7a was prepared according to the above described procedure by the reaction of (2,4-dichlorophenyl)hydrazine hydrochloride (1.6 g, 7.5 mmol) and was isolated by column chromatography (silica gel, 0-20\% ethyl acetate in petroleum ether) as pale white solid $(1.12 \mathrm{~g}, 3.7 \mathrm{mmol})$ in $74 \%$ yield.

${ }^{1} \mathbf{H}$ NMR (400 MHz, CDCl 3 ), $\delta$ 7,65 (s, 1H), 7.40 (s, 1H), 7.31-7.29 (m, 3H), 7.23 (br, 2H), 7.14-7.12 (m, $2 \mathrm{H}), 2.16(\mathrm{~s}, 3 \mathrm{H})$.

${ }^{13} \mathrm{C}$ NMR $\left(101 \mathrm{MHz}, \mathrm{CDCl}_{3}\right), \delta 142.1,141.9,137.1,135.1,133.2,130.8,130.2,129.7,129.4,128.5$, $128.3,127.7,115.5,9.4$.

HRMS (APPI) m/z calcd. for $\mathrm{C}_{16} \mathrm{H}_{13} \mathrm{Cl}_{2} \mathrm{~N}_{2}\left([\mathrm{M}]^{+}\right)$: 303.0456 ; found: 303.0455 .

4-Methyl-1,5-diphenylpyrazole 7b was prepared according to the above described procedure by the reaction of phenylhydrazine hydrochloride $(1.1 \mathrm{~g}, 7.5 \mathrm{mmol})$ and was isolated by column chromatography (silica gel, 0-20\% ethyl acetate in petroleum ether) as yellow solid (0.48 g, $2.1 \mathrm{mmol})$ in $41 \%$ yield. The NMR data match previously reported data for the title product. ${ }^{48}$

${ }^{1} \mathbf{H}$ NMR $\left(400 \mathrm{MHz}, \mathrm{CDCl}_{3}\right), \delta$ 7,64 (s, 1H), 7.38-7.35 (m, 3H), 7.32-7.28 (m, 3H), 7.25-7.20 (m, 4H), $2.15(\mathrm{~s}, 3 \mathrm{H})$.

\section{Synthesis of 3-bromo-1-(2,4-dichlorophenyl)-4-methyl-5-phenyl-1H-pyrazole 8}

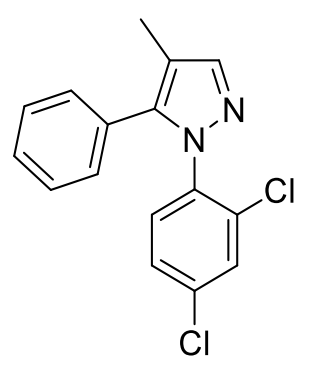

$7 a$

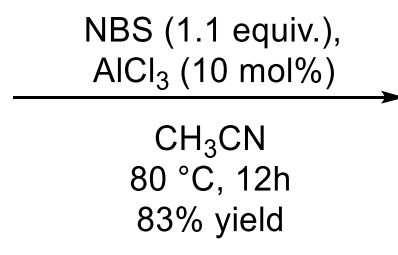

$83 \%$ yield

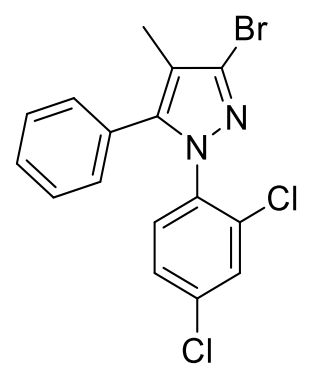

8

The procedure was developed by adapting reported procedure. ${ }^{49}$ Under an atmosphere of nitrogen, a small, oven-dried vial was charged with a Teflon-coated magnetic stir bar, N-bromosuccinimide (32 mg, $0.18 \mathrm{mmol})$, aluminum trichloride (2.2 $\mathrm{mg}, 0.016 \mathrm{mmol}, 10 \mathrm{~mol} \%)$, pyrazole $7 \mathbf{a}(50 \mathrm{mg}, 0.16 \mathrm{mmol})$, and acetonitrile $(1.5 \mathrm{~mL})$. The vial was sealed with a Teflon-lined cap. The reaction mixture was allowed to stir for $12 \mathrm{~h}$ at $80{ }^{\circ} \mathrm{C}$. The mixture was cooled down, diluted with ethyl acetate $(2.0 \mathrm{~mL})$, and filtered. The volatile material from the filtrate was evaporated under reduced pressure. The product was purified by column chromatography on silica gel, with a mixture of petroleum ether and ethyl acetate as the eluent. 
Fractions containing the pure product were combined, and the solvent was evaporated, yielding compound 8 as a white crystalline solid (52 $\mathrm{mg}$ ) in $83 \%$ yield.

${ }^{1} \mathbf{H}$ NMR (400 MHz, CDCl $), \delta 7.38(\mathrm{~d}, J=2.0 \mathrm{~Hz}, 1 \mathrm{H}), 7.32-7.30(\mathrm{~m}, 3 \mathrm{H}), 7.28-7.23(\mathrm{~m}, 2 \mathrm{H}), 7.14-7.12$ (m, 2H), $2.10(\mathrm{~s}, 3 \mathrm{H})$.

${ }^{13}$ C NMR (101 MHz, $\left.\mathrm{CDCl}_{3}\right), \delta 143.5,136.3,135.6,133.3,131.0,130.9,130.3,129.4,129.1,128.9$, 128.7, 127.8, 115.9, 9.7.

HRMS (APPI) $\mathrm{m} / \mathrm{z}$ calcd. for $\mathrm{C}_{16} \mathrm{H}_{12} \mathrm{Cl}_{2} \mathrm{~N}_{2} \mathrm{Br}\left([\mathrm{M}+\mathrm{H}]^{+}\right)$: 380.9561 ; found: 380.9559 .

Synthesis of 1-(2,4-dichlorophenyl)-4-methyl-5-phenyl-N-(piperidin-1-yl)-1H-pyrazole-3carboxamide 9

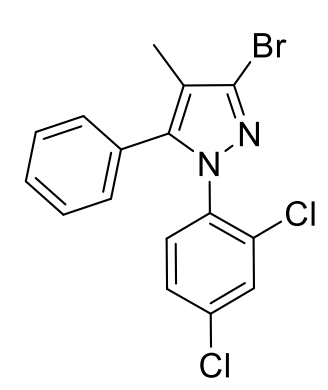

8

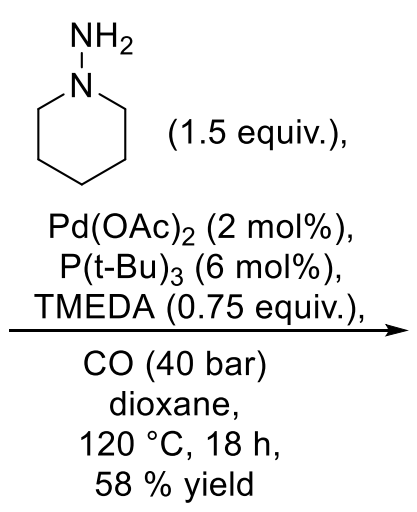

$58 \%$ yield

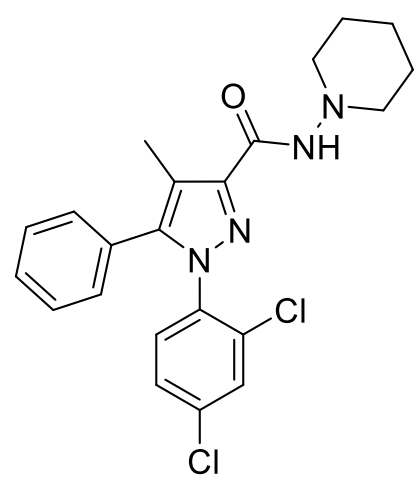

9

CAUTION: CO is highly TOXIC and flammable. Therefore, all manipulations with CO should be performed with great care in a well-ventilated fume hood. The use of a personal detector of CO is highly advised.

Under nitrogen atmosphere, a $2 \mathrm{~mL}$ oven-dried vial equipped with a Teflon-coated magnetic stir bar was charged with $\mathrm{Pd}(\mathrm{OAc})_{2}(0.5 \mathrm{mg}, 2 \mathrm{~mol} \%), \mathrm{P}(\mathrm{t}-\mathrm{Bu})_{3}(1.4 \mathrm{mg}, 6 \mathrm{~mol} \%)$ and dioxane $(1 \mathrm{~mL})$. The resulting solution was stirring for $1 \mathrm{~h}$ at room temperature. Then, the compound 8 (43 $\mathrm{mg}, 0.12 \mathrm{mmol}$ ), piperidin-1-amine (17 mg, $0.17 \mathrm{mmol}$ ), and TMEDA $(9.8 \mathrm{mg}, 0.08 \mathrm{mmol})$ were added. The vial was closed with a cap containing a Teflon-coated septum, which was then punctured with a needle (the tip of the needle should not be in contact with the reaction mixture). The charged vial was placed into a $300-\mathrm{mL}$ stainless steel Parr autoclave, equipped with a heating mantel, temperature controller and an internal thermocouple, enabling to maintain the internal temperature of the autoclave as required. The charged autoclave was purged three times with 20 bar of $\mathrm{CO}$ and then pressurized with 40 bar $\mathrm{CO}$. The reaction mixture was allowed to stir for $18 \mathrm{~h}$ at $120{ }^{\circ} \mathrm{C}$. Upon cooling to room temperature, the pressure was 
released, and the autoclave was opened. After removing the volatiles under reduced pressure, the product was isolated by column chromatography on silica gel, with a mixture of petroleum ether and ethyl acetate as the eluent. Fractions containing the pure product were combined, and the solvent was evaporated, yielding amide product $9(27 \mathrm{mg}, 58 \%)$ as a white solid. The NMR data match previously reported data for the title product. ${ }^{50}$

${ }^{1} \mathbf{H}$ NMR $\left(400 \mathrm{MHz}, \mathrm{CDCl}_{3}\right), \delta 7.64(\mathrm{~s}, 1 \mathrm{H}), 7.41-7.26(\mathrm{~m}, 6 \mathrm{H}), 7.12-7.10(\mathrm{~m}, 2 \mathrm{H}), 2.87(\mathrm{t}, J=5.2 \mathrm{~Hz}$, $4 \mathrm{H}), 2.38$ (s, 3H), 1.79-1.73 (m, 4H), 1.46-1.42 (m, 2H).

\section{Synthesis of 2-(1,5-diphenyl-1H-pyrazol-4-yl)acetonitrile 11 (one pot-procedure)}

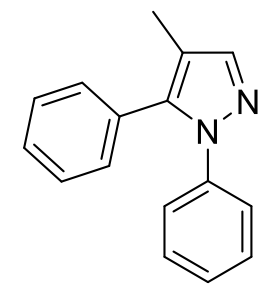

7b

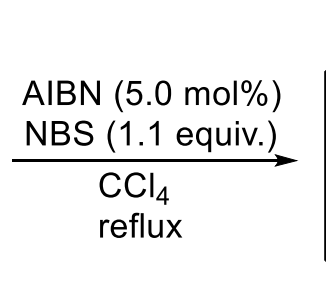

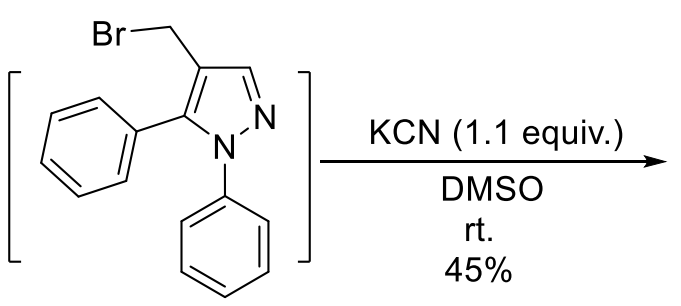

10

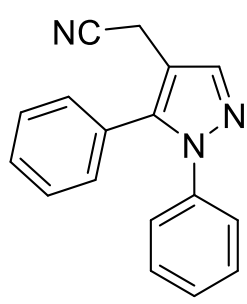

11

To the solution of methyl pyrazole $7 \mathbf{b}(200 \mathrm{mg}, 0.85 \mathrm{mmol})$ in $\mathrm{CCl}_{4}(6 \mathrm{~mL}), N$-bromosuccinimide (182 mg, $1.0 \mathrm{mmol})$ and AIBN (7 mg, $0.045 \mathrm{mmol})$ were added. The reaction mixture was allowed to stir at $80{ }^{\circ} \mathrm{C}$ for $12 \mathrm{~h}$. Reaction mixture was filtered. The volatiles from the filtrate were removed under reduced pressure, yielding oily liquid containing bromide 10. Because compound $\mathbf{1 0}$ is unstable, the oily material was directly subjected to the next step without further purification.

The material containing bromide 10 was diluted with anhydrous DMSO (3 mL). The resulting solution was slowly added to a stirred solution of potassium cyanide (41 mg, $0.94 \mathrm{mmol})$ in anhydrous DMSO (3 $\mathrm{mL}$ ). The mixture was allowed to stir at room temperature for another $30 \mathrm{~min}$, then cooled to $0{ }^{\circ} \mathrm{C}$, diluted with water $(15 \mathrm{~mL})$, and washed with chloroform $(3 \times 10 \mathrm{~mL})$. The combined chloroform washes were dried over $\mathrm{Na}_{2} \mathrm{SO}_{4}$. After filtration, the volatile material from the filtrate was evaporated under reduced pressure. The product was purified by column chromatography on silica gel, with a mixture of petroleum ether and ethyl acetate as the eluent. Fractions containing the pure product were combined, and the solvent was evaporated, yielding the title compound 11 (98 mg, 45\% over 2 steps) as yellow oily liquid. The NMR data match previously reported data for the title product. ${ }^{51}$

${ }^{1} \mathbf{H}$ NMR (400 MHz, $\left.\mathrm{CDCl}_{3}\right), \delta 7.82(\mathrm{~S}, 1 \mathrm{H}), 7.30-7.17$ (m, 10H), 3.56 (s, 2H). 


\section{Mechanistic experiments}

\subsection{Activation of xantphos-Pd(II) $X_{2}$ bearing different anions under syngas}

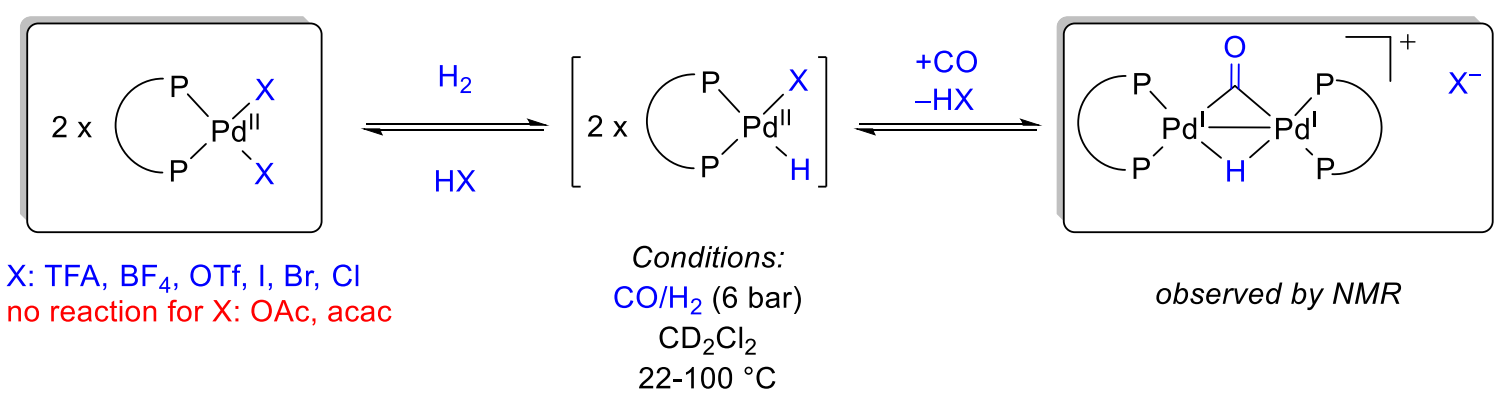

The NMR studies on activation of palladium(II) complexes under syngas were performed in high-pressure J. Young tubes. Xantphos-palladium(II) complexes were either pre-formed in situ (prior to treatment of the solution under syngas) or they were prepared separately (no noticeable difference was recorded). Typically, the solution of a xantphos-palladium(II) complex under 6 bar of syngas was first treated at room temperature, and the reaction progress was monitored by collecting the NMR spectra periodically (typically $1 \mathrm{~h}$ intervals). In cases where no conversion was observed after several hours, increased temperature (typically 50-60 ${ }^{\circ} \mathrm{C}$ ) was applied and the reaction progress was followed by collecting the NMR spectra periodically. For the experiments at elevated temperatures, treatment of the sample was performed either inside of the NMR spectrometer or the sample was kept in a preheated aluminum heating block (the temperature of which was controlled by a standard laboratory heating plate equipped with a thermocouple) and periodically subjected to the NMR spectrometer to collect the spectra.

A representative procedure for the in-situ NMR studies: In a nitrogen-filled glovebox, a J. Young tube was charged with palladium(II) trifluoroacetate $(8.3 \mathrm{mg}, 0.025 \mathrm{mmol})$, xantphos (17.3 mg, 1.2 equiv. $0.03 \mathrm{mmol})$ and $\mathrm{CD}_{2} \mathrm{Cl}_{2}(500 \mu \mathrm{L})$. Then, the $\mathrm{J}$. Young tube was pressurized to 6 bar $\mathrm{CO} / \mathrm{H}_{2}(1: 1)$ followed by release of pressure. This process was repeated 5 times. The J. Young tube was then pressurized (6 bar $\mathrm{CO} / \mathrm{H}_{2}(1: 1)$ ), sealed, shaken, and the NMR spectra were collected (Figs. S2-S3). After $1 \mathrm{~h}$ treatment at room temperature, no conversion of the initial complex was observed. The sample was then treated at 60 ${ }^{\circ} \mathrm{C}$, and the reaction was monitored over time. Quantitative conversion was observed after $3 \mathrm{~h}$ at $60{ }^{\circ} \mathrm{C}$.

Dinuclear palladium(I) hydrido-carbonyl complex, $\left[(\text { xantphos })_{2} \mathrm{Pd}_{2}(\mu-\mathrm{H})(\mu-\mathrm{CO})\right]^{+} \mathrm{CF}_{3} \mathrm{COO}^{-}$, can be prepared on a preparative scale under similar conditions, by following the procedure described below.

Because excess ligand was found to inhibit catalytic activity of the xantphos-Pd(II) complexes (see Fig. 2B, in the main text), we investigated the activation process of the xantphos-Pd(II) complexes both 
in the presence (Figs. S2-S3, S6-S7) and absence of excess xantphos (Fig. S4-S5). Although, the same hydride species are formed in these experiments, we observed that the activation process in the absence of free xantphos seems to be somewhat faster than in the presence of excess ligand. Without excess ligand, the activation process is completed within $1 \mathrm{~h}$ at $50{ }^{\circ} \mathrm{C}$, while in the presence of excess xantphos $(0.1-0.2$ equiv.) 2-4 h at $60^{\circ} \mathrm{C}$ are required.

The treatment of a solution of xantphos-Pd(II) tetrafluoroborate in the presence of excess ligand (0.2 equiv.) under syngas led to the formation of the hydride complex within $\sim 2-3 \mathrm{~h}$ at room temperature (Fig. S8). The treatment of a solution of the preformed tetrafluoroborate complex at $60{ }^{\circ} \mathrm{C}$ occurred at similar rate (Fig. S9). The ${ }^{31} \mathrm{P}\left\{{ }^{1} \mathrm{H}\right\}$ NMR spectra also indicated formation of other uncharacterized complexes (Fig. S10).

Noteworthy, the treatment of a solution of the preformed xantphos-Pd(II) triflate complex in absence of excess ligand led to facile formation of the hydride species $(<1 \mathrm{~h})$ even at room temperature (Figs. S11-S12). The ${ }^{31} \mathrm{P}\left\{{ }^{1} \mathrm{H}\right\}$ NMR spectra also indicated formation of other uncharacterized complexes (Fig. S12).

The treatment of solutions of xantphos-Pd(II) complexes bearing a chloride, a bromide, an iodide, an acetyloacetonate, or an acetate under syngas at $22-100{ }^{\circ} \mathrm{C}$ did not result in the formation of new complexes. In case of complexes bearing an acetyloacetonate or an acetate, slow decomposition and formation of 'palladium black' was observed upon prolonged treatment at elevated temperatures (60-100 $\left.{ }^{\circ} \mathrm{C}\right)$.

\section{Activation in the presence of base to neutralize HX formed.}

Because the activation of xantphos-Pd(II) complexes by heterolytic dihydrogen splitting forms the Pd-hydride species along with a Brønsted acid (HX in the scheme above) that can reverse the reaction, ${ }^{52}$ we studied the process also in the presence of a base $\left(\mathrm{Et}_{3} \mathrm{~N}\right)$. Considering that the Pd-hydride species are susceptible to the presence of a base ${ }^{53}$ we started with a series of control experiments. Firstly, we observed that addition of excess base ( 3 equiv. of $\mathrm{Et}_{3} \mathrm{~N}$ ) to the solution of preformed Pd-hydride species (bearing a tetrafluoroborate) led to facile conversion of the hydride species to a new complex, as indicated by the disappearance of the characteristic hydride signal at $-8.7 \mathrm{ppm}$ in the ${ }^{1} \mathrm{H}$ NMR spectrum, as well as the disappearance of a signal at $8.7 \mathrm{ppm}$ (characteristic for Pd-hydride bearing a tetrafluoroborate), and appearance of a new signal at $9.5 \mathrm{ppm}$ in the ${ }^{31} \mathrm{P}\left\{{ }^{1} \mathrm{H}\right\}$ NMR spectrum (Figs. S13-S14). Secondly, the latter complex was directly generated from xantphos-Pd(II) tetrafluoroborate in the presence of excess base (3 equiv. $\mathrm{Et}_{3} \mathrm{~N}$ ) under syngas (Figs. S15-S16). Lastly, the treatment of xantphos-Pd(II) (bearing a 
tetrafluoroborate) in the presence of substochiometric base $\left(0.5\right.$ equiv. $\left.\mathrm{Et}_{3} \mathrm{~N}\right)$ under syngas led to the formation of the Pd-hydride species, and the complex appeared stable under these conditions (Figs. S17S18).

The NMR studies on the treatment of a xantphos-Pd(II) iodide solution under syngas in the presence of base indicated facile activation of the complex at $60{ }^{\circ} \mathrm{C}$. The activation of the complex is evident by the appearance of new signals in the ${ }^{31} \mathrm{P}\left\{{ }^{1} \mathrm{H}\right\}$ NMR spectra and the signals corresponding to $\mathrm{Et}_{3} \mathrm{NH}^{+} \mathrm{I}^{-}$in the ${ }^{1} \mathrm{H}$ NMR (Figs. S19-S20). The characteristic hydride signal at $-8.7 \mathrm{ppm}$ in the ${ }^{1} \mathrm{H}$ NMR spectrum and a signal at $5.2 \mathrm{ppm}$ in the ${ }^{31} \mathrm{P}\left\{{ }^{1} \mathrm{H}\right\}$ NMR spectrum was observed upon $2 \mathrm{~h}$ treatment at 80 ${ }^{\circ} \mathrm{C}$; further treatment led to the decomposition of the hydride complex due to excess base (in experiments with substochiometric amounts of base, no signals of Pd-hydride species were observed). The ${ }^{1} \mathrm{H}-{ }^{31} \mathrm{P}$ HMBC NMR experiment further confirmed the assignment of the signals (Fig. S21).

The analogous NMR studies of xantphos-Pd(II) bromide or chloride complexes under syngas in the presence of base indicated facile activation at $60-80^{\circ} \mathrm{C}$, which is apparent by the signals corresponding to $\mathrm{Et}_{3} \mathrm{NH}^{+} \mathrm{Br}^{-}$or $\mathrm{Et}_{3} \mathrm{NH}^{+} \mathrm{Cl}^{-}$in the ${ }^{1} \mathrm{H}$ NMR spectra as well as by the characteristic signals of the cationic Pd-hydride complex at $-8.7 \mathrm{ppm}$ in the ${ }^{1} \mathrm{H}$ NMR spectra as well as appearance of a signal (at 8.6 and 8.5 ppm, for a chloride and for a bromide, respectively) in the ${ }^{31} \mathrm{P}\left\{{ }^{1} \mathrm{H}\right\}$ NMR spectra (Figs. S22-S25).

Noteworthy, we observed that a resonance in the ${ }^{31} \mathrm{P}\left\{{ }^{1} \mathrm{H}\right\}$ NMR spectrum for the cationic $\mathrm{Pd}-$ hydride depends on the counterion identity, that is, $8.7 \mathrm{ppm}$ for a tetrafluoroborate, $8.6 \mathrm{ppm}$ for a chloride, $8.5 \mathrm{ppm}$ for a bromide, $5.2 \mathrm{ppm}$ for an iodide, or $4.4 \mathrm{ppm}$ for a trifluoroacetate. This observation suggests some degree of Pd-anion interaction in solution.

No Pd-hydride complexes could be observed following reaction of xantphos-Pd(II) acetate or acetyloacetonate under various conditions evaluated $\left(0.5,1.0\right.$ or 3.0 equiv. $\mathrm{Et}_{3} \mathrm{~N}$, under syngas at 22-100 ${ }^{\circ} \mathrm{C}$ ); slow decomposition and formation of 'palladium black' was observed upon prolonged treatment at elevated temperatures $\left(\sim 60^{\circ} \mathrm{C},>1 \mathrm{~h}\right)$. 


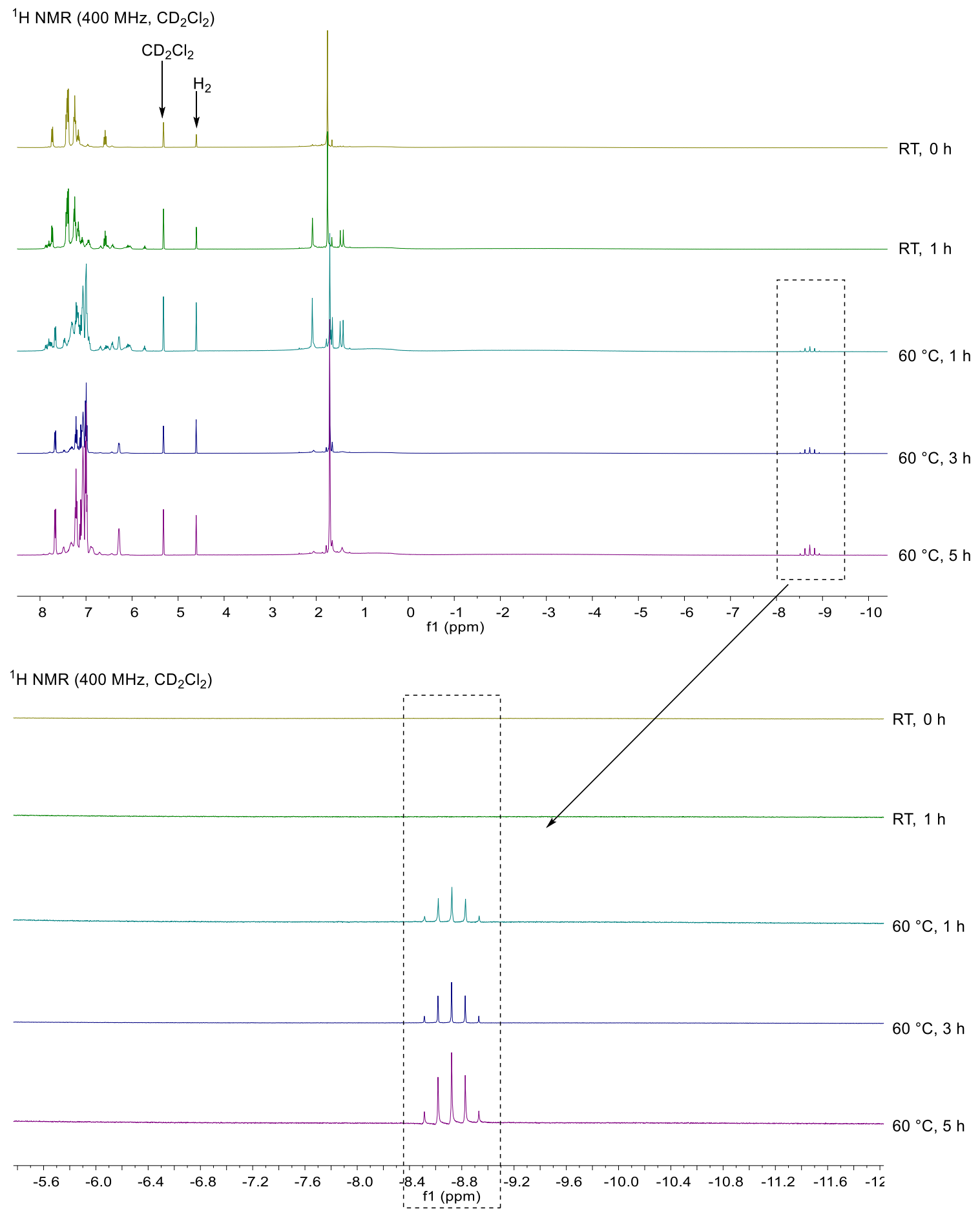

Fig. S2 ${ }^{l} H$ NMR spectra for the activation of xantphos-Pd(II) trifluoroacetate (prepared in situ, Pd(II)(OOCCF 3$)_{2}$ +1.2 equiv. xantphos) followed over time under 6 bar syngas in $\mathrm{CD}_{2} \mathrm{Cl}_{2}$. 
${ }^{31} \mathrm{P}\left\{{ }^{1} \mathrm{H}\right\}$ NMR $\left(162 \mathrm{MHz}, \mathrm{CD}_{2} \mathrm{Cl}_{2}\right)$

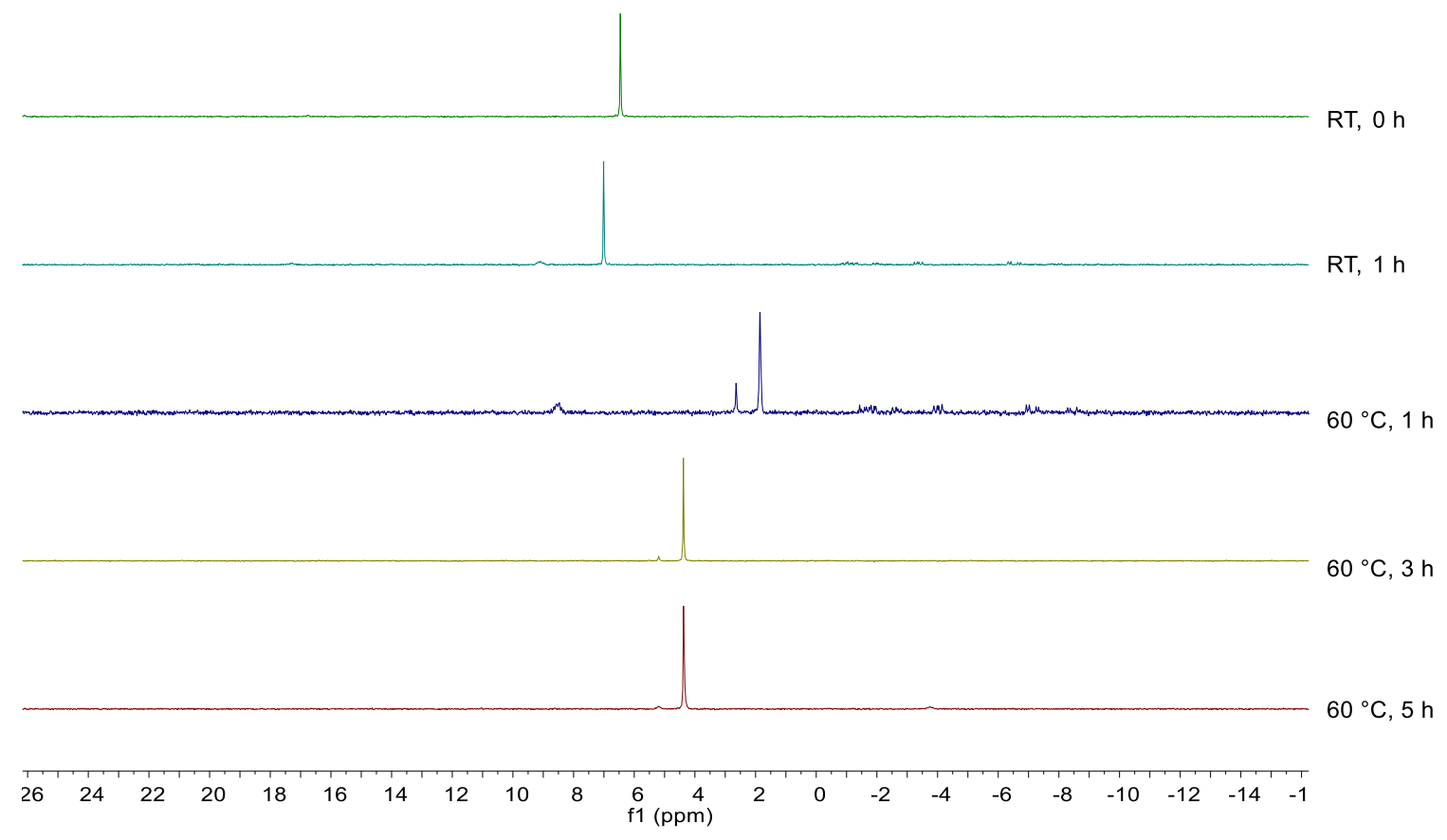

Fig. $S 3{ }^{31} P\left\{{ }^{1} H\right\} N M R$ spectra for the activation of xantphos-Pd(II) trifluoroacetate (prepared in situ, $\mathrm{Pd}(\mathrm{II})\left(\mathrm{OOCCF}_{3}\right)_{2}+1.2$ equiv. xantphos) followed over time under 6 bar syngas in $\mathrm{CD}_{2} \mathrm{Cl}_{2}$. 


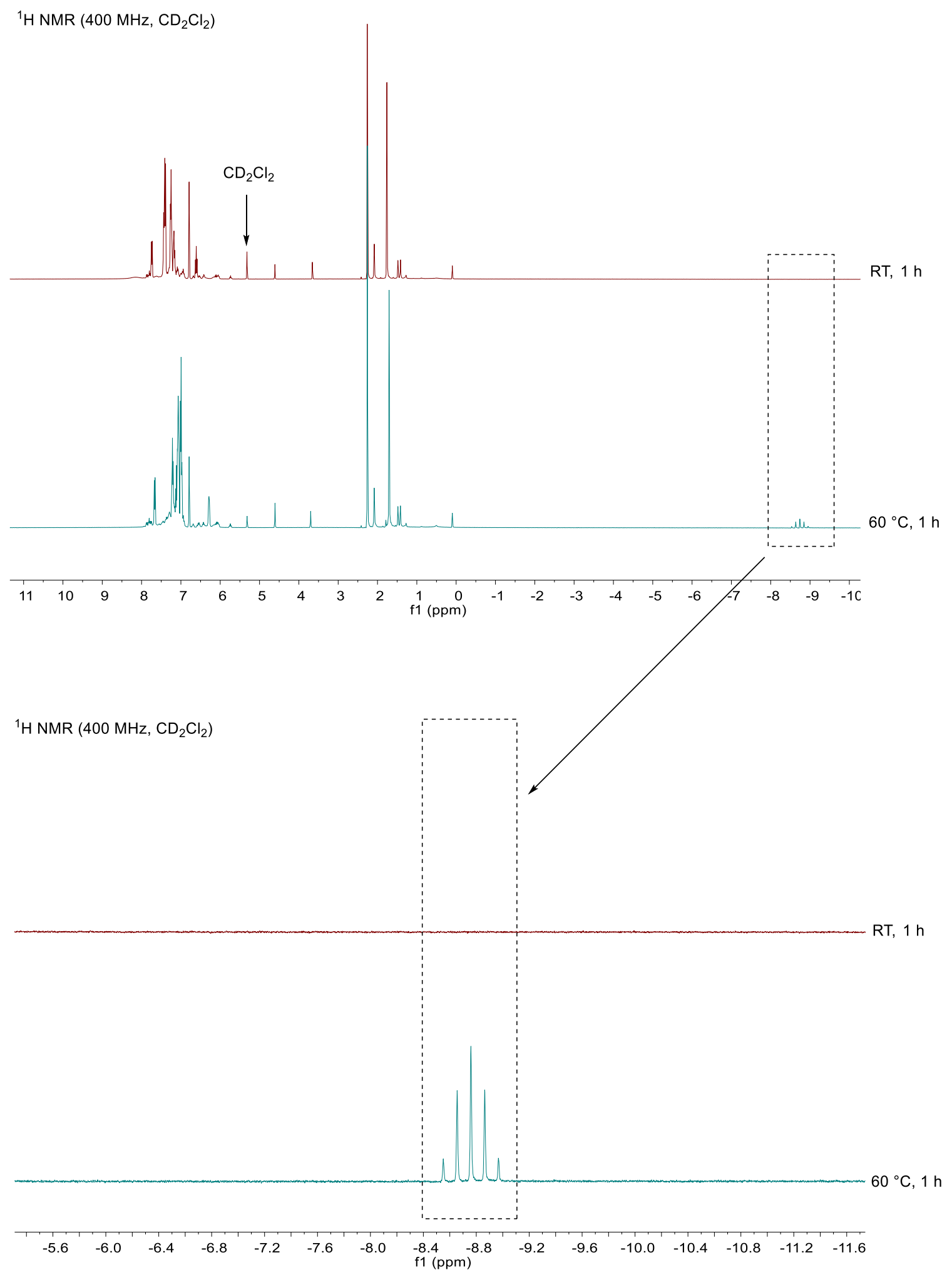

Fig. $S 4{ }^{1} H$ NMR spectra for the activation of xantphos-Pd(II) trifluoroacetate (prepared in situ, $\mathrm{Pd}(\mathrm{II})\left(\mathrm{OOCCF}_{3}\right)_{2}+1.0$ equiv. xantphos) under 6 bar syngas in $\mathrm{CD}_{2} \mathrm{Cl}_{2}$. 
${ }^{31} \mathrm{P}\left\{{ }^{1} \mathrm{H}\right\} \mathrm{NMR}\left(162 \mathrm{MHz}, \mathrm{CD}_{2} \mathrm{Cl}_{2}\right)$

$\mid$

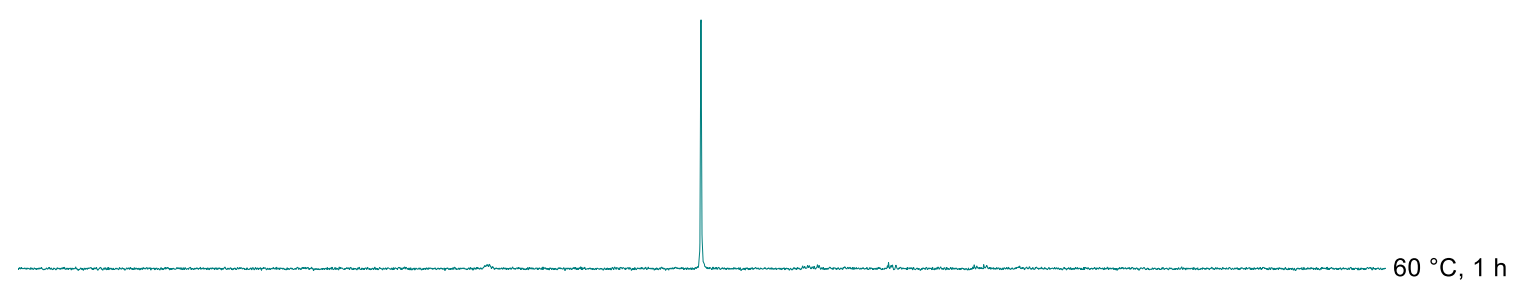

\begin{tabular}{llllllllllllllllllllllll}
\hline 26 & 24 & 22 & 20 & 18 & 16 & 14 & 12 & 10 & 8 & 6 & 4 & 4 & 4 & 0 & -2 & -4 & -6 & -8 & -10 & -12 & -14 & -16
\end{tabular}

Fig. S5 ${ }^{31} P\left({ }^{1} H\right\}$ NMR spectra for the activation of xantphos-Pd(II) trifluoroacetate (prepared in situ, $\mathrm{Pd}(\mathrm{II})\left(\mathrm{OOCCF}_{3}\right)_{2}+1.0$ equiv. xantphos) under 6 bar syngas in $\mathrm{CD}_{2} \mathrm{Cl}_{2}$. 


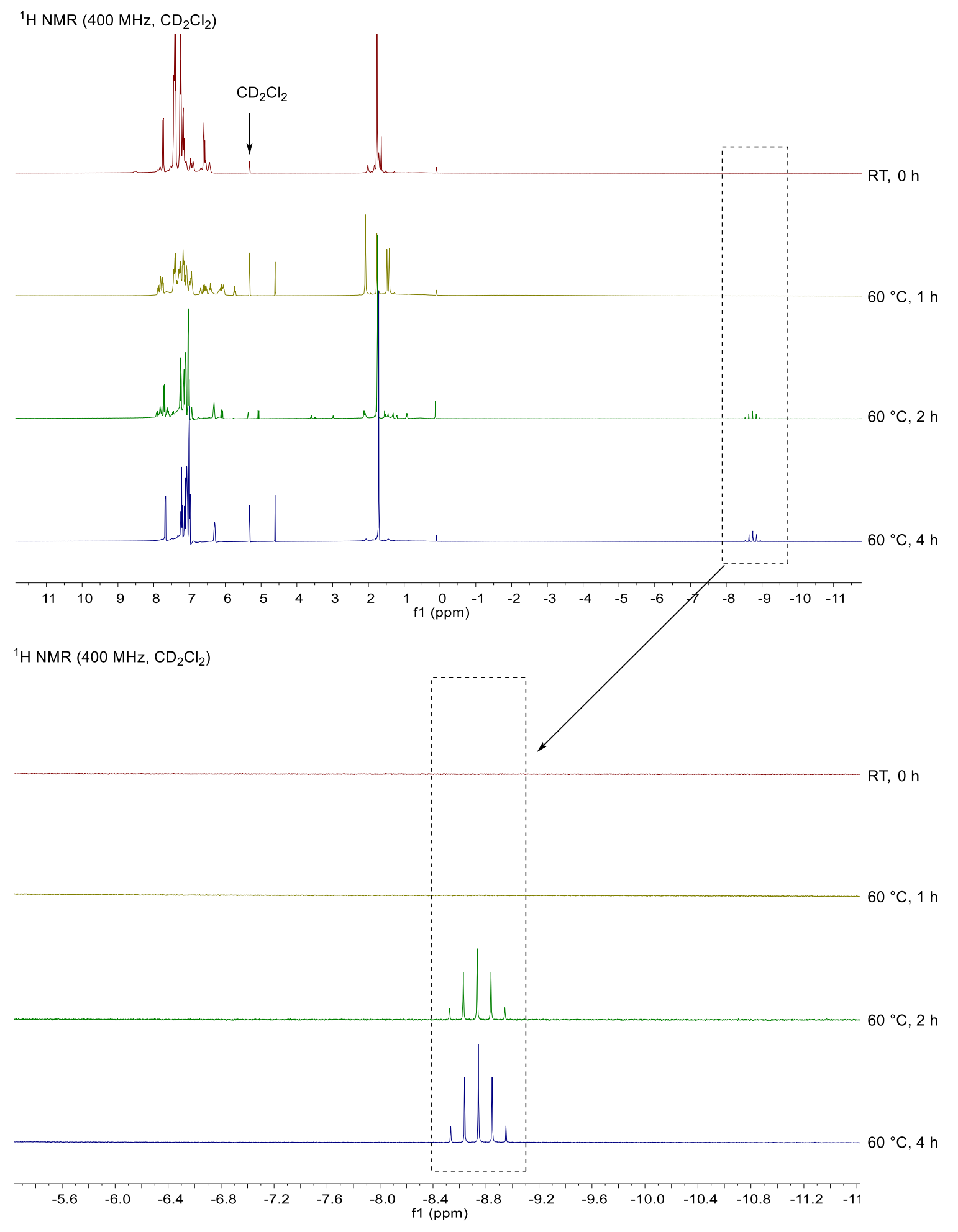

Fig. S6 ${ }^{1} H$ NMR spectra for the activation of xantphos-Pd(II) trifluoroacetate (prepared in situ, $\mathrm{Pd}(\mathrm{II})\left(\mathrm{OOCCF}_{3}\right)_{2}+1.1$ equiv. xantphos) under 6 bar syngas in $\mathrm{CD}_{2} \mathrm{Cl}_{2}$. 


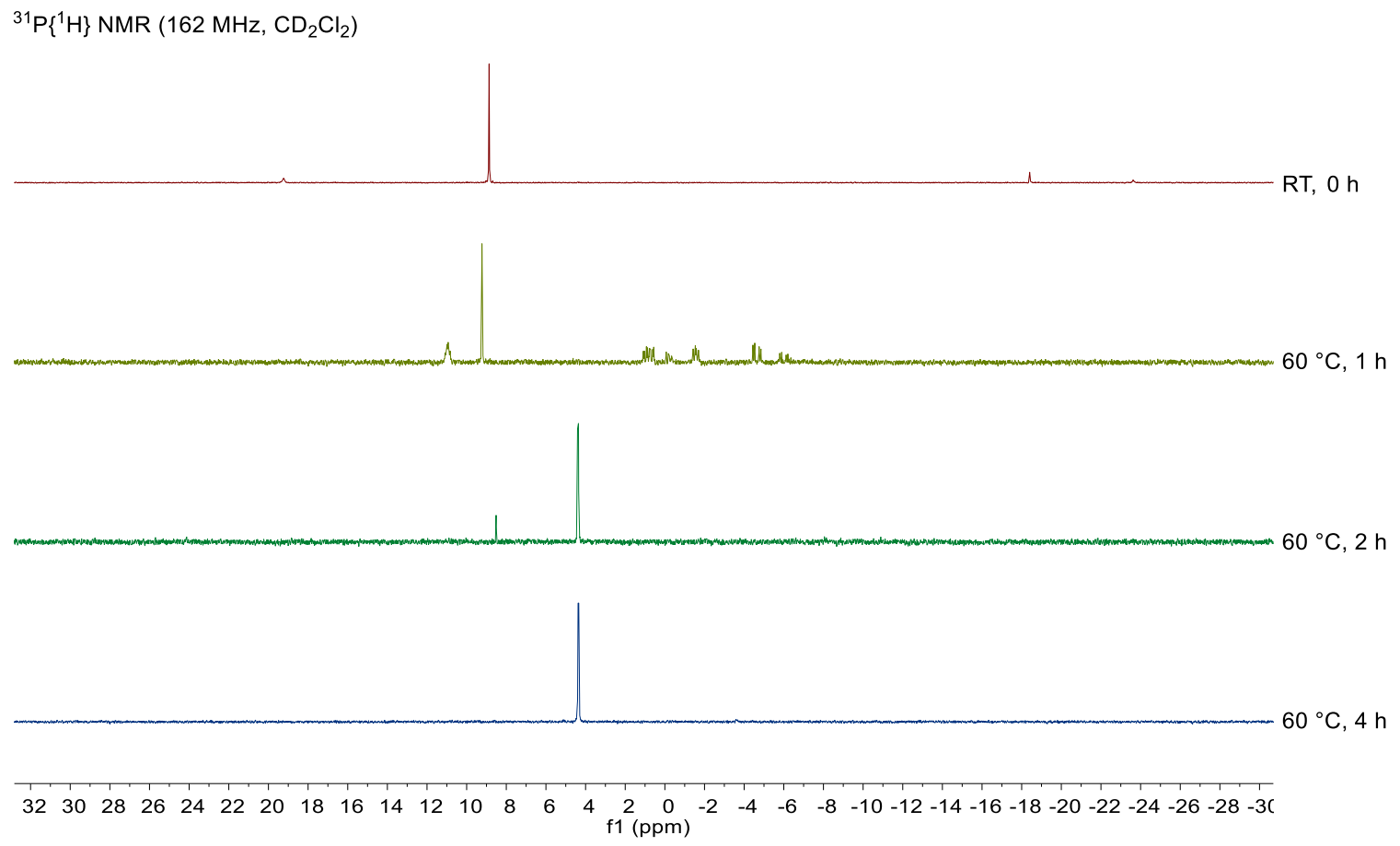

Fig. $\left.S 7^{31} P\left({ }^{1} H\right\}\right)$ NMR spectra for the activation of xantphos-Pd(II) trifluoroacetate (prepared in situ, $\mathrm{Pd}(\mathrm{II})\left(\mathrm{OOCCF}_{3}\right)_{2}+1.1$ equiv. xantphos) under 6 bar syngas in $\mathrm{CD}_{2} \mathrm{Cl}_{2}$. 


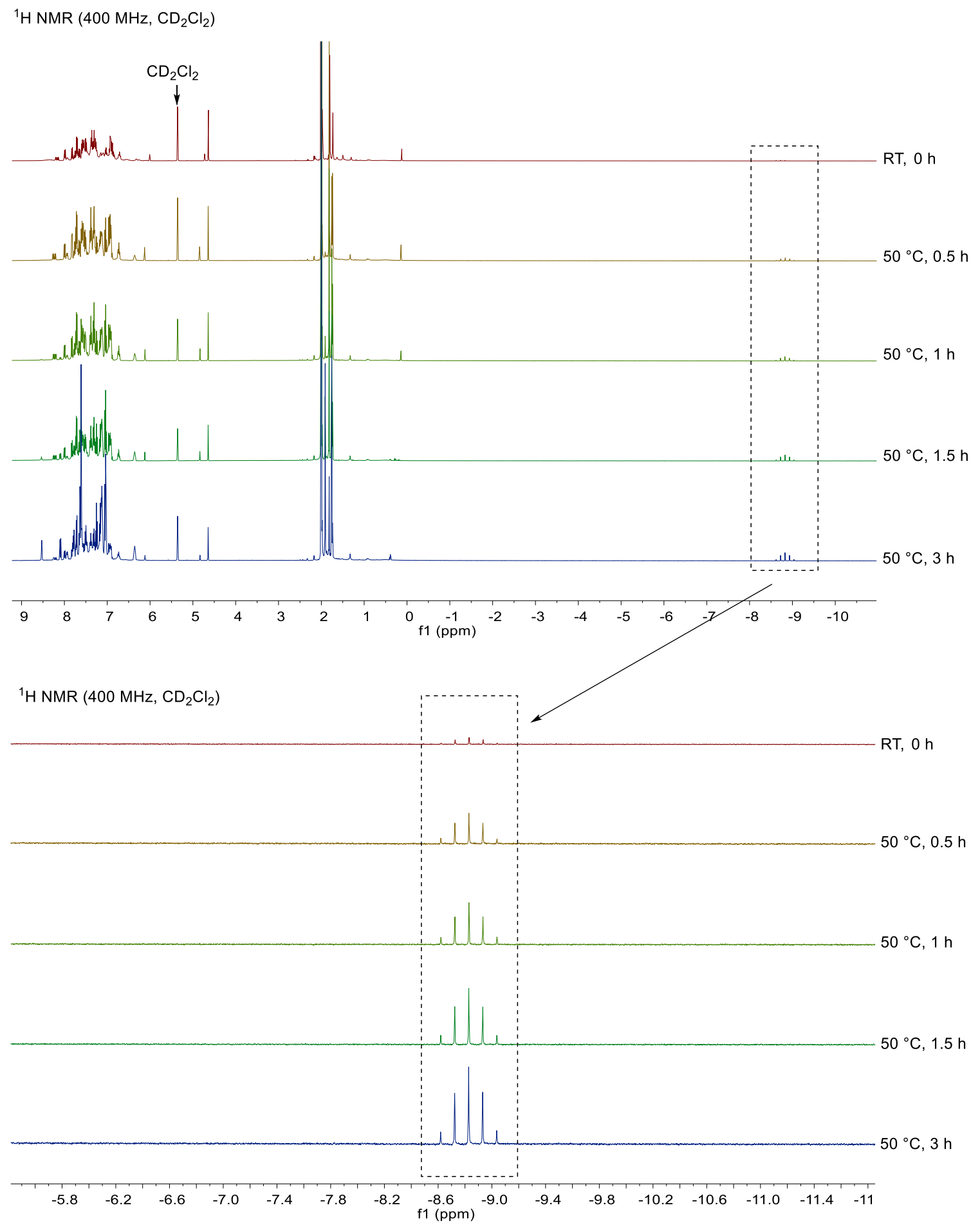

Fig. $S 8^{1} H$ NMR spectra for the activation of xantphos-Pd(II) tetrafluoroborate (prepared in situ, $\left[\mathrm{Pd}(\mathrm{II})\left(\mathrm{CH}_{3} \mathrm{CN}\right)_{4}\right]\left(\mathrm{BF}_{4}\right)_{2}+1.2$ equiv. xantphos $)$ under 6 bar syngas in $\mathrm{CD}_{2} \mathrm{Cl}_{2}$. 


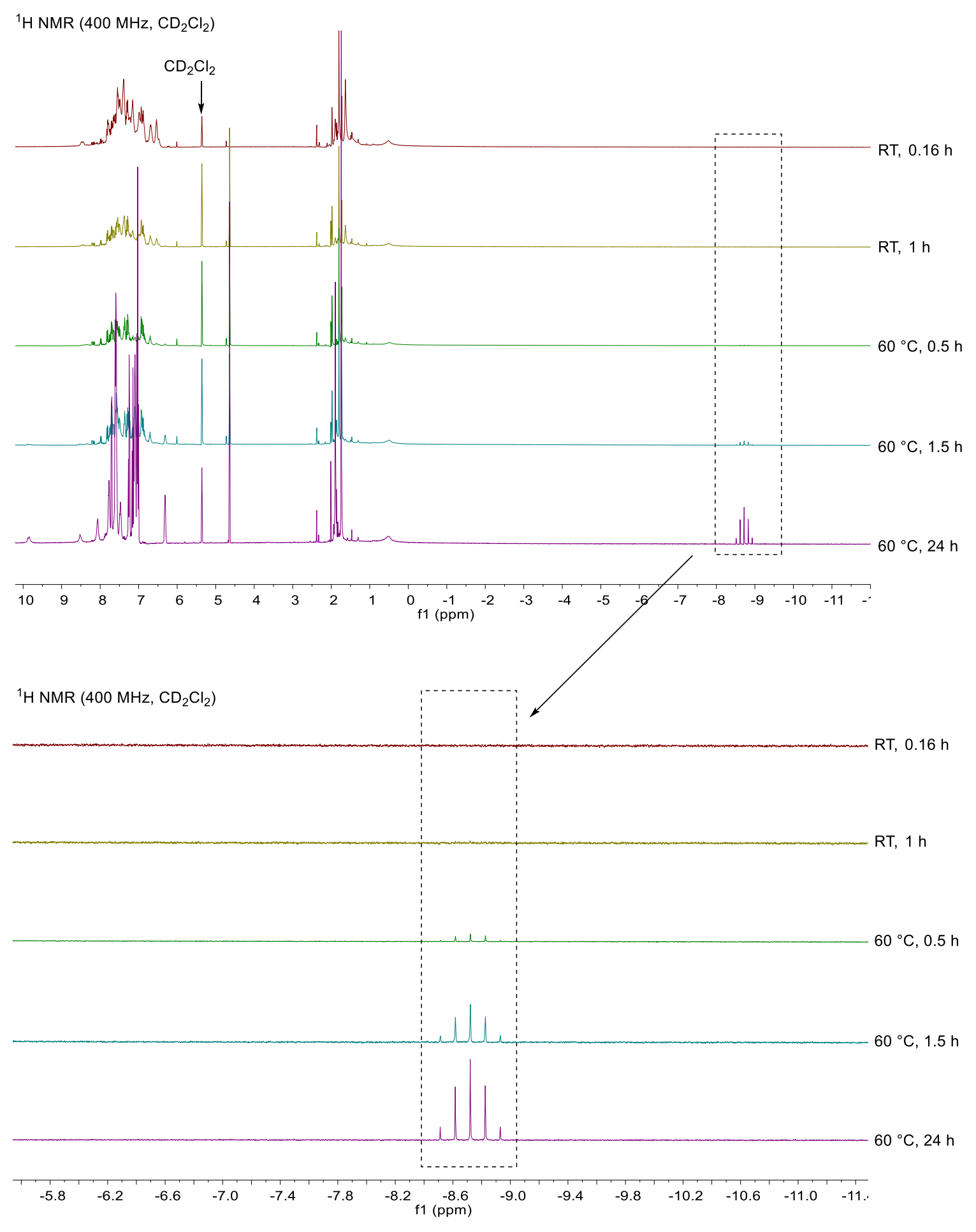

Fig. $S 9{ }^{1} H$ NMR spectra for the activation of preformed xantphos-Pd(II) tetrafluoroborate under 6 bar syngas in $\mathrm{CD}_{2} \mathrm{Cl}_{2}$. 

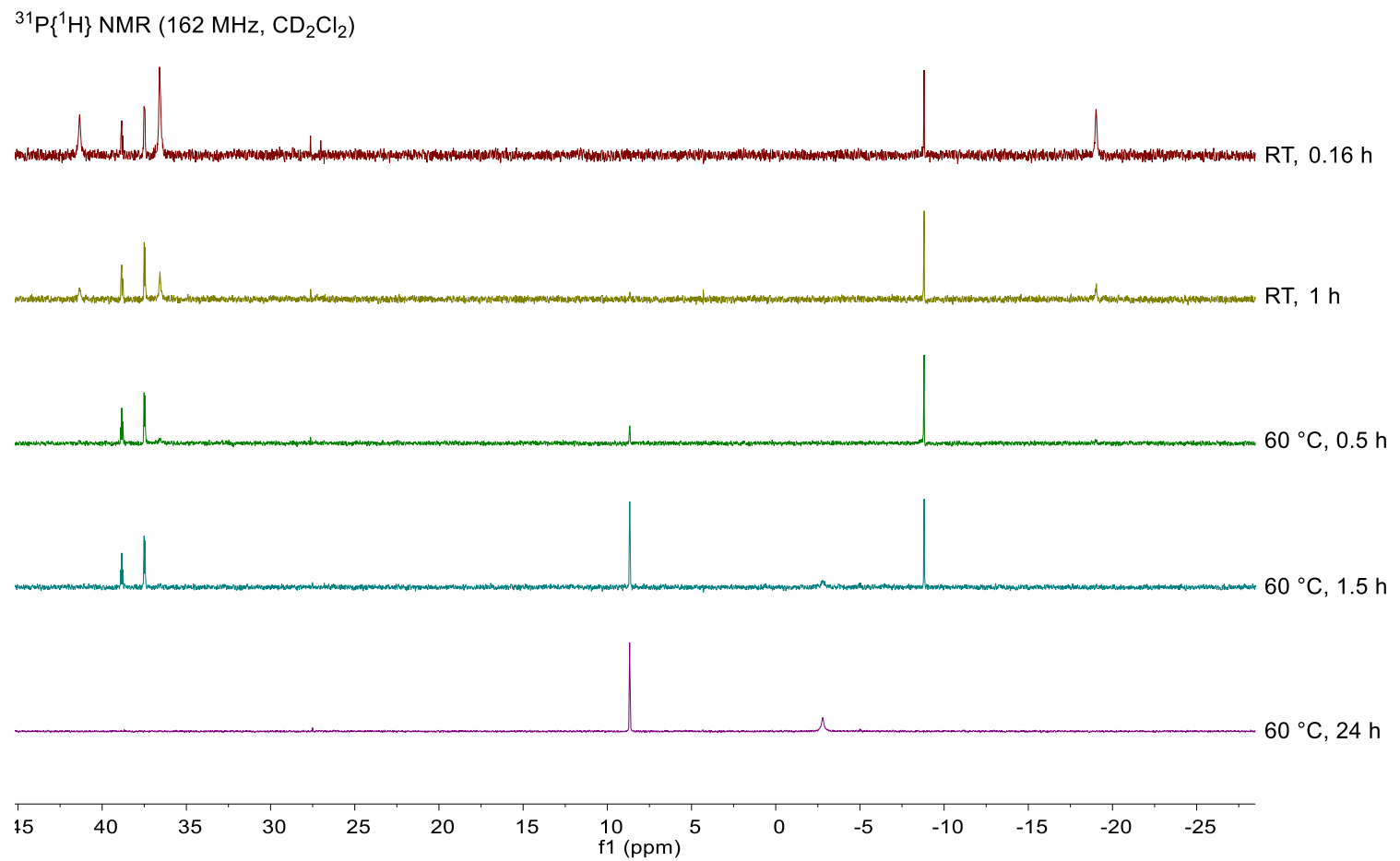

Fig. S10 ${ }^{31} P\left\{{ }^{1} H\right\} N M R$ spectra for the activation of preformed xantphos-Pd(II) tetrafluoroborate under 6 bar syngas in $\mathrm{CD}_{2} \mathrm{Cl}_{2}$. 


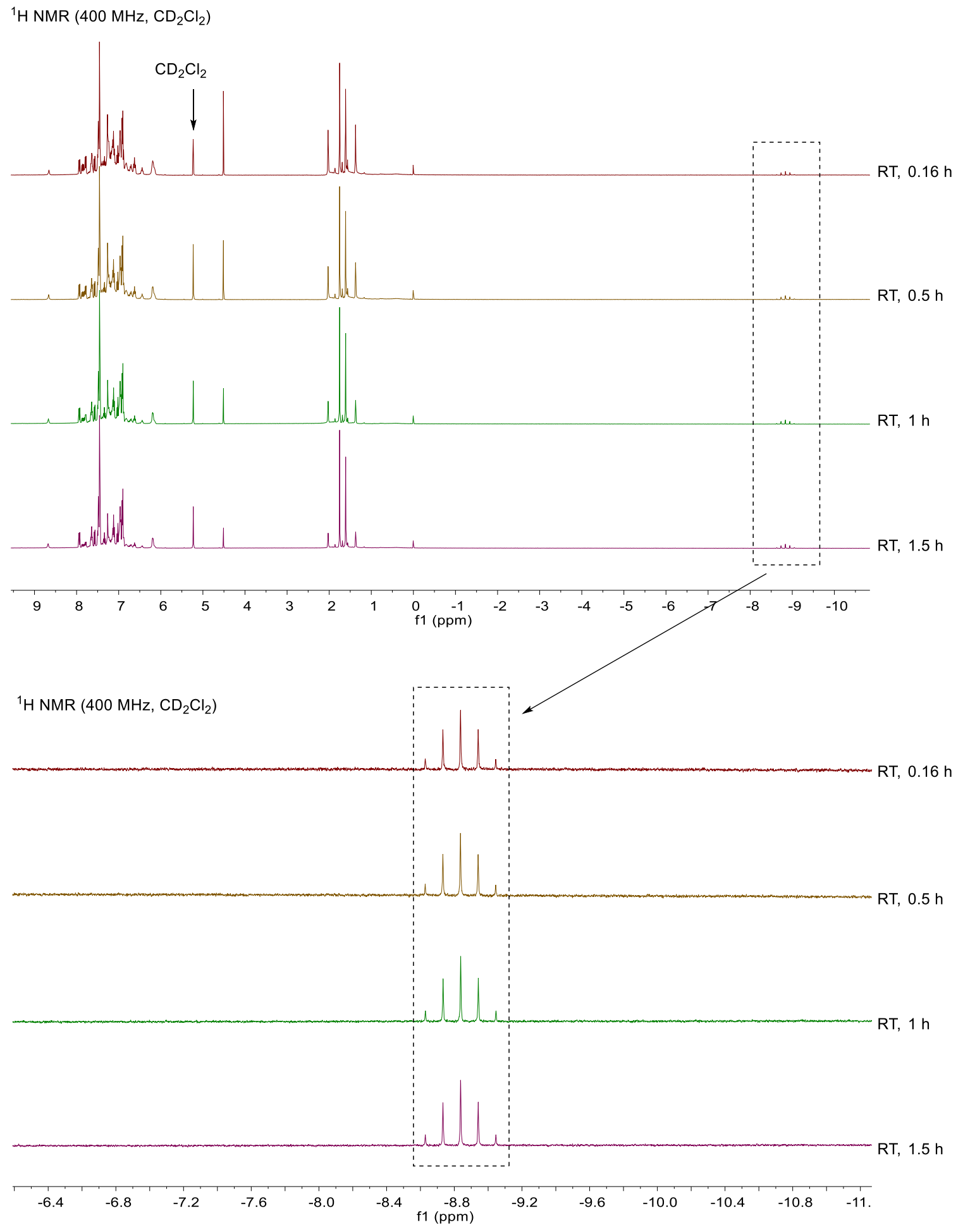

Fig. S11 ${ }^{1}$ H NMR spectra for the activation of xantphos-Pd(II) triflate (prepared separately) under 6 bar syngas in $\mathrm{CD}_{2} \mathrm{Cl}_{2}$. 
${ }^{31} \mathrm{P}\left\{{ }^{1} \mathrm{H}\right\}$ NMR $\left(162 \mathrm{MHz}, \mathrm{CD}_{2} \mathrm{Cl}_{2}\right)$
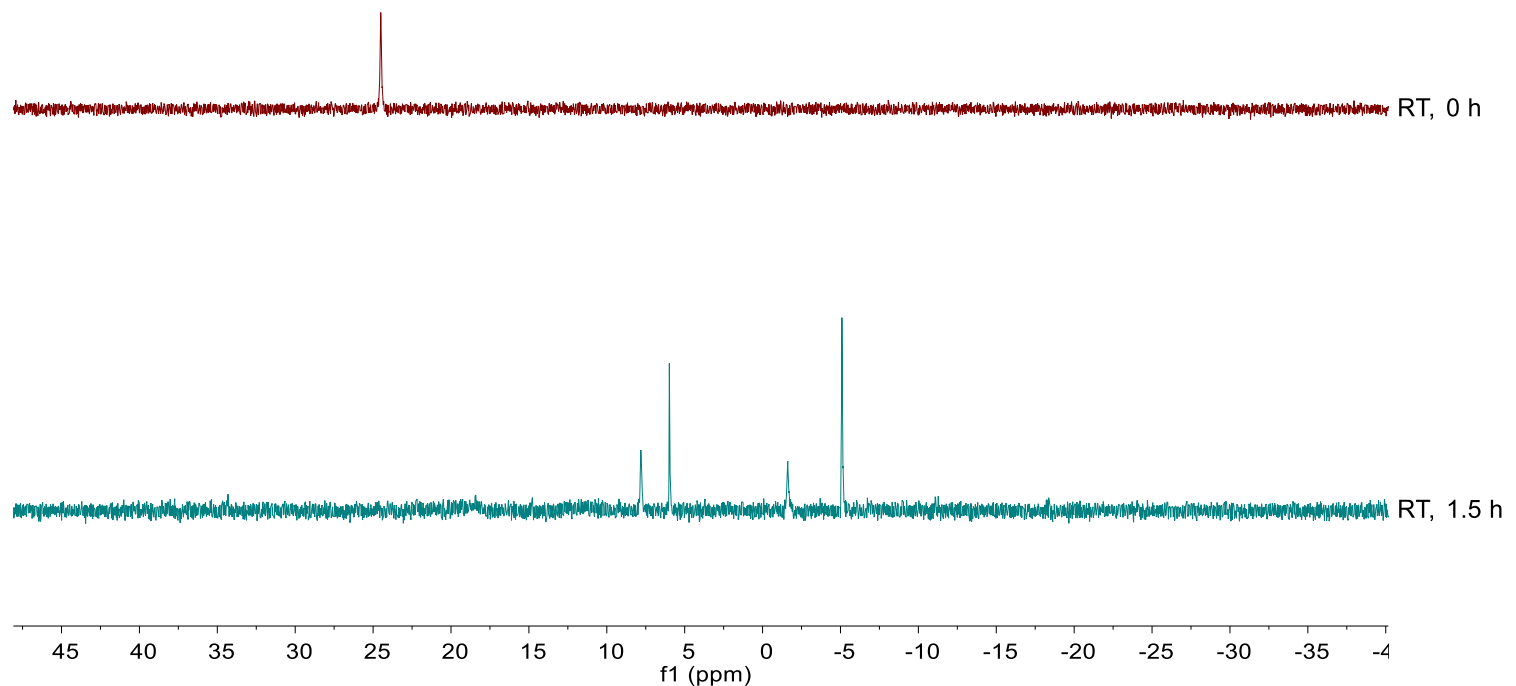

Fig. S12 ${ }^{31} P\left\{{ }^{1} H\right\}$ NMR spectra for the activation of xantphos-Pd(II) triflate (prepared separately) under 6 bar syngas in $\mathrm{CD}_{2} \mathrm{Cl}_{2}$. 


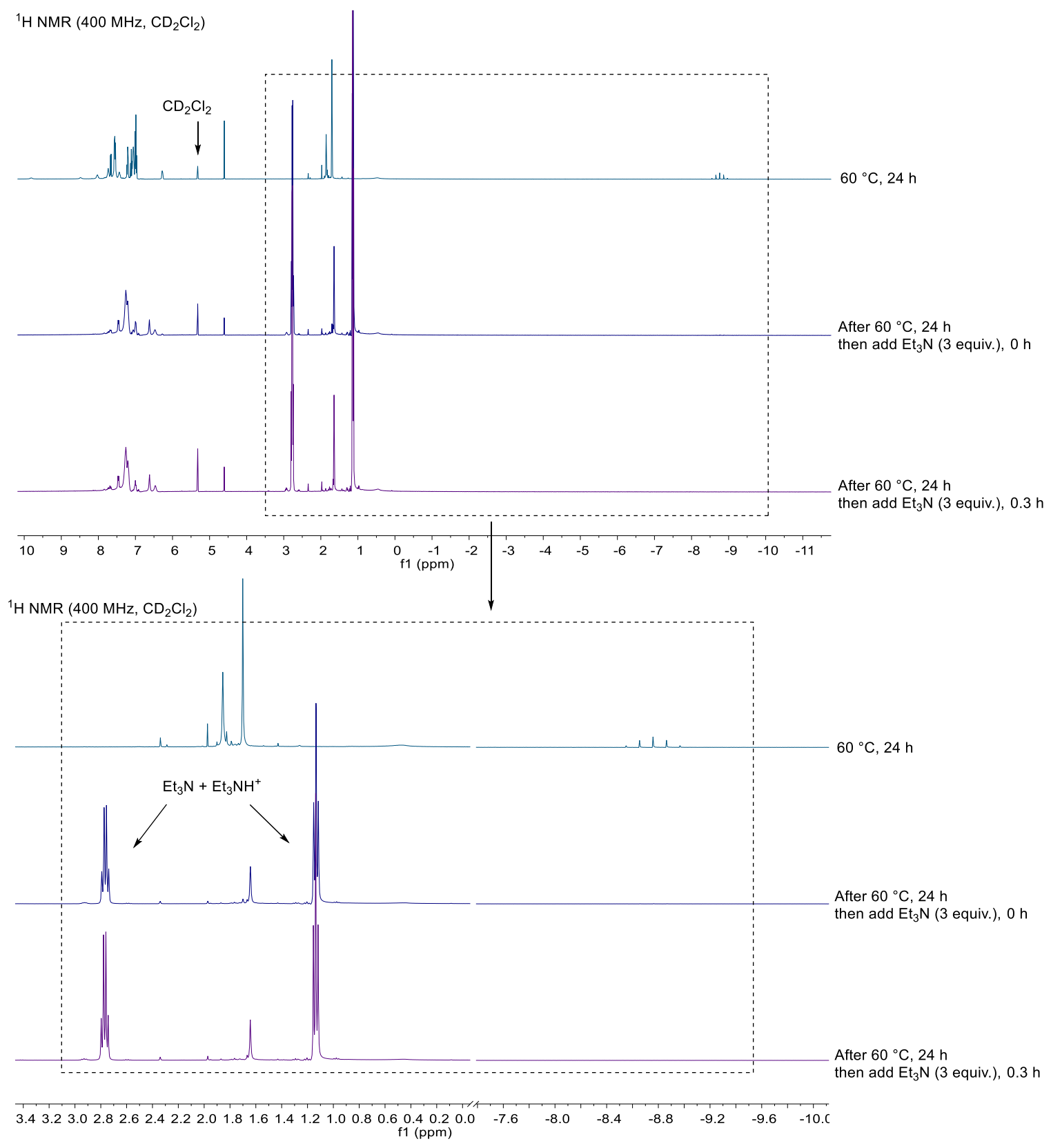

Fig. $S 13{ }^{1}$ H NMR spectra for the (activated) xantphos-Pd-hydride complex (bearing a tetrafluoroborate) upon addition of $\mathrm{Et}_{3} \mathrm{~N}$ (3 equiv.) in $\mathrm{CD}_{2} \mathrm{Cl}_{2}$. 
${ }^{31} \mathrm{P}\left\{{ }^{1} \mathrm{H}\right\} \mathrm{NMR}\left(162 \mathrm{MHz}, \mathrm{CD}_{2} \mathrm{Cl}_{2}\right)$

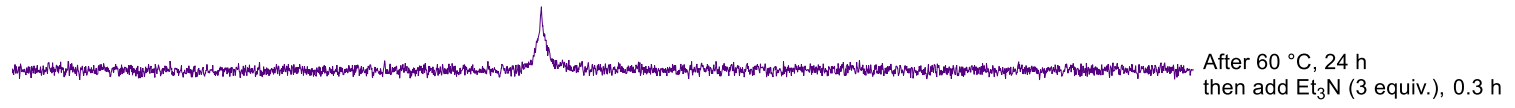

$\begin{array}{llllllllllllllllllllllllllll}20 & 19 & 18 & 17 & 16 & 15 & 14 & 13 & 12 & 11 & 10 & \underset{\mathrm{f} 1}{9(\mathrm{ppm})} \mathbf{8} & 7 & 6 & 5 & 4 & 3 & 2 & 1 & 0 & -1 & -2 & -3 & -4\end{array}$

Fig. $S 14{ }^{31} P\left\{{ }^{1} H\right\} N M R$ spectra for the (activated) xantphos-Pd-hydride complex (bearing a tetrafluoroborate) upon addition of $E t_{3} \mathrm{~N}$ (3 equiv.) in $\mathrm{CD}_{2} \mathrm{Cl}_{2}$. 


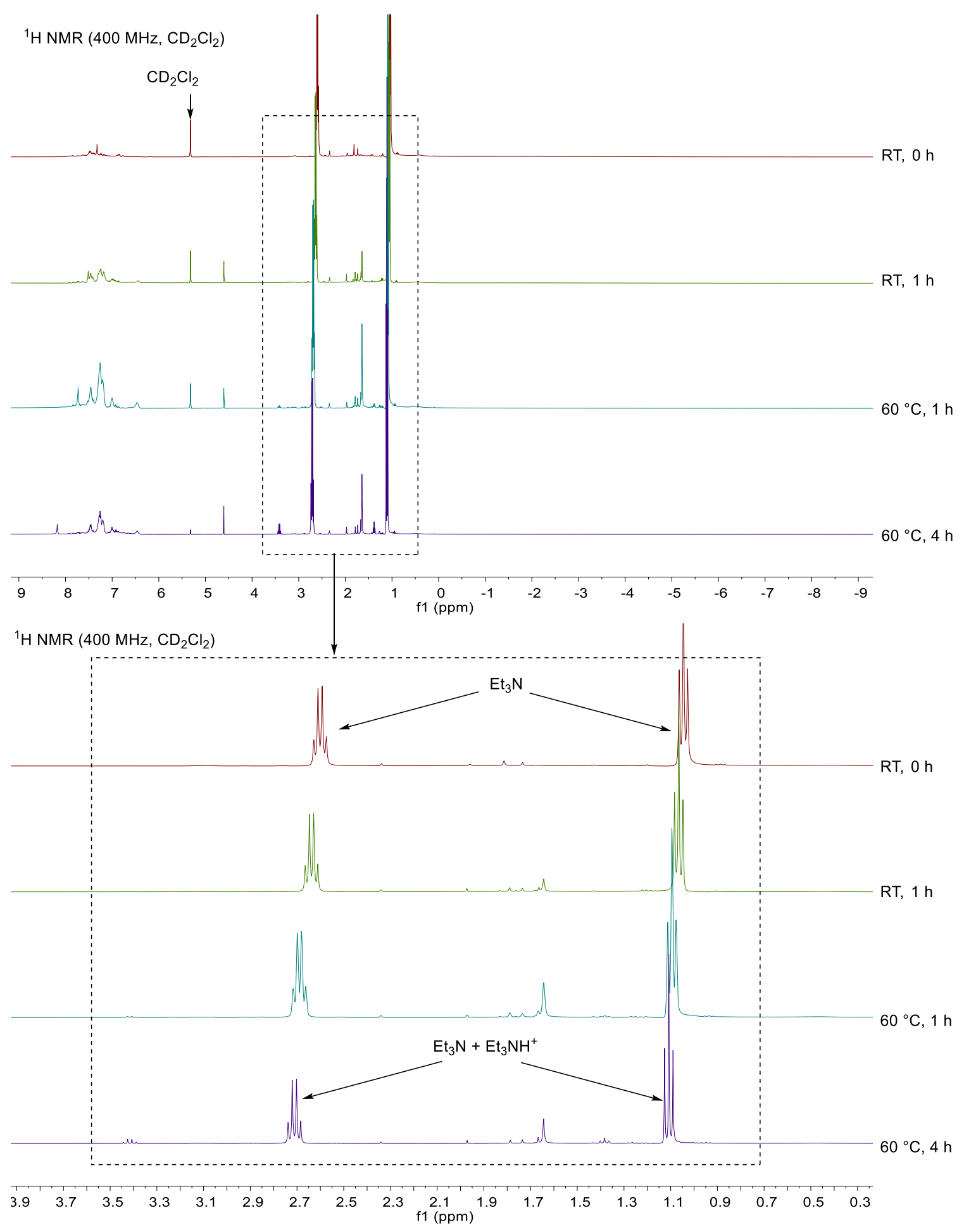

Fig. S15 ${ }^{1} H$ NMR spectra for the activation of preformed xantphos-Pd(II) tetrafluoroborate in the presence of 3 equiv. of Et ${ }_{3} \mathrm{~N}$ under 6 bar syngas in $\mathrm{CD}_{2} \mathrm{Cl}_{2}$. 
${ }^{31} \mathrm{P}\left\{{ }^{1} \mathrm{H}\right\}$ NMR $\left(162 \mathrm{MHz}, \mathrm{CD}_{2} \mathrm{Cl}_{2}\right)$

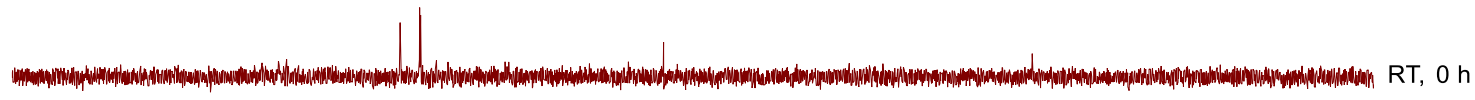
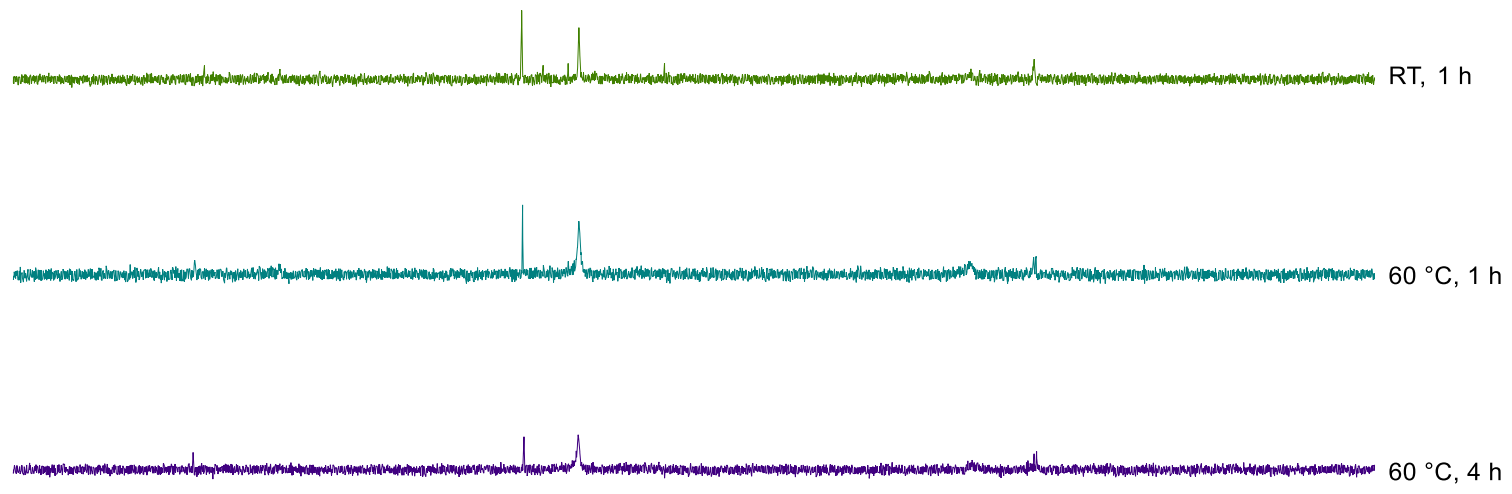

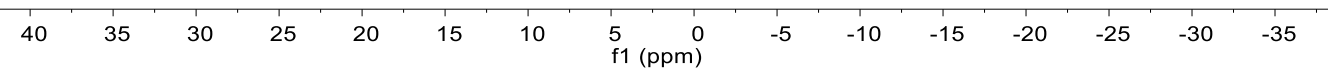

Fig. $S 16{ }^{31} P\left\{{ }^{1} H\right\}$ NMR spectra for the activation of preformed xantphos-Pd(II) tetrafluoroborate in the presence of 3 equiv. of Et $t_{3} \mathrm{~N}$ under 6 bar syngas in $\mathrm{CD}_{2} \mathrm{Cl}_{2}$. 


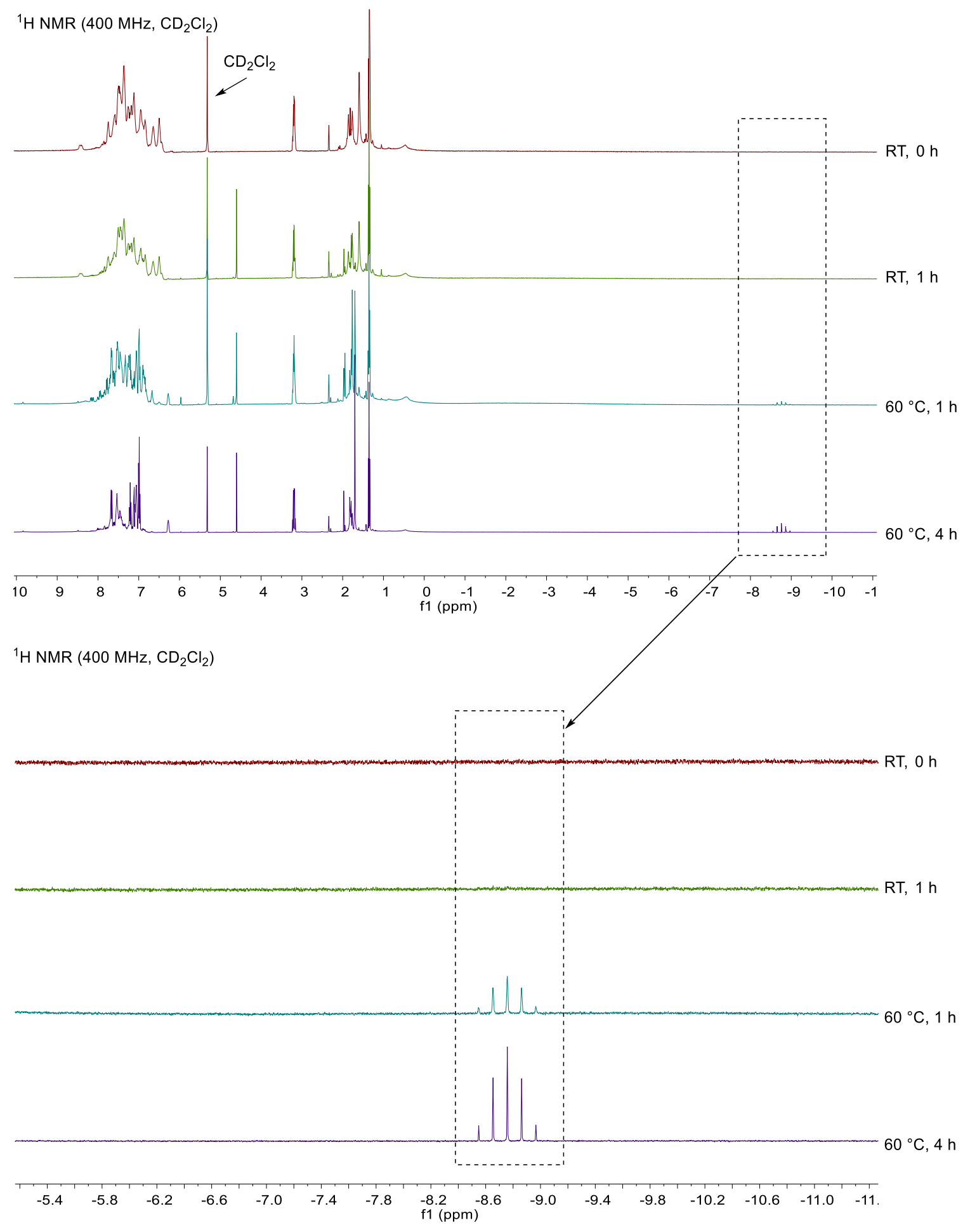

Fig. S17 ${ }^{1} H$ NMR spectra for the activation of preformed xantphos-Pd(II) tetrafluoroborate in the presence of 0.5 equiv. of Et $t_{3} \mathrm{~N}$ under 6 bar syngas in $\mathrm{CD}_{2} \mathrm{Cl}_{2}$. 
${ }^{31} \mathrm{P}\left\{{ }^{1} \mathrm{H}\right\} \operatorname{NMR}\left(162 \mathrm{MHz}, \mathrm{CD}_{2} \mathrm{Cl}_{2}\right)$
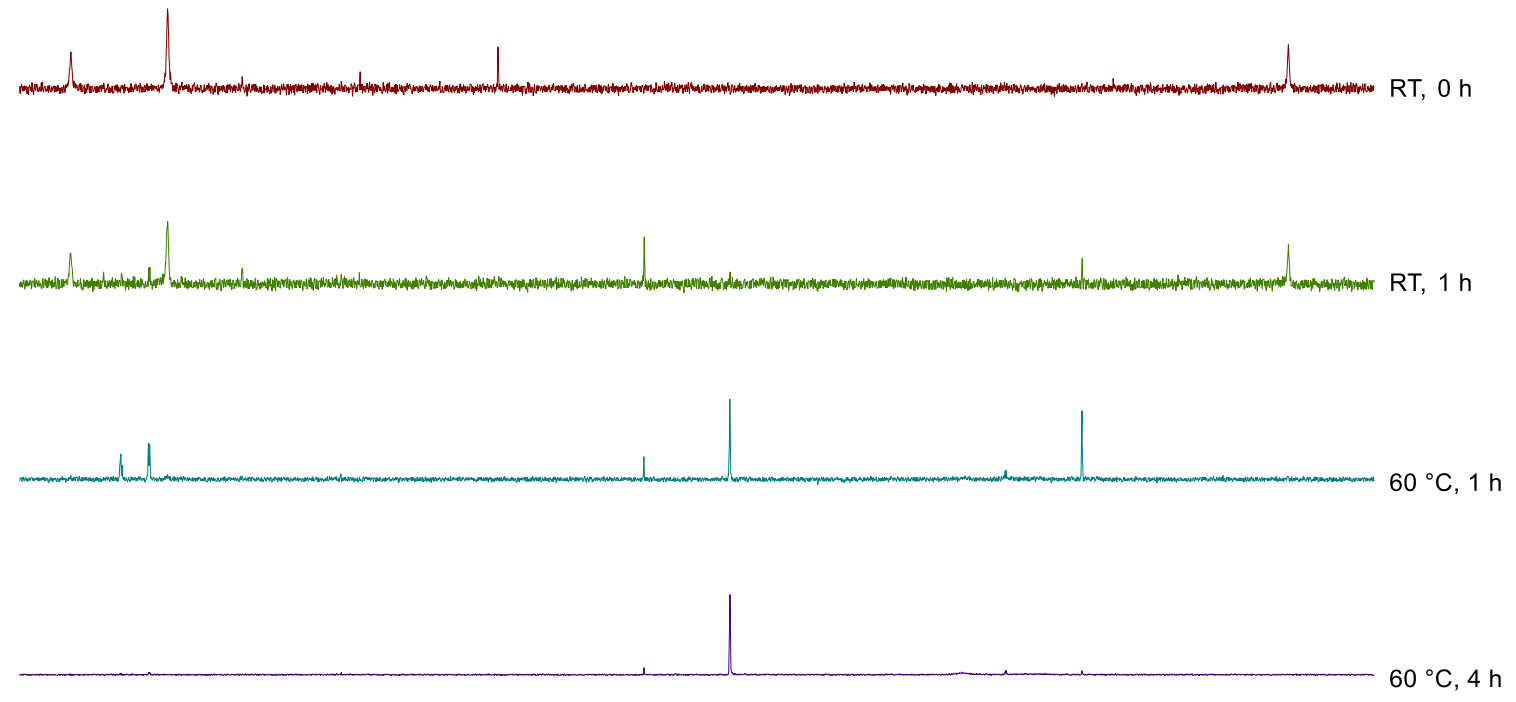

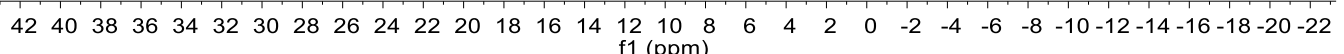

Fig. $S 18{ }^{31} P\left\{{ }^{1} H\right\}$ NMR spectra for the activation of preformed xantphos-Pd(II) tetrafluoroborate in the presence of 0.5 equiv. of Et ${ }_{3} \mathrm{~N}$ under 6 bar syngas in $\mathrm{CD}_{2} \mathrm{Cl}_{2}$. 

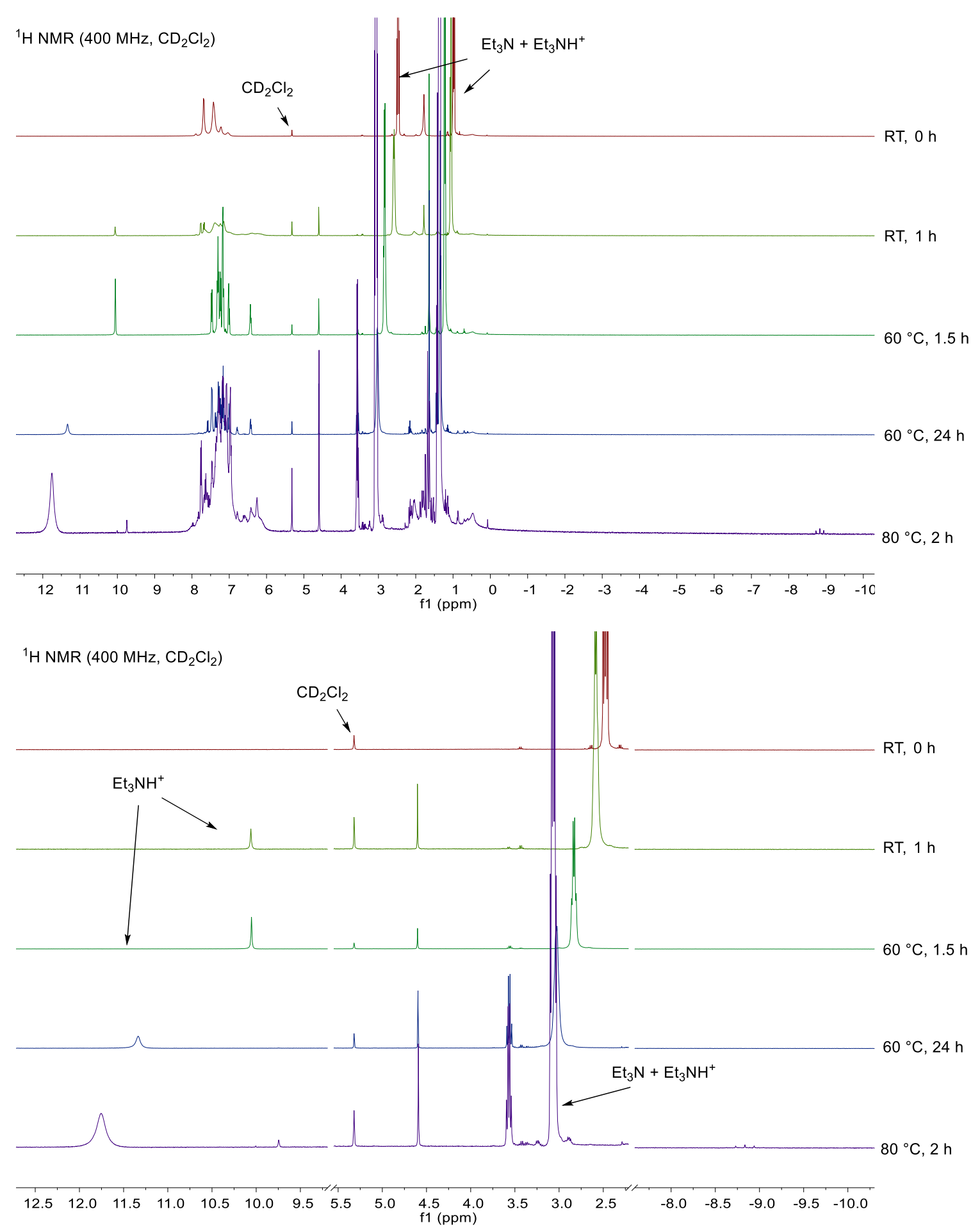

Fig. S19 ${ }^{1} H$ NMR spectra for the activation of preformed xantphos-Pd(II) iodide in the presence of 3 equiv. of Et $t_{3} \mathrm{~N}$ under 6 bar syngas in $\mathrm{CD}_{2} \mathrm{Cl}_{2}$. Shift of the signals of Et $t_{3} \mathrm{~N}$ over time indicates formation of increasing amount of $\mathrm{HI}$, which forms $\mathrm{Et}_{3} \mathrm{NH}^{+}$. 
${ }^{31} \mathrm{P}\left\{{ }^{1} \mathrm{H}\right\}$ NMR $\left(162 \mathrm{MHz}, \mathrm{CD}_{2} \mathrm{Cl}_{2}\right)$

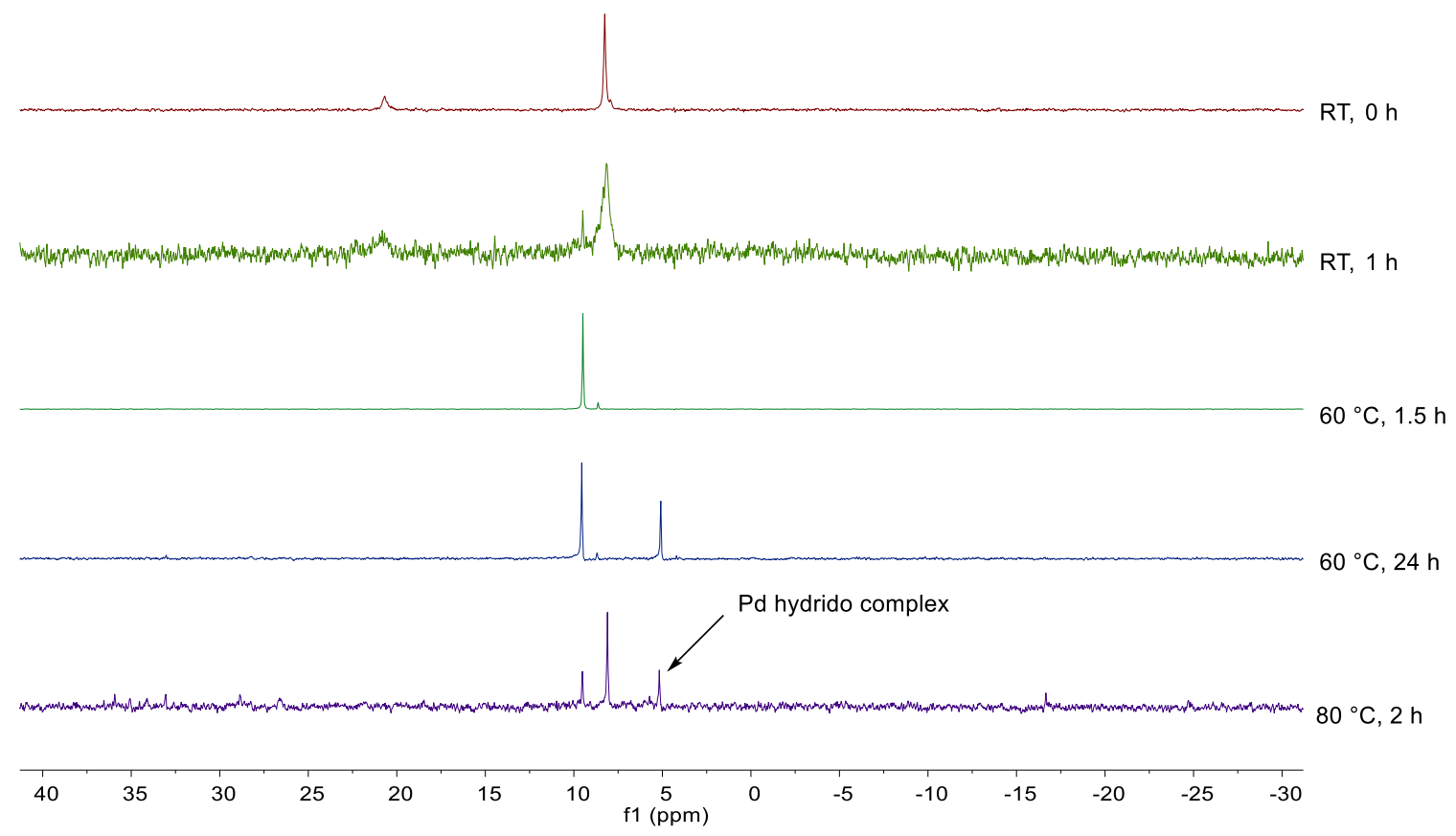

Fig. S20 ${ }^{31} P\left\{{ }^{1} H\right\} N M R$ spectra for the activation of preformed xantphos-Pd(II) iodide in the presence of 3 equiv. of $\mathrm{Et}_{3} \mathrm{~N}$ under 6 bar syngas in $\mathrm{CD}_{2} \mathrm{Cl}_{2}$.

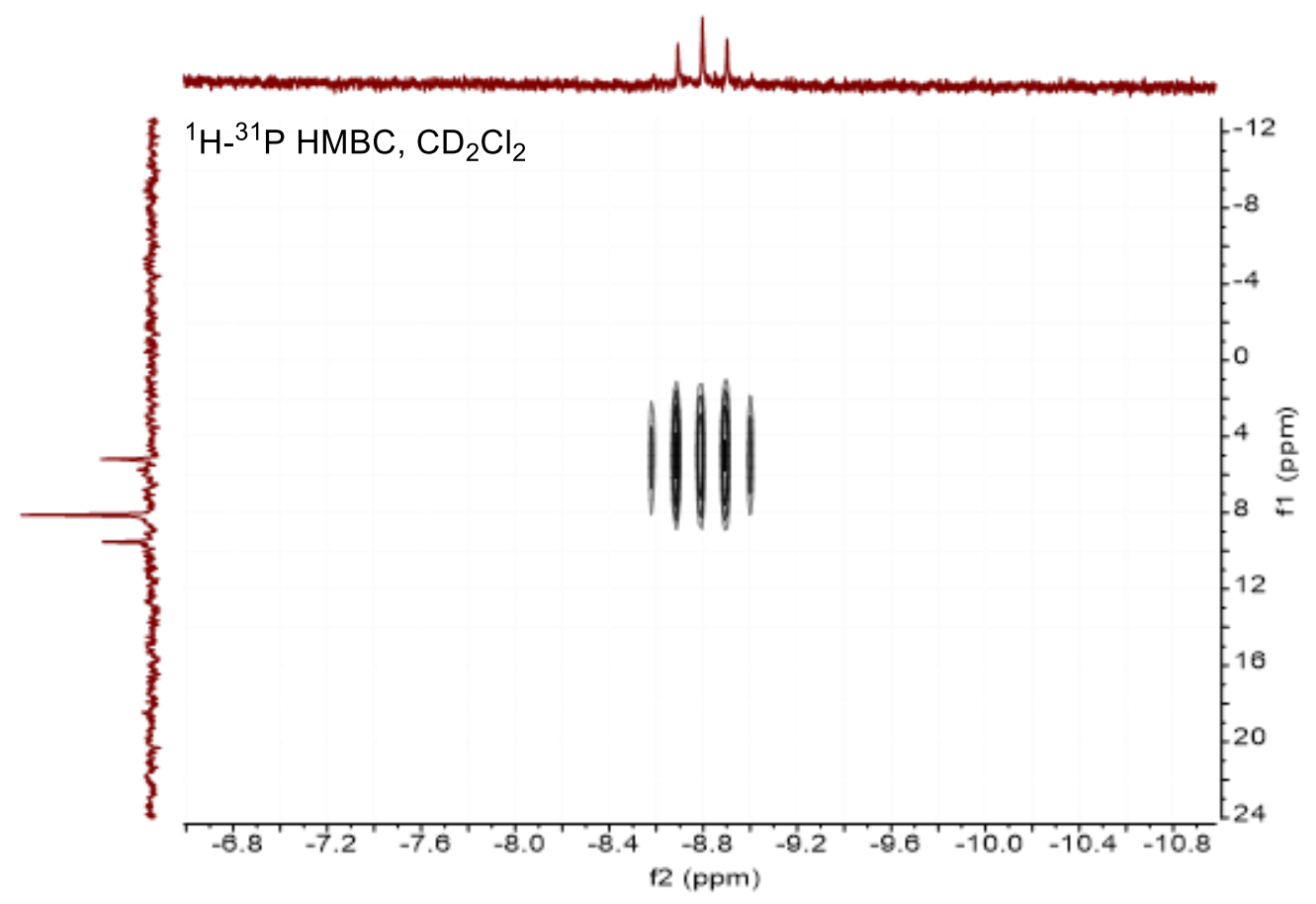

Fig. S21 ${ }^{1} H_{-}{ }^{31} P$ HMBC NMR spectrum of the xantphos-Pd(II) iodide complex in the presence of 3 equiv. of Et $t_{3} \mathrm{~N}$ treated at $80^{\circ} \mathrm{C}$ under 6 bar syngas for 90 min in $\mathrm{CD}_{2} \mathrm{Cl}_{2}$. 

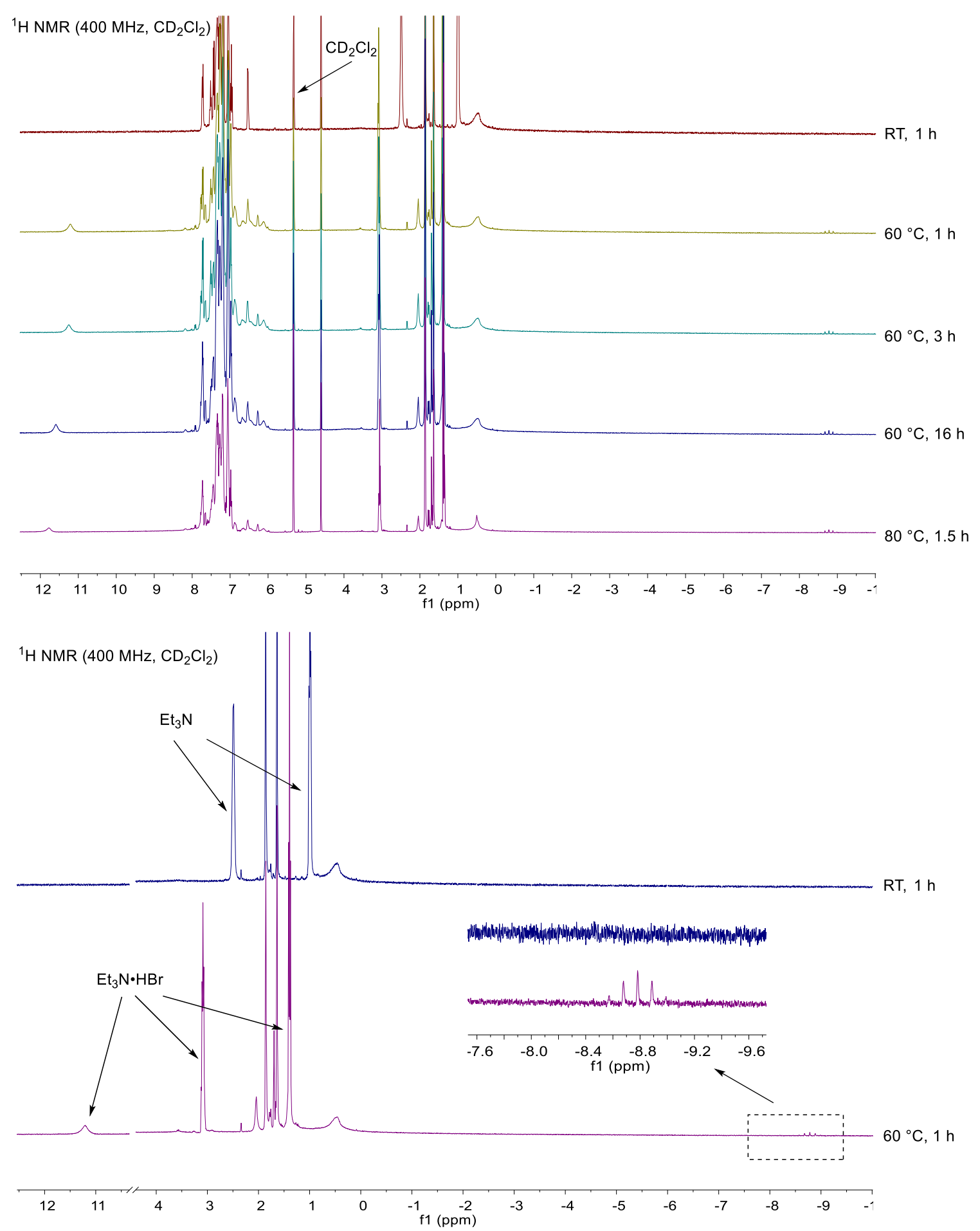

Fig. S22 ${ }^{1}$ H NMR spectra for the activation of preformed xantphos-Pd(II) bromide in the presence of 0.5 equiv. of $\mathrm{Et}_{3} \mathrm{~N}$ under 6 bar syngas in $\mathrm{CD}_{2} \mathrm{Cl}_{2}$. 


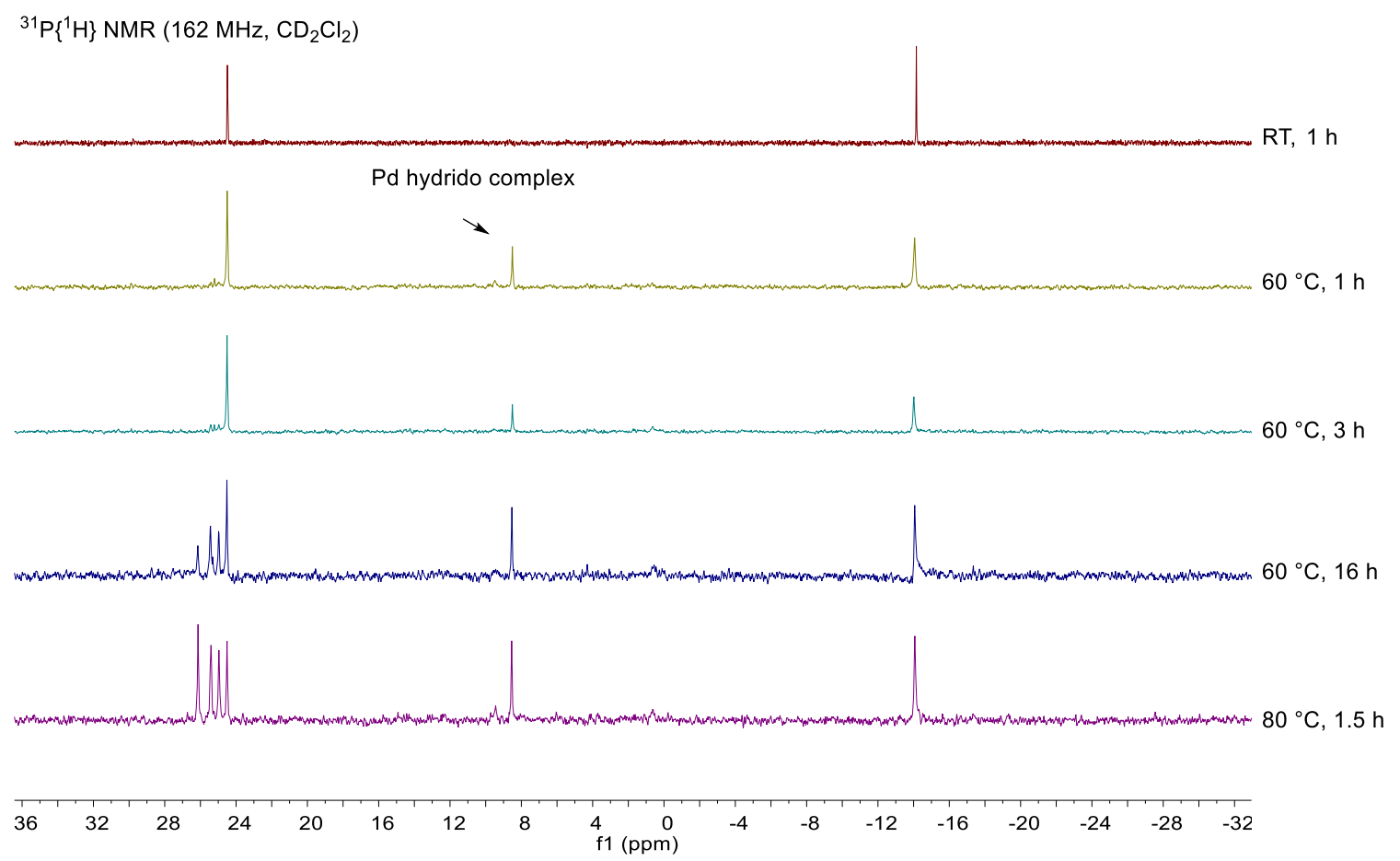

Fig. $\mathbf{S 2 3}{ }^{31} P\left\{{ }^{1} H\right\}$ NMR spectra for the activation of preformed xantphos-Pd(II) bromide in the presence of 0.5 equiv. of Et $t_{3} \mathrm{~N}$ under 6 bar syngas in $\mathrm{CD}_{2} \mathrm{Cl}_{2}$. 

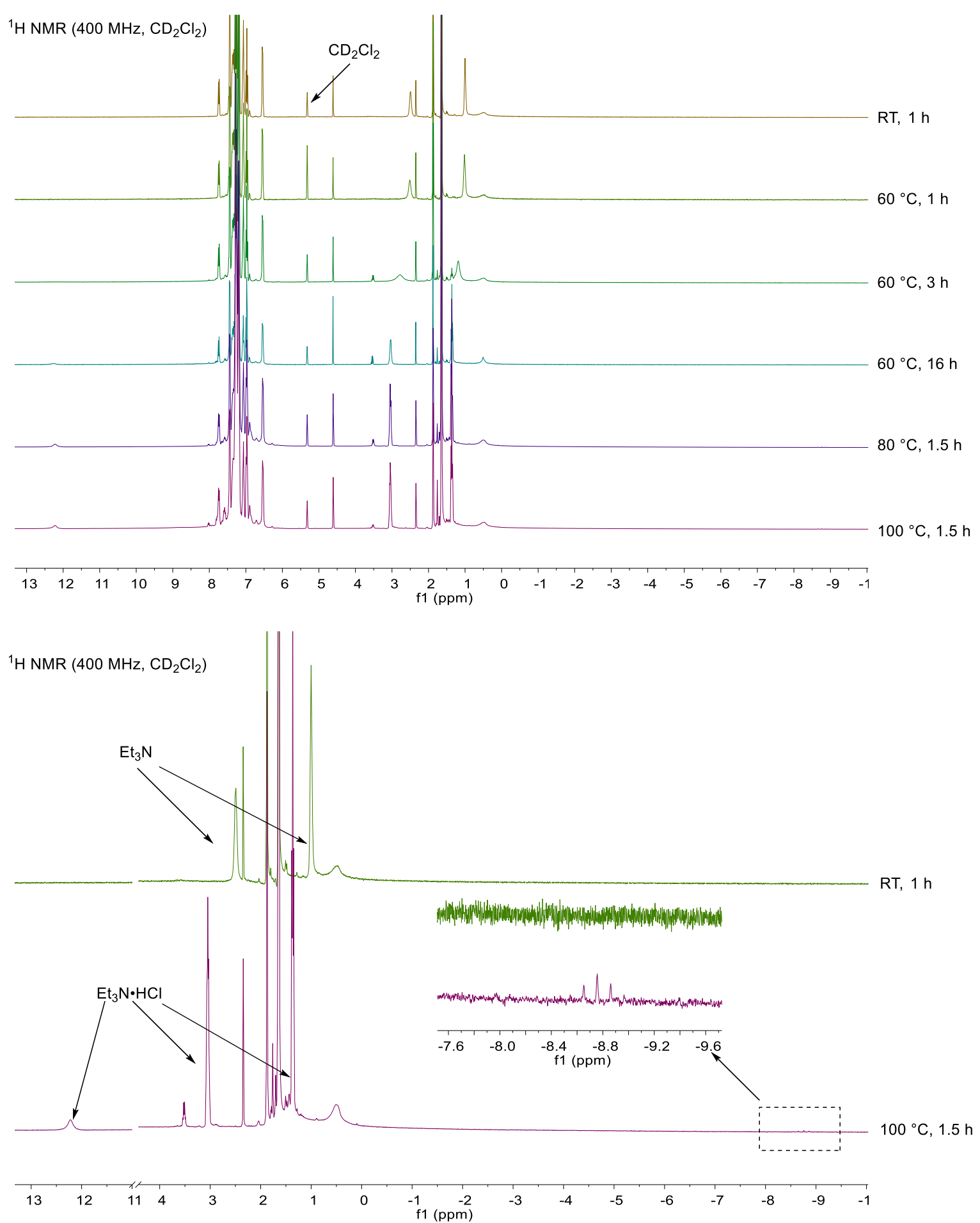

Fig. S24 ${ }^{1} H$ NMR spectra for the activation of preformed xantphos-Pd(II) chloride in the presence of 0.5 equiv. of Et ${ }_{3} \mathrm{~N}$ under 6 bar syngas in $\mathrm{CD}_{2} \mathrm{Cl}_{2}$. 


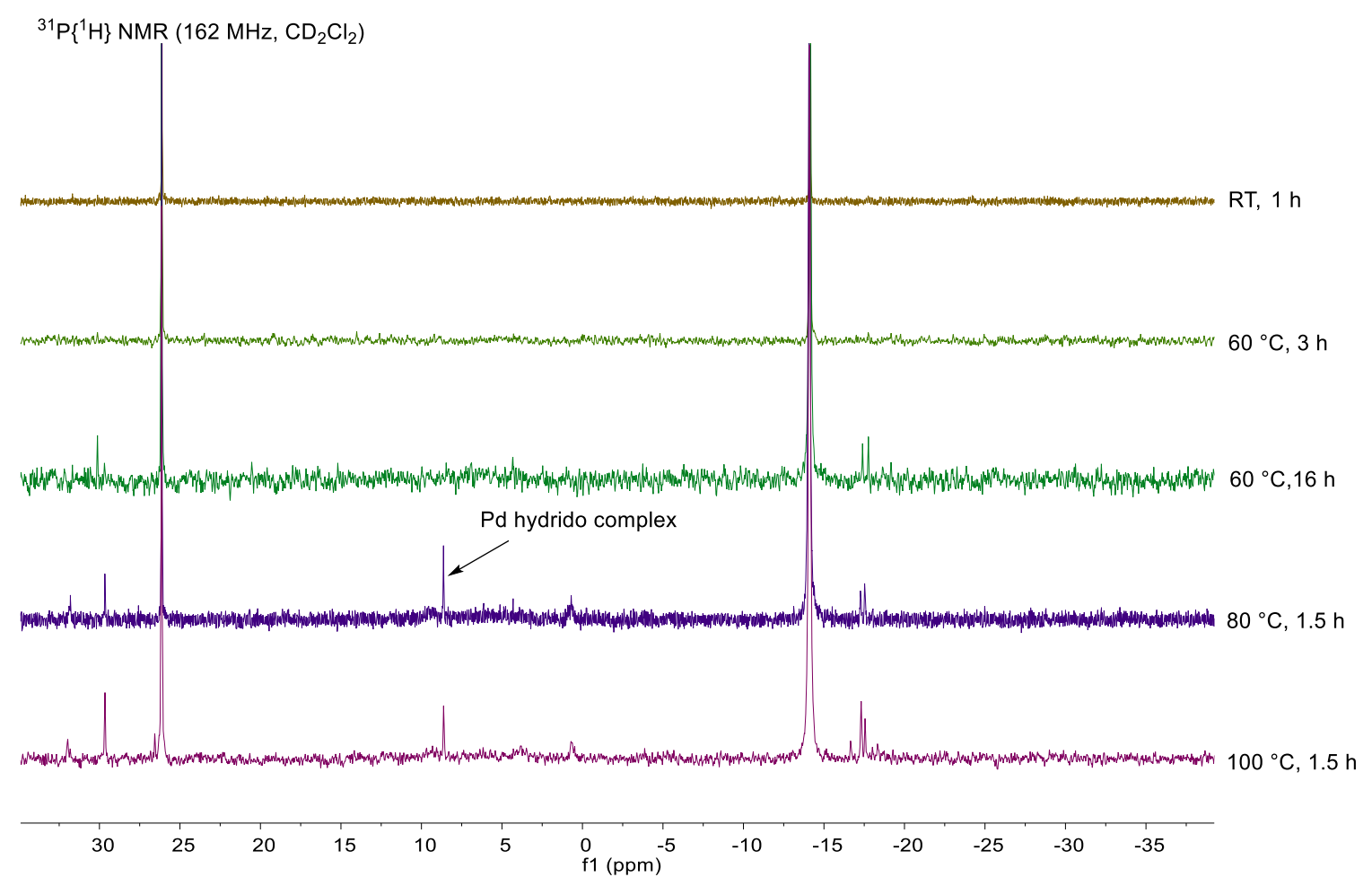

Fig. S25 ${ }^{31} P\left\{{ }^{1} \mathrm{H}\right\}$ NMR spectra for the activation of preformed xantphos-Pd(II) chloride in the presence of 0.5 equiv. of Et $t_{3} \mathrm{~N}$ under 6 bar syngas in $\mathrm{CD}_{2} \mathrm{Cl}_{2}$.

\subsubsection{Preparative synthesis of $\left[(\text { xantphos })_{2} \mathrm{Pd}_{2}(\mu-\mathrm{H})(\mu-\mathrm{CO})\right]^{+} \mathrm{TFA}^{-}$}

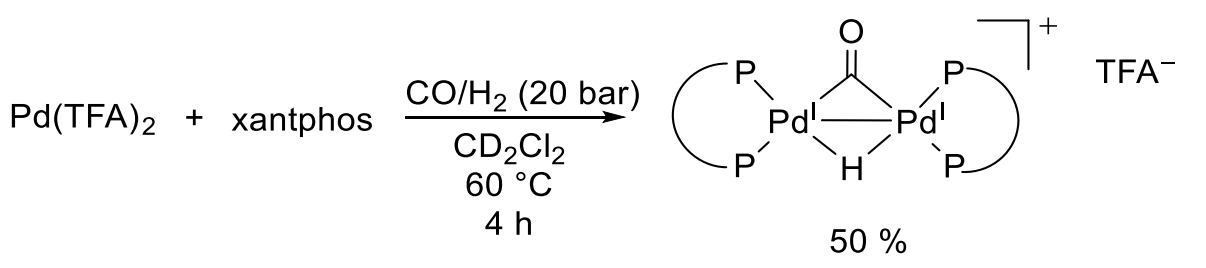

In a nitrogen -filled glovebox, a $20 \mathrm{~mL}$ oven-dried vial was charged with $\mathrm{Pd}(\mathrm{TFA})_{2}(265 \mathrm{mg}, 0.8$ mmol), xantphos $(509 \mathrm{mg}, 0.88 \mathrm{mmol})$, and $\mathrm{CH}_{2} \mathrm{Cl}_{2}(8 \mathrm{~mL})$. The mixture was stirred at room temperature for $4 \mathrm{~h}$ until a clear deep yellow solution was obtained. Then, the vial was capped with a cap containing a Teflon-coated septum, punctured with a needle, and placed into a 300-mL autoclave under nitrogen atmosphere. The autoclave was taken out of the glovebox. After flushing with syngas, the autoclave was pressurized with 20 bar syngas, and heated to $60{ }^{\circ} \mathrm{C}$ for $4 \mathrm{~h}$. Then, the autoclave was allowed to cool to room temperature and the pressure was released. The vial was transferred to a glovebox. The reaction mixture was concentrated to $\sim 2 \mathrm{~mL}$ under reduced pressure, followed by the addition of hexane $(20 \mathrm{~mL})$ to precipitate the complex. The yellow green solid was isolated by filtration, washed with hexane $(3 \times 10$ 
$\mathrm{mL}$ ) and dried under high vacuum. The title compound was obtained in 50\% yield (300 mg). An analytically pure sample can be obtained by recrystallization from hexane/DCM (5/1).

${ }^{1}$ H NMR (400 MHz, CD $\mathbf{C l}_{2}$ ) $\delta 7.67$ (d, J = 7.7 Hz, 4H), 7.27-6.93 (m, 44H), 6.33-6.22 (m, 4H), 1.71 (s, $12 \mathrm{H}),-8.77(\mathrm{p}, J=41.8 \mathrm{~Hz}, 1 \mathrm{H})$.

${ }^{13} \mathbf{C}\left\{{ }^{1} \mathbf{H}\right\}$ NMR (101 MHz, $\left.\mathbf{C D}_{2} \mathbf{C l}_{2}\right) \delta 218.1,160.7(\mathrm{~d}, J=37.6 \mathrm{~Hz}), 154.8,134.2,133.9,132.3,131.9(\mathrm{~m})$, $130.7,129.1,128.3,125.3,119.8(\mathrm{~m}), 117.6,115.3,36.3,28.5$.

${ }^{31} \mathbf{P}\left\{{ }^{1} \mathrm{H}\right\}$ NMR (162 MHz, $\left.\mathbf{C D}_{2} \mathrm{Cl}_{2}\right) \delta 4.4(\mathrm{~s})$.

${ }^{19}$ F NMR (376 MHz, $\left.\mathrm{CD}_{2} \mathrm{Cl}_{2}\right) \delta-76.33$.

HRMS (APPI) m/z calcd. for $\mathrm{C}_{39} \mathrm{H}_{33} \mathrm{OP}_{2} \mathrm{Pd}\left(\left[\mathrm{M}-\left(\mathrm{C}_{40} \mathrm{H}_{32} \mathrm{O}_{2} \mathrm{P}_{2} \mathrm{Pd}\right)\right]^{+}\right): 685.1041$; found: 685.1042 .

${ }^{1} \mathrm{H} \mathrm{NMR}\left(400 \mathrm{MHz}, \mathrm{CD}_{2} \mathrm{Cl}_{2}\right)$

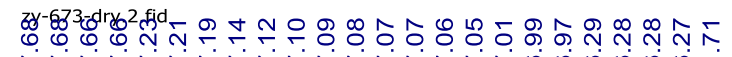

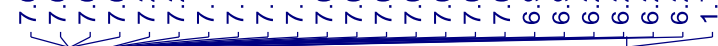

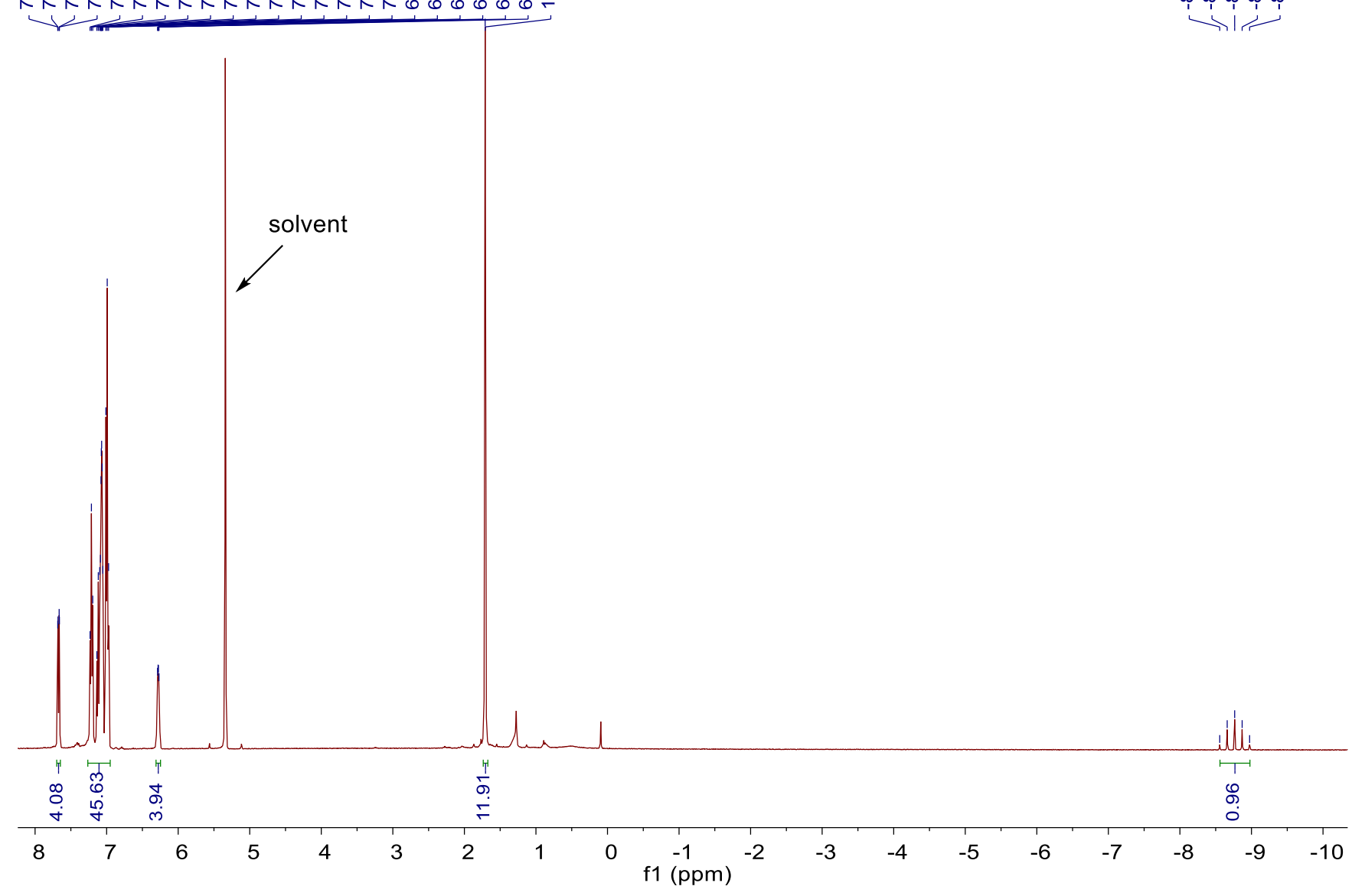

Fig. S26 ${ }^{1} H$ NMR spectrum of the $\left[(\text { xantphos })_{2} \mathrm{Pd}_{2}(\mu-H)(\mu-C O)\right]^{+} \mathrm{TFA}^{-}$complex. 


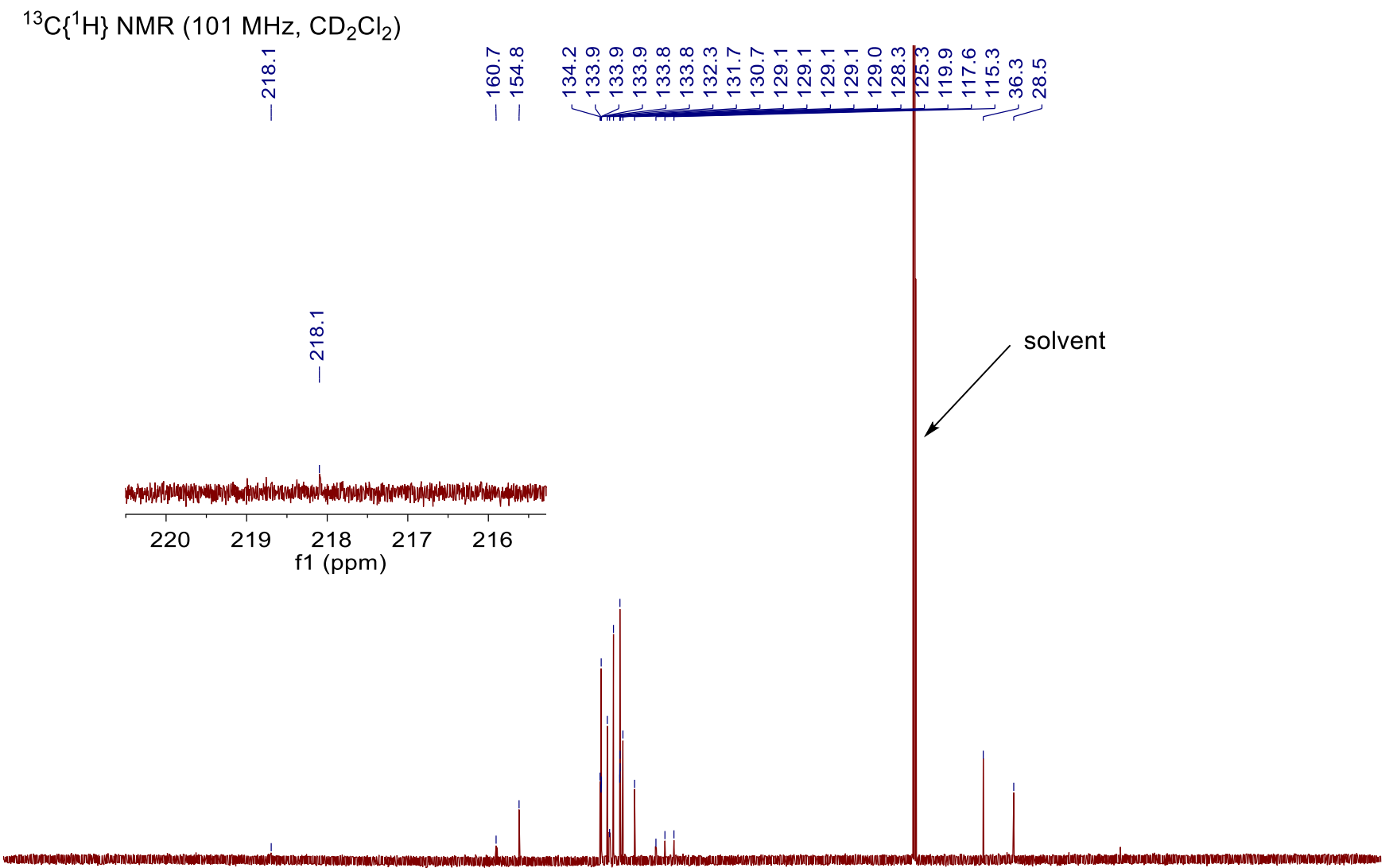

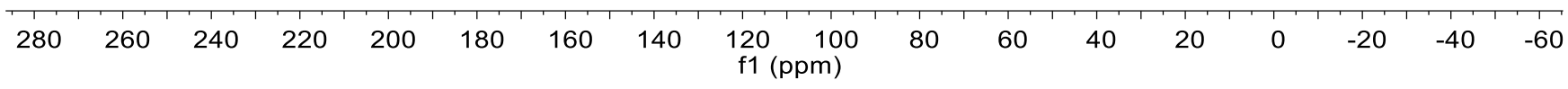

Fig. S27 $\left.{ }^{13} C_{\{}^{1} H\right\} N M R$ spectrum of the $\left[(\text { xantphos })_{2} P d_{2}(\mu-H)(\mu-C O)\right]^{+}$TFA $^{-}$complex. 
${ }^{31} \mathrm{P}\left\{{ }^{1} \mathrm{H}\right\}$ NMR $\left(162 \mathrm{MHz}, \mathrm{CD}_{2} \mathrm{Cl}_{2}\right)$

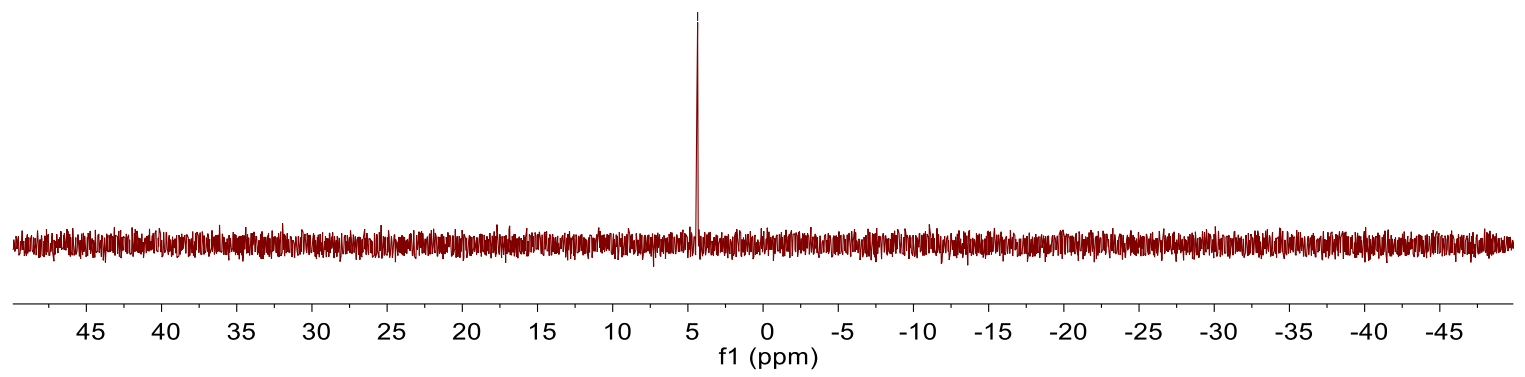

${ }^{19} \mathrm{~F}$ NMR $\left(376 \mathrm{MHz}, \mathrm{CD}_{2} \mathrm{Cl}_{2}\right)$

Fig. S28 ${ }^{31} P\left\{{ }^{1} H\right\}$ and ${ }^{19} F$ NMR spectra of the $\left[(x a n t p h o s)_{2} P d_{2}(\mu-H)(\mu-C O)\right]^{+} T_{F A}^{-}$complex. 
.لب.
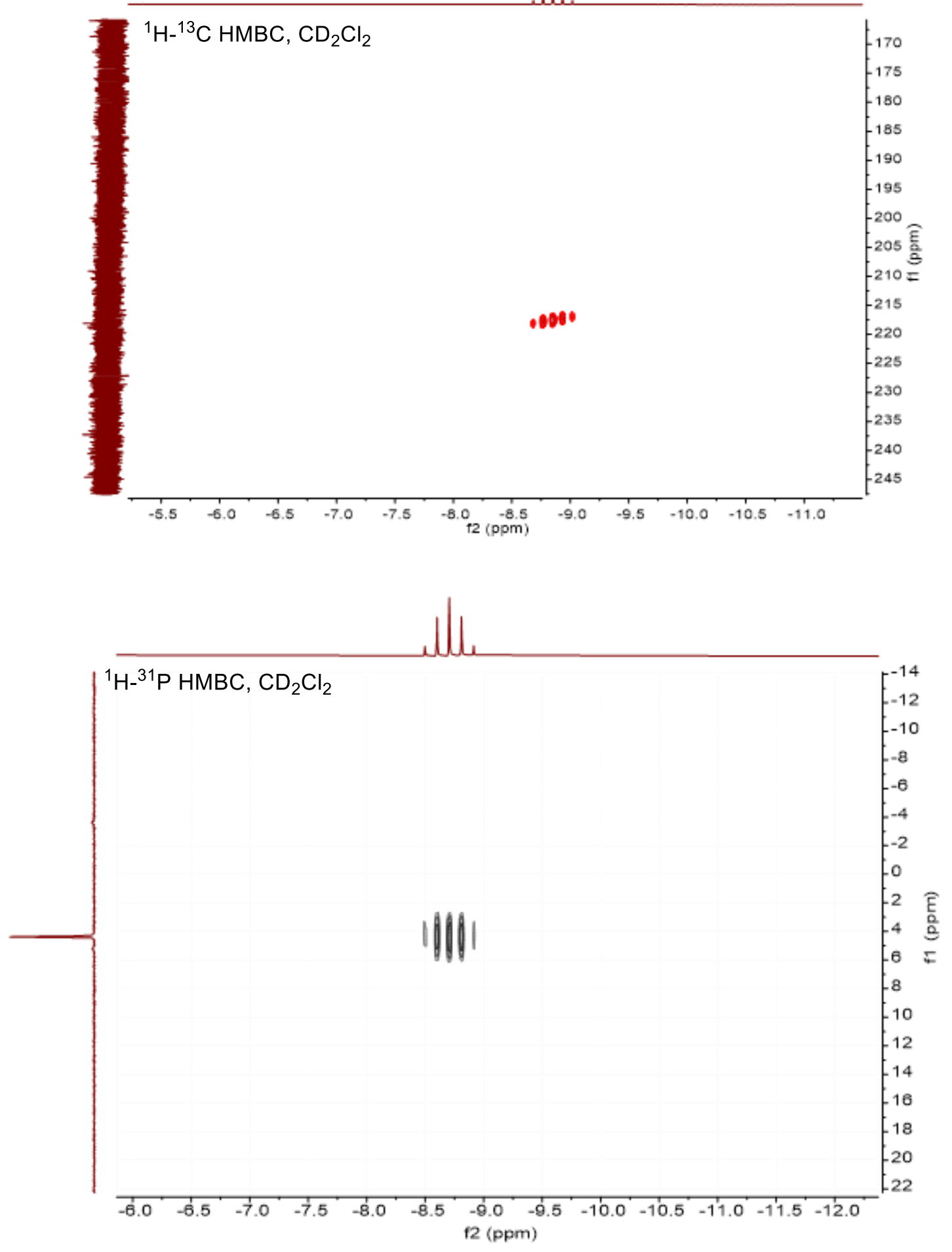

Fig. S29 $\mathrm{HMBC}\left({ }^{1} \mathrm{H}-^{13} \mathrm{C}\right) \&\left({ }^{1} \mathrm{H}^{31} \mathrm{P}\right) \mathrm{NMR}$ spectra of the $\left[(\text { xantphos })_{2} \mathrm{Pd} d_{2}(\mu-\mathrm{H})(\mu-\mathrm{CO})\right]^{+} \mathrm{TFA}^{-}$complex. 


\subsubsection{Activation of xantphos- $\mathrm{Pd}(\mathrm{TFA})_{2}$ under $\mathrm{D}_{2} / \mathrm{CO}$}

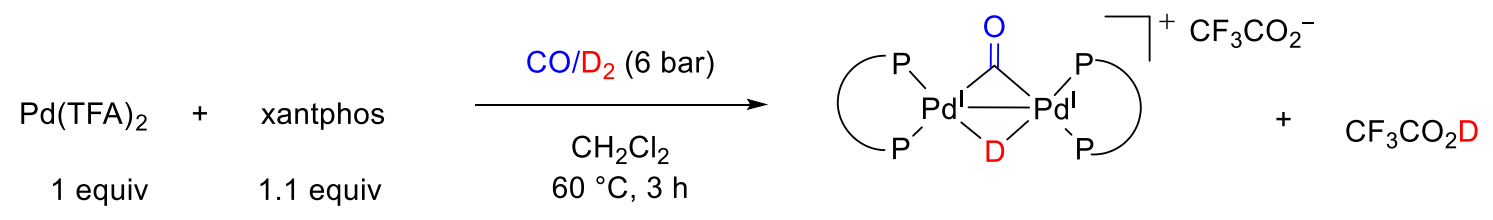

$$
\text { observed by }{ }^{2} H \text { NMR }
$$

The NMR study on activation of xantphos-palladium(II) triflate under $\mathrm{D}_{2} / \mathrm{CO}$ was performed in analogy to the above described studies under $\mathrm{H}_{2} / \mathrm{CO}$ (syngas), with the following exceptions: the initial concentration of the complex was increased (palladium(II) trifluoroacetate (16.6 $\mathrm{mg}, 0.05 \mathrm{mmol}$ ), xantphos (32.0 mg, 1.1 equiv. $0.055 \mathrm{mmol}$ ) in $\mathrm{CH}_{2} \mathrm{Cl}_{2}(500 \mu \mathrm{L})$ ), $\mathrm{CH}_{2} \mathrm{Cl}_{2}$ was used in place of $\mathrm{CD}_{2} \mathrm{Cl}_{2}$, and 0.1 vol\% of $\mathrm{C}_{6} \mathrm{D}_{6}$ was added as an internal standard. For comparison purposes, in parallel the same reaction mixture was treated with $\mathrm{H}_{2} / \mathrm{CO}$.

The NMR spectra of a reaction mixture under $\mathrm{D}_{2} / \mathrm{CO}$ confirm formation of $\mathbf{P d}_{2}$-deuteride ${ }^{+}$complex, analogous to $\mathbf{P d}_{2}$-hydride ${ }^{+}$formed under $\mathrm{H}_{2} / C O$. In particular, a quintet signal $\left(J_{\mathrm{P}-\mathrm{D}}=\sim 7 \mathrm{~Hz}\right)$ and a singlet signal, both at $-8.62 \mathrm{ppm}$, in the phosphorus-coupled and phosphorus-decoupled ${ }^{2} \mathrm{H}$ NMR spectra, respectively, indicate a fluxional cationic binuclear $\operatorname{Pd}(\mathrm{I})-\mathrm{Pd}(\mathrm{I})$ deuteridocarbonyl complex $\left[(\mathrm{xantphos})_{2} \mathrm{Pd}_{2}(\mu-\mathrm{D})(\mu-\mathrm{CO})\right]^{+}$(Fig. S30). Furthermore, a triplet signal $\left(J_{\mathrm{P}-\mathrm{D}}=6.3 \mathrm{~Hz}\right)$ in the protondecoupled ${ }^{31} \mathrm{P}$ NMR spectrum is also in agreement with formation of fluxional $\left[(x a n t p h o s){ }_{2} \operatorname{Pd}_{2}(\mu-D)(\mu-\right.$ CO) $]^{+}$complex (Fig. S31). The latter spectrum also indicates the presence of $\sim 35$ mol\% of Pd2-hydride ${ }^{+}$ complex in the sample, the presence of which is further confirmed by the ${ }^{1} \mathrm{H}$ NMR spectroscopy (the hydride signal at $-8.74 \mathrm{ppm}$ is $\sim 3$-fold smaller in the reaction under $\mathrm{D}_{2} / \mathrm{CO}$ than in the analogues control reaction under $\mathrm{H}_{2} / \mathrm{CO}$; Fig. S32). The presence of $\mathbf{P d}_{2}$-hydride ${ }^{+}$complex in the reaction under $\mathrm{D}_{2} / \mathrm{CO}$ most likely originates from trace water in the sample: This hypothesis was confirmed by addition of $\mathrm{D}_{2} \mathrm{O}$ to the mixture leading to conversion of $\mathbf{P d} \mathbf{d}_{2}$-hydride ${ }^{+}$to $\mathbf{P d}_{2}$-deuteride ${ }^{+}$, while addition of $\mathrm{H}_{2} \mathrm{O}$ leads to conversion of $\mathbf{P d}_{2}$-deuteride ${ }^{+}$to $\mathbf{P d}_{2}$-hydride ${ }^{+}$(Fig. S33). It is worth noting that the phosphorus atoms within these complexes are coupled not only with the Pd-deuteride or Pd-hydride, but also with C-H of xantphos, as indicated by comparing phosphorus-coupled and phosphorus decoupled ${ }^{1} \mathrm{H}$ NMR spectra (Fig. S34). The coupling results in the broadening of the ${ }^{31} \mathrm{P}$ NMR signals in proton-coupled vs. protondecoupled experiments (Fig. S31). 

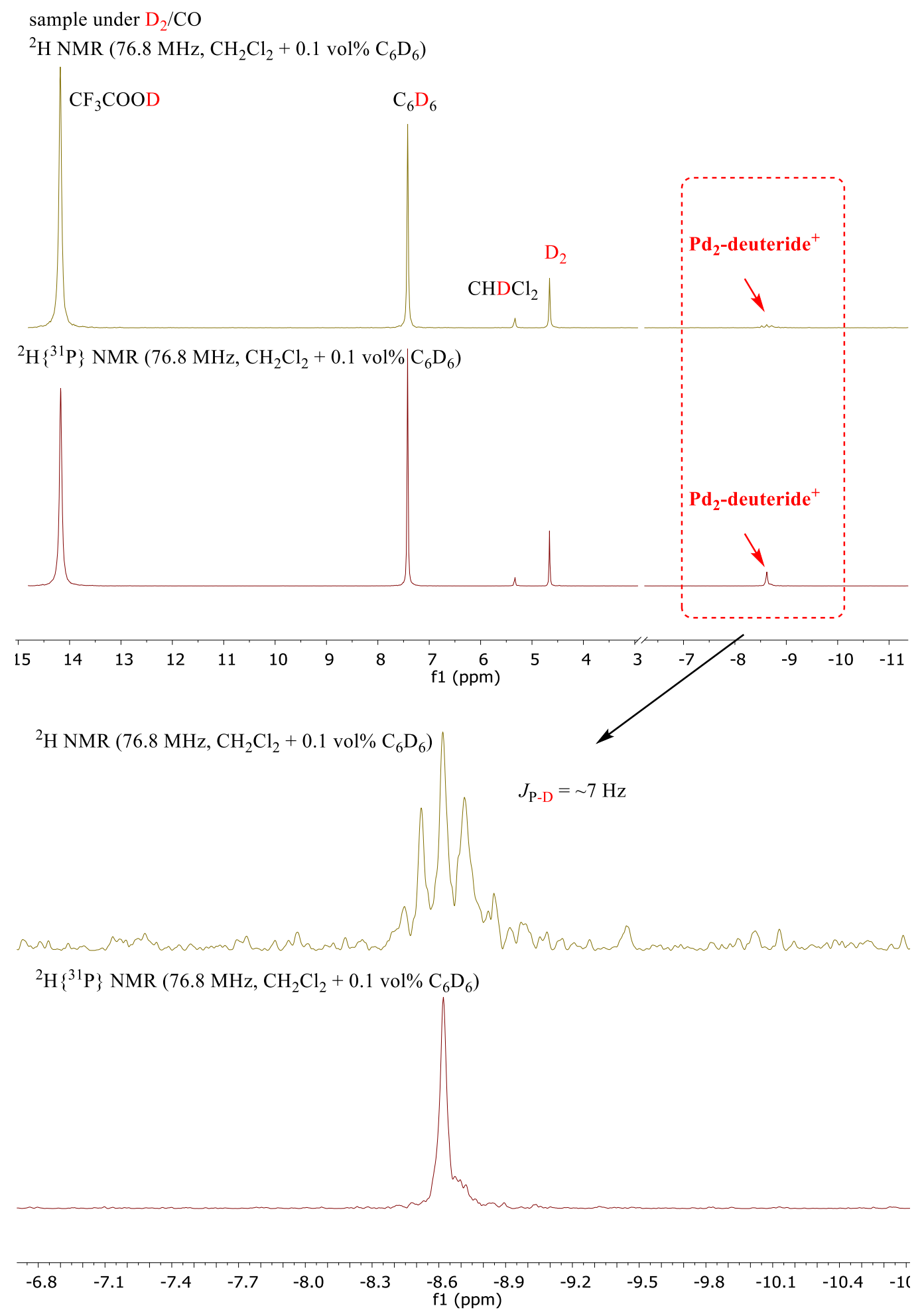

Fig. S30 ${ }^{2} \mathrm{H}$ and ${ }^{2} \mathrm{H}\left\{{ }^{3 l} \mathrm{P}\right\}$ NMR spectra for the activation of xantphos-Pd(II) trifluoroacetate under 6 bar $\mathrm{D}_{2} / \mathrm{CO}$ in $\mathrm{CH}_{2} \mathrm{Cl}_{2}+0.1$ vol\% $\mathrm{C}_{6} D_{6}$. To increase the signal-to-noise ratio, the spectra were obtained by a specific Bruker Topspin Power Spectrum (ps) processing. 


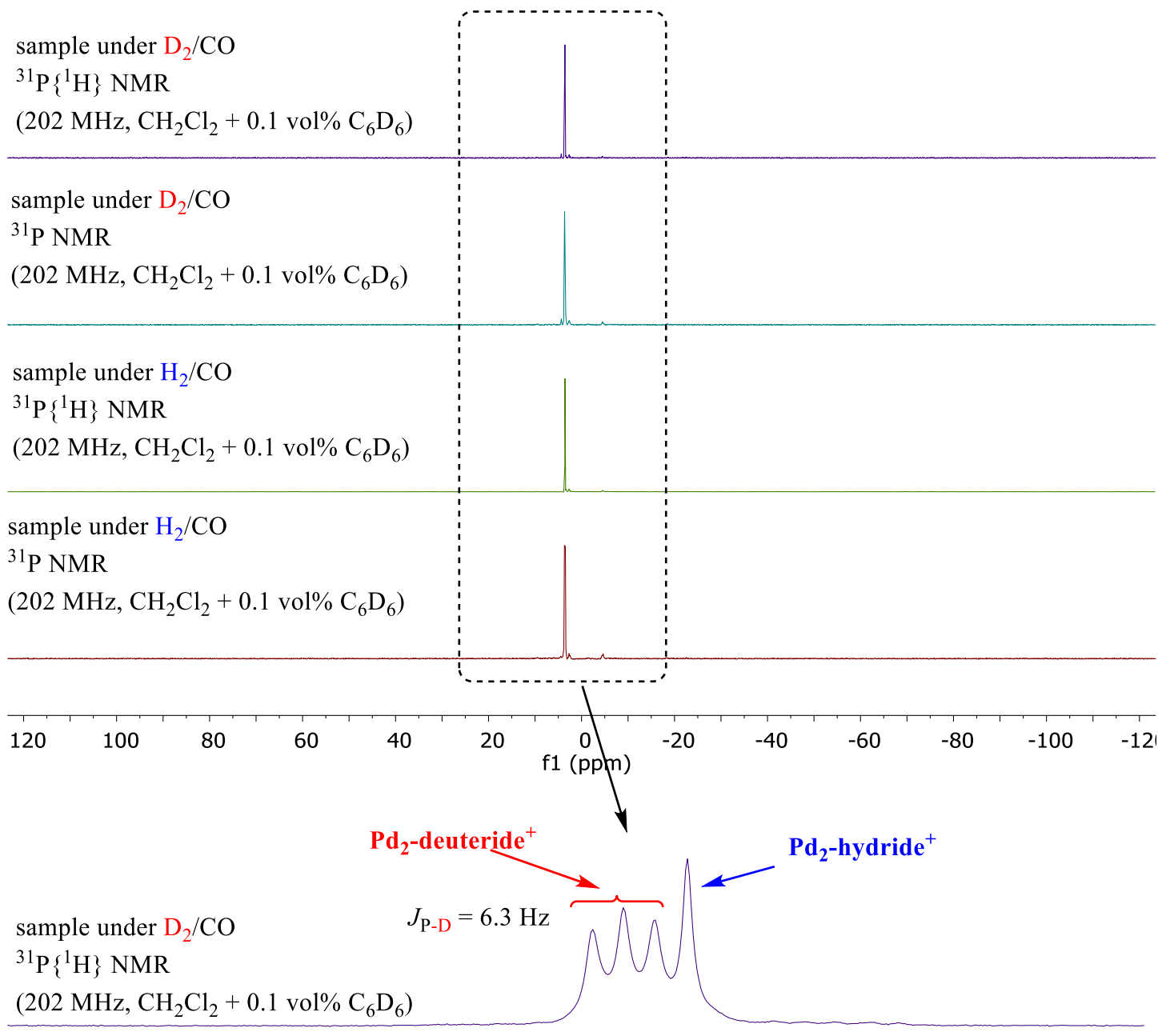

sample under $\mathrm{D}_{2} / \mathrm{CO}$

${ }^{31} \mathrm{P}$ NMR

(202 $\mathrm{MHz}, \mathrm{CH}_{2} \mathrm{Cl}_{2}+0.1$ vol\% $\mathrm{C}_{6} \mathrm{D}_{6}$ )

sample under $\mathrm{H}_{2} / \mathrm{CO}$

${ }^{31} \mathrm{P}\left\{{ }^{1} \mathrm{H}\right\} \mathrm{NMR}$

(202 MHz, $\mathrm{CH}_{2} \mathrm{Cl}_{2}+0.1 \mathrm{vol} \% \mathrm{C}_{6} \mathrm{D}_{6}$ )

sample under $\mathrm{H}_{2} / \mathrm{CO}$

${ }^{31} \mathrm{P}$ NMR

(202 MHz, $\mathrm{CH}_{2} \mathrm{Cl}_{2}+0.1$ vol\% $\mathrm{C}_{6} \mathrm{D}_{6}$ )
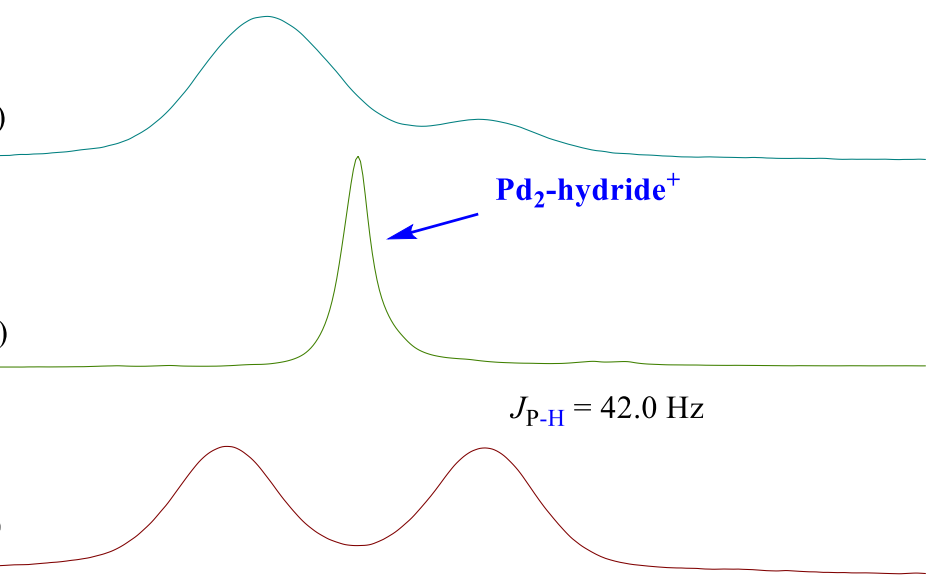

4.20 4.15 4.10 4.05 4.00 3.95 3.90 3.85 3.80 3.75 3.70 3.65 3.60 3.55 3.50 3.45 3.40 3.35 3.30 3.25 3.20 3.15

Fig. S31 Comparison of ${ }^{31} P\left\{{ }^{1} H\right\}$ and ${ }^{31} P$ NMR spectra for the activation of xantphos-Pd(II) trifluoroacetate under 6 bar $\mathrm{D}_{2} / \mathrm{CO}$ or under $\mathrm{H}_{2} / \mathrm{CO}$ in $\mathrm{CH}_{2} \mathrm{Cl}_{2}+0.1$ vol\% $\mathrm{C}_{6} \mathrm{D}_{6}$. 


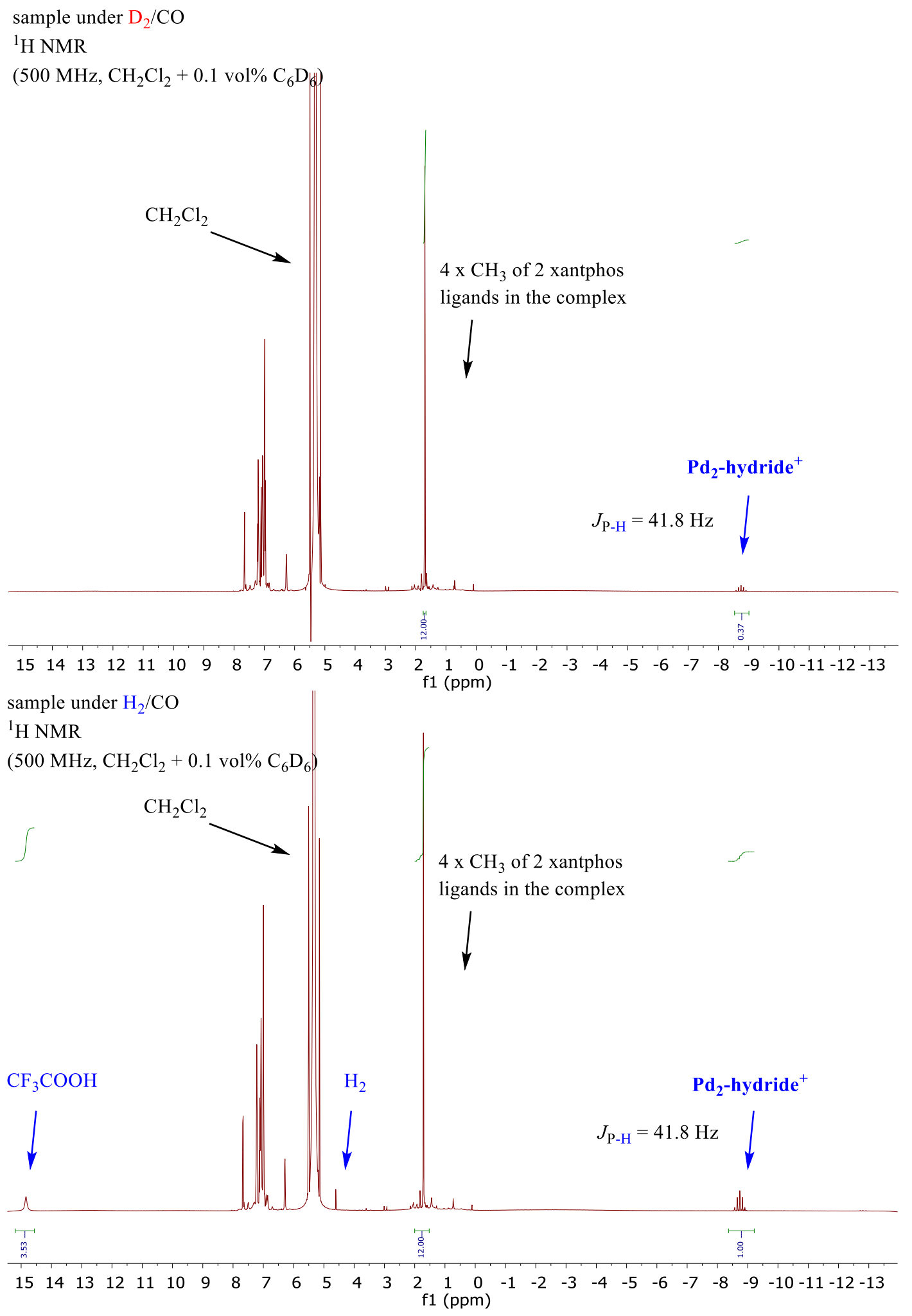

Fig. S32 Comparison of ${ }^{1} H$ NMR spectra for the activation of xantphos-Pd(II) trifluoroacetate under 6 bar $\mathrm{D}_{2} / \mathrm{CO}$ or under $\mathrm{H}_{2} / \mathrm{CO}$ in $\mathrm{CH}_{2} \mathrm{Cl}_{2}+0.1$ vol\% $\mathrm{C}_{6} D_{6}$. 


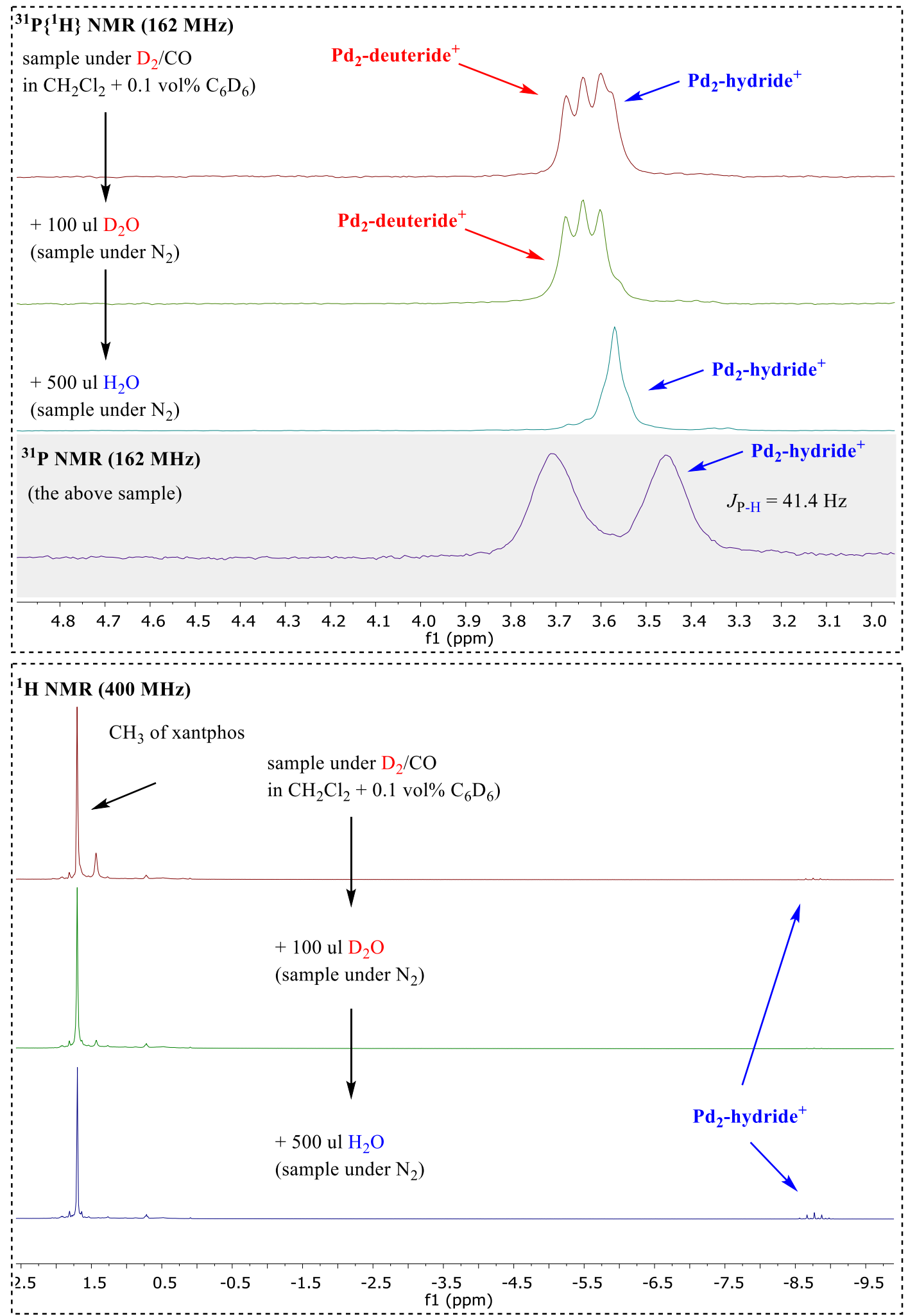

Fig. S33 Influence of addition of $\mathrm{D}_{2} \mathrm{O}$ and $\mathrm{H}_{2} \mathrm{O}$ on the pre-activated xantphos-Pd(II) trifluoroacetate under 6 bar $\mathrm{D}_{2} / \mathrm{CO}$ in $\mathrm{CH}_{2} \mathrm{Cl}_{2}+0.1$ vol\% $\mathrm{C}_{6} \mathrm{D}_{6}$ followed by ${ }^{31} \mathrm{P}\left\{{ }^{1} \mathrm{H}\right\}$ and ${ }^{1} \mathrm{H} \mathrm{NMR}$ spectroscopy. 


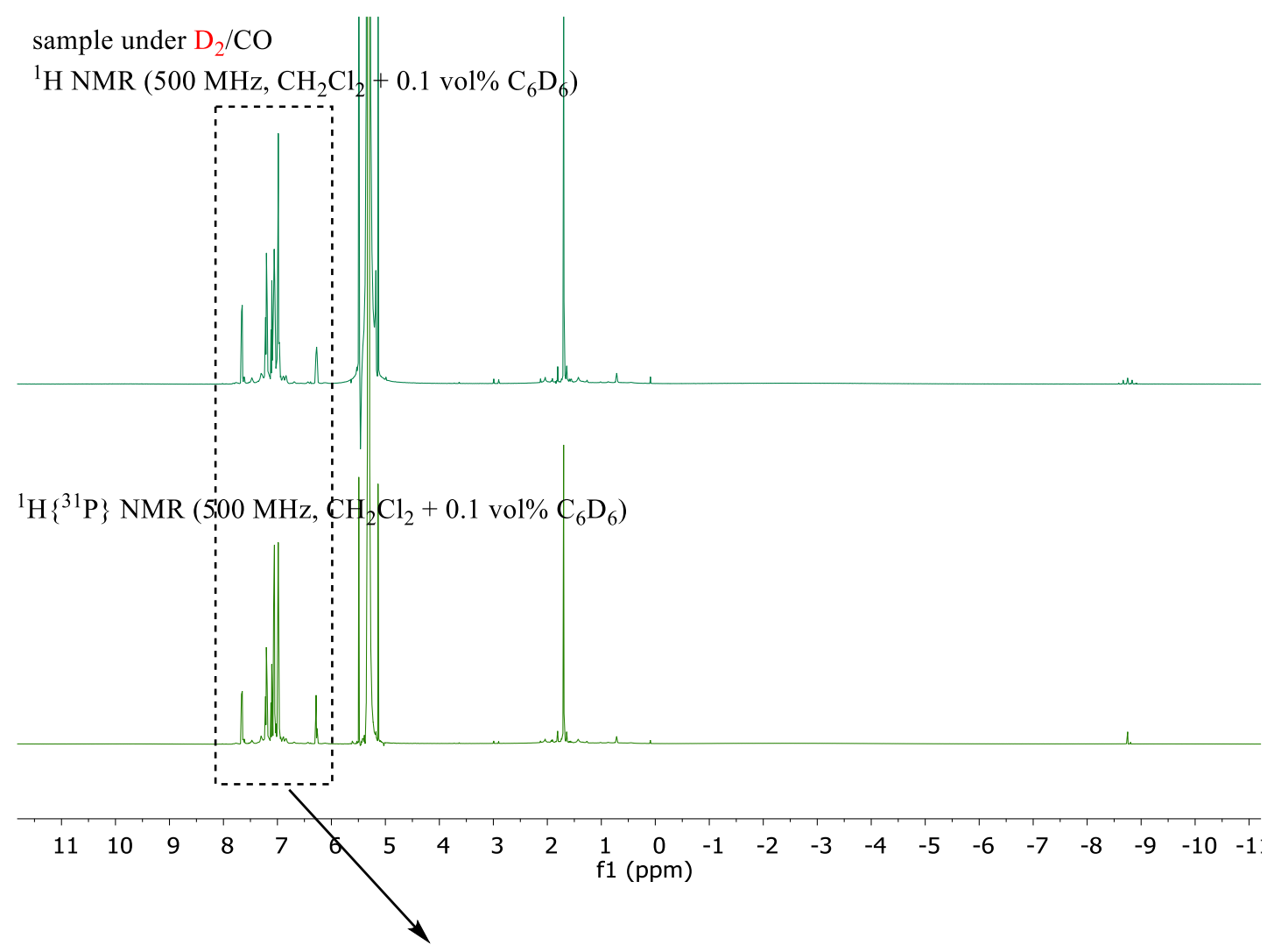

${ }^{1} \mathrm{H}$ NMR (500 MHz, $\mathrm{CH}_{2} \mathrm{Cl}_{2}+0.1$ vol $\left.\% \mathrm{C}_{6} \mathrm{D}_{6}\right)$
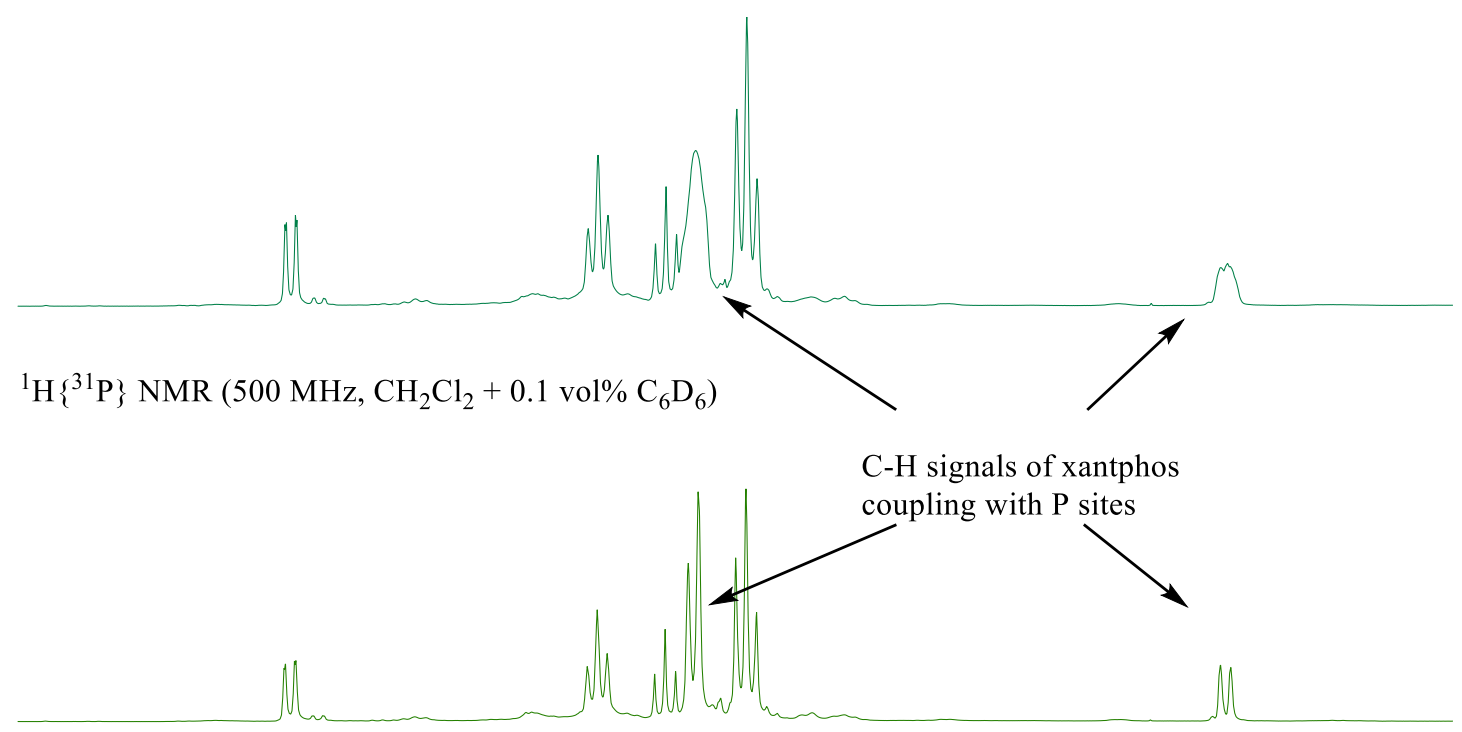

$\begin{array}{lllllllllllllllllllll}8.0 & 7.9 & 7.8 & 7.7 & 7.6 & 7.5 & 7.4 & 7.3 & 7.2 & 7.1 & 7.0 & 6.9 & 6.8 & 6.7 & 6.6 & 6.5 & 6.4 & 6.3 & 6.2 & 6.1 & 6.0\end{array}$

Fig. $S 34{ }^{1} \mathrm{H}$ and ${ }^{1} \mathrm{H}\left\{{ }^{3 l} \mathrm{P}\right\}$ NMR spectra for the activation of xantphos-Pd(II) trifluoroacetate under 6 bar $D_{2} / C O$ in $\mathrm{CH}_{2} \mathrm{Cl}_{2}+0.1$ vol\% $\mathrm{C}_{6} \mathrm{D}_{6}$. 


\subsection{Activation of xantphos-Pd(II) $I_{2}$ under dihydrogen}

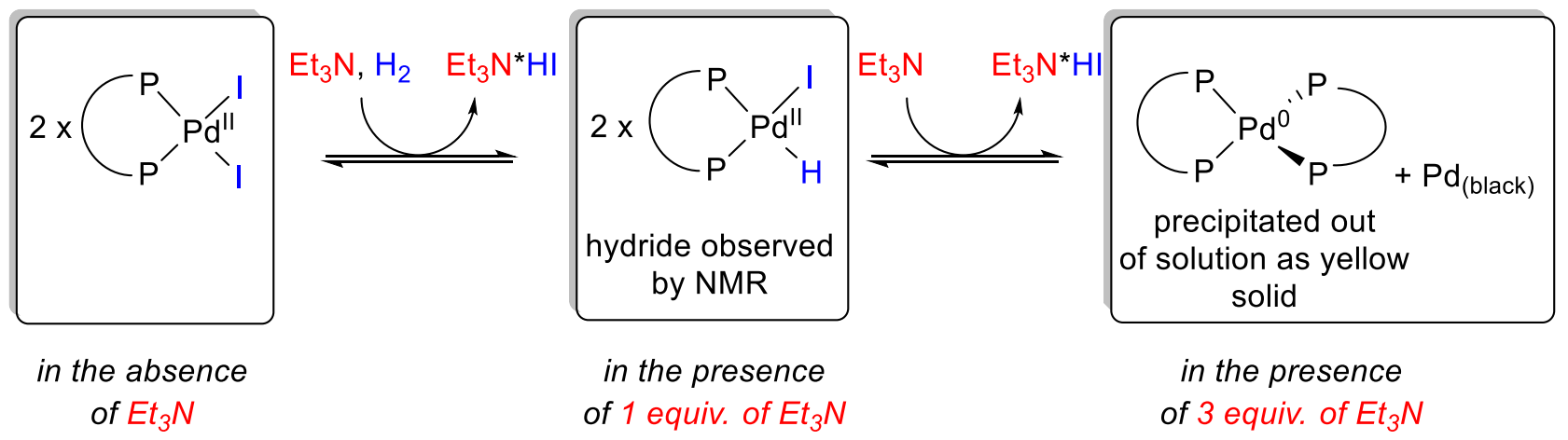

The NMR studies on the activation of palladium(II) iodide under hydrogen were performed in analogy to above described experiments with hydrogen (6 bar) used instead of syngas. A pronounced influence of the base $\left(\mathrm{Et}_{3} \mathrm{~N}\right)$ on the outcome of the reaction was observed (Figs. S35-S36). In the absence of any base, xantphos- $-\mathrm{PdI}_{2}$ did not react; only decomposition was observed upon prolonged treatment at elevated temperature $\left(24 \mathrm{~h}, 80{ }^{\circ} \mathrm{C}\right.$ ). (A control experiment with xantphos- $\mathrm{PdI}_{2}$ and alkene 1q under hydrogen resulted in quantitative hydrogenation of the alkene to the alkane (N-ethylphtalimide) within $<15 \mathrm{~min}$ at room temperature, suggesting facile formation of the Pd-hydride species under these conditions). In the presence of excess base ( 3 equiv. $\mathrm{Et}_{3} \mathrm{~N}$ ), conversion of xantphos- $-\mathrm{PdI}_{2}$ occurred readily at room temperature, as indicated by the signals corresponding to the $\mathrm{Et}_{3} \mathrm{NH}^{+}$( 2 equiv. of $\mathrm{Et}_{3} \mathrm{NH}^{+}$were formed per 1 equiv. of xantphos- $\mathrm{PdI}_{2}$, as judged by the $\mathrm{NH}^{+}$resonance in the ${ }^{1} \mathrm{H}$ NMR spectrum) and appearance of a characteristic yellow precipitate corresponding to (xantphos) $)_{2}-\operatorname{Pd}(0)$ (poorly soluble in organic solvents, ${ }^{54}$ accompanied by nearly quantitative disappearance of the signals of xantphos in the ${ }^{31} \mathrm{P}\left\{{ }^{1} \mathrm{H}\right\}$ or ${ }^{1} \mathrm{H}$ NMR spectra upon $2 \mathrm{~h}$ treatment at room temperature. When only a stochiometric amount of base was applied ( 1 equiv. $\mathrm{Et}_{3} \mathrm{~N}$ ), conversion of xantphos-PdI 2 occurred readily at room temperature, as indicated by the signals for the $\mathrm{Et}_{3} \mathrm{NH}^{+}$signals (1 equiv. of $\mathrm{Et}_{3} \mathrm{NH}^{+}$formed per 1 equiv. of xantphos- $-\mathrm{PdI}_{2}$ ) and appearance of a broad signal at $-12.7 \mathrm{ppm}$, in the hydride region of ${ }^{1} \mathrm{H}$ NMR; no precipitate was formed (Fig. S37). Upon further treatment at room temperature or at $60{ }^{\circ} \mathrm{C}$, the broad signal at $-12.7 \mathrm{ppm}$ decreased to form well-resolved signals at $-9.27 \mathrm{ppm}\left(\mathrm{dd}, J_{\mathrm{P}-\mathrm{H}}=95.3 \mathrm{~Hz}, 10.1 \mathrm{~Hz}\right)$, tentatively assigned to cis-xantphos-PdHI (Fig. S37). The ${ }^{31}$ P NMR data indicate formation of a mixture of complexes (Fig. S36b). All attempts to isolate the mononuclear Pd-hydrido complex to confirm its structure failed. 


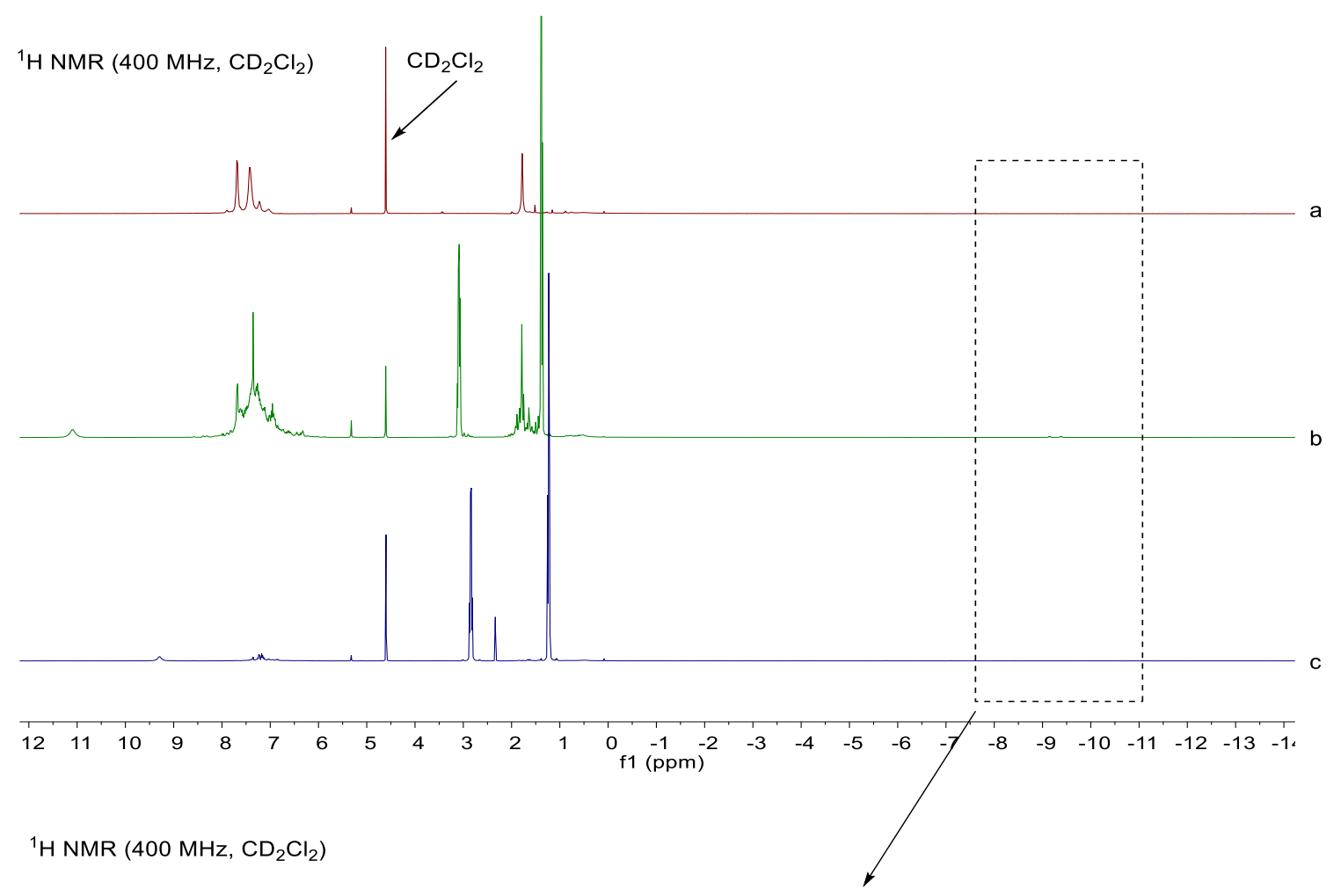

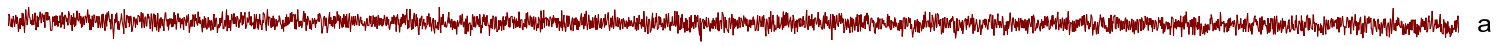

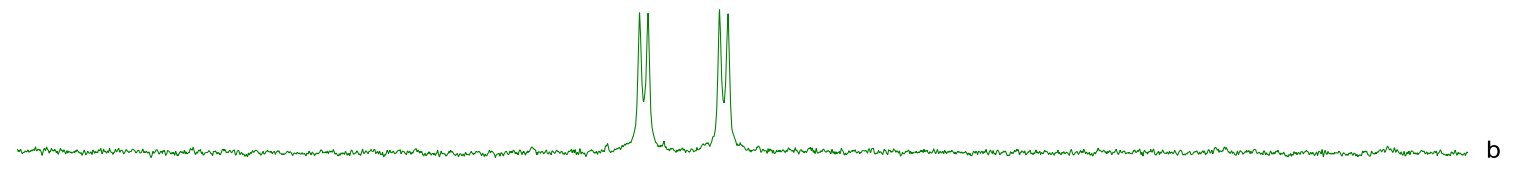

$\begin{array}{llllllllllllllllllllllllllllllllll}-7.4 & -7.6 & -7.8 & -8.0 & -8.2 & -8.4 & -8.6 & -8.8 & -9.0 & -9.2 & -9.4 & -9.6 & -9.8 & -10.0 & -10.2 & -10.4 & -10.6 & -10.8 & -11.0 & -11.2 & -11.4\end{array}$

Fig. S35 ${ }^{1} \mathrm{H}$ NMR spectra for the treatment of xantphos-Pd(II) iodide under 6 bar hydrogen in $\mathrm{CD}_{2} \mathrm{Cl}_{2}$, in the absence of base ( $a$ ), and in the presence of 1 or 3 equiv. of $E t_{3} N$ ( $b$ and $c$, respectively). 

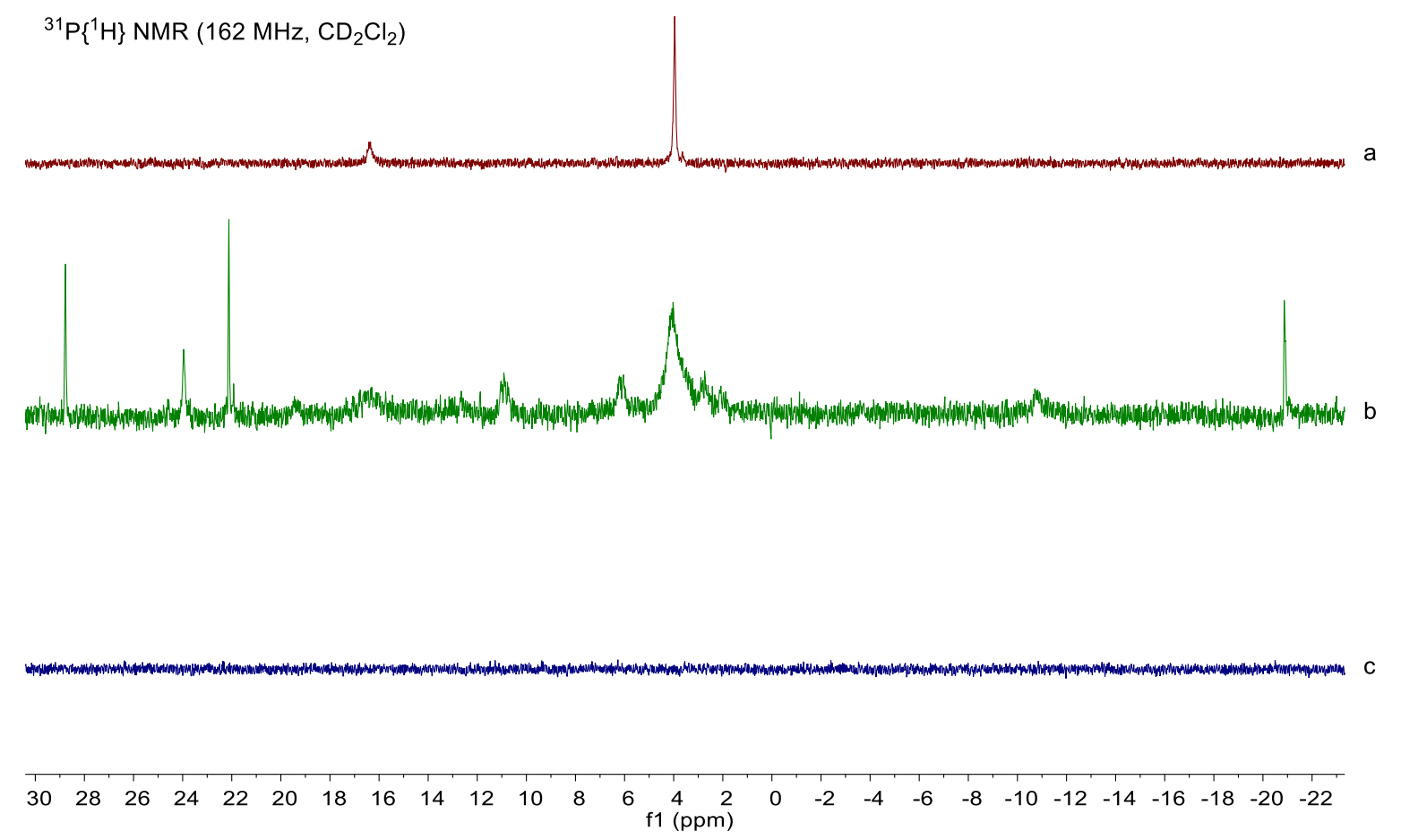

Fig. S36 ${ }^{31} P\left\{{ }^{1} H\right\}$ NMR spectra for the treatment of xantphos-Pd(II) iodide under 6 bar hydrogen in $\mathrm{CD}_{2} \mathrm{Cl}_{2}$, in the absence of any base (a), in the presence of 1 or 3 equiv. of Et ${ }_{3} \mathrm{~N}$ ( $b$ and c, respectively).

${ }^{1} \mathrm{H}$ NMR $\left(400 \mathrm{MHz}, \mathrm{CD}_{2} \mathrm{Cl}_{2}\right)$

$\mathrm{RT}, 1 \mathrm{~h}$

$\mathrm{RT}, 6 \mathrm{~h}$

$M$

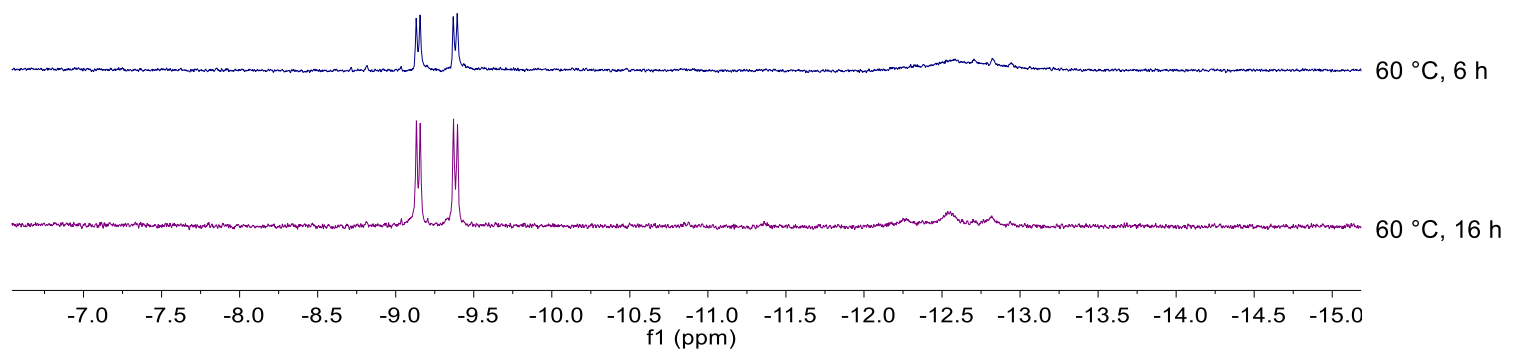

Fig. $S 37{ }^{1} \mathrm{H} N M R$ spectra for the treatment of xantphos-Pd(II) iodide under 6 bar hydrogen in $\mathrm{CD}_{2} \mathrm{Cl}_{2}$, in the in the presence of 1 equiv. of Et ${ }_{3} N$ followed over time. 


\subsection{Reaction of xantphos-Pd(II)X $X_{2}$ and an alkene under syngas}

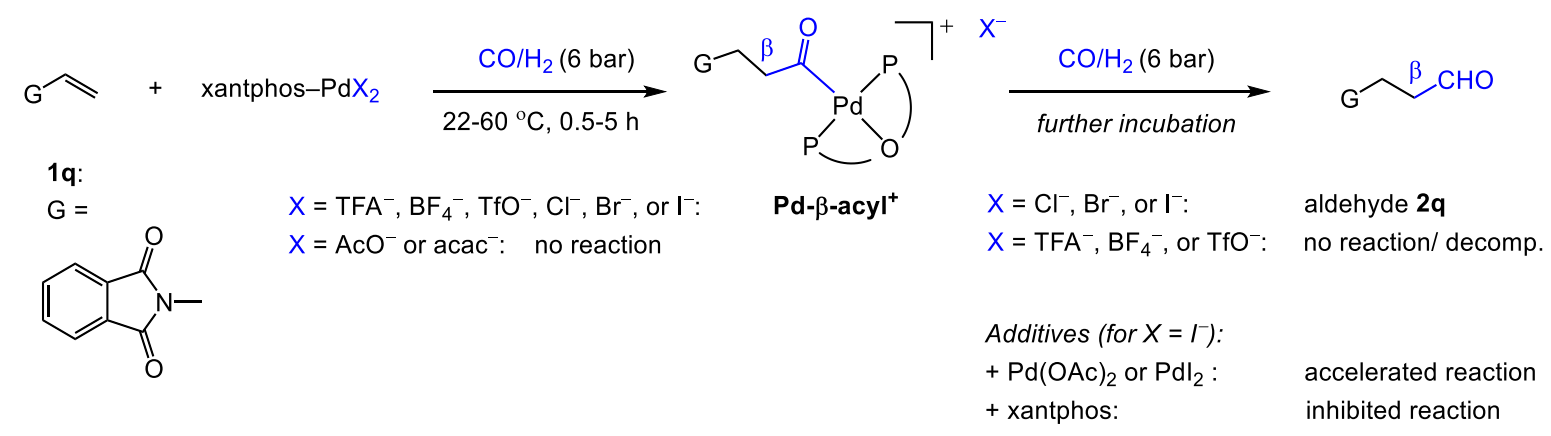

In analogy to the NMR studies of the activation described above, the reactions of xantphos-Pd(II) complexes with an alkene and syngas were performed in high-pressure J. Young tubes, using either in situ preformed complexes (prior to treatment of the solution under syngas) or complexes that had been isolated and purified (no noticeable difference in reactivity was recorded). Typically, the reaction mixture under 6 bar of syngas $\left(\mathrm{H}_{2} / \mathrm{CO} 1: 1\right)$ was first treated at room temperature, and the reaction progress was monitored by periodically recording NMR spectra (typically $1 \mathrm{~h}$ intervals). In case, no conversion was observed after several hours at that temperature, the sample was further treated at elevated temperature (typically $50{ }^{\circ} \mathrm{C}$ or $60{ }^{\circ} \mathrm{C}$ ) either directly inside the NMR spectrometer in a preheated aluminum block (the temperature of which was controlled by a standard laboratory heating plate equipped with a thermocouple) and periodically subjected to the NMR spectrometer to collect the spectra.

The NMR data corresponding to independently prepared Pd- $\beta$-acyl complexes (for the synthetic procedures, see below) are fully consistent with the data of Pd- $\beta$-acyls formed under syngas (Figs. S3839). Moreover, the NMR resonance for the Pd- $\beta$-acyl species containing different anions display similar chemical shifts, with certain resonances for complexes containing a chloride, a bromide, or an iodide being slightly shifted (Fig. S38), pointing to a pronounced degree of Pd-halide interaction. Most significant differences are observed at temperatures below $-20^{\circ} \mathrm{C}$, for the iodide complex indicating the existence of dynamic processes and/or equilibria (Figs. S40-S41). In contrast, the NMR signals of the complex containing a weakly coordinating tetrafluoroborate do not change significantly upon lowering the temperature (Figs. S42-S43). 


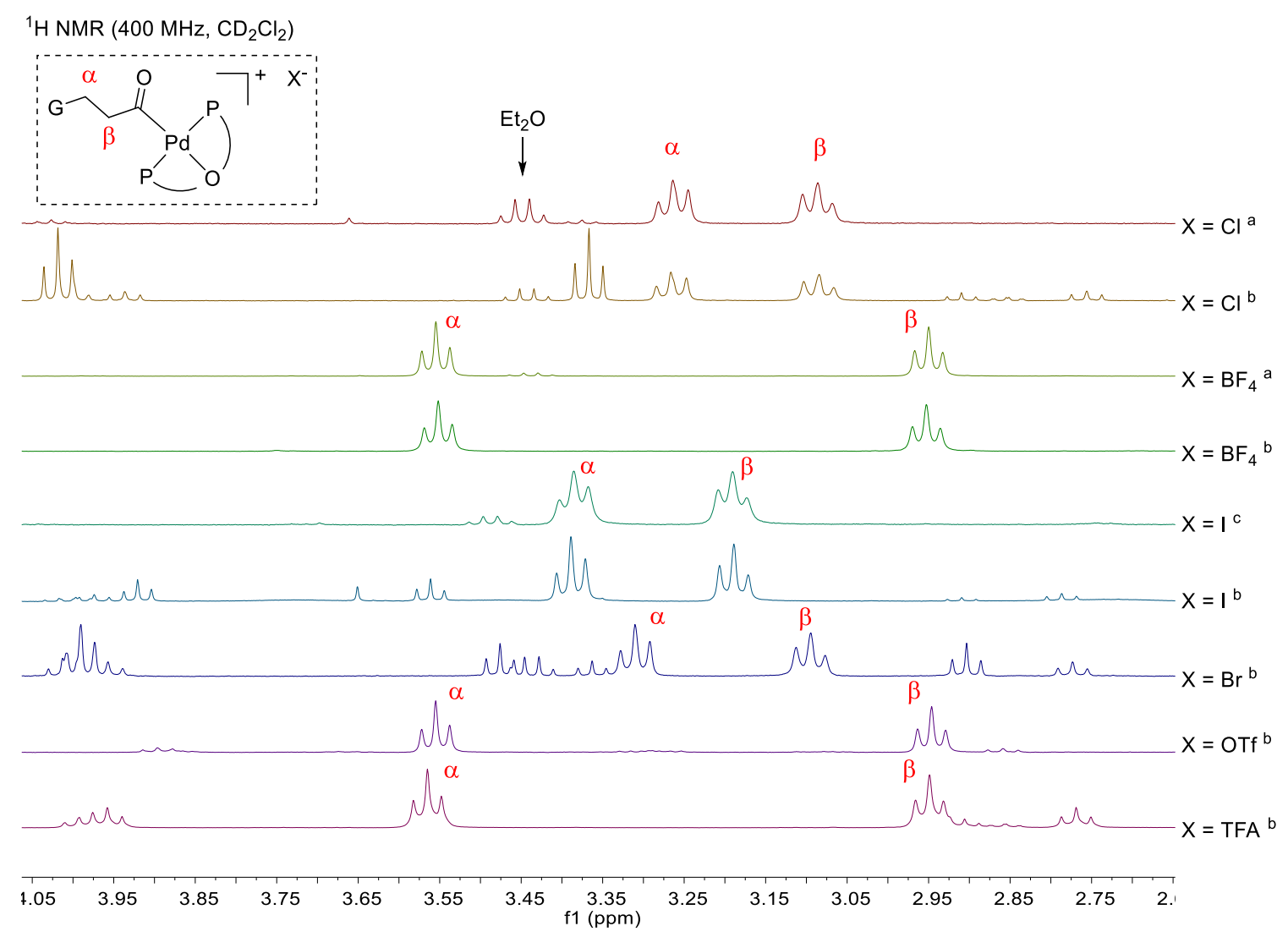

a. Independently sythesized complexes; b. generated from xantphos-PdX 2 vinylphthalimide under syngas (6 bar) in-situ; c. formed from the independently synthesized complex $\mathrm{BF}_{4}$ upon addition of $\mathrm{PPh}_{4} \mathrm{I}$

Fig. $S 38{ }^{1} H$ NMR spectra of $P d$ - $\beta$-acyl complexes bearing different anions: observed in situ in reactions of xantphos-Pd(II) complexes and alkene $1 q$ under syngas (6 bar) and of the same complexes synthesized independently. 


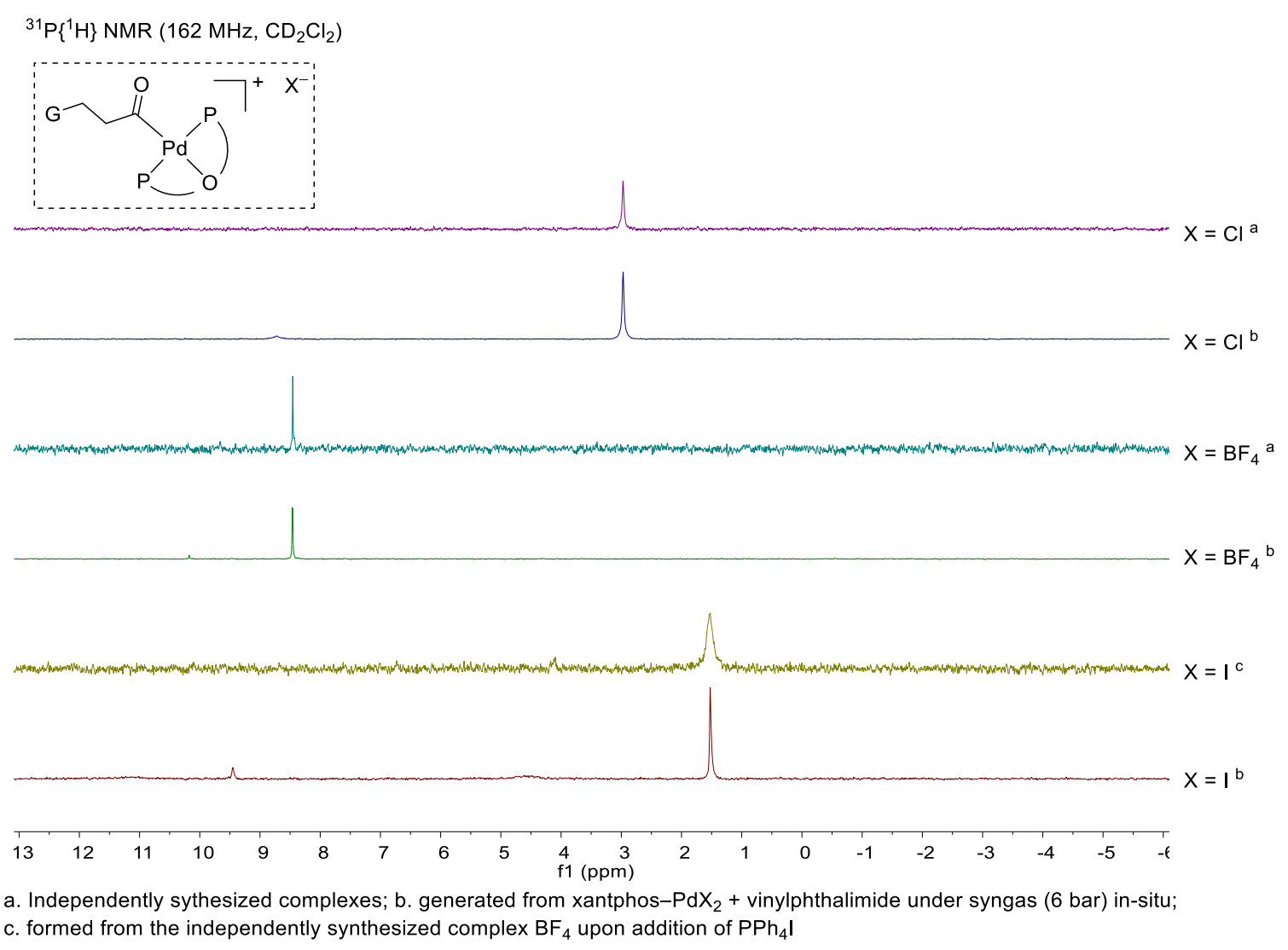

Fig. S39 ${ }^{31} P\left\{{ }^{1} H\right\} N M R$ spectra of the xantphos-Pd- $\beta$-acyl complexes bearing a tetrafluoroborate, a chloride, or an iodide: observed in situ in reactions of xantphos-Pd(II) complexes with alkene $1 \mathbf{q}$ under syngas, and of the same complexes synthesized independently. 


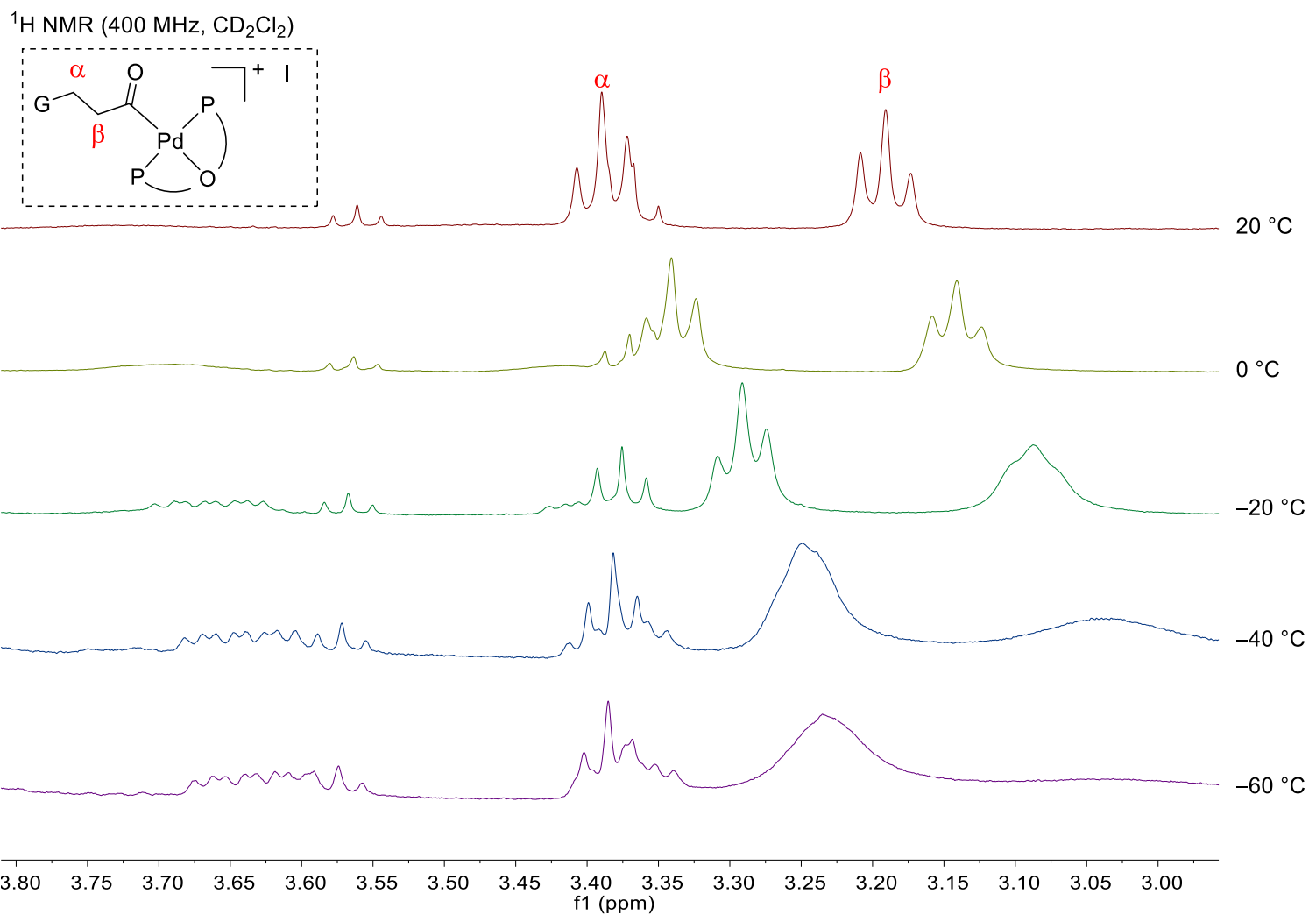

Fig. $\mathbf{S 4 0}{ }^{1} H$ NMR spectra of xantphos-Pd- $\beta$-acyl iodide complex at variable temperature.

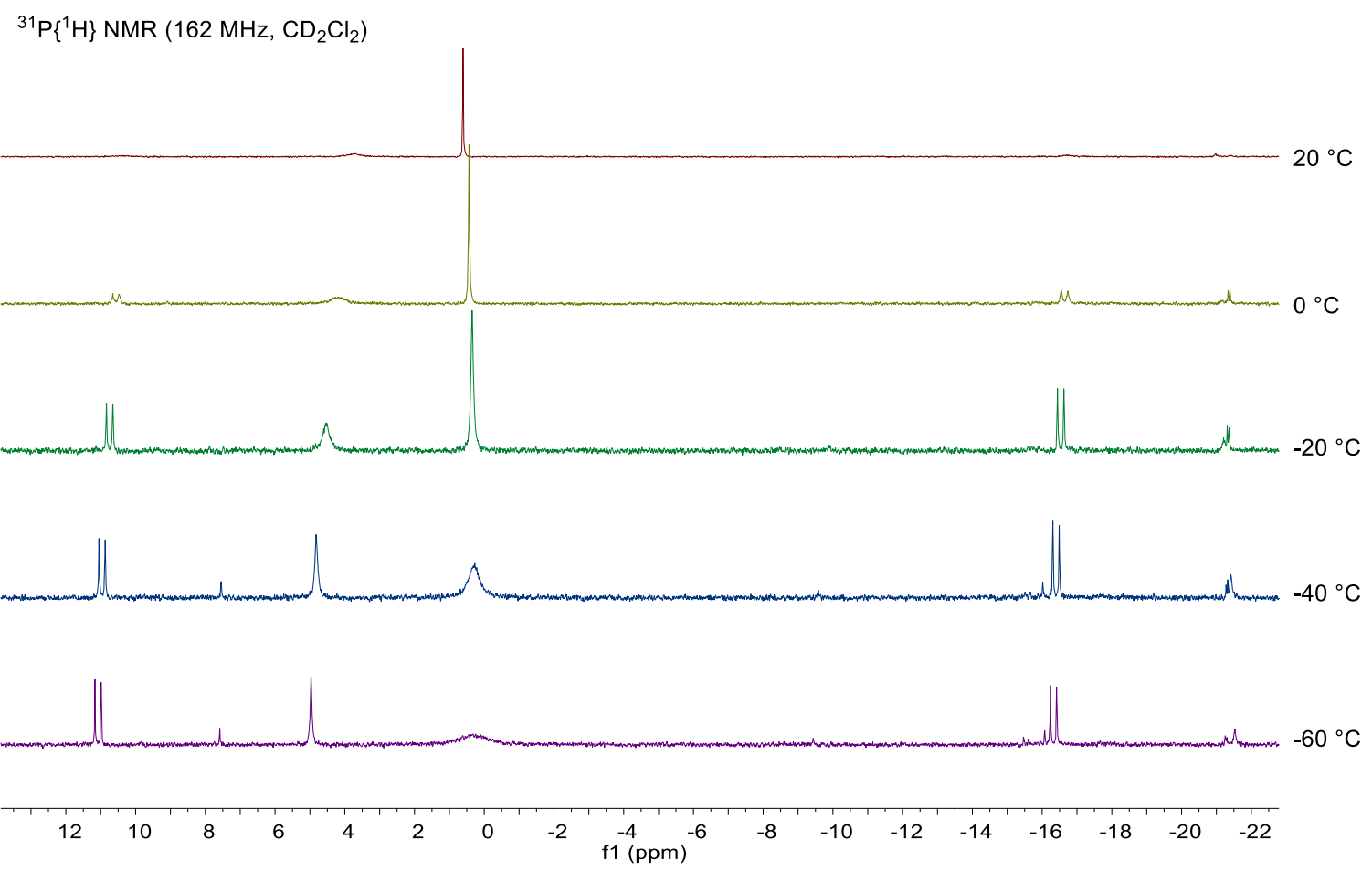

Fig. $\mathbf{S 4 1}{ }^{31} P\left\{{ }^{1} H\right\} N M R$ spectra of xantphos-Pd- $\beta$-acyl iodide complex at variable temperature. 


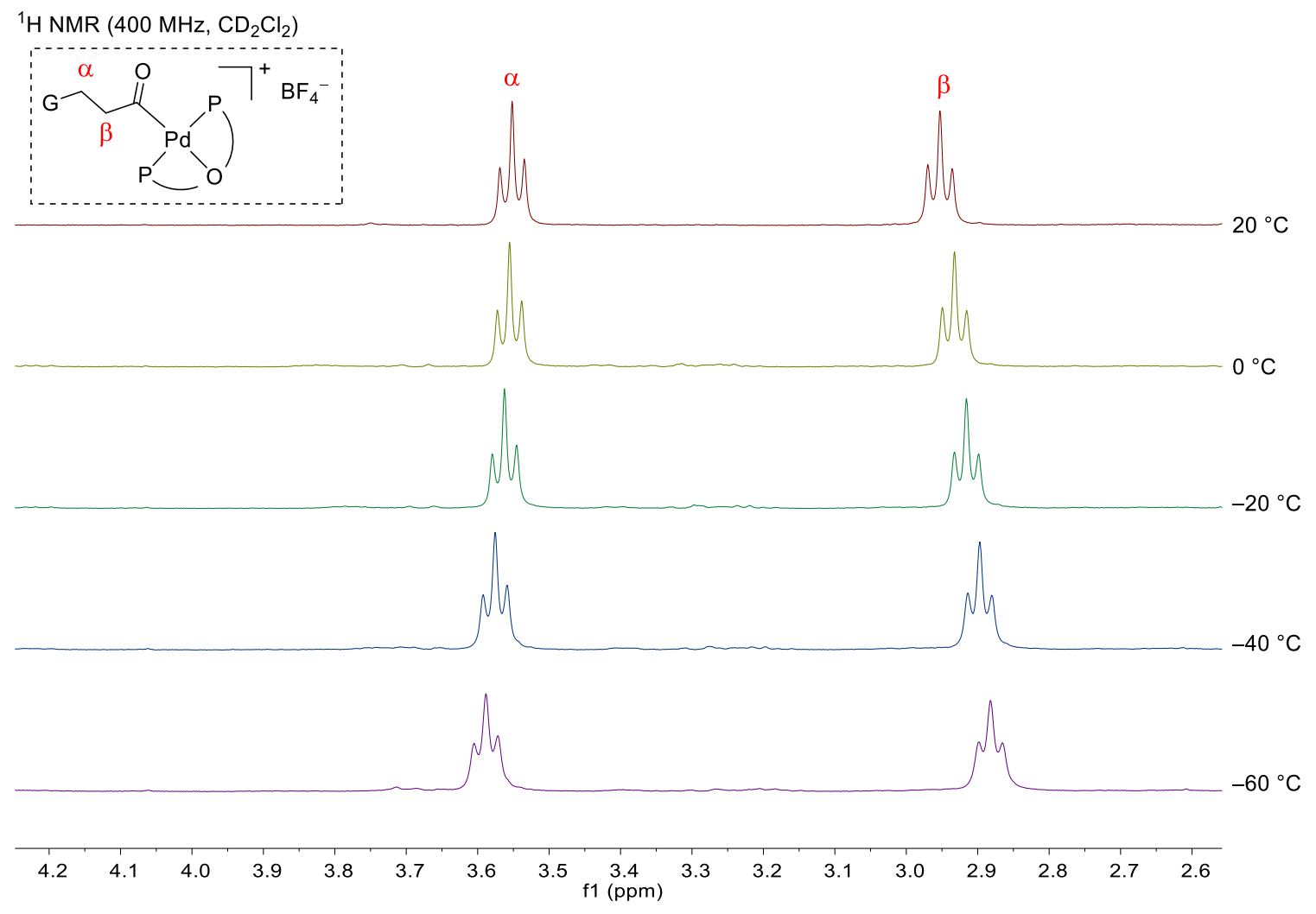

Fig. $\mathbf{S 4 2}{ }^{1} \mathrm{H} N M R$ spectra of xantphos-Pd- $\beta$-acyl BF ${ }_{4}$ complex (prepared in situ) at variable temperature.

${ }^{31} \mathrm{P}\left\{{ }^{1} \mathrm{H}\right\} \mathrm{NMR}\left(162 \mathrm{MHz}, \mathrm{CD}_{2} \mathrm{Cl}_{2}\right)$
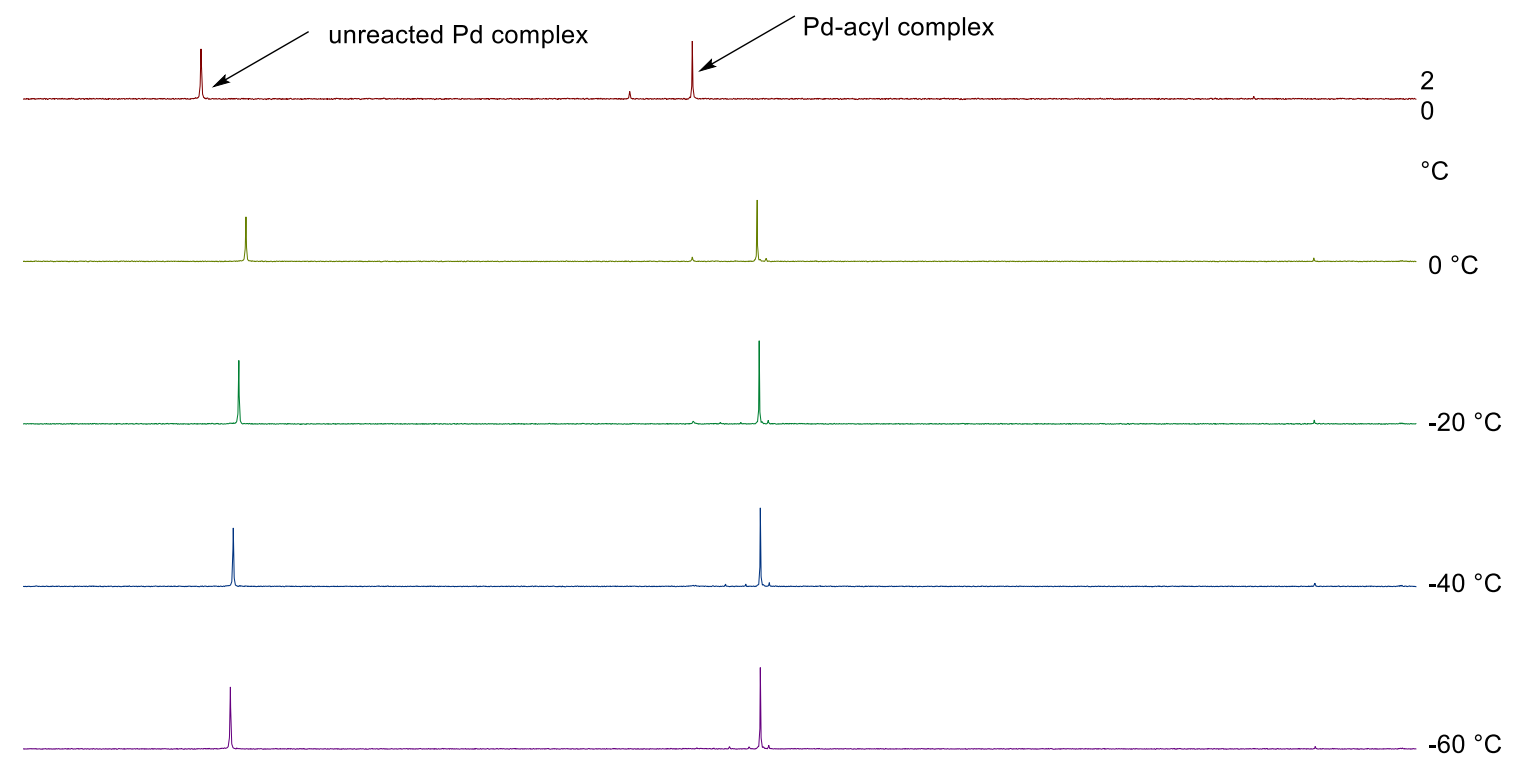

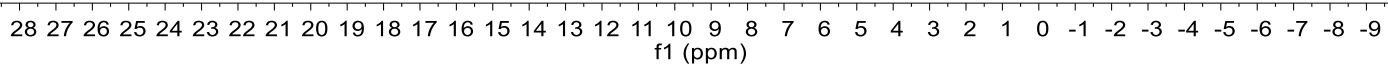

Fig. $\mathbf{S 4 3}{ }^{31} P\left\{{ }^{1} H\right\} N M R$ spectra of xantphos-Pd- $\beta$-acyl BF ${ }_{4}$ complex (prepared in situ) at variable temperature. 
A representative procedure for the in-situ NMR studies: In a nitrogen-filled glovebox, a J. Young tube was charged with vinyl phthalimide $(6.9 \mathrm{mg}, 0.040 \mathrm{mmol})$, palladium(II) trifluoroacetate $(13.3 \mathrm{mg}$, $0.040 \mathrm{mmol}$ ), xantphos (18.5 mg, 0.8 equiv., $0.032 \mathrm{mmol})$ and $\mathrm{CD}_{2} \mathrm{Cl}_{2}(500 \mu \mathrm{L})$. The tube was then sealed and shaken. Then, the tube was pressurized to $6 \mathrm{bar} \mathrm{CO} / \mathrm{H}_{2}(1: 1)$ and the pressure was released, and this process was repeated 5 times. Finally, the tube was pressurized $\left(6\right.$ bar $\left.\mathrm{CO} / \mathrm{H}_{2}\right)$, sealed, shaken, and the NMR spectra were collected. After $1 \mathrm{~h}$ treatment at room temperature, low conversion of the initial complex was observed to form cationic binuclear Pd-hydrido species and a new complex, later identified as a cationic xantphos-Pd- $\beta$-acyl species (Figs. S44-S45). The sample was then treated at $60{ }^{\circ} \mathrm{C}$, and the reaction was followed over time. The clean conversion of the initial complex into cationic binuclear Pdhydrido species and cationic xantphos-Pd- $\beta$-acyl species was observed within several hours at that temperature (Figs. S44-S45). The assignment of the structure of the cationic xantphos-Pd- $\beta$-acyl complex was supported by the 2D NMR spectra $\left({ }^{1} \mathrm{H}^{-31} \mathrm{P}\right.$ HMBC, ${ }^{1} \mathrm{H}^{-13} \mathrm{C}$ HMBC, COSY; Fig. S48), through comparison with the NMR data of the independently prepared cationic xantphos-Pd- $\beta$-acyl complex (containing tetrafluoroborate, another weakly coordinating anion; vide infra), and the crystal structure of the analogous complex (containing tetrafluoroborate). Further treatment of the sample did not lead to formation of the aldehyde product.

Because the ratio of xantphos to palladium(II) precursor was found to have a pronounced effect on the activity of the xantphos-Pd(II) complexes (see catalytic experiments above), we investigated the reaction of the xantphos-Pd(II) complexes with an alkene at different ligand:metal ratio: $0.8,1.0$ or 1.1 (Figs. S44-S47). In all cases, we observed formation of the same cationic xantphos-Pd- $\beta$-acyl species at $60{ }^{\circ} \mathrm{C}$; further treatment of the samples did not result in the formation of the aldehyde product. Only upon prolonged treatment at elevated temperatures $\left(80-100{ }^{\circ} \mathrm{C}, 2\right.$ days), did we observe conversion of the cationic xantphos-Pd- $\beta$-acyl into a new unidentified species along with traces of the aldehyde $(<2 \%)$.

The NMR studies of xantphos-Pd(II) tetrafluoroborate or triflate complexes with alkene 1q under syngas revealed formation of analogous cationic xantphos-Pd- $\beta$-acyl species at $50-60{ }^{\circ} \mathrm{C}$ (Figs. S49 and $\mathrm{S} 51)$. Again, no conversion to the aldehyde products was observed upon further treatment. The assignment of the structure of the cationic xantphos-Pd- $\beta$-acyl complex was supported by the $2 \mathrm{D}$ NMR spectra $\left({ }^{1} \mathrm{H}\right.$ ${ }^{31} \mathrm{P}$ HMBC, ${ }^{1} \mathrm{H}^{-}{ }^{13} \mathrm{C}$ HMBC, COSY; Figs. S50 and S52), through comparison with the NMR data of the independently prepared Pd- $\beta$-acyl complex bearing weakly coordinating $\mathrm{BF}_{4}^{-}$anion, and the $\mathrm{x}$-ray 
structure of the tetrafluoroborate complex: the complex was crystalized by removing the syngas atmosphere and slow infusion of hexane (top-layering) at room temperature.

The NMR studies of xantphos-Pd(II) chloride, bromide, or iodide complexes with an alkene under syngas indicated facile formation of xantphos-Pd- $\beta$-acyl species at 50-60 ${ }^{\circ} \mathrm{C}$ (Figs. S53, S56-S57). The assignment of the structures was supported by 2D NMR spectra $\left({ }^{1} \mathrm{H}^{3}{ }^{31} \mathrm{P} \mathrm{HMBC},{ }^{1} \mathrm{H}-{ }^{13} \mathrm{C} \mathrm{HMBC}, \mathrm{COSY}\right.$; Figs. S55, S59 and 4C in the main text)), and through comparison with the NMR data of the independently prepared complex (containing a chloride or an iodide; vide infra). Formation of xantphos-Pd- $\beta$-acyl species bearing an iodidie occurred also at room temperature, but at slower rate (Fig. S58). The subsequent conversion of the xantphos-Pd- $\beta$-acyl species to the aldehyde product strongly depended on the ratio of metal to ligand. When xantphos was used in stochiometric amount (Fig. S57) or in excess (1.1 equiv.; Fig. S60) with respect to the palladium(II) precursor, only small amount of aldehyde was formed upon prolonged treatment (7-24 h at 50-60 $\left.{ }^{\circ} \mathrm{C}\right)$. In contrast, when a substochiometric amount of xantphos $(0.5$ or 0.8 equiv.; Figs. S62-S62) was used or when $\mathrm{Pd}(\mathrm{OAc})_{2}(0.2$ equiv.; Fig. S63) was added, the aldehyde was quantitatively formed within $7 \mathrm{~h}$ at $50{ }^{\circ} \mathrm{C}$.

In case of $\mathrm{Pd}$-complexes bearing a halide in the presence of a stochiometric amount of xantphos (or excess), not only generation of xantphos-Pd- $\beta$-acyl intermediates occurred more slowly, but also the reaction was accompanied by formation of another compound identified as a transition metal free $\beta$-acyl halide (i.e., 3-phthalimidopropanoyl halide). Formation of a $\beta$-acyl halide occurred to the large extent for Pd-complexes bearing a chloride or a bromide (Figs. S53 and S56). The assignment was supported by 2D NMR experiments and through comparison with NMR data the authentic sample (3-phthalimidopropanoyl chloride; Fig. S54). Presumably, the $\beta$-acyl halides are formed by (reversible) reductive elimination from the xantphos-Pd- $\beta$-acyl intermediates promoted by CO coordination. Indeed, when a solution of xantphosPd- $\beta$-acyl iodide (preformed under syngas) was treated under CO (6 bar), the $\beta$-acyl halide was formed as the main species (Fig. S64). Upon further treatment with $\mathrm{H}_{2}$ (6 bar), the $\beta$-acyl halide was converted to the $\beta$-aldehyde product (Fig. S64), indicating that the formation of the $\beta$-acyl halide species is reversible under these conditions.

It is worth mentioning that, because the activation of the $\mathrm{Pd}$-complex bearing a halide is accompanied by the formation of hydrogen halide $(\mathrm{HCl}, \mathrm{HBr}$, or $\mathrm{HI})$, formation of hydrohalogenation products from an alkene was observed in some experiments. Control experiments indicated that the Pdcomplex is not involved in the formation of the hydrohalogenation products (i.e., a reaction of alkene $\mathbf{1 q}$ 
and HI led to the same hydrohalogenated product; Fig. S65). Remarkably, the hydrohalogenated compound was finally converted to the aldehyde upon further treatment (see e.g., Fig. S61). Most likely the halogenated compound can enter the catalytic cycle through oxidative addition to form the Pd-alkyl intermediate. 


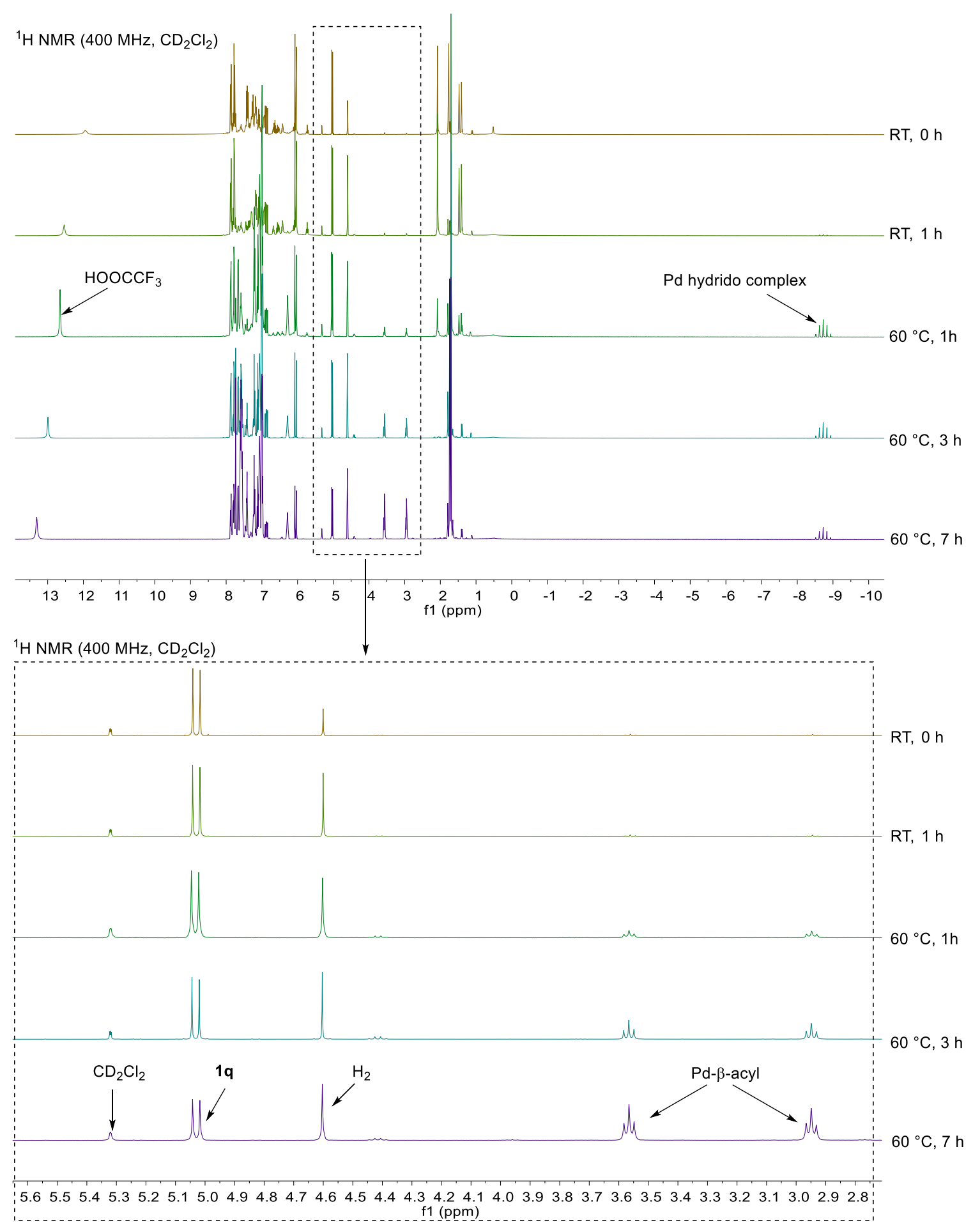

Fig. $\mathbf{S 4 4}{ }^{l} \mathrm{H}$ NMR spectra for the reaction of xantphos-Pd(II) trifluoroacetate (prepared in situ, $\mathrm{Pd}(\mathrm{II})\left(\mathrm{OCOCF}_{3}\right)_{2}$ +0.8 equiv. xantphos) and alkene $1 q$ under 6 bar syngas in $\mathrm{CD}_{2} \mathrm{Cl}_{2}$. 


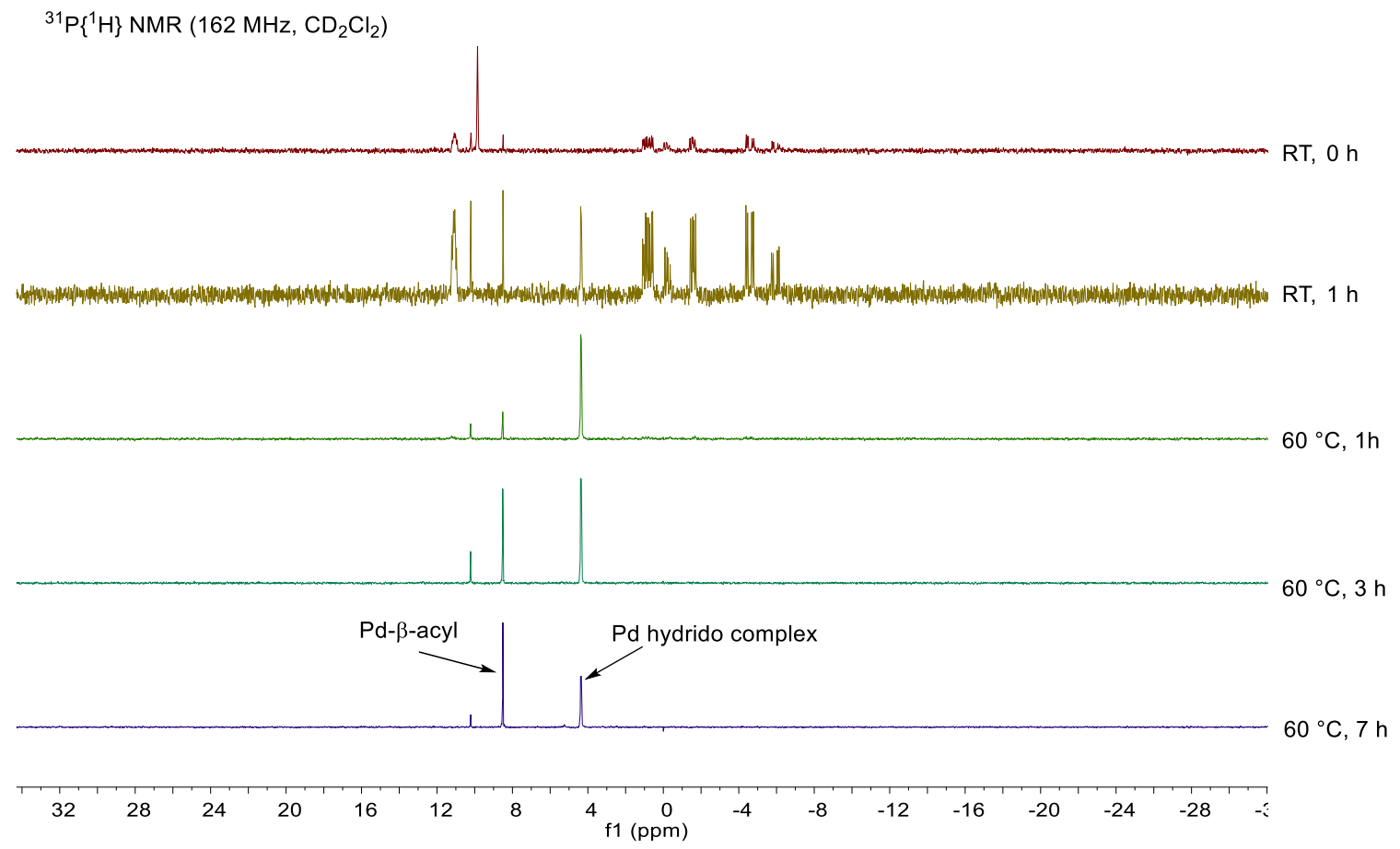

Fig. $\mathbf{S 4 5}{ }^{31} P\left\{{ }^{1} H\right\} N M R$ spectra for the reaction of xantphos-Pd(II) trifluoroacetate (prepared in situ, $\mathrm{Pd}(\mathrm{II})\left(\mathrm{OCOCF}_{3}\right)_{2}+0.8$ equiv. xantphos) and alkene $1 q$ under 6 bar syngas in $\mathrm{CD}_{2} \mathrm{Cl}_{2}$. 
${ }^{1} \mathrm{H}$ NMR $\left(400 \mathrm{MHz}, \mathrm{CD}_{2} \mathrm{Cl}_{2}\right)$
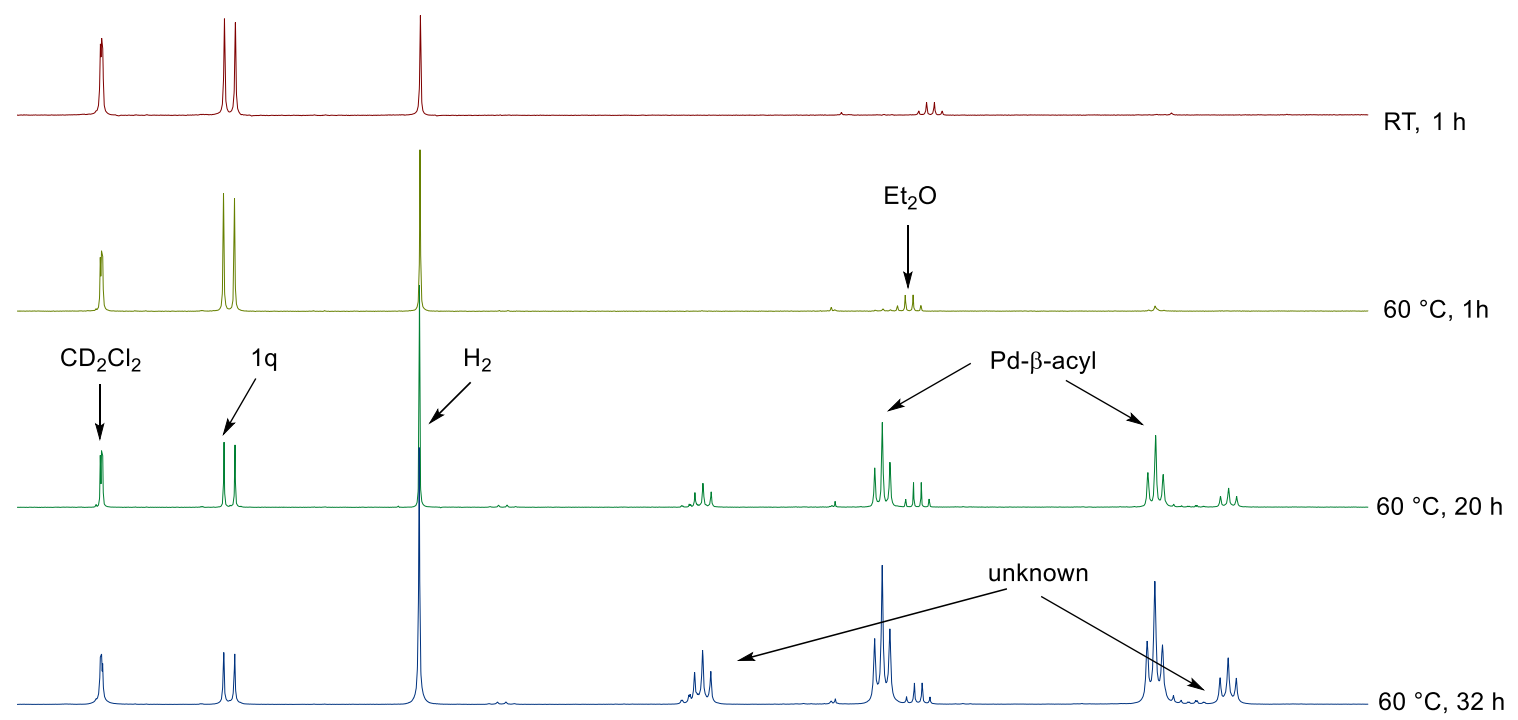

\begin{tabular}{lllllllllllllllllllllllllllllllllllllll}
\hline .5 & 5.4 & 5.3 & 5.2 & 5.1 & 5.0 & 4.9 & 4.8 & 4.7 & 4.6 & 4.5 & 4.4 & 4.3 & 4.2 & 4.1 & 4.0 & 3.9 & 3.8 & 3.7 & 3.6 & 3.5 & 3.4 & 3.3 & 3.2 & 3.1 & 3.0 & 2.9 & 2.8 & 2.7 & 2.6 & 2.5
\end{tabular}

$\mathrm{f1}(\mathrm{ppm})$

Fig. $\mathbf{S 4 6}{ }^{1} \mathrm{H} N \mathrm{NR}$ spectra for the reaction of xantphos-Pd(II) trifluoroacetate (prepared in situ, $\mathrm{Pd}(\mathrm{II})\left(\mathrm{OCOCF}_{3}\right)_{2}$ +1.0 equiv. xantphos) and alkene $1 q$ under 6 bar syngas in $\mathrm{CD}_{2} \mathrm{Cl}_{2}$.

${ }^{1} \mathrm{H}$ NMR $\left(400 \mathrm{MHz}, \mathrm{CD}_{2} \mathrm{Cl}_{2}\right)$

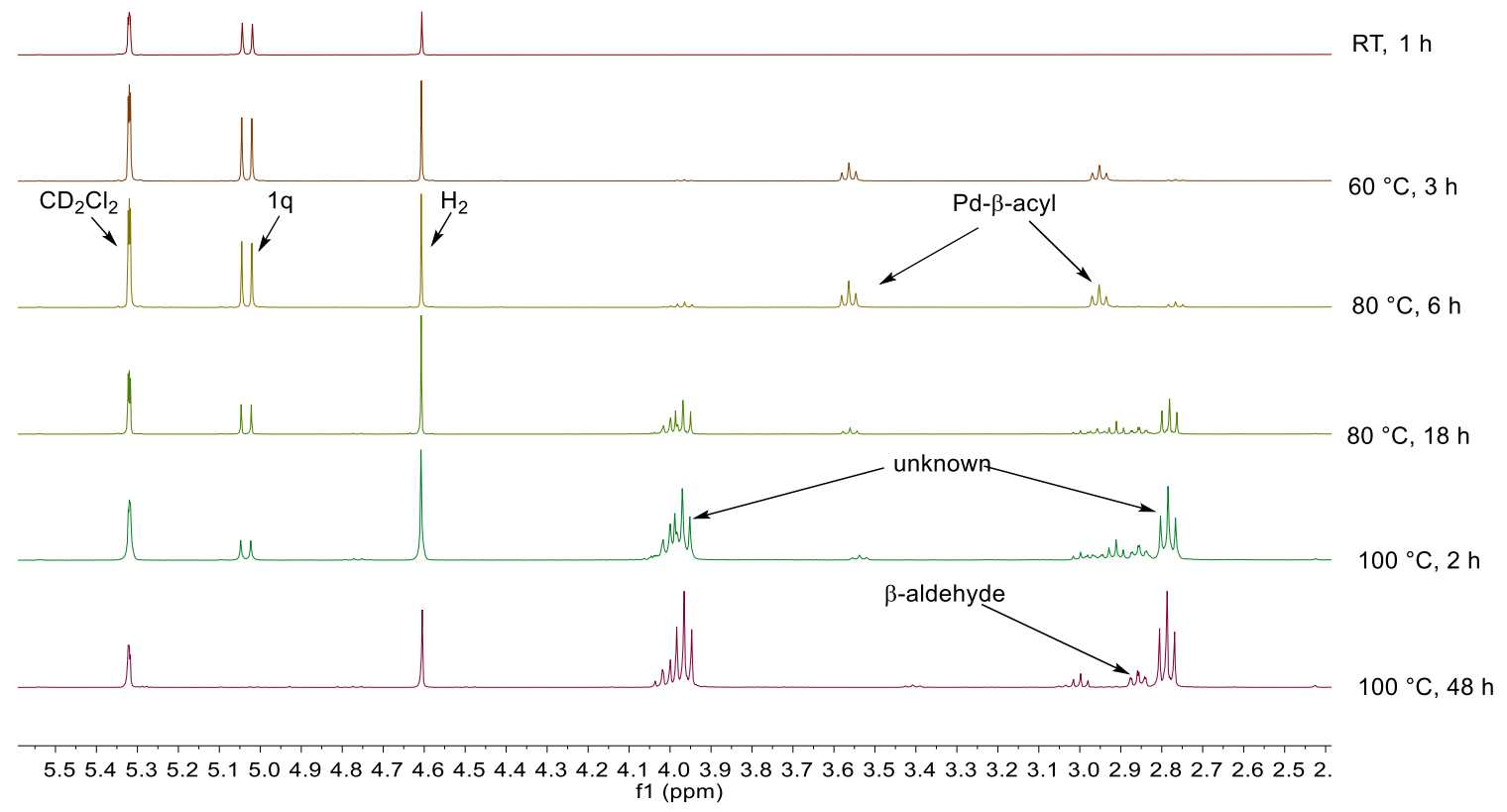

Fig. $\mathbf{S 4 7}{ }^{1} \mathrm{H}$ NMR spectra for the reaction of xantphos-Pd(II) trifluoroacetate (prepared in situ, Pd(II)(OCOCF $)_{2}$ +1.1 equiv. xantphos) and alkene $1 q$ under 6 bar syngas in $\mathrm{CD}_{2} \mathrm{Cl}_{2}$. 


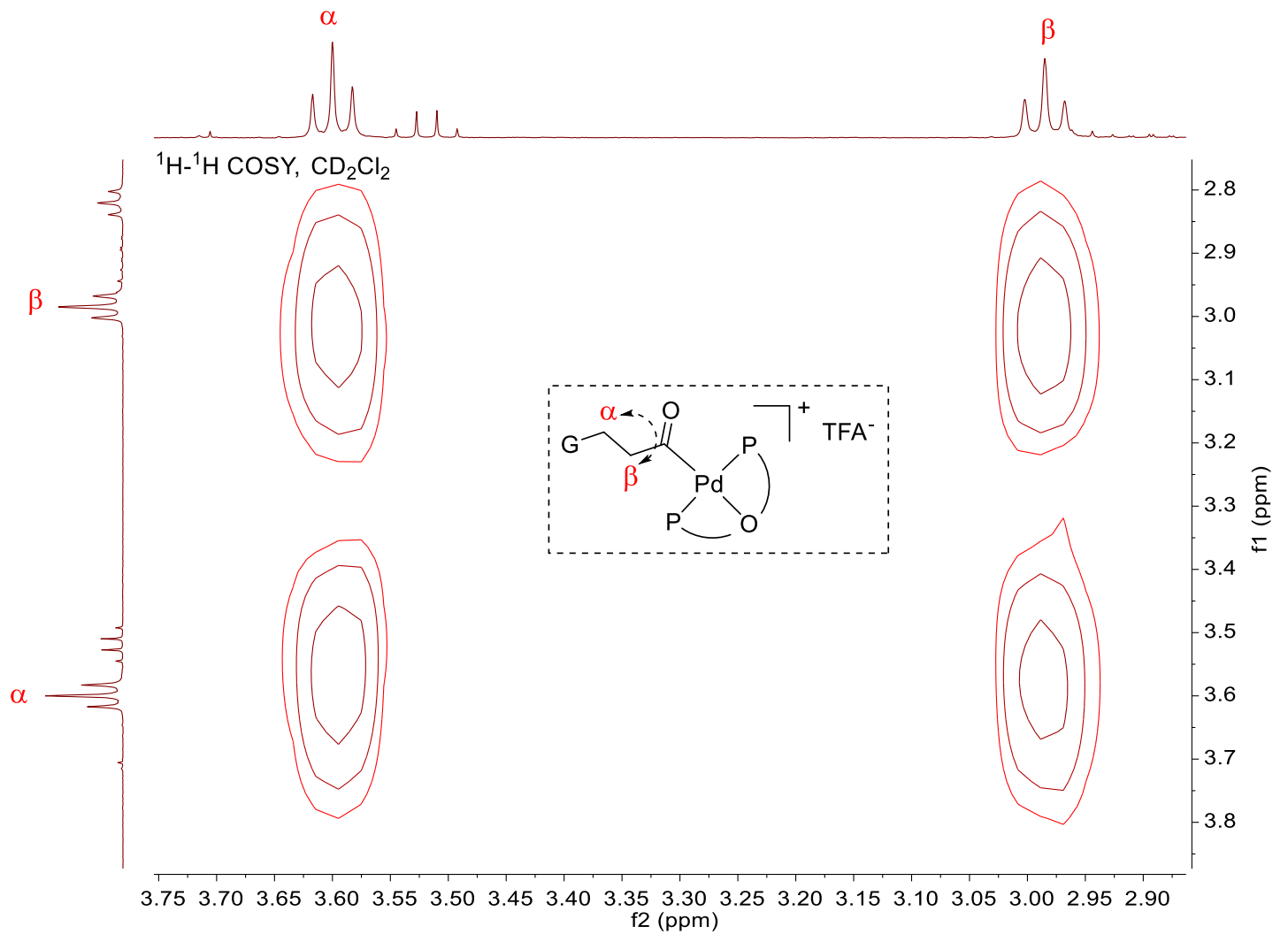




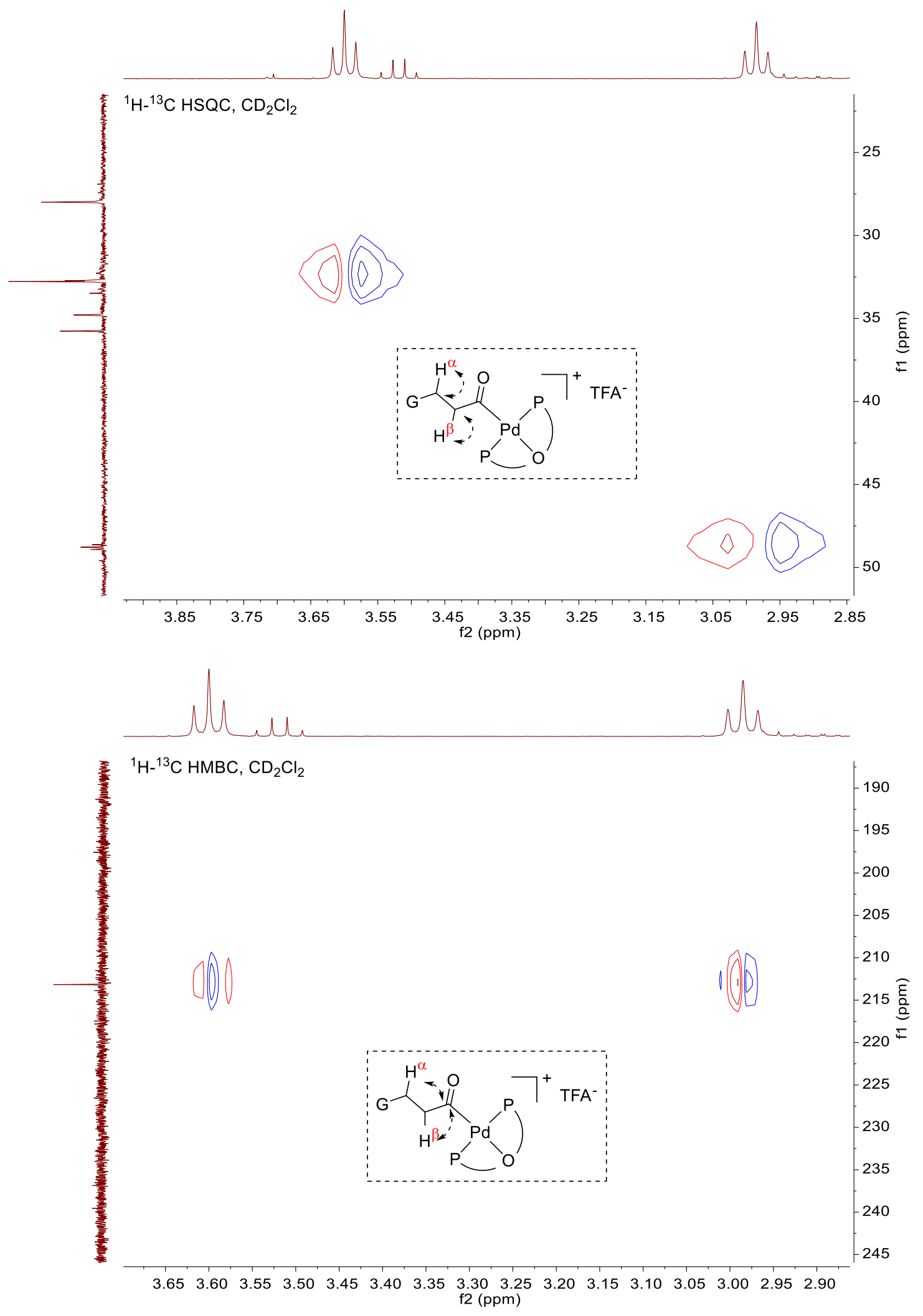

Fig. S48 2D NMR spectra for xantphos-Pd- $\beta$-acyl TFA complex. 

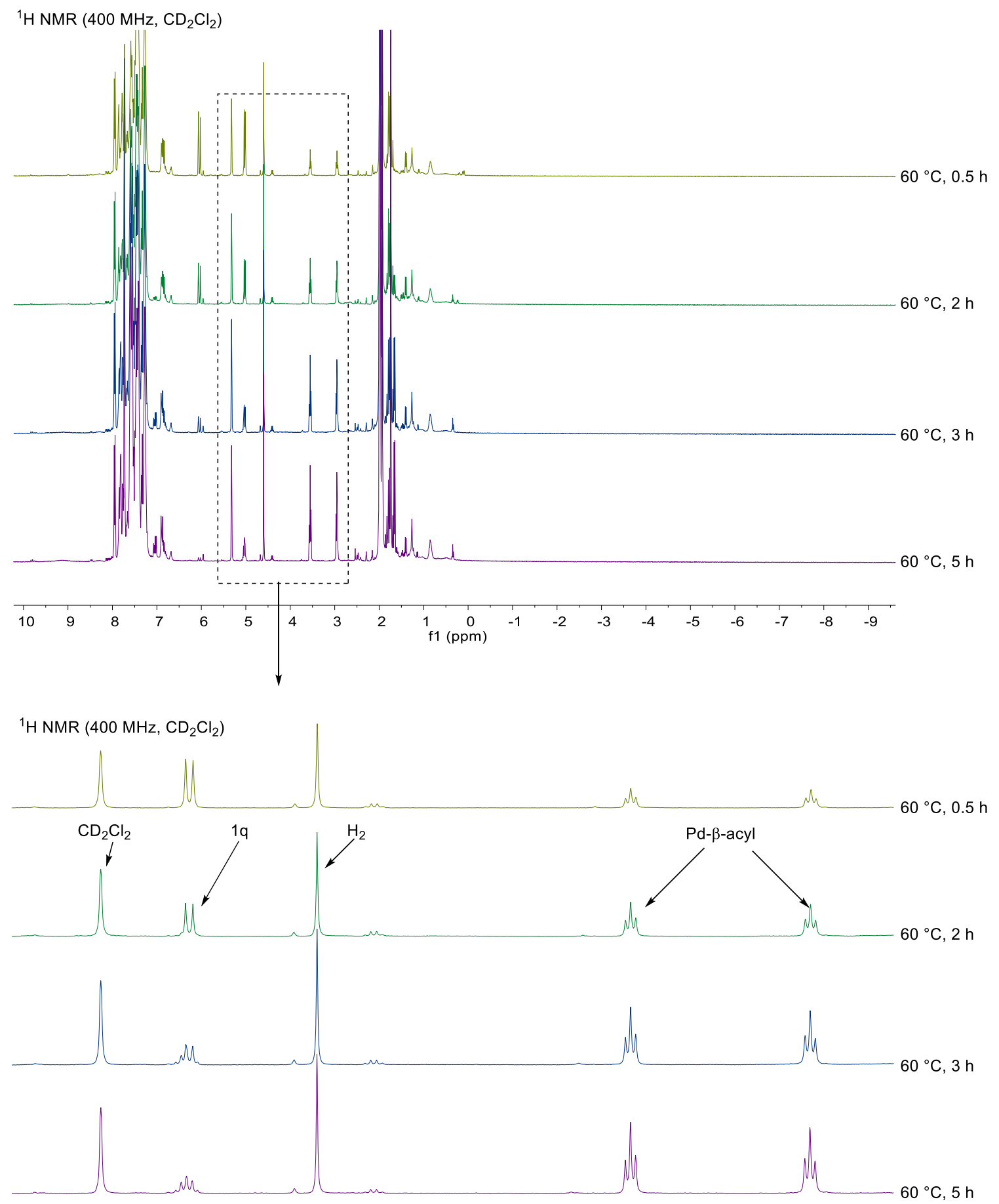

$\begin{array}{llllllllllllllllllllllllllllllllll}5.6 & 5.5 & 5.4 & 5.3 & 5.2 & 5.1 & 5.0 & 4.9 & 4.8 & 4.7 & 4.6 & 4.5 & 4.4 & 4.3 & 4.2 & 4.1 & 4.0 & 3.9 & 3.8 & 3.7 & 3.6 & 3.5 & 3.4 & 3.3 & 3.2 & 3.1 & 3.0 & 2.9 & 2.8 & 1\end{array}$ :

Fig. S49 ${ }^{1} H$ NMR spectra for the reaction of xantphos-Pd(II) tetrafluoroborate (prepared in situ, $\left[\mathrm{Pd}(\mathrm{II})\left(\mathrm{NCCH}_{3}\right)\right]\left(\mathrm{BF}_{4}\right)_{2}+1.1$ equiv. xantphos) and alkene $1 \mathrm{q}$ under 6 bar syngas in $\mathrm{CD}_{2} \mathrm{Cl}_{2}$. 

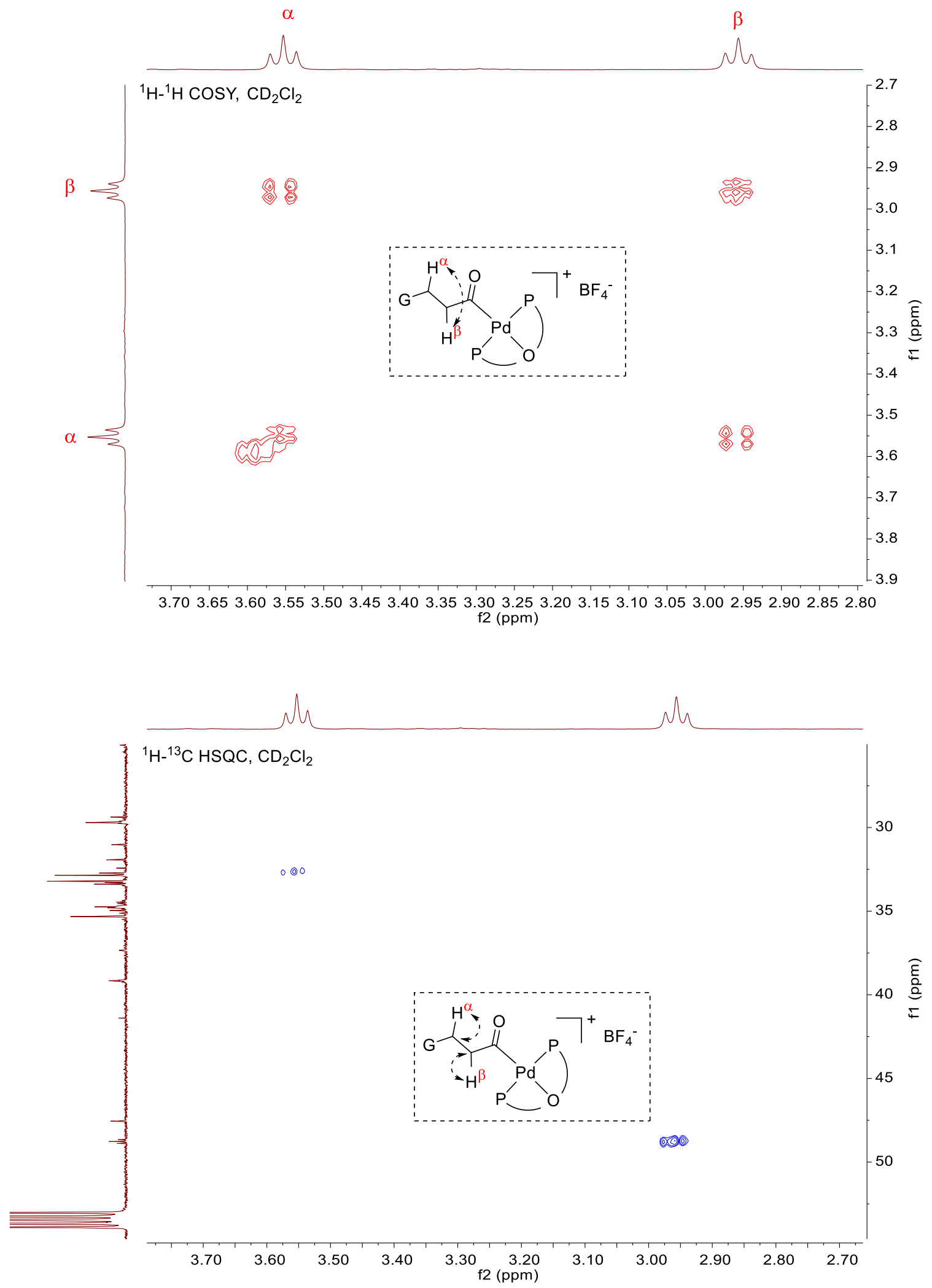


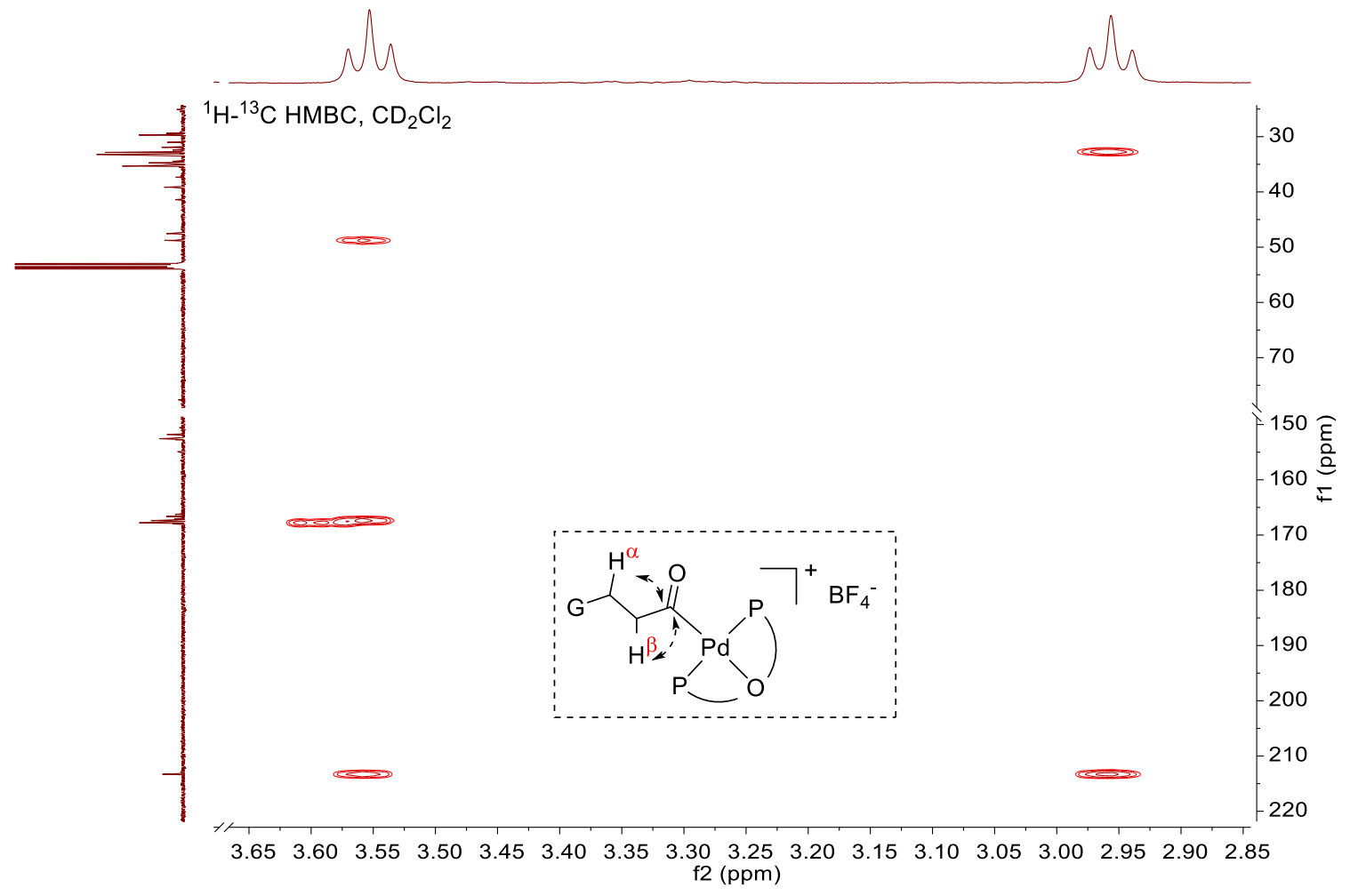

Fig. S50 2D NMR spectra for xantphos-Pd- $\beta$-acyl BF $F_{4}$ complex. 

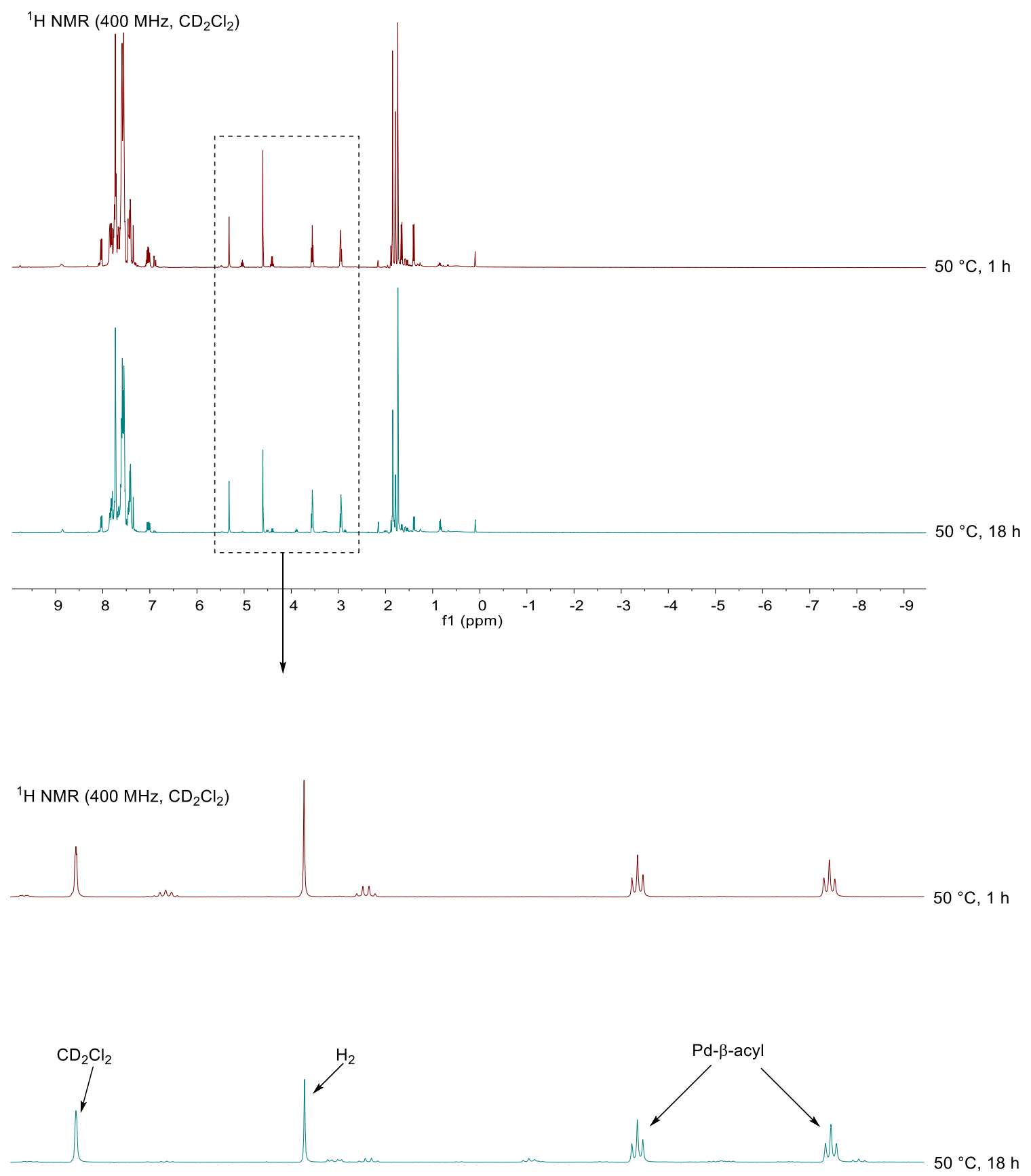

$\begin{array}{lllllllllllllllllllllllllllllllllllllllllll}5.5 & 5.4 & 5.3 & 5.2 & 5.1 & 5.0 & 4.9 & 4.8 & 4.7 & 4.6 & 4.5 & 4.4 & 4.3 & 4.2 & 4.1 & 4.0 & 3.9 & 3.8 & 3.7 & 3.6 & 3.5 & 3.4 & 3.3 & 3.2 & 3.1 & 3.0 & 2.9 & 2.8 & 2.7\end{array}$

Fig. $\mathbf{S 5 1}{ }^{1} H$ NMR spectra for the reaction of xantphos-Pd(II) triflate (prepared separately) and alkene $\mathbf{1 q}$ under 6 bar syngas in $\mathrm{CD}_{2} \mathrm{Cl}_{2}$. 

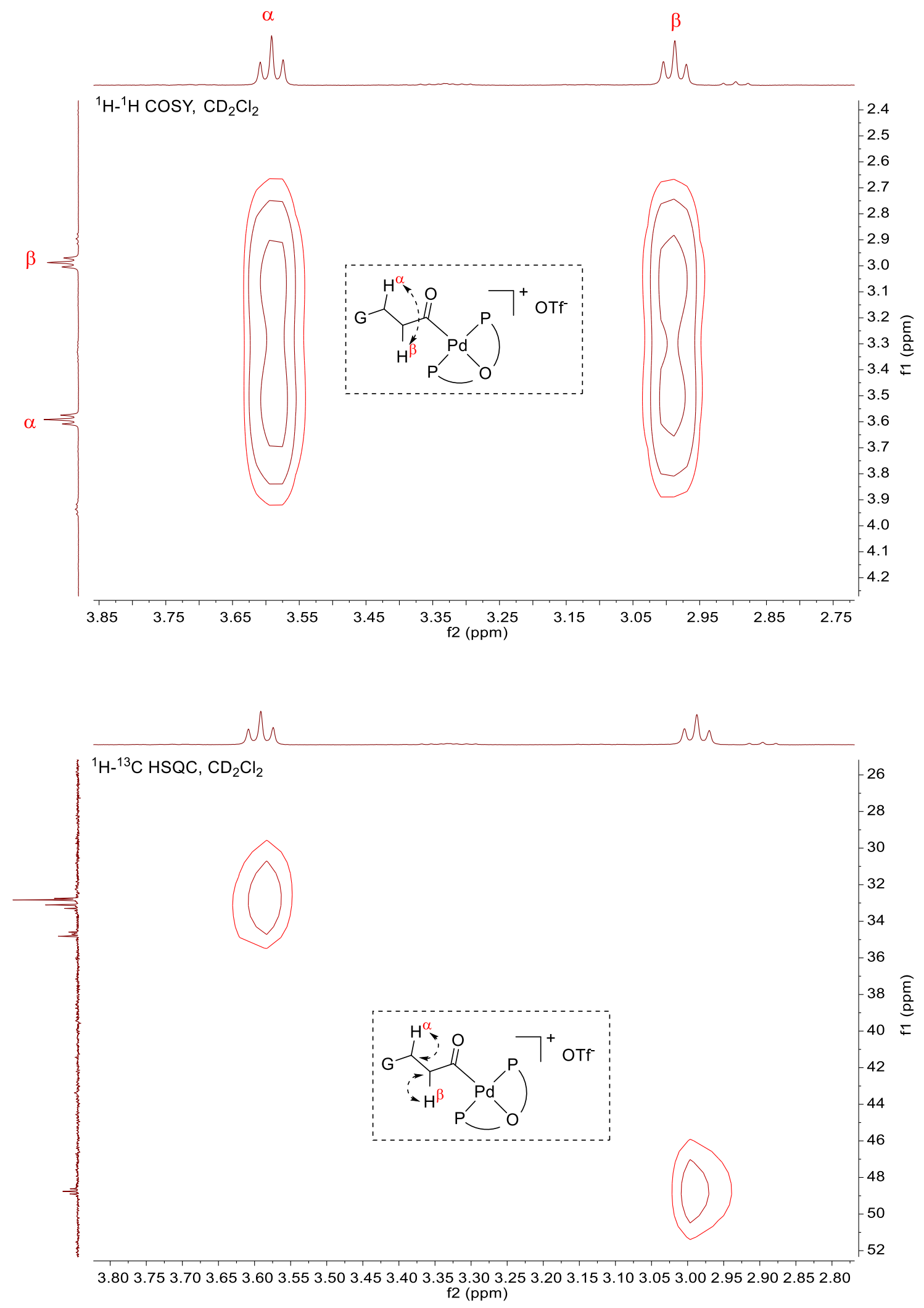


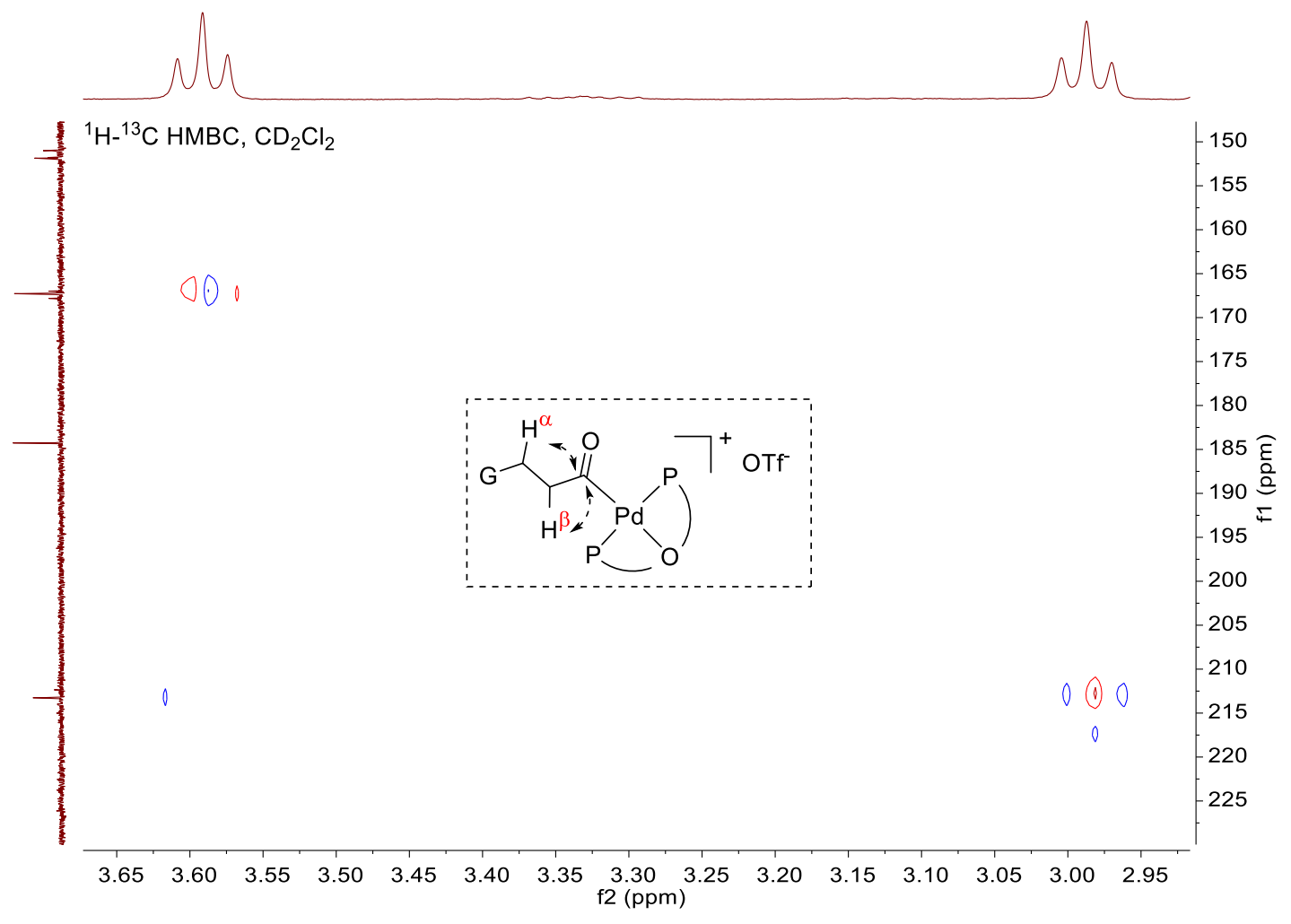

Fig. S52 2D NMR spectra for xantphos-Pd- $\beta$-acyl triflate complex. 

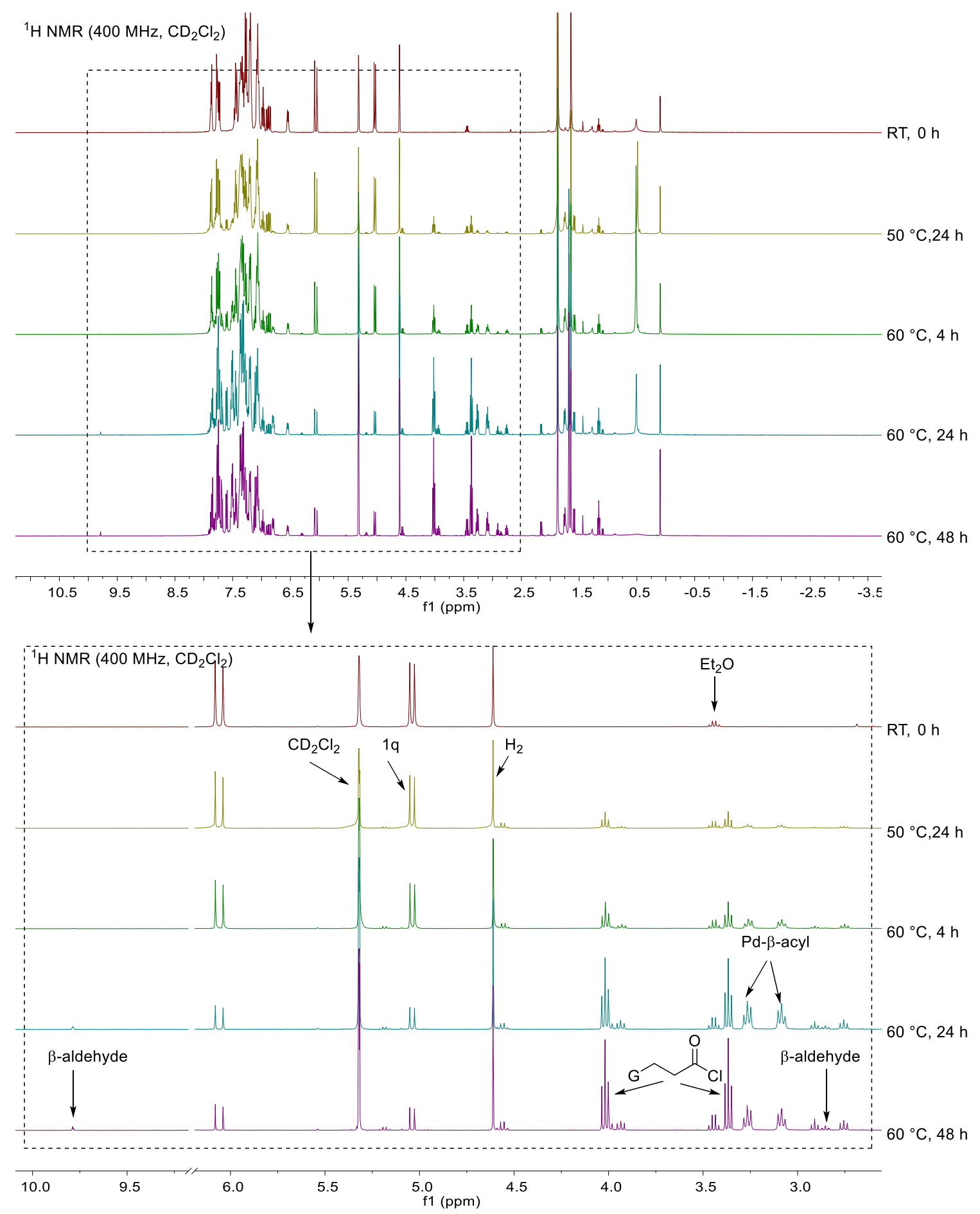

Fig. S53 ${ }^{1} \mathrm{H} N M R$ spectra for the reaction of xantphos-Pd(II) chloride (prepared in situ, $\mathrm{PdCl}_{2}+1.0$ equiv. xantphos) and alkene $1 q$ under 6 bar syngas in $\mathrm{CD}_{2} \mathrm{Cl}_{2}$. 

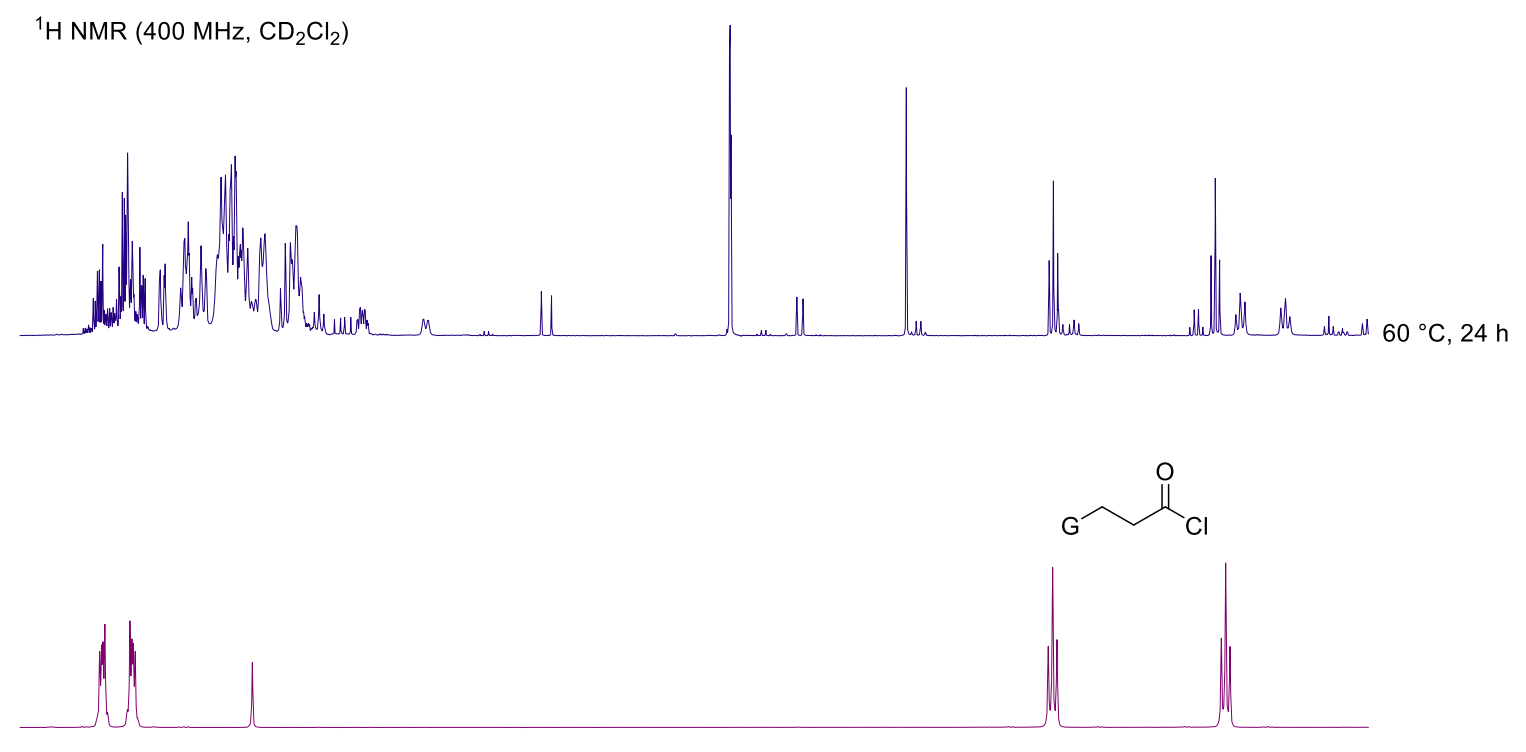

$\begin{array}{llllllllllllllllllllllllllllllllllllllllll}3.2 & 8.0 & 7.8 & 7.6 & 7.4 & 7.2 & 7.0 & 6.8 & 6.6 & 6.4 & 6.2 & 6.0 & 5.8 & 5.6 & 5.4 & 5.2 & 5.0 & 4.8 & 4.6 & 4.4 & 4.2 & 4.0 & 3.8 & 3.6 & 3.4 & 3.2 & 3.0 & 2\end{array}$

Fig. S54 ${ }^{l} \mathrm{H} N \mathrm{NM}$ spectra for the reaction of xantphos-Pd(II) chloride (prepared in situ, $\mathrm{PdCl}_{2}+1.0$ equiv. xantphos) and alkene $1 q$ (under 6 bar syngas after $24 \mathrm{~h}$ at $60^{\circ} \mathrm{C}$; top); and for an authentic sample of 3phthalimidopropionyl chloride (bottom). 


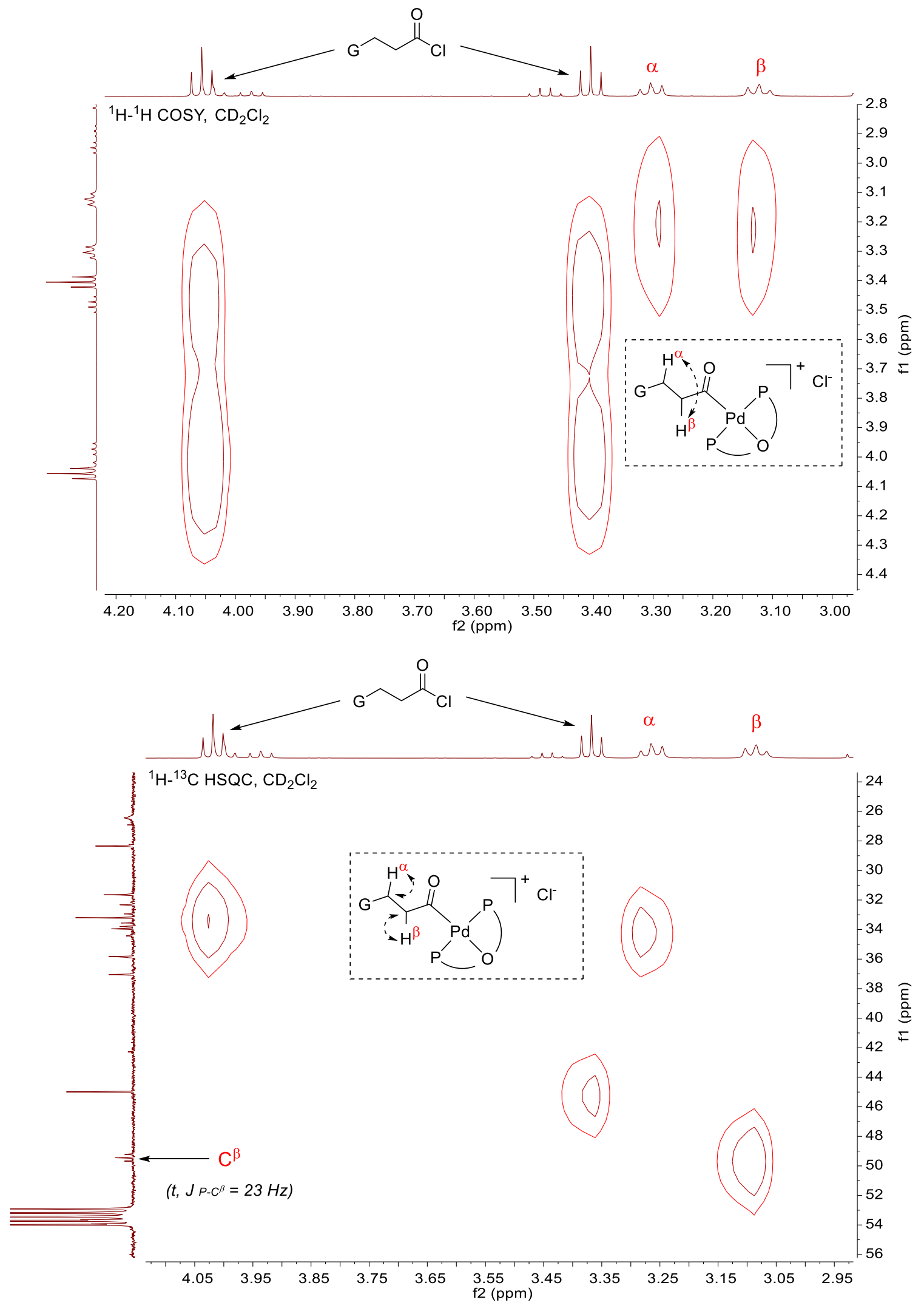




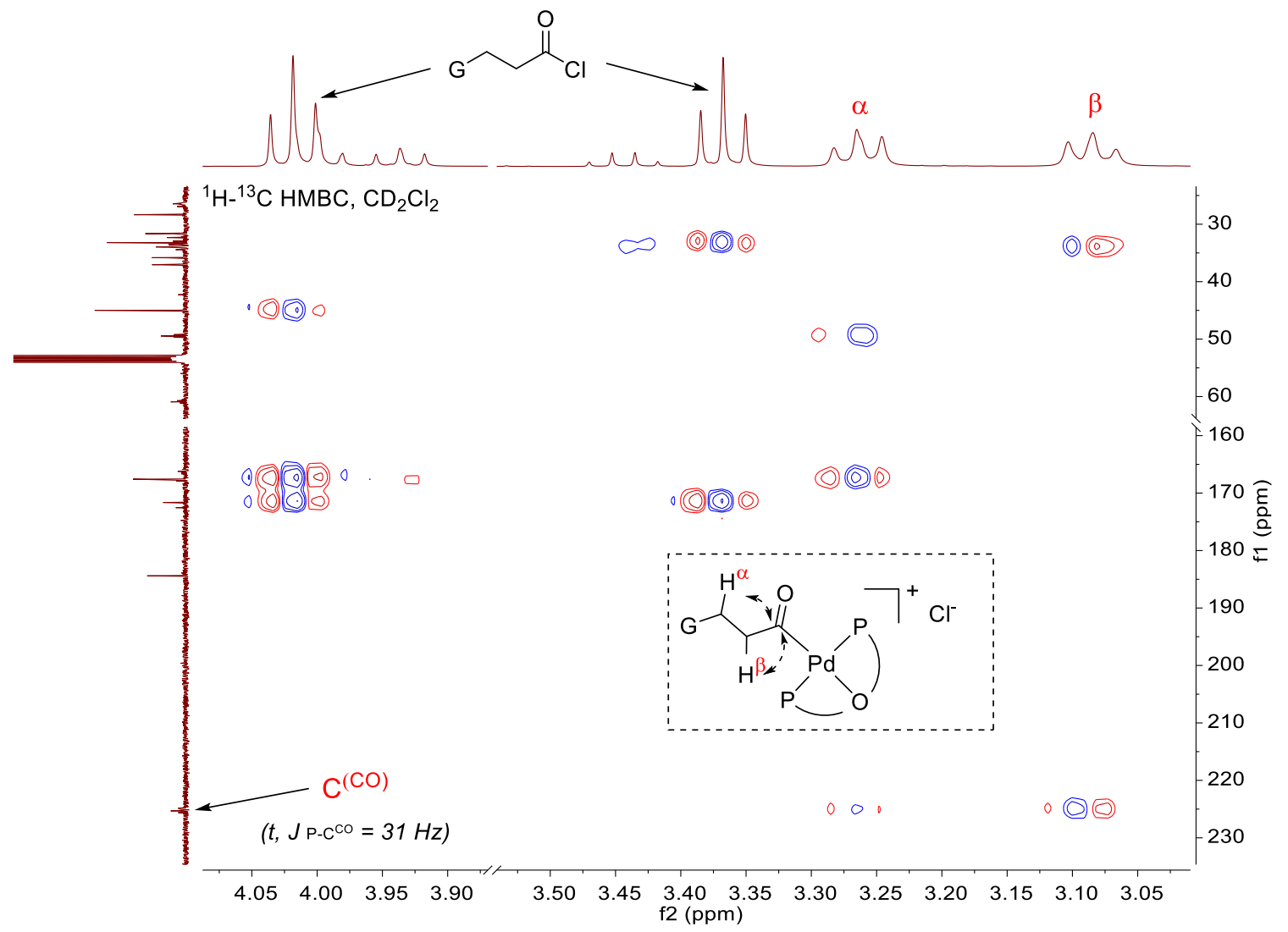

Fig. S55 ${ }^{1} \mathrm{H}$ COSY, ${ }^{1} \mathrm{H}_{-}{ }^{13} \mathrm{CHSQC},{ }^{1} \mathrm{H}_{-}{ }^{13} \mathrm{C} \mathrm{HMBC}$ NMR spectra for the reaction mixture of xantphos-Pd(II) chloride (prepared in situ, $\mathrm{PdCl}+1.0$ equiv. xantphos) and alkene $\mathbf{I q}$ (under 6 bar syngas after 24 hat $60^{\circ} \mathrm{C}$ ). 


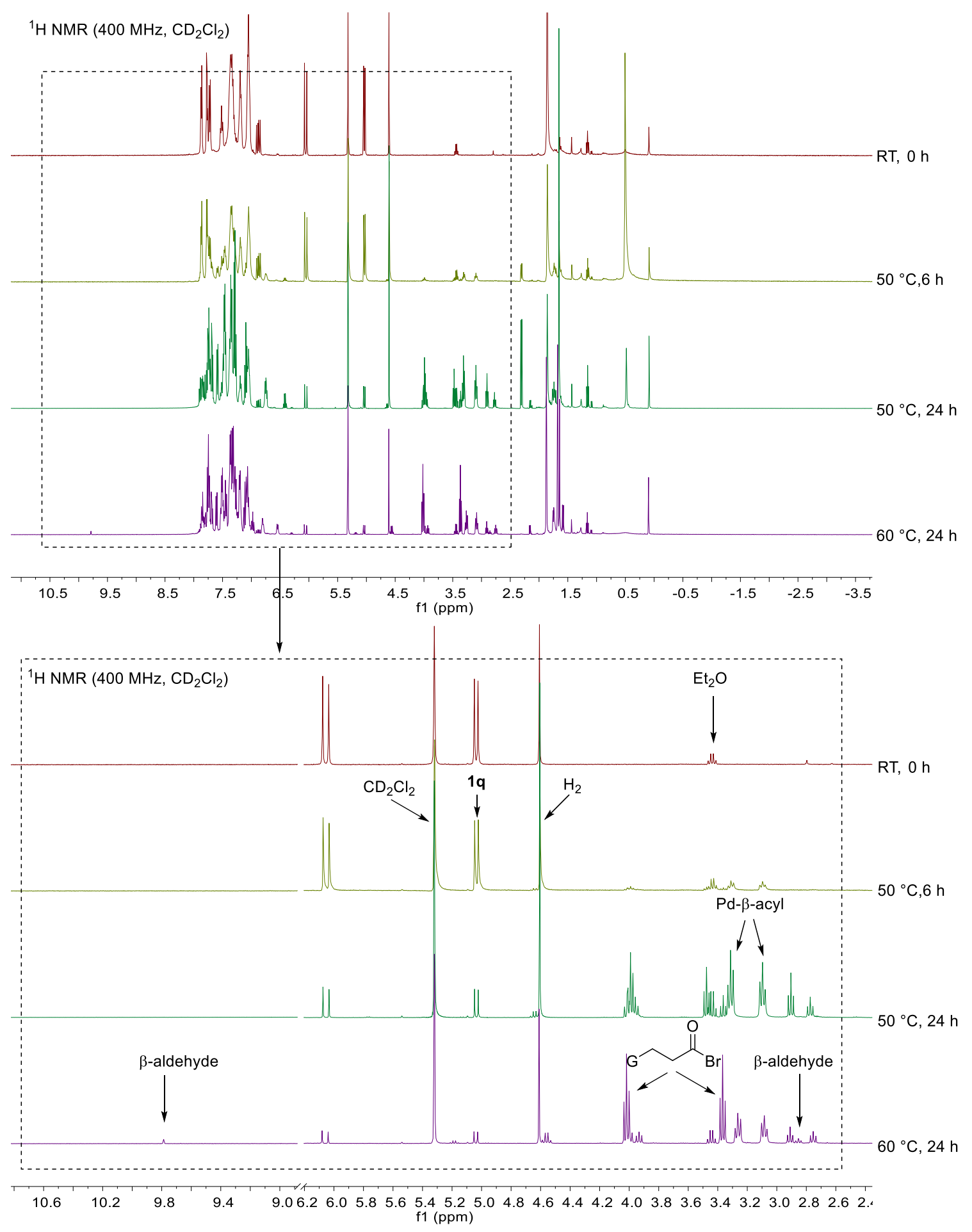

Fig. S56 ${ }^{1} \mathrm{H} N M R$ spectra for the reaction of xantphos-Pd(II) bromide (prepared in situ, $\mathrm{PdBr}_{2}+1.0$ equiv. xantphos) and alkene $1 \boldsymbol{q}$ under 6 bar syngas in $\mathrm{CD}_{2} \mathrm{Cl}_{2}$. 


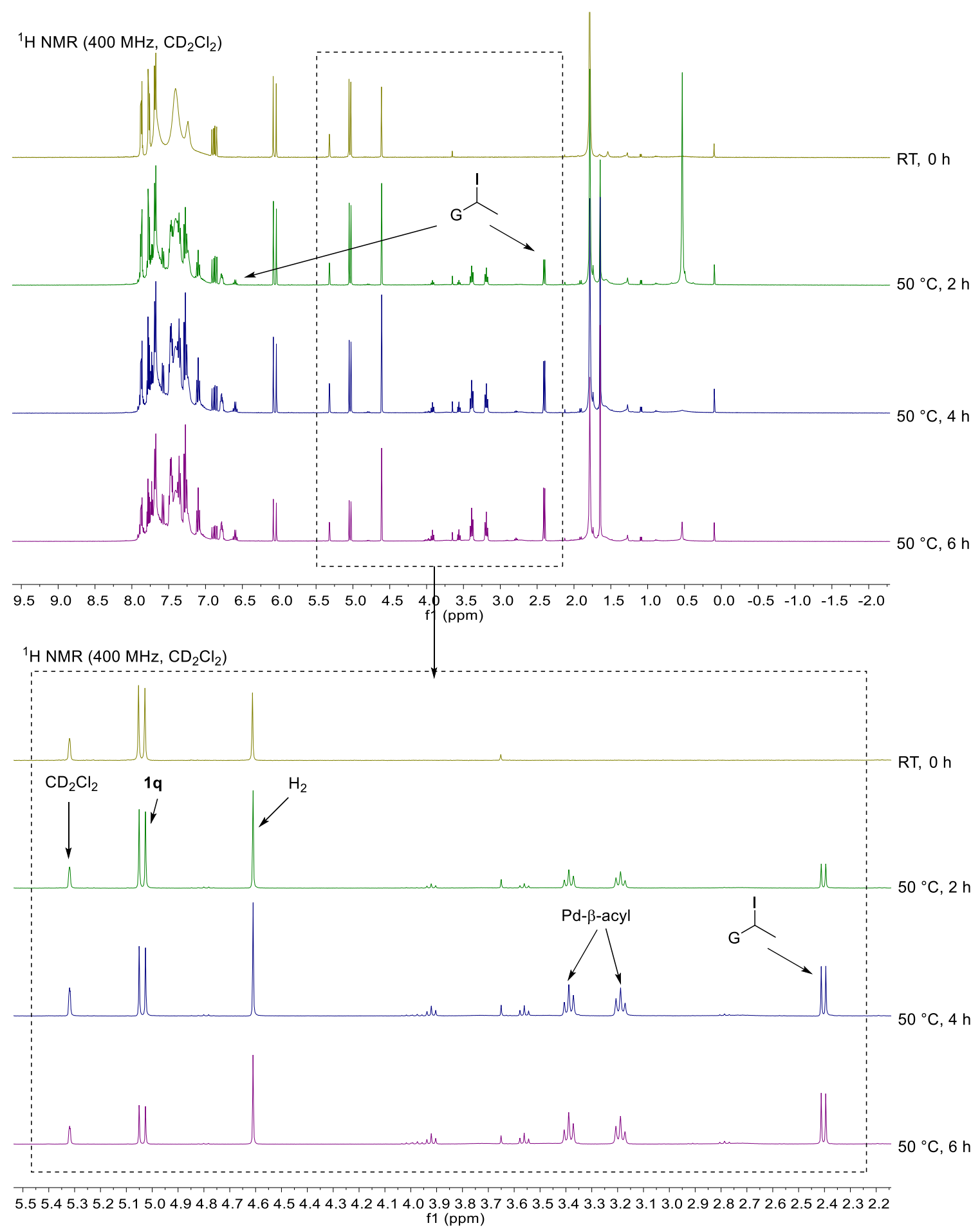

Fig. $S 57{ }^{1} H$ NMR spectra for the reaction of xantphos-Pd(II) iodide (prepared in situ, $\mathrm{PdI}_{2}+1.0$ equiv. xantphos) and alkene $1 q$ under 6 bar syngas in $\mathrm{CD}_{2} \mathrm{Cl}_{2}$. 


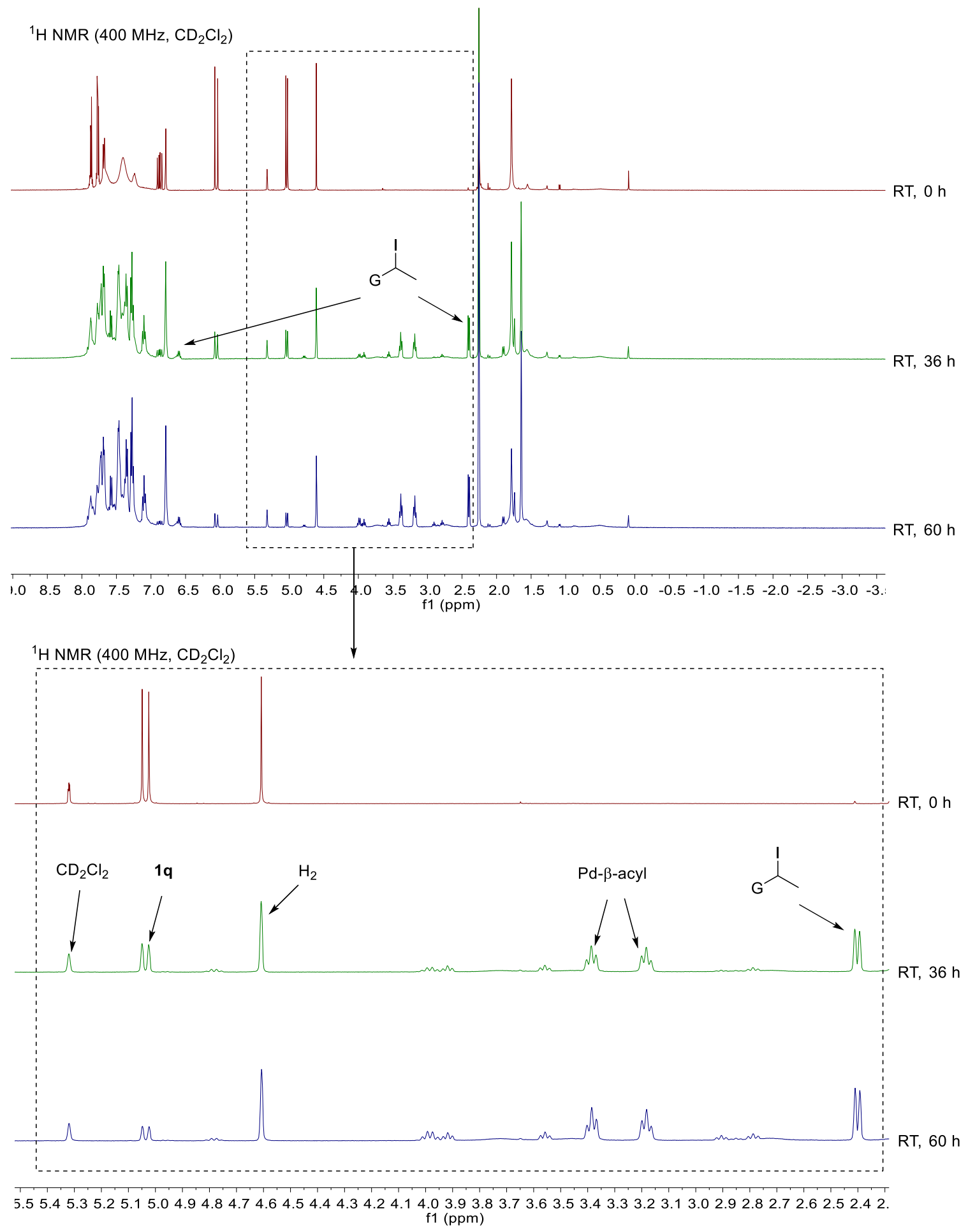

Fig. S58 ${ }^{1} \mathrm{H}$ NMR spectra for the reaction of xantphos-Pd(II) iodide (prepared in situ, $\mathrm{PdI}_{2}+1.0$ equiv. xantphos) and alkene $\mathbf{1 q}$ under 6 bar syngas at room temperature in $\mathrm{CD}_{2} \mathrm{Cl}_{2}$. 

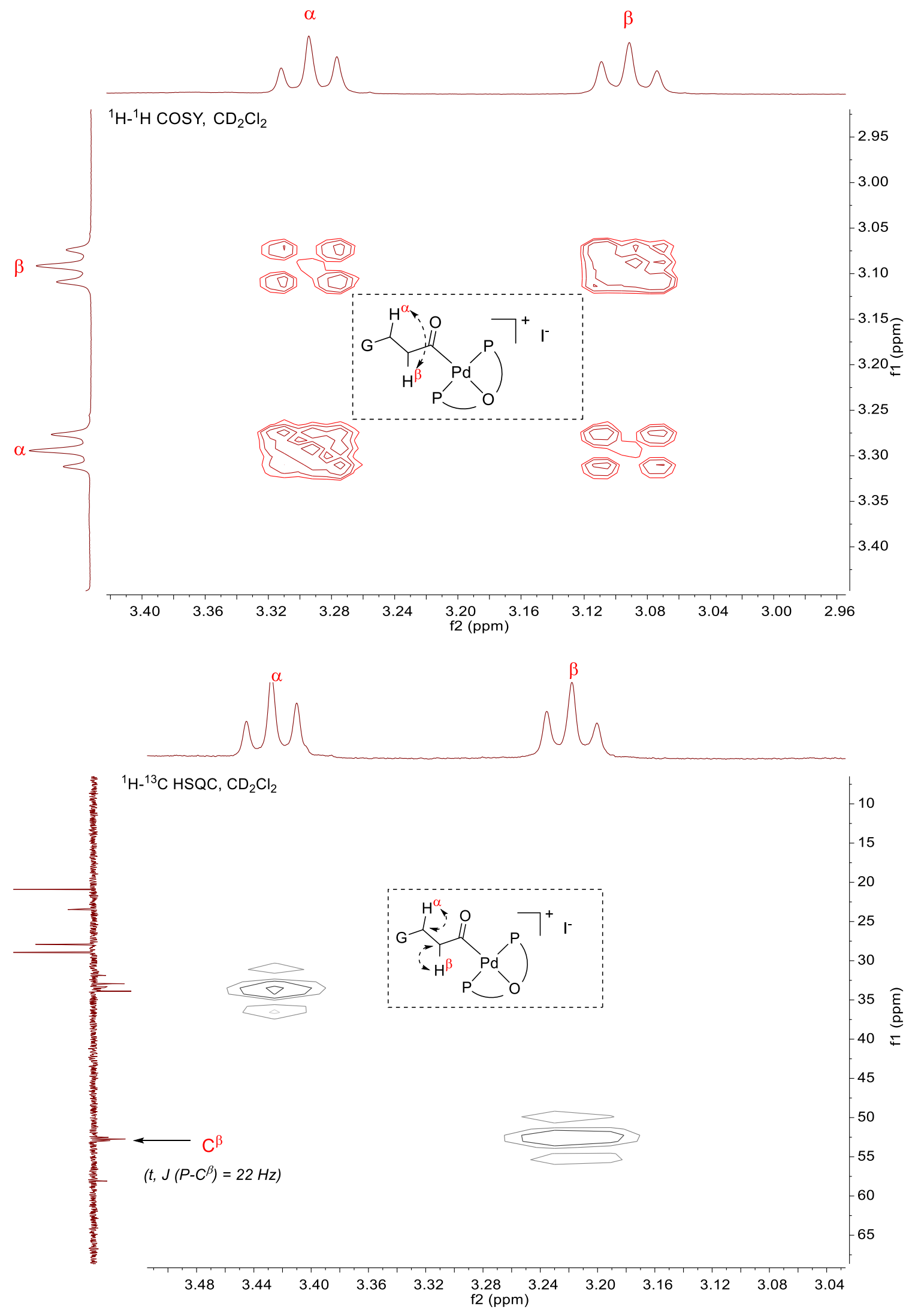


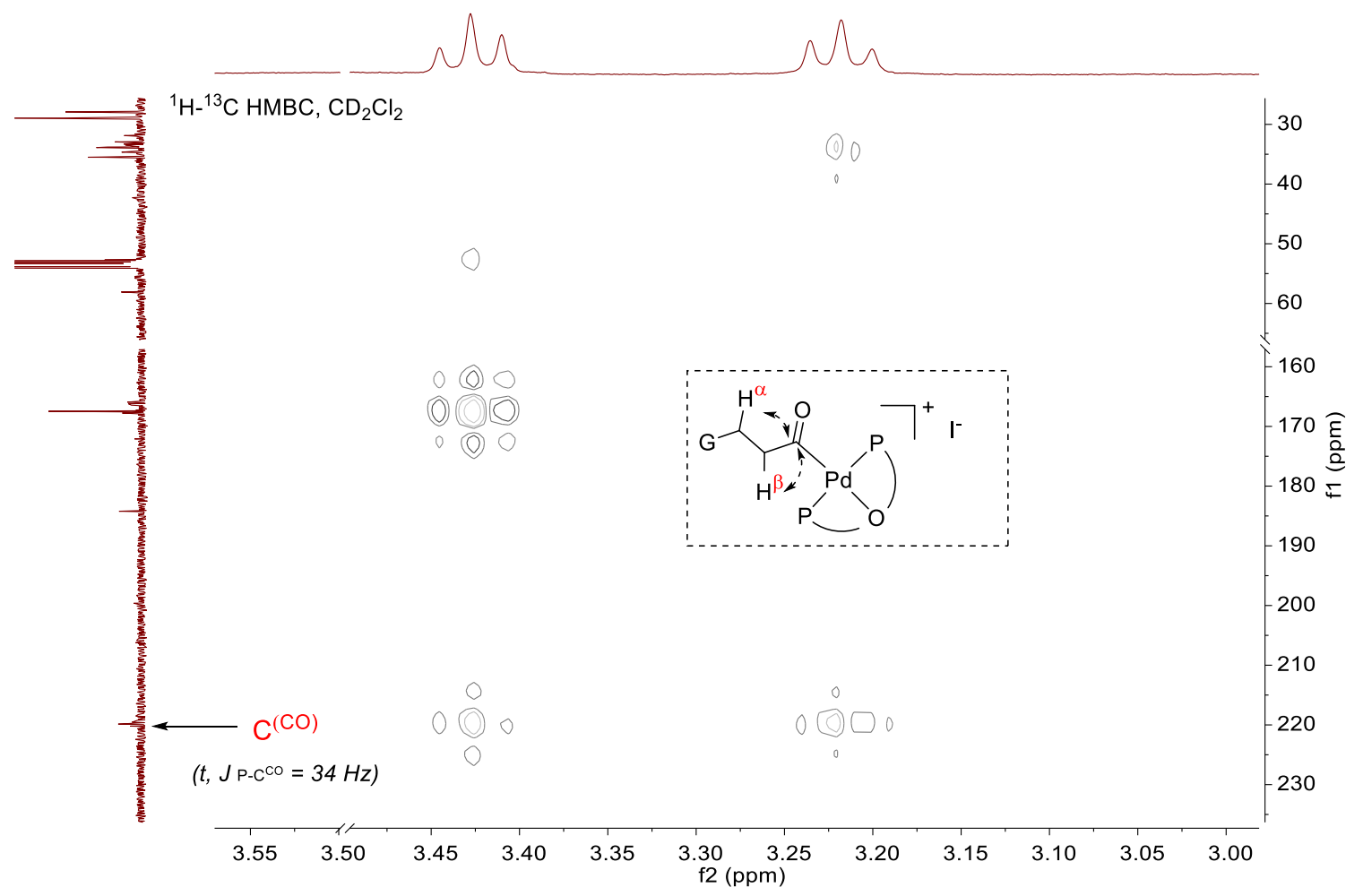

Fig. S59 2D NMR spectra for xantphos-Pd- $\beta$-acyl iodide complex.

${ }^{1} \mathrm{H}$ NMR $\left(400 \mathrm{MHz}, \mathrm{CD}_{2} \mathrm{Cl}_{2}\right)$
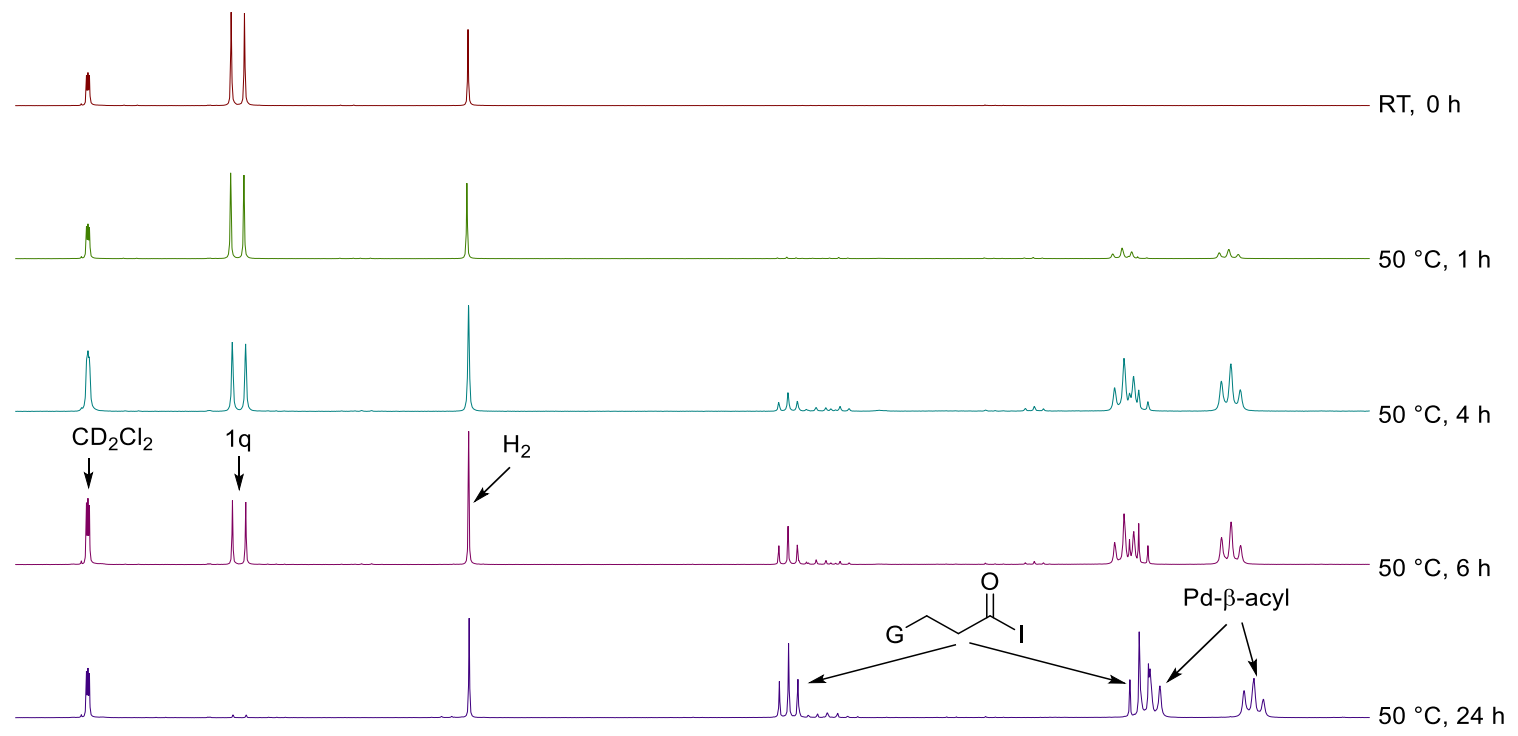

$\begin{array}{lllllllllllllllllllllllllllllll}5.4 & 5.3 & 5.2 & 5.1 & 5.0 & 4.9 & 4.8 & 4.7 & 4.6 & 4.5 & 4.4 & 4.3 & 4.2 & 4.1 & 4.0 & 3.9 & 3.8 & 3.7 & 3.6 & 3.5 & 3.4 & 3.3 & 3.2 & 3.1 & 3.1\end{array}$

Fig. S60 ${ }^{1} H$ NMR spectra for the reaction of xantphos-Pd(II) iodide (prepared in situ, $P d I_{2}+1.1$ equiv. xantphos) and alkene $1 \mathrm{q}$ under 6 bar syngas in $\mathrm{CD}_{2} \mathrm{Cl}_{2}$. 

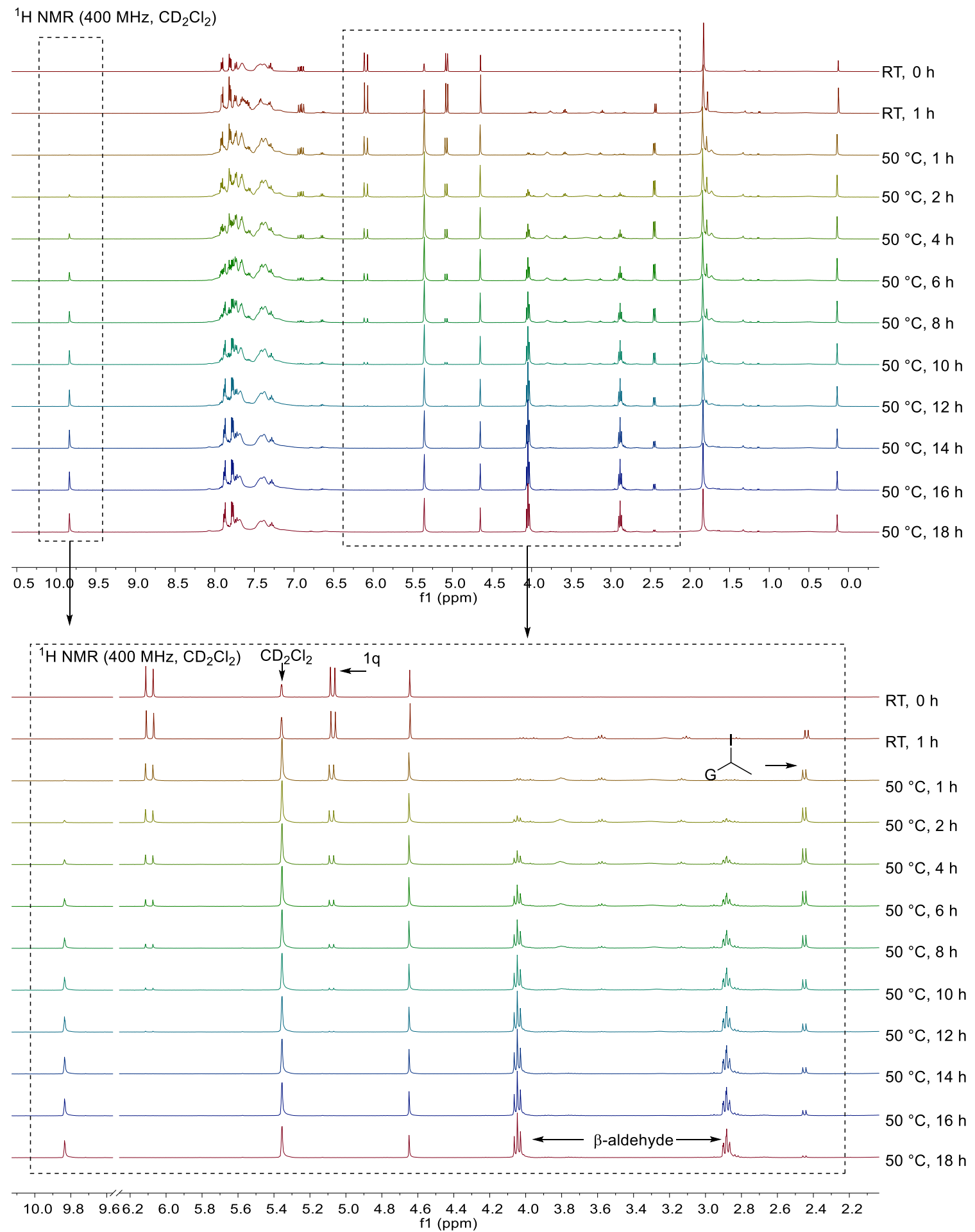

Fig. $\mathbf{S 6 1}{ }^{1} H$ NMR spectra for the reaction of xantphos-Pd(II) iodide (prepared in situ, $P d I_{2}+0.5$ equiv. xantphos) and alkene $1 q$ under 6 bar syngas in $\mathrm{CD}_{2} \mathrm{Cl}_{2}$. 


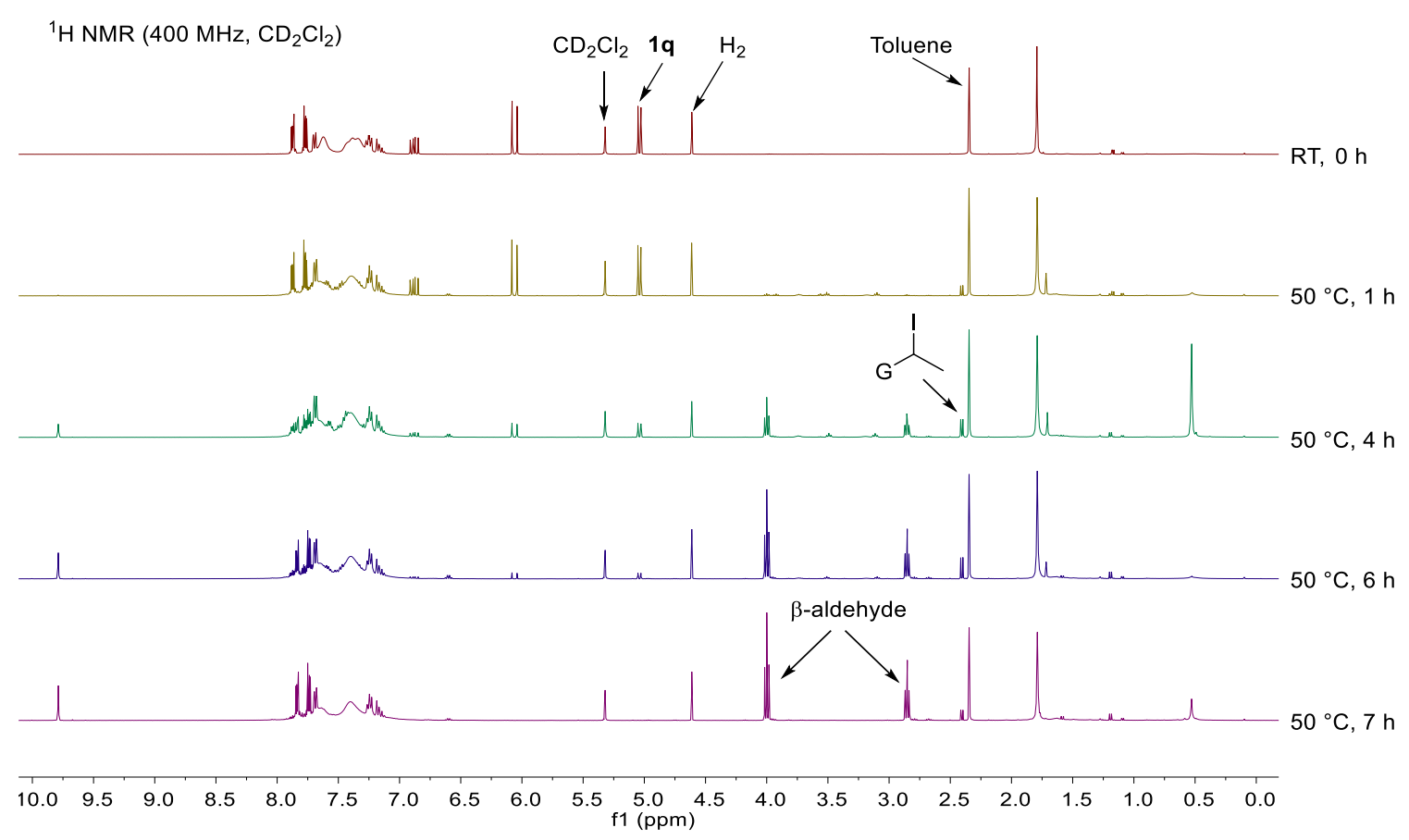

Fig. S62 ${ }^{1} H$ NMR spectra for the reaction of xantphos-Pd(II) iodide (prepared in situ, $P d I_{2}+0.8$ equiv. xantphos) and alkene $1 q$ under 6 bar syngas in $\mathrm{CD}_{2} \mathrm{Cl}_{2}$.

${ }^{1} \mathrm{H}$ NMR $\left(400 \mathrm{MHz}, \mathrm{CD}_{2} \mathrm{Cl}_{2}\right)$

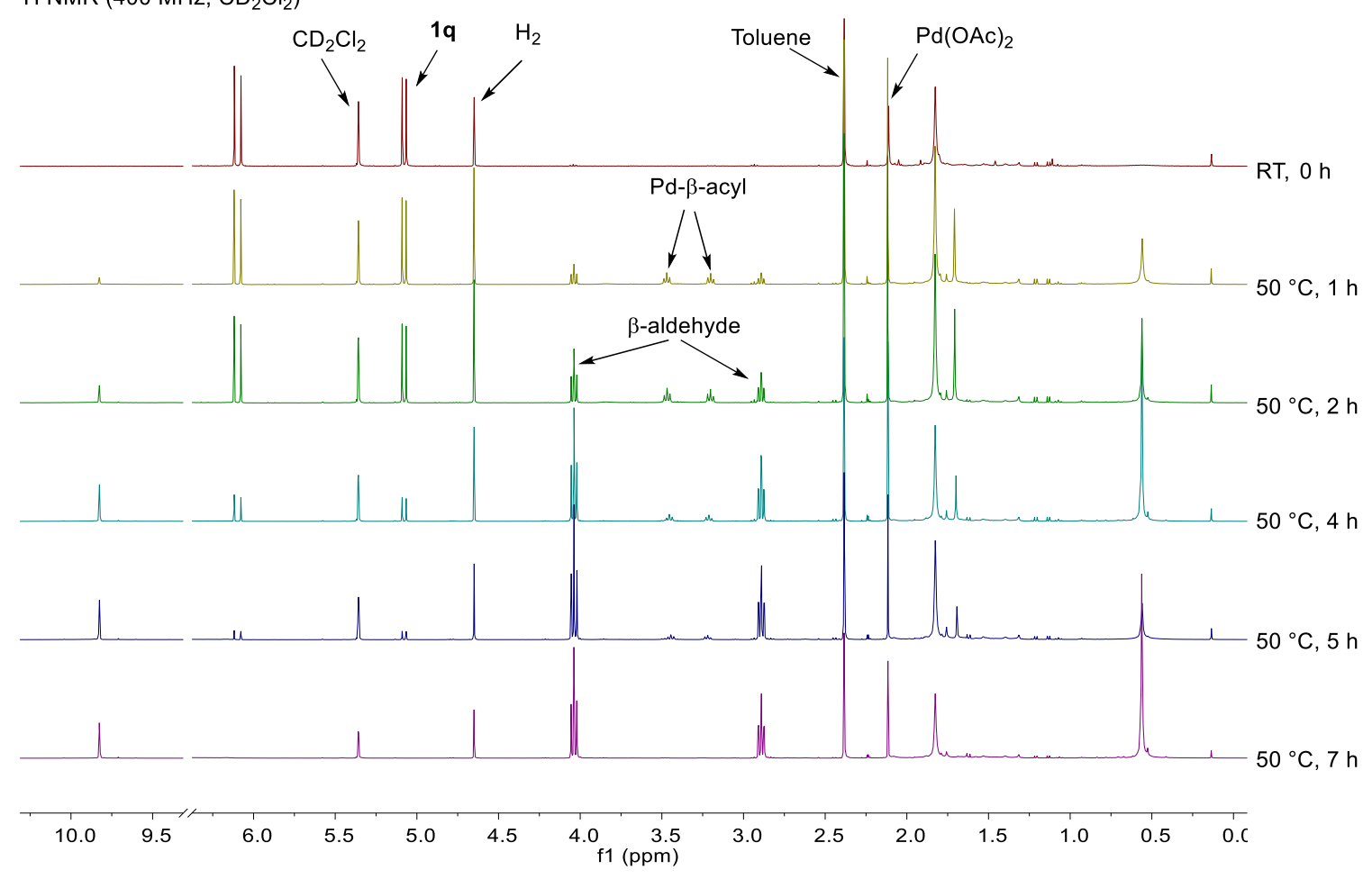

Fig. S63 ${ }^{1} H$ NMR spectra for the reaction of xantphos-Pd(II) iodide (prepared in situ, $\mathrm{PdI}_{2}+1.0$ equiv. xantphos), $\mathrm{Pd}(\mathrm{OAc})_{2}$ (0.2 equiv.) and alkene $1 q$ under 6 bar syngas in $\mathrm{CD}_{2} \mathrm{Cl}_{2}$. 


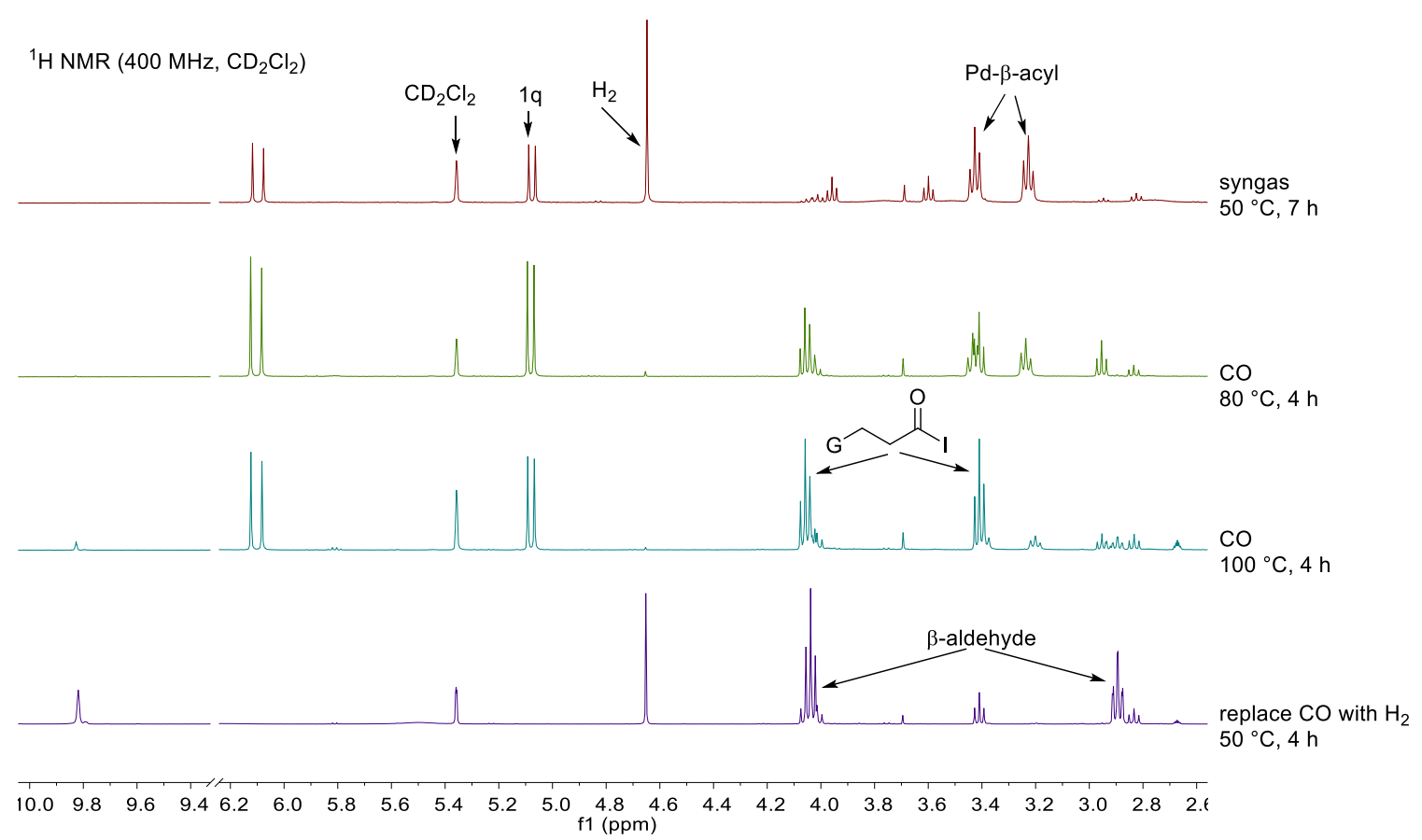

Fig. S64 ${ }^{1} \mathrm{H}$ NMR spectra for the reaction of xantphos-Pd(II) iodide (prepared in situ, $\mathrm{PdI}+1.0$ equiv. xantphos) and alkene 1q: under 6 bar syngas for $7 \mathrm{~h}$ at $50^{\circ} \mathrm{C}(1)$; followed by treatment under 6 bar $\mathrm{CO}$ at $80^{\circ} \mathrm{C}$ for $4 \mathrm{~h}$ (2) and $100^{\circ} \mathrm{C}$ for $4 \mathrm{~h}(3)$, and finally under 6 bar hydrogen at $50^{\circ} \mathrm{C}$ for $4 \mathrm{~h}$ (4).

${ }^{1} \mathrm{H}$ NMR $\left(400 \mathrm{MHz}, \mathrm{CD}_{2} \mathrm{Cl}_{2}\right)$
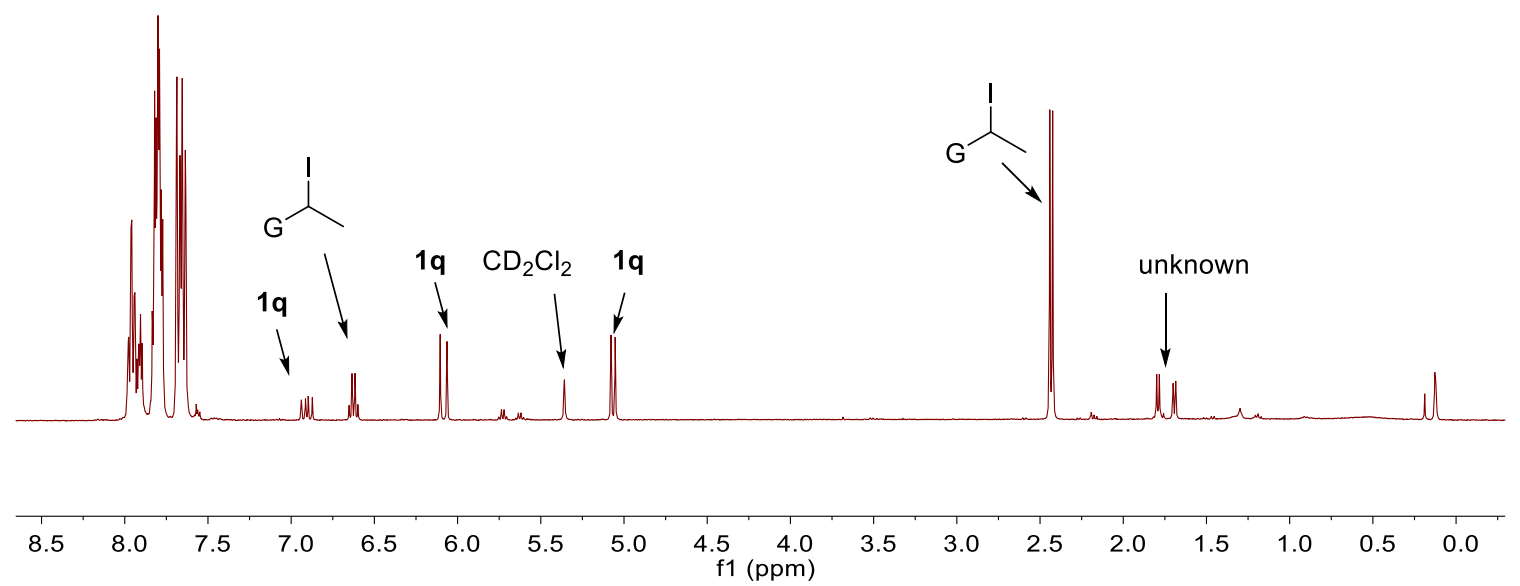

Fig. $\mathbf{S 6 5}{ }^{1} \mathrm{H} N M R$ spectrum for the reaction of alkene $\mathbf{1 q}$ with HI generated in situ $\left(\mathrm{HOTf}+\mathrm{PPh} \mathrm{h}_{4}\right)$ after $3 \mathrm{~h}$ at room temperature in $\mathrm{CD}_{2} \mathrm{Cl}_{2}$. GCMS analysis of the reaction mixture confirmed the presence of hydroiodination product derived from $\mathbf{1 q}$. 


\subsection{Studies of CO insertion into a Pd-alkyl bond in the presence of different anions}

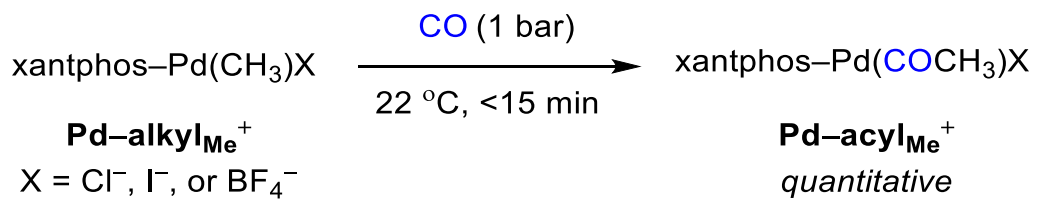

In analogy to the NMR studies described above, the reactions of CO with xantphos-palladium(II)-alkyl complexes bearing different anions were performed inside high-pressure J. Young tubes. Xantphos- $\mathrm{Pd}(\mathrm{Me}) \mathrm{Cl}$ and $\mathrm{xantphos}-\mathrm{Pd}(\mathrm{Me}) \mathrm{BF}_{4}$ complexes were prepared following literature procedures, ${ }^{55}$ which are detailed in the following section. Xantphos-Pd(Me)I (prepared by mixing a solution of xantphos- $\mathrm{Pd}(\mathrm{Me}) \mathrm{BF}_{4}$ and $\left.\mathrm{PPh}_{4} \mathrm{I}\right)$ was unstable in solution, as indicated by darkening of the solution within $1 \mathrm{~h}$, and the observation of several decomposition products in the ${ }^{31} \mathrm{P}\left\{{ }^{1} \mathrm{H}\right\} \mathrm{NMR}$ spectrum. Therefore, for the studies of $\mathrm{CO}$ insertion into the Pd-alkyl bond in the presence of iodide anions, the xantphos- $\mathrm{Pd}(\mathrm{Me}) \mathrm{I}$ complex was prepared in situ by mixing solutions of xantphos- $\mathrm{Pd}(\mathrm{Me}) \mathrm{BF}_{4}$ and $\mathrm{PPh}_{4} \mathrm{I}$ (2 equiv.) followed by 5 min treatment period prior to exposition to $\mathrm{CO}$ atmosphere.

The ${ }^{1} \mathrm{H}$ and ${ }^{31} \mathrm{P}\left\{{ }^{1} \mathrm{H}\right\}$ NMR spectra for the experiments with xantphos-Pd(II) $\left(\mathrm{CH}_{3}\right) \mathrm{BF}_{4}$, xantphos- $\mathrm{Pd}(\mathrm{II})\left(\mathrm{CH}_{3}\right) \mathrm{Cl}$, or xantphos- $\mathrm{Pd}(\mathrm{II})\left(\mathrm{CH}_{3}\right) \mathrm{I}$ collected after 15 min treatment under $\mathrm{CO}$ atmosphere indicated full conversion of the initial complex and formation of a single new complex (Figs. S66-S67). In all cases ${ }^{1} \mathrm{H}_{-}{ }^{13} \mathrm{C}$ HSQC, ${ }^{1} \mathrm{H}_{-}{ }^{13} \mathrm{C}$ HMBC,,${ }^{1} \mathrm{H}_{-}{ }^{31} \mathrm{P}$ HMBC NMR data confirmed the insertion of CO into the $\mathrm{Pd}-\mathrm{CH}_{3}$ bond leading to generation of the $\mathrm{Pd}-\mathrm{COCH}_{3}$ (Figs. S68-S72). Furthermore, the NMR data of the new complexes match previously reported data for related Pd-acyl complexes. ${ }^{56}$

A representative procedure for the in-situ NMR studies of $\mathrm{CO}$ insertion: In a nitrogen-filled glovebox, a J. Young tube was charged with xantphos- $\mathrm{Pd}(\mathrm{II}) \mathrm{MeCl}(20.0 \mathrm{mg}, 0.027 \mathrm{mmol})$ and $\mathrm{CD}_{2} \mathrm{Cl}_{2}$ $(500 \mu \mathrm{L})$. The tube was then sealed, shaken, and NMR spectra were collected. Then, the tube was pressurized twice to 6 bar $\mathrm{CO}$ followed by release of pressure. Finally, the tube under $\mathrm{CO}$ atmosphere (1 bar) was sealed and shaken, followed by collection of NMR spectra. 


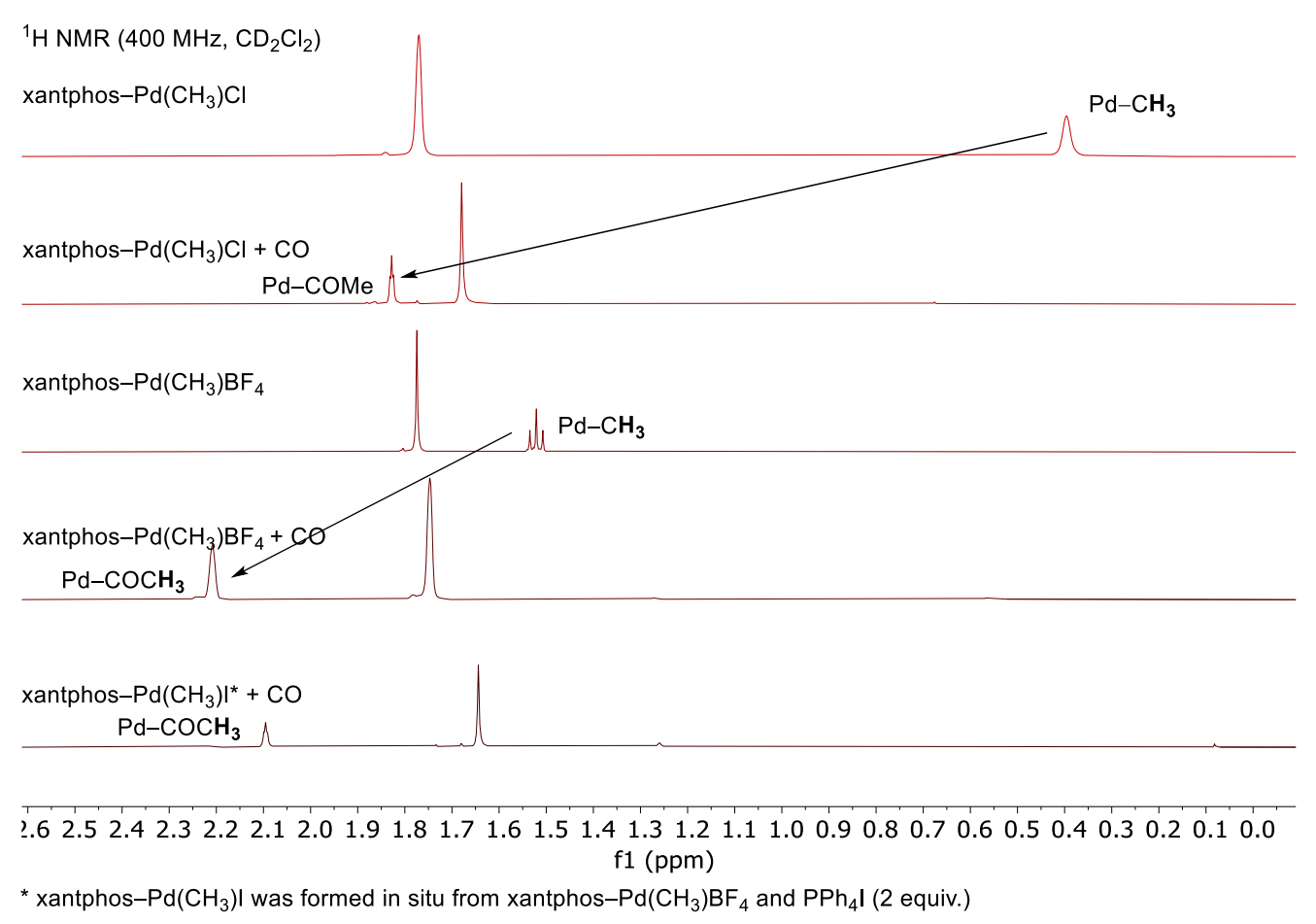

Fig. S66 ${ }^{1} \mathrm{H} N M R$ spectra for the experiments with xantphos- $\mathrm{Pd}(\mathrm{II})\left(\mathrm{CH}_{3}\right) \mathrm{BF}$, xantphos- $\mathrm{Pd}(\mathrm{II})\left(\mathrm{CH}_{3}\right) \mathrm{Cl}$, or xantphos- $\mathrm{Pd}(\mathrm{II})\left(\mathrm{CH}_{3}\right) \mathrm{BF}_{4}$ and $\mathrm{PPh}_{4} \mathrm{I}$ (2 equiv.), under $\mathrm{N}_{2}$ or under $\mathrm{CO}$ in $\mathrm{CD}_{2} \mathrm{Cl}_{2}$.

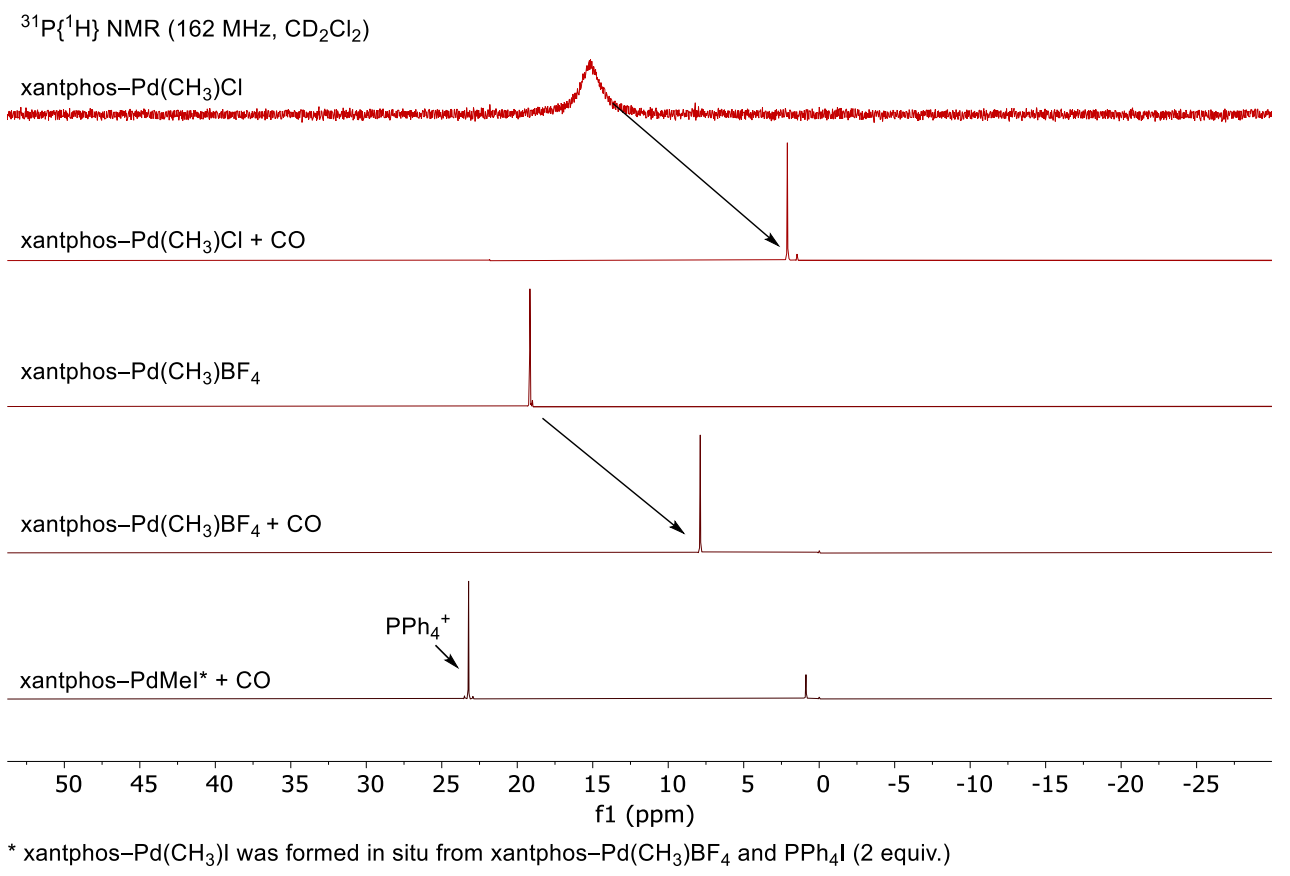

Fig. S67 ${ }^{31} P\left\{{ }^{1} \mathrm{H}\right\} \mathrm{NMR}$ spectra for the experiments with xantphos- $\mathrm{Pd}(\mathrm{II})\left(\mathrm{CH}_{3}\right) \mathrm{BF}$, xantphos- $\mathrm{Pd}(\mathrm{II})\left(\mathrm{CH}_{3}\right) \mathrm{Cl}$, or xantphos- $\mathrm{Pd}(\mathrm{II})\left(\mathrm{CH}_{3}\right) \mathrm{BF}_{4}$ and $\mathrm{PPh}_{4} \mathrm{I}$ (2 equiv.), under $\mathrm{N}_{2}$ or under $\mathrm{CO}$ in $\mathrm{CD}_{2} \mathrm{Cl}_{2}$. 


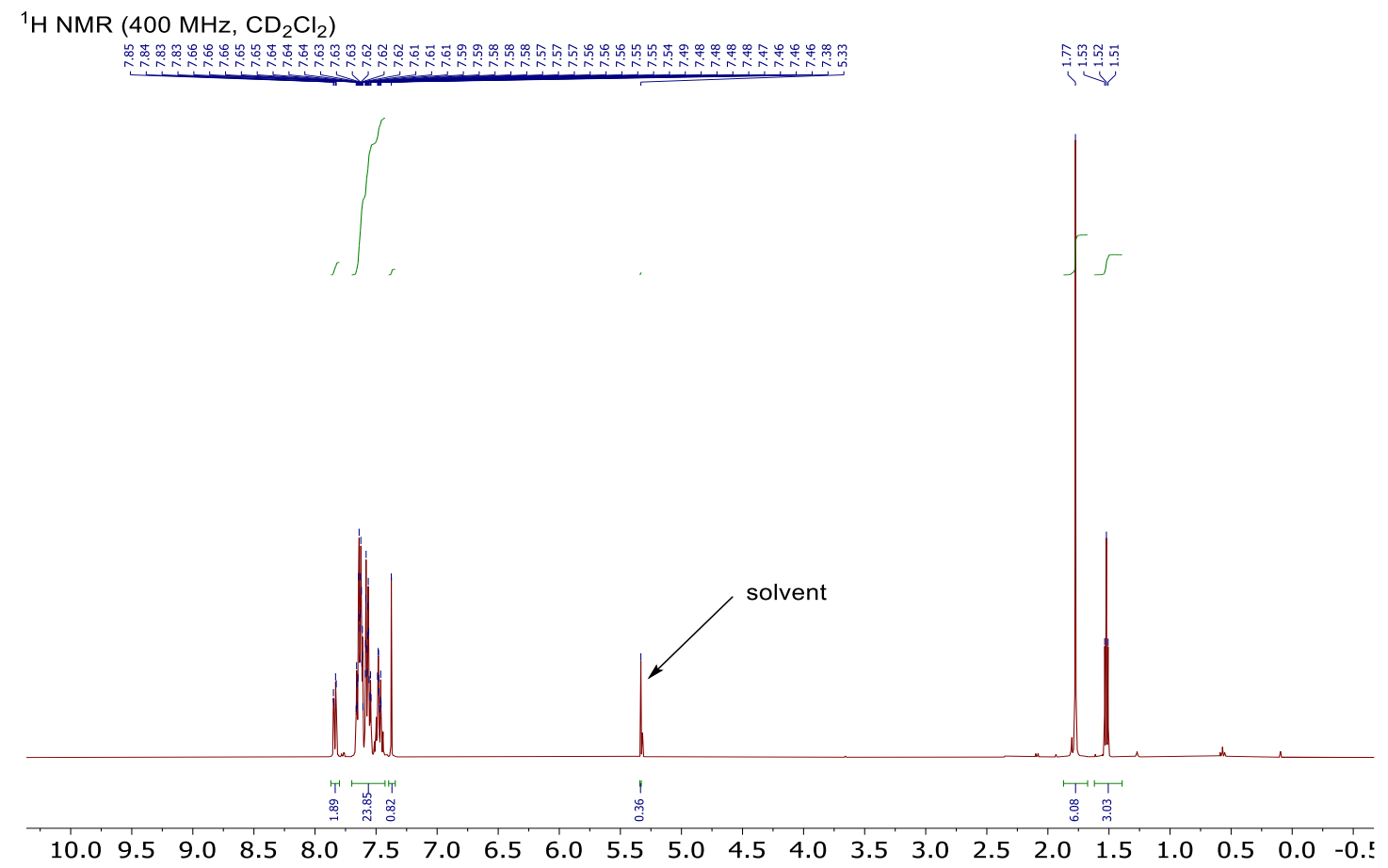

${ }^{13} \mathrm{C}\left\{{ }^{1} \mathrm{H}\right\}$ NMR (101 MHz, $\mathrm{CD}_{2} \mathrm{Cl}_{2}$ )

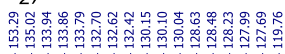
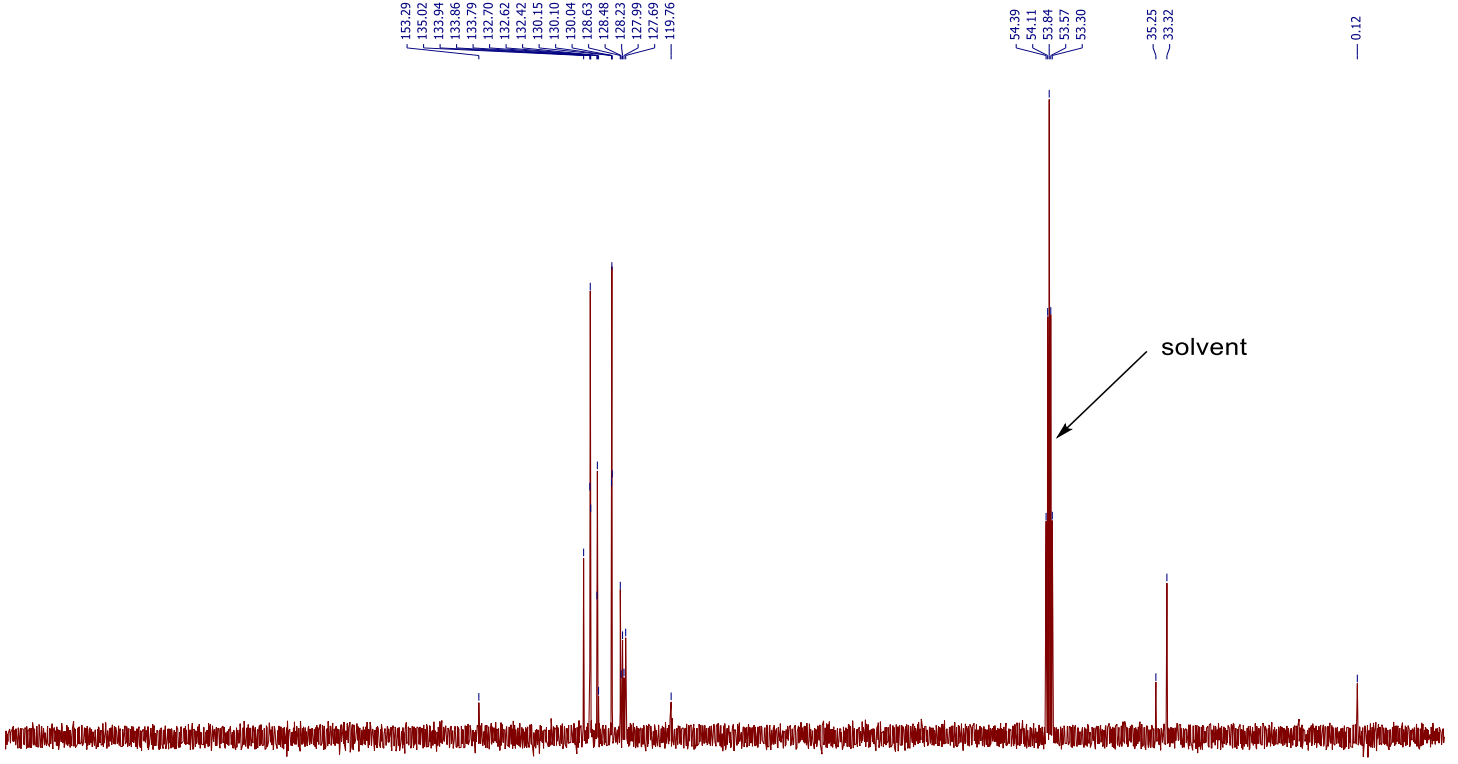

$230220210200190180170160150140130120110100 \quad 90 \quad 8070 \quad 60 \begin{array}{llllllll}1 & 40 & 30 & 20 & 10 & 0 & -10\end{array}$ (1..... 
${ }^{31} \mathrm{P}\left\{{ }^{1} \mathrm{H}\right\}$ NMR $\left(162 \mathrm{MHz}, \mathrm{CD}_{2} \mathrm{Cl}_{2}\right)$

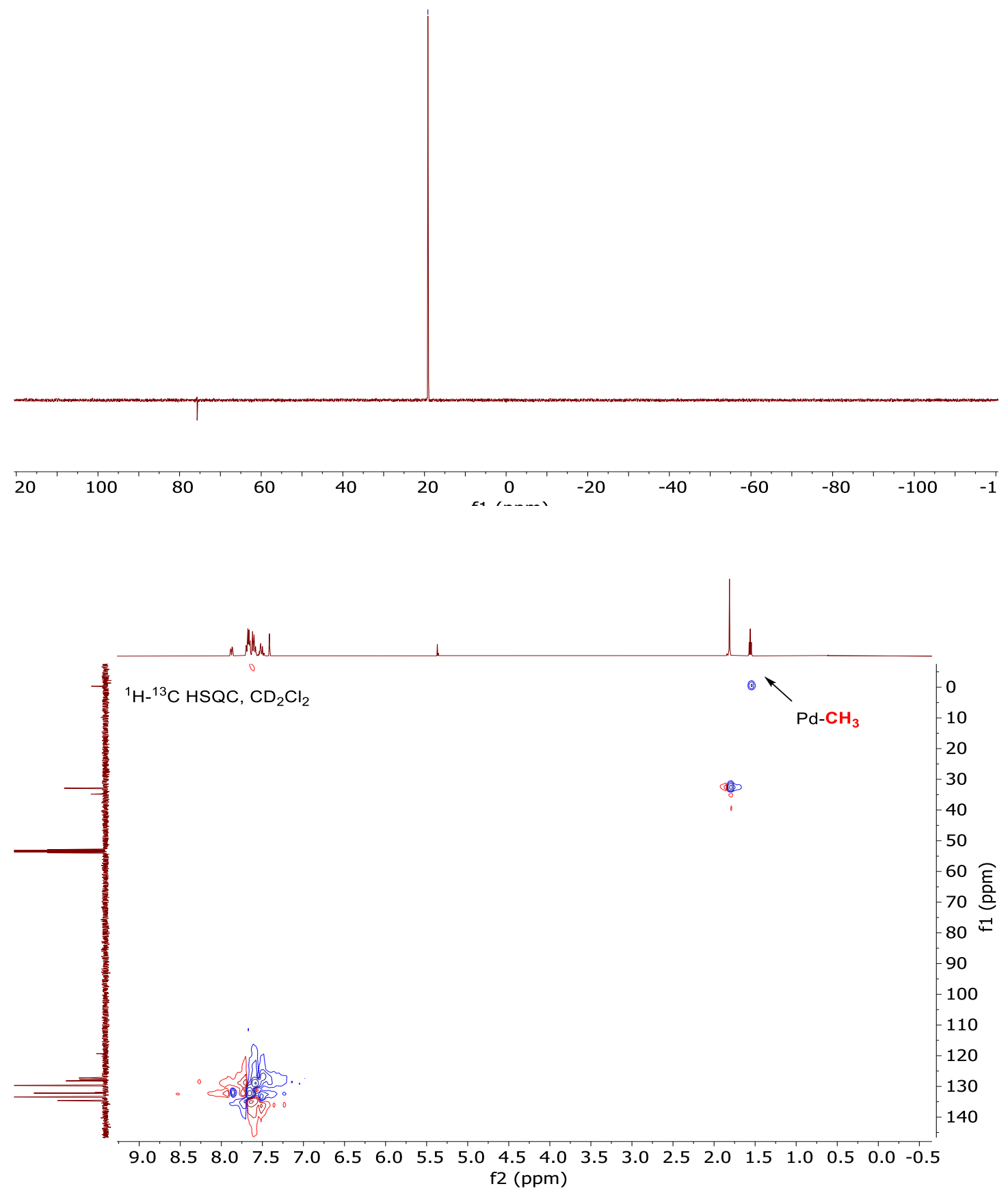




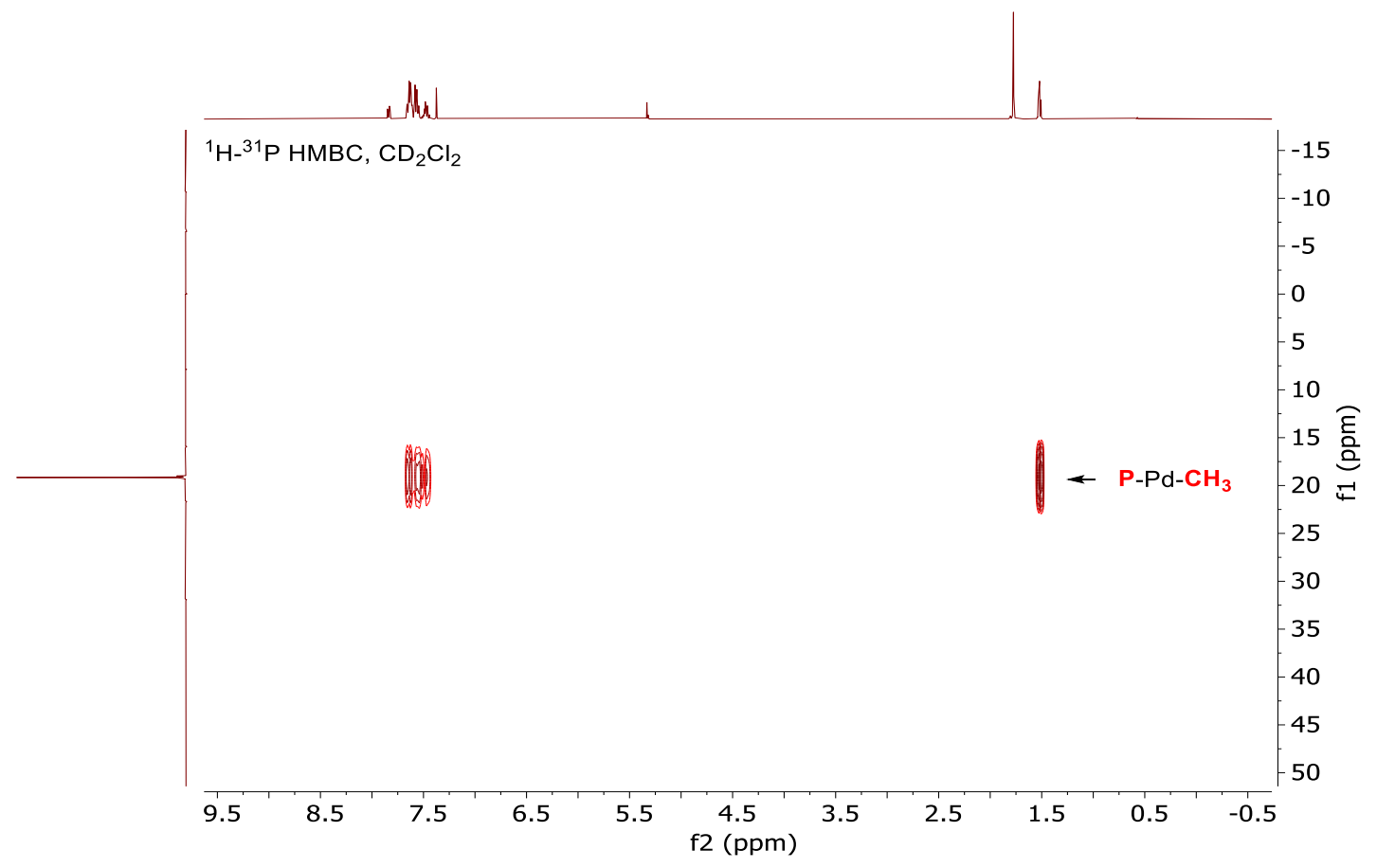

Fig. S68 The NMR spectra for xantphos- $\mathrm{Pd}(\mathrm{II})\left(\mathrm{CH}_{3}\right) \mathrm{BF}_{4}$ under $\mathrm{N}_{2}$ in $\mathrm{CD}_{2} \mathrm{Cl}_{2}$.

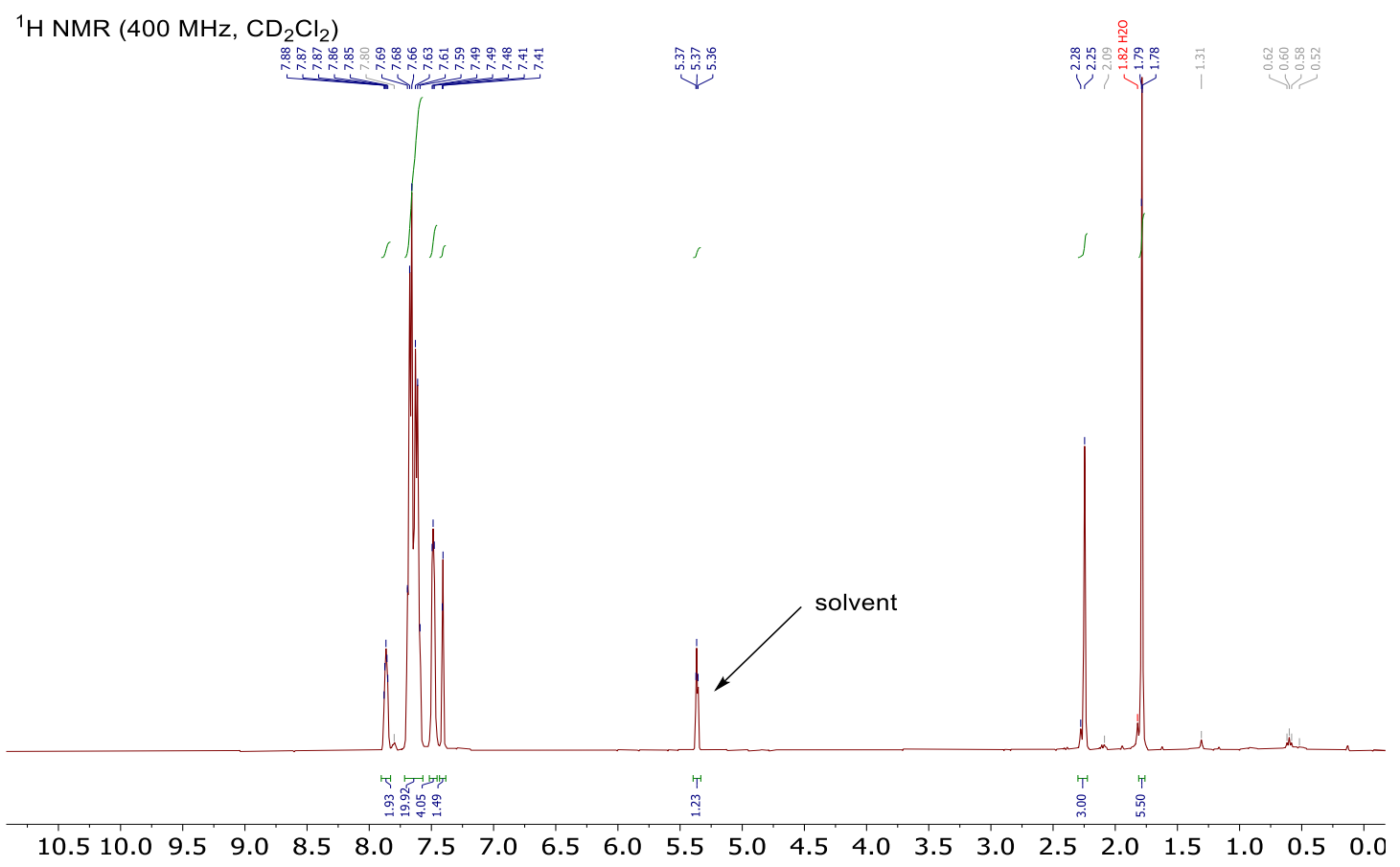




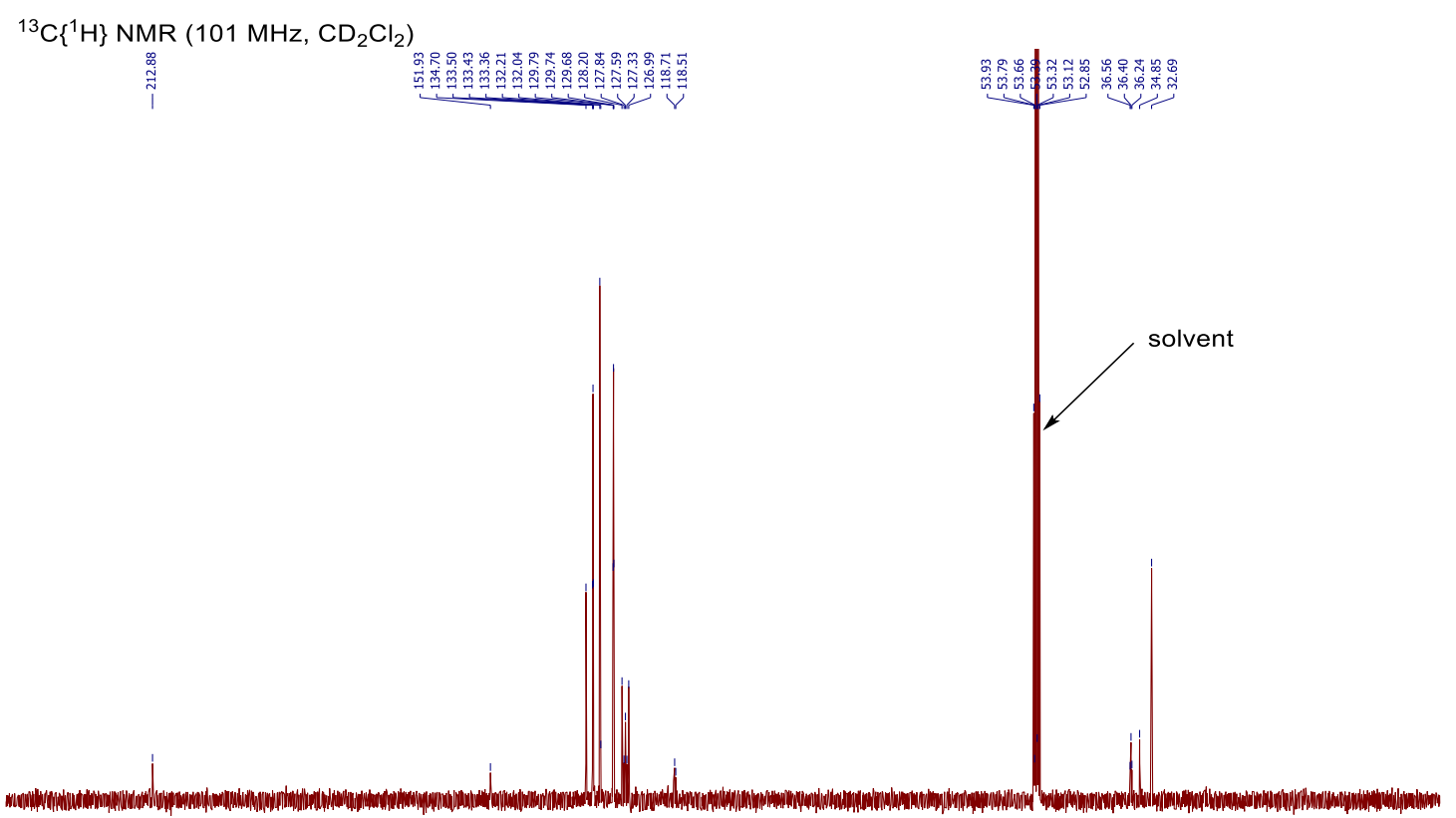

$23022021020019018017016015014013012011010090 \quad 80 \quad 70 \quad 60 \quad 50 \quad 40 \quad 30 \quad 20 \quad 10 \quad 0 \quad-10$

${ }^{31} \mathrm{P}\left\{{ }^{1} \mathrm{H}\right\}$ NMR (162 MHz, $\left.\mathrm{CD}_{2} \mathrm{Cl}_{2}\right)$
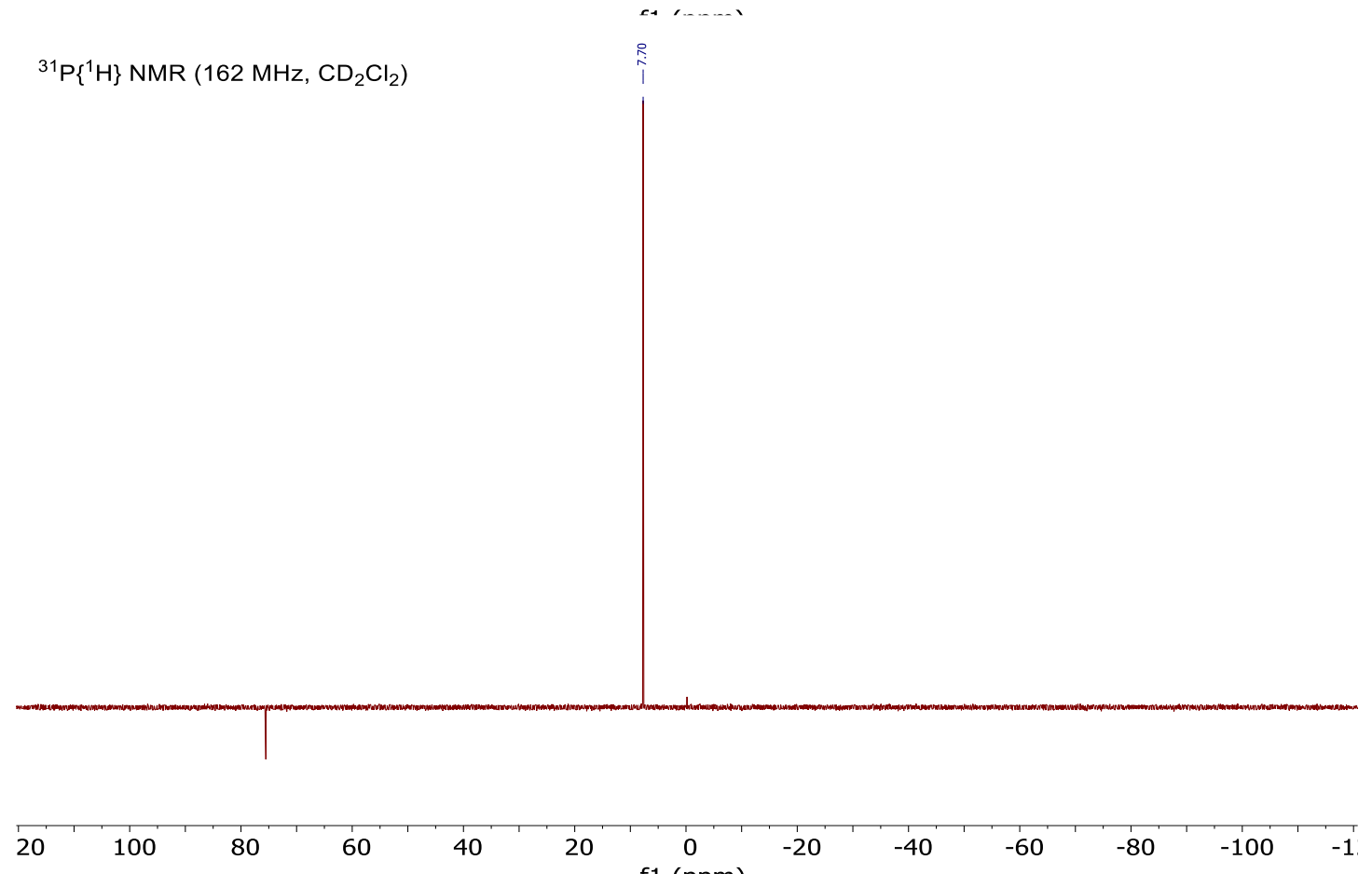

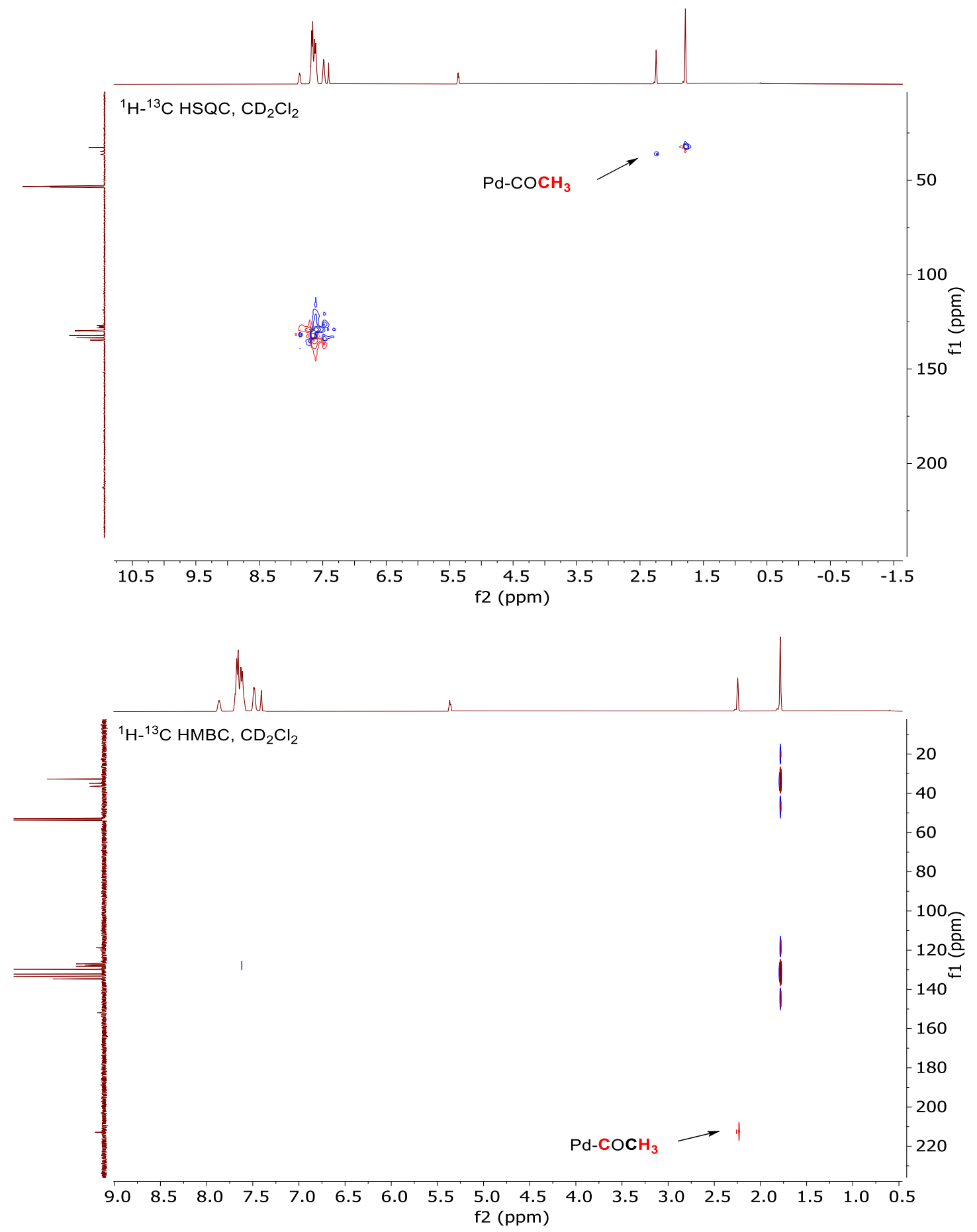


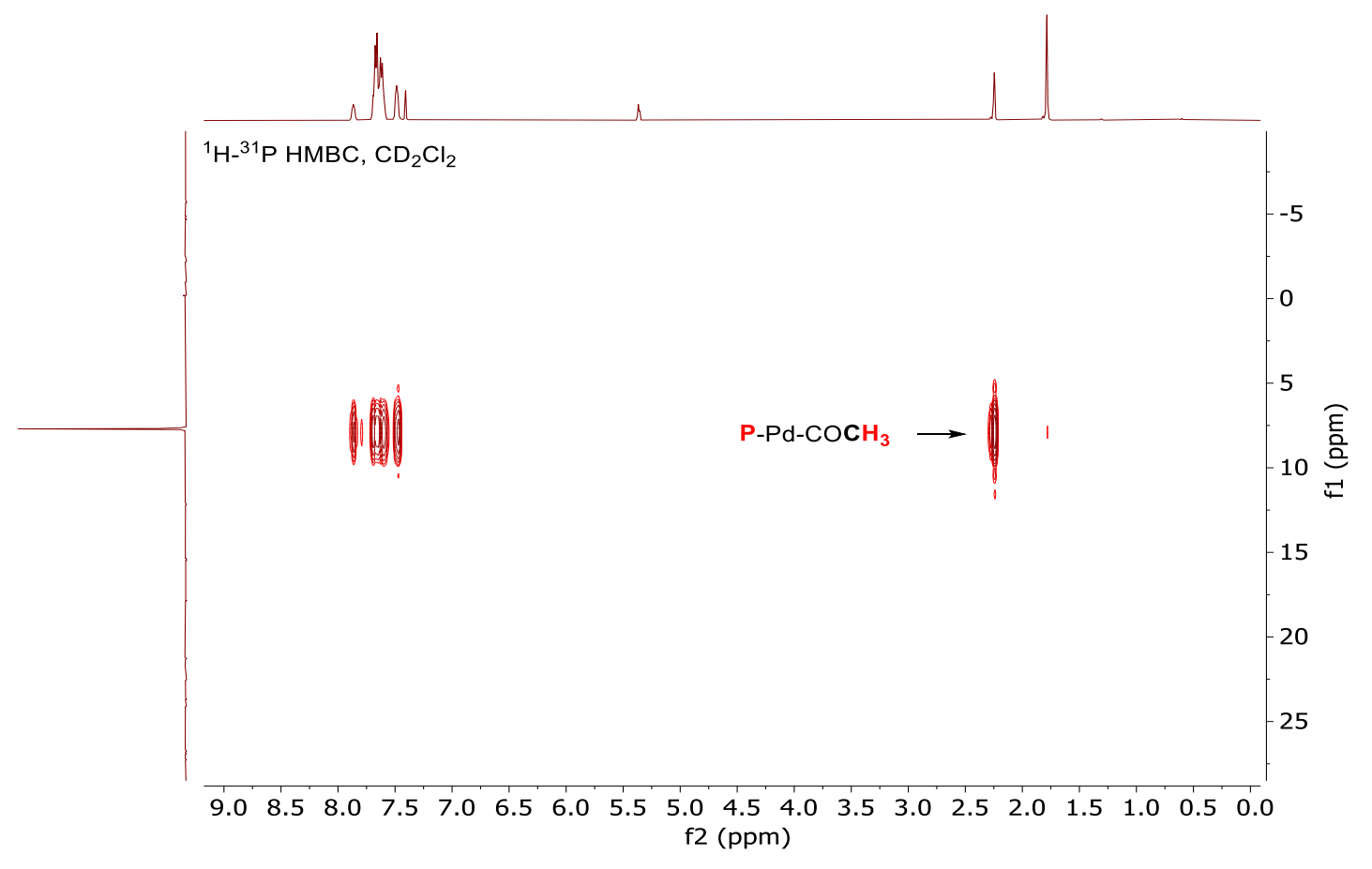

Fig. S69 NMR spectra for xantphos- $\mathrm{Pd}(\mathrm{II})\left(\mathrm{CH}_{3}\right) \mathrm{BF}_{4}$ under $\mathrm{CO}$ in $\mathrm{CD}_{2} \mathrm{Cl}_{2}$. 


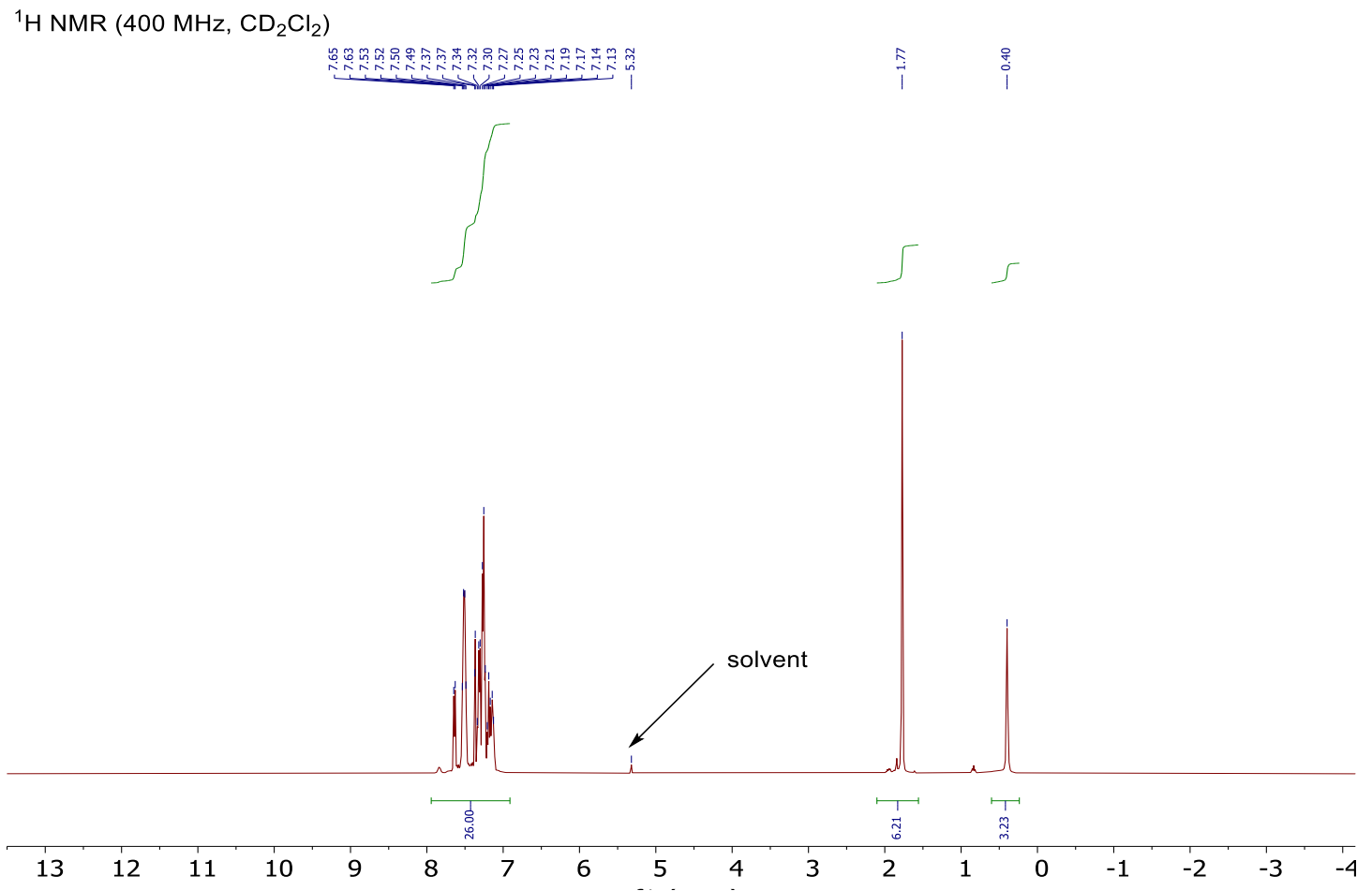

${ }^{31} \mathrm{P}\left\{{ }^{1} \mathrm{H}\right\} \mathrm{NMR}\left(162 \mathrm{MHz}, \mathrm{CD}_{2} \mathrm{Cl}_{2}\right)$

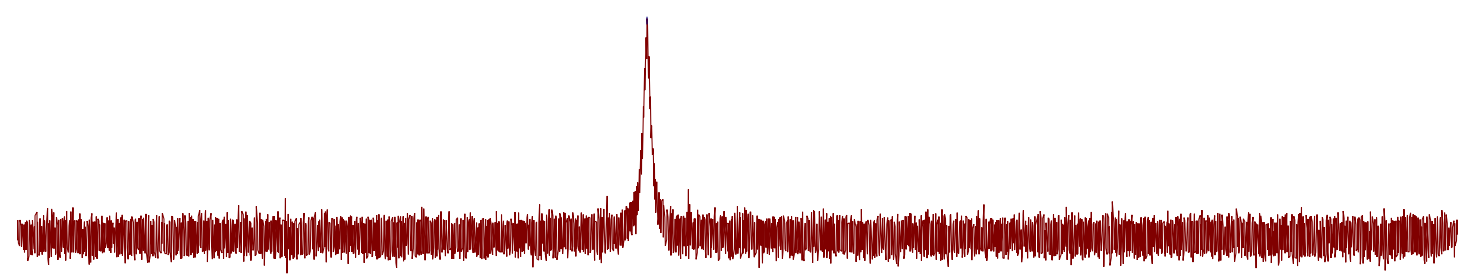

\begin{tabular}{llllllllllllll}
\hline 20 & 100 & 80 & 60 & 40 & 20 & 0 & -20 & -40 & -60 & -80 & -100 & -1
\end{tabular}

Fig. S70 NMR spectra for xantphos-Pd(II)(CH$)$ Cl under $\mathrm{N}_{2}$ in $\mathrm{CD}_{2} \mathrm{Cl}_{2}$. 


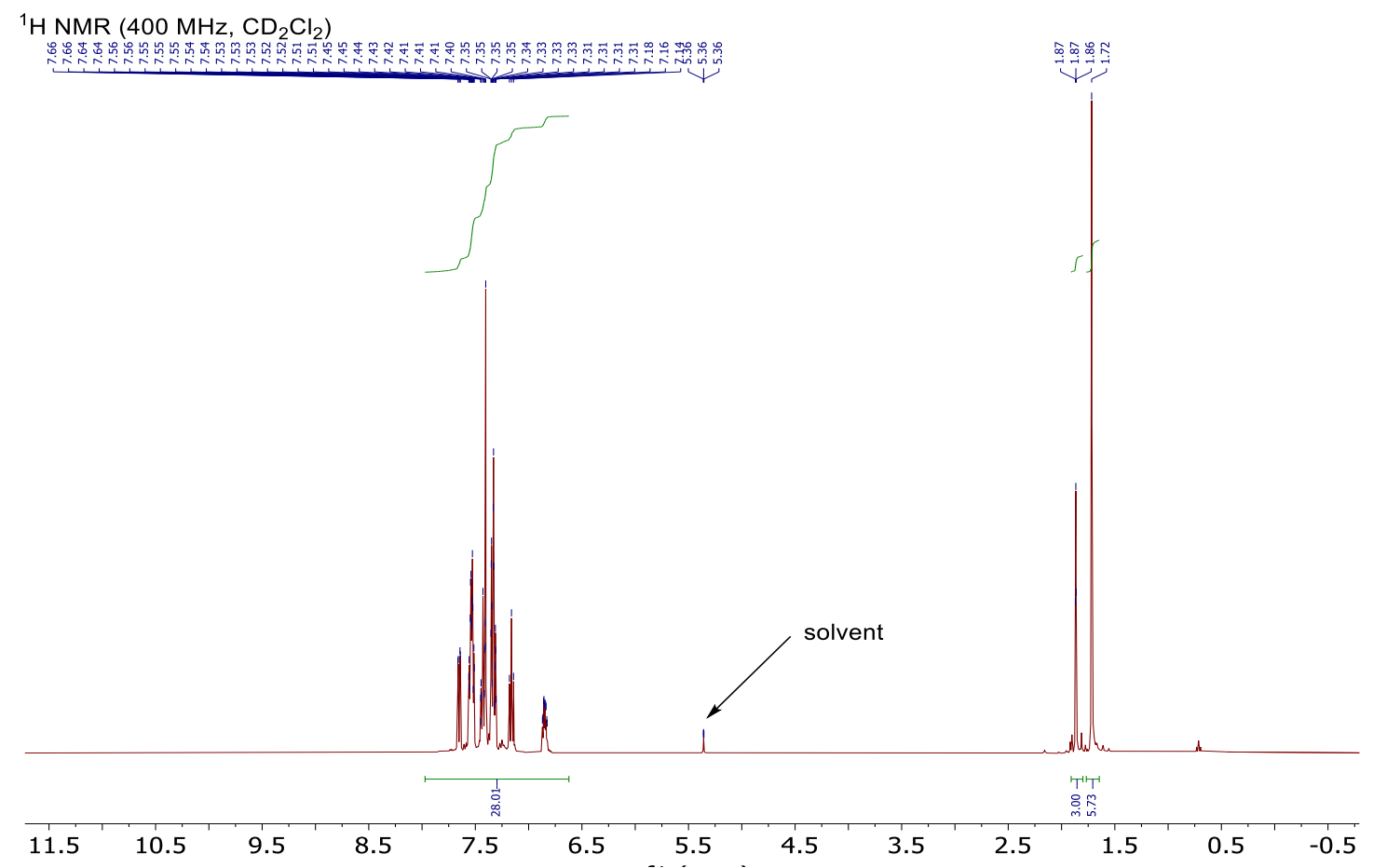

${ }^{13} \mathrm{C}\left\{{ }^{1} \mathrm{H}\right\}$ NMR (101 MHz, $\mathrm{CD}_{2} \mathrm{Cl}_{2}$ ) สุ
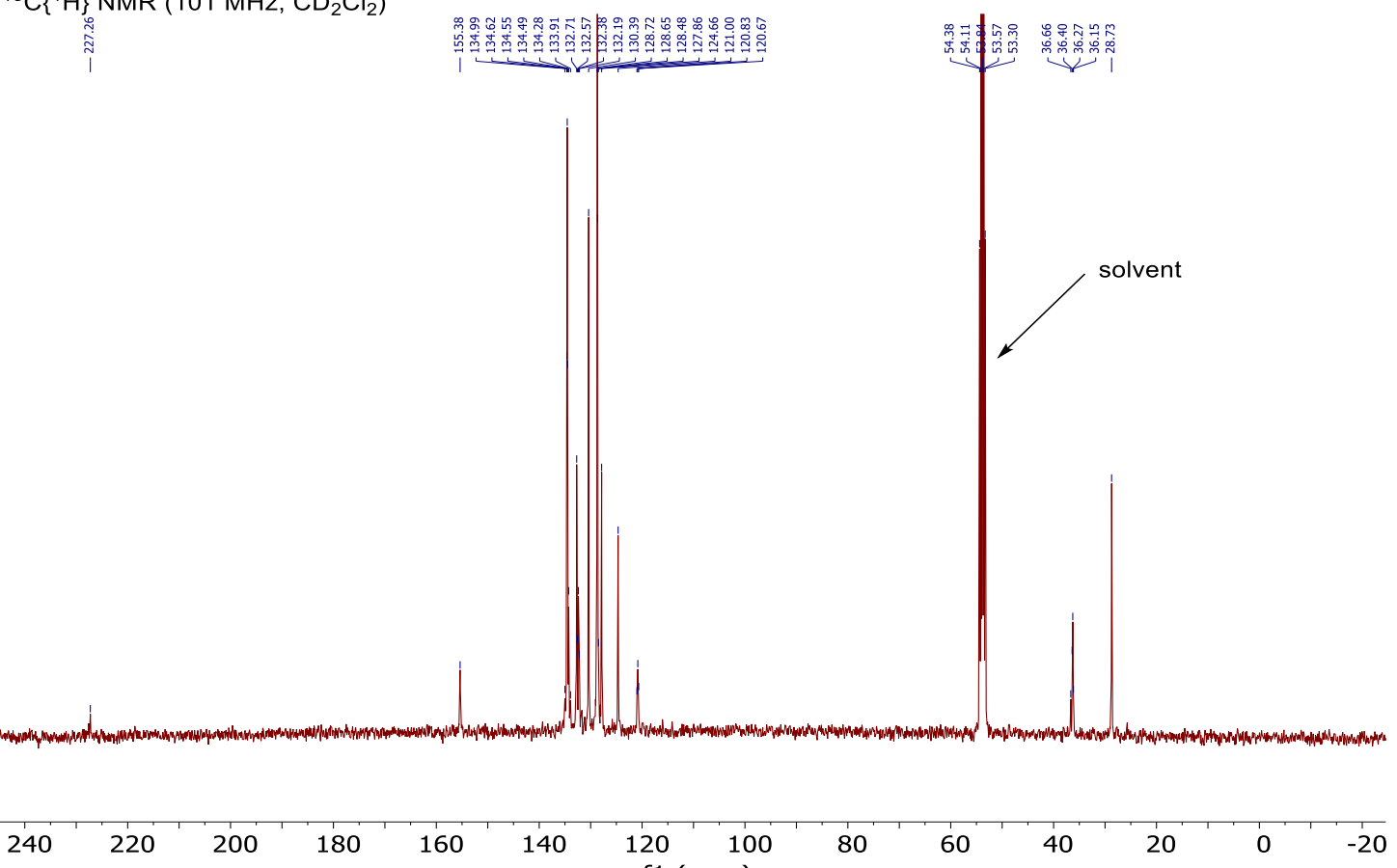


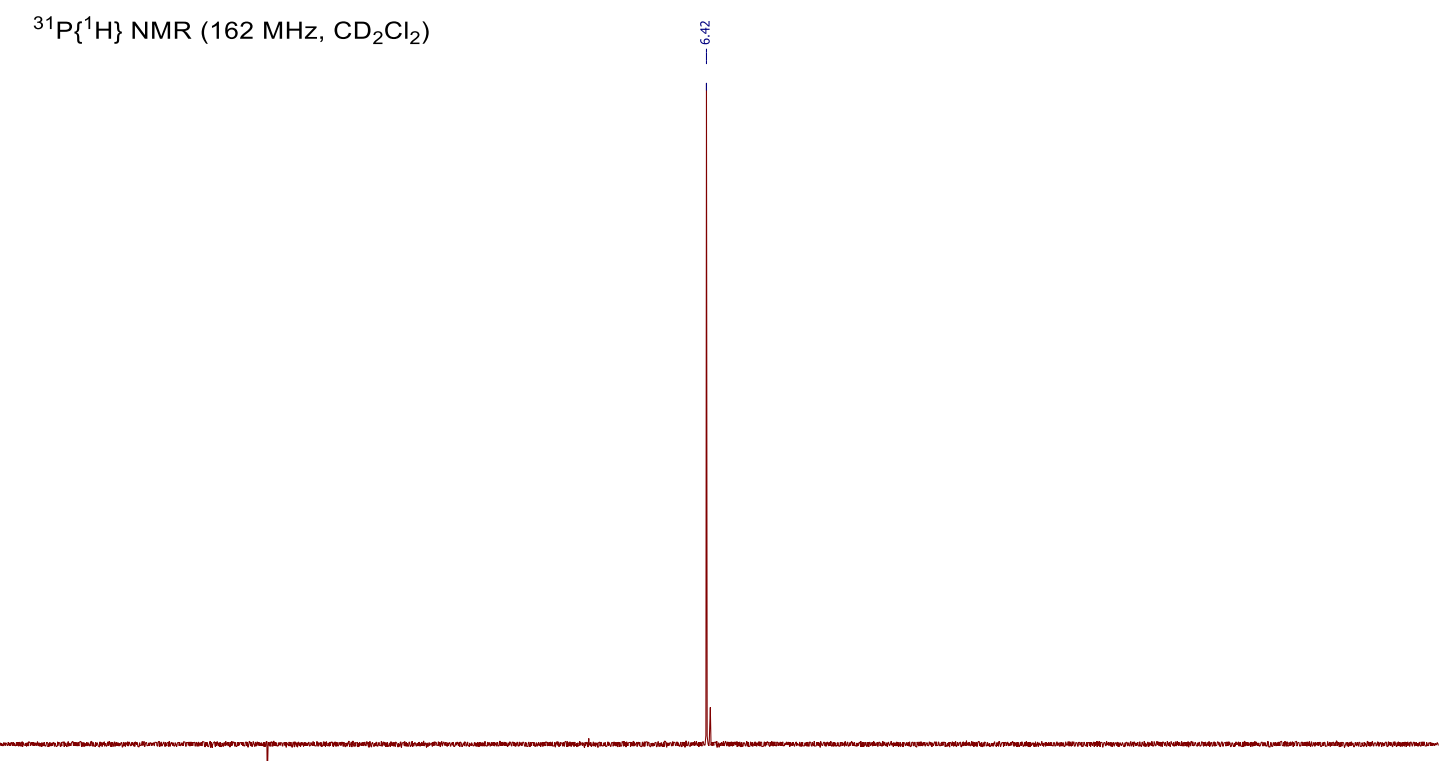

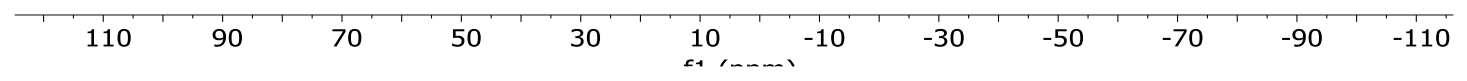

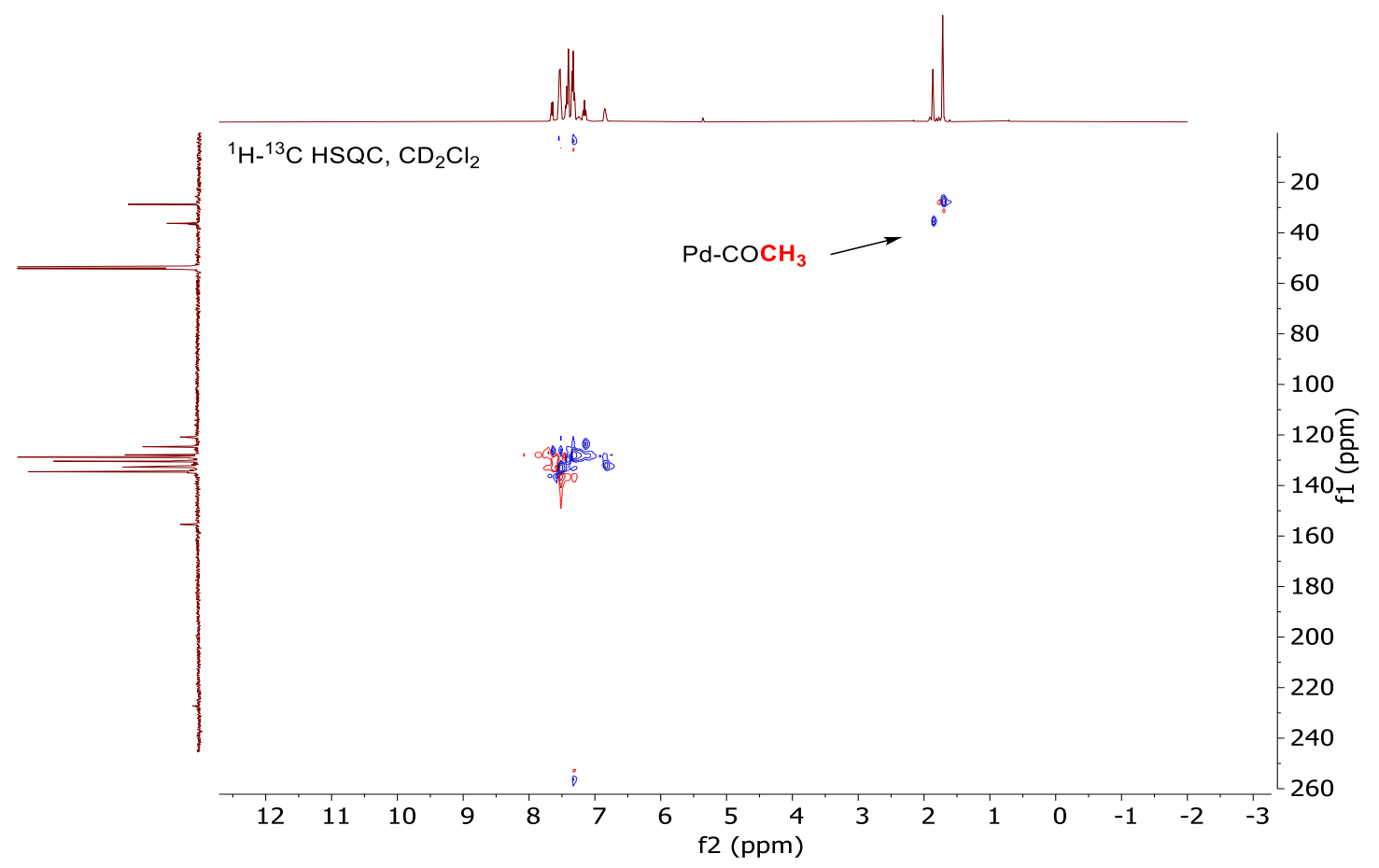



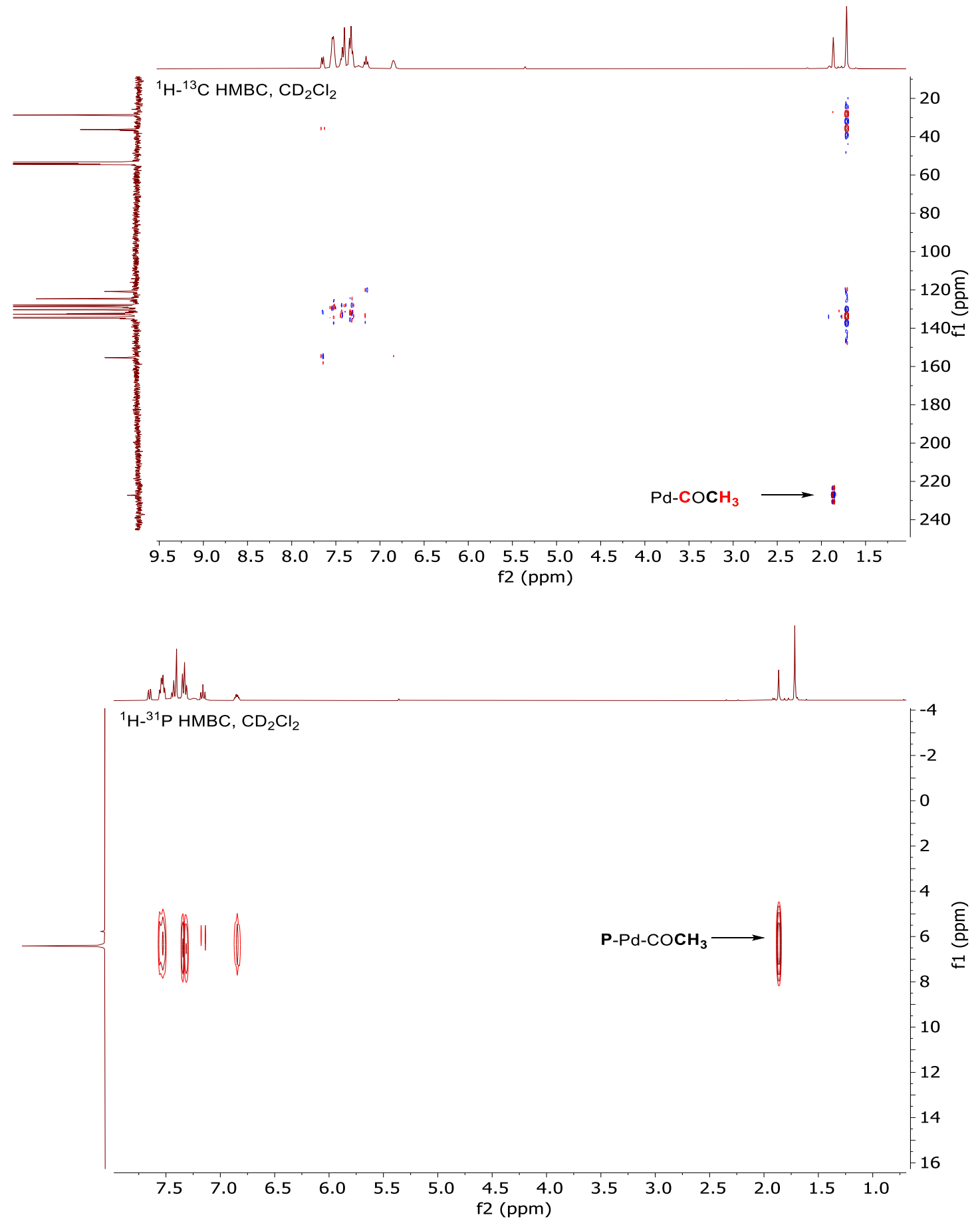

Fig. S71 NMR spectra for xantphos-Pd(II)(CH3)Cl under $\mathrm{CO}$ in $\mathrm{CD}_{2} \mathrm{Cl}_{2}$. 
${ }^{1} \mathrm{H}$ NMR $\left(400 \mathrm{MHz}, \mathrm{CD}_{2} \mathrm{Cl}_{2}\right)$

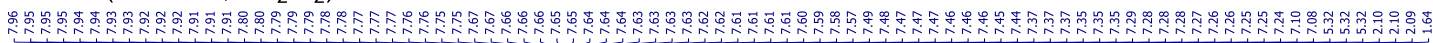

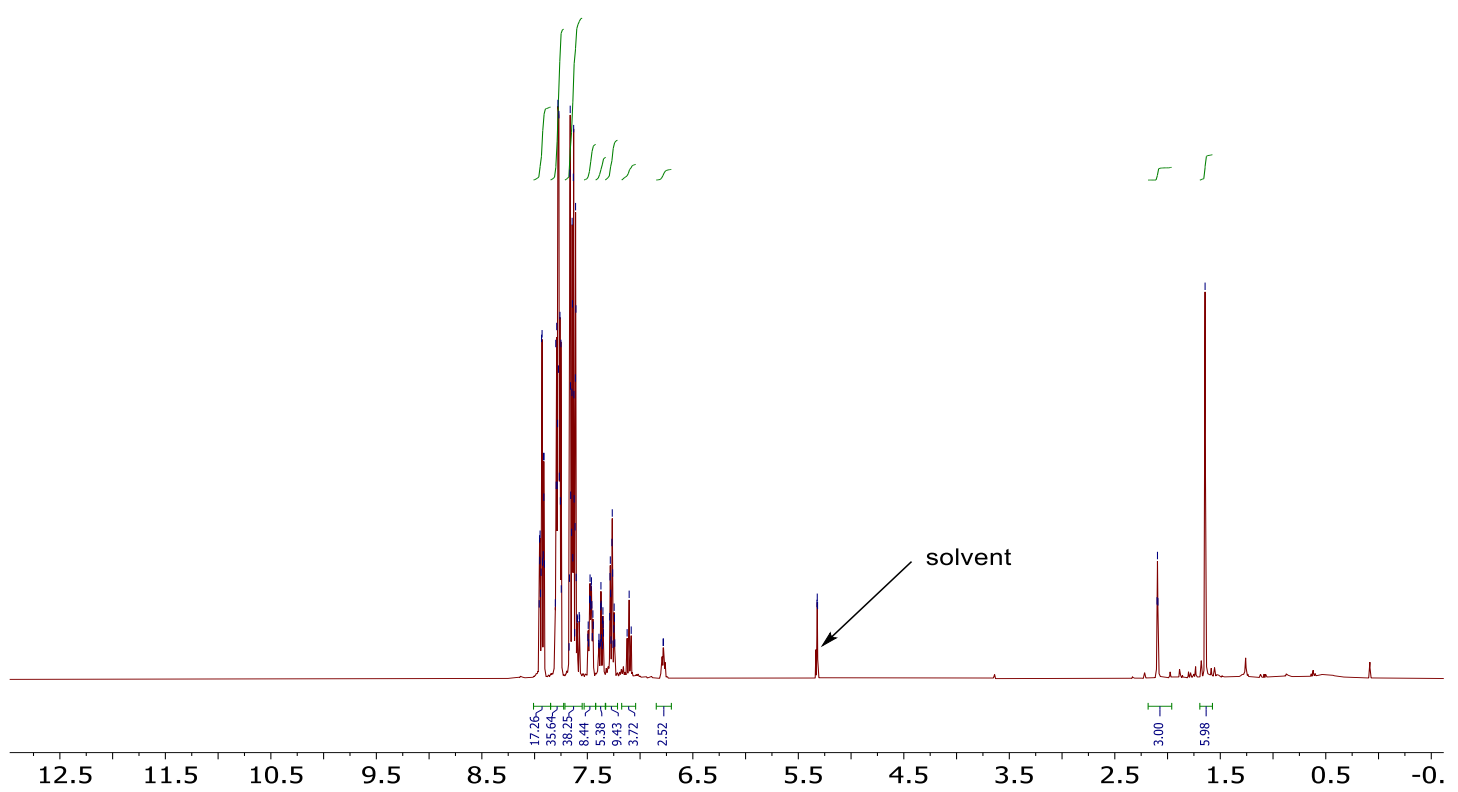

${ }^{31} \mathrm{P}\left\{{ }^{1} \mathrm{H}\right\}$ NMR $\left(162 \mathrm{MHz}, \mathrm{CD}_{2} \mathrm{Cl}_{2}\right) \quad \underset{\sim}{\sim} \quad \stackrel{\infty}{i}$

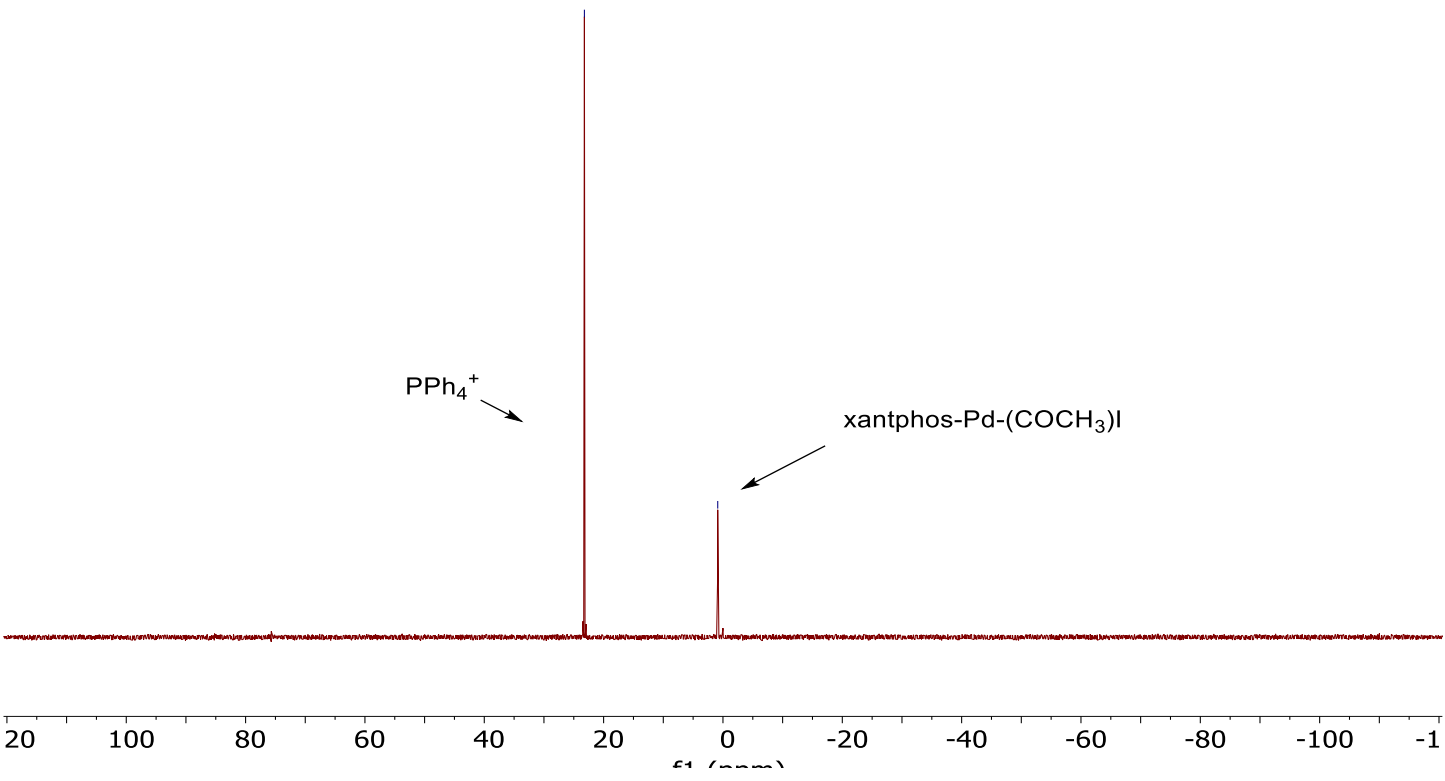



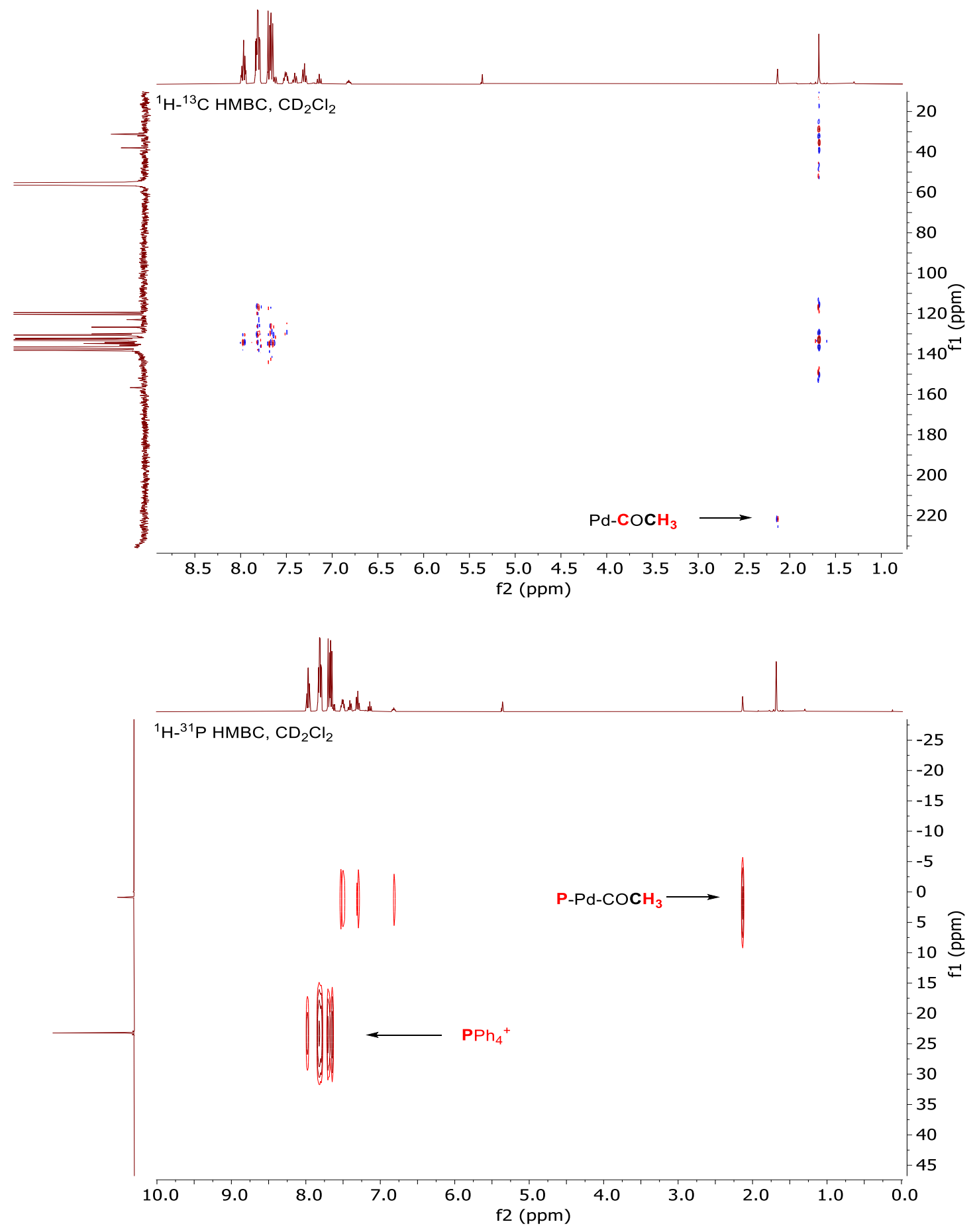

Fig. S72 NMR spectra for xantphos-Pd(II)(CH3)BF $+P P h_{4} I$ (2 equiv.) under $\mathrm{CO}$ in $\mathrm{CD}_{2} \mathrm{Cl}_{2}$. 


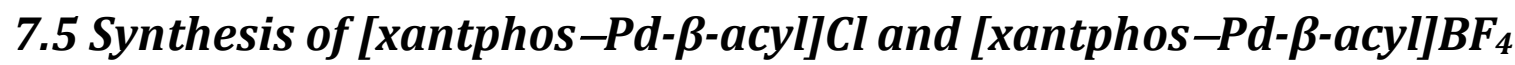

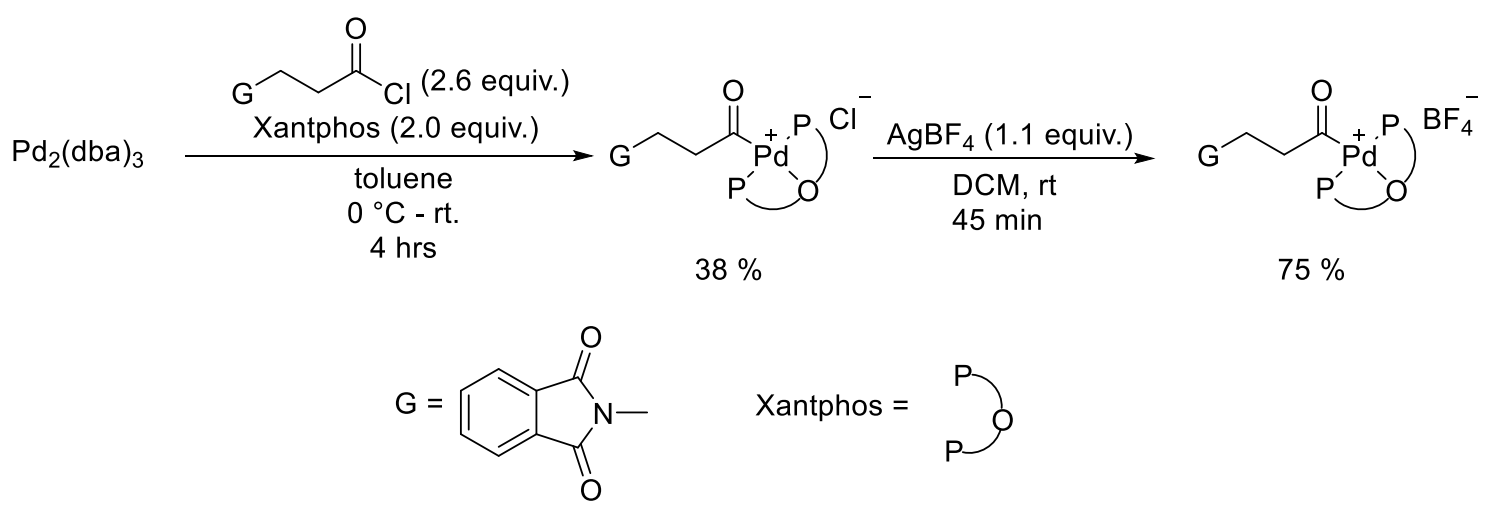

a). Synthesis of 3-phthalimidopropanoyl chloride

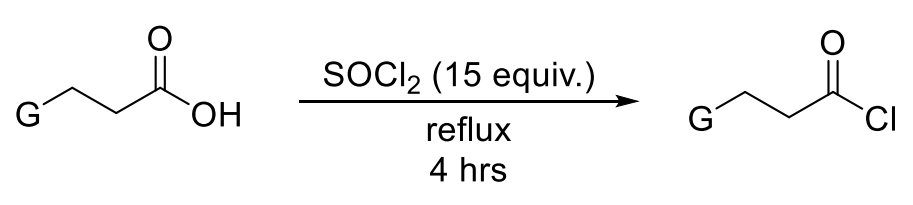<smiles>CN1C(=O)c2ccc(Cl)cc2C1=O</smiles>

3-Phthalimidopropanoic acid $(2.0 \mathrm{~g}, 9.12 \mathrm{mmol})$ was refluxed with thionyl chloride $(9.9 \mathrm{~mL}$, $136.86 \mathrm{mmol}$ ) for $4 \mathrm{~h}$ under nitrogen. The volatiles were removed under reduced pressure. The resulting solid material was dissolved in dry benzene $(20 \mathrm{~mL})$ and the volatiles were removed under reduced pressure. This procedure was repeated three times to afford 3-phthalimodopropanoyl chloride $(2.17 \mathrm{~g}$, 99\%), as white solid. The NMR data match previously reported data for the title product. ${ }^{57}$

${ }^{1} \mathbf{H}$ NMR (400 MHz, $\left.\mathbf{C D C l}_{3}\right) \delta 7.85(\mathrm{~m}, 2 \mathrm{H}), 7.75(\mathrm{~m}, 2 \mathrm{H}), 4.04(\mathrm{t}, 2 \mathrm{H}, J=7.0 \mathrm{~Hz}), 3.34(\mathrm{t}, 2 \mathrm{H}, J=7.0$ $\mathrm{Hz})$

\section{b). Synthesis of the [xantphos-Pd- $\beta$-acyl]Cl complex}

An oven-dried Schlenk tube equipped with a magnetic stirring bar was charged with $\mathrm{Pd}_{2}\left(\mathrm{dba}_{3}\right)_{3}(0.5$ $\mathrm{g}, 0.54 \mathrm{mmol})$ and xantphos $(0.63 \mathrm{~g}, 1.09 \mathrm{mmol})$. The tube was sealed with a rubber septum and put under an atmosphere of $\mathrm{N}_{2}$ (by 3 vacuum-nitrogen cycles). Degassed, dry toluene $(10 \mathrm{~mL})$ was added to the flask with the aid of a syringe, resulting in a dark-purple solution. The flask was placed in an ice/water bath and the solution was allowed to stir for $10 \mathrm{~min}$. The solution of 3-phthalimidopropanoyl chloride ( $0.34 \mathrm{~g}, 1.42$ $\mathrm{mmol})$ in toluene $(5 \mathrm{~mL})$ was added with the aid of a syringe. The resulting mixture was allowed to stir for $15 \mathrm{~min}$. The flask was removed from the cooling bath and the solution was warmed to room temperature. The mixture was allowed to stir for $4 \mathrm{~h}$. The resulting green grey solution was filtered under nitrogen to remove residual palladium-black. The filtrate was concentrated under reduced pressure to a 
volume of ca. $5 \mathrm{~mL}$. Degassed, dry ether $(20 \mathrm{~mL})$ was added with the aid of a syringe and the resulting single-phase solution was allowed to stand overnight resulting in the formation of a yellow solid. The supernatant was decanted (with the aid of a syringe) and the product was washed with degassed, dry ether $(2 \times 10 \mathrm{~mL})$ under nitrogen atmosphere. The product was dried under high vacuum to provide $350 \mathrm{mg}$ (38\%) of the title compound as a moisture-sensitive, yellow solid. The isolated complex contained $\sim 5 \%$ organic impurities. Because of the instability of the complex in solution at room temperature, no further purification was performed.

${ }^{1}$ H NMR (400 MHz, $\left.\mathbf{C D}_{2} \mathrm{Cl}_{2}\right) \delta$ 7.78-6.79 (m, 30H), $3.25(\mathrm{t}, J=7.6 \mathrm{~Hz}, 2 \mathrm{H}), 3.07(\mathrm{t}, J=7.4 \mathrm{~Hz}, 2 \mathrm{H})$, $1.67(\mathrm{~s}, 6 \mathrm{H})$.

${ }^{13}$ C NMR (101 MHz, CD $\left.\mathbf{C l}_{2}\right) \delta 225.9,168.2,155.4,134.6,134.3,132.8,132.7,132.2,130.6,128.9$, $128.9,128.1,124.8,123.4,120.9,50.0,36.4,34.5,28.9$.

${ }^{31}$ P NMR (162 MHz, $\left.\mathbf{C D}_{2} \mathrm{Cl}_{2}\right) \delta 2.97$.

HRMS (APPI) m/z calcd. for $\mathrm{C}_{50} \mathrm{H}_{40} \mathrm{NO}_{4} \mathrm{P}_{2} \mathrm{Pd}\left([\mathrm{M}-\mathrm{Cl}]^{+}\right)$: 886.1462; found: 886.1460.

${ }^{1} \mathrm{H} \mathrm{NMR}\left(400 \mathrm{MHz}, \mathrm{CD}_{2} \mathrm{Cl}_{2}\right)$

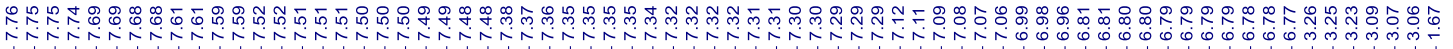

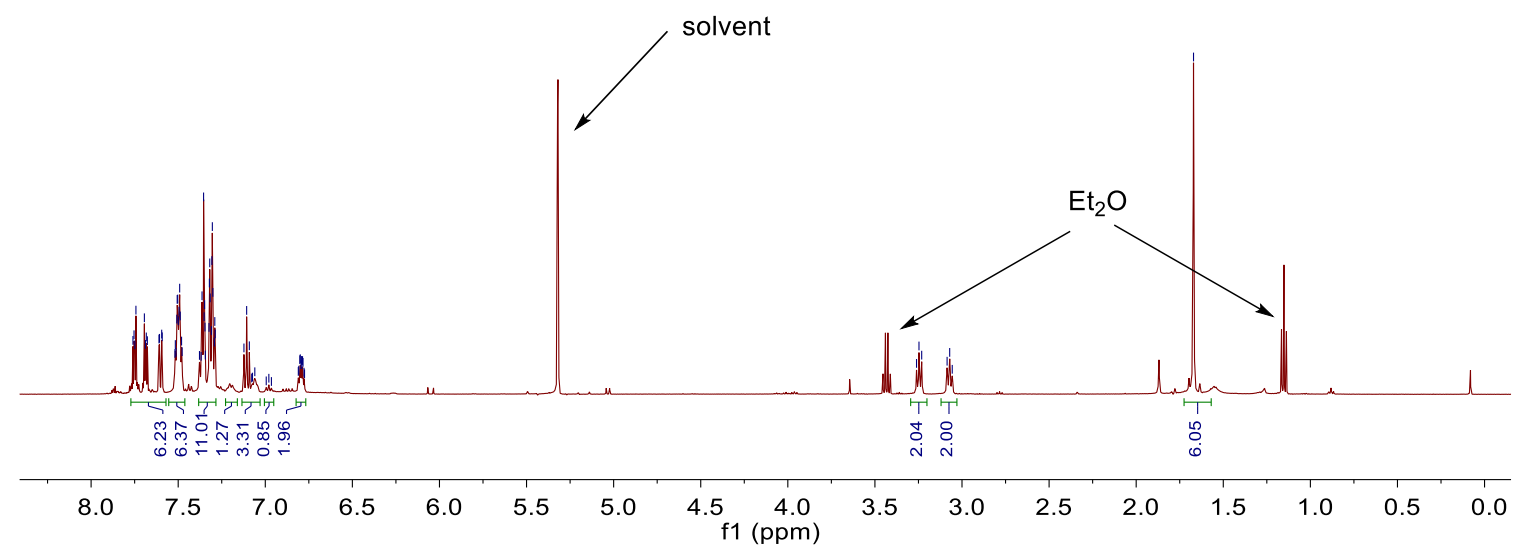




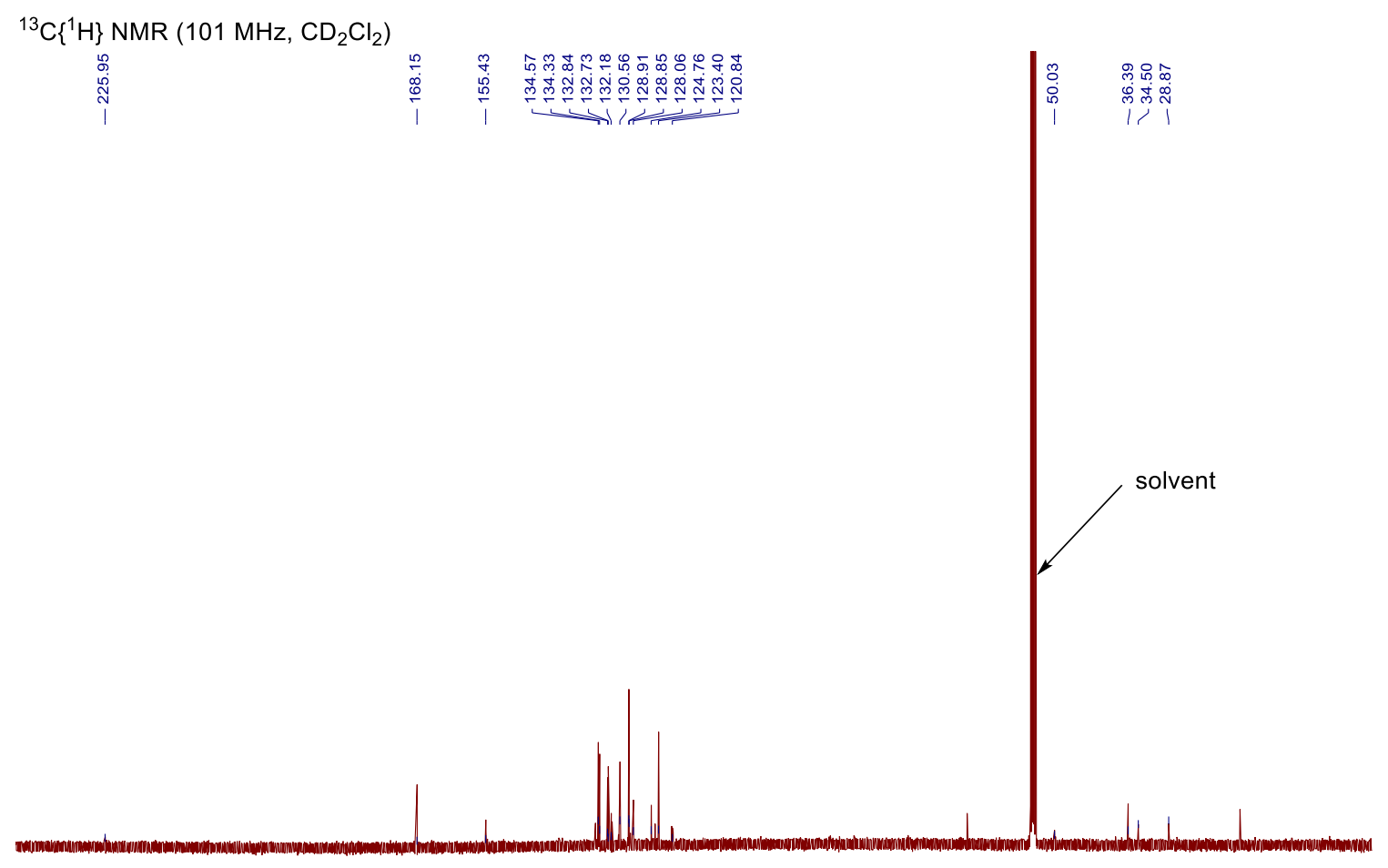

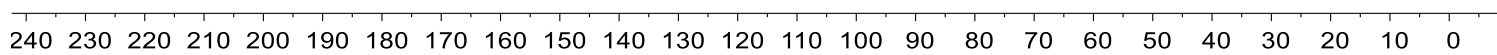
f1 (ppm)

${ }^{31} \mathrm{P}\left\{{ }^{1} \mathrm{H}\right\} \mathrm{NMR}\left(162 \mathrm{MHz}, \mathrm{CD}_{2} \mathrm{Cl}_{2}\right) \quad \stackrel{\text { aे }}{\mathrm{N}}$

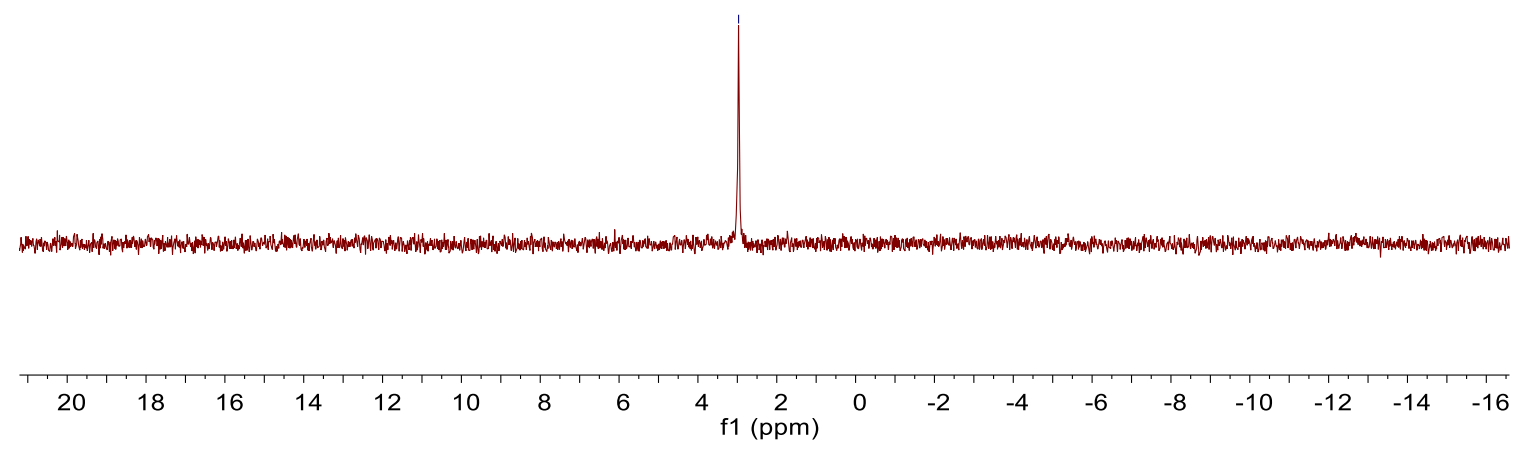

Fig. S73 NMR spectra for synthesized [xantphos-Pd- $\beta$-acyl]Cl complex in $\mathrm{CD}_{2} \mathrm{Cl}_{2}$. 
c). Synthesis of the [xantphos-Pd- $\beta$-acyl]BF 4 complex

To a yellow solution of [xantphos-Pd- $\beta$-acyl]Cl $(300 \mathrm{mg}, 0.33 \mathrm{mmol})$ in $\operatorname{dry~} \mathrm{CH}_{2} \mathrm{Cl}_{2}(10 \mathrm{~mL})$ at room temperature, $\mathrm{AgBF}_{4}(69.6 \mathrm{mg}, 0.36 \mathrm{mmol})$ was added. The resulting deep-red suspension was allowed to stir for $45 \mathrm{~min}$ at room temperature in dark. The solid material was filtered off under nitrogen. The filtrate was concentrated under reduced pressure to a volume of ca. $5 \mathrm{~mL}$. Degassed, dry ether (30 $\mathrm{mL}$ ) was added with the aid of a syringe and the resulting single-phase solution was allowed to stand overnight at $-22{ }^{\circ} \mathrm{C}$, resulting in the formation of a pink solid. The supernatant was decanted (with the aid of a syringe $)$ and the product was washed with degassed, dry ether $(2 \times 10 \mathrm{~mL})$ under nitrogen. The product was dried under high-vacuum to provide $235 \mathrm{mg}(76 \%)$ of the title compound. Recrystallization of the product from hexane and dichloromethane afforded the crystals of crystallographic quality.

${ }^{1} \mathbf{H}$ NMR (400 MHz, CD $\left.\mathbf{C l}_{2}\right) \delta 7.80-6.88(\mathrm{~m}, 30 \mathrm{H}), 3.54(\mathrm{t}, J=6.9 \mathrm{~Hz}, 2 \mathrm{H}), 2.93(\mathrm{t}, J=6.9 \mathrm{~Hz}, 2 \mathrm{H})$, $1.73(\mathrm{~s}, 3 \mathrm{H})$.

${ }^{13}$ C NMR (101 MHz, $\left.\mathbf{C D}_{2} \mathbf{C l}_{2}\right) \delta$ 213.9, 168.1, 49.3, 33.4, 33.3.

${ }^{31}$ P NMR (162 MHz, $\left.\mathrm{CD}_{2} \mathrm{Cl}_{2}\right) \delta 8.46$.

${ }^{19}$ F NMR (376 MHz, $\left.\mathrm{CD}_{2} \mathrm{Cl}_{2}\right) \delta-151.5$.

HRMS (APPI) m/z calcd. for $\mathrm{C}_{50} \mathrm{H}_{40} \mathrm{NO}_{4} \mathrm{P}_{2} \mathrm{Pd}\left([\mathrm{M}-\mathrm{BF} 4]^{+}\right)$: 886.1462; found: 886.1510.

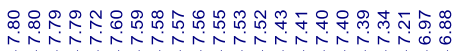

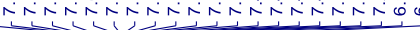

${ }^{1} \mathrm{H}$ NMR $\left(400 \mathrm{MHz}, \mathrm{CD}_{2} \mathrm{Cl}_{2}\right)$

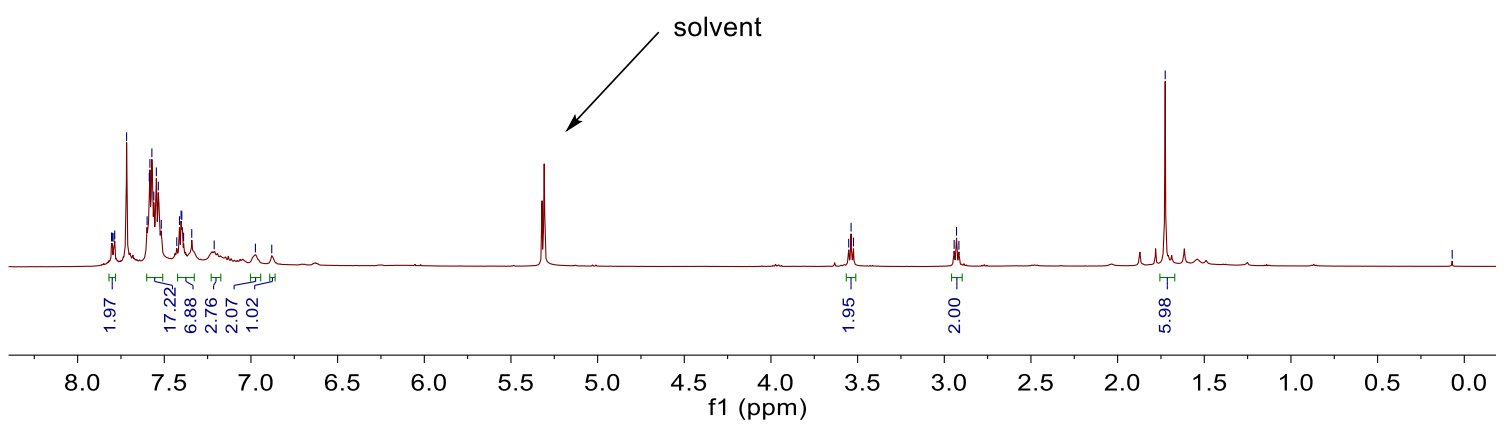


${ }^{31} \mathrm{P}\left\{{ }^{1} \mathrm{H}\right\}$ NMR $\left(162 \mathrm{MHz}, \mathrm{CD}_{2} \mathrm{Cl}_{2}\right)$

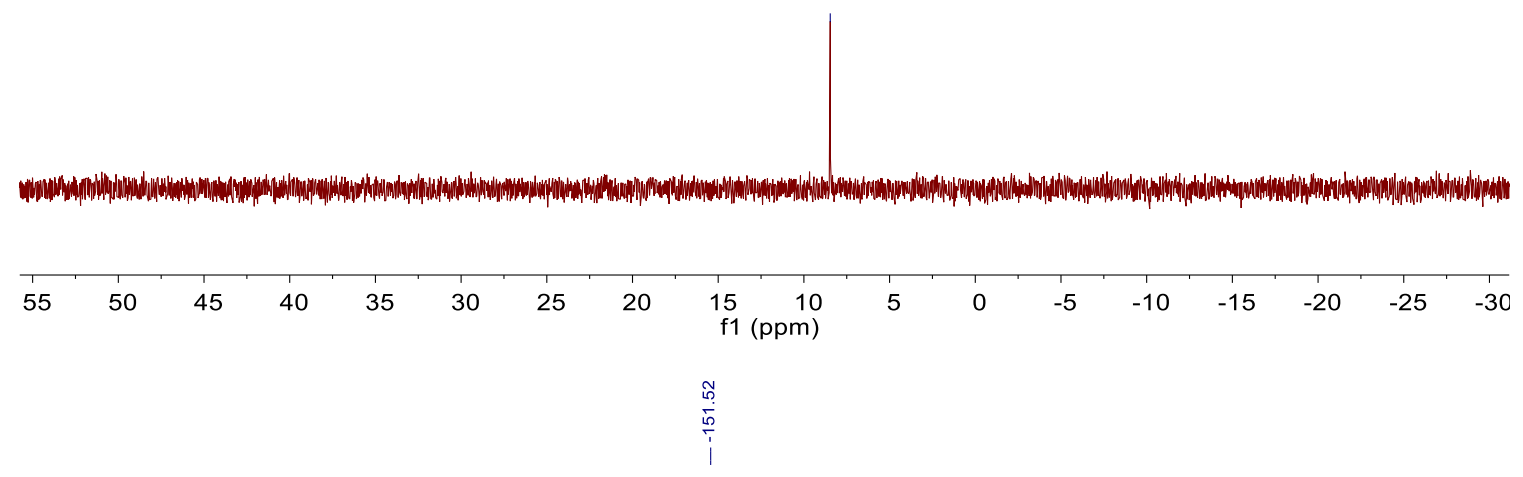

${ }^{19} \mathrm{~F}$ NMR $\left(376 \mathrm{MHz}, \mathrm{CD}_{2} \mathrm{Cl}_{2}\right)$

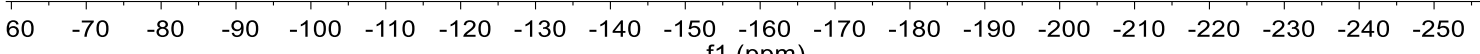
f1 (ppm)

Fig. S74 NMR spectra for synthesized [xantphos-Pd- $\beta$-acyl]BF $F_{4}$ complex in $\mathrm{CD}_{2} \mathrm{Cl}_{2}$. 


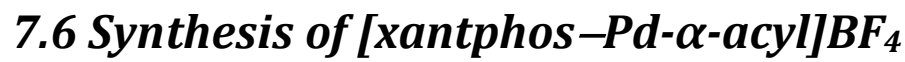

a). Synthesis of 2-phthalimidopropanoyl chloride
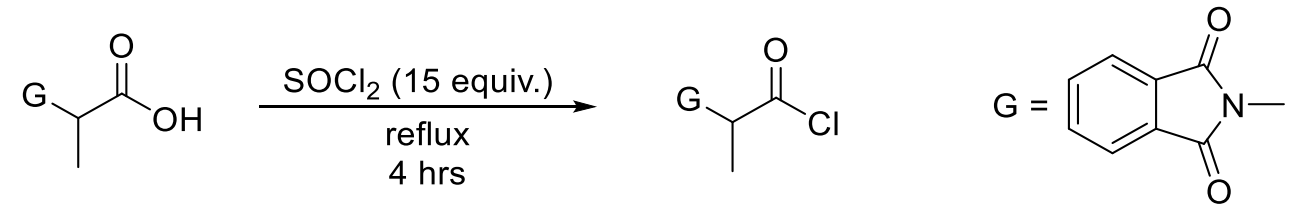

2-Phthalimidopropanoic acid (2.0 g, $9.12 \mathrm{mmol})$ was refluxed with thionyl chloride $(9.9 \mathrm{~mL}$, $136.86 \mathrm{mmol}$ ) for $4 \mathrm{~h}$ under nitrogen. The volatiles were removed under reduced pressure. The resulting solid material was dissolved in dry benzene $(20 \mathrm{~mL})$ and the volatiles were removed under reduced pressure. This procedure was repeated three times to afford 2-phthalimidopropanoyl chloride (2.17 g, 99\%), as white solid. The NMR data match previously reported data for the title product. ${ }^{58}$

${ }^{1}$ H NMR (400 MHz, CD2 $\left.\mathbf{C l}_{2}\right) \delta$ 7.93-7.78 (m, 4H), $5.17(\mathrm{q}, J=7.1 \mathrm{~Hz}, 1 \mathrm{H}), 1.79(\mathrm{~d}, J=7.1 \mathrm{~Hz}, 3 \mathrm{H})$.

b). Synthesis of the $[(x a n t p h o s) P d-\alpha-a c y l]^{+} \mathrm{BF}_{4}{ }^{-}$complex

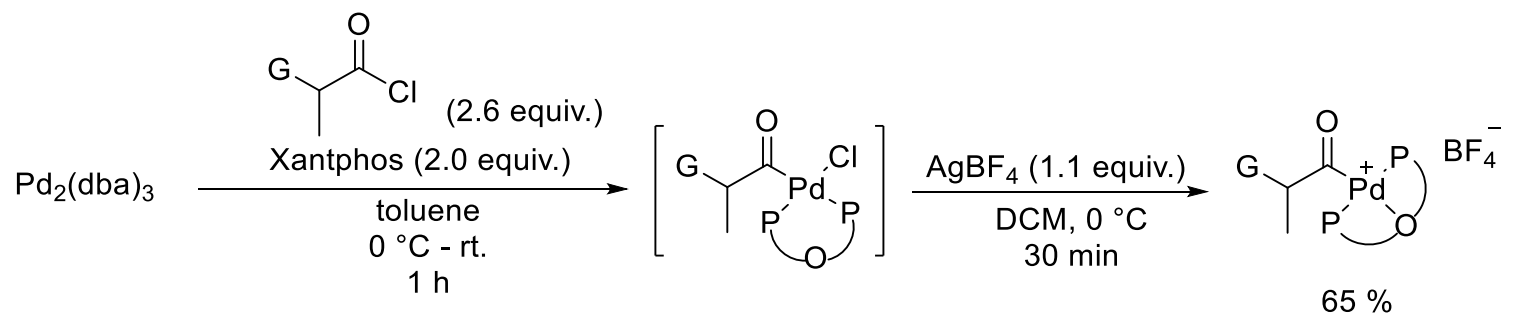

An oven-dried Schlenk tube equipped with a magnetic stirring bar was charged with $\operatorname{Pd}_{2}(\mathrm{dba})_{3}$ $(0.36 \mathrm{~g}, 0.4 \mathrm{mmol})$ and xantphos $(0.46 \mathrm{~g}, 0.8 \mathrm{mmol})$. The tube was sealed with a rubber septum and placed under an atmosphere of $\mathrm{N}_{2}$ (by 3 vacuum-nitrogen cycles). Degassed, dry toluene (8 mL) was added to the flask with the aid of a syringe, resulting in a dark-purple solution. The flask was placed in an ice/water bath and the mixture was allowed to stir for $10 \mathrm{~min}$. A solution of 2-phthalimidopropanoyl chloride $(0.25$ $\mathrm{g}, 1.0 \mathrm{mmol})$ in toluene $(2 \mathrm{~mL})$ was added with the aid of a syringe. The resulting mixture was allowed to stir for $30 \mathrm{~min}$. The flask was removed from the cooling bath. The mixture was allowed to warm to room temperature and allowed to stir for $1 \mathrm{~h}$. The resulting brown mixture was filtered under nitrogen to remove residual palladium-black. The filtrate was concentrated under reduced pressure to a volume of ca. $5 \mathrm{~mL}$. Degassed, dry diethyl ether $(20 \mathrm{~mL})$ was added with the aid of a syringe. The resulting single-phase solution was allowed to stand overnight, resulting in the formation of a yellow solid. The supernatant was decanted with the aid of a syringe, the residue was washed with degassed, dry ether $(2 \times 10 \mathrm{~mL})$ under 
nitrogen and dried under high vacuum to provide title compound as a moisture-sensitive, yellow solid. It was subjected to the next step without any further purification due to its instability in solution at room temperature.

To a yellow solution of (xantphos)Pd- $\alpha$-acyl-Cl (190 mg, $0.21 \mathrm{mmol})$ in dry $\mathrm{CD}_{2} \mathrm{Cl}_{2}(5 \mathrm{~mL})$ under nitrogen at $0{ }^{\circ} \mathrm{C}, \mathrm{AgBF}_{4}(44.1 \mathrm{mg}, 0.23 \mathrm{mmol})$ was added. The resulting deep red suspension was allowed to stir for $45 \mathrm{~min}$ at $0{ }^{\circ} \mathrm{C}$ in dark, followed by filtration under nitrogen. The filtrate was concentrated under reduced pressure to a volume of ca. $2 \mathrm{~mL}$. Degassed, dry ether $(20 \mathrm{~mL})$ was added with the aid of a syringe. The resulting single-phase solution was allowed to stand overnight at $-22{ }^{\circ} \mathrm{C}$, resulting in the formation of a deep-green solid. The supernatant was decanted (syringe), the solid residue was washed with degassed, dry diethyl ether $(2 \times 10 \mathrm{~mL})$ under nitrogen, and dried under high vacuum to provide $126 \mathrm{mg}(65 \%)$ of the title compound. Recrystallization of product by slow diffusion of pentane into a dichloromethane solution afforded x-ray quality crystals.

${ }^{1}$ H NMR (400 MHz, CD2Cl ) $\delta$ 7.96-6.59 (m, 30 H), 4.39 (q, J = 7.7 Hz, 1H), 1.78-1.25 (s, 6H), 1.39 (d, $J=7.7 \mathrm{~Hz}, 3 \mathrm{H})$.

${ }^{13}$ C NMR (101 MHz, $\left.\mathbf{C D}_{2} \mathbf{C l}_{2}\right) \delta 212.9,167.5,60.5,33.9,14.4$.

${ }^{31}$ P NMR (162 MHz, $\left.\mathrm{CD}_{2} \mathrm{Cl}_{2}\right) \delta 10.2$.

${ }^{19}$ F NMR (376 MHz, $\left.\mathrm{CD}_{2} \mathrm{Cl}_{2}\right) \delta-153.5$.

HRMS (APPI) m/z calcd. for $\mathrm{C}_{50} \mathrm{H}_{40} \mathrm{NO}_{4} \mathrm{P}_{2} \mathrm{Pd}\left([\mathrm{M}-\mathrm{BF} 4]^{+}\right)$: 886.1462; found: 886.1687. 


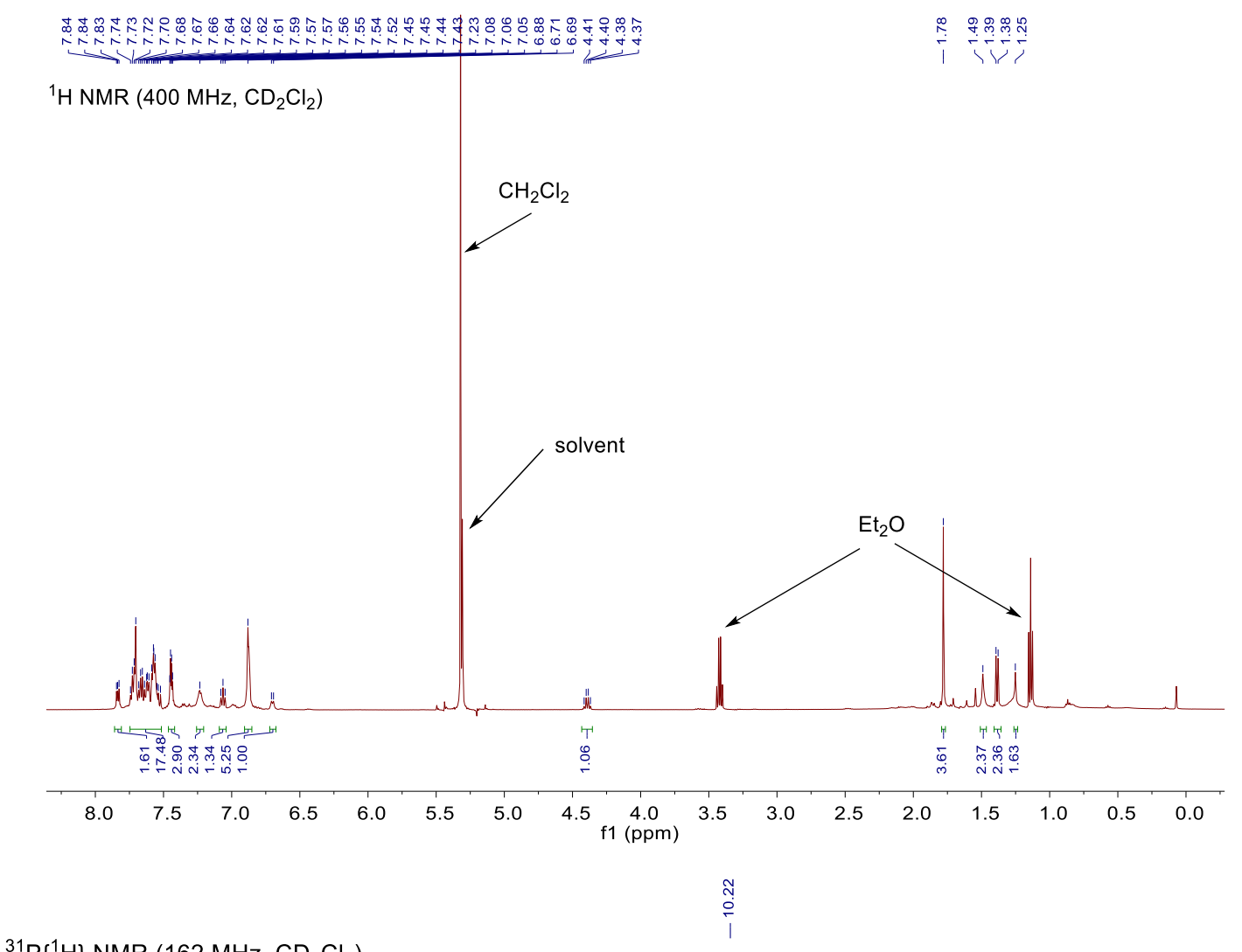

${ }^{31} \mathrm{P}\left\{{ }^{1} \mathrm{H}\right\}$ NMR (162 MHz, $\mathrm{CD}_{2} \mathrm{Cl}_{2}$ )

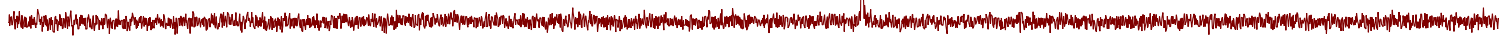

$\begin{array}{llllllllllllllllllllll}34 & 32 & 30 & 28 & 26 & 24 & 22 & 20 & 18 & 16 & \begin{array}{c}14 \\ \mathrm{f} 1(\mathrm{ppm})\end{array} & 10 & 8 & 6 & 4 & 2 & 0 & -2 & -4 & -6 & \end{array}$


${ }^{19} \mathrm{~F}$ NMR $\left(376 \mathrm{MHz}, \mathrm{CD}_{2} \mathrm{Cl}_{2}\right)$

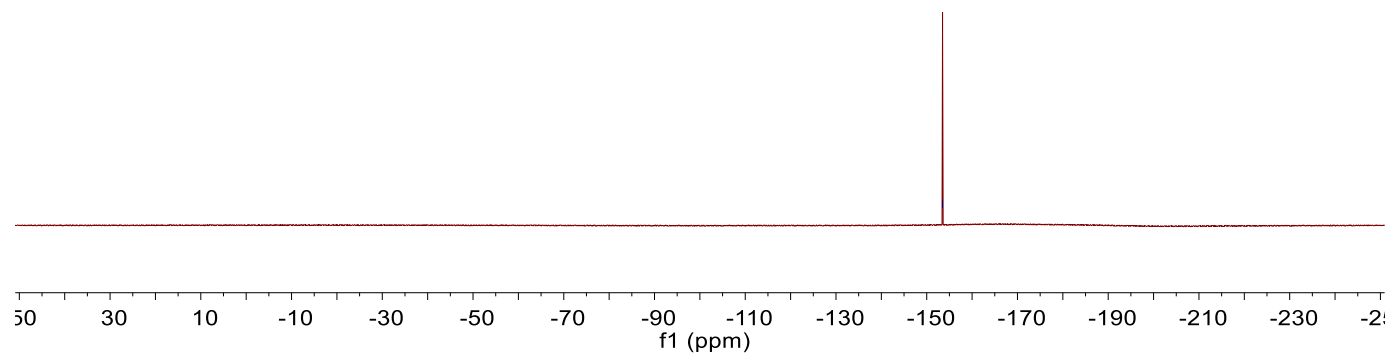

Fig. S75 NMR spectra for synthesized [xantphos-Pd- $\alpha$-acyl]BF 4 complex in $\mathrm{CD}_{2} \mathrm{Cl}_{2}$.

\subsection{Synthesis of xantphos-Pd(CH$) C l$ and xantphos $-\mathrm{Pd}\left(\mathrm{CH}_{3}\right) \mathrm{BF}_{4}$}

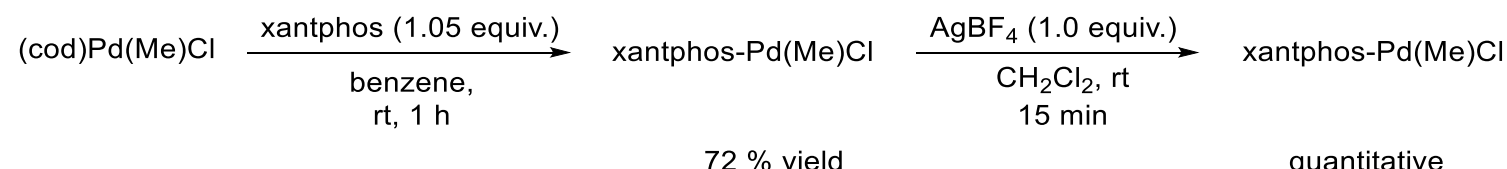

a). Synthesis of xantphos $-P d(\mathrm{Me}) \mathrm{Cl}$

The title product was prepared following the literature procedure: ${ }^{55} \mathrm{In}$ a nitrogen-filled glovebox, a $20-\mathrm{mL}$ vial was charged with (cod) $\mathrm{Pd}(\mathrm{Me}) \mathrm{Cl}(95.4 \mathrm{mg}, 0.36 \mathrm{mmol}$ ), xantphos (214 mg, $0.37 \mathrm{mmol}$ ) in dry and degassed benzene $(5 \mathrm{~mL})$, and the content was allowed to stir for $1 \mathrm{~h}$ at room temperature. An offwhite/ yellowish solid material was formed while stirring. The precipitate was separated from the liquid by centrifugation $\left(2000 \mathrm{rpm}, 10 \mathrm{~min}, 22^{\circ} \mathrm{C}\right.$ ), after which the liquid was removed by decanting. The residue was suspended in benzene $(2 \mathrm{~mL})$, the mixture centrifuged $\left(2000 \mathrm{rpm}, 10 \mathrm{~min}, 22{ }^{\circ} \mathrm{C}\right)$, and the liquid decanted. The resulting solid was dried overnight under high vacuum at rt, yielding $190 \mathrm{mg}$ (72\%) of a light-grey powder. The NMR data match those previously reported data for the title product. ${ }^{55}$

${ }^{1}$ H NMR (400 MHz, $\mathbf{C D}_{2} \mathbf{C l}_{2}$ ) $\delta$ 7.90-7.0 (m, 26H), 1.77 (s, 6H), 0.40 (s, 3H);

${ }^{31} \mathbf{P}\left\{{ }^{1} \mathbf{H}\right\}$ NMR (162 MHz, $\left.\mathbf{C D}_{2} \mathbf{C l}_{2}\right) \delta 15.2$ (br s). 


\section{b). Synthesis of xantphos $-P d(M e) B F_{4}$}

The title product was prepared adapting literature procedure for the triflate analogue of the complex ${ }^{55}$ with small modifications: In a nitrogen-filled glovebox, a $20-\mathrm{mL}$ vial was charged with xantphos- $\mathrm{Pd}(\mathrm{Me}) \mathrm{Cl}(73.6 \mathrm{mg}, 0.10 \mathrm{mmol}), \mathrm{AgBF}_{4}(19.5 \mathrm{mg}, 0.10 \mathrm{mmol})$ in dry and degassed $\mathrm{CH}_{2} \mathrm{Cl}_{2}(5$ $\mathrm{mL}$ ), and the content was allowed to stir for $15 \mathrm{~min}$ at room temperature in the dark (aluminum foil). A white solid material was formed in the course of stirring. The precipitate was separated from the liquid with the aid of a syringe and a syringe filter. The vial and the syringe were rinsed with an additional portion of $\mathrm{CH}_{2} \mathrm{Cl}_{2}(2 \mathrm{~mL})$, and the filtrates were combined. The volatiles were removed under reduced pressure and the resulting solid was dried for overnight under high vacuum at room temperature, yielding off-white powder in quantitative yield (the material contains traces of $\mathrm{CH}_{2} \mathrm{Cl}_{2}(\sim 0.2$ equiv.) and benzene $\left(\sim 0.1\right.$ equiv.)). The NMR data match previously reported data for a triflate analogue of the title product. ${ }^{55}$ ${ }^{1} \mathbf{H}$ NMR (400 MHz, $\left.\mathbf{C D}_{2} \mathbf{C l}_{2}\right) \delta$ 7.86-7.81 (m, 2H), 7.67-7.43 (m, 24H) $1.77(\mathrm{~s}, 6 \mathrm{H}), 1.52\left(\mathrm{PdCH}_{3}, \mathrm{t},{ }^{3} \mathrm{~J}_{\mathrm{PH}}\right.$ $=5.5 \mathrm{~Hz}, 3 \mathrm{H})$.

${ }^{31} \mathbf{P}\left\{{ }^{1} \mathrm{H}\right\}$ NMR (162 MHz, $\left.\mathbf{C D}_{2} \mathrm{Cl}_{2}\right) \delta 19.2$ (s).

${ }^{13} \mathbf{C}\left\{{ }^{1} \mathbf{H}\right\}$ NMR (101 MHz, $\left.\mathbf{C D}_{2} \mathrm{Cl}_{2}\right) \delta 0.1\left(\mathrm{PdCH}_{3}\right)$.

\subsection{Synthesis of the (xantphos) $)_{2}-\mathrm{Pd}_{2}\left(\mathrm{BF}_{4}\right)_{2}$}

a) Synthesis of dipalladium complex $\mathrm{Pd}_{2}\left(\mathrm{CH}_{3} \mathrm{CN}\right)_{6}\left(\mathrm{BF}_{4}\right)_{2}$

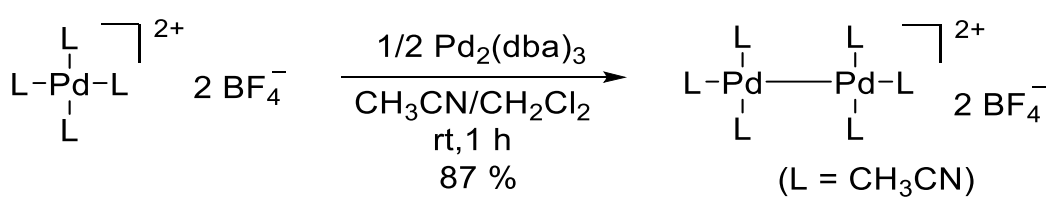

The title compound was prepared following a previously described procedure: ${ }^{59}$ In a nitrogenfilled glovebox, to a solution of $\mathrm{Pd}\left(\mathrm{CH}_{3} \mathrm{CN}\right)_{4}\left(\mathrm{BF}_{4}\right)_{2}(0.1 \mathrm{~g}, 0.22 \mathrm{mmol})$ in $\mathrm{CH}_{3} \mathrm{CN}(20 \mathrm{~mL})$, a solution of $\mathrm{Pd}_{2}(\mathrm{dba})_{3}(0.11 \mathrm{~g}, 0.11 \mathrm{mmol})$ in $\mathrm{CH}_{2} \mathrm{Cl}_{2}(20 \mathrm{~mL})$ was added. The mixture was allowed to stir for $1 \mathrm{~h}$ at room temperature after which it was filtered through Celite. The filtrate was poured into $\operatorname{dry} \mathrm{Et}_{2} \mathrm{O}(50 \mathrm{~mL})$ resulting in formation of an orange precipitate. The solid material was filtrated off, washed several times with $\mathrm{Et}_{2} \mathrm{O}$, and dried under high vacuum, yielding the title compound in $87 \%$ yield $(0.12 \mathrm{~g})$. The compound was subjected to the subsequent step without any further purification.

b) Synthesis of binuclear palladium complex (xantphos $)_{2}-\mathrm{Pd}_{2}\left(\mathrm{BF}_{4}\right)_{2}$ 


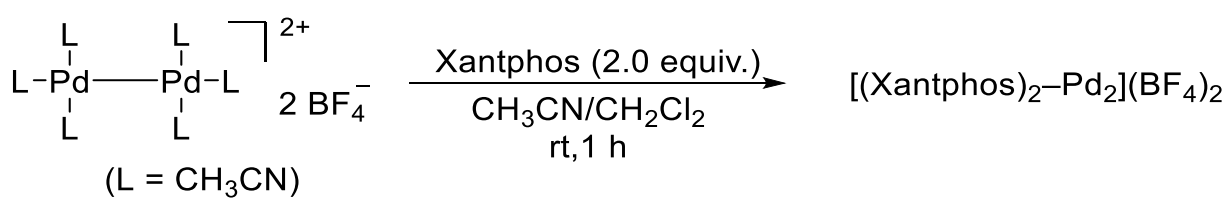

In a nitrogen-filled glovebox, to a solution of $\mathrm{Pd}_{2}\left(\mathrm{CH}_{3} \mathrm{CN}\right)_{6}\left(\mathrm{BF}_{4}\right)_{2}(0.06 \mathrm{~g}, 0.09 \mathrm{mmol})$ in a mixture of $\mathrm{CH}_{3} \mathrm{CN}(10 \mathrm{~mL})$ and $\mathrm{CH}_{2} \mathrm{Cl}_{2}(10 \mathrm{~mL})$, xantphos $(0.1 \mathrm{~g}, 0.19 \mathrm{mmol})$ was added, and the mixture was allowed to stir for $1 \mathrm{~h}$ at room temperature. The resulting brown mixture was filtered and the volatiles from the filtrate were removed under reduced pressure. The brown solid residue was recrystallized from a mixture of dichloromethane/acetonitrile and hexanes at $-20{ }^{\circ} \mathrm{C}$ to yield $\mathrm{x}$-ray quality crystals.

${ }^{1}$ H NMR (400 MHz, $\left.\mathbf{C D}_{2} \mathbf{C l}_{2}\right) \delta$ 8.0-8.05 (d, $\left.J=7.6 \mathrm{~Hz}, 2 \mathrm{H}\right), 7.75(\mathrm{~m}, 6 \mathrm{H}), 7.43-7.11(\mathrm{~m}, 26 \mathrm{H}), 7.01$ $6.93(\mathrm{~m}, 10 \mathrm{H}), 6.31-6.24(\mathrm{~m}, 4 \mathrm{H}), 5.95(\mathrm{~s}, 4 \mathrm{H}), 2.14(\mathrm{~s}, 6 \mathrm{H}), 1.61(\mathrm{~s}, 6 \mathrm{H})$.

${ }^{31} \mathbf{P}$ NMR (162 MHz, $\left.\mathbf{C D}_{2} \mathbf{C l}_{2}\right) \delta 7.5(\mathrm{td}, J=31.9,9.4 \mathrm{~Hz})$.

${ }^{19}$ F NMR (376 MHz, $\left.\mathrm{CD}_{2} \mathrm{Cl}_{2}\right) \delta-152.8$.

HRMS (APPI) m/z calcd. For $\mathrm{C}_{78} \mathrm{H}_{65} \mathrm{O}_{2} \mathrm{P}_{4} \mathrm{Pd}_{2}\left([\mathrm{M}+\mathrm{H}]^{+}\right)$: 1369.1999; found: 1369.2087.

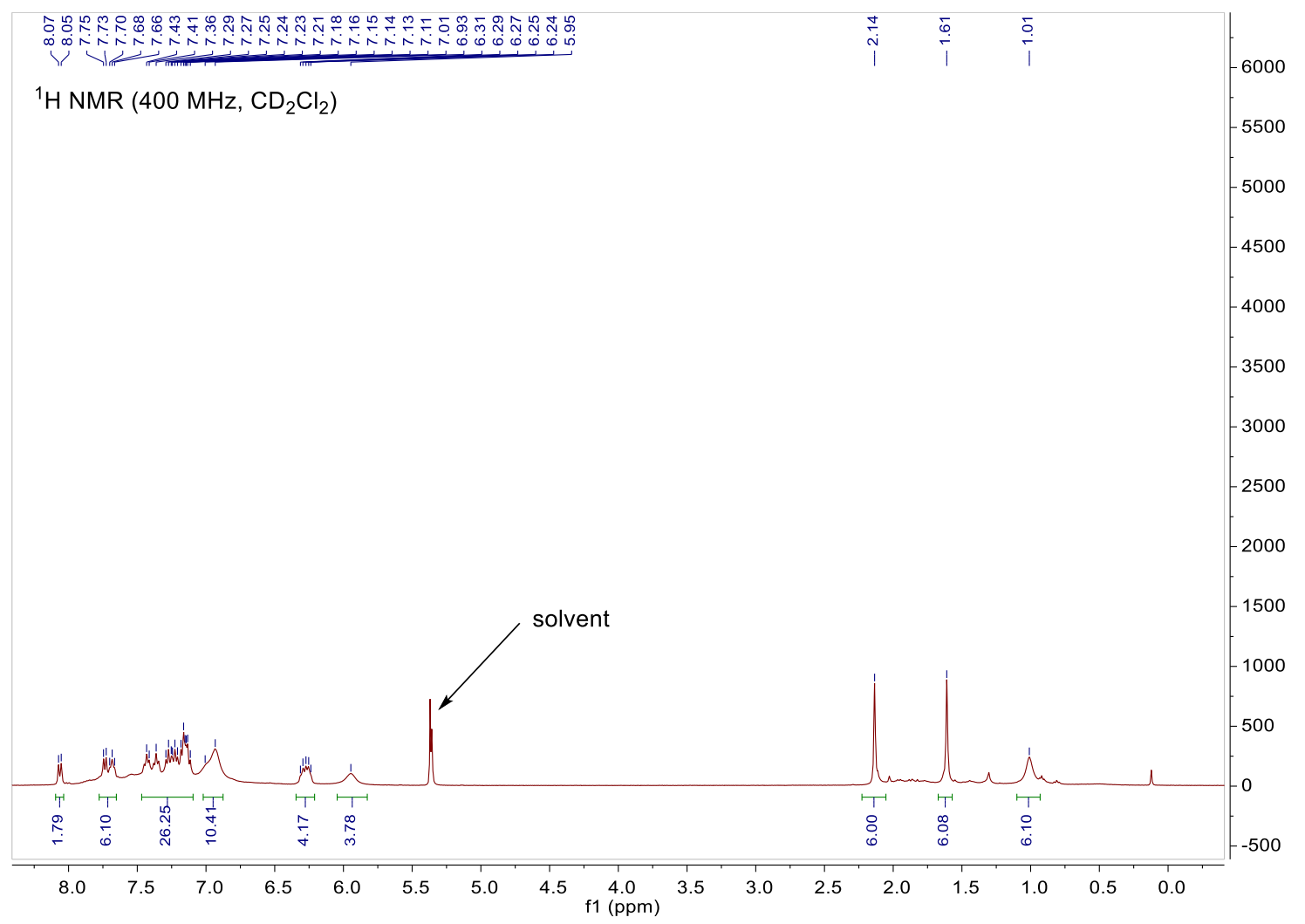




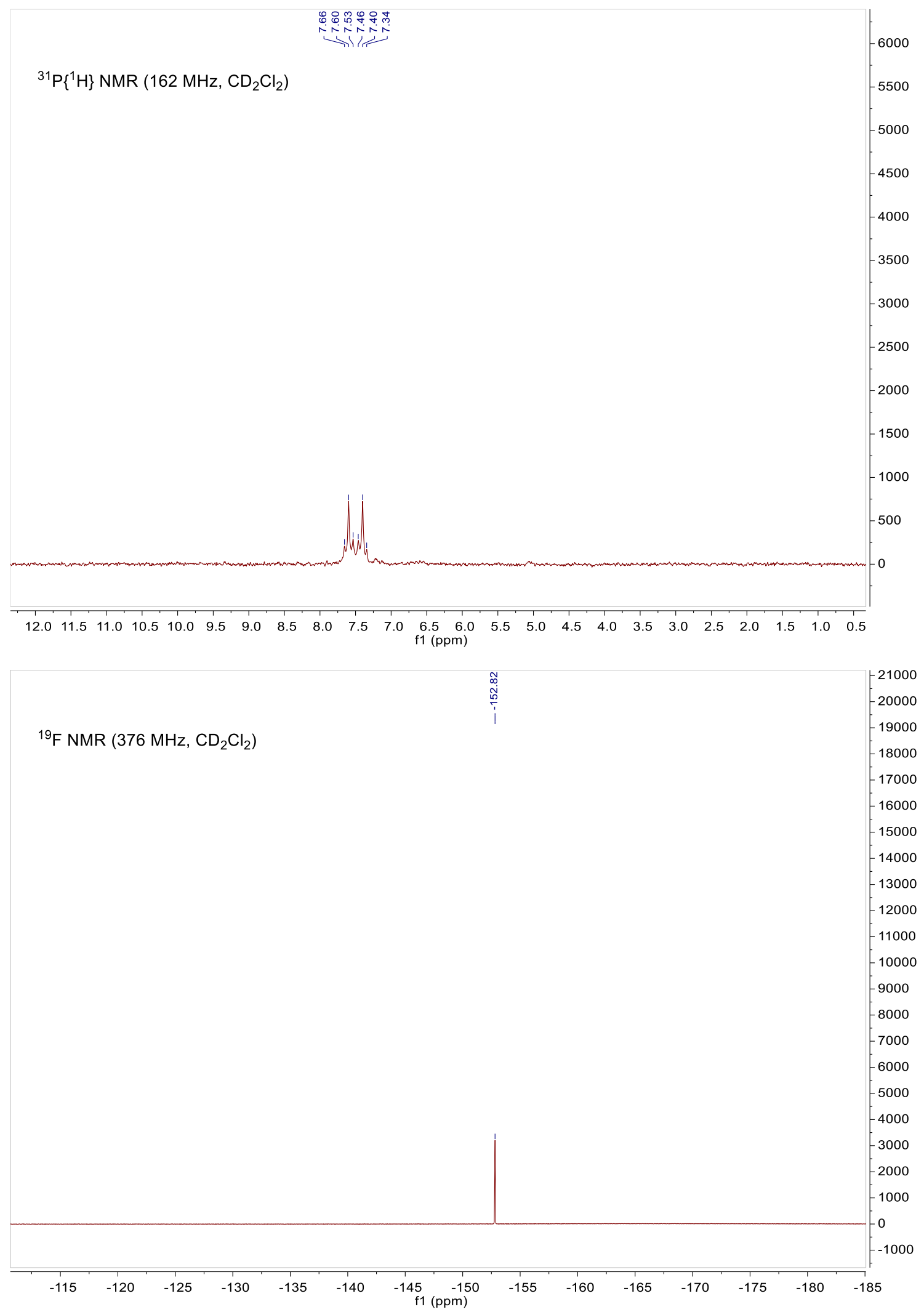

Fig. S76 NMR spectra of complex (xantphos) $)_{2}-\mathrm{Pd}_{2}\left(\mathrm{BF}_{4}\right)_{2}$ in $\mathrm{CD}_{2} \mathrm{Cl}_{2}$ 


\subsection{Synthesis of the xantphos-Pd${ }_{2} I_{2}$ complex}

$$
\text { Xantphos-Pdl } 2+1 / 2 \mathrm{Pd}_{2}(\mathrm{dba})_{3} \underset{\mathrm{rt}}{\stackrel{\mathrm{DCM} / \mathrm{CH}_{3} \mathrm{CN}}{\longrightarrow}} \text { Xantphos- } \mathrm{Pd}_{2} \mathrm{I}_{2}
$$

In a nitrogen-filled glovebox, to a solution of $\mathrm{Pd}_{2}(\mathrm{dba})_{3}(0.14 \mathrm{~g}, 0.14 \mathrm{mmol})$ in a mixture of $\mathrm{CH}_{3} \mathrm{CN}$ and $\mathrm{CH}_{2} \mathrm{Cl}_{2}(1: 1 \mathrm{v} / \mathrm{v}, 10 \mathrm{~mL})$, xantphos- $\mathrm{PdI}_{2}(0.27 \mathrm{~g}, 0.27 \mathrm{mmol})$ was added. The mixture was allowed to stir for $1 \mathrm{~h}$ at room temperature. The resulting brown solution was filtered and the volatiles from the filtrate were removed under vacuum to afford the title product as a brown solid material in quantitative yield. The product was recrystallized from a mixture of dichloromethane/acetonitrile and hexanes at $-20{ }^{\circ} \mathrm{C}$ to yield $\mathrm{X}$-ray quality crystals.

${ }^{1}$ H NMR (400 MHz, CD $\left.\mathbf{C l}_{2}\right) \delta$ 7.73-6.68 (m, 22H), 6.41-5.95 (m, 4H), 2.05 (s, 3H), 1.39 (s, 3H).

${ }^{31}$ P NMR (162 MHz, CD2 $\left.\mathbf{C l}_{2}\right) \delta 7.40(\mathrm{~d}, J=7.6 \mathrm{~Hz}), 4.18(\mathrm{~d}, J=7.6 \mathrm{~Hz})$.

HRMS (APPI) m/z calcd. for $\mathrm{C}_{39} \mathrm{H}_{32} \mathrm{IOP}_{2} \mathrm{Pd}_{2}$ ([M-I] $\left.]^{+}\right)$: 916.9037; found: 916.9017.

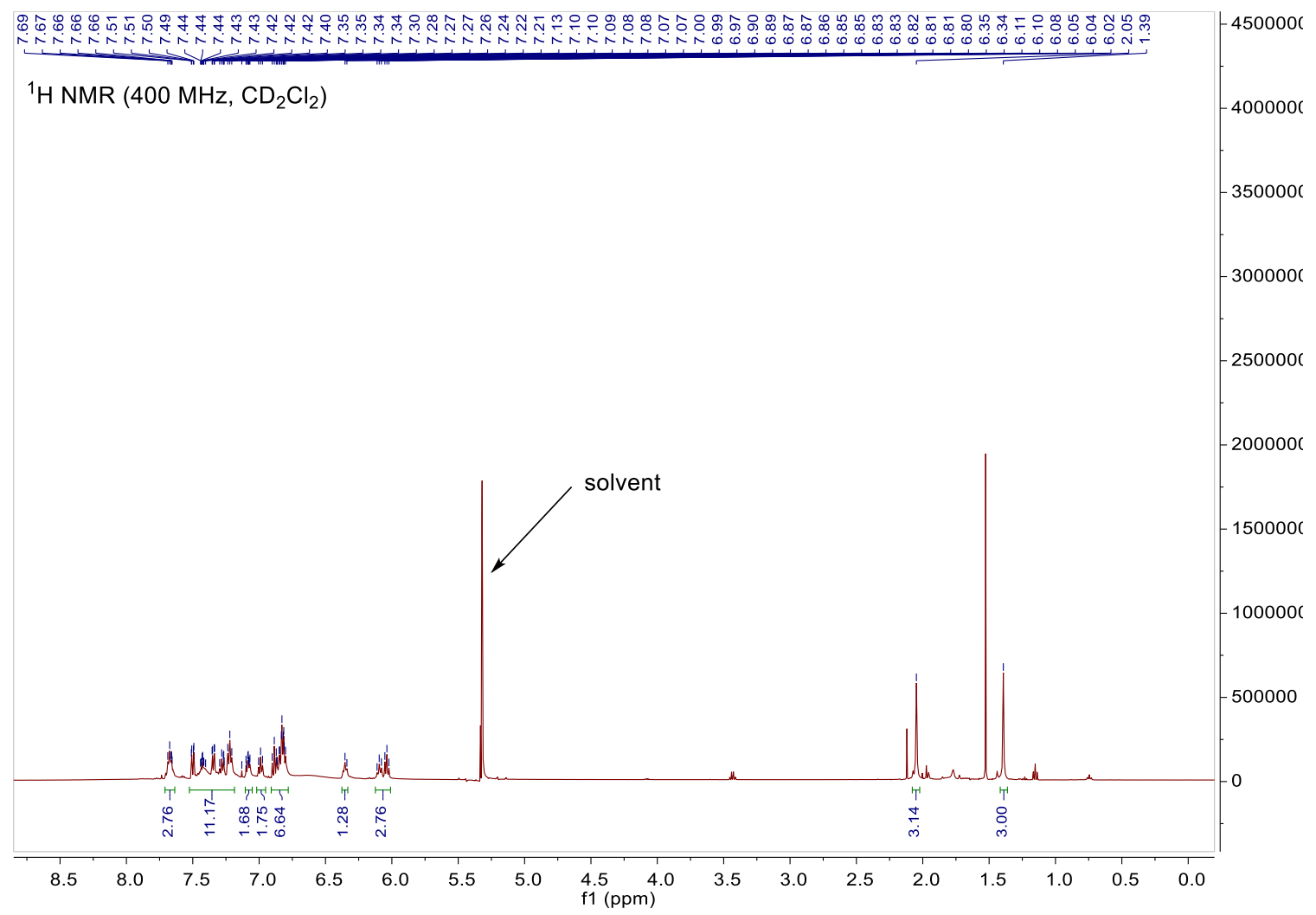




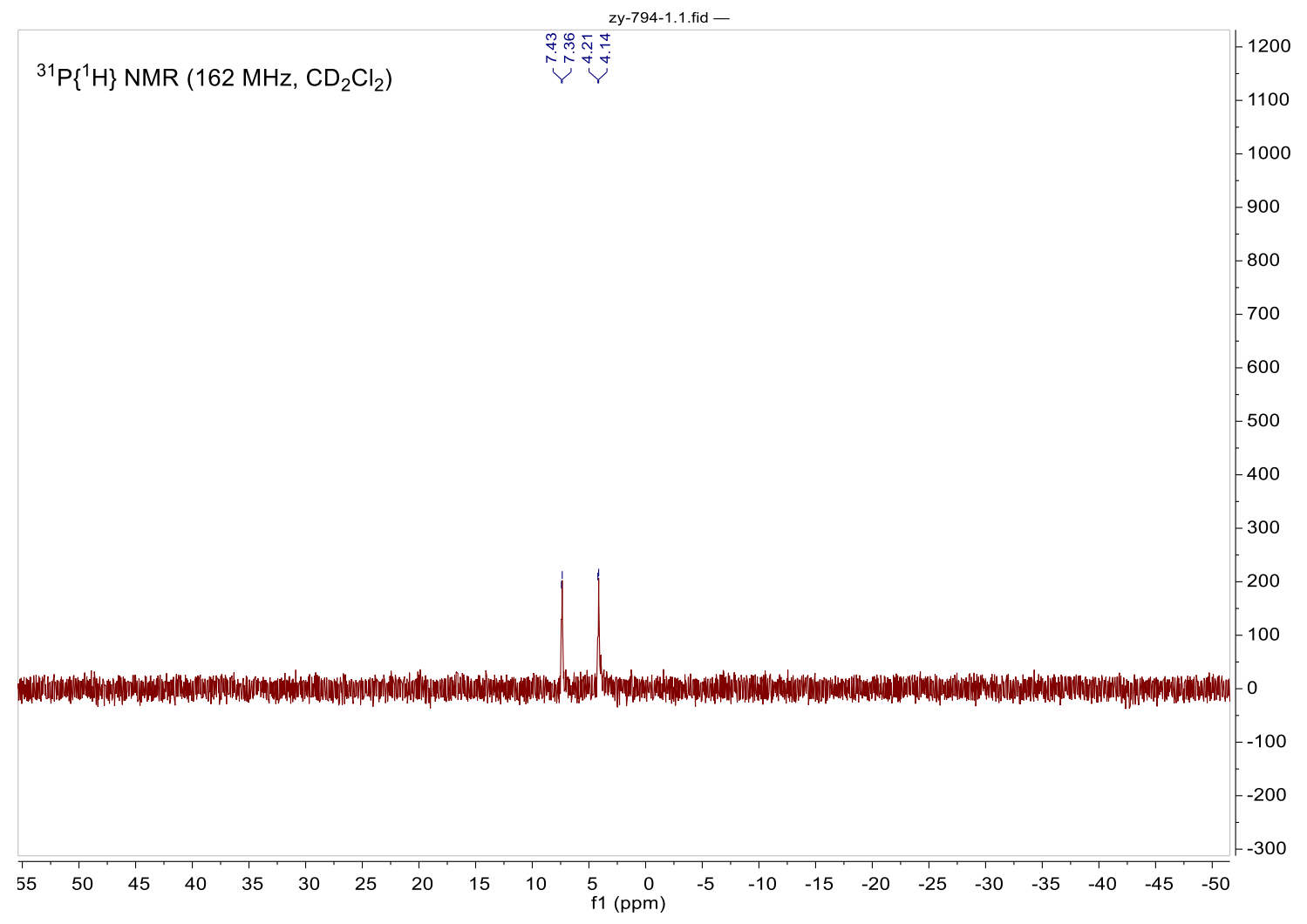

Fig. S77 NMR spectra of complex xantphos $-\mathrm{Pd}_{2} \mathrm{I}_{2}$ in $\mathrm{CD}_{2} \mathrm{Cl}_{2}$. 


\subsection{Evaluation of reactivity of reaction intermediates - stoichiometric experiments}

Unless specified otherwise, the experiments were conducted in J. Young tubes. The NMR samples were prepared in a nitrogen-filled glovebox and the NMR spectra recorded over time at room temperature.

1) Reaction of $\left[(\text { xantphos })_{2}-\mathrm{Pd}_{2}(\mu-\mathrm{H})(\mu-\mathrm{CO})\right]^{+} \mathrm{TFA}^{-}$complex $(0.025 \mathrm{mmol})$ with alkene $1 \mathrm{q}(0.025 \mathrm{mmol})$ in $\mathrm{CD}_{2} \underline{\mathrm{Cl}_{2}} \underline{(0.50 \mathrm{~mL})}$

i. In absence of iodide

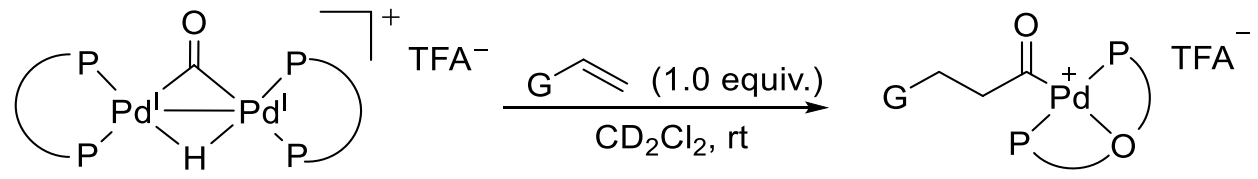

${ }^{1} \mathrm{H}$ NMR $\left(400 \mathrm{MHz}, \mathrm{CD}_{2} \mathrm{Cl}_{2}\right)$
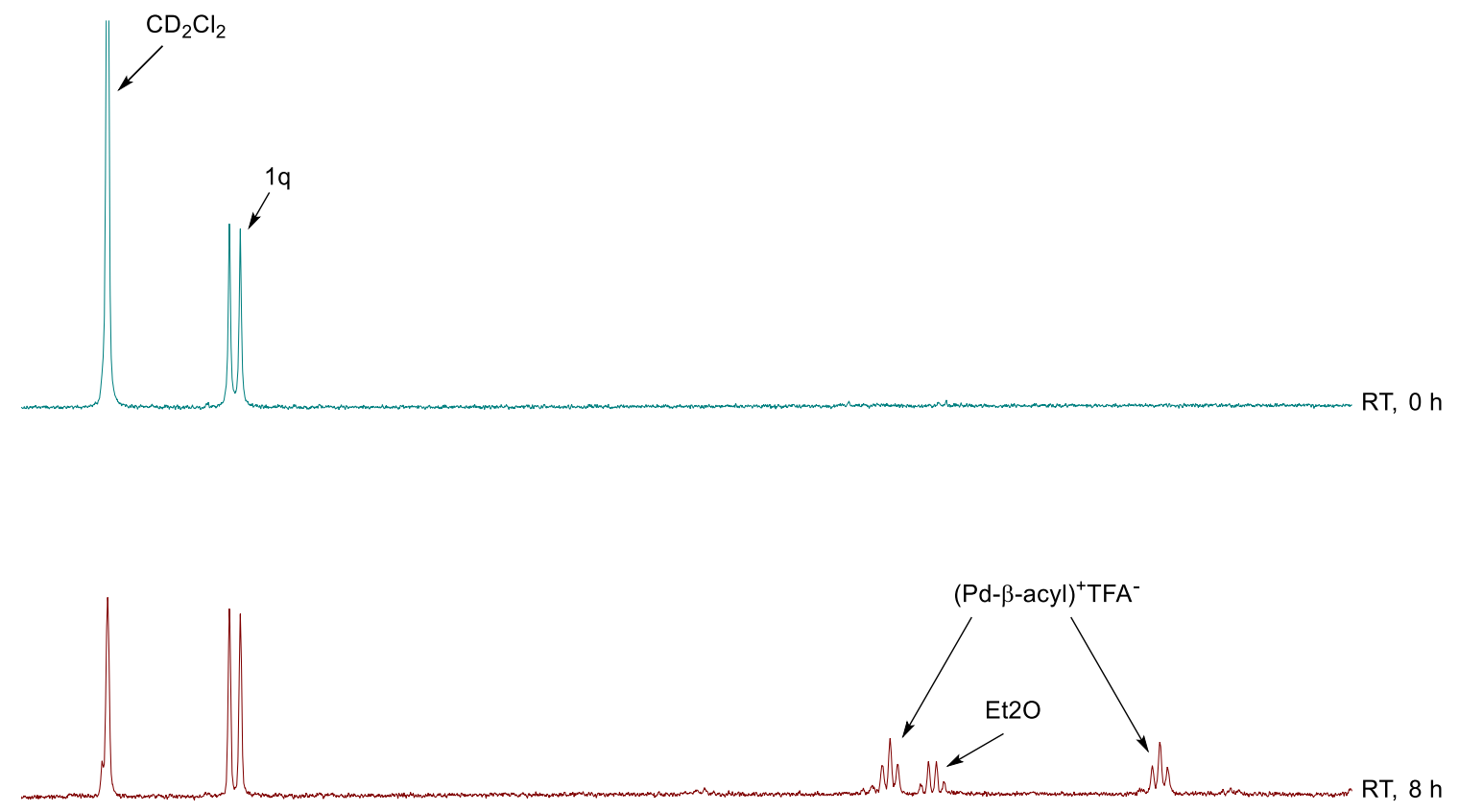

$\begin{array}{llllllllllllllllllllllllllllllll}5.5 & 5.4 & 5.3 & 5.2 & 5.1 & 5.0 & 4.9 & 4.8 & 4.7 & 4.6 & 4.5 & 4.4 & 4.3 & 4.2 & 4.1 & 4.0 & 3.9 & 3.8 & 3.7 & 3.6 & 3.5 & 3.4 & 3.3 & 3.2 & 3.1 & 3.0 & 2.9 & 2.8 & 2.7 & 2.6\end{array}$

f1 (ppm)

Fig. $\mathbf{S 7 8}{ }^{1} \mathrm{H} N M R$ spectra for the reaction of $\left[(\text { xantphos })_{2}-P d_{2}(\mu-H)(\mu-C O)\right]^{+} T F A^{-}$and alkene $\mathbf{1 q}$ in $C D_{2} C l_{2}$. 
ii. In the presence of iodide ( 1 equiv. of $\mathrm{PPh}_{4}{ }^{+} \mathrm{I}^{-}$per Pd-dimer; 0.5 equiv. per $\mathrm{Pd}$-center)

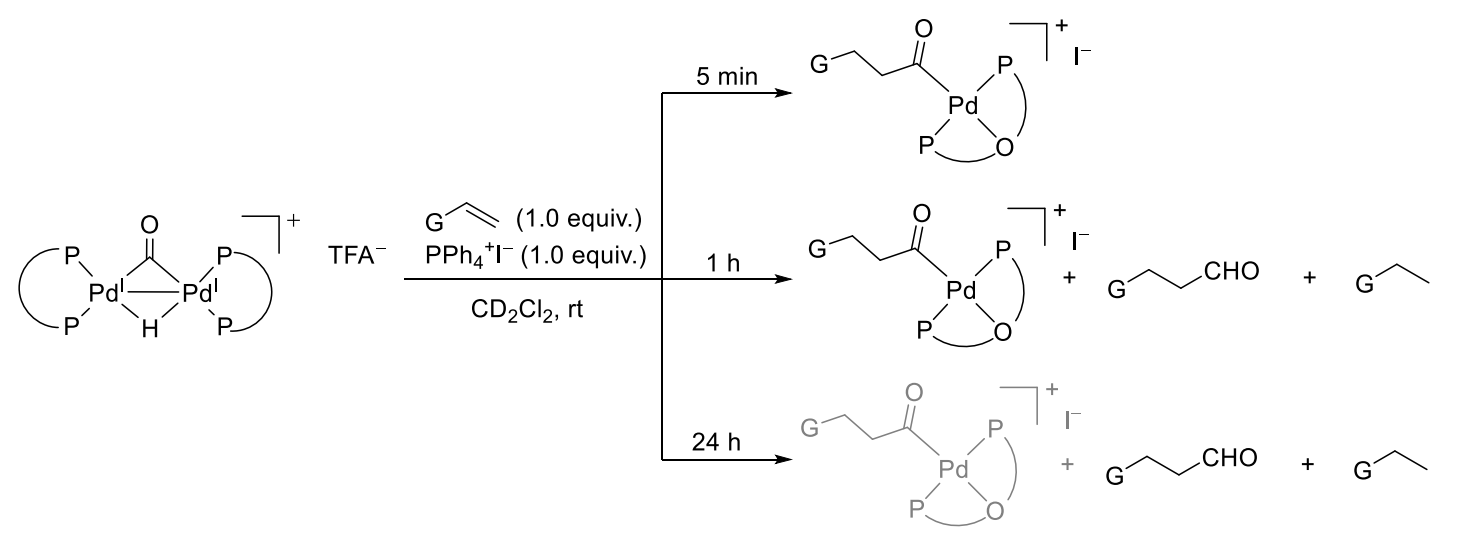

${ }^{1} \mathrm{H}$ NMR $\left(400 \mathrm{MHz}, \mathrm{CD}_{2} \mathrm{Cl}_{2}\right)$
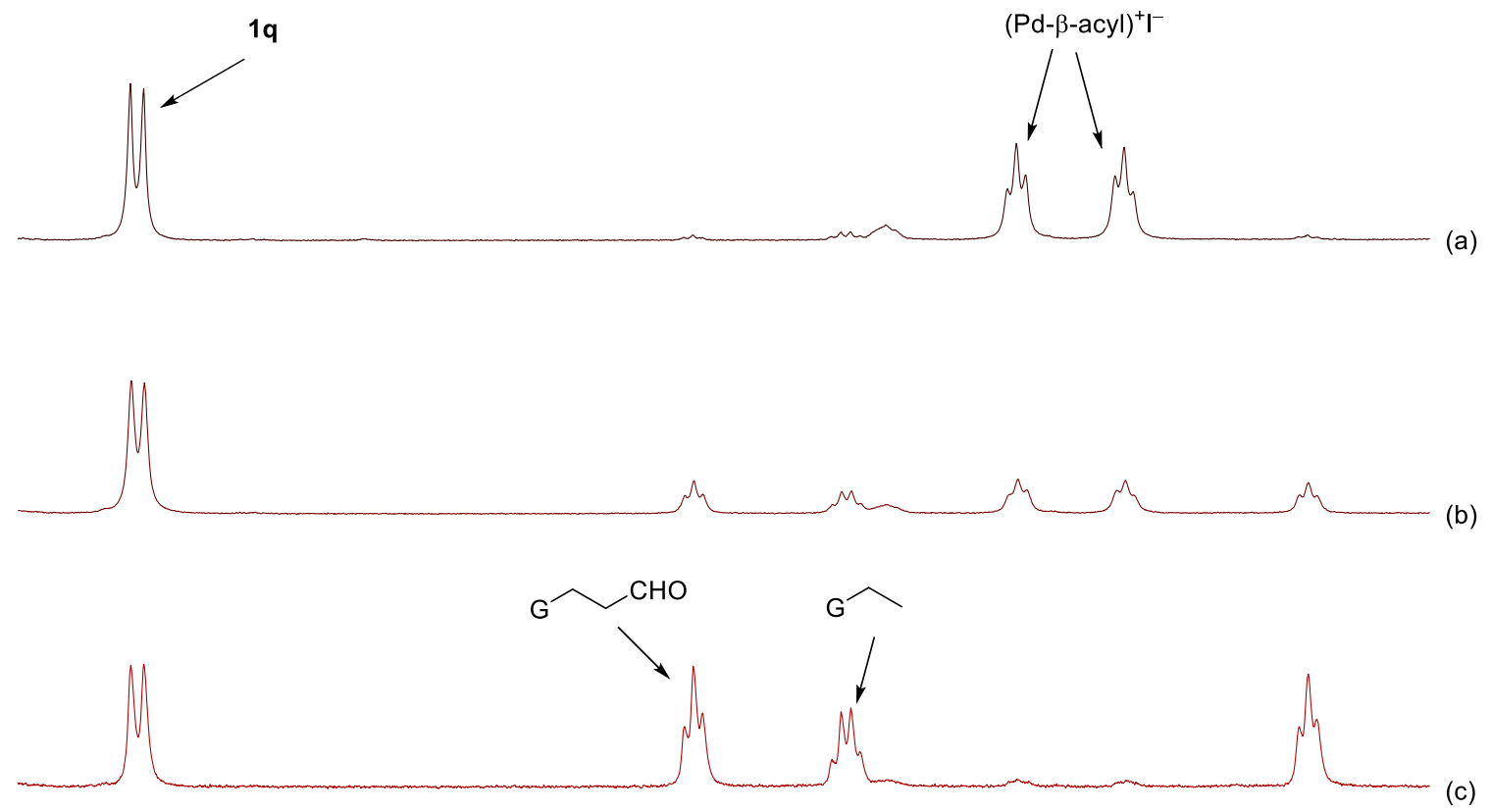

$\begin{array}{llllllllllllllllllllllllll}5.2 & 5.1 & 5.0 & 4.9 & 4.8 & 4.7 & 4.6 & 4.5 & 4.4 & 4.3 & 4.2 & 4.1 & 4.0 & 3.9 & 3.8 & 3.7 & 3.6 & 3.5 & 3.4 & 3.3 & 3.2 & 3.1 & 3.0 & 2.9 & 2.8 & 2.7\end{array}$ f1 (ppm)

Fig. $\mathbf{S 7 9}{ }^{1} H$ NMR spectra for the reaction of $\left[(x a n t p h o s)_{2}-P d_{2}(\mu-H)(\mu-C O)\right]^{+} T F A^{-}$and alkene $\mathbf{1 q}$ in the presence of 1 equiv. of $\mathrm{PPh}_{4} \mathrm{I}$ in $\mathrm{CD}_{2} \mathrm{Cl}_{2}$. 
iii. In the presence of iodide (2 equiv. of $\mathrm{PPh}_{4}{ }^{+} \mathrm{I}^{-}$per Pd-dimer; 1 equiv. per Pd-center)

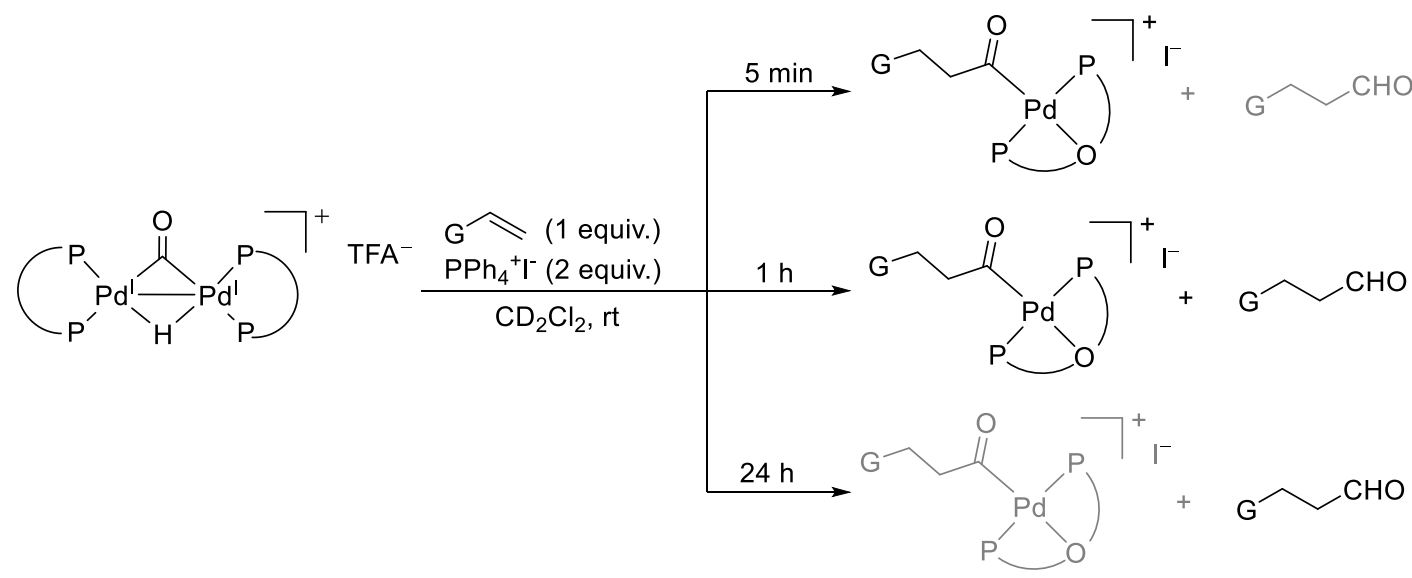

${ }^{1} \mathrm{H}$ NMR $\left(400 \mathrm{MHz}, \mathrm{CD}_{2} \mathrm{Cl}_{2}\right)$
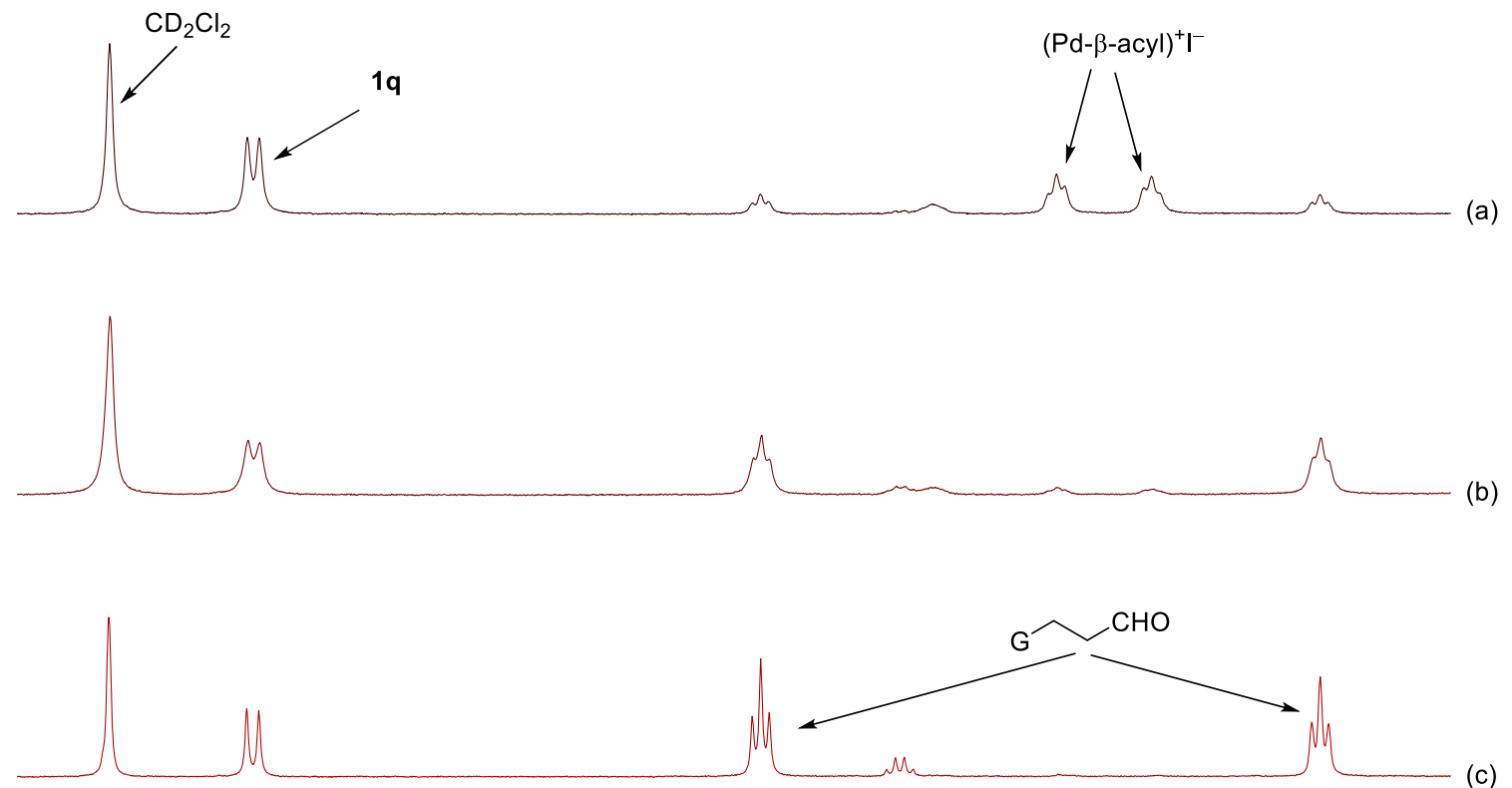

$\begin{array}{lllllllllllllllllllllllllllllllllllllllllll}5.5 & 5.4 & 5.3 & 5.2 & 5.1 & 5.0 & 4.9 & 4.8 & 4.7 & 4.6 & 4.5 & 4.4 & 4.3 & 4.2 & 4.1 & 4.0 & 3.9 & 3.8 & 3.7 & 3.6 & 3.5 & 3.4 & 3.3 & 3.2 & 3.1 & 3.0 & 2.9 & 2.8 & 2.7\end{array}$

Fig. $\mathbf{S 8 0}{ }^{1} \mathrm{H} N M R$ spectra for the reaction of $\left[(x a n t p h o s)_{2}-P d_{2}(\mu-H)(\mu-C O)\right]^{+} T_{F A}^{-}$and alkene $\mathbf{1 q}$ in the presence of 2 equiv. of $\mathrm{PPh}_{4} \mathrm{I}$ in $\mathrm{CD}_{2} \mathrm{Cl}_{2}$. 
2) Reactivity of the independently synthesized $[\text { xantphos-Pd- } \beta \text {-acyl }]^{+} \mathrm{BF}_{4}^{-}$- evaluation of different pathways to form the aldehyde product (experiments with $0.025 \mathrm{mmol}$ complex in $0.50 \mathrm{~mL} \mathrm{CD}_{2} \underline{\mathrm{Cl}}_{2}$ )

i. $\quad$ Reactions under syngas in absence or in the presence of iodide $\left(\mathrm{Bu}_{4}^{+} \mathrm{I}^{-}, 1\right.$ equiv.)

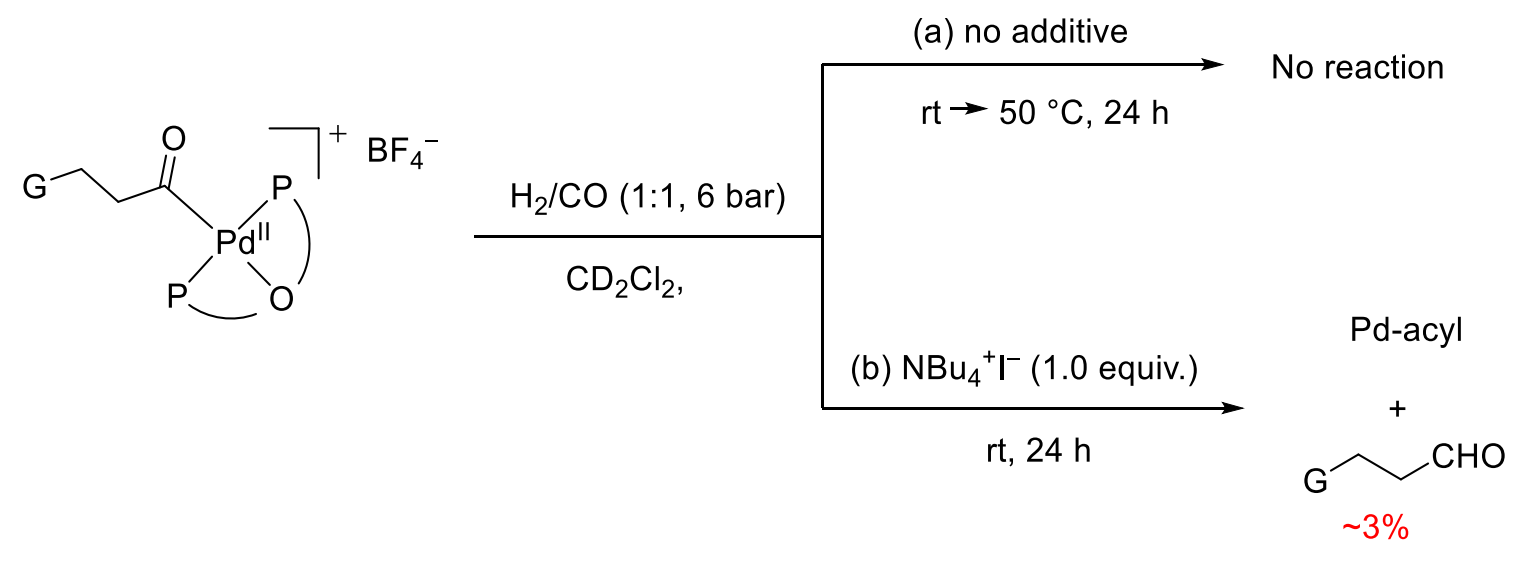

${ }^{1} \mathrm{H}$ NMR $\left(400 \mathrm{MHz}, \mathrm{CD}_{2} \mathrm{Cl}_{2}\right)$
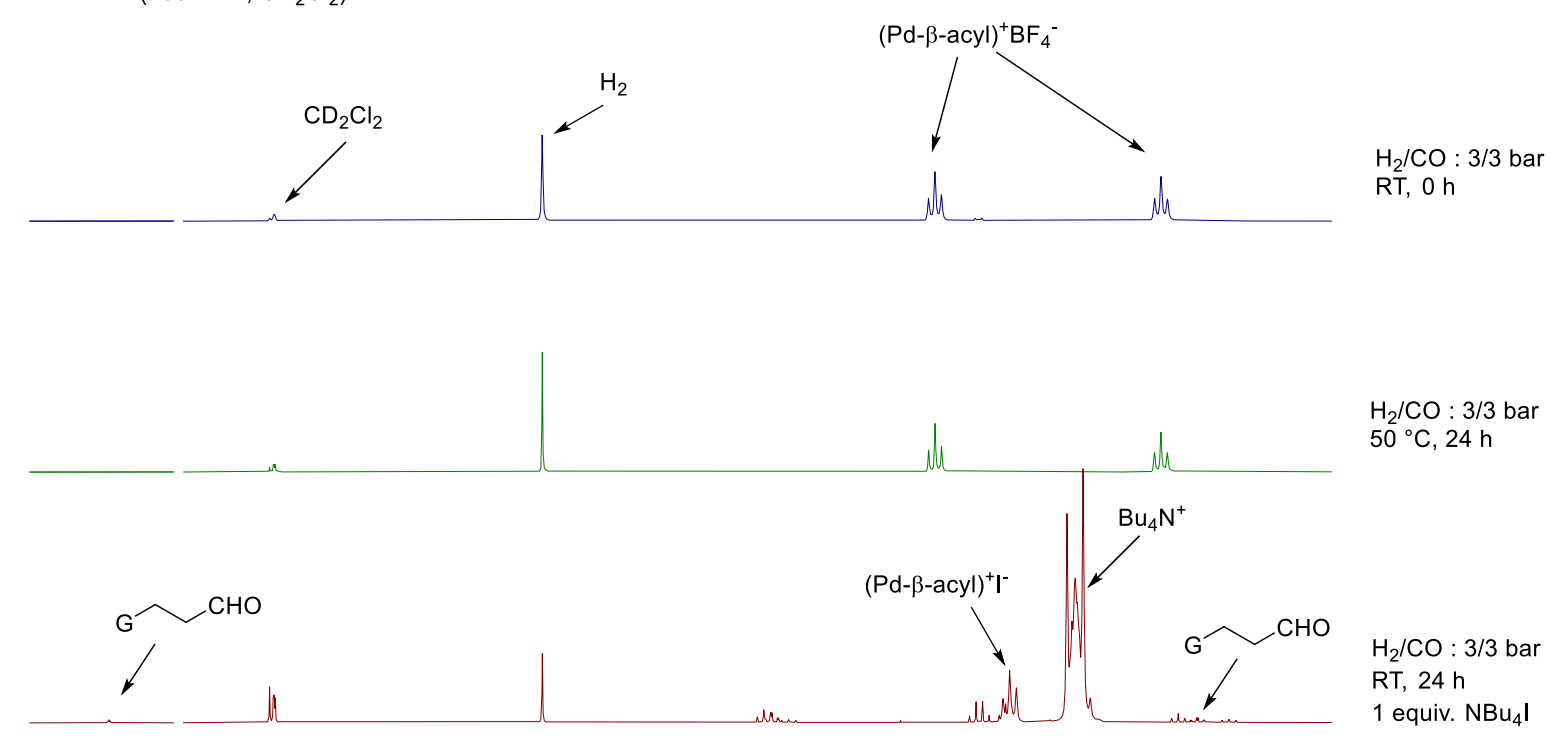

$\begin{array}{llllllllllllllllllllllllllllllllllll}9.9 & 9.8 & 9.7 & 5.5 & 5.4 & 5.3 & 5.2 & 5.1 & 5.0 & 4.9 & 4.8 & 4.7 & 4.6 & 4.5 & 4.4 & 4.3 & 4.2 & 4.1 & 4.0 & 3.9 & 3.8 & 3.7 & 3.6 & 3.5 & 3.4 & 3.3 & 3.2 & 3.1 & 3.0 & 2.9 & 2.8 & 2.7 & 1.6 & 2 .\end{array}$

Fig. $\mathbf{S 8 1}{ }^{1} \mathrm{H} N M R$ spectra for the reactions of [xantphos-Pd- $\beta$-acyl $]^{+} \mathrm{BF}_{4}^{-}$and syngas (6 bar) in the presence or absence of iodide (1 equiv. $\mathrm{NBu} 4$ ) in $\mathrm{CD}_{2} \mathrm{Cl}_{2}$. 
ii. Reactions with Brønsted acids TsOH or HI (generated in-situ) and in the presence of iodide $\left(\mathrm{PPh}_{4}{ }^{+} \mathrm{I}^{-}, 1\right.$ equiv. $)$

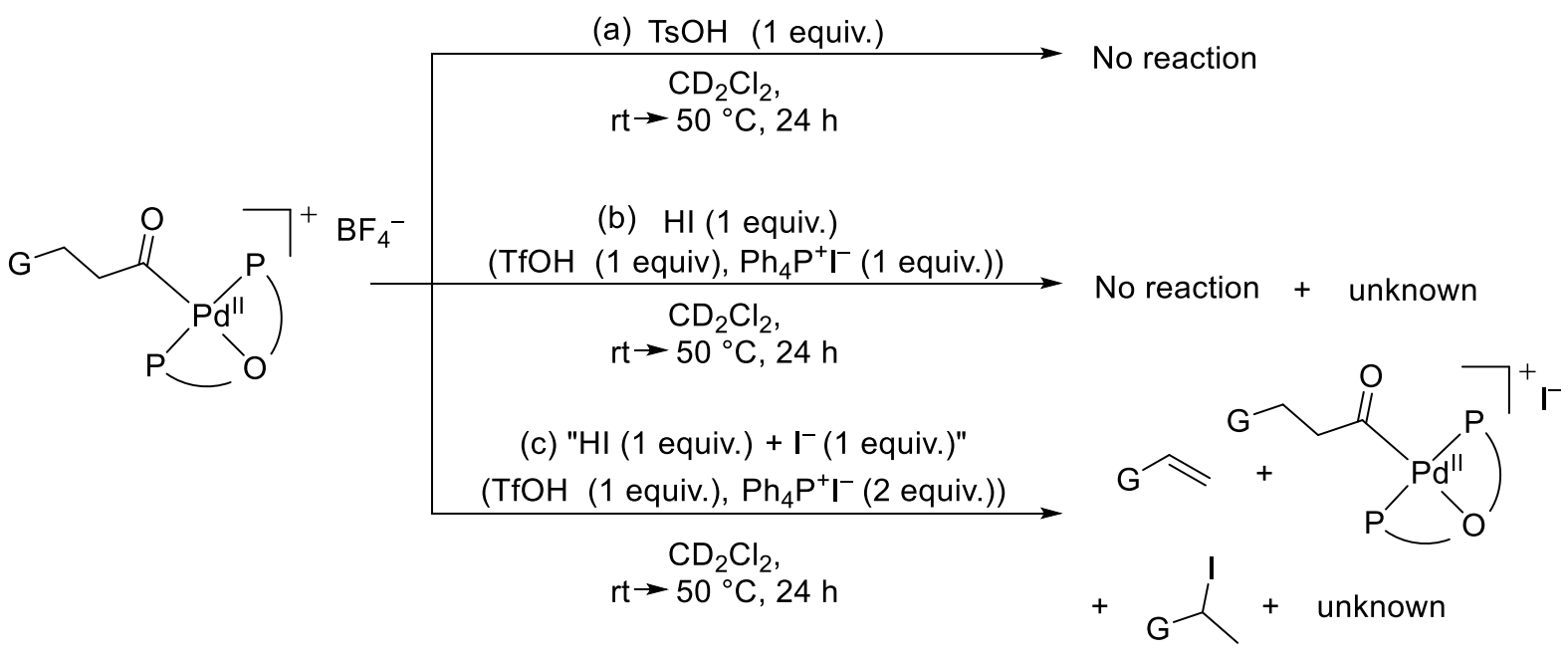

${ }^{1} \mathrm{H} \mathrm{NMR}\left(400 \mathrm{MHz}, \mathrm{CD}_{2} \mathrm{Cl}_{2}\right)$
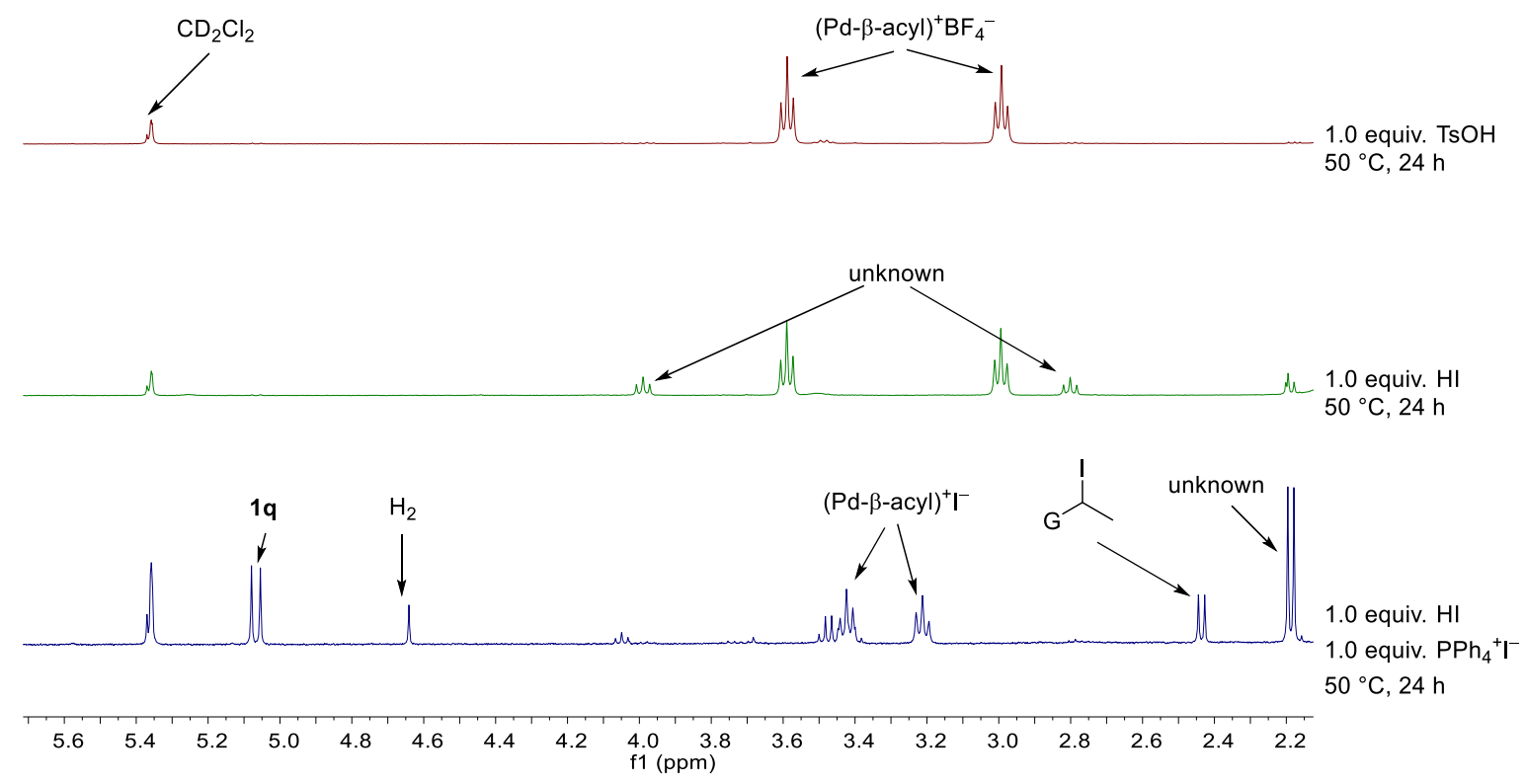

Fig. S82 ${ }^{1} \mathrm{H}$ NMR spectra for the reactions of [xantphos-Pd- $\beta$-acyl $]^{+} \mathrm{BF}_{4}^{-}$and Brønsted acids in the presence or absence of iodide (1 equiv. PPh $\mathrm{I}_{4}$ ) in $\mathrm{CD}_{2} \mathrm{Cl}_{2}$. 
iii. Reactions with $\left[(\text { xantphos })_{2}-\mathrm{Pd}_{2}(\mu-\mathrm{H})(\mu-\mathrm{CO})\right]^{+} \mathrm{TFA}^{-}$complex $(0.025 \mathrm{mmol})$ in absence and in the presence of iodide $\left(\mathrm{PPh}_{4}{ }^{+} \mathrm{I}^{-}, 2\right.$ equiv. $)$

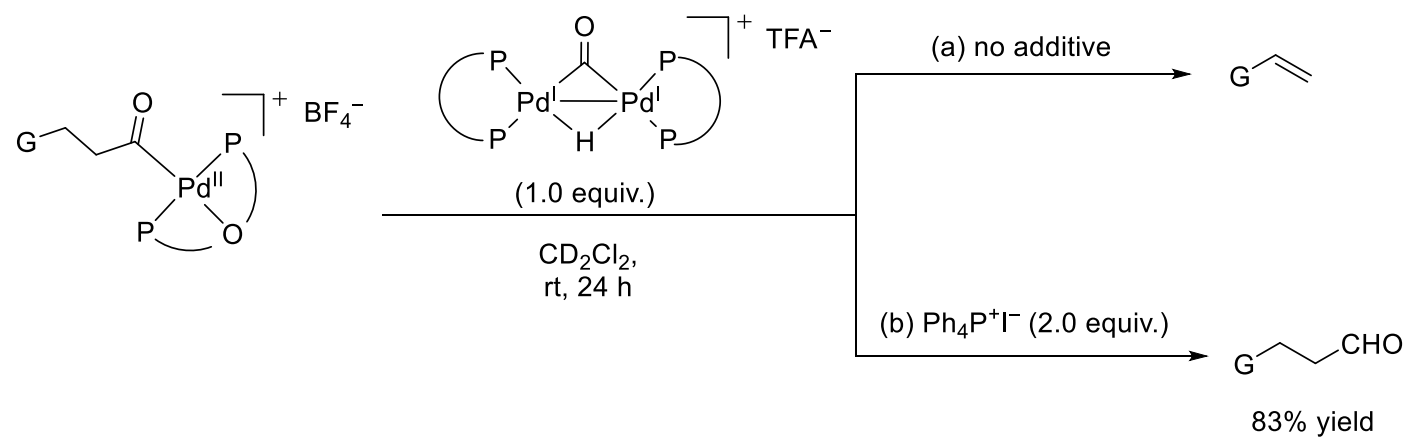

${ }^{1} \mathrm{H}$ NMR $\left(400 \mathrm{MHz}, \mathrm{CD}_{2} \mathrm{Cl}_{2}\right)$

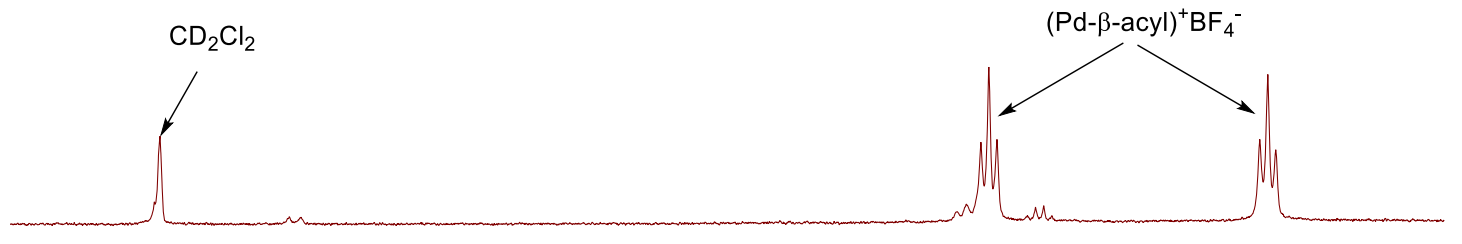

$1 \mathrm{q}$
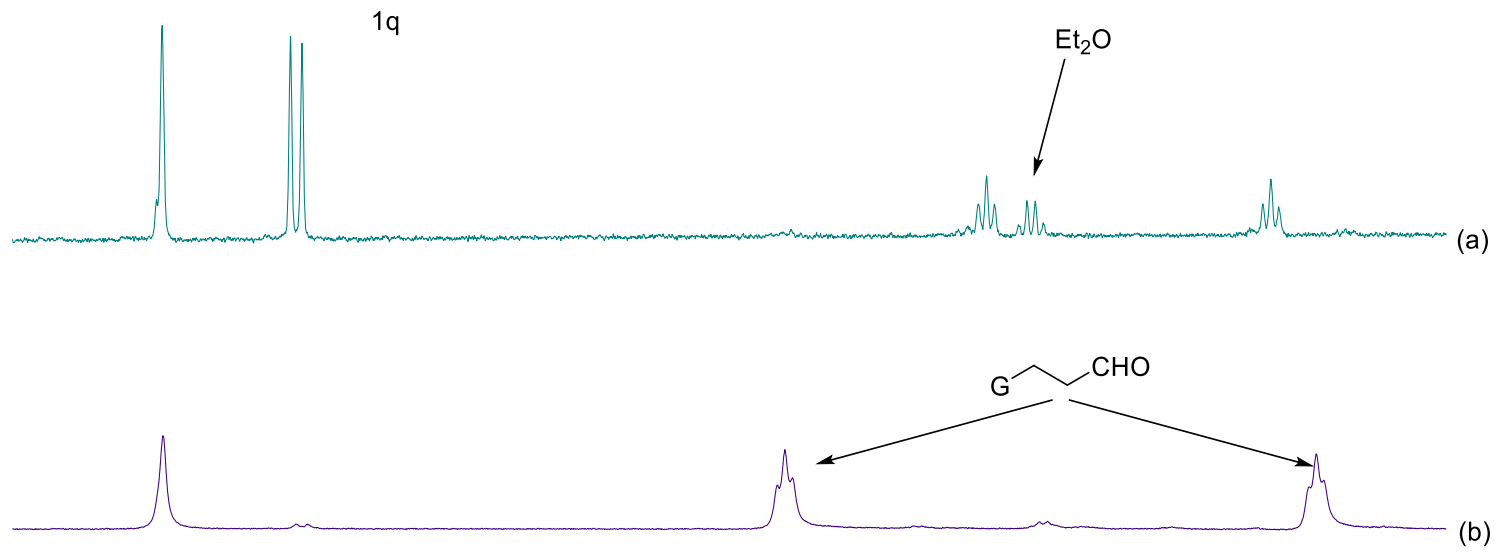

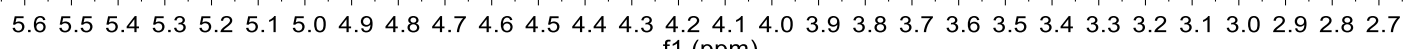
f1 (ppm)

Fig. S83 ${ }^{l} H$ NMR spectra for the reactions of [xantphos $-P d$ - $\beta$-acyl $]^{+} B F_{4}{ }^{-}$and $\left[(\text {xantphos })_{2}-P d_{2}(\mu-H)(\mu\right.$ $\mathrm{CO})]^{+} \mathrm{TFA}^{-}(\mathrm{a})$ in absence or (b) in the presence of iodide (2 equiv. $\mathrm{PPh} \mathrm{H}_{4}$ ) in $\mathrm{CD}_{2} \mathrm{Cl}_{2}$. 
3) Reactivity of the independently synthesized $[\text { (xantphos) } \mathrm{Pd}-\beta \text {-acyl }]^{+} \mathrm{BF}_{4}^{-}{ }^{-}$complex in the presence of an alkene analogue (1qB) - evaluation of reversibility of the $\mathrm{CO}$ and alkene insertion steps in the presence of $\mathrm{PPh}_{4} \underline{I}^{+}$

The sample was prepared by the following procedure. In a nitrogen-filled glovebox, a J Young tube was charged with [(xantphos) $\mathrm{Pd}-\beta$-acyl $]^{+} \mathrm{BF}_{4}{ }^{-}$complex $(0.025 \mathrm{mmol})$, alkene $\mathbf{1 q} \mathbf{B}(0.025 \mathrm{mmol})$, and $500 \mu \mathrm{L}$ of $\mathrm{CD}_{2} \mathrm{Cl}_{2}$. The NMR tube was sealed, shaken, and NMR spectrum (a) was recorded after 10 min. Then, a solution of $\mathrm{PPh}_{4} \mathrm{I}(0.05 \mathrm{mmol})$ in $\mathrm{CD}_{2} \mathrm{Cl}_{2}(100 \mu \mathrm{L})$ was added. The NMR tube was sealed, shaken, and NMR spectrum (b) was recorded after $10 \mathrm{~min}$.

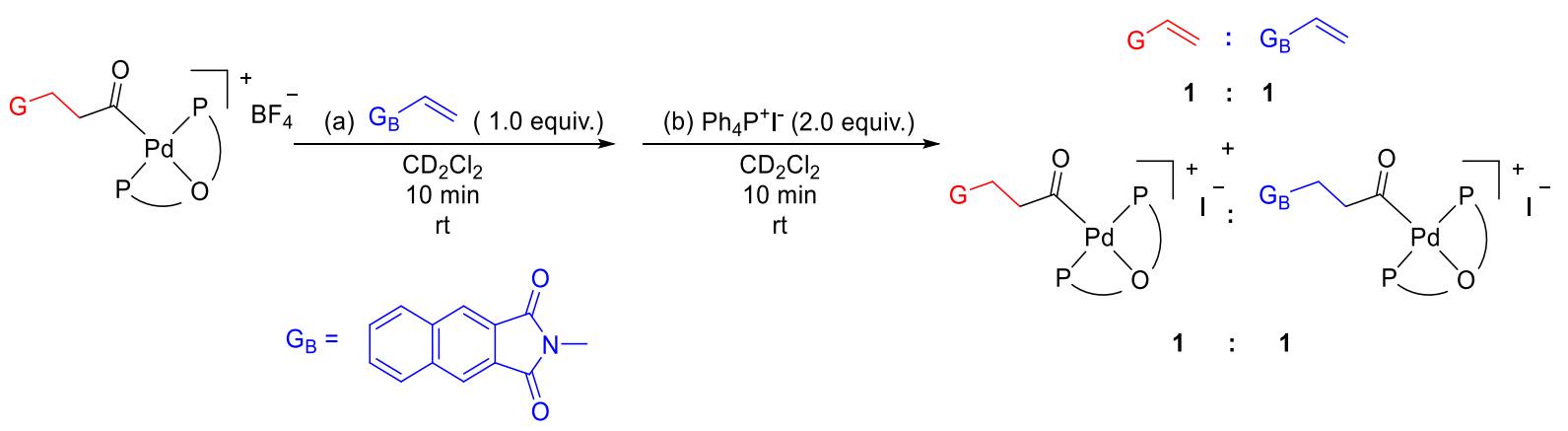




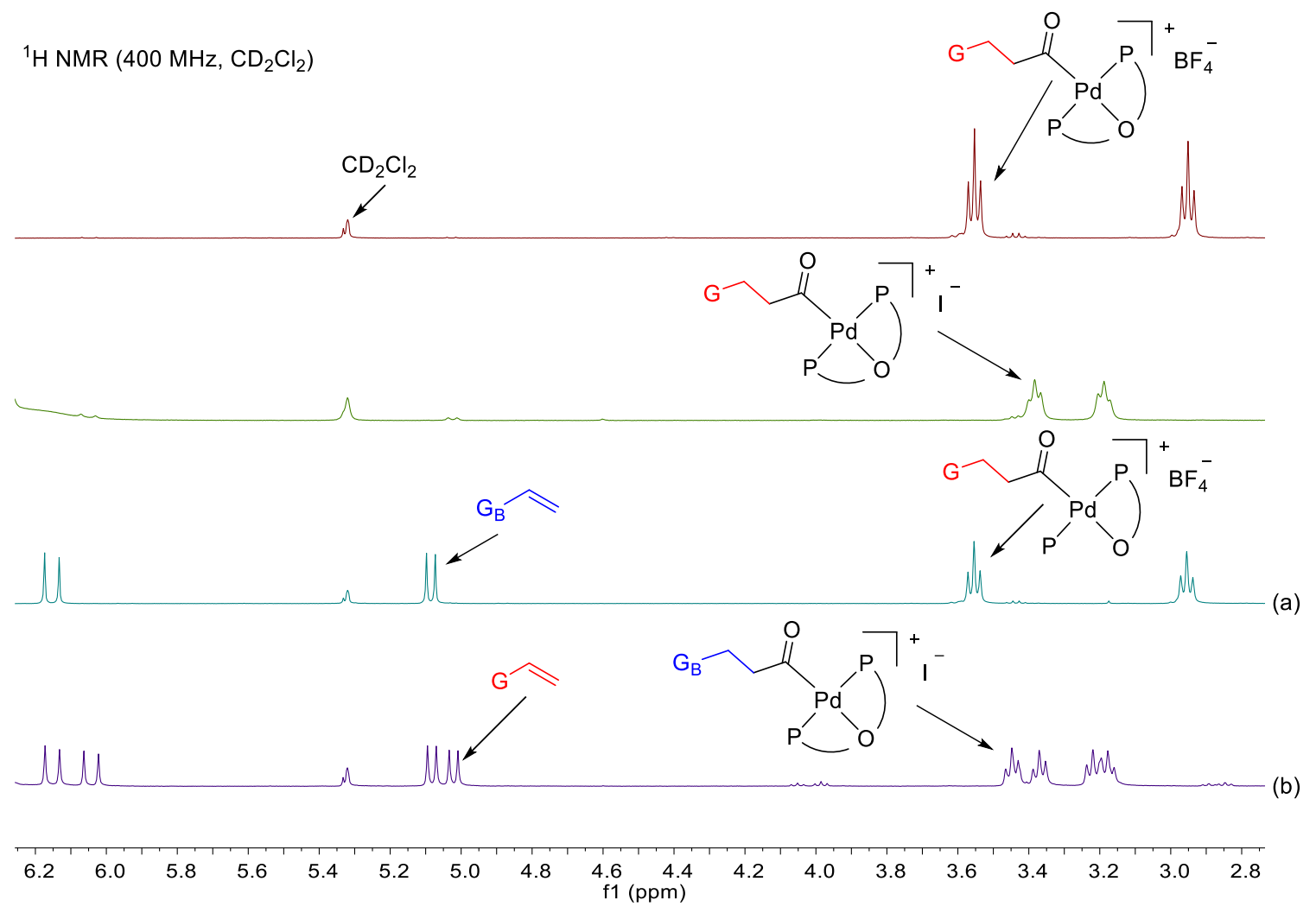

Fig. $\mathbf{S 8 4}{ }^{1} \mathrm{H}$ NMR spectra for the reactions of [xantphos $-P d$ - $\beta$-acyl ${ }^{+} \mathrm{BF}_{4}{ }^{-}$and alkene $\mathbf{I q}_{\boldsymbol{B}}(\mathrm{a})$ in absence or (b) in the presence of iodide (2 equiv. PPh ${ }_{4}$ ) in $\mathrm{CD}_{2} \mathrm{Cl}_{2}$.

4) Reactivity of the independently synthesized [xantphos-Pd- $\alpha$-acyl] $]^{+} \mathrm{BF}_{4}^{-}$complex with $\left[(\text { xantphos })_{2}-\mathrm{Pd}_{2}(\mu-\mathrm{H})(\mu-\mathrm{CO})\right]^{+} \mathrm{TFA}^{-}$complex in the presence of iodide - evaluation of a potential pathway to form the $\alpha$-aldehyde product (experiments with $0.025 \mathrm{mmol} \mathrm{Pd}$-complexes and 2 equiv. of $\mathrm{PPh}_{4} \underline{I}^{+}$(source of an iodide), in $0.50 \mathrm{~mL} \mathrm{CD} 2 \underline{\mathrm{Cl}}_{2}$ )

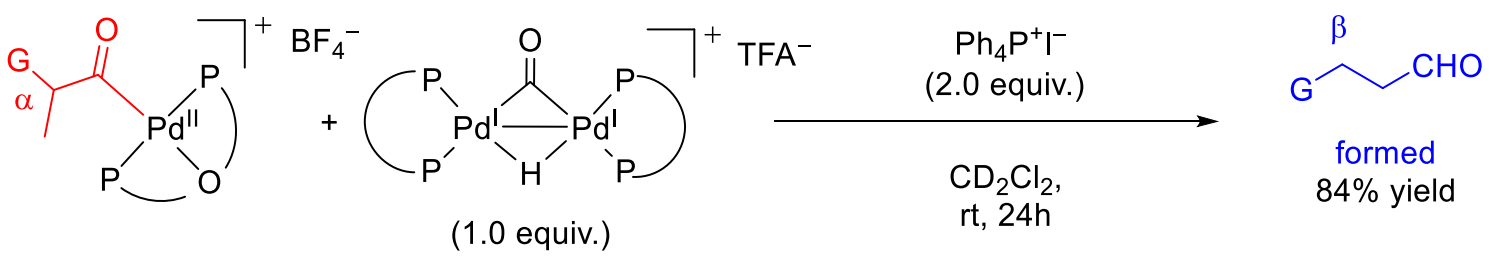

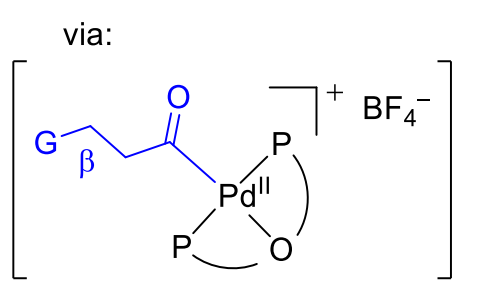

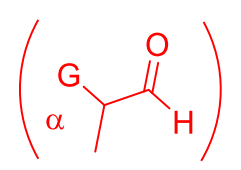

not observed 

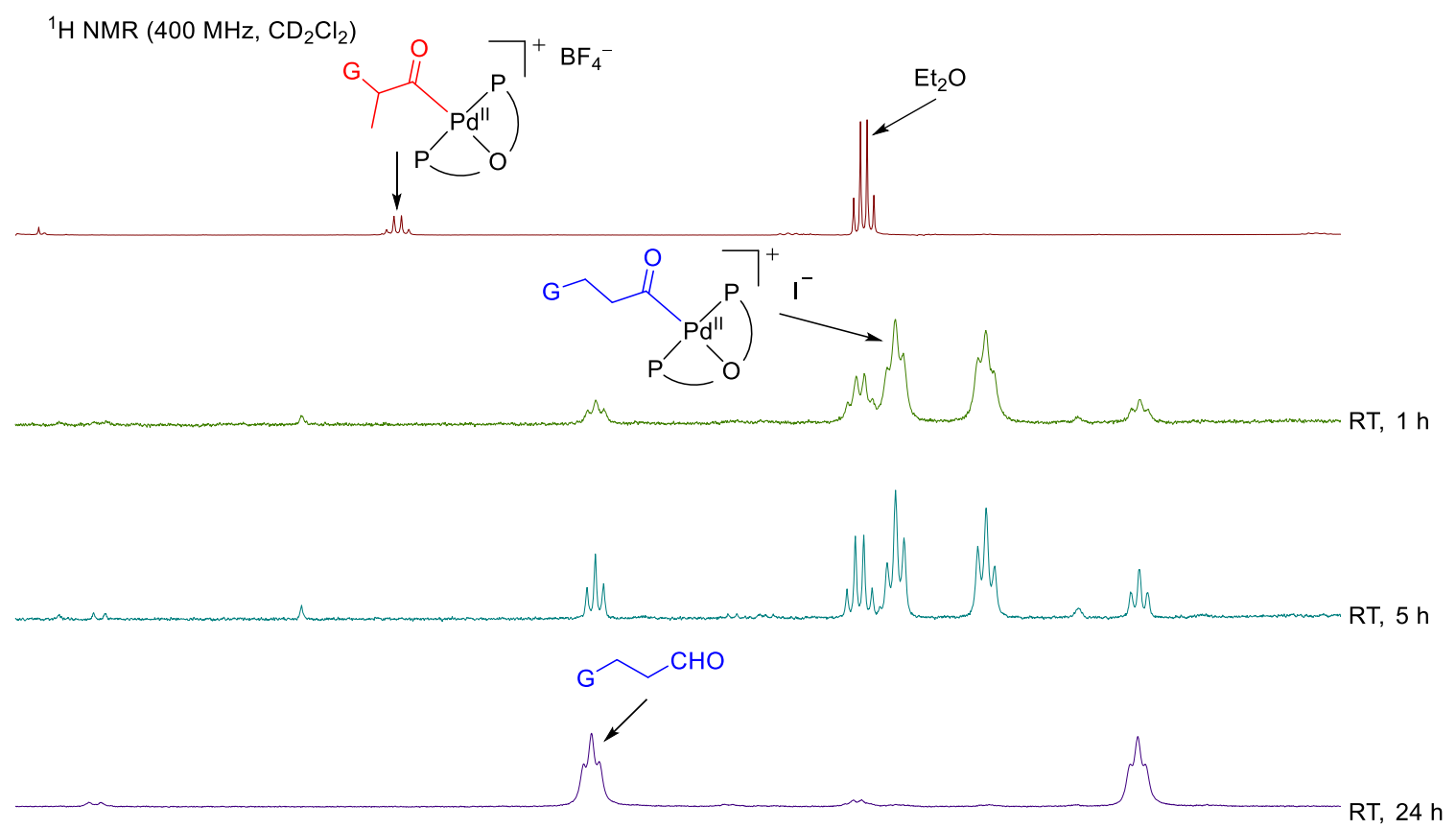

$\begin{array}{lllllllllllllllllllllllllllllllllllllllll}5.2 & 5.1 & 5.0 & 4.9 & 4.8 & 4.7 & 4.6 & 4.5 & 4.4 & 4.3 & 4.2 & 4.1 & 4.0 & 3.9 & 3.8 & 3.7 & 3.6 & 3.5 & 3.4 & 3.3 & 3.2 & 3.1 & 3.0 & 2.9 & 2.8 & 2.7 & 2.6 & 2.5\end{array}$

f1 (ppm)

Fig. $S 85{ }^{l} H$ NMR spectra for the reaction of [xantphos $-P d$-a-acyl $]^{+} B F_{4}^{-}$and $\left[(\text {xantphos })_{2}-P d_{2}(\mu-H)(\mu-\right.$ $\mathrm{CO})]^{+} \mathrm{TFA}$ in the presence of iodide (2 equiv. PPh $\mathrm{I}$ ) over time in $\mathrm{CD}_{2} \mathrm{Cl}_{2}$. 
5) Evaluation of the catalytic activity of $\left[(\mathrm{xantphos})_{2}-\mathrm{Pd}_{2}{ }_{2}\right]\left(\mathrm{BF}_{4}\right)_{2} \underline{\text { with }}$ an alkene $(\mathbf{1 q})$ under syngas

The experiments were conducted following the above described procedures for the in-situ NMR studies of xantphos-Pd(II) complexes under syngas.

i. In absence of iodide: the $\left[(\text { xantphos })_{2}-\mathrm{Pd}_{2}(\mu-\mathrm{H})(\mu-\mathrm{CO})\right]^{+}$and $\mathrm{Pd}-$ acyl complexes were formed, similar to the experiments of $\left[\mathrm{xantphos}-\mathrm{Pd}^{\mathrm{II}}\right]\left(\mathrm{BF}_{4}\right)_{2}$ and $\mathbf{1 q}$ under syngas; no aldehyde formed was upon prolonged treatment.
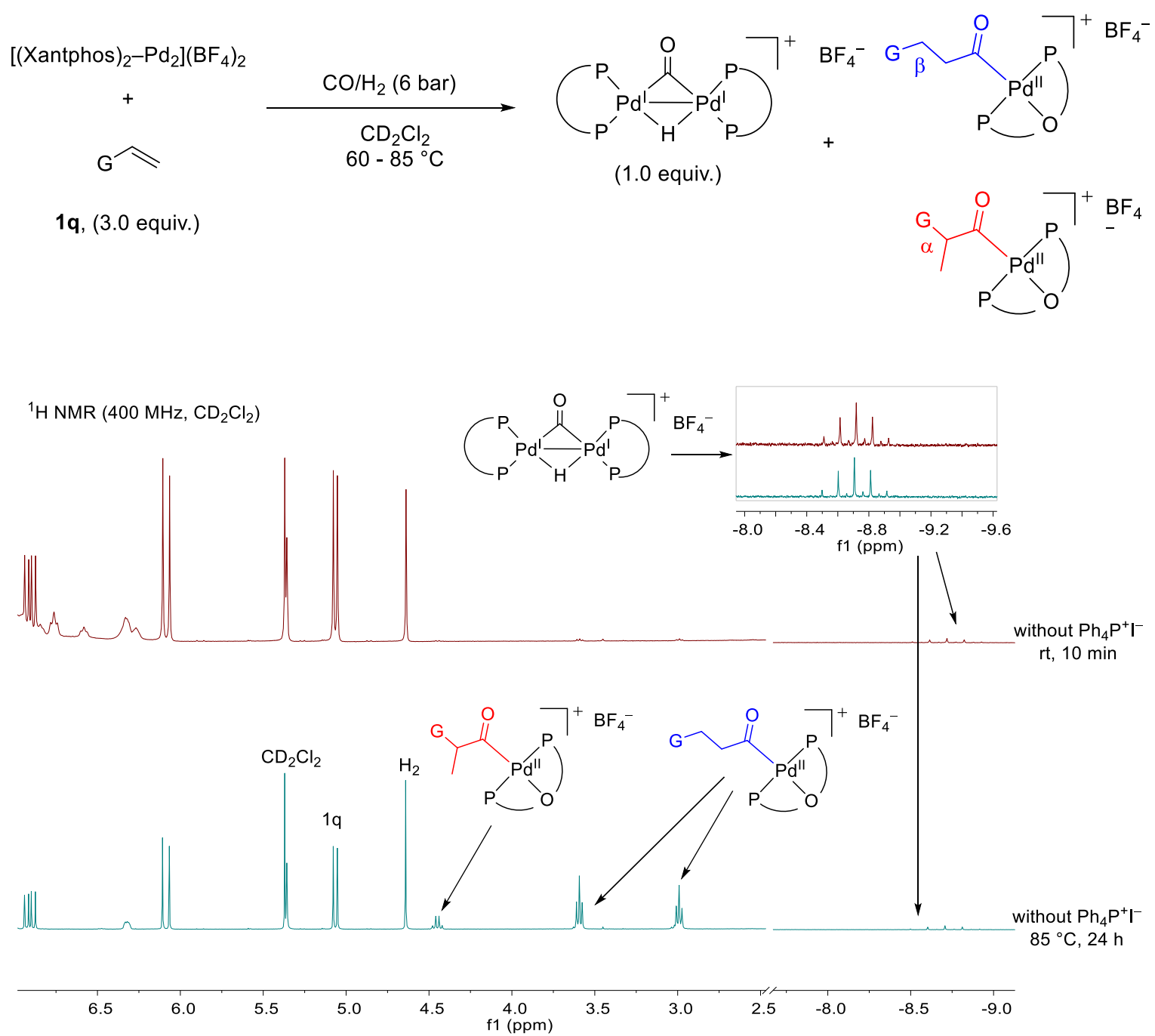

Fig. $\mathbf{S 8 6}{ }^{1} \mathrm{H} N M R$ spectra for the reaction of $\left[(\text { xantphos })_{2}-\mathrm{Pd}_{2}\right]\left(\mathrm{BF}_{4}\right)_{2}$, alkene $\mathbf{1 q}$ and syngas $\left(6\right.$ bar) in $\mathrm{CD}_{2} \mathrm{Cl}_{2}$. 
ii. In the presence of iodide (4.0 equiv. of $\mathrm{PPh}_{4}{ }^{+} \mathrm{I}^{-}$) - the Pd- $\beta$-acyl complex was formed, as described earlier for the experiments of xantphos-Pd(II) $\mathrm{I}_{2}$ and 1q under syngas; upon prolonged treatment the $\beta$-aldehyde was formed (nearly quantitatively).

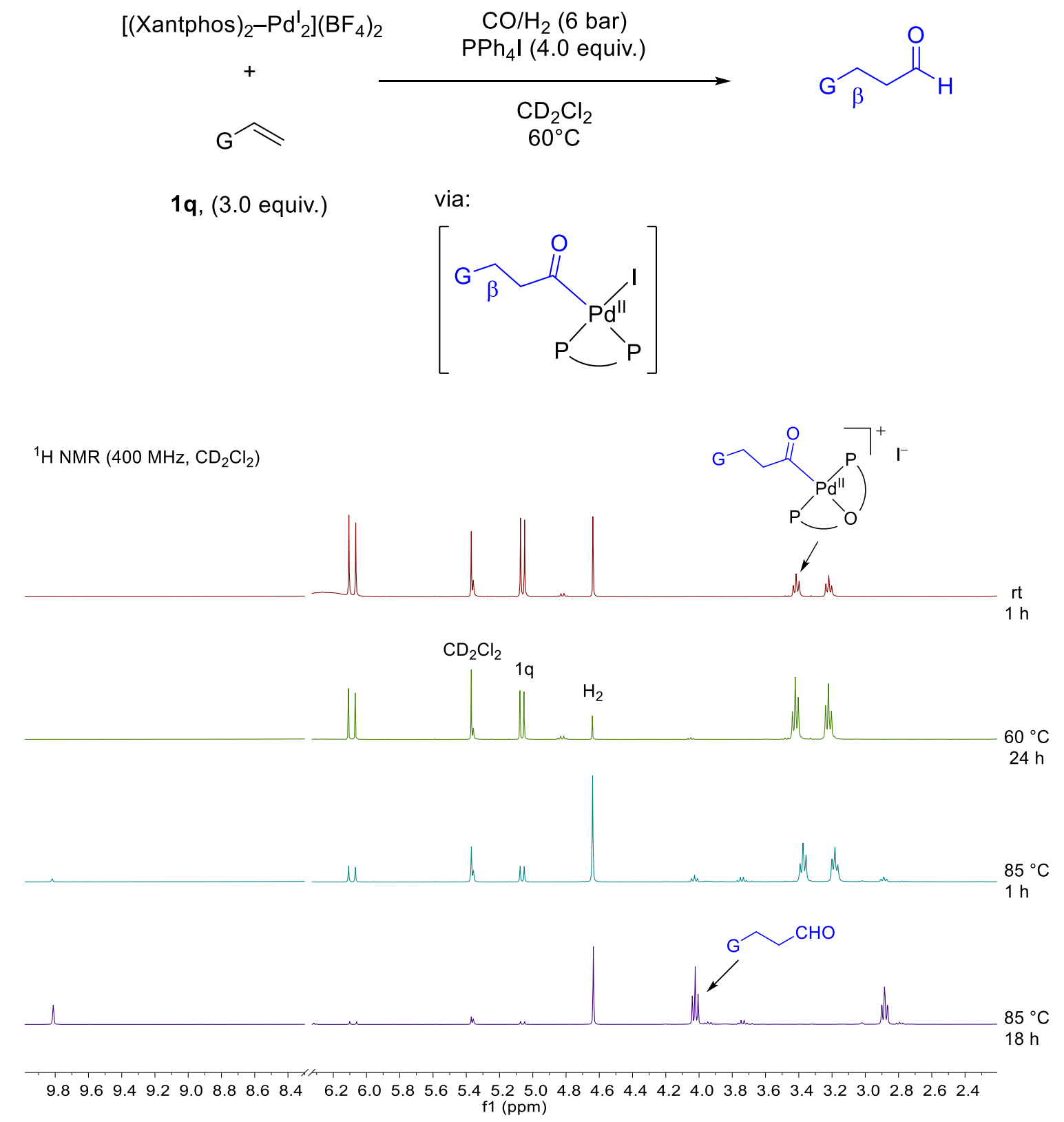

Fig. $\mathbf{S 8 7}{ }^{1} \mathrm{H}$ NMR spectra for the reaction of $\left[(\text { xantphos })_{2}-P d_{2}\right]\left(B F_{4}\right)_{2}$, alkene $\mathbf{1 q}$ and syngas (6 bar) in the presence of iodide (4 equiv. $\mathrm{PPh} \mathrm{H}_{4}$ ) in $\mathrm{CD}_{2} \mathrm{Cl}_{2}$. 
6) Evaluation of the catalytic activity of $\left[\right.$ xantphos- $\left.-\mathrm{Pd}_{2}{ }_{2}\right] \underline{I}_{2}$ with an alkene (1q) under syngas

The experiments were conducted following the above described procedures for the in-situ NMR studies of xantphos-Pd(II) complexes under syngas.

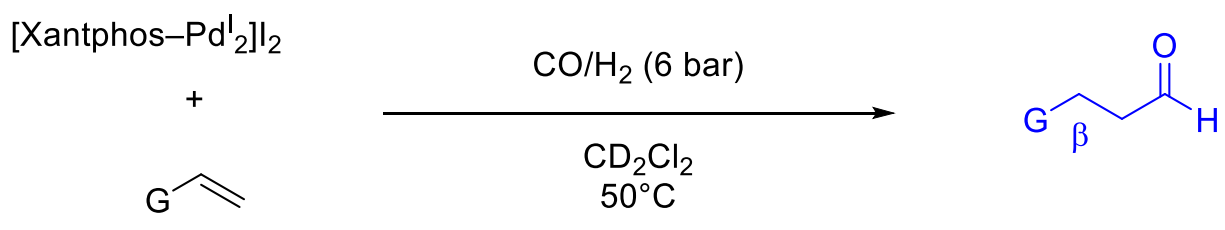

1q, (3.0 equiv.) via:
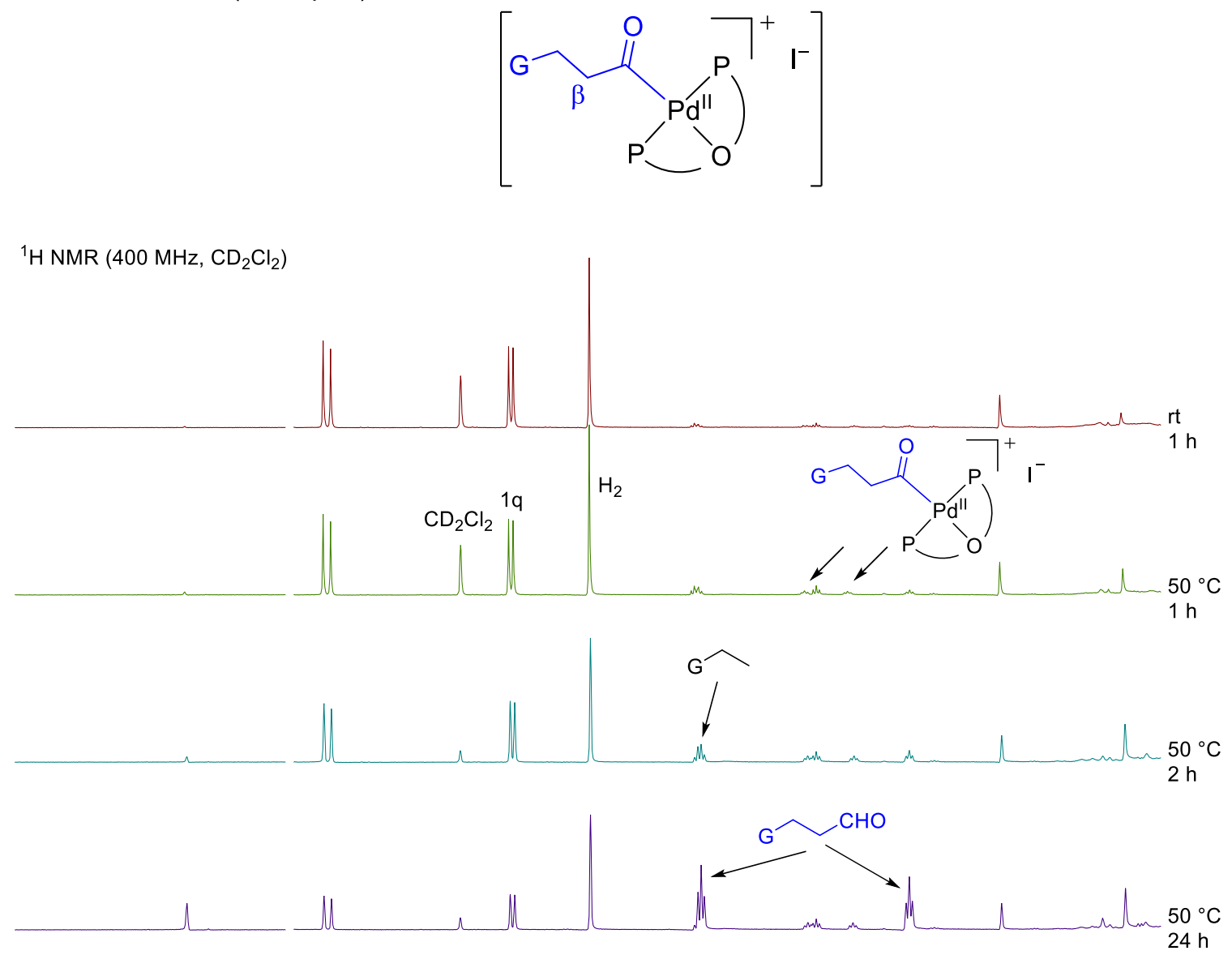

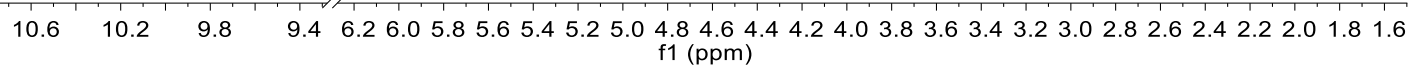

Fig. S88 ${ }^{1} \mathrm{H} N M R$ spectra for the reaction of [xantphos $\left.-\mathrm{Pd}_{2}\right] \mathrm{I}_{2}$, alkene $\mathbf{1 q}$ and syngas (6 bar) over time in $\mathrm{CD}_{2} \mathrm{Cl}_{2}$. 


\subsection{Analysis of reaction intermediates with high resolution mass spectrometry}

The samples for HRMS analysis was prepared by the following procedure: In a nitrogen-filled glovebox, a J. Young tube was charged with vinyl phthalimide (4.3 mg, $0.025 \mathrm{mmol}), \mathrm{PdI}_{2}(9.0 \mathrm{mg}, 0.025$ mmol), xantphos (14.4 mg, $0.025 \mathrm{mmol})$, and $500 \mu \mathrm{L}$ of $\mathrm{CD}_{2} \mathrm{Cl}_{2}$. The tube was then sealed and shaken. Then, the tube was pressurized with $10 \mathrm{bar} \mathrm{CO} / \mathrm{H}_{2}(1: 1)$ and the pressure was released, a process that was repeated 5 times. Finally, the tube was pressurized $\left(6\right.$ bar $\left.\mathrm{CO} / \mathrm{H}_{2}\right)$, sealed, shaken, and treated in a preheated aluminum block at $50{ }^{\circ} \mathrm{C}$. The reaction was followed over time by ${ }^{1} \mathrm{H}$ NMR spectroscopy. When approximately $50 \%$ of vinyl phthalimide (1q) was consumed, the sample was cooled, degassed at room temperature, and transferred into the glovebox. Considering the potential instabilities of the intermediates, the sample was freshly prepared before the HRMS analysis $(<1 \mathrm{~h})$, using degassed and anhydrous acetonitrile as a solvent. The analysis was performed at the analytical center of the University of Strasbourg on Bruker Instrument micrOTOF II (acquisition parameters: Source Type ESI; Capillary 4500 V Nebulizer 0.3 bar; Set Hexapole RF 330.0 Vpp; Ion Polarity Positive Dry Heater $200{ }^{\circ} \mathrm{C}$ Dry Gas 3.0 1/min Set Capillary Exit 150.0 V) 


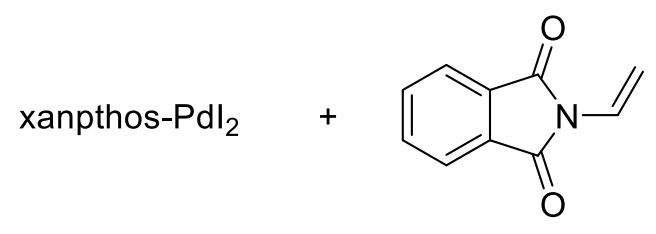

(1q)
1. $\mathrm{CO} / \mathrm{H}_{2}$ (6 bar),

$\mathrm{CD}_{2} \mathrm{Cl}_{2}$,

$50{ }^{\circ} \mathrm{C}, 6 \mathrm{~h}$

2. depressurized

3. ESI-TOF-HRMS analysis

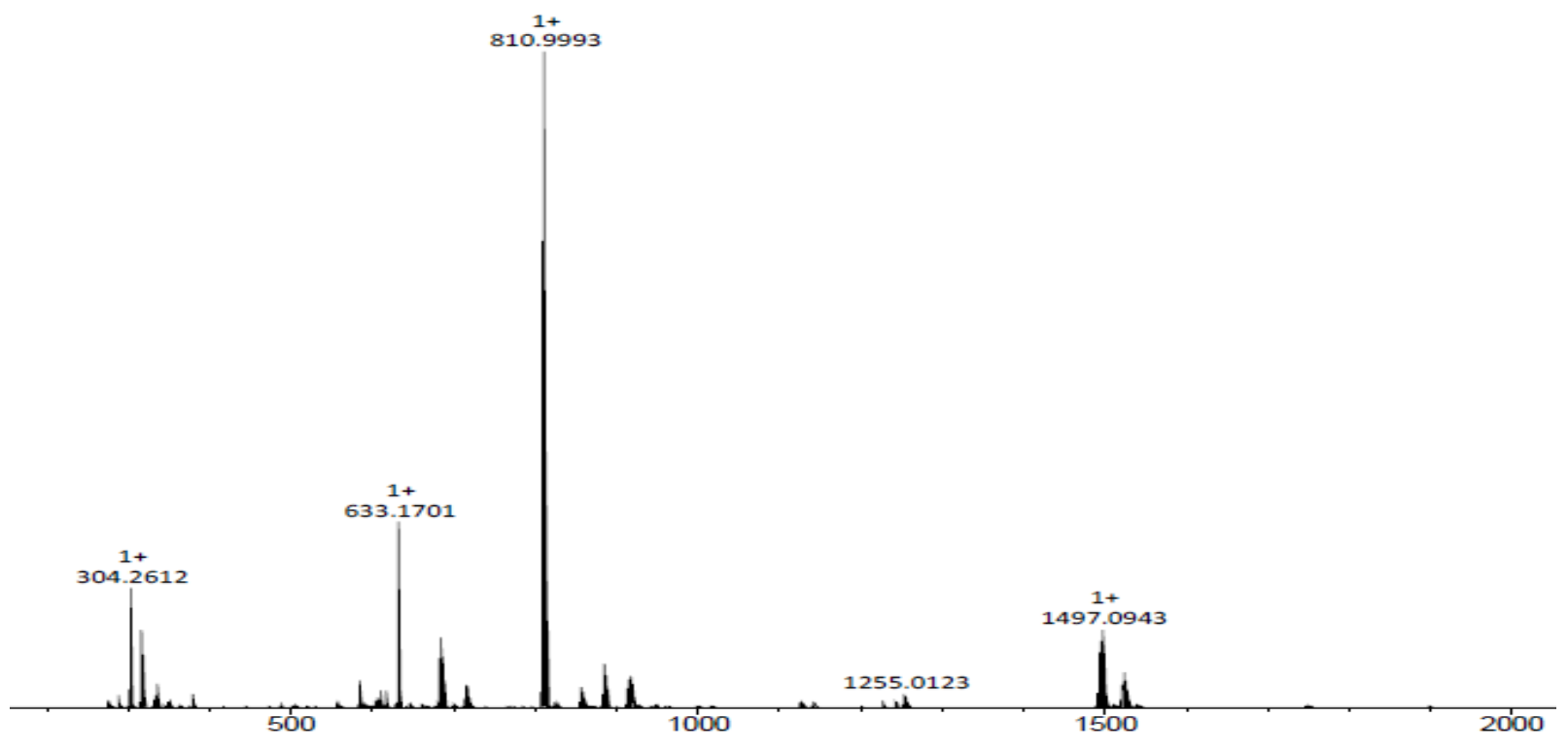

Fig. $\mathbf{S 8 9}$ HRMS spectrum (m/z range: 150-2000). 
The assignment of the HRMS data was confirmed by comparison with simulated signals of isotopomeric clusters of the molecular ions reported (see below):

a) Multiple reaction intermediates detected in the $660-1550 \mathrm{~m} / \mathrm{z}$ region of the spectrum.

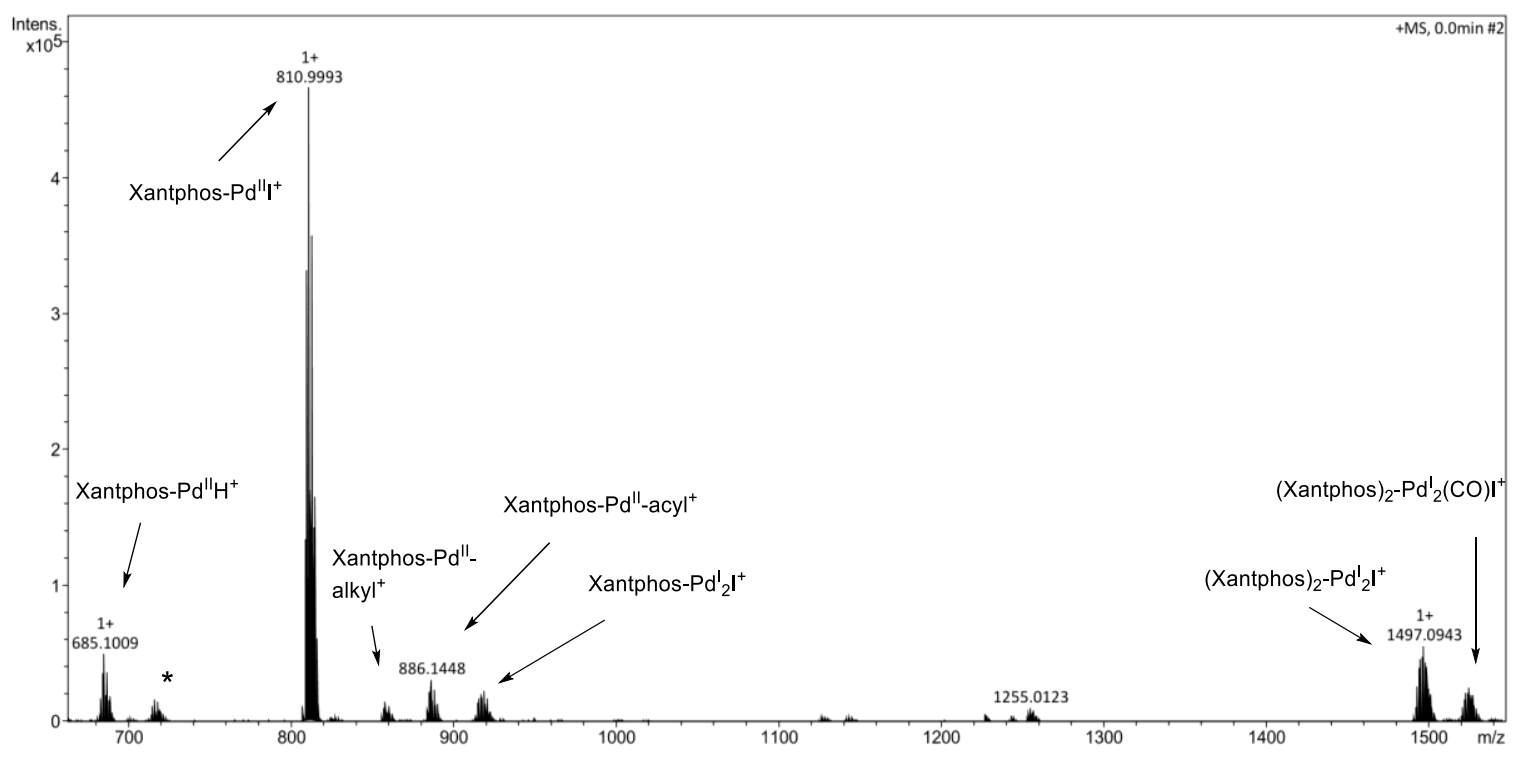

* The signal corresponding to the aduct of Xan-Pd" $\mathrm{H}^{+}$and dioxygen: Xantphos- $\mathrm{Pd}^{\prime \prime}\left(\mathrm{O}_{2}\right) \mathrm{H}^{+}$; for zoom, see below.

b) Found and simulated signals of isotopomeric cluster of the molecular ion [xantphos- $\left.\mathrm{PdH}^{+}\right]$

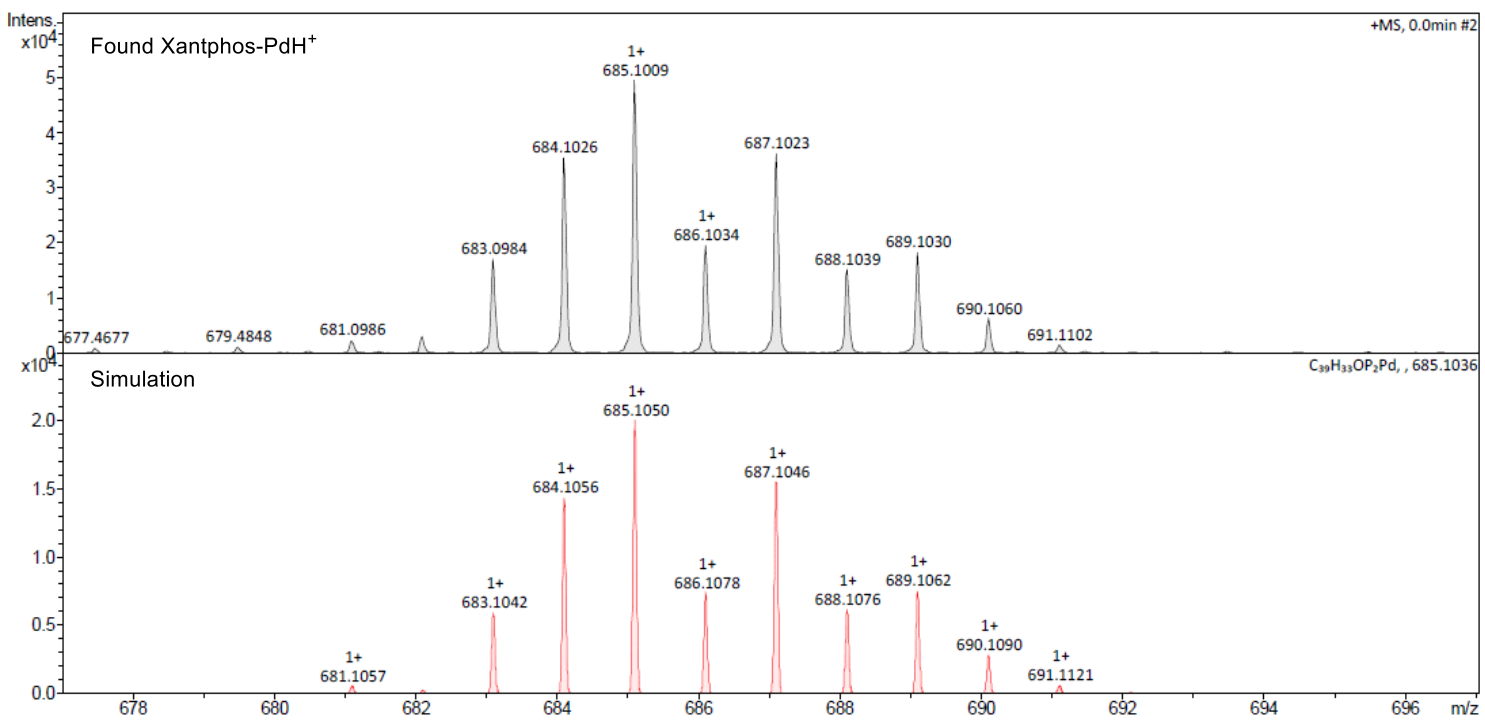


c) Found and simulated signals of isotopomeric cluster of the molecular ion [xantphos-PdI ${ }^{+}$]

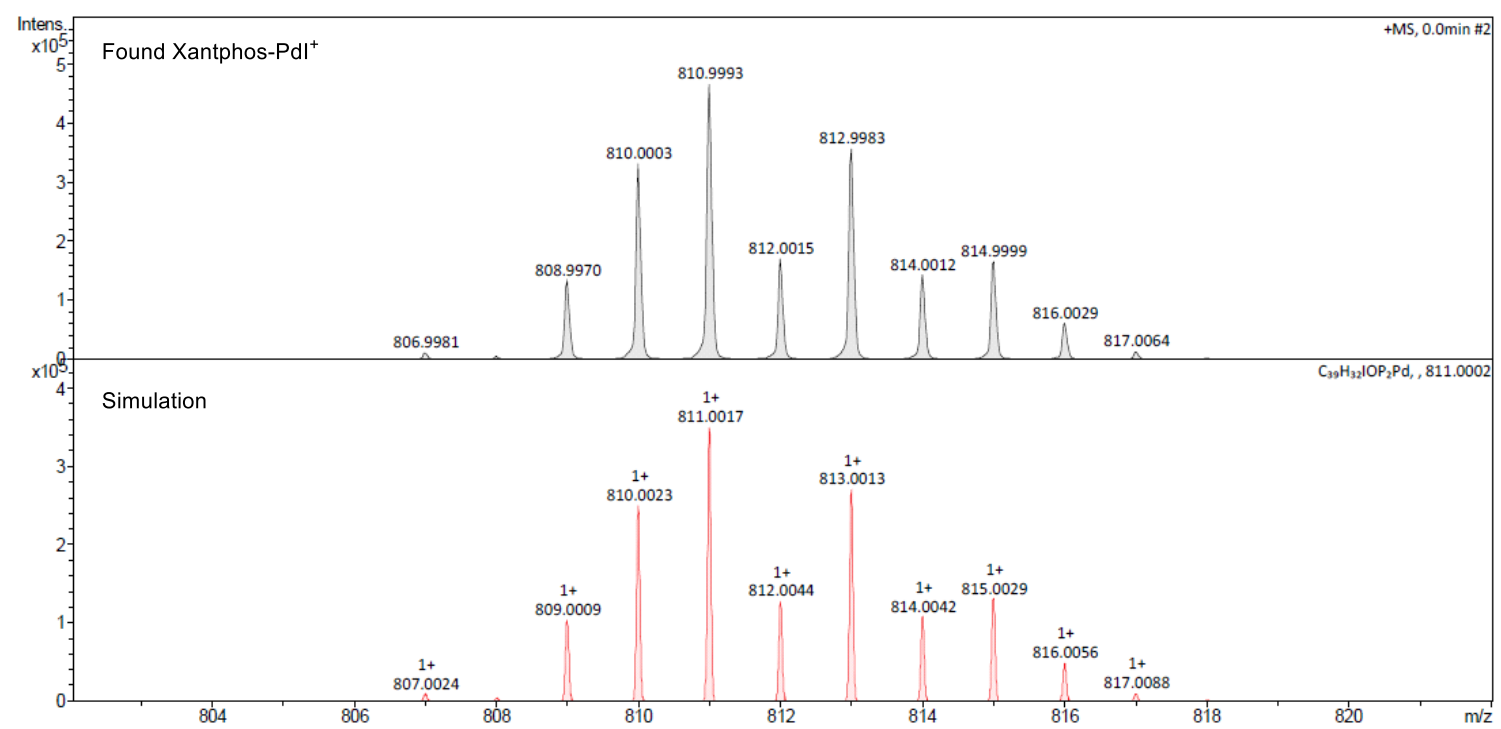

d) Found and simulated signals of isotopomeric cluster of the molecular ion [xantphos-Pd-alkyl $\left.{ }^{+}\right]$

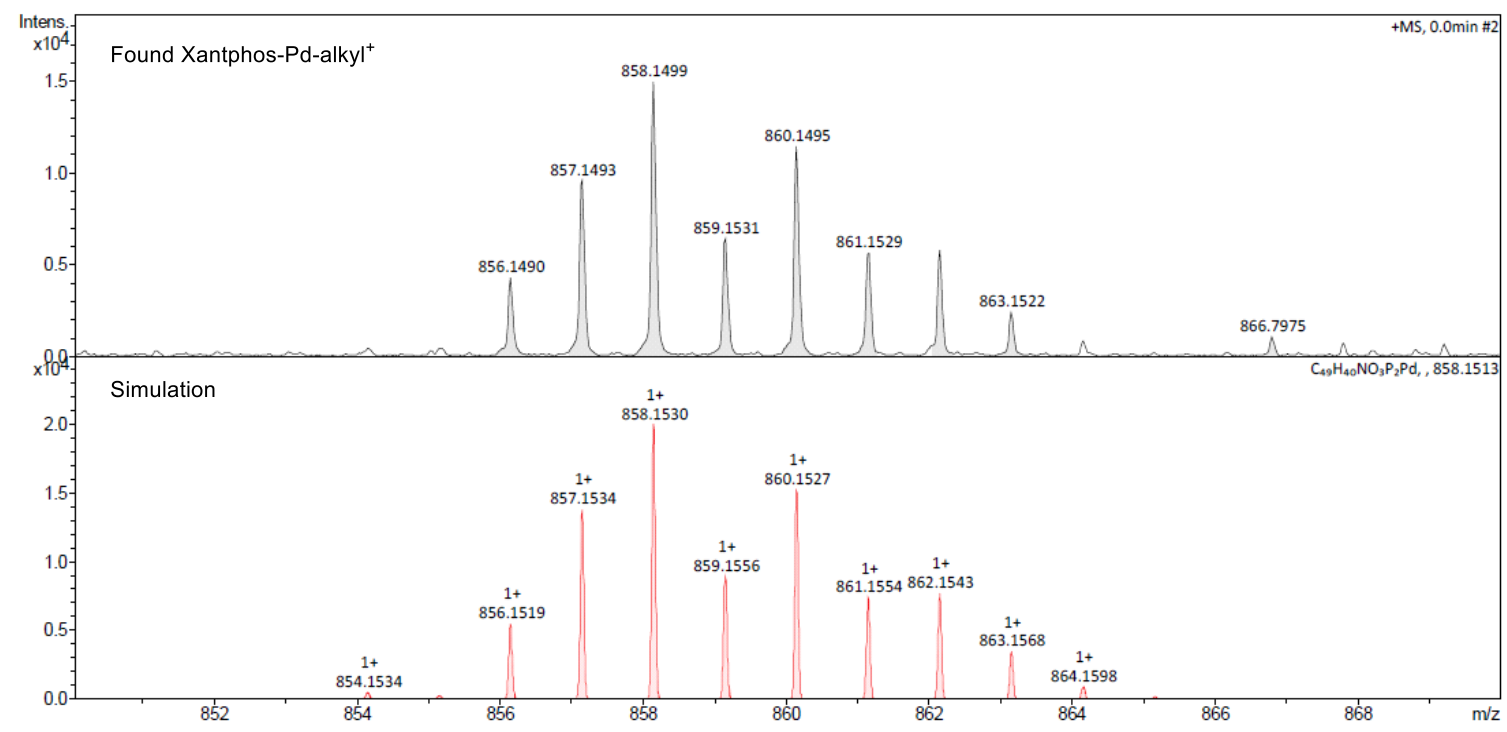


e) Found and simulated signals of isotopomeric cluster of the molecular ion [xantphos-Pd-acyl ${ }^{+}$]

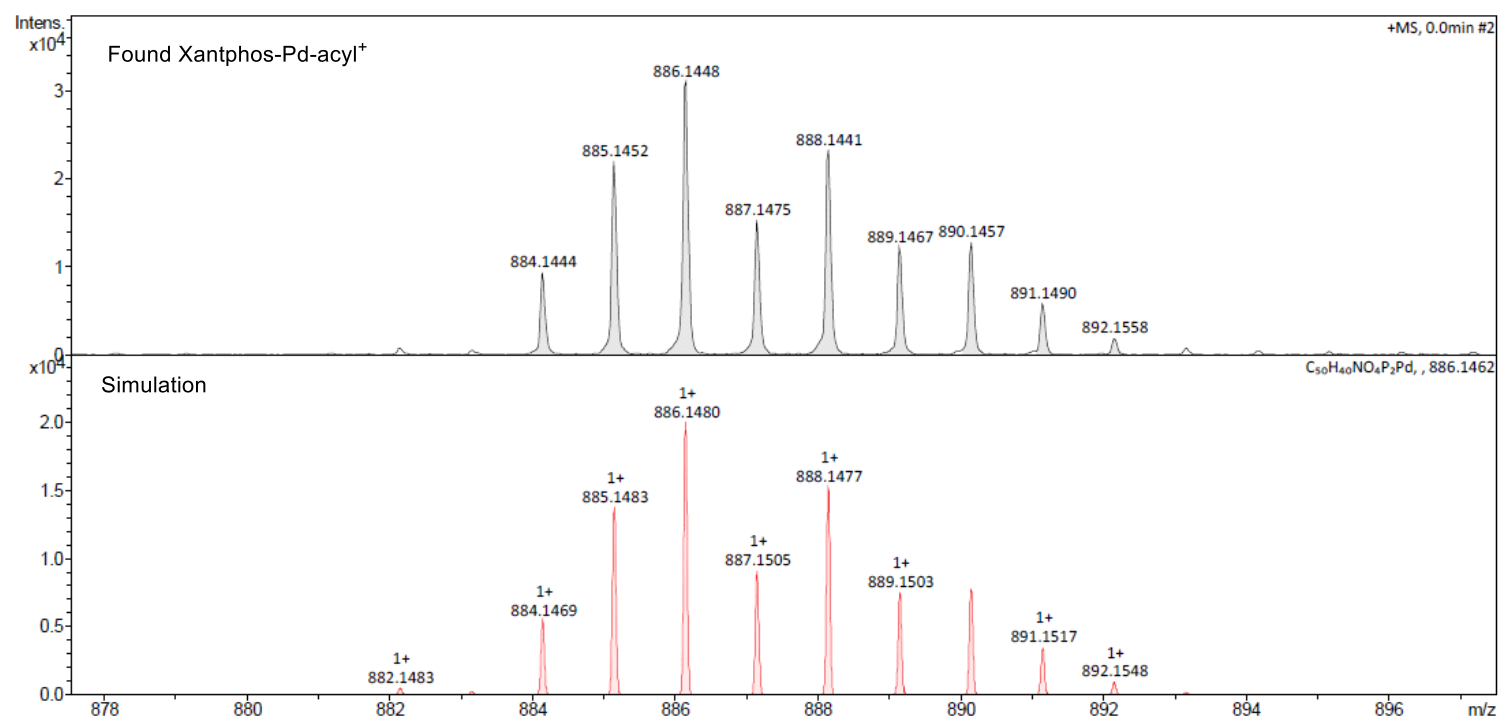

f) Found and simulated signals of isotopomeric cluster of the molecular ion [xantphos $\left.-\mathrm{Pd}_{2} \mathrm{I}^{+}\right]$

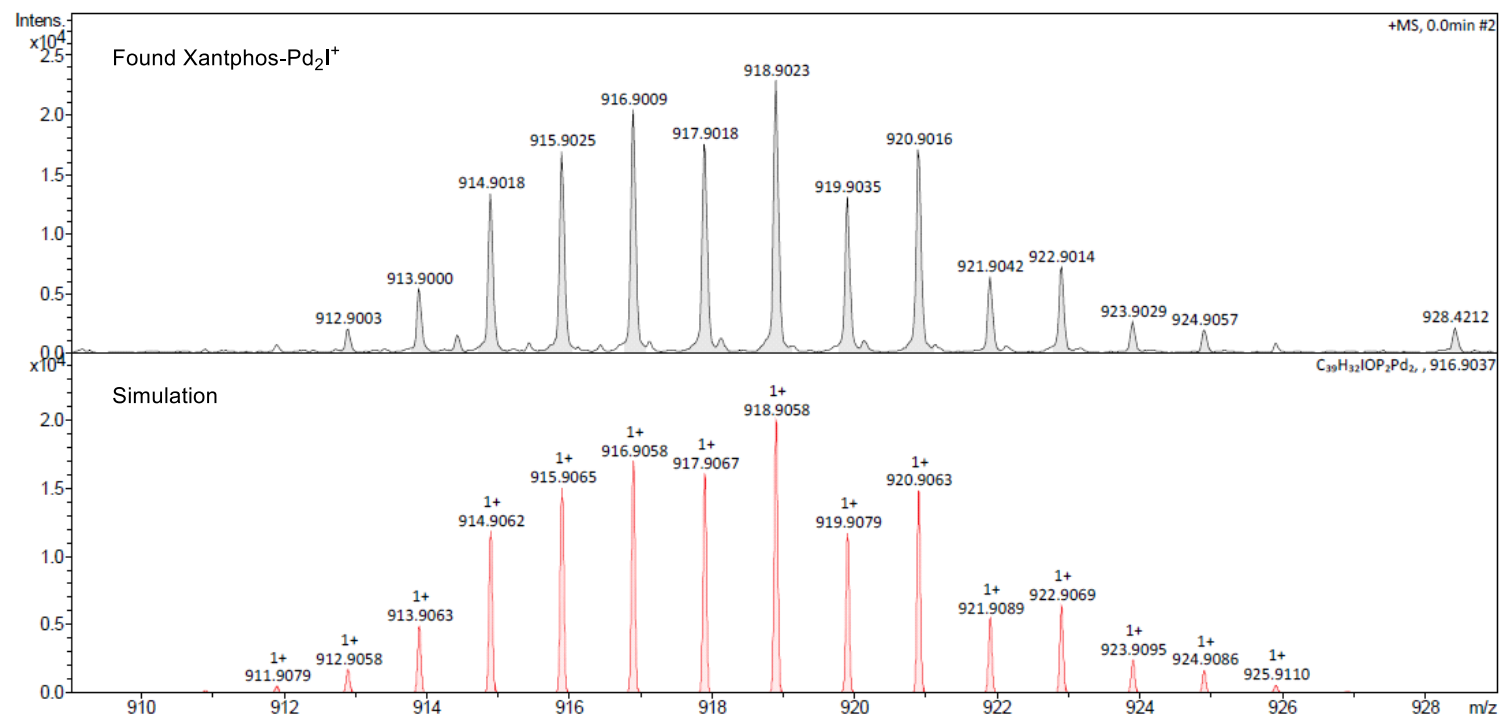


g) Found and simulated signals of isotopomeric cluster of the molecular ion [(xantphos $\left.)_{2}-\mathrm{Pd}_{2} \mathrm{I}^{+}\right]$

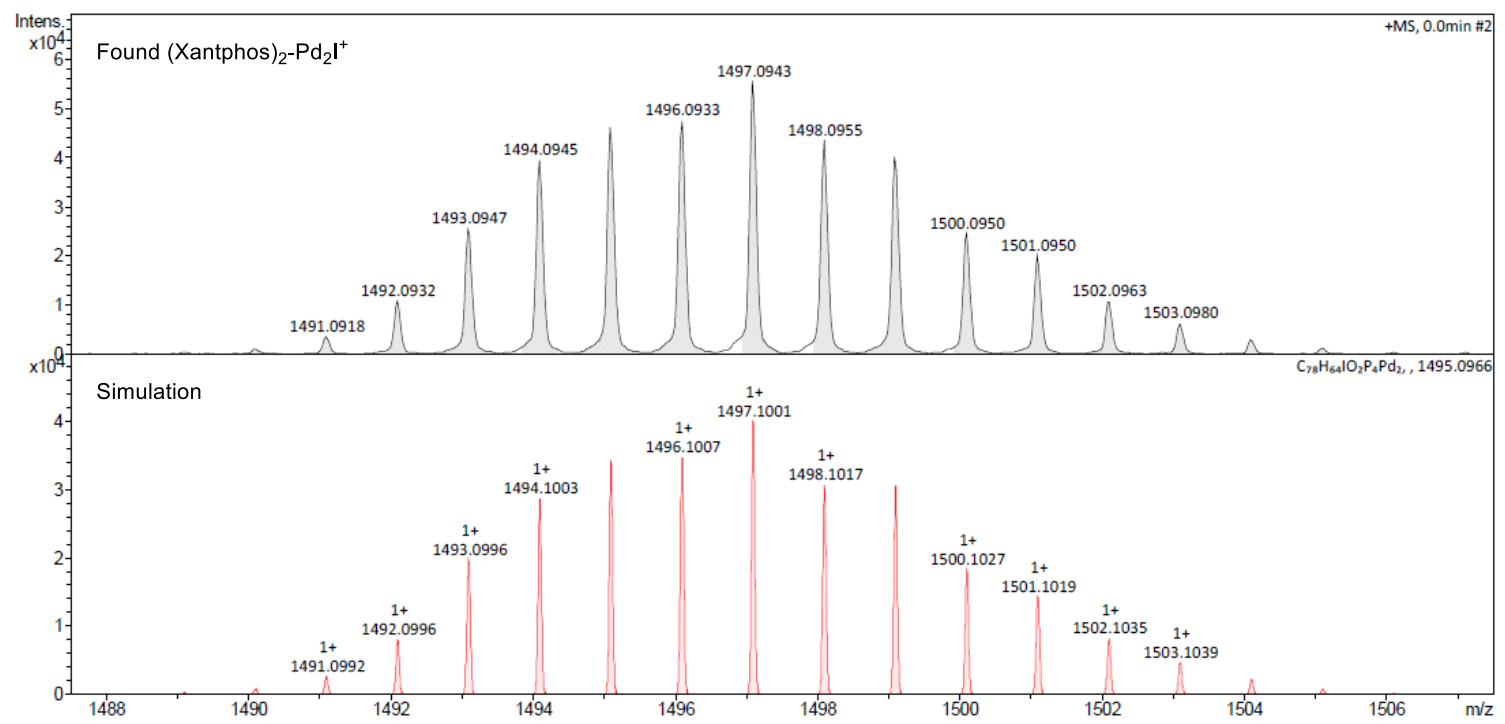

h) Found and simulated signals of isotopomeric cluster of the molecular ion $\left[(\text { xantphos })_{2}-\mathrm{Pd}_{2}(\mathrm{CO}) \mathrm{I}^{+}\right]$

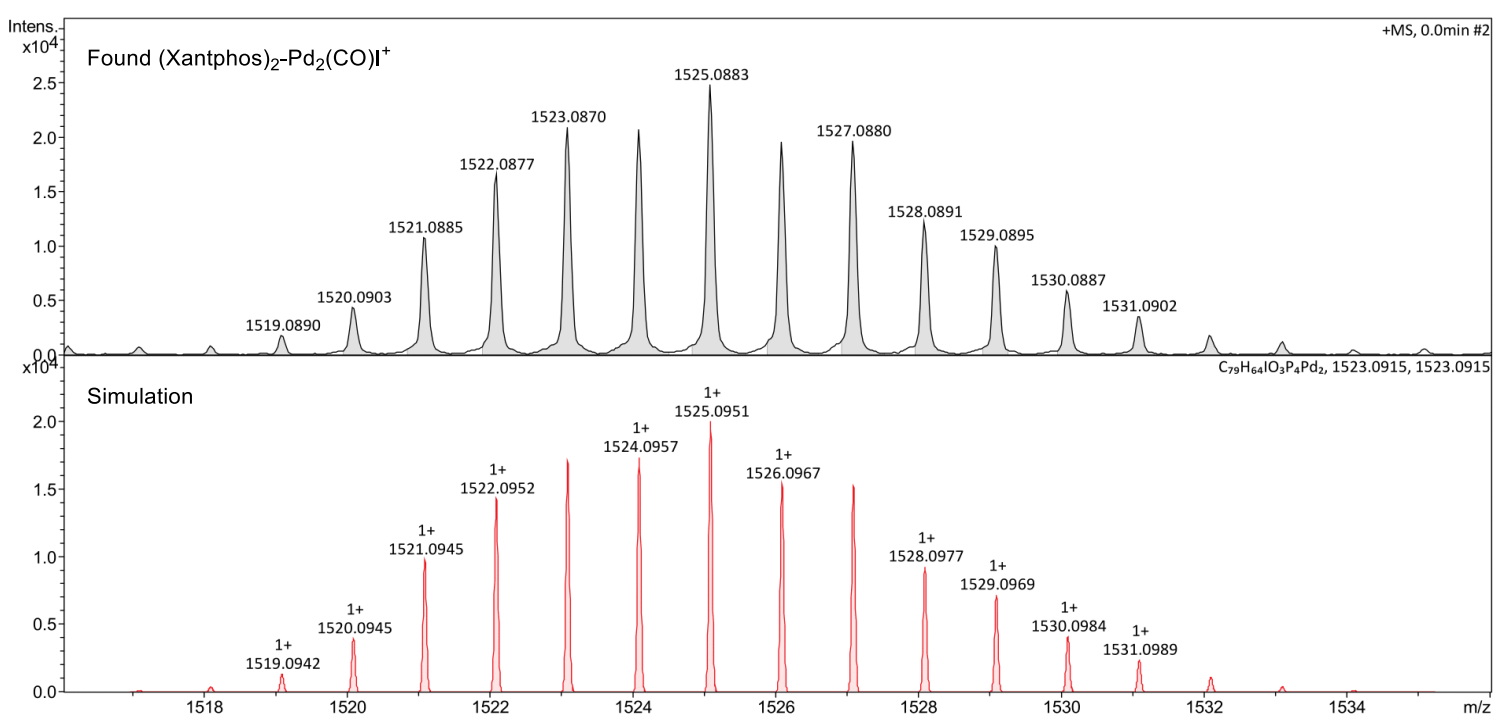


i) The signal corresponding to the adduct of Xantphos- $-\mathrm{Pd}^{\mathrm{I}} \mathrm{H}^{+}$and dioxygen: $\mathrm{Xantphos}-\mathrm{PdII}\left(\mathrm{O}_{2}\right) \mathrm{H}^{+}$:

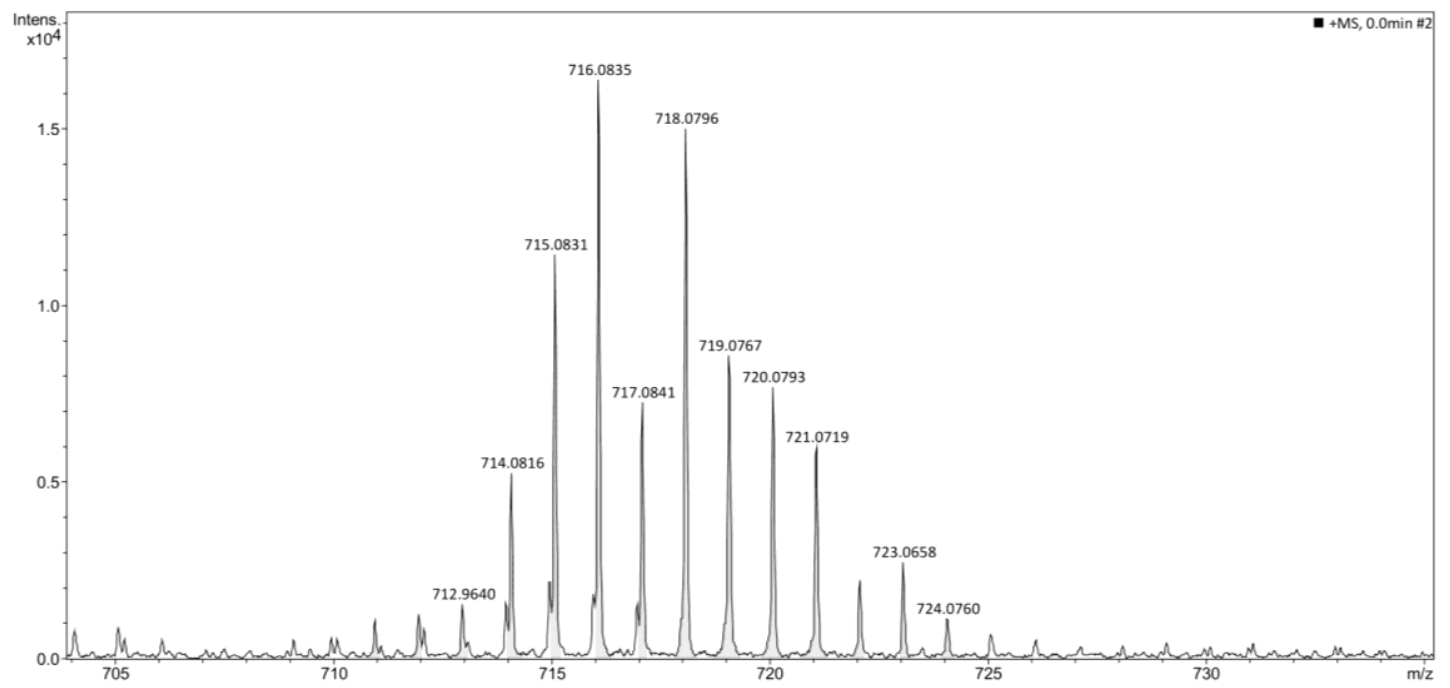

Fig. $\mathbf{S 9 0}$ The assignment of the HRMS data to the reaction intermediates though comparison with simulated signals of isotopomeric clusters of the molecular ions. 


\subsection{Kinetic experiments}

The kinetic experiments were conducted in analogous manner to the standard catalytic reactions described above. To guarantee consistent reaction conditions, the series of kinetic experiments were conducted in parallel. The reaction mixtures were prepared using stock solutions of alkene 1q, xantphos-Pd(II) complex, $\mathrm{Pd}(\mathrm{II})$ acetate, and $\mathrm{PPh}_{4} \mathrm{I}$, aliquots of which were added to $4 \mathrm{~mL}$ vials containing octagonal stir bars ( $20 \mathrm{~mm} \times 5 \mathrm{~mm}$ ), followed by addition of solvent to adjust the final concentrations. In case of experiments with (dative ligand free) $\mathrm{Pd}$ (II) iodide, because of its low solubility in toluene (or any common solvent), the stock was prepared in methyl acetate by sonication of the mixture until a homogenous solution/ suspension was obtained, which was distributed to $4 \mathrm{~mL}$ vials, followed by removal of the solvent under vacuum. The vials were closed with a cap containing a Teflon-coated septum, which was then punctured with a needle (the tip of the needle should not be in contact with the reaction mixture). The vials were placed into a 300-mL stainless steel Parr autoclave, charged with an aluminum insert suitable to contain multiple 4-mL vials for conducting parallel reactions, and equipped with a heating mantel, temperature controller and an internal thermocouple, enabling to maintain the internal temperature of the autoclave as required. The charged autoclave was purged three times with 40 bar of syngas and then pressurized subsequently with 40 bar syngas and 60 bar dihydrogen. Then the reactions were allowed to stir $(800 \mathrm{rpm})$ at $70^{\circ} \mathrm{C}$ for the indicated amount of time. Upon cooling to room temperature, the pressure was released, and a solution of a standard (1,3,5-trimethoxybenzene) was added. The reaction mixtures were then analyzed by GC-FID or ${ }^{1} \mathrm{H}$ NMR spectroscopy, and the thus obtained yields were used to calculate the initial reaction rates. Experiments at different time points and with different catalyst concentrations resulted in similar initial reaction rates and kinetic trends, confirming the fast catalyst activation under these conditions (Fig. S91).

\section{Reaction order in Pd:}

Because it was initially unclear whether the turnover-limiting step involves only xantphos-ligated Pd species or both xantphos-ligated and non-ligated Pd species, we used a 5:1 mixture of xanptphos-PdI 2 to $\mathrm{Pd}(\mathrm{OAc})_{2}$. Importantly, upon varying the total concentration of the mixture, the ratio of xantphosligated and non-ligated Pd species remains constant. Therefore, these experiments determine the rate order in Pd, regardless of whether only xantphos-ligated or ligated and non-ligated Pd species are involved. These experiments do not provide information regarding the involvement of xantphos. The influence of the Pd to xantphos ratio was studied independently, as described in the following section. The reaction 
order in Pd was calculated by non-linear data fitting to the standard kinetic model rate $=\boldsymbol{a} *[P d]^{\boldsymbol{b}}$, using the data fitting software package Origin 2020 to find $\mathbf{b}=2.0( \pm 0.1)$, i.e., a reaction order of $2.0( \pm 0.1)$ in Pd (Fig. S93). For comparison purposes, linear data fitting to the classic kinetic model $\ln ($ rate $)=\boldsymbol{a}+$ $\boldsymbol{b} * \ln ([P d])$ was also performed, returning $\mathbf{b}=2.1( \pm 0.1)($ Fig. S94). Thus, the found kinetic parameters are consistent. We further performed additional experiments at broader range of concentrations of the catalyst. Fig. S95 reports all kinetic data from 6 datasets originating from 3 independent experiments with 2 time points for each experiment. Each dataset from each experiment is reported with a different color. Applying the global non-linear regression analysis, all 6 datasets were simultaneously fitted to the general model rate $=\mathbf{a}^{*}[\mathrm{Pd}]^{\mathbf{b}} . \underline{\text { Parameter } \mathbf{b}}$ is inherently independent of the reaction conditions, while parameter $\underline{\mathbf{a}}$ is constant only under identical reaction conditions. To account for small variations of the conditions in each of 6 datasets, the global fitting procedures with parameter sharing method for parameter $\mathbf{b}$ and independent parameters $\mathbf{a}$ was applied, i.e., model rate $=\mathbf{a}_{1-6} *[\mathrm{Pd}]^{\mathbf{b}}$. The fitting procedure returned $\mathbf{b}=1.9$ $( \pm 0.1), \mathbf{a}_{1}-\mathbf{a}_{6}=3.8-5.4( \pm 0.4)$ (as reported in Figure S95). The values are consistent with the data reported in Fig. $S 93(\mathbf{b}=2.0( \pm 0.1), \mathbf{a}=5.0( \pm 0.15))$. For comparison purpose, we also report the global linear regression analysis of all raw data from Fig. S95 to the classic linearized kinetic model $\ln ($ rate $)=a+$ $\mathrm{b}^{*} \ln ([\mathrm{Pd}])$ in Fig. S96. The analysis indicates a reaction order of $\mathbf{b}=1.74( \pm 0.05)$ in Pd. Notably, the

global fitting of all data from Fig. S95 with shared parameters $\mathbf{a}$ and $\mathbf{b}$ between sets, i.e., fitting to the model rate $=\mathbf{a}^{*}[\mathrm{Pd}]^{\mathbf{b}}$ converged to $\mathbf{b}=1.6( \pm 0.1), \mathbf{a}=5.25( \pm 0.4)$ (however, with lower quality of fitting), while independent fitting of each dataset converged to the parameters in a range of: $\mathbf{b}_{\mathbf{1 - 6}}=1.7-2.2( \pm 0.35)$, $\mathbf{a}_{1}-\mathbf{a}_{6}=3.6-5.1( \pm 1.0)-$ not shown below. Overall, the kinetic analysis of the reaction is consistent with the $2^{\text {nd }}$ rate order in $\mathrm{Pd}$.

\section{Reaction order in alkene:}

The reaction order in alkene was obtained by non-linear data fitting to the standard kinetic model rate $=a^{*}[\text { alkene }]^{b}$, to find $\mathbf{b}=-1.0( \pm 0.1)$, i.e., a reaction order of $-1.0( \pm 0.1)$ in alkene 1q (Fig. S97). For comparison purposes, linear data fitting to the classic kinetic model $\ln ($ rate $)=\boldsymbol{a}+\boldsymbol{b} * \ln ($ [alkene]) returned $\mathbf{b}=-1.1( \pm 0.1)$ (Fig. S98).

\section{Rate dependence on Pd to xantphos ratio:}

The influence of the Pd to xantphos ratio on the catalytic activity was studied by the method of continuous variations, often referred to as a Job analysis, using xantphos and $\mathrm{PdI}_{2}$ as the source of Pd. The 
concentrations of $\mathrm{PdI}_{2}$ and xantphos were varied, but the sum of concentrations was maintained constant. The highest catalytic activity was observed in reactions with $\sim 2: 1 \mathrm{PdI}_{2}$ to xantphos ratio (Fig. S99).

\section{Rate dependence on the concentration of iodide:}

The influence of the iodide concentration on the catalytic activity was studied at constant concentrations of $\mathrm{Pd}$ and xantphos (2:1 ratio). $\mathrm{PdTFA}_{2}$ and $\mathrm{PdI}_{2}$ were used as a source of $\mathrm{Pd}$; while the sum of concentrations of $\mathrm{PdI}_{2}$ and $\mathrm{PdTFA}_{2}$ was maintained constant, the ratio of $\mathrm{PdI}_{2}$ to $\mathrm{PdTFA}_{2}$ was varied to change the concentration of iodide. In experiments with excess of iodide, the $\mathrm{PPh}_{4} \mathrm{I}$ along with $\mathrm{PdI}_{2}$ were used as a source of iodide. The highest catalytic activity was observed with $\sim 3: 1 \mathrm{PdI}_{2}$ to $\mathrm{PdTFA}_{2}$ ratio (i.e., a 3:2:1 iodide to $\mathrm{Pd}$ to xantphos ratio) and with a 1:1 ratio (i.e., a 2:2:1 iodide to Pd to xantphos ratio), and slightly lowered activity with only $\mathrm{PdI}_{2}$ (i.e., a 4:2:1 iodide to $\mathrm{Pd}$ to xantphos ratio). The catalytic activity significantly decreased outside of that range (Fig. S100).

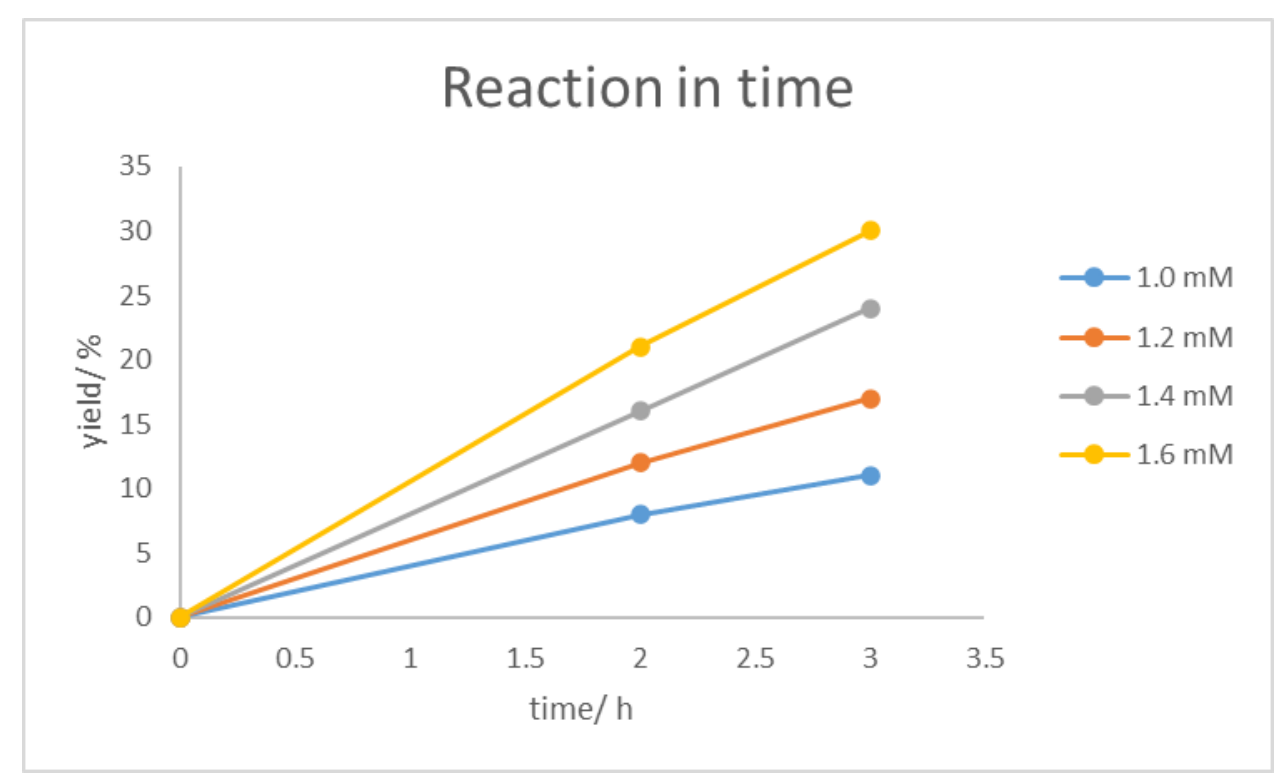




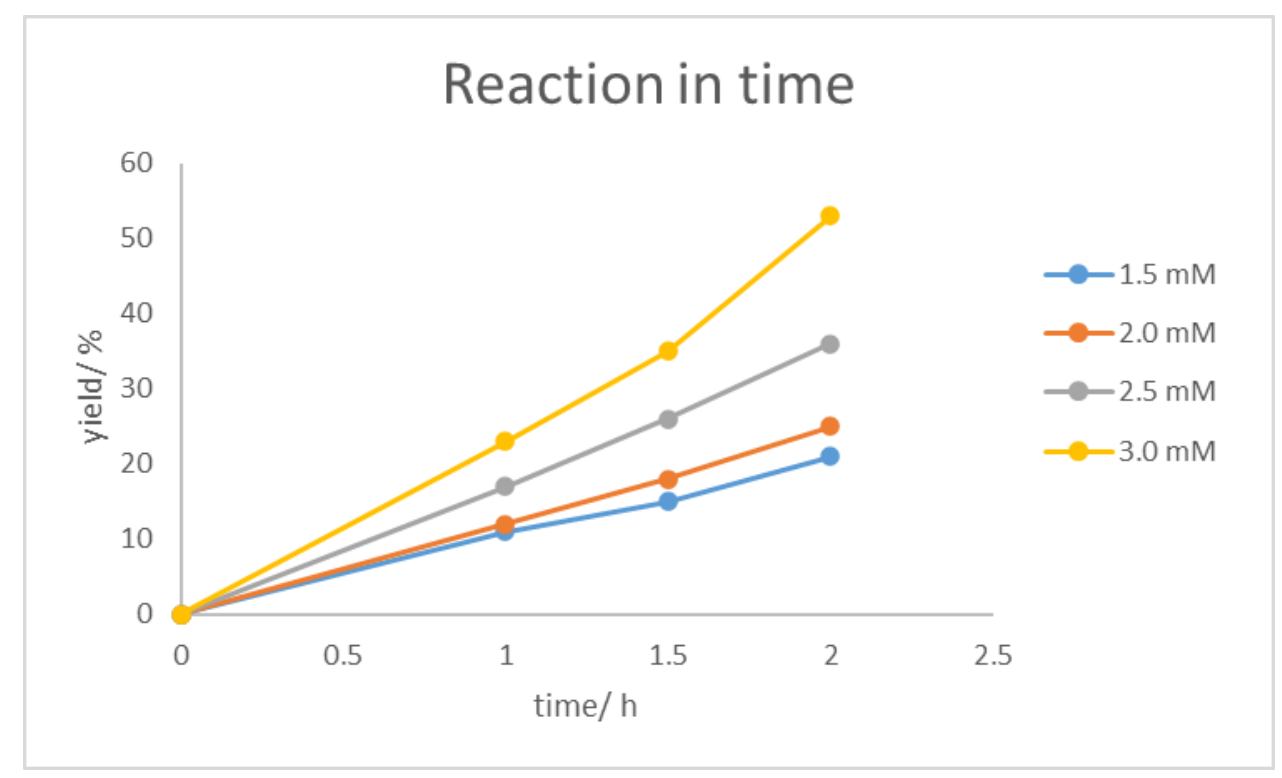

Fig. S91 Reaction progress over time for experiments at varied catalyst concentration.

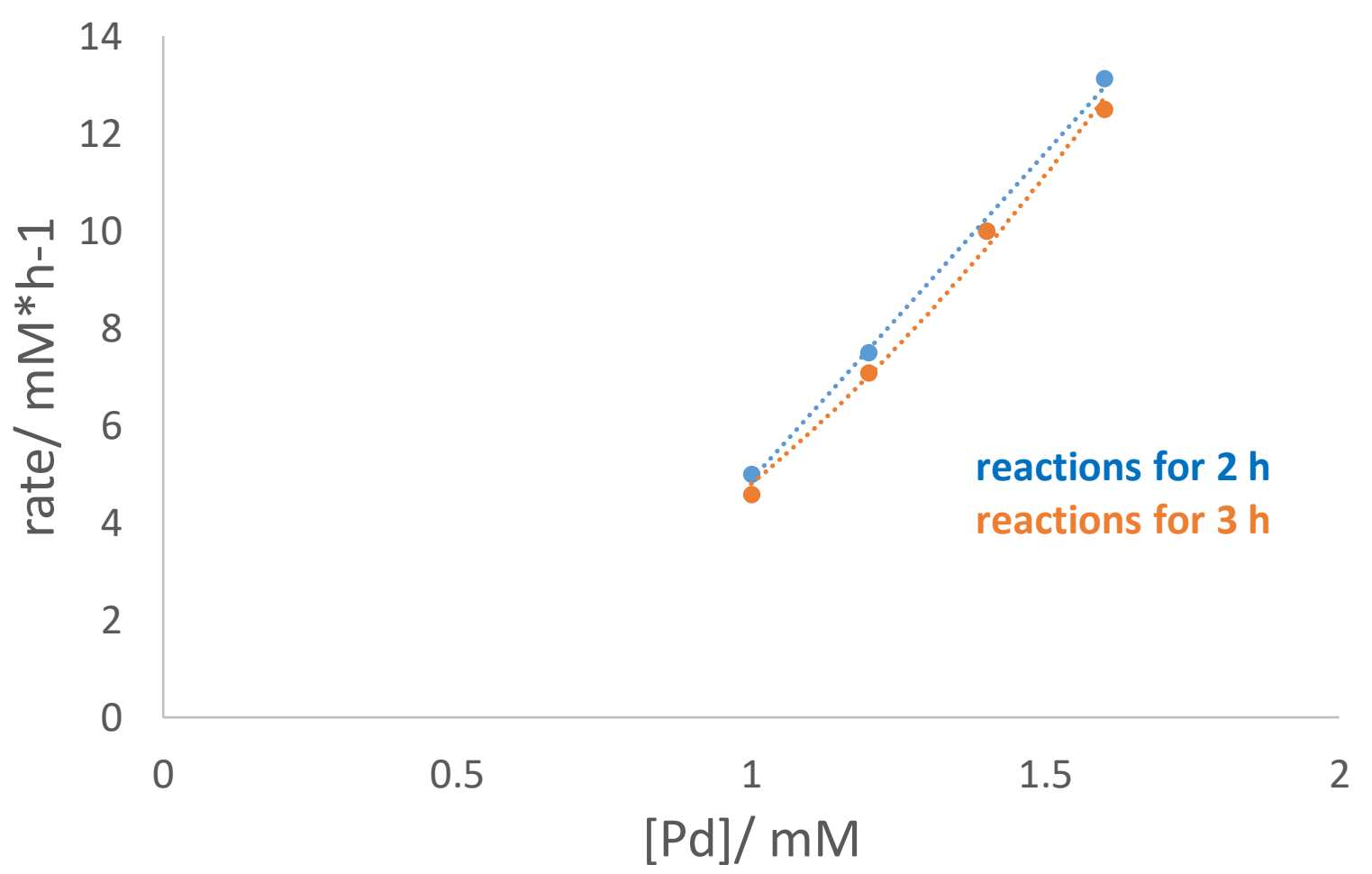

Fig. $\mathbf{S 9 2}$ Reaction rate for experiments at varied catalyst concentration (different time points). 

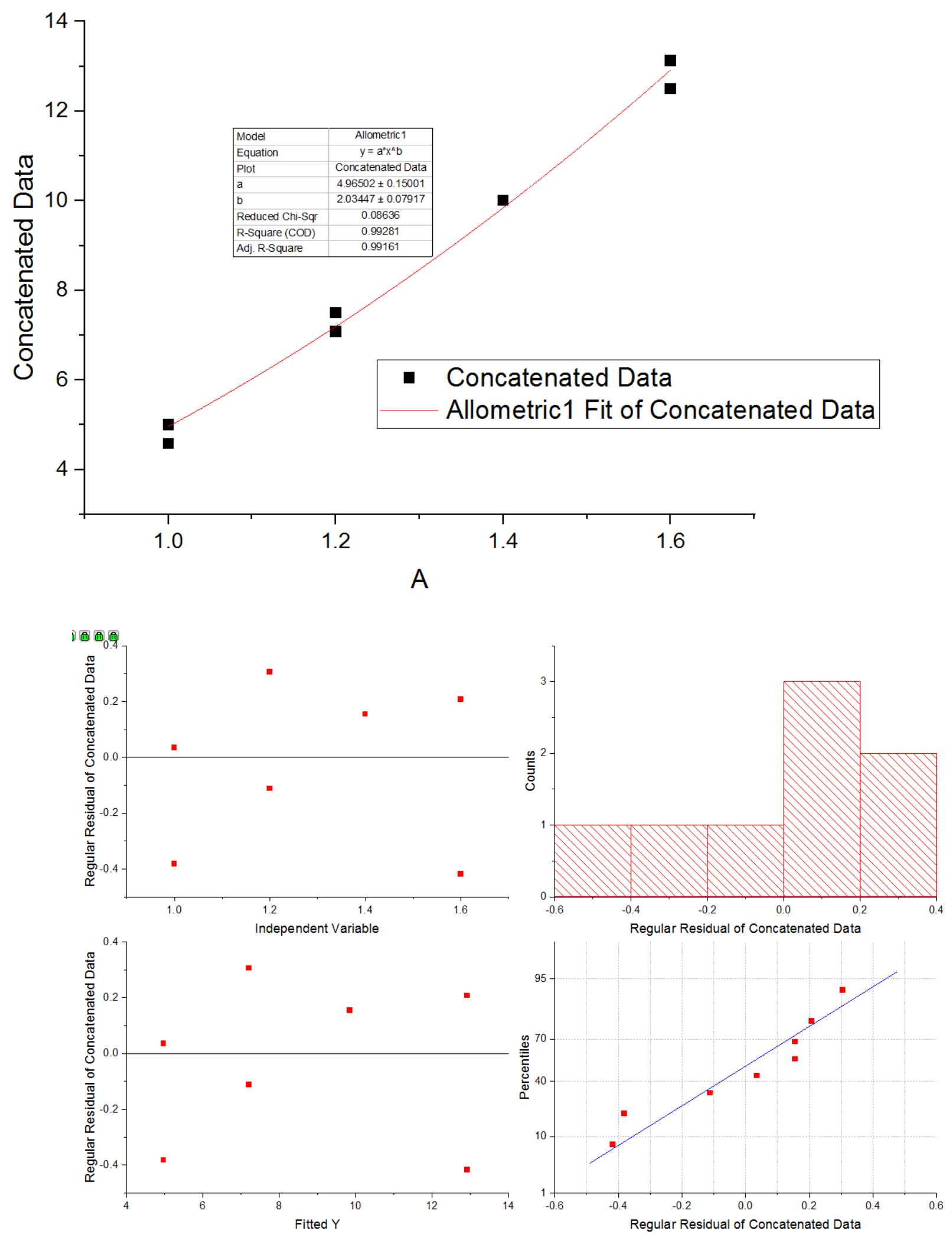

Fig. S93 Non-linear fitting of kinetic data for experiments at varied catalyst concentration. 

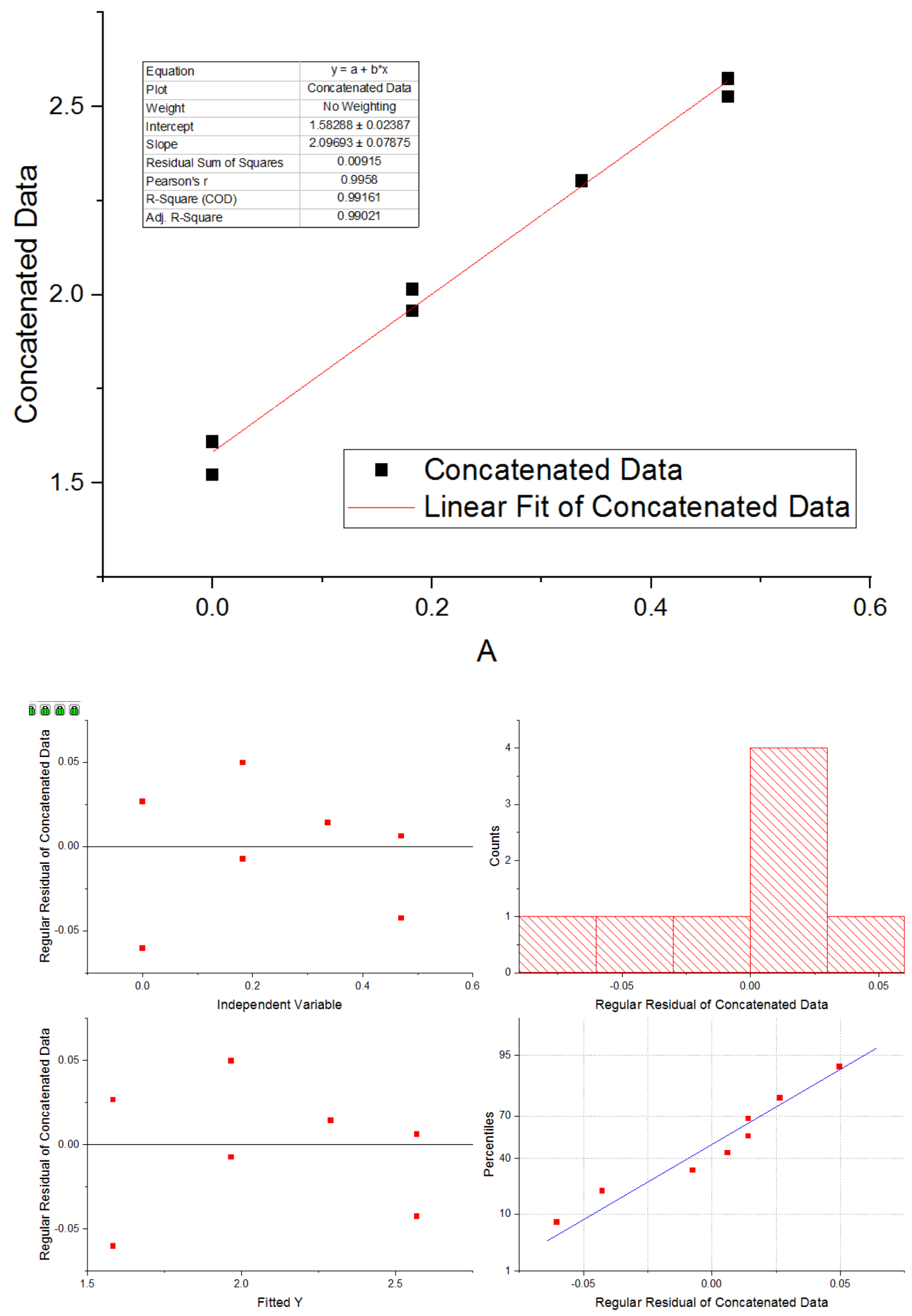

Fig. $\mathbf{5 9 4}$ Linear fitting of kinetic data for experiments at varied catalyst concentration. 


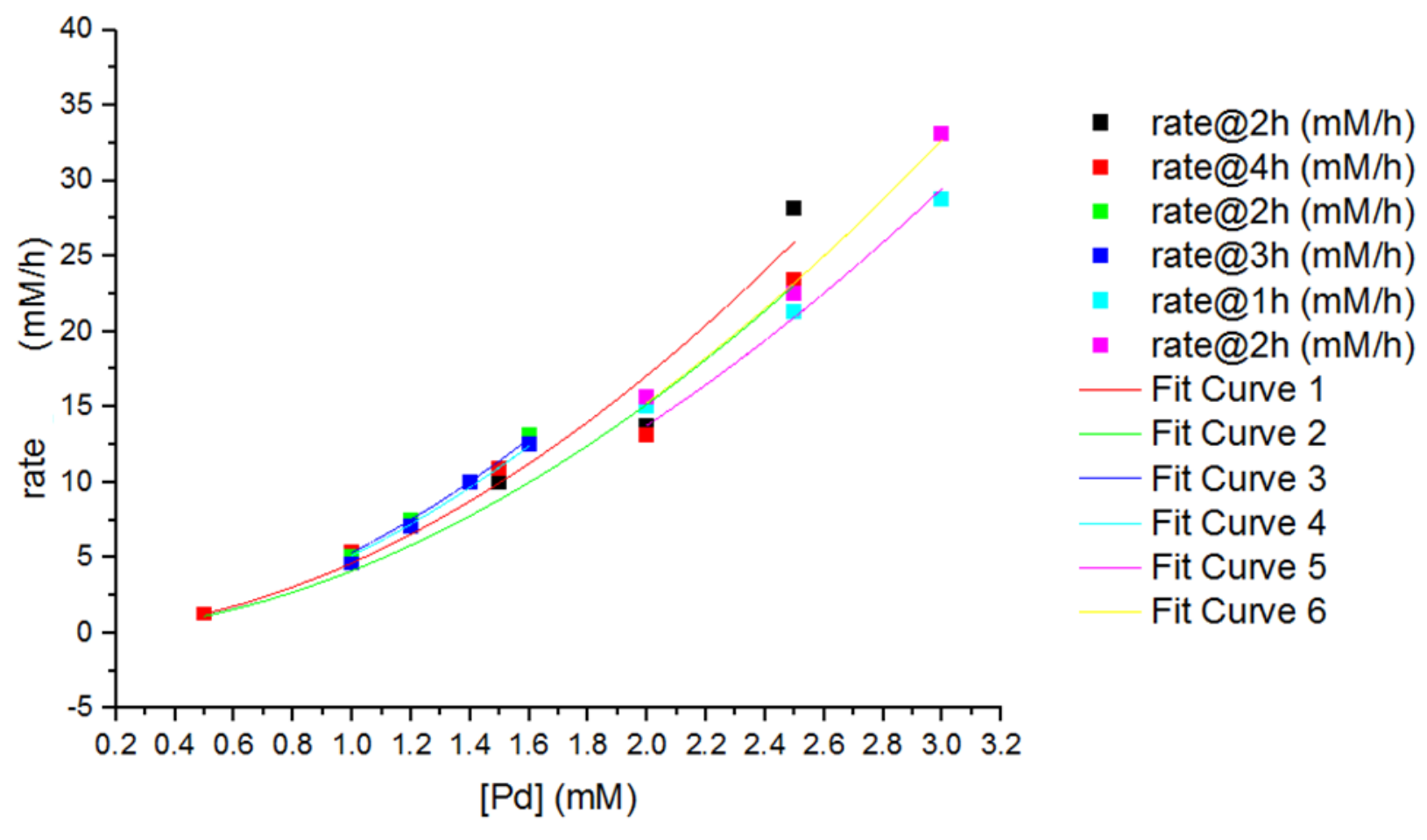

\begin{tabular}{|c|c|c|c|c|c|c|}
\hline Model & \multicolumn{6}{|c|}{ Allometric1 } \\
\hline Equation & \multicolumn{6}{|c|}{$y=a^{*} x^{\wedge} b$} \\
\hline Plot & rate@2h & rate@4h & rate@2h & rate@3h & rate@1h & rate@2h \\
\hline a & $4.6639 \pm 0.42534$ & $4.14352 \pm 0.38744$ & $5.35169 \pm 0.42237$ & $5.14811 \pm 0.41906$ & $3.76308 \pm 0.40908$ & $4.17409 \pm 0.44957$ \\
\hline$b^{\star}$ & $1.87468 \pm 0.10388$ & $1.87468 \pm 0.10388$ & $1.87468 \pm 0.10388$ & $1.87468 \pm 0.10388$ & $1.87468 \pm 0.10388$ & $1.87468 \pm 0.10388$ \\
\hline Reduced Chi-Sqr* & \multicolumn{6}{|c|}{1.74039} \\
\hline R-Square (COD) & 0.96303 & 0.96474 & 0.99527 & 0.98715 & 0.97785 & 0.99468 \\
\hline R-Square (COD)* & \multicolumn{6}{|c|}{0.98347} \\
\hline Adj. R-Square* & \multicolumn{6}{|c|}{0.97763} \\
\hline
\end{tabular}

Fig. S95 Global non-linear fitting of kinetic data for multiple experiments conducted for a broad range of catalyst concentration. 

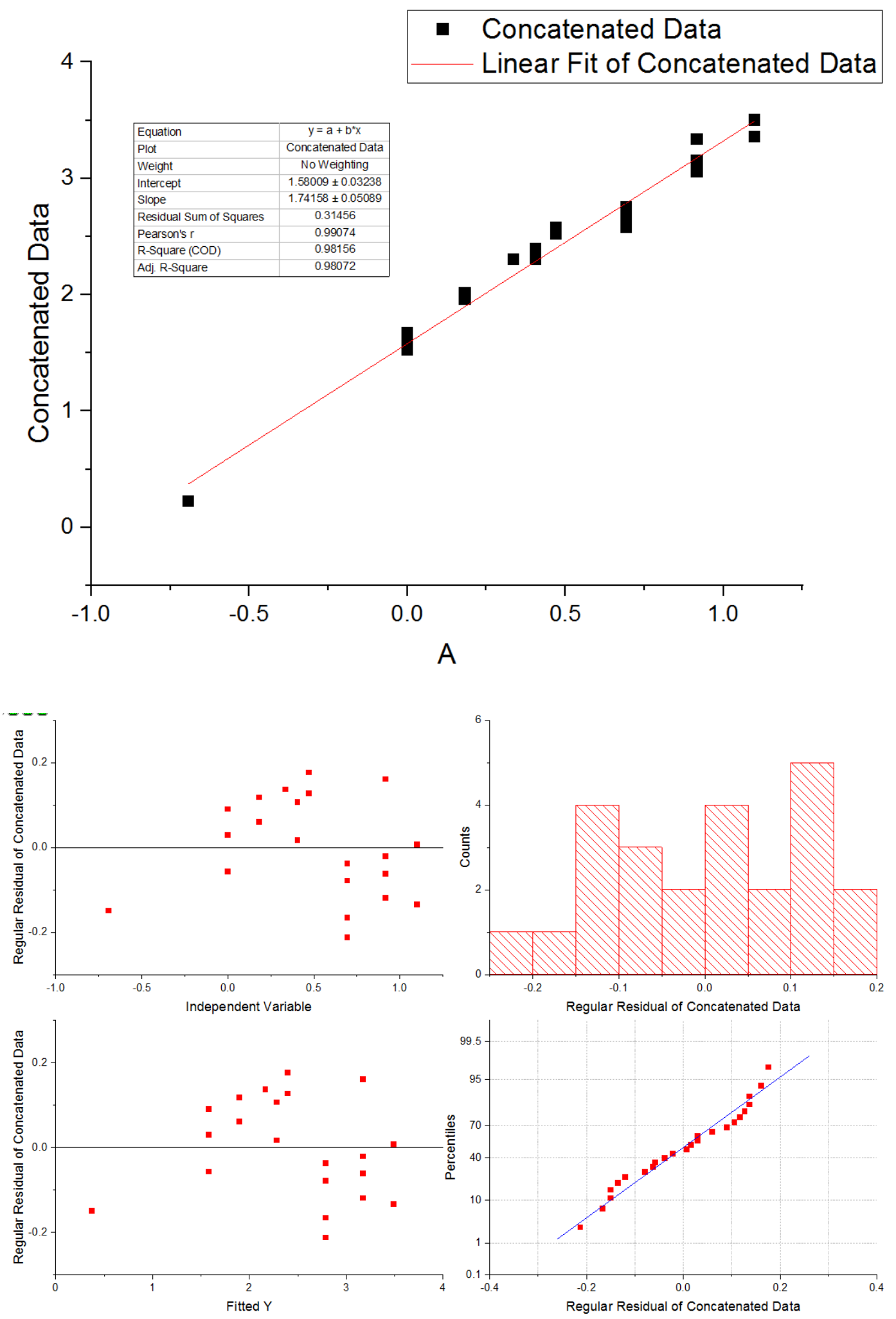

Fig. S96 Global linear fitting of kinetic data for multiple experiments conducted for a broad range of catalyst concentration. 


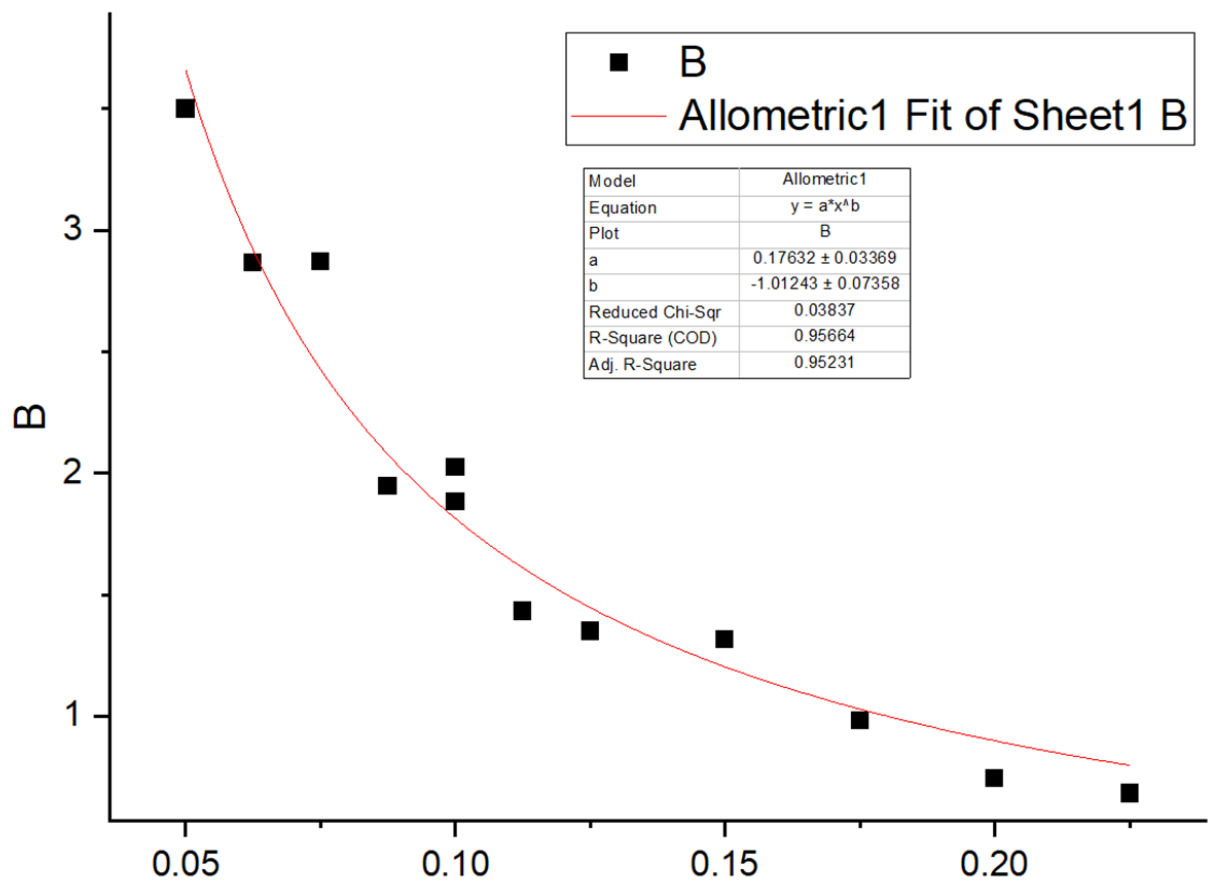

A
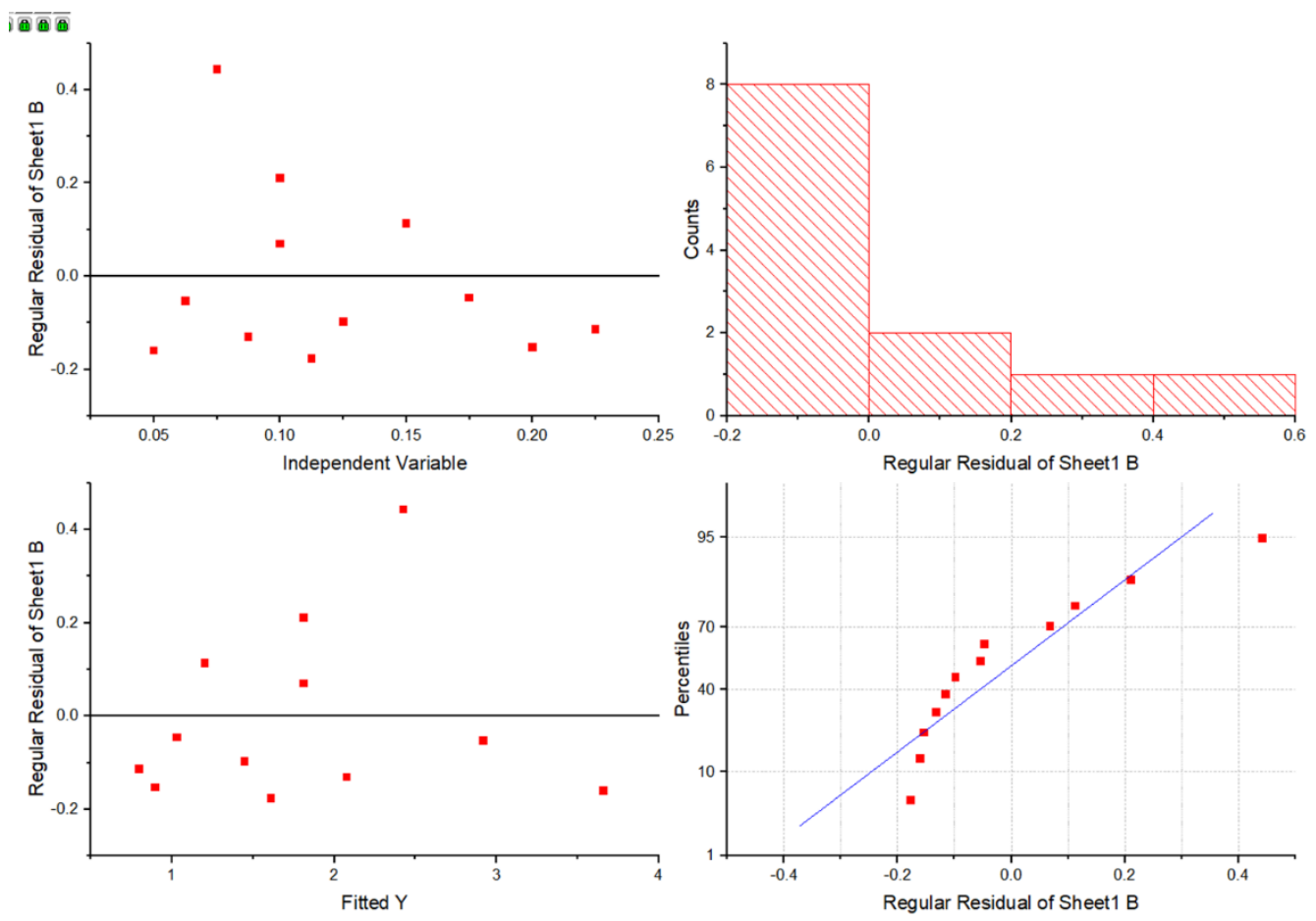

Fig. $\mathbf{5 9 7}$ Non-linear fitting of kinetic data for experiments at varied alkene concentration. 


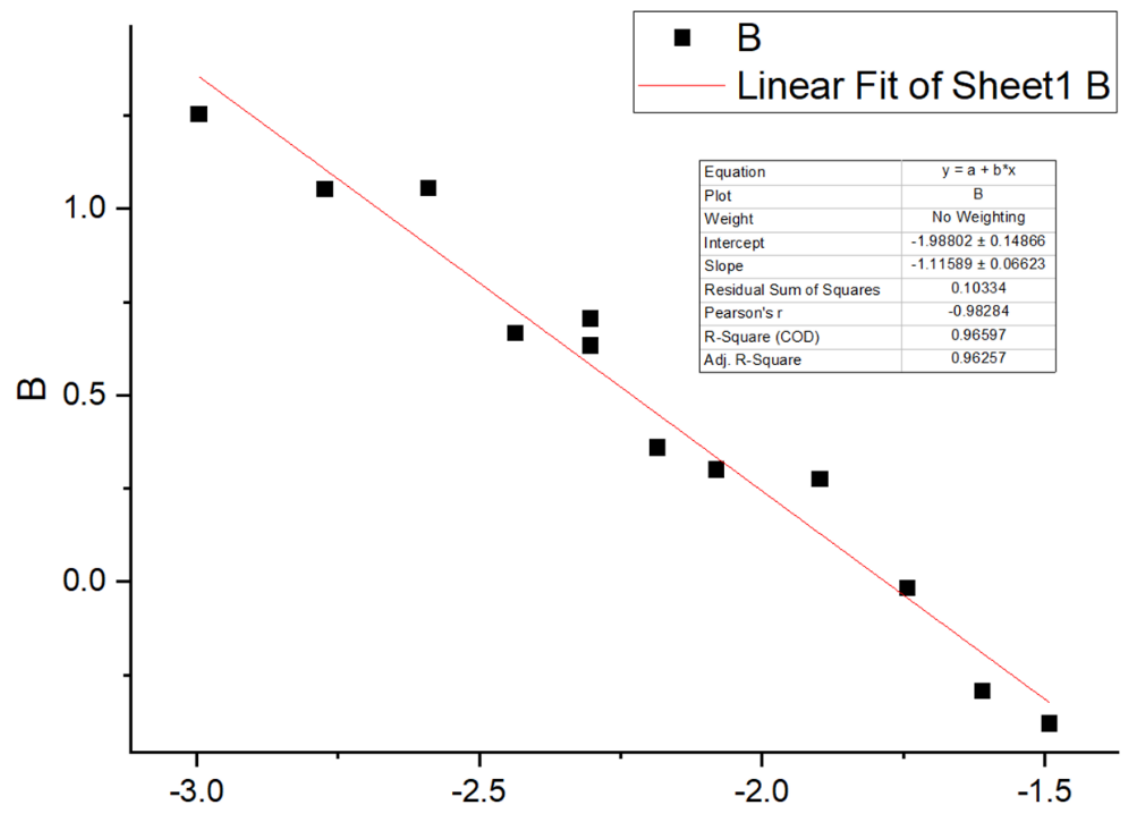

A
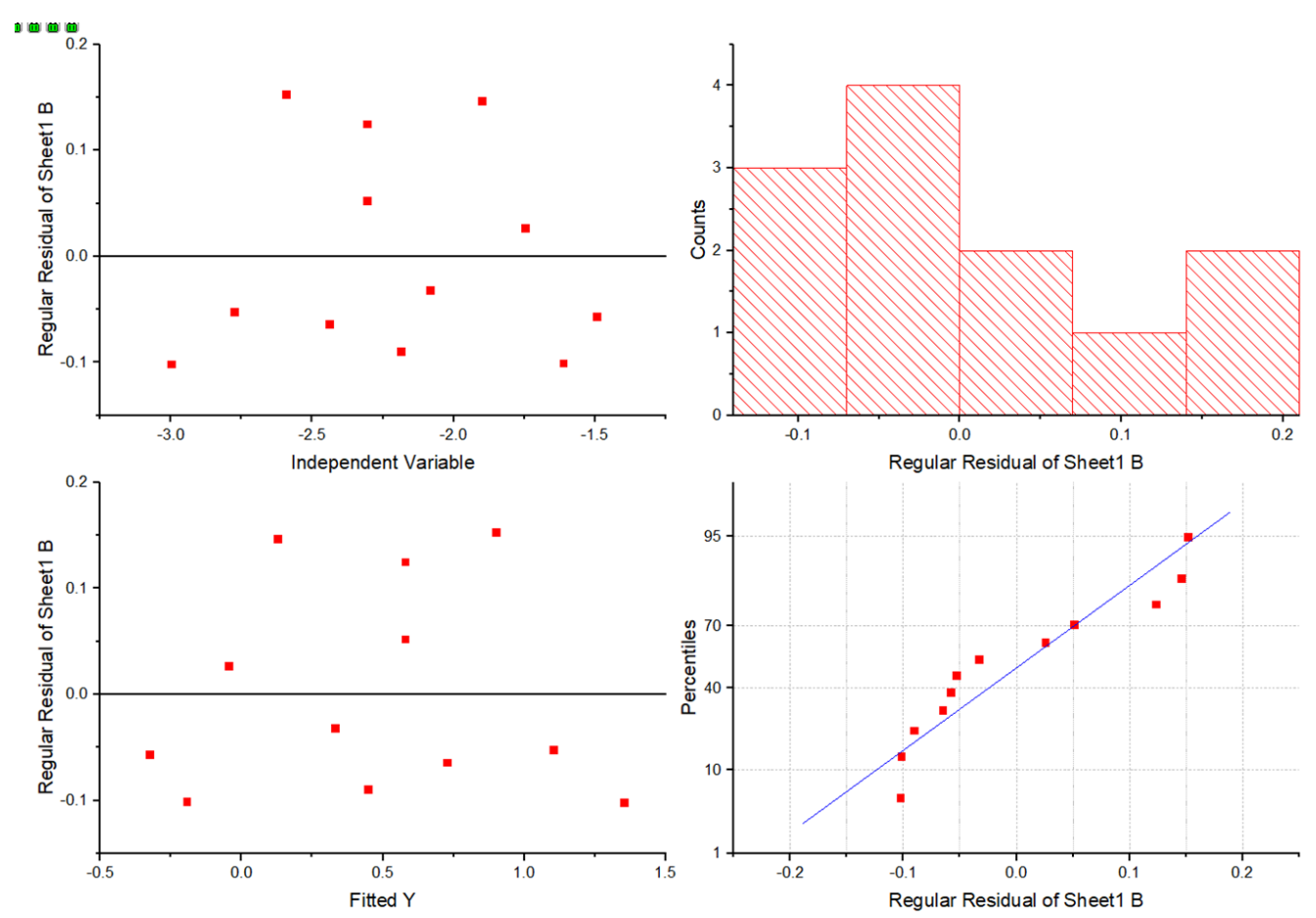

Fig. $\mathbf{5 9 8}$ Linear fitting of kinetic data for experiments at varied alkene concentration. 


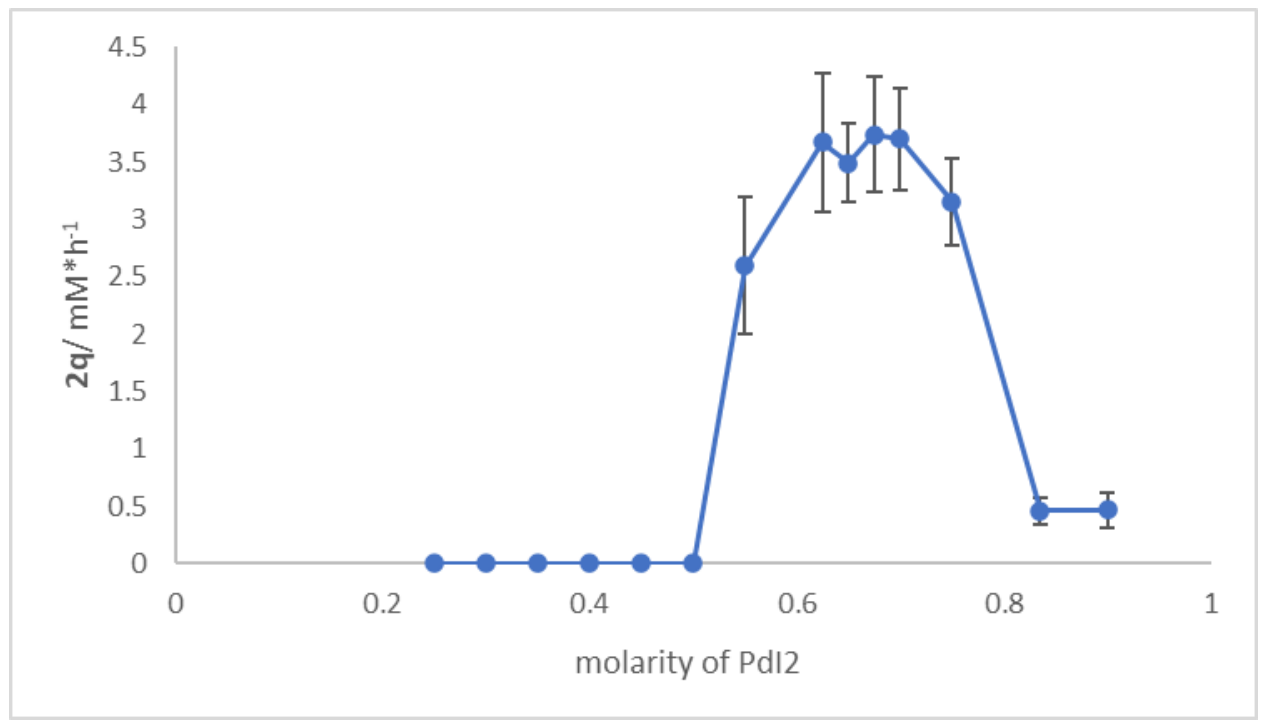

Fig. $S 99$ A Job analysis for the rate dependence on $P d I_{2}$ to xantphos ratio. The sum of concentrations of $P d I_{2}$ and xantphos is maintained constant; the molarity of $P d I_{2}$ is calculated as $n_{P d I 2} /\left(n_{P d I 2}+n_{x a n t p h o s}\right)$; the error bar represents the standard error of the mean, sem, $(n=5)$.

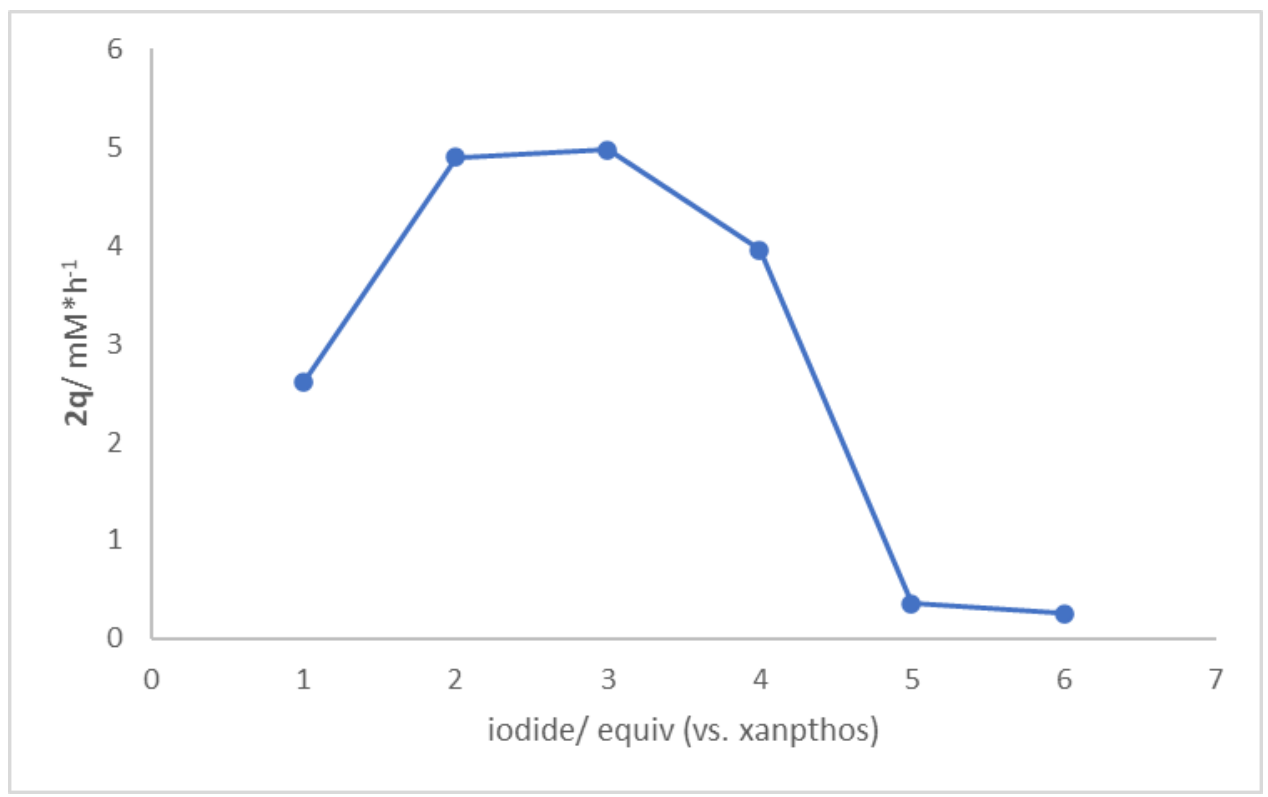

Fig. S100 The influence of the concentration of iodide on the activity of a $2: 1$ mixture of Pd and xantphos. 


\subsection{Evaluation of the resting state of the catalytic cycle by the in-situ ${ }^{1} \mathrm{H} N M R$ spectroscopy}

In analogy to the NMR studies of the stochiometric reaction, investigation of the catalytic reaction was performed in a high-pressure J. Young tube. In a nitrogen-filled glovebox, a stock solution of vinyl phthalimide (43.3 mg, $0.25 \mathrm{mmol})$, xantphos $-\mathrm{PdI}_{2}(23.5 \mathrm{mg}, 0.025 \mathrm{mmol})$, and $\mathrm{Pd}(\mathrm{OAc})_{2}(1.1 \mathrm{mg}, 0.0050$ mmol), was prepared in $1 \mathrm{~mL}$ of $\mathrm{CD}_{2} \mathrm{Cl}_{2}$. A portion of $200 \mu \mathrm{L}$ of this stock solution was added to a $\mathrm{J}$. Young tube, diluted with $300 \mu \mathrm{L}$ of $\mathrm{CD}_{2} \mathrm{Cl}_{2}$, then sealed and shaken. Then, the tube was pressurized to 10 bar $\mathrm{CO} / \mathrm{H}_{2}$ (1:1) and the pressure was released, a process which was repeated 5 times. Finally, the tube was pressurized (6 bar $\mathrm{CO} / \mathrm{H}_{2}$ ), sealed, shaken, and placed inside a pre-heated $\mathrm{NMR}$ machine at $50{ }^{\circ} \mathrm{C}$. The reaction was followed over time by ${ }^{1} \mathrm{H}$ NMR spectroscopy. Clean conversion of alkene 1q was accompanied by transient formation of the Pd- $\beta$-acyl species, which was finally converted to the single product, aldehyde $\mathbf{2 q}$. No Pd- $\alpha$-acyl or any other intermediates were observed under these conditions.

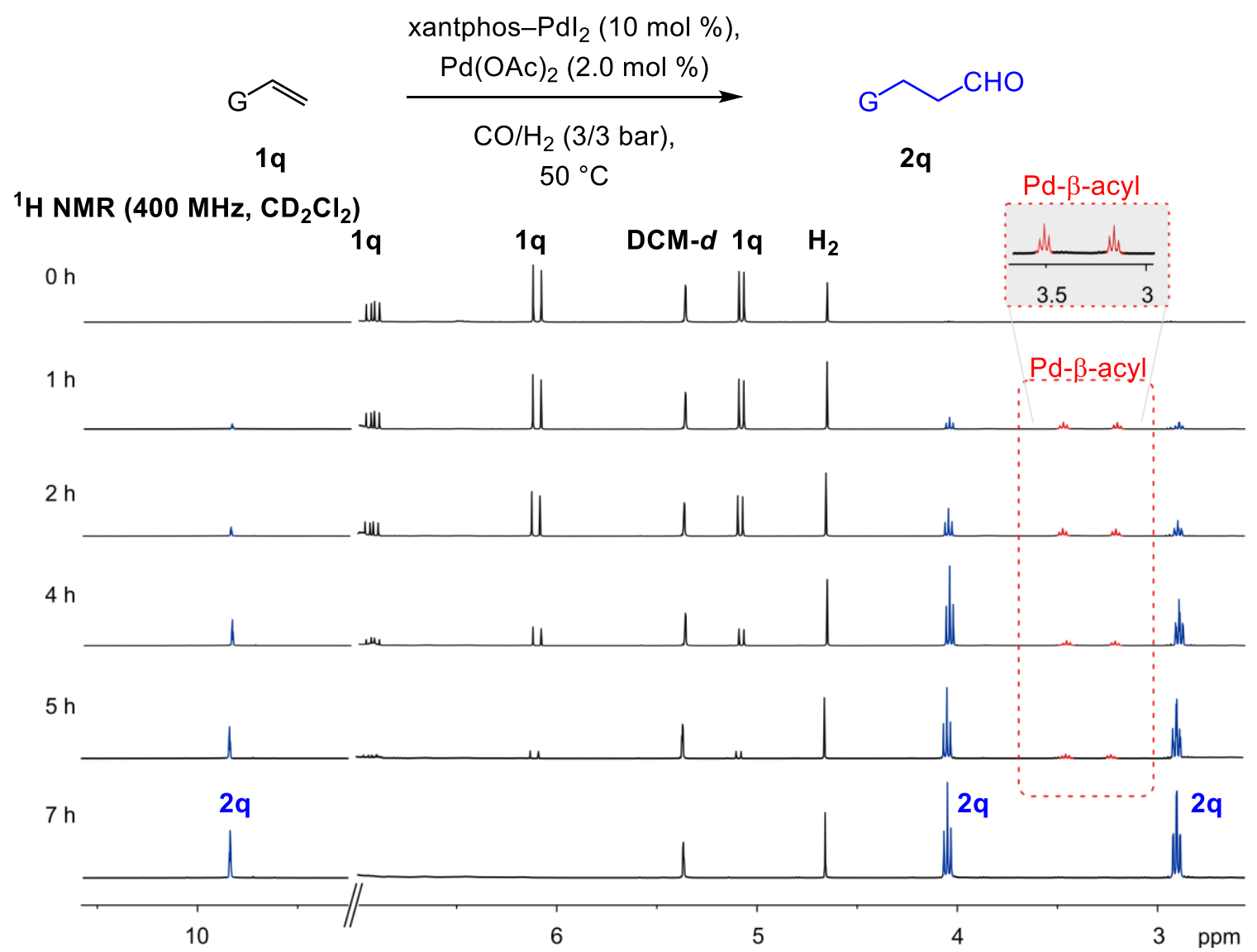

Fig. S101 ${ }^{1} \mathrm{H}$ NMR spectra for the catalytic reaction of alkene $\mathbf{1 q}$ and syngas (6 bar) in the presence of $10 \mathrm{~mol} \%$ xantphos- $\mathrm{PdI}_{2}$ and $2 \mathrm{~mol} \% \mathrm{Pd}(\mathrm{OAc})_{2}$ over time at $50^{\circ} \mathrm{C}$ in $\mathrm{CD}_{2} \mathrm{Cl}_{2}$. 


\subsection{Evaluation of the catalytic activity of isolated intermediates by the in-situ ${ }^{1} \mathrm{H}$ NMR spectroscopy}

Investigation of the catalytic activity of isolated intermediates was performed in analogy to the NMR studies described above. In a nitrogen-filled glovebox, by using stock solutions in $\mathrm{CD}_{2} \mathrm{Cl}_{2}$, high-pressure J. Young tubes were charged with vinyl phthalimide $(10.8 \mathrm{mg}, 0.0625 \mathrm{mmol})$ and one of the catalytic systems: A: xantphos-PdI 2 (5.9 mg, $0.00625 \mathrm{mmol})$, and $\mathrm{Pd}(\mathrm{OAc})_{2}(0.28 \mathrm{mg}, 0.00125 \mathrm{mmol})$, B: Pd- $\alpha-$ $\mathrm{acyl}^{+} \mathrm{BF}_{4}^{-}(6.1 \mathrm{mg}, 0.00625 \mathrm{mmol}), \mathrm{PPh}_{4} \mathrm{I}(4.4 \mathrm{mg}, 0.0094 \mathrm{mmol})$, and $\mathrm{Pd}(\mathrm{OAc})_{2}(0.28 \mathrm{mg}, 0.00125$ mmol), C: Pd- $\beta$-acyl ${ }^{+} \mathrm{BF}_{4}^{-}(6.1 \mathrm{mg}, 0.00625 \mathrm{mmol}), \mathrm{PPh}_{4} \mathrm{I}(4.4 \mathrm{mg}, 0.0094 \mathrm{mmol})$, and Pd(OAc) ${ }_{2}(0.28$ mg, $0.00125 \mathrm{mmol}$ ), or D: Pd2-hydride+TFA- (4.7 mg, $0.003125 \mathrm{mmol}), \mathrm{PPh}_{4} \mathrm{I}$ (4.4 mg, $\left.0.0094 \mathrm{mmol}\right)$, and $\mathrm{Pd}(\mathrm{OAc})_{2}(0.28 \mathrm{mg}, 0.00125 \mathrm{mmol})$; the final volume of $\mathrm{CD}_{2} \mathrm{Cl}_{2}$ in each sample was $500 \mu \mathrm{L}$. The tubes were sealed and shaken. Then, each tube was pressurized to 6 bar $\mathrm{CO} / \mathrm{H}_{2}(1: 1)$ and the pressure was released, a process which was repeated twice. Finally, each tube was pressurized (6 bar $\left.\mathrm{CO} / \mathrm{H}_{2}\right)$, sealed, shaken, kept inside a pre-heated aluminum heating block at $70{ }^{\circ} \mathrm{C}$, and periodically subjected to the NMR spectrometer to collect the spectra. Irrespective of the initial catalytic system (A-D), formation of the Pd$\beta$-acyl species was observed after $1 \mathrm{~h}$; no Pd- $\alpha$-acyl intermediate was observed under these conditions. Further reaction resulted in conversion of alkene $\mathbf{1 q}$ to $\beta$-aldehyde $\mathbf{2 q}$. No $\alpha$-aldehyde $\mathbf{2 q}$ was formed in any of the reactions. Noteworthy, reactions B-D occurred at slower rate (most noticeable in case of reaction with $\mathbf{P d}_{2}$-hydride ${ }^{+} \mathrm{TFA}^{-}$), most likely due to the lack of $\mathrm{HI}$ in the initial mixture of activated complexes (otherwise formed during the activation of xantphos- $\mathrm{PdI}_{2}$, i.e., $x$ antphos $-\mathrm{PdI} \mathrm{I}_{2}+\mathrm{H}_{2}->$ xantphos-PdHI $+\mathrm{HI})$; HI oxidizes reduced $\mathrm{Pd}(\mathrm{I})$-species to active $\mathrm{Pd}(\mathrm{II})$ species - see Figure 8 in the main text. 

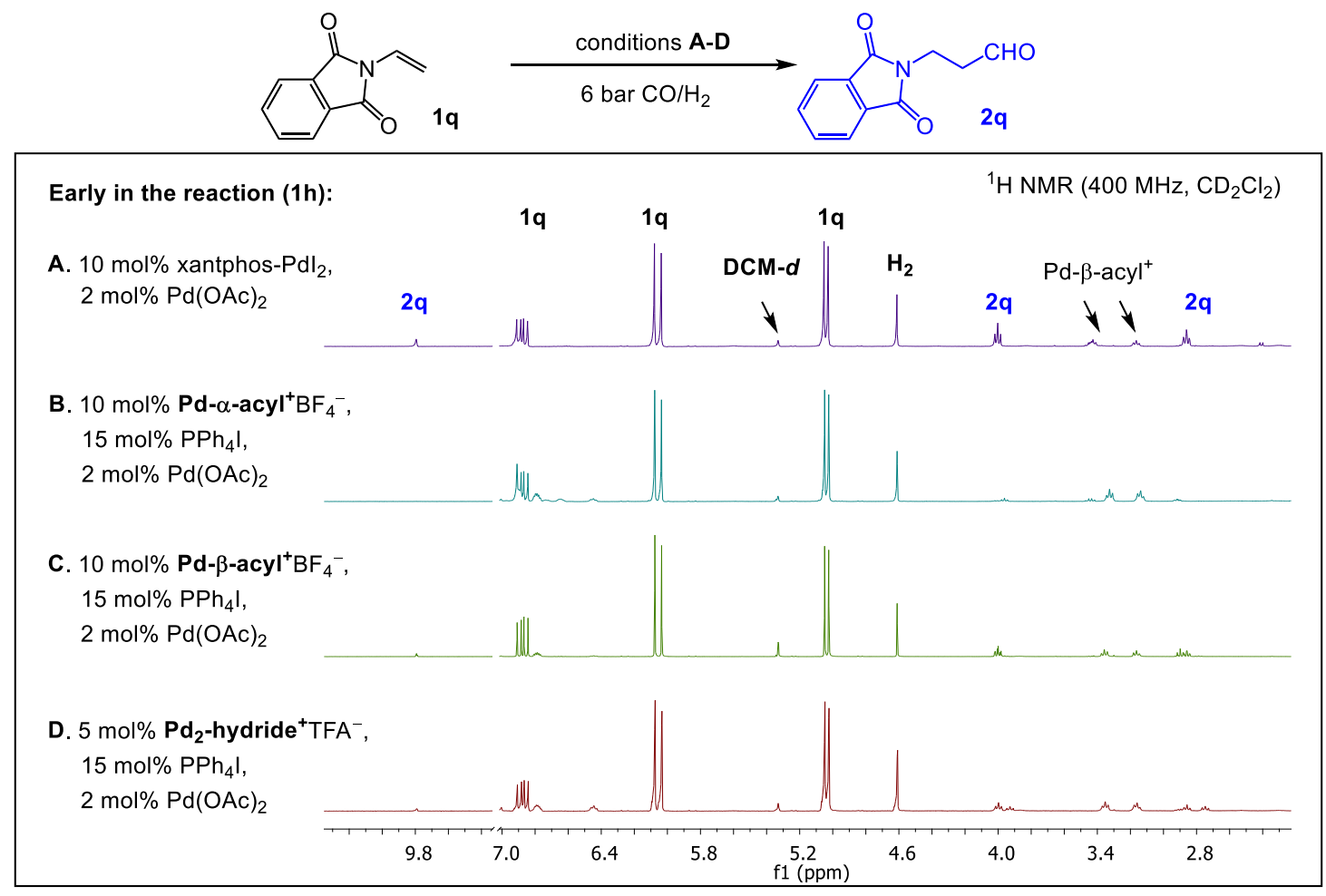

$\sqrt{ }$ further incubation until full conversion of 1q

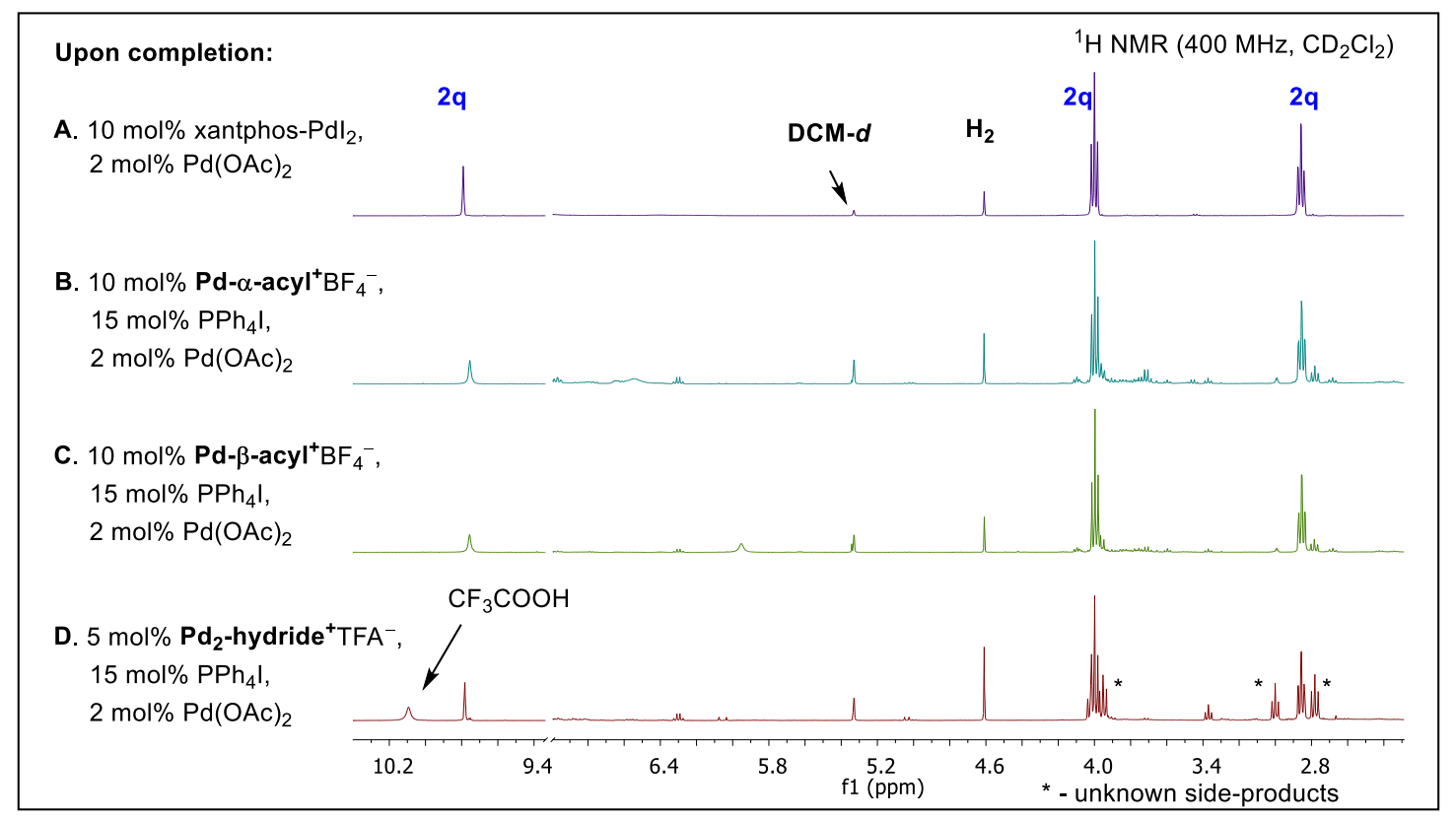

Fig. $\mathbf{S 1 0 2}{ }^{l} H$ NMR spectra for the catalytic reaction of alkene $\mathbf{1 q}$ and syngas (6 bar) in the presence of xantphos$\mathrm{PdI}_{2}$ or different isolated $\mathrm{Pd}$-intermediates in $\mathrm{CD}_{2} \mathrm{Cl}_{2}$ early in the reaction (top) and upon completion (bottom). 


\subsection{Evaluation of the catalytic reaction under $D_{2} / C O$ by the in-situ ${ }^{2} \mathrm{H} N M R$ spectroscopy - deuterioformylation study}

In analogy to the other NMR studies described above (section 7.13), investigation of the catalytic reaction under $\mathrm{D}_{2} / \mathrm{CO}$ was performed in a high-pressure J. Young tube. In a nitrogen-filled glovebox, a stock solution of vinyl phthalimide (43.3 mg, $0.25 \mathrm{mmol}$ ), xantphos- $\mathrm{PdI}_{2}(23.5 \mathrm{mg}, 0.025 \mathrm{mmol})$, and $\mathrm{Pd}(\mathrm{OAc})_{2}$ (1.1 mg, $0.0050 \mathrm{mmol}$ ), was prepared in $1 \mathrm{~mL}$ of $\mathrm{CH}_{2} \mathrm{Cl}_{2}$. A portion of $200 \mu \mathrm{L}$ of this stock solution was added to a J. Young tube, diluted with $300 \mu \mathrm{L}$ of $\mathrm{CH}_{2} \mathrm{Cl}_{2}$, then sealed and shaken. The tube was pressurized to 10 bar $C O / \mathrm{D}_{2}(1: 1)$ and the pressure was released, a process which was repeated 5 times. Finally, the tube was pressurized (6 bar $\mathrm{CO} / \mathrm{D}_{2}$ ), sealed, shaken, and placed inside a pre-heated NMR machine at 70 ${ }^{\circ} \mathrm{C}$. The reaction was followed over time by ${ }^{2} \mathrm{H}$ NMR spectroscopy. ${ }^{2} \mathrm{H}$ NMR data revealed fast incorporation of deuterium into 1q, at both $\alpha$ - and $\beta$ - vinyl C-H sites of the double bond ( $<10$ min), prior to formation of any observable amount of aldehyde $\mathbf{2 q}$. These data indicate that alkene insertion into the Pd-hydride bond occurs to form both Pd- $\alpha$-alkyl and Pd- $\beta$-alkyl species and that this step is reversible.

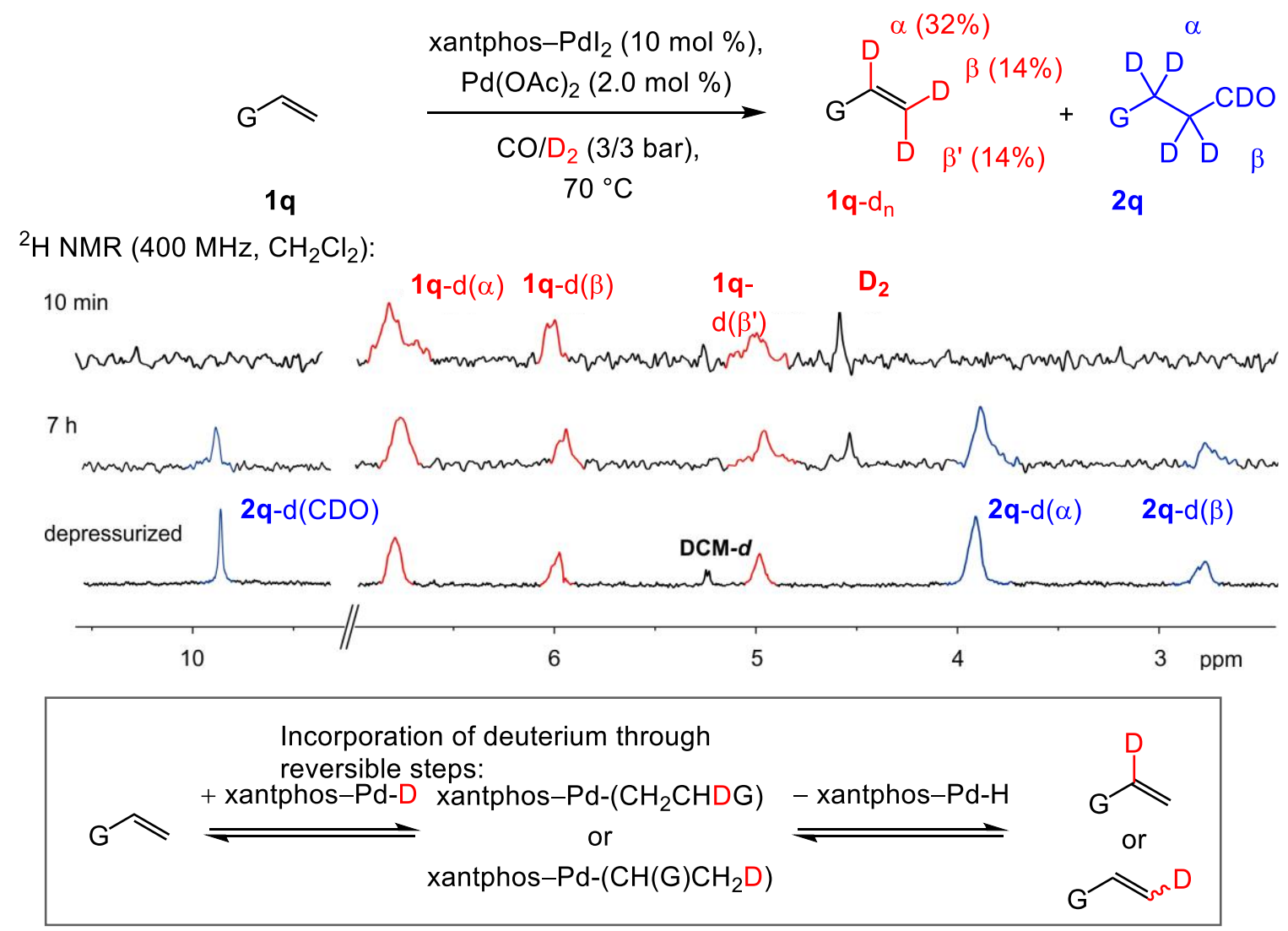

Fig. $\mathbf{S 1 0 3}{ }^{1} \mathrm{H}$ NMR spectra for the catalytic reaction of alkene $\mathbf{1 q}$ and $\mathrm{CO} / \mathrm{D}_{2}(3: 3$ bar) in the presence of 10 mol \% xantphos- $P d I_{2}$ and $2 \mathrm{~mol} \% \mathrm{Pd}(\mathrm{OAc})_{2}$ over time at $70^{\circ} \mathrm{C}$ in $\mathrm{CD}_{2} \mathrm{Cl}_{2}$. 


\section{Density Functional Theory (DFT) Calculations}

\subsection{Computational details}

DFT computations ${ }^{60}$ were performed with the Gaussian 09/Gaussian 16 suite of programs. ${ }^{61}$ Geometries were optimized with the M06- $\mathrm{L}^{62}$ functional and the def2-SVP basis $\operatorname{set}^{63}$ in conjunction with the corresponding Coulomb fitting basis set to speed up calculations. ${ }^{64}$ The effect of a polar reaction medium (dichloromethane, DCM) was approximated by means of the SMD solvation model. ${ }^{65}$ Several conformers have been investigated through manual screening and only the most stable transition state structure is reported. Stationary points were probed through vibrational analysis and Gibbs free energy corrections were performed under standard conditions $(298.15 \mathrm{~K}, 1.0 \mathrm{~atm})$. Transition states have been verified through Intrinsic Reaction Coordiante calculations (IRC) employing the L(ocal) Q(uadratic) $\mathrm{A}$ (approximation) method, ${ }^{66,67}$ followed by subsequent optimization of the end points with the abovementioned optimization method. We furthermore performed single point energy calculations with the $\omega-\mathrm{B} 97 \mathrm{MV}^{68}$ functional applying the SMD solvation model with dichloromethane as solvent and the larger def2-QZVPP ${ }^{63}$ basis set. These calculations have been carried out with the program ORCA 4.1.1. ${ }^{69}$ The complete free energy surfaces related to Figs. 6-7 in the manuscript are provided in Figs. S104-S107 and the computed geometries in .xyz file format are listed in Section 9. In addition, a separate file of computed geometries for convenient viewing with the program Mercury 3.3 (Zhang et al_coordinates.xyz) is included as part of the Supplementary Materials. ${ }^{70}$

\subsection{Modeling of dispersion interactions}

Several state-of-the-art DFT approaches and benchmark studies have been developed over the past 15 years by Truhlar, ${ }^{71,72}$ Grimme, ${ }^{73,74}$ Head-Gordon, ${ }^{75,76}$ et al. ${ }^{77,78}$ with particular focus on treatment of dispersion interactions ${ }^{79}$ and employed, for example, in modeling the olefin metathesis reaction. ${ }^{80,81,82,83}$ A notable impact of dispersion is related to the correct description of ligand association/dissociation steps during a catalytic cycle. ${ }^{83}$ Nonetheless, there have been raised concerns regarding the accurate modeling of dispersion interactions in solution. ${ }^{84,85}$ In particular, although structural information of precatalysts is available through $\mathrm{x}$-ray crystallography, ${ }^{81}$ there is very little information regarding their structure and that of related reactive intermediates in solution. Since dispersion effects might rather be overestimated by the applied solvation model, ${ }^{85}$ we report a second set of free energy values in addition to $\omega$-B97MV/def2-

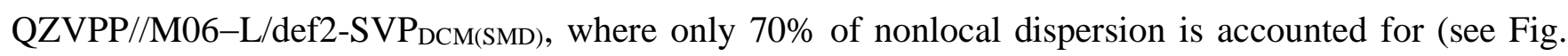
S99). 


\subsection{Free energy surfaces for reaction of cationic $L-P d-a c y l^{+}$intermediate}

\subsubsection{Reaction of cationic $\mathrm{L}-\mathrm{Pd}-\left.\mathrm{acy}\right|^{+}$intermediate with $\mathrm{LPdHX}$ (transition states $\mathrm{A}$ and $\mathrm{B}$ )}

Reaction of the Pd-hydride dimer $\mathbf{L}-\mathbf{P d H}(\mathbf{C O}) \mathbf{P d}-\mathbf{L}^{+}$with $\mathbf{P P h} \mathbf{h}_{4} \mathbf{I}$ or $\mathbf{P P h} \mathbf{h}_{4} \mathbf{O T f}$ leads to formation of the monomeric $\mathbf{L}-\mathbf{P d H X}$ species ( $\mathrm{X}=$ iodide or triflate), while one molecule of neutral $\mathbf{L}-\mathbf{P d}(\mathbf{C O})$ is generated (Fig. S104). Subsequent transformation with $\mathbf{L}-\mathbf{P d}-\mathbf{a c y l}^{+}$generates complexes $\mathbf{I N T}_{\mathbf{L P d H X}}{ }^{+}$ which are transformed via $\mathbf{T S}_{\mathbf{L P d H}}{ }^{+}$to the corresponding $\sigma$-complexes $\left(\mathbf{I N T} \mathbf{2}_{\mathbf{L P d H X}}{ }^{+}\right.$), wherein the aldehyde $\mathrm{C}-\mathrm{H}$ bond interacts with one of the Pd centers. Liberation of the aldehyde product ( $\mathrm{RCHO}$ ) leads to cationic bimetallic complexes $\mathbf{L}-\mathbf{P d}(\mathbf{I}) \mathbf{P d}-\mathbf{L}^{+}$and $\mathbf{L}-\mathbf{P d}(\mathbf{O T f}) \mathbf{P d}-\mathbf{L}^{+}$. For computed structures that are not displayed in Fig. S104, see Chart S2.

\subsubsection{Reaction of cationic $\mathrm{L}-\mathrm{Pd}-\mathrm{acy} \mathrm{I}^{+}$intermediate with $\mathrm{I}_{2} \mathrm{Pd}-\mathrm{H}^{-}$anion (transition states $\mathrm{C}, \mathrm{C}^{\prime}$} and D)

Further reaction of the monomeric $\mathbf{L P d H I}$ species with $\mathbf{P P h} \mathbf{h}_{4} \mathbf{I}$ assisted by polymeric $\mathrm{PdI}_{2}$ (modeled as $\mathbf{P d} \mathbf{d}_{4} \mathbf{I}_{10}{ }^{2-}$ dianion; see Chart S2) to scavenge liberated xantphos ligand as $\mathbf{L P d I _ { 2 }}$ leads to generation of the $\mathbf{I}_{2} \mathbf{P d}-\mathbf{H}^{-}$anion together with the $\mathbf{P d}_{3} \mathbf{I}_{\mathbf{8}}{ }^{2-}$ dianion (Fig. S105). $\mathbf{I}_{2} \mathbf{P d}-\mathbf{H}^{-}$subsequently reacts with $\mathbf{L}-\mathbf{P d}-\mathbf{a c y l}^{+}$through a neutral sequence of $\mathbf{I N T}_{\mathbf{C}} \rightarrow \mathbf{T S}_{\mathbf{C}} \rightarrow \mathbf{I N T}_{\mathbf{C}}$, where the bidentate xantphos ligand is simultaneously bound to both Pd centers. The corresponding sequence (INT1 $\mathbf{C}^{\prime} \rightarrow$ TS $_{\mathbf{C}^{\prime}} \rightarrow$ INT2 $_{\mathbf{C}^{\prime}}$ ), where the phosphine ligand is only bound to one Pd atom, is significantly higher in energy $(32.0 \mathrm{kcal} / \mathrm{mol}$ for $\mathbf{T S}_{\mathbf{C}}$, vs $21.5 \mathrm{kcal} / \mathrm{mol}$ for $\mathbf{T} \mathbf{S}_{\mathbf{C}}$, respectively). Liberation of the aldehyde product ( $\mathrm{RCHO}$ ) leads to bimetallic complex $\mathbf{L P d}_{2} \mathbf{I}_{2}$. Sequence INT1 $\mathbf{I}_{\mathbf{C}} \rightarrow \mathbf{T S}_{\mathbf{C}} \rightarrow \mathbf{I N T}_{\mathbf{C}}$ can be stabilized through binding of an additional iodide anion upon reaction with $\mathbf{P P h}_{4} \mathbf{I}$ (anionic sequence INT1 $\rightarrow \mathbf{T S}_{\mathbf{D}} \rightarrow$ INT2 $_{\mathbf{D}} ; 14.5$ $\mathrm{kcal} / \mathrm{mol}$ for $\left.\mathbf{T S}_{\mathbf{D}}\right)$. For computed structures that are not displayed in Fig. S105, see Chart S2.

\subsubsection{Reaction of cationic $\mathrm{L}-\mathrm{Pd}-\mathrm{acyl}{ }^{+}$intermediate with $\mathrm{H}_{2}$ (transition state $\mathrm{E}$ )}

Reaction of $\mathbf{L}-\mathbf{P d}-\mathbf{a c y l}^{+}$with $\mathrm{H}_{2}$ initially generates the $\sigma$-dihydrogen complex ( $\mathbf{I N T 1}_{\mathbf{H}_{2}}{ }^{+}$; Fig. S106). The latter is transformed via $\mathbf{T S}_{\mathrm{H}_{2}}{ }^{+}$to the $\sigma$-aldehyde complex $\left(\mathbf{I N T} \mathbf{H}_{2}{ }^{+}\right)$. Upon liberation of the aldehyde product $(\mathrm{RCHO})$ the cationic $\mathrm{Pd}-$ hydride monomer is formed $\left(\mathbf{L}-\mathbf{P d}-\mathbf{H}^{+}\right)$. For computed structures that are not displayed in Fig. S106, see Chart S2. 
8.3.4 Reaction of cationic $\mathrm{L}-\mathrm{Pd}-\mathrm{acy} \mathrm{I}^{+}$intermediate with $\mathrm{HI}$ (transition state $\mathrm{F}$ )

Reaction of L-Pd-acyl ${ }^{+}$with HI initially generates a $\sigma-$ complex (INT1 ${ }^{+}{ }^{+}$; Fig. S107), wherein the proton of HI interacts with the d-electrons of Pd. Further transformation of $\mathbf{I N T 1}_{\mathrm{HI}^{+}}{ }^{+}$via $\mathbf{T S}_{\mathbf{H I}^{+}}{ }^{+}$leads to activation of $\mathrm{HI}$ (INT2 $\mathbf{H I}^{+}$; oxidative addition). The latter reacts through $\mathbf{T S} \mathbf{H}_{\mathbf{H I}}{ }^{+}$to form van der Waals complex INT3 $\mathrm{HII}^{+}$. Upon liberation of the aldehyde product (RCHO) the cationic Pd-iodide monomer is formed $\left(\mathbf{L}-\mathbf{P d}-\mathbf{I}^{+}\right)$. For computed structures that are not displayed in Fig. S107, see Chart S2. 


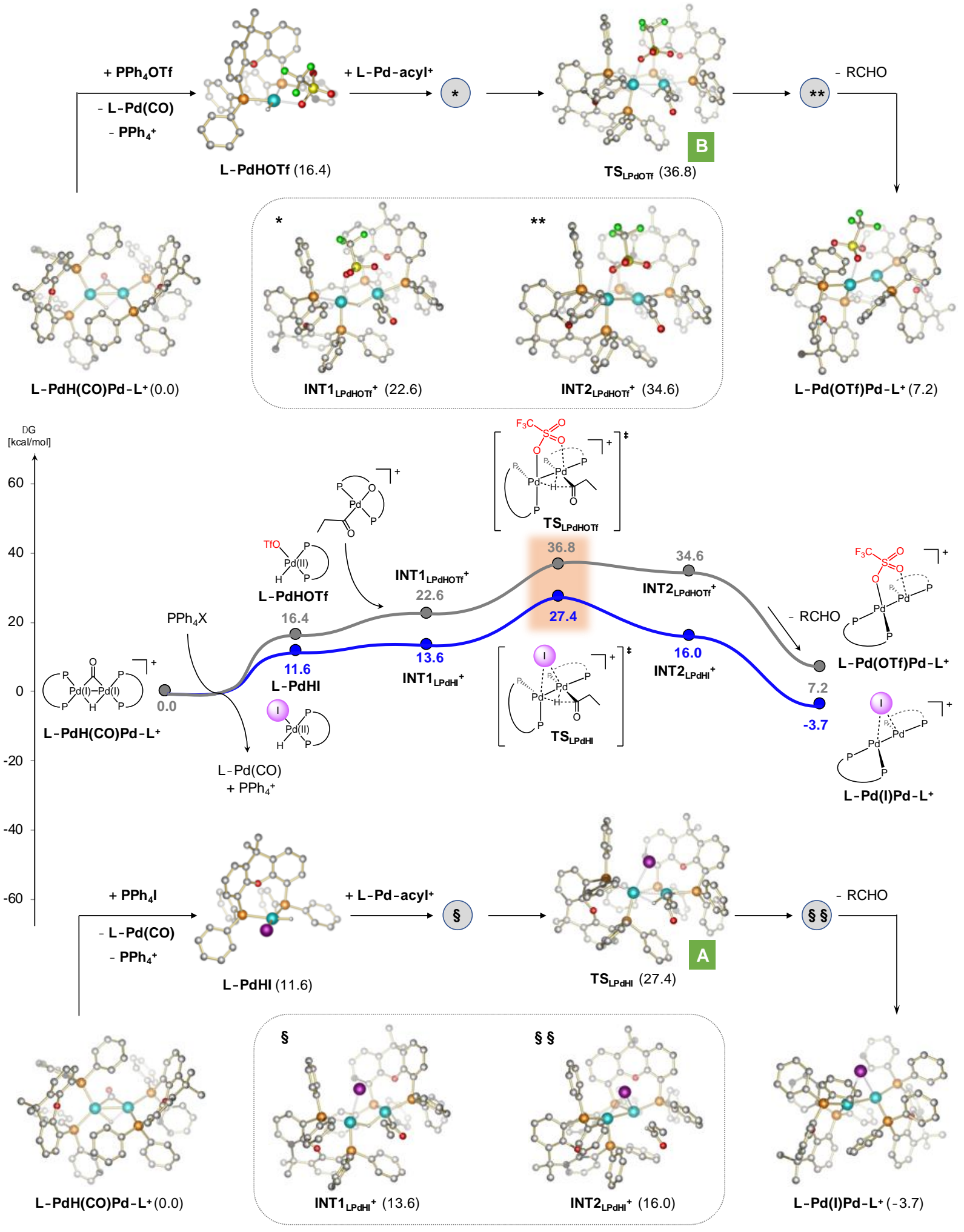

Fig. S104 Free energy surface for reaction of cationic $\mathbf{L}-\boldsymbol{P d}$-acyl $\boldsymbol{l}^{+}$intermediate with $\mathbf{L P d H X}$ (see transition states

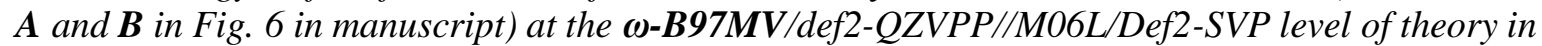
dichloromethane as solvent (SMD solvation model); SMD, solvation model based on density; INT1 and INT2, intermediates; $\boldsymbol{T S}$, transition state; $\boldsymbol{X}$, iodide or triflate anion. 


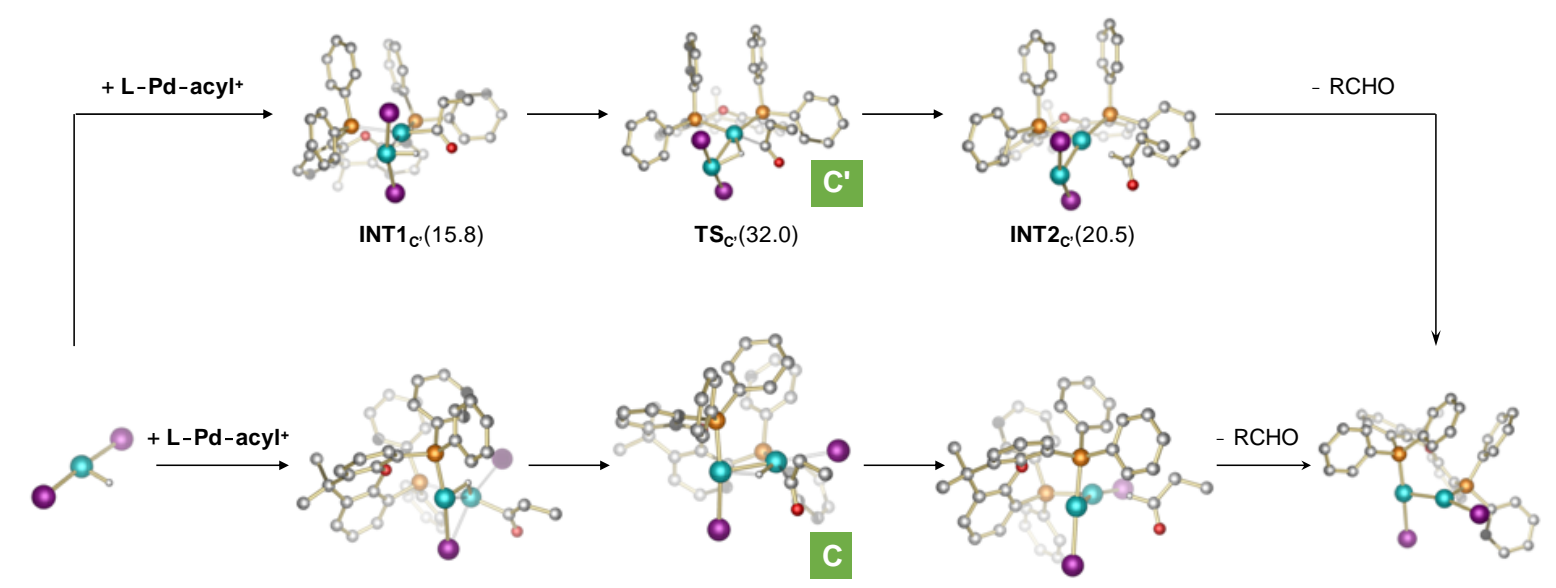

$\begin{array}{lllll}\mathbf{l}_{2} \mathbf{P d} \mathbf{H}(19.5) & \mathbf{I N T}_{\mathrm{C}}(15.1) & \mathbf{T S}_{\mathrm{C}}(21.5) & \mathbf{I N T 2}_{\mathrm{C}}(14.2) & \mathbf{L P d}_{2} \mathbf{I}_{\mathbf{2}}(6.9)\end{array}$

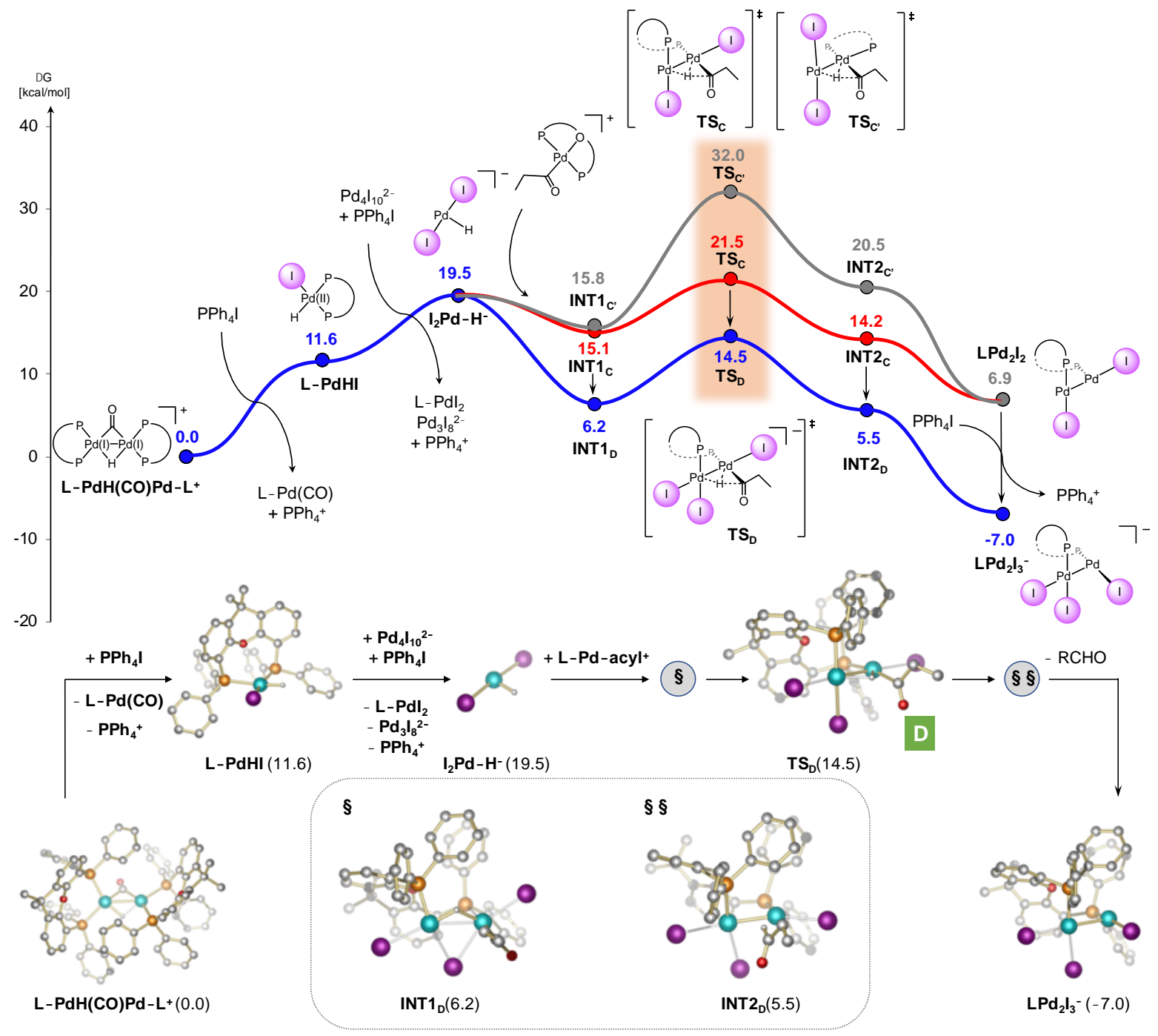

Fig. S105 Free energy surface for reaction of cationic $\mathbf{L}-\mathbf{P d}$-acyl $\boldsymbol{l}^{+}$intermediate with $\mathbf{I}_{2} \mathbf{P d}-\boldsymbol{H}^{-}$anion (see transition

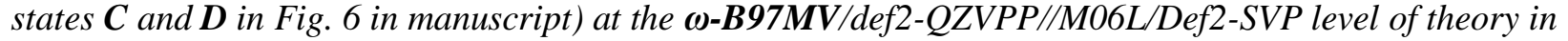
dichloromethane as solvent (SMD solvation model); SMD, solvation model based on density; INT1 and INT2, intermediates; $\mathbf{T S}$, transition state. 


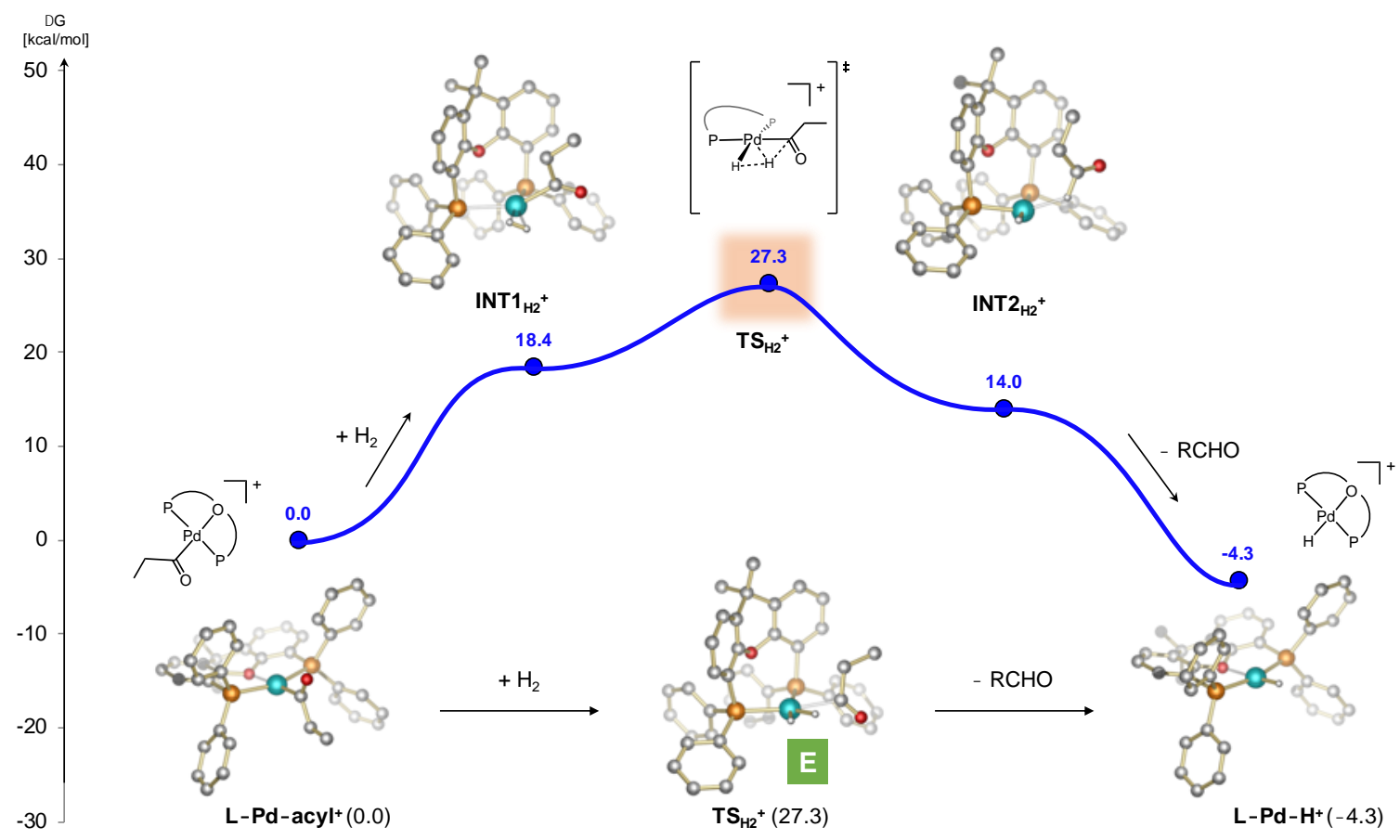

Fig. S106 Free energy surface for reaction of cationic $\mathbf{L}-\boldsymbol{P d}$-acyl $\boldsymbol{l}^{+}$intermediate with $\boldsymbol{H}_{2}$ (see transition state $\boldsymbol{E}$ in

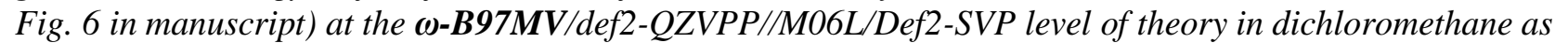
solvent (SMD solvation model); SMD, solvation model based on density; INT1 and INT2, intermediates; TS, transition state.

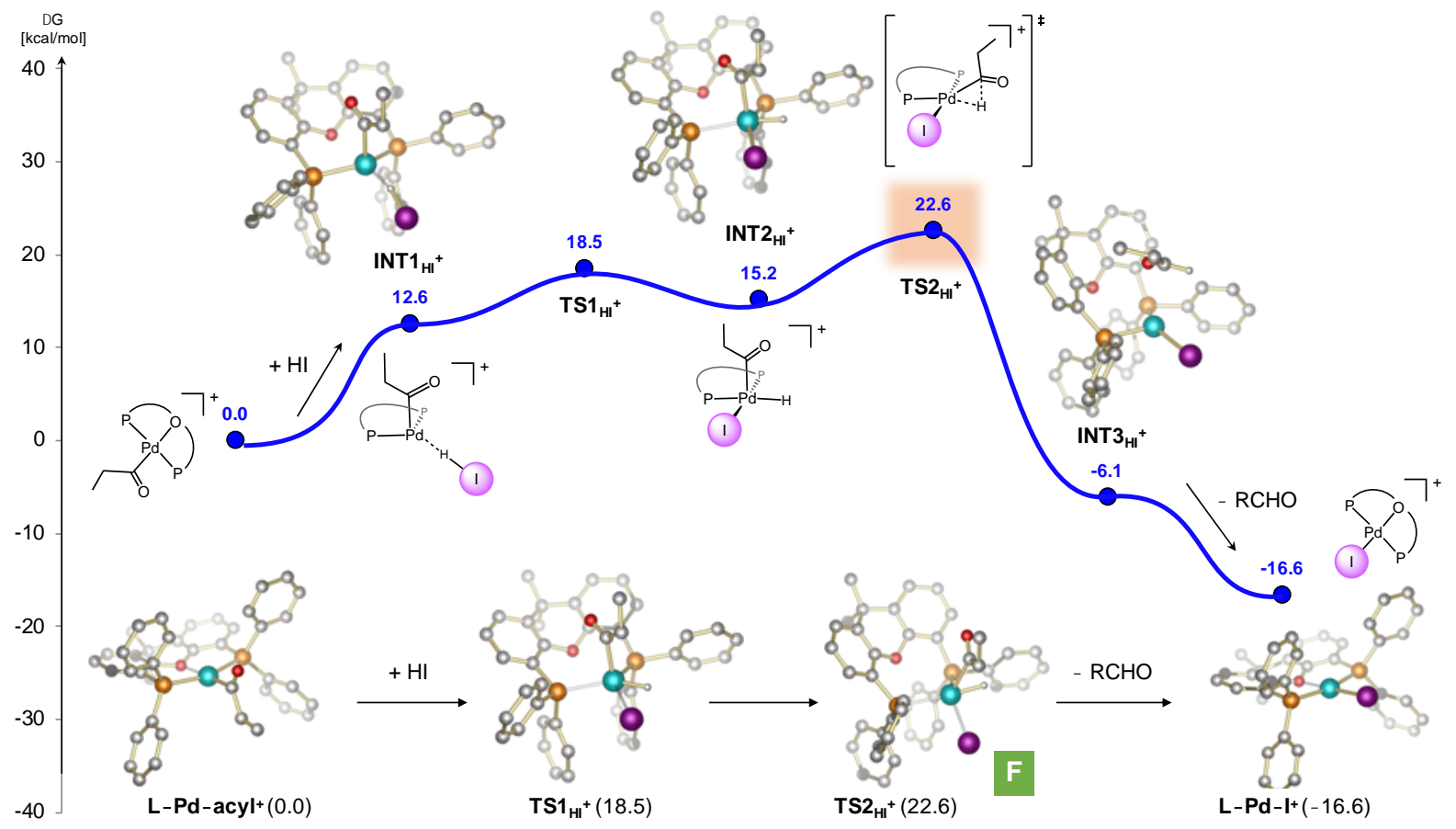

Fig. $\mathbf{S 1 0 7}$ Free energy surface for reaction of cationic $\mathbf{L}-\boldsymbol{P d}$-acyl $\boldsymbol{l}^{+}$intermediate with $\mathbf{H I}$ (see transition state $\boldsymbol{F}$ in

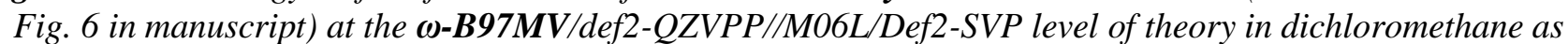
solvent (SMD solvation model); SMD, solvation model based on density; INT1 and INT2, intermediates; TS, transition state. 
additional structures:
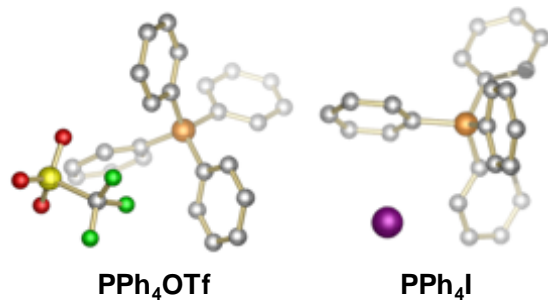

$\mathrm{PPh}_{4} \mathrm{I}$

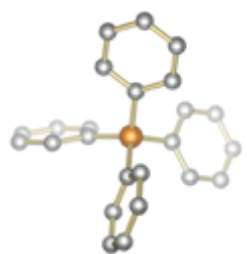

$\mathrm{PPh}_{4}{ }^{+}$

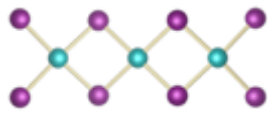

$\mathrm{Pd}_{3} \mathbf{I}_{8}^{2}$

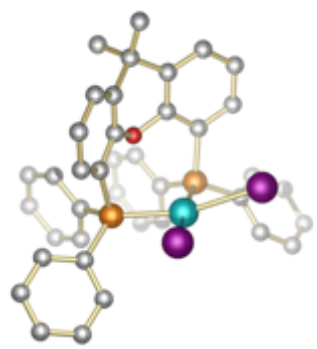

$\mathbf{L} \mathrm{PdI}_{2}$

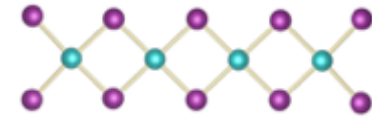

$\mathrm{Pd}_{4} \mathrm{I}_{10}{ }^{2}$

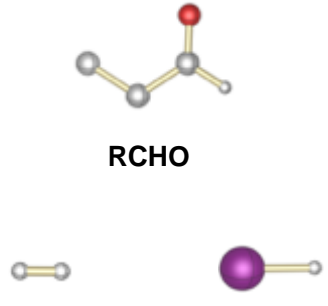

$\mathrm{H}_{2}$

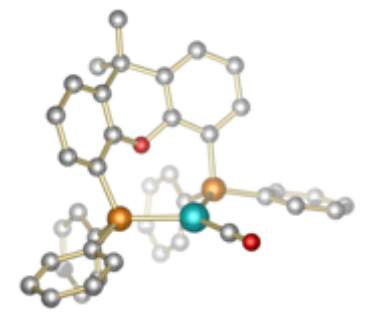

L Pd CO
Chart $\mathbf{S} 2$ Additional computed structures for reaction of cationic $\mathbf{L}-\boldsymbol{P d}$-acyl $\boldsymbol{l}^{+}$intermediate with various $P d$ hydride species, HI and $\mathrm{H}_{2}$ (see Figs. S96-S99) at the $\omega$-B97MV/def2-QZVPP//MO6L/Def2-SVP level of theory in dichloromethane as solvent (SMD solvation model); SMD, solvation model based on density. 


\subsection{The effect of nonlocal dispersion on the free energy surfaces}

As mentioned above, accurate modelling of dispersion interactions appears to be crucial for predicting the correct relative energies of transition states A-F (Fig. S108). For example, generation of the monomeric $\mathbf{L}-\mathbf{P d H I}$ species from $\mathbf{L}-\mathbf{P d H}(\mathbf{C O}) \mathbf{P d}-\mathbf{L}^{+}$is favored when the amount of dispersion is reduced [11.6 (Fig. S108a) vs $4.8 \mathrm{kcal} / \mathrm{mol}$ (Fig. S108e), respectively]. In contrast, bimetallic transition states $\mathbf{A}$ and $\mathbf{B}$ become less favored when only $70 \%$ nonlocal dispersion is accounted for [33.6 and 45.1 kcal/mol (Fig. S108e) vs 27.4 and 36.8 kcal/mol (Fig. S108a), respectively]. Furthermore, reaction of the cationic $\mathbf{L}-\mathbf{P d}-\mathbf{a c y l}^{+}$species with the smaller $\mathbf{I}_{2} \mathbf{P d}-\mathbf{H}^{-}$anion appears to be less sensitive to inclusion of dispersion, as comparison of the free energies for transition states $\mathbf{C}, \mathbf{C}^{\prime}$ and $\mathbf{D}$ in Fig. S108b and Fig. S108f indicate. Even for reaction of $\mathbf{L}-\mathbf{P d}-\mathbf{a c y l}^{+}$with $\mathrm{H}_{2}$ and $\mathrm{HI}$ minor destabilization of transition states $\mathbf{E}$ and $\mathbf{F}$ is predicted when the contribution of dispersion is reduced (Figs. S108c-d vs Figs. S108g-h). These latter trends can likely be explained by a change of ligand geometry in $\mathbf{L}-\mathbf{P d}-\mathbf{a c y l}{ }^{+}$vs $\mathbf{T S}_{\mathbf{H}_{2}}{ }^{+}$or TS $_{\mathbf{H I}^{+}}{ }^{+}$(see Figs. S106-S107). In contrast to $\mathbf{L}-\mathbf{P d - a c y l}{ }^{+}$there is a $\pi-\pi$ stacking interaction in transition states $\mathbf{T S}_{\mathbf{H} 2}{ }^{+}$or $\mathbf{T S}_{\mathrm{HI}^{+}}{ }^{+}$, which will be stabilized through attractive dispersion interactions. 


\section{$\omega \mathrm{B} 97 \mathrm{MV} /$ def2QZVPP//M06L/def2SVP $\mathrm{DCM(SMD)}(100 \%$ nonlocal dispersion)}

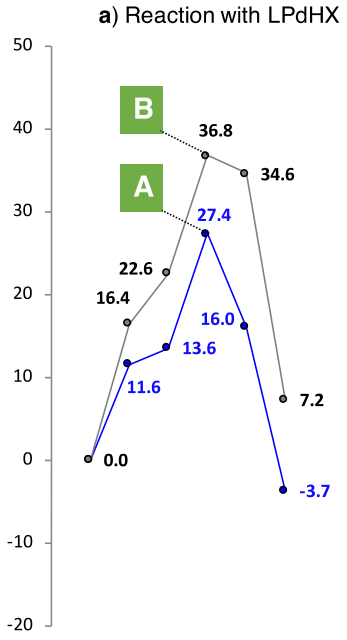

b) Reaction with $\mathrm{I}_{2} \mathrm{PdH}^{-}$

c) Reaction with $\mathrm{H}_{2}$

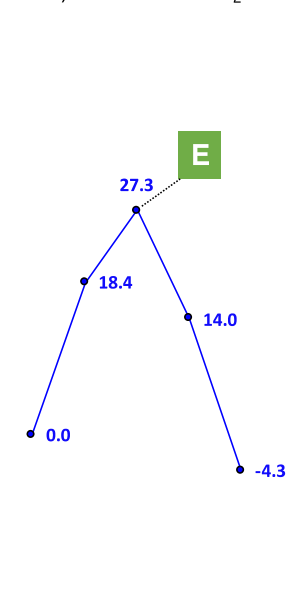

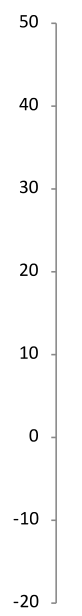

d) Reaction with $\mathrm{HI}$

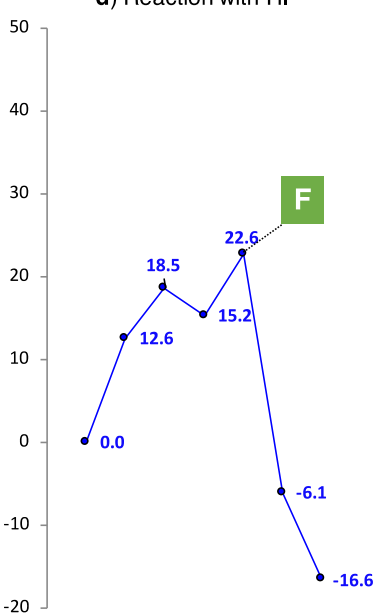

g) Reaction with $\mathrm{H}_{2}$

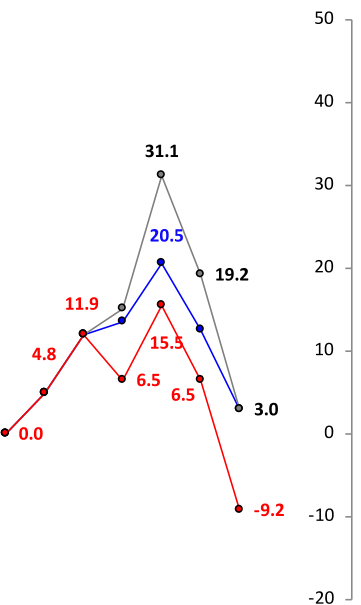

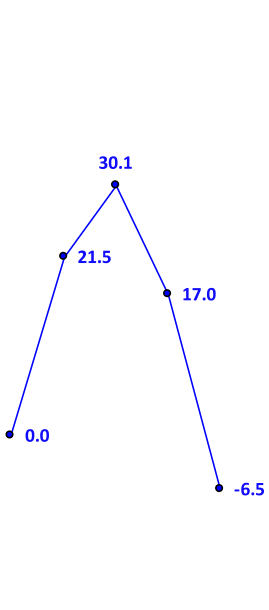

h) Reaction with $\mathrm{HI}$

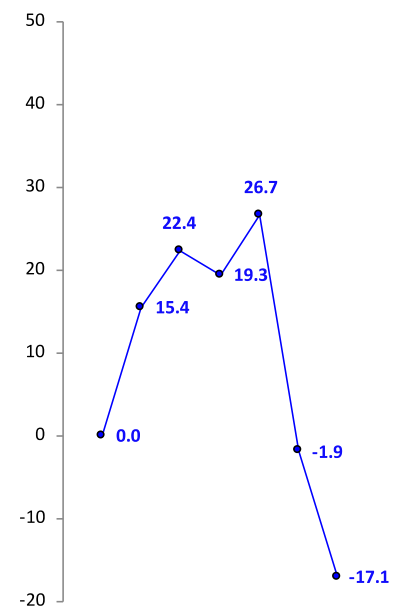

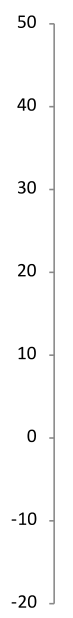

f) Reaction with $\mathrm{I}_{2} \mathrm{PdH}^{-}$

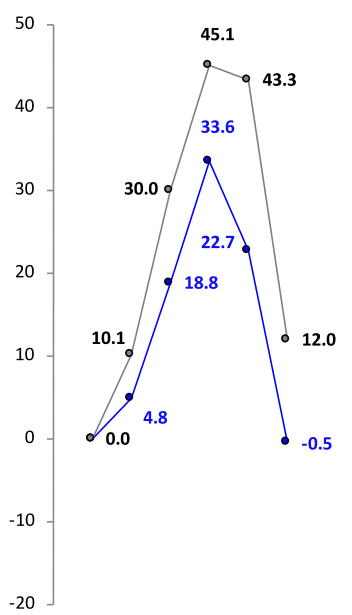

Fig. S108 The effect of nonlocal dispersion on the free energy surfaces for reaction of cationic $\mathbf{L}_{-P d-a c y l}{ }^{+}$ intermediate with various Pd-hydride species, HI and $\mathrm{H}_{2}$ at the $\omega$-B97MV/def2-QZVPP//M06L/Def2-SVP level of theory in dichloromethane as solvent (SMD solvation model, top) and when only 70\% on nonlocal dispersion is accounted for (bottom); SMD, solvation model based on density. 


\section{Coordinates after optimization with M06L/Def2SVP}

46

Fig._S104_PPh4I / electronic energy: -1564.99223757 a.u. / lowest freq: $1.66 \mathrm{~cm}-1$

H $0.886573 \quad 4.767143 \quad-2.319091$

H $\quad-0.858973 \quad 4.877420 \quad-0.545811$

C $\quad 0.488558 \quad 3.846060 \quad-1.887359$

$\begin{array}{llll}\text { C } & -0.489714 & 3.910444 & -0.893439\end{array}$

$\begin{array}{llll}C & 0.960446 & 2.611430 & -2.329534\end{array}$

$\begin{array}{llll}\text { C } & -0.998894 & 2.739416 & -0.339975\end{array}$

C $0.458173 \quad 1.432346-1.782480$

C $-0.524645 \quad 1.494892 \quad-0.786144$

H $\quad 0.370603 \quad 1.753104 \quad 1.797607$

H $1.557585 \quad 1.318681 \quad 3.921653$

C $0.396020 \quad 0.739566 \quad 2.205354$

$\begin{array}{llll}P & -1.124428 & -0.012604 & -0.002566\end{array}$

C $1.069478 \quad 0.493612 \quad 3.399364$

C $-3.423063-0.319766 \quad 1.546815$

$\begin{array}{llll}C & -0.216987 & -0.319847 & 1.523594\end{array}$

$\begin{array}{llll}\text { H } & -2.783526 & -0.820152 & 2.278439\end{array}$

C $1.138328-0.801424 \quad 3.910748$

C $-0.150062-1.623064 \quad 2.040304$

H $1.678686-0.991535 \quad 4.840805$

$\begin{array}{llll}\text { C } & 0.529940 & -1.858028 & 3.231960\end{array}$

H $\quad-0.621141-2.455064 \quad 1.510003$

H $\quad 0.588591 \quad-2.873769 \quad 3.628213$

H $\quad-1.763476 \quad 2.793702 \quad 0.440161$

H $\quad-5.713405 \quad 1.482656-1.026781$

$\begin{array}{llll}\text { C } & -5.070911 & 0.974885 & -0.304488\end{array}$

$\begin{array}{llll}\text { C } & -3.708646 & 0.850340 & -0.563332\end{array}$

$\begin{array}{llll}\text { C } & -5.610219 & 0.455626 & 0.873341\end{array}$

$\begin{array}{llll}\text { H } & -6.678929 & 0.558308 & 1.074600\end{array}$

$\begin{array}{llll}\text { C } & -2.879468 & 0.199122 & 0.364137\end{array}$

$\begin{array}{llll}C & -4.787799 & -0.189233 & 1.796397\end{array}$

H $\quad-5.207648 \quad-0.591135 \quad 2.720739$

H $\quad-3.291075 \quad 1.260316 \quad-1.487081$

$\begin{array}{lllll}\text { H } & 0.838330 & 0.469737 & -2.132778\end{array}$

H $1.7300852 .558965-3.102090$

$\begin{array}{llll}\text { C } & -1.756835 & -2.965453 & -2.755036\end{array}$

C $-1.965891-1.903577-1.877688$

$\begin{array}{llll}\text { C }-0.493862 & -3.547881 & -2.862244\end{array}$

$\begin{array}{llll}\text { C } & -0.900586 & -1.423801 & -1.102979\end{array}$

$\begin{array}{llll}\text { C } & 0.565911 & -3.072797 & -2.088866\end{array}$

$\begin{array}{llll}\text { C } & 0.369030 & -2.014296 & -1.206206\end{array}$

H $1.556132-3.526294-2.168763$

$\begin{array}{llll}H & 1.207543 & -1.643183 & -0.606516\end{array}$

H $-0.335418-4.380705-3.551197$

$\begin{array}{llll}H & -2.960385 & -1.458200 & -1.794113\end{array}$

$\begin{array}{llll}\text { H } & -2.588560 & -3.340630 & -3.354894\end{array}$

\begin{tabular}{llll}
\hline & 3.797453 & 0.041099 & -0.014303
\end{tabular}

Fig._S104_PPh4(+) / electronic energy: -1266.94473206 a.u. / lowest freq: $-\mathbf{2 1 . 9 3} \mathrm{cm}-1$

H $-3.315805-4.593781 \quad 0.437567$

H $-3.875099-2.792592-1.187549$

$\begin{array}{llll}\text { C } & -2.676863 & -3.711328 & 0.360497\end{array}$

$\begin{array}{llll}\text { C } & -2.992647 & -2.702566 & -0.551000\end{array}$

C $-1.552701-3.593315 \quad 1.176718$

C $\quad-2.186328-1.572343-0.648565$

C $-0.736329-2.467514 \quad 1.085969$

$\begin{array}{llll}\text { C } & -1.051537 & -1.454459 & 0.170619\end{array}$

H $-0.089323-1.750850 \quad-2.369859$

H $\quad 1.388738-1.909985-4.34794$

C $0.780712-1.094640-2.449898$

$\begin{array}{llll}\text { P } & -0.000567 & 0.000329 & -0.000299\end{array}$

C $1.614321-1.185249-3.563193$

$\begin{array}{llll}\text { C } & -0.765094 & 2.449963 & -1.107165\end{array}$

$\begin{array}{llll}\text { C } & 1.072801 & -0.170191 & -1.438540\end{array}$

H $0.114417 \quad 2.369431-1.750551$

$\begin{array}{llll}\text { C } & 2.733244 & -0.360286 & -3.669917\end{array}$

$\begin{array}{llll}\text { C } & 2.203160 & 0.657267 & -1.544589\end{array}$

H $3.385825-0.437468$ - 4.542313

$\begin{array}{llll}\text { C } 3.026826 & 0.559642 & -2.662109\end{array}$

H $2.441477 \quad 1.374826-0.754180$

H $3.905372 \quad 1.202773 \quad-2.742733$

H $-2.441722 \quad-0.781008 \quad-1.35912$

H $-3.921821 \quad 2.744412 \quad 1.145639$

$\begin{array}{llll}\text { C } & -3.034131 & 2.663522 & 0.515158\end{array}$

$\begin{array}{llll}C & -2.213182 & 1.545034 & 0.623507\end{array}$

$\begin{array}{llll}\text { C } & -2.726274 & 3.671723 & -0.399697\end{array}$

$\begin{array}{llll}\text { H } & -3.376121 & 4.545406 & -0.485003\end{array}$

$\begin{array}{llll}\text { C } & -1.070955 & 1.438666 & -0.187040\end{array}$

C -1.5961113 .564066 -1.209080

$\begin{array}{llll}\text { H } & -1.359424 & 4.349020 & -1.930083\end{array}$

$\begin{array}{llll}\text { H } & -2.461991 & 0.753551 & 1.336241\end{array}$

H $\quad 0.138405-2.378858 \quad 1.734824$

$\begin{array}{lllll}\text { H } & -1.309394 & -4.379033 & 1.894617\end{array}$ 
$\begin{array}{llll}\text { C } & 1.534934 & 1.199180 & 3.593087\end{array}$

C $0.719490 \quad 1.095971 \quad 2.467643$

C $2.671793 \quad 0.400691 \quad 3.710590$

C $1.048113 \quad 0.185884 \quad 1.454485$

C $3.001407-0.505289 \quad 2.701334$

$\begin{array}{llll}C & 2.196070 & -0.614971 & 1.571550\end{array}$

H $3.893682-1.128041 \quad 2.790727$

H $2.461601-1.321622 \quad 0.780008$

H $3.3095260 .487506 \quad 4.593011$

H $\quad-0.164683 \quad 1.731698 \quad 2.379917$

H $1.280544 \quad 1.912944 \quad 4.379086$

77

Fig._S104_LPdCO / electronic energy: -2503.16331913 a.u. / lowest freq: $11.14 \mathrm{~cm}-1$

C $1.917493-0.756127 \quad 1.670488$

C $2.123012-2.070003 \quad 2.124812$

H $2.320829-2.870298 \quad 1.403946$

$\begin{array}{llll}\text { C } & 2.096031 & -2.364087 & 3.485327\end{array}$

H $2.272425 \quad-3.389490 \quad 3.820471$

C $1.840150-1.354741 \quad 4.415481$

$\begin{array}{llll}\text { H } & 1.813717 & -1.584845 & 5.483613\end{array}$

C $1.608771-0.053511 \quad 3.972354$

H $1.3994720 .741891 \quad 4.692577$

C $1.648343 \quad 0.247421 \quad 2.609743$

H $1.484103 \quad 1.2792792 .287003$

C $3.619370-1.131399-0.571920$

$\begin{array}{llll}\text { C } 3.804756 & -1.744726 & -1.816650\end{array}$

$\begin{array}{llll}\text { H } & 2.949992 & -1.846676 & -2.494362\end{array}$

$\begin{array}{llll}\text { C } & 5.059193 & -2.229033 & -2.190056\end{array}$

$\begin{array}{lllll}\text { H } & 5.188474 & -2.707028 & -3.164152\end{array}$

C $6.139939-2.113680-1.31703$

H $7.121136-2.499068$-1.605165

$\begin{array}{llll}\text { C } & 5.965210 & -1.506679 & -0.071282\end{array}$

$\begin{array}{llll}\text { H } & 6.809627 & -1.413021 & 0.616204\end{array}$

$\begin{array}{llll}\text { C } & 4.714502 & -1.017538 & 0.299441\end{array}$

H $4.590332-0.536365 \quad 1.274578$

$\begin{array}{llll}\text { C } & 2.192015 & 1.336921 & -0.327435\end{array}$

C $3.3801801 .939303-0.764573$

$\begin{array}{lllll}\text { H } & 4.275803 & 1.332368 & -0.916321\end{array}$

C $3.423544 \quad 3.305610-1.037031$

$\begin{array}{llll}\text { H } & 4.356200 & 3.756264 & -1.383454\end{array}$

$\begin{array}{llll}\text { C } 2.287109 & 4.100060 & -0.880802\end{array}$

H $2.341838 \quad 5.167129-1.106178$

$\begin{array}{llll}\text { C } & 1.085661 & 3.543708 & -0.434721\end{array}$

$\begin{array}{lllll}\text { C } & -0.196851 & 4.323800 & -0.163833\end{array}$

$\begin{array}{llll}\text { C } & -1.361329 & 3.429376 & -0.576209\end{array}$

$\begin{array}{llll}C & -2.558182 & 3.868603 & -1.150428\end{array}$

H $-2.6894804 .924851-1.395245$

$\begin{array}{llll}\text { C } & -3.596607 & 2.971532 & -1.406391\end{array}$

H $\quad-4.526313 \quad 3.333794 \quad-1.850738$

$\begin{array}{llll}\text { C } & -3.462644 & 1.617982 & -1.096825\end{array}$

$\begin{array}{lllll}\text { H } & -4.285078 & 0.928883 & -1.306009\end{array}$

$\begin{array}{llll}\text { C } & -2.273492 & 1.136302 & -0.536087\end{array}$

$\begin{array}{llll}C & -1.252348 & 2.065503 & -0.296972\end{array}$

$\begin{array}{llll}\text { C } & 1.074992 & 2.170456 & -0.171318\end{array}$

$\begin{array}{lrrr}\text { C } & -0.297955 & 4.565057 & 1.355110\end{array}$

$\begin{array}{llll}H & -0.286752 & 3.622838 & 1.923412\end{array}$

$\begin{array}{llll}\text { H } & -1.230569 & 5.093740 & 1.602193\end{array}$

H $\quad 0.545180 \quad 5.177957 \quad 1.706724$

$\begin{array}{llll}\text { C } & -0.218251 & 5.663532 & -0.884182\end{array}$

$\begin{array}{llll}\text { H } & 0.614160 & 6.300801 & -0.557019\end{array}$

H $-1.138753 \quad 6.217299 \quad-0.655890$

$\begin{array}{llll}\text { H } & -0.151310 & 5.550074 & -1.975959\end{array}$

$\begin{array}{lllll}\text { C }-3.493129 & -1.446410 & -0.573948\end{array}$

$\begin{array}{llll}\text { C } & -4.585710 & -1.431394 & 0.305942\end{array}$

H $-4.501415 \quad-0.932273 \quad 1.27605$

$\begin{array}{llll}\text { C } & -5.785680 & -2.045864 & -0.048658\end{array}$

$\begin{array}{llll}\text { H } & -6.628684 & -2.029638 & 0.646696\end{array}$

$\begin{array}{llll}\text { C } & -5.911155 & -2.678519 & -1.286773\end{array}$

$\begin{array}{llll}\text { H } & -6.851859 & -3.161877 & -1.561822\end{array}$

$\begin{array}{llll}\text { C } & -4.830397 & -2.697692 & -2.168299\end{array}$

$\begin{array}{lllll}\text { H } & -4.920599 & -3.195493 & -3.136916\end{array}$

C $-3.626667-2.090401-1.811024$

H $-2.771474-2.115421 \quad-2.495793$

$\begin{array}{llll}C & -1.884148 & -0.669415 & 1.655401\end{array}$

$\begin{array}{llll}\text { C } & -1.516996 & -1.879173 & 2.265142\end{array}$

H $-1.225036-2.732402 \quad 1.642813$

C $-1.526785-2.006273 \quad 3.652194$

H $-1.243040-2.956809 \quad 4.111284$

$\begin{array}{llll}\text { C } & -1.883542 & -0.919670 & 4.452864\end{array}$

$\begin{array}{llll}\text { H } & -1.884027 & -1.017018 & 5.541498\end{array}$

$\begin{array}{llll}\text { C } & -2.227774 & 0.293160 & 3.857538\end{array}$

$\begin{array}{llll}\text { H } & -2.503849 & 1.149938 & 4.477735\end{array}$

C $\quad-2.231206 \quad 0.418527 \quad 2.467591$

H $-2.522501 \quad 1.371936 \quad 2.016843$

$\begin{array}{lllll}\mathrm{O} & -0.089260 & 1.570263 & 0.237051\end{array}$

$\begin{array}{llll}\text { Pd } & 0.071408 & -1.290532 & -1.434302\end{array}$

$\begin{array}{llll}P & 1.955433 & -0.476967 & -0.142675\end{array}$

$\begin{array}{llll}P & -1.897130 & -0.622416 & -0.18145\end{array}$ 
$\begin{array}{llll}C & 0.136546 & -2.158754 & -3.123820\end{array}$

$\begin{array}{llll}0 & 0.182049 & -2.682347 & -4.159273\end{array}$

Fig. S104_Pd-acyl(+) / electronic energy: -2582.17852429 a.u. / lowest freq: $18.05 \mathrm{~cm}-1$

$\begin{array}{lll}\text { Pd }-0.006524 & -0.675121 & -0.185512\end{array}$

$\begin{array}{llll}P & -2.299572 & -0.291652 & 0.009144\end{array}$

$\begin{array}{llll}\text { P } & 2.295916 & -0.356819 & 0.002961\end{array}$

$\begin{array}{lllll}O & 0.024358 & 1.659386 & -0.207410\end{array}$

$\begin{array}{llll}\text { C } & -1.169636 & 2.311458 & 0.071909\end{array}$

C $-2.330963 \quad 1.529903 \quad 0.205586$

$\begin{array}{llll}\text { C } & -3.534996 & 2.179551 & 0.509181\end{array}$

H $-4.450331 \quad 1.591306 \quad 0.620750$

C $-3.571759 \quad 3.558324 \quad 0.674077$

H $-4.511847 \quad 4.056131 \quad 0.918454$

$\begin{array}{llll}\text { C } & -2.407738 & 4.306971 & 0.513171\end{array}$

H $\quad-2.456932 \quad 5.391213 \quad 0.624075$

$\begin{array}{llll}\text { C } & -1.186861 & 3.705800 & 0.194634\end{array}$

C $0.065260 \quad 4.504591-0.139842$

C $1.290445 \quad 3.669855 \quad 0.206860$

C $2.525042 \quad 4.234750 \quad 0.538796$

$\begin{array}{lllll}\text { H } & 2.604456 & 5.316879 & 0.652673\end{array}$

C $3.6650593 .452250 \quad 0.709996$

H $4.616508 \quad 3.921844 \quad 0.965875$

C $3.590463 \quad 2.075694 \quad 0.539349$

H $4.487592 \quad 1.460864 \quad 0.656089$

$\begin{array}{lllll}\text { C } & 2.371364 & 1.461831 & 0.222352\end{array}$

$\begin{array}{lllll}\text { C } & 1.234247 & 2.276825 & 0.081767\end{array}$

$\begin{array}{llll}\text { C } & 0.075937 & 4.734473 & -1.664648\end{array}$

H $0.0640623 .786906 \quad-2.222810$

H $\quad 0.976628 \quad 5.290319 \quad-1.963891$

H $-0.804840 \quad 5.317108 \quad-1.972094$

C $\quad 0.081348 \quad 5.857790 \quad 0.562151$

$\begin{array}{lllll}\text { H } & 0.071617 & 5.759918 & 1.657085\end{array}$

$\begin{array}{llll}\text { H } & -0.780756 & 6.467234 & 0.264571\end{array}$

$\begin{array}{lllll}\text { H } & 0.967329 & 6.438822 & 0.278037\end{array}$

C $-3.408063-0.679302-1.376606$

$\begin{array}{llll}\text { C } & -3.802304 & -2.017666 & -1.546545\end{array}$

$\begin{array}{llll}\text { H } & -3.503647 & -2.776144 & -0.815160\end{array}$

C $-4.580874-2.385235-2.640330$

H $-4.888921-3.426601-2.758800$

$\begin{array}{llll}\text { C } & -4.965109 & -1.427055 & -3.580797\end{array}$

H $\quad-5.576004-1.716739-4.438775$

$\begin{array}{llll}\text { C } & -4.565818 & -0.100611 & -3.423824\end{array}$

$\begin{array}{lllll}\text { H } & -4.863147 & 0.652085 & -4.157476\end{array}$

$\begin{array}{llll}\text { C } & -3.788381 & 0.276163 & -2.328264\end{array}$

$\begin{array}{lllll}\text { H } & -3.480649 & 1.319497 & -2.217028\end{array}$

C $-3.100061-0.958603 \quad 1.501418$

C $-4.485541-1.150802 \quad 1.601728$

$\begin{array}{llll}\text { H } & -5.138709 & -0.919811 & 0.755538\end{array}$

$\begin{array}{llll}\text { C } & -5.035172 & -1.641854 & 2.784625\end{array}$

$\begin{array}{llll}\text { H } & -6.114791 & -1.791861 & 2.856950\end{array}$

$\begin{array}{llll}\text { C }-4.212136 & -1.940923 & 3.871317\end{array}$

H $-4.647921 \quad-2.329260 \quad 4.794761$

C $-2.833091-1.751601 \quad 3.776413$

H -2.185508 -1.991927 4.622554

$\begin{array}{llll}\text { C } & -2.277332 & -1.267166 & 2.59432\end{array}$

$\begin{array}{llll}\text { H } & -1.193969 & -1.132542 & 2.505443\end{array}$

C $3.406582-0.741348-1.383309$

$\begin{array}{llll}\text { C } 3.794062 & -2.079857 & -1.565555\end{array}$

$\begin{array}{llll}\text { H } & 3.482699 & -2.845267 & -0.846968\end{array}$

C $4.580878-2.439306 \quad-2.656306$

$\begin{array}{llll}\text { H } & 4.883870 & -3.481035 & -2.784025\end{array}$

$\begin{array}{llll}\text { C } & 4.979578 & -1.472835 & -3.581962\end{array}$

H $5.597056-1.756275-4.437306$

$\begin{array}{llll}\text { C } & 4.585750 & -0.146134 & -3.413775\end{array}$

$\begin{array}{llll}\text { H } & 4.893836 & 0.613213 & -4.13605\end{array}$

$\begin{array}{llll}\text { C } 3.800898 & 0.222566 & -2.320874\end{array}$

$\begin{array}{llll}\text { H } & 3.498782 & 1.266488 & -2.200644\end{array}$

C $3.081201-1.061230 \quad 1.486515$

C $4.467244 \quad-1.245119 \quad 1.597440$

H $5.127301 \quad-0.989887 \quad 0.763587$

C $5.008305-1.760423 \quad 2.773786$

H $6.088298 \quad-1.903289 \quad 2.854407$

$\begin{array}{llll}\text { C } & 4.175849 & -2.093687 & 3.843387\end{array}$

H $\quad 4.604934 \quad-2.500980 \quad 4.761800$

$\begin{array}{llll}\text { C } & 2.796377 & -1.914971 \quad 3.737224\end{array}$

H $2.141445 \quad-2.183177 \quad 4.56922$

C $2.249105 \quad-1.405230 \quad 2.561589$

$\begin{array}{llll}\text { H } & 1.165550 & -1.280415 & 2.463358\end{array}$

\begin{tabular}{lllll}
\hline & -0.072948 & -3.333787 & 0.743154
\end{tabular}

H $\quad-1.227558-4.973543 \quad-1.324136$

H $0.526213-5.210793 \quad-1.248097$

$\begin{array}{llll}\text { C } & -0.271325 & -4.662251 & -1.767085\end{array}$

$\begin{array}{llll}\text { C } & -0.055368 & -2.655149 & -0.244600\end{array}$

$\begin{array}{llll}\text { H } & -0.269354 & -4.979405 & -2.817873\end{array}$

$\begin{array}{llll}\text { C } & -0.073449 & -3.166185 & -1.664746\end{array}$

H $-0.848426-2.605723 \quad-2.213534$

$\begin{array}{llll}\text { H } & 0.874719 & -2.842836 & -2.127737\end{array}$ 
Fig._S104_RCHO / electronic energy: -192.984065824 a.u. / lowest freq: $153.26 \mathrm{~cm}-1$

$\begin{array}{llll}0 & 1.401165 & -0.687132 & 0.000000\end{array}$

H $-1.252324-1.124869-0.883551$

$\begin{array}{llll}\text { C } & 0.919697 & 0.422075 & 0.000000\end{array}$

$\begin{array}{llll}\text { H } & -1.252326 & -1.124867 & 0.883553\end{array}$

C $-1.432393 \quad-0.496718 \quad 0.000000$

H $1.580685 \quad 1.330267 \quad 0.000000$

C $-0.542228 \quad 0.720552 \quad 0.000000$

H $-2.494356-0.218374-0.000001$

$\begin{array}{lllll}\text { H } & -0.730725 & 1.379719 & -0.866637\end{array}$

$\begin{array}{llll}\text { H } & -0.730726 & 1.379719 & 0.866637\end{array}$

153

Fig._S104_LPdH(CO)PdL(+) / electronic energy: -4893.59579005 a.u. / lowest freq: $9.67 \mathrm{~cm}-1$

C $3.275432 \quad 2.757857-2.077960$

C $2.422543 \quad 3.778934-1.632281$

H $1.8548093 .642447-0.706206$

$\begin{array}{llll}\text { C } & 2.293332 & 4.960460 & -2.356318\end{array}$

H $1.629605 \quad 5.749747-1.993970$

$\begin{array}{llll}\text { C } 2.999295 & 5.127645 & -3.549156\end{array}$

H $2.892178 \quad 6.050855 \quad-4.123674$

C $3.837074 \quad 4.111763 \quad-4.007796$

H $4.390362 \quad 4.237611-4.941551$

C $3.980797 \quad 2.932320 \quad-3.275420$

H $4.6510182 .150080-3.641816$

$\begin{array}{llll}\text { C } & 4.554456 & 0.167914 & -1.971968\end{array}$

$\begin{array}{llll}C & 3.997112 & -0.659870 & -2.957441\end{array}$

$\begin{array}{llll}\text { H } & 2.913253 & -0.647283 & -3.124201\end{array}$

$\begin{array}{llll}\text { C } 4.810969 & -1.492381 & -3.722810\end{array}$

H $4.365941-2.126790-4.493153$

$\begin{array}{llll}\text { C } & 6.187460 & -1.524345 & -3.495061\end{array}$

$\begin{array}{llll}\text { H } & 6.824898 & -2.185918 & -4.086856\end{array}$

$\begin{array}{llll}\text { C } & 6.746755 & -0.715772 & -2.505448\end{array}$

$\begin{array}{llll}\text { H } & 7.823629 & -0.739313 & -2.321488\end{array}$

$\begin{array}{lllll}\text { C } & 5.937141 & 0.132704 & -1.750318\end{array}$

H $6.3910650 .771241-0.986728$

$\begin{array}{llll}\text { C } & 4.434738 & 1.861402 & 0.356642\end{array}$

C $4.859536 \quad 3.182550 \quad 0.544636$

$\begin{array}{llll}\text { H } & 4.619076 & 3.947713 & -0.196794\end{array}$

C $5.581224 \quad 3.530047 \quad 1.685970$

H $\quad 5.898644 \quad 4.565393 \quad 1.827571$

C $5.913235 \quad 2.568130 \quad 2.641303$

H $6.490516 \quad 2.861616 \quad 3.520440$

$\begin{array}{llll}\text { C } & 5.534569 & 1.233187 & 2.472755\end{array}$

$\begin{array}{llll}\text { C } & 4.788698 & 0.924202 & 1.333081\end{array}$

C $5.939651 \quad 0.078766 \quad 3.381462$

C $6.3439810 .552561 \quad 4.769597$

H $7.201743 \quad 1.236080 \quad 4.717487$

H $\quad 6.660252-0.291076 \quad 5.397314$

H $\quad 5.524721 \quad 1.072930 \quad 5.286578$

$\begin{array}{llll}\text { C } & 7.131969 & -0.644508 & 2.724020\end{array}$

H $6.888222 \quad-1.007893 \quad 1.714313$

H 7.437764 -1.511682 3.327573

H $7.994188 \quad 0.032859 \quad 2.636770$

C $4.764315 \quad-0.891137 \quad 3.421850$

$\begin{array}{llll}\text { C } 4.388779 & -1.652638 & 4.530737\end{array}$

$\begin{array}{llll}\text { H } & 4.923946 & -1.535877 & 5.475288\end{array}$

C $3.341839-2.571413 \quad 4.445113$

H $3.068696-3.165011 \quad 5.319979$

$\begin{array}{llll}\text { C } & 2.636465 & -2.735655 & 3.255368\end{array}$

H $\quad 1.808849 \quad-3.447139 \quad 3.213266$

$\begin{array}{llll}\text { C } & 2.970235 & -1.977502 & 2.123822\end{array}$

$\begin{array}{llll}\text { C } & 4.040450 & -1.083234 & 2.240586\end{array}$

$\begin{array}{llll}\text { C } 2.934229 & -3.136097 & -0.552615\end{array}$

$\begin{array}{llll}\text { C } 4.241027 & -3.571029 & -0.304706\end{array}$

$\begin{array}{llll}\text { H } & 4.760088 & -3.273624 & 0.611264\end{array}$

$\begin{array}{llll}\text { C } & 4.888452 & -4.399657 & -1.223505\end{array}$

$\begin{array}{llll}\text { H } & 5.909925 & -4.731438 & -1.022239\end{array}$

$\begin{array}{llll}\text { C } & 4.235914 & -4.809073 & -2.385126\end{array}$

$\begin{array}{llll}\text { H } & 4.744028 & -5.463920 & -3.097134\end{array}$

$\begin{array}{llll}\text { C } & 2.933307 & -4.373740 & -2.640315\end{array}$

H $2.416917-4.684653 \quad-3.552171$

$\begin{array}{llll}\text { C } & 2.291830 & -3.530511 & -1.738098\end{array}$

$\begin{array}{llll}\text { H } & 1.275285 & -3.178481 & -1.949998\end{array}$

$\begin{array}{llll}\text { C } & 0.546416 & -2.984998 & 1.062366\end{array}$

$\begin{array}{llll}\text { C } & 0.477498 & -4.379468 & 0.952554\end{array}$

$\begin{array}{llll}\text { H } & 1.318327 & -4.941130 & 0.535444\end{array}$

$\begin{array}{llll}\text { C } & -0.664293 & -5.062506 & 1.374880\end{array}$

$\begin{array}{llll}\text { H } & -0.710946 & -6.149713 & 1.275783\end{array}$

$\begin{array}{llll}\text { C }-1.736808 & -4.363544 & 1.928237\end{array}$

H $\quad-2.627318 \quad-4.901238 \quad 2.262805$

C $-1.669391-2.974247 \quad 2.055884$

$\begin{array}{llll}\text { H } & -2.504999 & -2.420831 & 2.493817\end{array}$

C $-0.538998 \quad-2.288518 \quad 1.616455$

$\begin{array}{llll}\text { H } & -0.497370 & -1.194554 & 1.700266\end{array}$

$\begin{array}{llll}\text { C } & -0.882860 & 3.153409 & 1.133524\end{array}$

$\begin{array}{llll}\text { C } & -0.900081 & 4.545640 & 0.996033\end{array}$

H $\quad-1.777103 \quad 5.047486 \quad 0.57779$ 
$\begin{array}{llll}\text { C } & 0.203601 & 5.304329 & 1.395742\end{array}$ H $\quad 0.181732 \quad 6.390352 \quad 1.276850$

C $1.323383 \quad 4.684273 \quad 1.948296$

H $2.184396 \quad 5.280967 \quad 2.260498$

C $1.345870 \quad 3.294515 \quad 2.093857$

$\begin{array}{cccc}\text { H } & \mathbf{2 . 2 1 8 9 4 4} 2.798662 & 2.527308\end{array}$

C $0.256841 \quad 2.534481 \quad 1.675988$

$\begin{array}{llll}\text { H } & 0.287564 & 1.441978 & 1.773833\end{array}$

$\begin{array}{llll}\text { C } & -3.492660 & 3.154719 & -0.166522\end{array}$

$\begin{array}{llll}\text { C } & -3.240657 & 3.578361 & -1.481037\end{array}$

$\begin{array}{llll}\text { H } & -2.329870 & 3.254387 & -1.994034\end{array}$

$\begin{array}{llll}\text { C } & -4.141598 & 4.414009 & -2.136932\end{array}$

H $-3.930870 \quad 4.739149-3.15876$

$\begin{array}{lllll}\text { C } & -5.315209 & 4.818004 & -1.49862\end{array}$

H $\quad-6.026099 \quad 5.465992 \quad-2.016933$

$\begin{array}{llll}\text { C } & -5.580226 & 4.387589 & -0.199044\end{array}$

$\begin{array}{llll}\text { H } & -6.498063 & 4.698525 & 0.305621\end{array}$

C $-4.673731 \quad 3.563549 \quad 0.468261$

H $-4.892541 \quad 3.245029 \quad 1.491374$

C $-3.031908 \quad 1.624428 \quad 2.227750$

$\begin{array}{llll}\text { C } & -2.675913 & 2.186611 & 3.460489\end{array}$

H $-1.8841862 .938102 \quad 3.509789$

$\begin{array}{llll}\text { C } & -3.326238 & 1.788669 & 4.627198\end{array}$

$\begin{array}{llll}\text { H } & -3.034236 & 2.226325 & 5.584042\end{array}$

$\begin{array}{llll}\text { C } & -4.358389 & 0.849997 & 4.581496\end{array}$

H $-4.868726 \quad 0.567695 \quad 5.504816$

$\begin{array}{llll}\text { C } & -4.758289 & 0.283919 & 3.368355\end{array}$

$\begin{array}{llll}\text { C } & -4.059767 & 0.673198 & 2.221737\end{array}$

$\begin{array}{llll}\text { C } & -5.945556 & -0.655325 & 3.185787\end{array}$

$\begin{array}{llll}C & -7.132593 & 0.180307 & 2.668035\end{array}$

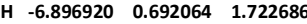

H $\quad-7.413599 \quad 0.948215 \quad 3.403695$

$\begin{array}{llll}\text { H } & -8.008705 & -0.461224 & 2.492898\end{array}$

$\begin{array}{llll}\text { C } & -6.343671 & -1.337888 & 4.485483\end{array}$

H $\quad-7.213347 \quad-1.991096 \quad 4.335600$

H $-6.638945 \quad-0.599024 \quad 5.242233$

H $\quad-5.528090 \quad-1.946270 \quad 4.902835$

C $-5.559909-1.656863 \quad 2.103762$

$\begin{array}{llll}\text { C } & -5.937099 & -3.002564 & 2.076539\end{array}$

$\begin{array}{lllll}\text { H } & -6.533021 & -3.415659 & 2.893113\end{array}$

$\begin{array}{llll}C & -5.569044 & -3.826059 & 1.011268\end{array}$

H $-5.881991 \quad-4.872335 \quad 1.002797$

$\begin{array}{llll}\text { C } & -4.792095 & -3.331919 & -0.035261\end{array}$

$\begin{array}{llll}\text { H } & -4.486066 & -3.997904 & -0.845954\end{array}$

$\begin{array}{llll}\text { C } & -4.379891 & -1.992827 & -0.034795\end{array}$

$\begin{array}{llll}\text { C } & -4.796558 & -1.187773 & 1.032299\end{array}$

$\begin{array}{lllll}C & -4.193419 & -0.181242 & -2.30246\end{array}$

$\begin{array}{llll}\text { C } & -5.544689 & 0.103596 & -2.074242\end{array}$

H $\quad-6.074983-0.364759-1.240352$

$\begin{array}{lllll}\text { C } & -6.228849 & 0.981813 & -2.916512\end{array}$

$\begin{array}{llll}\text { H } & -7.282512 & 1.200124 & -2.726011\end{array}$

$\begin{array}{llll}\text { C } & -5.576151 & 1.572814 & -3.997004\end{array}$

H $-6.116223 \quad 2.257461-4.655672$

$\begin{array}{llll}C & -4.227489 & 1.294356 & -4.230158\end{array}$

$\begin{array}{lllll}\text { H } & -3.707754 & 1.759272 & -5.071563\end{array}$

$\begin{array}{llll}\text { C } & -3.536497 & 0.433406 & -3.382182\end{array}$

$\begin{array}{llll}\text { H } & -2.474296 & 0.229420 & -3.561232\end{array}$

$\begin{array}{llll}C & -2.800091 & -2.708193 & -2.295873\end{array}$

$\begin{array}{llll}C & -1.709263 & -3.512179 & -1.937591\end{array}$

$\begin{array}{llll}\text { H } & -1.098811 & -3.236783 & -1.070214\end{array}$

$\begin{array}{llll}\text { C } & -1.404364 & -4.657762 & -2.671134\end{array}$

H $-0.558865-5.284766-2.374785$

$\begin{array}{llll}\text { C } & -2.174743 & -4.998429 & -3.783946\end{array}$

$\begin{array}{llll}\text { H } & -1.932129 & -5.891072 & -4.365495\end{array}$

$\begin{array}{llll}\text { C } & -3.254443 & -4.195682 & -4.154561\end{array}$

$\begin{array}{llll}\text { H } & -3.858647 & -4.458636 & -5.026183\end{array}$

$\begin{array}{llll}C & -3.572764 & -3.059050 & -3.411568\end{array}$

$\begin{array}{llll}\text { H } & -4.431301 & -2.445935 & -3.700661\end{array}$

C $0.114756 \quad 1.371381 \quad-1.434042$

\begin{tabular}{lllll}
\hline & 4.357836 & -0.360547 & 1.121236
\end{tabular}

\begin{tabular}{lllll}
\hline & -4.380048 & 0.120398 & 1.008452
\end{tabular}

$\begin{array}{lllll}0 & -0.009995 & 2.246006 & -2.207135\end{array}$

$\begin{array}{llll}\text { P } & 3.419582 & 1.259546 & -1.042325\end{array}$

$\begin{array}{llll}\text { P } & 2.016748 & -2.015878 & 0.558551\end{array}$

$\begin{array}{llll}P & -2.262722 & 2.059637 & 0.626401\end{array}$

P $-3.196703-1.276637-1.229479$

$\begin{array}{lllll}\text { Pd } & 1.372258 & 0.033998 & -0.653022\end{array}$

$\begin{array}{lllll}\text { Pd } & -1.324035 & 0.189531 & -0.619058\end{array}$

$\begin{array}{llll}\text { H } & -0.120101 & -0.979249 & -0.976158\end{array}$

Fig._S104_LPdHI / electronic energy: -2688.42445650 a.u. / lowest freq: $20.09 \mathrm{~cm}-1$

Pd $-0.018417-0.953805-1.185825$

$\begin{array}{llll}P & 1.640194 & -0.379894 & 0.557841\end{array}$

$\begin{array}{llll}P & -2.029701 & -0.591427 & -0.167157\end{array}$

\begin{tabular}{lllll}
\hline & -0.319894 & 1.667105 & 0.524623
\end{tabular}

$\begin{array}{llll}\text { C } & 0.878418 & 2.220330 & 0.134290\end{array}$

C $1.984929 \quad 1.362814 \quad 0.126191$

$\begin{array}{llll}\text { C } & 3.199576 & 1.884182 & -0.331933\end{array}$ 
$\begin{array}{lllll}\text { H } & 4.082477 & 1.243269 & -0.390369\end{array}$ $\begin{array}{llll}\text { C } 3.277203 & 3.213687 & -0.747367\end{array}$

H $\quad 4.227579 \quad 3.607639 \quad-1.113552$

C $2.156311 \quad 4.044950-0.703849$

$\begin{array}{llll}\text { H } & 2.246060 & 5.084053 & -1.027384\end{array}$

$\begin{array}{lllll}\text { C } & 0.925978 & 3.560764 & -0.249835\end{array}$

$\begin{array}{llll}\text { C } & -0.351254 & 4.379150 & -0.084634\end{array}$

$\begin{array}{llll}\text { C } & -1.510456 & 3.474700 & -0.493586\end{array}$

$\begin{array}{lllll}\text { C } & -2.654899 & 3.886233 & -1.181757\end{array}$

$\begin{array}{lllll}\text { H } & -2.758454 & 4.928559 & -1.490624\end{array}$

$\begin{array}{llll}\text { C } & -3.671359 & 2.978682 & -1.481715\end{array}$

$\begin{array}{llll}\text { H } & -4.560303 & 3.318675 & -2.017087\end{array}$

$\begin{array}{llll}\text { C } & -3.555298 & 1.635387 & -1.127360\end{array}$

$\begin{array}{llll}\text { H } & -4.342380 & 0.932994 & -1.410366\end{array}$

$\begin{array}{llll}\text { C } & -2.418192 & 1.180124 & -0.447562\end{array}$

$\begin{array}{llll}\text { C } & -1.433783 & 2.127050 & -0.132506\end{array}$

$\begin{array}{llll}\text { C } & -0.508082 & 4.720390 & 1.410086\end{array}$

H $\quad-0.540299 \quad 3.817618 \quad 2.038258$

H $\quad-1.437663 \quad 5.2820301 .584225$

H $0.333506 \quad 5.338573 \quad 1.756037$

$\begin{array}{lllll}\text { C } & -0.316646 & 5.667790 & -0.891958\end{array}$

$\begin{array}{llll}\text { H } & -0.212183 & 5.479907 & -1.970255\end{array}$

$\begin{array}{lllll}H & 0.518950 & 6.306619 & -0.575885\end{array}$

$\begin{array}{llll}\text { H } & -1.231632 & 6.254662 & -0.735587\end{array}$

C $1.288449 \quad-0.306622 \quad 2.362047$

$\begin{array}{llll}\text { C } & 1.022884 & -1.518874 & 3.016762\end{array}$

$\begin{array}{llll}\text { H } & 0.974375 & -2.449612 & 2.441191\end{array}$

$\begin{array}{llll}\text { C } & 0.838360 & -1.552040 & 4.396747\end{array}$

$\begin{array}{llll}\text { H } & 0.637838 & -2.504972 & 4.89315\end{array}$

$\begin{array}{llll}\text { C } & 0.899744 & -0.372837 & 5.141292\end{array}$

$\begin{array}{llll}\text { H } & 0.753017 & -0.399249 & 6.223944\end{array}$

C $1.143518 \quad 0.838482 \quad 4.496214$

H $\quad 1.191885 \quad 1.767060 \quad 5.070708$

$\begin{array}{llll}\text { C } & 1.338513 & 0.873674 & 3.114707\end{array}$

H $1.5493261 .831082 \quad 2.630250$

C $3.265648-1.221351 \quad 0.594934$

$\begin{array}{llll}\text { C } 4.326918 & -0.721659 & 1.366293\end{array}$

H $4.204863 \quad 0.211414 \quad 1.925293$

C $5.535078-1.411473 \quad 1.430884$

H $6.357296 \quad-1.010974 \quad 2.028781$

$\begin{array}{llll}\text { C } & 5.690745 & -2.615986 & 0.741103\end{array}$

H $6.638138-3.157827 \quad 0.796008$

$\begin{array}{llll}\text { C } 4.634561 & -3.130142 & -0.009154\end{array}$

$\begin{array}{lllll}\text { H } & 4.748533 & -4.077250 & -0.541658\end{array}$

C $3.426257-2.435874-0.082910$

$\begin{array}{lllll}\text { H } & 2.596752 & -2.840594 & -0.669972\end{array}$

$\begin{array}{llll}\text { C } & -2.195391 & -0.868655 & 1.633838\end{array}$

$\begin{array}{llll}\text { C } & -2.298663 & -2.199294 & 2.070151\end{array}$

$\begin{array}{llll}\text { H } & -2.241660 & -3.017254 & 1.344795\end{array}$

$\begin{array}{llll}\text { C } & -2.498811 & -2.486282 & 3.417179\end{array}$

$\begin{array}{llll}\text { H } & -2.591905 & -3.525571 & 3.741747\end{array}$

$\begin{array}{llll}\text { C }-2.579122 & -1.448767 & 4.347731\end{array}$

$\begin{array}{llll}\text { H } & -2.734496 & -1.672484 & 5.406124\end{array}$

$\begin{array}{llll}\text { C } & -2.448923 & -0.126935 & 3.925000\end{array}$

$\begin{array}{llll}\text { H } & -2.500602 & 0.688533 & 4.650884\end{array}$

$\begin{array}{lllll}C & -2.259293 & 0.166668 & 2.573843\end{array}$

$\begin{array}{llll}\text { H } & -2.181801 & 1.210329 & 2.257864\end{array}$

C $-3.509341-1.481218-0.781514$

$\begin{array}{llll}\text { C }-4.730001 & -1.337810 & -0.099103\end{array}$

$\begin{array}{lllll}\text { H } & -4.790938 & -0.698558 & 0.78700\end{array}$

$\begin{array}{llll}\text { C } & -5.869956 & -1.998612 & -0.547253\end{array}$

$\begin{array}{llll}\text { H } & -6.814091 & -1.872074 & -0.012313\end{array}$

$\begin{array}{llll}C & -5.805272 & -2.821662 & -1.673904\end{array}$

$\begin{array}{llll}\text { H } & -6.699435 & -3.344827 & -2.021329\end{array}$

$\begin{array}{llll}\text { C } & -4.596805 & -2.978491 & -2.349161\end{array}$

$\begin{array}{lllll}\text { H } & -4.536738 & -3.627377 & -3.225887\end{array}$

$\begin{array}{llll}\text { C } & -3.453577 & -2.311456 & -1.905597\end{array}$

$\begin{array}{llll}\text { H } & -2.505658 & -2.442993 & -2.434768\end{array}$

$\begin{array}{llll}H & -1.001855 & -1.106494 & -2.399984\end{array}$

I $1.865334-0.974736-3.186951$

161

Fig._S104_INT1(LPdHI)(+) / electronic energy: -5270.65031575 a.u. / lowest freq: -15.97 cm-1

Pd $-1.593909-0.725802-0.258553$

C $-1.172500-2.288455-1.461088$

C $-0.400489-2.048127-2.733716$

$\begin{array}{llll}\text { C } & -0.101157 & -3.305016 & -3.517092\end{array}$

H $-1.022802-3.802257-3.851788$

$\begin{array}{llll}0 & -1.458913 & -3.376721 & -1.042388\end{array}$

H $\quad 0.496527-3.068856-4.408991$

$\begin{array}{llll}\text { H } & 0.462237 & -4.034122 & -2.917301\end{array}$

H $\quad-0.941764-1.294210-3.32619$

$\begin{array}{llll}\text { H } & 0.513561 & -1.508635 & -2.418529\end{array}$

H $\quad 0.109536-0.874758 \quad 0.160505$

$\begin{array}{llll}\text { Pd } & 1.346944 & 0.034964 & -0.460847\end{array}$

$\begin{array}{llll}-0.543055 & 1.629834 & -1.903470\end{array}$

H $-6.940195 \quad 5.142166-0.949493$

H $-7.039688 \quad 3.498921 \quad-2.246817$

$\begin{array}{llll}\text { C }-5.907692 & 5.166426 & -0.577155\end{array}$ 
$\begin{array}{cccc}\text { H } & -5.858198 & 6.004961 & 0.129869\end{array}$

H $-5.243606 \quad 5.393399 \quad-1.423619$

H $\quad-7.271251 \quad 1.414682$-3.56000

$\begin{array}{llll}\text { C } & -6.466808 & 2.615462 & -1.958398\end{array}$

$\begin{array}{lllll}\text { C } & -6.598218 & 1.442508 & -2.700688\end{array}$

$\begin{array}{lllll}\text { H } & -7.550964 & 3.541804 & 0.906883\end{array}$

$\begin{array}{llll}\text { C } & -5.540701 & 3.857009 & 0.107397\end{array}$

C $-6.516256 \quad 3.605787 \quad 1.274971$

$\begin{array}{llll}\text { C } & -5.635604 & 2.665544 & -0.837386\end{array}$

$\begin{array}{llll}\text { H } & -6.463615 & 4.424857 & 2.007580\end{array}$

$\begin{array}{llll}\text { H } & -3.878168 & 6.021120 & 0.849728\end{array}$

$\begin{array}{llll}C & -5.878940 & 0.302579 & -2.353052\end{array}$

$\begin{array}{llll}\text { C } & -3.441533 & 5.041499 & 1.053881\end{array}$

C $-4.130848 \quad 3.883657 \quad 0.682596$

H $\quad-6.289564 \quad 2.667754 \quad 1.804499$

$\begin{array}{llll}\text { C } & -4.922218 & 1.505639 & -0.514565\end{array}$

$\begin{array}{llll}\text { C } & -5.003439 & 0.320244 & -1.257776\end{array}$

$\begin{array}{llll}\text { C } & -2.212385 & 4.963785 & 1.708685\end{array}$

$\begin{array}{llll}\text { H } & -6.346934 & -0.422933 & 0.862673\end{array}$

$\begin{array}{llll}H & -1.697266 & 5.879981 & 2.005100\end{array}$

$\begin{array}{llll}\text { C } & -3.513110 & 2.661746 & 0.956293\end{array}$

\begin{tabular}{lllll}
\hline & -4.107090 & 1.482315 & 0.583378
\end{tabular}

$\begin{array}{llll}\text { H } & -7.445739 & -1.622342 & 2.722962\end{array}$

$\begin{array}{llll}\text { C } & -5.951559 & -1.389342 & 1.187847\end{array}$

$\begin{array}{llll}C & -1.644616 & 3.726411 & 2.008068\end{array}$

$\begin{array}{llll}\text { P } & -3.949018 & -1.110171 & -0.802563\end{array}$

$\begin{array}{llll}\text { C } & -2.285813 & 2.544720 & 1.620356\end{array}$

$\begin{array}{llll}\text { C } & -6.576397 & -2.069088 & 2.234394\end{array}$

$\begin{array}{llll}C & -4.783965 & -3.438977 & -2.247324\end{array}$

$\begin{array}{llll}\text { H } & -3.446881 & 2.096647 & 3.939606\end{array}$

$\begin{array}{llll}C & -4.834831 & -1.948548 & 0.55428\end{array}$

H $\quad-5.218889-3.826888-1.323417$

$\begin{array}{llll}H & -0.695509 & 3.686008 & 2.546383\end{array}$

$\begin{array}{llll}\text { H } & -4.814666 & 1.088621 & 5.742065\end{array}$

C $-3.480912 \quad 1.008668 \quad 4.050336$

$\begin{array}{llll}\text { C } & -6.102532 & -3.312988 & 2.647679\end{array}$

$\begin{array}{lllll}\text { P } & -1.669254 & 0.839477 & 1.857346\end{array}$

$\begin{array}{llll}\text { C } & -4.246665 & 0.441901 & 5.068814\end{array}$

$\begin{array}{llll}\text { C } & -4.338967 & -3.185841 & 1.000505\end{array}$

C $-2.7532130 .188020 \quad 3.177999$

H $-6.600739-3.845633 \quad 3.461484$

C $-4.981144 \quad-3.869807 \quad 2.028690$

$\begin{array}{llll}\text { C } & -0.066482 & 1.091315 & 2.709890\end{array}$

$\begin{array}{llll}\text { H } & -3.447728 & -3.615253 & 0.530257\end{array}$

$\begin{array}{llll}\text { C } & -4.277372 & -0.943006 & 5.238896\end{array}$

$\begin{array}{lllll}\text { C } & 0.932907 & 1.821340 & 2.042450\end{array}$

H $-0.534209-0.019100 \quad 4.514036$

C $0.2222590 .554787 \quad 3.971515$

$\begin{array}{llll}\text { C } & -2.818649 & -1.202387 & 3.333150\end{array}$

$\begin{array}{llll}\text { H } & -4.869436 & -1.382684 & 6.045351\end{array}$

$\begin{array}{lllll}\text { H } & -4.595786 & -4.838741 & 2.357511\end{array}$

C -3.560666 - $1.765841 \quad 4.369692$

C $2.175699 \quad 2.037346 \quad 2.634106$

C $1.474510 \quad 0.759270 \quad 4.556422$

H $\quad-2.282022 \quad-1.842554 \quad 2.624163$

C $2.449527 \quad 1.505366 \quad 3.895826$

H $1.682858 \quad 0.337624 \quad 5.542890$

H $\quad-3.591511 \quad-2.851577 \quad 4.489962$

H $3.422060 \quad 1.676096 \quad 4.365107$

H $0.716807 \quad 2.253253 \quad 1.058712$

H $\quad 2.931214 \quad 2.631153 \quad 2.110190$

$\begin{array}{llll}H & -5.996385 & -0.605676 & -2.946569\end{array}$

$\begin{array}{llll}H & -3.307658 & -2.082850 & -5.575915\end{array}$

$\begin{array}{llll}\text { C } & -3.719807 & -2.470929 & -4.641197\end{array}$

$\begin{array}{llll}\text { C } & -3.625281 & -1.712332 & -3.478005\end{array}$

$\begin{array}{llll}\text { C } & -4.334397 & -3.724610 & -4.609493\end{array}$

H $-4.403096-4.324908-5.519726$

$\begin{array}{llll}\text { C } & -4.156856 & -2.189187 & -2.268096\end{array}$

$\begin{array}{llll}\text { C } & -4.864000 & -4.203907 & -3.412827\end{array}$

$\begin{array}{llll}\text { H } & -5.353770 & -5.180057 & -3.382180\end{array}$

$\begin{array}{llll}\text { H } & -3.146690 & -0.727217 & -3.51013\end{array}$

$\begin{array}{llll}\text { H } & 7.401514 & 0.368592 & 4.690623\end{array}$

H $5.672672-0.822626 \quad 5.105000$

C $7.054404 \quad 1.141828 \quad 3.992691$

H $7.9290841 .764657 \quad 3.763475$

H $\quad 6.317743 \quad 1.768483 \quad 4.516478$

H $3.791088-2.409601 \quad 5.329893$

C $5.032151-1.021098 \quad 4.242736$

$\begin{array}{llll}\text { C } 3.970160 & -1.918249 & 4.371164\end{array}$

$\begin{array}{llll}\text { H } & 7.913155 & -1.137020 & 2.715385\end{array}$

$\begin{array}{llll}\text { C } 6.483122 & 0.517227 & 2.728136\end{array}$

C $7.570560-0.335122 \quad 2.044866$

C $5.293644 \quad-0.390034 \quad 3.022903$

H $\quad 8.439304 \quad 0.286548 \quad 1.782974$

H $7.195108 \quad 3.242116 \quad 2.416344$

$\begin{array}{llll}\text { C } 3.141981 & -2.208496 & 3.286626\end{array}$

$\begin{array}{llll}\text { C } & 6.479474 & 2.885592 & 1.672441\end{array}$

C $6.015791 \quad 1.569693 \quad 1.727873$ 
H $7.203649 \quad-0.804009 \quad 1.119606$

C $4.428752-0.681315 \quad 1.968920$

$\begin{array}{llll}\text { C } 3.359180 & -1.575970 & 2.057740\end{array}$

C $6.053544 \quad 3.749246 \quad 0.661750$

$\begin{array}{lllll}\text { H } & 5.123035 & -3.055016 & 0.890207\end{array}$

$\begin{array}{lllll}\text { H } & 6.445705 & 4.767384 & 0.618356\end{array}$

C $5.095918 \quad 1.180570 \quad 0.749137$

$\begin{array}{lllll}\text { O } & 4.605658 & -0.095219 & 0.745006\end{array}$

H $\quad 6.615159-4.227053 \quad-0.687625$

$\begin{array}{llll}\text { C } 4.827686 & -3.147923 & -0.158503\end{array}$

$\begin{array}{llll}\text { C } & 5.125571 & 3.331557 & -0.289641\end{array}$

$\begin{array}{llll}\text { P } & 2.403493 & -1.828570 & 0.521239\end{array}$

$\begin{array}{llll}\text { C } & 4.601562 & 2.030477 & -0.244708\end{array}$

$\begin{array}{llll}\text { C } 5.667331 & -3.819026 & -1.046800\end{array}$

$\begin{array}{llll}\text { C } & 1.530385 & -4.529259 & 0.546227\end{array}$

$\begin{array}{llll}\text { H } & 6.033340 & 0.542099 & -1.905329\end{array}$

$\begin{array}{llll}\text { C } & 3.611229 & -2.615404 & -0.606419\end{array}$

H $2.363919-4.751176-0.124576$

H $4.795756 \quad 4.031998 \quad-1.058807$

H $\quad 6.974683 \quad-0.718045 \quad-3.817264$

C $5.375970 \quad 0.223664 \quad-2.719776$

$\begin{array}{llll}\text { C } 5.294909 & -3.982855 & -2.381170\end{array}$

$\begin{array}{llll}\text { P } & 3.226360 & 1.441614 & -1.316079\end{array}$

$\begin{array}{llll}\text { C } 5.907898 & -0.482040 & -3.800249\end{array}$

C $3.256877-2.762245-1.953020$

$\begin{array}{llll}\text { C } & 4.010505 & 0.528522 & -2.685887\end{array}$

$\begin{array}{llll}\text { H } & 5.951097 & -4.518679 & -3.071273\end{array}$

$\begin{array}{llll}\text { C } 4.084992 & -3.455557 & -2.832826\end{array}$

$\begin{array}{llll}\text { C } & 2.700173 & 3.034688 & -2.050441\end{array}$

$\begin{array}{llll}\text { H } & 2.316133 & -2.336023 & -2.310817\end{array}$

$\begin{array}{llll}\text { C } 5.086705 & -0.877491 & -4.854941\end{array}$

$\begin{array}{llll}\text { C } & 2.073940 & 3.953681 & -1.192644\end{array}$

$\begin{array}{llll}\text { H } & 3.379798 & 2.684656 & -4.079279\end{array}$

$\begin{array}{lllll}\text { C } & 2.886404 & 3.376816 & -3.392861\end{array}$

$\begin{array}{llll}\text { C } & 3.181557 & 0.097834 & -3.736089\end{array}$

H $5.509515-1.422275 \quad-5.702611$

H $3.786071 \quad-3.575672 \quad-3.877072$

$\begin{array}{llll}\text { C } & 3.720978 & -0.586787 & -4.821130\end{array}$

$\begin{array}{llll}\text { C } & 1.649796 & 5.190669 & -1.665764\end{array}$

$\begin{array}{llll}C & 2.447733 & 4.614826 & -3.869041\end{array}$

H $2.1069910 .317180-3.705813$

C $1.830365 \quad 5.521933 \quad-3.010617$

H $2.598223 \quad 4.870001-4.920759$

H $3.071012-0.901926-5.641380$

H $1.488841 \quad 6.488880-3.387480$

$\begin{array}{lllll}H & 1.922841 & 3.698900 & -0.138241\end{array}$

H $\quad 1.1638195 .893427 \quad-0.984854$

H $2.327274 \quad-2.926595 \quad 3.403030$

$\begin{array}{llll}\text { H } & -1.397325 & -3.824205 & 2.995857\end{array}$

$\begin{array}{llll}\text { C } & -0.582428 & -4.020935 & 2.294167\end{array}$

$\begin{array}{llll}\text { C } 0.225667 & -2.974874 & 1.857193\end{array}$

$\begin{array}{llll}\text { C } & -0.355066 & -5.321124 & 1.838459\end{array}$

$\begin{array}{llll}\text { H } & -0.999064 & -6.138839 & 2.170994\end{array}$

$\begin{array}{llll}\text { C } & 1.298327 & -3.220207 & 0.985336\end{array}$

$\begin{array}{llll}\text { C } & 0.696533 & -5.569963 & 0.960707\end{array}$

$\begin{array}{lllll}\text { H } & 0.881713 & -6.583565 & 0.597717\end{array}$

$\begin{array}{llll}\text { H } & 0.030508 & -1.954242 & 2.209064\end{array}$

161

Fig._S104_TS(LPdHI)(+) / electronic energy: -5270.63153375 a.u. / lowest freq: $-833.00 \mathrm{~cm}-1$

$\begin{array}{llll}P d & 1.514327 & -0.577252 & 0.222611\end{array}$

C $0.946928-1.826423 \quad 1.995625$

C $0.785307-1.176229 \quad 3.344609$

C $0.811089-2.151767 \quad 4.495772$

H $1.746333-2.728243 \quad 4.516253$

$\begin{array}{lllll}0 & 1.115279 & -3.010460 & 1.830880\end{array}$

H $0.719478-1.627346 \quad 5.456679$

H $\quad-0.012143-2.878013 \quad 4.427128$

H $\quad \begin{array}{llll}1.556361 & -0.393818 & 3.437162\end{array}$

$\begin{array}{llll}\text { H } & -0.154612 & -0.595374 & 3.304181\end{array}$

H $\quad 0.116681 \quad-1.178121 \quad 1.110001$

Pd $-1.184566 \quad 0.115383 \quad 0.537036$

$\begin{array}{llll}0.536129 & 2.105385 & 1.483493\end{array}$

H $\quad 5.720116 \quad 5.409307 \quad 1.141741$

$\begin{array}{llll}\text { H } & 7.078971 & 3.717310 & 1.324554\end{array}$

C $4.7870595 .201041 \quad 0.600290$

H $4.483277 \quad 6.139937 \quad 0.117400$

H $4.017858 \quad 4.937315 \quad 1.340815$

H $\quad 7.765781 \quad 1.646138 \quad 2.491950$

C $6.510350 \quad 2.796848 \quad 1.167126$

C $6.894441 \quad 1.6340201 .834081$

H $7.016373 \quad 4.685830-0.942964$

C $4.979443 \quad 4.081624-0.430526$

$\begin{array}{llll}\text { C } & 6.056348 & 4.494416 & -1.444657\end{array}$

$\begin{array}{llll}\text { C } & 5.420859 & 2.809607 & 0.290657\end{array}$

H $5.7665575 .415268 \quad-1.971980$

H $3.308019 \quad 5.903424-1.686453$

C $6.153435 \quad 0.463257 \quad 1.688785$

$\begin{array}{llll}\text { C } & 2.940435 & 4.877121 & -1.768425\end{array}$ 
C $3.668623 \quad 3.839617 \quad-1.172584$ H $6.220736 \quad 3.711637-2.199300$

C 4.7535491 .5950320 .107220

$\begin{array}{llll}\text { C } & 5.041051 & 0.432849 & 0.838326\end{array}$

$\begin{array}{lllll}\text { C } & 1.769398 & 4.627791 & -2.482024\end{array}$

H $6.325436-0.842340-1.014216$

H $\quad 1.232658 \quad 5.456427 \quad-2.948819$

C $3.1526852 .555260-1.330274$

$\begin{array}{lllll}\text { O } & 3.772016 & 1.457589 & -0.818318\end{array}$

$\begin{array}{llll}\text { H } & 7.325704 & -2.463088 & -2.595820\end{array}$

$\begin{array}{llll}\text { C } & 5.854758 & -1.819017 & -1.157254\end{array}$

C $1.282333 \quad 3.326153-2.616065$

$\begin{array}{llll}\text { P } & 3.894357 & -1.006713 & 0.727961\end{array}$

$\begin{array}{llll}\text { C } & 1.969872 & 2.263747 & -2.026519\end{array}$

$\begin{array}{llll}\text { C } & 6.421604 & -2.734462 & -2.045361\end{array}$

$\begin{array}{llll}\text { C } & 4.580201 & -3.095271 & 2.572561\end{array}$

H $3.227407 \quad 1.600754-4.200930$

$\begin{array}{llll}\text { C } & 4.693755 & -2.152585 & -0.448686\end{array}$

H $4.719255 \quad-3.762551 \quad 1.719399$

H $\quad 0.368845 \quad 3.146643 \quad-3.186925$

H $4.6684090 .481071 \quad-5.872522$

C $3.322924 \quad 0.511383-4.188986$

$\begin{array}{llll}\text { C } & 5.844205 & -3.990413 & -2.224977\end{array}$

$\begin{array}{llll}\text { P } & 1.493188 & 0.494936 & -2.008785\end{array}$

$\begin{array}{llll}\text { C } 4.130142 & -0.119639 & -5.135315\end{array}$

$\begin{array}{llll}\text { C } 4.093646 & -3.404354 & -0.665660\end{array}$

$\begin{array}{llll}\text { C } & 2.633930 & -0.247464 & -3.233461\end{array}$

$\begin{array}{llll}\text { H } & 6.296525 & -4.708424 & -2.913355\end{array}$

$\begin{array}{llll}\text { C } & 4.677005 & -4.323345 & -1.533758\end{array}$

$\begin{array}{lllll}\text { C } & -0.117393 & 0.490433 & -2.888409\end{array}$

$\begin{array}{llll}\text { H } & 3.165227 & -3.659006 & -0.141943\end{array}$

$\begin{array}{llll}\text { C } & 4.240669 & -1.510518 & -5.151970\end{array}$

$\begin{array}{llll}\text { C } & -1.155199 & 1.288989 & -2.377050\end{array}$

H $0.419896-0.927571-4.440261$

$\begin{array}{llll}\text { C } & -0.367581 & -0.295286 & -4.021084\end{array}$

$\begin{array}{llll}\text { C } 2.775888 & -1.640674 & -3.237995\end{array}$

H $4.864426-2.001192-5.903180$

H $4.213136-5.302681-1.679426$

$\begin{array}{llll}\text { C } 3.558397 & -2.272131 & -4.202806\end{array}$

$\begin{array}{lllll}\text { C } & -2.398430 & 1.329184 & -3.003366\end{array}$

$\begin{array}{llll}\text { C } & -1.622901 & -0.270663 & -4.634041\end{array}$

$\begin{array}{llll}\text { H } & 2.268806 & -2.229539 & -2.468499\end{array}$

$\begin{array}{lllll}\text { C } & -2.636068 & 0.546649 & -4.135637\end{array}$

H $\quad-1.802871 \quad-0.888539-5.517355$

H $3.644711-3.361577-4.205276$

$\begin{array}{lllll}\text { H } & -3.611132 & 0.578107 & -4.629161\end{array}$

H $-0.967614 \quad 1.906244-1.492031$

$\begin{array}{llll}\text { H } & -3.182545 & 1.983830 & -2.611817\end{array}$

$\begin{array}{llll}\text { H } & 6.435785 & -0.428724 & 2.252472\end{array}$

H $4.168205-0.760816 \quad 5.647005$

C $4.283293-1.423827 \quad 4.785920$

$\begin{array}{llll}\text { C } 4.049312 & -0.933836 & 3.504319\end{array}$

$\begin{array}{llll}C & 4.662257 & -2.755091 & 4.968382\end{array}$

H $4.846643 \quad-3.141168 \quad 5.973691$

$\begin{array}{llll}\text { C } & 4.203520 & -1.761218 & 2.378501\end{array}$

$\begin{array}{llll}\text { C } 4.804145 & -3.587454 & 3.859789\end{array}$

H $\quad 5.104168$-4.629974 3.990362

H 3.7666730 .1159593 .374036

H $-7.516666-1.013293-4.347003$

$\begin{array}{llll}\text { H } & -5.754525 & -2.188184 & -4.552055\end{array}$

$\begin{array}{llll}\text { C } & -7.185283 & -0.081766 & -3.869477\end{array}$

$\begin{array}{llll}\text { H } & -8.082669 & 0.539125 & -3.750417\end{array}$

$\begin{array}{lllll}H & -6.504438 & 0.433022 & -4.563194\end{array}$

$\begin{array}{llll}H & -3.787237 & -3.685765 & -4.514147\end{array}$

$\begin{array}{llll}C & -5.060918 & -2.142442 & -3.709820\end{array}$

$\begin{array}{llll}\text { C } & -3.951931 & -2.989329 & -3.689391\end{array}$

H $\quad-7.857249-2.033162-2.046788$

$\begin{array}{llll}C & -6.532011 & -0.360827 & -2.523399\end{array}$

C $-7.540612-1.077061-1.604692$

$\begin{array}{llll}\text { C } & -5.302984 & -1.253386 & -2.659054\end{array}$

$\begin{array}{llll}\text { H } & -8.436032 & -0.455728 & -1.456653\end{array}$

$\begin{array}{llll}H & -7.404182 & 2.319364 & -2.808912\end{array}$

$\begin{array}{llll}\text { C } & -3.056517 & -2.969227 & -2.620647\end{array}$

$\begin{array}{llll}\text { C } & -6.627836 & 2.187401 & -2.052348\end{array}$

$\begin{array}{llll}C & -6.086846 & 0.919836 & -1.825727\end{array}$

H $-7.112771-1.289252-0.613383$

$\begin{array}{llll}\text { C } & -4.372192 & -1.241118 & -1.620297\end{array}$

$\begin{array}{llll}\text { C } & -3.252070 & -2.073338 & -1.562308\end{array}$

$\begin{array}{llll}\text { C } & -6.202632 & 3.288673 & -1.307273\end{array}$

$\begin{array}{llll}\text { H } & -4.892254 & -3.263611 & 0.049251\end{array}$

H $-6.655842 \quad 4.266908$ - 1.480220

$\begin{array}{llll}\text { C } & -5.097141 & 0.821857 & -0.844027\end{array}$

$\begin{array}{lllll}\text { O } & -4.525876 & -0.387387 & -0.562560\end{array}$

H $\quad-6.201380-4.131754 \quad 1.954834$

$\begin{array}{llll}\text { C } & -4.506652 & -3.142745 & 1.065206\end{array}$

$\begin{array}{lllll}C & -5.197875 & 3.158117 & -0.351227\end{array}$

$\begin{array}{lllll}\text { P } & -2.197895 & -1.933474 & -0.071384\end{array}$

$\begin{array}{llll}\text { C } & -4.601832 & 1.909068 & -0.120112\end{array}$ 
\begin{tabular}{llll}
$C$ & -5.242912 & -3.640777 & 2.139634 \\
\hline
\end{tabular} $\begin{array}{llll}C & -1.253873 & -4.577548 & 0.299764\end{array}$

H $\quad-5.825976 \quad 0.662286 \quad 1.869194$

$\begin{array}{llll}\text { C } & -3.276170 & -2.510970 & 1.287804\end{array}$

H $-2.046601-4.702016 \quad 1.041276$

H $-4.868321 \quad 4.0379620 .203686$

$\begin{array}{llll}\text { H } & -6.590515 & -0.216092 & 4.050631\end{array}$

C $-5.1201620 .599636 \quad 2.702569$

$\begin{array}{lllll}\text { C } & -4.753873 & -3.526911 & 3.440889\end{array}$

$\begin{array}{lllll}\text { P } & -3.139087 & 1.652429 & 0.960923\end{array}$

$\begin{array}{llll}\text { C } & -5.553790 & 0.109583 & 3.935675\end{array}$

$\begin{array}{llll}\text { C } & -2.799911 & -2.384248 & 2.600075\end{array}$

$\begin{array}{llll}\text { C } & -3.793830 & 1.017161 & 2.541335\end{array}$

H $\quad-5.330502 \quad-3.924368 \quad 4.279592$

$\begin{array}{llll}\text { C } & -3.528991 & -2.899173 & 3.669386\end{array}$

$\begin{array}{llll}C & -2.694850 & 3.399173 & 1.290799\end{array}$

$\begin{array}{llll}\text { H } & -1.843530 & -1.883863 & 2.783605\end{array}$

$\begin{array}{llll}\text { C } & -4.674486 & 0.040480 & 5.014952\end{array}$

$\begin{array}{llll}\text { C } & -2.148927 & 4.138260 & 0.228514\end{array}$

H $\quad-3.323501 \quad 3.478107 \quad 3.364562$

$\begin{array}{lllll}\text { C } & -2.887384 & 4.025401 & 2.525739\end{array}$

$\begin{array}{llll}\text { C } & -2.904015 & 0.915634 & 3.624727\end{array}$

$\begin{array}{llll}\text { H } & -5.020858 & -0.337953 & 5.979740\end{array}$

$\begin{array}{llll}\text { H } & -3.142387 & -2.800008 & 4.686687\end{array}$

$\begin{array}{llll}\text { C } & -3.346716 & 0.444375 & 4.857100\end{array}$

C $-1.798508 \quad 5.472963 \quad 0.400664$

$\begin{array}{lllll}\text { C } & -2.526848 & 5.363978 & 2.698093\end{array}$

H $\quad-1.859680 \quad 1.227640 \quad 3.501018$

$\begin{array}{llll}\text { C } & -1.980613 & 6.088620 & 1.641202\end{array}$

$\begin{array}{lllll} & \text { H } & -2.680406 & 5.841284 & 3.668827\end{array}$

$\begin{array}{lllll}\text { H } & -2.649143 & 0.385687 & 5.696583\end{array}$

H $-1.697926 \quad 7.134646 \quad 1.780991$

$\begin{array}{lllll}H & -1.998233 & 3.667133 & -0.748182\end{array}$

$\begin{array}{llll}\text { H } & -1.371493 & 6.032248 & -0.435339\end{array}$

$\begin{array}{llll}H & -2.205672 & -3.653176 & -2.617341\end{array}$

H $1.537296-4.214190-2.37355$

C $0.759799-4.310856-1.611113$

$\begin{array}{llll}\text { C } & -0.038960 & -3.216904 & -1.286317\end{array}$

$\begin{array}{llll}\text { C } & 0.568795 & -5.534970 & -0.967058\end{array}$

H $1.201351-6.390046-1.218081$

$\begin{array}{llll}\text { C } & -1.063268 & -3.346514 & -0.337758\end{array}$

$\begin{array}{llll}C & -0.433821 & -5.663605 & -0.009160\end{array}$

H $-0.588148-6.617072 \quad 0.501237$

H $\quad 0.108472 \quad-2.257144 \quad-1.796645$

161

Fig._S104_INT2(LPdHI)(+) / electronic energy: -5270.65702640 a.u. / lowest freq: $-26.87 \mathrm{~cm}-1$

$\begin{array}{llll}\text { Pd } & 1.410544 & 0.417845 & 0.327509\end{array}$

C $0.398664 \quad 4.091460-0.824880$

C $0.084684 \quad 4.237974 \quad-2.27973$

$\begin{array}{llll}\text { C } & -0.075027 & 5.664588 & -2.743923\end{array}$

$\begin{array}{llll}\text { H } & 0.846683 & 6.243772 & -2.589304\end{array}$

\begin{tabular}{lllll}
\hline & 0.84683 & 6.243772 & -2.589304 \\
\hline & 0.497446 & 5.008741 & -0.044584
\end{tabular}

H $-0.323581 \quad 5.711562-3.812457$

$\begin{array}{llll}\text { H } & -0.870456 & 6.182853 & -2.190235\end{array}$

H $0.865156 \quad 3.694611-2.841726$

$\begin{array}{llll}H & -0.820646 & 3.632187 & -2.474870\end{array}$

$\begin{array}{llll}\text { H } & 0.531927 & 3.018196 & -0.472314\end{array}$

$\begin{array}{lllll}\text { Pd } & -1.087047 & -0.009263 & -0.444342\end{array}$

I $0.696264 \quad 0.272130-2.535304$

H $5.576740-3.368544-4.667912$

H $6.014312-1.339421 \quad-4.374189$

$\begin{array}{llll}\text { C } 4.575775 & -3.546335 & -4.253743\end{array}$

$\begin{array}{lllll}\text { H } & 4.385407 & -4.621597 & -4.366238\end{array}$

H $3.847811-3.004143-4.874607$

H $6.6021970 .997309 \quad-3.820964$

$\begin{array}{llll}\text { C } & 5.614856 & -0.887464 & -3.463844\end{array}$

C $5.9456640 .433153-3.155300$

$\begin{array}{llll}\text { H } & 6.563548 & -3.723820 & -2.356844\end{array}$

$\begin{array}{llll}\text { C } & 4.504923 & -3.126630 & -2.791700\end{array}$

$\begin{array}{llll}\text { C } 5.548682 & -3.919959 & -1.980321\end{array}$

$\begin{array}{llll}\text { C } 4.807645 & -1.643227 & -2.610531\end{array}$

$\begin{array}{llll}\text { H } & 5.358440 & -5.000923 & -2.055647\end{array}$

$\begin{array}{llll}\text { H } & 2.528056 & -5.023962 & -3.486279\end{array}$

C $5.443744 \quad 1.039755-2.006560$

$\begin{array}{llll}\text { C } & 2.276473 & -4.430729 & -2.604553\end{array}$

C $3.137104-3.414076-2.181722$

H $\quad 5.528110-3.649288-0.913590$

$\begin{array}{llll}\text { C } 4.326320 & -1.005776 & -1.463583\end{array}$

$\begin{array}{llll}\text { C } 4.588695 & 0.333023 & -1.150678\end{array}$

$\begin{array}{llll}\text { C } 1.115886 & -4.726129 & -1.889343\end{array}$

H $6.214500-0.5580760 .623276$

$\begin{array}{llll}\text { H } & 0.473272 & -5.547656 & -2.213580\end{array}$

$\begin{array}{llll}\text { C } & 2.753568 & -2.689812 & -1.051898\end{array}$

$\begin{array}{lllll}\text { C } & 3.7556313 & -1.694168 & -0.569305\end{array}$

$\begin{array}{llll}\text { H } & 7.701217 & -0.922283 & 2.558998\end{array}$

$\begin{array}{llll}\text { C } & 5.998844 & -0.051130 & 1.567659\end{array}$

$\begin{array}{llll}\text { C } & 0.770527 & -3.993863 & -0.754008\end{array}$

$\begin{array}{llll}\text { P } & 3.731248 & 1.071883 & 0.296148\end{array}$ 
$\begin{array}{llll}C & 1.576168 & -2.931199 & -0.327970\end{array}$ $\begin{array}{llll}\text { C } & 6.842539 & -0.254213 & 2.660244\end{array}$

$\begin{array}{llll}\text { C } & 4.322728 & 3.844682 & 0.770222\end{array}$

$\begin{array}{llll}\text { H } & 2.957761 & -4.262783 & 1.382354\end{array}$

C $4.892147 \quad 0.802020 \quad 1.679511$

H $4.711930 \quad 3.571988 \quad 1.752731$

H $-0.129642-4.264372-0.200930$

H $4.663410 \quad-4.907719 \quad 3.049089$

C $3.228736-3.559456 \quad 2.174742$

$\begin{array}{llll}\text { C } & 6.600577 & 0.395823 & 3.869788\end{array}$

$\begin{array}{llll}\text { P } & 1.271837 & -1.811122 & 1.094775\end{array}$

$\begin{array}{llll}\text { C } & 4.185450 & -3.927588 & 3.119545\end{array}$

C $4.632315 \quad 1.417224 \quad 2.914741$

$\begin{array}{llll}\text { C } & 2.614422 & -2.300859 & 2.24732\end{array}$

H $\quad 7.270718 \quad 0.241526 \quad 4.718895$

C $5.490121 \quad 1.232613 \quad 3.994872$

$\begin{array}{llll}C & -0.212704 & -2.517088 & 1.913526\end{array}$

H $3.744386 \quad 2.043416 \quad 3.028889$

C $4.520843 \quad-3.057875 \quad 4.158331$

$\begin{array}{llll}\text { C } & -1.395487 & -2.722841 & 1.180196\end{array}$

$\begin{array}{llll}\text { H } & 0.688829 & -2.678173 & 3.882026\end{array}$

$\begin{array}{llll}\text { C } & -0.211676 & -2.829021 & 3.281623\end{array}$

$\begin{array}{llll}\text { C } & 2.981979 & -1.422272 & 3.271195\end{array}$

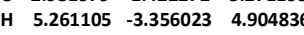

H $\quad 5.280489 \quad 1.733194 \quad 4.944202$

C $3.914233-1.804816 \quad 4.234534$

$\begin{array}{llll}\text { C } & -2.526500 & -3.261883 & 1.787914\end{array}$

$\begin{array}{llll}\text { C } & -1.355375 & -3.344682 & 3.893282\end{array}$

$\begin{array}{lllll}\text { H } & 2.530679 & -0.428044 & 3.307030\end{array}$

$\begin{array}{lllll}C & -2.511097 & -3.572200 & 3.149125\end{array}$

H $\quad-1.334318-3.578545 \quad 4.960513$

H $4.175436-1.115528 \quad 5.041271$

$\begin{array}{llll}\text { H } & -3.399633 & -3.992047 & 3.627435\end{array}$

$\begin{array}{llll}\text { H } & -1.425166 & -2.476490 & 0.113230\end{array}$

H $\quad-3.424674 \quad-3.444397 \quad 1.191486$

$\begin{array}{lllll}\text { H } & 5.704908 & 2.076894 & -1.785776\end{array}$

H $3.0778794 .882214 \quad-2.756201$

C $3.423740 \quad 4.598231 \quad-1.759045$

$\begin{array}{llll}\text { C } 3.353538 & 3.266182 & -1.362421\end{array}$

$\begin{array}{llll}\text { C } 3.919935 & 5.566210 & -0.884908\end{array}$

H $3.962544 \quad 6.614313-1.190448$

C $3.8246112 .865688-0.099372$

C $4.358079 \quad 5.185248 \quad 0.381482$

H $\quad 4.750748 \quad 5.932845 \quad 1.074772$

$\begin{array}{llll}\text { H } & 2.944844 & 2.519494 & -2.053236\end{array}$

$\begin{array}{llll}\text { H } & -7.310391 & -2.158840 & 4.136493\end{array}$

H $\quad-5.467121 \quad-1.600240 \quad 5.07120$

$\begin{array}{llll}\text { C } & -7.013172 & -2.528499 & 3.146117\end{array}$

$\begin{array}{llll}\text { H } & -7.938344 & -2.836889 & 2.641314\end{array}$

$\begin{array}{llll}H & -6.390516 & -3.423955 & 3.290083\end{array}$

$\begin{array}{llll}\text { H } & -3.414603 & -0.616555 & 6.039912\end{array}$

$\begin{array}{llll}\text { C } & -4.757584 & -1.086087 & 4.419347\end{array}$

$\begin{array}{llll}\text { C } & -3.598148 & -0.535284 & 4.966398\end{array}$

H $\quad-7.531955 \quad 0.160977 \quad 3.164245$

$\begin{array}{llll}\text { C } & -6.294559 & -1.446538 & 2.353917\end{array}$

$\begin{array}{llll}\text { C } & -7.230886 & -0.234090 & 2.182963\end{array}$

$\begin{array}{llll}\text { C } & -5.027211 & -0.966521 & 3.053353\end{array}$

H $-8.141373-0.521060 \quad 1.636743$

$\begin{array}{llll}\text { H } & -7.198708 & -3.627651 & 0.767997\end{array}$

$\begin{array}{llll}\text { C } & -2.669217 & 0.123834 & 4.161399\end{array}$

$\begin{array}{llll}\text { C } & -6.431905 & -3.016550 & 0.287252\end{array}$

$\begin{array}{llll}\text { C } & -5.881107 & -1.927639 & 0.966567\end{array}$

$\begin{array}{llll}\text { H } & -6.748641 & 0.584364 & 1.627620\end{array}$

$\begin{array}{llll}\text { C } & -4.076419 & -0.303275 & 2.277316\end{array}$

C $-2.885405 \quad 0.231961 \quad 2.782226$

$\begin{array}{llll}\text { C } & -6.018049 & -3.332424 & -1.008663\end{array}$

H $\quad-3.9776792 .585383 \quad 2.881160$

$\begin{array}{llll}\text { H } & -6.464024 & -4.184590 & -1.525635\end{array}$

$\begin{array}{llll}\text { C } & -4.896327 & -1.195506 & 0.297226\end{array}$

\begin{tabular}{lllll}
\hline & -4.282623 & -0.148705 & 0.930503
\end{tabular}

H $\quad-5.187177 \quad 4.637026 \quad 2.217004$

C $-3.761299 \quad 3.050629 \quad 1.915204$

$\begin{array}{llll}C & -5.045163 & -2.570913 & -1.653559\end{array}$

$\begin{array}{llll}\text { P } & -1.800047 & 1.035856 & 1.542487\end{array}$

$\begin{array}{llll}\text { C } & -4.457668 & -1.477933 & -1.000146\end{array}$

$\begin{array}{llll}\text { C } & -4.438238 & 4.211616 & 1.544730\end{array}$

C $-0.180369 \quad 3.169736 \quad 2.434770$

H $\quad-5.800846 \quad 0.815598 \quad-1.237120$

$\begin{array}{llll}\text { C } & -2.802507 & 2.492595 & 1.058316\end{array}$

$\begin{array}{llll}\text { H } & -0.751436 & 3.803717 & 1.755480\end{array}$

H $-4.735129-2.837295-2.666525$

$\begin{array}{lllll}\text { H } & -6.789057 & 2.906280 & -2.107251\end{array}$

$\begin{array}{llll}\text { C } & -5.223140 & 1.436116 & -1.927785\end{array}$

$\begin{array}{lllll}\text { C } & -4.150839 & 4.838080 & 0.330829\end{array}$

$\begin{array}{llll}\text { P } & -3.110008 & -0.454727 & -1.710153\end{array}$

$\begin{array}{llll}C & -5.785040 & 2.613793 & -2.424063\end{array}$

$\begin{array}{llll}\text { C } & -2.544059 & 3.109016 & -0.170221\end{array}$

$\begin{array}{llll}\text { C } & -3.938911 & 1.048275 & -2.327762\end{array}$ 
$\begin{array}{lllll}\text { H } & -4.675631 & 5.754687 & 0.050797\end{array}$

$\begin{array}{lllll}\text { C } & -3.199999 & 4.286083 & -0.526764\end{array}$

$\begin{array}{lllll}\text { C } & -2.710459 & -1.396880 & -3.229482\end{array}$

$\begin{array}{lllll}\text { H } & -1.823533 & 2.643677 & -0.851487\end{array}$

$\begin{array}{llll}\text { C } & -5.076455 & 3.407832 & -3.324119\end{array}$

$\begin{array}{lllll}C & -5.076455 & 3.407832 & -3.324119 \\ \text { C } & -1.761066 & -2.424504 & -3.138169\end{array}$

H $-4.111280-0.385551-4.540882$

$\begin{array}{llll}\text { C } & -3.356090 & -1.170944 & -4.452002\end{array}$

$\begin{array}{llll}C & -3.220650 & 1.865015 & -3.217817\end{array}$

H $\quad-5.523053 \quad 4.325159 \quad-3.715269$

H $\quad-2.976624 \quad 4.765793 \quad-1.482997$

C $-3.791386 \quad 3.029771 \quad-3.721250$

C $-1.460101-3.210316-4.247704$

$\begin{array}{llll}\text { C } & -3.044600 & -1.952104 & -5.565464\end{array}$

$\begin{array}{llll}\text { H } & -2.209014 & 1.575702 & -3.526467\end{array}$

$\begin{array}{llll}\text { C } & -2.099181 & -2.971970 & -5.465648\end{array}$

H $-3.550199-1.763030-6.515410$

H $-3.226773 \quad 3.650360-4.422402$

$\begin{array}{llll}\text { H } & -1.856300 & -3.581233 & -6.339466\end{array}$

H $\quad-1.239482-2.599417 \quad-2.190048$

H $-0.713849-4.003953-4.164398$

$\begin{array}{llll}\text { H } & -1.779244 & 0.558411 & 4.619267\end{array}$

H $1.846577 \quad 1.001478 \quad 4.932363$

C $1.280866 \quad 1.613472 \quad 4.224163$

C $0.310833 \quad 1.019033 \quad 3.421108$

C $1.546964 \quad 2.980564 \quad 4.114691$

$\begin{array}{llll}\text { H } & 2.320994 & 3.439015 & 4.735642\end{array}$

$\begin{array}{llll}\text { C } & -0.463431 & 1.800028 & 2.542945\end{array}$

C $0.832843 \quad 3.749596 \quad 3.199744$

H $1.047051 \quad 4.814513 \quad 3.082185$

$\begin{array}{llll}H & 0.131697 & -0.058305 & 3.497147\end{array}$

151

Fig._S104_LPd(I)PdL(+) / electronic energy: -5077.67075461 a.u. / lowest freq: $8.55 \mathrm{~cm}-1$

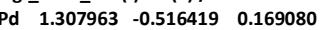

Pd $-1.308026-0.516463 \quad-0.169011$

I $-0.000022-3.029042 \quad 0.000064$

C $3.376561-2.266393 \quad 2.18755$

C $4.255489-3.321424 \quad 2.465667$

H $5.098072-3.528341 \quad 1.799620$

C $4.059733-4.112146 \quad 3.598380$

$\begin{array}{llll}\text { H } & 4.745872 & -4.936663 & 3.806189\end{array}$

$\begin{array}{llll}\text { C } & 2.997194 & -3.852307 & 4.465356\end{array}$

H $\quad 2.849184-4.476129 \quad 5.350091$

C $2.122450-2.797976 \quad 4.198813$

H $1.284908 \quad-2.588125 \quad 4.869751$

$\begin{array}{llll}\text { C } 2.309663 & -2.015595 & 3.062236\end{array}$

H $1.610582-1.200436 \quad 2.83813$

$\begin{array}{llll}\text { C } 4.461860 & -2.097151 & -0.505671\end{array}$

$\begin{array}{llll}\text { C } 4.019669 & -3.391108 & -0.827798\end{array}$

$\begin{array}{llll}\text { H } & 3.163959 & -3.825071 & -0.299978\end{array}$

$\begin{array}{llll}\text { C } 4.670386 & -4.133176 & -1.809821\end{array}$

$\begin{array}{lllll}\text { H } & 4.324832 & -5.143781 & -2.040718\end{array}$

$\begin{array}{llll}\text { C } & 5.754211 & -3.587070 & -2.500203\end{array}$

$\begin{array}{llll}\text { H } & 6.260736 & -4.168098 & -3.274717\end{array}$

$\begin{array}{llll}\text { C } & 6.185094 & -2.295588 & -2.200209\end{array}$

$\begin{array}{llll}\text { H } & 7.029606 & -1.858485 & -2.738767\end{array}$

$\begin{array}{llll}\text { C } & 5.546009 & -1.552700 & -1.207536\end{array}$

$\begin{array}{llll}\text { H } & 5.909273 & -0.547722 & -0.976639\end{array}$

C $4.732913 \quad 0.108462 \quad 1.354516$

C $5.456906 \quad 0.008471 \quad 2.549970$

H $\quad 5.387983 \quad-0.896599 \quad 3.158284$

C $6.250993 \quad 1.071705 \quad 2.976207$

H $6.809443 \quad 0.985888 \quad 3.910707$

C $6.334073 \quad 2.247390 \quad 2.226934$

H $\quad 6.958430 \quad 3.068134 \quad 2.586249$

C $5.635050 \quad 2.380137 \quad 1.024032$

C $4.853281 \quad 1.294149 \quad 0.623620$

C $5.689901 \quad 3.588498 \quad 0.095149$

$\begin{array}{llll}\text { C } 6.660490 & 3.264364 & -1.057043\end{array}$

H $6.3554862 .364824-1.612518$

H $7.675543 \quad 3.092255-0.670193$

$\begin{array}{llll}\text { H } & 6.704359 & 4.099333 & -1.771691\end{array}$

C $6.163443 \quad 4.842568 \quad 0.813829$

$\begin{array}{llll}\text { H } & 6.213843 & 5.695329 & 0.123988\end{array}$

H $7.177224 \quad 4.708046 \quad 1.213599$

H $5.501986 \quad 5.117767 \quad 1.648772$

C $4.293830 \quad 3.758596-0.496480$

$\begin{array}{llll}\text { C } 3.679312 & 4.980177 & -0.785087\end{array}$

H $4.187178 \quad 5.915800 \quad-0.541559$

C $2.428223 \quad 5.019768-1.403307$

$\begin{array}{llll}\text { H } & 1.972812 & 5.983342 & -1.641457\end{array}$

C $1.753810 \quad 3.843925-1.729026$

H $0.781078 \quad 3.901795 \quad-2.221390$

$\begin{array}{llll}\text { C } 2.319297 & 2.599325 & -1.420972\end{array}$

$\begin{array}{llll}C & 3.584599 & 2.599825 & -0.820330\end{array}$

$\begin{array}{llll}\text { C } 2.524164 & 0.120097 & -2.890407\end{array}$

C $3.4726210 .792946-3.671914$

$\begin{array}{llll}\text { H } 3.663720 & 1.858429 & -3.514746\end{array}$ 
$\begin{array}{llll}\text { C } & 4.174618 & 0.109198 & -4.664579\end{array}$

$\begin{array}{llll}\text { H } & 4.914240 & 0.642393 & -5.266857\end{array}$

$\begin{array}{llll}\text { C } 3.930186 & -1.244998 & -4.892681\end{array}$

H $4.480876-1.777060 \quad-5.672449$

$\begin{array}{llll}\text { C } & 2.987511 & -1.921056 & -4.116818\end{array}$

$\begin{array}{lllll}\text { H } & 2.795782 & -2.983830 & -4.284379\end{array}$

C $2.294525-1.245556-3.114694$

H $1.563743-1.781292 \quad-2.496433$

$\begin{array}{lllll}\text { C } & -0.032942 & 1.377668 & -2.527388\end{array}$

$\begin{array}{llll}\text { C } & -1.007776 & 2.149619 & -1.868897\end{array}$

$\begin{array}{lllll}\text { H } & -0.817279 & 2.506056 & -0.851455\end{array}$

$\begin{array}{llll}\text { C } & -2.189379 & 2.505080 & -2.514575\end{array}$

H $-2.9223843 .131549-1.997904$

$\begin{array}{llll}\text { C } & -2.434207 & 2.061053 & -3.816435\end{array}$

H $\quad-3.365550 \quad 2.328955$ - 4.321152

$\begin{array}{llll}\text { C } & -1.481088 & 1.284057 & -4.472699\end{array}$

$\begin{array}{lllll}\text { H } & -1.664226 & 0.937107 & -5.492647\end{array}$

$\begin{array}{llll}\text { C } & -0.281799 & 0.951381 & -3.83948\end{array}$

$\begin{array}{llll}\text { H } & 0.459127 & 0.354502 & -4.377467\end{array}$

$\begin{array}{lllll}\text { O } & 4.119264 & 1.370916 & -0.532625\end{array}$

$\begin{array}{lllll}\text { P } & 3.545999 & -1.147572 & 0.753385\end{array}$

$\begin{array}{lllll}P & 1.510767 & 0.969255 & -1.626538\end{array}$

C $-3.376539-2.266461-2.187461$

$\begin{array}{lllll}C & -4.255329 & -3.321623 & -2.465507\end{array}$

$\begin{array}{llll}\text { H } & -5.097870 & -3.528628 & -1.79943\end{array}$

$\begin{array}{lllll}\text { C } & -4.059487 & -4.112371 & -3.598189\end{array}$

$\begin{array}{llll}\text { H } & -4.745518 & -4.936990 & -3.805946\end{array}$

$\begin{array}{llll}\text { C } & -2.997000 & -3.852429 & -4.465197\end{array}$

H $-2.848924-4.476275 \quad-5.349905$

C $-2.122395 \quad-2.797966-4.198722$

$\begin{array}{llll}\text { H } & -1.284893 & -2.588035 & -4.86968\end{array}$

$\begin{array}{llll}\text { C } & -2.309692 & -2.015557 & -3.062179\end{array}$

$\begin{array}{llll}\text { H } & -1.610712 & -1.200297 & -2.838125\end{array}$

$\begin{array}{llll}\text { C } & -4.461973 & -2.097203 & 0.505700\end{array}$

$\begin{array}{llll}\text { C } & -4.019598 & -3.391040 & 0.828060\end{array}$

$\begin{array}{llll}\text { H } & -3.163709 & -3.824902 & 0.300442\end{array}$

$\begin{array}{llll}\text { C } & -4.670337 & -4.133103 & 1.810070\end{array}$

H $\quad-4.324629 \quad-5.143611 \quad 2.041163$

$\begin{array}{llll}\text { C } & -5.754378 & -3.587108 & 2.500205\end{array}$

$\begin{array}{llll}\text { H } & -6.260917 & -4.168128 & 3.274716\end{array}$

$\begin{array}{llll}\text { C } & -6.185470 & -2.295756 & 2.199958\end{array}$

$\begin{array}{llll}\text { H } & -7.030170 & -1.858752 & 2.738299\end{array}$

$\begin{array}{llll}\text { C } & -5.546358 & -1.552877 & 1.207292\end{array}$

H $\quad-5.909782-0.548004 \quad 0.976190$

$\begin{array}{llll}C & -4.732937 & 0.108402 & -1.354505\end{array}$

$\begin{array}{lllll}C & -5.456931 & 0.008353 & -2.549952\end{array}$

$\begin{array}{llll}\text { H } & -5.388010 & -0.896749 & -3.158218\end{array}$

$\begin{array}{llll}\text { C } & -6.251017 & 1.071567 & -2.976240\end{array}$

$\begin{array}{llll}\text { H } & -6.809467 & 0.985706 & -3.910737\end{array}$

$\begin{array}{llll}\text { C } & -6.334095 & 2.247287 & -2.227022\end{array}$

$\begin{array}{llll}\text { H } & -6.958450 & 3.068013 & -2.586378\end{array}$

$\begin{array}{llll}\text { C } & -5.635076 & 2.380088 & -1.024124\end{array}$

$\begin{array}{llll}\text { C } & -4.853303 & 1.294121 & -0.623658\end{array}$

$\begin{array}{llll}\text { C } & -5.689939 & 3.588493 & -0.095297\end{array}$

$\begin{array}{llll}\text { C } & -6.660552 & 3.264425 & 1.056892\end{array}$

$\begin{array}{llll}\text { H } & -6.355555 & 2.364926 & 1.612438\end{array}$

$\begin{array}{llll}\text { H } & -7.675594 & 3.092283 & 0.670028\end{array}$

H $-6.704446 \quad 4.099441 \quad 1.771483$

$\begin{array}{llll}\text { C } & -6.163463 & 4.842531 & -0.814046\end{array}$

H $\quad-6.213866 \quad 5.695326 \quad-0.124249$

$\begin{array}{llll}H & -7.177242 & 4.707997 & -1.213819\end{array}$

$\begin{array}{llll}\text { H } & -5.501993 & 5.117683 & -1.648994\end{array}$

$\begin{array}{lllll}\text { C } & -4.293875 & 3.758620 & 0.496337\end{array}$

C $-3.679376 \quad 4.980222 \quad 0.784899$

H $-4.1872605 .915827 \quad 0.541338$

C $-2.428288 \quad 5.019857 \quad 1.403116$

H $-1.972894 \quad 5.983447 \quad 1.641235$

$\begin{array}{llll}C & -1.753852 & 3.844036 & 1.728861\end{array}$

$\begin{array}{llll}\text { H } & -0.781118 & 3.901939 & 2.221218\end{array}$

C $-2.319316 \quad 2.599416 \quad 1.420851$

$\begin{array}{llll}\text { C } & -3.584629 & 2.599869 & 0.820229\end{array}$

C $-2.524088 \quad 0.120333 \quad 2.890505$

$\begin{array}{llll}\text { C } & -3.472271 & 0.793340 & 3.672214\end{array}$

$\begin{array}{llll}\text { H } & -3.663206 & 1.858861 & 3.515105\end{array}$

$\begin{array}{llll}C & -4.174206 & 0.109696 & 4.664993\end{array}$

$\begin{array}{lllll}\text { H } & -4.913613 & 0.643010 & 5.267428\end{array}$

$\begin{array}{llll}\text { C } & -3.929974 & -1.244551 & 4.893017\end{array}$

H $-4.480607 \quad-1.776529 \quad 5.672883$

C $-2.987574-1.920764 \quad 4.116955$

$\begin{array}{llll}\text { H } & -2.796004 & -2.983576 & 4.284460\end{array}$

$\begin{array}{llll}C & -2.294656 & -1.245366 & 3.114715\end{array}$

$\begin{array}{llll}\text { H } & -1.564090 & -1.781217 & 2.496299\end{array}$

C $0.032997 \quad 1.377840 \quad 2.527242$

C $1.007758 \quad 2.149845 \quad 1.868702$

$\begin{array}{llll}\text { H } & 0.817183 & 2.506310 & 0.851283\end{array}$

C $2.189396 \quad 2.505325 \quad 2.514306$

H $2.922339 \quad 3.131844 \quad 1.997605$

C $2.434346 \quad 2.061248 \quad 3.816126$ 
$\begin{array}{llll}\text { H } & 3.365719 & 2.329162 & 4.320780\end{array}$

C $1.481309 \quad 1.284187 \quad 4.472430$

H $1.664544 \quad 0.937191 \quad 5.492344$

C $\quad 0.281976 \quad 0.951503 \quad 3.839299$

H $-0.458882 \quad 0.354570 \quad 4.377316$

\begin{tabular}{lllll}
\hline & -4.119290 & 1.370943 & 0.532587
\end{tabular}

$\begin{array}{llll}\text { P } & -3.546053 & -1.147626 & -0.753314\end{array}$

$\begin{array}{llll}P & -1.510757 & 0.969365 & 1.626492\end{array}$

53

ig. S104_PPh4l / electronic energy: -2227.92848832 a.u. / lowest freq: $25.71 \mathrm{~cm}-1$

H $-0.438697 \quad 4.952939-1.919639$

H $1.900000 \quad 4.282421-2.44948$

C $-0.039728 \quad 4.012686-1.531765$

C $1.271643 \quad 3.639559-1.82932$

$\begin{array}{lrrrr}\text { C } & -0.843820 & 3.185285 & -0.747809\end{array}$

C $1.786383 \quad 2.440810 \quad-1.340681$

$\begin{array}{llll}\text { C } & -0.339274 & 1.987260 & -0.247369\end{array}$

C $0.981606 \quad 1.616842-0.538969$

H $\quad 0.686070 \quad 0.126564-2.763824$

$\begin{array}{llll}H & -0.162894 & -1.617215 & -4.303359\end{array}$

$\begin{array}{llll}\text { C } & 0.602655 & -0.907822 & -2.420491\end{array}$

$\begin{array}{lllll}\text { P } & 1.584980 & 0.009658 & 0.013906\end{array}$

$\begin{array}{llll}\text { C } & 0.120727 & -1.888222 & -3.284481\end{array}$

$\begin{array}{lllll}\text { C } & 4.098049 & -1.049040 & -0.563944\end{array}$

C $0.955643-1.252134-1.108536$

$\begin{array}{llll}\text { H } & 3.568579 & -1.881223 & -1.034876\end{array}$

$\begin{array}{llll}\text { C } & -0.011602 & -3.204986 & -2.844528\end{array}$

$\begin{array}{llll}\text { C } & 0.830002 & -2.578648 & -0.668569\end{array}$

H $-0.399729-3.968709-3.522232$

$\begin{array}{llll}\text { C } & 0.344636 & -3.550016 & -1.539831\end{array}$

$\begin{array}{lllll}\text { H } & 1.103515 & -2.850767 & 0.354748\end{array}$

H $0.239908-4.581048 \quad-1.195905$

$\begin{array}{llll}H & 2.809826 & 2.148626 & -1.589211\end{array}$

H $6.0000921 .912325 \quad 1.090973$

$\begin{array}{llll}\text { C } & 5.466608 & 1.080012 & 0.627499\end{array}$

C $4.075288 \quad 1.0855360 .598806$

$\begin{array}{llll}\text { C } & 6.173986 & 0.016834 & 0.063534\end{array}$

H $7.266091 \quad 0.017893 \quad 0.085403$

$\begin{array}{llll}\text { C } 3.386272 & 0.016424 & 0.002291\end{array}$

$\begin{array}{llll}\text { C } 5.491486 & -1.043553 & -0.530903\end{array}$

H $6.044393-1.873013-0.976320$

H $\quad 3.524629 \quad 1.922051 \quad 1.038415$

H $\quad-0.999302 \quad 1.359087 \quad 0.359626$

$\begin{array}{lllll}\text { H } & -1.879829 & 3.447928 & -0.525230\end{array}$

$\begin{array}{llll}\text { C } & 1.311468 & -0.519648 & 4.063745\end{array}$

$\begin{array}{llll}\text { C } & 1.820920 & -0.249056 & 2.795978\end{array}$

$\begin{array}{llll}\text { C } & -0.021043 & -0.904543 & 4.219476\end{array}$

$\begin{array}{llll}\text { C } & 0.988653 & -0.371999 & 1.673828\end{array}$

$\begin{array}{llll}\text { C } & -0.849274 & -1.028098 & 3.104688\end{array}$

$\begin{array}{llll}\text { C } & -0.346550 & -0.771506 & 1.832743\end{array}$

H $-1.896560-1.317069 \quad 3.212772$

H $\quad-0.999310-0.8843240 .966460$

H $-0.414749-1.110742 \quad 5.217366$

H $2.866531 \quad 0.047382 \quad 2.687138$

H $1.962854-0.429345 \quad 4.935460$

F $-3.620593 \quad-1.781850 \quad 0.576962$

\begin{tabular}{llll}
\hline & -2.940225 & 0.945078 & 1.429971
\end{tabular}

$\begin{array}{llll}\text { C } & -3.638784 & -0.821730 & -0.359046\end{array}$

$\begin{array}{lllll}\text { O } & -3.807939 & 1.744633 & -0.768295\end{array}$

F $-4.564436-1.153758-1.264118$

S $-3.983270 \quad 0.845066 \quad 0.386185$

$\begin{array}{llll}F & -2.445243 & -0.848617 & -0.978868\end{array}$

$\begin{array}{llll}0 & -5.357717 & 0.691144 & 0.885864\end{array}$

45

Fig._S104_PPh4(+) / electronic energy: -1266.94473206 a.u. / lowest freq: $-\mathbf{2 1 . 9 3 ~ c m - 1 ~}$

H $-3.315805-4.593781 \quad 0.437567$

$\begin{array}{llll}\text { H } & -3.875099 & -2.792592 & -1.187549\end{array}$

$\begin{array}{llll}\text { C } & -2.676863 & -3.711328 & 0.360497\end{array}$

$\begin{array}{llll}\text { C } & -2.992647 & -2.702566 & -0.551000\end{array}$

$\begin{array}{llll}\text { C } & -1.552701 & -3.593315 & 1.176718\end{array}$

$\begin{array}{llll}\text { C } & -2.186328 & -1.572343 & -0.648565\end{array}$

$\begin{array}{lllll}\text { C } & -0.736329 & -2.467514 & 1.085969\end{array}$

$\begin{array}{llll}\text { C } & -1.051537 & -1.454459 & 0.170619\end{array}$

$\begin{array}{llll}\text { H } & -0.089323 & -1.750850 & -2.369859\end{array}$

$\begin{array}{llll}\text { H } & 1.388738 & -1.909985 & -4.347945\end{array}$

$\begin{array}{llll}\text { C } & 0.780712 & -1.094640 & -2.449898\end{array}$

$\begin{array}{lllll}\text { P } & -0.000567 & 0.000329 & -0.000299\end{array}$

$\begin{array}{llll}\text { C } & 1.614321 & -1.185249 & -3.563193\end{array}$

$\begin{array}{llll}\text { C } & -0.765094 & 2.449963 & -1.107165\end{array}$

C $1.072801-0.170191-1.438540$

H $0.114417 \quad 2.369431-1.750551$

$\begin{array}{llll}\text { C } & 2.733244 & -0.360286 & -3.669917\end{array}$

$\begin{array}{llll}\text { C } & 2.203160 & 0.657267 & -1.544589\end{array}$

$\begin{array}{llll}\text { H } & 3.385825 & -0.437468 & -4.542313\end{array}$

$\begin{array}{llll}\text { C } 3.026826 & 0.559642 & -2.662109\end{array}$

H $2.441477 \quad 1.374826-0.754180$

H $3.905372 \quad 1.202773-2.742733$

$\begin{array}{llll}\text { H } & -2.441722 & -0.781008 & -1.359122\end{array}$ 
$\begin{array}{llll}\text { H } & -3.921821 & 2.744412 & 1.145639\end{array}$

$\begin{array}{llll}C & -3.034131 & 2.663522 & 0.515158\end{array}$

C $-2.213182 \quad 1.545034 \quad 0.623507$

$\begin{array}{lllll}\text { C } & -2.726274 & 3.671723 & -0.399697\end{array}$

$\begin{array}{llll}\text { H } & -3.376121 & 4.545406 & -0.485003\end{array}$

$\begin{array}{lllll}\text { C } & -1.070955 & 1.438666 & -0.187040\end{array}$

C $-1.5961113 .564066-1.209080$

H $-1.359424 \quad 4.349020-1.930083$

H $\quad-2.461991 \quad 0.753551 \quad 1.336241$

$\begin{array}{llll}\text { H } & 0.138405 & -2.378858 & 1.734824\end{array}$

$\begin{array}{llll}\text { H } & -1.309394 & -4.379033 & 1.894617\end{array}$

$\begin{array}{llll}\text { C } & 1.534934 & 1.199180 & 3.593087\end{array}$

C $0.719490 \quad 1.095971 \quad 2.467643$

C $2.671793 \quad 0.400691 \quad 3.710590$

C $1.048113 \quad 0.185884 \quad 1.454485$

$\begin{array}{llll}\text { C } 3.001407 & -0.505289 & 2.701334\end{array}$

$\begin{array}{llll}\text { C } & 2.196070 & -0.614971 & 1.571550\end{array}$

H $3.893682-1.1280412 .790727$

H $2.461601-1.321622 \quad 0.780008$

H $3.3095260 .487506 \quad 4.593011$

$\begin{array}{llll}\text { H } & -0.164683 & 1.731698 & 2.379917\end{array}$

$\begin{array}{cccc}\text { H } & 1.280544 & 1.912944 & 4.379086\end{array}$

Fig._S104_LPdCO / electronic energy: -2503.16331913 a.u. / lowest freq: $11.14 \mathrm{~cm}-1$

C $1.917493-0.756127 \quad 1.670488$

C $2.123012-2.070003 \quad 2.124812$

$\begin{array}{llll}\text { H } & 2.320829 & -2.870298 & 1.403946\end{array}$

$\begin{array}{llll}\text { C } 2.096031 & -2.364087 & 3.485327\end{array}$

H $2.272425-3.389490 \quad 3.820471$

C $1.840150-1.354741 \quad 4.41548$

H $1.813717-1.584845 \quad 5.483613$

C $1.608771-0.053511 \quad 3.972354$

H $1.399472 \quad 0.741891 \quad 4.692577$

C $1.648343 \quad 0.247421 \quad 2.609743$

H $1.484103 \quad 1.279279 \quad 2.287003$

C $3.619370-1.131399-0.571920$

C $3.804756-1.744726-1.816650$

H $2.949992-1.846676-2.494362$

C $5.059193-2.229033-2.190056$

$\begin{array}{lllll}\text { H } & 5.188474 & -2.707028 & -3.164152\end{array}$

C $6.139939-2.113680-1.31703$

H $7.121136-2.499068$-1.605165

$\begin{array}{llll}\text { C } & 5.965210 & -1.506679 & -0.071282\end{array}$

H $6.809627 \quad-1.413021 \quad 0.616204$

$\begin{array}{llll}\text { C } 4.714502 & -1.017538 & 0.299441\end{array}$

$\begin{array}{lllll}\text { H } & 4.590332 & -0.536365 & 1.274578\end{array}$

$\begin{array}{llll}\text { C } & 2.192015 & 1.336921 & -0.327435\end{array}$

C $3.3801801 .939303-0.764573$

$\begin{array}{llll}\text { H } & 4.275803 & 1.332368 & -0.916321\end{array}$

C $3.423544 \quad 3.305610 \quad-1.037031$

$\begin{array}{lllll}\text { H } & 4.356200 & 3.756264 & -1.383454\end{array}$

$\begin{array}{llll}\text { C } & 2.287109 & 4.100060 & -0.880802\end{array}$

$\begin{array}{llll}\text { H } & 2.341838 & 5.167129 & -1.106178\end{array}$

C $1.085661 \quad 3.543708-0.434721$

$\begin{array}{llll}\text { C } & -0.196851 & 4.323800 & -0.163833\end{array}$

$\begin{array}{lllll}C & -1.361329 & 3.429376 & -0.576209\end{array}$

$\begin{array}{llll}\text { C } & -2.558182 & 3.868603 & -1.150428\end{array}$

H $-2.6894804 .924851-1.395245$

$\begin{array}{llll}\text { C } & -3.596607 & 2.971532 & -1.406391\end{array}$

H $-4.526313 \quad 3.333794 \quad-1.850738$

$\begin{array}{llll}C & -3.462644 & 1.617982 & -1.096825\end{array}$

$\begin{array}{llll}\text { H } & -4.285078 & 0.928883 & -1.306009\end{array}$

$\begin{array}{llll}\text { C } & -2.273492 & 1.136302 & -0.536087\end{array}$

$\begin{array}{llll}C & -1.252348 & 2.065503 & -0.296972\end{array}$

C $1.074992 \quad 2.170456-0.171318$

$\begin{array}{llll}\text { C } & -0.297955 & 4.565057 & 1.355110\end{array}$

H $\quad-0.286752 \quad 3.622838 \quad 1.923412$

$\begin{array}{llll}H & -1.230569 & 5.093740 & 1.602193\end{array}$

$\begin{array}{llll}\text { H } & 0.545180 & 5.177957 & 1.706724\end{array}$

$\begin{array}{llll}C & -0.218251 & 5.663532 & -0.884182\end{array}$

H $0.614160 \quad 6.300801-0.557019$

$\begin{array}{lllll}H & -1.138753 & 6.217299 & -0.655890\end{array}$

$\begin{array}{lllll}\text { H } & -0.151310 & 5.550074 & -1.975959\end{array}$

$\begin{array}{llll}\text { C } & -3.493129 & -1.446410 & -0.573948\end{array}$

$\begin{array}{llll}\text { C } & -4.585710 & -1.431394 & 0.305942\end{array}$

$\begin{array}{llll}\text { H } & -4.501415 & -0.932273 & 1.276051\end{array}$

$\begin{array}{llll}\text { C } & -5.785680 & -2.045864 & -0.048658\end{array}$

$\begin{array}{lllll}\text { H } & -6.628684 & -2.029638 & 0.646696\end{array}$

$\begin{array}{llll}\text { C } & -5.911155 & -2.678519 & -1.28\end{array}$

H $-6.851859-3.161877-1.561$

$\begin{array}{llll}\text { C } & -4.830397 & -2.697692 & -2.168299\end{array}$

H $-4.920599-3.195493 \quad-3.136916$

$\begin{array}{llll}\text { C } & -3.626667 & -2.090401 & -1.811024\end{array}$

$\begin{array}{llll}\text { H } & -2.771474 & -2.115421 & -2.495793\end{array}$

$\begin{array}{llll}\text { C } & -1.884148 & -0.669415 & 1.655401\end{array}$

$\begin{array}{llll}\text { C } & -1.516996 & -1.879173 & 2.265142\end{array}$

$\begin{array}{llll}\text { H } & -1.225036 & -2.732402 & 1.642813\end{array}$

$\begin{array}{llll}\text { C } & -1.526785 & -2.006273 & 3.652194\end{array}$ 
$\begin{array}{llll}\text { H } & -1.243040 & -2.956809 & 4.111284\end{array}$ C $-1.883542-0.919670 \quad 4.452864$ H $\quad-1.884027-1.017018 \quad 5.541498$

$\begin{array}{llll}\text { C } & -2.227774 & 0.293160 & 3.857538\end{array}$

$\begin{array}{llll}\text { H } & -2.503849 & 1.149938 & 4.477735\end{array}$

\begin{tabular}{llll}
\hline C & -2.231206 & 0.418527 & 2.467591 \\
\hline
\end{tabular}

H $-2.522501 \quad 1.371936 \quad 2.016843$

$\begin{array}{llll}O & -0.089260 & 1.570263 & 0.237051\end{array}$

Pd $0.071408-1.290532-1.434302$

$\begin{array}{llll}P & 1.955433 & -0.476967 & -0.142675\end{array}$

$\begin{array}{llll}P & -1.897130 & -0.622416 & -0.181451\end{array}$

$\begin{array}{llll}\text { C } & 0.136546 & -2.158754 & -3.123820\end{array}$

$\begin{array}{lllll}\text { O } & 0.182049 & -2.682347 & -4.159273\end{array}$

Fig. S104_Pd-acyl(+) / electronic energy: - 2582.17852429 a.u. / lowest freq: $18.05 \mathrm{~cm}-1$

$\begin{array}{llll}\text { Pd }-0.006524 & -0.675121 & -0.185512\end{array}$

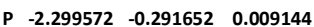

$\begin{array}{llll}\text { P } & 2.295916 & -0.356819 & 0.002961\end{array}$

$\begin{array}{llll}O & 0.024358 & 1.659386 & -0.207410\end{array}$

$\begin{array}{llll}\text { C } & -1.169636 & 2.311458 & 0.071909\end{array}$

$\begin{array}{lllll}C & -2.330963 & 1.529903 & 0.205586\end{array}$

$\begin{array}{llll}C & -3.534996 & 2.179551 & 0.509181\end{array}$

H $\quad-4.450331 \quad 1.591306 \quad 0.620750$

C $-3.571759 \quad 3.558324 \quad 0.674077$

H $\quad-4.511847 \quad 4.056131 \quad 0.918454$

$\begin{array}{llll}\text { C } & -2.407738 & 4.306971 & 0.513171\end{array}$

$\begin{array}{llll}\text { H } & -2.456932 & 5.391213 & 0.624075\end{array}$

C $-1.186861 \quad 3.705800 \quad 0.194634$

$\begin{array}{llll}\text { C } & 0.065260 & 4.504591 & -0.139842\end{array}$

C $1.290445 \quad 3.669855 \quad 0.206860$

$\begin{array}{llll}\text { C } & 2.525042 & 4.234750 & 0.538796\end{array}$

H $2.604456 \quad 5.3168790 .652673$

C $3.6650593 .452250 \quad 0.709996$

H $4.616508 \quad 3.921844 \quad 0.965875$

C $3.590463 \quad 2.075694 \quad 0.539349$

H $4.487592 \quad 1.460864 \quad 0.656089$

C $2.371364 \quad 1.461831 \quad 0.222352$

$\begin{array}{llll}\text { C } & 1.234247 & 2.276825 & 0.081767\end{array}$

$\begin{array}{llll}\text { C } & 0.075937 & 4.734473 & -1.664648\end{array}$

H $0.0640623 .786906 \quad-2.222810$

H $0.976628 \quad 5.290319-1.963891$

$\begin{array}{llll}\text { H } & -0.804840 & 5.317108 & -1.972094\end{array}$

C $0.081348 \quad 5.857790 \quad 0.562151$

$\begin{array}{lllll}\text { H } & 0.071617 & 5.759918 & 1.657085\end{array}$

$\begin{array}{lllll}H & -0.780756 & 6.467234 & 0.264571\end{array}$

$\begin{array}{lllll}\text { H } & 0.967329 & 6.438822 & 0.278037\end{array}$

$\begin{array}{llll}\text { C } & -3.408063 & -0.679302 & -1.376606\end{array}$

$\begin{array}{llll}\text { C }-3.802304 & -2.017666 & -1.546545\end{array}$

$\begin{array}{llll}\text { H } & -3.503647 & -2.776144 & -0.815160\end{array}$

$\begin{array}{llll}\text { C } & -4.580874 & -2.385235 & -2.640330\end{array}$

$\begin{array}{lllll}\text { H } & -4.888921 & -3.426601 & -2.758800\end{array}$

$\begin{array}{llll}C & -4.965109 & -1.427055 & -3.580797\end{array}$

H $\quad-5.576004-1.716739-4.438775$

$\begin{array}{llll}\text { C } & -4.565818 & -0.100611 & -3.423824\end{array}$

$\begin{array}{llll}\text { H } & -4.863147 & 0.652085 & -4.157476\end{array}$

$\begin{array}{llll}\text { C } & -3.788381 & 0.276163 & -2.328264\end{array}$

$\begin{array}{lllll}\text { H } & -3.480649 & 1.319497 & -2.217028\end{array}$

$\begin{array}{llll}\text { C } & -3.100061 & -0.958603 & 1.501418\end{array}$

C $-4.485541-1.150802 \quad 1.601728$

$\begin{array}{llll}\text { H } & -5.138709 & -0.919811 & 0.755538\end{array}$

$\begin{array}{llll}\text { C } & -5.035172 & -1.641854 & 2.784625\end{array}$

$\begin{array}{llll}\text { H } & -6.114791 & -1.791861 & 2.856950\end{array}$

$\begin{array}{llll}C & -4.212136 & -1.940923 & 3.871317\end{array}$

$\begin{array}{llll}\text { H } & -4.647921 & -2.329260 & 4.794761\end{array}$

C $-2.833091-1.751601 \quad 3.776413$

H $\quad-2.185508 \quad-1.991927 \quad 4.622554$

H $-1.193969-1.132542 \quad 2.505443$

$\begin{array}{llll}\text { C } & 3.406582 & -0.741348 & -1.383309\end{array}$

$\begin{array}{llll}\text { C } 3.794062 & -2.079857 & -1.565555\end{array}$

$\begin{array}{llll}\text { H } & 3.482699 & -2.845267 & -0.846968\end{array}$

$\begin{array}{llll}\text { C } 4.580878 & -2.439306 & -2.656306\end{array}$

H $4.883870-3.481035 \quad-2.784025$

$\begin{array}{llll}\text { C } 4.979578 & -1.472835 & -3.581962\end{array}$

H $5.597056-1.756275-4.437306$

$\begin{array}{llll}\text { C } 4.585750 & -0.146134 & -3.413775\end{array}$

H $4.893836 \quad 0.613213 \quad-4.136053$

$\begin{array}{llll}\text { C } 3.800898 & 0.222566 & -2.320874\end{array}$

$\begin{array}{lllll}\text { H } & 3.498782 & 1.266488 & -2.200644\end{array}$

$\begin{array}{lll}\text { C } 3.081201 & -1.061230 & 1.486515\end{array}$

$\begin{array}{llll}\text { C } 4.467244 & -1.245119 & 1.597440\end{array}$

$\begin{array}{llll}\text { H } & 5.127301 & -0.989887 & 0.763587\end{array}$

C $5.008305 \quad-1.760423 \quad 2.773786$

$\begin{array}{llll}\text { H } & 6.088298 & -1.903289 & 2.854407\end{array}$

$\begin{array}{llll}\text { C } & 4.175849 & -2.093687 & 3.843387\end{array}$

H $4.604934 \quad-2.500980 \quad 4.761800$

C $2.796377 \quad-1.914971 \quad 3.73722$

$\begin{array}{llll}\text { H } & 2.141445 & -2.183177 & 4.569223\end{array}$ 
$\begin{array}{llll}C & 2.249105 & -1.405230 & 2.561589\end{array}$

H $\quad 1.165550-1.280415 \quad 2.463358$

$\begin{array}{lllll}0 & -0.072948 & -3.333787 & 0.74315\end{array}$

H $-1.227558-4.973543-1.324136$

H $\quad 0.526213-5.210793-1.248097$

$\begin{array}{llll}\text { C } & -0.271325 & -4.662251 & -1.767085\end{array}$

C $-0.055368-2.655149-0.244600$

H $-0.269354-4.979405-2.817873$

C $-0.073449-3.166185-1.664746$

H $-0.848426-2.605723-2.213534$

$\begin{array}{llll}H & 0.874719 & -2.842836 & -2.127737\end{array}$

10

Fig._S104_RCHO / electronic energy: $-\mathbf{1 9 2 . 9 8 4 0 6 5 8 2 4}$ a.u. / lowest freq: $153.26 \mathrm{~cm}-1$

O $1.401165-0.687132 \quad 0.000000$

H $-1.252324-1.124869-0.883551$

$\begin{array}{lll}\text { C } 0.919697 & 0.422075 \quad 0.000000\end{array}$

$\begin{array}{llll}\text { H } & -1.252326 & -1.124867 & 0.883553\end{array}$

$\begin{array}{llll}\text { C } & -1.432393 & -0.496718 & 0.000000\end{array}$

H $1.5806851 .330267 \quad 0.000000$

$\begin{array}{llll}\text { C } & -0.542228 & 0.720552 & 0.000000\end{array}$

H $-2.494356-0.218374-0.000001$

$\begin{array}{llll}H & -0.730725 & 1.379719 & -0.866637\end{array}$

\begin{tabular}{lllll}
\hline & -0.730726 & 1.379719 & 0.866637
\end{tabular}

153

Fig._S104_LPdH(CO)PdL(+) / electronic energy: -4893.59579005 a.u. / lowest freq: $9.67 \mathrm{~cm}-1$

C $3.275432 \quad 2.757857-2.077960$

C $2.422543 \quad 3.778934-1.632281$

$\begin{array}{llll}\text { H } & 1.854809 & 3.642447 & -0.706206\end{array}$

C $2.2933324 .960460-2.356318$

H $1.629605 \quad 5.749747-1.993970$

C $2.999295 \quad 5.127645-3.549156$

H $2.892178 \quad 6.050855-4.123674$

$\begin{array}{llll}\text { C } 3.837074 & 4.111763 & -4.007796\end{array}$

H $4.390362 \quad 4.237611-4.941551$

C $3.980797 \quad 2.932320-3.275420$

H $4.651018 \quad 2.150080 \quad-3.641816$

$\begin{array}{llll}\text { C } 4.554456 & 0.167914 & -1.971968\end{array}$

$\begin{array}{llll}\text { C } 3.997112 & -0.659870 & -2.957441\end{array}$

$\begin{array}{llll}\text { H } & 2.913253 & -0.647283 & -3.12420\end{array}$

$\begin{array}{llll}\text { C } & 4.810969 & -1.492381 & -3.722810\end{array}$

H $4.365941-2.126790-4.493153$

C $6.187460-1.524345-3.495061$

$\begin{array}{llll}\text { H } & 6.824898 & -2.185918 & -4.086856\end{array}$

$\begin{array}{llll}\text { C } & 6.746755 & -0.715772 & -2.505448\end{array}$

H $7.823629-0.739313-2.321488$

$\begin{array}{llll}\text { C } & 5.937141 & 0.132704 & -1.750318\end{array}$

H $6.3910650 .771241-0.986728$

$\begin{array}{llll}\text { C } 4.434738 & 1.861402 & 0.356642\end{array}$

$\begin{array}{llll}\text { C } 4.859536 & 3.182550 & 0.544636\end{array}$

H $4.619076 \quad 3.947713 \quad-0.196794$

C $5.581224 \quad 3.530047 \quad 1.685970$

H $5.898644 \quad 4.565393 \quad 1.827571$

C $5.913235 \quad 2.568130 \quad 2.641303$

H $6.4905162 .861616 \quad 3.520440$

$\begin{array}{llll}\text { C } & 5.534569 & 1.233187 & 2.472755\end{array}$

$\begin{array}{llll}\text { C } & 4.788698 & 0.924202 & 1.333081\end{array}$

$\begin{array}{llll}\text { C } & 5.939651 & 0.078766 & 3.381462\end{array}$

C $6.343981 \quad 0.552561 \quad 4.769597$

H $7.201743 \quad 1.236080 \quad 4.717487$

H $6.660252 \quad-0.291076 \quad 5.397314$

H $5.524721 \quad 1.072930 \quad 5.286578$

$\begin{array}{llll}\text { C } & 7.131969 & -0.644508 & 2.724020\end{array}$

$\begin{array}{llll}\text { H } & 6.888222 & -1.007893 & 1.714313\end{array}$

H $7.437764-1.5116823 .327573$

H $7.994188 \quad 0.0328592 .636770$

$\begin{array}{llll}\text { C } & 4.764315 & -0.891137 & 3.421850\end{array}$

$\begin{array}{llll}C & 4.388779 & -1.652638 & 4.530737\end{array}$

$\begin{array}{llll}\text { H } & 4.923946 & -1.535877 & 5.475288\end{array}$

C $3.341839-2.571413 \quad 4.445113$

H $3.068696-3.165011 \quad 5.319979$

C $2.636465 \quad-2.735655 \quad 3.255368$

H $1.808849-3.447139 \quad 3.213266$

$\begin{array}{llll}\text { C } & 2.970235 & -1.977502 & 2.123822\end{array}$

$\begin{array}{llll}\text { C } 4.040450 & -1.083234 & 2.240586\end{array}$

$\begin{array}{llll}\text { C } 2.934229 & -3.136097 & -0.552615\end{array}$

$\begin{array}{llll}\text { C } & 4.241027 & -3.571029 & -0.304706\end{array}$

H 4.760088 -3.273624 0.611264

$\begin{array}{llll}\text { C } & 4.888452 & -4.399657 & -1.223505\end{array}$

$\begin{array}{llll}\text { H } & 5.909925 & -4.731438 & -1.022239\end{array}$

$\begin{array}{llll}\text { C } 4.235914 & -4.809073 & -2.385126\end{array}$

$\begin{array}{lllll}\text { H } & 4.744028 & -5.463920 & -3.097134\end{array}$

$\begin{array}{llll}\text { C } 2.933307 & -4.373740 & -2.640315\end{array}$

$\begin{array}{llll}\text { H } & 2.416917 & -4.684653 & -3.552171\end{array}$

$\begin{array}{llll}\text { C } & 2.291830 & -3.530511 & -1.738098\end{array}$

$\begin{array}{lllll}\text { H } & 1.275285 & -3.178481 & -1.949998\end{array}$

$\begin{array}{llll}\text { C } & 0.546416 & -2.984998 & 1.062366\end{array}$

$\begin{array}{llll}\text { C } & 0.477498 & -4.379468 & 0.952554\end{array}$

$\begin{array}{lllll}\text { H } & 1.318327 & -4.941130 & 0.535444\end{array}$ 
$\begin{array}{llll}C & -0.664293 & -5.062506 & 1.374880\end{array}$ $\begin{array}{llll}\text { H } & -0.710946 & -6.149713 & 1.275783\end{array}$

$\begin{array}{llll}\text { C } & -1.736808 & -4.363544 & 1.928237\end{array}$

H $\quad-2.627318 \quad-4.901238 \quad 2.262805$

$\begin{array}{llll}C & -1.669391 & -2.974247 & 2.055884\end{array}$

$\begin{array}{llll}\text { H } & -2.504999 & -2.420831 & 2.493817\end{array}$

$\begin{array}{llll}\text { C } & -0.538998 & -2.288518 & 1.616455\end{array}$

H $-0.497370-1.194554 \quad 1.70026$

$\begin{array}{llll}\text { C } & -0.882860 & 3.153409 & 1.133524\end{array}$

$\begin{array}{llll}\text { C } & -0.900081 & 4.545640 & 0.996033\end{array}$

H $\quad-1.777103 \quad 5.047486 \quad 0.577791$

$\begin{array}{llll}\text { C } & 0.203601 & 5.304329 & 1.395742\end{array}$

H $\quad 0.1817326 .390352 \quad 1.276850$

C $1.323383 \quad 4.684273 \quad 1.948296$

H $2.184396 \quad 5.280967 \quad 2.260498$

C $1.345870 \quad 3.294515 \quad 2.093857$

$\begin{array}{llll}\text { H } & 2.218944 & 2.798662 & 2.527308\end{array}$

$\begin{array}{llll}\text { C } & 0.256841 & 2.534481 & 1.675988\end{array}$

H $0.287564 \quad 1.441978 \quad 1.77383$

$\begin{array}{llll}\text { C } & -3.492660 & 3.154719 & -0.166522\end{array}$

$\begin{array}{lllll}C & -3.240657 & 3.578361 & -1.481037\end{array}$

$\begin{array}{llll}\text { H } & -2.329870 & 3.254387 & -1.994034\end{array}$

$\begin{array}{llll}\text { C } & -4.141598 & 4.414009 & -2.136932\end{array}$

H $\quad-3.930870 \quad 4.739149-3.158767$

$\begin{array}{lllll}\text { C } & -5.315209 & 4.818004 & -1.498626\end{array}$

H $\quad-6.026099 \quad 5.465992 \quad-2.016933$

$\begin{array}{lllll}\text { C } & -5.580226 & 4.387589 & -0.199044\end{array}$

$\begin{array}{llll}\text { H } & -6.498063 & 4.698525 & 0.305621\end{array}$

$\begin{array}{llll}\text { C } & -4.673731 & 3.563549 & 0.468261\end{array}$

H $\quad-4.892541 \quad 3.245029 \quad 1.491374$

C $-3.031908 \quad 1.624428 \quad 2.227750$

C $-2.675913 \quad 2.186611 \quad 3.460489$

H $-1.884186 \quad 2.938102 \quad 3.509789$

$\begin{array}{llll}\text { C } & -3.326238 & 1.788669 & 4.627198\end{array}$

H $-3.034236 \quad 2.226325 \quad 5.584042$

C $-4.3583890 .849997 \quad 4.581496$

$\begin{array}{llll}\text { H } & -4.868726 & 0.567695 & 5.504816\end{array}$

$\begin{array}{llll}\text { C } & -4.758289 & 0.283919 & 3.368355\end{array}$

$\begin{array}{llll}\text { C } & -4.059767 & 0.673198 & 2.221737\end{array}$

$\begin{array}{llll}C & -5.945556 & -0.655325 & 3.185787\end{array}$

$\begin{array}{llll}\text { C } & -7.132593 & 0.180307 & 2.668035\end{array}$

H $-6.8969200 .692064 \quad 1.722686$

$\begin{array}{llll}\text { H } & -7.413599 & 0.948215 & 3.403695\end{array}$

$\begin{array}{llll}\text { H } & -8.008705 & -0.461224 & 2.492898\end{array}$

C $-6.343671-1.337888 \quad 4.485483$

$\begin{array}{llll}\text { H } & -7.213347 & -1.991096 & 4.335600\end{array}$

$\begin{array}{llll}\text { H } & -6.638945 & -0.599024 & 5.242233\end{array}$

H $\quad-5.528090 \quad-1.946270 \quad 4.902835$

$\begin{array}{llll}\text { C } & -5.559909 & -1.656863 & 2.103762\end{array}$

$\begin{array}{llll}\text { C } & -5.937099 & -3.002564 & 2.076539\end{array}$

$\begin{array}{llll}\text { H } & -6.533021 & -3.415659 & 2.893113\end{array}$

$\begin{array}{llll}\text { C } & -5.569044 & -3.826059 & 1.011268\end{array}$

$\begin{array}{llll}\text { H } & -5.881991 & -4.872335 & 1.002797\end{array}$

$\begin{array}{llll}\text { C } & -4.792095 & -3.331919 & -0.035261\end{array}$

H $-4.486066-3.997904 \quad-0.845954$

$\begin{array}{llll}C & -4.379891 & -1.992827 & -0.034795\end{array}$

$\begin{array}{llll}\text { C } & -4.796558 & -1.187773 & 1.032299\end{array}$

$\begin{array}{llll}C & -4.193419 & -0.181242 & -2.302461\end{array}$

$\begin{array}{llll}\text { C } & -5.544689 & 0.103596 & -2.074242\end{array}$

H $\quad-6.074983 \quad-0.364759-1.240352$

$\begin{array}{llll}\text { C } & -6.228849 & 0.981813 & -2.916512\end{array}$

H $\quad-7.282512 \quad 1.200124 \quad-2.726011$

$\begin{array}{llll}\text { C } & -5.576151 & 1.572814 & -3.997004\end{array}$

H $-6.116223 \quad 2.257461 \quad-4.655672$

$\begin{array}{llll}C & -4.227489 & 1.294356 & -4.230158\end{array}$

$\begin{array}{lllll}\text { H } & -3.707754 & 1.759272 & -5.071563\end{array}$

$\begin{array}{llll}\text { C } & -3.536497 & 0.433406 & -3.382182\end{array}$

$\begin{array}{llll}\text { H } & -2.474296 & 0.229420 & -3.561232\end{array}$

$\begin{array}{llll}C & -2.800091 & -2.708193 & -2.295873\end{array}$

$\begin{array}{llll}\text { C } & -1.709263 & -3.512179 & -1.937591\end{array}$

H $\quad-1.098811-3.236783 \quad-1.070214$

$\begin{array}{llll}\text { C } & -1.404364 & -4.657762 & -2.671134\end{array}$

H $\quad-0.558865 \quad-5.284766-2.374785$

$\begin{array}{llll}\text { C }-2.174743 & -4.998429 & -3.783946\end{array}$

$\begin{array}{lllll}\text { H } & -1.932129 & -5.891072 & -4.365495\end{array}$

$\begin{array}{llll}\text { C } & -3.254443 & -4.195682 & -4.154561\end{array}$

$\begin{array}{llll}\text { H } & -3.858647 & -4.458636 & -5.026183\end{array}$

$\begin{array}{llll}\text { C } & -3.572764 & -3.059050 & -3.411568\end{array}$

$\begin{array}{llll}\text { H } & -4.431301 & -2.445935 & -3.700661\end{array}$

$\begin{array}{llll}C & 0.114756 & 1.371381 & -1.434042\end{array}$

$\begin{array}{llll}\text { O } & 4.357836 & -0.360547 & 1.121236\end{array}$

\begin{tabular}{lllll}
\hline & -4.380048 & 0.120398 & 1.008452
\end{tabular}

$\begin{array}{lllll}0 & -0.009995 & 2.246006 & -2.207135\end{array}$

$\begin{array}{llll}P & 3.419582 & 1.259546 & -1.042325\end{array}$

$\begin{array}{llll}P & 2.016748 & -2.015878 & 0.558551\end{array}$

$\begin{array}{lllll}P & -2.262722 & 2.059637 & 0.626401\end{array}$

$\begin{array}{lllll}P & -3.196703 & -1.276637 & -1.229479\end{array}$

$\begin{array}{llll}\text { Pd } & 1.372258 & 0.033998 & -0.653022\end{array}$ 
$\begin{array}{llll}\text { Pd } & -1.324035 & 0.189531 & -0.619058\end{array}$

$\begin{array}{llll}\text { H } & -0.120101 & -0.979249 & -0.976158\end{array}$

84

Fig._S104_LPdHOTf / electronic energy: - 3351.35642436 a.u. / lowest freq: 21.22 cm-1

Pd $0.000308-0.390837-1.449630$

$\begin{array}{llll}\text { P } & -2.075292 & -0.048219 & -0.671137\end{array}$

$\begin{array}{llll}P & 1.465847 & 1.198908 & -0.184027\end{array}$

\begin{tabular}{lllll}
\hline & -0.457093 & 0.051076 & 1.668652
\end{tabular}

C $-1.321536 \quad-1.005604 \quad 1.793244$

$\begin{array}{llll}\text { C }-2.233236 & -1.186138 & 0.746255\end{array}$

$\begin{array}{llll}\text { C } & -3.098505 & -2.282677 & 0.813470\end{array}$

H $-3.812844-2.468485 \quad 0.007729$

C $-3.030163 \quad-3.154315 \quad 1.899996$

H $-3.701028-4.014726 \quad 1.943183$

$\begin{array}{llll}\text { C } & -2.112814 & -2.941140 & 2.930661\end{array}$

$\begin{array}{llll}\text { H } & -2.081794 & -3.638145 & 3.770759\end{array}$

$\begin{array}{llll}\text { C } & -1.241831 & -1.847756 & 2.903287\end{array}$

C $-0.249635 \quad-1.472208 \quad 3.999658$

C $0.994104-0.918186 \quad 3.309990$

$\begin{array}{llll}\text { C } & 2.305906 & -1.090934 & 3.757567\end{array}$

H $2.502184 \quad-1.692773 \quad 4.647389$

$\begin{array}{llll}\text { C } 3.373569 & -0.499518 & 3.080630\end{array}$

H $4.392920-0.645585 \quad 3.444280$

C $3.157354 \quad 0.252790 \quad 1.928893$

H $4.010778 \quad 0.657260 \quad 1.381442$

$\begin{array}{llll}\text { C } & 1.859634 & 0.441903 & 1.439851\end{array}$

$\begin{array}{llll}\text { C } & 0.812399 & -0.140690 & 2.162861\end{array}$

$\begin{array}{llll}\text { C } & -0.873186 & -0.343985 & 4.843516\end{array}$

$\begin{array}{llll}\text { H } & -1.127130 & 0.535322 & 4.232549\end{array}$

H $\quad-0.173391-0.015404 \quad 5.625969$

$\begin{array}{llll}\text { H } & -1.795558 & -0.689046 & 5.33375\end{array}$

$\begin{array}{llll}\text { C } & 0.075939 & -2.652549 & 4.902550\end{array}$

$\begin{array}{llll}\text { H } & 0.525782 & -3.487483 & 4.346202\end{array}$

$\begin{array}{llll}\text { H } & -0.826918 & -3.024483 & 5.405028\end{array}$

$\begin{array}{llll}H & 0.773048 & -2.358965 & 5.698454\end{array}$

$\begin{array}{llll}\text { C }-2.568134 & 1.587372 & -0.014199\end{array}$

$\begin{array}{lllll}\text { C } & -2.520386 & 2.682604 & -0.888293\end{array}$

$\begin{array}{lllll}\text { H } & -2.114740 & 2.558604 & -1.898014\end{array}$

$\begin{array}{llll}\text { C } & -2.999471 & 3.925508 & -0.482853\end{array}$

$\begin{array}{lllll}\text { H } & -2.961144 & 4.771444 & -1.173478\end{array}$

$\begin{array}{llll}\text { C } & -3.520344 & 4.090839 & 0.801480\end{array}$

H $-3.893822 \quad 5.067585 \quad 1.118837$

$\begin{array}{lllll}\text { C } & -3.554470 & 3.009844 & 1.680848\end{array}$

H $\quad-3.958003 \quad 3.133278 \quad 2.688835$

$\begin{array}{llll}C & -3.080264 & 1.761380 & 1.277933\end{array}$

$\begin{array}{llll}\text { H } & -3.133094 & 0.918684 & 1.972751\end{array}$

C $-3.499311-0.424106-1.756842$

$\begin{array}{llll}\text { C } & -4.798589 & -0.243608 & -1.252849\end{array}$

H $\quad-4.945576 \quad 0.110302 \quad-0.227716$

$\begin{array}{llll}\text { C } & -5.906448 & -0.524630 & -2.046927\end{array}$

$\begin{array}{llll}\text { H } & -6.911613 & -0.393231 & -1.639886\end{array}$

$\begin{array}{lllll}\text { C } & -5.732301 & -0.968683 & -3.359584\end{array}$

H $\quad-6.602942-1.183579-3.983708$

C $-4.447341-1.132265-3.872483$

H $-4.304886-1.470204 \quad-4.901415$

$\begin{array}{llll}\text { C } & -3.334244 & -0.861862 & -3.075071\end{array}$

$\begin{array}{llll}\text { H } & -2.327821 & -0.989213 & -3.483510\end{array}$

$\begin{array}{llll}\text { C } & 0.778720 & 2.851995 & 0.227135\end{array}$

C $0.766811 \quad 3.818232-0.792196$

H $\quad 1.127281 \quad 3.559805-1.793381$

$\begin{array}{llll}\text { C } & 0.326045 & 5.113400 & -0.535595\end{array}$

$\begin{array}{lllll}\text { H } & 0.338373 & 5.858337 & -1.335245\end{array}$

$\begin{array}{lllll}\text { C } & -0.129418 & 5.457869 & 0.738206\end{array}$

H $-0.474252 \quad 6.474701 \quad 0.942109$

$\begin{array}{llll}C & -0.149374 & 4.496582 & 1.747159\end{array}$

H $\quad-0.513117 \quad 4.756006 \quad 2.744780$

C $\quad 0.303840 \quad 3.199999 \quad 1.496876$

$\begin{array}{lllll}\text { H } & 0.302161 & 2.466879 & 2.308262\end{array}$

$\begin{array}{llll}\text { C } 3.094301 & 1.707900 & -0.857107\end{array}$

$\begin{array}{llll}\text { C } 3.847221 & 2.699647 & -0.206896\end{array}$

H 3.4713963 .1550960 .714445

C $5.071321 \quad 3.111129-0.726795$

$\begin{array}{lllll}\text { H } & 5.649632 & 3.879736 & -0.208379\end{array}$

$\begin{array}{llll}\text { C } & 5.553627 & 2.546578 & -1.909655\end{array}$

H $\begin{array}{llll}6.512021 & 2.873934 & -2.320204\end{array}$

$\begin{array}{llll}\text { C } 4.807455 & 1.570040 & -2.566679\end{array}$

H $5.177501 \quad 1.129253-3.495447$

$\begin{array}{llll}C & 3.583437 & 1.149336 & -2.043494\end{array}$

$\begin{array}{llll}\text { H } & 3.004967 & 0.380748 & -2.559604\end{array}$

$\begin{array}{lllll}\text { O } & 3.501334 & -3.089997 & -2.493782\end{array}$

\begin{tabular}{llll}
\hline & 1.645179 & -1.471616 & -2.432047
\end{tabular}

$\begin{array}{llll}\text { S } & 2.603597 & -2.322427 & -1.633190\end{array}$

$\begin{array}{lllll}0 & 3.171341 & -1.644776 & -0.463235\end{array}$

$\begin{array}{llll}\text { F } & 0.690617 & -4.148081 & -1.823218\end{array}$

$\begin{array}{llll}\text { C } & 1.484969 & -3.616830 & -0.893846\end{array}$

F $2.220593-4.591975-0.361884$

F $0.713869 \quad-3.107723 \quad 0.072518$

H $-0.944155 \quad-1.469679-2.092902$ 
168

Fig._S104_INT1(LPdHOTf)(+) / electronic energy: -5933.58659659 a.u. / lowest freq: $13.21 \mathrm{~cm}-1$

$\begin{array}{llll}\text { Pd } & 1.563950 & -0.871156 & 0.326047\end{array}$

C $1.135307-1.833677 \quad 2.037351$

C $0.465336-1.007701 \quad 3.108397$

C $0.106945 \quad-1.793201 \quad 4.349572$

H $\quad \begin{array}{lll}1.004315 & -2.184070 & 4.850001\end{array}$

$\begin{array}{lllll}O & 1.323559 & -3.016762 & 2.103665\end{array}$

H $\quad-0.428193-1.156023 \quad 5.068095$

H $-0.534894-2.654827 \quad 4.116301$

H $\quad 1.110885-0.143157 \quad 3.323553$

$\begin{array}{llll}\text { H } & -0.418540 & -0.546948 & 2.624477\end{array}$

$\begin{array}{llll}\text { H } & -0.167281 & -0.978552 & -0.037408\end{array}$

$\begin{array}{llll}\text { Pd } & -1.392595 & 0.078518 & 0.276190\end{array}$

H $6.473155 \quad 5.174986-0.298118$

H $7.054483 \quad 3.696496 \quad 0.981565$

$\begin{array}{llll}\text { C } 5.489200 & 4.992544 & -0.748463\end{array}$

H $5.4096565 .691100-1.591616$

H $4.720203 \quad 5.259628-0.009475$

H $7.443388 \quad 1.986507 \quad 2.72164$

C $6.470007 \quad 2.774251 \quad 0.965188$

$\begin{array}{llll}\text { C } & 6.692301 & 1.812429 & 1.948640\end{array}$

H $7.4385843 .384485-1.843881$

C $5.350695 \quad 3.544375-1.215338$

C $6.433344 \quad 3.240898-2.267628$

$\begin{array}{llll}\text { C } 5.536812 & 2.569245 & -0.055765\end{array}$

H $\quad 6.329638 \quad 3.907842 \quad-3.136479$

$\begin{array}{lllll}\text { H } & 3.788589 & 5.239148 & -2.795739\end{array}$

$\begin{array}{llll}\text { C } & 5.956208 & 0.630792 & 1.955074\end{array}$

$\begin{array}{llll}\text { C } 3.347413 & 4.248040 & -2.670602\end{array}$

C $3.991067 \quad 3.304722-1.862139$

H $6.365309 \quad 2.203899 \quad-2.629641$

$\begin{array}{llll}\text { C } 4.831525 & 1.361748 & -0.034352\end{array}$

$\begin{array}{lllll}\text { C } & 4.990441 & 0.394764 & 0.968743\end{array}$

$\begin{array}{llll}\text { C } & 2.167742 & 3.939622 & -3.346125\end{array}$

$\begin{array}{llll}\text { H } & 6.322537 & -1.083470 & -0.764218\end{array}$

$\begin{array}{llll}\text { H } & 1.697290 & 4.689414 & -3.985789\end{array}$

$\begin{array}{llll}\text { C } 3.382994 & 2.052902 & -1.754148\end{array}$

$\begin{array}{lllll}\text { O } & 3.945934 & 1.046702 & -1.020397\end{array}$

$\begin{array}{llll}\text { H } & 7.329436 & -2.869561 & -2.151459\end{array}$

$\begin{array}{llll}\text { C } 5.865152 & -2.076881 & -0.78251\end{array}$

C $1.591656 \quad 2.675960-3.223016$

$\begin{array}{llll}\text { P } & 3.896621 & -1.075594 & 1.000352\end{array}$

$\begin{array}{llll}\text { C } & 2.190258 & 1.711030 & -2.407734\end{array}$

$\begin{array}{llll}\text { C } & 6.435866 & -3.085550 & -1.560771\end{array}$

$\begin{array}{llll}C & 4.608707 & -2.893573 & 3.094084\end{array}$

$\begin{array}{llll}\text { H } & 3.429029 & 0.604377 & -4.428983\end{array}$

$\begin{array}{llll}\text { C } 4.717381 & -2.340236 & -0.025495\end{array}$

$\begin{array}{lllll}\text { H } & 4.949645 & -3.597934 & 2.331969\end{array}$

$\begin{array}{lllll}H & 0.676966 & 2.441807 & -3.771974\end{array}$

$\begin{array}{llll}\text { H } & 4.804211 & -0.887857 & -5.846104\end{array}$

$\begin{array}{llll}\text { C } & 3.437938 & -0.471572 & -4.231878\end{array}$

$\begin{array}{llll}\text { C } 5.876568 & -4.362169 & -1.578644\end{array}$

$\begin{array}{llll}\text { P } & 1.588518 & 0.009672 & -2.116895\end{array}$

$\begin{array}{lllll}\text { C } 4.208808 & -1.312597 & -5.034220\end{array}$

$\begin{array}{llll}\text { C } 4.135341 & -3.618788 & -0.078230\end{array}$

$\begin{array}{llll}\text { C } & 2.675951 & -1.003671 & -3.183325\end{array}$

H $6.332968-5.150989-2.181671$

C $4.723709-4.627116-0.835770$

$\begin{array}{llll}\text { C } & -0.021057 & -0.025699 & -2.99563\end{array}$

H $3.219587 \quad-3.822488 \quad 0.488315$

$\begin{array}{llll}\text { C } & 4.211554 & -2.690064 & -4.811811\end{array}$

$\begin{array}{lllll}\text { C } & -1.011026 & 0.897758 & -2.614207\end{array}$

$\begin{array}{llll}\text { H } & 0.422213 & -1.697007 & -4.305370\end{array}$

$\begin{array}{llll}\text { C } & -0.326945 & -0.966535 & -3.98730\end{array}$

$\begin{array}{llll}\text { C } 2.711805 & -2.383850 & -2.945133\end{array}$

$\begin{array}{llll}\text { H } & 4.808821 & -3.346438 & -5.449420\end{array}$

$\begin{array}{llll}H & 4.272570 & -5.622995 & -0.855992\end{array}$

$\begin{array}{llll}\text { C } & 3.459590 & -3.226043 & -3.765866\end{array}$

C $-2.260981 \quad 0.900271-3.230520$

$\begin{array}{llll}\text { C } & -1.586800 & -0.973245 & -4.59174\end{array}$

$\begin{array}{llll}\text { H } & 2.147671 & -2.795235 & -2.101254\end{array}$

$\begin{array}{llll}\text { C } & -2.553157 & -0.039164 & -4.221444\end{array}$

$\begin{array}{llll}\text { H } & -1.807005 & -1.711158 & -5.367266\end{array}$

$\begin{array}{lllll}\text { H } & 3.467353 & -4.302740 & -3.578557\end{array}$

H $\quad-3.531774-0.037824 \quad-4.708812$

H $\quad-0.777512 \quad 1.649842 \quad-1.855642$

$\begin{array}{llll}\text { H } & -3.006453 & 1.646907 & -2.939893\end{array}$

$\begin{array}{llll}H & 6.129238 & -0.106773 & 2.740700\end{array}$

$\begin{array}{llll}\text { H } & 3.461219 & -0.409311 & 5.851823\end{array}$

C $3.781377-1.113123 \quad 5.079499$

C $3.694991-0.750047 \quad 3.738391$

$\begin{array}{llll}\text { C } & 4.268599 & -2.372979 & 5.434050\end{array}$

H $4.330198-2.661744 \quad 6.485986$

$\begin{array}{llll}\text { C } 4.108399 & -1.638817 & 2.731354\end{array}$

C $4.682183-3.2577714 .439855$

H $\quad 5.073519-4.241568 \quad 4.709753$

H $3.316433 \quad 0.239975 \quad 3.464195$ 
H $\quad-7.522147 \quad-1.367890 \quad-4.427286$ $\begin{array}{llll}\text { H } & -5.792860 & -2.633329 & -4.429477\end{array}$

$\begin{array}{llll}\text { C } & -7.152954 & -0.399478 & -4.064600\end{array}$

$\begin{array}{llll}\text { H } & -8.016189 & 0.278747 & -4.062910\end{array}$

$\begin{array}{llll}\text { H } & -6.421541 & -0.019090 & -4.792618\end{array}$

$\begin{array}{llll}\text { H } & -3.910850 & -4.202852 & -4.115747\end{array}$

$\begin{array}{lllll}\text { C } & -5.137323 & -2.517968 & -3.563622\end{array}$

$\begin{array}{lllll}\text { C } & -4.074630 & -3.406044 & -3.387404\end{array}$

H $\quad-7.998205-2.053706 \quad-2.038603$

$\begin{array}{llll}\text { C } & -6.560821 & -0.532973 & -2.669380\end{array}$

$\begin{array}{llll}\text { C }-7.640140 & -1.067679 & -1.707891\end{array}$

$\begin{array}{llll}\text { C } & -5.381552 & -1.499104 & -2.638426\end{array}$

$\begin{array}{llll}\text { H } & -8.501391 & -0.384492 & -1.67726\end{array}$

$\begin{array}{llll}H & -7.215948 & 2.141151 & -3.364070\end{array}$

$\begin{array}{llll}\text { C } & -3.223140 & -3.295726 & -2.288563\end{array}$

$\begin{array}{llll}C & -6.494075 & 2.059911 & -2.548785\end{array}$

$\begin{array}{llll}C & -6.061633 & 0.801527 & -2.124519\end{array}$

H $-7.261078-1.174319-0.680453$

C $-4.499390 \quad-1.405466-1.562473$

$\begin{array}{llll}\text { C } & -3.421946 & -2.270703 & -1.356145\end{array}$

$\begin{array}{lllll}\text { C } & -6.027319 & 3.220494 & -1.928694\end{array}$

$\begin{array}{llll}\text { H } & -5.137296 & -3.242133 & 0.312899\end{array}$

$\begin{array}{lllll}\text { H } & -6.393190 & 4.194657 & -2.259196\end{array}$

$\begin{array}{llll}C & -5.133685 & 0.772621 & -1.080206\end{array}$

$\begin{array}{lllll}\text { O } & -4.661097 & -0.426740 & -0.620208\end{array}$

$\begin{array}{llll}\text { H } & -6.546624 & -3.839189 & 2.250395\end{array}$

$\begin{array}{llll}\text { C } & -4.807485 & -2.974223 & 1.320231\end{array}$

$\begin{array}{llll}C & -5.093623 & 3.153967 & -0.896607\end{array}$

$\begin{array}{llll}\text { P } & -2.430229 & -1.979768 & 0.149430\end{array}$

$\begin{array}{llll}\text { C } & -4.605431 & 1.911003 & -0.466879\end{array}$

C $-5.599263 \quad-3.320336 \quad 2.414385$

$\begin{array}{llll}\text { C } & -1.523397 & -4.506562 & 1.053261\end{array}$

$\begin{array}{llll}\text { H } & -6.030476 & 0.929579 & 1.553220\end{array}$

$\begin{array}{llll}\text { C } & -3.589768 & -2.309609 & 1.518785\end{array}$

H $-2.321108-4.468956 \quad 1.798803$

$\begin{array}{llll}\text { H } & -4.732736 & 4.077401 & -0.440214\end{array}$

$\begin{array}{llll}H & -6.994305 & 0.397508 & 3.768208\end{array}$

$\begin{array}{llll}\text { C } & -5.390090 & 0.952184 & 2.439855\end{array}$

$\begin{array}{llll}\text { C } & -5.178431 & -3.022367 & 3.710626\end{array}$

$\begin{array}{lllll}\text { P } & -3.238779 & 1.693837 & 0.742138\end{array}$

$\begin{array}{llll}\text { C } & -5.936088 & 0.658594 & 3.690267\end{array}$

C $-3.186423 \quad-1.989547 \quad 2.820755$

$\begin{array}{llll}\text { C } & -4.035405 & 1.286903 & 2.329592\end{array}$

H $\quad-5.796978 \quad-3.305583 \quad 4.565645$

C $-3.969633-2.356054 \quad 3.912486$

$\begin{array}{lllll}\text { C } & -2.705283 & 3.436440 & 0.916915\end{array}$

$\begin{array}{llll}\text { H } & -2.244391 & -1.459611 & 2.980504\end{array}$

$\begin{array}{llll}C & -5.140074 & 0.705272 & 4.833853\end{array}$

$\begin{array}{llll}\text { C } & -2.038631 & 4.024303 & -0.168932\end{array}$

$\begin{array}{lllll}\text { H } & -3.603335 & 3.808583 & 2.856842\end{array}$

$\begin{array}{llll}\text { C } & -3.076016 & 4.239238 & 2.002739\end{array}$

C $-3.228739 \quad 1.301356 \quad 3.480522$

H $-5.574598 \quad 0.483272 \quad 5.811674$

H $\quad-3.634874 \quad-2.112390 \quad 4.923856$

$\begin{array}{llll}\text { C } & -3.785357 & 1.026382 & 4.726562\end{array}$

$\begin{array}{llll}\text { C } & -1.780213 & 5.391951 & -0.183253\end{array}$

$\begin{array}{llll}C & -2.800793 \quad 5.606944 & 1.991365\end{array}$

H $\quad-2.165452 \quad 1.554217 \quad 3.396561$

$\begin{array}{llll}\text { C } & -2.164639 & 6.188201 & 0.895752\end{array}$

H $-3.100076 \quad 6.222337 \quad 2.843133$

H $\quad-3.155723 \quad 1.057768 \quad 5.619327$

$\begin{array}{llll}\text { H } & -1.959014 & 7.261254 & 0.886553\end{array}$

$\begin{array}{lllll}\text { H } & -1.739617 & 3.412236 & -1.024471\end{array}$

H $\quad-1.2636615 .834271 \quad-1.038398$

$\begin{array}{llll}\text { H } & -2.405655 & -4.008629 & -2.163013\end{array}$

$\begin{array}{llll}\text { H } & 1.288114 & -4.738865 & -1.614281\end{array}$

$\begin{array}{llll}\text { C } & 0.505872 & -4.668850 & -0.853585\end{array}$

$\begin{array}{llll}\text { C } & -0.293530 & -3.531687 & -0.784391\end{array}$

$\begin{array}{lllll}\text { C } & 0.312287 & -5.718698 & 0.046895\end{array}$

$\begin{array}{lllll}\text { H } & 0.951199 & -6.604079 & 0.001980\end{array}$

$\begin{array}{llll}C & -1.321796 & -3.442440 & 0.167091\end{array}$

$\begin{array}{llll}\text { C } & -0.698523 & -5.632278 & 0.999578\end{array}$

$\begin{array}{llll}\text { H } & -0.856507 & -6.446803 & 1.710034\end{array}$

$\begin{array}{lllll}H & -0.130133 & -2.709309 & -1.491511\end{array}$

F $0.595001 \quad 4.870343 \quad 1.823821$

\begin{tabular}{lllll}
\hline & -0.062145 & 2.366149 & 2.771806
\end{tabular}

C $1.298089 \quad 3.990065 \quad 1.122405$

$\begin{array}{llll}0 & 0.027212 & 1.812332 & 0.340703\end{array}$

F $2.587935 \quad 4.159246 \quad 1.407316$

S $0.781093 \quad 2.236926 \quad 1.578941$

F $1.123548 \quad 4.228821 \quad-0.171356$

$\begin{array}{llll}\text { O } & 2.071004 & 1.549828 & 1.75283\end{array}$

168

Fig._S104_TS(LPdHOTf)(+) / electronic energy: -5933.56961471 a.u. / lowest freq: $-695.82 \mathrm{~cm}-1$

$\begin{array}{lll}\text { Pd } 1.354456 & -0.782853 & 0.213323\end{array}$

C $0.775787-1.705183 \quad 2.143261$

C $0.653745-0.766611 \quad 3.308738$

C $0.674707-1.441934 \quad 4.657098$ 
H $\quad \begin{array}{llll}1.580374 & -2.050250 & 4.788986\end{array}$ $\begin{array}{lllll}O & 0.865323 & -2.905953 & 2.228655\end{array}$

$\begin{array}{llll}\text { H } & 0.645938 & -0.700612 & 5.467069\end{array}$

$\begin{array}{llll}H & -0.186087 & -2.115067 & 4.783687\end{array}$

H $1.436209 \quad 0.002427 \quad 3.200940$

H $\quad-0.274588-0.189487 \quad 3.143500$

H $-0.053566 \quad-1.202707 \quad 1.12328$

$\begin{array}{lllll}\text { Pd } & -1.265635 & 0.081339 & 0.348281\end{array}$

H $6.845981 \quad 4.785877 \quad-0.655988$

H $7.431552 \quad 3.188687 \quad 0.507924$

$\begin{array}{llll}\text { C } & 5.798509 & 4.708883 & -0.975170\end{array}$

H $5.671475 \quad 5.445429-1.779371$

H $5.162590 \quad 5.012721-0.131183$

H $7.831014 \quad 1.388353 \quad 2.154442$

C $6.746320 \quad 2.339173 \quad 0.549256$

C $6.973209 \quad 1.327343 \quad 1.481721$

$\begin{array}{llll}\text { H } & 7.442410 & 2.947251 & -2.323817\end{array}$

C $5.4649113 .298933-1.458885$

$\begin{array}{llll}\text { C } & 6.387319 & 2.928799 & -2.635300\end{array}$

$\begin{array}{llll}\text { C } 5.679840 & 2.271042 & -0.350738\end{array}$

H $\quad 6.263118 \quad 3.639396 \quad-3.466141$

$\begin{array}{llll}\text { H } & 3.915761 & 5.178887 & -2.843905\end{array}$

C $6.101552 \quad 0.246100 \quad 1.569129$

C $3.400075 \quad 4.228112-2.69148$

C $4.026729 \quad 3.213995-1.958428$

$\begin{array}{lllll}\text { H } & 6.166134 & 1.921385 & -3.018861\end{array}$

$\begin{array}{llll}\text { C } 4.851503 & 1.145799 & -0.265852\end{array}$

$\begin{array}{llll}\text { C } & 4.996388 & 0.153473 & 0.711961\end{array}$

$\begin{array}{llll}C & 2.144280 & 4.036370 & -3.266655\end{array}$

$\begin{array}{llll}\text { H } & 6.294564 & -1.707190 & -0.540659\end{array}$

H $1.687746 \quad 4.838841 \quad-3.850164$

$\begin{array}{llll}\text { C } & 3.318467 & 2.020847 & -1.814547\end{array}$

$\begin{array}{lllll}\text { O } & 3.850389 & 0.948630 & -1.163315\end{array}$

$\begin{array}{llll}\text { H } & 7.168367 & -3.758346 & -1.614739\end{array}$

$\begin{array}{llll}\text { C } & 5.694385 & -2.620827 & -0.528060\end{array}$

$\begin{array}{llll}\text { C } & 1.471737 & 2.823637 & -3.117364\end{array}$

$\begin{array}{llll}\text { P } & 3.719902 & -1.158543 & 0.903179\end{array}$

$\begin{array}{llll}\text { C } & 2.051708 & 1.794798 & -2.370227\end{array}$

$\begin{array}{llll}\text { C } 6.188691 & -3.778504 & -1.131357\end{array}$

$\begin{array}{llll}C & 4.174693 & -2.789008 & 3.212936\end{array}$

H $2.6958550 .643849-4.737764$

$\begin{array}{llll}\text { C } 4.439602 & -2.631210 & 0.093252\end{array}$

$\begin{array}{llll}\text { H } & 4.229236 & -3.653236 & 2.546993\end{array}$

$\begin{array}{lllll}H & 0.500043 & 2.680845 & -3.595324\end{array}$

H $4.080784-0.788619-6.209806$

$\begin{array}{llll}\text { C } & 2.925695 & -0.382637 & -4.436151\end{array}$

$\begin{array}{llll}\text { C } & 5.441308 & -4.955007 & -1.113354\end{array}$

$\begin{array}{lllll}\text { P } & 1.391421 & 0.110498 & -2.098800\end{array}$

$\begin{array}{llll}\text { C } 3.702698 & -1.188656 & -5.265875\end{array}$

$\begin{array}{llll}\text { C } 3.678135 & -3.811766 & 0.081098\end{array}$

$\begin{array}{llll}\text { C } & 2.440145 & -0.886596 & -3.220809\end{array}$

H $5.835016-5.861537-1.579395$

$\begin{array}{llll}\text { C } 4.183027 & -4.969221 & -0.506394\end{array}$

$\begin{array}{llll}\text { C } & -0.230636 & 0.148536 & -2.955843\end{array}$

$\begin{array}{lllll}\text { H } & 2.683461 & -3.820153 & 0.542037\end{array}$

$\begin{array}{llll}\text { C } 3.996240 & -2.503279 & -4.895845\end{array}$

$\begin{array}{lllll}\text { C } & -1.186771 & 1.096578 & -2.549539\end{array}$

$\begin{array}{lllll}\text { H } & 0.145683 & -1.522212 & -4.288211\end{array}$

C $-0.576128-0.770744 \quad-3.955505$

$\begin{array}{llll}\text { C } & 2.746743 & -2.200041 & -2.852844\end{array}$

H $4.605348-3.131762 \quad-5.549967$

$\begin{array}{llll}\text { H } & 3.588433 & -5.886360 & -0.495887\end{array}$

$\begin{array}{llll}\text { C } 3.514771 & -3.010414 & -3.689639\end{array}$

$\begin{array}{llll}C & -2.446654 & 1.138959 & -3.143199\end{array}$

$\begin{array}{llll}\text { C } & -1.843366 & -0.731789 & -4.54283\end{array}$

H $2.380626-2.580211-1.893811$

$\begin{array}{lllll}\text { C } & -2.778007 & 0.222558 & -4.144175\end{array}$

$\begin{array}{llll}\text { H } & -2.095743 & -1.451423 & -5.325521\end{array}$

$\begin{array}{lllll}\text { H } & 3.744266 & -4.037139 & -3.392275\end{array}$

H $\quad-3.7635310 .257695 \quad-4.615984$

H $-0.921957 \quad 1.822871 \quad-1.775582$

$\begin{array}{llll}H & -3.170149 & 1.897285 & -2.828218\end{array}$

H $6.275626-0.525680 \quad 2.321784$

H $4.0416690 .246797 \quad 5.628963$

$\begin{array}{llll}\text { C } & 4.079804 & -0.611484 & 4.953649\end{array}$

C $3.870019-0.423117 \quad 3.590473$

$\begin{array}{llll}\text { C } & 4.340450 & -1.888642 & 5.454007\end{array}$

H $4.511052-2.035810 \quad 6.523171$

C $3.930478-1.509555 \quad 2.700106$

$\begin{array}{llll}\text { C } 4.377137 & -2.975052 & 4.582024\end{array}$

H $4.578866 \quad-3.979213 \quad 4.962679$

H $3.6771180 .583027 \quad 3.205160$

H $-7.772586-1.366021-4.071850$

$\begin{array}{llll}\text { H } & -5.988266 & -2.529873 & -4.285772\end{array}$

$\begin{array}{llll}\text { C } & -7.426450 & -0.394627 & -3.694771\end{array}$

H $-8.323581 \quad 0.227101-3.576035$

H $-6.793346 \quad 0.064721 \quad-4.467919$

$\begin{array}{llll}\text { H } & -4.020769 & -4.025168 & -4.200767\end{array}$ 
$\begin{array}{llll}C & -5.265513 & -2.420773 & -3.474378\end{array}$ $\begin{array}{llll}\text { C } & -4.156261 & -3.267021 & -3.426843\end{array}$ H $\quad-7.985674-2.177220 \quad-1.676035$ $\begin{array}{llll}\text { C } & -6.697036 & -0.552819 & -2.368883\end{array}$ $\begin{array}{llll}\text { C } & -7.650612 & -1.186123 & -1.336255\end{array}$ $\begin{array}{llll}C & -5.471742 & -1.453491 & -2.487455\end{array}$ $\begin{array}{llll}\text { H } & -8.539920 & -0.554486 & -1.196189\end{array}$ $\begin{array}{llll}H & -7.545388 & 2.112845 & -2.875348\end{array}$

$\begin{array}{llll}\text { C } & -3.223743 & -3.168053 & -2.395533\end{array}$

$\begin{array}{llll}\text { C } & -6.746301 & 2.034663 & -2.135213\end{array}$

$\begin{array}{llll}C & -6.217784 & 0.782860 & -1.812273\end{array}$

H $-7.171574-1.311915-0.353636$

C $-4.502776-1.361249-1.487955$

$\begin{array}{llll}\text { C } & -3.382484 & -2.191253 & -1.403793\end{array}$

$\begin{array}{llll}\text { C } & -6.274266 & 3.191651 & -1.511285\end{array}$

$\begin{array}{llll}\text { H } & -5.018010 & -3.194334 & 0.352507\end{array}$

$\begin{array}{lllll}H & -6.715098 & 4.158605 & -1.76192\end{array}$

$\begin{array}{llll}C & -5.195154 & 0.759208 & -0.861683\end{array}$

$\begin{array}{lllll}0 & -4.623630 & -0.429118 & -0.496264\end{array}$

$\begin{array}{llll}\text { H } & -6.281819 & -3.877783 & 2.359254\end{array}$

$\begin{array}{llll}\text { C } & -4.598314 & -2.999300 & 1.342950\end{array}$

$\begin{array}{llll}C & -5.239546 & 3.131915 & -0.580050\end{array}$

$\begin{array}{lllll}\text { P } & -2.295781 & -1.966211 & 0.049199\end{array}$

$\begin{array}{llll}C & -4.660970 & 1.896103 & -0.253658\end{array}$

C $-5.309075 \quad-3.394236 \quad 2.475575$

$\begin{array}{llll}\text { C } & -1.422922 & -4.586496 & 0.633979\end{array}$

$\begin{array}{llll}\text { H } & -5.805088 & 0.760246 & 1.912673\end{array}$

$\begin{array}{llll}\text { C } & -3.349579 & -2.378583 & 1.480193\end{array}$

H $-2.193972-4.612505 \quad 1.407218$

$\begin{array}{llll}\text { H } & -4.873036 & 4.052762 & -0.122489\end{array}$

$\begin{array}{lllll}\text { H } & -6.445619 & 0.105648 & 4.210813\end{array}$

$\begin{array}{llll}\text { C } & -5.057252 & 0.789486 & 2.710746\end{array}$

$\begin{array}{llll}\text { C } & -4.776173 & -3.188173 & 3.747933\end{array}$

$\begin{array}{lllll}\text { P } & -3.167206 & 1.684511 & 0.785959\end{array}$

C $-5.420674 \quad 0.426265 \quad 4.008661$

C $-2.829206 \quad-2.156205 \quad 2.762082$

$\begin{array}{llll}\text { C } & -3.747070 & 1.201817 & 2.442798\end{array}$

H $\quad-5.332755 \quad-3.506292 \quad 4.632688$

$\begin{array}{llll}\text { C } & -3.533716 & -2.569639 & 3.889833\end{array}$

$\begin{array}{lllll}\text { C } & -2.663298 & 3.434361 & 0.956751\end{array}$

$\begin{array}{llll}\text { H } & -1.858886 & -1.664134 & 2.873012\end{array}$

C $-4.486706 \quad 0.476761 \quad 5.042454$

$\begin{array}{llll}\text { C } & -2.103800 & 4.063415 & -0.166137\end{array}$

$\begin{array}{llll}\text { H } & -3.413694 & 3.740260 & 2.970332\end{array}$

C $-2.968573 \quad 4.203373 \quad 2.086714$

C $-2.801292 \quad 1.226326 \quad 3.482462$

$\begin{array}{llll}\text { H } & -4.779140 & 0.196718 & 6.057424\end{array}$

H $\quad-3.113711 \quad-2.400119 \quad 4.883958$

$\begin{array}{llll}\text { C } & -3.174850 & 0.876087 & 4.776985\end{array}$

$\begin{array}{llll}\text { C } & -1.885413 & 5.437291 & -0.170735\end{array}$

$\begin{array}{llll}C & -2.737289 & 5.579805 & 2.081868\end{array}$

$\begin{array}{lllll}\text { H } & -1.773942 & 1.554604 & 3.281689\end{array}$

$\begin{array}{llll}\text { C } & -2.206587 & 6.200387 & 0.952736\end{array}$

H $\quad-2.986437 \quad 6.169231 \quad 2.967407$

$\begin{array}{llll}H & -2.436055 & 0.914798 & 5.581870\end{array}$

$\begin{array}{llll}\text { H } & -2.032313 & 7.278992 & 0.950883\end{array}$

H $-1.854622 \quad 3.476317 \quad-1.054790$

H $-1.4485435 .911380-1.052901$

$\begin{array}{llll}\text { H } & -2.374837 & -3.853619 & -2.368533\end{array}$

$\begin{array}{llll}H & 1.296883 & -4.572513 & -2.137424\end{array}$

$\begin{array}{llll}\text { C } & 0.540896 & -4.573879 & -1.348026\end{array}$

C $-0.199709-3.421431-1.096024$

$\begin{array}{lllll}\text { C } & 0.313679 & -5.730388 & -0.599225\end{array}$

$\begin{array}{llll}\text { H } & 0.896892 & -6.633223 & -0.796063\end{array}$

$\begin{array}{llll}\text { C } & -1.200822 & -3.424543 & -0.114013\end{array}$

$\begin{array}{llll}\text { C } & -0.660344 & -5.730667 & 0.395938\end{array}$

H $-0.839811 \quad-6.629492 \quad 0.990120$

H $-0.022982-2.519161 \quad-1.692318$

$\begin{array}{llll}\text { F } & 0.606849 & 4.961242 & 1.700526\end{array}$

\begin{tabular}{lllll}
\hline & 0.440749 & 2.464249 & 2.87876
\end{tabular}

C $1.347010 \quad 4.112203 \quad 0.998217$

$\begin{array}{lllll}\text { O } & -0.030296 & 1.927613 & 0.484609\end{array}$

$\begin{array}{llll}\text { F } & 2.630559 & 4.381294 & 1.232229\end{array}$

S $0.986260 \quad 2.347081 \quad 1.522659$

$\begin{array}{lllll}\text { F } & 1.109478 & 4.299364 & -0.293623\end{array}$

$\begin{array}{llll}\text { O } & 2.292325 & 1.681870 & 1.385617\end{array}$

168

Fig._S104_INT2(LPdHOTf)(+) / electronic energy: -5933.59221933 a.u. / lowest freq: $13.48 \mathrm{~cm}-1$

Pd $1.353998 \quad-0.766074 \quad 0.220628$

$\begin{array}{lll}\text { C } 0.444446 & -1.532875 & 3.149084\end{array}$

$\begin{array}{llll}\text { C } & 0.089527 & -0.201245 & 3.698481\end{array}$

C $-0.443079-0.205386 \quad 5.107145$

H $\quad 0.278194-0.650063 \quad 5.807445$

\begin{tabular}{llll}
\hline & 0.375716 & -2.595112 & 3.704195
\end{tabular}

H $\quad-0.650597 \quad 0.817603 \quad 5.448204$

$\begin{array}{llll}H & -1.372104 & -0.788447 & 5.189635\end{array}$

H $\quad 0.9731130 .445447 \quad 3.576778$

$\begin{array}{lllll}\text { H } & -0.614731 & 0.244390 & 2.966961\end{array}$ 
$\begin{array}{llll}\text { H } & 0.802738 & -1.498919 & 2.049161\end{array}$ $\begin{array}{llll}H & 0.802738 & -1.498919 & 2.049161\end{array}$

H $\quad 6.569676 \quad 4.941409-0.619600$

$\begin{array}{lllll}\text { H } & 6.890977 & 3.601974 & 0.943447\end{array}$

$\begin{array}{llll}\text { C } 5.547486 & 4.818356 & -1.000643\end{array}$

$\begin{array}{lllll}\text { H } & 5.479756 & 5.451398 & -1.895013\end{array}$

H $4.8506205 .215643-0.248591$

H $7.202154 \quad 1.937428 \quad 2.741636$

C $\quad 6.297869 \quad 2.685211 \quad 0.931424$

C $6.475901 \quad 1.746409 \quad 1.948966$

$\begin{array}{lllll}\text { H } & 7.287324 & 2.944558 & -2.026223\end{array}$

C $5.253742 \quad 3.360071-1.335655$

C $6.254957 \quad 2.867548-2.398796$

$\begin{array}{llll}\text { C } & 5.397616 & 2.457426 & -0.112893\end{array}$

H $\quad 6.175892 \quad 3.469804 \quad-3.316131$

$\begin{array}{llll}\text { H } & 3.673004 & 5.116473 & -2.868036\end{array}$

C 5.7368810 .5658451 .961031

C $3.2026874 .145438-2.699384$

C $3.850098 \quad 3.190718-1.909858$

H $6.073953 \quad 1.816613-2.671439$

$\begin{array}{llll}\text { C } & 4.672270 & 1.263870 & -0.066369\end{array}$

$\begin{array}{llll}C & 4.796353 & 0.316626 & 0.954525\end{array}$

$\begin{array}{llll}C & 1.975870 & 3.867475 & -3.301346\end{array}$

$\begin{array}{llll}\text { H } & 6.286682 & -1.079328 & -0.604408\end{array}$

H $1.501283 \quad 4.619337 \quad-3.935504$

C $3.1989491 .967275 \quad-1.745621$

$\begin{array}{lllll}\text { O } & 3.791023 & 0.949180 & -1.057771\end{array}$

$\begin{array}{llll}\text { H } & 7.525523 & -2.833583 & -1.823357\end{array}$

$\begin{array}{llll}\text { C } & 5.892247 & -2.098864 & -0.625484\end{array}$

$\begin{array}{llll}\text { C } & 1.349548 & 2.636679 & -3.110265\end{array}$

$\begin{array}{llll}\text { P } & 3.704297 & -1.153474 & 0.912745\end{array}$

$\begin{array}{llll}\text { C } & 1.950468 & 1.663435 & -2.304675\end{array}$

C $6.594815 \quad-3.090328-1.311838$

$\begin{array}{llll}\text { C } & 3.934161 & -2.971698 & 3.123041\end{array}$

$\begin{array}{llll}\text { H } & 2.885339 & 0.566699 & -4.464679\end{array}$

$\begin{array}{llll}C & 4.695840 & -2.411073 & 0.034485\end{array}$

$\begin{array}{llll}\text { H } & 4.208542 & -3.761962 & 2.422101\end{array}$

$\begin{array}{llll}\text { H } & 0.401694 & 2.437006 & -3.612428\end{array}$

H $4.354352-0.816031-5.890370$

$\begin{array}{llll}\text { C } & 3.084411 & -0.471679 & -4.185468\end{array}$

C $6.120913-4.401110-1.339636$

$\begin{array}{lllll}\text { P } & 1.345689 & -0.040676 & -2.000256\end{array}$

$\begin{array}{llll}\text { C } 3.907685 & -1.252906 & -4.994015\end{array}$

$\begin{array}{llll}\text { C } & 4.205259 & -3.725123 & -0.034812\end{array}$

$\begin{array}{llll}\text { C } 2.511163 & -1.018398 & -3.027505\end{array}$

H $6.680071-5.175655-1.869925$

$\begin{array}{llll}\text { C } & 4.920918 & -4.716615 & -0.699207\end{array}$

$\begin{array}{llll}C & -0.211670 & -0.141715 & -2.959630\end{array}$

$\begin{array}{llll}\text { H } & 3.247680 & -3.969373 & 0.433764\end{array}$

$\begin{array}{llll}\text { C } 4.153122 & -2.587925 & -4.668152\end{array}$

$\begin{array}{llll}\text { C } & -1.223684 & 0.812827 & -2.747697\end{array}$

H $0.329223-1.931150-4.061402$

$\begin{array}{llll}\text { C } & -0.437056 & -1.171960 & -3.882997\end{array}$

$\begin{array}{llll}C & 2.780173 & -2.349297 & -2.69638\end{array}$

H $4.791897-3.199561 \quad-5.309863$

$\begin{array}{llll}H & 4.531232 & -5.737791 & -0.730292\end{array}$

$\begin{array}{llll}\text { C } 3.584742 & -3.136643 & -3.519749\end{array}$

$\begin{array}{lllll}\text { C } & -2.410158 & 0.762494 & -3.474827\end{array}$

$\begin{array}{llll}\text { C } & -1.637481 & -1.231406 & -4.594027\end{array}$

$\begin{array}{llll}\text { H } & 2.357289 & -2.762599 & -1.777829\end{array}$

$\begin{array}{llll}\text { C } & -2.619895 & -0.262348 & -4.400714\end{array}$

$\begin{array}{llll}\text { H } & -1.797032 & -2.038590 & -5.312880\end{array}$

H $3.775497-4.179906 \quad-3.256362$

H $-3.550325 \quad-0.301744 \quad-4.97297$

$\begin{array}{llll}\text { H } & -1.060358 & 1.624198 & -2.033818\end{array}$

$\begin{array}{llll}H & -3.169177 & 1.535182 & -3.324753\end{array}$

$\begin{array}{llll}H & 5.883854 & -0.158792 & 2.764949\end{array}$

$\begin{array}{llll}H & 3.050275 & -0.202334 & 5.696606\end{array}$

C $3.294892-0.988133 \quad 4.977223$

C $3.377193 \quad-0.675350 \quad 3.623013$

$\begin{array}{llll}\text { C } 3.519297 & -2.295343 \quad 5.411280\end{array}$

H $3.449327-2.543111 \quad 6.473051$

$\begin{array}{llll}\text { C } & 3.701379 & -1.664198 & 2.677043\end{array}$

C $3.840790 \quad-3.281525 \quad 4.480588$

$\begin{array}{llll}\text { H } & 4.029852 & -4.306262 & 4.809307\end{array}$

H $3.1944180 .351438 \quad 3.291826$

$\begin{array}{lllll}\text { H } & -7.206098 & -2.043324 & -4.347662\end{array}$

$\begin{array}{llll}\text { H } & -5.412569 & -3.209615 & -4.270779\end{array}$

$\begin{array}{llll}\text { C } & -6.891440 & -1.027567 & -4.074763\end{array}$

$\begin{array}{llll}\text { H } & -7.796961 & -0.407066 & -4.106197\end{array}$

H $\quad-6.202715-0.664500-4.851375$

$\begin{array}{llll}\text { H } & -3.445222 & -4.647036 & -3.849907\end{array}$

$\begin{array}{lllll}\text { C } & -4.747010 & -2.978178 & -3.436157\end{array}$

$\begin{array}{lllll}\text { C } & -3.637075 & -3.790090 & -3.200747\end{array}$

$\begin{array}{llll}\text { H } & -7.593550 & -2.551398 & -1.903649\end{array}$

$\begin{array}{llll}\text { C } & -6.263415 & -1.005823 & -2.689042\end{array}$

$\begin{array}{llll}\text { C }-7.288703 & -1.522917 & -1.660335\end{array}$

$\begin{array}{llll}\text { C } & -5.026296 & -1.893067 & -2.601512\end{array}$ 
$\begin{array}{llll}\text { H } & -8.189005 & -0.891008 & -1.659811\end{array}$ H $\quad-7.074907 \quad 1.555364 \quad-3.612103$ $\begin{array}{llll}\text { C } & -2.772544 & -3.530419 & -2.138154\end{array}$ $\begin{array}{llll}\text { C } & -6.350851 & 1.587397 & -2.795201\end{array}$ $\begin{array}{llll}\text { C } & -5.841535 & 0.398227 & -2.269476\end{array}$ $\begin{array}{llll}\text { H } & -6.882087 & -1.527149 & -0.637999\end{array}$ C $-4.130736-1.651643-1.558469$ $\begin{array}{llll}\text { C } & -2.997926 & -2.430875 & -1.301158\end{array}$ $\begin{array}{lllll}\text { C } & -5.958464 & 2.822577 & -2.274669\end{array}$ $\begin{array}{llll}\text { H } & -4.450319 & -3.686552 & 0.377747\end{array}$ $\begin{array}{lllll}H & -6.381994 & 3.741392 & -2.685553\end{array}$ $\begin{array}{llll}\text { C } & -4.910297 & 0.512790 & -1.234109\end{array}$ \begin{tabular}{lllll}
\hline & -4.349149 & -0.612126 & -0.695179
\end{tabular}

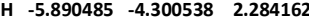
$\begin{array}{llll}\text { C } & -4.260788 & -3.240377 & 1.357969\end{array}$ $\begin{array}{llll}C & -5.036163 & 2.899147 & -1.232835\end{array}$ $\begin{array}{llll}\text { P } & -2.023124 & -1.964832 & 0.184548\end{array}$ $\begin{array}{llll}\text { C } & -4.474668 & 1.728840 & -0.701310\end{array}$ $\begin{array}{llll}\text { C } & -5.069889 & -3.595325 & 2.435955\end{array}$ $\begin{array}{llll}\text { C } & -0.844107 & -4.251750 & 1.393282\end{array}$ H $\quad-5.918572 \quad 0.736776 \quad 1.251577$ $\begin{array}{llll}\text { C } & -3.204882 & -2.334422 & 1.536710\end{array}$ $\begin{array}{llll}\text { H } & -1.537629 & -4.112844 & 2.224746\end{array}$ $\begin{array}{llll}\text { H } & -4.744250 & 3.876652 & -0.844069\end{array}$ H $\begin{array}{cccc}-7.000671 & 0.270098 & 3.421257\end{array}$

$\begin{array}{llll}\text { C } & -5.352652 & 0.882890 & 2.175636\end{array}$

$\begin{array}{llll}\text { C } & -4.825005 & -3.068183 & 3.704481\end{array}$

$\begin{array}{lllll}\text { P } & -3.153904 & 1.689430 & 0.573264\end{array}$

$\begin{array}{llll}\text { C } & -5.967560 & 0.625412 & 3.401224\end{array}$

C $-2.984811 \quad-1.789576 \quad 2.806085$

$\begin{array}{llll}\text { C } & -4.028990 & 1.339435 & 2.134708\end{array}$

H $-5.453863 \quad-3.358442 \quad 4.549532$

$\begin{array}{llll}\text { C } & -3.779651 & -2.164467 & 3.888187\end{array}$

$\begin{array}{llll}\text { C } & -2.737178 & 3.473353 & 0.655602\end{array}$

H $-2.186153-1.059564 \quad 2.945500$

$\begin{array}{llll}\text { C } & -5.274155 & 0.831780 & 4.592692\end{array}$

$\begin{array}{llll}C & -2.055112 & 4.035416 & -0.435238\end{array}$

H $\quad-3.710014 \quad 3.911420 \quad 2.545557$

C $-3.166524 \quad 4.315363 \quad 1.688886$

$\begin{array}{lllll}\text { C } & -3.323822 & 1.516120 & 3.338071\end{array}$

H $\quad \begin{array}{llll}\text { C } & 5.763383 & 0.640357 & 5.550917\end{array}$

H $\quad-3.585749-1.739843 \quad 4.87590$

C $-3.951397 \quad 1.278207 \quad 4.558313$

$\begin{array}{llll}\text { C } & -1.829511 & 5.407119 & -0.501976\end{array}$

$\begin{array}{llll}\text { C } & -2.926357 & 5.688431 & 1.625843\end{array}$

$\begin{array}{lllll}\text { H } & -2.286407 & 1.869113 & 3.312434\end{array}$

$\begin{array}{llll}\text { C }-2.265106 & 6.239310 & 0.529725\end{array}$

H $\quad-3.271519 \quad 6.331340 \quad 2.439100$

$\begin{array}{llll}H & -3.403955 & 1.441247 & 5.490025\end{array}$

$\begin{array}{llll}H & -2.082905 & 7.315583 & 0.482008\end{array}$

$\begin{array}{llll}H & -1.708358 & 3.397716 & -1.252457\end{array}$

$\begin{array}{llll}H & -1.297310 & 5.824440 & -1.360344\end{array}$

H $-1.926687 \quad-4.196901-1.964317$

$\begin{array}{llll}H & 1.604437 & -4.840380 & -1.563044\end{array}$

$\begin{array}{llll}\text { C } & 0.924886 & -4.669859 & -0.723844\end{array}$

$\begin{array}{llll}\text { C } 0.078751 & -3.564520 & -0.732142\end{array}$

$\begin{array}{llll}\text { C } & 0.912238 & -5.554011 & 0.358045\end{array}$

$\begin{array}{llll}\text { H } & 1.588449 & -6.412650 & 0.371520\end{array}$

$\begin{array}{llll}\text { C } & -0.836051 & -3.358378 & 0.315013\end{array}$

$\begin{array}{llll}\text { C } & 0.037754 & -5.334432 & 1.418493\end{array}$

$\begin{array}{lllll}\text { H } & 0.026508 & -6.014673 & 2.273125\end{array}$

$\begin{array}{llll}\text { H } & 0.089852 & -2.872187 & -1.581590\end{array}$

$\begin{array}{llll}\text { F } & 0.657729 & 5.108874 & 1.672803\end{array}$

\begin{tabular}{llll}
\hline & -0.161721 & 2.698283 & 2.594904
\end{tabular}

C $1.353139 \quad 4.194767 \quad 1.006342$

$\begin{array}{llll}\text { o } & 0.048969 & 2.045865 & 0.191452\end{array}$

F $2.636600 \quad 4.315030 \quad 1.341298$

S $0.742491 \quad 2.471374 \quad 1.461682$

$\begin{array}{lllll}\text { F } & 1.235317 & 4.433032 & -0.292693\end{array}$

$\begin{array}{llll}\mathrm{O} & 1.975941 & 1.713354 & 1.736638\end{array}$

158

Fig._S104_LPd(OTf)PdL(+) / electronic energy: -5740.60722604 a.u. / lowest freq: $-14.73 \mathrm{~cm}-1$

$\begin{array}{lll}\text { Pd } 1.309840 & -0.330421 & 0.291386\end{array}$

Pd $-1.287231-0.403462-0.086222$

C $3.574332-1.599060 \quad 2.537238$

$\begin{array}{llll}\text { C } & 4.587998 & -2.462625 & 2.977990\end{array}$

H $\quad 5.451625 \quad-2.669145 \quad 2.339242$

C $4.503205 \quad-3.058039 \quad 4.235419$

H $\quad 5.297778-3.728734 \quad 4.570882$

C $3.409611-2.798754 \quad 5.063588$

H $3.344979-3.270968 \quad 6.046758$

C $2.397572-1.941434 \quad 4.632305$

H $1.534334-1.739233 \quad 5.271869$

C $2.479204-1.348141 \quad 3.374102$

H $1.672482-0.690159 \quad 3.030568$

$\begin{array}{llll}\text { C } & 4.561787 & -1.897320 & -0.151628\end{array}$

$\begin{array}{llll}\text { C } 4.173367 & -3.246425 & -0.176076\end{array}$

$\begin{array}{lllll}\text { H } & 3.352423 & -3.587198 & 0.461549\end{array}$ 
$\begin{array}{llll}C & 4.836086 & -4.153820 & -0.997759\end{array}$

H $4.525819-5.201909-1.002619$

$\begin{array}{llll}\text { C } & 5.884051 & -3.724403 & -1.814141\end{array}$

$\begin{array}{llll}\text { H } & 6.403638 & -4.436868 & -2.459574\end{array}$

$\begin{array}{llll}\text { C } & 6.262559 & -2.381992 & -1.807258\end{array}$

$\begin{array}{lllll}\text { H } & 7.078069 & -2.038787 & -2.448661\end{array}$

$\begin{array}{llll}\text { C } 5.606173 & -1.469142 & -0.981931\end{array}$

H $5.921893-0.421763-0.980806$

C $4.765128 \quad 0.649443 \quad 1.210031$

$\begin{array}{llll}\text { C } 5.552731 & 0.807716 & 2.357543\end{array}$

H $5.5842230 .019762 \quad 3.113758$

C $6.271203 \quad 1.985494 \quad 2.555936$

H $6.876640 \quad 2.101951 \quad 3.457290$

C $6.2108313 .024026 \quad 1.624641$

H $6.766963 \quad 3.945353 \quad 1.811249$

$\begin{array}{llll}C & 5.448406 & 2.896063 & 0.460766\end{array}$

$\begin{array}{llll}\text { C } 4.751602 & 1.698393 & 0.286551\end{array}$

$\begin{array}{llll}\text { C } 5.323872 & 3.948117 & -0.634574\end{array}$

C $6.245513 \quad 3.544025-1.801604$

$\begin{array}{llll}\text { H } & 6.006808 & 2.542372 & -2.188769\end{array}$

$\begin{array}{llll}H & 7.296223 & 3.534875 & -1.477043\end{array}$

$\begin{array}{lllll}\text { H } & 6.151637 & 4.257084 & -2.633695\end{array}$

$\begin{array}{llll}\text { C } & 5.713948 & 5.333543 & -0.142578\end{array}$

H $5.6381826 .074293-0.949667$

H $6.758731 \quad 5.348342 \quad 0.194594$

H $5.0817115 .671816 \quad 0.691514$

C $3.882495 \quad 3.898927 \quad-1.131945$

$\begin{array}{llll}\text { C } 3.132486 & 5.003998 & -1.543020\end{array}$

H $3.553924 \quad 6.007888-1.460430$

C $1.856886 \quad 4.837931 \quad-2.083806$

H $1.2922595 .710700-2.418493$

C $1.297844 \quad 3.568085 \quad-2.216766$

$\begin{array}{lllll}\text { H } & 0.306606 & 3.465067 & -2.661345\end{array}$

C $1.999900 \quad 2.437282 \quad-1.778046$

C $3.2812712 .642858-1.246965$

$\begin{array}{llll}\text { C } 2.493539 & -0.237515 & -2.798602\end{array}$

C $3.3859530 .362936-3.695148$

$\begin{array}{lllll}\text { H } & 3.471394 & 1.452249 & -3.747080\end{array}$

$\begin{array}{llll}\text { C } 4.161961 & -0.429682 & -4.540767\end{array}$

$\begin{array}{lllll}\text { H } & 4.859132 & 0.044500 & -5.235848\end{array}$

$\begin{array}{llll}\text { C } & 4.041630 & -1.819496 & -4.508047\end{array}$

$\begin{array}{llll}\text { H } & 4.648712 & -2.436438 & -5.175413\end{array}$

$\begin{array}{llll}\text { C } 3.152390 & -2.421153 & -3.616578\end{array}$

H $3.057282-3.509436 \quad-3.582102$

$\begin{array}{llll}\text { C } & 2.389794 & -1.634570 & -2.756376\end{array}$

$\begin{array}{llll}\text { H } & 1.691890 & -2.100551 & -2.053517\end{array}$

$\begin{array}{llll}\text { C } & -0.155280 & 0.829803 & -2.795628\end{array}$

$\begin{array}{llll}\text { C } & -1.251474 & 1.595441 & -2.356198\end{array}$

$\begin{array}{llll}\text { H } & -1.205335 & 2.104375 & -1.388742\end{array}$

$\begin{array}{lllll}\text { C } & -2.371328 & 1.761180 & -3.169079\end{array}$

$\begin{array}{lllll}\text { H } & -3.199567 & 2.387618 & -2.828631\end{array}$

$\begin{array}{llll}\text { C } & -2.432568 & 1.135948 & -4.415316\end{array}$

$\begin{array}{lllll}\text { H } & -3.314298 & 1.262254 & -5.048289\end{array}$

$\begin{array}{llll}\text { C } & -1.363040 & 0.354471 & -4.848179\end{array}$

$\begin{array}{llll}\text { H } & -1.402344 & -0.140363 & -5.821499\end{array}$

$\begin{array}{llll}\text { C } & -0.228848 & 0.203363 & -4.049457\end{array}$

$\begin{array}{llll}\text { H } & 0.602136 & -0.400610 & -4.419151\end{array}$

$\begin{array}{lllll}O & 3.949113 & 1.528430 & -0.814147\end{array}$

$\begin{array}{llll}\text { P } & 3.629802 & -0.754862 & 0.91823\end{array}$

$\begin{array}{llll}P & 1.350261 & 0.724723 & -1.748729\end{array}$

$\begin{array}{llll}\text { C } & -3.706006 & -2.381612 & -1.652162\end{array}$

$\begin{array}{llll}C & -4.593712 & -3.464491 & -1.631858\end{array}$

$\begin{array}{lllll}\text { H } & -5.301184 & -3.586680 & -0.808036\end{array}$

$\begin{array}{llll}\text { C } & -4.593770 & -4.387191 & -2.678842\end{array}$

$\begin{array}{llll}\text { H } & -5.289450 & -5.229412 & -2.65453\end{array}$

$\begin{array}{llll}\text { C } & -3.718555 & -4.233497 & -3.753825\end{array}$

H $\quad-3.721931-4.960134 \quad-4.569911$

$\begin{array}{llll}\text { C } & -2.839430 & -3.149416 & -3.785258\end{array}$

$\begin{array}{lllll}\text { H } & -2.149738 & -3.021187 & -4.623401\end{array}$

$\begin{array}{lllll}C & -2.829538 & -2.234804 & -2.736738\end{array}$

$\begin{array}{llll}\text { H } & -2.129217 & -1.392453 & -2.75211\end{array}$

$\begin{array}{llll}\text { C } & -4.673238 & -1.652026 & 0.998127\end{array}$

$\begin{array}{llll}\text { C } & -4.396085 & -2.914610 & 1.548192\end{array}$

$\begin{array}{llll}\text { H } & -3.578264 & -3.517121 & 1.147000\end{array}$

$\begin{array}{llll}\text { C } & -5.160079 & -3.404506 & 2.604657\end{array}$

$\begin{array}{llll}\text { H } & -4.942431 & -4.395331 & 3.010935\end{array}$

$\begin{array}{llll}\text { C } & -6.189519 & -2.634239 & 3.146802\end{array}$

H $\quad-6.786195 \quad-3.019254 \quad 3.977375$

$\begin{array}{llll}\text { C } & -6.448863 & -1.366708 & 2.627090\end{array}$

$\begin{array}{llll}\text { H } & -7.246790 & -0.751446 & 3.050126\end{array}$

$\begin{array}{llll}\text { C } & -5.698802 & -0.876499 & 1.558449\end{array}$

$\begin{array}{llll}\text { H } & -5.934739 & 0.111923 & 1.156029\end{array}$

C $-4.739411 \quad 0.209675-1.194524$

$\begin{array}{llll}C & -5.521285 & -0.015653 & -2.334986\end{array}$

$\begin{array}{llll}\text { H } & -5.564916 & -1.011047 & -2.783272\end{array}$

C $-6.227391 \quad 1.036021-2.917177$

H $\quad-6.8289810 .850440 \quad-3.809545$

$\begin{array}{llll}C & -6.168525 & 2.323015 & -2.378430\end{array}$ 
$\begin{array}{llll}\text { H } & -6.723036 & 3.131139 & -2.859907\end{array}$ $\begin{array}{llll}C & -5.412616 & 2.582196 & -1.232330\end{array}$ $\begin{array}{llll}\text { C } & -4.721363 & 1.505190 & -0.673490\end{array}$ $\begin{array}{llll}\text { C } & -5.294078 & 3.930734 & -0.531702\end{array}$ $\begin{array}{llll}\text { C } & -6.219127 & 3.916644 & 0.700956\end{array}$ H $\quad-5.9753693 .094626 \quad 1.390656$

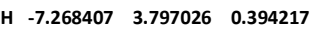
H $\quad-6.132233 \quad 4.860105 \quad 1.259307$ $\begin{array}{llll}\text { C } & -5.682833 & 5.088090 & -1.438519\end{array}$ $\begin{array}{llll}\text { H } & -5.600255 & 6.046098 & -0.908427\end{array}$ H $-6.7295265 .001776-1.758696$ H $\quad-5.053760 \quad 5.142016-2.339379$ $\begin{array}{llll}\text { C } & -3.855839 & 4.045625 & -0.036741\end{array}$ $\begin{array}{lllll}\text { C } & -3.101559 & 5.221069 & -0.001541\end{array}$ $\begin{array}{lllll}\text { H } & -3.516882 & 6.145364 & -0.408709\end{array}$ $\begin{array}{llll}\text { C } & -1.829689 & 5.233682 & 0.573332\end{array}$ H $-1.263183 \quad 6.1663530 .614171$ $\begin{array}{llll}\text { C } & -1.275471 & 4.072036 & 1.108723\end{array}$ H $\quad-0.285696 \quad 4.115278 \quad 1.565985$ C $\begin{array}{llll}-1.980181 & 2.862040 & 1.049476\end{array}$ $\begin{array}{llll}\text { C } & -3.260396 & 2.893233 & 0.481763\end{array}$ $\begin{array}{lllll}C & -2.463438 & 0.628440 & 2.854388\end{array}$ C $-3.323394 \quad 1.488061 \quad 3.549355$ $\begin{array}{lllll}\text { H } & -3.398036 & 2.542509 & 3.267456\end{array}$ C $-4.079573 \quad 1.004574 \quad 4.615976$

H $-4.752787 \quad 1.678644 \quad 5.151153$

$\begin{array}{llll}\text { C } & -3.970216 & -0.331349 & 5.004395\end{array}$

H $\quad-4.561914-0.706977 \quad 5.843004$

C $-3.114633 \quad-1.190648 \quad 4.314386$ $\begin{array}{llll}\text { H } & -3.034090 & -2.240132 & 4.606938\end{array}$ $\begin{array}{llll}\text { C } & -2.371483 & -0.717219 & 3.235080\end{array}$

H $\quad-1.714361 \quad-1.398280 \quad 2.679317$

$\begin{array}{llll}\text { C } & 0.172097 & 1.640222 & 2.501128\end{array}$

$\begin{array}{llll}\text { C } & 1.266886 & 2.244511 & 1.853098\end{array}$

H $1.222611 \quad 2.445375 \quad 0.778940$

$\begin{array}{llll}\text { C } & 2.386089 & 2.649182 & 2.579452\end{array}$

H $3.211272 \quad 3.148891 \quad 2.065619$

C $2.451386 \quad 2.420710 \quad 3.954159$

H $3.333917 \quad 2.729347 \quad 4.519759$

C $1.382286 \quad 1.804479 \quad 4.601977$

H $1.4230371 .621566 \quad 5.678395$

$\begin{array}{llll}\text { C } & 0.246968 & 1.424272 & 3.886505\end{array}$

H $\quad-0.581853 \quad 0.958368 \quad 4.422901$

$\begin{array}{lllll}\text { O } & -3.929508 & 1.700801 & 0.430288\end{array}$

$\begin{array}{lllll}\text { P } & -3.666074 & -1.050288 & -0.403203\end{array}$

$\begin{array}{llll}P & -1.339518 & 1.217457 & 1.544468\end{array}$

F $1.060423 \quad-5.515999 \quad 0.488490$

$\begin{array}{llll}\text { C } & 0.522208 & -4.759650 & -0.463320\end{array}$

$\begin{array}{llll}\text { F } & -0.438164 & -5.447984 & -1.070625\end{array}$

$\begin{array}{llll}\text { F } & 1.465482 & -4.468852 & -1.356493\end{array}$

$\begin{array}{lllll}S & -0.194140 & -3.219280 & 0.284034\end{array}$

$00.925698-2.619086 \quad 1.060877$

$\begin{array}{llll}0 & -0.545759 & -2.432070 & -0.943658\end{array}$

$\begin{array}{lllll}0 & -1.321506 & -3.707934 & 1.079745\end{array}$

14

Fig._S105_Pd4110(2-) / electronic energy: - 3491.42317156 a.u. / lowest freq: $-\mathbf{2 1 . 7 9} \mathrm{cm}-1$

I $0.000000 \quad 1.957217 \quad 7.753161$

Pd $0.000000 \quad 0.000000 \quad 5.911320$

I $0.000000-1.957217 \quad 7.753161$

Pd $\quad 0.000000 \quad 0.000000 \quad-5.911320$

I $0.000000 \quad-1.855609$-3.926059

\begin{tabular}{llll}
\hline & 0.000000 & 1.957217 & -7.753161
\end{tabular}

$\begin{array}{llll}\text { Pd } & 0.000000 & 0.000000 & -1.962247\end{array}$

I $0.000000 \quad 1.855609-3.926059$

I $0.000000-1.883655 \quad 0.000000$

$\begin{array}{llll}\text { I } & 0.000000 & -1.957217 & -7.753161\end{array}$

$\begin{array}{llll}1 & 0.000000 & 1.883655 & 0.000000\end{array}$

1 $0.000000-1855609 \quad 3.926059$

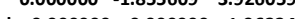

$\begin{array}{llll}\text { Pd } & 0.000000 & 0.000000 & 1.962247\end{array}$

I $0.000000 \quad 1.855609 \quad 3.926059$

46

Fig._S105_PPh4l / electronic energy: $-\mathbf{1 5 6 4 . 9 9 2 2 3 7 5 7 ~ a . u . ~ / ~ l o w e s t ~ f r e q : ~} 1.66 \mathrm{~cm}-1$

H $0.886573 \quad 4.767143 \quad-2.319091$

H $-0.858973 \quad 4.877420 \quad-0.545811$

$\begin{array}{lllll}\text { C } & 0.488558 & 3.846060 & -1.887359\end{array}$

$\begin{array}{llll}\text { C } & -0.489714 & 3.910444 & -0.893439\end{array}$

C $0.960446 \quad 2.611430 \quad-2.329534$

C $\quad-0.998894 \quad 2.739416 \quad-0.339975$

C $0.458173 \quad 1.432346-1.782480$

$\begin{array}{llll}\text { C } & -0.524645 & 1.494892 & -0.786144\end{array}$

H $\quad 0.370603 \quad 1.753104 \quad 1.797607$

H $1.557585 \quad 1.318681 \quad 3.921653$

C $0.396020 \quad 0.739566 \quad 2.205354$

$\begin{array}{llll}\text { P } & -1.124428 & -0.012604 & -0.002566\end{array}$

C $1.069478 \quad 0.493612 \quad 3.399364$

$\begin{array}{llll}C & -3.423063 & -0.319766 & 1.546815\end{array}$

$\begin{array}{llll}\text { C } & -0.216987 & -0.319847 & 1.523594\end{array}$

H $\quad-2.783526-0.820152 \quad 2.278439$ 
$\begin{array}{llll}C & 1.138328 & -0.801424 & 3.910748\end{array}$ C $-0.150062-1.623064 \quad 2.040304$

H $1.678686-0.991535 \quad 4.840805$

C $0.529940-1.858028 \quad 3.231960$

H $\quad-0.621141-2.455064 \quad 1.510003$

H $0.588591 \quad-2.873769 \quad 3.628213$

H $-1.763476 \quad 2.793702 \quad 0.440161$

$\begin{array}{llll}\text { H } & -5.713405 & 1.482656 & -1.026781\end{array}$

$\begin{array}{llll}\text { C } & -5.070911 & 0.974885 & -0.304488\end{array}$

$\begin{array}{llll}C & -3.708646 & 0.850340 & -0.563332\end{array}$

$\begin{array}{lllll}\text { C } & -5.610219 & 0.455626 & 0.873341\end{array}$

$\begin{array}{llll}\text { H } & -6.678929 & 0.558308 & 1.074600\end{array}$

$\begin{array}{llll}\text { C } & -2.879468 & 0.199122 & 0.364137\end{array}$

$\begin{array}{llll}\text { C } & -4.787799 & -0.189233 & 1.796397\end{array}$

H $\quad-5.207648 \quad-0.591135 \quad 2.720739$

H $\quad-3.291075 \quad 1.260316 \quad-1.487081$

$\begin{array}{llll}\text { H } & 0.838330 & 0.469737 & -2.132778\end{array}$

H $1.7300852 .558965-3.102090$

$\begin{array}{llll}C & -1.756835 & -2.965453 & -2.755036\end{array}$

$\begin{array}{llll}\text { C } & -1.965891 & -1.903577 & -1.877688\end{array}$

$\begin{array}{llll}\text { C } & -0.493862 & -3.547881 & -2.862244\end{array}$

$\begin{array}{llll}\text { C }-0.900586 & -1.423801 & -1.102979\end{array}$

$\begin{array}{llll}\text { C } & 0.565911 & -3.072797 & -2.088866\end{array}$

$\begin{array}{llll}C & 0.369030 & -2.014296 & -1.206206\end{array}$

H $1.556132-3.526294 \quad-2.168763$

H $1.207543-1.643183-0.606516$

$\begin{array}{llll}\text { H } & -0.335418 & -4.380705 & -3.551197\end{array}$

H $-2.960385-1.458200-1.794113$

H $-2.588560-3.340630-3.354894$

$\begin{array}{lllll}\text { I } & 3.797453 & 0.041099 & -0.014303\end{array}$

84

Fig. S105 Pd-aycl(+) / electronic energy: -2582.17852429 a.u. / lowest freq: $18.05 \mathrm{~cm}-1$

Pd $-0.006524-0.675121-0.185512$

$\begin{array}{llll}P & -2.299572 & -0.291652 & 0.009144\end{array}$

$\begin{array}{llll}\text { P } & 2.295916 & -0.356819 & 0.002961\end{array}$

$\begin{array}{lllll}O & 0.024358 & 1.659386 & -0.20741\end{array}$

$\begin{array}{llll}\text { C } & -1.169636 & 2.311458 & 0.071909\end{array}$

$\begin{array}{lllll}C & -2.330963 & 1.529903 & 0.205586\end{array}$

$\begin{array}{llll}\text { C } & -3.534996 & 2.179551 & 0.509181\end{array}$

H $-4.450331 \quad 1.591306 \quad 0.620750$

$\begin{array}{llll}\text { C } & -3.571759 & 3.558324 & 0.674077\end{array}$

H $-4.511847 \quad 4.056131 \quad 0.91845$

C $-2.407738 \quad 4.306971 \quad 0.513171$

H $\quad-2.456932 \quad 5.391213 \quad 0.624075$

C $-1.186861 \quad 3.705800 \quad 0.194634$

$\begin{array}{llll}\text { C } & 0.065260 & 4.504591 & -0.139842\end{array}$

C $1.290445 \quad 3.669855 \quad 0.206860$

$\begin{array}{llll}\text { C } & 2.525042 & 4.234750 & 0.538796\end{array}$

H 2.6044565 .3168790 .652673

$\begin{array}{llll}\text { C } & 3.665059 & 3.452250 & 0.709996\end{array}$

$\begin{array}{lllll}\text { H } & 4.616508 & 3.921844 & 0.965875\end{array}$

$\begin{array}{llll}\text { C } 3.590463 & 2.075694 & 0.539349\end{array}$

H 4.4875921 .4608640 .656089

C $2.371364 \quad 1.461831 \quad 0.222352$

$\begin{array}{llll}\text { C } & 1.234247 & 2.276825 & 0.081767\end{array}$

$\begin{array}{llll}\text { C } & 0.075937 & 4.734473 & -1.664648\end{array}$

H $0.064062 \quad 3.786906 \quad-2.222810$

\begin{tabular}{llll} 
H & 0.976628 & 5.290319 & -1.963891 \\
\hline & -0.804840 & 5.317108 & -1.972094
\end{tabular}

$\begin{array}{llll}\text { H } & -0.804840 & 5.317108 & -1.972094\end{array}$

C $0.081348 \quad 5.857790 \quad 0.562151$

H $\quad 0.071617 \quad 5.759918 \quad 1.657085$

$\begin{array}{lllll}\text { H } & -0.780756 & 6.467234 & 0.264571\end{array}$

$\begin{array}{lllll}\text { H } & 0.967329 & 6.438822 & 0.278037\end{array}$

$\begin{array}{llll}\text { C } & -3.408063 & -0.679302 & -1.376606\end{array}$

$\begin{array}{llll}C & -3.802304 & -2.017666 & -1.546545\end{array}$

$\begin{array}{llll}\text { H } & -3.503647 & -2.776144 & -0.815160\end{array}$

C $-4.580874-2.385235-2.640330$

$\begin{array}{llll}\text { H } & -4.888921 & -3.426601 & -2.758800\end{array}$

$\begin{array}{llll}\text { C } & -4.965109 & -1.427055 & -3.580797\end{array}$

H $\quad-5.576004-1.716739-4.438775$

$\begin{array}{llll}\text { C } & -4.565818 & -0.100611 & -3.423824\end{array}$

$\begin{array}{llll}\text { H } & -4.863147 & 0.652085 & -4.157476\end{array}$

$\begin{array}{llll}\text { C } & -3.788381 & 0.276163 & -2.328264\end{array}$

$\begin{array}{llll}\text { H } & -3.480649 & 1.319497 & -2.217028\end{array}$

$\begin{array}{llll}\text { C } & -3.100061 & -0.958603 & 1.501418\end{array}$

$\begin{array}{llll}\text { C } & -4.485541 & -1.150802 & 1.601728\end{array}$

$\begin{array}{llll}\text { H } & -5.138709 & -0.919811 & 0.755538\end{array}$

$\begin{array}{llll}C & -5.035172 & -1.641854 & 2.784625\end{array}$

$\begin{array}{llll}\text { H } & -6.114791 & -1.791861 & 2.856950\end{array}$

C $-4.212136-1.940923 \quad 3.871317$

$\begin{array}{llll}\text { H } & -4.647921 & -2.329260 & 4.794761\end{array}$

C $-2.833091-1.751601 \quad 3.776413$

$\begin{array}{llll}\text { H } & -2.185508 & -1.991927 & 4.622554\end{array}$

$\begin{array}{llll}\text { C } & -2.277332 & -1.267166 & 2.594326\end{array}$

$\begin{array}{llll}\text { H } & -1.193969 & -1.132542 & 2.505443\end{array}$

$\begin{array}{llll}\text { C } 3.406582 & -0.741348 & -1.383309\end{array}$

C $3.794062-2.079857-1.565555$

$\begin{array}{llll}\text { H } & 3.482699 & -2.845267 & -0.846968\end{array}$ 
$\begin{array}{llll}C & 4.580878 & -2.439306 & -2.656306\end{array}$

H $4.883870-3.481035$ - 2.784025

$\begin{array}{llll}\text { C } & 4.979578 & -1.472835 & -3.581962\end{array}$

$\begin{array}{llll}\text { H } & 5.597056 & -1.756275 & -4.437306\end{array}$

$\begin{array}{llll}\text { C } 4.585750 & -0.146134 & -3.413775\end{array}$

H $4.8938360 .613213-4.136053$

$\begin{array}{llll}\text { C } 3.800898 & 0.222566 & -2.320874\end{array}$

$\begin{array}{llll}\text { H } & 3.498782 & 1.266488 & -2.200644\end{array}$

C $3.081201-1.0612301 .486515$

$\begin{array}{llll}\text { C } 4.467244 & -1.245119 & 1.597440\end{array}$

$\begin{array}{llll}\text { H } & 5.127301 & -0.989887 & 0.763587\end{array}$

C $5.008305-1.760423 \quad 2.773786$

$\begin{array}{llll}\text { H } & 6.088298 & -1.903289 & 2.854407\end{array}$

$\begin{array}{llll}\text { C } & 4.175849 & -2.093687 & 3.843387\end{array}$

H $\quad 4.604934 \quad-2.500980 \quad 4.761800$

$\begin{array}{llll}\text { C } 2.796377 & -1.914971 \quad 3.737224\end{array}$

H $2.141445-2.183177 \quad 4.569223$

C $2.249105-1.405230 \quad 2.561589$

H $\quad 1.165550 \quad-1.280415 \quad 2.463358$

$\begin{array}{lllll}\mathrm{O} & -0.072948 & -3.333787 & 0.743154\end{array}$

H $\quad-1.227558-4.973543 \quad-1.324136$

$\begin{array}{llll}\text { H } & 0.526213 & -5.210793 & -1.248097\end{array}$

$\begin{array}{llll}\text { C } & -0.271325 & -4.662251 & -1.767085\end{array}$

$\begin{array}{llll}C & -0.055368 & -2.655149 & -0.244600\end{array}$

$\begin{array}{llll}\text { H } & -0.269354 & -4.979405 & -2.817873\end{array}$

$\begin{array}{llll}\text { C } & -0.073449 & -3.166185 & -1.664746\end{array}$

$\begin{array}{lllll}\text { H } & -0.848426 & -2.605723 & -2.213534\end{array}$

$\begin{array}{lllll}H & 0.874719 & -2.842836 & -2.127737\end{array}$

45

Fig._S105_PPh4(+) / electronic energy: $-\mathbf{1 2 6 6 . 9 4 4 7 3 2 0 6}$ a.u. / lowest freq: $-\mathbf{2 1 . 9 3 ~ c m - 1}$

H $-3.315805-4.593781 \quad 0.437567$

H $-3.875099-2.792592-1.187549$

$\begin{array}{llll}\text { C } & -2.676863 & -3.711328 & 0.360497\end{array}$

$\begin{array}{llll}C & -2.992647 & -2.702566 & -0.551000\end{array}$

$\begin{array}{llll}\text { C } & -1.552701 & -3.593315 & 1.176718\end{array}$

C $-2.186328-1.572343-0.648565$

$\begin{array}{llll}\text { C } & -0.736329 & -2.467514 & 1.085969\end{array}$

C $-1.051537-1.454459 \quad 0.170619$

H $-0.089323-1.750850 \quad-2.369859$

H $1.388738-1.909985-4.347945$

C $0.780712-1.094640-2.449898$

$\begin{array}{llll}\text { P } & -0.000567 & 0.000329 & -0.000299\end{array}$

C $1.614321-1.185249-3.563193$

$\begin{array}{llll}\text { C } & -0.765094 & 2.449963 & -1.107165\end{array}$

C $1.072801-0.170191-1.438540$

$\begin{array}{llll}\text { H } & 0.114417 & 2.369431 & -1.750551\end{array}$

$\begin{array}{llll}\text { C } & 2.733244 & -0.360286 & -3.669917\end{array}$

$\begin{array}{llll}\text { C } & 2.203160 & 0.657267 & -1.544589\end{array}$

$\begin{array}{llll}\text { H } & 3.385825 & -0.437468 & -4.542313\end{array}$

$\begin{array}{llll}C & 3.026826 & 0.559642 & -2.662109\end{array}$

$\begin{array}{llll}\text { H } & 2.441477 & 1.374826 & -0.754180\end{array}$

H $3.905372 \quad 1.202773 \quad-2.742733$

$\begin{array}{llll}\text { H } & -2.441722 & -0.781008 & -1.359122\end{array}$

$\begin{array}{llll}\text { H } & -3.921821 & 2.744412 & 1.145639\end{array}$

$\begin{array}{llll}\text { C } & -3.034131 & 2.663522 & 0.515158\end{array}$

$\begin{array}{llll}C & -2.213182 & 1.545034 & 0.623507\end{array}$

$\begin{array}{llll}\text { C } & -2.726274 & 3.671723 & -0.399697\end{array}$

$\begin{array}{lllll}\text { H } & -3.376121 & 4.545406 & -0.485003\end{array}$

$\begin{array}{llll}\text { C } & -1.070955 & 1.438666 & -0.187040\end{array}$

$\begin{array}{llll}C & -1.596111 & 3.564066 & -1.209080\end{array}$

H $-1.359424 \quad 4.349020 \quad-1.930083$

$\begin{array}{llll}\text { H } & -2.461991 & 0.753551 & 1.336241\end{array}$

$\begin{array}{llll}\text { H } & 0.138405 & -2.378858 & 1.734824\end{array}$

H $-1.309394-4.379033 \quad 1.894617$

C $1.534934 \quad 1.199180 \quad 3.593087$

C $0.719490 \quad 1.095971 \quad 2.467643$

C $2.671793 \quad 0.400691 \quad 3.710590$

C $1.048113 \quad 0.185884 \quad 1.454485$

$\begin{array}{llll}\text { C } 3.001407 & -0.505289 & 2.701334\end{array}$

C $2.196070-0.614971 \quad 1.571550$

H 3.893682 -1.128041 2.790727

$\begin{array}{llll}H & 2.461601 & -1.321622 & 0.780008\end{array}$

H $3.309526 \quad 0.487506 \quad 4.593011$

$\begin{array}{cccc}\text { H } & -0.164683 & 1.731698 & 2.379917\end{array}$

$\begin{array}{lllll}H & 1.280544 & 1.912944 & 4.379086\end{array}$

77

Fig._S105_LPdCO / electronic energy: -2503.16331913 a.u. / lowest freq: $11.14 \mathrm{~cm}-1$

C $1.917493-0.756127 \quad 1.670488$

C $2.123012-2.070003 \quad 2.124812$

$\begin{array}{llll}\text { H } & 2.320829 & -2.870298 & 1.403946\end{array}$

$\begin{array}{llll}\text { C } & 2.096031 & -2.364087 & 3.485327\end{array}$

H $2.272425 \quad-3.389490 \quad 3.82047$

C $1.840150-1.354741 \quad 4.415481$

H $\quad 1.813717-1.584845 \quad 5.483613$

$\begin{array}{llll}\text { C } & 1.608771 & -0.053511 & 3.972354\end{array}$

H $1.399472 \quad 0.741891 \quad 4.692577$

C $1.648343 \quad 0.247421 \quad 2.609743$

H $\quad 1.484103 \quad 1.279279 \quad 2.287003$ 
$\begin{array}{llll}\text { C } & 3.619370 & -1.131399 & -0.571920\end{array}$

C $3.804756-1.744726-1.816650$

$\begin{array}{llll}\text { H } & 2.949992 & -1.846676 & -2.494362\end{array}$

$\begin{array}{llll}\text { C } 5.059193 & -2.229033 & -2.190056\end{array}$

$\begin{array}{llll}\text { H } & 5.188474 & -2.707028 & -3.16415\end{array}$

$\begin{array}{llll}\text { C } & 6.139939 & -2.113680 & -1.317033\end{array}$

H $7.121136-2.499068-1.605165$

C $5.965210-1.506679-0.071282$

$\begin{array}{llll}\text { H } & 6.809627 & -1.413021 & 0.616204\end{array}$

$\begin{array}{llll}\text { C } 4.714502 & -1.017538 & 0.299441\end{array}$

$\begin{array}{llll}\text { H } & 4.590332 & -0.536365 & 1.274578\end{array}$

$\begin{array}{llll}\text { C } 2.192015 & 1.336921 & -0.327435\end{array}$

C $3.380180 \quad 1.939303 \quad-0.764573$

H $4.275803 \quad 1.332368 \quad-0.916321$

C $3.423544 \quad 3.305610 \quad-1.037031$

$\begin{array}{llll}\text { H } & 4.356200 & 3.756264 & -1.383454\end{array}$

$\begin{array}{llll}\text { C } & 2.287109 & 4.100060 & -0.880802\end{array}$

$\begin{array}{llll}\text { H } & 2.341838 & 5.167129 & -1.106178\end{array}$

C $1.085661 \quad 3.543708-0.434721$

$\begin{array}{llll}\text { C } & -0.196851 & 4.323800 & -0.163833\end{array}$

$\begin{array}{lllll}\text { C } & -1.361329 & 3.429376 & -0.576209\end{array}$

$\begin{array}{llll}\text { C } & -2.558182 & 3.868603 & -1.150428\end{array}$

H $-2.6894804 .924851 \quad-1.395245$

$\begin{array}{llll}\text { C } & -3.596607 & 2.971532 & -1.406391\end{array}$

H $-4.526313 \quad 3.333794 \quad-1.850738$

$\begin{array}{llll}\text { C } & -3.462644 & 1.617982 & -1.096825\end{array}$

$\begin{array}{lllll}\text { H } & -4.285078 & 0.928883 & -1.306009\end{array}$

$\begin{array}{llll}\text { C } & -2.273492 & 1.136302 & -0.536087\end{array}$

$\begin{array}{llll}\text { C } & -1.252348 & 2.065503 & -0.296972\end{array}$

$\begin{array}{llll}\text { C } & 1.074992 & 2.170456 & -0.171318\end{array}$

C $-0.297955 \quad 4.565057 \quad 1.355110$

H $\quad-0.286752 \quad 3.622838 \quad 1.923412$

$\begin{array}{llll}\text { H } & -1.230569 & 5.093740 & 1.602193\end{array}$

H $\quad 0.545180 \quad 5.177957 \quad 1.706724$

$\begin{array}{llll}\text { C } & -0.218251 & 5.663532 & -0.884182\end{array}$

H $0.614160 \quad 6.300801-0.557019$

H $-1.138753 \quad 6.217299 \quad-0.655890$

H $\quad-0.151310 \quad 5.550074 \quad-1.975959$

$\begin{array}{llll}\text { C } & -3.493129 & -1.446410 & -0.573948\end{array}$

$\begin{array}{llll}\text { C } & -4.585710 & -1.431394 & 0.305942\end{array}$

$\begin{array}{llll}H & -4.501415 & -0.932273 & 1.276051\end{array}$

$\begin{array}{llll}C & -5.785680 & -2.045864 & -0.048658\end{array}$

$\begin{array}{llll}\text { H } & -6.628684 & -2.029638 & 0.646696\end{array}$

$\begin{array}{lllll}C & -5.911155 & -2.678519 & -1.286773\end{array}$

H $\quad-6.851859-3.161877 \quad-1.561822$

$\begin{array}{llll}\text { C } & -4.830397 & -2.697692 & -2.168299\end{array}$

H $-4.920599-3.195493 \quad-3.136916$

$\begin{array}{llll}\text { C } & -3.626667 & -2.090401 & -1.811024\end{array}$

$\begin{array}{llll}\text { H } & -2.771474 & -2.115421 & -2.495793\end{array}$

$\begin{array}{llll}\text { C } & -1.884148 & -0.669415 & 1.655401\end{array}$

$\begin{array}{llll}\text { C }-1.516996 & -1.879173 & 2.265142\end{array}$

$\begin{array}{llll}\text { H } & -1.225036 & -2.732402 & 1.642813\end{array}$

C $-1.526785-2.006273 \quad 3.652194$

H $\quad-1.243040-2.956809 \quad 4.111284$

C $-1.883542 \quad-0.919670 \quad 4.452864$

$\begin{array}{llll}\text { H } & -1.884027 & -1.017018 & 5.541498\end{array}$

$\begin{array}{llll}C & -2.227774 & 0.293160 & 3.857538\end{array}$

H $\quad-2.503849 \quad 1.149938 \quad 4.477735$

C $-2.231206 \quad 0.418527 \quad 2.467591$

$\begin{array}{llll}\text { H } & -2.522501 & 1.371936 & 2.016843\end{array}$

$\begin{array}{lllll}\mathrm{O} & -0.089260 & 1.570263 & 0.237051\end{array}$

$\begin{array}{llll}\text { Pd } & 0.071408 & -1.290532 & -1.434302\end{array}$

$\begin{array}{lllll}P & 1.955433 & -0.476967 & -0.142675\end{array}$

$\begin{array}{llll}P & -1.897130 & -0.622416 & -0.18145\end{array}$

$\begin{array}{llll}\text { C } 0.136546 & -2.158754 & -3.123820\end{array}$

$\begin{array}{lllll}\text { O } & 0.182049 & -2.682347 & -4.159273\end{array}$

Fig._S105_LPd12 / electronic energy: -2985.75000800 a.u. / lowest freq: $18.74 \mathrm{~cm}-1$

$\begin{array}{llll}\text { Pd } 0.045816 & -0.893035 & -0.779241\end{array}$

$\begin{array}{lllll}P & -1.820933 & 0.487220 & -0.329585\end{array}$

$\begin{array}{llll}P & 1.765868 & 0.670987 & -0.412835\end{array}$

$\begin{array}{lllll}0 & -0.025487 & 0.850049 & 1.812667\end{array}$

$\begin{array}{llll}\text { C } & -1.114586 & 0.158814 & 2.289835\end{array}$

$\begin{array}{llll}\text { C } & -2.157565 & -0.055963 & 1.380808\end{array}$

C $-3.261416-0.792605 \quad 1.822691$

H $-4.083539-1.014604 \quad 1.138137$

C $-3.289538-1.281387 \quad 3.128613$

H $-4.149621-1.864243 \quad 3.464415$

C $-2.227300-1.051847$

$\begin{array}{llll}\text { C } & -1.110183 & -0.315093 & 3.601415\end{array}$

C $0.085921 \quad 0.053504 \quad 4.476328$

C $1.325792 \quad-0.013384 \quad 3.587640$

$\begin{array}{lll}\text { C } 2.587697 & -0.464079 & 3.984117\end{array}$

H $2.739669-0.824091 \quad 5.003715$

$\begin{array}{llll}\text { C } 3.659284 & -0.466999 & 3.089407\end{array}$

H $4.636485 \quad-0.826458 \quad 3.41796$

C $3.490640 \quad-0.051794 \quad 1.769518$ 
$\begin{array}{llll}\text { H } & 4.323836 & -0.126910 & 1.067822\end{array}$ C $2.240479 \quad 0.402535 \quad 1.333252$

C $1.199512 \quad 0.426706 \quad 2.269393$

$\begin{array}{llll}\text { C } & -0.095154 & 1.509834 & 4.946137\end{array}$

$\begin{array}{cccc}\text { H } & -0.184251 & 2.208048 & 4.100296\end{array}$

H $\quad 0.7638551 .8294895 .554296$

H $-1.002853 \quad 1.608524 \quad 5.559539$

C $0.206205 \quad-0.855419 \quad 5.690104$

H $0.342046 \quad-1.909004 \quad 5.406824$

$\begin{array}{llll}H & -0.688644 & -0.785379 & 6.322725\end{array}$

$\begin{array}{llll}H & 1.055593 & -0.560086 & 6.320530\end{array}$

$\begin{array}{llll}\text { C } & -1.811789 & 2.319208 & -0.215614\end{array}$

$\begin{array}{llll}\text { C } & -1.666494 & 3.046871 & -1.40561\end{array}$

$\begin{array}{llll}\text { H } & -1.452281 & 2.523721 & -2.343496\end{array}$

$\begin{array}{lllll}\text { C } & -1.811547 & 4.431113 & -1.406535\end{array}$

$\begin{array}{llll}\text { H } & -1.696759 & 4.985729 & -2.341062\end{array}$

$\begin{array}{llll}C & -2.098675 & 5.107215 & -0.219511\end{array}$

H $-2.2162306 .193639-0.222603$

C $-2.230873 \quad 4.392081 \quad 0.969332$

H $-2.455276 \quad 4.913943 \quad 1.902885$

$\begin{array}{llll}\text { C } & -2.086565 & 3.004609 & 0.975201\end{array}$

H $-2.215763 \quad 2.460588 \quad 1.914120$

$\begin{array}{llll}\text { C }-3.347390 & 0.296029 & -1.316160\end{array}$

$\begin{array}{llll}C & -4.576589 & 0.749385 & -0.815657\end{array}$

H $\quad-4.644266 \quad 1.151495 \quad 0.199509$

$\begin{array}{llll}\text { C } & -5.716946 & 0.701890 & -1.615784\end{array}$

$\begin{array}{llll}\text { H } & -6.673376 & 1.045609 & -1.214983\end{array}$

$\begin{array}{llll}C & -5.633881 & 0.230862 & -2.926715\end{array}$

$\begin{array}{llll}\text { H } & -6.528193 & 0.200877 & -3.55370\end{array}$

$\begin{array}{llll}\text { C } & -4.407543 & -0.193413 & -3.438387\end{array}$

$\begin{array}{llll}\text { H } & -4.335802 & -0.553366 & -4.467196\end{array}$

$\begin{array}{llll}\text { C } & -3.268431 & -0.165680 & -2.635465\end{array}$

$\begin{array}{llll}\text { H } & -2.307946 & -0.506941 & -3.032442\end{array}$

$\begin{array}{llll}\text { C } & 1.549458 & 2.482463 & -0.597609\end{array}$

C $1.631525 \quad 3.017633-1.893927$

H $\quad 1.7421192 .351969-2.755351$

$\begin{array}{llll}\text { C } & 1.604300 & 4.394338 & -2.092741\end{array}$

H $1.6838394 .796506 \quad-3.105510$

C $1.478876 \quad 5.255633-1.001882$

H $1.461601 \quad 6.337309 \quad-1.155895$

$\begin{array}{llll}\text { C } & 1.368054 & 4.730894 & 0.284726\end{array}$

H $1.260753 \quad 5.399014 \quad 1.142851$

C $1.402871 \quad 3.351351 \quad 0.490633$

H $\quad 1.339286 \quad 2.962417 \quad 1.509739$

$\begin{array}{llll}\text { C } 3.261469 & 0.473237 & -1.447507\end{array}$

$\begin{array}{llll}\text { C } 4.421422 & 1.205746 & -1.151826\end{array}$

$\begin{array}{llll}\text { H } & 4.461187 & 1.838112 & -0.259942\end{array}$

$\begin{array}{lllll}\text { C } & 5.523703 & 1.145444 & -2.001782\end{array}$

H $6.426576 \quad 1.709749 \quad-1.757087$

$\begin{array}{llll}\text { C } 5.468146 & 0.379575 & -3.167357\end{array}$

$\begin{array}{lllll}\text { H } & 6.330700 & 0.340584 & -3.836983\end{array}$

$\begin{array}{llll}\text { C } & 4.306863 & -0.325072 & -3.482606\end{array}$

H $4.252683-0.913875-4.401056$

$\begin{array}{llll}\text { C } 3.208313 & -0.281756 & -2.624937\end{array}$

H $2.297573-0.834949-2.871385$

I $1.984811-2.826975-0.450574$

$\begin{array}{llll}1 & -1.757166 & -2.974721 & -1.003615\end{array}$

11

Fig._S105_Pd318(2-) / electronic energy: -2767.58674461 a.u. / lowest freq: $-\mathbf{2 2 . 1 8} \mathrm{cm}-1$

Pd $0.000000 \quad 0.000000 \quad 3.948502$

$0.000000 \quad 1.860076 \quad 1.963634$

I $0.000000-1.939204 \quad 5.812236$

$\begin{array}{llll} & 0.000000 & 0.000000 & 0.000000\end{array}$

$\begin{array}{cccc}\text { Pd } & 0.000000 & 0.000000 & 0.000000 \\ \text { I } & 0.0000000 & -1.860076 & 1.963634\end{array}$

I $0.000000 \quad 1.860076-1.963634$

$0.0000001 .939204 \quad 5.812236$

I $0.000000-1.860076-1.963634$

$10.000000-1.939204-5.812236$

d $0.000000 \quad 0.000000-3.94850$

I $0.000000 \quad-1.939204-5.812236$

Fig._S105_RCHO / electronic energy: -192.984065824 a.u. / lowest freq: $153.26 \mathrm{~cm}-1$

$\begin{array}{llll}0 & 1.401165 & -0.687132 & 0.000000\end{array}$

$\begin{array}{llll}\text { H } & -1.252324 & -1.124869 & -0.88355\end{array}$

C $0.919697 \quad 0.422075 \quad 0.000000$

H $-1.252326-1.124867 \quad 0.883553$

C $-1.432393 \quad-0.496718 \quad 0.000000$

H $1.580685 \quad 1.330267 \quad 0.000000$

C -0.54228

H -2.49435

$\begin{array}{lllll}\text { H } & -0.730725 & 1.379719 & -0.866637\end{array}$

$\begin{array}{llll}H & -0.730726 & 1.379719 & 0.866637\end{array}$

153

Fig. S105 LPdH(CO)PdL(+) / electronic energy: -4893.59579005 a.u. / lowest freq: $9.67 \mathrm{~cm}-1$

C $3.275432 \quad 2.757857-2.077960$

C $2.422543 \quad 3.778934-1.632281$

H $1.854809 \quad 3.642447-0.706206$

$\begin{array}{llll}\text { C } 2.293332 & 4.960460 & -2.356318\end{array}$ 
H $\quad 1.629605 \quad 5.749747 \quad-1.993970$

$\begin{array}{llll}\text { C } & 2.999295 & 5.127645 & -3.549156\end{array}$

H $2.892178 \quad 6.050855 \quad-4.123674$

C $3.837074 \quad 4.111763-4.007796$

H $4.390362 \quad 4.237611-4.941551$

C $3.980797 \quad 2.932320 \quad-3.275420$

H $4.6510182 .150080-3.641816$

$\begin{array}{llll}\text { C } & 4.554456 & 0.167914 & -1.971968\end{array}$

$\begin{array}{llll}\text { C } & 3.997112 & -0.659870 & -2.957441\end{array}$

H $2.913253-0.647283 \quad-3.124201$

$\begin{array}{llll}\text { C } 4.810969 & -1.492381 & -3.722810\end{array}$

$\begin{array}{llll}\text { H } & 4.365941 & -2.126790 & -4.493153\end{array}$

$\begin{array}{llll}\text { C } & 6.187460 & -1.524345 & -3.495061\end{array}$

$\begin{array}{llll}\text { H } & 6.824898 & -2.185918 & -4.086856\end{array}$

$\begin{array}{llll}\text { C } & 6.746755 & -0.715772 & -2.505448\end{array}$

$\begin{array}{llll}\text { H } & 7.823629 & -0.739313 & -2.321488\end{array}$

$\begin{array}{llll}\text { C } & 5.937141 & 0.132704 & -1.750318\end{array}$

H $6.3910650 .771241 \quad-0.986728$

$\begin{array}{llll}\text { C } & 4.434738 & 1.861402 & 0.356642\end{array}$

$\begin{array}{llll}\text { C } 4.859536 & 3.182550 & 0.544636\end{array}$

H $4.619076 \quad 3.947713 \quad-0.196794$

C $5.581224 \quad 3.530047 \quad 1.685970$

H $5.898644 \quad 4.565393 \quad 1.827571$

C $5.913235 \quad 2.568130 \quad 2.641303$

H $6.4905162 .861616 \quad 3.520440$

C $5.534569 \quad 1.233187 \quad 2.472755$

C $4.788698 \quad 0.924202 \quad 1.333081$

C $5.9396510 .078766 \quad 3.381462$

C $6.343981 \quad 0.552561 \quad 4.769597$

H $7.201743 \quad 1.236080 \quad 4.717487$

H $6.660252 \quad-0.291076 \quad 5.397314$

H $\quad 5.524721 \quad 1.072930 \quad 5.286578$

$\begin{array}{llll}\text { C } & 7.131969 & -0.644508 & 2.724020\end{array}$

H $6.888222-1.007893 \quad 1.714313$

H 7.437764 -1.511682 3.327573

H $7.994188 \quad 0.0328592 .636770$

C $4.764315-0.891137 \quad 3.421850$

$\begin{array}{llll}\text { C } & 4.388779 & -1.652638 & 4.530737\end{array}$

$\begin{array}{llll}\text { H } & 4.923946 & -1.535877 & 5.475288\end{array}$

$\begin{array}{llll}\text { C } & 3.341839 & -2.571413 & 4.445113\end{array}$

H $3.068696-3.165011 \quad 5.319979$

$\begin{array}{llll}\text { C } & 2.636465 & -2.735655 & 3.255368\end{array}$

H $\quad 1.808849 \quad-3.447139 \quad 3.213266$

C $2.970235-1.977502 \quad 2.123822$

$\begin{array}{llll}\text { C } 4.040450 & -1.083234 & 2.240586\end{array}$

$\begin{array}{llll}\text { C } & 2.934229 & -3.136097 & -0.552615\end{array}$

$\begin{array}{llll}\text { C } & 4.241027 & -3.571029 & -0.304706\end{array}$

H $4.760088-3.273624 \quad 0.611264$

$\begin{array}{llll}\text { C } & 4.888452 & -4.399657 & -1.223505\end{array}$

$\begin{array}{lllll}\text { H } & 5.909925 & -4.731438 & -1.022239\end{array}$

$\begin{array}{llll}\text { C } 4.235914 & -4.809073 & -2.385126\end{array}$

$\begin{array}{lllll}\text { H } & 4.744028 & -5.463920 & -3.097134\end{array}$

$\begin{array}{llll}\text { C } & 2.933307 & -4.373740 & -2.640315\end{array}$

$\begin{array}{llll}\text { H } & 2.416917 & -4.684653 & -3.55217\end{array}$

$\begin{array}{llll}\text { C } & 2.291830 & -3.530511 & -1.738098\end{array}$

H 1.275285 -3.178481 -1.949998

$\begin{array}{llll}\text { C } & 0.546416 & -2.984998 & 1.062366\end{array}$

$\begin{array}{llll}\text { C } & 0.477498 & -4.379468 & 0.952554\end{array}$

$\begin{array}{lllll}\text { H } & 1.318327 & -4.941130 & 0.535444\end{array}$

$\begin{array}{llll}\text { C } & -0.664293 & -5.062506 & 1.374880\end{array}$

H $-0.710946-6.149713 \quad 1.275783$

$\begin{array}{llll}C & -1.736808 & -4.363544 & 1.928237\end{array}$

$\begin{array}{llll}\text { H } & -2.627318 & -4.901238 & \mathbf{2 . 2 6 2 8 0 5}\end{array}$

C $-1.669391-2.974247 \quad 2.055884$

$\begin{array}{llll}\text { H } & -2.504999 & -2.420831 & 2.493817\end{array}$

$\begin{array}{llll}\text { C } & -0.538998 & -2.288518 & 1.616455\end{array}$

H $-0.497370-1.194554 \quad 1.700266$

C $-0.882860 \quad 3.153409 \quad 1.133524$

$\begin{array}{llll}\text { C } & -0.900081 & 4.545640 & 0.996033\end{array}$

H $-1.777103 \quad 5.047486 \quad 0.577791$

C $0.203601 \quad 5.304329 \quad 1.395742$

H $\quad 0.181732 \quad 6.390352 \quad 1.276850$

C $1.323383 \quad 4.684273 \quad 1.948296$

$\begin{array}{llll}\text { H } & 2.184396 & 5.280967 & 2.260498\end{array}$

$\begin{array}{llll}\text { C } & 1.345870 & 3.294515 & 2.093857\end{array}$

H $2.218944 \quad 2.798662 \quad 2.527308$

C $\quad 0.256841 \quad 2.534481 \quad 1.675988$

H $\quad 0.287564 \quad 1.441978 \quad 1.773833$

$\begin{array}{llll}\text { C } & -3.492660 & 3.154719 & -0.166522\end{array}$

$\begin{array}{llll}\text { C } & -3.240657 & 3.578361 & -1.481037\end{array}$

H $-2.329870 \quad 3.254387 \quad-1.994034$

$\begin{array}{llll}\text { C } & -4.141598 & 4.414009 & -2.136932\end{array}$

H $-3.9308704 .739149-3.158767$

$\begin{array}{llll}\text { C } & -5.315209 & 4.818004 & -1.498626\end{array}$

$\begin{array}{lllll}\text { H } & -6.026099 & 5.465992 & -2.016933\end{array}$

$\begin{array}{llll}\text { C } & -5.580226 & 4.387589 & -0.199044\end{array}$

H $-6.498063 \quad 4.698525 \quad 0.305621$

$\begin{array}{lllll}\text { C } & -4.673731 & 3.563549 & 0.468261\end{array}$ 
$\begin{array}{cccc}\text { H } & -4.892541 & 3.245029 & 1.491374\end{array}$ $\begin{array}{llll}\text { C } & -3.031908 & 1.624428 & 2.227750\end{array}$

C $-2.675913 \quad 2.186611 \quad 3.460489$

$\begin{array}{llll}\text { H } & -1.884186 & 2.938102 & 3.509789\end{array}$

$\begin{array}{llll}\text { C } & -3.326238 & 1.788669 & 4.627198\end{array}$

\begin{tabular}{lllll}
\hline H & -3.034236 & 2.226325 & 5.584042
\end{tabular}

C $-4.3583890 .849997 \quad 4.581496$

H $-4.8687260 .567695 \quad 5.504816$

C $-4.758289 \quad 0.283919 \quad 3.368355$

$\begin{array}{llll}C & -4.059767 & 0.673198 & 2.221737\end{array}$

$\begin{array}{llll}\text { C } & -5.945556 & -0.655325 & 3.185787\end{array}$

$\begin{array}{llll}\text { C } & -7.132593 & 0.180307 & 2.668035\end{array}$

H $-6.8969200 .692064 \quad 1.722686$

$\begin{array}{llll}H & -7.413599 & 0.948215 & 3.403695\end{array}$

$\begin{array}{llll}\text { H } & -8.008705 & -0.461224 & 2.492898\end{array}$

$\begin{array}{llll}\text { C } & -6.343671 & -1.337888 & 4.485483\end{array}$

H $\quad-7.213347 \quad-1.991096 \quad 4.335600$

H $-6.638945 \quad-0.599024 \quad 5.242233$

H $\quad-5.528090 \quad-1.946270 \quad 4.902835$

$\begin{array}{llll}\text { C } & -5.559909 & -1.656863 & 2.103762\end{array}$

$\begin{array}{llll}\text { C } & -5.937099 & -3.002564 & 2.076539\end{array}$

$\begin{array}{llll}\text { H } & -6.533021 & -3.415659 & 2.893113\end{array}$

$\begin{array}{lllll}\text { C } & -5.569044 & -3.826059 & 1.011268\end{array}$

$\begin{array}{llll}\text { H } & -5.881991 & -4.872335 & 1.002797\end{array}$

$\begin{array}{llll}\text { C } & -4.792095 & -3.331919 & -0.035261\end{array}$

$\begin{array}{llll}\text { H } & -4.486066 & -3.997904 & -0.845954\end{array}$

$\begin{array}{llll}C & -4.379891 & -1.992827 & -0.034795\end{array}$

$\begin{array}{llll}\text { C } & -4.796558 & -1.187773 & 1.032299\end{array}$

$\begin{array}{llll}\text { C } & -4.193419 & -0.181242 & -2.302461\end{array}$

$\begin{array}{llll}C & -5.544689 & 0.103596 & -2.074242\end{array}$

$\begin{array}{llll}\text { H } & -6.074983 & -0.364759 & -1.240352\end{array}$

$\begin{array}{lllll}\text { C } & -6.228849 & 0.981813 & -2.916512\end{array}$

$\begin{array}{llll}\text { H } & -7.282512 & 1.200124 & -2.726011\end{array}$

$\begin{array}{lllll}C & -5.576151 & 1.572814 & -3.997004\end{array}$

H $-6.116223 \quad 2.257461-4.655672$

$\begin{array}{llll}C & -4.227489 & 1.294356 & -4.230158\end{array}$

$\begin{array}{lllll}\text { H } & -3.707754 & 1.759272 & -5.071563\end{array}$

$\begin{array}{llll}\text { C } & -3.536497 & 0.433406 & -3.382182\end{array}$

H $-2.4742960 .229420 \quad-3.561232$

$\begin{array}{lllll}\text { C } & -2.800091 & -2.708193 & -2.295873\end{array}$

$\begin{array}{llll}\text { C } & -1.709263 & -3.512179 & -1.937591\end{array}$

H $-1.098811-3.236783 \quad-1.070214$

$\begin{array}{llll}\text { C } & -1.404364 & -4.657762 & -2.671134\end{array}$

$\begin{array}{llll}\text { H } & -0.558865 & -5.284766 & -2.374785\end{array}$

$\begin{array}{llll}\text { C } & -2.174743 & -4.998429 & -3.783946\end{array}$

$\begin{array}{lllll}\text { H } & -1.932129 & -5.891072 & -4.365495\end{array}$

$\begin{array}{llll}\text { C } & -3.254443 & -4.195682 & -4.154561\end{array}$

$\begin{array}{lllll}\text { H } & -3.858647 & -4.458636 & -5.026183\end{array}$

$\begin{array}{llll}\text { C } & -3.572764 & -3.059050 & -3.411568\end{array}$

$\begin{array}{lllll}\text { H } & -4.431301 & -2.445935 & -3.700661\end{array}$

$\begin{array}{llll}\text { C } & 0.114756 & 1.371381 & -1.434042\end{array}$

$\begin{array}{llll}\text { o } & 4.357836 & -0.360547 & 1.121236\end{array}$

\begin{tabular}{lllll}
\hline & -4.380048 & 0.120398 & 1.008452
\end{tabular}

\begin{tabular}{lllll}
\hline & -0.009995 & 2.246006 & -2.207135
\end{tabular}

$\begin{array}{llll}\text { P } & 3.419582 & 1.259546 & -1.042325\end{array}$

$\begin{array}{llll}\text { P } & 2.016748 & -2.015878 & 0.558551\end{array}$

$\begin{array}{llll}P & -2.262722 & 2.059637 & 0.626401\end{array}$

$\begin{array}{llll}P & -3.196703 & -1.276637 & -1.229479\end{array}$

$\begin{array}{llll}P d & 1.372258 & 0.033998 & -0.653022\end{array}$

$\begin{array}{llll}\text { Pd } & -1.324035 & 0.189531 & -0.619058\end{array}$

$\begin{array}{llll}\text { H } & -0.120101 & -0.979249 & -0.976158\end{array}$

Fig._S105_LPdHI / electronic energy: -2688.42445650 a.u. / lowest freq: $20.09 \mathrm{~cm}-1$

$\begin{array}{llll}\text { Pd } & -0.018417 & -0.953805 & -1.185825\end{array}$

$\begin{array}{llll}P & 1.640194 & -0.379894 & 0.557841\end{array}$

$\begin{array}{llll}\text { P } & -2.029701 & -0.591427 & -0.167157\end{array}$

$\begin{array}{lllll}\mathrm{O} & -0.319894 & 1.667105 & 0.524623\end{array}$

$\begin{array}{llll}\text { C } & 0.878418 & 2.220330 & 0.134290\end{array}$

C $1.984929 \quad 1.362814 \quad 0.126191$

C $3.199576 \quad 1.884182-0.331933$

$\begin{array}{lllll}\text { H } & 4.082477 & 1.243269 & -0.390369\end{array}$

$\begin{array}{llll}\text { C } & 3.277203 & 3.213687 & -0.747367\end{array}$

H $4.227579 \quad 3.607639-1.113552$

C $2.156311 \quad 4.044950-0.703849$

H $2.246060 \quad 5.084053 \quad-1.027384$

C $0.925978 \quad 3.560764-0.249835$

$\begin{array}{llll}\text { C } & -0.351254 & 4.379150 & -0.084634\end{array}$

$\begin{array}{llll}C & -1.510456 & 3.474700 & -0.493586\end{array}$

C $-2.654899 \quad 3.886233 \quad-1.18175$

$\begin{array}{llll}\text { H } & -2.758454 & 4.928559 & -1.490624\end{array}$

$\begin{array}{llll}\text { C } & -3.671359 & 2.978682 & -1.481715\end{array}$

H $-4.560303 \quad 3.318675 \quad-2.017087$

C $-3.555298 \quad 1.635387-1.127360$

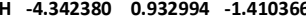

$\begin{array}{llll}\text { C } & -2.418192 & 1.180124 & -0.447562\end{array}$

C $-1.433783 \quad 2.127050-0.132506$

$\begin{array}{llll}\text { C } & -0.508082 & 4.720390 & 1.410086\end{array}$

$\begin{array}{llll}\text { H } & -0.540299 & 3.817618 & 2.038258\end{array}$ 
\begin{tabular}{cccc} 
H & -1.437663 & 5.282030 & 1.584225 \\
\hline & 0.333506 & 5.338573 & 1.756037
\end{tabular}

H $0.333506 \quad 5.338573 \quad 1.756037$

$\begin{array}{llll}\text { C } & -0.316646 & 5.667790 & -0.891958\end{array}$

$\begin{array}{llll}\text { H } & -0.212183 & 5.479907 & -1.970255\end{array}$

$\begin{array}{llll}\text { H } & 0.518950 & 6.306619 & -0.575885\end{array}$

H $-1.2316326 .254662-0.735587$

C $1.288449-0.306622 \quad 2.362047$

$\begin{array}{llll}\text { C } & 1.022884 & -1.518874 & 3.016762\end{array}$

H $0.974375 \quad-2.449612 \quad 2.441191$

$\begin{array}{llll}\text { C } 0.838360 & -1.552040 & 4.396747\end{array}$

$\begin{array}{llll}\text { H } & 0.637838 & -2.504972 & 4.893151\end{array}$

$\begin{array}{llll}\text { C } & 0.899744 & -0.372837 & 5.141292\end{array}$

H $\quad 0.753017 \quad-0.399249 \quad 6.223944$

C $1.143518 \quad 0.838482 \quad 4.496214$

H $\quad 1.191885 \quad 1.767060 \quad 5.070708$

C $1.338513 \quad 0.873674 \quad 3.114707$

H $1.549326 \quad 1.831082 \quad 2.630250$

C $3.265648-1.221351 \quad 0.594934$

C $4.326918-0.721659 \quad 1.366293$

$\begin{array}{llll}\text { H } & 4.204863 & 0.211414 & 1.925293\end{array}$

C $5.535078-1.411473 \quad 1.430884$

$\begin{array}{llll}\text { H } & 6.357296 & -1.010974 & 2.028781\end{array}$

$\begin{array}{llll}\text { C } & 5.690745 & -2.615986 & 0.741103\end{array}$

H $6.638138-3.157827 \quad 0.796008$

$\begin{array}{llll}\text { C } 4.634561 & -3.130142 & -0.009154\end{array}$

$\begin{array}{llll}\text { H } & 4.748533 & -4.077250 & -0.541658\end{array}$

$\begin{array}{llll}\text { C } 3.426257 & -2.435874 & -0.082910\end{array}$

$\begin{array}{llll}\text { H } & 2.596752 & -2.840594 & -0.669972\end{array}$

$\begin{array}{lrll}\text { C } & -2.195391 & -0.868655 & 1.633838\end{array}$

$\begin{array}{llll}C & -2.298663 & -2.199294 & 2.070151\end{array}$

$\begin{array}{llll}\text { H } & -2.241660 & -3.017254 & 1.344795\end{array}$

$\begin{array}{llll}\text { C } & -2.498811 & -2.486282 & 3.417179\end{array}$

$\begin{array}{llll}\text { H } & -2.591905 & -3.525571 & 3.741747\end{array}$

$\begin{array}{llll}\text { C } & -2.579122 & -1.448767 & 4.347731\end{array}$

H $-2.734496-1.672484 \quad 5.406124$

C $-2.448923-0.126935 \quad 3.925000$

$\begin{array}{lllll}\text { H } & -2.500602 & 0.688533 & 4.650884\end{array}$

$\begin{array}{llll}\text { C } & -2.259293 & 0.166668 & 2.573843\end{array}$

H $\quad-2.181801 \quad 1.210329 \quad 2.257864$

$\begin{array}{lllll}\text { C } & -3.509341 & -1.481218 & -0.781514\end{array}$

$\begin{array}{llll}\text { C } & -4.730001 & -1.337810 & -0.099103\end{array}$

$\begin{array}{llll}\text { H } & -4.790938 & -0.698558 & 0.787004\end{array}$

C $-5.869956-1.998612-0.547253$

H $-6.814091-1.872074-0.012313$

C $-5.805272-2.821662-1.673904$

$\begin{array}{lllll}\text { H } & -6.699435 & -3.344827 & -2.021329\end{array}$

$\begin{array}{llll}C & -4.596805 & -2.978491 & -2.349161\end{array}$

$\begin{array}{llll}\text { H } & -4.536738 & -3.627377 & -3.225887\end{array}$

C $-3.453577-2.311456-1.905597$

H $-2.505658-2.442993 \quad-2.434768$

H $-1.001855-1.106494-2.399984$

$\begin{array}{lllll} & 1.865334 & -0.974736 & -3.186951\end{array}$

Fig._S105_12PdH(-) / electronic energy: -724.532836984 a.u. / lowest freq: $28.44 \mathrm{~cm}-1$

I $-\begin{array}{lll}-2.645870 & 0.019347 \quad 0.000142\end{array}$

$\begin{array}{llll}\text { Pd } & -0.000004 & -0.075745 & -0.000307\end{array}$

H $-0.000242 \quad 1.433399-0.000948$

$\begin{array}{llll}\text { I } & 2.645878 & 0.019349 & 0.000142\end{array}$

Fig._S105_INT1C / electronic energy: - -3306.75833170 a.u. / lowest freq: $17.29 \mathrm{~cm}-1$

C $-3.197514-2.876509 \quad 0.452706$

$\begin{array}{llll}C & -3.196875 & -3.730858 & -0.657647\end{array}$

$\begin{array}{llll}\text { H } & -2.625399 & -3.450185 & -1.549843\end{array}$

$\begin{array}{llll}C & -3.909840 & -4.928914 & -0.623986\end{array}$

H $-3.903038-5.590331-1.493386$

C $-4.622343-5.283409 \quad 0.521561$

H $-5.176590 \quad-6.224584 \quad 0.550720$

$\begin{array}{llll}C & -4.620482 & -4.440344 & 1.634651\end{array}$

H $\quad-5.175253 \quad-4.718495 \quad 2.533854$

C $-3.911432-3.241454 \quad 1.603561$

H $\quad-3.916003 \quad-2.584485 \quad 2.478670$

C $-1.707622-1.034272 \quad 2.052234$

$\begin{array}{llll}\text { C } & -2.287469 & -0.089307 & 2.908476\end{array}$

H $-3.064155 \quad 0.587758 \quad 2.539358$

$\begin{array}{llll}\text { C } & -1.892420 & -0.022944 & 4.244035\end{array}$

H $\quad-2.354165 \quad 0.712048 \quad 4.908050$

$\begin{array}{llll}\text { C } & -0.914641 & -0.890310 & 4.731115\end{array}$

H $-0.609137-0.835716 \quad 5.779000$

$\begin{array}{llll}\text { C } & -0.312137 & -1.812837 & 3.875205\end{array}$

$\begin{array}{llll}\text { H } & 0.468056 & -2.482305 & 4.245618\end{array}$

$\begin{array}{llll}\text { C } & -0.703771 & -1.883106 & 2.540136\end{array}$

H $-0.237905 \quad-2.618101 \quad 1.874424$

$\begin{array}{llll}\text { C } & -3.562902 & -0.043358 & 0.014099\end{array}$

$\begin{array}{llll}\text { C } & -4.897690 & -0.386841 & -0.239909\end{array}$

$\begin{array}{llll}\text { H } & -5.231941 & -1.414558 & -0.079561\end{array}$

$\begin{array}{llll}\text { C } & -5.792601 & 0.563570 & -0.722341\end{array}$

$\begin{array}{lllll}\text { H } & -6.829661 & 0.284140 & -0.918917\end{array}$

$\begin{array}{llll}\text { C } & -5.362537 & 1.865138 & -0.969501\end{array}$ 
\begin{tabular}{llll} 
H & -6.070531 & 2.596112 & -1.364282 \\
\hline
\end{tabular}

$\begin{array}{lllll}C & -4.044709 & 2.253034 & -0.708525\end{array}$

$\begin{array}{llll}\text { C } & -3.527109 & 3.670290 & -0.87546\end{array}$

$\begin{array}{llll}C & -2.061692 & 3.578678 & -1.282205\end{array}$

$\begin{array}{llll}\text { C } & -1.435230 & 4.491453 & -2.134059\end{array}$

H $-2.031486 \quad 5.239893 \quad-2.659190$

C $-0.052396 \quad 4.477019 \quad-2.298008$

$\begin{array}{llll}\text { H } & 0.427001 & 5.188945 & -2.973029\end{array}$

C $0.727616 \quad 3.593932-1.557410$

$\begin{array}{lllll}\text { H } & 1.815083 & 3.642751 & -1.644125\end{array}$

$\begin{array}{llll}\text { C } & 0.142389 & 2.648331 & -0.702913\end{array}$

$\begin{array}{llll}\text { C } & -1.263382 & 2.610481 & -0.656657\end{array}$

$\begin{array}{llll}\text { C } & -3.165152 & 1.289526 & -0.203924\end{array}$

$\begin{array}{llll}\text { C } & -4.354229 & 4.478251 & -1.865298\end{array}$

H $-3.978675 \quad 5.506913 \quad-1.942206$

H $-5.3972914 .559569 \quad-1.533111$

$\begin{array}{lllll}\text { H } & -4.349841 & 4.037280 & -2.872554\end{array}$

$\begin{array}{lllll}\text { C } & -3.587128 & 4.357058 & 0.504215\end{array}$

H $\quad-3.044540 \quad 3.784218 \quad 1.271505$

$\begin{array}{llll}\text { H } & -4.630295 & 4.453312 & 0.84022\end{array}$

$\begin{array}{lllll}\text { H } & -3.147146 & 5.364583 & 0.458778\end{array}$

C $2.821762 \quad 2.376253 \quad 0.239043$

$\begin{array}{llll}\text { C } & 3.147310 & 3.501336 & 1.010825\end{array}$

H $2.4168213 .918057 \quad 1.710006$

$\begin{array}{llll}\text { C } 4.400773 & 4.100406 & 0.895823\end{array}$

H $4.639738 \quad 4.975106 \quad 1.505786$

$\begin{array}{llll}\text { C } & 5.346871 & 3.587180 & 0.007637\end{array}$

$\begin{array}{lllll}\text { H } & 6.329994 & 4.056381 & -0.078334\end{array}$

$\begin{array}{llll}\text { C } & 5.033866 & 2.470680 & -0.766862\end{array}$

H $5.767761 \quad 2.059665$-1.463987

C $3.7816281 .868390 \quad-0.648985$

$\begin{array}{lllll}\text { H } & 3.548493 & 0.992707 & -1.267498\end{array}$

$\begin{array}{llll}\text { C } & 0.675040 & 2.033371 & 2.049741\end{array}$

$\begin{array}{llll}\text { C } & -0.215262 & 3.078032 & 2.336429\end{array}$

H $-0.713052 \quad 3.622207 \quad 1.530600$

$\begin{array}{llll}\text { C } & -0.448774 & 3.468140 & 3.655313\end{array}$

H $-1.143401 \quad 4.287898 \quad 3.858108$

C $\quad 0.2143592 .833656 \quad 4.705665$

H $0.039587 \quad 3.149372 \quad 5.737349$

C $1.101053 \quad 1.7932314 .429267$

H $1.622376 \quad 1.283079 \quad 5.243342$

C $1.320842 \quad 1.387680 \quad 3.114383$

H $2.019047 \quad 0.569453 \quad 2.909685$

\begin{tabular}{lllll}
\hline & -1.858249 & 1.610262 & 0.083054
\end{tabular}

$\begin{array}{llll}P & -2.285041 & -1.298385 & 0.345410\end{array}$

$\begin{array}{lllll}P & 1.177240 & 1.543533 & 0.347047\end{array}$

l $3.273902 \quad-1.805480 \quad 1.672896$

H 1.927065 -5.923767 -1.687224

$\begin{array}{llll}\text { C } & 2.582782 & -5.044177 & -1.726986\end{array}$

$\begin{array}{llll}\text { H } & 2.983151 & -4.966652 & -2.746567\end{array}$

H $3.428861-5.226856-1.049634$

H $0.965231-3.600745 \quad-1.998342$

$\begin{array}{llll}\text { C } & 1.823200 & -3.798637 & -1.329821\end{array}$

$\begin{array}{llll}\text { H } & 1.382318 & -3.875922 & -0.324148\end{array}$

$\begin{array}{llll}\text { C } & 2.656128 & -2.543753 & -1.384241\end{array}$

H $0.281816-1.623296 \quad-0.383981$

$\begin{array}{llll}\text { Pd } & -0.851742 & -1.037664 & -1.375774\end{array}$

o $3.710937-2.428027-1.938256$

$\begin{array}{llll}\text { Pd } & 1.885207 & -0.900130 & -0.533982\end{array}$

$\begin{array}{llll}1 & 0.942203 & -0.263888 & -3.270442\end{array}$

Fig. S105_TSC / electronic energy: $-\mathbf{3 3 0 6 . 7 4 4 1 7 6 3 2}$ a.u. / lowest freq: $-\mathbf{5 1 2 . 5 0} \mathrm{cm}-1$

C $-2.838293 \quad-2.839968 \quad 0.631803$

C $-3.189296-3.395455-0.608117$

$\begin{array}{lllll}\text { H } & -2.924998 & -2.864212 & -1.530970\end{array}$

$\begin{array}{llll}\text { C } & -3.861200 & -4.614316 & -0.666274\end{array}$

$\begin{array}{llll}\text { H } & -4.130772 & -5.040690 & -1.635127\end{array}$

$\begin{array}{llll}\text { C }-4.178547 & -5.291373 & 0.512352\end{array}$

$\begin{array}{llll}\text { H } & -4.697999 & -6.251482 & 0.467295\end{array}$

C $-3.828365-4.746030 \quad 1.747999$

H $-4.074915 \quad-5.276249 \quad 2.670763$

C $-3.161108 \quad-3.523425 \quad 1.812296$

H $\quad-2.892779 \quad-3.102825 \quad 2.785534$

C $-1.165157-1.138909 \quad 2.248550$

C $-1.606619-0.276266 \quad 3.260374$

$\begin{array}{llll}\text { H } & -2.414805 & 0.435319 & 3.068937\end{array}$

$\begin{array}{llll}\text { C } & -1.031847 & -0.339690 & 4.529725\end{array}$

H $\quad-1.3835520 .334361 \quad 5.314640$

$\begin{array}{lllll}\text { C } & -0.016519 & -1.257184 & 4.79\end{array}$

$\begin{array}{llll}\text { H } & 0.428172 & -1.304869 & 5.793775\end{array}$

$\begin{array}{llll}\text { C } & 0.444590 & -2.101345 & 3.785401\end{array}$

H $\quad 1.252284-2.810756 \quad 3.98141$

$\begin{array}{llll}\text { C } & -0.123911 & -2.039887 & 2.515989\end{array}$

$\begin{array}{llll}\text { H } & 0.228633 & -2.712755 & 1.728796\end{array}$

$\begin{array}{llll}\text { C } & -3.310990 & 0.024459 & 0.636436\end{array}$

C $-4.672086-0.290386 \quad 0.533388$

H $-4.998118-1.329830 \quad 0.619429$

$\begin{array}{llll}\text { C } & -5.604572 & 0.716090 & 0.296093\end{array}$ 
\begin{tabular}{cccc} 
H & -6.664429 & 0.465839 & 0.217941 \\
\hline
\end{tabular}

$\begin{array}{llll}C & -5.189336 & 2.037893 & 0.136918\end{array}$

$\begin{array}{lllll}\text { H } & -5.932776 & 2.809279 & -0.073047\end{array}$

$\begin{array}{llll}\text { C } & -3.840970 & 2.392005 & 0.250735\end{array}$

$\begin{array}{lllll}\text { C } & -3.305331 & 3.810876 & 0.152503\end{array}$

$\begin{array}{llll}\text { C } & -1.922272 & 3.729569 & -0.484476\end{array}$

$\begin{array}{llll}\text { C } & -1.392610 & 4.701788 & -1.33728\end{array}$

H $-2.0246445 .522625-1.68114$

$\begin{array}{llll}\text { C } & -0.058509 & 4.650400 & -1.733600\end{array}$

$\begin{array}{llll}\text { H } & 0.341779 & 5.414125 & -2.403307\end{array}$

$\begin{array}{llll}\text { C } & 0.781739 & 3.651643 & -1.247251\end{array}$

H $1.836724 \quad 3.656801-1.527628$

$\begin{array}{llll}\text { C } & 0.287324 & 2.643077 & -0.410291\end{array}$

$\begin{array}{llll}\text { C } & -1.080632 & 2.681650 & -0.094966\end{array}$

$\begin{array}{llll}\text { C } & -2.926843 & 1.371836 & 0.521366\end{array}$

$\begin{array}{llll}\text { C } & -4.243952 & 4.730840 & -0.614535\end{array}$

$\begin{array}{lllll}\text { H } & -3.852647 & 5.756321 & -0.642733\end{array}$

H $-5.223417 \quad 4.791231-0.122374$

H $\quad-4.401599 \quad 4.396890 \quad-1.650113$

$\begin{array}{llll}\text { C } & -3.129940 & 4.351299 & 1.585810\end{array}$

H $\quad-2.487518 \quad 3.699107 \quad 2.196424$

$\begin{array}{llll}\text { H } & -4.104217 & 4.425151 & 2.091309\end{array}$

H $\quad-2.6765495 .353522 \quad 1.570171$

C $3.044057 \quad 1.941915-0.192629$

$\begin{array}{llll}\text { C } 3.821380 & 2.821154 & 0.570191\end{array}$

H $3.452822 \quad 3.194191 \quad 1.529940$

$\begin{array}{llll}\text { C } 5.075886 & 3.224229 & 0.110773\end{array}$

$\begin{array}{llll}\text { H } & 5.679747 & 3.904732 & 0.715959\end{array}$

$\begin{array}{llll}\text { C } & 5.556818 & 2.761972 & -1.113767\end{array}$

H $6.540246 \quad 3.078546-1.469734$

$\begin{array}{llll}\text { C } & 4.783177 & 1.889163 & -1.881150\end{array}$

H $\quad 5.156811 \quad 1.519225-2.838701$

$\begin{array}{llll}\text { C } 3.536716 & 1.473849 & -1.419931\end{array}$

$\begin{array}{llll}\text { H } & 2.936972 & 0.772438 & -2.012046\end{array}$

C $\quad \begin{array}{llll}1.330808 & 1.783865 & 2.118527\end{array}$

$\begin{array}{llll}\text { C } & 0.703938 & 2.935220 & 2.618344\end{array}$

H $0.167890 \quad 3.612850 \quad 1.949063$

C $\quad 0.779044 \quad 3.245080 \quad 3.975910$

H $\quad 0.286474 \quad 4.146014 \quad 4.350657$

C $1.492363 \quad 2.421305 \quad 4.847111$

H $\quad 1.558887 \quad 2.672520 \quad 5.908595$

C $2.118127 \quad 1.275686 \quad 4.356238$

H $2.6733640 .619553 \quad 5.031204$

C $2.027733 \quad 0.950608 \quad 3.004450$

H $2.517076 \quad 0.046875 \quad 2.626757$

\begin{tabular}{lllll}
\hline & -1.586762 & 1.647482 & 0.661023
\end{tabular}

$\begin{array}{lllll}\text { P } & -1.991522 & -1.227087 & 0.630016\end{array}$

$\begin{array}{llll}P & 1.386930 & 1.369008 & 0.333838\end{array}$

$\begin{array}{llll}\text { I } & 3.693843 & -1.775912 & 0.633352\end{array}$

$\begin{array}{llll}\text { H } & 1.642759 & -6.193246 & -0.639084\end{array}$

$\begin{array}{llll}\text { C } & 1.901536 & -5.289020 & -1.205228\end{array}$

H $1.714514-5.491326-2.268391$

H $2.980561-5.116083-1.086669$

$\begin{array}{lllll}\text { H } & 0.014896 & -4.270860 & -0.814179\end{array}$

$\begin{array}{llll}\text { C } & 1.104128 & -4.103095 & -0.717211\end{array}$

$\begin{array}{lllll}\text { H } & 1.262432 & -3.907669 & 0.354870\end{array}$

$\begin{array}{llll}\text { C } & 1.377756 & -2.835813 & -1.477050\end{array}$

$\begin{array}{lllll}\text { H } & 0.190575 & -1.946166 & -1.329114\end{array}$

$\begin{array}{llll}\text { Pd } & -1.152247 & -0.696600 & -1.411497\end{array}$

$\begin{array}{lllll}0 & 1.930906 & -2.774088 & -2.541308\end{array}$

Pd $1.236345 \quad-0.910665 \quad-0.398539$

\begin{tabular}{llll}
\hline & -0.344031 & 0.323042 & -3.756307
\end{tabular}

88

Fig._S105_INT2C / electronic energy: - -3306.76304166 a.u. / lowest freq: $-43.87 \mathrm{~cm}-1$

C $0.961386 \quad 3.7412790 .415037$

$\begin{array}{lllll}\text { C } & 0.707444 & 4.290619 & -0.849898\end{array}$

$\begin{array}{lll}4.290619 & -0.849898\end{array}$

C $0.552801 \quad 5.668164-1.001402$

$\begin{array}{lllll}\text { H } & 0.351119 & 6.086764 & -1.990013\end{array}$

C $0.644364 \quad 6.505104 \quad 0.111181$

H $0.514445 \quad 7.583809 \quad-0.004291$

$\begin{array}{llll}\text { C } & 0.898315 & 5.965151 & 1.373522\end{array}$

H $0.970778 \quad 6.620113 \quad 2.244987$

$\begin{array}{llll}\text { C } & 1.056661 & 4.589188 & 1.528402\end{array}$

H $\quad \begin{array}{lll}1.252663 & 4.173872 & 2.521497\end{array}$

C $0.508845 \quad 1.570970 \quad 2.228046$

C $1.330159 \quad 1.097271 \quad 3.258231$

$\begin{array}{llll}\text { H } & \mathbf{2 . 3 8 3 2 4 0} & 0.870437 & \mathbf{3 . 0 6 6 3 2 5}\end{array}$

C $0.813806 \quad 0.933260 \quad 4.544829$

$\begin{array}{cccc}\text { H } & 1.462995 & 0.564793 \quad 5.343095\end{array}$

C $-0.520217 \quad 1.237043 \quad 4.811892$

$\begin{array}{llll}\text { H } & -0.918377 & 1.109981 & 5.821587\end{array}$

C $-1.350847 \quad 1.689766 \quad 3.784865$

H $\quad-2.401907 \quad 1.915648 \quad 3.981940$

C $-0.839581 \quad 1.852091 \quad 2.500068$

H $\quad-1.488277 \quad 2.215319 \quad 1.696436$

C $2.932968 \quad 1.6071380 .607571$

$\begin{array}{llll}\text { C } 3.924147 & 2.588367 & 0.486898\end{array}$ 
$\begin{array}{llll}\text { H } & 3.654198 & 3.645810 & 0.546506\end{array}$

$\begin{array}{llll}\text { C } & 5.246964 & 2.216039 & 0.251112\end{array}$

H $6.0173332 .984544 \quad 0.158056$

$\begin{array}{llll}\text { C } & 5.588258 & 0.872185 & 0.098314\end{array}$

$\begin{array}{lllll}\text { H } & 6.622874 & 0.606243 & -0.126868\end{array}$

$\begin{array}{lllll}\text { C } & 4.625100 & -0.134940 & 0.226445\end{array}$

$\begin{array}{llll}\text { C } 4.885478 & -1.627480 & 0.085437\end{array}$

$\begin{array}{llll}\text { C } 3.649825 & -2.232873 & -0.572968\end{array}$

$\begin{array}{llll}\text { C } 3.677007 & -3.286377 & -1.490334\end{array}$

$\begin{array}{llll}\text { H } & 4.634576 & -3.658682 & -1.860255\end{array}$

$\begin{array}{llll}\text { C } 2.495597 & -3.884025 & -1.924957\end{array}$

H $2.531881-4.702589-2.646534$

C $1.267028-3.467058-1.419496$

$\begin{array}{lllll}\text { H } & 0.354620 & -3.972513 & -1.741774\end{array}$

$\begin{array}{llll}\text { C } & 1.193482 & -2.400302 & -0.513080\end{array}$

$\begin{array}{llll}\text { C } 2.397553 & -1.774195 & -0.151600\end{array}$

$\begin{array}{llll}\text { C } & 3.320792 & 0.262338 & 0.518093\end{array}$

C $6.156705-1.917535-0.698744$

H $6.335595-2.998732-0.770991$

$\begin{array}{llll}H & 7.034644 & -1.494246 & -0.193734\end{array}$

H $6.119537-1.508765-1.718830$

$\begin{array}{llll}\text { C } & 5.010907 & -2.233761 & 1.496784\end{array}$

H $4.129776-2.016171 \quad 2.118915$

$\begin{array}{llll}\text { H } & 5.891829 & -1.826074 & 2.014111\end{array}$

H $\quad 5.123413 \quad-3.326629 \quad 1.440814$

$\begin{array}{llll}\text { C } & -1.525141 & -3.260977 & -0.252906\end{array}$

$\begin{array}{llll}\text { C } & -1.595940 & -4.462283 & 0.464072\end{array}$

$\begin{array}{llll}\text { H } & -0.988360 & -4.608104 & 1.361575\end{array}$

$\begin{array}{llll}C & -2.446241 & -5.480771 & 0.033824\end{array}$

$\begin{array}{llll}\text { H } & -2.502190 & -6.412500 & 0.601540\end{array}$

$\begin{array}{llll}\text { C } & -3.222161 & -5.310652 & -1.112940\end{array}$

H $-3.887933-6.110756-1.445248$

C $-3.152489-4.115900 \quad-1.831125$

$\begin{array}{llll}\text { H } & -3.762260 & -3.974991 & -2.726349\end{array}$

$\begin{array}{llll}C & -2.313727 & -3.090906 & -1.400064\end{array}$

$\begin{array}{llll}\text { H } & -2.270780 & -2.144437 & -1.950559\end{array}$

$\begin{array}{llll}\text { C } & -0.111241 & -2.201388 & 2.042472\end{array}$

$\begin{array}{lllll}\text { C } & 1.012275 & -2.898810 & 2.513827\end{array}$

H $1.787374-3.241251 \quad 1.824470$

$\begin{array}{llll}\text { C } & 1.140864 & -3.189318 & 3.870862\end{array}$

H $2.020903 \quad-3.733639 \quad 4.222292$

C $0.147320 \quad-2.803066 \quad 4.770777$

H $\quad 0.248136 \quad-3.038886 \quad 5.832969$

$\begin{array}{llll}\text { C } & -0.973340 & -2.113986 & 4.308067\end{array}$

H $\quad-1.755587-1.802730 \quad 5.004691$

$\begin{array}{llll}\text { C } & -1.098140 & -1.804817 & 2.955458\end{array}$

H $-1.976282 \quad-1.256688 \quad 2.600243$

$\begin{array}{lllll}\text { O } & 2.324475 & -0.677203 & 0.671499\end{array}$

$\begin{array}{llll}\text { P } & 1.139871 & 1.928662 & 0.550755\end{array}$

$\begin{array}{llll}P & -0.400032 & -1.910993 & 0.256495\end{array}$

$\begin{array}{llll}\text { I } & -4.066226 & -0.367079 & 0.720476\end{array}$

$\begin{array}{llll}\text { H } & -4.626779 & 5.266026 & 0.139632\end{array}$

$\begin{array}{llll}\text { C }-4.279666 & 4.587452 & -0.649806\end{array}$

H $\quad-3.920617 \quad 5.202927 \quad-1.486335$

$\begin{array}{llll}H & -5.149143 & 4.020786 & -1.010404\end{array}$

$\begin{array}{lllll}\text { H } & -2.331123 & 4.216371 & 0.266228\end{array}$

$\begin{array}{lllll}\text { C } & -3.200847 & 3.666276 & -0.138226\end{array}$

H $\quad-3.542282 \quad 3.050773 \quad 0.713624$

C $-2.665192 \quad 2.716145-1.154005$

$\begin{array}{llll}\text { H } & -1.827529 & 2.033154 & -0.759931\end{array}$

$\begin{array}{lllll}\text { Pd } & 0.565325 & 0.873958 & -1.371768\end{array}$

$\begin{array}{lllll}0 & -2.994161 & 2.637156 & -2.307027\end{array}$

$\begin{array}{llll}\text { Pd } & -1.503894 & 0.003691 & -0.141101\end{array}$

$\begin{array}{llll}\text { I } & 0.096735 & -0.086999 & -3.844104\end{array}$

Fig._S105_LPd212 / electronic energy: -3113.76387097 a.u. / lowest freq: $16.81 \mathrm{~cm}-1$

C $-3.233671-2.497404-0.424947$

C $-3.463522-2.659314-1.798302$

H $-2.953260-1.998190-2.509331$

$\begin{array}{llll}\text { C } & -4.324657 & -3.655367 & -2.255809\end{array}$

H $-4.496799-3.774676-3.327950$

C $-4.956277-4.502081-1.344476$

H $\quad-5.626735-5.287242-1.702072$

$\begin{array}{llll}C & -4.727296 & -4.350707 & 0.024243\end{array}$

$\begin{array}{llll}\text { H } & -5.219551 & -5.014665 & 0.73882\end{array}$

$\begin{array}{llll}\text { C } & -3.870121 & -3.352963 & 0.485657\end{array}$

$\begin{array}{llll}\text { H } & -3.698871 & -3.239045 & 1.560277\end{array}$

C $-1.450696-1.736918 \quad 1.689555$

C $-1.781292-1.168064 \quad 2.925049$

$\begin{array}{llll}\text { H } & -2.436644 & -0.293304 & 2.972787\end{array}$

C $-1.290759-1.727762 \quad 4.105788$

H $\quad-1.555994 \quad-1.278869 \quad 5.066270$

$\begin{array}{llll}\text { C } & -0.466829 & -2.851598 & 4.061626\end{array}$

H $\quad-0.086354 \quad-3.287650 \quad 4.988663$

$\begin{array}{llll}\text { C } & -0.115592 & -3.410792 & 2.831273\end{array}$

H $0.540898-4.283400 \quad 2.788139$

$\begin{array}{llll}\text { C } & -0.602329 & -2.855329 & 1.650573\end{array}$

$\begin{array}{llll}\text { H } & -0.337973 & -3.305897 & 0.686819\end{array}$ 
$\begin{array}{llll}C & -3.288340 & 0.220908 & 0.530681\end{array}$ $\begin{array}{lllll}\text { C } & -4.678319 & 0.156687 & 0.374023\end{array}$

$\begin{array}{llll}\text { H } & -5.160456 & -0.801961 & 0.166338\end{array}$

$\begin{array}{llll}\text { C } & -5.443718 & 1.320156 & 0.440848\end{array}$

$\begin{array}{lllll}\text { H } & -6.527113 & 1.262781 & 0.316641\end{array}$

$\begin{array}{lllll}\text { C } & -4.833284 & 2.559543 & 0.631387\end{array}$

H $-5.445616 \quad 3.463386 \quad 0.642125$

$\begin{array}{llll}\text { C } & -3.449200 & 2.659654 & 0.806992\end{array}$

C $-2.685784 \quad 3.956144 \quad 1.030954$

$\begin{array}{llll}C & -1.339152 & 3.805593 & 0.328463\end{array}$

$\begin{array}{lllll}C & -0.658970 & 4.841591 & -0.317546\end{array}$

$\begin{array}{lllll}\text { H } & -1.140401 & 5.814344 & -0.435185\end{array}$

$\begin{array}{llll}\text { C } & 0.637929 & 4.656815 & -0.794827\end{array}$

$\begin{array}{llll}\text { H } & 1.153997 & 5.475076 & -1.300635\end{array}$

$\begin{array}{llll}\text { C } & 1.296305 & 3.445851 & -0.598367\end{array}$

$\begin{array}{lllll}\text { H } & 2.326887 & 3.332090 & -0.940149\end{array}$

$\begin{array}{llll}\text { C } & 0.642879 & 2.375173 & 0.026916\end{array}$

$\begin{array}{llll}\text { C } & -0.687668 & 2.571839 & 0.429659\end{array}$

C $-2.714738 \quad 1.474001 \quad 0.789394$

$\begin{array}{llll}\text { C } & -3.460049 & 5.170462 & 0.540328\end{array}$

H $\quad-2.899585 \quad 6.095896 \quad 0.727984$

$\begin{array}{lllll}\text { H } & -4.411729 & 5.271933 & 1.078451\end{array}$

$\begin{array}{llll}\text { H } & -3.680459 & 5.117199 & -0.535495\end{array}$

C $-2.416171 \quad 4.105170 \quad 2.541129$

H $\quad-1.892967 \quad 3.230224 \quad 2.954566$

H $-3.362313 \quad 4.216392 \quad 3.091023$

$\begin{array}{llll}\text { H } & -1.799658 & 4.994233 & 2.740928\end{array}$

$\begin{array}{llll}\text { C } 3.268441 & 1.233562 & 0.080667\end{array}$

$\begin{array}{llll}\text { C } & 4.083598 & 1.837543 & 1.046658\end{array}$

H $3.690896 \quad 2.062683 \quad 2.042028$

$\begin{array}{llll}\text { C } & 5.407871 & 2.152928 & 0.741812\end{array}$

H $\quad 6.040404 \quad 2.616371 \quad 1.502626$

$\begin{array}{llll}\text { C } 5.922260 & 1.877038 & -0.524587\end{array}$

$\begin{array}{lllll}\text { H } & 6.960756 & 2.123214 & -0.758478\end{array}$

C $5.111399 \quad 1.278796-1.490553$

H $5.510306 \quad 1.054244 \quad-2.482364$

C $3.792245 \quad 0.950964-1.188731$

$\begin{array}{lllll}\text { H } & 3.160104 & 0.462266 & -1.938086\end{array}$

C $1.425585 \quad 0.739078 \quad 2.259775$

C $1.006847 \quad 1.830311 \quad 3.037479$

H $\quad 0.661314 \quad 2.753485 \quad 2.566599$

$\begin{array}{llll}\text { C } & 1.053980 & 1.760219 & 4.428717\end{array}$

H $0.724803 \quad 2.617638 \quad 5.021068$

C $1.5333520 .612475 \quad 5.060536$

H $1.575827 \quad 0.564552 \quad 6.151398$

$\begin{array}{llll}\text { C } & 1.955024 & -0.472586 & 4.293250\end{array}$

$\begin{array}{llll}\text { H } & 2.328144 & -1.378581 & 4.776912\end{array}$

$\begin{array}{llll}\text { C } & 1.890607 & -0.416066 & 2.902923\end{array}$

$\begin{array}{llll}\text { H } & 2.211134 & -1.276088 & 2.306841\end{array}$

\begin{tabular}{lllll}
\hline & -1.349779 & 1.498717 & 0.969900
\end{tabular}

\begin{tabular}{lllll}
\hline & -2.139487 & -1.135302 & 0.109927
\end{tabular}

$\begin{array}{lllll}\text { P } & 1.521048 & 0.819354 & 0.432199\end{array}$

$\begin{array}{llll}\text { I } & 3.352000 & -2.694188 & 0.041817\end{array}$

$\begin{array}{llll}\text { Pd } & -0.951354 & -0.250793 & -1.602225\end{array}$

Pd $1.165973-1.166246-0.506535$

I $0.374605 \quad 0.788745 \quad-3.702100$

153

Fig._S105_LPdH(CO)PdL(+) / electronic energy: -4893.59579005 a.u. / lowest freq: $9.67 \mathrm{~cm}-1$

C $3.275432 \quad 2.757857-2.077960$

$\begin{array}{llll}C & 2.422543 & 3.778934 & -1.632281\end{array}$

H $\quad 1.854809 \quad 3.642447 \quad-0.706206$

$\begin{array}{llll}\text { C } 2.293332 & 4.960460 & -2.356318\end{array}$

H $1.629605 \quad 5.749747-1.993970$

C $2.999295 \quad 5.127645-3.549156$

H $2.892178 \quad 6.050855 \quad-4.123674$

C $3.837074 \quad 4.111763-4.007796$

H $\quad 4.390362 \quad 4.237611 \quad-4.941551$

$\begin{array}{llll}\text { C } 3.980797 & 2.932320 & -3.275420\end{array}$

H $4.651018 \quad 2.150080 \quad-3.641816$

C $4.5544560 .167914-1.971968$

$\begin{array}{llll}\text { C } 3.997112 & -0.659870 & -2.957441\end{array}$

H $2.913253-0.647283-3.124201$

C $4.810969-1.492381-3.722810$

H $4.365941-2.126790-4.493153$

C $6.187460-1.524345-3.495061$

$\begin{array}{llll}\text { H } & 6.824898 & -2.185918 & -4.086856\end{array}$

$\begin{array}{llll}\text { C } & 6.746755 & -0.715772 & -2.505448\end{array}$

H $7.823629-0.739313-2.32148$

$\begin{array}{llll}\text { C } & 5.937141 & 0.132704 & -1.750318\end{array}$

$\begin{array}{llll}\text { H } & 6.391065 & 0.771241 & -0.986728\end{array}$

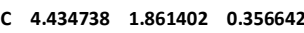

C $4.859536 \quad 3.1825500 .544636$

H $4.6190763 .947713-0.196794$

C $5.5812243 .530047 \quad 1.685970$

H $5.898644 \quad 4.565393 \quad 1.827571$

C $5.913235 \quad 2.568130 \quad 2.641303$

H $\quad 6.490516 \quad 2.861616 \quad 3.520440$

C $\quad 5.534569 \quad 1.233187 \quad 2.472755$ 
$\begin{array}{llll}C & 4.788698 & 0.924202 & 1.333081\end{array}$ C $5.939651 \quad 0.078766 \quad 3.381462$

C $6.343981 \quad 0.552561 \quad 4.769597$

H $7.201743 \quad 1.2360804 .717487$

H $6.660252 \quad-0.291076 \quad 5.397314$

H $5.524721 \quad 1.072930 \quad 5.286578$

C $7.131969 \quad-0.644508 \quad 2.724020$

H $6.888222-1.007893 \quad 1.714313$

H 7.437764 -1.511682 3.327573

H $7.994188 \quad 0.0328592 .636770$

$\begin{array}{llll}\text { C } 4.764315 & -0.891137 & 3.421850\end{array}$

$\begin{array}{llll}\text { C } & 4.388779 & -1.652638 & 4.530737\end{array}$

H $4.923946-1.535877 \quad 5.47528$

$\begin{array}{llll}\text { C } 3.341839 & -2.571413 \quad 4.445113\end{array}$

H 3.068696 -3.165011 5.319979

C $2.636465-2.735655 \quad 3.255368$

$\begin{array}{llll}\text { H } & 1.808849 & -3.447139 & 3.213266\end{array}$

C $2.970235-1.977502 \quad 2.123822$

C $4.040450-1.083234 \quad 2.240586$

$\begin{array}{llll}\text { C } 2.934229 & -3.136097 & -0.552615\end{array}$

$\begin{array}{llll}\text { C } & 4.241027 & -3.571029 & -0.304706\end{array}$

$\begin{array}{lllll}\text { H } & 4.760088 & -3.273624 & 0.611264\end{array}$

$\begin{array}{llll}\text { C } & 4.888452 & -4.399657 & -1.223505\end{array}$

$\begin{array}{llll}\text { H } & 5.909925 & -4.731438 & -1.022239\end{array}$

$\begin{array}{llll}\text { C } 4.235914 & -4.809073 & -2.385126\end{array}$

$\begin{array}{lllll}\text { H } & 4.744028 & -5.463920 & -3.097134\end{array}$

$\begin{array}{llll}\text { C } & 2.933307 & -4.373740 & -2.640315\end{array}$

$\begin{array}{llll}\text { H } & 2.416917 & -4.684653 & -3.55217\end{array}$

$\begin{array}{lllll}\text { C } & 2.291830 & -3.530511 & -1.738098\end{array}$

$\begin{array}{llll}\text { H } & 1.275285 & -3.178481 & -1.949998\end{array}$

C $0.546416 \quad-2.984998 \quad 1.062366$

$\begin{array}{llll}\text { C } & 0.477498 & -4.379468 & 0.952554\end{array}$

$\begin{array}{lllll}\text { H } & 1.318327 & -4.941130 & 0.535444\end{array}$

$\begin{array}{llll}\text { C } & -0.664293 & -5.062506 & 1.374880\end{array}$

$\begin{array}{llll}\text { H } & -0.710946 & -6.149713 & 1.275783\end{array}$

$\begin{array}{llll}\text { C } & -1.736808 & -4.363544 & 1.92823\end{array}$

H $\quad-2.627318-4.901238 \quad 2.262805$

$\begin{array}{llll}\text { C } & -1.669391 & -2.974247 & 2.055884\end{array}$

$\begin{array}{llll}\text { H } & -2.504999 & -2.420831 & 2.493817\end{array}$

$\begin{array}{llll}\text { C } & -0.538998 & -2.288518 & 1.616455\end{array}$

H $-0.497370-1.194554 \quad 1.700266$

C $-0.882860 \quad 3.153409 \quad 1.133524$

C $-0.900081 \quad 4.545640 \quad 0.996033$

H $\quad-1.777103 \quad 5.047486 \quad 0.577791$

C $\quad 0.203601 \quad 5.304329 \quad 1.395742$

H $0.181732 \quad 6.390352 \quad 1.276850$

C $1.323383 \quad 4.684273 \quad 1.948296$

H $2.184396 \quad 5.280967 \quad 2.260498$

$\begin{array}{llll}\text { C } & 1.345870 & 3.294515 & 2.093857\end{array}$

$\begin{array}{lllll}\text { H } & 2.218944 & 2.798662 & 2.527308\end{array}$

$\begin{array}{llll}\text { C } & 0.256841 & 2.534481 & 1.675988\end{array}$

H $\quad 0.287564 \quad 1.441978 \quad 1.773833$

$\begin{array}{llll}\text { C } & -3.492660 & 3.154719 & -0.166522\end{array}$

C $-3.240657 \quad 3.578361 \quad-1.481037$

H $-2.3298703 .254387 \quad-1.994034$

$\begin{array}{lllll}C & -4.141598 & 4.414009 & -2.136932\end{array}$

H $\quad-3.930870 \quad 4.739149 \quad-3.158767$

$\begin{array}{lllll}H & -3.930870 & 4.739149 & -3.158767 \\ \text { C } & -5.315209 & 4.818004 & -1.498626\end{array}$

$\begin{array}{llll}\text { H } & -6.026099 & 5.465992 & -2.016933\end{array}$

$\begin{array}{llll}\text { C } & -5.580226 & 4.387589 & -0.199044\end{array}$

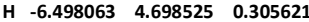

$\begin{array}{llll}\text { C } & -4.673731 & 3.563549 & 0.468261\end{array}$

$\begin{array}{llll}\text { H } & -4.892541 & 3.245029 & 1.491374\end{array}$

$\begin{array}{llll}\text { C } & -3.031908 & 1.624428 & 2.227750\end{array}$

C $-2.675913 \quad 2.186611 \quad 3.460489$

H $-1.884186 \quad 2.938102 \quad 3.509789$

$\begin{array}{llll}\text { C } & -3.326238 & 1.788669 & 4.62\end{array}$

H $-3.034236 \quad 2.226325 \quad 5.584042$

$\begin{array}{llll}\text { C } & -4.358389 & 0.849997 & 4.581496\end{array}$

H $-4.868726 \quad 0.567695 \quad 5.504816$

C $-4.758289 \quad 0.283919 \quad 3.368355$

$\begin{array}{llll}\text { C } & -4.059767 & 0.673198 & 2.221737\end{array}$

$\begin{array}{llll}\text { C } & -5.945556 & -0.655325 & 3.185787\end{array}$

$\begin{array}{llll}\text { C } & -7.132593 & 0.180307 & 2.668035\end{array}$

$\begin{array}{lllll}\text { H } & -6.896920 & 0.692064 & 1.722686\end{array}$

$\begin{array}{cccc}\text { H } & -7.413599 & 0.948215 & 3.403695\end{array}$

H $\quad-8.008705 \quad-0.461224 \quad 2.492898$

C $-6.343671 \quad-1.337888 \quad 4.485483$

H $-7.213347-1.9910$

$\begin{array}{llll}H & -6.638945 & -0.599024 & 5.242233\end{array}$

H $\quad-5.528090 \quad-1.946270 \quad 4.902835$

$\begin{array}{llll}\text { C } & -5.559909 & -1.656863 & 2.103762\end{array}$

$\begin{array}{llll}\text { C } & -5.937099 & -3.002564 & 2.076539\end{array}$

H $\quad-6.533021 \quad-3.415659 \quad 2.893113$

$\begin{array}{llll}\text { C } & -5.569044 & -3.826059 & 1.011268\end{array}$

H $\quad-5.881991 \quad-4.872335 \quad 1.002797$

$\begin{array}{llll}\text { C } & -4.792095 & -3.331919 & -0.035261\end{array}$

$\begin{array}{llll}\text { H } & -4.486066 & -3.997904 & -0.845954\end{array}$ 
$\begin{array}{llll}C & -4.379891 & -1.992827 & -0.034795\end{array}$ C $-4.796558-1.187773 \quad 1.032299$

$\begin{array}{llll}\text { C } & -4.193419 & -0.181242 & -2.302461\end{array}$

$\begin{array}{llll}\text { C } & -5.544689 & 0.103596 & -2.074242\end{array}$

$\begin{array}{llll}\text { H } & -6.074983 & -0.364759 & -1.240352\end{array}$

$\begin{array}{lllll}\text { C } & -6.228849 & 0.981813 & -2.916512\end{array}$

$\begin{array}{llll}\text { H } & -7.282512 & 1.200124 & -2.726011\end{array}$

$\begin{array}{llll}\text { C } & -5.576151 & 1.572814 & -3.997004\end{array}$

$\begin{array}{lllll}\text { H } & -6.116223 & 2.257461 & -4.655672\end{array}$

$\begin{array}{lllll}\text { C } & -4.227489 & 1.294356 & -4.230158\end{array}$

$\begin{array}{lllll}\text { H } & -3.707754 & 1.759272 & -5.071563\end{array}$

$\begin{array}{llll}\text { C } & -3.536497 & 0.433406 & -3.382182\end{array}$

H $-2.4742960 .229420 \quad-3.561232$

$\begin{array}{llll}\text { C } & -2.800091 & -2.708193 & -2.295873\end{array}$

$\begin{array}{llll}\text { C } & -1.709263 & -3.512179 & -1.937591\end{array}$

$\begin{array}{llll}\text { H } & -1.098811 & -3.236783 & -1.070214\end{array}$

$\begin{array}{llll}C & -1.404364 & -4.657762 & -2.671134\end{array}$

$\begin{array}{llll}\text { H } & -0.558865 & -5.284766 & -2.374785\end{array}$

$\begin{array}{llll}\text { C } & -2.174743 & -4.998429 & -3.783946\end{array}$

H $-1.932129 \quad-5.891072 \quad-4.365495$

$\begin{array}{llll}\text { C } & -3.254443 & -4.195682 & -4.154561\end{array}$

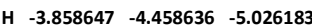

$\begin{array}{llll}C & -3.572764 & -3.059050 & -3.411568\end{array}$

H $-4.431301-2.445935-3.70066$

C $0.114756 \quad 1.371381-1.434042$

$\begin{array}{lllll}\text { O } & 4.357836 & -0.360547 & 1.121236\end{array}$

$\begin{array}{lllll}0 & -4.380048 & 0.120398 & 1.008452\end{array}$

$\begin{array}{lllll}0 & -0.009995 & 2.246006 & -2.207135\end{array}$

$\begin{array}{lllll}\text { P } & 3.419582 & 1.259546 & -1.042325\end{array}$

$\begin{array}{llll}\text { P } & 2.016748 & -2.015878 & 0.558551\end{array}$

$\begin{array}{lllll}P & -2.262722 & 2.059637 & 0.626401\end{array}$

$\begin{array}{lllll}P & -3.196703 & -1.276637 & -1.229479\end{array}$

$\begin{array}{llll}\text { Pd } & 1.372258 & 0.033998 & -0.653022\end{array}$

$\begin{array}{llll}\text { Pd } & -1.324035 & 0.189531 & -0.619058\end{array}$

$\begin{array}{llll}\text { H } & -0.120101 & -0.979249 & -0.976158\end{array}$

77

Fig._S105_LPdHI / electronic energy: -2688.42445650 a.u. / lowest freq: $20.09 \mathrm{~cm}-1$

Pd $-0.018417-0.953805-1.185825$

$\begin{array}{llll}\text { P } & 1.640194 & -0.379894 & 0.557841\end{array}$

$\begin{array}{lllll}P & -2.029701 & -0.591427 & -0.167157\end{array}$

\begin{tabular}{llll}
\hline & -0.319894 & 1.667105 & 0.524623
\end{tabular}

C $0.878418 \quad 2.220330 \quad 0.134290$

C $1.984929 \quad 1.362814 \quad 0.126191$

C $3.199576 \quad 1.884182-0.331933$

H $4.082477 \quad 1.243269-0.390369$

C $3.277203 \quad 3.213687-0.747367$

H $4.227579 \quad 3.607639 \quad-1.113552$

C $2.156311 \quad 4.044950-0.703849$

H $2.246060 \quad 5.084053-1.027384$

$\begin{array}{llll}\text { C } & 0.925978 & 3.560764 & -0.249835\end{array}$

$\begin{array}{llll}\text { C } & -0.351254 & 4.379150 & -0.084634\end{array}$

$\begin{array}{lllll}C & -1.510456 & 3.474700 & -0.493586\end{array}$

C $-2.654899 \quad 3.886233-1.181757$

H $-2.758454 \quad 4.928559-1.490624$

C $-3.671359 \quad 2.978682-1.481715$

$\begin{array}{lllll}\text { H } & -4.560303 & 3.318675 & -2.017087\end{array}$

$\begin{array}{llll}\text { C } & -3.555298 & 1.635387 & -1.127360\end{array}$

H $-4.3423800 .932994 \quad-1.410366$

$\begin{array}{llll}\text { C }-2.418192 & 1.180124 & -0.447562\end{array}$

$\begin{array}{llll}\text { C } & -1.433783 & 2.127050 & -0.132506\end{array}$

C $-0.508082 \quad 4.720390 \quad 1.410086$

$\begin{array}{llll}\text { H } & -0.540299 & 3.817618 & 2.038258\end{array}$

$\begin{array}{llll}\text { H } & -1.437663 & 5.282030 & 1.584225\end{array}$

$\begin{array}{lllll}\text { H } & 0.333506 & 5.338573 & 1.756037\end{array}$

C $-0.316646 \quad 5.667790 \quad-0.891958$

H $-0.212183 \quad 5.479907 \quad-1.970255$

H $\quad 0.518950 \quad 6.306619 \quad-0.575885$

$\begin{array}{llll}\text { H } & -1.231632 & 6.254662 & -0.735587\end{array}$

$\begin{array}{llll}\text { C } & 1.288449 & -0.306622 & 2.362047\end{array}$

C $1.022884-1.518874 \quad 3.016762$

H $0.974375 \quad-2.449612 \quad 2.441191$

$\begin{array}{llll}\text { C } & 0.838360 & -1.552040 & 4.396747\end{array}$

$\begin{array}{llll}\text { H } & 0.637838 & -2.504972 & 4.893151\end{array}$

C $0.899744 \quad-0.372837 \quad 5.141292$

$\begin{array}{llll}\text { H } & 0.753017 & -0.399249 & 6.223944\end{array}$

C $1.143518 \quad 0.838482 \quad 4.496214$

H $1.191885 \quad 1.7670605 .070708$

$\begin{array}{llll}\text { C } & 1.338513 & 0.873674 & 3.114707\end{array}$

H $1.549326 \quad 1.831082 \quad 2.630250$

$\begin{array}{llll}\text { C } 3.265648 & -1.221351 & 0.594934\end{array}$

$\begin{array}{llll}\text { C } & 4.326918 & -0.721659 & 1.366293\end{array}$

H $4.2048630 .211414 \quad 1.925293$

C $5.535078 \quad-1.411473 \quad 1.430884$

H $6.357296-1.010974 \quad 2.028781$

$\begin{array}{llll}\text { C } 5.690745 & -2.615986 & 0.741103\end{array}$

$\begin{array}{llll}\text { H } & 6.638138 & -3.157827 & 0.796008\end{array}$

$\begin{array}{llll}\text { C } 4.634561 & -3.130142 & -0.009154\end{array}$

$\begin{array}{llll}\text { H } & 4.748533 & -4.077250 & -0.541658\end{array}$ 
$\begin{array}{llll}\text { C } & 3.426257 & -2.435874 & -0.082910\end{array}$

$\begin{array}{llll}\text { H } & 2.596752 & -2.840594 & -0.669972\end{array}$

$\begin{array}{llll}\text { C } & -2.195391 & -0.868655 & 1.633838\end{array}$

$\begin{array}{llll}C & -2.298663 & -2.199294 & 2.070151\end{array}$

$\begin{array}{llll}\text { H } & -2.241660 & -3.017254 & 1.344795\end{array}$

$\begin{array}{llll}\text { C } & -2.498811 & -2.486282 & 3.417179\end{array}$

$\begin{array}{llll}\text { H } & -2.591905 & -3.525571 & 3.741747\end{array}$

$\begin{array}{llll}\text { C } & -2.579122 & -1.448767 & 4.347731\end{array}$

H $-2.734496-1.672484 \quad 5.406124$

$\begin{array}{llll}\text { C } & -2.448923 & -0.126935 & 3.925000\end{array}$

$\begin{array}{llll}\text { H } & -2.500602 & 0.688533 & 4.650884\end{array}$

$\begin{array}{llll}\text { C } & -2.259293 & 0.166668 & 2.573843\end{array}$

$\begin{array}{llll}\text { H } & -2.181801 & 1.210329 & 2.257864\end{array}$

C $-3.509341-1.481218-0.781514$

$\begin{array}{llll}\text { C } & -4.730001 & -1.337810 & -0.099103\end{array}$

$\begin{array}{lllll}\text { H } & -4.790938 & -0.698558 & 0.787004\end{array}$

$\begin{array}{llll}C & -5.869956 & -1.998612 & -0.547253\end{array}$

$\begin{array}{llll}\text { H } & -6.814091 & -1.872074 & -0.012313\end{array}$

$\begin{array}{llll}\text { C } & -5.805272 & -2.821662 & -1.673904\end{array}$

$\begin{array}{llll}\text { H } & -6.699435 & -3.344827 & -2.021329\end{array}$

$\begin{array}{lllll}\text { C } & -4.596805 & -2.978491 & -2.349161\end{array}$

$\begin{array}{llll}\text { H } & -4.536738 & -3.627377 & -3.225887\end{array}$

$\begin{array}{llll}\text { C } & -3.453577 & -2.311456 & -1.905597\end{array}$

$\begin{array}{llll}\text { H } & -2.505658 & -2.442993 & -2.434768\end{array}$

H $-1.001855 \quad-1.106494-2.399984$

$\begin{array}{llll}\text { I } & 1.865334 & -0.974736 & -3.186951\end{array}$

Fig._S105_I2PdH(-) / electronic energy: - 724.532836984 a.u. / lowest freq: $28.44 \mathrm{~cm}-1$

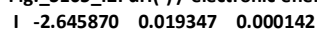

$\begin{array}{llll}\text { Pd } & -0.000004 & -0.075745 & -0.000307\end{array}$

$\begin{array}{llll}\text { H } & -0.000242 & 1.433399 & -0.000948\end{array}$

\begin{tabular}{lllll}
\hline & 2.645878 & 0.019349 & 0.000142
\end{tabular}

88

Fig._S105_INT1C' / electronic energy: -3306.75231981 a.u. / lowest freq: $13.69 \mathrm{~cm}-1$

I $4.376414 \quad 1.027738 \quad 0.855162$

$\begin{array}{lllll}\text { Pd } & 0.208782 & 0.813228 & -0.287784\end{array}$

$\begin{array}{llll}\text { C } & 0.653935 & 2.727728 & -0.676130\end{array}$

$\begin{array}{lllll}\text { C } & 0.978367 & 3.468677 & 0.603127\end{array}$

C $1.677262 \quad 4.788071 \quad 0.364578$

H $1.063823 \quad 5.454150 \quad-0.258567$

$\begin{array}{llll}\mathrm{O} & 0.747413 & 3.192858 & -1.775178\end{array}$

H $1.874945 \quad 5.299157 \quad 1.315970$

$\begin{array}{llll}\text { H } & 2.639652 & 4.645659 & -0.146654\end{array}$

H $\quad 0.013661 \quad 3.606522 \quad 1.123380$

H $\quad 1.5585592 .797101 \quad 1.258109$

H $2.878063 \quad 1.569474-1.512125$

Pd $2.821356 \quad 0.113807-1.08847$

$\begin{array}{llll}\text { I } & 1.180036 & -0.253130 & -3.210279\end{array}$

C $2.155987-2.27$

C $2.681726-2.541887-0.588520$

$\begin{array}{llll}\text { H } & 2.037965 & -2.461197 & -1.469488\end{array}$

$\begin{array}{llll}\text { C } 4.005716 & -2.957010 & -0.744899\end{array}$

$\begin{array}{llll}\text { H } & 4.392164 & -3.149476 & -1.74883\end{array}$

$\begin{array}{llll}\text { C } 4.819568 & -3.134608 & 0.373351\end{array}$

$\begin{array}{llll}\text { H } & 5.858009 & -3.451461 & 0.254148\end{array}$

$\begin{array}{llll}\text { C } 4.293812 & -2.915565 \quad 1.646121\end{array}$

$\begin{array}{llll}\text { H } & 4.917586 & -3.071954 & 2.529530\end{array}$

$\begin{array}{llll}\text { C } 2.974907 & -2.489699 & 1.808605\end{array}$

$\begin{array}{llll}\text { H } & 2.594147 & -2.318172 & 2.817465\end{array}$

$\begin{array}{llll}\text { C } & 0.101078 & -1.471516 & 2.559047\end{array}$

$\begin{array}{llll}\text { C } & -0.899881 & -2.216270 & 3.194495\end{array}$

$\begin{array}{llll}\text { H } & -1.506010 & -2.925799 & 2.623383\end{array}$

$\begin{array}{llll}\text { C } & -1.121779 & -2.067778 & 4.564667\end{array}$

H $-1.907885-2.651905 \quad 5.049699$

C $-0.339146-1.190551 \quad 5.314040$

$\begin{array}{llll}\text { H } & -0.508963 & -1.086533 & 6.388630\end{array}$

$\begin{array}{llll}\text { C } & 0.652124 & -0.434935 & 4.684933\end{array}$

$\begin{array}{llll}\text { H } & 1.261500 & 0.264404 & 5.262830\end{array}$

$\begin{array}{llll}\text { C } & 0.856982 & -0.558137 & 3.313733\end{array}$

H $\quad \begin{array}{llll}1.626542 & 0.048721 & 2.821430\end{array}$

$\begin{array}{llll}\text { C } & -0.562331 & -2.971039 & 0.155188\end{array}$

$\begin{array}{llll}\text { C } & -0.088342 & -4.266443 & -0.089072\end{array}$

$\begin{array}{lllll}\text { H } & 0.935621 & -4.5334443 & 0.182509\end{array}$

$\begin{array}{llll}\text { C } & -0.911018 & -5.211115 & -0.698225\end{array}$

H $-0.529885-6.216061-0.891542$

$\begin{array}{llll}C & -2.216646 & -4.883413 & -1.066936\end{array}$

$\begin{array}{llll}\text { H } & -2.841593 & -5.638203 & -1.54868\end{array}$

$\begin{array}{llll}\text { C } & -2.736805 & -3.611774 & -0.813024\end{array}$

$\begin{array}{llll}\text { C } & -4.175928 & -3.189637 & -1.078589\end{array}$

$\begin{array}{llll}\text { C } & -4.163364 & -1.708373 & -1.437821\end{array}$

$\begin{array}{llll}\text { C } & -5.064311 & -1.094614 & -2.312145\end{array}$

$\begin{array}{llll}\text { H } & -5.784088 & -1.703091 & -2.863452\end{array}$

$\begin{array}{llll}\text { C } & -5.074682 & 0.290668 & -2.472119\end{array}$

$\begin{array}{llll}\text { H } & -5.795209 & 0.753876 & -3.149261\end{array}$

$\begin{array}{llll}\text { C } & -4.185658 & 1.093881 & -1.760816\end{array}$

$\begin{array}{lllll}\text { H } & -4.228736 & 2.177946 & -1.879764\end{array}$

$\begin{array}{llll}\text { C } & -3.244648 & 0.515764 & -0.899976\end{array}$

$\begin{array}{llll}\text { C } & -3.255303 & -0.880077 & -0.772538\end{array}$ 
$\begin{array}{llll}C & -1.886472 & -2.687458 & -0.200358\end{array}$ $\begin{array}{llll}C & -4.834237 & -4.037634 & -2.157442\end{array}$

$\begin{array}{llll}\text { H } & -5.880376 & -3.740665 & -2.309123\end{array}$

$\begin{array}{llll}\text { H } & -4.856110 & -5.095953 & -1.866045\end{array}$

$\begin{array}{lllll}\text { H } & -4.312867 & -3.959568 & -3.122274\end{array}$

\begin{tabular}{lllll}
\hline C & -4.963450 & -3.345075 & 0.237884
\end{tabular}

H $-4.515459-2.761170 \quad 1.056144$

$\begin{array}{llll}\text { H } & -4.984537 & -4.398940 & 0.552510\end{array}$

H $-6.002016-3.004760 \quad 0.111608$

$\begin{array}{lllll}\text { C } & -2.440954 & 3.197785 & -0.260336\end{array}$

$\begin{array}{llll}\text { C } & -2.912452 & 4.080320 & 0.721670\end{array}$

$\begin{array}{llll}H & -3.105793 & 3.727064 & 1.737902\end{array}$

C $-3.134260 \quad 5.422934 \quad 0.412104$

$\begin{array}{llll}\text { H } & -3.497918 & 6.100945 & 1.187907\end{array}$

$\begin{array}{lllll}\text { C } & -2.896807 & 5.896865 & -0.877167\end{array}$

$\begin{array}{llll}\text { H } & -3.069516 & 6.949048 & -1.115528\end{array}$

$\begin{array}{llll}C & -2.438855 & 5.021717 & -1.863763\end{array}$

H $-2.252291 \quad 5.382950-2.877801$

$\begin{array}{lllll}C & -2.206709 & 3.683787 & -1.557254\end{array}$

$\begin{array}{lllll}\text { H } & -1.832332 & 3.008670 & -2.332115\end{array}$

$\begin{array}{llll}\text { C } & -2.597494 & 1.216017 & 1.815264\end{array}$

$\begin{array}{llll}\text { C } & -3.885496 & 0.756681 & 2.122831\end{array}$

$\begin{array}{llll}\text { H } & -4.577056 & 0.472371 & 1.324606\end{array}$

$\begin{array}{llll}\text { C } & -4.298866 & 0.667775 & 3.451633\end{array}$

H $\begin{array}{cccc}-5.303159 & 0.303771 & 3.681628\end{array}$

$\begin{array}{llll}\text { C } & -3.441126 & 1.054044 & 4.481728\end{array}$

H $\quad-3.770652 \quad 0.991071 \quad 5.521719$

$\begin{array}{llll}C & -2.158333 & 1.512993 & 4.181814\end{array}$

$\begin{array}{lllll}\text { H } & -1.479799 & 1.811079 & 4.984539\end{array}$

$\begin{array}{llll}\text { C } & -1.732580 & 1.578778 & 2.856552\end{array}$

H $\quad-0.718275 \quad 1.921682 \quad 2.623885$

\begin{tabular}{lllll}
\hline & -2.329129 & -1.420117 & 0.080086
\end{tabular}

$\begin{array}{lllll}\text { P } & 0.455584 & -1.583611 & 0.771561\end{array}$

$\begin{array}{lllll}P & -2.023406 & 1.451019 & 0.094980\end{array}$

88

Fig._S105_TSC' / electronic energy: -3306.73476668 a.u. / lowest freq: $-634.40 \mathrm{~cm}-1$

I $4.2215190 .863557 \quad 1.042660$

$\begin{array}{llll}\text { Pd } & 0.348491 & 0.660638 & -0.243069\end{array}$

$\begin{array}{llll}\text { C } & 1.007163 & 2.838952 & -0.662744\end{array}$

C $1.185561 \quad 3.523621 \quad 0.664893$

C $1.580602 \quad 4.978554 \quad 0.548786$

H $0.8424525 .550993-0.029472$

$\begin{array}{llll}\text { O } & 0.861522 & 3.409373 & -1.712355\end{array}$

H $\quad 1.663833 \quad 5.440185 \quad 1.541501$

H $2.552074 \quad 5.089951 \quad 0.046448$

$\begin{array}{lllll}\text { H } & 0.218094 & 3.418093 & 1.189281\end{array}$

H $\quad \begin{array}{llll}1.897722 & 2.935470 & 1.265977\end{array}$

H $1.745464 \quad 1.684263-0.812154$

Pd $2.825876 \quad 0.319390 \quad-1.155278$

I $1.294568 \quad-0.172592 \quad-3.314534$

$\begin{array}{llll}\text { C } & 2.055685 & -2.447729 & 0.665263\end{array}$

$\begin{array}{llll}C & 2.692737 & -2.650804 & -0.570328\end{array}$

$\begin{array}{llll}\text { H } & 2.196975 & -2.338378 & -1.495552\end{array}$

C $3.942944-3.259074-0.635834$

H $4.420865-3.407363 \quad-1.607382$

$\begin{array}{llll}\text { C } 4.582818 & -3.671867 & 0.535663\end{array}$

$\begin{array}{llll}\text { H } & 5.571212 & -4.134985 & 0.488491\end{array}$

C $3.948146-3.497521 \quad 1.762157$

H $4.433375 \quad-3.827916 \quad 2.683685$

$\begin{array}{llll}\text { C } & 2.686555 & -2.898637 & 1.829030\end{array}$

H $\quad 2.207718 \quad-2.783730 \quad 2.803402$

$\begin{array}{llll}\text { C } & -0.011168 & -1.517362 & 2.439470\end{array}$

$\begin{array}{llll}\text { C } & -1.085095 & -2.200097 & 3.022259\end{array}$

$\begin{array}{llll}\text { H } & -1.735360 & -2.833612 & 2.412182\end{array}$

$\begin{array}{llll}\text { C } & -1.322208 & -2.091510 & 4.393691\end{array}$

H $\quad-2.165437 \quad-2.625771 \quad 4.838555$

$\begin{array}{llll}\text { C } & -0.482672 & -1.318676 & 5.194475\end{array}$

H $-0.665491-1.247010 \quad 6.26960$

$\begin{array}{llll}C & 0.582651 & -0.625159 & 4.616908\end{array}$

$\begin{array}{llll}\text { H } & 1.238241 & -0.007473 & 5.235749\end{array}$

$\begin{array}{llll}\text { C } & 0.805531 & -0.707113 & 3.245945\end{array}$

$\begin{array}{llll}\text { H } & 1.637660 & -0.153284 & 2.793577\end{array}$

$\begin{array}{llll}\text { C } & -0.652824 & -2.953084 & -0.013314\end{array}$

$\begin{array}{llll}\text { C }-0.207433 & -4.237890 & -0.352100\end{array}$

$\begin{array}{lllll}\text { H } & 0.820205 & -4.537663 & -0.136768\end{array}$

$\begin{array}{llll}\text { C } & -1.068820 & -5.133872 & -0.981815\end{array}$

H $\quad-0.709625-6.130590-1.246454$

C $-2.382047-4.769700 \quad-1.284084$

$\begin{array}{llll}\text { H } & -3.034736 & -5.487007 & -1.786099\end{array}$

$\begin{array}{llll}\text { C } & -2.871175 & -3.507565 & -0.938884\end{array}$

$\begin{array}{lllll}\text { C } & -4.306388 & -3.034731 & -1.136831\end{array}$

$\begin{array}{llll}C & -4.254046 & -1.540733 & -1.436256\end{array}$

$\begin{array}{llll}\text { C } & -5.141216 & -0.855914 & -2.270391\end{array}$

$\begin{array}{llll}\text { H } & -5.899569 & -1.408596 & -2.828694\end{array}$

$\begin{array}{llll}\text { C } & -5.086236 & 0.533686 & -2.380906\end{array}$

$\begin{array}{llll}H & -5.798192 & 1.054707 & -3.024359\end{array}$

C $-4.139967 \quad 1.269222 \quad-1.669482$

$\begin{array}{llll}\text { H } & -4.131199 & 2.356695 & -1.758027\end{array}$ 
$\begin{array}{llll}C & -3.209599 & 0.617345 & -0.850180\end{array}$

$\begin{array}{llll}\text { C } & -3.301587 & -0.775493 & -0.759027\end{array}$

$\begin{array}{llll}\text { C } & -1.983620 & -2.637225 & -0.302073\end{array}$

$\begin{array}{llll}\text { C } & -5.022194 & -3.815217 & -2.229420\end{array}$

$\begin{array}{lllll}\text { H } & -6.062592 & -3.480410 & -2.335488\end{array}$

$\begin{array}{llll}\text { H } & -5.066878 & -4.884427 & -1.983913\end{array}$

$\begin{array}{llll}\text { H } & -4.527699 & -3.709667 & -3.205819\end{array}$

$\begin{array}{llll}\text { C } & -5.057462 & -3.220603 & 0.196644\end{array}$

H $-4.576746-2.670486 \quad 1.019817$

$\begin{array}{llll}H & -5.090201 & -4.283646 & 0.477493\end{array}$

$\begin{array}{llll}\text { H } & -6.092407 & -2.857391 & 0.111467\end{array}$

$\begin{array}{llll}\text { C } & -2.209425 & 3.203514 & -0.207461\end{array}$

C $-2.616829 \quad 4.117433 \quad 0.774892$

H $-2.781986 \quad 3.788273 \quad 1.804105$

$\begin{array}{llll}\text { C } & -2.819794 & 5.458820 & 0.447891\end{array}$

$\begin{array}{llll}\text { H } & -3.136839 & 6.159662 & 1.223887\end{array}$

$\begin{array}{llll}C & -2.627332 & 5.901077 & -0.860285\end{array}$

H $-2.789616 \quad 6.951408-1.114045$

$\begin{array}{lllll}\text { C } & -2.224865 & 4.997115 & -1.844646\end{array}$

$\begin{array}{llll}\text { H } & -2.068414 & 5.333969 & -2.87212\end{array}$

$\begin{array}{llll}\text { C } & -2.010267 & 3.660606 & -1.519893\end{array}$

H $-1.6842252 .962380-2.296100$

$\begin{array}{llll}\text { C } & -2.497521 & 1.236580 & 1.862504\end{array}$

$\begin{array}{llll}\text { C } & -3.812993 & 0.858958 & 2.166210\end{array}$

$\begin{array}{lllll}\text { H } & -4.516247 & 0.610085 & 1.366452\end{array}$

C $-4.240729 \quad 0.810950 \quad 3.492570$

H $\quad-5.267624 \quad 0.513311 \quad 3.718185$

$\begin{array}{llll}C & -3.368017 & 1.153528 & 4.525479\end{array}$

H $-3.708273 \quad 1.1231115 .563475$

$\begin{array}{llll}C & -2.056128 & 1.524564 & 4.230400\end{array}$

H $-1.363046 \quad 1.781547 \quad 5.035046$

$\begin{array}{llll}\text { C } & -1.618375 & 1.551440 & 2.907693\end{array}$

H $-0.581795 \quad 1.824874 \quad 2.681586$

$\begin{array}{lllll}\text { O } & -2.396466 & -1.385241 & 0.068642\end{array}$

$\begin{array}{llll}P & 0.406657 & -1.622624 & 0.665107\end{array}$

$\begin{array}{lllll}P & -1.898644 & 1.430932 & 0.144506\end{array}$

Fig. S105 INT2C' / electronic energy: -3306.75585064 a.u. / lowest freq: $9.86 \mathrm{~cm}-1$

I $3.969796 \quad 0.116813 \quad 1.042620$

$\begin{array}{llll}\text { Pd } & 0.413414 & 0.410542 & -0.220751\end{array}$

$\begin{array}{llll}\text { C } 2.327160 & 2.915909 & -1.021185\end{array}$

C $2.470835 \quad 3.849510 \quad 0.131099$

C $3.436732 \quad 4.983418-0.104823$

H $3.138666 \quad 5.592999 \quad-0.969656$

$\begin{array}{lllll}\text { O } & 2.861910 & 3.010969 & -2.093492\end{array}$

H $3.492033 \quad 5.645952 \quad 0.768583$

$\begin{array}{cccc}\text { H } & 4.450175 & 4.607988 & -0.304434\end{array}$

H $\quad \begin{array}{llll}1.451144 & 4.206008 & 0.36875\end{array}$

$\begin{array}{llll}H & 2.745309 & 3.229588 & 1.003421\end{array}$

$\begin{array}{llll}H & 1.615934 & 2.037687 & -0.815360\end{array}$

Pd $2.585109-0.572969-1.157021$

I $0.845544 \quad-0.677882 \quad-3.211942$

C $1.485014-2.828205 \quad 0.99556$

$\begin{array}{llll}\text { C } & 2.187821 & -3.340290 & -0.109044\end{array}$

H $1.886717-3.062832-1.125191$

C $3.263803 \quad-4.2028710 .075866$

$\begin{array}{llll}\text { H } & 3.793275 & -4.597669 & -0.794381\end{array}$

$\begin{array}{llll}\text { C } & 3.671761 & -4.548589 & 1.366601\end{array}$

H $4.528448 \quad-5.210947 \quad 1.511728$

$\begin{array}{llll}\text { C } 2.980941 & -4.046496 & 2.465795\end{array}$

H $3.289924-4.312947 \quad 3.479185$

$\begin{array}{llll}\text { C } & 1.887095 & -3.196303 & 2.284894\end{array}$

$\begin{array}{llll}\text { H } & 1.359991 & -2.817800 & 3.163035\end{array}$

C $-0.629521-1.476097 \quad 2.393820$

C $-1.685513 \quad-2.274164 \quad 2.853689$

$\begin{array}{llll}\text { H } & -2.150972 & -3.010810 & 2.193002\end{array}$

$\begin{array}{llll}C & -2.140944 & -2.141690 & 4.164771\end{array}$

$\begin{array}{llll}\text { H } & -2.967078 & -2.765517 & 4.514366\end{array}$

$\begin{array}{llll}\text { C } & -1.538269 & -1.226534 & 5.028297\end{array}$

$\begin{array}{llll}\text { H } & -1.893331 & -1.129338 & 6.057315\end{array}$

$\begin{array}{llll}\text { C } & -0.485140 & -0.431354 & 4.574879\end{array}$

$\begin{array}{lllll}\text { H } & -0.010874 & 0.287857 & 5.246618\end{array}$

$\begin{array}{llll}\text { C } & -0.040467 & -0.544547 & 3.259656\end{array}$

$\begin{array}{llll}\text { H } & 0.781399 & 0.085862 & 2.900086\end{array}$

$\begin{array}{llll}C & -1.135337 & -2.685421 & -0.193253\end{array}$

$\begin{array}{llll}\text { C } & -0.900403 & -3.962219 & -0.720112\end{array}$

$\begin{array}{llll}\text { H } & 0.049182 & -4.468520 & -0.542626\end{array}$

$\begin{array}{lllll}\text { C } & -1.878993 & -4.594578 & -1.484207\end{array}$

$\begin{array}{llll}\text { H } & -1.678624 & -5.584466 & -1.898927\end{array}$

$\begin{array}{llll}\text { C } & -3.109476 & -3.981122 & -1.721859\end{array}$

$\begin{array}{llll}\text { H } & -3.858381 & -4.498028 & -2.325243\end{array}$

$\begin{array}{llll}\text { C } & -3.399587 & -2.727676 & -1.176933\end{array}$

$\begin{array}{llll}\text { C } & -4.747624 & -2.018195 & -1.267142\end{array}$

$\begin{array}{llll}C & -4.468246 & -0.520676 & -1.340024\end{array}$

$\begin{array}{llll}\text { C } & -5.226561 & 0.414195 & -2.049098\end{array}$

$\begin{array}{lllll}\text { H } & -6.073730 & 0.081484 & -2.652547\end{array}$

C $-4.921773 \quad 1.776122-1.99158$

$\begin{array}{llll}\text { H } & -5.534578 & 2.490754 & -2.544917\end{array}$ 
$\begin{array}{llll}\text { C } & -3.835810 & 2.232926 & -1.247798\end{array}$ $\begin{array}{lllll}\text { H } & -3.594517 & 3.298524 & -1.234240\end{array}$ $\begin{array}{lllll}C & -3.039111 & 1.322368 & -0.541065\end{array}$ $\begin{array}{llll}\text { C } & -3.397108 & -0.026798 & -0.592610\end{array}$ $\begin{array}{llll}\text { C } & -2.392610 & -2.115937 & -0.428091\end{array}$ $\begin{array}{lllll}C & -5.573778 & -2.503709 & -2.449137\end{array}$ $\begin{array}{llll}\text { H } & -6.546597 & -1.995609 & -2.482805\end{array}$ $\begin{array}{llll}\text { H } & -5.790015 & -3.577125 & -2.365323\end{array}$ $\begin{array}{llll}H & -5.065446 & -2.331375 & -3.408709\end{array}$ $\begin{array}{llll}\text { C } & -5.515670 & -2.296629 & 0.039919\end{array}$ $\begin{array}{llll}\text { H } & -4.955317 & -1.961862 & 0.925984\end{array}$ $\begin{array}{llll}H & -5.709706 & -3.373372 & 0.153057\end{array}$ $\begin{array}{llll}\text { H } & -6.483090 & -1.773179 & 0.03825\end{array}$ $\begin{array}{llll}\text { C } & -1.145566 & 3.423687 & -0.356853\end{array}$ $\begin{array}{lllll}\text { C } & -1.383571 & 4.619162 & 0.333378\end{array}$ H $\quad-1.811177 \quad 4.602881 \quad 1.338701$ $\begin{array}{llll}C & -1.079245 & 5.844417 & -0.262109\end{array}$ H $\begin{array}{llll} & -1.266053 & 6.770602 & 0.286675\end{array}$ $\begin{array}{llll}\text { C } & -0.544561 & 5.889398 & -1.549463\end{array}$ $\begin{array}{llll}\text { H } & -0.302351 & 6.850501 & -2.009271\end{array}$

$\begin{array}{lllll}\text { C } & -0.322698 & 4.702587 & -2.250745\end{array}$

$\begin{array}{llll}\text { H } & 0.096582 & 4.727032 & -3.259353\end{array}$

$\begin{array}{llll}\text { C } & -0.621242 & 3.478199 & -1.658865\end{array}$

$\begin{array}{llll}\text { H } & -0.434393 & 2.548042 & -2.209216\end{array}$

$\begin{array}{llll}\text { C } & -1.937690 & 2.024115 & 2.062906\end{array}$

$\begin{array}{llll}\text { C } & -3.146859 & 1.565984 & 2.600995\end{array}$

H $-3.873946 \quad 1.050759 \quad 1.966312$

$\begin{array}{llll}\text { C } & -3.436910 & 1.774334 & 3.949826\end{array}$

H $\quad-4.383036 \quad 1.412168 \quad 4.359405$

$\begin{array}{llll}\text { C } & -2.531472 & 2.448209 & 4.768121\end{array}$

H $\quad-2.767408 \quad 2.619071 \quad 5.821288$

C $-1.317863 \quad 2.895196 \quad 4.241073$

H $\quad-0.598358 \quad 3.412806 \quad 4.880036$

$\begin{array}{llll}\text { C } & -1.013403 & 2.668869 & 2.902338\end{array}$

H $\quad-0.051318 \quad 3.004207 \quad 2.499761$

\begin{tabular}{llll}
\hline & -2.610034 & -0.884521 & 0.127558
\end{tabular}

$\begin{array}{lllll}P & 0.081969 & -1.673110 & 0.724930\end{array}$

$\begin{array}{llll}P & -1.485132 & 1.758062 & 0.320453\end{array}$

Fig._S105_LPd212 / electronic energy: -3113.76387097 a.u. / lowest freq: $16.81 \mathrm{~cm}-1$

$\begin{array}{llll}C & -3.233671 & -2.497404 & -0.424947\end{array}$

$\begin{array}{llll}\text { C } & -3.463522 & -2.659314 & -1.798302\end{array}$

$\begin{array}{llll}\text { H } & -2.953260 & -1.998190 & -2.509331\end{array}$

$\begin{array}{lllll}\text { C } & -4.324657 & -3.655367 & -2.255809\end{array}$

H $\quad-4.496799 \quad-3.774676 \quad-3.327950$

C $-4.956277-4.502081-1.344476$

$\begin{array}{llll}H & -5.626735 & -5.287242 & -1.702072\end{array}$

$\begin{array}{llll}\text { C } & -4.727296 & -4.350707 & 0.024243\end{array}$

$\begin{array}{llll}\text { H } & -5.219551 & -5.014665 & 0.738821\end{array}$

$\begin{array}{llll}\text { C } & -3.870121 & -3.352963 & 0.485657\end{array}$

H $-3.698871 \quad-3.239045 \quad 1.560277$

C $-1.450696-1.736918 \quad 1.689555$

C $-1.781292-1.168064 \quad 2.925049$

$\begin{array}{llll}\text { H } & -2.436644 & -0.293304 & 2.972787\end{array}$

$\begin{array}{llll}\text { C } & -1.290759 & -1.727762 & 4.105788\end{array}$

$\begin{array}{llll}\text { H } & -1.555994 & -1.278869 & 5.066270\end{array}$

$\begin{array}{llll}\text { C } & -0.466829 & -2.851598 & 4.061626\end{array}$

H $-0.086354-3.287650 \quad 4.988663$

$\begin{array}{llll}\text { C } & -0.115592 & -3.410792 & 2.831273\end{array}$

$\begin{array}{llll}\text { H } & 0.540898 & -4.283400 & 2.788139\end{array}$

$\begin{array}{llll}\text { C } & -0.602329 & -2.855329 & 1.650573\end{array}$

$\begin{array}{llll}\text { H } & -0.337973 & -3.305897 & 0.686819\end{array}$

$\begin{array}{lll}\text { C }-3.288340 & 0.220908 & 0.530681\end{array}$

$\begin{array}{llll}\text { C } & -4.678319 & 0.156687 & 0.374023\end{array}$

H $-5.160456 \quad-0.801961 \quad 0.166338$

$\begin{array}{llll}\text { C } & -5.443718 & 1.320156 & 0.440848\end{array}$

H $\quad-6.527113 \quad 1.262781 \quad 0.316641$

$\begin{array}{llll}\text { C } & -4.833284 & 2.559543 & 0.631387\end{array}$

$\begin{array}{llll}\text { H } & -5.445616 & 3.463386 & 0.642125\end{array}$

C $-3.449200 \quad 2.659654 \quad 0.806992$

C $-2.685784 \quad 3.956144 \quad 1.03095$

$\begin{array}{lllll}\text { C } & -1.339152 & 3.805593 & 0.328463\end{array}$

$\begin{array}{lllll}\text { C } & -0.658970 & 4.841591 & -0.317546\end{array}$

$\begin{array}{llll}\text { H } & -1.140401 & 5.814344 & -0.435185\end{array}$

C $0.637929 \quad 4.656815-0.794827$

H $1.1539975 .475076-1.300635$

C $1.296305 \quad 3.445851-0.598367$

H $2.3268873 .332090 \quad-0.940149$

C $0.6428792 .375173 \quad 0.026916$

C $-0.687668 \quad 2.5718390 .429659$

$\begin{array}{llll}\text { C } & -2.714738 & 1.474001 & 0.789394\end{array}$

$\begin{array}{llll}C & -3.460049 & 5.170462 & 0.540328\end{array}$

H $-2.89958566 .095896 \quad 0.727984$

H $-4.411729 \quad 5.271933 \quad 1.078451$

$\begin{array}{llll}\text { H } & -3.680459 & 5.117199 & -0.535495\end{array}$

$\begin{array}{llll}\text { C } & -2.416171 & 4.105170 & 2.541129\end{array}$

H $-1.892967 \quad 3.230224 \quad 2.954566$

$\begin{array}{llll}\text { H } & -3.362313 & 4.216392 & 3.091023\end{array}$ 
$\begin{array}{lllll}\text { H } & -1.799658 & 4.994233 & 2.740928\end{array}$

C $3.268441 \quad 1.233562 \quad 0.080667$

C $4.083598 \quad 1.837543 \quad 1.046658$

$\begin{array}{llll}\text { H } & 3.690896 & 2.062683 & 2.042028\end{array}$

$\begin{array}{lll}\text { C } 5.407871 & 2.152928 & 0.741812\end{array}$

$\begin{array}{llll}\text { H } & 6.040404 & 2.616371 & 1.502626\end{array}$

$\begin{array}{llll}\text { C } & 5.922260 & 1.877038 & -0.524587\end{array}$

$\begin{array}{llll}\text { H } & 6.960756 & 2.123214 & -0.758478\end{array}$

C $5.111399 \quad 1.278796-1.490553$

$\begin{array}{llll}\text { H } & 5.510306 & 1.054244 & -2.482364\end{array}$

$\begin{array}{llll}\text { C } 3.792245 & 0.950964 & -1.188731\end{array}$

H $3.1601040 .462266-1.938086$

C $1.425585 \quad 0.739078 \quad 2.259775$

C $1.006847 \quad 1.830311 \quad 3.037479$

H $\quad 0.661314 \quad 2.753485 \quad 2.566599$

$\begin{array}{llll}\text { C } & 1.053980 & 1.760219 & 4.428717\end{array}$

$\begin{array}{lllll}\text { H } & 0.724803 & 2.617638 & 5.021068\end{array}$

C $1.5333520 .612475 \quad 5.060536$

H 1.5758270 .5645526 .151398

C $1.955024 \quad-0.472586 \quad 4.293250$

H $\quad 2.328144-1.378581 \quad 4.776912$

$\begin{array}{llll}\text { C } & 1.890607 & -0.416066 & 2.902923\end{array}$

$\begin{array}{llll}\text { H } & 2.211134 & -1.276088 & 2.306841\end{array}$

\begin{tabular}{lllll}
\hline & -1.349779 & 1.498717 & 0.969900
\end{tabular}

$\begin{array}{lllll}\text { P } & -2.139487 & -1.135302 & 0.109927\end{array}$

$\begin{array}{llll}\text { P } & 1.521048 & 0.819354 & 0.432199\end{array}$

$\begin{array}{llll}\text { I } & 3.352000 & -2.694188 & 0.041817\end{array}$

$\begin{array}{llll}\text { Pd } & -0.951354 & -0.250793 & -1.602225\end{array}$

Pd $1.165973-1.166246-0.506535$

I $0.374605 \quad 0.788745 \quad-3.702100$

153

Fig. S105_LPdH(CO)PdL(+) / electronic energy: -4893.59579005 a.u. / lowest freq: $9.67 \mathrm{~cm}-1$

C $3.275432 \quad 2.757857-2.077960$

C $2.422543 \quad 3.778934-1.632281$

H $1.854809 \quad 3.642447-0.706206$

C $2.293332 \quad 4.960460-2.356318$

H $1.629605 \quad 5.749747-1.993970$

C $2.999295 \quad 5.127645 \quad-3.549156$

H $2.892178 \quad 6.050855-4.123674$

C $3.837074 \quad 4.111763-4.007796$

H $\quad 4.390362 \quad 4.237611-4.94155$

C $3.980797 \quad 2.932320-3.275420$

H $4.651018 \quad 2.150080-3.641816$

C $4.554456 \quad 0.167914-1.971968$

$\begin{array}{llll}\text { C } 3.997112 & -0.659870 & -2.957441\end{array}$

$\begin{array}{llll}\text { H } & 2.913253 & -0.647283 & -3.124201\end{array}$

C $4.810969-1.492381-3.722810$

H $4.365941-2.126790 \quad-4.49315$

$\begin{array}{llll}\text { C } 6.187460 & -1.524345 & -3.495061\end{array}$

$\begin{array}{llll}\text { H } & 6.824898 & -2.185918 & -4.086856\end{array}$

$\begin{array}{llll}\text { C } 6.746755 & -0.715772 & -2.505448\end{array}$

$\begin{array}{llll}\text { H } & 7.823629 & -0.739313 & -2.321488\end{array}$

C $5.9371410 .132704 \quad-1.750318$

H $6.3910650 .771241 \quad-0.986728$

$\begin{array}{llll}\text { C } & 4.434738 & 1.861402 & 0.356642\end{array}$

$\begin{array}{llll}\text { C } 4.859536 & 3.182550 & 0.544636\end{array}$

$\begin{array}{lllll}\text { H } & 4.619076 & 3.947713 & -0.196794\end{array}$

$\begin{array}{llll}\text { C } & 5.581224 & 3.530047 & 1.685970\end{array}$

H $5.898644 \quad 4.565393 \quad 1.82757$

C $5.913235 \quad 2.568130 \quad 2.641303$

H $\quad 6.490516 \quad 2.861616 \quad 3.520440$

$\begin{array}{llll}\text { C } & 5.534569 & 1.233187 & 2.472755\end{array}$

C $4.788698 \quad 0.924202 \quad 1.333081$

C $5.9396510 .078766 \quad 3.381462$

C $6.343981 \quad 0.552561 \quad 4.769597$

H $7.201743 \quad 1.236080 \quad 4.717487$

H $\quad 6.660252 \quad-0.291076 \quad 5.397314$

$\begin{array}{llll}\text { H } & 5.524721 & 1.072930 & 5.286578\end{array}$

$\begin{array}{llll}\text { C } & 7.131969 & -0.644508 & 2.724020\end{array}$

H $6.888222 \quad-1.007893 \quad 1.71431$

H $7.437764 \quad-1.511682 \quad 3.327573$

$\begin{array}{llll}\text { H } & 7.994188 & 0.032859 & 2.636770\end{array}$

$\begin{array}{llll}\text { C } & 4.764315 & -0.891137 & 3.421850\end{array}$

C $4.388779-1.652638 \quad 4.530737$

H $4.923946-1.535877 \quad 5.475288$

C $3.341839-2.571413 \quad 4.445113$

H $3.068696-3.165011 \quad 5.319979$

C $2.636465-2.735655 \quad 3.255368$

H $\quad 1.808849 \quad-3.447139 \quad 3.213266$

$\begin{array}{lll}\text { C } 2.970235 & -1.977502 & 2.123822\end{array}$

C $4.040450 \quad-1.083234 \quad 2.240586$

$\begin{array}{llll}\text { C } 2.934229 & -3.136097 & -0.552615\end{array}$

$\begin{array}{llll}\text { C } & 4.241027 & -3.571029 & -0.304706\end{array}$

H $4.760088-3.273624 \quad 0.611264$

$\begin{array}{llll}\text { C } & 4.888452 & -4.399657 & -1.223505\end{array}$

$\begin{array}{lllll}\text { H } & 5.909925 & -4.731438 & -1.022239\end{array}$

C $4.235914-4.809073-2.385126$

$\begin{array}{lllll}\text { H } & 4.744028 & -5.463920 & -3.097134\end{array}$ 
$\begin{array}{llll}\text { C } & 2.933307 & -4.373740 & -2.640315\end{array}$

$\begin{array}{llll}\text { H } & 2.416917 & -4.684653 & -3.552171\end{array}$

$\begin{array}{llll}\text { C } & 2.291830 & -3.530511 & -1.738098\end{array}$

$\begin{array}{llll}\text { H } & 1.275285 & -3.178481 & -1.949998\end{array}$

$\begin{array}{llll}\text { C } & 0.546416 & -2.984998 & 1.062366\end{array}$

$\begin{array}{llll}\text { C } & 0.477498 & -4.379468 & 0.952554\end{array}$

H $\quad \begin{array}{llll}1.318327 & -4.941130 & 0.535444\end{array}$

$\begin{array}{llll}\text { C } & -0.664293 & -5.062506 & 1.374880\end{array}$

H $-0.710946-6.149713 \quad 1.275783$

$\begin{array}{llll}\text { C } & -1.736808 & -4.363544 & 1.928237\end{array}$

$\begin{array}{llll}\text { H } & -2.627318 & -4.901238 & 2.262805\end{array}$

$\begin{array}{llll}\text { C } & -1.669391 & -2.974247 & 2.055884\end{array}$

$\begin{array}{llll}\text { H } & -2.504999 & -2.420831 & 2.493817\end{array}$

$\begin{array}{llll}\text { C } & -0.538998 & -2.288518 & 1.616455\end{array}$

H $\quad-0.497370-1.194554 \quad 1.700266$

$\begin{array}{llll}C & -0.882860 & 3.153409 & 1.133524\end{array}$

$\begin{array}{llll}\text { C } & -0.900081 & 4.545640 & 0.996033\end{array}$

H $-1.777103 \quad 5.047486 \quad 0.577791$

C $0.203601 \quad 5.304329 \quad 1.395742$

H $\quad 0.181732 \quad 6.390352 \quad 1.276850$

C $1.323383 \quad 4.684273 \quad 1.948296$

$\begin{array}{llll}\text { H } & 2.184396 & 5.280967 & 2.260498\end{array}$

$\begin{array}{llll}\text { C } & 1.345870 & 3.294515 & 2.093857\end{array}$

H $2.218944 \quad 2.798662 \quad 2.527308$

$\begin{array}{llll}\text { C } & 0.256841 & 2.534481 & 1.675988\end{array}$

H $\quad 0.287564 \quad 1.441978 \quad 1.773833$

$\begin{array}{llll}\text { C } & -3.492660 & 3.154719 & -0.166522\end{array}$

$\begin{array}{llll}\text { C } & -3.240657 & 3.578361 & -1.481037\end{array}$

H $-2.329870 \quad 3.254387 \quad-1.994034$

$\begin{array}{llll}\text { C } & -4.141598 & 4.414009 & -2.136932\end{array}$

H $-3.9308704 .739149 \quad-3.158767$

$\begin{array}{llll}\text { C } & -5.315209 & 4.818004 & -1.498626\end{array}$

$\begin{array}{lllll}\text { H } & -6.026099 & 5.465992 & -2.016933\end{array}$

$\begin{array}{lllll}C & -5.580226 & 4.387589 & -0.199044\end{array}$

H $\quad-6.498063 \quad 4.698525 \quad 0.305621$

C $-4.673731 \quad 3.563549 \quad 0.468261$

$\begin{array}{llll}\text { H } & -4.892541 & 3.245029 & 1.491374\end{array}$

$\begin{array}{llll}\text { C } & -3.031908 & 1.624428 & 2.227750\end{array}$

$\begin{array}{llll}\text { C } & -2.675913 & 2.186611 & 3.460489\end{array}$

$\begin{array}{llll}\text { H } & -1.884186 & 2.938102 & 3.509789\end{array}$

$\begin{array}{llll}\text { C } & -3.326238 & 1.788669 & 4.627198\end{array}$

H $-3.034236 \quad 2.226325 \quad 5.584042$

C $-4.3583890 .849997 \quad 4.581496$

H $\quad-4.868726 \quad 0.567695 \quad 5.504816$

$\begin{array}{llll}\text { C } & -4.758289 & 0.283919 & 3.368355\end{array}$

$\begin{array}{llll}\text { C } & -4.059767 & 0.673198 & 2.221737\end{array}$

$\begin{array}{llll}\text { C } & -5.945556 & -0.655325 & 3.185787\end{array}$

C $-7.132593 \quad 0.180307 \quad 2.668035$

$\begin{array}{llll}\text { H } & -6.896920 & 0.692064 & 1.722686\end{array}$

$\begin{array}{llll}\text { H } & -7.413599 & 0.948215 & 3.403695\end{array}$

$\begin{array}{llll}\text { H } & -8.008705 & -0.461224 & 2.492898\end{array}$

$\begin{array}{llll}\text { C } & -6.343671 & -1.337888 & 4.485483\end{array}$

H $\quad-7.213347 \quad-1.991096 \quad 4.335600$

H $\quad-6.638945-0.599024 \quad 5.242233$

$\begin{array}{llll}H & -5.528090 & -1.946270 & 4.902835\end{array}$

$\begin{array}{llll}\text { C } & -5.559909 & -1.656863 & 2.103762\end{array}$

$\begin{array}{llll}\text { C } & -5.937099 & -3.002564 & 2.076539\end{array}$

H $-6.533021 \quad-3.4156592 .893113$

$\begin{array}{llll}\text { C } & -5.569044 & -3.826059 & 1.011268\end{array}$

$\begin{array}{llll}\text { H } & -5.881991 & -4.872335 & 1.002797\end{array}$

$\begin{array}{llll}C & -4.792095 & -3.331919 & -0.035261\end{array}$

$\begin{array}{llll}\text { H } & -4.486066 & -3.997904 & -0.845954\end{array}$

$\begin{array}{lllll}C & -4.379891 & -1.992827 & -0.034795\end{array}$

$\begin{array}{llll}\text { C } & -4.796558 & -1.187773 & 1.032299\end{array}$

$\begin{array}{llll}\text { C } & -4.193419 & -0.181242 & -2.302461\end{array}$

$\begin{array}{llll}\text { C } & -5.544689 & 0.103596 & -2.074242\end{array}$

H $\quad-6.074983-0.364759 \quad-1.240352$

$\begin{array}{llll}\text { C } & -6.228849 & 0.981813 & -2.916512\end{array}$

H $\quad-7.282512 \quad 1.200124$ - 2.726011

$\begin{array}{lllll}\text { C } & -5.576151 & 1.572814 & -3.997004\end{array}$

H $\quad-6.116223 \quad 2.257461 \quad-4.655672$

$\begin{array}{llll}\text { C } & -4.227489 & 1.294356 & -4.230158\end{array}$

$\begin{array}{llll}\text { H } & -3.707754 & 1.759272 & -5.071563\end{array}$

$\begin{array}{llll}\text { C } & -3.536497 & 0.433406 & -3.382182\end{array}$

H $\quad-2.474296 \quad 0.229420 \quad-3.561232$

C $-2.800091-2.708193 \quad-2.295873$

C $-1.709263 \quad-3.512179 \quad-1.937591$

H $\quad-1.098811-3.236783 \quad-1.070214$

$\begin{array}{llll}\text { C } & -1.404364 & -4.657762 & -2.671134\end{array}$

$\begin{array}{llll}\text { H } & -0.558865 & -5.284766 & -2.374785\end{array}$

$\begin{array}{llll}\text { C } & -2.174743 & -4.998429 & -3.783946\end{array}$

$\begin{array}{llll}\text { H } & -1.932129 & -5.891072 & -4.365495\end{array}$

C $-3.254443-4.195682-4.154561$

H $-3.858647-4.458636-5.026183$

$\begin{array}{llll}\text { C } & -3.572764 & -3.059050 & -3.411568\end{array}$

H $-4.431301-2.445935$ - -3.700661

$\begin{array}{llll}\text { C } & 0.114756 & 1.371381 & -1.434042\end{array}$

$\begin{array}{lllll}\text { O } & 4.357836 & -0.360547 & 1.121236\end{array}$ 
$\begin{array}{llll}0 & -4.380048 & 0.120398 & 1.008452\end{array}$ $\begin{array}{lllll}O & -0.009995 & 2.246006 & -2.207135\end{array}$

$\begin{array}{llll}\text { P } & 3.419582 & 1.259546 & -1.042325\end{array}$

$\begin{array}{llll}\text { P } & 2.016748 & -2.015878 & 0.558551\end{array}$

$\begin{array}{lllll}P & -2.262722 & 2.059637 & 0.626401\end{array}$

$\begin{array}{llll}P & -3.196703 & -1.276637 & -1.229479\end{array}$

$\begin{array}{lllll}\text { Pd } & 1.372258 & 0.033998 & -0.653022\end{array}$

$\begin{array}{lllll}\text { Pd } & -1.324035 & 0.189531 & -0.619058\end{array}$

$\begin{array}{llll}\text { H } & -0.120101 & -0.979249 & -0.976158\end{array}$

Fig._S105_LPdHI / electronic energy: -2688.42445650 a.u. / lowest freq: $20.09 \mathrm{~cm}-1$

$\begin{array}{llll}\text { Pd }-0.018417 & -0.953805 & -1.185825\end{array}$

$\begin{array}{llll}P & 1.640194 & -0.379894 & 0.55784\end{array}$

$\begin{array}{llll}\text { P } & -2.029701 & -0.591427 & -0.167157\end{array}$

$\begin{array}{lllll}\text { O } & -0.319894 & 1.667105 & 0.524623\end{array}$

$\begin{array}{lllll}\text { C } & 0.878418 & 2.220330 & 0.134290\end{array}$

C $1.984929 \quad 1.362814 \quad 0.126191$

C $3.1995761 .884182-0.331933$

$\begin{array}{lllll}\text { H } & 4.082477 & 1.243269 & -0.390369\end{array}$

C $3.277203 \quad 3.213687-0.747367$

H $\quad 4.227579 \quad 3.607639 \quad-1.113552$

C $2.156311 \quad 4.044950-0.703849$

H $2.246060 \quad 5.084053-1.027384$

C $0.925978 \quad 3.560764-0.249835$

$\begin{array}{lllll}\text { C } & -0.351254 & 4.379150 & -0.084634\end{array}$

$\begin{array}{llll}\text { C } & -1.510456 & 3.474700 & -0.493586\end{array}$

$\begin{array}{llll}\text { C } & -2.654899 & 3.886233 & -1.181757\end{array}$

$\begin{array}{llll}\text { H } & -2.758454 & 4.928559 & -1.490624\end{array}$

C $-3.6713592 .978682-1.481715$

$\begin{array}{lllll}\text { H } & -4.560303 & 3.318675 & -2.017087\end{array}$

C $-3.555298 \quad 1.635387-1.127360$

H $-4.342380 \quad 0.932994 \quad-1.410366$

$\begin{array}{llll}C & -2.418192 & 1.180124 & -0.447562\end{array}$

$\begin{array}{llll}\text { C } & -1.433783 & 2.127050 & -0.132506\end{array}$

C $-0.508082 \quad 4.720390 \quad 1.410086$

H $\quad-0.540299 \quad 3.817618 \quad 2.038258$

H $\quad-1.437663 \quad 5.282030 \quad 1.584225$

H $\quad 0.333506 \quad 5.338573 \quad 1.756037$

$\begin{array}{llll}\text { C } & -0.316646 & 5.667790 & -0.891958\end{array}$

H $-0.212183 \quad 5.479907-1.970255$

$\begin{array}{llll}\text { H } & 0.518950 & 6.306619 & -0.575885\end{array}$

$\begin{array}{llll}H & -1.231632 & 6.254662 & -0.735587\end{array}$

$\begin{array}{llll}\text { C } & 1.288449 & -0.306622 & 2.362047\end{array}$

C $1.022884-1.518874 \quad 3.016762$

$\begin{array}{llll}\text { H } & 0.974375 & -2.449612 & 2.441191\end{array}$

$\begin{array}{llll}\text { C } & 0.838360 & -1.552040 & 4.396747\end{array}$

$\begin{array}{llll}\text { H } & 0.637838 & -2.504972 & 4.893151\end{array}$

C $\quad 0.899744-0.372837 \quad 5.141292$

$\begin{array}{llll}\text { H } & 0.753017 & -0.399249 & 6.223944\end{array}$

C $1.143518 \quad 0.838482 \quad 4.496214$

$\begin{array}{llll}\text { H } & 1.191885 & 1.767060 & 5.070708\end{array}$

$\begin{array}{llll}C & 1.338513 & 0.873674 & 3.114707\end{array}$

H $1.549326 \quad 1.831082 \quad 2.630250$

C $3.265648-1.221351 \quad 0.594934$

$\begin{array}{llll}\text { C } & 4.326918 & -0.721659 & 1.366293\end{array}$

$\begin{array}{llll}\text { H } & 4.204863 & 0.211414 & 1.925293\end{array}$

$\begin{array}{llll}\text { C } 5.535078 & -1.411473 & 1.430884\end{array}$

H $6.357296 \quad-1.010974 \quad 2.028781$

C $5.690745-2.615986 \quad 0.741103$

$\begin{array}{llll}\text { H } & 6.638138 & -3.157827 & 0.796008\end{array}$

$\begin{array}{llll}\text { C } 4.634561 & -3.130142 & -0.009154\end{array}$

$\begin{array}{llll}\text { H } & 4.748533 & -4.077250 & -0.541658\end{array}$

$\begin{array}{llll}\text { C } & 3.426257 & -2.435874 & -0.082910\end{array}$

H $2.596752-2.840594-0.669972$

C $-2.195391-0.868655 \quad 1.633838$

$\begin{array}{llll}C & -2.298663 & -2.199294 & 2.07015\end{array}$

H $-2.241660 \quad-3.017254 \quad 1.344795$

$\begin{array}{llll}C & -2.498811 & -2.486282 & 3.417179\end{array}$

$\begin{array}{llll}\text { H } & -2.591905 & -3.525571 & 3.741747\end{array}$

$\begin{array}{llll}\text { C } & -2.579122 & -1.448767 & 4.34773\end{array}$

H $-2.734496-1.672484 \quad 5.40612$

C $-2.448923-0.126935 \quad 3.925000$

$\begin{array}{lllll}\text { H } & -2.500602 & 0.688533 & 4.650884\end{array}$

C $-2.259293 \quad 0.166668 \quad 2.573843$

$\begin{array}{llll}\text { H } & -2.181801 & 1.210329 & 2.257864\end{array}$

$\begin{array}{llll}\text { C } & -3.509341 & -1.481218 & -0.781514\end{array}$

$\begin{array}{llll}\text { C } & -4.730001 & -1.337810 & -0.099103\end{array}$

$\begin{array}{lllll}\text { H } & -4.790938 & -0.698558 & 0.787004\end{array}$

$\begin{array}{llll}C & -5.869956 & -1.998612 & -0.547253\end{array}$

$\begin{array}{llll}\text { H } & -6.814091 & -1.872074 & -0.012313\end{array}$

$\begin{array}{llll}\text { C } & -5.805272 & -2.821662 & -1.673904\end{array}$

$\begin{array}{llll}\text { H } & -6.699435 & -3.344827 & -2.021329\end{array}$

$\begin{array}{llll}\text { C } & -4.596805 & -2.978491 & -2.349161\end{array}$

$\begin{array}{llll}\text { H } & -4.536738 & -3.627377 & -3.225887\end{array}$

$\begin{array}{llll}\text { C } & -3.453577 & -2.311456 & -1.905597\end{array}$

$\begin{array}{lllll}\text { H } & -2.505658 & -2.442993 & -2.434768\end{array}$

H $-1.001855-1.106494 \quad-2.39998$

$\begin{array}{llll}\text { I } & 1.865334 & -0.974736 & -3.186951\end{array}$ 
Fig._S105_12PdH(-) / electronic energy: $-\mathbf{7 2 4 . 5 3 2 8 3 6 9 8 4}$ a.u. / lowest freq: $28.44 \mathrm{~cm}-1$

I $\quad-2.645870 \quad 0.019347 \quad 0.000142$

Pd $-0.000004-0.075745-0.000307$

H $\quad-0.000242 \quad 1.433399 \quad-0.000948$

I 2.6458780 .0193490 .000142

Fig._S105_INT1D(-) / electronic energy: - -3604.81625077 a.u. / lowest freq: $15.16 \mathrm{~cm}-1$

C $-2.626456-2.748459 \quad 1.425783$

$\begin{array}{llll}\text { C }-2.991842 & -3.510505 & 0.307809\end{array}$

H $\quad-2.752173 \quad-3.137913 \quad-0.694819$

$\begin{array}{llll}\text { C } & -3.652239 & -4.727968 & 0.471260\end{array}$

H $-3.932014-5.314452-0.406970$

C $-3.946283 \quad-5.196520 \quad 1.751547$

H $-4.459200 \quad-6.152858 \quad 1.880132$

$\begin{array}{llll}\text { C } & -3.579766 & -4.445706 & 2.870217\end{array}$

H $\quad-3.806437 \quad-4.811437 \quad 3.874678$

$\begin{array}{llll}\text { C } & -2.920808 & -3.228155 & 2.710918\end{array}$

H $\quad-2.636072 \quad-2.646586 \quad 3.593227$

$\begin{array}{llll}\text { C } & -0.690505 & -1.043878 & 2.628445\end{array}$

$\begin{array}{llll}\text { C } & -0.992732 & -0.205519 & 3.710027\end{array}$

$\begin{array}{llll}\text { H } & -1.831983 & 0.493282 & 3.646265\end{array}$

$\begin{array}{llll}\text { C } & -0.248134 & -0.279323 & 4.886681\end{array}$

H $\quad-0.498809 \quad 0.375019 \quad 5.725556$

C $0.810073-1.181415 \quad 4.992480$

H $1.389236-1.2412645 .917422$

C $1.140851-1.992493 \quad 3.906244$

$\begin{array}{llll}\text { H } & 1.981556 & -2.687487 & 3.971934\end{array}$

C $0.398586-1.921215 \quad 2.729166$

$\begin{array}{lllll}\text { H } & 0.657311 & -2.570998 & 1.886692\end{array}$

C $-3.052173 \quad 0.122157 \quad 1.408789$

$\begin{array}{llll}\text { C } & -4.396280 & -0.183215 & 1.643404\end{array}$

$\begin{array}{llll}\text { H } & -4.685716 & -1.205245 & 1.900034\end{array}$

$\begin{array}{llll}\text { C } & -5.374083 & 0.798474 & 1.497178\end{array}$

H $\quad-6.422650 \quad 0.553136 \quad 1.678336$

$\begin{array}{llll}\text { C } & -5.021763 & 2.077158 & 1.072289\end{array}$

$\begin{array}{llll}\text { H } & -5.804999 & 2.820391 & 0.91138\end{array}$

$\begin{array}{lllll}\text { C } & -3.685487 & 2.423306 & 0.845629\end{array}$

$\begin{array}{llll}\text { C } & -3.225604 & 3.795995 & 0.383417\end{array}$

$\begin{array}{lllll}\text { C } & -1.969463 & 3.607258 & -0.462971\end{array}$

$\begin{array}{llll}C & -1.629570 & 4.429305 & -1.539834\end{array}$

H $\quad-2.345326 \quad 5.167818 \quad-1.905555$

C $-0.376228 \quad 4.334616-2.141201$

$\begin{array}{lllll}\text { H } & -0.127933 & 4.971808 & -2.992570\end{array}$

$\begin{array}{lllll}\text { C } & 0.581448 & 3.466314 & -1.625271\end{array}$

H $\quad 1.582189 \quad 3.450580 \quad-2.063114$

$\begin{array}{llll}\text { C } & 0.281857 & 2.611221 & -0.555134\end{array}$

$\begin{array}{llll}\text { C } & -1.034731 & 2.642652 & -0.061544\end{array}$

$\begin{array}{llll}\text { C } & -2.716978 & 1.443053 & 1.067895\end{array}$

$\begin{array}{lllll}\text { C } & -4.320821 & 4.534924 & -0.374945\end{array}$

H $-3.984855 \quad 5.534775 \quad-0.680101$

$\begin{array}{lllll}H & -5.204380 & 4.691836 & 0.257457\end{array}$

H $-4.637758 \quad 3.989790 \quad-1.275999$

$\begin{array}{llll}C & -2.830985 & 4.615483 & 1.627680\end{array}$

H $-2.0667114 .100189 \quad 2.228585$

$\begin{array}{llll}H & -3.705237 & 4.780430 & 2.275431\end{array}$

H $\begin{array}{llll}-2.428890 & 5.598559 & 1.339287\end{array}$

$\begin{array}{llll}\text { C } 3.110189 & 2.393519 & -0.357326\end{array}$

C $3.482661 \quad 3.6443490 .158175$

H $2.859546 \quad 4.133751 \quad 0.912899$

$\begin{array}{llll}\text { C } & 4.642319 & 4.276761 & -0.284795\end{array}$

H $4.919625 \quad 5.250695 \quad 0.126436$

C $5.448492 \quad 3.668564 \quad-1.249301$

H $6.359597 \quad 4.163925-1.594102$

C $5.0890362 .425586-1.767270$

H $5.7150361 .940129-2.519789$

$\begin{array}{llll}\text { C } 3.928230 & 1.791172 & -1.322227\end{array}$

$\begin{array}{llll}\text { H } & 3.653757 & 0.812783 & -1.733814\end{array}$

C $1.537869 \quad 2.032582 \quad 1.962350$

$\begin{array}{llll}\text { C } & 0.850026 & 3.155410 & 2.446184\end{array}$

H $\quad 0.241892 \quad 3.764578 \quad 1.772879$

C $0.955228 \quad 3.530847 \quad 3.785216$

H $0.410138 \quad 4.408867 \quad 4.142611$

C $1.765853 \quad 2.804450 \quad 4.658110$

H $1.856368 \quad 3.106443 \quad 5.704696$

C $2.457837 \quad 1.690176 \quad 4.185019$

H $3.0924251 .108863 \quad 4.859094$

C $2.333868 \quad 1.298551 \quad 2.852735$

$\begin{array}{llll}\text { H } & 2.873747 & 0.415367 & 2.495208\end{array}$

$\begin{array}{lllll}\text { O } & -1.380392 & 1.714962 & 0.893760\end{array}$

$\begin{array}{lllll}P & -1.774026 & -1.150891 & 1.158015\end{array}$

$\begin{array}{llll}P & 1.572539 & 1.525952 & 0.189127\end{array}$

$\begin{array}{llll}\text { I } & 4.044979 & -1.774898 & 0.934444\end{array}$

H $0.950124-5.988730 \quad-1.338687$

$\begin{array}{llll}\text { C } & 1.688029 & -5.233503 & -1.640515\end{array}$

H $1.792252-5.281010-2.732730$

H $2.655667-5.517201-1.202786$

H $0.284514 \quad-3.559518-1.612474$ 
C $1.259086-3.857925-1.183254$

$\begin{array}{llll}\text { H } & 1.107689 & -3.805690 & -0.093684\end{array}$

C $2.216303-2.759383-1.585542$

H $0.319156-1.466301-0.135765$

$\begin{array}{llll}\text { Pd } & -0.965789 & -0.870451 & -0.944094\end{array}$

$\begin{array}{llll}0 & 3.086164 & -2.883076 & -2.401517\end{array}$

$\begin{array}{llll}\text { Pd } & 1.926837 & -0.983710 & -0.717117\end{array}$

$\begin{array}{lllll}1 & -3.411078 & -0.191019 & -2.327978\end{array}$

$\begin{array}{llll}\text { I } & 0.604360 & -0.257255 & -3.226236\end{array}$

Fig._S105_TSD(-) / electronic energy: - 3604.80503681 a.u. / lowest freq: $-605.42 \mathrm{~cm}-1$

C $-2.381088-2.828933 \quad 1.281647$

$\begin{array}{llll}\text { C }-2.717749 & -3.559527 & 0.134627\end{array}$

$\begin{array}{llll}\text { H } & -2.496831 & -3.140084 & -0.853097\end{array}$

$\begin{array}{lllll}\text { C } & -3.323296 & -4.810899 & 0.250349\end{array}$

$\begin{array}{llll}\text { H } & -3.578631 & -5.373686 & -0.650401\end{array}$

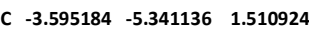

H $-4.067404-6.322455 \quad 1.601420$

$\begin{array}{llll}\text { C } & -3.259186 & -4.620219 & 2.658796\end{array}$

$\begin{array}{llll}\text { H } & -3.469295 & -5.034319 & 3.647898\end{array}$

$\begin{array}{llll}\text { C } & -2.651365 & -3.371560 & 2.547626\end{array}$

$\begin{array}{llll}\text { H } & -2.389112 & -2.813598 & 3.451914\end{array}$

$\begin{array}{llll}\text { C } & -0.449449 & -1.142383 & 2.521305\end{array}$

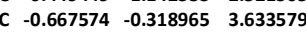

$\begin{array}{llll}\text { H } & -1.488613 & 0.402936 & 3.637707\end{array}$

$\begin{array}{llll}\text { C } & 0.146786 & -0.433195 & 4.760939\end{array}$

$\begin{array}{lllll}\text { H } & -0.037584 & 0.210984 & 5.624448\end{array}$

$\begin{array}{llll}\text { C } & 1.189309 & -1.358273 \quad 4.786739\end{array}$

H $1.823524-1.444797 \quad 5.672679$

C $1.430082-2.162840 \quad 3.671951$

$\begin{array}{lllll}\text { H } & 2.252687 & -2.882648 & 3.674875\end{array}$

$\begin{array}{llll}\text { C } & 0.615276 & -2.053437 & 2.547890\end{array}$

H $0.788009-2.700693 \quad 1.685182$

$\begin{array}{llll}\text { C } & -2.901226 & 0.012738 & 1.551941\end{array}$

$\begin{array}{llll}\text { C } & -4.225931 & -0.327700 & 1.834160\end{array}$

H $-4.499798 \quad-1.373353 \quad 1.996352$

$\begin{array}{llll}\text { C } & -5.208187 & 0.661670 & 1.851048\end{array}$

H $\quad-6.243773 \quad 0.394081 \quad 2.071210$

$\begin{array}{llll}C & -4.885489 & 1.979034 & 1.530676\end{array}$

$\begin{array}{llll}\text { H } & -5.679457 & 2.727426 & 1.489943\end{array}$

$\begin{array}{llll}\text { C } & -3.566207 & 2.355498 & 1.254182\end{array}$

$\begin{array}{llll}C & -3.127785 & 3.761703 & 0.875444\end{array}$

$\begin{array}{llll}\text { C } & -1.920659 & 3.641329 & -0.053612\end{array}$

$\begin{array}{lllll}C & -1.625462 & 4.549941 & -1.073367\end{array}$

H $\quad-2.347005 \quad 5.326549 \quad-1.334398$

C $-0.407094 \quad 4.494731 \quad-1.747960$

H $\quad-0.194538 \quad 5.206342 \quad-2.548495$

$\begin{array}{lllll}\text { C } & 0.560888 & 3.564725 & -1.377204\end{array}$

H $\quad 1.529766 \quad 3.570597 \quad-1.880733$

$\begin{array}{llll}\text { C } & 0.300892 & 2.618379 & -0.377243\end{array}$

$\begin{array}{llll}\text { C } & -0.974760 & 2.642643 & 0.209737\end{array}$

C $-2.592242 \quad 1.361672 \quad 1.331208$

$\begin{array}{llll}\text { C } & -4.262375 & 4.551534 & 0.236880\end{array}$

$\begin{array}{lllll}\text { H } & -3.942478 & 5.571790 & -0.012798\end{array}$

$\begin{array}{lllll}H & -5.108569 & 4.658389 & 0.928131\end{array}$

$\begin{array}{lllll}\text { H } & -4.629934 & 4.072239 & -0.682331\end{array}$

$\begin{array}{llll}\text { C } & -2.662189 & 4.485362 & 2.153655\end{array}$

H $-1.863292 \quad 3.930922 \quad 2.668734$

H $\quad-3.497910 \quad 4.595886 \quad 2.861114$

H $\quad-2.279050 \quad 5.489731 \quad 1.918024$

$\begin{array}{llll}\text { C } & 3.096149 & 2.148654 & -0.557021\end{array}$

C $3.766901 \quad 3.241592 \quad 0.007195$

H 3.4075653 .6859110 .939895

$\begin{array}{lllll}\text { C } & 4.895945 & 3.773354 & -0.614834\end{array}$

H $5.413543 \quad 4.622699-0.161869$

C $5.361702 \quad 3.224004-1.809736$

H $\quad 6.247343 \quad 3.641483 \quad-2.295404$

$\begin{array}{llll}C & 4.697950 & 2.136707 & -2.379011\end{array}$

$\begin{array}{llll}\text { H } & 5.060686 & 1.697787 & -3.311513\end{array}$

$\begin{array}{llll}\text { C } 3.575453 & 1.596221 & -1.753175\end{array}$

H $3.062766 \quad 0.732658-2.192374$

$\begin{array}{llll}\text { C } & 1.785973 & 1.902314 & 1.969578\end{array}$

C $1.211996 \quad 3.048507 \quad 2.539069$

$\begin{array}{ccccc}\text { H } & 0.562158 & 3.697029 & 1.945868\end{array}$

C $1.483239 \quad 3.392539 \quad 3.863166$

H $1.025677 \quad 4.288475 \quad 4.291394$

C $\quad 2.347560 \quad 2.610722 \quad 4.630466$

H $\quad 2.569082 \quad 2.889347 \quad 5.663865$

C $2.924414 \quad 1.471524 \quad 4.070296$

H $3.5979620 .846900 \quad 4.662803$

C $2.633867 \quad 1.110796 \quad 2.755818$

H $3.082161 \quad 0.208814 \quad 2.325629$

$\begin{array}{llll}\text { O } & -1.266266 & 1.648658 & 1.111529\end{array}$

$\begin{array}{llll}P & -1.603413 & -1.183875 & 1.096076\end{array}$

$\begin{array}{lllll}P & 1.584460 & 1.428144 & 0.203022\end{array}$

$\begin{array}{lllll}\text { I } & 4.278542 & -1.560120 & 0.295667\end{array}$

$\begin{array}{llll}\text { H } & 2.000943 & -6.204621 & -0.371198\end{array}$

C $2.106257-5.342896-1.043701$ 
$\begin{array}{llll}\text { H } & 1.613951 & -5.594429 & -1.993075\end{array}$

H $3.177156-5.211650-1.254306$

H $0.449893-4.228065-0.166608$

$\begin{array}{llll}\text { C } & 1.516834 & -4.098125 & -0.423423\end{array}$

$\begin{array}{llll}\text { H } \quad 2.011498 & -3.852199 & 0.530144\end{array}$

$\begin{array}{llll}\text { C } & 1.597463 & -2.882515 & -1.312617\end{array}$

$\begin{array}{llll}\text { H } & 0.424701 & -2.003401 & -1.058927\end{array}$

Pd $-0.982517-0.701449-1.073852$

o $1.981215-2.919804 \quad-2.454708$

Pd $1.571228-0.914235-0.387071$

I $-3.610990-0.188661-1.964806$

I $0.014591 \quad 0.096439-3.514790$

Fig._S105_INT2D(-) / electronic energy: -3604.82717493 a.u. / lowest freq: $21.19 \mathrm{~cm}-1$

C $-1.353098 \quad-3.170244 \quad 1.128871$

$\begin{array}{llll}\text { C }-1.423992 & -3.879016 & -0.077974\end{array}$

$\begin{array}{lllll}\text { H } & -1.380127 & -3.331570 & -1.02562\end{array}$

$\begin{array}{llll}\text { C } & -1.525911 & -5.270083 & -0.074733\end{array}$

$\begin{array}{llll}\text { H } & -1.566611 & -5.810235 & -1.023874\end{array}$

$\begin{array}{llll}C & -1.558931 & -5.965192 & 1.133721\end{array}$

H $-1.629786-7.055766 \quad 1.137102$

$\begin{array}{llll}C & -1.497489 & -5.266025 & 2.341274\end{array}$

$\begin{array}{llll}\text { H } & -1.525946 & -5.806791 & 3.290395\end{array}$

$\begin{array}{llll}C & -1.393330 & -3.876119 & 2.341659\end{array}$

$\begin{array}{llll}\text { H } & -1.337975 & -3.338627 & 3.293339\end{array}$

$\begin{array}{llll}\text { C } & -0.107852 & -1.046174 & 2.554387\end{array}$

$\begin{array}{llll}\text { C } & -0.544971 & -0.304528 & 3.658853\end{array}$

$\begin{array}{lllll}\text { H } & -1.528022 & 0.173702 & 3.650431\end{array}$

$\begin{array}{llll}\text { C } & 0.263121 & -0.188103 & 4.791744\end{array}$

$\begin{array}{lllll}\text { H } & -0.091456 & 0.390858 & 5.648360\end{array}$

$\begin{array}{llll}\text { C } & 1.513258 & -0.803314 & 4.831258\end{array}$

H $2.142126-0.710355 \quad 5.720383$

C $1.966230-1.526197 \quad 3.725870$

$\begin{array}{llll}\text { H } & 2.950579 & -2.001094 & 3.738562\end{array}$

C $1.161726-1.643775 \quad 2.595471$

H $1.516324 \quad-2.222547 \quad 1.736546$

$\begin{array}{llll}\text { C } & -2.793714 & -0.676721 & 1.560063\end{array}$

$\begin{array}{llll}\text { C } & -3.951740 & -1.430377 & 1.769054\end{array}$

$\begin{array}{llll}\text { H } & -3.885456 & -2.515600 & 1.885329\end{array}$

$\begin{array}{llll}\text { C } & -5.197015 & -0.801090 & 1.767116\end{array}$

H $\quad-6.101471 \quad-1.391747 \quad 1.92822$

C $-5.302350 \quad 0.564829 \quad 1.502938$

H $\quad-6.291846 \quad 1.022816 \quad 1.441964$

$\begin{array}{llll}\text { C } & -4.160581 & 1.348039 & 1.300872\end{array}$

$\begin{array}{llll}C & -4.147734 & 2.831094 & 0.959138\end{array}$

$\begin{array}{llll}\text { C } & -2.984885 & 3.052855 & -0.009199\end{array}$

$\begin{array}{llll}C & -3.002791 & 3.936683 & -1.090439\end{array}$

$\begin{array}{lllll}\text { H } & -3.922863 & 4.466283 & -1.345583\end{array}$

$\begin{array}{lllll}\text { C } & -1.850216 & 4.160715 & -1.844136\end{array}$

$\begin{array}{lllll}\text { H } & -1.882306 & 4.843054 & -2.696093\end{array}$

C $-0.648255 \quad 3.546486-1.501478$

$\begin{array}{lllll}\text { H } & 0.250098 & 3.759050 & -2.084929\end{array}$

$\begin{array}{llll}\text { C } & -0.584585 & 2.646560 & -0.427629\end{array}$

$\begin{array}{llll}\text { C } & -1.784757 & 2.379939 & 0.249193\end{array}$

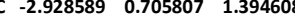

$\begin{array}{llll}\text { C } & -5.475361 & 3.287375 & 0.372424\end{array}$

$\begin{array}{llll}\text { H } & -5.456623 & 4.360620 & 0.139998\end{array}$

$\begin{array}{llll}\text { H } & -6.293285 & 3.140695 & 1.090589\end{array}$

$\begin{array}{lllll}\text { H } & -5.727539 & 2.741824 & -0.548598\end{array}$

$\begin{array}{lllll}\text { C } & -3.858578 & 3.626497 & 2.246231\end{array}$

H $\quad-2.922887 \quad 3.303634 \quad 2.726490$

$\begin{array}{llll}\text { H } & -4.670082 & 3.486665 & 2.975947\end{array}$

$\begin{array}{llll}\text { H } & -3.775454 & 4.702576 & 2.031948\end{array}$

C $2.232723 \quad 2.974975-0.699223$

$\begin{array}{llll}\text { C } \quad 2.333000 & 4.319537 & -0.309726\end{array}$

H $1.675042 \quad 4.7168190 .469503$

$\begin{array}{llll}\text { C } 3.265586 & 5.160216 & -0.913009\end{array}$

H $3.335348 \quad 6.204903 \quad-0.599966$

C $4.108605 \quad 4.668611-1.911932$

H $4.841277 \quad 5.328604-2.383212$

C $4.016065 \quad 3.333775-2.302506$

$\begin{array}{llll}\text { H } & 4.674632 & 2.941025 & -3.080826\end{array}$

C $3.083998 \quad 2.488835 \quad-1.698216$

H $3.015273 \quad 1.438625 \quad-1.999224$

C $1.159910 \quad 2.375661 \quad 1.859782$

$\begin{array}{llll}\text { C } & 0.310001 & 3.297226 & 2.487984\end{array}$

H $-0.540002 \quad 3.726123 \quad 1.951619$

$\begin{array}{llll}\text { C } & 0.553676 \quad 3.703509 & 3.800017\end{array}$

H $\quad-0.121172 \quad 4.420590 \quad 4.274913$

C $1.657247 \quad 3.210518 \quad 4.496278$

H $1.849510 \quad 3.534781 \quad 5.522160$

C $2.514037 \quad 2.302041 \quad 3.874212$

H $3.380742 \quad 1.906122 \quad 4.409639$

C $2.261685 \quad 1.878421 \quad 2.571370$

H $2.930090 \quad 1.153330 \quad 2.092610$

\begin{tabular}{lllll}
\hline & -1.759258 & 1.412887 & 1.223469
\end{tabular}

$\begin{array}{llll}\text { P } & -1.165776 & -1.348744 & 1.086817\end{array}$

$\begin{array}{lllll}P & 0.998287 & 1.860310 & 0.098205\end{array}$ 


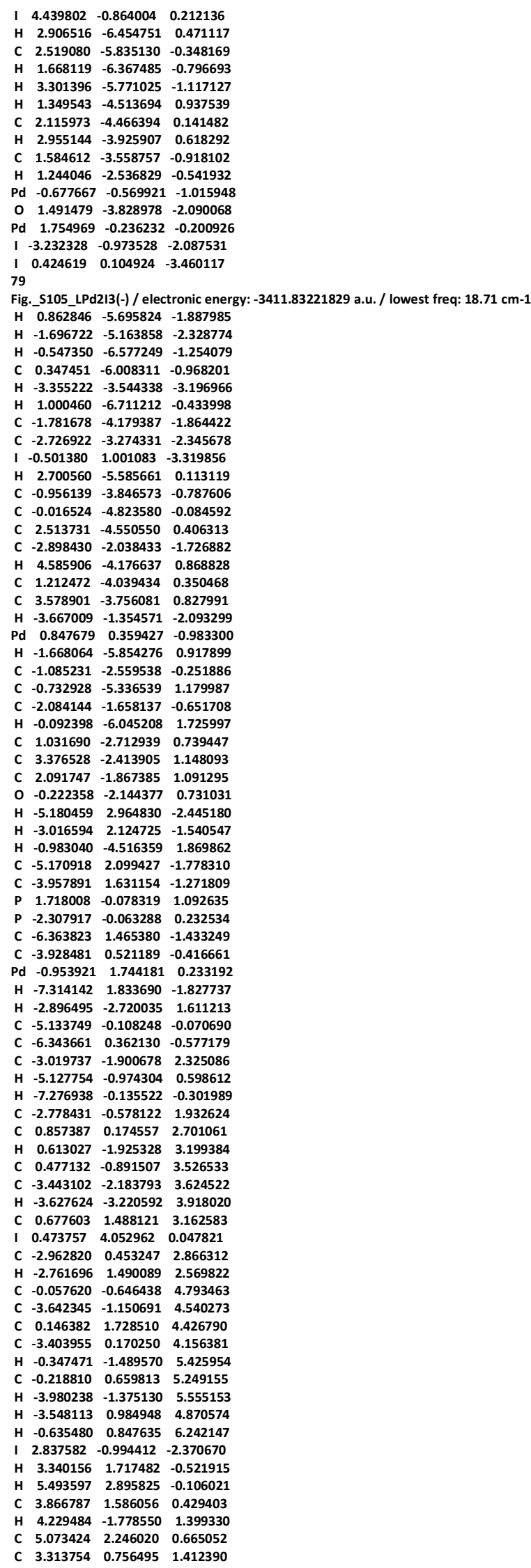

$\begin{array}{llll}\text { H } & 2.906516 & -6.454751 & 0.471117\end{array}$

$3.301396-5.771025-1.117127$

$\begin{array}{lllll}H & 1.349543 & -4.513694 & 0.937539\end{array}$

$\begin{array}{llll}\text { O } & 1.491479 & -3.828978 & -2.090068\end{array}$

H $0.862846-5.695824 \quad-1.887985$

$\begin{array}{llll}-1.696722 & -5.163858 & -2.328774\end{array}$

$\begin{array}{llll}\text { C } & 0.347451 & -6.008311 & -0.968201\end{array}$

$\begin{array}{llll}\text { H } & -3.355222 & -3.544338 & -3.196966\end{array}$

$\begin{array}{llll}\text { H } & 1.000460 & -6.711212 & -0.433998\end{array}$

$56081 \quad 0.827991$
-10.04

$\begin{array}{llll}\text { Pd } & 0.847679 & 0.359427 & -0.983300\end{array}$

$\begin{array}{llll}C & -2.084144 & -1.658137 & -0.65170\end{array}$

$\begin{array}{lllll}H & 1.031690 & -2.712939 & 0.73944\end{array}$

$\begin{array}{llll}-2.307917 & -0.063288 & 0.232534\end{array}$

$\begin{array}{llll}C & -6.363823 & 1.465380 & -1.433249\end{array}$

$\begin{array}{llll}H & -2.896495 & -2.720035 & 1.611213\end{array}$

$\begin{array}{llll}C & -5.133749 & -0.108248 & -0.070690\end{array}$

$-0.362130-0.577$

$\begin{array}{lllll}\text { H } & -5.127754 & -0.974304 & 0.598612\end{array}$

$\begin{array}{llll}H & -7.276938 & -0.135522 & -0.301989\end{array}$

$\begin{array}{llll}C & -2.778431 & -0.578122 & 1.93262\end{array}$

$\begin{array}{lll}0.473757 & 4.052962 & 0.047821\end{array}$

$\begin{array}{llll} & .962820 & 0.453247 & 2.86631\end{array}$

$\begin{array}{llll}-3.642345 & -1.150691 & 4.540273\end{array}$

$\begin{array}{llll}H & -0.635480 & 0.847635 & 6.242147\end{array}$

$\begin{array}{llll}2.837582 & -0.994412 & -2.370670\end{array}$

$\begin{array}{llll}\text { H } & 4.229484 & -1.778550 & 1.399330\end{array}$

C $3.313754 \quad 0.756495 \quad 1.412390$ 
$\begin{array}{llll}\text { C } & 5.734902 & 2.080429 & 1.880853\end{array}$

H $\quad 6.6788632 .599504 \quad 2.065256$

C $3.979285 \quad 0.603031 \quad 2.638976$

C $5.187148 \quad 1.257694 \quad 2.867912$

H $3.549490 \quad-0.032702 \quad 3.419761$

H $\quad 5.701710 \quad 1.128969 \quad 3.823330$

$\begin{array}{llll}\text { H } & 0.974988 & 2.330357 & 2.529270\end{array}$

H $\quad 0.024638 \quad 2.758051 \quad 4.77294$

Fig. S106 H2 / electronic energy: -1.16702456542 a.u. / lowest freq: $4397.33 \mathrm{~cm}-1$

H $0.000000 \quad 0.000000 \quad 0.377453$

H $\quad 0.000000 \quad 0.000000 \quad-0.37745$

Fig._S106_RCHO / electronic energy: $-\mathbf{1 9 2 . 9 8 4 0 6 5 8 2 4}$ a.u. / lowest freq: $153.26 \mathrm{~cm}-1$

$\begin{array}{llll}0 & 1.401165 & -0.687132 & 0.000000\end{array}$

H $-1.252324-1.124869-0.883551$

$\begin{array}{llll}\text { C } & 0.919697 & 0.422075 & 0.000000\end{array}$

H $-1.252326-1.124867 \quad 0.883553$

C $-1.432393 \quad-0.496718 \quad 0.000000$

$\begin{array}{llll}\text { H } & 1.580685 & 1.330267 & 0.000000\end{array}$

$\begin{array}{llll}\text { C } & -0.542228 & 0.720552 & 0.000000\end{array}$

H $-2.494356-0.218374-0.000001$

$\begin{array}{lllll}\text { H } & -0.730725 & 1.379719 & -0.866637\end{array}$

$\begin{array}{lllll}\text { H } & -0.730726 & 1.379719 & 0.866637\end{array}$

84

Fig._S106_Pd-acyl(+) / electronic energy: -2582.17852429 a.u. / lowest freq: $18.05 \mathrm{~cm}-1$

Pd $-0.006524-0.675121-0.185512$

$\begin{array}{llll}P & -2.299572 & -0.291652 & 0.009144\end{array}$

$\begin{array}{llll}P & 2.295916 & -0.356819 & 0.002961\end{array}$

$\begin{array}{llll}O & 0.024358 & 1.659386 & -0.207410\end{array}$

C $-1.169636 \quad 2.311458 \quad 0.071909$

C $-2.330963 \quad 1.529903 \quad 0.205586$

C $-3.534996 \quad 2.179551 \quad 0.509181$

H $\quad-4.450331 \quad 1.591306 \quad 0.620750$

$\begin{array}{lllll}\text { C } & -3.571759 & 3.558324 & 0.674077\end{array}$

H $\quad-4.511847 \quad 4.056131 \quad 0.91845$

$\begin{array}{llll}\text { C } & -2.407738 & 4.306971 & 0.513171\end{array}$

H $\quad-2.456932 \quad 5.391213 \quad 0.624075$

$\begin{array}{llll}\text { C } & -1.186861 & 3.705800 & 0.194634\end{array}$

$\begin{array}{llll}\text { C } & 0.065260 & 4.504591 & -0.139842\end{array}$

C $1.290445 \quad 3.669855 \quad 0.206860$

C $2.525042 \quad 4.234750 \quad 0.538796$

H $2.604456 \quad 5.316879 \quad 0.652673$

C $3.665059 \quad 3.452250 \quad 0.709996$

H $4.616508 \quad 3.921844 \quad 0.965875$

$\begin{array}{llll}\text { C } 3.590463 & 2.075694 & 0.539349\end{array}$

H $4.4875921 .460864 \quad 0.656089$

C $2.371364 \quad 1.461831 \quad 0.222352$

$\begin{array}{llll}\text { C } & 1.234247 & 2.276825 & 0.081767\end{array}$

$\begin{array}{llll}\text { C } & 0.075937 & 4.734473 & -1.664648\end{array}$

$\begin{array}{llll}\text { H } & 0.064062 & 3.786906 & -2.222810\end{array}$

H $0.976628 \quad 5.290319-1.963891$

H $\quad-0.804840 \quad 5.317108 \quad-1.97209$

C $0.081348 \quad 5.857790 \quad 0.562151$

$\begin{array}{llll}\text { H } & 0.071617 & 5.759918 & 1.657085\end{array}$

$\begin{array}{lllll}H & -0.780756 & 6.467234 & 0.264571\end{array}$

$\begin{array}{lllll}\text { H } & 0.967329 & 6.438822 & 0.278037\end{array}$

$\begin{array}{llll}\text { C } & -3.408063 & -0.679302 & -1.376606\end{array}$

$\begin{array}{llll}\text { C } & -3.802304 & -2.017666 & -1.546545\end{array}$

$\begin{array}{llll}\text { H } & -3.503647 & -2.776144 & -0.815160\end{array}$

$\begin{array}{llll}\text { C } & -4.580874 & -2.385235 & -2.640330\end{array}$

H $-4.888921-3.426601-2.758800$

$\begin{array}{llll}\text { C } & -4.965109 & -1.427055 & -3.580797\end{array}$

H $\quad-5.576004-1.716739-4.438775$

$\begin{array}{llll}\text { C } & -4.565818 & -0.100611 & -3.423824\end{array}$

$\begin{array}{llll}\text { H } & -4.863147 & 0.652085 & -4.157476\end{array}$

$\begin{array}{llll}\text { C } & -3.788381 & 0.276163 & -2.328264\end{array}$

$\begin{array}{llll}\text { H } & -3.480649 & 1.319497 & -2.217028\end{array}$

$\begin{array}{llll}\text { C } & -3.100061 & -0.958603 & 1.501418\end{array}$

$\begin{array}{llll}\text { C } & -4.485541 & -1.150802 & 1.601728\end{array}$

$\begin{array}{llll}\text { H } & -5.138709 & -0.919811 & 0.755538\end{array}$

C $-5.035172 \quad-1.641854 \quad 2.784625$

H $\quad-6.114791 \quad-1.791861 \quad 2.856950$

C $-4.212136-1.940923 \quad 3.871317$

$\begin{array}{llll}\text { H } & -4.647921 & -2.329260 & 4.794761\end{array}$

C $-2.833091-1.751601 \quad 3.776413$

H $\quad-2.185508-1.991927 \quad 4.622554$

$\begin{array}{llll}\text { C } & -2.277332 & -1.267166 & 2.594326\end{array}$

$\begin{array}{llll}\text { H } & -1.193969 & -1.132542 & 2.505443\end{array}$

$\begin{array}{llll}\text { C } 3.406582 & -0.741348 & -1.383309\end{array}$

$\begin{array}{llll}\text { C } & 3.794062 & -2.079857 & -1.565555\end{array}$

$\begin{array}{llll}\text { H } & 3.482699 & -2.845267 & -0.846968\end{array}$

$\begin{array}{llll}\text { C } & 4.580878 & -2.439306 & -2.656306\end{array}$

$\begin{array}{lllll}\text { H } & 4.883870 & -3.481035 & -2.784025\end{array}$

$\begin{array}{llll}\text { C } 4.979578 & -1.472835 & -3.581962\end{array}$

H $5.597056-1.756275-4.437306$

$\begin{array}{llll}\text { C } & 4.585750 & -0.146134 & -3.413775\end{array}$

$\begin{array}{llll}\text { H } & 4.893836 & 0.613213 & -4.136053\end{array}$ 
$\begin{array}{llll}\text { C } & 3.800898 & 0.222566 & -2.320874\end{array}$

$\begin{array}{llll}\text { H } & 3.498782 & 1.266488 & -2.200644\end{array}$

$\begin{array}{llll}\text { C } 3.081201 & -1.061230 & 1.486515\end{array}$

$\begin{array}{llll}\text { C } 4.467244 & -1.245119 & 1.597440\end{array}$

$\begin{array}{llll}\text { H } & 5.127301 & -0.989887 & 0.763587\end{array}$

$\begin{array}{llll}\text { C } 5.008305 & -1.760423 & 2.773786\end{array}$

$\begin{array}{llll}\text { H } & 6.088298 & -1.903289 & 2.854407\end{array}$

$\begin{array}{llll}\text { C } & 4.175849 & -2.093687 & 3.843387\end{array}$

H $\quad 4.604934-2.500980 \quad 4.761800$

$\begin{array}{llll}\text { C } & 2.796377 & -1.914971 \quad 3.737224\end{array}$

$\begin{array}{llll}\text { H } & 2.141445 & -2.183177 & 4.569223\end{array}$

C $2.249105-1.405230 \quad 2.561589$

H $\quad 1.165550-1.280415 \quad 2.463358$

\begin{tabular}{lllll}
\hline & -0.072948 & -3.333787 & 0.74315
\end{tabular}

$\begin{array}{llll}\text { H } & -1.227558 & -4.973543 & -1.324136\end{array}$

$\begin{array}{llll}\text { H } & 0.526213 & -5.210793 & -1.248097\end{array}$

$\begin{array}{llll}C & -0.271325 & -4.662251 & -1.767085\end{array}$

$\begin{array}{llll}\text { C } & -0.055368 & -2.655149 & -0.244600\end{array}$

$\begin{array}{lllll}\text { H } & -0.269354 & -4.979405 & -2.817873\end{array}$

C $-0.073449-3.166185-1.664746$

H $\quad-0.848426-2.605723 \quad-2.213534$

$\begin{array}{llll}H & 0.874719 & -2.842836 & -2.127737\end{array}$

Fig._S106_INT1(H2)(+) / electronic energy: - 2583.33916698 a.u. / lowest freq: $24.43 \mathrm{~cm}-1$

P $1.958946-0.417974-0.516830$

$\begin{array}{llll}P & -1.769823 & -0.786086 & 0.057783\end{array}$

$\begin{array}{llll}\text { O } & 0.087000 & 1.131263 & 1.067821\end{array}$

$\begin{array}{llll}\text { C } & 1.040645 & 1.978730 & 0.546285\end{array}$

$\begin{array}{llll}\text { C } 2.038853 & 1.395500 & -0.248185\end{array}$

C $2.969007 \quad 2.256585-0.844109$

H $3.7550561 .851786-1.485874$

C $2.890214 \quad 3.632801-0.633115$

H $3.616788 \quad 4.293185-1.110868$

C $1.903582 \quad 4.172769 \quad 0.192662$

H $1.873464 \quad 5.251490 \quad 0.359252$

C $0.961679 \quad 3.347625 \quad 0.814104$

C $-\mathbf{- 0 . 1 0 7 1 7 3} \quad 3.814833 \quad 1.799160$

C $\quad-1.357667 \quad 2.996485 \quad 1.501612$

$\begin{array}{llll}\text { C } & -2.668579 & 3.481806 & 1.517917\end{array}$

$\begin{array}{llll}\text { H } & -2.856209 & 4.528187 & 1.766357\end{array}$

$\begin{array}{llll}\text { C } & -3.744735 & 2.649177 & 1.208318\end{array}$

H $-4.760315 \quad 3.049395 \quad 1.223355$

C $\quad-3.536663 \quad 1.317672 \quad 0.851703$

H $\quad-4.3852130 .696359 \quad 0.557156$

$\begin{array}{llll}\text { C } & -2.237630 & 0.795119 & 0.828037\end{array}$

$\begin{array}{llll}\text { C } & -1.182078 & 1.651497 & 1.171465\end{array}$

C $0.368880 \quad 3.477633 \quad 3.225050$

H $\quad 0.555087 \quad 2.401528 \quad 3.357065$

H $-0.388480 \quad 3.778310 \quad 3.963425$

H $\quad 1.301766 \quad 4.011403 \quad 3.457950$

$\begin{array}{llll}\text { C }-0.365115 & 5.310339 & 1.697485\end{array}$

$\begin{array}{llll}\text { H } & -0.707854 & 5.607550 & 0.695425\end{array}$

H $0.543853 \quad 5.881263 \quad 1.928787$

H $\quad-1.123928 \quad 5.628002 \quad 2.424633$

$\begin{array}{llll}\text { C } & 2.433239 & -1.117925 & 1.111427\end{array}$

$\begin{array}{llll}\text { C } 2.600966 & -2.508949 & 1.185593\end{array}$

$\begin{array}{llll}\text { H } & 2.395373 & -3.131017 & 0.308294\end{array}$

$\begin{array}{llll}\text { C } & 3.050755 & -3.103870 & 2.361423\end{array}$

H $3.183205 \quad-4.187963 \quad 2.401974$

$\begin{array}{llll}\text { C } & 3.322034 & -2.320693 & 3.484127\end{array}$

H $3.675042 \quad-2.787975 \quad 4.406582$

C $3.139611-0.939715 \quad 3.423841$

$\begin{array}{llll}\text { H } & 3.352237 & -0.319360 & 4.297995\end{array}$

$\begin{array}{llll}\text { C } & 2.699482 & -0.337937 & 2.244567\end{array}$

H $2.589350 \quad 0.7490302 .20976$

$\begin{array}{llll}\text { C } 3.450465 & -0.801498 & -1.506839\end{array}$

$\begin{array}{llll}\text { C } & 4.737885 & -0.569062 & -0.994983\end{array}$

$\begin{array}{llll}\text { H } & 4.858501 & -0.134121 & 0.001981\end{array}$

$\begin{array}{llll}\text { C } & 5.862609 & -0.887688 & -1.750554\end{array}$

H $6.859476-0.698250-1.345748$

C $5.717296-1.453502-3.019694$

$\begin{array}{llll}\text { H } & 6.601904 & -1.707114 & -3.608612\end{array}$

$\begin{array}{llll}\text { C } 4.444612 & -1.703185 & -3.528830\end{array}$

$\begin{array}{llll}\text { H } & 4.326733 & -2.158715 & -4.514698\end{array}$

$\begin{array}{llll}\text { C } & 3.314836 & -1.380407 & -2.774959\end{array}$

H $2.319371-1.598358-3.171930$

$\begin{array}{llll}\text { C } & -1.083532 & -1.859881 & 1.361213\end{array}$

$\begin{array}{llll}C & -0.887513 & -3.212014 & 1.038761\end{array}$

$\begin{array}{llll}\text { H } & -1.099399 & -3.568779 & 0.025671\end{array}$

$\begin{array}{llll}\text { C } & -0.445601 & -4.106741 & 2.008261\end{array}$

$\begin{array}{llll}\text { H } & -0.305847 & -5.159352 & 1.750881\end{array}$

$\begin{array}{llll}C & -0.181262 & -3.657883 & 3.303299\end{array}$

$\begin{array}{llll}\text { H } & 0.169440 & -4.358888 & 4.064624\end{array}$

$\begin{array}{llll}\text { C } & -0.354125 & -2.312015 & 3.622122\end{array}$

$\begin{array}{llll}\text { H } & -0.140831 & -1.956261 & 4.633113\end{array}$

$\begin{array}{llll}\text { C } & -0.806320 & -1.410958 & 2.657373\end{array}$

$\begin{array}{llll}\text { H } & -0.956905 & -0.362321 & 2.927852\end{array}$

C $-3.293411-1.671731-0.389745$ 
$\begin{array}{llll}C & -4.301983 & -1.893248 & 0.561501\end{array}$

H $-4.208031 \quad-1.480943 \quad 1.570432$

$\begin{array}{llll}\text { C } & -5.420068 & -2.652094 & 0.226075\end{array}$

$\begin{array}{llll}\text { H } & -6.204735 & -2.817480 & 0.967717\end{array}$

$\begin{array}{llll}\text { C } & -5.530961 & -3.209750 & -1.049606\end{array}$

$\begin{array}{llll}\text { H } & -6.407810 & -3.808213 & -1.307734\end{array}$

C $-4.520413-3.013054-1.989556$

$\begin{array}{lllll}\text { H } & -4.599822 & -3.459038 & -2.983457\end{array}$

C $-3.403011-2.245392 \quad-1.662122$

H $-2.604701-2.088726-2.393406$

$\begin{array}{llll}H & -2.193675 & 4.265564 & -2.822238\end{array}$

H $\quad-0.509607 \quad 2.385231 \quad-2.830388$

$\begin{array}{llll}\text { H } & -2.655927 & 3.055248 & -4.036278\end{array}$

$\begin{array}{llll}\text { C } & -2.520538 & 3.226563 & -2.959947\end{array}$

$\begin{array}{lllll}C & -1.505201 & 2.274597 & -2.366982\end{array}$

$\begin{array}{llll}\text { H } & -1.333168 & 2.478010 & -1.295996\end{array}$

H $-3.502639 \quad 3.115337-2.480844$

$\begin{array}{llll}C & -1.901633 & 0.819925 & -2.484458\end{array}$

$\begin{array}{llll}\text { H } & 0.073273 & -0.288031 & -3.515416\end{array}$

H $0.7435380 .073631-3.205520$

\begin{tabular}{lllll}
\hline & -2.908881 & 0.416482 & -2.982040
\end{tabular}

$\begin{array}{llll}\text { Pd }-0.340408 & -0.276814 & -1.726739\end{array}$

Fig._S106_TS(H2)(+) / electronic energy: -2583.31506681 a.u. / lowest freq: $-1123.29 \mathrm{~cm}-1$

$\begin{array}{llll}P & 1.978124 & -0.481836 & -0.505966\end{array}$

\begin{tabular}{lllll}
\hline & 0.271211 & 1.258782 & 0.960931
\end{tabular}

$\begin{array}{llll}\text { C } & 1.336950 & 1.994769 & 0.503352\end{array}$

$\begin{array}{llll}\text { C } & 2.316660 & 1.287807 & -0.204163\end{array}$

$\begin{array}{llll}\text { C } 3.407904 & 2.007989 & -0.701266\end{array}$

H $4.192376 \quad 1.496328-1.264410$

C $3.483033 \quad 3.385629-0.494219$

$\begin{array}{lllll}\text { H } & 4.334357 & 3.943262 & -0.889713\end{array}$

$\begin{array}{llll}\text { C } & 2.483392 & 4.059317 & 0.209864\end{array}$

H $2.567860 \quad 5.137790 \quad 0.358693$

C $1.385593 \quad 3.369555 \quad 0.734442$

C $0.276222 \quad 3.977853 \quad 1.586552$

C $\quad-1.018104 \quad 3.261232 \quad 1.212512$

$\begin{array}{llll}\text { C } & -2.281003 & 3.855407 & 1.140038\end{array}$

$\begin{array}{llll}\text { H } & -2.388938 & 4.926689 & 1.321648\end{array}$

$\begin{array}{llll}\text { C } & -3.412047 & 3.094441 & 0.841147\end{array}$

H $\quad-4.390164 \quad 3.577014 \quad 0.789207$

C $\quad-3.308961 \quad 1.725725 \quad 0.597196$

$\begin{array}{lllll}\text { H } & -4.203789 & 1.158710 & 0.332990\end{array}$

$\begin{array}{llll}C & -2.060537 & 1.092328 & 0.650509\end{array}$

C $-0.949351 \quad 1.888849 \quad 0.961230$

$\begin{array}{lllll}\text { C } & 0.584718 & 3.666019 & 3.063986\end{array}$

H $\quad 0.669982 \quad 2.584678 \quad 3.249548$

H $-0.211668 \quad 4.055495 \quad 3.714729$

H $1.532296 \quad 4.134325 \quad 3.367705$

C $0.172428 \quad 5.484073 \quad 1.402795$

$\begin{array}{lllll} & \text { H } & -0.053069 & 5.763139 & 0.363385\end{array}$

H $1.1082825 .979805 \quad 1.692444$

H $-0.611445 \quad 5.905071 \quad 2.046115$

$\begin{array}{llll}\text { C } & 2.192975 & -1.273672 & 1.125296\end{array}$

$\begin{array}{llll}C & 1.969081 & -2.654906 & 1.216622\end{array}$

H $1.607635-3.209101 \quad 0.344102$

$\begin{array}{lllll}\text { C } & 2.217309 & -3.328068 & 2.409818\end{array}$

$\begin{array}{llll}\text { H } 2.041893 & -4.404876 & 2.470227\end{array}$

$\begin{array}{llll}\text { C } & 2.680137 & -2.628560 & 3.525420\end{array}$

H $2.873100 \quad-3.158616 \quad 4.461328$

C $2.886167-1.252162 \quad 3.446208$

$\begin{array}{llll}\text { H } & 3.244915 & -0.699137 & 4.317602\end{array}$

$\begin{array}{llll}\text { C } & 2.643653 & -0.573448 & 2.252086\end{array}$

H $2.827664 \quad 0.503253 \quad 2.200219$

$\begin{array}{llll}\text { C } 3.427212 & -1.095519 & -1.433471\end{array}$

$\begin{array}{llll}\text { C } 4.681011 & -1.161699 & -0.802895\end{array}$

$\begin{array}{llll}\text { H } & 4.787263 & -0.853369 & 0.241580\end{array}$

$\begin{array}{llll}\text { C } & 5.795333 & -1.612222 & -1.504987\end{array}$

H $6.767450-1.652716-1.008417$

$\begin{array}{llll}\text { C } & 5.670092 & -2.013999 & -2.836615\end{array}$

$\begin{array}{llll}\text { H } & 6.545260 & -2.372769 & -3.383424\end{array}$

$\begin{array}{llll}\text { C } 4.426834 & -1.965271 & -3.464210\end{array}$

$\begin{array}{llll}\text { H } & 4.321804 & -2.288788 & -4.502195\end{array}$

$\begin{array}{llll}\text { C } 3.308684 & -1.509338 & -2.765173\end{array}$

H $2.331951-1.484477-3.257461$

C $-1.336453-1.566235 \quad 1.633043$

$\begin{array}{llll}\text { C } & -1.455165 & -2.964238 & 1.574592\end{array}$

$\begin{array}{llll}\text { H } & -1.729269 & -3.453349 & 0.634171\end{array}$

C $-1.249766-3.736806 \quad 2.714016$

H $\quad-1.356959-4.822732 \quad 2.657714$

$\begin{array}{llll}\text { C } & -0.910181 & -3.125791 & 3.921790\end{array}$

H $-0.749046-3.731026 \quad 4.817218$

C $-0.771699-1.740240 \quad 3.981297$

$\begin{array}{llll}\text { H } & -0.502440 & -1.254887 & 4.92267\end{array}$

$\begin{array}{llll}\text { C } & -0.985394 & -0.959620 & 2.844466\end{array}$

$\begin{array}{lllll}\text { H } & -0.895747 & 0.126939 & 2.919321\end{array}$

$\begin{array}{llll}\text { C } & -3.339348 & -1.357499 & -0.314644\end{array}$ 
$\begin{array}{llll}C & -4.395504 & -1.359192 & 0.612278\end{array}$ H $\quad-4.272781-0.872446 \quad 1.584355$

$\begin{array}{llll}\text { C } & -5.596370 & -1.991596 & 0.304669\end{array}$

H $\quad-6.414129-1.982580 \quad 1.029032$

$\begin{array}{llll}C & -5.750441 & -2.646210 & -0.920145\end{array}$

H $-6.692374-3.146842-1.156538$

$\begin{array}{llll}\text { C } & -4.696931 & -2.675568 & -1.831193\end{array}$

$\begin{array}{lllll}\text { H } & -4.805785 & -3.202584 & -2.78174\end{array}$

$\begin{array}{llll}\text { C } & -3.494176 & -2.034412 & -1.529573\end{array}$

$\begin{array}{llll}\text { H } & -2.665098 & -2.075277 & -2.239303\end{array}$

$\begin{array}{llll}\text { H } & -3.530845 & 3.337058 & -2.853728\end{array}$

H - $-1.237086 \quad 2.434531-3.494102$

H $-3.6610602 .157699-4.174189$

$\begin{array}{llll}\text { C } & -3.383069 & 2.282620 & -3.119300\end{array}$

$\begin{array}{lllll}\text { C } & -1.952785 & 1.865455 & -2.871402\end{array}$

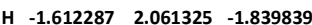

H $-4.084276 \quad 1.683052 \quad-2.520958$

$\begin{array}{llll}\text { C } & -1.682051 & 0.433199 & -3.191048\end{array}$

H $\quad-0.244395 \quad 0.181724 \quad-3.280290$

H $0.8414370 .015296 \quad-2.991050$

$\begin{array}{lllll}0 & -2.350493 & -0.297283 & -3.858899\end{array}$

$\begin{array}{llll}\text { Pd } & -0.073755 & -0.361767 & -1.694292\end{array}$ 86

Fig._S106_INT2(H2)(+) / electronic energy: - 2583.34399044 a.u. / lowest freq: $13.21 \mathrm{~cm}-1$

P $2.002107-0.522231-0.528838$

$\begin{array}{llll}P & -1.780482 & -0.740893 & -0.138499\end{array}$

$\begin{array}{llll}0 & 0.181329 & 0.956810 & 1.141623\end{array}$

C $1.269674 \quad 1.745433 \quad 0.868871$

$\begin{array}{llll}\text { C } & 2.284997 & 1.165449 & 0.095694\end{array}$

C $3.3830531 .961391-0.249440$

H $4.1889921 .548691-0.861203$

C $3.434782 \quad 3.289650 \quad 0.171060$

H $4.290144 \quad 3.908898-0.106092$

C $2.407138 \quad 3.836261 \quad 0.942178$

$\begin{array}{llll}\text { H } & 2.474874 & 4.879392 & 1.257678\end{array}$

C $1.300649 \quad 3.067585 \quad 1.316800$

C $0.148219 \quad 3.537010 \quad 2.200389$

$\begin{array}{llll}\text { C } & -1.123513 & 2.902068 & 1.644611\end{array}$

$\begin{array}{llll}\text { C } & -2.382732 & 3.507258 & 1.613531\end{array}$

H $-2.502916 \quad 4.530063 \quad 1.976239$

C $-3.493606 \quad 2.822317 \quad 1.118538$

H $-4.468542 \quad 3.313554 \quad 1.101835$

$\begin{array}{llll}\text { C } & -3.371191 & 1.522842 & 0.630381\end{array}$

$\begin{array}{llll}\text { H } & -4.244376 & 1.016856 & 0.212263\end{array}$

$\begin{array}{llll}C & -2.125547 & 0.882723 & 0.638107\end{array}$

$\begin{array}{llll}\text { C } & -1.037219 & 1.595529 & 1.158408\end{array}$

$\begin{array}{llll}\text { C } & 0.378481 & 2.988151 & 3.621631\end{array}$

H $0.453993 \quad 1.890636 \quad 3.634225$

$\begin{array}{lllll}\text { H } & -0.453217 & 3.273245 & 4.282210\end{array}$

H $\quad 1.307506 \quad 3.394087 \quad 4.047733$

C $0.050482 \quad 5.054085 \quad 2.259064$

$\begin{array}{llll}\text { H } & -0.129057 & 5.499359 & 1.269619\end{array}$

H $0.970974 \quad 5.491665 \quad 2.667565$

H $\quad-0.762457 \quad 5.369040 \quad 2.926426$

$\begin{array}{llll}\text { C } & 1.910638 & -1.592891 & 0.942651\end{array}$

$\begin{array}{llll}C & 1.554307 & -2.936595 & 0.759655\end{array}$

$\begin{array}{llll}\text { H } & 1.278554 & -3.298783 & -0.236443\end{array}$

$\begin{array}{lllll}\text { C } & 1.552369 & -3.812113 & 1.842059\end{array}$

H $1.274172 \quad-4.857991 \quad 1.692694$

$\begin{array}{llll}\text { C } & 1.894931 & -3.352405 & 3.114489\end{array}$

H $\quad 1.886772 \quad-4.040373 \quad 3.963431$

C $2.237059-2.013885 \quad 3.303721$

$\begin{array}{llll}\text { H } & 2.503664 & -1.649869 & 4.298728\end{array}$

$\begin{array}{llll}\text { C } 2.244762 & -1.132778 & 2.223489\end{array}$

H $2.528914-0.088911 \quad 2.381763$

$\begin{array}{llll}\text { C } 3.570729 & -1.019858 & -1.315934\end{array}$

$\begin{array}{llll}\text { C } & 4.690409 & -1.218100 & -0.489561\end{array}$

$\begin{array}{llll}\text { H } & 4.604709 & -1.094645 & 0.593888\end{array}$

$\begin{array}{llll}\text { C } & 5.918955 & -1.561834 & -1.045585\end{array}$

H $6.7844455-1.705868-0.395175$

$\begin{array}{llll}\text { C } & 6.042405 & -1.724834 & -2.426698\end{array}$

$\begin{array}{llll}\text { H } & 7.006321 & -2.000864 & -2.860326\end{array}$

C $4.933364-1.541974-3.250148$

$\begin{array}{llll}\text { H } & 5.022042 & -1.676980 & -4.330266\end{array}$

C $3.701087-1.192003-2.697720$

$\begin{array}{llll}\text { H } & 2.833383 & -1.056810 & -3.349797\end{array}$

C $-1.734251 \quad-1.939855 \quad 1.240686$

$\begin{array}{llll}\text { C } & -1.972883 & -3.293090 & 0.951336\end{array}$

$\begin{array}{llll}\text { H } & -2.176822 & -3.606299 & -0.077262\end{array}$

$\begin{array}{llll}\text { C } & -1.972443 & -4.241143 & 1.970971\end{array}$

$\begin{array}{llll}\text { H } & -2.174028 & -5.288756 & 1.734725\end{array}$

$\begin{array}{llll}C & -1.716531 & -3.854789 & 3.287581\end{array}$

$\begin{array}{llll}\text { H } & -1.718598 & -4.599152 & 4.087555\end{array}$

$\begin{array}{llll}\text { C } & -1.454134 & -2.516824 & 3.577217\end{array}$

$\begin{array}{llll}\text { H } & -1.245443 & -2.207639 & 4.604403\end{array}$

$\begin{array}{llll}\text { C } & -1.462108 & -1.560854 & 2.560841\end{array}$

H $-1.273405-0.513120 \quad 2.810419$

C $-3.309206-1.184156-1.026303$ 
C $-4.490723-1.540650-0.357765$

$\begin{array}{llll}\text { H } & -4.516534 & -1.560431 & 0.735901\end{array}$

$\begin{array}{llll}\text { C } & -5.631928 & -1.871154 & -1.084097\end{array}$

$\begin{array}{llll}\text { H } & -6.549299 & -2.144356 & -0.557587\end{array}$

$\begin{array}{llll}C & -5.603575 & -1.854844 & -2.480504\end{array}$

H $-6.500309-2.116832-3.047046$

$\begin{array}{llll}\text { C } & -4.431462 & -1.510993 & -3.152379\end{array}$

$\begin{array}{lllll}\text { H } & -4.404644 & -1.505388 & -4.244290\end{array}$

C $-3.287963-1.177969-2.426936$

$\begin{array}{llll}\text { H } & -2.361043 & -0.917388 & -2.952343\end{array}$

H $-0.0901454 .923116-1.669478$

H $0.420553 \quad 2.860830-3.056465$

$\begin{array}{llll}H & -1.352977 & 4.702312 & -2.892604\end{array}$

$\begin{array}{llll}\text { C } & -0.896873 & 4.254878 & -1.998561\end{array}$

$\begin{array}{lllll}\text { C } & -0.370296 & 2.872381 & -2.284899\end{array}$

H $\quad 0.127947 \quad 2.410305 \quad-1.407836$

H $-1.667241 \quad 4.239035-1.214594$

C $-1.396917 \quad 1.879186-2.701418$

$\begin{array}{llll}\text { H } & -0.948389 & 0.851666 & -2.981057\end{array}$

$\begin{array}{llll}\text { H } & 1.292787 & -0.068893 & -2.679438\end{array}$

$\begin{array}{lllll}0 & -2.582763 & 2.048054 & -2.782960\end{array}$

$\begin{array}{llll}\text { Pd } & 0.093814 & -0.404936 & -1.709029\end{array}$

76

Fig._S106_LPdH(+) / electronic energy: -2390.35167658 a.u. / lowest freq: $16.15 \mathrm{~cm}-1$

$\begin{array}{llll}P d & -0.005554 & -0.883393 & 0.281983\end{array}$

$\begin{array}{llll}P & 2.280877 & -0.651140 & 0.129542\end{array}$

$\begin{array}{llll}\text { P } & -2.291020 & -0.640692 & 0.131788\end{array}$

\begin{tabular}{lllll}
\hline & 0.003237 & 1.341364 & -0.053482
\end{tabular}

H $-0.010616-2.413991 \quad 0.451272$

$\begin{array}{llll}\text { C } & 1.204922 & 1.884299 & -0.514647\end{array}$

C $2.338896 \quad 1.057528-0.532072$

C $3.5323891 .586064-1.041015$

$\begin{array}{llll}\text { H } & 4.428359 & 0.959613 & -1.068079\end{array}$

C $3.580965 \quad 2.893130-1.510550$

H $4.5113853 .293045-1.917456$

C $2.445465 \quad 3.698598-1.446410$

H $2.505128 \quad 4.730323-1.796072$

$\begin{array}{llll}\text { C } & 1.238398 & 3.219029 & -0.930009\end{array}$

$\begin{array}{llll}\text { C } 0.013622 & 4.092368 & -0.702128\end{array}$

$\begin{array}{llll}\text { C } & -1.225277 & 3.233365 & -0.907159\end{array}$

C $-2.436183 \quad 3.729409-1.397633$

H $-2.4903894 .763144 \quad-1.742124$

$\begin{array}{lllll}\text { C } & -3.582891 & 2.938586 & -1.439590\end{array}$

$\begin{array}{lllll}\text { H } & -4.517213 & 3.351670 & -1.823743\end{array}$

$\begin{array}{llll}\text { C } & -3.539745 & 1.628565 & -0.978499\end{array}$

$\begin{array}{lllll}\text { H } & -4.443929 & 1.014045 & -0.991969\end{array}$

$\begin{array}{llll}C & -2.342031 & 1.081735 & -0.499511\end{array}$

$\begin{array}{llll}\text { C } & -1.199495 & 1.896651 & -0.496707\end{array}$

$\begin{array}{llll}\text { C } & 0.029827 & 4.543639 & 0.772402\end{array}$

H $\quad 0.031090 \quad 3.690750 \quad 1.466770$

$\begin{array}{llll}H & -0.854835 & 5.157462 & 0.995463\end{array}$

H $0.925450 \quad 5.1470620 .979504$

$\begin{array}{llll}\text { C } & 0.012362 & 5.327298 & -1.592979\end{array}$

H $\quad-0.000897 \quad 5.074659 \quad-2.662773$

$\begin{array}{llll}H & 0.894518 & 5.950195 & -1.398781\end{array}$

$\begin{array}{lllll}\text { H } & -0.856528 & 5.962501 & -1.379779\end{array}$

$\begin{array}{llll}\text { C } 3.237262 & -0.614274 & 1.675894\end{array}$

$\begin{array}{llll}\text { C } 3.475865 & -1.834504 & 2.330031\end{array}$

H $3.123382 \quad-2.772006 \quad 1.888692$

$\begin{array}{llll}\text { C } & 4.163917 & -1.856170 & 3.539468\end{array}$

H $4.350909 \quad-2.809645 \quad 4.038567$

C $4.608427-0.663835 \quad 4.115116$

$\begin{array}{llll}\text { H } & 5.145899 & -0.683055 & 5.065899\end{array}$

C $4.360460 \quad 0.550397 \quad 3.477674$

H $4.703276 \quad 1.485877 \quad 3.925540$

C $3.676635 \quad 0.579978 \quad 2.261882$

H $\quad 3.490289 \quad 1.539079 \quad 1.771806$

C $3.235531-1.666219-1.038447$

$\begin{array}{llll}\text { C } & 4.615189 & -1.870426 & -0.894580\end{array}$

$\begin{array}{llll}\text { H } & 5.152041 & -1.434844 & -0.047098\end{array}$

$\begin{array}{llll}\text { C } & 5.307091 & -2.631278 & -1.835691\end{array}$

H $6.381589-2.788853 \quad-1.718498$

$\begin{array}{llll}\text { C } & 4.631227 & -3.189286 & -2.920964\end{array}$

$\begin{array}{llll}\text { H } & 5.176705 & -3.787565 & -3.654411\end{array}$

$\begin{array}{llll}\text { C } & 3.257675 & -2.989741 & -3.067030\end{array}$

$\begin{array}{llll}\text { H } & 2.725594 & -3.431815 & -3.912212\end{array}$

$\begin{array}{llll}\text { C } & 2.559370 & -2.235270 & -2.127340\end{array}$

H $1.479334-2.088584-2.231237$

$\begin{array}{llll}\text { C } & -3.271313 & -0.627186 & 1.662572\end{array}$

$\begin{array}{llll}\text { C } & -3.679854 & -1.855530 & 2.207440\end{array}$

$\begin{array}{llll}\text { H } & -3.462017 & -2.790101 & 1.681388\end{array}$

$\begin{array}{llll}\text { C } & -4.369985 & -1.888439 & 3.415830\end{array}$

$\begin{array}{llll}\text { H } & -4.691801 & -2.847370 & 3.828152\end{array}$

$\begin{array}{llll}\text { C } & -4.647178 & -0.702219 & 4.098442\end{array}$

$\begin{array}{llll}\text { H } & -5.186957 & -0.731095 & 5.047685\end{array}$

$\begin{array}{lllll}C & -4.231339 & 0.518178 & 3.568433\end{array}$

H $\quad-4.443948 \quad 1.448629 \quad 4.099799$

$\begin{array}{llll}\text { C } & -3.545215 & 0.560238 & 2.354781\end{array}$ 
$\begin{array}{llll}\text { H } & -3.226289 & 1.523908 & 1.948297\end{array}$

C $-3.223191-1.641377-1.065605$

C $-4.618017-1.774885-1.002029$

H $-5.182793-1.293552-0.198479$

C $-5.289284-2.525711-1.965418$

H $-6.375336-2.628255-1.910314$

$\begin{array}{llll}C & -4.578013 & -3.144992 & -2.993762\end{array}$

H $\quad-5.107831-3.735597-3.744697$

C $-3.190219-3.016819-3.059680$

H $-2.630662-3.507396-3.859113$

C $-2.512749-2.271673-2.097035$

H $-1.422298-2.180931-2.136179$

Fig._S107_HI / electronic energy: - 298.468679029 a.u. / lowest freq: $2333.82 \mathrm{~cm}-1$

H $\quad 0.000000 \quad 0.000000 \quad-1.593145$

I $0.000000 \quad 0.000000 \quad 0.030059$

10

Fig._S107_RCHO / electronic energy: -192.984065824 a.u. / lowest freq: $153.26 \mathrm{~cm}-1$

O $1.401165-0.687132 \quad 0.000000$

$\begin{array}{llll}H & -1.252324 & -1.124869 & -0.883551\end{array}$

C $0.919697 \quad 0.422075 \quad 0.000000$

$\begin{array}{llll}\text { H } & -1.252326 & -1.124867 & 0.883553\end{array}$

$\begin{array}{llll}\text { C } & -1.432393 & -0.496718 & 0.000000\end{array}$

H $1.5806851 .330267 \quad 0.000000$

$\begin{array}{llll}\text { C } & -0.542228 & 0.720552 & 0.000000\end{array}$

H $-2.494356-0.218374-0.000001$

$\begin{array}{llll}H & -0.730725 & 1.379719 & -0.866637\end{array}$

$\begin{array}{llll}H & -0.730726 & 1.379719 & 0.866637\end{array}$

Fig._S107_Pd-acyl(+) / electronic energy: - 2582.17852429 a.u. / lowest freq: $18.05 \mathrm{~cm}-1$

Pd $-0.006524-0.675121-0.185512$

$\begin{array}{llll}P & -2.299572 & -0.291652 & 0.009144\end{array}$

$\begin{array}{llll}P & 2.295916 & -0.356819 & 0.002961\end{array}$

\begin{tabular}{lllll}
\hline & 0.024358 & 1.659386 & -0.207410
\end{tabular}

$\begin{array}{llll}\text { C } & -1.169636 & 2.311458 & 0.071909\end{array}$

C $-2.330963 \quad 1.529903 \quad 0.20558$

$\begin{array}{llll}\text { C } & -3.534996 & 2.179551 & 0.509181\end{array}$

H $\quad-4.450331 \quad 1.591306 \quad 0.620750$

$\begin{array}{lllll}\text { C } & -3.571759 & 3.558324 & 0.674077\end{array}$

$\begin{array}{lllll}\text { H } & -4.511847 & 4.056131 & 0.918454\end{array}$

$\begin{array}{llll}C & -2.407738 & 4.306971 & 0.513171\end{array}$

H $-2.456932 \quad 5.391213 \quad 0.624075$

$\begin{array}{llll}\text { C } & -1.186861 & 3.705800 & 0.194634\end{array}$

$\begin{array}{llll}\text { C } & 0.065260 & 4.504591 & -0.139842\end{array}$

C $1.290445 \quad 3.669855 \quad 0.206860$

C $2.525042 \quad 4.234750 \quad 0.538796$

H $2.604456 \quad 5.316879 \quad 0.652673$

C $3.6650593 .452250 \quad 0.709996$

H $4.616508 \quad 3.921844 \quad 0.965875$

$\begin{array}{llll}\text { C } 3.590463 & 2.075694 & 0.539349\end{array}$

H $4.487592 \quad 1.4608640 .656089$

$\begin{array}{llll}\text { C } & 2.371364 & 1.461831 & 0.222352\end{array}$

$\begin{array}{llll}\text { C } & 1.234247 & 2.276825 & 0.081767\end{array}$

$\begin{array}{llll}\text { C } & 0.075937 & 4.734473 & -1.664648\end{array}$

H $0.064062 \quad 3.786906-2.222810$

$\begin{array}{lllll}H & 0.976628 & 5.290319 & -1.963891\end{array}$

$\begin{array}{llll}H & -0.804840 & 5.317108 & -1.972094\end{array}$

C $0.081348 \quad 5.857790 \quad 0.562151$

H $\quad 0.071617 \quad 5.759918 \quad 1.657085$

$\begin{array}{llll}H & -0.780756 & 6.467234 & 0.26457\end{array}$

$\begin{array}{lllll}H & 0.967329 & 6.438822 & 0.278037\end{array}$

$\begin{array}{llll}\text { C }-3.408063 & -0.679302 & -1.376606\end{array}$

$\begin{array}{llll}\text { C } & -3.802304 & -2.017666 & -1.546545\end{array}$

$\begin{array}{llll}\text { H } & -3.503647 & -2.776144 & -0.815160\end{array}$

$\begin{array}{llll}\text { C } & -4.580874 & -2.385235 & -2.640330\end{array}$

H $-4.888921-3.426601-2.758800$

$\begin{array}{llll}\text { C } & -4.965109 & -1.427055 & -3.580797\end{array}$

H $\quad-5.576004-1.716739-4.438775$

$\begin{array}{lllll}C & -4.565818 & -0.100611 & -3.423824\end{array}$

$\begin{array}{lllll}\text { H } & -4.863147 & 0.652085 & -4.157476\end{array}$

C $-3.7883810 .276163 \quad-2.328264$

$\begin{array}{llll}\text { H } & -3.480649 & 1.319497 & -2.217028\end{array}$

$\begin{array}{llll}\text { C } & -3.100061 & -0.958603 & 1.501418\end{array}$

$\begin{array}{llll}C & -4.485541 & -1.150802 & 1.601728\end{array}$

H $\quad-5.138709-0.919811 \quad 0.755538$

$\begin{array}{llll}\text { C } & -5.035172 & -1.641854 & 2.784625\end{array}$

H $\quad-6.114791 \quad-1.791861 \quad 2.856950$

$\begin{array}{llll}\text { C } & -4.212136 & -1.940923 & 3.871317\end{array}$

$\begin{array}{llll}\text { H } & -4.647921 & -2.329260 & 4.794761\end{array}$

C $-2.833091-1.751601 \quad 3.776413$

H $-2.185508-1.991927 \quad 4.622554$

$\begin{array}{llll}C & -2.277332 & -1.267166 & 2.59432\end{array}$

$\begin{array}{llll}\text { H } & -1.193969 & -1.132542 & 2.505443\end{array}$

C $3.406582-0.741348-1.383309$

$\begin{array}{llll}\text { C } & 3.794062 & -2.079857 & -1.565555\end{array}$

$\begin{array}{llll}\text { H } & 3.482699 & -2.845267 & -0.846968\end{array}$

$\begin{array}{llll}\text { C } & 4.580878 & -2.439306 & -2.656306\end{array}$

$\begin{array}{llll}\text { H } & 4.883870 & -3.481035 & -2.784025\end{array}$ 
C $4.979578-1.472835 \quad-3.581962$

H $5.597056-1.756275-4.437306$

$\begin{array}{llll}\text { C } 4.585750 & -0.146134 & -3.413775\end{array}$

H $4.8938360 .613213-4.136053$

$\begin{array}{llll}\text { C } 3.800898 & 0.222566 & -2.320874\end{array}$

H $3.498782 \quad 1.266488-2.200644$

C $3.081201-1.061230 \quad 1.486515$

$\begin{array}{llll}\text { C } 4.467244 & -1.245119 & 1.597440\end{array}$

$\begin{array}{llll}\text { H } & 5.127301 & -0.989887 & 0.763587\end{array}$

C $5.008305-1.760423 \quad 2.773786$

$\begin{array}{llll}\text { H } & 6.088298 & -1.903289 & 2.854407\end{array}$

C $4.175849-2.093687 \quad 3.843387$

H $\quad 4.604934 \quad-2.500980 \quad 4.761800$

C $2.796377-1.914971 \quad 3.737224$

H $2.141445-2.183177 \quad 4.569223$

$\begin{array}{llll}\text { C } & 2.249105 & -1.405230 & 2.561589\end{array}$

H $\quad \begin{array}{llll}1.165550 & -1.280415 & 2.463358\end{array}$

$\begin{array}{llll}0 & -0.072948 & -3.333787 & 0.74315\end{array}$

H $\quad-1.227558 \quad-4.973543 \quad-1.324136$

$\begin{array}{lllll}\text { H } & 0.526213 & -5.210793 & -1.248097\end{array}$

$\begin{array}{llll}\text { C } & -0.271325 & -4.662251 & -1.767085\end{array}$

$\begin{array}{llll}\text { C } & -0.055368 & -2.655149 & -0.244600\end{array}$

H $-0.269354-4.979405-2.817873$

C $-0.073449-3.166185-1.664746$

$\begin{array}{lllll}\text { H } & -0.848426 & -2.605723 & -2.213534\end{array}$

$\begin{array}{llll}H & 0.874719 & -2.842836 & -2.127737\end{array}$

Fig._S107_INT1(HI)(+) / electronic energy: $-\mathbf{2 8 8 0 . 6 5 5 6 2 4 0 6}$ a.u. / lowest freq: $0.88 \mathrm{~cm}-1$

C $-3.645206-1.111068-0.549862$

C $-3.709467-1.359009-1.930343$

$\begin{array}{lllll}\text { H } & -2.917384 & -0.983084 & -2.587701\end{array}$

$\begin{array}{llll}\text { C } & -4.781070 & -2.070694 & -2.461785\end{array}$

$\begin{array}{llll}\text { H } & -4.830228 & -2.256440 & -3.536982\end{array}$

$\begin{array}{llll}\text { C } & -5.784096 & -2.553898 & -1.618548\end{array}$

$\begin{array}{llll}\text { H } & -6.620553 & -3.119635 & -2.035148\end{array}$

$\begin{array}{llll}\text { C } & -5.717092 & -2.319175 & -0.245462\end{array}$

$\begin{array}{llll}\text { H } & -6.501462 & -2.697085 & 0.414198\end{array}$

$\begin{array}{lllll}\text { C } & -4.652250 & -1.597089 & 0.293382\end{array}$

H $\quad-4.609019 \quad-1.409953 \quad 1.369864$

$\begin{array}{llll}\text { C } & -2.182627 & -0.279959 & 1.876944\end{array}$

$\begin{array}{llll}C & -2.502928 & 0.811797 & 2.695768\end{array}$

H $\quad-2.848563 \quad 1.750857 \quad 2.254336$

C $-2.384849 \quad 0.701249 \quad 4.080804$

H $\quad-2.638339 \quad 1.555005 \quad 4.713450$

$\begin{array}{llll}\text { C } & -1.948119 & -0.491815 & 4.656723\end{array}$

$\begin{array}{llll}\text { H } & -1.853540 & -0.571567 & 5.742227\end{array}$

C $-1.626211 \quad-1.581858 \quad 3.846230$

H $\quad-1.278055 \quad-2.516203 \quad 4.292744$

$\begin{array}{llll}\text { C } & -1.734956 & -1.477004 & 2.461755\end{array}$

$\begin{array}{lllll}\text { H } & -1.472579 & -2.332271 & 1.828746\end{array}$

$\begin{array}{llll}\text { C } & -2.499641 & 1.557349 & -0.355070\end{array}$

$\begin{array}{lllll}C & -3.736718 & 2.003565 & -0.840290\end{array}$

$\begin{array}{llll}\text { H } & -4.557897 & 1.292622 & -0.959517\end{array}$

$\begin{array}{llll}\text { C } & -3.923628 & 3.340088 & -1.176739\end{array}$

H $-4.8889713 .673651 \quad-1.562011$

$\begin{array}{llll}C & -2.888400 & 4.257131 & -1.002234\end{array}$

H $\quad-3.058312 \quad 5.306920 \quad-1.247856$

C $-1.647504 \quad 3.858369-0.499529$

$\begin{array}{lllll}\text { C } & -0.522505 & 4.818064 & -0.140180\end{array}$

$\begin{array}{llll}\text { C } & 0.796013 & 4.116296 & -0.434267\end{array}$

$\begin{array}{lllll}\text { C } & 1.948746 & 4.773821 & -0.868994\end{array}$

$\begin{array}{lllll}\text { H } & 1.906971 & 5.840080 & -1.098439\end{array}$

$\begin{array}{llll}\text { C } & 3.160186 & 4.096514 & -0.995491\end{array}$

H $4.052818 \quad 4.630402 \quad-1.326799$

$\begin{array}{llll}\text { C } 3.237346 & 2.743244 & -0.687591\end{array}$

$\begin{array}{llll}\text { H } & 4.191829 & 2.219828 & -0.781500\end{array}$

$\begin{array}{llll}\text { C } & 2.099327 & 2.037371 & -0.270207\end{array}$

$\begin{array}{llll}\text { C } & 0.885678 & 2.745549 & -0.163181\end{array}$

$\begin{array}{llll}\text { C } & -1.463748 & 2.501150 & -0.214711\end{array}$

$\begin{array}{llll}\text { C } & -0.643637 & 6.148928 & -0.867651\end{array}$

H $\quad 0.158287 \quad 6.835258-0.566931$

$\begin{array}{llll}H & -1.585503 & 6.651787 & -0.613035\end{array}$

$\begin{array}{lllll}\text { H } & -0.602169 & 6.031813 & -1.960126\end{array}$

$\begin{array}{llll}\text { C } & -0.591442 & 5.067458 & 1.380380\end{array}$

H $\quad-0.513659 \quad 4.132167 \quad 1.955279$

H $\quad-1.5434715 .548051 \quad 1.649812$

H $\quad 0.2277295 .727932 \quad 1.700601$

C $3.755642 \quad-0.314879-0.667385$

$\begin{array}{llll}\text { C } & 4.906205 & -0.564716 & 0.091536\end{array}$

$\begin{array}{llll}\text { H } & 4.898157 & -0.414400 & 1.174347\end{array}$

$\begin{array}{llll}\text { C } & 6.071687 & -1.001133 & -0.538233\end{array}$

H $6.966263-1.196328 \quad 0.057483$

C $6.098725-1.182122-1.920834$

$\begin{array}{lllll}\text { H } & 7.013997 & -1.524807 & -2.408830\end{array}$

$\begin{array}{llll}\text { C } 4.956350 & -0.926555 & -2.681659\end{array}$

H $4.974532-1.065373-3.764852$

$\begin{array}{llll}\text { C } 3.786349 & -0.501847 & -2.058393\end{array}$

$\begin{array}{llll}\text { H } & 2.891220 & -0.298602 & -2.65567\end{array}$ 
$\begin{array}{llll}\text { C } & 2.291637 & 0.033104 & 1.861963\end{array}$

C $2.066072 \quad 1.091336 \quad 2.753636$

H $1.9060432 .106103 \quad 2378328$

C $2.056929 \quad 0.855066 \quad 4.128134$

$\begin{array}{llll}\text { H } & 1.883627 & 1.685659 & 4.816179\end{array}$

$\begin{array}{llll}\text { C } & 2.274601 & -0.430501 & 4.622736\end{array}$

H $2.269495-0.610295 \quad 5.700260$

C $2.494672 \quad-1.489323 \quad 3.739199$

H $2.663606 \quad-2.498693 \quad 4.121210$

$\begin{array}{llll}\text { C } 2.493117 & -1.264395 & 2.365673\end{array}$

H $2.660440-2.100006 \quad 1.678503$

$\begin{array}{lllll}0 & -0.239758 & 2.060858 & 0.239870\end{array}$

$\begin{array}{lllll}\text { P } & -2.212587 & -0.188530 & 0.060042\end{array}$

$\begin{array}{llll}P & 2.192782 & 0.247420 & 0.058345\end{array}$

$\begin{array}{llll}\text { H } & 0.803112 & -0.341626 & -4.964157\end{array}$

$\begin{array}{llll}\text { H } & -0.961532 & -0.500648 & -4.901021\end{array}$

$\begin{array}{llll}\text { C } & -0.016759 & -1.004717 & -4.656848\end{array}$

H $0.044466-1.918837-5.260638$

$\begin{array}{lllll}\text { O } & -0.123291 & 1.000622 & -2.625989\end{array}$

$\begin{array}{llll}\text { C } & 0.067053 & -1.349574 & -3.186473\end{array}$

$\begin{array}{llll}\text { C } & -0.018050 & -0.139631 & -2.293705\end{array}$

H $1.002011-1.876785-2.933811$

$\begin{array}{lllll}\text { H } & -0.730657 & -2.042547 & -2.872915\end{array}$

$\begin{array}{llll}\text { Pd } & 0.058674 & -0.633316 & -0.353507\end{array}$

$\begin{array}{lllll}H & 0.285085 & -2.478683 & -0.394523\end{array}$

\begin{tabular}{llll}
\hline & 0.429473 & -4.184072 & -0.170109
\end{tabular}

86

Fig._S107_TS1(HI)(+) / electronic energy: $-\mathbf{2 8 8 0 . 6 4 9 1 9 6 9 0 ~ a . u . ~ / ~ l o w e s t ~ f r e q : ~}-537.19 \mathrm{~cm}-1$

$\begin{array}{lll}\text { C }-2.902707 & -2.427367 & -0.081431\end{array}$

$\begin{array}{llll}\text { C } & -2.834984 & -3.042251 & -1.340500\end{array}$

$\begin{array}{llll}\text { H } & -2.160469 & -2.643135 & -2.105658\end{array}$

$\begin{array}{llll}\text { C } & -3.627439 & -4.152014 & -1.620437\end{array}$

$\begin{array}{llll}\text { H } & -3.573402 & -4.623915 & -2.603909\end{array}$

$\begin{array}{llll}\text { C } & -4.481550 & -4.663729 & -0.641324\end{array}$

H $-5.096185-5.540273-0.858624$

$\begin{array}{llll}\text { C } & -4.545891 & -4.060429 & 0.614091\end{array}$

$\begin{array}{llll}\text { H } & -5.212117 & -4.460930 & 1.381470\end{array}$

$\begin{array}{llll}\text { C } & -3.762865 & -2.941238 & 0.897052\end{array}$

$\begin{array}{llll}\text { H } & -3.824682 & -2.469348 & 1.881415\end{array}$

$\begin{array}{llll}\text { C } & -1.830200 & -0.690577 & 2.006886\end{array}$

$\begin{array}{llll}C & -2.586550 & 0.289459 & 2.662988\end{array}$

H $\begin{array}{llll}\text { H } & -3.264839 & 0.936028 & 2.099080\end{array}$

$\begin{array}{llll}\text { C } & -2.481425 & 0.435157 & 4.045603\end{array}$

H $\quad-3.074986 \quad 1.198396 \quad 4.553982$

$\begin{array}{llll}\text { C } & -1.625577 & -0.388689 & 4.777209\end{array}$

$\begin{array}{llll}\text { H } & -1.544732 & -0.267325 & 5.860052\end{array}$

C $-0.867445-1.363647 \quad 4.126923$

H $\quad-0.192515 \quad-2.006988 \quad 4.696056$

$\begin{array}{llll}\text { C } & -0.963645 & -1.512178 & 2.746020\end{array}$

$\begin{array}{llll}\text { H } & -0.363039 & -2.272379 & 2.232047\end{array}$

$\begin{array}{llll}\text { C } & -2.861447 & 0.419063 & -0.485071\end{array}$

C $-4.117856 \quad 0.244068-1.081318$

H $-4.573856 \quad-0.748056-1.11518$

$\begin{array}{llll}\text { C } & -4.781978 & 1.333553 & -1.637453\end{array}$

$\begin{array}{lllll}\text { H } & -5.757139 & 1.190382 & -2.106775\end{array}$

$\begin{array}{llll}C & -4.215872 & 2.608358 & -1.588116\end{array}$

$\begin{array}{lllll}\text { H } & -4.760687 & 3.451131 & -2.018323\end{array}$

$\begin{array}{llll}\text { C } & -2.974616 & 2.824557 & -0.984612\end{array}$

$\begin{array}{llll}\text { C } & -2.333171 & 4.189720 & -0.773726\end{array}$

$\begin{array}{lllll}\text { C } & -0.827738 & 4.005819 & -0.917180\end{array}$

$\begin{array}{llll}\text { C } & 0.045319 & 4.960237 & -1.444594\end{array}$

$\begin{array}{lllll}\text { H } & -0.353295 & 5.893344 & -1.847348\end{array}$

C $1.424193 \quad 4.746717-1.452893$

H $2.089438 \quad 5.510239-1.860927$

C $1.958783 \quad 3.567122-0.942421$

H $3.039304 \quad 3.406218-0.96056$

$\begin{array}{llll}\text { C } & 1.114550 & 2.577305 & -0.421138\end{array}$

$\begin{array}{llll}\text { C } & -0.263809 & 2.827206 & -0.419893\end{array}$

$\begin{array}{llll}\text { C } & -2.312726 & 1.709008 & -0.464343\end{array}$

$\begin{array}{llll}\text { C } & -2.881594 & 5.238913 & -1.729222\end{array}$

H $-2.4259196 .219484-1.539170$

H $-3.962262 \quad 5.371555-1.587856$

$\begin{array}{lllll}\text { H } & -2.703595 & 4.978255 & -2.782447\end{array}$

C $-2.622643 \quad 4.626880 \quad 0.676167$

H $-2.2410213 .901361 \quad 1.410426$

\begin{tabular}{lllll}
\hline H & -3.705327 & 4.731004 & 0.839726
\end{tabular}

$\begin{array}{lllll}\text { H } & -2.150098 & 5.597271 & 0.887849\end{array}$

$\begin{array}{llll}\text { C } 3.434708 & 0.900006 & -0.431886\end{array}$

$\begin{array}{llll}\text { C } & 4.538567 & 1.240748 & 0.359750\end{array}$

$\begin{array}{llll}\text { H } & 4.397232 & 1.555527 & 1.397144\end{array}$

C $5.825687 \quad 1.187436-0.175668$

H $6.6814491 .453995 \quad 0.448925$

C $6.0208690 .802699-1.501985$

H $7.030627 \quad 0.762608$-1.916906

$\begin{array}{llll}\text { C } 4.924681 & 0.466653 & -2.298136\end{array}$

$\begin{array}{lllll}\text { H } & 5.071644 & 0.164706 & -3.337593\end{array}$

C $3.6394420 .507785-1.763755$

$\begin{array}{lllll}\text { H } & 2.780366 & 0.241817 & -2.390129\end{array}$ 
$\begin{array}{llll}\text { C } & 1.808152 & 1.071224 & 1.974339\end{array}$

C $1.189374 \quad 2.096027 \quad 2.702406$

H $\quad 0.666390 \quad 2.905716 \quad 2.185213$

C $1.246356 \quad 2.096759 \quad 4.096507$

$\begin{array}{llll}\text { H } & 0.760575 & 2.900948 \quad 4.654352\end{array}$

C $1.922203 \quad 1.083270 \quad 4.774653$

H $1.967932 \quad 1.090739 \quad 5.866316$

C $2.538303 \quad 0.0575384 .055255$

H $3.069078 \quad-0.740551 \quad 4.579679$

$\begin{array}{lll}\text { C } 2.472586 & 0.042874 & 2.664712\end{array}$

$\begin{array}{llll}\text { H } & 2.954527 & -0.768072 & 2.107740\end{array}$

\begin{tabular}{lllll}
\hline & -1.070545 & 1.841780 & 0.095964
\end{tabular}

$\begin{array}{llll}\text { P } & -1.894009 & -0.944582 & 0.210580\end{array}$

$\begin{array}{llll}P & 1.711999 & 0.957508 & 0.157503\end{array}$

$\begin{array}{llll}\text { H } & 0.460721 & -0.389347 & -5.022180\end{array}$

H $-1.032501-1.318151-4.775226$

$\begin{array}{llll}\text { C } & 0.060948 & -1.352333 & -4.679352\end{array}$

$\begin{array}{lllll}\text { H } & 0.434957 & -2.134419 & -5.351788\end{array}$

$\begin{array}{lllll}\mathrm{O} & -0.457120 & 0.447117 & -2.530390\end{array}$

$\begin{array}{llll}\text { C } & 0.485969 & -1.660717 & -3.260609\end{array}$

$\begin{array}{llll}C & 0.016935 & -0.610542 & -2.289990\end{array}$

H $\quad 1.582479-1.706555-3.148868$

H $0.132485-2.641022 \quad-2.909748$

$\begin{array}{lllll}\text { Pd } & 0.399933 & -1.153008 & -0.355164\end{array}$

H $0.234864-2.764322 \quad-0.485406$

$\begin{array}{llll}\text { I } & 2.328109 & -3.154252 & -0.350683\end{array}$

86

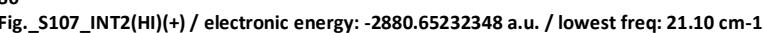

C $-2.907479-2.478970-0.012258$

$\begin{array}{llll}\text { C } & -2.841737 & -3.137723 & -1.248538\end{array}$

$\begin{array}{llll}H & -2.157289 & -2.776841 & -2.023710\end{array}$

$\begin{array}{lllll}\text { C } & -3.647738 & -4.245800 & -1.493052\end{array}$

$\begin{array}{lllll}\text { H } & -3.594410 & -4.753477 & -2.458463\end{array}$

$\begin{array}{llll}\text { C } & -4.514036 & -4.710396 & -0.501189\end{array}$

H $-5.138532-5.586446-0.690293$

$\begin{array}{llll}\text { C } & -4.577825 & -4.061321 & 0.730929\end{array}$

$\begin{array}{llll}\text { H } & -5.252200 & -4.425703 & 1.509012\end{array}$

$\begin{array}{llll}\text { C } & -3.781325 & -2.943007 & 0.978419\end{array}$

$\begin{array}{llll}\text { H } & -3.842316 & -2.435757 & 1.945017\end{array}$

$\begin{array}{llll}\text { C } & -1.829074 & -0.682579 & 2.019494\end{array}$

$\begin{array}{llll}\text { C } & -2.581312 & 0.314678 & 2.654000\end{array}$

H $\begin{array}{llll}\text {-3.258856 } & 0.950385 & 2.077240\end{array}$

$\begin{array}{llll}\text { C } & -2.473855 & 0.487873 & 4.032957\end{array}$

H $\quad-3.063381 \quad 1.263703 \quad 4.526596$

$\begin{array}{llll}\text { C } & -1.619915 & -0.324383 & 4.779851\end{array}$

H $-1.536484-0.180192 \quad 5.859677$

C $-0.867115-1.316676 \quad 4.149972$

H $\quad-0.193178 \quad-1.949598 \quad 4.731597$

$\begin{array}{llll}\text { C } & -0.966309 & -1.494767 & 2.773010\end{array}$

$\begin{array}{llll}\text { H } & -0.369252 & -2.267486 & 2.272644\end{array}$

$\begin{array}{llll}C & -2.893197 & 0.342166 & -0.507564\end{array}$

C $-4.138258 \quad 0.134016-1.117310$

H $-4.579250-0.865057-1.140582$

$\begin{array}{llll}\text { C } & -4.809710 & 1.204966 & -1.700256\end{array}$

H $\quad-5.776132 \quad 1.039375 \quad-2.180004$

$\begin{array}{llll}C & -4.262817 & 2.489164 & -1.667762\end{array}$

$\begin{array}{lllll}\text { H } & -4.814279 & 3.314576 & -2.122403\end{array}$

C $-3.032994 \quad 2.736484-1.052344$

$\begin{array}{llll}\text { C } & -2.408753 & 4.112978 & -0.861959\end{array}$

$\begin{array}{lllll}\text { C } & -0.898781 & 3.940625 & -0.971369\end{array}$

$\begin{array}{lllll}\text { C } & -0.021645 & 4.895002 & -1.492123\end{array}$

$\begin{array}{llll}\text { H } & -0.417824 & 5.821246 & -1.912785\end{array}$

$\begin{array}{llll}\text { C } & 1.358303 & 4.690349 & -1.468673\end{array}$

H $2.0269195 .454897-1.869132$

C $1.891524 \quad 3.517720-0.940049$

$\begin{array}{llll}\text { H } & 2.973230 & 3.366479 & -0.937378\end{array}$

$\begin{array}{lllll}\text { C } & 1.943093 & 2.526325 & -0.42848\end{array}$

$\begin{array}{llll}\text { C } & -0.333087 & 2.774792 & -0.448094\end{array}$

$\begin{array}{llll}\text { C } & -2.366390 & 1.639581 & -0.501936\end{array}$

C $-2.948514 \quad 5.130941-1.855564$

H $-2.507764 \quad 6.121281-1.682229$

H $-4.033346 \quad 5.254452-1.739865$

$\begin{array}{llll}\text { H } & -2.745678 & 4.844539 & -2.897501\end{array}$

C $-2.729305 \quad 4.584436 \quad 0.570434$

$\begin{array}{llll}\text { H } & -2.346413 & 3.886524 & 1.330360\end{array}$

H $\quad-3.8159094 .675565 \quad 0.714200$

H $\quad-2.275266 \quad 5.567794 \quad 0.761389$

$\begin{array}{llll}\text { C } 3.361400 & 0.884929 & -0.408371\end{array}$

$\begin{array}{llll}\text { C } & 4.468116 & 1.139774 & 0.408480\end{array}$

H $4.333368 \quad 1.372186 \quad 1.467796$

C $5.756354 \quad 1.105933-0.128240$

H $\quad 6.614559 \quad 1.304117 \quad 0.517965$

C $5.9486160 .829102-1.480552$

$\begin{array}{lllll}\text { H } & 6.958483 & 0.803681 & -1.896316\end{array}$

$\begin{array}{llll}\text { C } 4.847436 & 0.584752 & -2.303602\end{array}$

$\begin{array}{lllll}\text { H } & 4.990715 & 0.368208 & -3.364637\end{array}$

C $3.5630050 .604315-1.76886$

$\begin{array}{lllll}\text { H } & 2.703372 & 0.404660 & -2.417914\end{array}$ 
$\begin{array}{llll}\text { C } & 1.726146 & 1.072837 & 1.997377\end{array}$

C $\quad 1.131170 \quad 2.134687 \quad 2.691495$

$\begin{array}{lllll}\text { H } & 0.619435 & 2.935211 & 2.149468\end{array}$

C $\quad 1.196826 \quad 2.184086 \quad 4.084384$

H $0.729308 \quad 3.016610 \quad 4.615514$

C $1.859337 \quad 1.183666 \quad 4.794200$

H $1.913306 \quad 1.229924 \quad 5.884535$

C $2.451150 \quad 0.121322 \quad 4.108673$

$\begin{array}{llll}\text { H } & 2.970744 & -0.667167 & 4.658197\end{array}$

$\begin{array}{llll}\text { C } & 2.375811 & 0.057732 & 2.719946\end{array}$

$\begin{array}{llll}\text { H } & 2.837848 & -0.781601 & 2.188471\end{array}$

\begin{tabular}{lllll}
\hline & -1.137097 & 1.792118 & 0.076174
\end{tabular}

$\begin{array}{lllll}\text { P } & -1.908149 & -0.981295 & 0.23425\end{array}$

$\begin{array}{llll}P & 1.636006 & 0.911924 & 0.183013\end{array}$

$\begin{array}{llll}\text { H } & 0.434278 & -0.588535 & -5.066872\end{array}$

$\begin{array}{llll}\text { H } & -1.080066 & -1.473907 & -4.785054\end{array}$

$\begin{array}{llll}\text { C } & 0.013218 & -1.534696 & -4.703409\end{array}$

H $\quad 0.357690 \quad-2.337353 \quad-5.367138$

$\begin{array}{lllll}0 & -0.417859 & 0.306405 & -2.545520\end{array}$

$\begin{array}{llll}\text { C } & 0.450445 & -1.834178 & -3.286785\end{array}$

$\begin{array}{llll}\text { C } & 0.024555 & -0.766213 & -2.325976\end{array}$

$\begin{array}{lllll}\text { H } & 1.547282 & -1.898896 & -3.181090\end{array}$

$\begin{array}{lllll}H & 0.085943 & -2.801470 & -2.912782\end{array}$

$\begin{array}{llll}\text { Pd } & 0.382795 & -1.281362 & -0.356424\end{array}$

$\begin{array}{lllll}\text { H } & -0.165329 & -2.730440 & -0.573827\end{array}$

$\begin{array}{lllll}\text { I } & 2.635621 & -2.804671 & -0.358759\end{array}$

86

Fig._S107_TS2(HI)(+) / electronic energy: $-\mathbf{2 8 8 0 . 6 3 8 1 9 4 1 6}$ a.u. / lowest freq: $-465.20 \mathrm{~cm}-1$

C $-2.386512-2.894555 \quad 0.110153$

$\begin{array}{llll}\text { C } & -2.509505 & -3.520858 & -1.141768\end{array}$

$\begin{array}{llll}\text { H } & -2.233843 & -2.987790 & -2.055076\end{array}$

C $-2.996143-4.821190-1.230535$

$\begin{array}{llll}\text { H } & -3.092396 & -5.295507 & -2.209578\end{array}$

$\begin{array}{llll}\text { C } & -3.354327 & -5.516858 & -0.073955\end{array}$

H $-3.728069-6.540725-0.145214$

$\begin{array}{llll}\text { C } & -3.233438 & -4.902074 & 1.170353\end{array}$

$\begin{array}{llll}\text { H } & -3.513720 & -5.439569 & 2.078827\end{array}$

$\begin{array}{llll}\text { C } & -2.753542 & -3.595901 & 1.267599\end{array}$

$\begin{array}{llll}\text { H } & -2.670545 & -3.127877 & 2.250925\end{array}$

C $-1.702561-0.777279 \quad 1.969787$

C $-2.716210-0.026392 \quad 2.580429$

$\begin{array}{llll}\text { H } & -3.552369 & 0.359723 & 1.990696\end{array}$

$\begin{array}{llll}\text { C } & -2.665505 & 0.216895 & 3.951472\end{array}$

$\begin{array}{llll}\text { H } & -3.458441 & 0.799469 & 4.425843\end{array}$

$\begin{array}{llll}\text { C } & -1.613017 & -0.288272 & 4.716453\end{array}$

$\begin{array}{llll}\text { H } & -1.579954 & -0.097399 & 5.791858\end{array}$

$\begin{array}{llll}\text { C } & -0.599187 & -1.030859 & 4.110143\end{array}$

H $0.227195 \quad-1.423864 \quad 4.706236$

$\begin{array}{llll}\text { C } & -0.637060 & -1.268812 & 2.738657\end{array}$

$\begin{array}{lllll}\text { H } & 0.162825 & -1.846604 & 2.257401\end{array}$

$\begin{array}{llll}\text { C } & -2.971708 & -0.137105 & -0.577846\end{array}$

C $-4.144147-0.571359-1.208523$

H $-4.407248-1.631286-1.217247$

$\begin{array}{llll}\text { C } & -4.972603 & 0.360380 & -1.829802\end{array}$

H $\quad-5.8856860 .022973 \quad-2.323750$

$\begin{array}{llll}\text { C } & -4.652499 & 1.720437 & -1.824748\end{array}$

$\begin{array}{llll}\text { H } & -5.324798 & 2.426995 & -2.315727\end{array}$

C $-3.499425 \quad 2.189659-1.187786$

$\begin{array}{llll}\text { C } & -3.104915 & 3.653033 & -1.02328\end{array}$

$\begin{array}{llll}\text { C } & -1.580767 & 3.722133 & -1.057577\end{array}$

$\begin{array}{llll}\text { C } & -0.839539 & 4.792227 & -1.563084\end{array}$

$\begin{array}{lllll}\text { H } & -1.352862 & 5.635167 & -2.030332\end{array}$

$\begin{array}{llll}\text { C } & 0.552840 & 4.808853 & -1.465172\end{array}$

H $1.1126685 .663216-1.850536$

C $1.238363 \quad 3.743103 \quad-0.888393$

$\begin{array}{llll}\text { H } & 2.328649 & 3.766999 & -0.835283\end{array}$

$\begin{array}{lllll}\text { C } & 0.532699 & 2.634966 & -0.396659\end{array}$

$\begin{array}{llll}\text { C } & -0.862200 & 2.672463 & -0.477371\end{array}$

$\begin{array}{llll}\text { C } & -2.685788 & 1.232246 & -0.584813\end{array}$

$\begin{array}{llll}C & -3.742527 & 4.542671 & -2.080232\end{array}$

H $\quad-3.479230 \quad 5.595762 \quad-1.916624$

H $-4.837906 \quad 4.489207 \quad-2.029816$

$\begin{array}{lllll}\text { H } & -3.433363 & 4.266160 & -3.098433\end{array}$

$\begin{array}{llll}C & -3.567814 & 4.109335 & 0.374478\end{array}$

H $\quad-3.1330893 .491271 \quad 1.174626$

H $-4.662605 \quad 4.046663 \quad 0.458284$

H $\quad \begin{array}{llll}\text { H. } & -270947 & 5.152345 & 0.557533\end{array}$

$\begin{array}{llll}\text { C } & 3.052924 & 1.365753 & -0.393099\end{array}$

$\begin{array}{llll}\text { C } & 4.172775 & 1.695256 & 0.374897\end{array}$

H $4.082001 \quad 1.8572961 .451426$

$\begin{array}{llll}\text { C } & 5.421633 & 1.825886 & -0.236767\end{array}$

H $6.293152 \quad 2.080735 \quad 0.370530$

$\begin{array}{llll}\text { C } & 5.557916 & 1.638087 & -1.610637\end{array}$

H $6.537700 \quad 1.739532 \quad-2.082802$

$\begin{array}{llll}\text { C } 4.437566 & 1.325298 & -2.384655\end{array}$

H $4.534893 \quad 1.184872 \quad-3.463831$

C $3.193887 \quad 1.186854-1.778273$

H $2.3148240 .946286-2.386646$ 
$\begin{array}{llll}\text { C } & 1.462046 & 1.391182 & 2.073407\end{array}$

$\begin{array}{llll}\text { C } & 0.676511 & 2.346095 & 2.732685\end{array}$

$\begin{array}{lllll}\text { H } & 0.000921 & 2.995603 & 2.168598\end{array}$

C $0.760579 \quad 2.481910 \quad 4.118320$

$\begin{array}{llll}\text { H } & 0.145107 & 3.229672 & 4.623931\end{array}$

C $1.629312 \quad 1.675767 \quad 4.852897$

H $\quad 1.698674 \quad 1.792507 \quad 5.937042$

C $2.405253 \quad 0.715233 \quad 4.201796$

H $3.081803 \quad 0.074978 \quad 4.772657$

$\begin{array}{llll}\text { C } 2.313270 & 0.560754 & 2.821662\end{array}$

$\begin{array}{llll}\text { H } & 2.913649 & -0.203889 & 2.317246\end{array}$

\begin{tabular}{lllll}
\hline & -1.527811 & 1.596474 & 0.045567
\end{tabular}

$\begin{array}{lllll}P & -1.737609 & -1.195095 & 0.20734\end{array}$

$\begin{array}{llll}P & 1.369343 & 1.147612 & 0.274387\end{array}$

$\begin{array}{llll}\text { H } & 1.013015 & -0.301792 & -4.919321\end{array}$

$\begin{array}{llll}\text { H } & 0.338917 & -1.907574 & -5.257418\end{array}$

$\begin{array}{llll}\text { C } & 1.184251 & -1.379837 & -4.797462\end{array}$

H $2.091638-1.640993-5.356383$

$\begin{array}{lllll}O & -0.933624 & -1.139824 & -2.909373\end{array}$

$\begin{array}{llll}\text { C } & 1.359662 & -1.756868 & -3.345691\end{array}$

$\begin{array}{llll}\text { C } & 0.144662 & -1.449411 & -2.520844\end{array}$

$\begin{array}{llll}\text { H } & 2.234986 & -1.282614 & -2.880141\end{array}$

H $1.538791-2.836844-3.200601$

$\begin{array}{llll}\text { Pd } & 0.569045 & -1.126378 & -0.484884\end{array}$

$\begin{array}{lllll}\text { H } & 0.190013 & -2.512825 & -1.210962\end{array}$

$\begin{array}{llll}1 & 0.056298 & -2.295866 & -0.141058\end{array}$

Fig._S107_INT3(HI)(+) / electronic energy: - 2880.67558307 a.u. / lowest freq: $19.45 \mathrm{~cm}-1$

C $0.117944-2.803174-1.616430$

$\begin{array}{llll}\text { C } & 0.416308 & -2.187056 & -2.853759\end{array}$

H $\quad-0.051573 \quad-1.229780 \quad-3.106228$

$\begin{array}{llll}\text { C } & 1.291605 & -2.803359 & -3.744767\end{array}$

$\begin{array}{llll}\text { H } & 1.517007 & -2.323476 & -4.699337\end{array}$

$\begin{array}{llll}\text { C } & 1.879558 & -4.021738 & -3.410792\end{array}$

$\begin{array}{llll}\text { H } & 2.570138 & -4.502201 & -4.107168\end{array}$

$\begin{array}{llll}\text { C } & 1.585662 & -4.636736 & -2.189113\end{array}$

$\begin{array}{llll}\text { H } & 2.039905 & -5.597636 & -1.939207\end{array}$

$\begin{array}{llll}\text { C } & 0.714873 & -4.034883 & -1.288947\end{array}$

$\begin{array}{llll}\text { H } & 0.487022 & -4.525852 & -0.339838\end{array}$

C $-1.277427-2.745442 \quad 1.026469$

C $-2.614406-2.972542 \quad 1.388546$

H $-3.429043-2.606325 \quad 0.758004$

$\begin{array}{llll}\text { C } & -2.902821 & -3.678598 & 2.553846\end{array}$

H $\quad-3.943413 \quad-3.858242 \quad 2.832234$

$\begin{array}{llll}\text { C } & -1.868367 & -4.157494 & 3.358779\end{array}$

$\begin{array}{llll}\text { H } & -2.100082 & -4.712558 & 4.270787\end{array}$

C $-0.538143-3.923383 \quad 3.006280$

H $\quad 0.271552-4.288921 \quad 3.641628$

$\begin{array}{llll}\text { C } & -0.238453 & -3.208424 & 1.850816\end{array}$

$\begin{array}{llll}\text { H } & 0.804390 & -3.006099 & 1.584823\end{array}$

C $-2.355910-1.248604-1.265972$

$\begin{array}{llll}\text { C } & -2.940978 & -1.756041 & -2.431540\end{array}$

$\begin{array}{llll}\text { H } & -2.551433 & -2.662788 & -2.900110\end{array}$

$\begin{array}{llll}\text { C } & -4.011737 & -1.067588 & -3.000035\end{array}$

$\begin{array}{llll}\text { H } & -4.472854 & -1.452922 & -3.911510\end{array}$

$\begin{array}{llll}\text { C } & -4.495766 & 0.116221 & -2.432232\end{array}$

$\begin{array}{lllll}\text { H } & -5.322068 & 0.638789 & -2.918814\end{array}$

$\begin{array}{llll}C & -3.940228 & 0.635751 & -1.258719\end{array}$

$\begin{array}{llll}\text { C } & -4.383083 & 1.893175 & -0.515612\end{array}$

$\begin{array}{lllll}\text { C } & -3.117480 & 2.551919 & 0.035170\end{array}$

$\begin{array}{lllll}\text { C } & -2.913713 & 3.927016 & 0.170251\end{array}$

$\begin{array}{lllll}\text { H } & -3.685550 & 4.626267 & -0.158094\end{array}$

$\begin{array}{llll}\text { C } & -1.735298 & 4.423482 & 0.731670\end{array}$

H $-1.6068525 .500558 \quad 0.854955$

C $-0.704418 \quad 3.566177 \quad 1.106855$

H $\quad 0.224178 \quad 3.981967 \quad 1.501315$

$\begin{array}{llll}\text { C } & -0.855839 & 2.178045 & 0.953708\end{array}$

$\begin{array}{llll}\text { C } & -2.087884 & 1.718967 & 0.478680\end{array}$

C $-2.887943-0.088011-0.707728$

$\begin{array}{llll}\text { C } & -5.169553 & 2.835313 & -1.414849\end{array}$

H $\quad-5.509777 \quad 3.719007 \quad-0.859220$

$\begin{array}{llll}H & -6.074136 & 2.344761 & -1.798357\end{array}$

$\begin{array}{lllll}\text { H } & -4.576294 & 3.178535 & -2.274952\end{array}$

$\begin{array}{llll}C & -5.262788 & 1.465467 & 0.674282\end{array}$

$\begin{array}{llll}\text { H } & -4.732910 & 0.784297 & 1.356009\end{array}$

$\begin{array}{llll}H & -6.167129 & 0.950330 & 0.319377\end{array}$

H $\quad \begin{array}{llll}5.576967 & 2.344421 & 1.255536\end{array}$

C $1.936024 \quad 2.121981 \quad 1.432106$

$\begin{array}{llll}\text { C } & 2.567130 & 2.336724 & 2.661625\end{array}$

H $2.243506 \quad 1.801537 \quad 3.556915$

C $3.617079 \quad 3.253184 \quad 2.750526$

H $4.1119813 .411341 \quad 3.711261$

C $4.026030 \quad 3.967070 \quad 1.626224$

H $4.8466404 .684038 \quad 1.702774$

C $3.386565 \quad 3.765667 \quad 0.399996$

$\begin{array}{lllll}\text { H } & 3.702462 & 4.322739 & -0.485184\end{array}$

C $2.353842 \quad 2.8417420 .302045$

$\begin{array}{llll}\text { H } & 1.863684 & 2.667510 & -0.661028\end{array}$ 
$\begin{array}{llll}C & 0.257958 & 0.134172 & 2.779985 \\ \text { C } & -0.967161 & 0.175489 & 3.458292\end{array}$

$\begin{array}{llll}\text { C } & -0.967161 & 0.175489 & 3.458292\end{array}$

H $-1.803506 \quad 0.756299 \quad 3.060919$

$\begin{array}{llll}\text { C } & -1.117860 & -0.516422 & 4.659801\end{array}$

$\begin{array}{llll}\text { H } & -2.075219 & -0.481600 & 5.184649\end{array}$

$\begin{array}{llll}C & -0.051345 & -1.238881 & 5.193251\end{array}$

H $-0.172926-1.772126 \quad 6.139118$

C $1.168633-1.288886 \quad 4.515425$

$\begin{array}{llll}\text { H } & 2.003160 & -1.861516 & 4.926392\end{array}$

C $1.320296-0.622640 \quad 3.304032$

$\begin{array}{llll}\text { H } \quad 2.270752 & -0.682384 & 2.763165\end{array}$

\begin{tabular}{lllll}
\hline & -2.250930 & 0.361577 & 0.419530
\end{tabular}

$\begin{array}{llll}P & -0.855050 & -1.821529 & -0.456258\end{array}$

$\begin{array}{lllll}P & 0.520669 & 0.999655 & 1.212407\end{array}$

H $\quad-0.022995 \quad 3.779677 \quad-1.633090$

$\begin{array}{lllll}\text { H } & -1.071647 & 3.766849 & -3.055042\end{array}$

$\begin{array}{llll}\text { C } & -0.031069 & 3.901101 & -2.725946\end{array}$

H $0.259056 \quad 4.936123 \quad-2.948534$

\begin{tabular}{lllll}
\hline & -0.400301 & 1.091756 & -2.51852
\end{tabular}

$\begin{array}{llll}\text { C } & 0.891270 & 2.913780 & -3.395252\end{array}$

$\begin{array}{lllll}C & 0.550147 & 1.484187 & -3.165504\end{array}$

H $\quad 1.946799 \quad 3.037075 \quad-3.088248$

$\begin{array}{lllll}\text { H } & 0.933996 & 3.049389 & -4.491347\end{array}$

$\begin{array}{llll}\text { Pd } & 1.014411 & -0.526856 & -0.437643\end{array}$

H $1.2458550 .749162 \quad-3.651312$

I $3.650933-0.259807-0.996618$

Fig._S107_LPdI(+) / electronic energy: - 2687.67726355 a.u. / lowest freq: $15.32 \mathrm{~cm}-1$

$\begin{array}{lll}\text { Pd } 0.000000 & -0.440556 & 0.162037\end{array}$

$\begin{array}{llll}P & 2.301011 & -0.185682 & 0.029640\end{array}$

$\begin{array}{lllll}\text { P } & -2.301011 & -0.185677 & 0.029640\end{array}$

\begin{tabular}{lllll}
\hline & 0.000002 & 1.776693 & 0.008067
\end{tabular}

\begin{tabular}{llll}
\hline & -0.000002 & -3.048787 & 0.329696
\end{tabular}

$\begin{array}{llll}\text { C } & 1.207340 & 2.394450 & -0.331645\end{array}$

C $2.354616 \quad 1.592124-0.399850$

$\begin{array}{llll}\text { C } 3.562123 & 2.190382 & -0.783170\end{array}$

$\begin{array}{llll}\text { H } & 4.468577 & 1.581988 & -0.845548\end{array}$

C $3.6077963 .545666-1.085066$

$\begin{array}{lllll}\text { H } & 4.547668 & 4.004787 & -1.396323\end{array}$

$\begin{array}{llll}\text { C } & 2.456435 & 4.322074 & -0.972143\end{array}$

H $2.5140805 .390151-1.186894$

C $1.234965 \quad 3.771274-0.573354$

$\begin{array}{llll}\text { C } & 0.000005 & 4.608532 & -0.279851\end{array}$

$\begin{array}{lllll}C & -1.234957 & 3.771278 & -0.573353\end{array}$

C $-2.456426 \quad 4.322081-0.972140$

$\begin{array}{llll}\text { H } & -2.514069 & 5.390157 & -1.186891\end{array}$

C $-3.607790 \quad 3.545675-1.085062$

H $\quad-4.547661 \quad 4.004799 \quad-1.396318$

$\begin{array}{llll}\text { C } & -3.562120 & 2.190391 & -0.78316\end{array}$

$\begin{array}{lllll}\text { H } & -4.468574 & 1.582000 & -0.845544\end{array}$

$\begin{array}{llll}\text { C }-2.354613 & 1.592130 & -0.399847\end{array}$

C $-1.207335 \quad 2.394454-0.331643$

C $0.000007 \quad 4.916094 \quad 1.231458$

H $0.000005 \quad 3.998402 \quad 1.837931$

H $-0.890952 \quad 5.499930 \quad 1.504652$

$\begin{array}{llll}H & 0.890967 & 5.499927 & 1.504651\end{array}$

$\begin{array}{llll}\text { C } 0.000006 & 5.921160 & -1.052904\end{array}$

$\begin{array}{llll}\text { H } & 0.000006 & 5.763659 & -2.140839\end{array}$

$\begin{array}{lllll}H & 0.874857 & 6.530033 & -0.793710\end{array}$

$\begin{array}{lllll}H & -0.874842 & 6.530036 & -0.793709\end{array}$

C $3.282070-0.378309 \quad 1.539096$

$\begin{array}{llll}\text { C } 3.661306 & -1.672791 & 1.933323\end{array}$

H $3.419665-2.533244 \quad 1.302193$

C $4.352900-1.862050 \quad 3.126198$

H $4.651113-2.869982 \quad 3.422791$

C $4.662709-0.769806 \quad 3.939059$

H $\quad 5.206068-0.922305 \quad 4.874326$

$\begin{array}{llll}\text { C } & 4.275609 & 0.514538 & 3.558227\end{array}$

H $4.514995 \quad 1.371145 \quad 4.192211$

C $3.584485 \quad 0.714358 \quad 2.364179$

H $3.286304 \quad 1.725304 \quad 2.073634$

C $3.169291-1.057263-1.304034$

$\begin{array}{llll}C & 4.543200 & -1.331383 & -1.253000\end{array}$

$\begin{array}{llll}\text { H } & 5.132516 & -1.049812 & -0.376171\end{array}$

C $5.163843-1.965285-2.328571$

$\begin{array}{llll}\text { H } & 6.234077 & -2.179020 & -2.284315\end{array}$

$\begin{array}{llll}\text { C } & 4.423332 & -2.325200 & -3.454487\end{array}$

H $4.913968-2.824395 \quad-4.293169$

$\begin{array}{llll}\text { C } & 3.055431 & -2.053272 & -3.508870\end{array}$

$\begin{array}{llll}\text { H } & 2.472427 & -2.338548 & -4.387185\end{array}$

$\begin{array}{llll}\text { C } & 2.427818 & -1.425727 & -2.436294\end{array}$

$\begin{array}{llll}\text { H } & 1.352181 & -1.223371 & -2.469527\end{array}$

$\begin{array}{llll}\text { C } & -3.282068 & -0.378307 & 1.539097\end{array}$

$\begin{array}{llll}C & -3.661301 & -1.672790 & 1.933324\end{array}$

$\begin{array}{llll}\text { H } & -3.419657 & -2.533242 & 1.302194\end{array}$

$\begin{array}{llll}\text { C } & -4.352895 & -1.862050 & 3.126198\end{array}$

H $-4.651106-2.869983 \quad 3.422791$

$\begin{array}{llll}\text { C } & -4.662708 & -0.769807 & 3.939059\end{array}$ 
$\begin{array}{llll}\text { H } & -5.206067 & -0.922307 & 4.874325\end{array}$ $\begin{array}{llll}\text { C }-4.275610 & 0.514538 & 3.558228\end{array}$

H $\quad-4.514998 \quad 1.371145 \quad 4.192212$

$\begin{array}{llll}\text { C } & -3.584486 & 0.714360 & 2.364180\end{array}$

H $\quad-3.286306 \quad 1.725306 \quad 2.073636$

C $-3.169296-1.057255-1.304034$

$\begin{array}{llll}\text { C } & -4.543204 & -1.331376 & -1.252995\end{array}$

$\begin{array}{llll}\text { H } & -5.132517 & -1.049806 & -0.37616\end{array}$

$\begin{array}{llll}\text { C } & -5.163850 & -1.965277 & -2.328565\end{array}$

$\begin{array}{llll}\text { H } & -6.234084 & -2.179012 & -2.284306\end{array}$

$\begin{array}{llll}\text { C } & -4.423343 & -2.325190 & -3.454484\end{array}$

$\begin{array}{llll}\text { H } & -4.913981 & -2.824384 & -4.293165\end{array}$

$\begin{array}{llll}\text { C } & -3.055442 & -2.053260 & -3.508872\end{array}$

$\begin{array}{llll}\text { H } & -2.472441 & -2.338535 & -4.387189\end{array}$

$\begin{array}{llll}\text { C } & -2.427826 & -1.425716 & -2.436297\end{array}$

$\begin{array}{llll}\text { H } & -1.352190 & -1.223358 & -2.469534\end{array}$ 


\section{References}

(1) Miloserdov, F. M.; McMullin, C. L.; Belmonte, M. M.; Benet-Buchholz, J.; Bakhmutov, V. I.; Macgregor, S. A.; Grushin, V. V. The Challenge of Palladium-Catalyzed Aromatic Azidocarbonylation: From Mechanistic and Catalyst Deactivation Studies to a Highly Efficient Process. Organometallics 2014, 33 (3), 736-752. https://doi.org/10.1021/om401126m.

(2) Ding, G.; Lu, B.; Li, Y.; Wan, J.; Zhang, Z.; Xie, X. Zinc-Catalyzed Selective Reduction of Cyclic Imides with Hydrosilanes: Synthesis of $\omega$-Hydroxylactams. Adv. Synth. Catal. 2015, 357 (5), 1013-1021. https://doi.org/10.1002/adsc.201400961.

(3) Guha, S. K.; Shibayama, A.; Abe, D.; Sakaguchi, M.; Ukaji, Y.; Inomata, K. "Syn-Effect" in the Conversion of ( $E)-\alpha, \beta$-Unsaturated Esters into the Corresponding $\beta, \gamma$-Unsaturated Esters and Aldehydes into Silyl Enol Ethers. Bull. Chem. Soc. Jpn. 2004, 77 (12), 2147-2157. https://doi.org/10.1246/bcsj.77.2147.

(4) Kassir, A. F.; Ragab, S. S.; Nguyen, T. A. M.; Charnay-Pouget, F.; Guillot, R.; Scherrmann, M.-C.; Boddaert, T.; Aitken, D. J. Synthetic Access to All Four Stereoisomers of Oxetin. J. Org. Chem. 2016, 81 (20), 99839991. https://doi.org/10.1021/acs.joc.6b01795.

(5) Davis, F. A.; Lee, S. H.; Xu, H. Asymmetric Synthesis of Cyclic $\alpha$-Amino Phosphonates Using Masked Oxo Sulfinimines ( N -Sulfinyl Imines) . J. Org. Chem. 2007, 69 (11), 3774-3781. https://doi.org/10.1021/jo040127x.

(6) De Nanteuil, F.; Loup, J.; Waser, J. Catalytic Friedel-Crafts Reaction of Aminocyclopropanes. Org. Lett. 2013, 15 (14), 3738-3741. https://doi.org/10.1021/ol401616a.

(7) Qin, H. T.; Xu, X.; Liu, F. Aerobic Oxidation of Alkynes to 1,2-Diketones by Organic Photoredox Catalysis. ChemCatChem 2017, 9 (8), 1409-1412. https://doi.org/10.1002/cctc.201700061.

(8) Colley, H. E.; Muthana, M.; Danson, S. J.; Jackson, L. V.; Brett, M. L.; Harrison, J.; Coole, S. F.; Mason, D. P.; Jennings, L. R.; Wong, M.; Tulasi, V.; Norman, D.; Lockey, P. M.; Williams, L.; Dossetter, A. G.; Griffen, E. J.; Thompson, M. J. An Orally Bioavailable, Indole-3-Glyoxylamide Based Series of Tubulin Polymerization Inhibitors Showing Tumor Growth Inhibition in a Mouse Xenograft Model of Head and Neck Cancer. J. Med. Chem. 2015, 58 (23), 9309-9333. https://doi.org/10.1021/acs.jmedchem.5b01312.

(9) Ting, C. M.; Hsu, Y. L.; Liu, R. S. Gold-Catalyzed Isomerization of Unactivated Allenes into 1,3-Dienes under Ambient Conditions. Chem. Commun. 2012, 48 (52), 6577-6579. https://doi.org/10.1039/c2cc32131a.

(10) Yuan, Y.; Zhu, H.; Zhao, D.; Zhang, L. Ligand-Free Copper Oxide Nanoparticle-Catalyzed Sonogashira Coupling Reaction. Synthesis 2011, 2011 (11), 1792-1798. https://doi.org/10.1055/s-0030-1260023.

(11) Torres, G. H.; Choppin, S.; Colobert, F. Efficient Suzuki-Miyaura Coupling Reactions between Lithium Alkynyltrimethylborates and Aryl Chlorides. Eur. J. Org. Chem. 2006, 2006 (6), 1450-1454. https://doi.org/10.1002/ejoc.200500697.

(12) Zhang, W. W.; Zhang, X. G.; Li, J. H. Palladium-Catalyzed Decarboxylative Coupling of Alkynyl Carboxylic Acids with Benzyl Halides or Aryl Halides. J. Org. Chem. 2010, 75 (15), 5259-5264. https://doi.org/10.1021/jo1010284.

(13) Zhang, H.; Fu, X.; Chen, J.; Wang, E.; Liu, Y.; Li, Y. Generation of Allenic/Propargylic Zirconium Complexes and Subsequent Cross-Coupling Reactions: A Facile Synthesis of Multisubstituted Allenes. J. Org. Chem. 2009, 74 (24), 9351-9358. https://doi.org/10.1021/jo9020419.

(14) Truong, T.; Daugulis, O. Transition-Metal-Free Alkynylation of Aryl Chlorides. Org. Lett. 2011, 13 (16), 4172-4175. https://doi.org/10.1021/ol2014736.

(15) Jones, K. D.; Power, D. J.; Bierer, D.; Gericke, K. M.; Stewart, S. G. Nickel Phosphite/Phosphine-Catalyzed C-S Cross-Coupling of Aryl Chlorides and Thiols. Org. Lett. 2018, 20 (1), 208-211. https://doi.org/10.1021/acs.orglett.7b03560.

(16) Monnier, F.; Turtaut, F.; Duroure, L.; Taillefer, M. Copper-Catalyzed Sonogashira-Type Reactions under Mild Palladium-Free Conditions. Org. Lett. 2008, 10 (15), 3203-3206. https://doi.org/10.1021/ol801025u. 
(17) Urgaonkar, S.; Verkade, J. G. Ligand-, Copper-, and Amine-Free Sonogashira Reaction of Aryl lodides and Bromides with Terminal Alkynes. J. Org. Chem. 2004, 69 (17), 5752-5755.

https://doi.org/10.1021/jo049325e.

(18) Torborg, C.; Huang, J.; Schulz, T.; Schäffner, B.; Zapf, A.; Spannenberg, A.; Börner, A.; Beller, M. Improved Palladium-Catalyzed Sonogashira Coupling Reactions of Aryl Chlorides. Chem. - Eur. J. 2009, 15 (6), 13291336. https://doi.org/10.1002/chem.200802444.

(19) Yasui, H.; Nishikawa, T.; Yorimitsu, H.; Oshima, K. Cobalt-Catalyzed Allylzincations of Internal Alkynes. Bull. Chem. Soc. Jpn. 2006, 79 (8), 1271-1274. https://doi.org/10.1246/bcsj.79.1271.

(20) Reddy Dubbaka, S.; Vogel, P. Palladium-Catalyzed Desulfitative Sonogashira-Hagihara Cross-Couplings of Arenesulfonyl Chlorides and Terminal Alkynes. Adv. Synth. Catal. 2004, 346 (13-15), 1793-1797. https://doi.org/10.1002/adsc.200404146.

(21) Kirchberg, S.; Fröhlich, R.; Studer, A. Stereoselective Palladium-Catalyzed Carboaminoxylations of Indoles with Arylboronic Acids and TEMPO. Angew. Chem. Int. Ed. 2009, 48 (23), 4235-4238. https://doi.org/10.1002/anie.200901072.

(22) Negishi, E.; Luo, F.-T.; Frisbee, R.; Matsushita, H. A Regiospecific Synthesis of Carbosubstituted Heteroaromatic Derivatives via Pd-Catalyzed Cross Coupling. HETEROCYCLES 1982, 18 (1), 117. https://doi.org/10.3987/s(b)-1982-01-0117.

(23) Christensen, S. H.; Olsen, E. P. K.; Rosenbaum, J.; Madsen, R. Hydroformylation of Olefins and Reductive Carbonylation of Aryl Halides with Syngas Formed Ex Situ from Dehydrogenative Decarbonylation of Hexane-1,6-Diol. Org. Biomol. Chem. 2015, 13 (3), 938-945. https://doi.org/10.1039/C4OB01958J.

(24) Millet, A.; Baudoin, O. Palladium-Catalyzed $\gamma$-Selective Arylation of Zincated Boc-Allylamines. Org. Lett. 2014, 16 (15), 3998-4000. https://doi.org/10.1021/ol5018257.

(25) Colbon, P.; Ruan, J.; Purdie, M.; Mulholland, K.; Xiao, J. Double Arylation of Allyl Alcohol via a One-Pot Heck Arylation-Isomerization-Acylation Cascade. Org. Lett. 2011, 13 (20), 5456-5459. https://doi.org/10.1021/ol202144z.

(26) Frost, C. G.; Hartley, B. C. Lewis Base-Promoted Hydrosilylation of Cyclic Malonates: Synthesis of $\beta$ Substituted Aldehydes and y-Substituted Amines. J. Org. Chem. 2009, 74 (9), 3599-3602. https://doi.org/10.1021/jo900390d.

(27) Nestl, B. M.; Glueck, S. M.; Hall, M.; Kroutil, W.; Stuermer, R.; Hauer, B.; Faber, K. Biocatalytic Racemization of (Hetero)Aryl-Aliphatic $\alpha$-Hydroxycarboxylic Acids ByLactobacillus Spp. Proceeds via an Oxidation-Reduction Sequence. Eur. J. Org. Chem. 2006, 2006 (20), 4573-4577. https://doi.org/10.1002/ejoc.200600454.

(28) Kantee, K.; Rukachaisirikul, V.; Tadpetch, K. Synthesis of Tetrahydropyranyl Diarylheptanoids from Dioscorea Villosa. Tetrahedron Lett. 2016, 57 (31), 3505-3509. https://doi.org/10.1016/J.TETLET.2016.06.102.

(29) Frost, C. G. F.; Hartley, B. C. Tandem Molybdenum Catalyzed Hydrosilylations: An Expedient Synthesis of B-Aryl Aldehydes. Org. Lett. 2007, 9 (21), 4259-4261. https://doi.org/10.1021/OL701812W.

(30) Houjeiry, T. I.; Poe, S. L.; McQuade, D. T. Synthesis of Optically Active 4-Substituted 2-Cyclohexenones. Org. Lett. 2012, 14 (17), 4394-4397. https://doi.org/10.1021/ol301874x.

(31) Payne, D. T.; Zhao, Y.; Fossey, J. S. Ethylenation of Aldehydes to 3-Propanal, Propanol and Propanoic Acid Derivatives. Sci. Rep. 2017, 7 (1), 1720. https://doi.org/10.1038/s41598-017-01950-7.

(32) Lu, X.; Lin, S. Pd(II)-Bipyridine Catalyzed Conjugate Addition of Arylboronic Acid to $\alpha, \beta$-Unsaturated Carbonyl Compounds. J. Org. Chem. 2005, 70 (23), 9651-9653. https://doi.org/10.1021/jo051561h. (33) WO2010000738A1.Pdf.

(34) Zhang, X.; Cao, B.; Yu, S.; Zhang, X. Rhodium-Catalyzed Asymmetric Hydroformylation of N-Allylamides: Highly Enantioselective Approach to B2-Amino Aldehydes. Angew. Chem. Int. Ed. 2010, 49 (24), 40474050. https://doi.org/10.1002/anie.201000955. 
(35) Liu, F.; Martin-Mingot, A.; Jouannetaud, M.-P.; Bachmann, C.; Frapper, G.; Zunino, F.; Thibaudeau, S. Selective Synthesis of Gem -Chlorofluorinated Nitrogen-Containing Derivatives after Superelectrophilic Activation in Superacid HF/SbF 5. J. Org. Chem. 2011, 76 (5), 1460-1463. https://doi.org/10.1021/jo102225w.

(36) Schmidt, A. M.; Eilbracht, P. Tandem Hydroformylation-Hydrazone Formation-Fischer Indole Synthesis: A Novel Approach to Tryptamides. Org. Biomol. Chem. 2005, 3 (12), 2333. https://doi.org/10.1039/b503396a.

(37) Wickens, Z. K.; Skakuj, K.; Morandi, B.; Grubbs, R. H. Catalyst-Controlled Wacker-Type Oxidation: Facile Access to Functionalized Aldehydes. J. Am. Chem. Soc. 2014, 136 (3), 890-893.

https://doi.org/10.1021/ja411749k.

(38) Bonazzi, S.; Güttinger, S.; Zemp, I.; Kutay, U.; Gademann, K. Total Synthesis, Configuration, and Biological Evaluation of Anguinomycin C. Angew. Chem. Int. Ed. 2007, 46 (45), 8707-8710. https://doi.org/10.1002/anie.200703134.

(39) Wu, L.; Liu, Q.; Spannenberg, A.; Jackstell, R.; Beller, M. Highly Regioselective Osmium-Catalyzed Hydroformylation. Chem. Commun. 2015, 51 (15), 3080-3082. https://doi.org/10.1039/C4CC05626D.

(40) Helmboldt, H.; Aho, J. E.; Pihko, P. M. Synthetic Studies Toward Pectenotoxin 2. Part II. Synthesis of the CDE and CDEF Ring Systems. Org. Lett. 2008, 10 (19), 4183-4185. https://doi.org/10.1021/ol801585j.

(41) Sulima, A.; Folk, J.; Jacobson, A.; Rice, K. A New Approach to the Synthesis of the Nonpeptide NOP Receptor Antagonist J-113397. Synthesis 2007, 2007 (10), 1547-1553. https://doi.org/10.1055/s-2007966037.

(42) Teager, D. S.; Ward, H. D.; Murray, R. K. On the Reaction of (Dibromomethyl)Lithium with Bicyclic and Tricyclic Ketones. J. Org. Chem. 1993, 58 (20), 5493-5499. https://doi.org/10.1021/jo00072a037.

(43) Davis, F. A.; Lee, S. H.; Xu, H. Asymmetric Synthesis of Cyclic Alpha-Amino Phosphonates Using Masked Oxo Sulfinimines (N-Sulfinyl Imines). J. Org. Chem. 2004, 69 (11), 3774-3781. https://doi.org/10.1021/jo040127x.

(44) Gelb, M. H.; Svaren, J. P.; Abeles, R. H. Fluoro Ketone Inhibitors of Hydrolytic Enzymes; 1985; Vol. 24. https://doi.org/10.1021/bi00329a001.

(45) Read, C. D. G.; Moore, P. W.; Williams, C. M. N,N,N',N'-Tetramethylenediamine Dioxide (TMEDAO2) Facilitates Atom Economical/Open Atmosphere Ley-Griffith (TPAP) Tandem Oxidation-Wittig Reactions. Green Chem. 2015, 17 (9), 4537-4540. https://doi.org/10.1039/c5gc01346a.

(46) Fang, X.; Zhang, M.; Jackstell, R.; Beller, M. Selective Palladium-Catalyzed Hydroformylation of Alkynes to ??,??-Unsaturated Aldehydes. Angew. Chem. - Int. Ed. 2013, 52 (17), 4645-4649. https://doi.org/10.1002/anie.201300759.

(47) Zhang, X.; Kang, J.; Niu, P.; Wu, J.; Yu, W.; Chang, J. I2-Mediated Oxidative C-N Bond Formation for MetalFree One-Pot Synthesis of Di-, Tri-, and Tetrasubstituted Pyrazoles from $\alpha, \beta$-Unsaturated Aldehydes/Ketones and Hydrazines. J. Org. Chem. 2014, 79 (21), 10170-10178. https://doi.org/10.1021/jo501844x.

(48) Kashiwa, M.; Kuwata, Y.; Sonoda, M.; Tanimori, S. Oxone-Mediated Facile Access to Substituted Pyrazoles. Tetrahedron 2016, 72 (2), 304-311. https://doi.org/10.1016/j.tet.2015.11.035.

(49) Racys, D. T.; Warrilow, C. E.; Pimlott, S. L.; Sutherland, A. Highly Regioselective lodination of Arenes via Iron(III)-Catalyzed Activation of N-lodosuccinimide. Org. Lett. 2015, 17 (19), 4782-4785. https://doi.org/10.1021/acs.orglett.5b02345.

(50) Lan, R.; Liu, Q.; Fan, P.; Lin, S.; Fernando, S. R.; McCallion, D.; Pertwee, R.; Makriyannis, A. StructureActivity Relationships of Pyrazole Derivatives as Cannabinoid Receptor Antagonists. J. Med. Chem. 1999, 42 (4), 769-776. https://doi.org/10.1021/jm980363y.

(51) Menozzi, G.; Schenone, P.; Mosti, L.; Mattioli, F. Synthesis of 5-Substituted 1-Aryl-1 H -Pyrazole-4Acetonitriles, 4-Methyl-1-Phenyl-1 $H$-Pyrazole-3-Carbonitriles and Pharmacologically Active 1-Aryl-1 $H$ - 
Pyrazole-4-Acetic Acids. J. Heterocycl. Chem. 1993, 30 (4), 997-1002.

https://doi.org/10.1002/jhet.5570300427.

(52) Tóth, I.; Elsevier, C. J. Formation of Dinuclear Palladium(I) Hydride [Pd2 $(\mu-\mathrm{H})(\mu-\mathrm{CO})\{(\mathrm{S}, \mathrm{S})-\mathrm{BDPP}\} 2] \mathrm{Cl}$ by Methanolysis or Hydrolysis of $\mathrm{Pd}(\mathrm{COMe})(\mathrm{Cl})\{(\mathrm{S}, \mathrm{S})-\mathrm{BDPP}\}\{(\mathrm{S}, \mathrm{S})-\mathrm{BDPP}=(2 \mathrm{~S}, 4 \mathrm{~S})-2,4-$

Bis(Diphenylphosphino)Pentane\}. Organometallics 1994, 13 (5), 2118-2122.

https://doi.org/10.1021/om00017a084.

(53) Grushin, V. V. Hydrido Complexes of Palladium. Chem. Rev. 1996, 96 (6), 2011-2033. https://doi.org/10.1021/cr950272y.

(54) Klingensmith, L. M.; Strieter, E. R.; Barder, T. E.; Buchwald, S. L. New Insights into Xantphos/Pd-Catalyzed C-N Bond Forming Reactions: A Structural and Kinetic Study. Organometallics 2006, 25 (1), 82-91. https://doi.org/10.1021/om050715g.

(55) Zuideveld, M. A.; Swennenhuis, B. H. G.; Boele, M. D. K.; Guari, Y.; Van Strijdonck, G. P. F.; Reek, J. N. H.; Kamer, P. C. J.; Goubitz, K.; Fraanje, J.; Lutz, M.; Spek, A. L.; Van Leeuwen, P. W. N. M. The Coordination Behaviour of Large Natural Bite Angle Diphosphine Ligands towards Methyl and 4-

Cyanophenylpalladium(II) Complexes. J. Chem. Soc. Dalton Trans. 2002, No. 11, 2308-2317. https://doi.org/10.1039/b111596k.

(56) Van Leeuwen, P. W. N. M.; Zuideveld, M. A.; Swennenhuis, B. H. G.; Freixa, Z.; Kamer, P. C. J.; Goubitz, K.; Fraanje, J.; Lutz, M.; Spek, A. L. Alcoholysis of Acylpalladium(II) Complexes Relevant to the Alternating Copolymerization of Ethene and Carbon Monoxide and the Alkoxycarbonylation of Alkenes: The Importance of Cis-Coordinating Phosphines. J. Am. Chem. Soc. 2003, 125 (18), 5523-5539. https://doi.org/10.1021/ja029341y.

(57) Tan, C.; Wei, L.; Ottensmeyer, F. P.; Goldfine, I.; Maddux, B. A.; Yip, C. C.; Batey, R. A.; Kotra, L. P. Structure-Based de Novo Design of Ligands Using a Three-Dimensional Model of the Insulin Receptor. Bioorg. Med. Chem. Lett. 2004, 14 (6), 1407-1410. https://doi.org/10.1016/j.bmcl.2004.01.064.

(58) Krasnov, V. P.; Levit, G. L.; Kodess, M. I.; Charushin, V. N.; Chupakhin, O. N. N-Phthaloyl-(S)-Alanyl Chloride as a Chiral Resolving Agent for the Kinetic Resolution of Heterocyclic Amines. Tetrahedron Asymmetry 2004, 15 (5), 859-862. https://doi.org/10.1016/j.tetasy.2004.01.025.

(59) Murahashi, T.; Nagai, T.; Okuno, T.; Matsutani, T.; Kurosawa, H. Synthesis and Ligand Substitution Reactions of a Homoleptic Acetonitrile Dipalladium(I) Complex. Chem. Commun. 2000, No. 17, 16891690. https://doi.org/10.1039/b004726k.

(60) Cramer, C. J.; Truhlar, D. G. Density Functional Theory for Transition Metals and Transition Metal Chemistry. Phys. Chem. Chem. Phys. 2009, 11 (46), 10757-10816. https://doi.org/10.1039/b907148b.

(61) Frisch, M. J.; Trucks, G. W.; Schlegel, H. B.; Scuseria, G. E.; Robb, M. A.; Cheeseman, J. R.; Scalmani, G.; Barone, V.; Mennucci, B.; Petersson, G. A.; Nakatsuji, H.; Caricato, M.; Li, X.; Hratchian, H. P.; Izmaylov, A. F.; Bloino, J.; Zheng, G.; Sonnenb, D. J. Gaussian 09, Revision D.01; Gaussian, Inc., Wallingford CT, 2009.

(62) Zhao, Y.; Truhlar, D. G. Density Functionals with Broad Applicability in Chemistry. Acc. Chem. Res. 2008, 41 (2), 157-167. https://doi.org/10.1021/ar700111a.

(63) Weigend, F.; Ahlrichs, R. Balanced Basis Sets of Split Valence, Triple Zeta Valence and Quadruple Zeta Valence Quality for H to Rn: Design and Assessment of Accuracy. Phys. Chem. Chem. Phys. 2005, 7 (18), 3297-3305. https://doi.org/10.1039/b508541a.

(64) Weigend, F. Accurate Coulomb-Fitting Basis Sets for H to Rn. Phys. Chem. Chem. Phys. 2006, 8 (9), 10571065. https://doi.org/10.1039/b515623h.

(65) Marenich, A. V.; Cramer, C. J.; Truhlar, D. G. Universal Solvation Model Based on Solute Electron Density and on a Continuum Model of the Solvent Defined by the Bulk Dielectric Constant and Atomic Surface Tensions. J. Phys. Chem. B 2009, 113 (18), 6378-6396. https://doi.org/10.1021/jp810292n.

(66) Page, M.; Mclver, J. W. On Evaluating the Reaction Path Hamiltonian. J. Chem. Phys. 1988, 88 (2), $922-$ 935. https://doi.org/10.1063/1.454172. 
(67) Page, M.; Doubleday, C.; Mclver, J. W. Following Steepest Descent Reaction Paths. The Use of Higher Energy Derivatives with Ab Initio Electronic Structure Methods. J. Chem. Phys. 1990, 93 (8), 5634-5642. https://doi.org/10.1063/1.459634.

(68) Mardirossian, N.; Head-Gordon, M. w B97M-V: A Combinatorially Optimized, Range-Separated Hybrid, Meta-GGA Density Functional with VV10 Nonlocal Correlation. J. Chem. Phys. 2016, 144 (21), 214110. https://doi.org/10.1063/1.4952647.

(69) Neese, F. The ORCA Program System. WIREs Comput. Mol. Sci. 2012, 2 (1), 73-78. https://doi.org/10.1002/wcms.81.

(70) Lichtenberger, D. L.; Gladysz, J. A. New Author Guidelines for 2014: A Format for Computational Structural Data That Can Be Opened with Freely Available Programs Such as "Mercury"1. Organometallics. American Chemical Society February 2014, p 835. https://doi.org/10.1021/om500109u.

(71) Peverati, R.; Truhlar, D. G. Quest for a Universal Density Functional: The Accuracy of Density Functionals across a Broad Spectrum of Databases in Chemistry and Physics. Philosophical Transactions of the Royal Society A: Mathematical, Physical and Engineering Sciences. Royal Society March 2014. https://doi.org/10.1098/rsta.2012.0476.

(72) Yu, H. S.; He, X.; Li, S. L.; Truhlar, D. G. MN15: A Kohn-Sham Global-Hybrid Exchange-Correlation Density Functional with Broad Accuracy for Multi-Reference and Single-Reference Systems and Noncovalent Interactions. Chem. Sci. 2016, 7 (8), 5032-5051. https://doi.org/10.1039/c6sc00705h.

(73) Grimme, S.; Ehrlich, S.; Goerigk, L. Effect of the Damping Function in Dispersion Corrected Density Functional Theory. J. Comput. Chem. 2011, 32 (7), 1456-1465. https://doi.org/10.1002/jcc.21759.

(74) Goerigk, L.; Hansen, A.; Bauer, C.; Ehrlich, S.; Najibi, A.; Grimme, S. A Look at the Density Functional Theory Zoo with the Advanced GMTKN55 Database for General Main Group Thermochemistry, Kinetics and Noncovalent Interactions. Phys. Chem. Chem. Phys. 2017, 19 (48), 32184-32215. https://doi.org/10.1039/c7cp04913g.

(75) Mardirossian, N.; Head-Gordon, M. How Accurate Are the Minnesota Density Functionals for Noncovalent Interactions, Isomerization Energies, Thermochemistry, and Barrier Heights Involving Molecules Composed of Main-Group Elements? J. Chem. Theory Comput. 2016, 12 (9), 4303-4325. https://doi.org/10.1021/acs.jctc.6b00637.

(76) Mardirossian, N.; Head-Gordon, M. Thirty Years of Density Functional Theory in Computational Chemistry: An Overview and Extensive Assessment of 200 Density Functionals. Molecular Physics. Taylor and Francis Ltd. October 2017, pp 2315-2372. https://doi.org/10.1080/00268976.2017.1333644.

(77) Weymuth, T.; Couzijn, E. P. A.; Chen, P.; Reiher, M. New Benchmark Set of Transition-Metal Coordination Reactions for the Assessment of Density Functionals. J. Chem. Theory Comput. 2014, 10 (8), 3092-3103. https://doi.org/10.1021/ct500248h.

(78) Brauer, B.; Kesharwani, M. K.; Kozuch, S.; Martin, J. M. L. The S66x8 Benchmark for Noncovalent Interactions Revisited: Explicitly Correlated: Ab Initio Methods and Density Functional Theory. Phys. Chem. Chem. Phys. 2016, 18 (31), 20905-20925. https://doi.org/10.1039/c6cp00688d.

(79) Wagner, J. P.; Schreiner, P. R. London Dispersion in Molecular Chemistry-Reconsidering Steric Effects. Angew. Chem. Int. Ed. 2015, 54 (42), 12274-12296. https://doi.org/10.1002/anie.201503476.

(80) Torker, S.; Merki, D.; Chen, P. Gas-Phase Thermochemistry of Ruthenium Carbene Metathesis Catalysts. J. Am. Chem. Soc. 2008, 130 (14), 4808-4814. https://doi.org/10.1021/ja078149z.

(81) Minenkov, Y.; Singstad, Å.; Occhipinti, G.; Jensen, V. R. The Accuracy of DFT-Optimized Geometries of Functional Transition Metal Compounds: A Validation Study of Catalysts for Olefin Metathesis and Other Reactions in the Homogeneous Phase. Dalton Trans. 2012, 41 (18), 5526-5541. https://doi.org/10.1039/c2dt12232d.

(82) Minenkov, Y.; Occhipinti, G.; Jensen, V. R. Complete Reaction Pathway of Ruthenium-Catalyzed Olefin Metathesis of Ethyl Vinyl Ether: Kinetics and Mechanistic Insight from DFT. Organometallics 2013, 32 (7), 2099-2111. https://doi.org/10.1021/om301192a. 
(83) Khan, R. K. M.; Torker, S.; Hoveyda, A. H. Reactivity and Selectivity Differences between Catecholate and Catechothiolate Ru Complexes. Implications Regarding Design of Stereoselective Olefin Metathesis Catalysts. J. Am. Chem. Soc. 2014, 136 (41), 14337-14340. https://doi.org/10.1021/ja505961z.

(84) Yang, L.; Adam, C.; Nichol, G. S.; Cockroft, S. L. How Much Do van Der Waals Dispersion Forces Contribute to Molecular Recognition in Solution? Nat. Chem. 2013, 5 (12), 1006-1010.

https://doi.org/10.1038/nchem.1779.

(85) Pollice, R.; Bot, M.; Kobylianskii, I. J.; Shenderovich, I.; Chen, P. Attenuation of London Dispersion in Dichloromethane Solutions. J. Am. Chem. Soc. 2017, 139 (37), 13126-13140.

https://doi.org/10.1021/jacs.7b06997. 


\section{Copies of NMR spectra}

\subsection{Synthetic alkenes and alkynes}

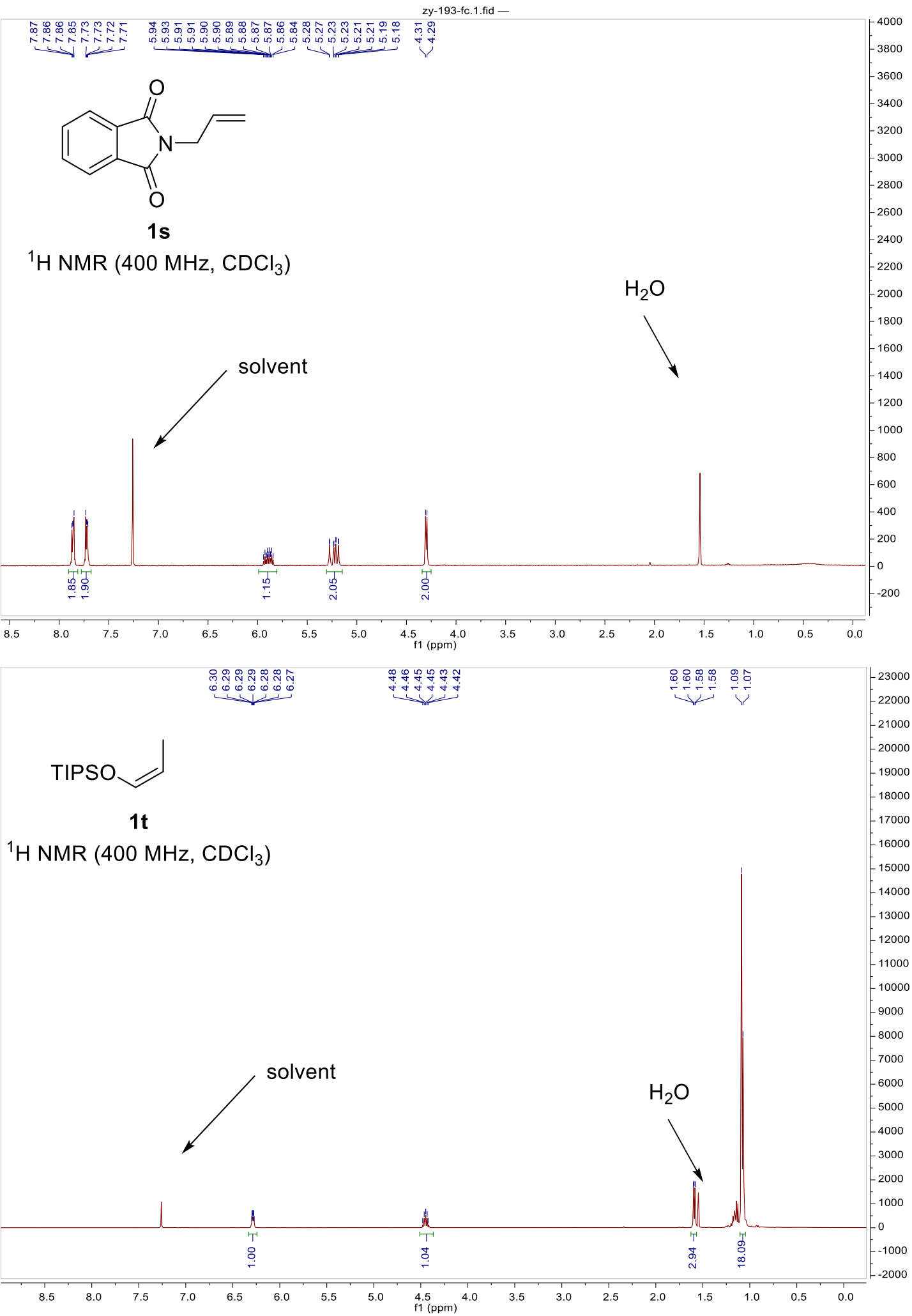



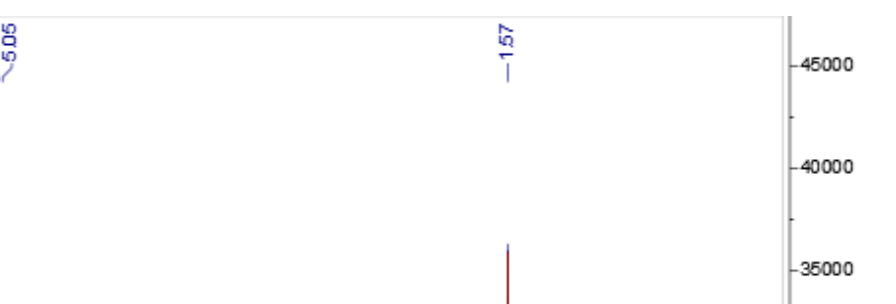<smiles>C=CN(C=O)C(=O)OCc1ccccc1</smiles>

$1 \mathrm{u}$

${ }^{1} \mathrm{H}$ NMR $\left(400 \mathrm{MHz}, \mathrm{CDCl}_{3}\right)$

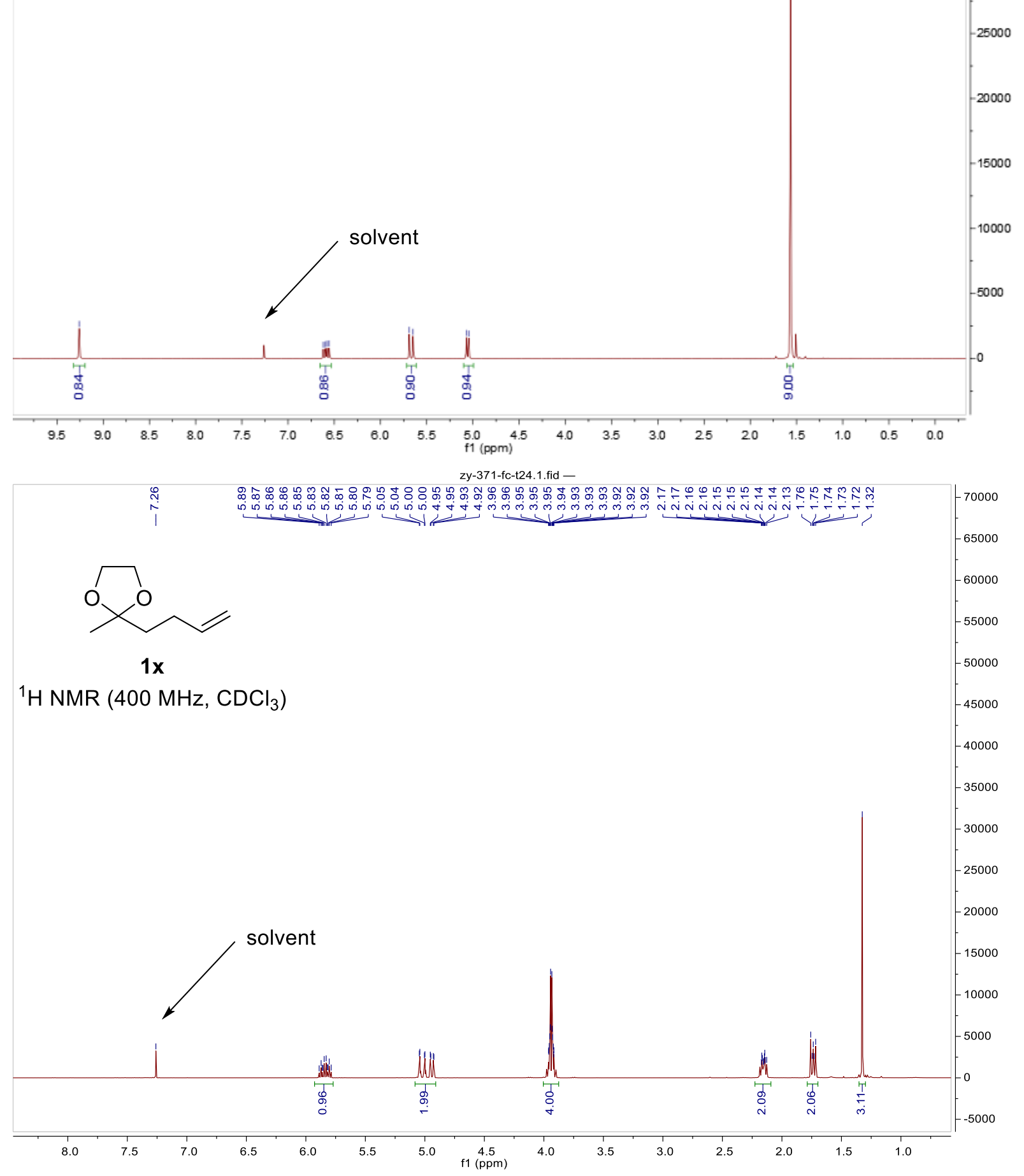




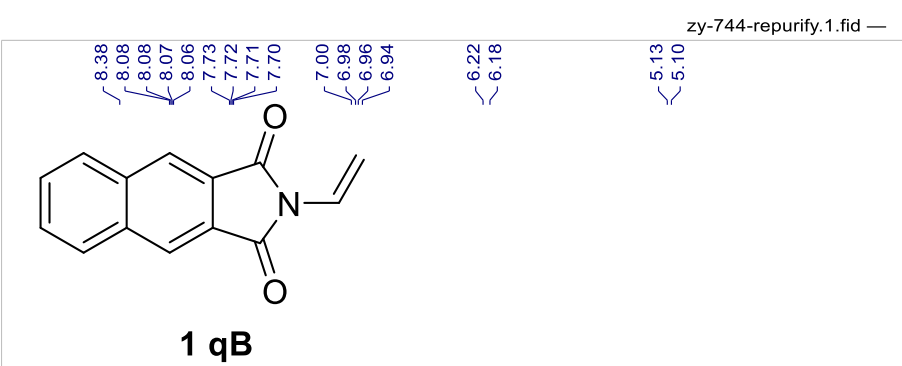

${ }^{1} \mathrm{H}$ NMR $\left(400 \mathrm{MHz}, \mathrm{CDCl}_{3}\right)$
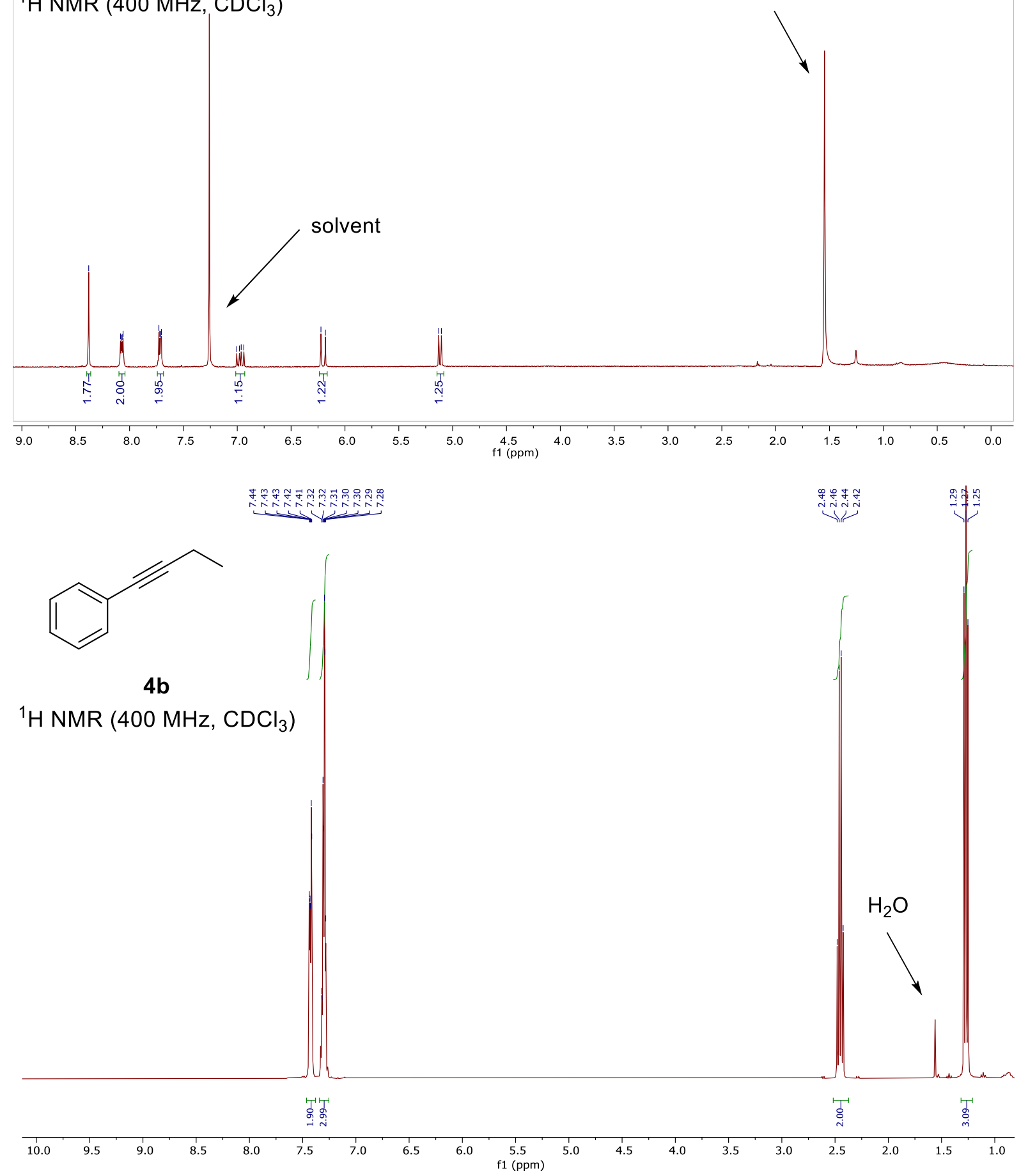


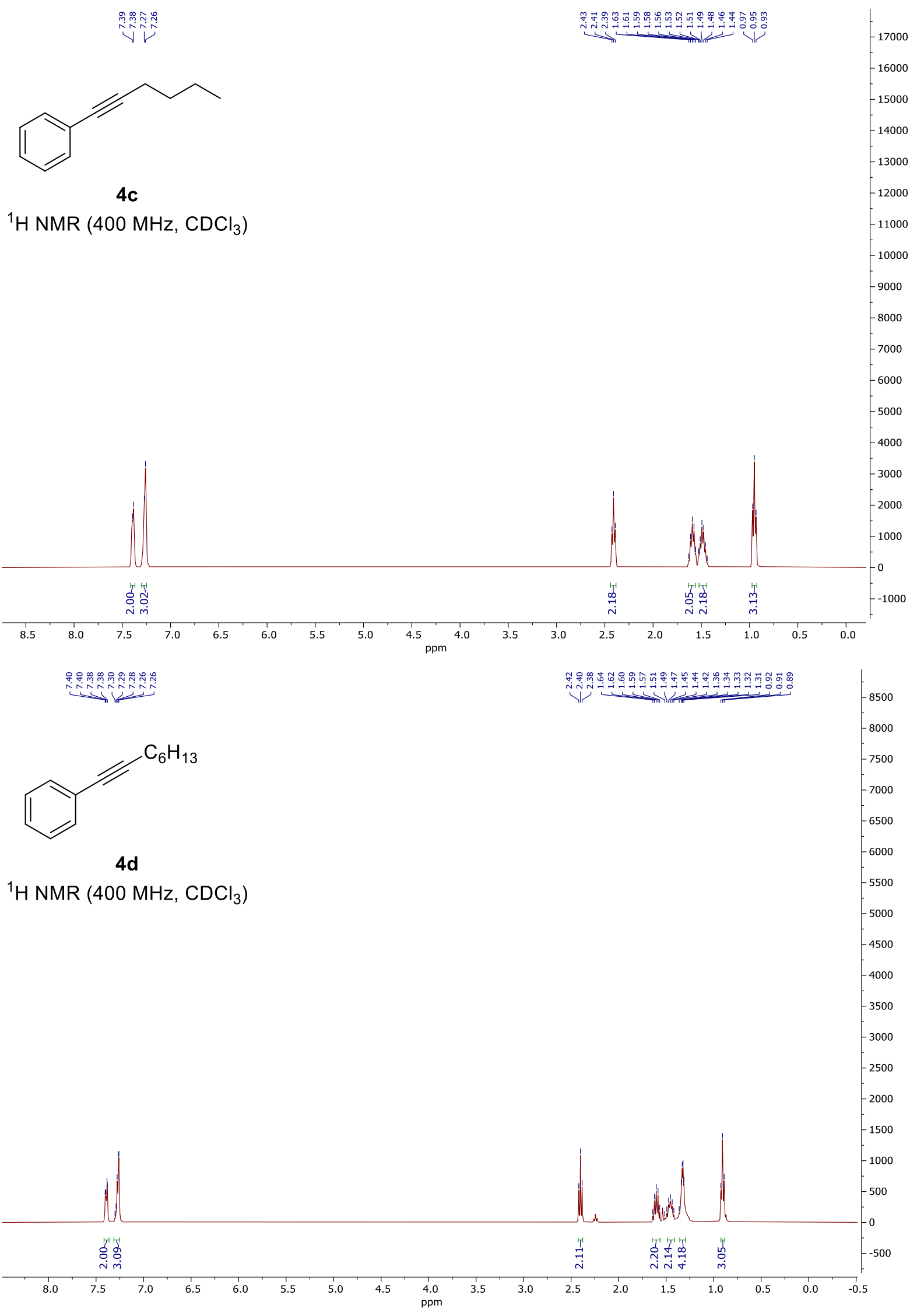




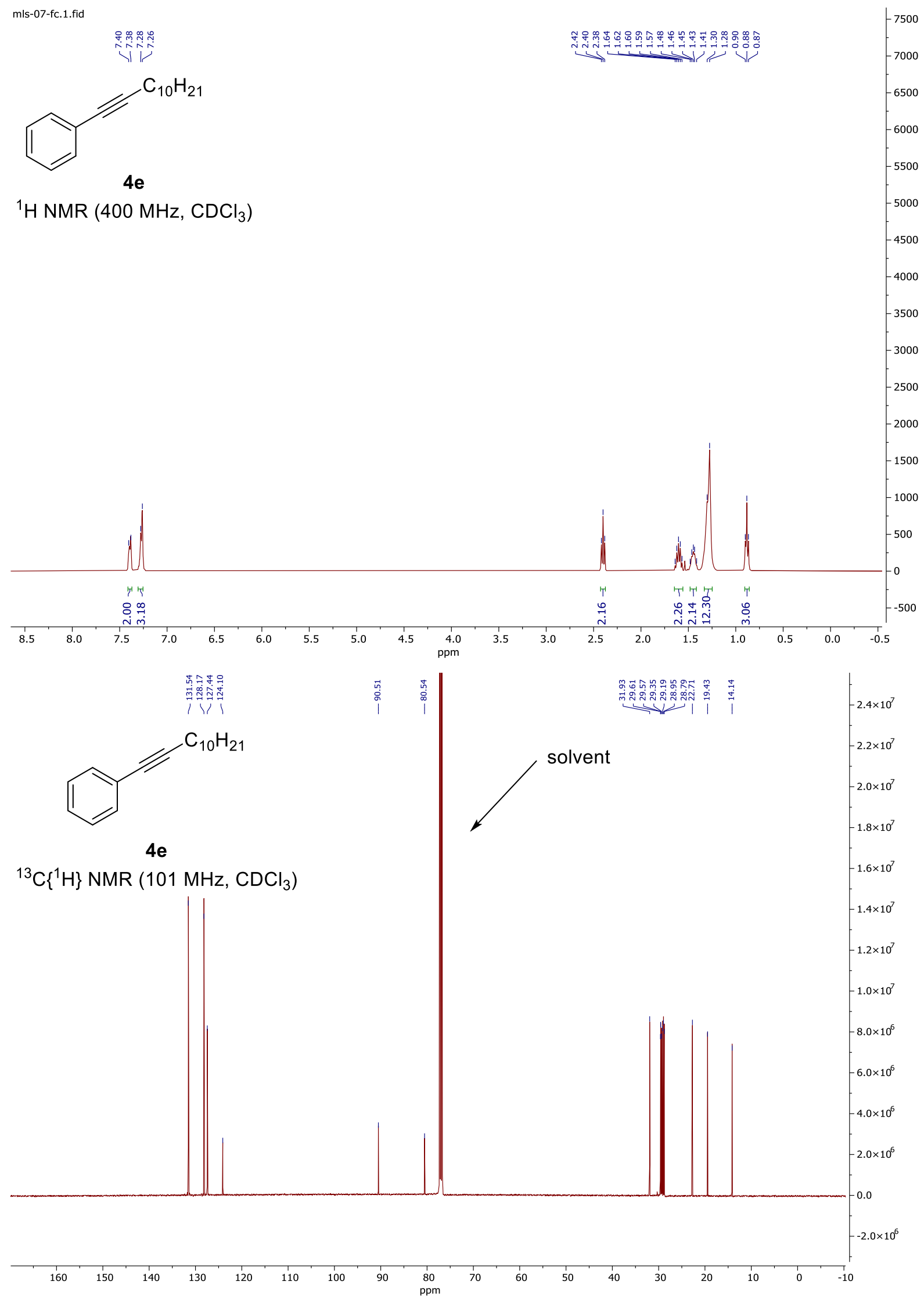




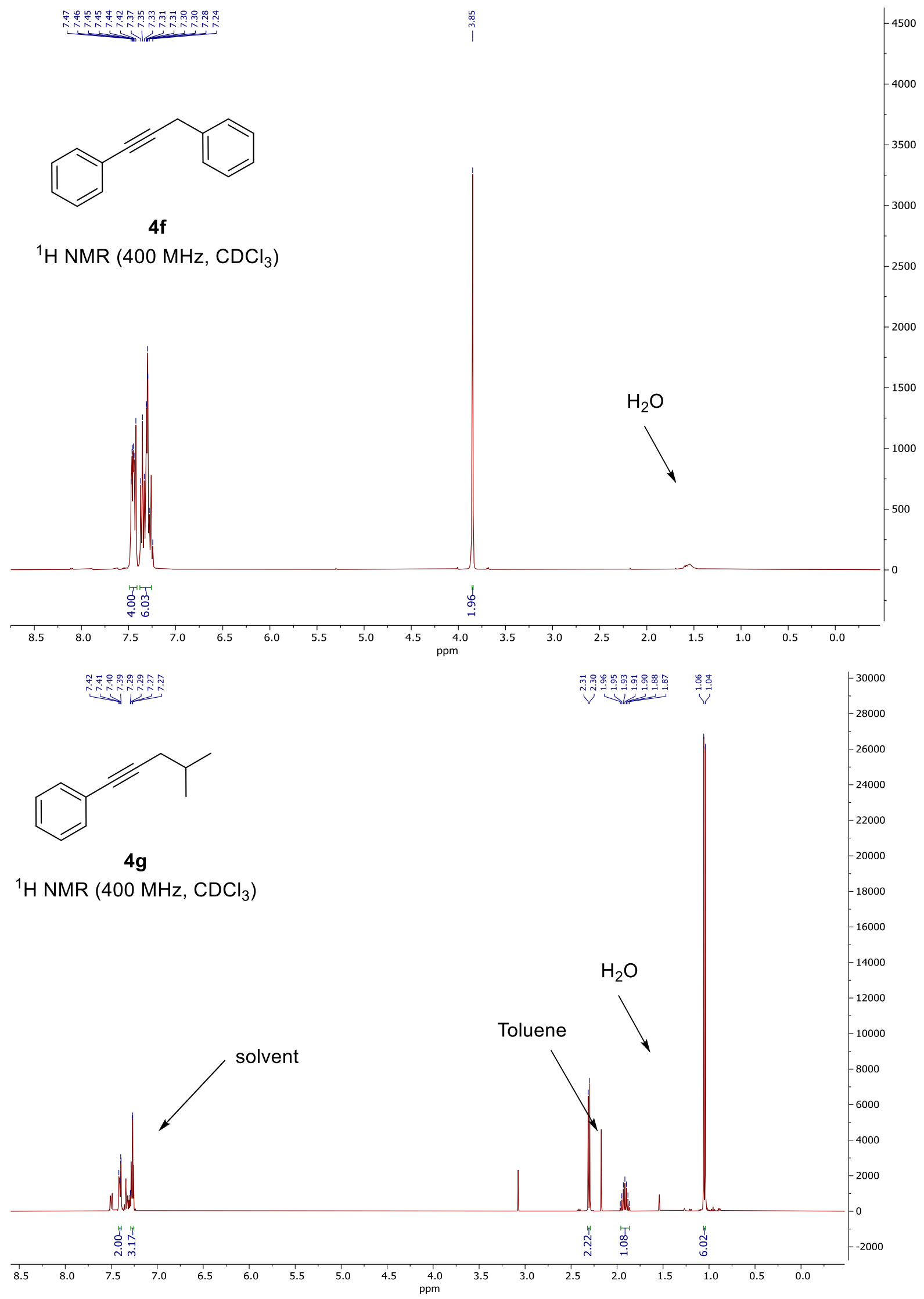



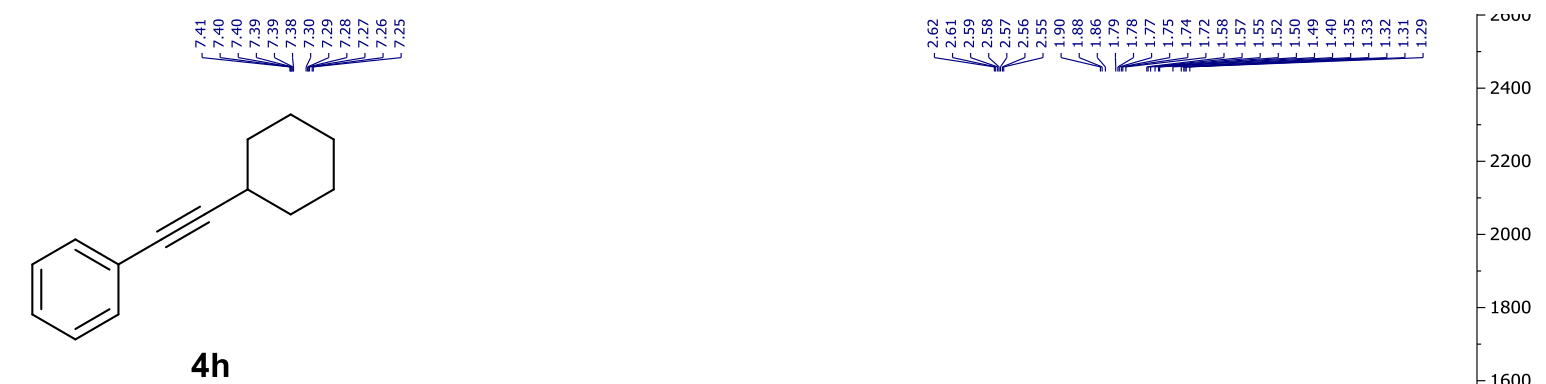

${ }^{1} \mathrm{H}$ NMR $\left(400 \mathrm{MHz}, \mathrm{CDCl}_{3}\right)$

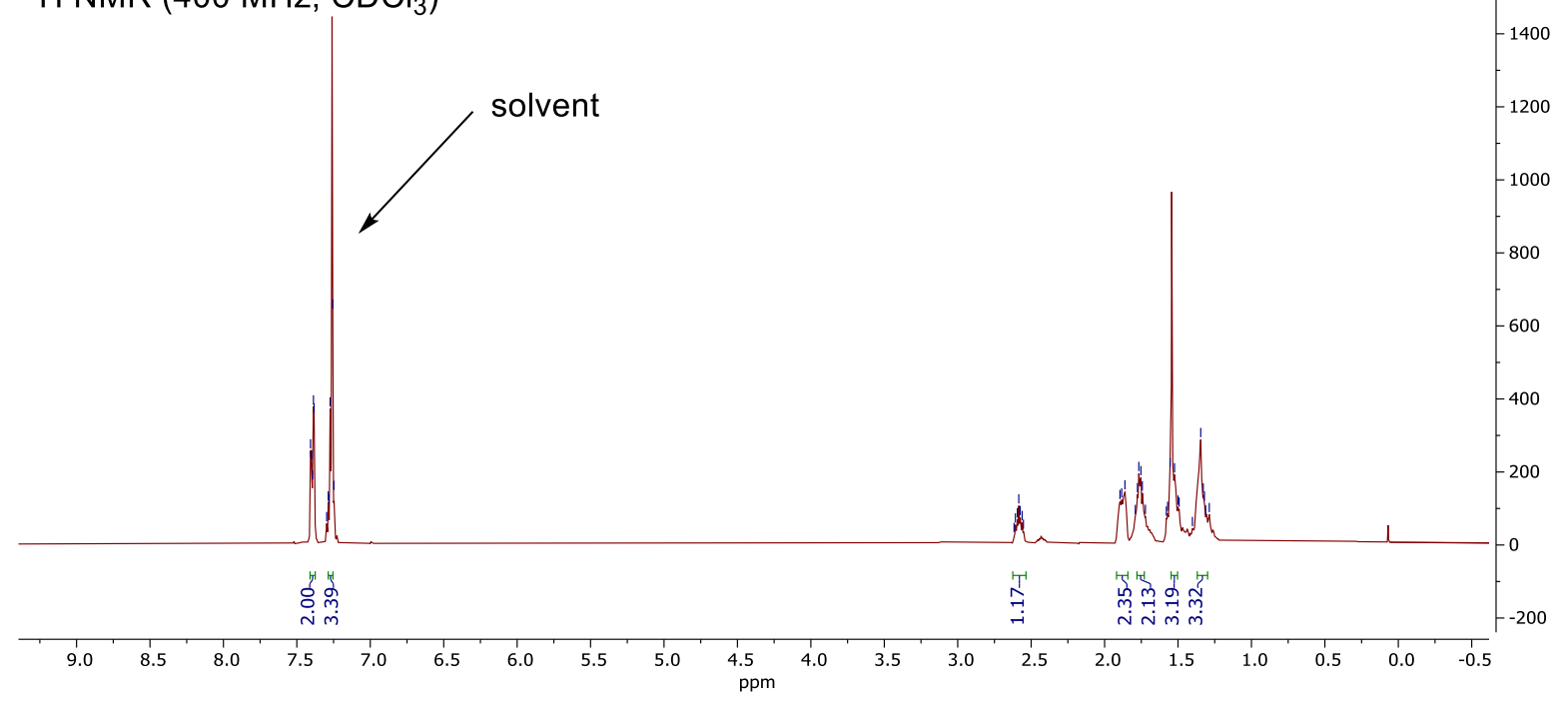

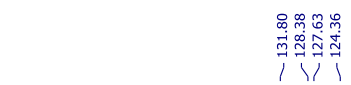

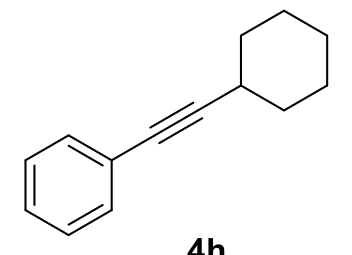

4h

${ }^{13} \mathrm{C}\left\{{ }^{1} \mathrm{H}\right\}$ NMR $\left(101 \mathrm{MHz}, \mathrm{CDCl}_{3}\right)$

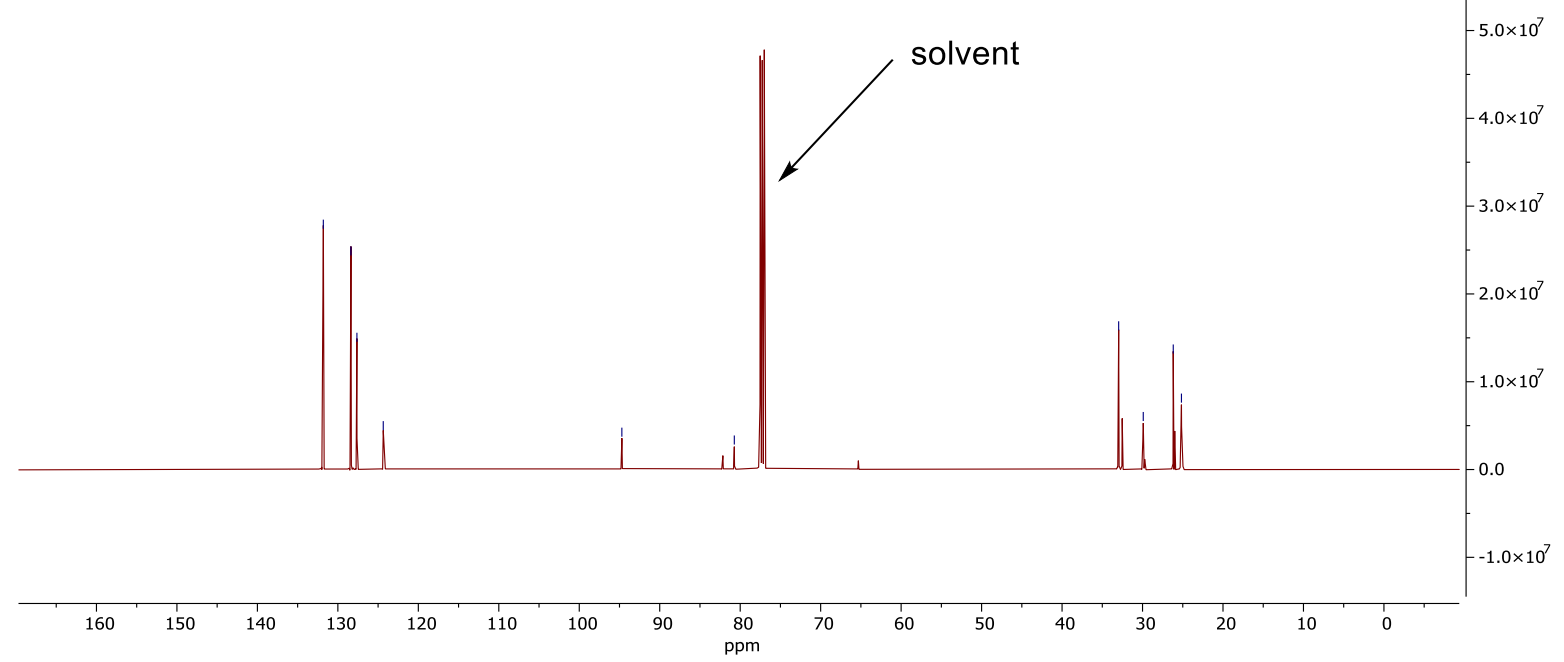




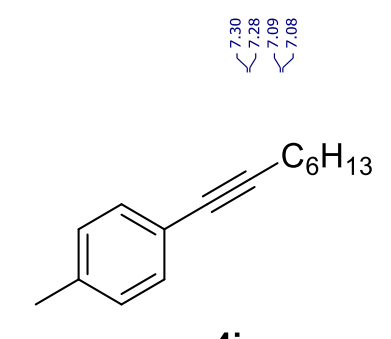

$4 \mathbf{i}$

${ }^{1} \mathrm{H}$ NMR $\left(400 \mathrm{MHz}, \mathrm{CDCl}_{3}\right)$
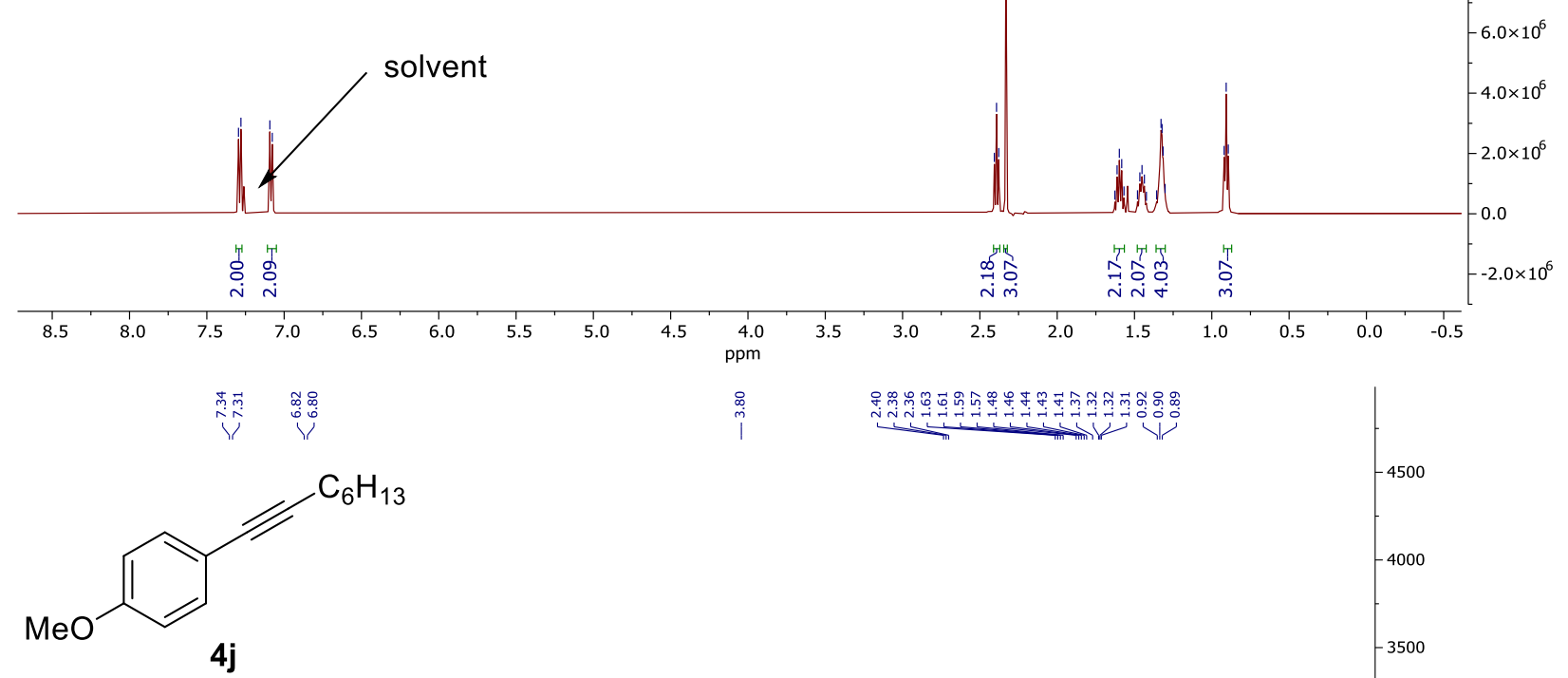

${ }^{1} \mathrm{H}$ NMR $\left(400 \mathrm{MHz}, \mathrm{CDCl}_{3}\right.$ )

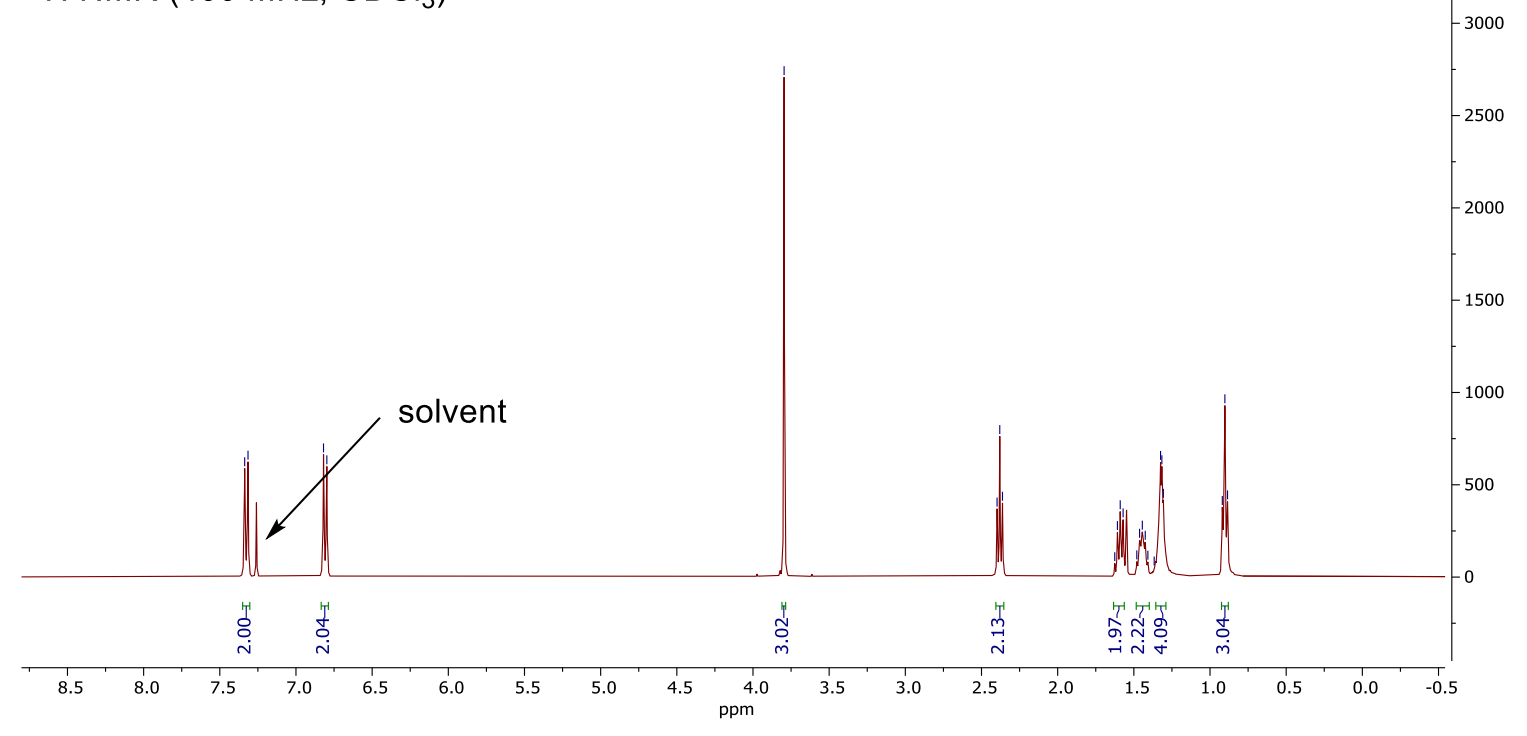



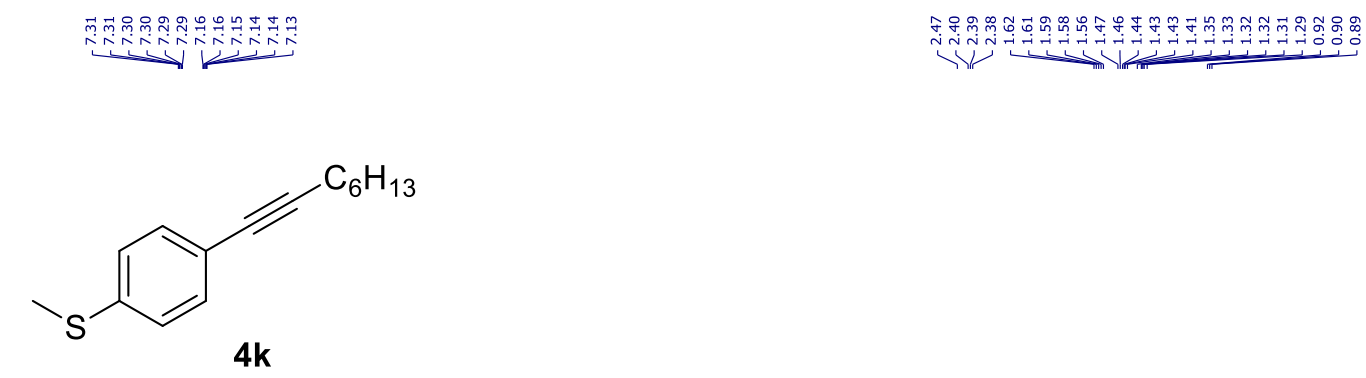

${ }^{1} \mathrm{H}$ NMR $\left(500 \mathrm{MHz}, \mathrm{CDCl}_{3}\right)$

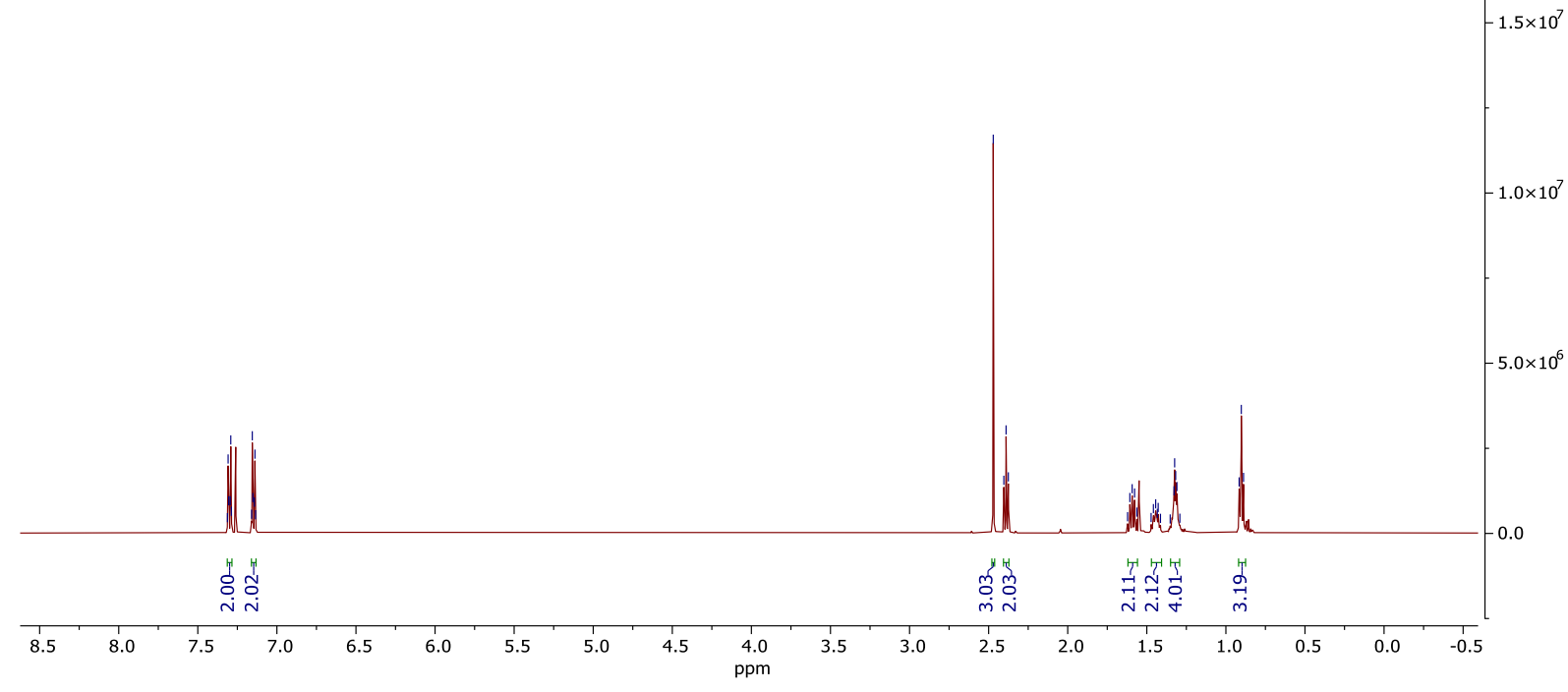

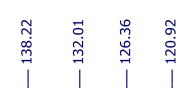<smiles>CSc1ccc(C#CCc2ccccc2)cc1</smiles>

4k

${ }^{13} \mathrm{C}\left\{{ }^{1} \mathrm{H}\right\}$ NMR $\left(101 \mathrm{MHz}, \mathrm{CDCl}_{3}\right)$

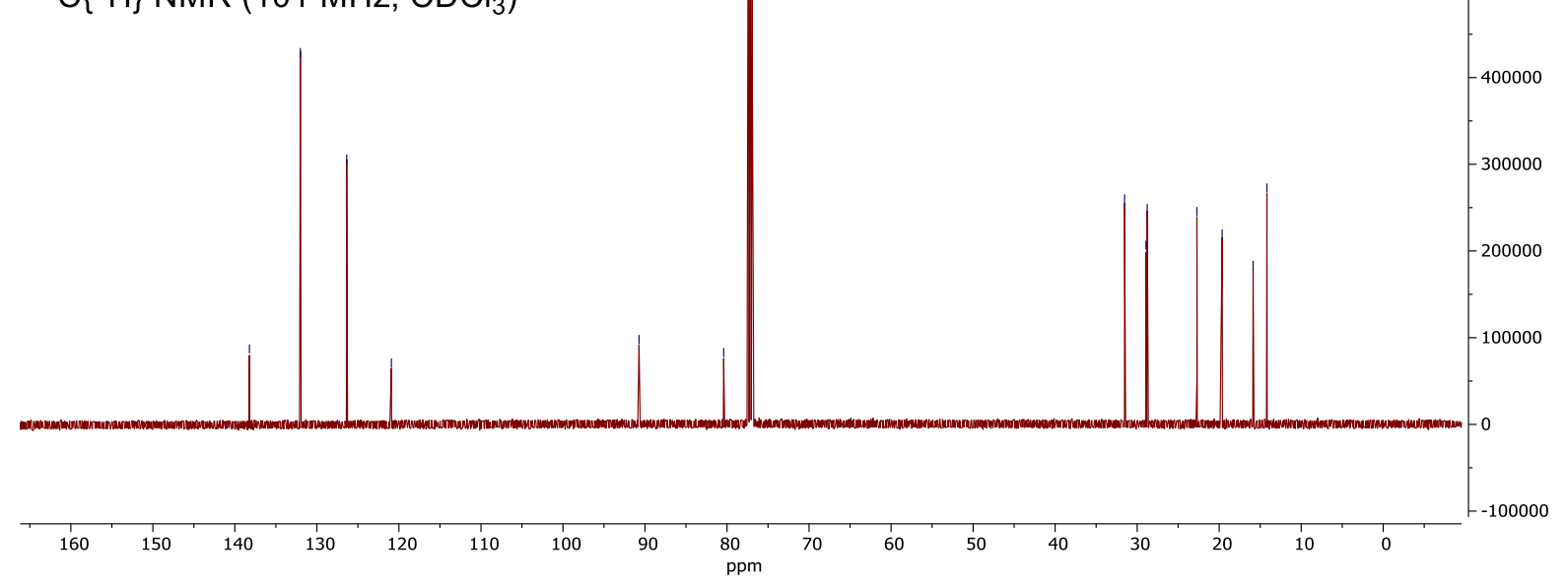




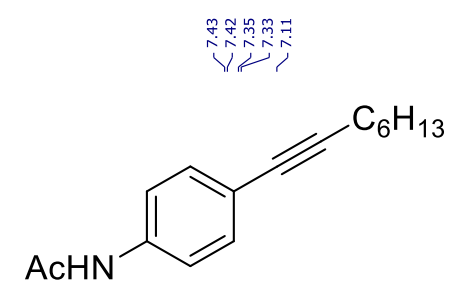

4I

${ }^{1} \mathrm{H}$ NMR $\left(400 \mathrm{MHz}, \mathrm{CDCl}_{3}\right)$
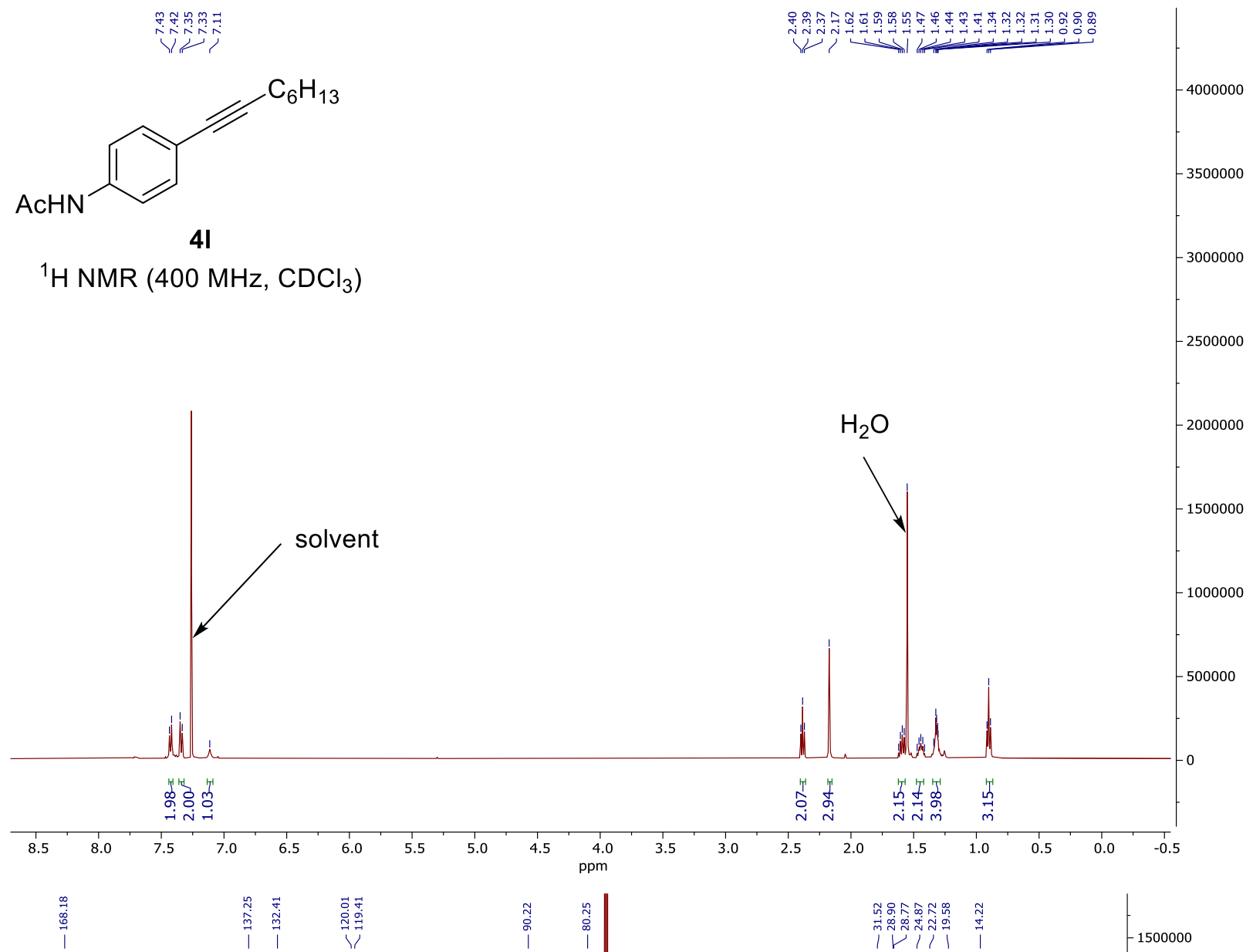<smiles>CC=Nc1ccc(C#CCc2ccccc2)cc1</smiles>

4I

${ }^{13} \mathrm{C}\left\{{ }^{1} \mathrm{H}\right\} \operatorname{NMR}\left(101 \mathrm{MHz}, \mathrm{CDCl}_{3}\right)$

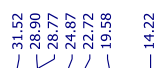

1500000

1400000 1300000 

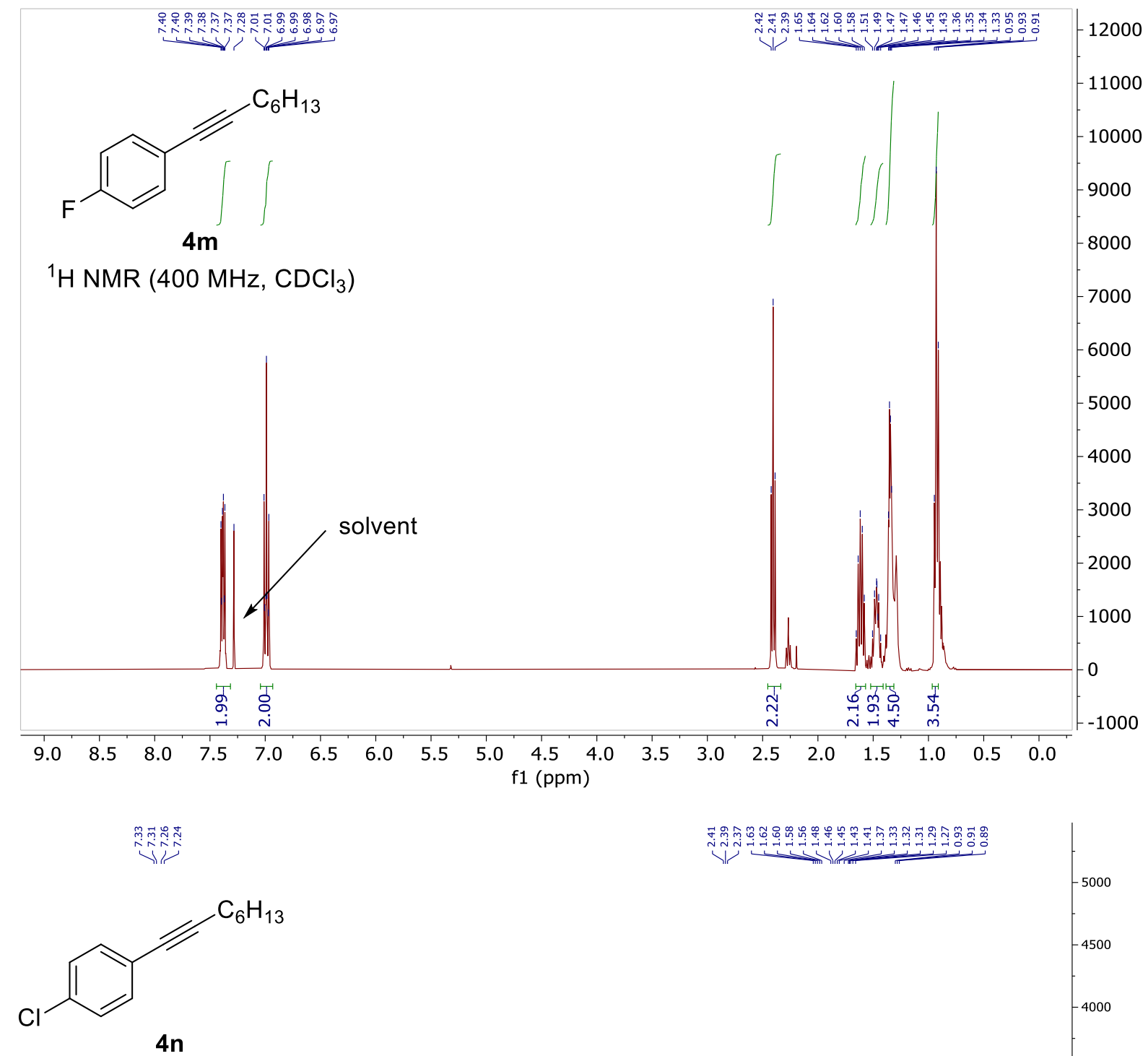

${ }^{1} \mathrm{H}$ NMR $\left(400 \mathrm{MHz}, \mathrm{CDCl}_{3}\right)$

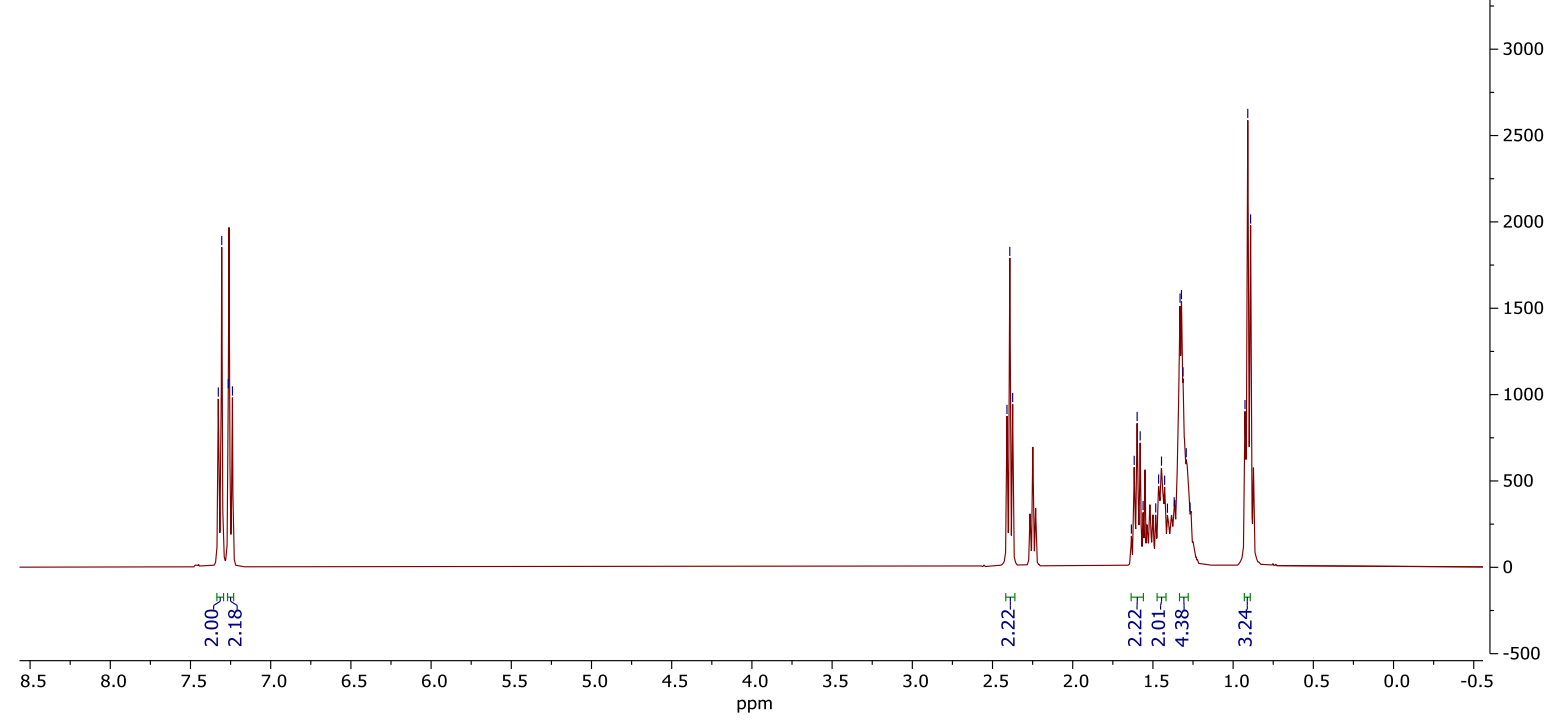



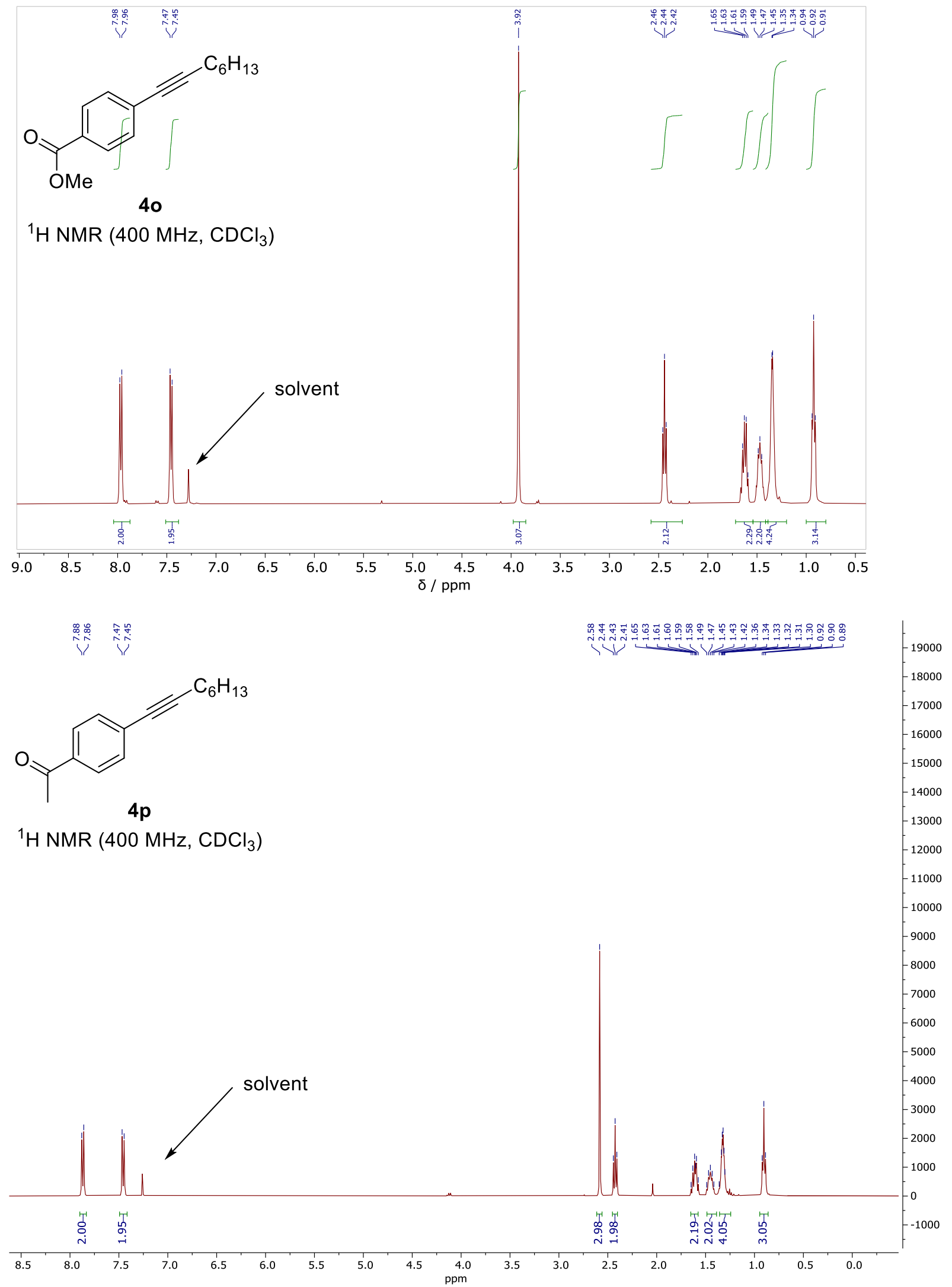

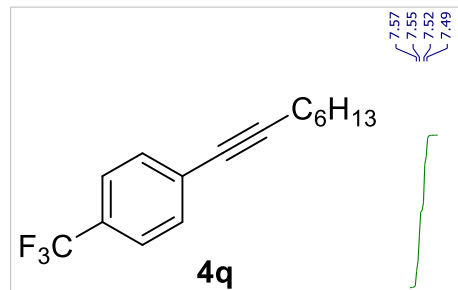

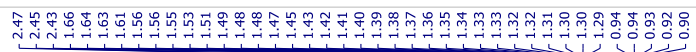

${ }^{1} \mathrm{H}$ NMR $\left(400 \mathrm{MHz}, \mathrm{CDCl}_{3}\right)$

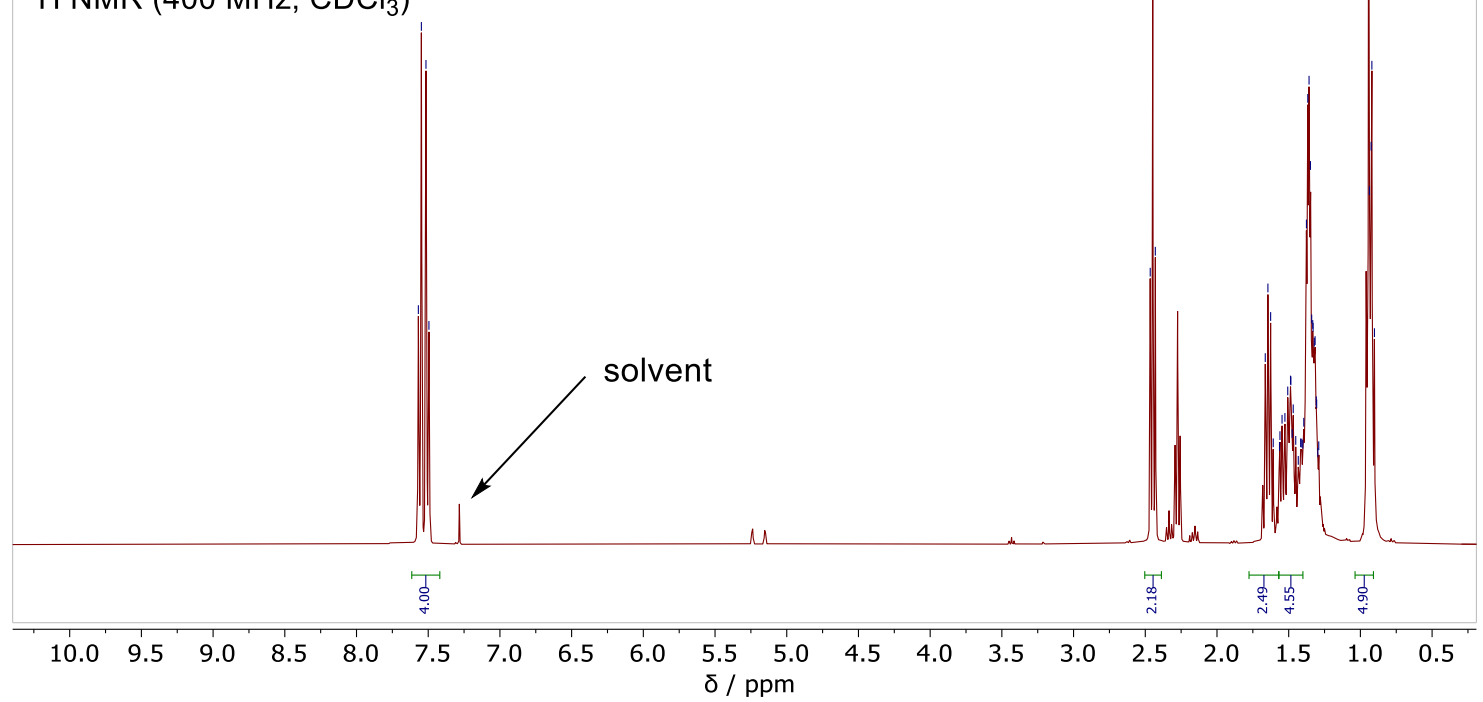

$\underset{\substack{i \\ i}}{i}$

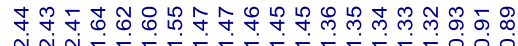

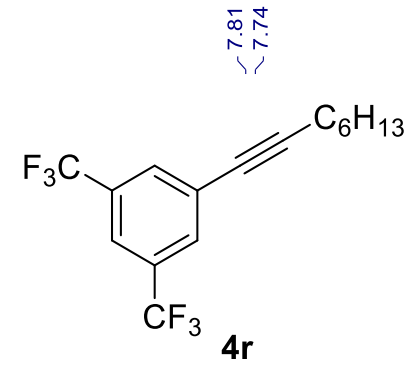

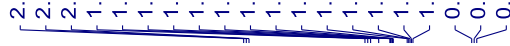

${ }^{1} \mathrm{H}$ NMR $\left(400 \mathrm{MHz}, \mathrm{CDCl}_{3}\right)$

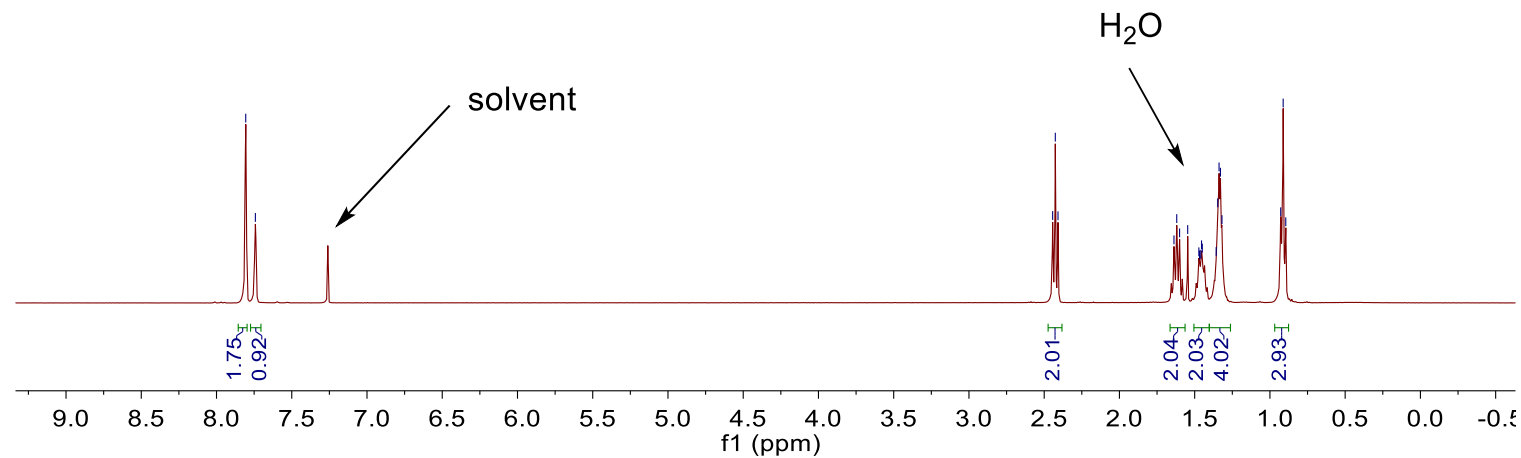




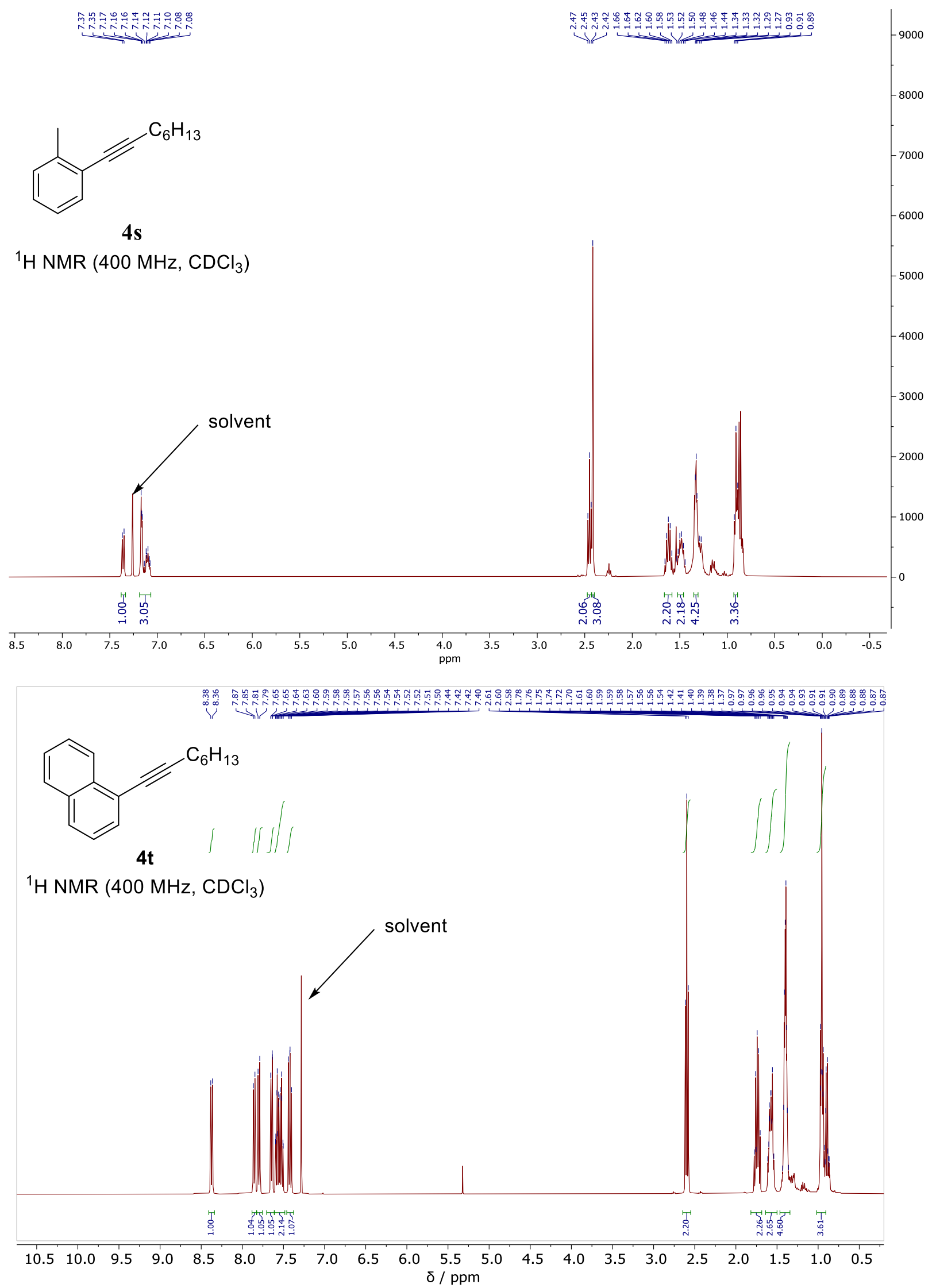




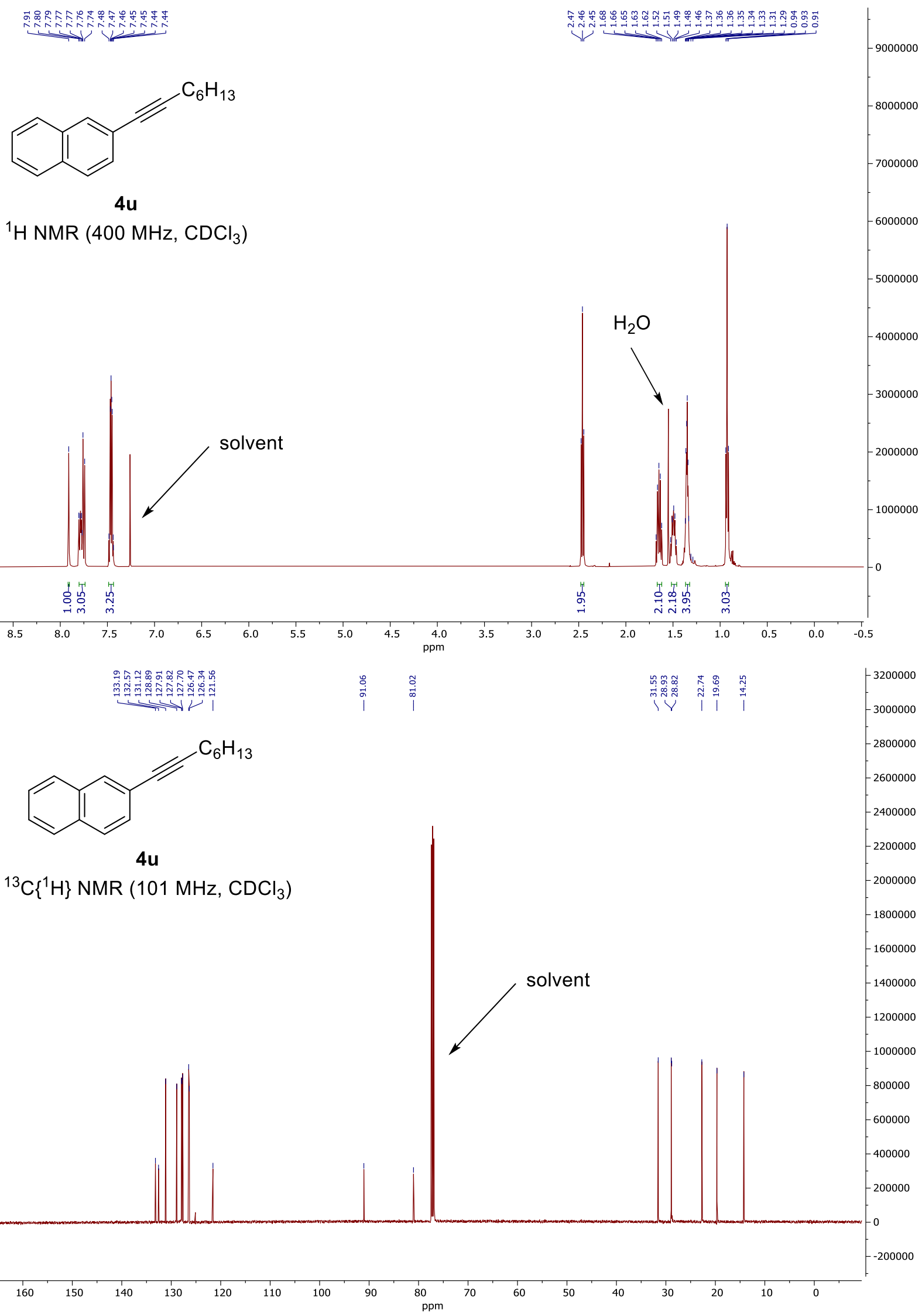




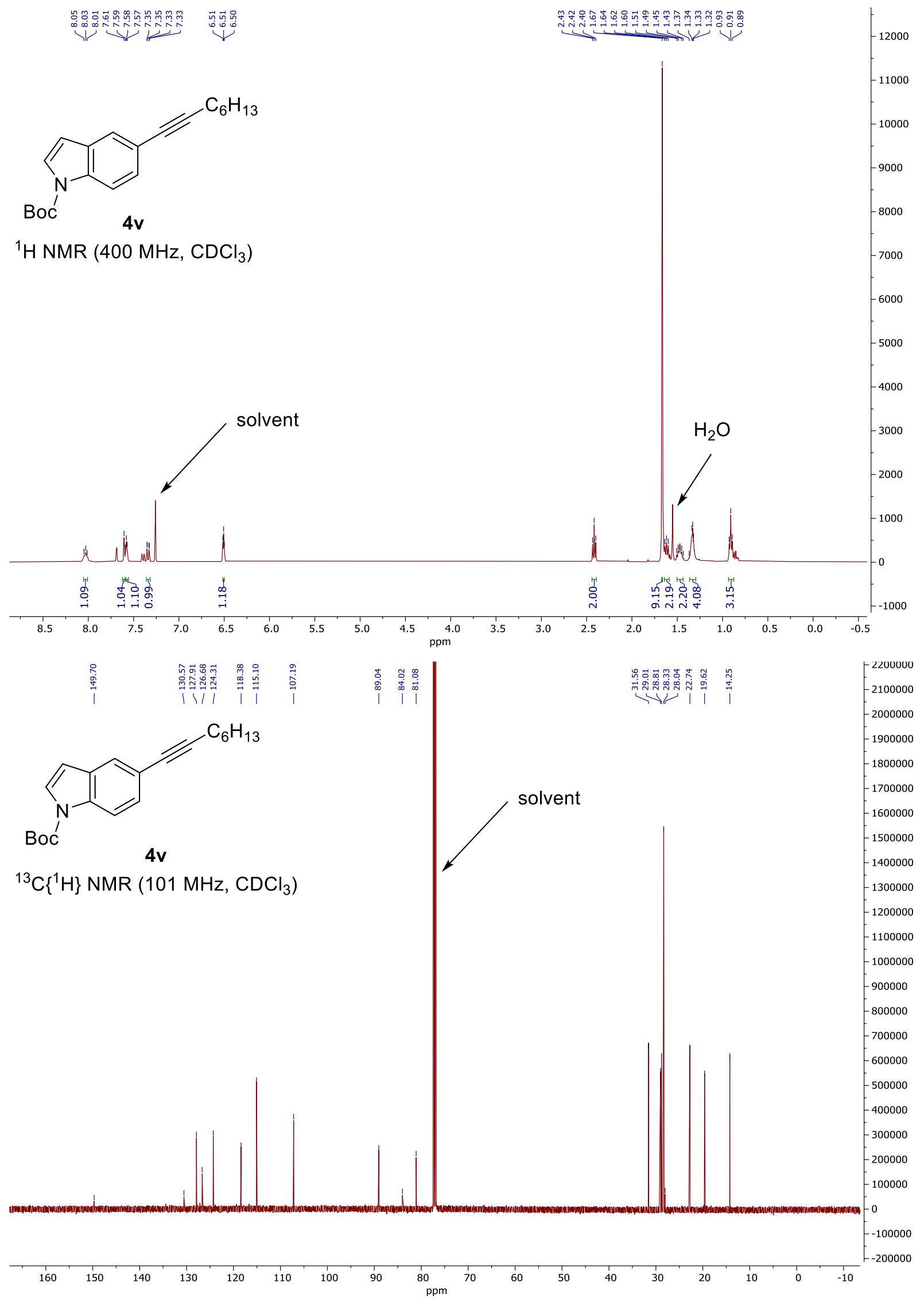




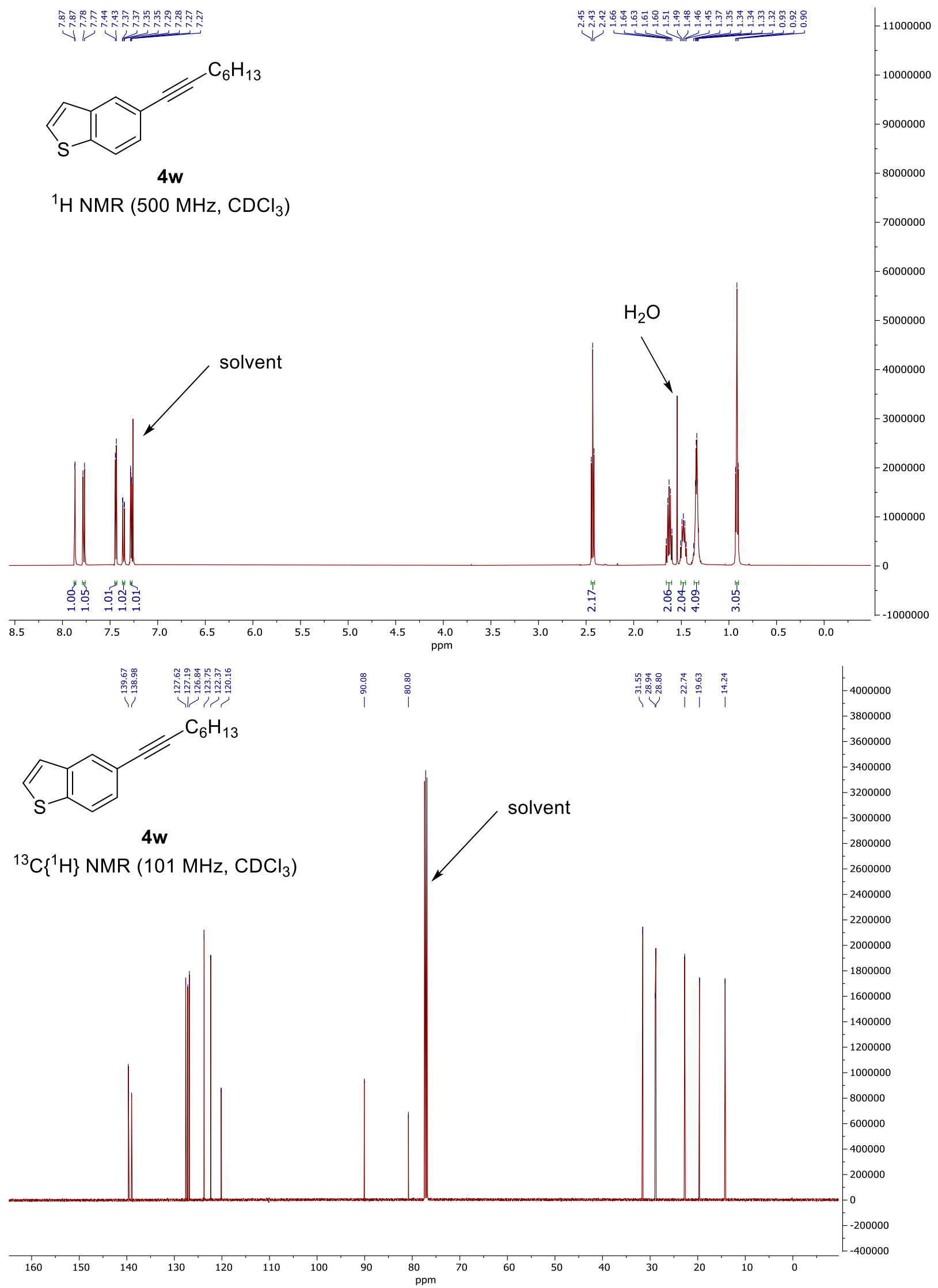




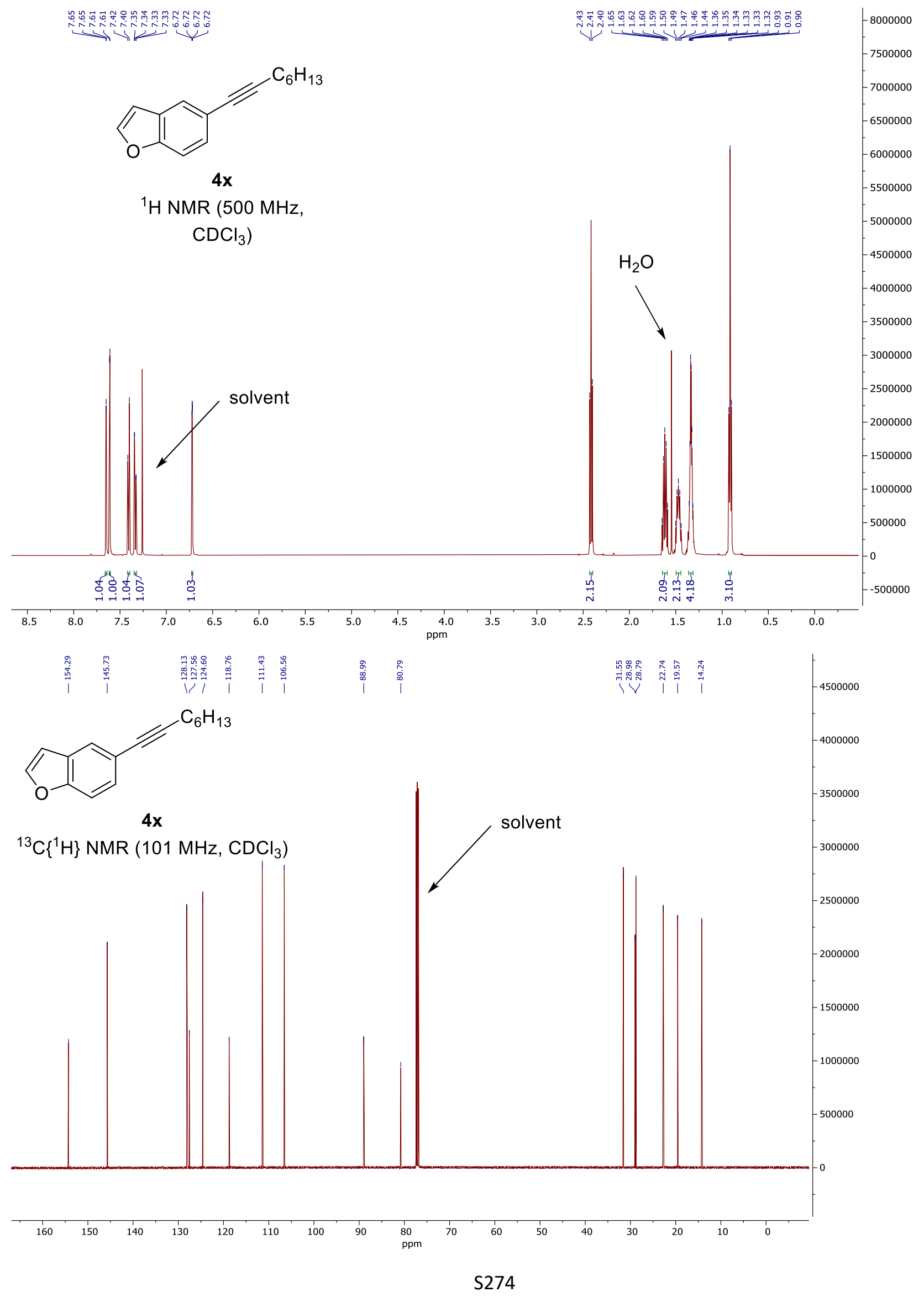




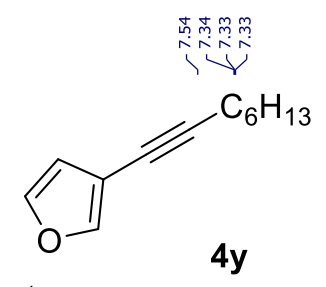

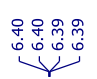

$\underbrace{-2100}_{-1900}$

${ }^{1} \mathrm{H}$ NMR $\left(400 \mathrm{MHz}, \mathrm{CDCl}_{3}\right)$

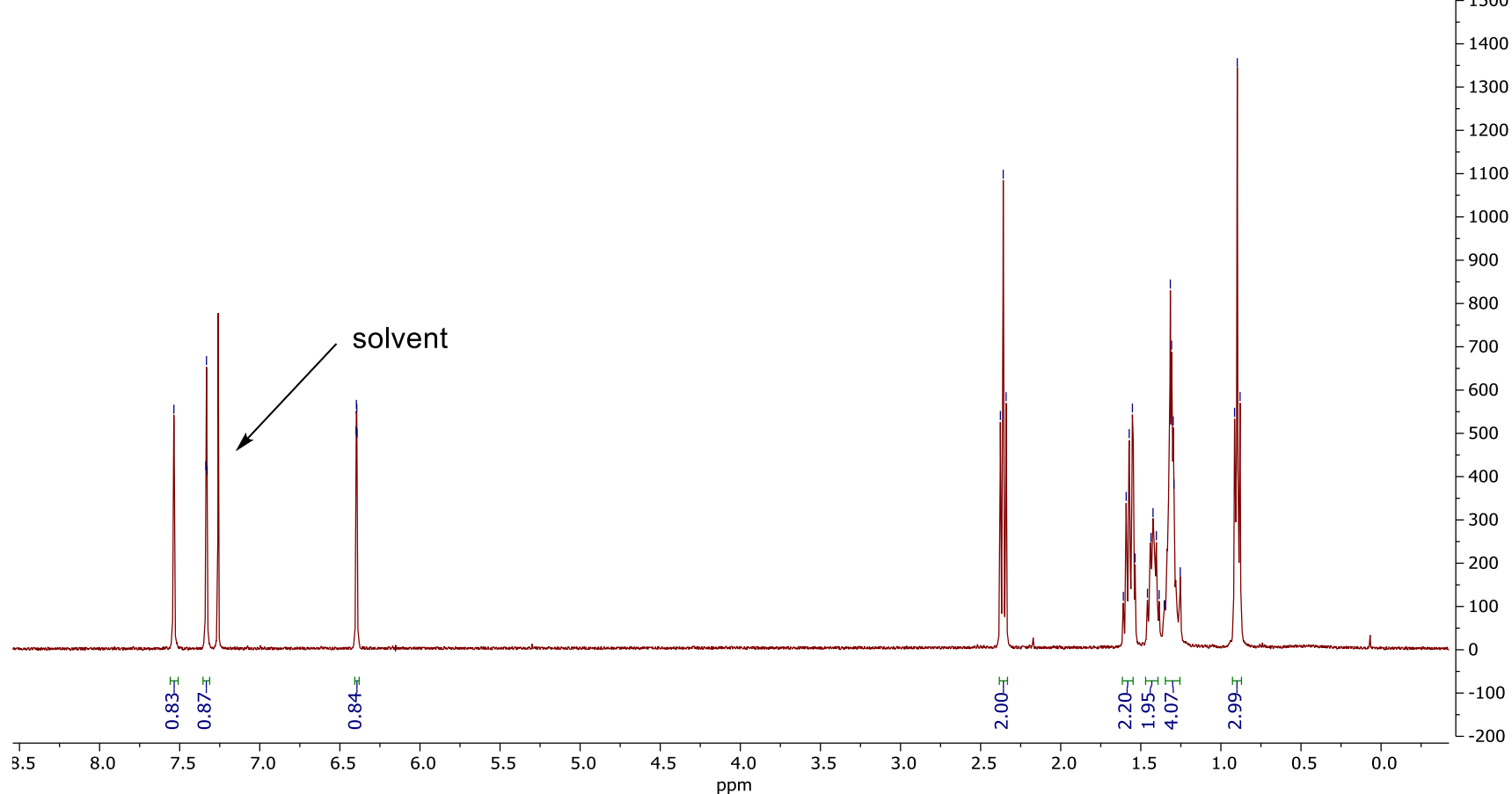




\subsection{Aldehyde products}
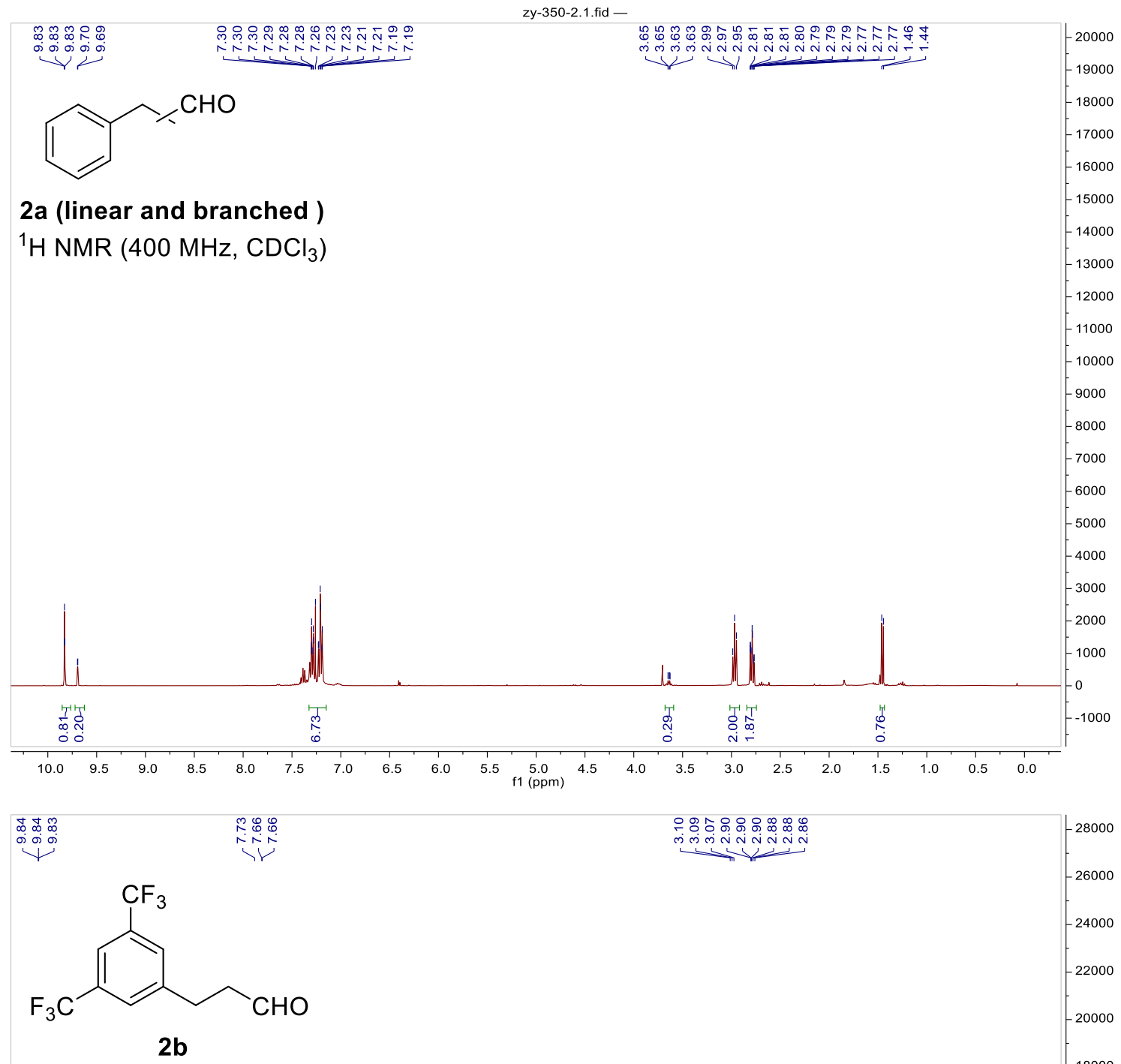

${ }^{1} \mathrm{H}$ NMR $\left(400 \mathrm{MHz}, \mathrm{CDCl}_{3}\right)$

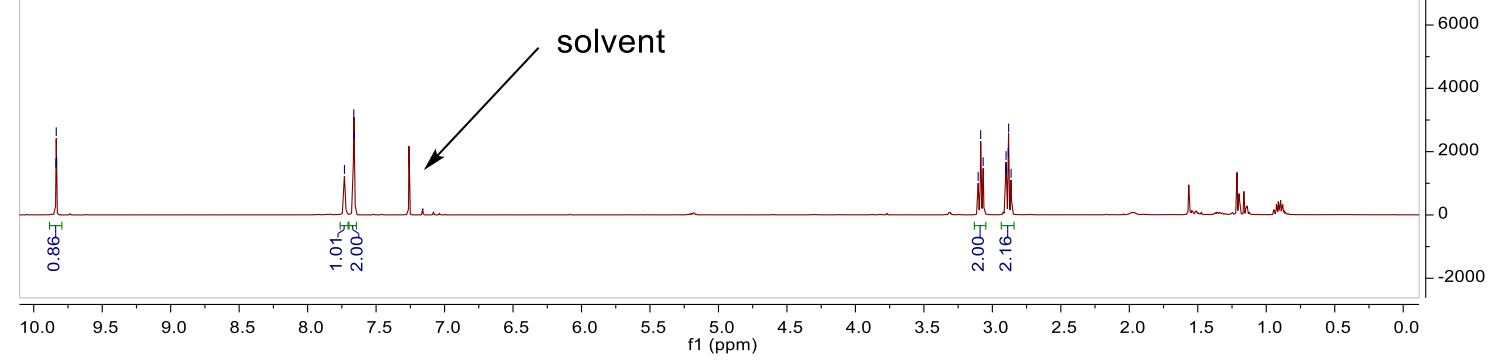




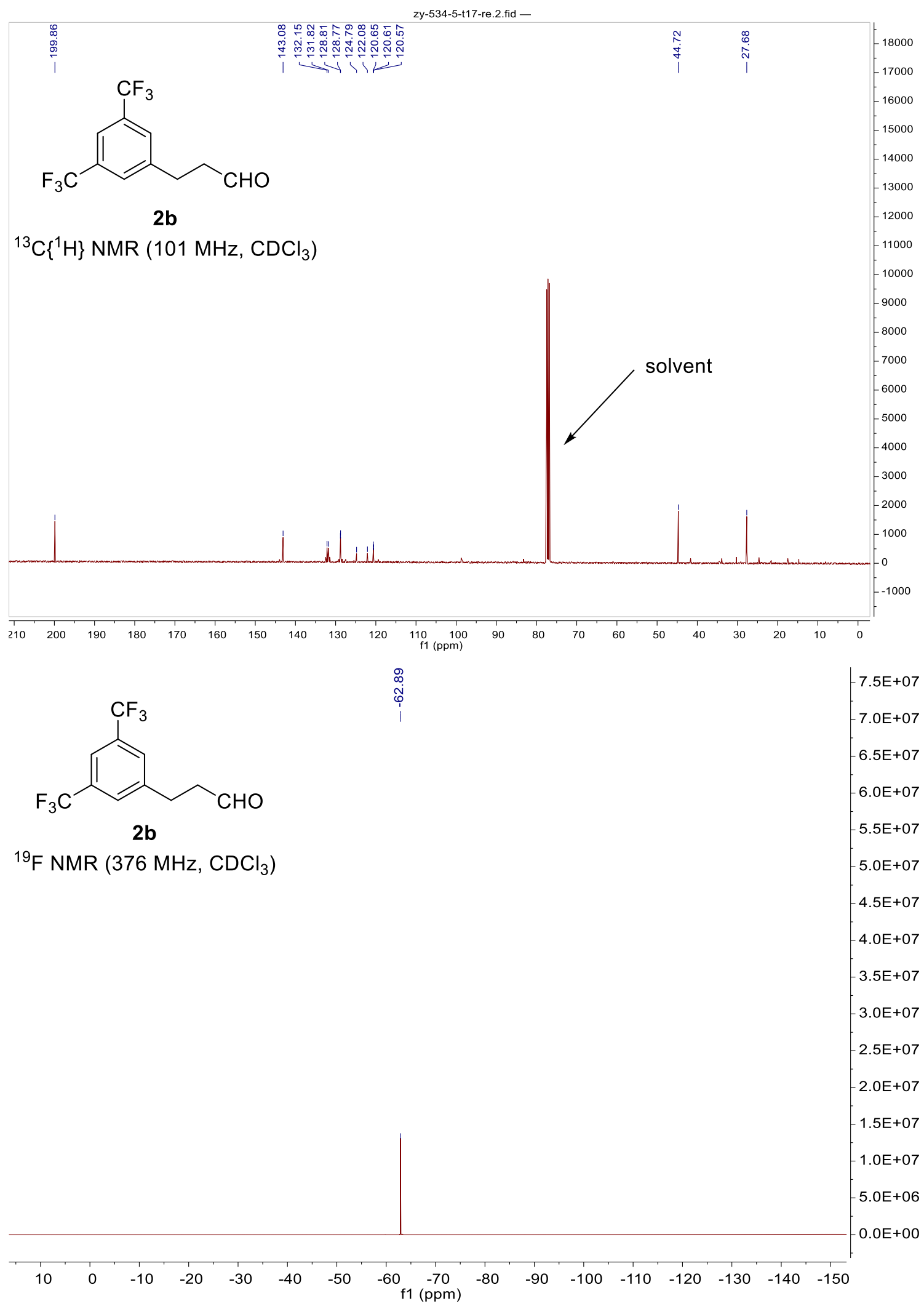



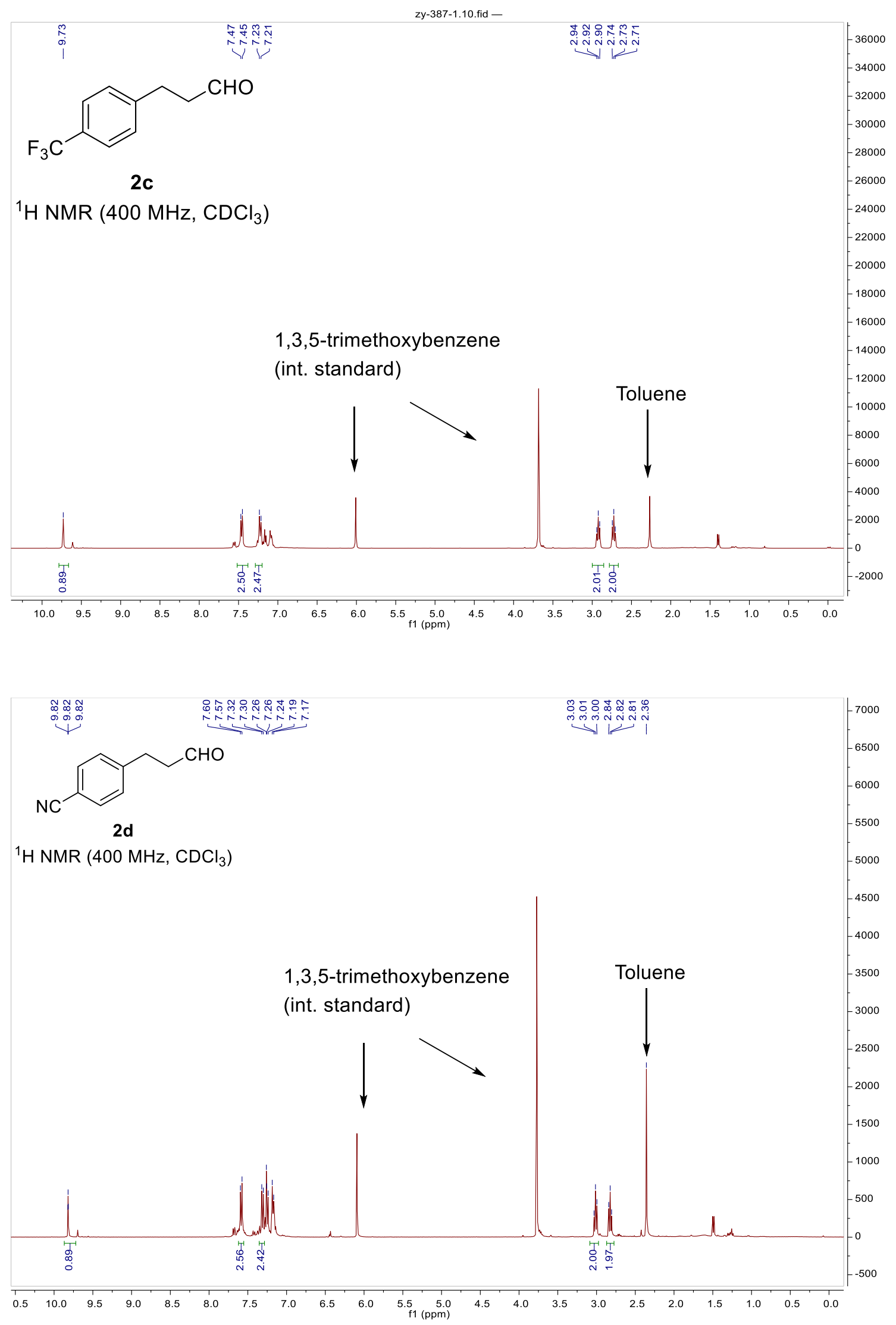

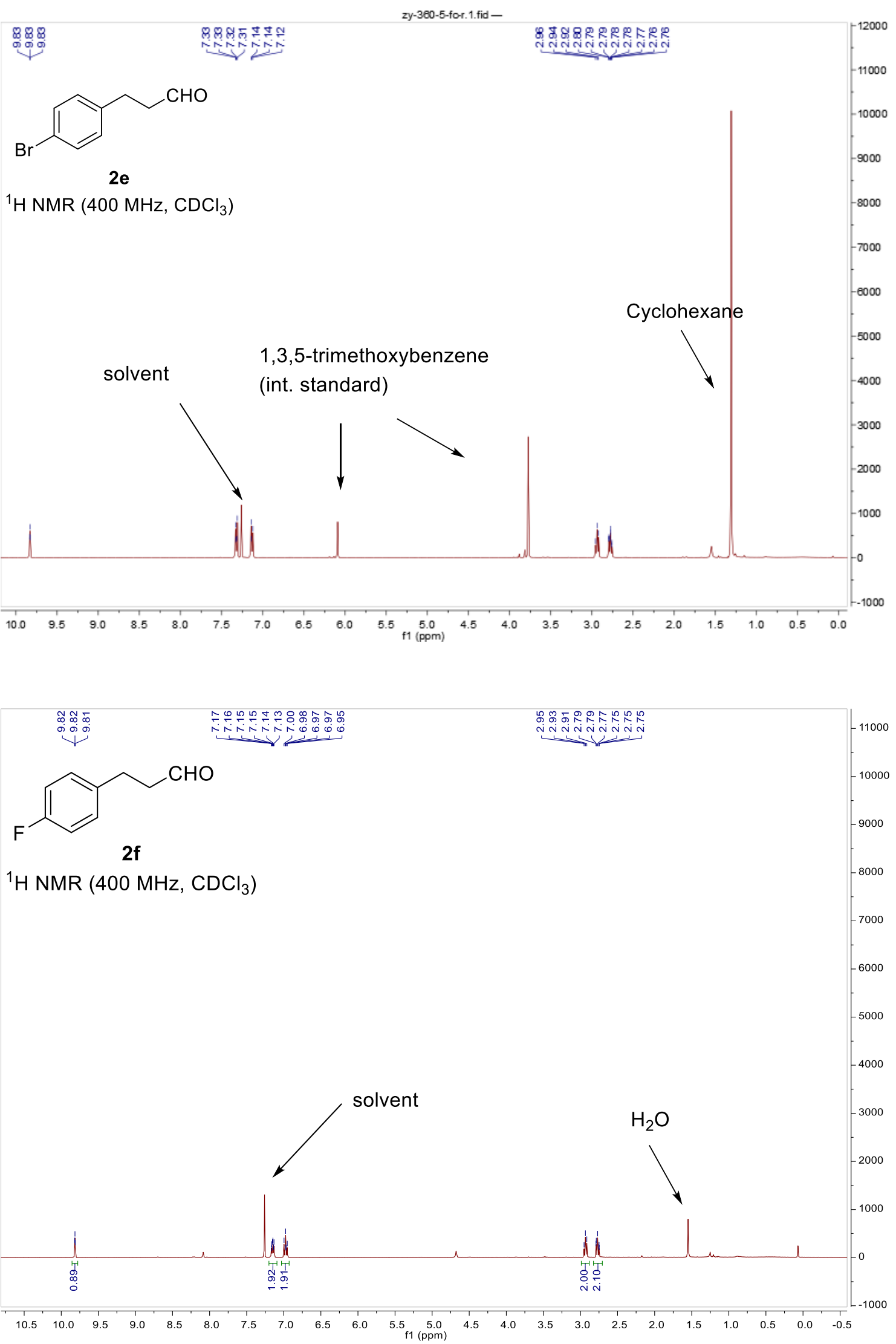


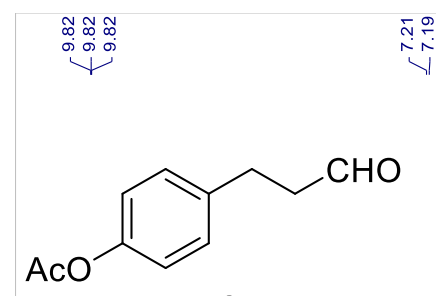

$2 \mathrm{~g}$

${ }^{1} \mathrm{H}$ NMR $\left(400 \mathrm{MHz}, \mathrm{CDCl}_{3}\right)$

iijo

16000

15000

14000

13000

$-12000$

11000

10000

9000

8000

7000

6000

solvent

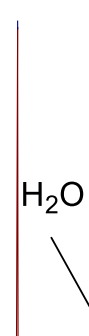

5000

$-4000$

$-3000$

$-2000$
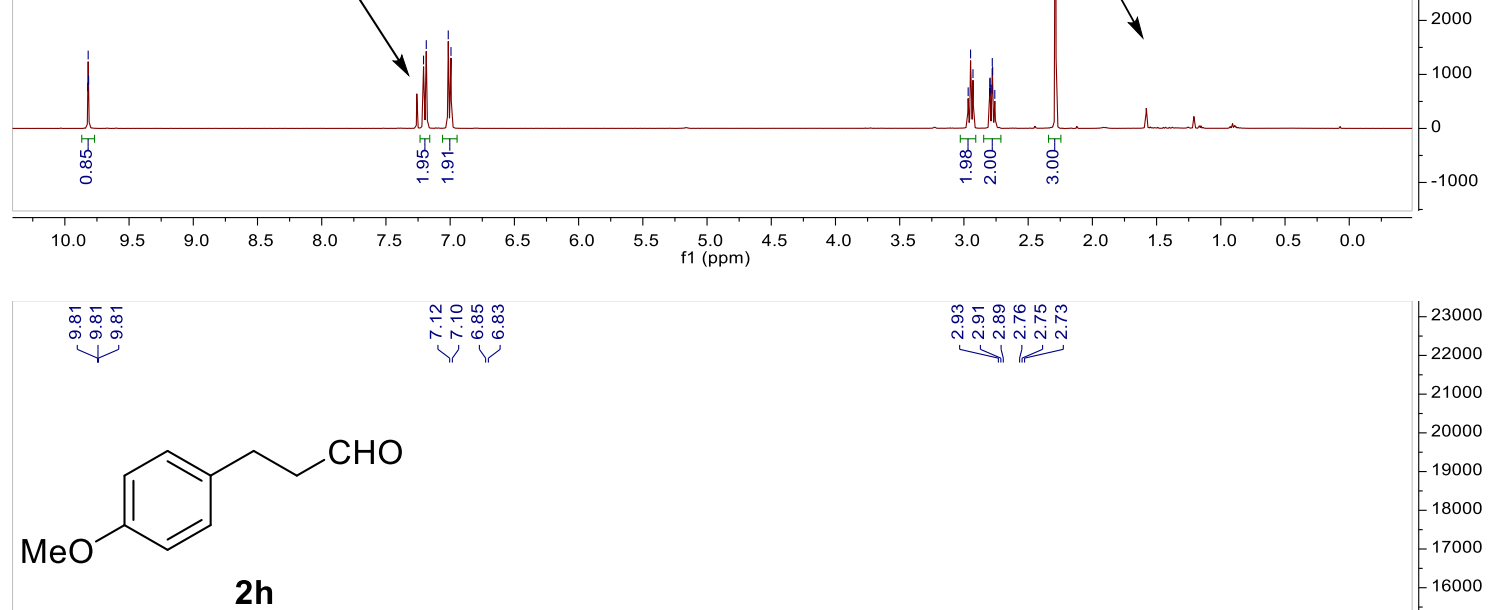

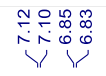

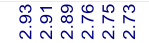

Nin

$2 \mathrm{~h}$

${ }^{1} \mathrm{H}$ NMR $\left(400 \mathrm{MHz}, \mathrm{CDCl}_{3}\right)$

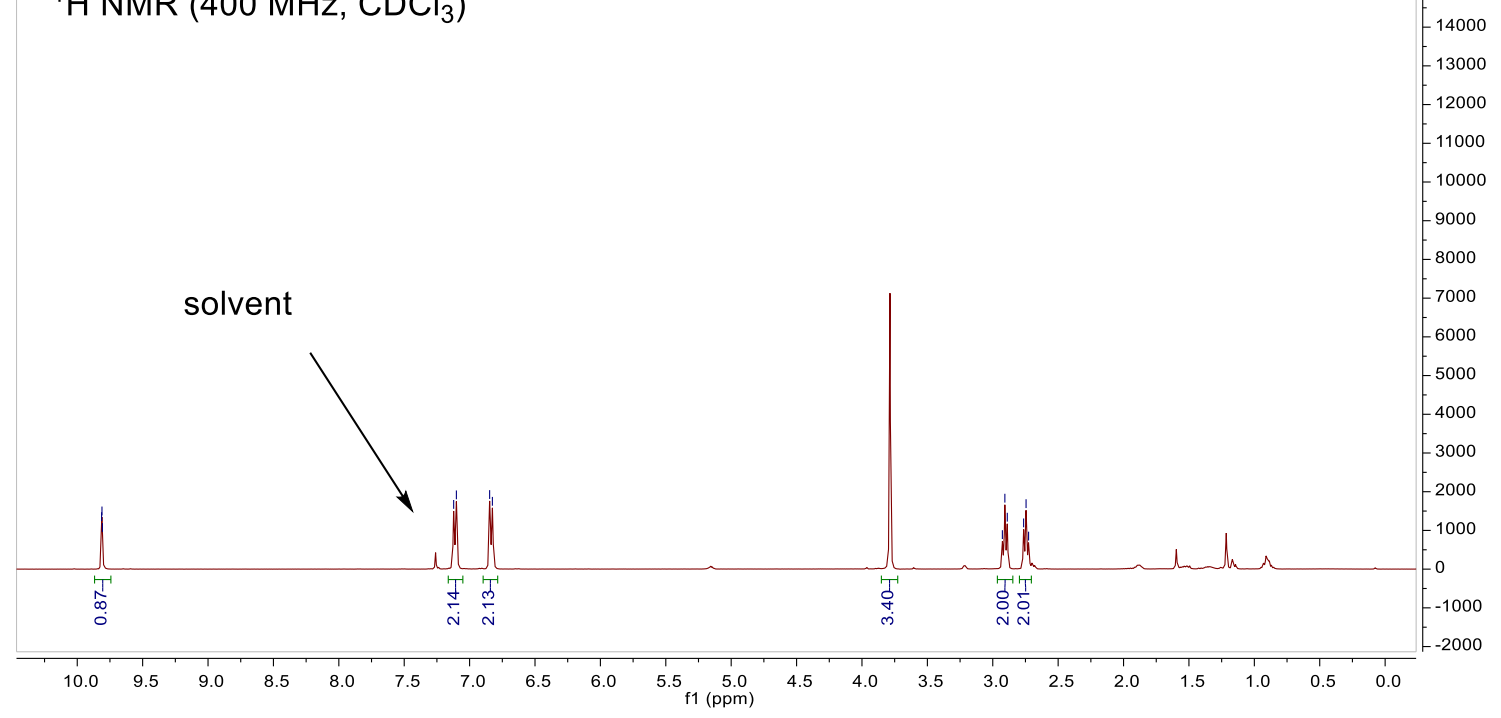



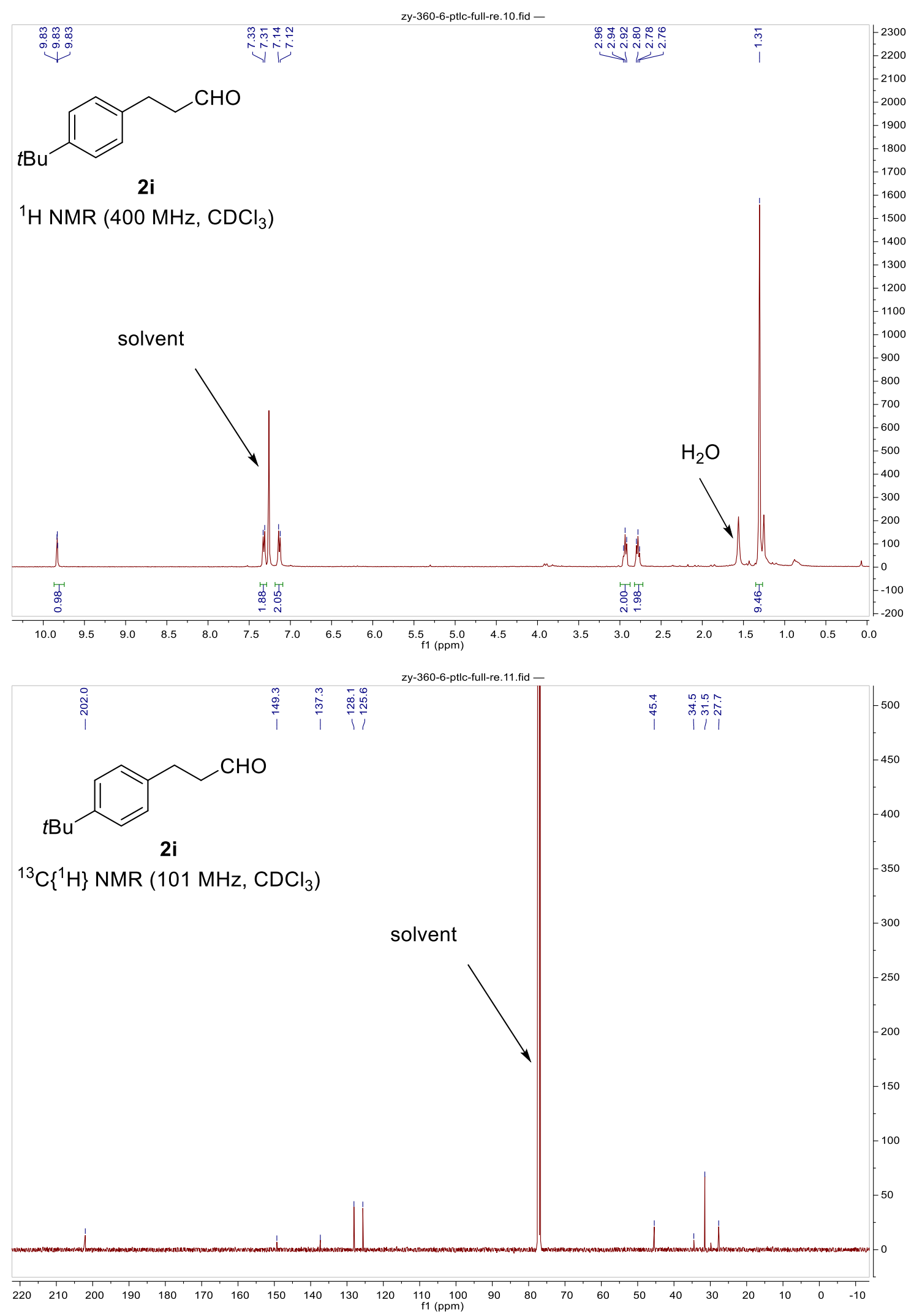


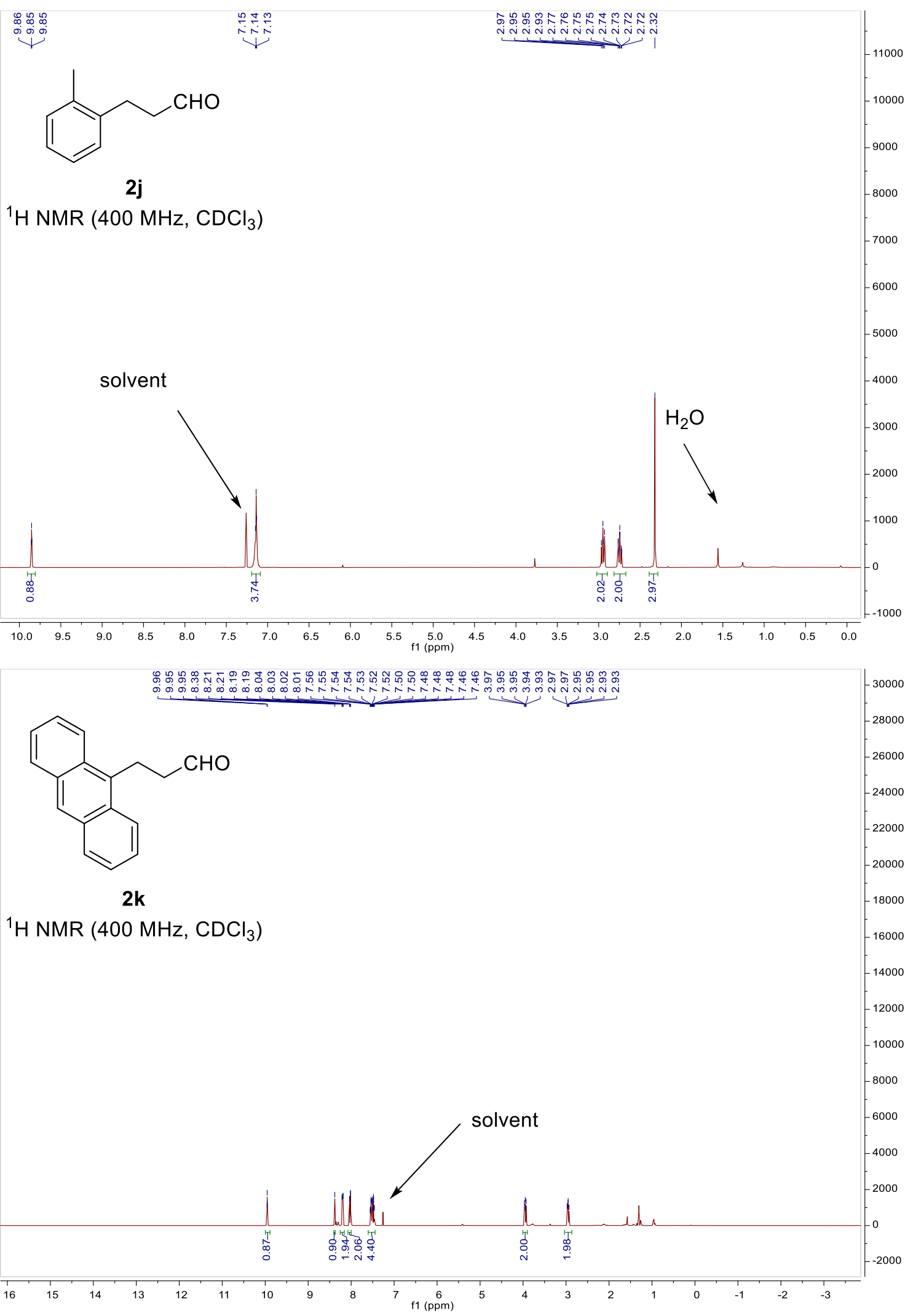



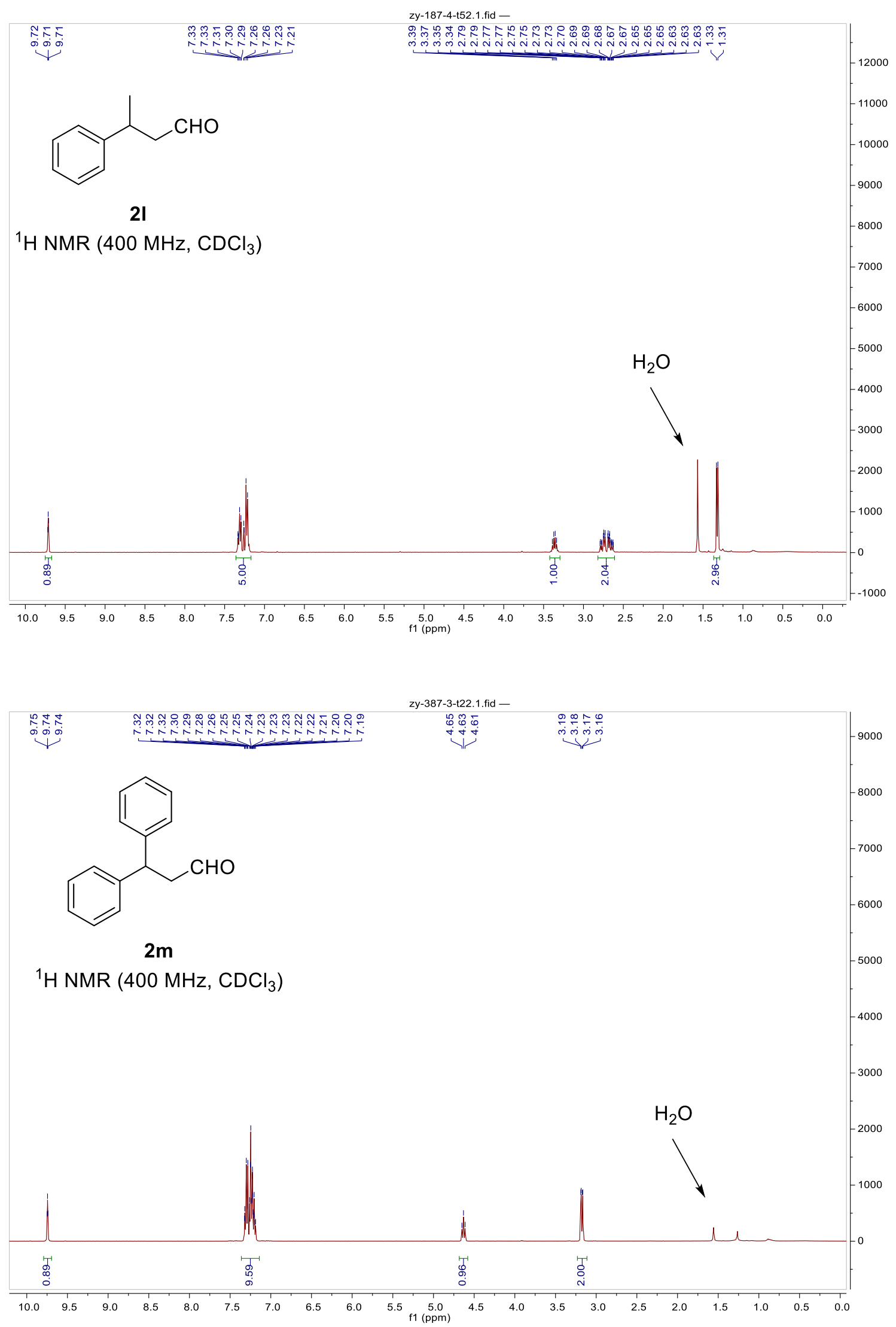

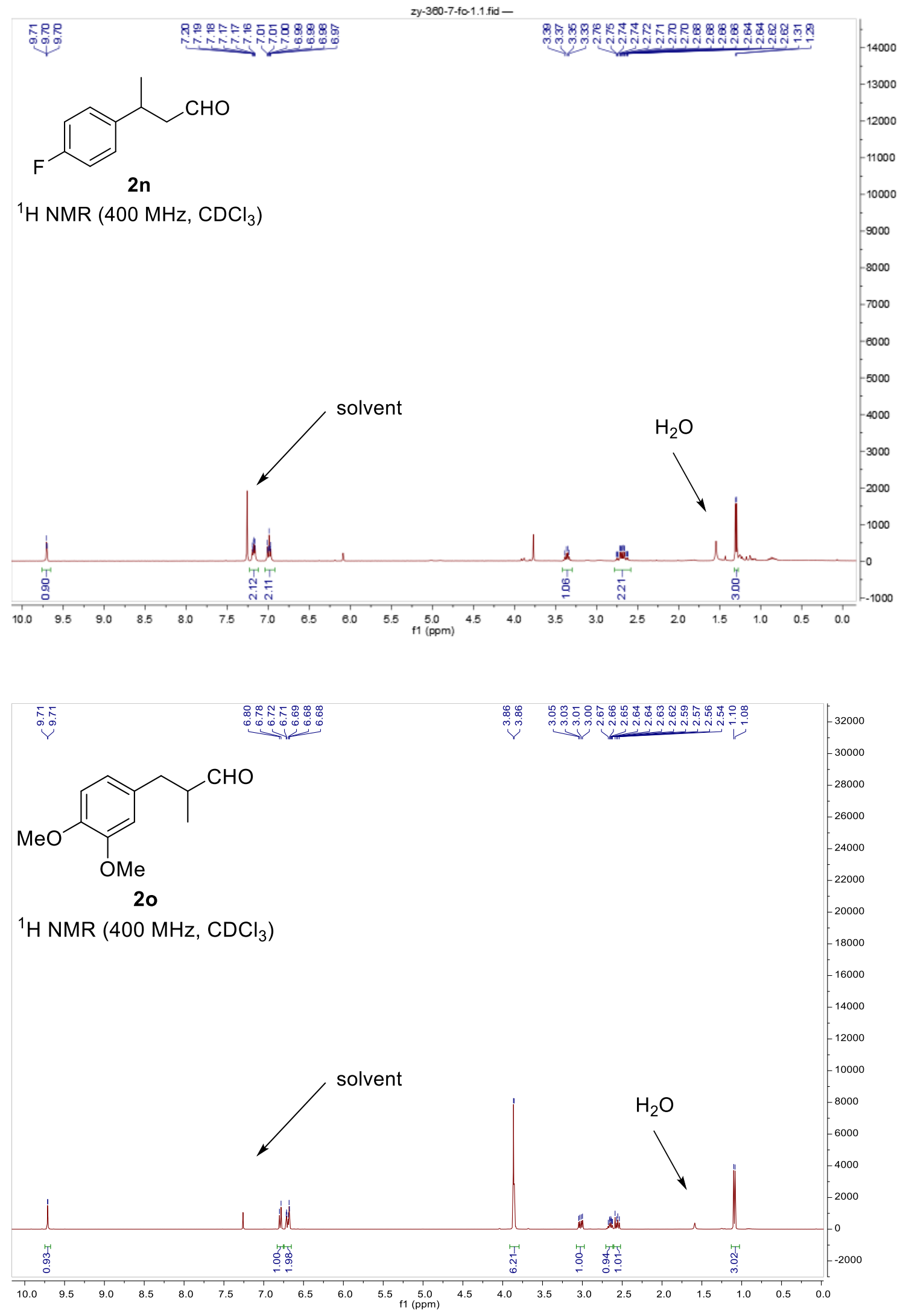


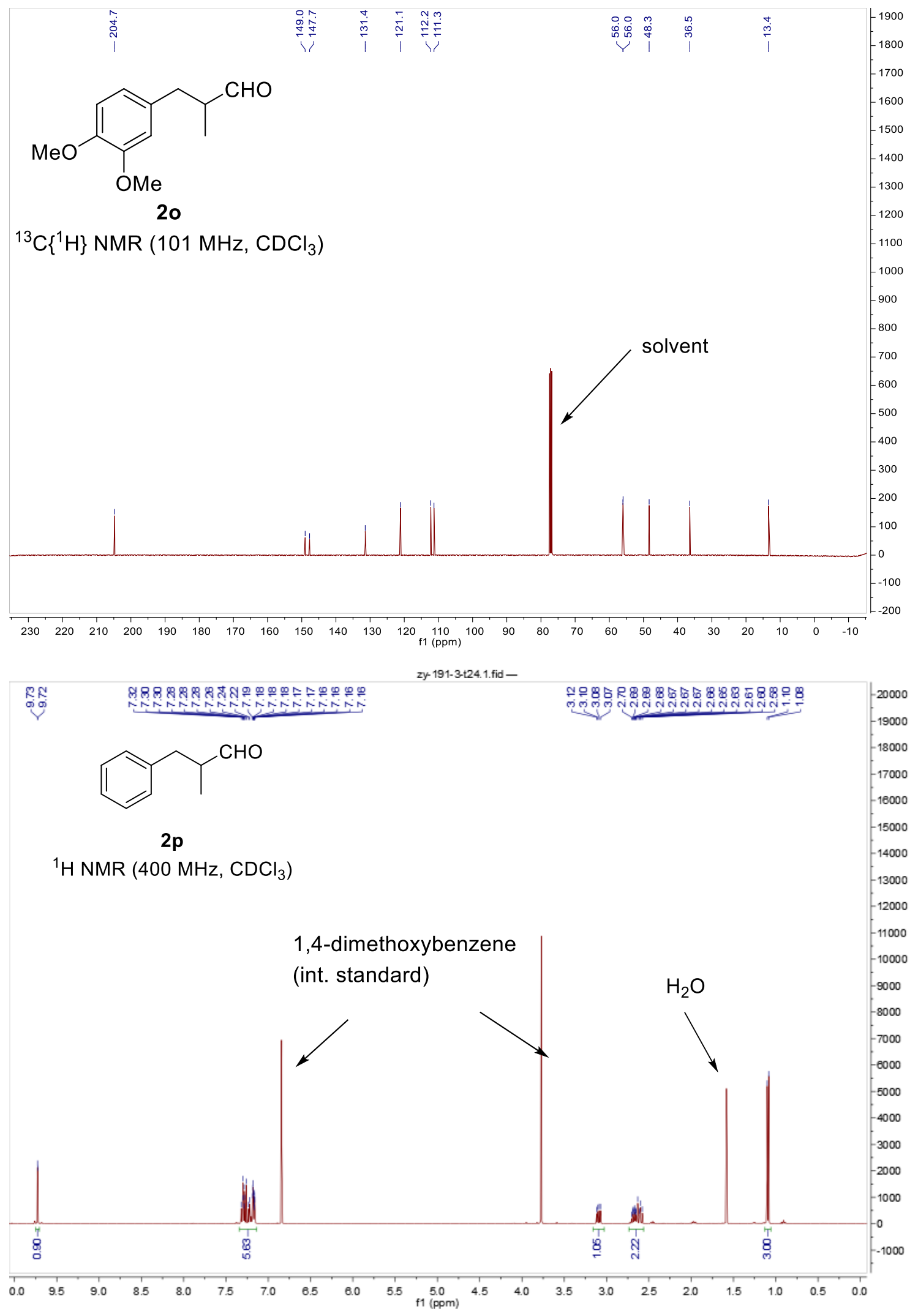




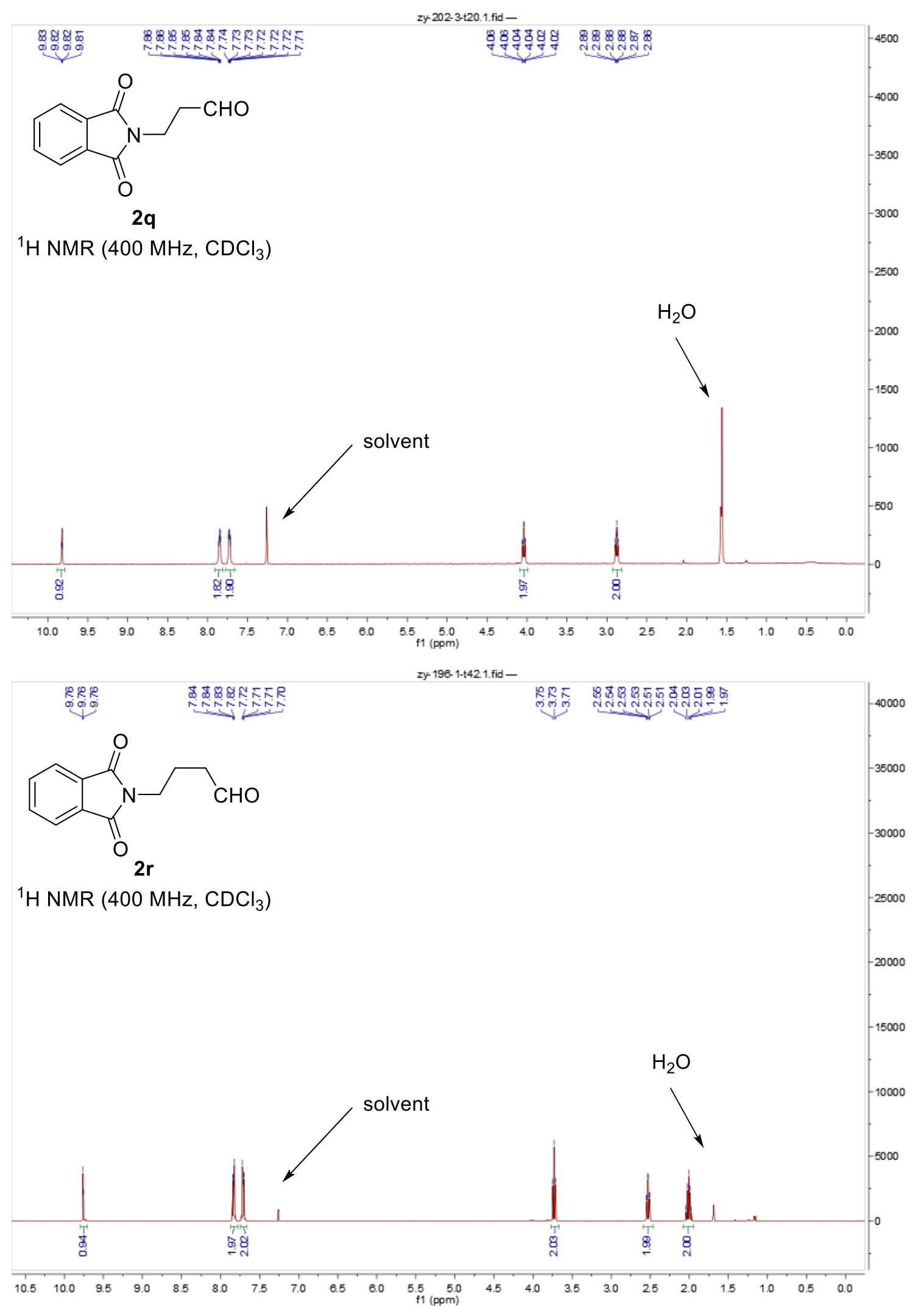



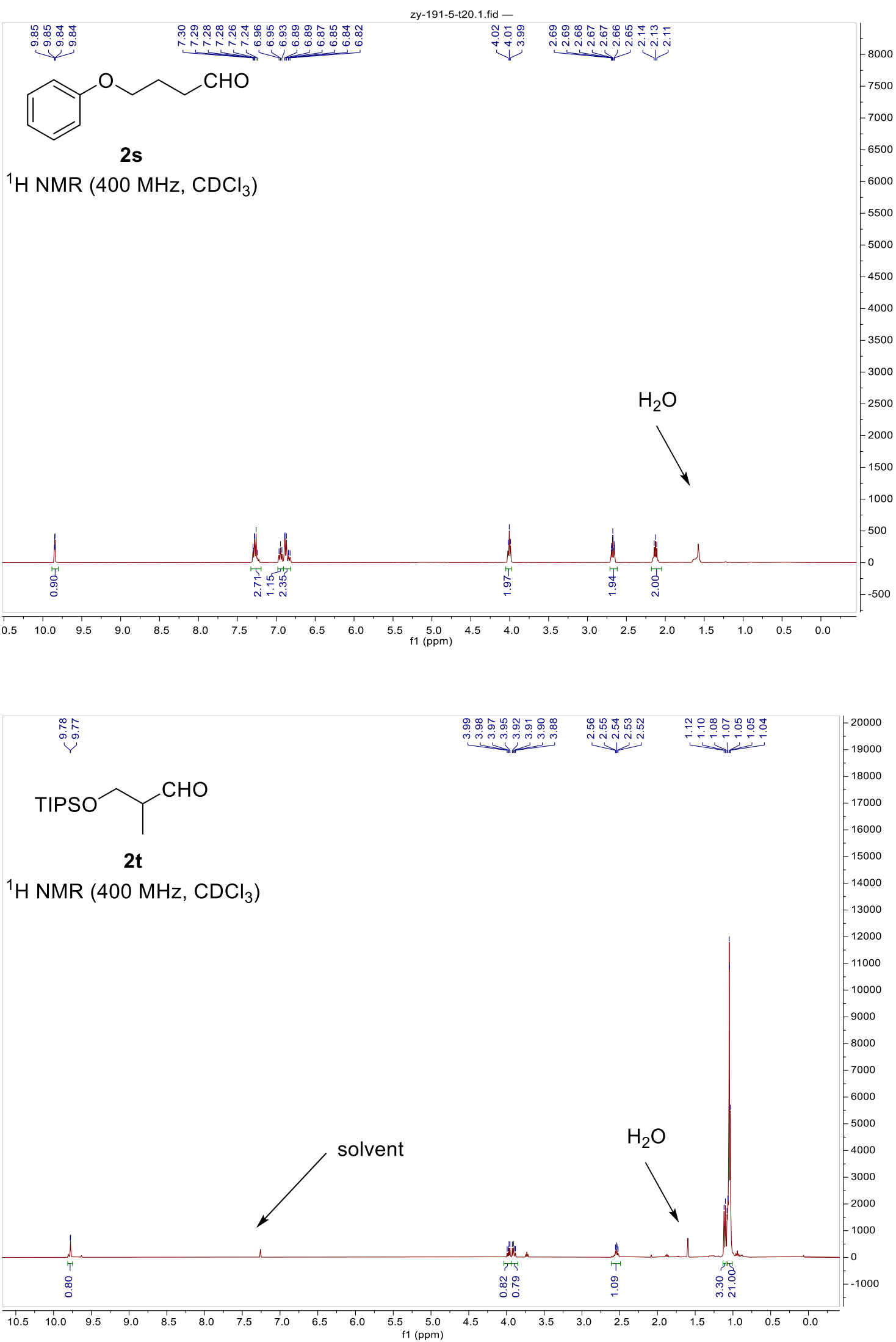


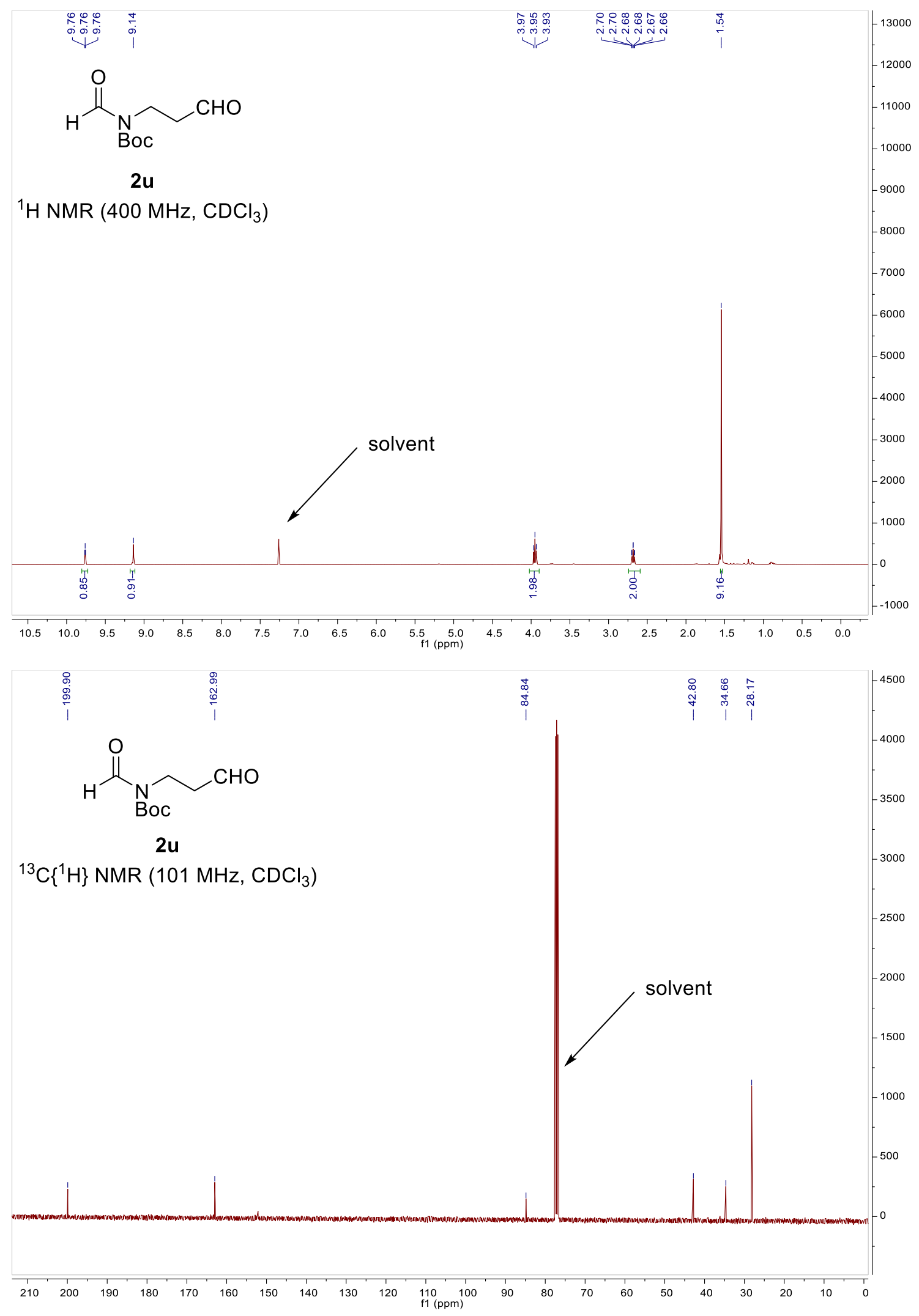



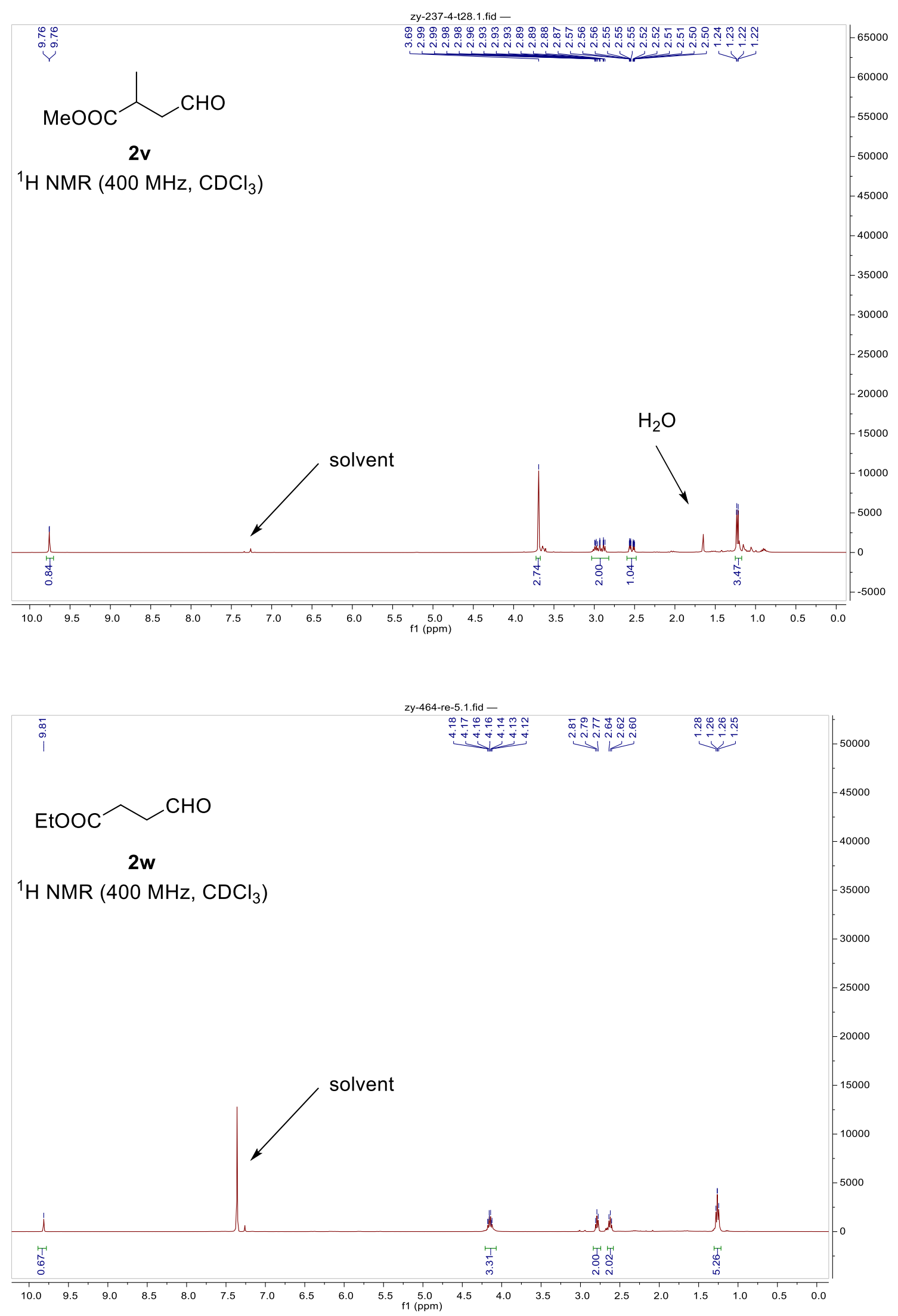


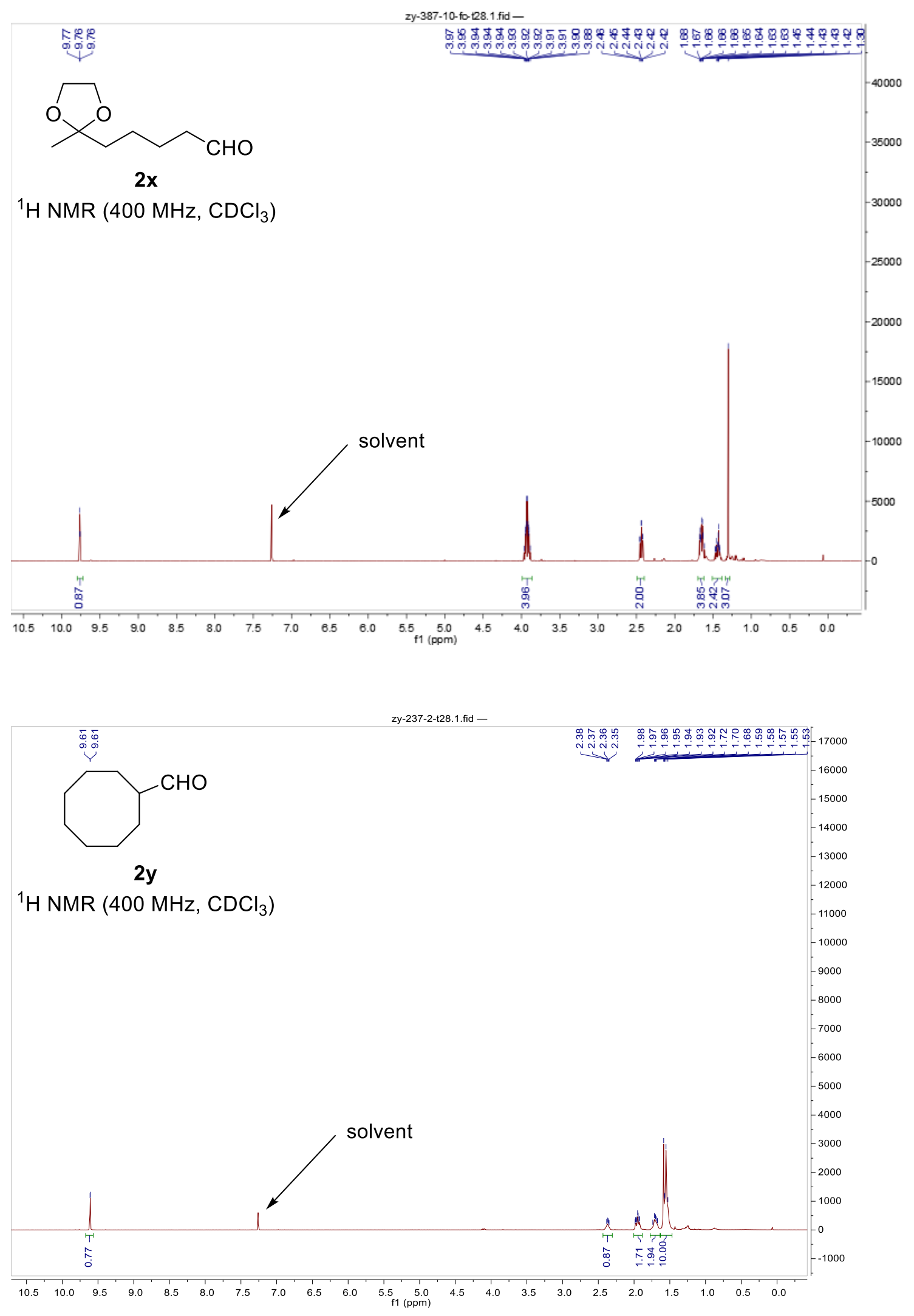




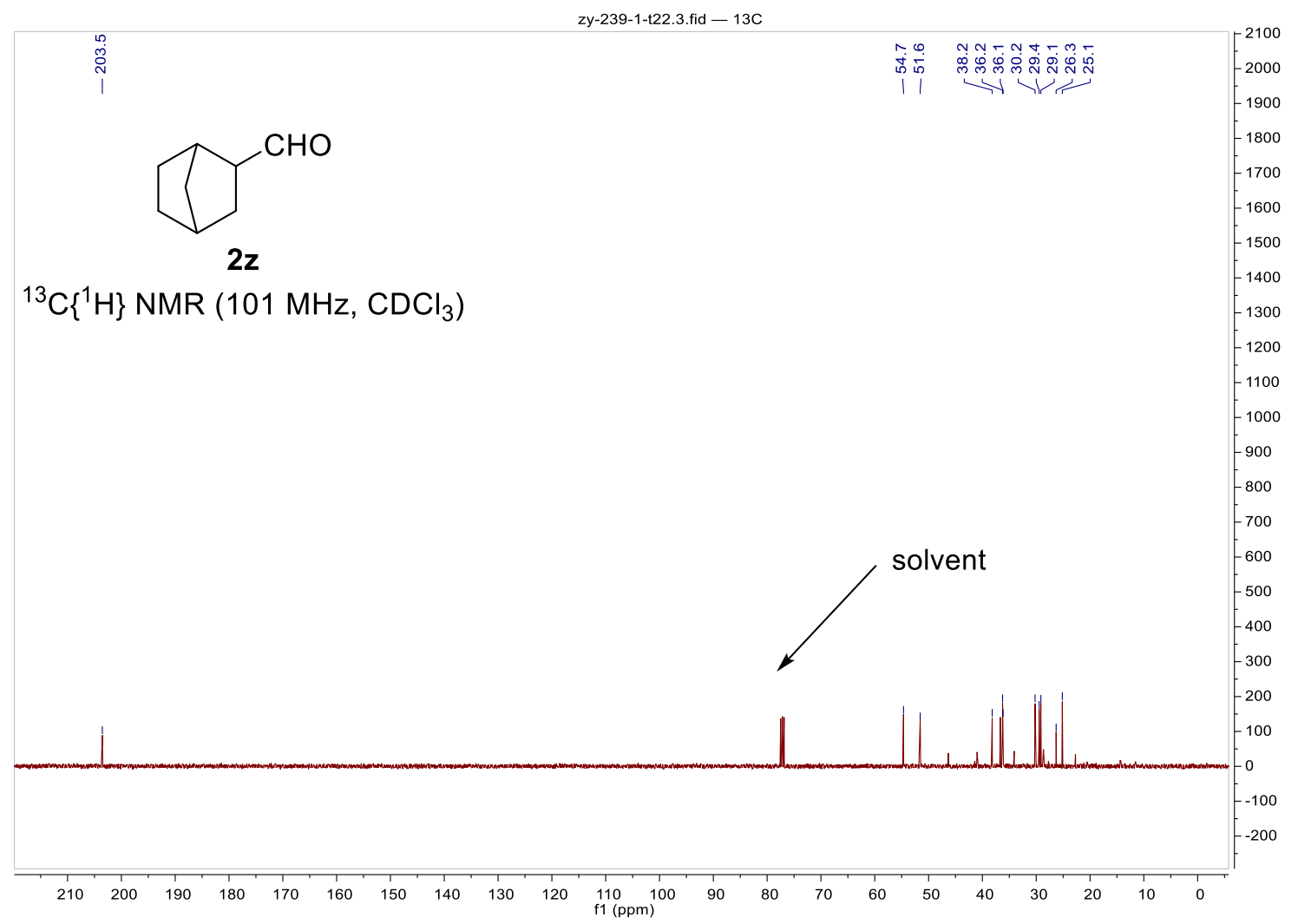




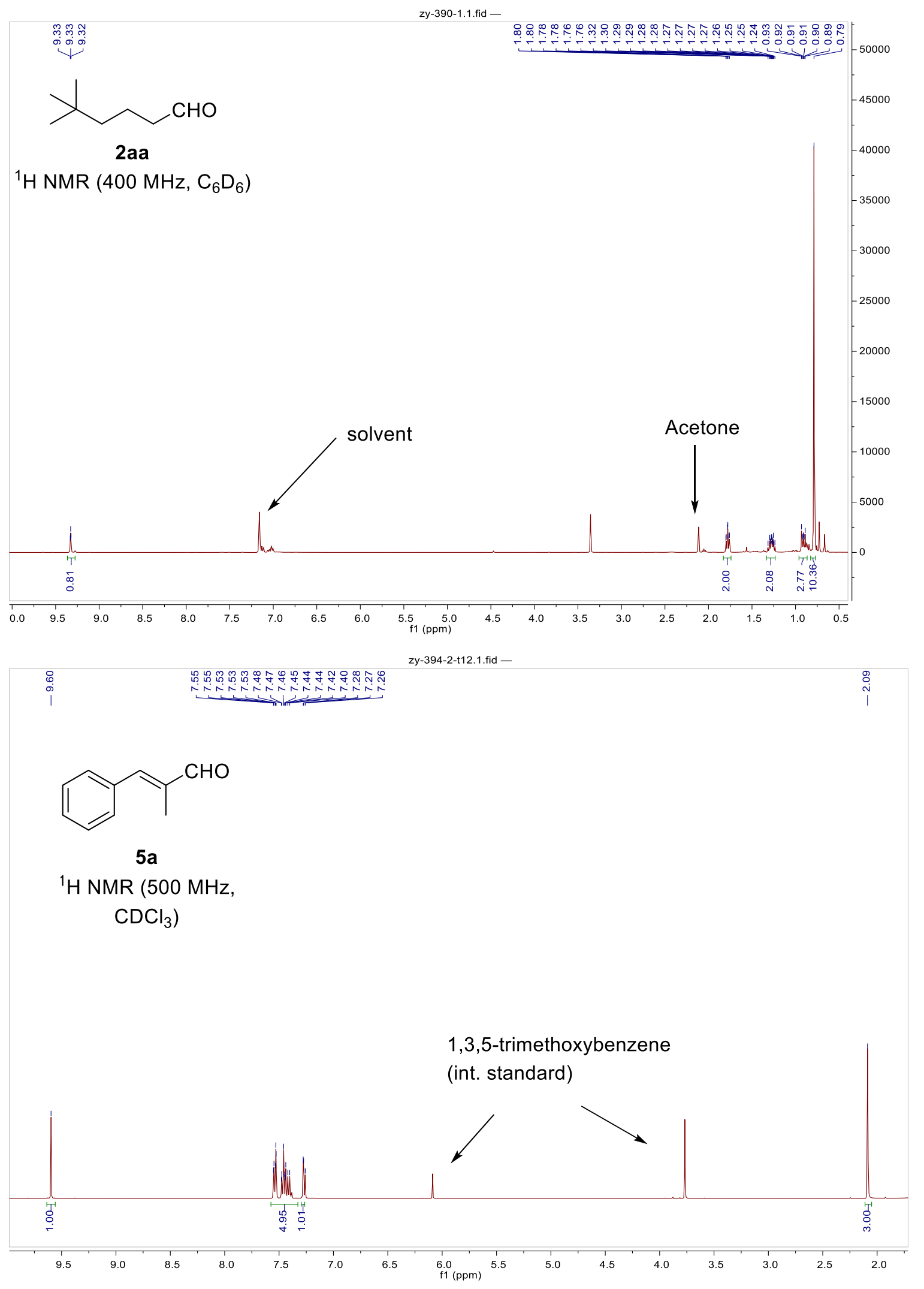



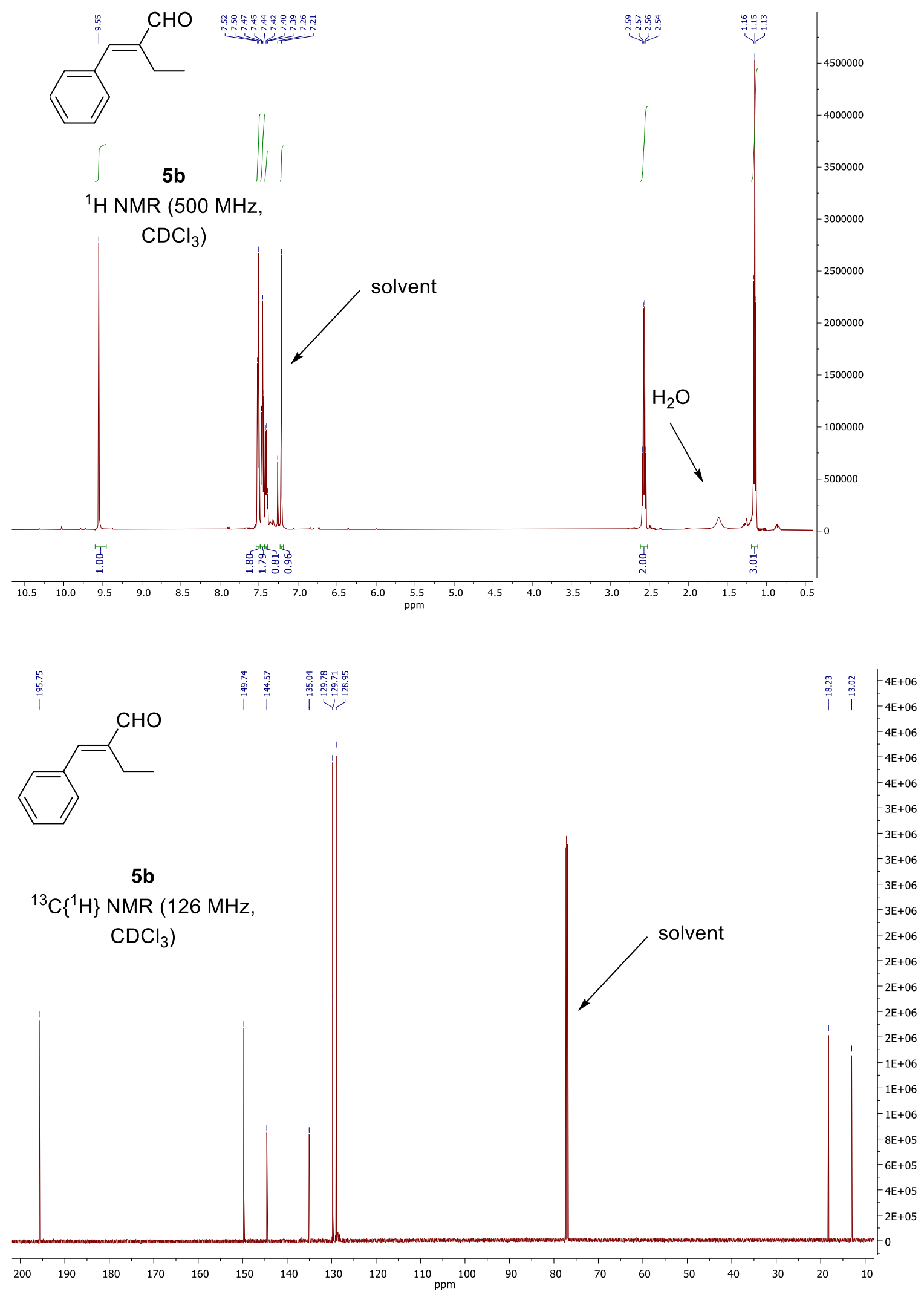


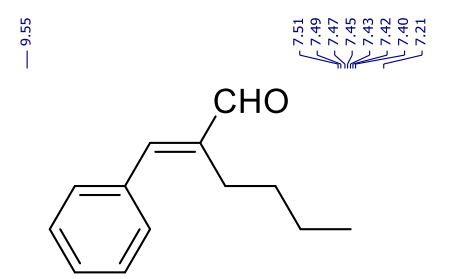

$5 c$
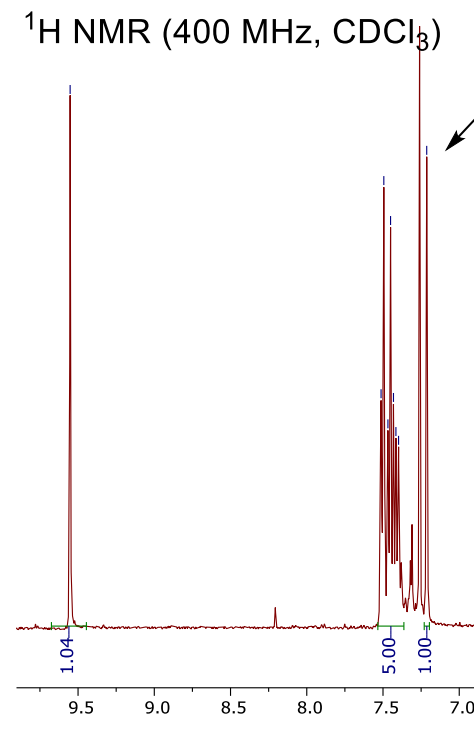
solvent
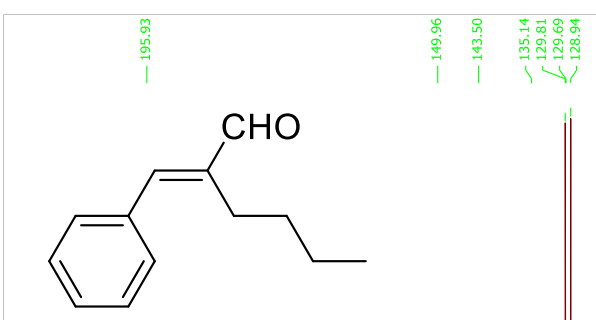

$5 c$ ${ }^{13} \mathrm{C}\left\{{ }^{1} \mathrm{H}\right\}$ NMR $\left(126 \mathrm{MHz},\left.\mathrm{CDCl}\right|_{3}\right)$

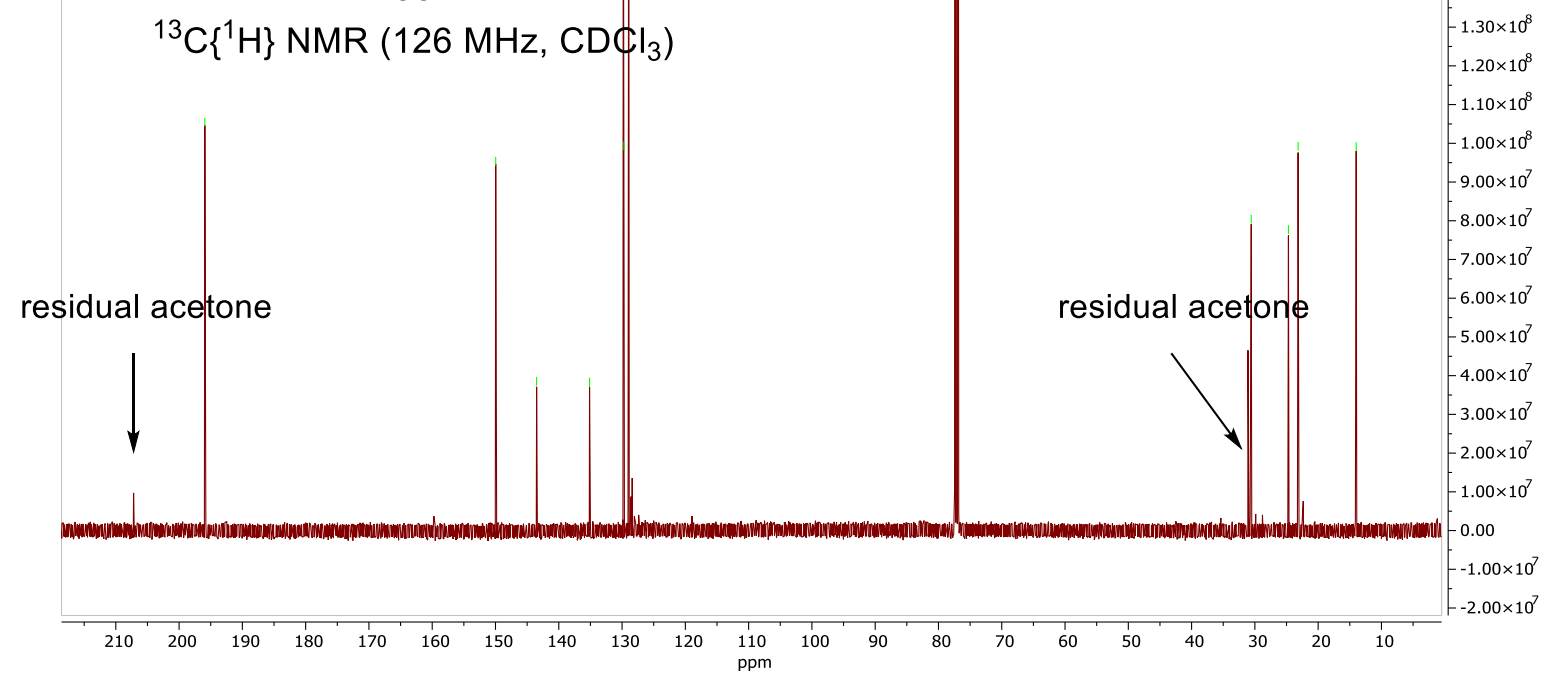



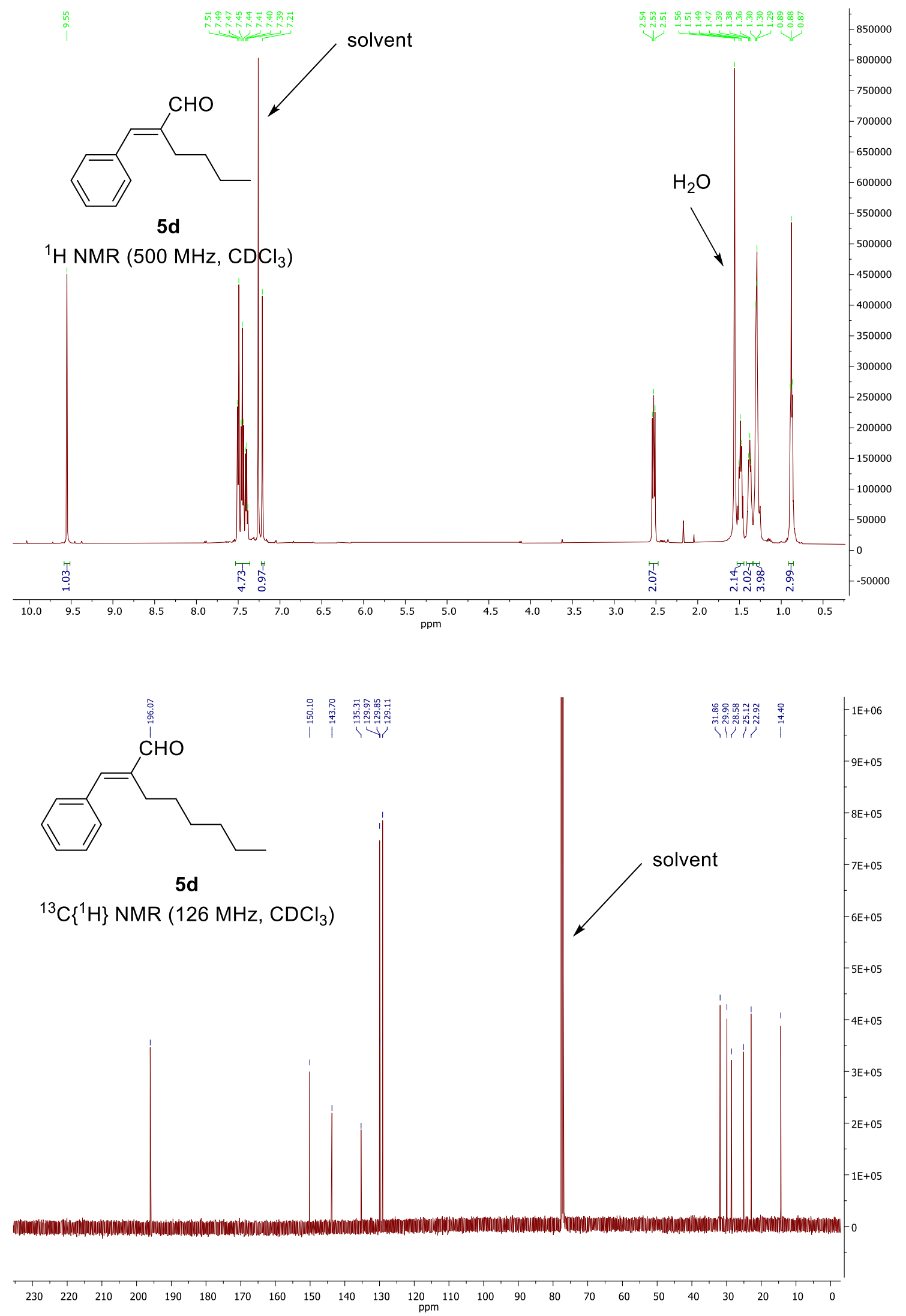

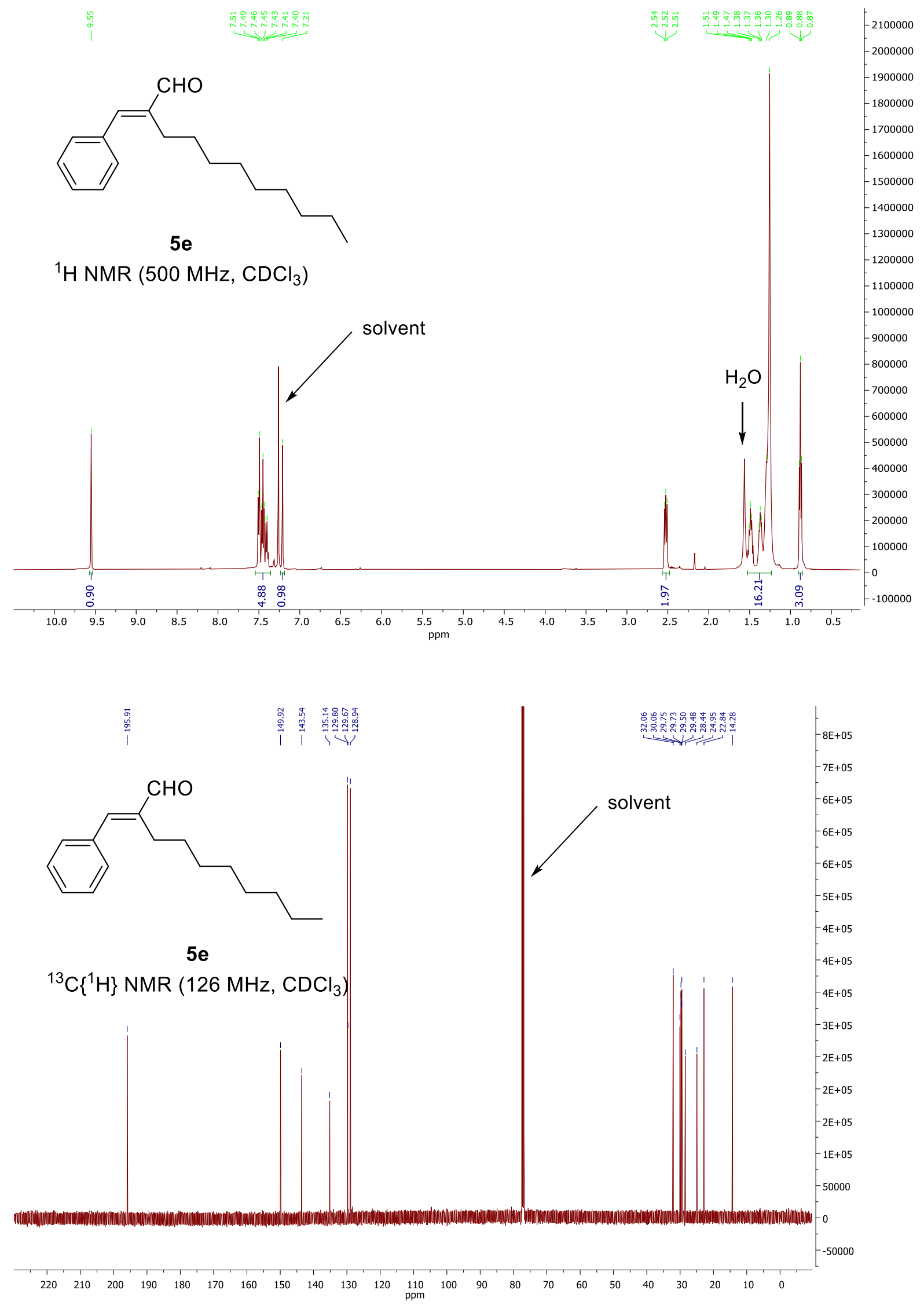

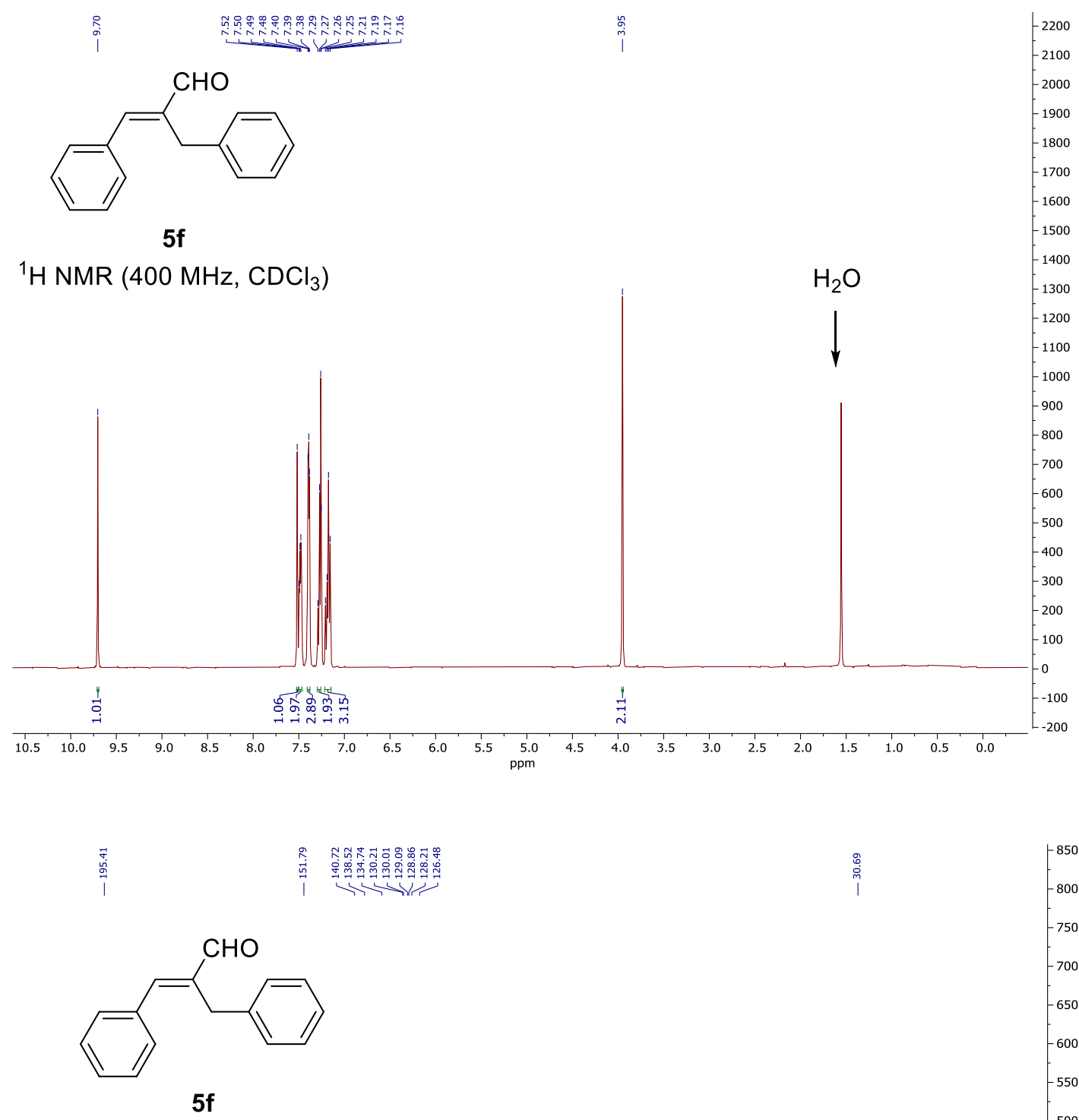

${ }^{13} \mathrm{C}\left\{{ }^{1} \mathrm{H}\right\}$ NMR $\left(101 \mathrm{MHz}, \mathrm{CDCl}_{3}\right)$

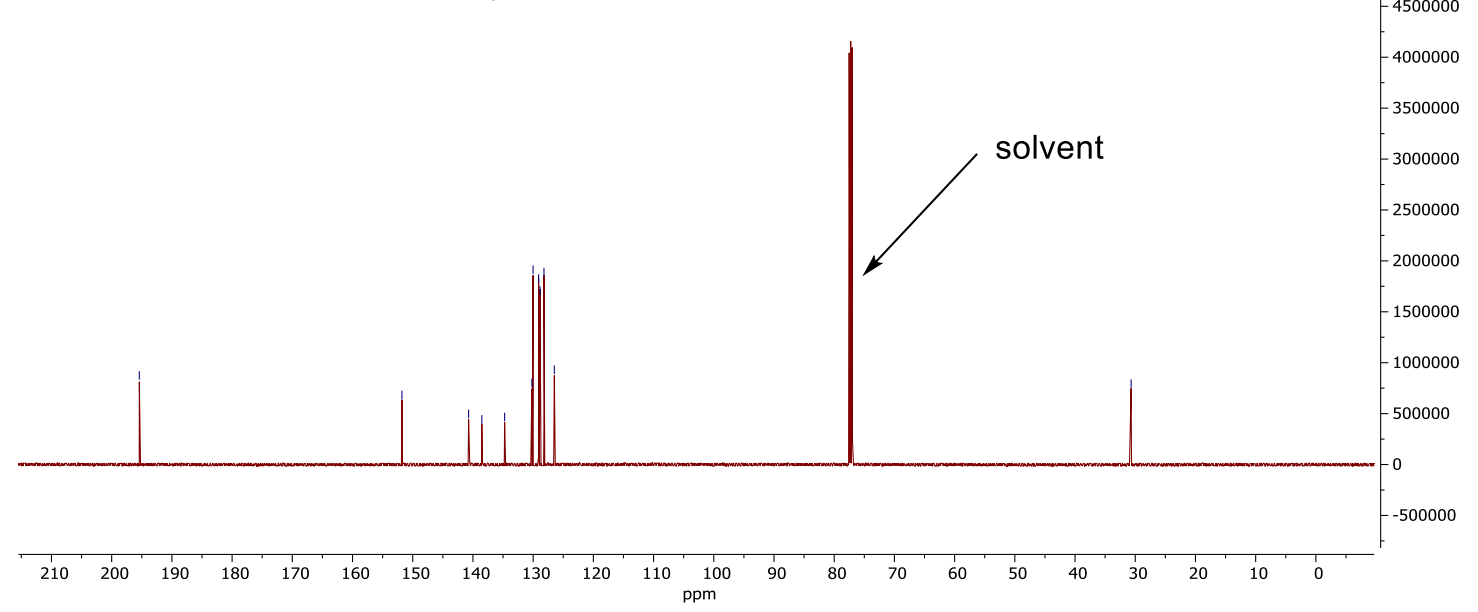




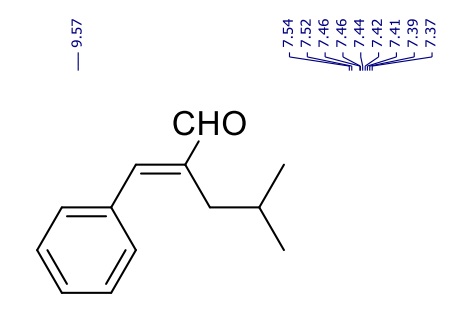

$5 \mathrm{~g}$

${ }^{1} \mathrm{H}$ NMR $\left(400 \mathrm{MHz}, \mathrm{CDCl}_{3}\right)$

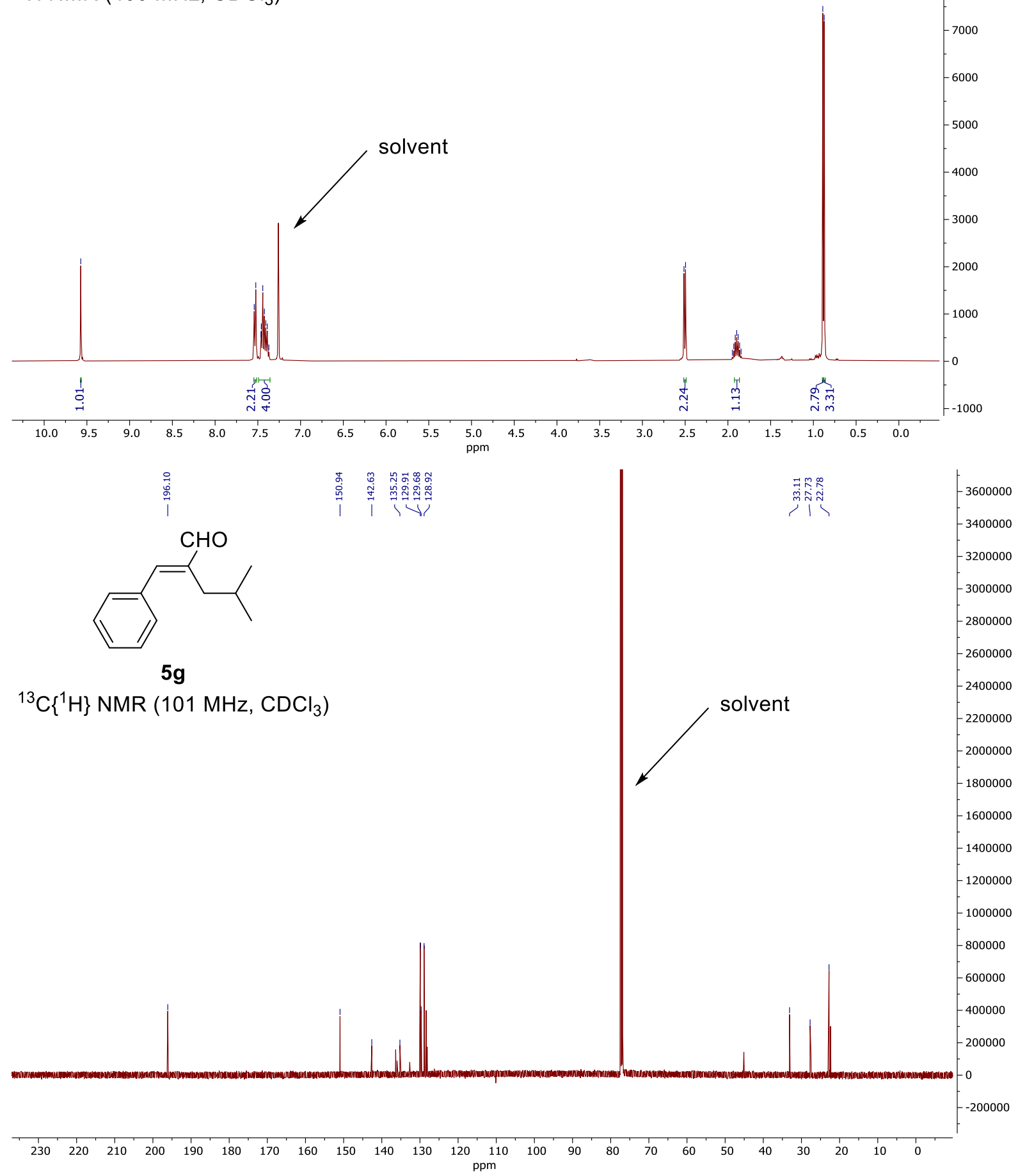




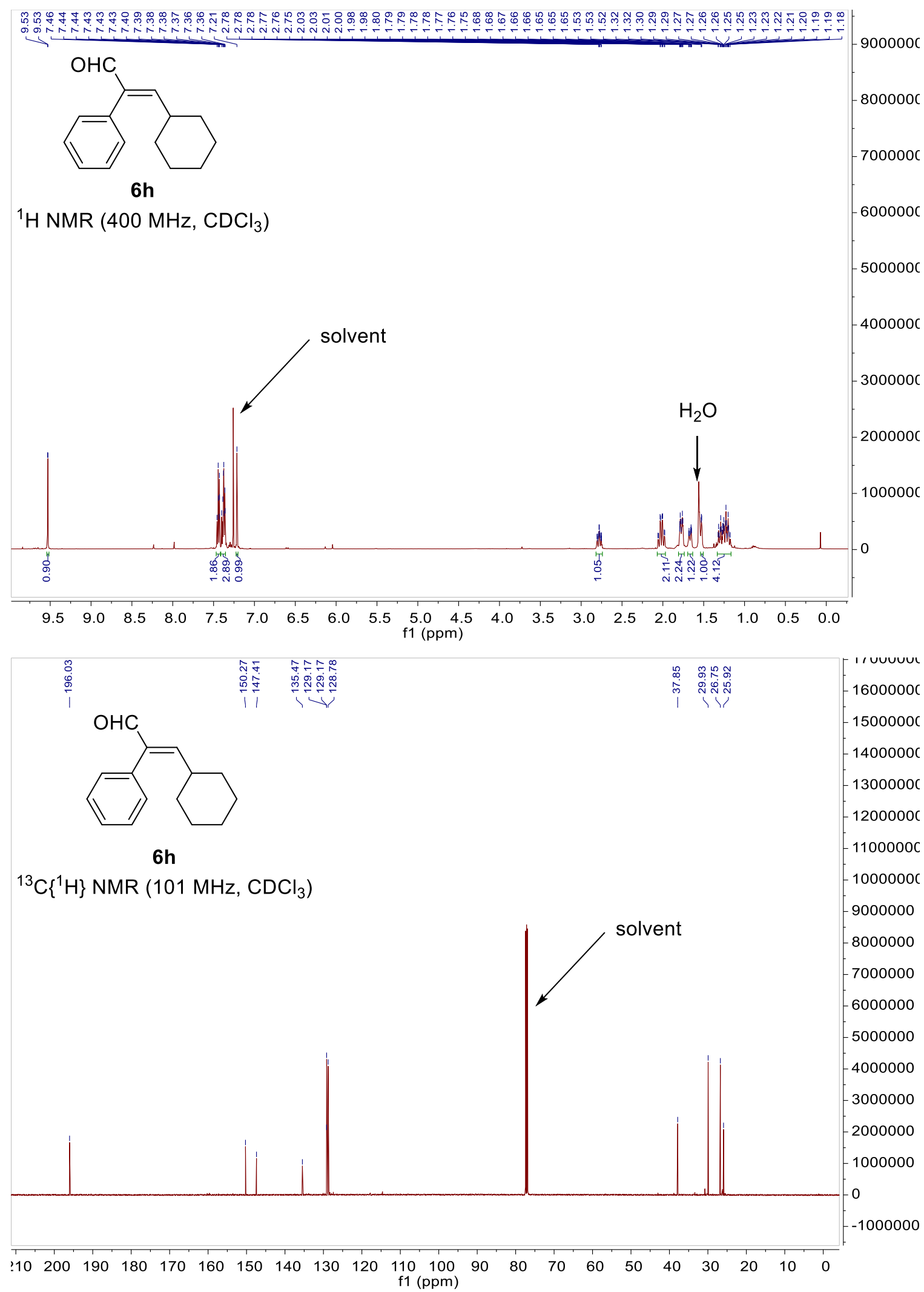




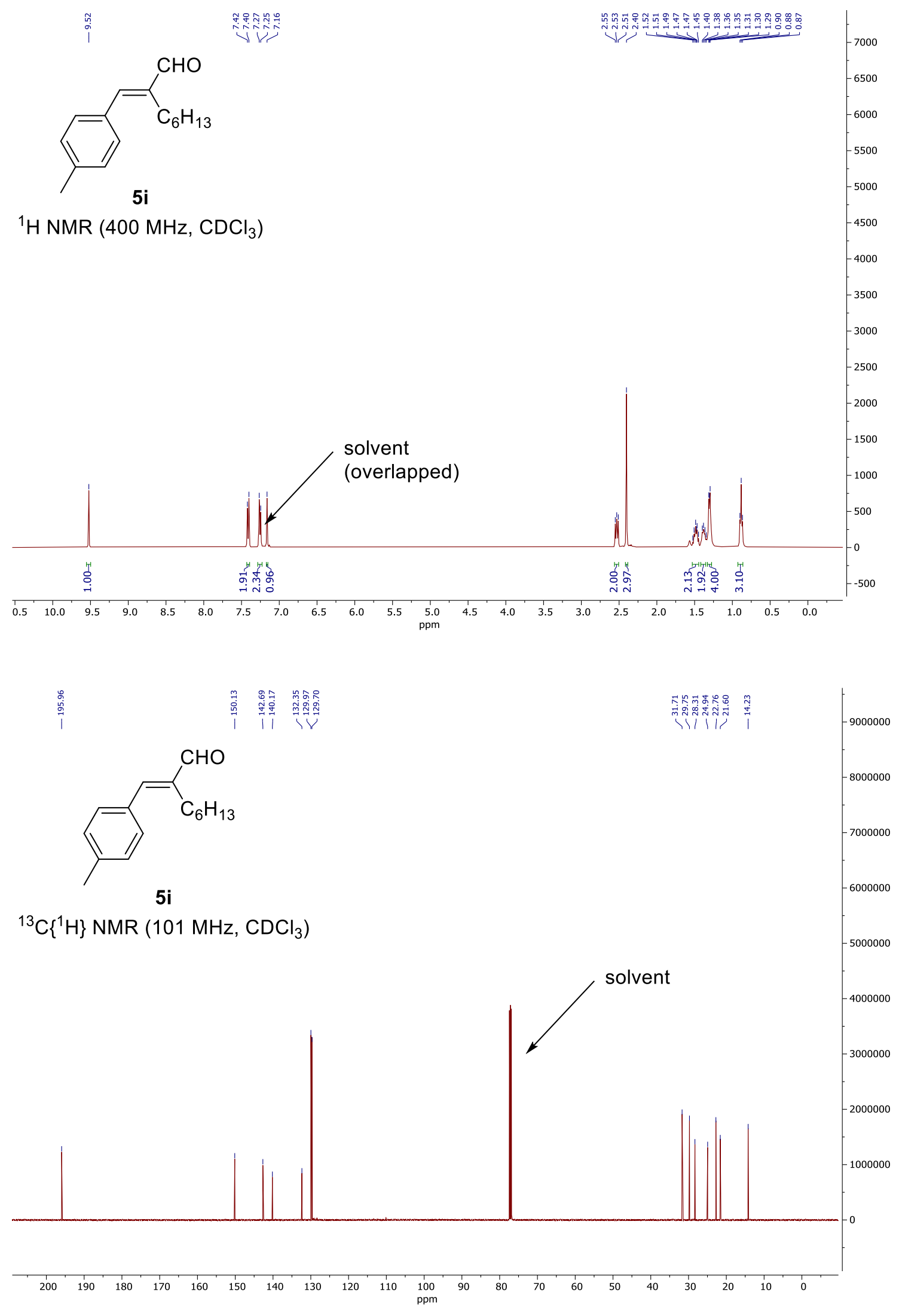




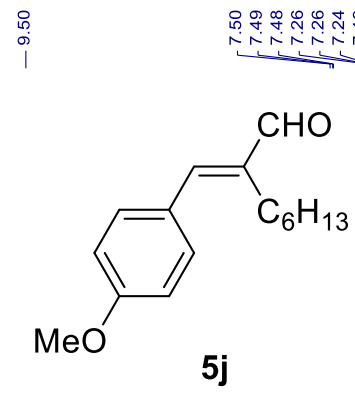

${ }^{1} \mathrm{H}$ NMR $\left(400 \mathrm{MHz}, \mathrm{CDCl}_{3}\right)$
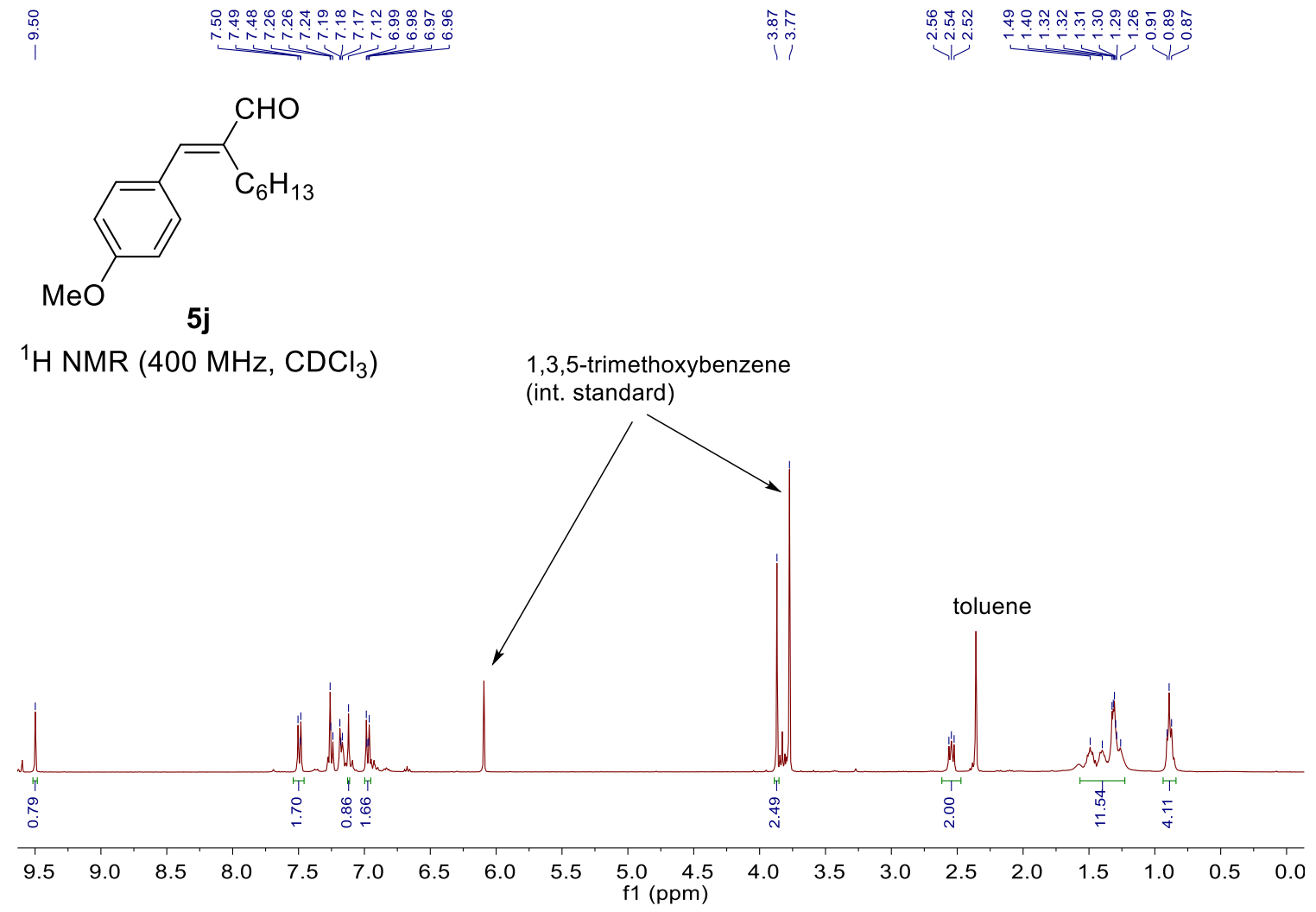

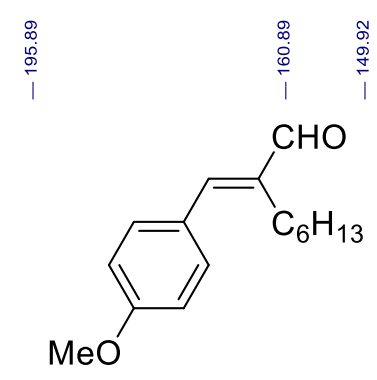

$5 \mathbf{j}$ 1,3,5-trimethoxybenzene (int. standard) 

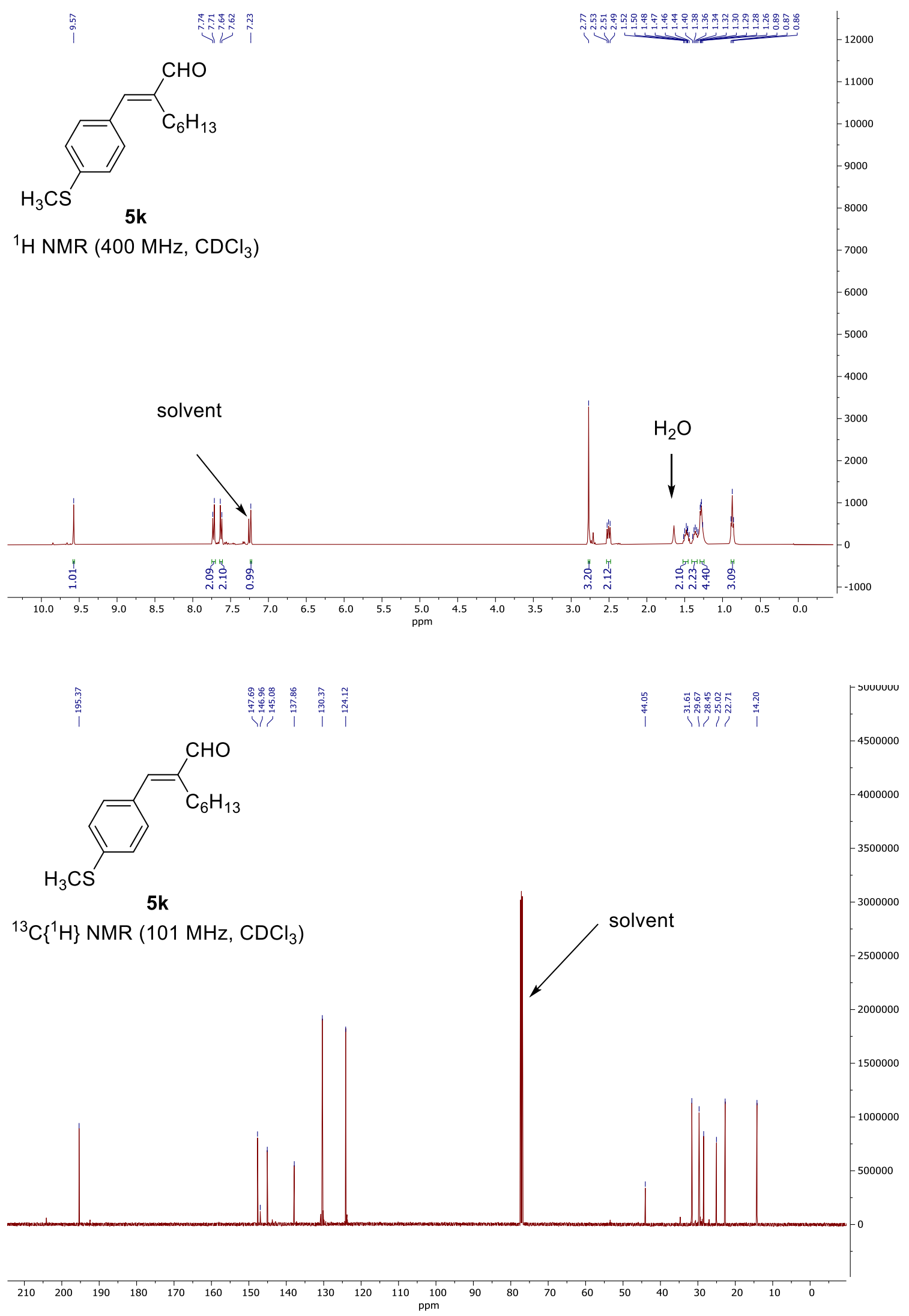

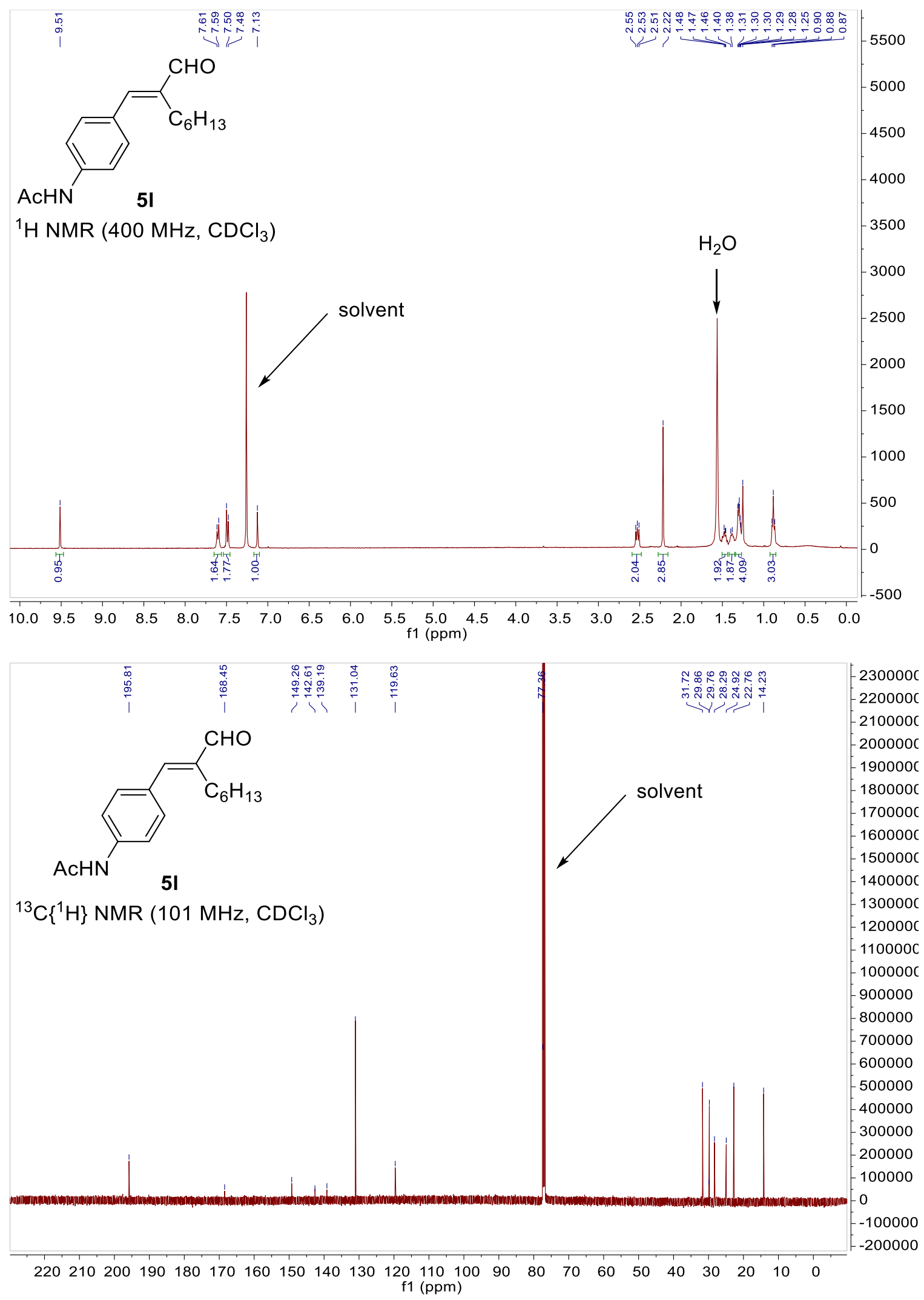


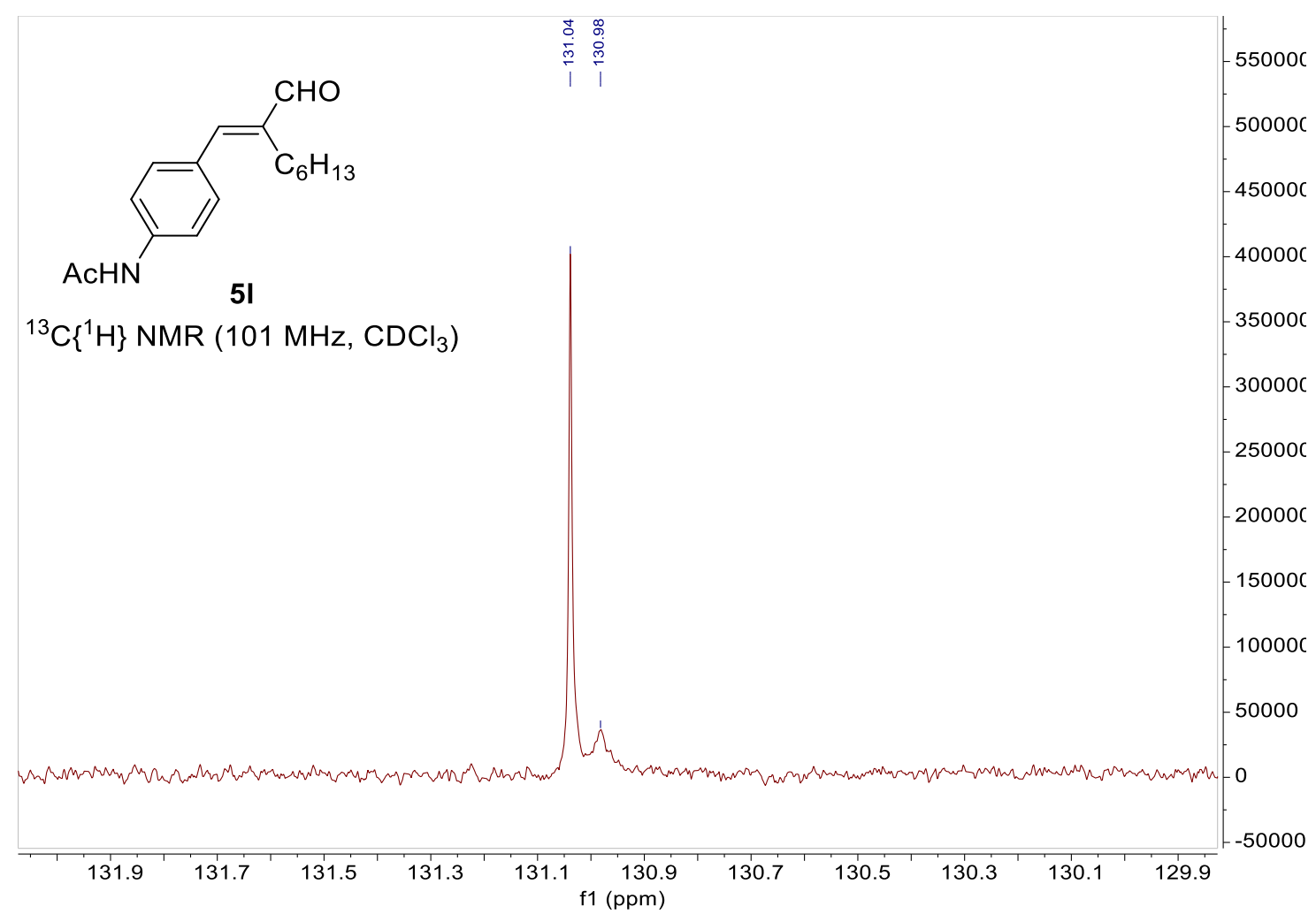



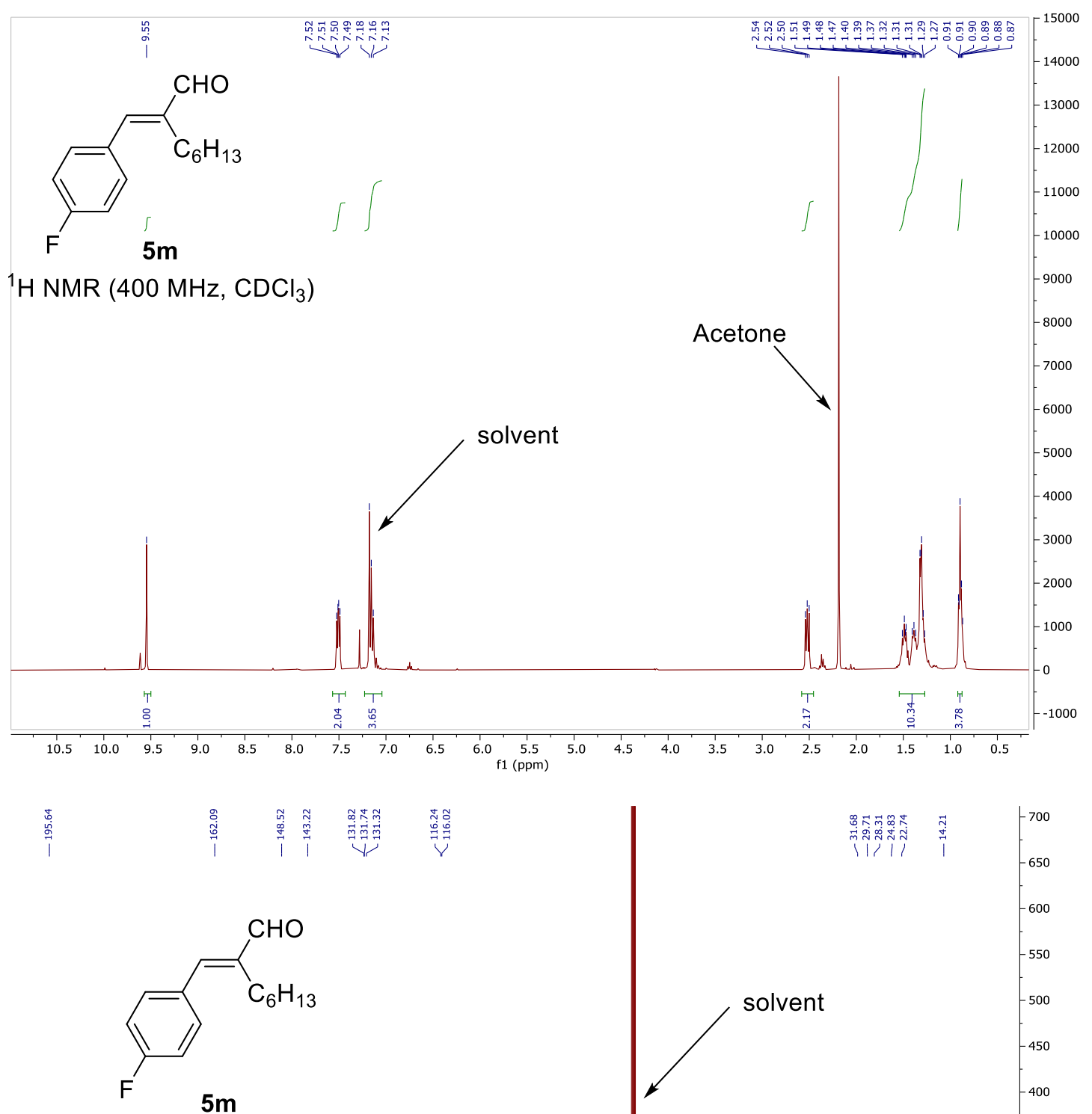

${ }^{13} \mathrm{C}\left\{{ }^{1} \mathrm{H}\right\}$ NMR $\left(101 \mathrm{MHz}, \mathrm{CDCl}_{3}\right)$

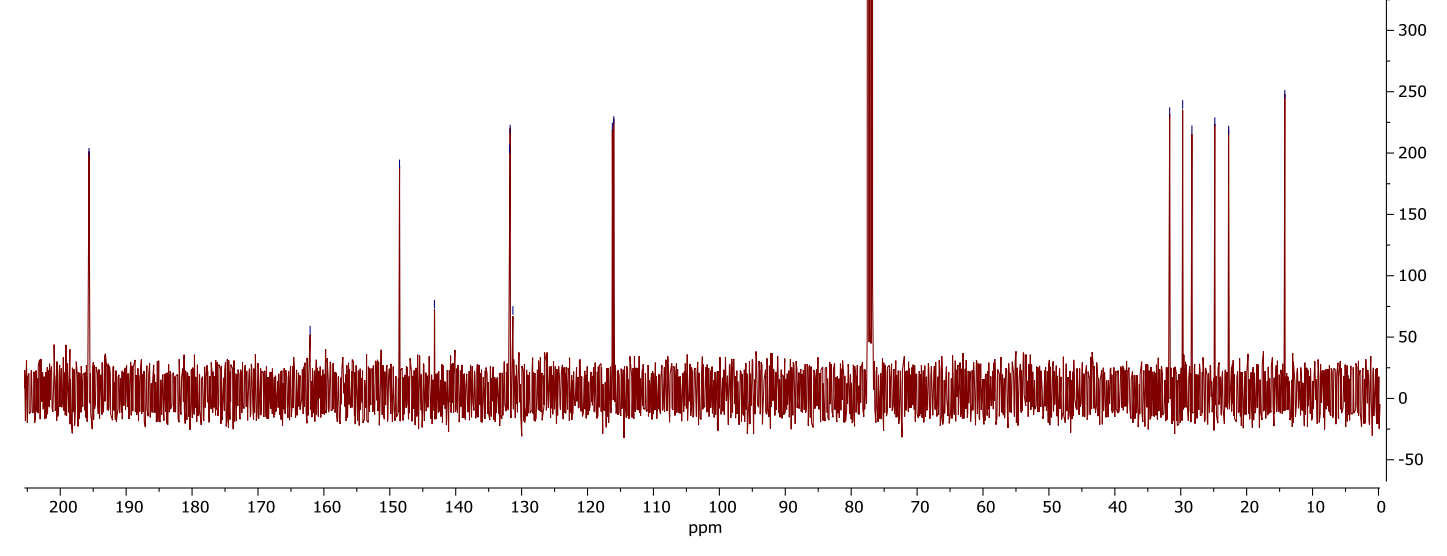



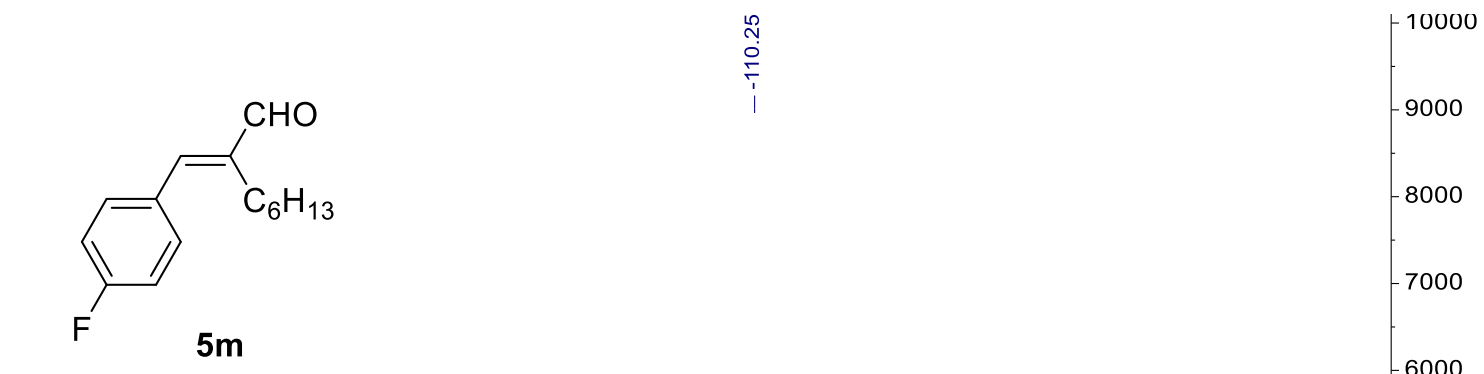

${ }^{19} \mathrm{~F} \mathrm{NMR}\left(376 \mathrm{MHz}, \mathrm{CDCl}_{3}\right) \quad-6000$
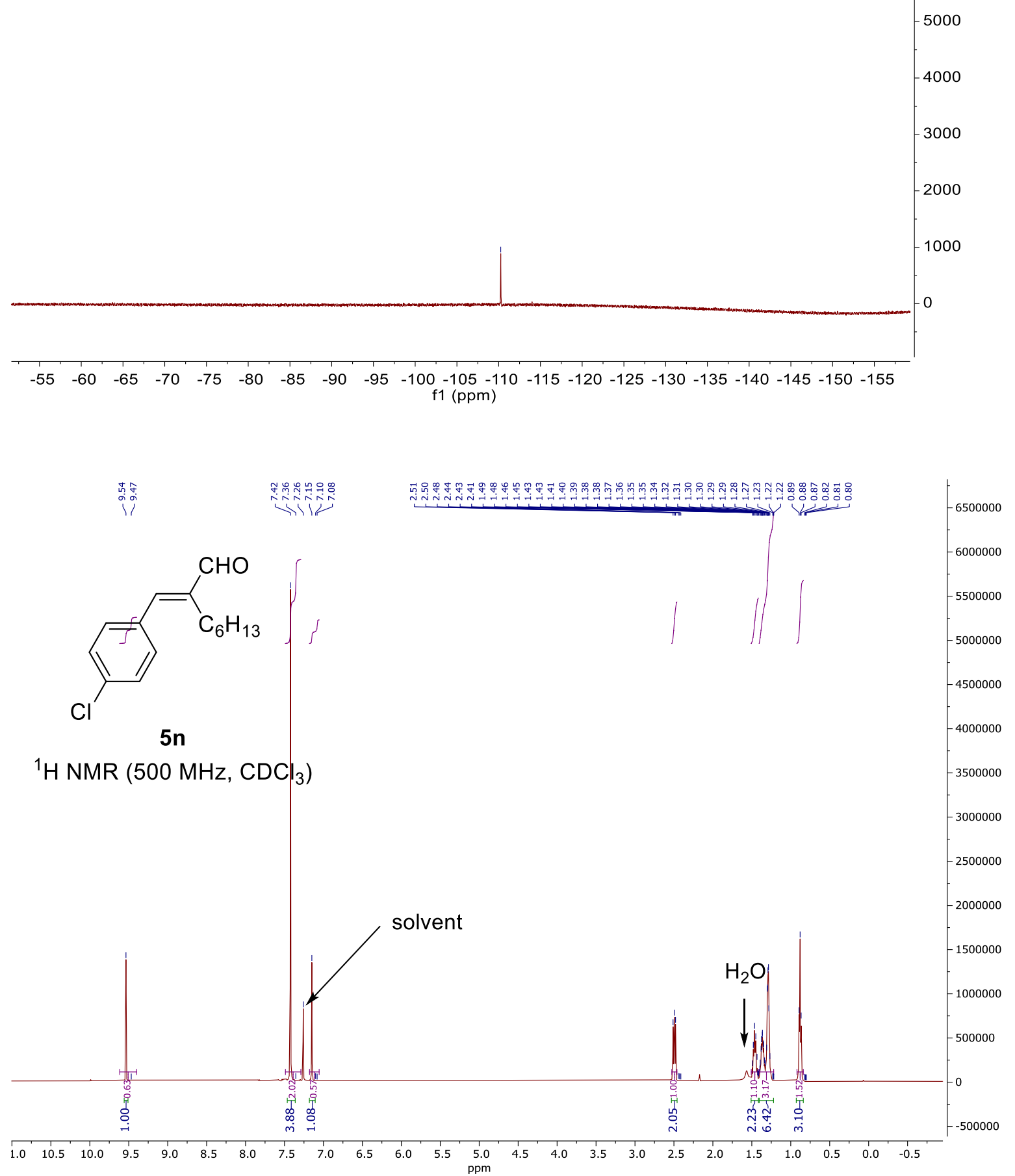


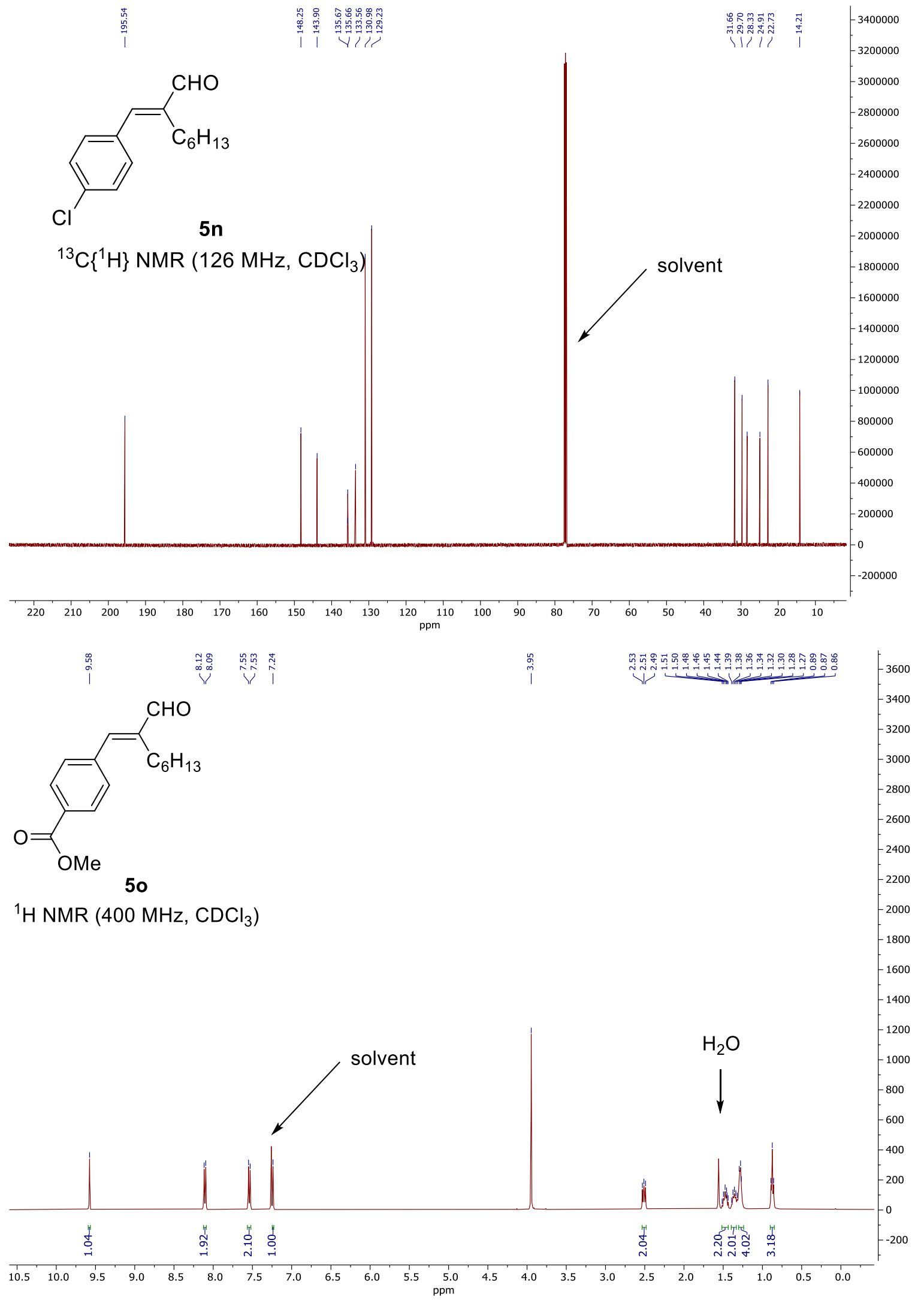




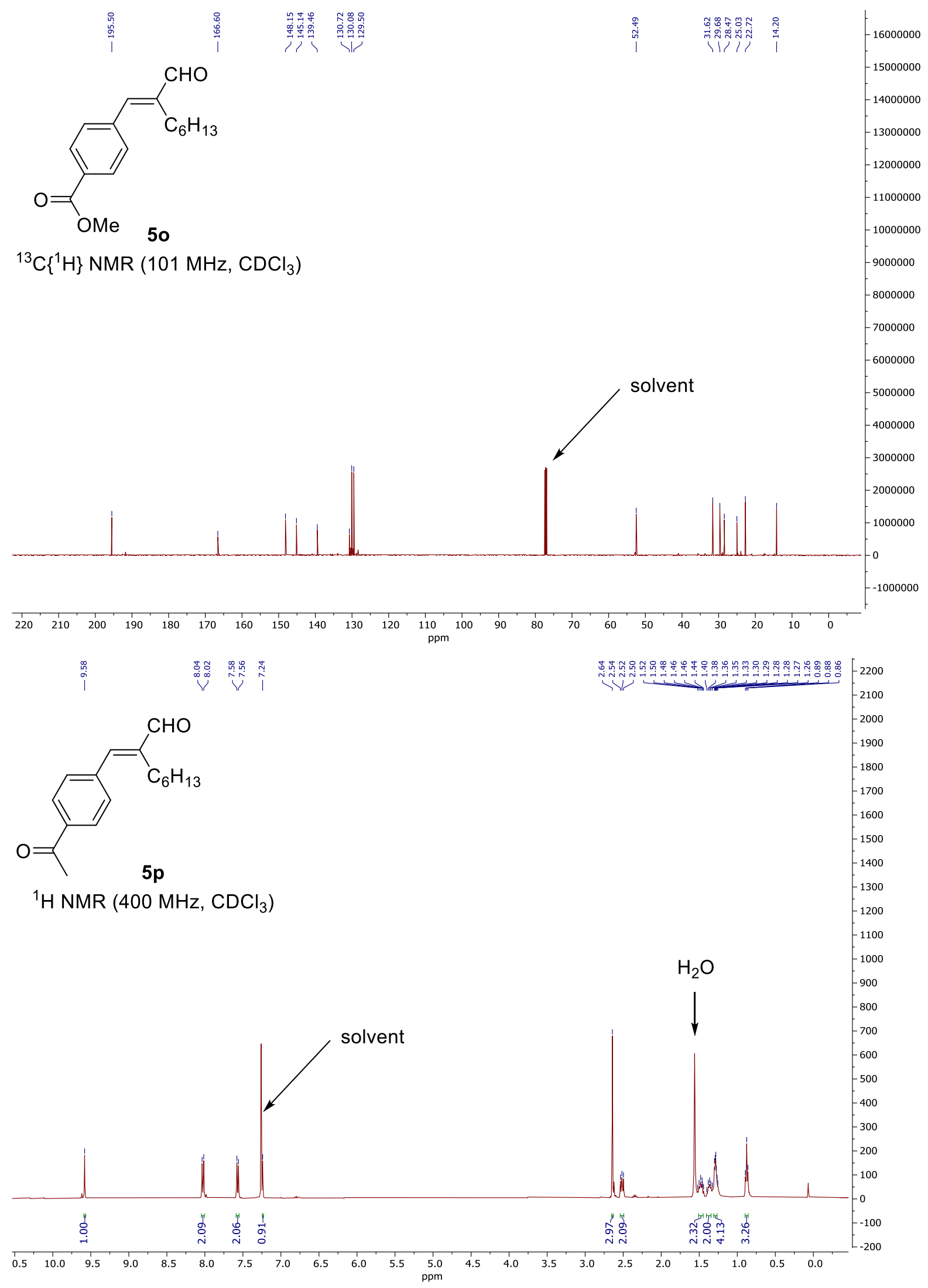




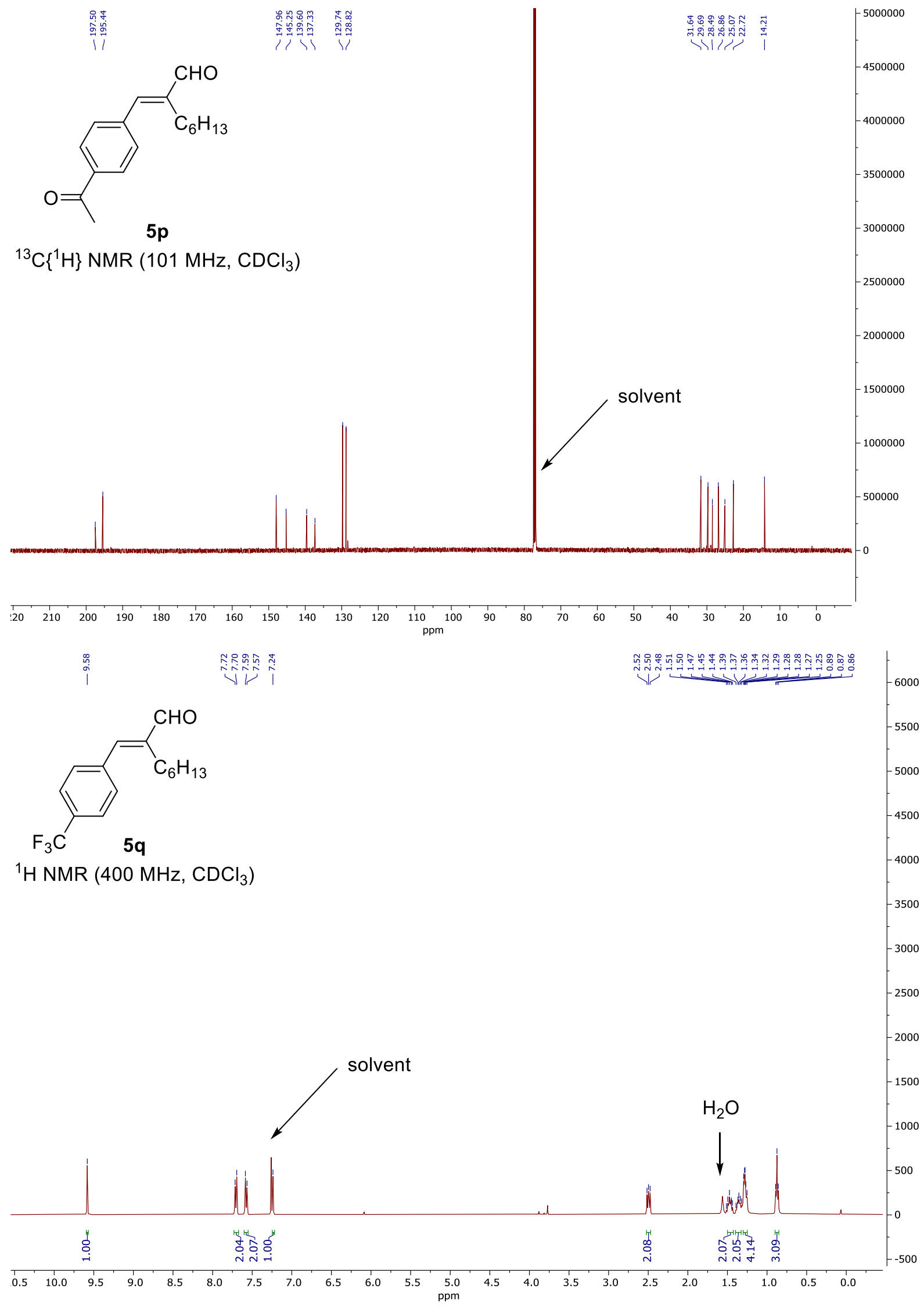




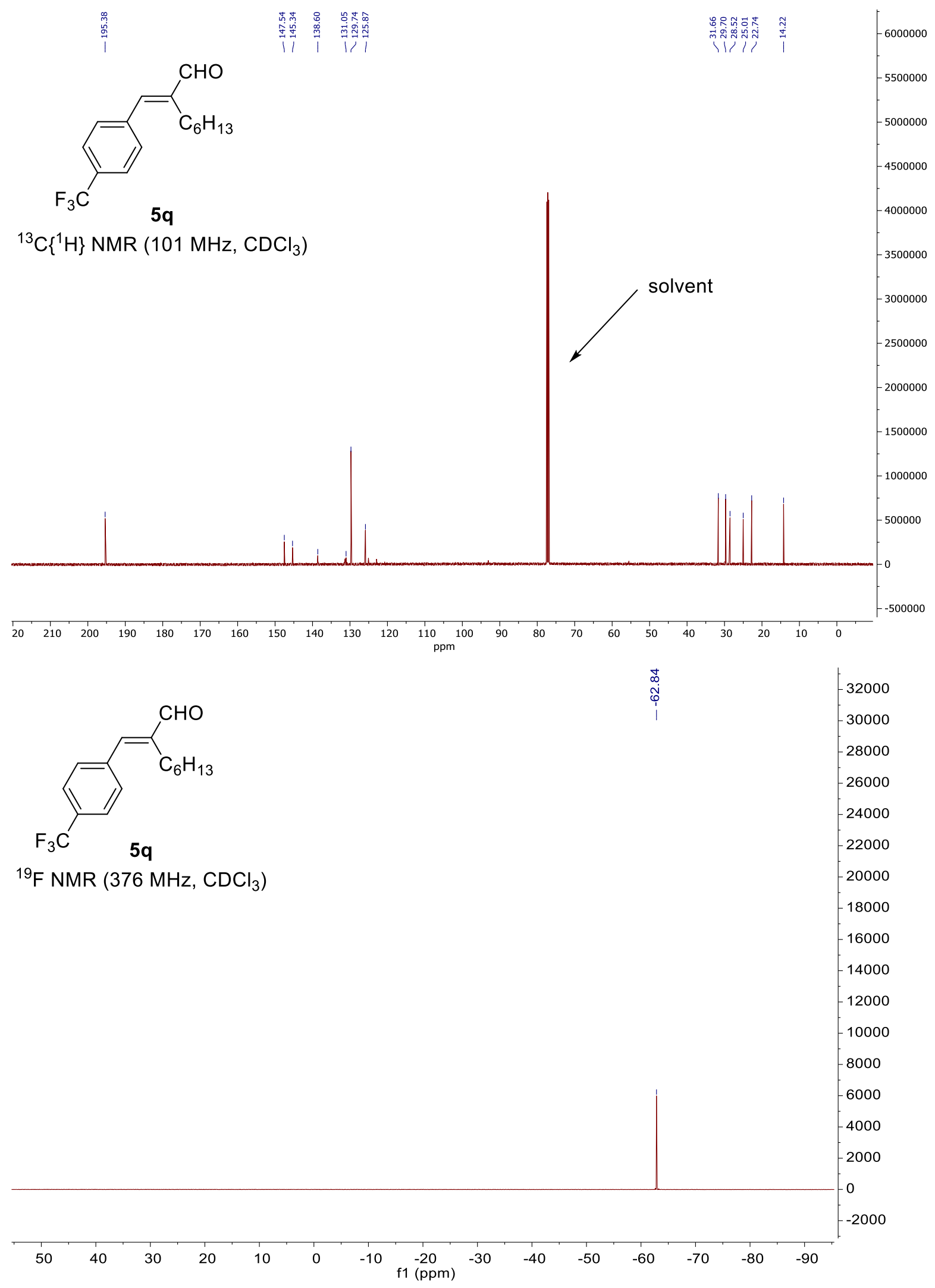



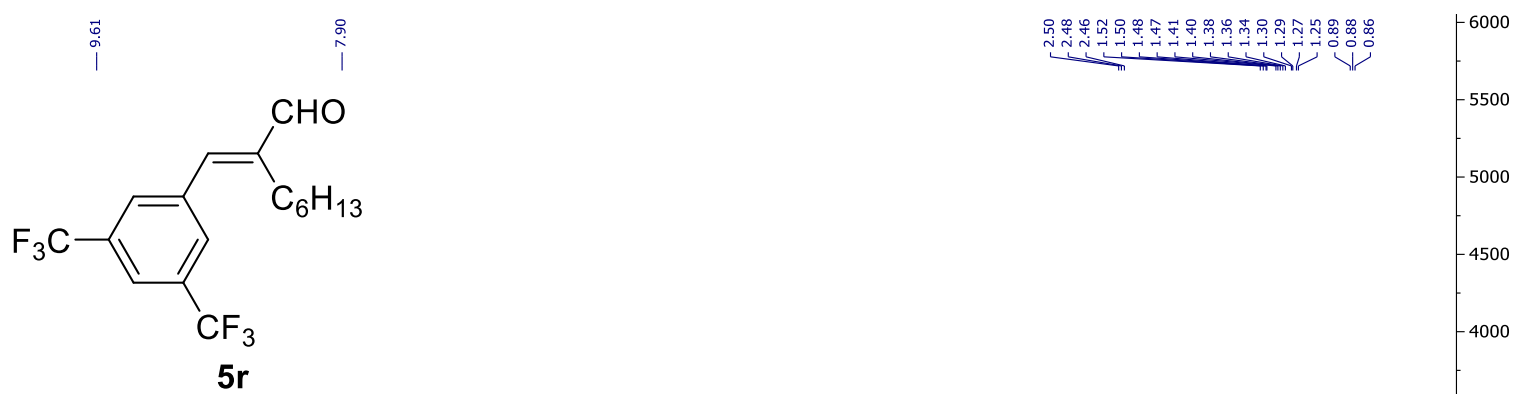

${ }^{1} \mathrm{H}$ NMR $\left(400 \mathrm{MHz}, \mathrm{CDCl}_{3}\right)$
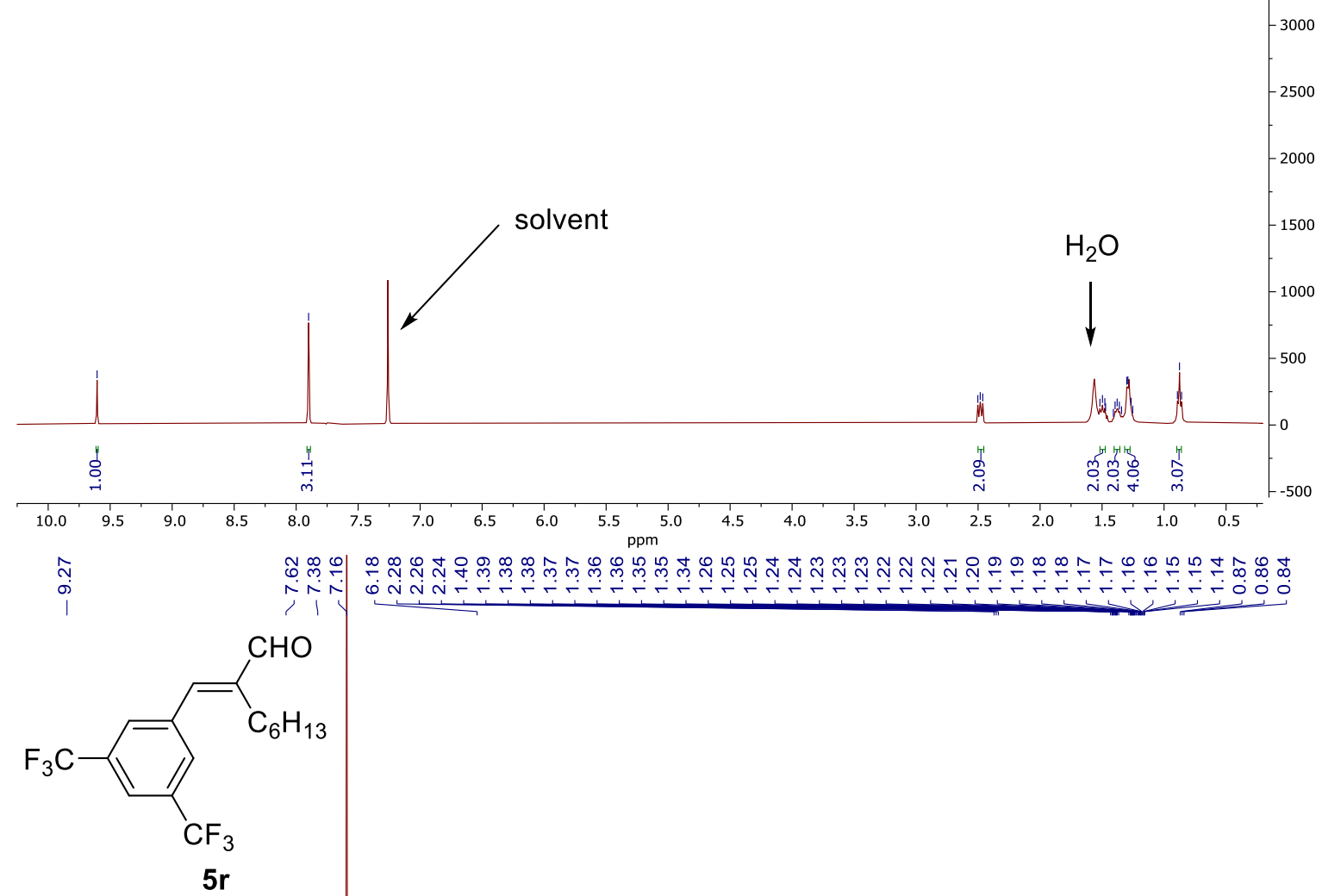

${ }^{1} \mathrm{H}$ NMR (500 MHz, $\left.\mathrm{C}_{6} \mathrm{P}_{6}\right)$

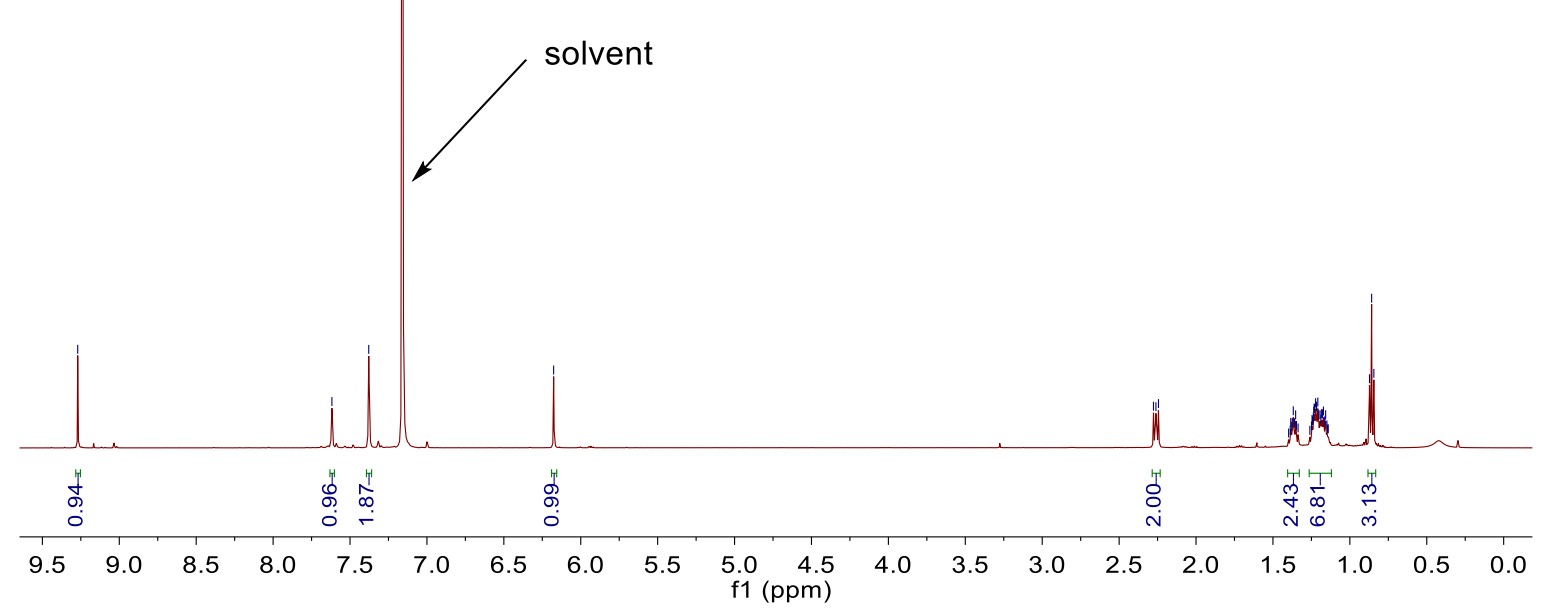




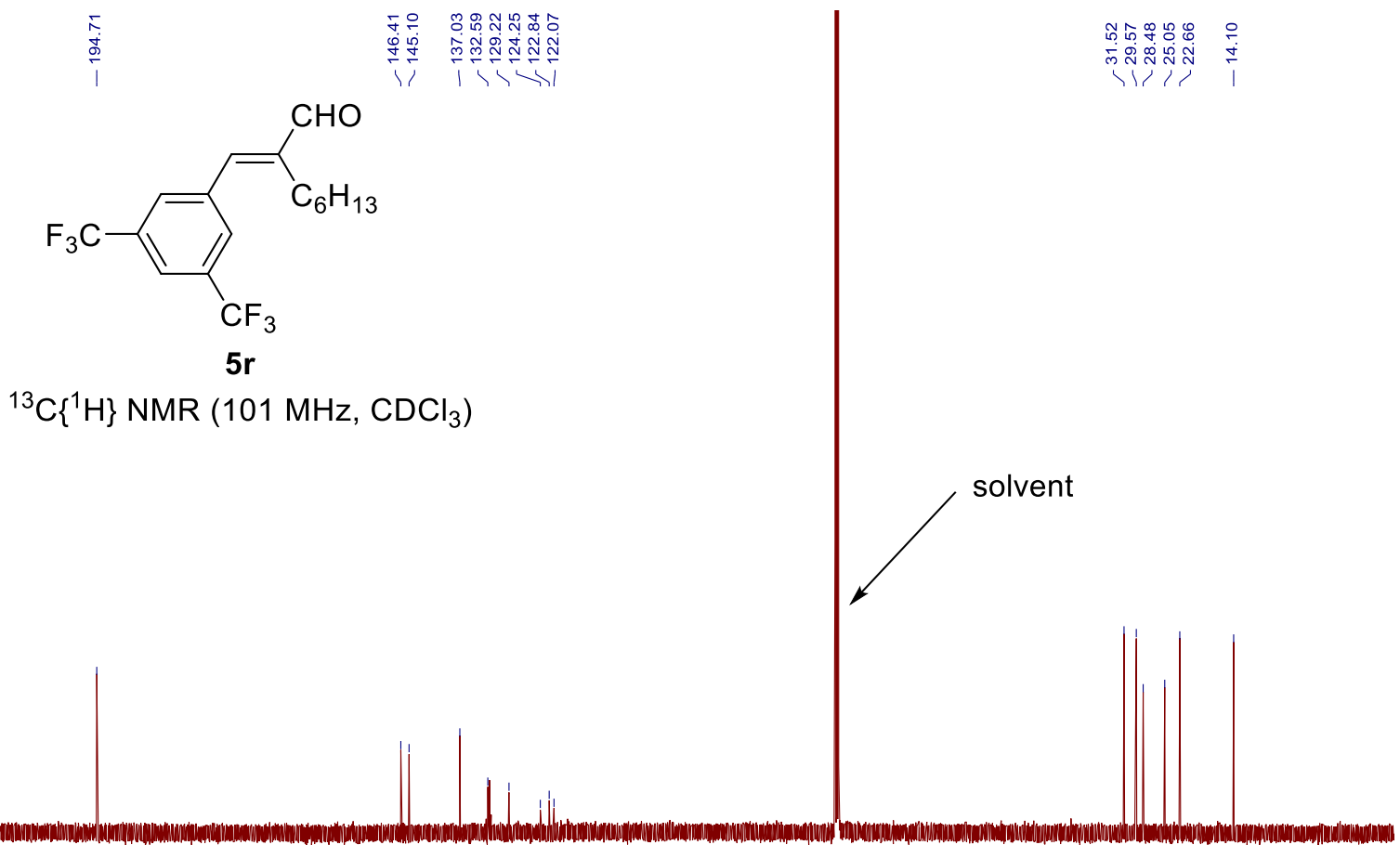

$\begin{array}{lllllllllllllllllllllllllll}10 & 200 & 190 & 180 & 170 & 160 & 150 & 140 & 130 & 120 & 110 & 100 & 90 & 80 & 70 & 60 & 50 & 40 & 30 & 20 & 10 & 0 & -1\end{array}$ $\hat{0}$
$\ddot{M}$
0
1<smiles>O=CC(=Cc1cc(C(F)(F)F)cc(C(F)(F)F)c1)c1ccccc1</smiles>

$5 r$

${ }^{19} \mathrm{~F} \mathrm{NMR}\left(376 \mathrm{MHz}, \mathrm{CDCl}_{3}\right)$

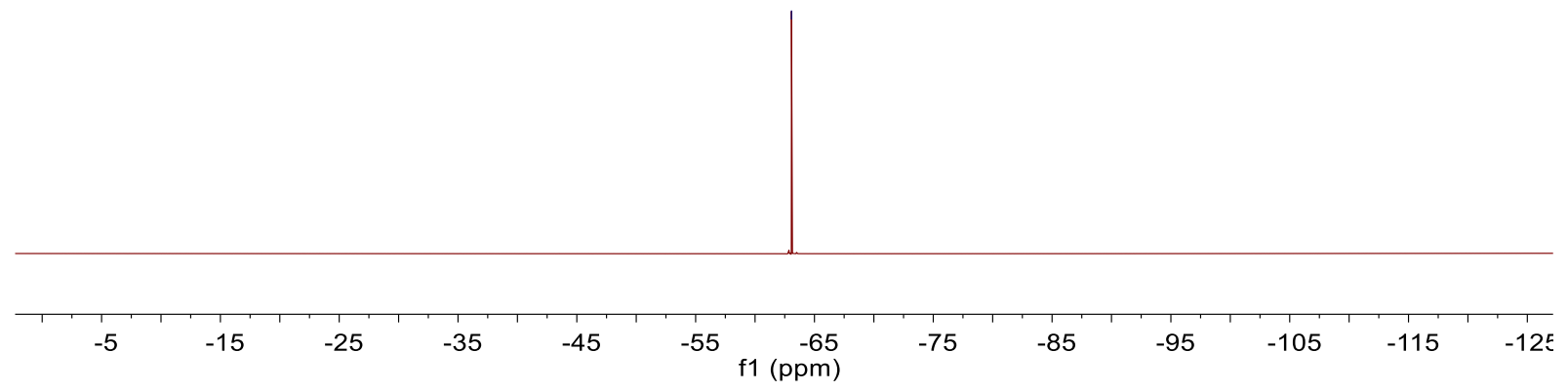




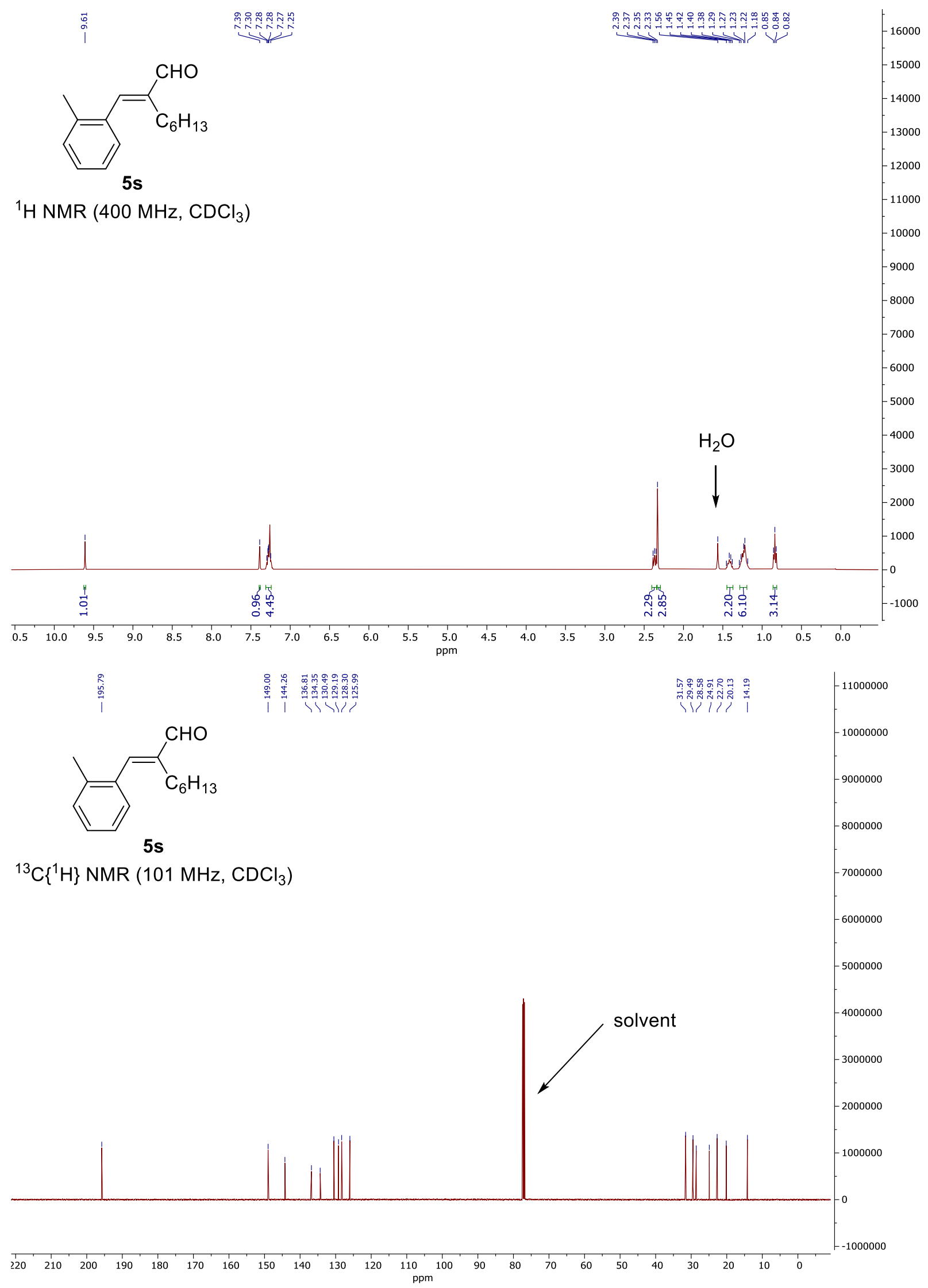



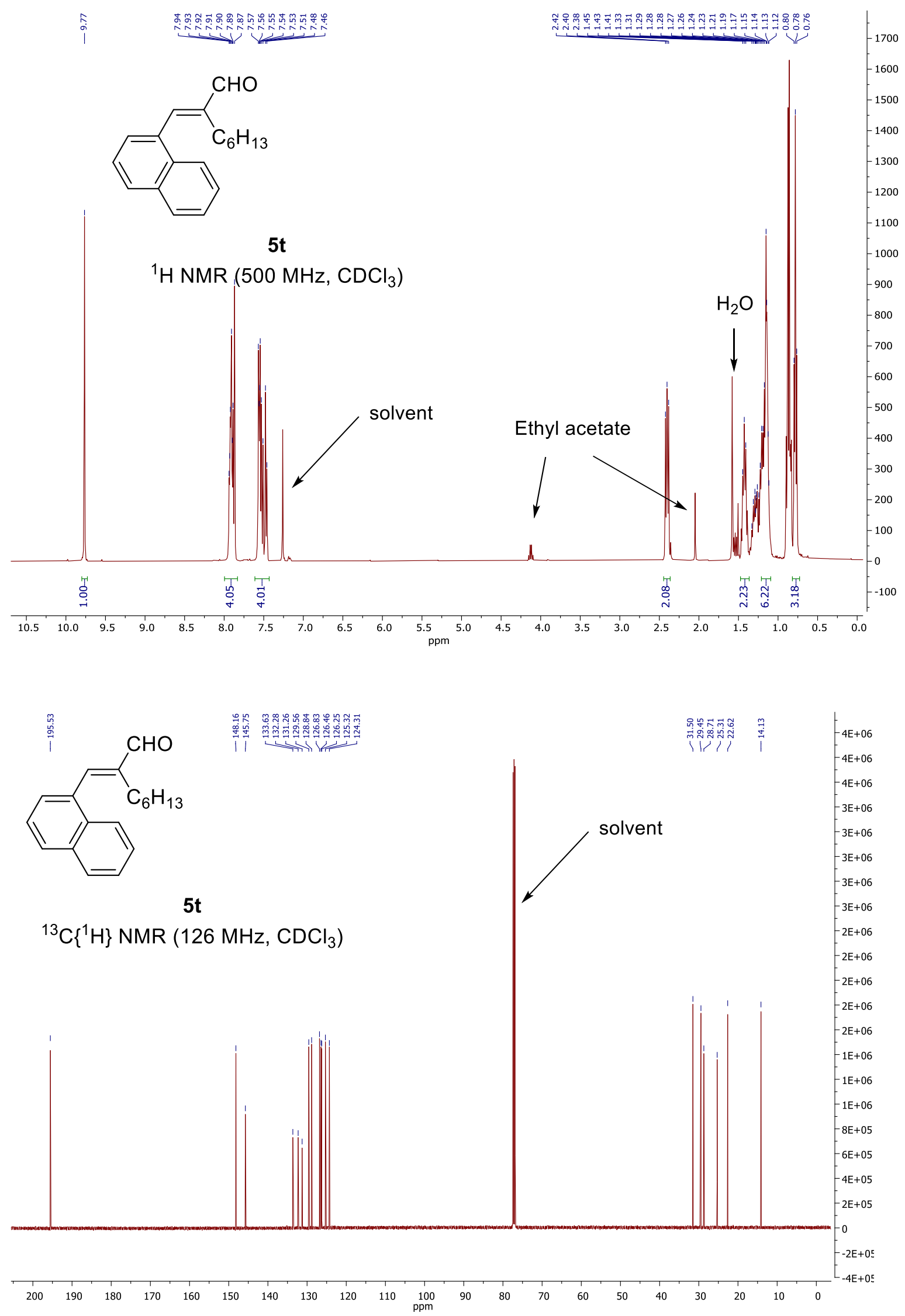

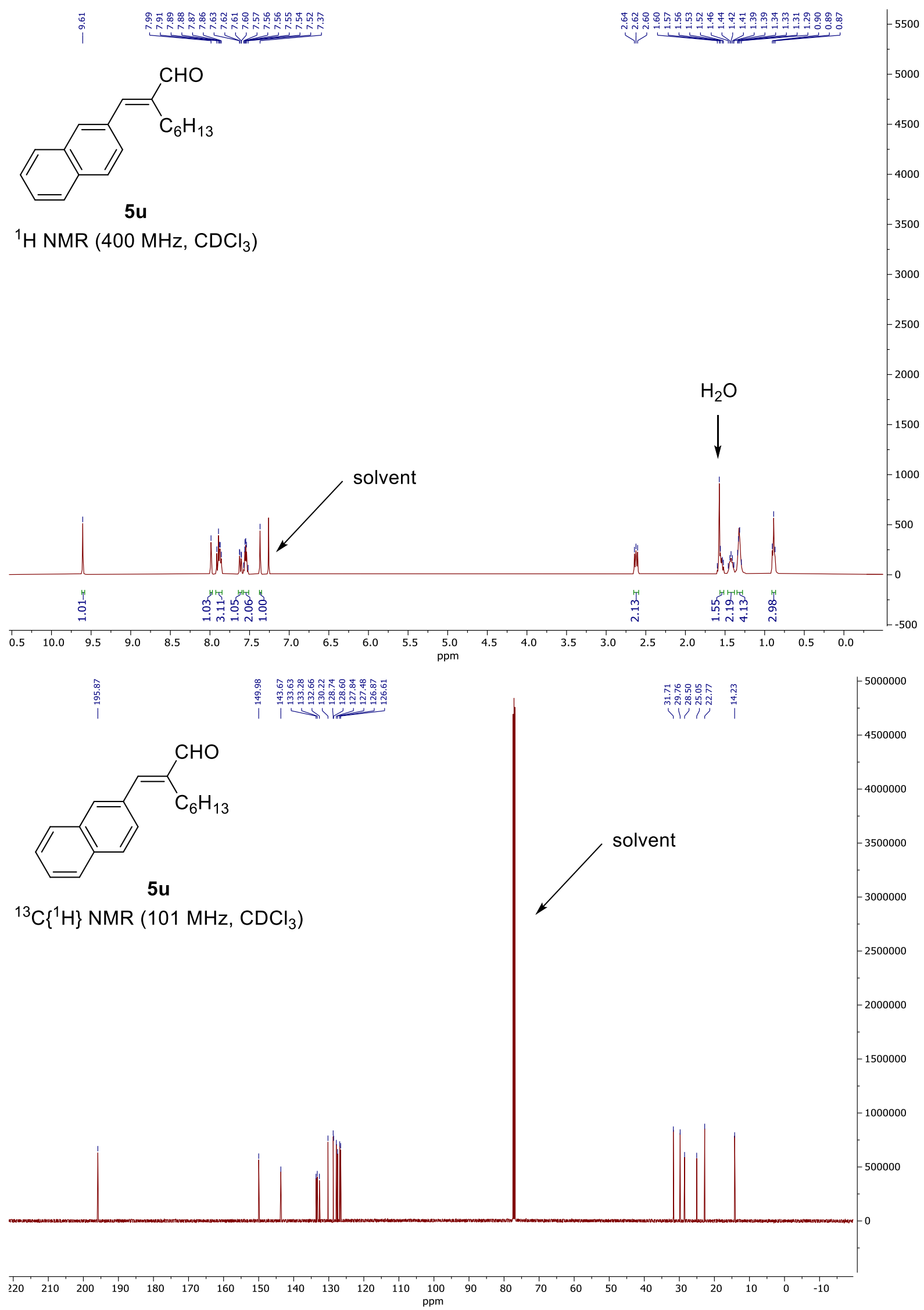


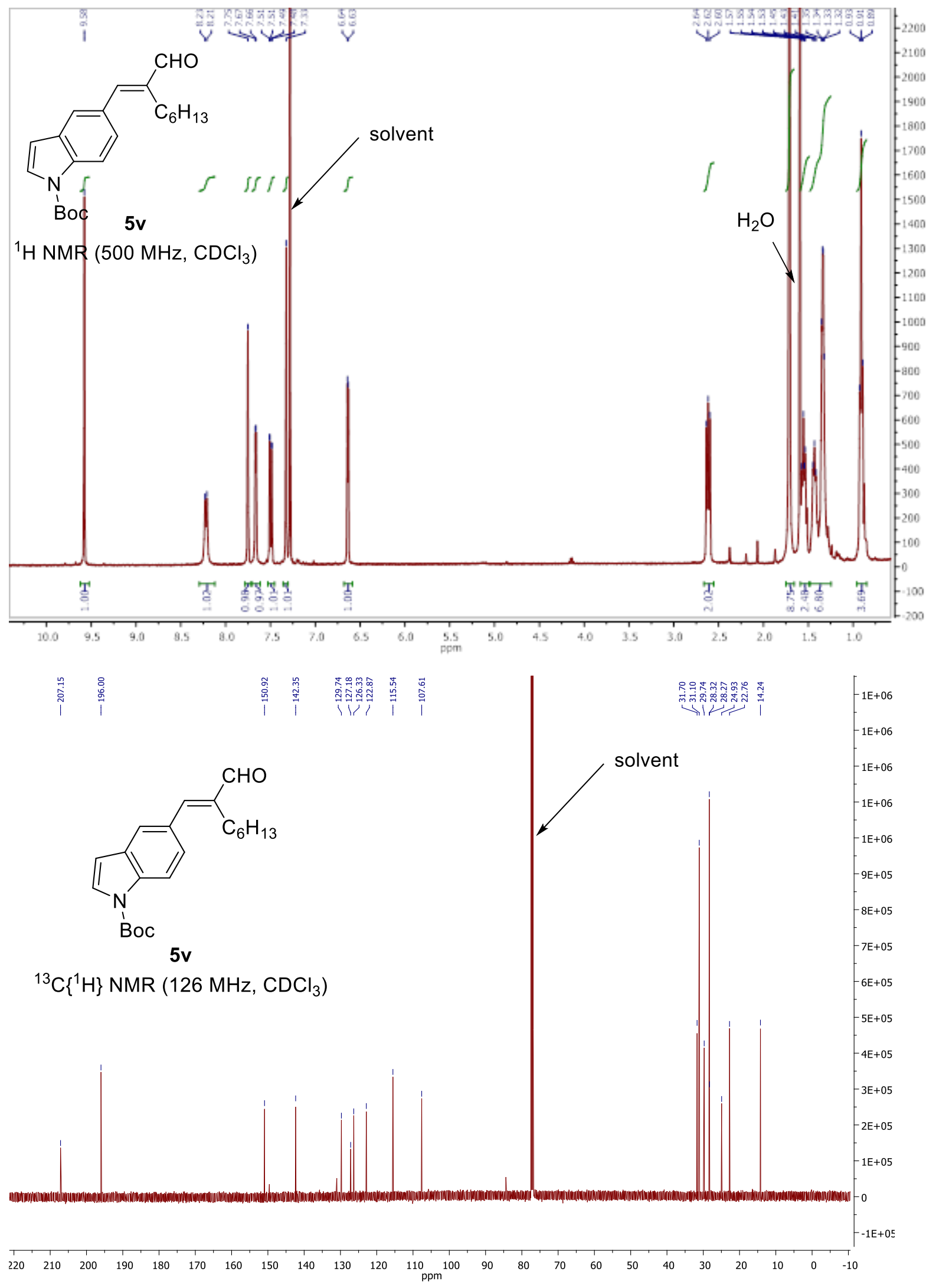



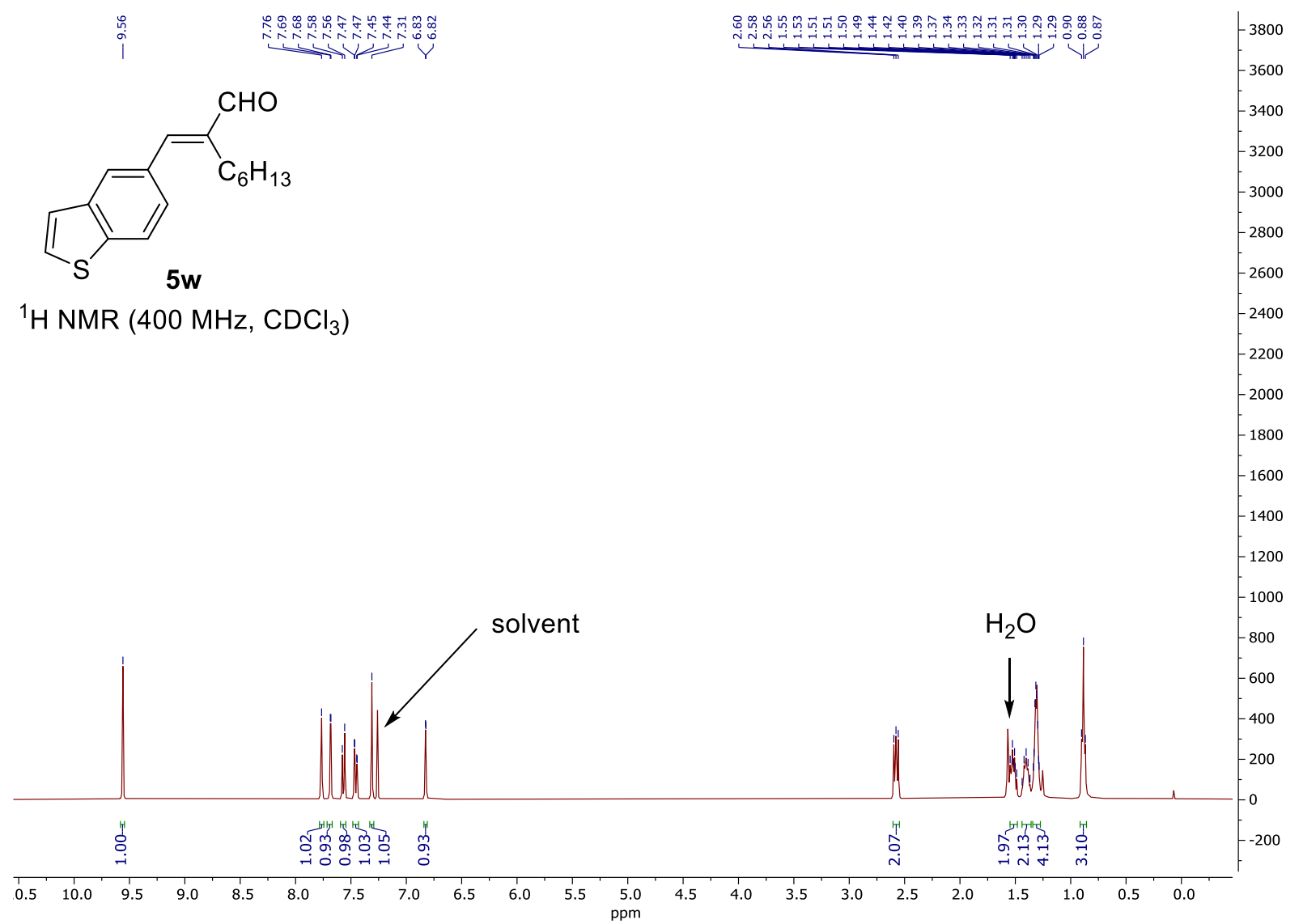

${ }^{1} \mathrm{H}$ NMR $\left(400 \mathrm{MHz}, \mathrm{CDCl}_{3}\right)$

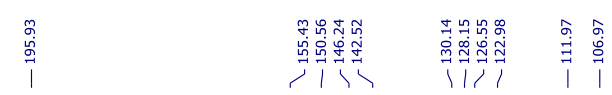
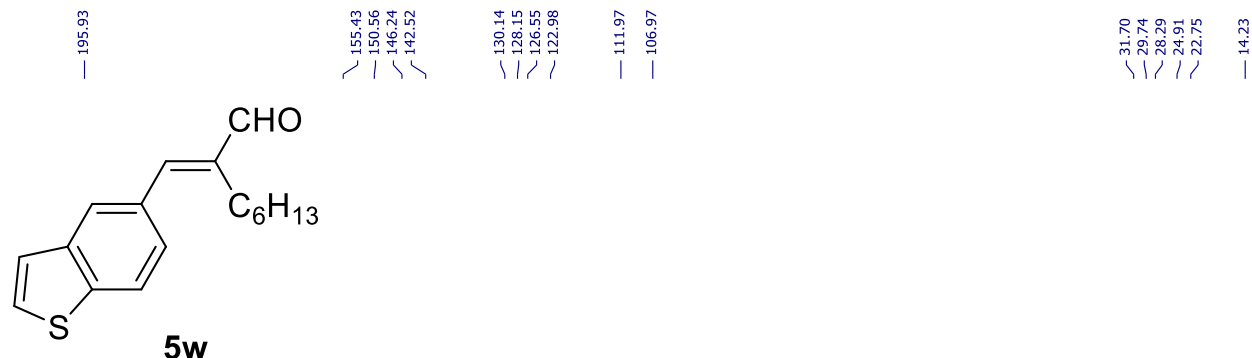

$5 w$

${ }^{13} \mathrm{C}\left\{{ }^{1} \mathrm{H}\right\}$ NMR $\left(101 \mathrm{MHz}, \mathrm{CDCl}_{3}\right)$

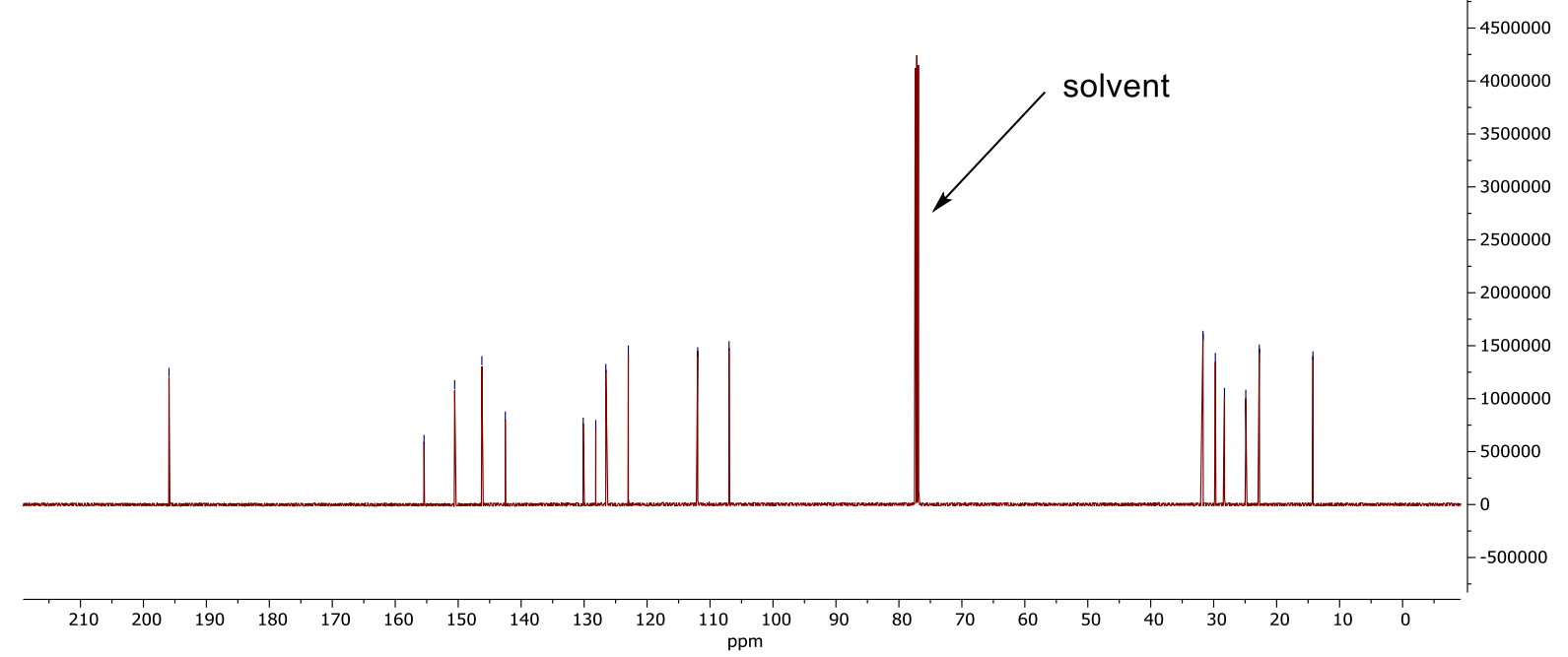



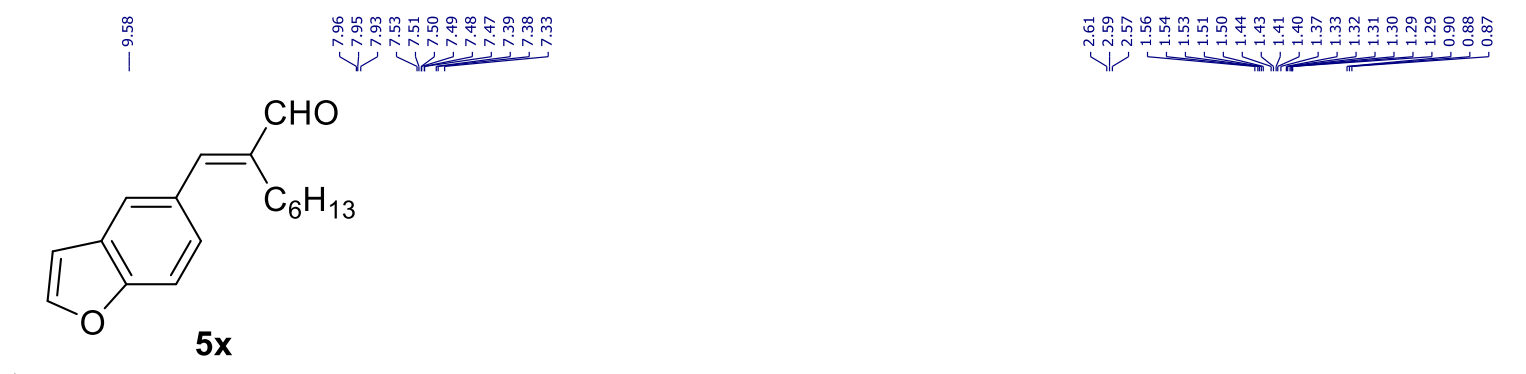

${ }^{1} \mathrm{H}$ NMR $\left(400 \mathrm{MHz}, \mathrm{CDCl}_{3}\right)$
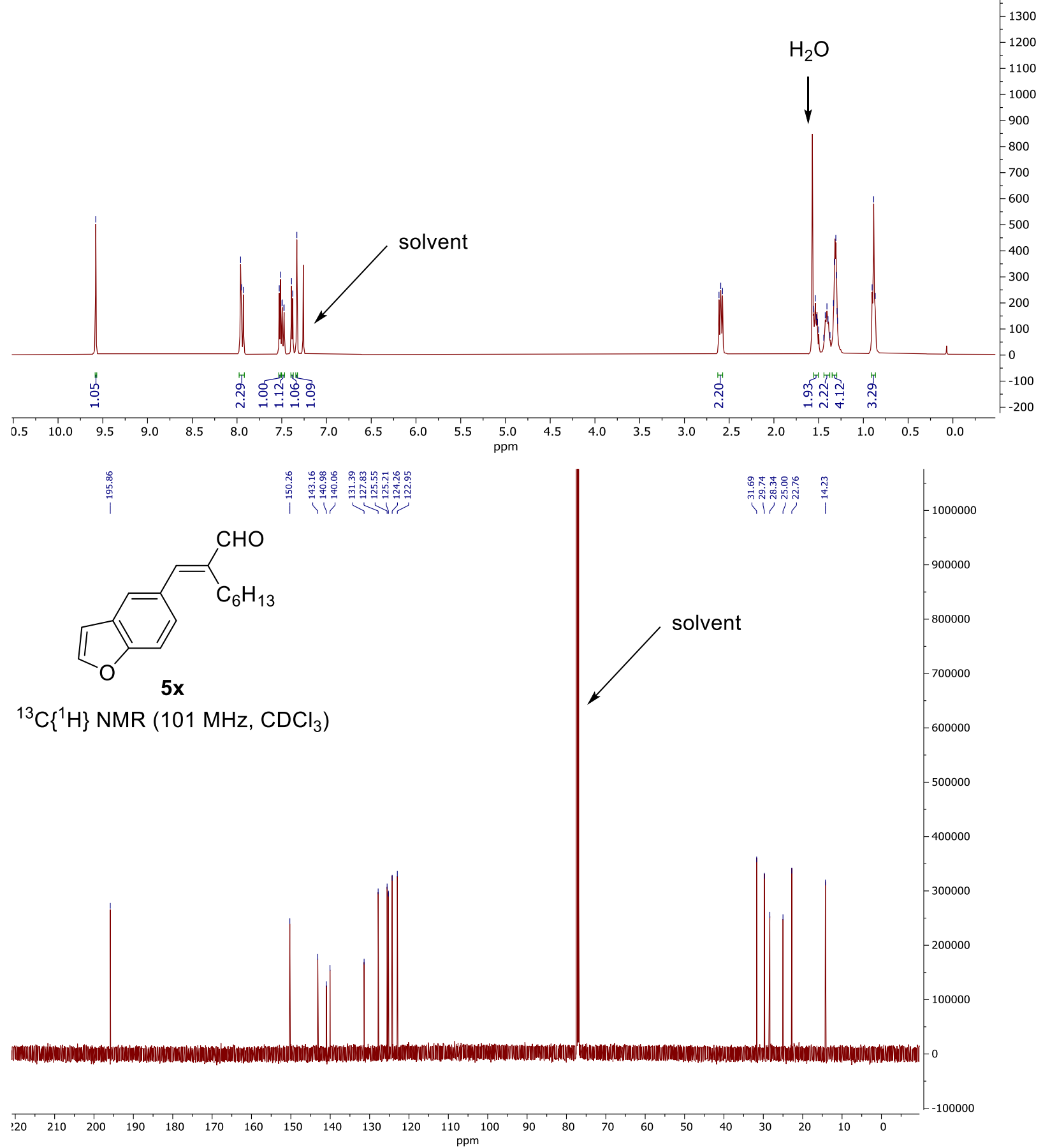


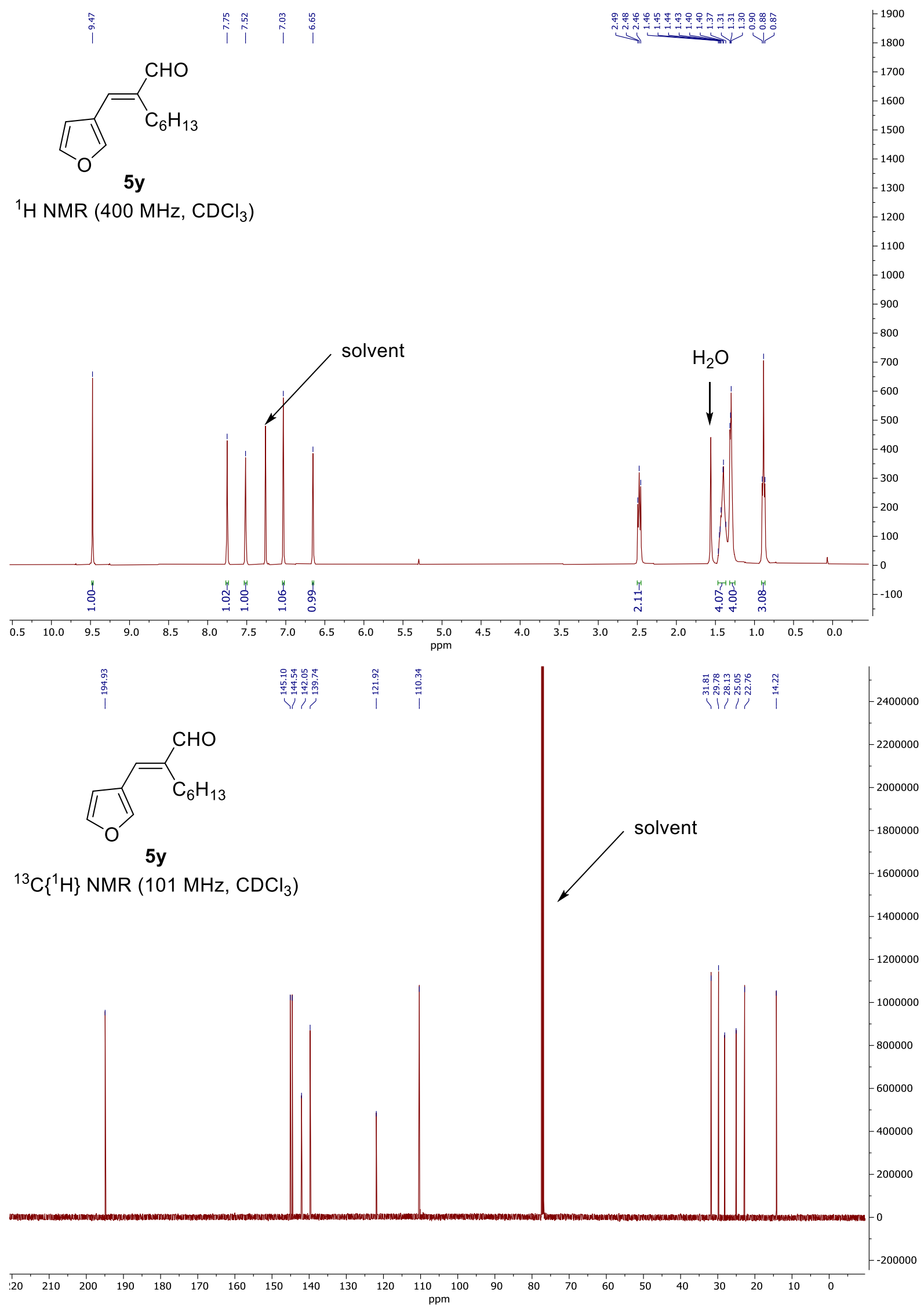




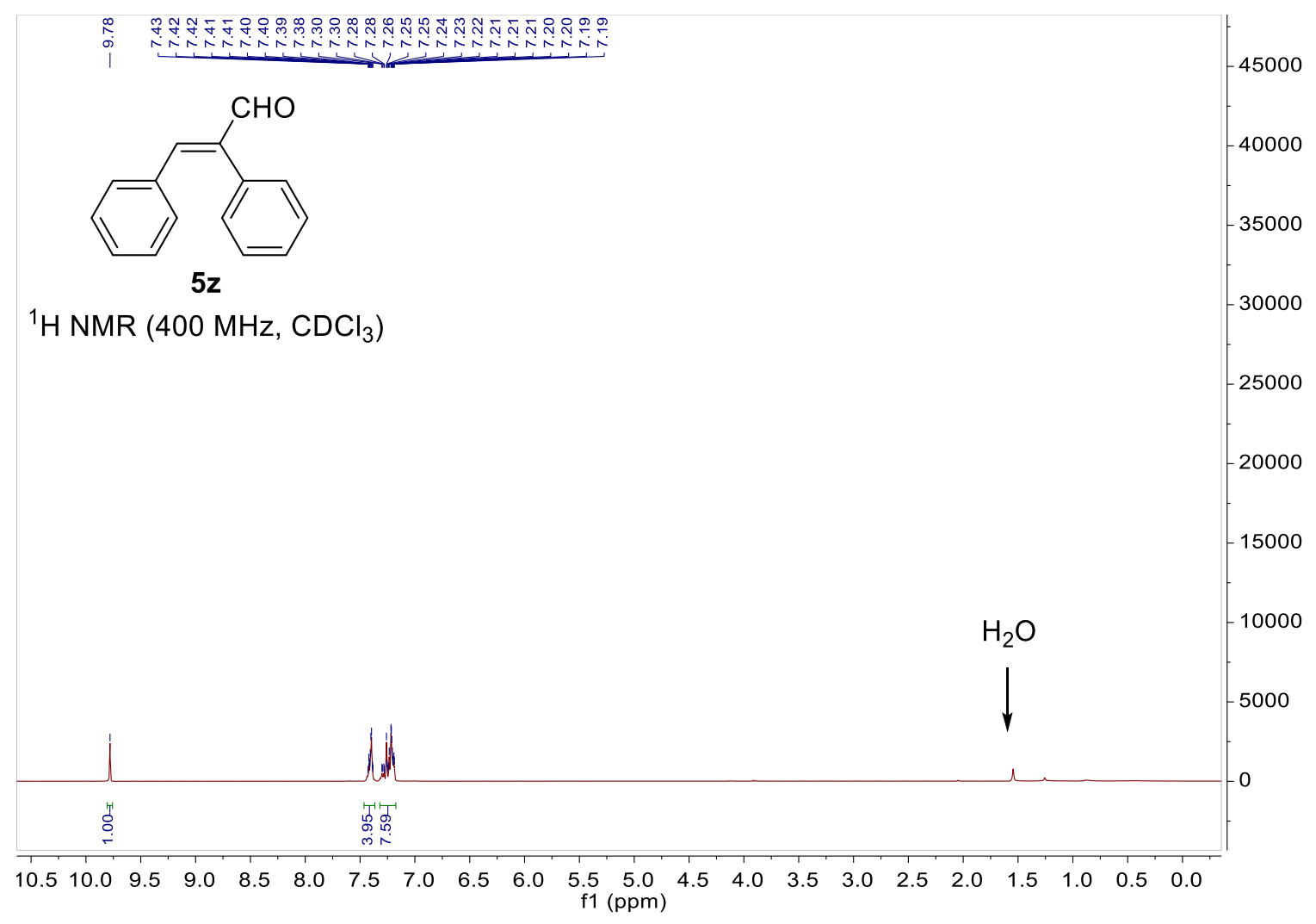




\subsection{Bisarylpyrazole derivatives}

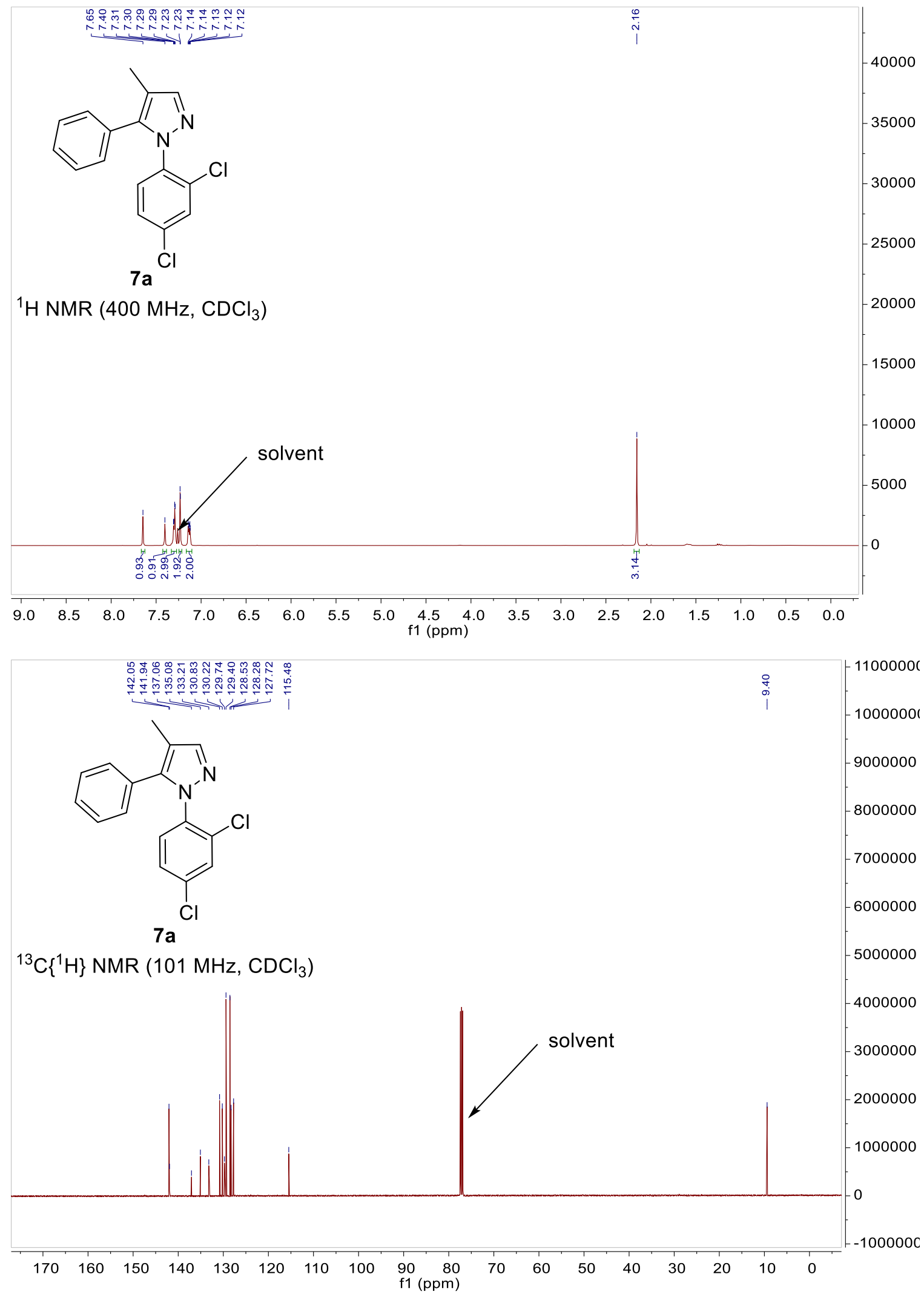




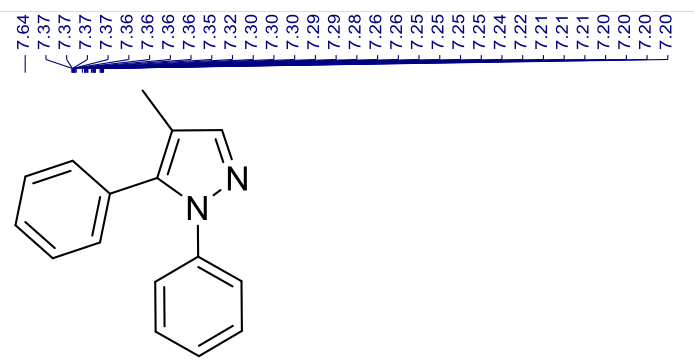

7b

${ }^{1} \mathrm{H}$ NMR $\left(400 \mathrm{MHz}, \mathrm{CDCl}_{3}\right)$
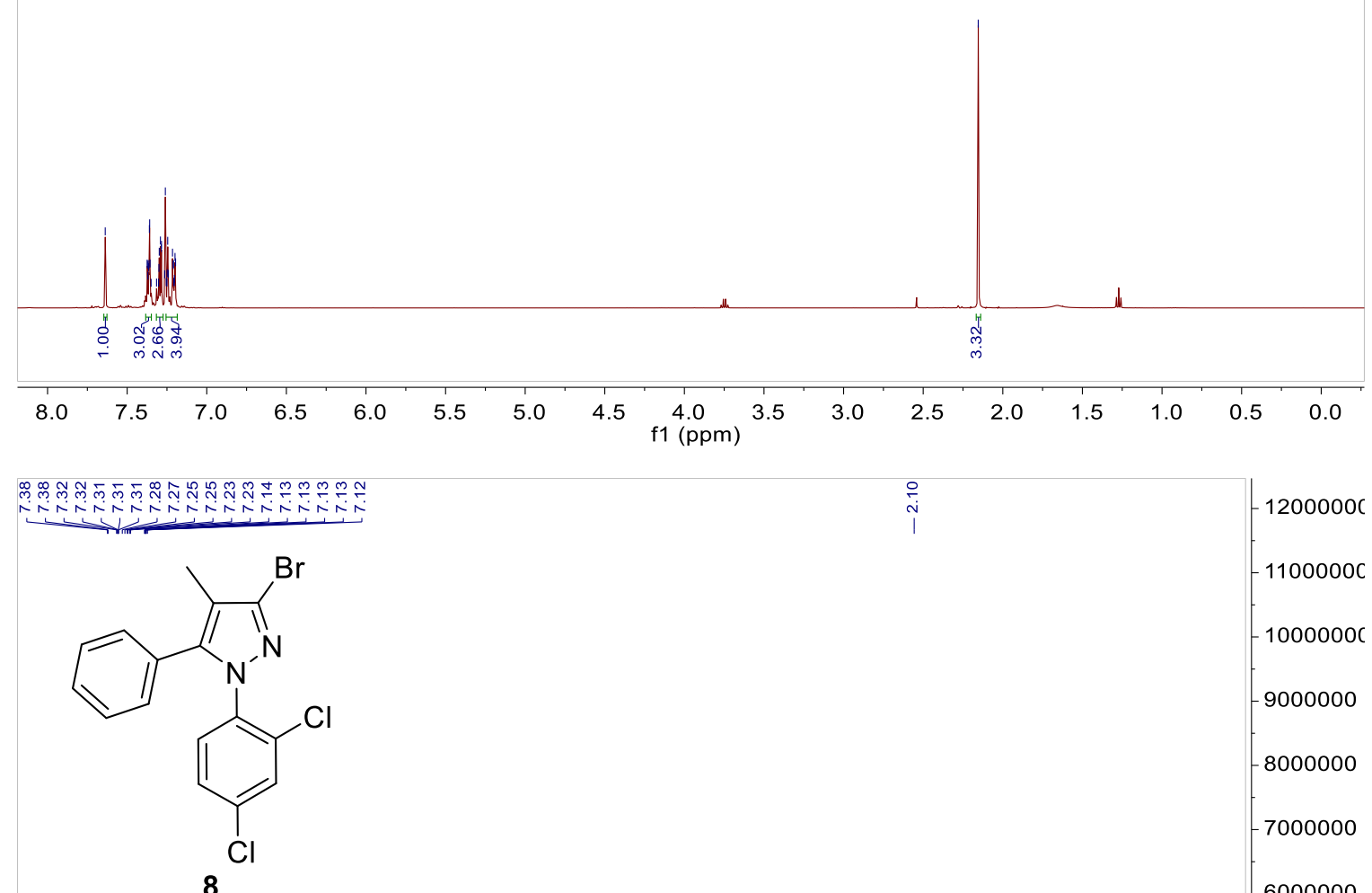

${ }^{1} \mathrm{H}$ NMR $\left(400 \mathrm{MHz}, \mathrm{CDCl}_{3}\right)$

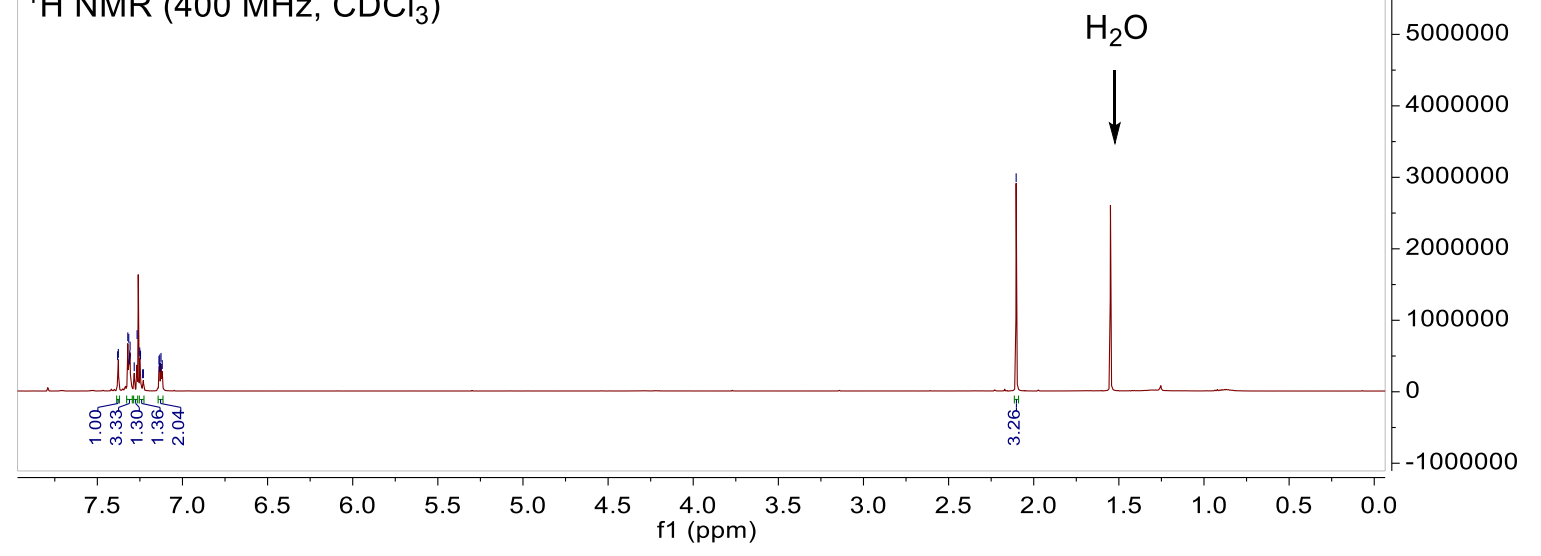




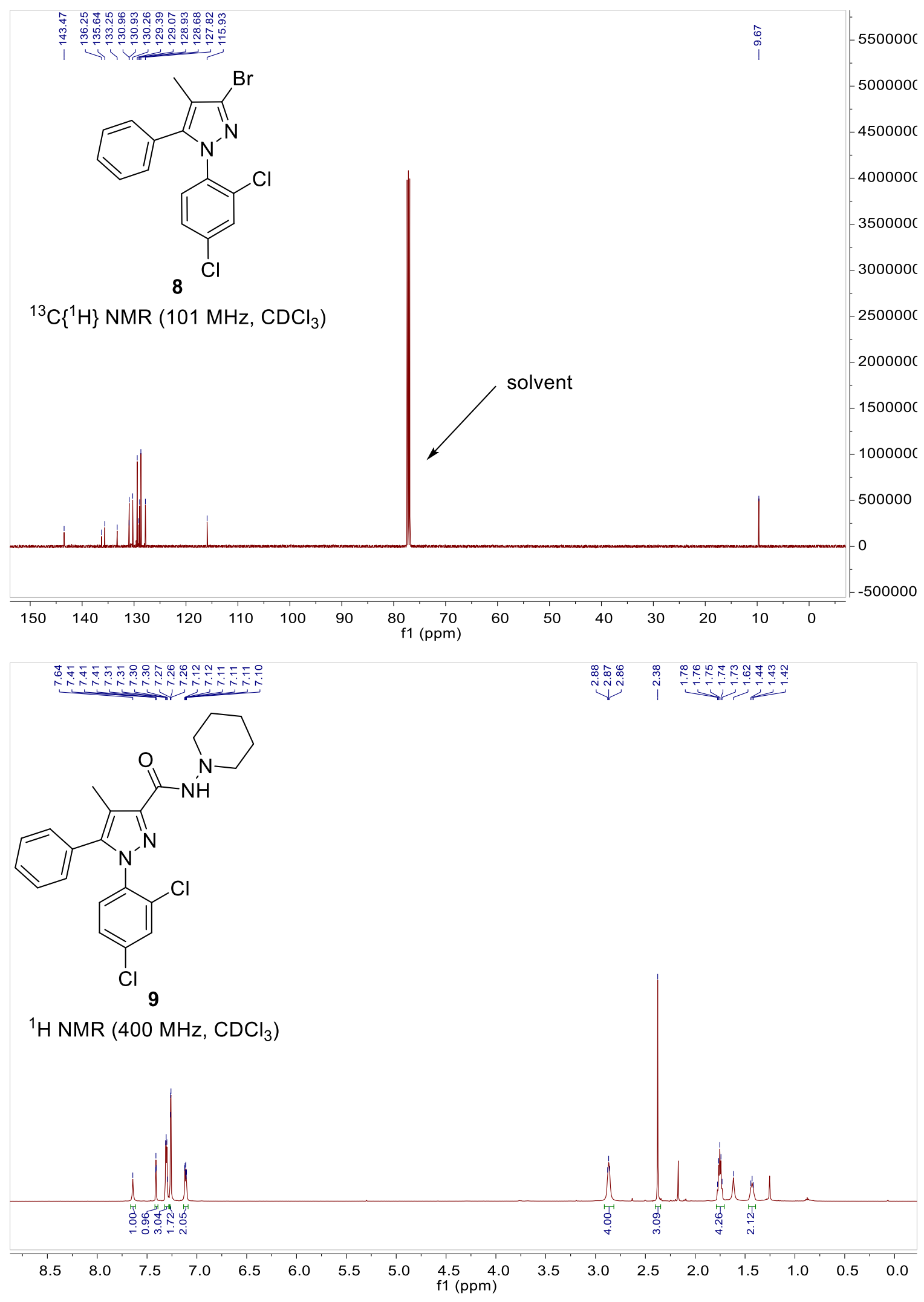




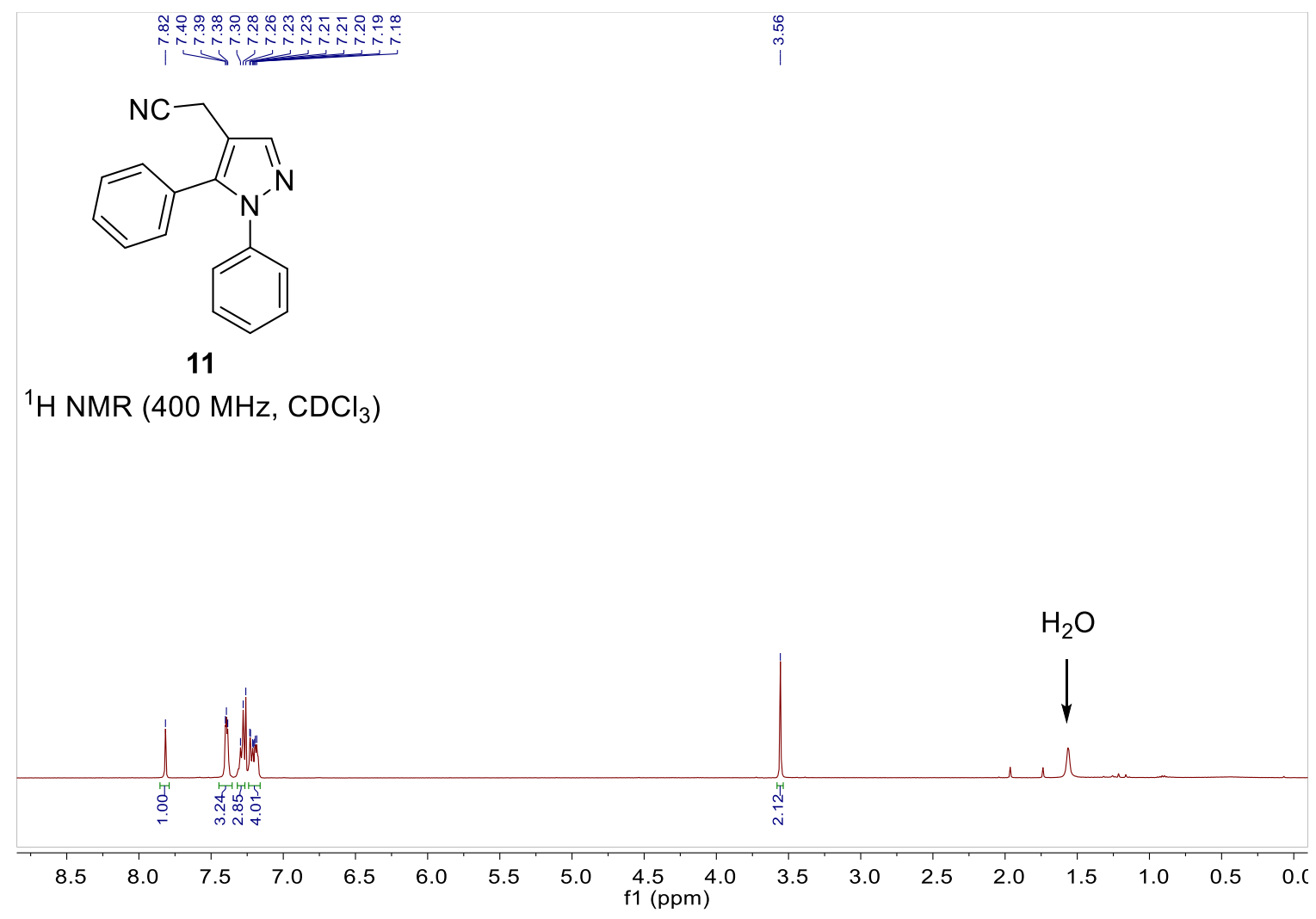




\section{ORTEP diagrams of $X$-ray structures}

$\mathbf{P d}_{2}$-hydride ${ }^{+}$bearing $\mathrm{CF}_{3} \mathrm{CO}_{2}{ }^{-}$anion: the anion co-crystalized with $\mathrm{CF}_{3} \mathrm{CO}_{2} \mathrm{H}$ acid to form a centrosymmetric anion $\left[\left(\mathrm{CF}_{3} \mathrm{CO}_{2}\right)_{2} \mathrm{H}\right]^{-}$. The hydride $\mathrm{H} 1$ one was located from the Fourier difference map (and not added in calculated position) and then refined with AFIX1 constraint to fix it. The checkcif indicates two alerts level B in the structure; both alerts are related to the anion $\left[\left(\mathrm{CF}_{3} \mathrm{CO}_{2}\right)_{2} \mathrm{H}\right]^{-}$, which is agitated.
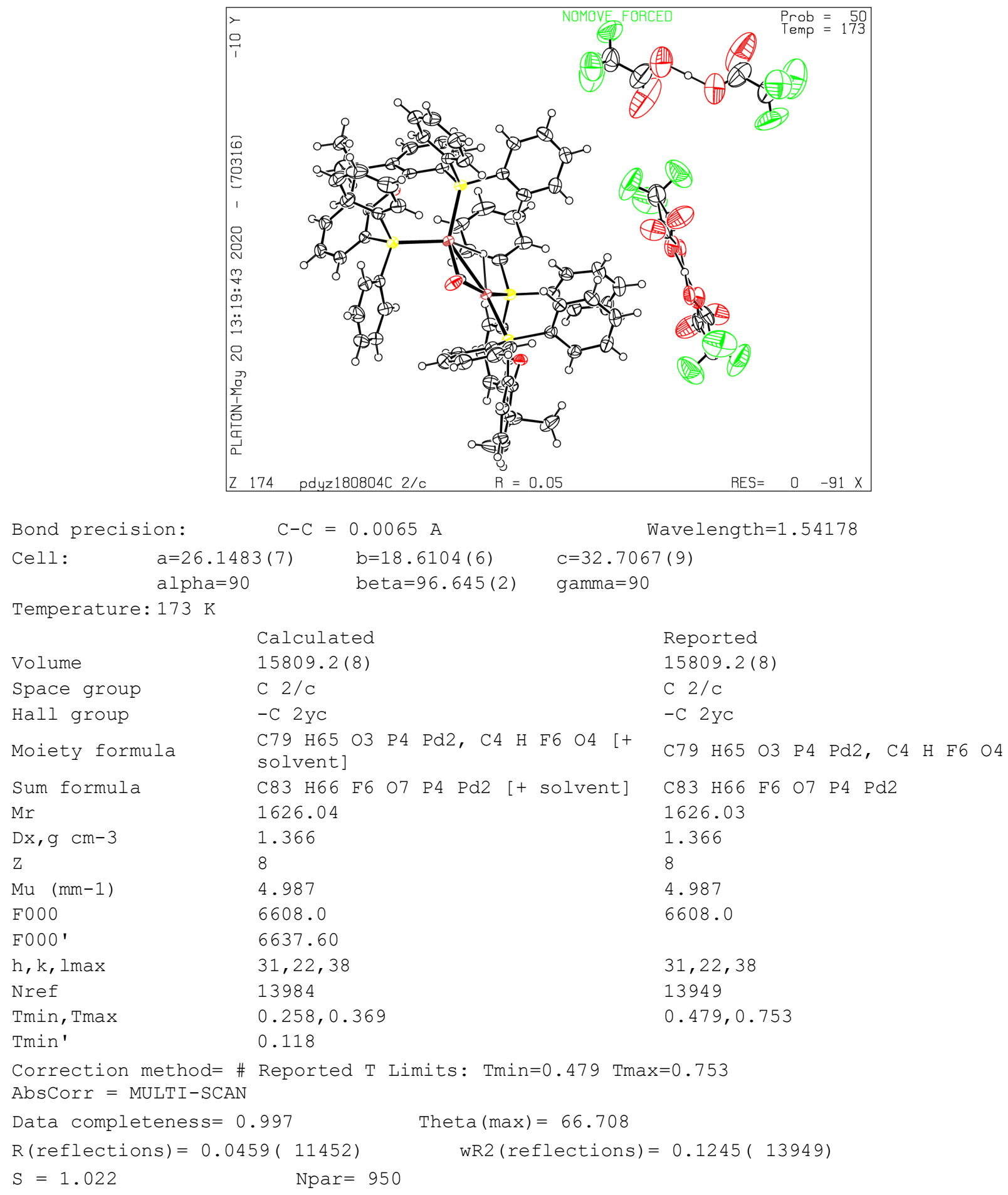

Tmin'

0.118

Correction method= \# Reported T Limits: Tmin=0.479 Tmax=0.753

AbsCorr = MULTI-SCAN

Data completeness $=0.997$

$\mathrm{R}$ (reflections) $=0.0459(11452)$

Theta $(\max )=66.708$

$\mathrm{S}=1.022$

Npar $=950$ 
Pd- $\beta$-acyl ${ }^{+}$bearing $\mathrm{BF}_{4}{ }^{-}$anion
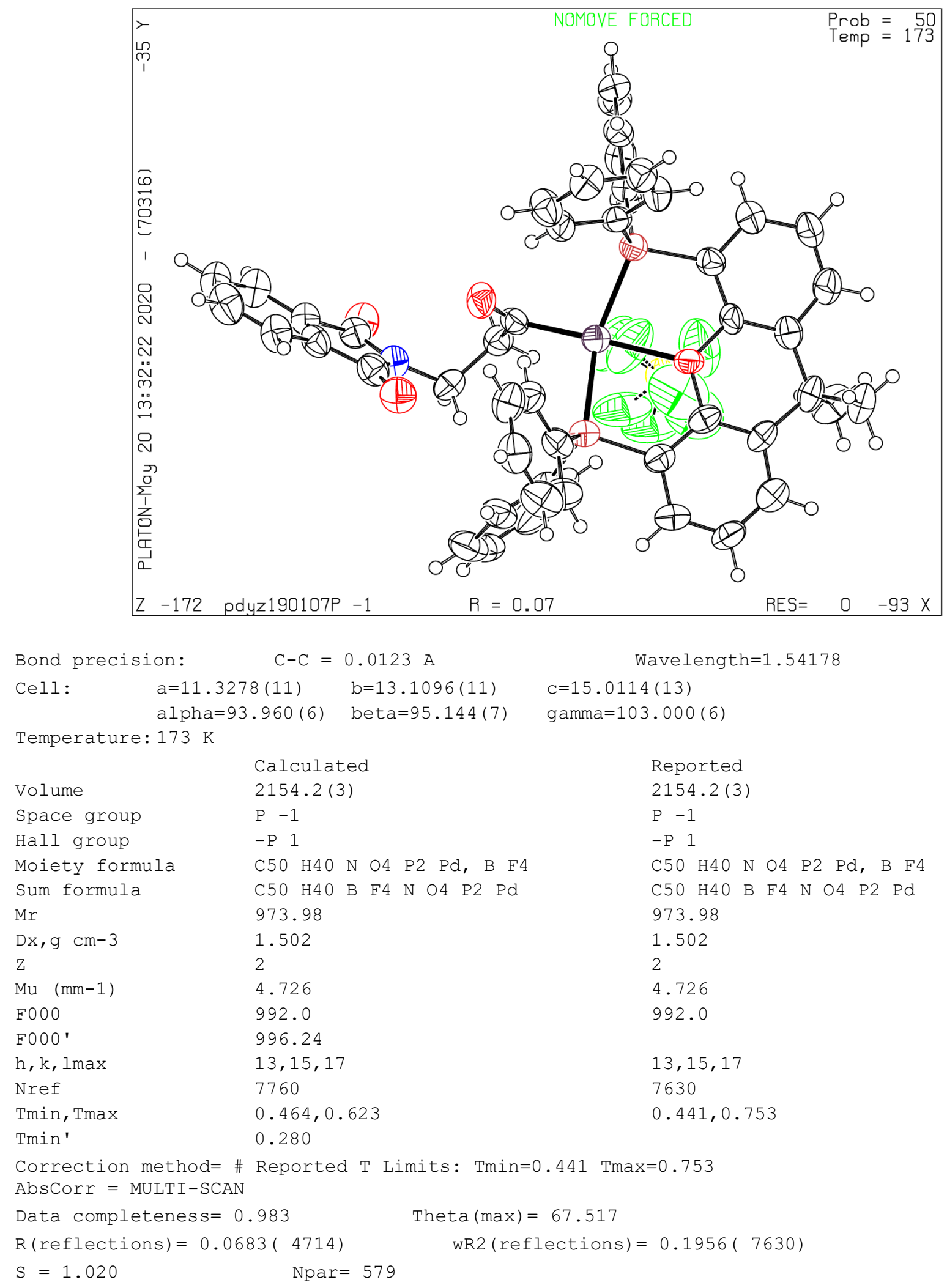

Correction method= \# Reported T Limits: Tmin=0.441 Tmax=0.753 AbsCorr = MULTI-SCAN

$\mathrm{R}$ (reflections) $=0.0683(4714)$

Theta $(\max )=67.517$

$\mathrm{S}=1.020$

Npar $=579$ 
Pd- $\alpha$-acyl ${ }^{+}$bearing $\mathrm{BF}_{4}{ }^{-}$anion
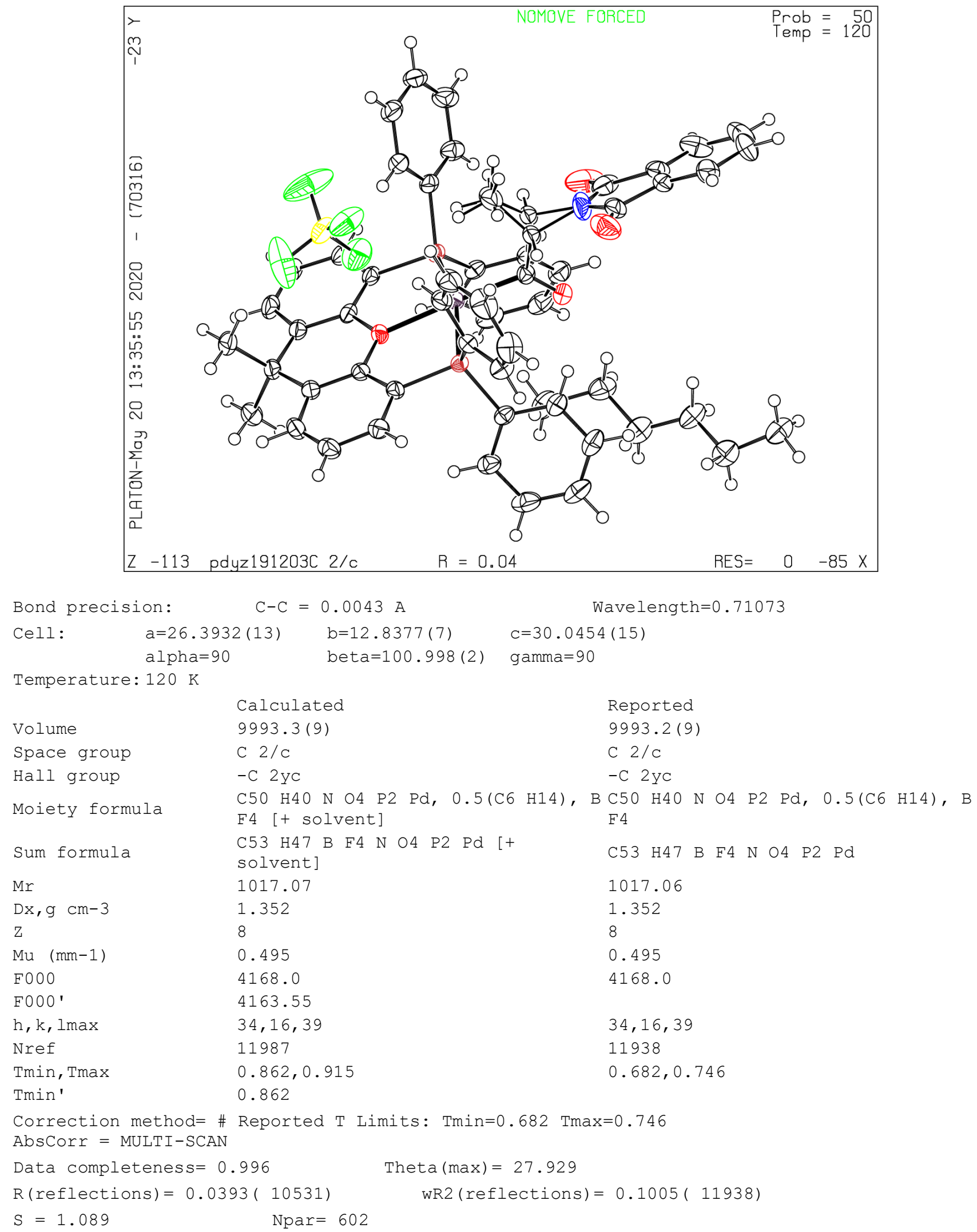
$\left[(\text { xantphos })_{2}-\mathrm{Pd}_{2}-\left(\mathrm{NCCH}_{3}\right)_{2}\right]^{2+}\left(\mathrm{BF}_{4}^{-}\right)_{2}$
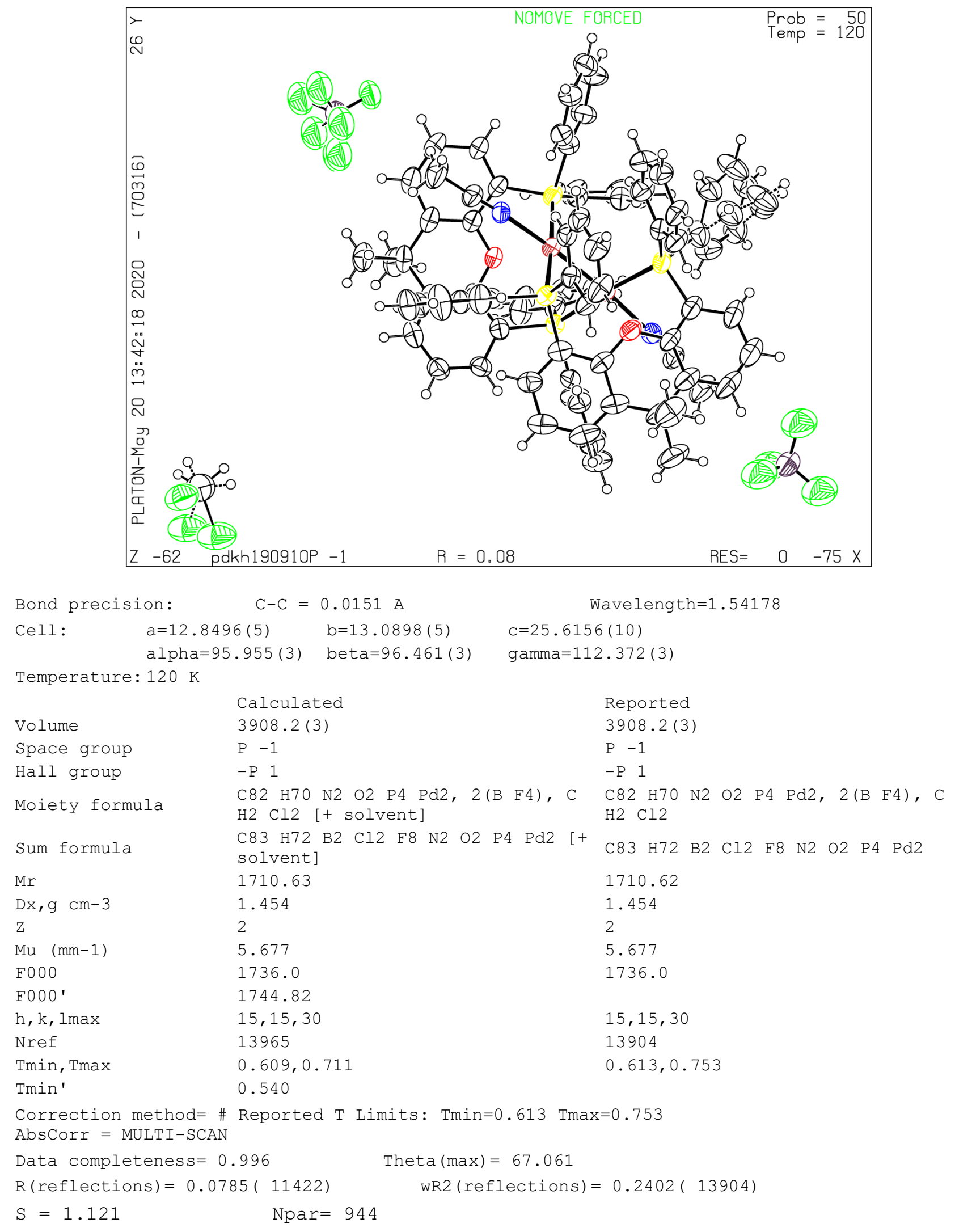
tetramer of xantphos-Pd $\mathbf{P d}_{\mathbf{2}} \mathbf{I}_{\mathbf{2}}$
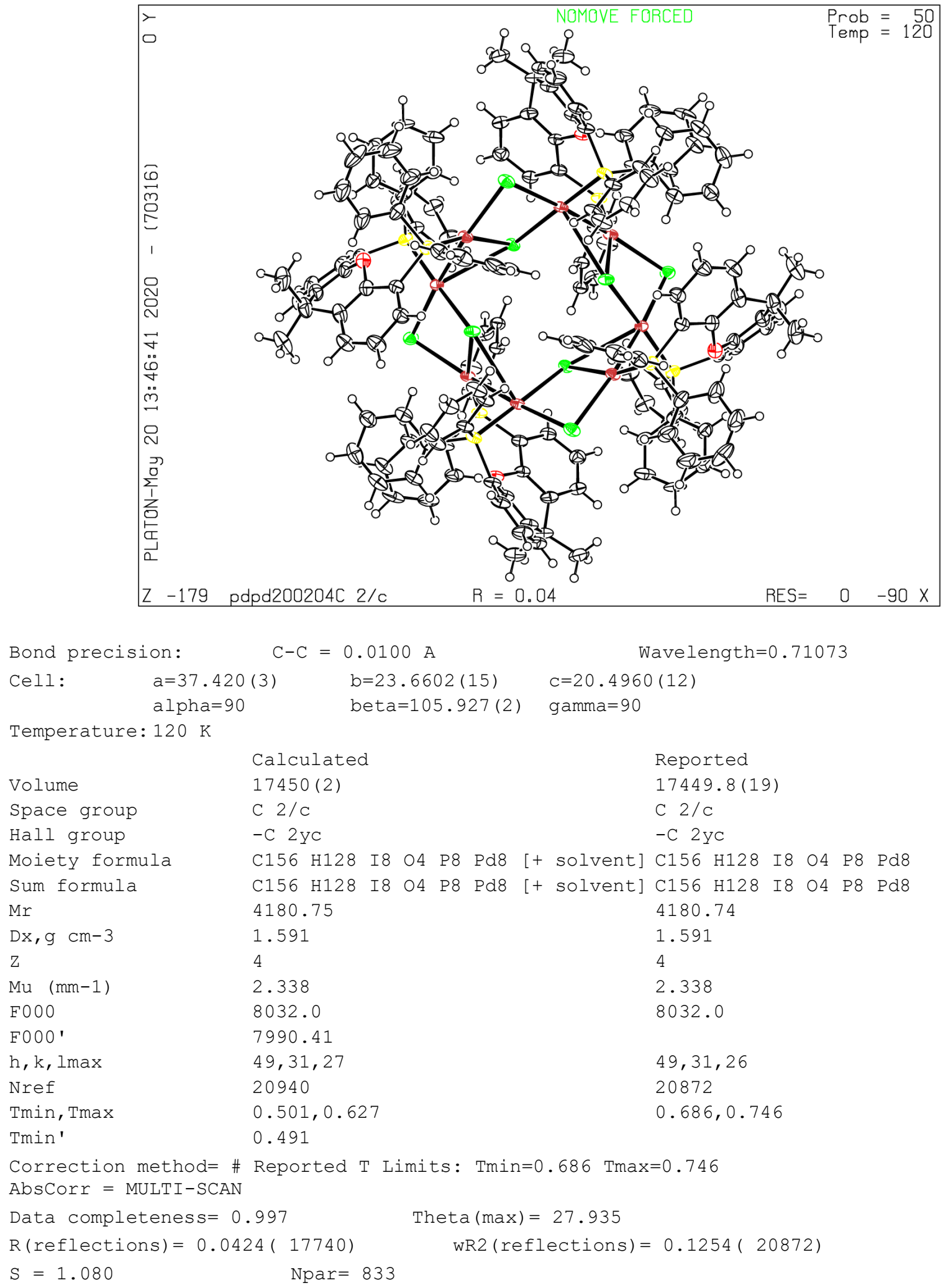